\title{
MIGRATION OF BIRDS
}

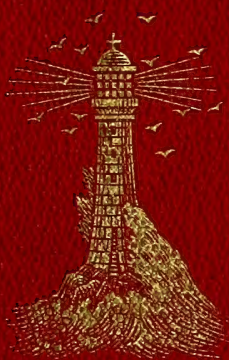

RICHARD M. BARRINGTON 


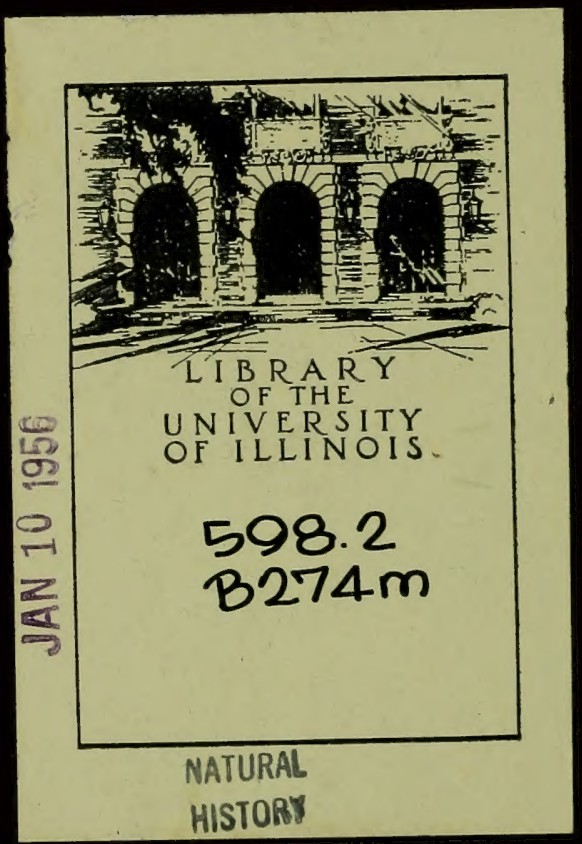


op.

(put 258) 


\section{THE MIGRATION OF BIRDS.}

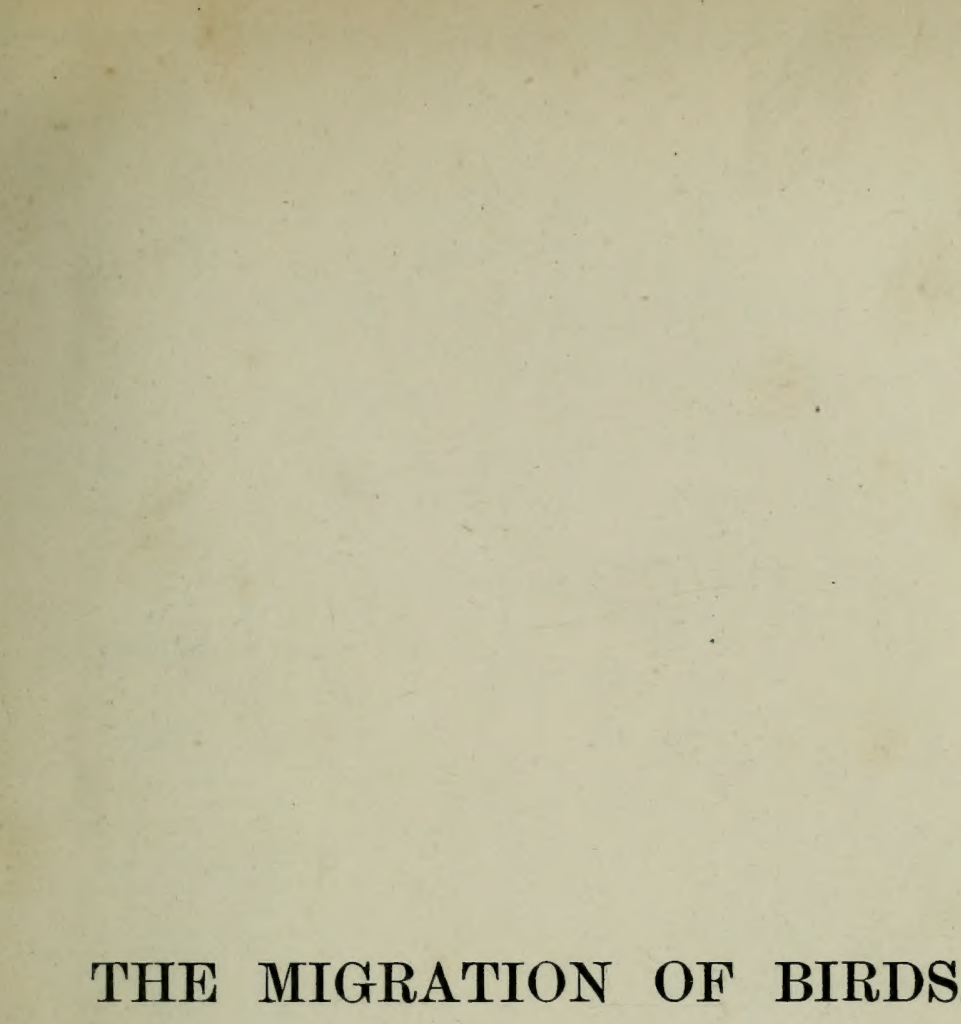




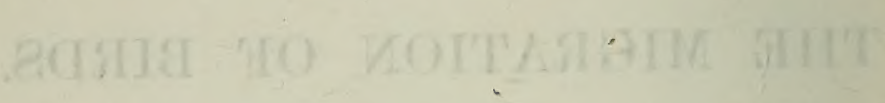




\section{MAP}

SHOWING THE POSITIONS OF THE

IRISH LIGHT STATIONS

FROM WHICH

OBSERVATIONS OR SPECIMENS HAVE BEEN RECEIVED.

Lighthouses

+ Light-Ships.

21. Ratbilin O'Bime.

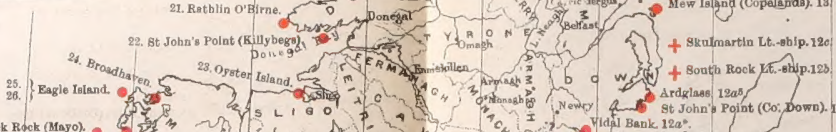

\section{sis}

27. Black Rock (Mayo).

28. Blackioul Pot

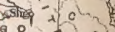

7 . Newcy a 5 st John's Point (Co; Down). I2as.

29. Olare Island.

290 ,

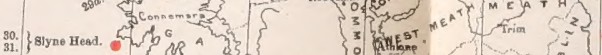

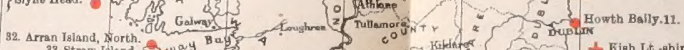

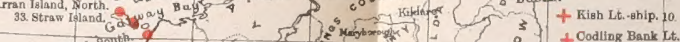

53 (25. Arran Island, North.

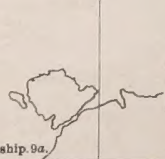

LIST OF STATIONS (58).

(1. Fastnet.

3. Old Head, Kinale.

3a. Spit Bank.

1. Mine Hesd.

5a. Hook Tower.

5". Coningbeg Lt.-ship.

6. Earrela Rock Lt.-8hip.

7 . Tuskar.

7a. Lacffer Shosls Lt. ship.

8. South Arkiow

$8^{*}$. North Arklow Lt.-ghip.

9. Wieklow Head.

9a. Codling Bank Lt-ehip.

10. Kigh Lt.-8hip.

11. Howth Baily.

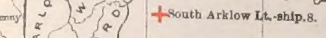

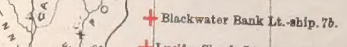

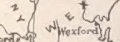
H Luciter Shoals Lt, -ship. 7a.

12a. Drogheda, North.

12a1 Dundalk

$12 a^{2}$. Carlingford Bar.

$12 a^{3}$. Green Islsnd.

12a4, St John's Point (Co. Down)

$12 a^{5}$. Ardglaea.

128. Sonth Roek Lt, -ship.

12o, skulmartin Lt.-ghip.

13. Mow Island (Copelando).

14. Maidens,

16. Rathlln.

16. Innishtrahull.

17. Dunree Head.

18. Lough 8 willy.

20. Aranmore.

21. Rathlin 0 .

22. St John'8 Point (Eillybegs).

23. Oyster Ialand

25. Eagle Ialand.

27. Black Rock (Mayo)

28. Blacksod Polnt

F 29. Olare Island.

30. Iniabgort.

30. Slyne Fead. 
(58).

ip.

hip. 5

t.-8)

hip.

hip.

hip.

Down).

pds).

lybegs). 


\section{MIGRATION OF BIRDS}

AS OBSERVED AT

\section{IRISH LIGHTHOUSES AND LIGHTSHIPS}

INCLUDING

\section{THE ORIGINAL REPORTS}

FROM 1888-97, NOW PUBLISHED FOR THE FIRST TIME, AND

\section{AN ANALYSIS}

OF THESE AND OF THE PREviOUSLy PUBLISHED REPORTS FROM 1881-87.

TOGETHER WITH

AN APPENDIX

GIVING THE MEASUREMENTS OF ABOUT 1600 WINGS.

BY

\section{RICHARD M. BARRINGTON, M.A., LL.B., F.L.S.,}

Member of the British Ornithologists' Union, and of the British Association Committee for obtaining Observations on the Migration of

Birds at Lighthouses and Lightships.

\section{LONDON :}

R. H. PORTER, 7 PRINCES STREET, CAVENDISH SQUARE, W.

DUBLIN :

EDWARD PONSONBY, 116 ĠRAFTON STREET. 
E D IN B O R G H :

PRINTED BY M'FARLANE AND ERSKINE, ST JAMES SQUARE. 



\section{NOTE ADDED IN PRESS.}

Some expressions in the Preface have, I deeply regret to find, been understood as reflecting on the results obtained by the British Association Committee and Mr Eagle Clarke.

So far from this being the case, no one could have a keener appreciation than myself of the great value of the work done by that Committee, and of the unique interest and merit of the digest prepared, after enormous labour, by Mr Eagle Clarke, as well as of the compilation of results on which he is now engaged.

R. M. B. 


\section{$598 \cdot 2$
$8274 \times 2$}

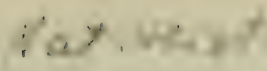

\section{P R E F A C E.}

THE present work is the result of many years' labour, but without the assistance of the Irish light-keepers, the Board of Irish Lights, the co-operation of my friend Mr C. B. Moffat, of Ballyhyland, and the help of my wife, it never could have been written.

The time and attention of the light-keepers were given voluntarily, and without payment they have filled over a thousand schedules, and made about thirty thousand separate observations on birds during the past eighteen years. Over two thousand specimens were forwarded to corroborate these observations. The light-keepers deserve not only my gratitude, but that of all their fellow-countrymen who take an interest in the Birds of Ireland.

The Irish Lights Board was favourably disposed to this inquiry from the beginning, provided it did not interfere with the duties of the light-keepers; and its officials were, at all times, courteous and anxious to facilitate the collection of statistics.

The enormous mass of records to be grappled with was sufficient to occupy an idle man for years, and would have disheartened a busy one like myself, had not Mr C. B. Moffat come to the rescue in 1898. If the accumulation of a more or less chaotic mass of information was mine-its analysis is largely his. The influence of the lunar phases on the number of birds killed striking was first detected by him, and illustrated diagrammatically; and to his ingenuity, scientific caution, and intelligent grasp of facts, not a few of the interesting conclusions deduced from the above data are directly traceable.

To Professor Newton, F.R.S., of Cambridge, my thanks are due for many kind words of encouragement, and to my friend Howard Saunders I am indebted in various ways. 
Bird migration is an old subject; but its systematic study at light-stations is quite new-and was never attempted in Ireland until 1881. Possibly in consequence of a visit to Heligoland, and an interview with that well-known observer, Herr Gätke-Mr John Cordeaux in England, and Mr HarvieBrown in Scotland, made a combined and successful attempt in 1879 to procure observations on migratory birds from the light-keepers on the coasts of Great Britain. When the results were known, a committee was appointed by the British Association for the Advancement of Science, at the Swansea Meeting in the following year (1880), to continue the investigation, and that committee has since been annually re-appointed.

Nineteen years ago, my friend Harvie-Brown suggested that I should become a member, my old friend A. G. More, then assistant-curator in the Science and Art Museum, Dublin, having been elected to the committee at the same time.

Blank schedules were first sent to the Irish light-keepers in the autumn of 1881 (a copy of the present form will be found on p. xxiii). More's advice was irvaluable-and it was he who, in 1884, first suggested that the Irish light-keepers should cut off and forward, for the purpose of identification, a leg and wing of any bird which was killed striking the lanterns.

From 1881 to 1887, "Reports on the Migration of Birds" as observed at Light-Stations were published by the British Association Committee. They were then discontinued, and the committee in 1888 commenced to make a digest of the Reports up to the end of 1887 . This work was entrusted to Mr Eagle Clarke, who, after great labour, completed the task in 1896.

Owing to the character of the observations, it was apparent to me that no digest would yield satisfactory results which was not based on a much longer series of years. Records which were anticipated were believed, but every uncorroborated entry by an untrained observer required repetition by independent light-keepers before it could be accepted as reasonably probable. Many blunders were made in the identification of species, and an element of uncertainty created, which, added to the bewildering mass of statistics, caused a few sceptics to doubt the value of the entire work. 
Schedules were therefore still sent out to the Irish lightkeepers and filled by them year after year, and over two thousand specimens were forwarded by them. It is much to be regretted that a similar course was not adopted in England and Scotland.

In reading this volume, three things must be borne in mind -first, that the British Association Committee is in no way connected with its publication, nor responsible for any expression of opinion therein; second, that Ireland lies comparatively out of the track of migrants along the west coast of Europe; third, that in almost every instance the conclusions are based only on the data received from light-stations.

Few, perhaps, can realise what the collection of statistics, the preparation, the printing and the publication, of this work have cost in time and money. Only 350 copies have been printed by M'Farlane \& Erskine, whose care and intelligence I am glad here to acknowledge. Birds are a very attractive subject, but even if all the copies were sold, the expenses would not nearly be defrayed.

There are so many industrious students nowadays, it becomes more difficult year by year to discover anything new, especially about our common English birds. The detailed results will be found under each species in the Analysis, and some of the principal points of interest at p. 263. All are, I hope, based on facts, for we have had enough migration theories. Some of these results may be new, and if so, to have placed them before other students of this most fascinating subject, Ornithology, is a more than sufficient reward.

RICHARD M. BARRINGTON. 



\section{CONTENTS.}

Map of Ireland showing Light-Stations, .

PAGE

ii

v-vii

Preface,

List of Irish Light-Stations referred to in this Volume, and Table of Distances at which Objects can be seen at Sea, according to their respective Elevations, and the Elevation of the Eye of the Observer. (Compiled by permission from the Admiralty List of Lights in British Islands),

Present Form of Schedule sent to the Light-keepers,

xi-xxii

xxiii

Present Form of Envelope for Leg and Wing, and of Label (front and back) for Specimens,

xxiv

TABLE showing for several Species both in Spring and Autumn, the Dates of Arrival and Departure (or it may be Second Immigration) of the majority, the Total Number of Specimens received at both Seasons, the part of the Coast from which most have been sent, whether the Long-winged or Short-winged Birds come first, the Dates on which the Earliest and Latest Specimens have been killed, and the Northernmost and Southernmost Light-Stations from which Examples of each Species have been forwarded, .

$\mathrm{XXY}$

Analysis of Irish Migration Reports, 1881-97-

Part I., containing detailed Results under each Species,

Part II., containing some of the principal points of interest in the Analysis, some General Remarks, and various Tables,

263-284

284

Recipe for Preserving Legs and Wings, . . . . 285

Report on the Migration of Birds as observed at LyghthoUses AND LIGHT-SHIPS ON THE IRISH COAST FOR 1888, . 1. 57

$\begin{array}{lllllr}\text { Do. } & \text { Do. } & \text { Do. } & 1889, & \text {. } & 59-123 \\ \text { Do. } & \text { Do. } & \text { Do. } & 1890, & \text {. } & 125-196 \\ \text { Do. } & \text { Do. } & \text { Do. } & 1891, & \text {. } & 197-265 \\ \text { Do. } & \text { Do. } & \text { Do. } & 1892, & \text {. } & 267-331 \\ \text { Do. } & \text { Do. } & \text { Do. } & 1893, & \text {. } & 333-383 \\ \text { Do. } & \text { Do. } & \text { Do. } & 1894, & \text {. } & 385-449 \\ \text { Do. } & \text { Do. } & \text { Do. } & 1895, & \text {. } & 451-496 \\ \text { Do. } & \text { Do. } & \text { Do. } & 1896, & \text {. } & 497-539 \\ \text { Do. } & \text { Do. } & \text { Do. } & 1897, & \text {. } & 541-619\end{array}$

APPENDIX-

Part I., Table showing the Measurements of 1543 Wings forwarded by the Light-keepers,

Part II., Table showing the A verage Lenoth of Wing, and the relative Amount of Variation in the Length of the Wings in 35 Splecies of Birds obtained at Irish Light-Stations, . . . . 
arily 0

either"

Oenasis

The

and th

ated ii

and C.

Ond

accord

apparara

Thu

Th

with

in uni

porrer

given

Inerarees

阴

figuree

and th

reath

20,00

$\mathrm{B}_{E}$

timgu 


\title{
LIST OF IRISH LIGHTS
}

\author{
REFERRED TO IN THIS VOLUME.
}

[Compiled by permission from Admiralty List of Lights in British Islands.]

\section{INTRODUCTORY REMARKS.}

\section{LIGHTS.}

Illuminating Apparatus.-The illuminating apparatus ordinarily consists of a flame, the light from which is concentrated either by reflectors, by refractors, or by a combination of the two. Occasionally the electric are light takes the place of the flame.

The system of reflectors is named Catoptric, of refractors Dioptric, and the combination of the two Catadioptric. They are abbreviated in the tables by the letters C. for Catoptric, D. for Dioptric, and C.D. for Catadioptric.

Order of Apparatus. - Lights have hitherto been classified according to their Order, which depends upon the diameter of the apparatus, etc.

Thus a light of the

1st order has an internal diameter of $6 \mathrm{ft} .0 .4$ ins.

\begin{tabular}{|c|c|c|c|c|}
\hline $2 \mathrm{nd}$ & ," & , & ", & \\
\hline 3rd & " & , & ," & 3 \\
\hline 4th & " & , & " & 1 \\
\hline 5 th & " & ", & ", & 1 \\
\hline 6 th & " & , & ", & 0 \\
\hline
\end{tabular}

The Power of the Lights does not, however, vary directly with the order, and whenever obtainable, the candle power is given in units of 1,000 candles. Thus, the figure 22 means 22,000 candle power, $\frac{1}{4}$ means 250 candles. Intensities above 2,000 candles are given to the nearest half unit, between 2,000 and 1,000 to the nearest quarter unit, and under 1,000 to the nearest tenth unit.

When the power of the light is capable of being varied, two figures are given, the lower representing the clear-weather power, and the higher the maximum power capable of being shown in thick weather. Thus, a light which can be varied from a power of 20,000 to 100,000 candles is noted as 20 to 100 .

Relative Importance of Lights. - In order to readily distinguish the important lights from those of less prominence, the 
names of all the main lights are printed in large black (CLARENDON) capitals, those of secondary importance in small black (Clarendon) letters, and those of the minor lights in ordinary (Roman) type, so that the relative value of a light can be ascertained at a glance. (Light-vessels are shown in italics, the most important being in capitals.)

In estimating the importance of a light, its position and its relation to other lights has been considered, rather than its power.

Characteristics.-Lights may either show a steady uniform brilliance or be varied by flashes, occultations, etc. The various lights at present exhibited are as follows:-

F. Fixed. A continuous steady light.

* Fr. Flashing. Showing a single flash, the duration of darkness always being greater than that of light.

* GP. FL. Group Flashing. Showing groups of two or more flashes in succession (not necessarily of the same colour) separated by eclipses.

F. \& FL. Fixed and Flashing. Fixed light raried by a single white or coloured flash, which may be preceded and followed by a short eclipse.

F. \& GP. Fu. Fixed and Group Flashing. The same as the preceding, but with groups of fiashes

Rev. Revolving. Light gradually increasing to full effect, then decreasing to eclipse. [At short distances and in clear weather a faint continuous light may be observed.]

* Occ. Occulting. A steady light with, at regular intervals, one sudden and total eolipse, the duration of light always being equal to or greater than that of darkness.

* Gr. Occ. Group Occulting. A steady light with, at regular intervals, groups of two or more sudden and total eclipses. ALT. Alternating. Lights of different colours (generally red and white) alternately, without any intervening eclipse.

Explanation.-In the following tables of lights the column headed "Period of Revolution or of System" gives the interval between the successive recurrences of the same phase; which in a simple revolving or flashing light is the interval between each successive flash ; and in an alternating, occulting, or group flashing light, is the time occupied by the exhibition of the entire system of changes.

* Note. -A light is classed as flashing or-occulting solely according to the duration of light and darkness, and withont any reference to the apparatus employed. 
The bearings are magnetic, and are given from seaward. The positions of the light-houses are given approximately.

The given distances from which the lights are visible are calculated in nautical miles, as seen from a height of 15 feet above the sea, the height of the lights being in all cases taken as above high water.

Under certain atmospheric conditions, and especially with the more powerful lights, the glare of the light is visible considerably beyond the radius given, which is calculated for the actual flame of the light.

Caution.-The intrinsic power of a light should always be considered when expecting to make it in thick weather. A weak light is easily obscured by haze, and no dependence can be placed on its being seen.

The power of a light whose candle power is not given can be estimated by remarking its order as entered in this list, and in some cases by noting how much its visibility in clear weather falls short of the range due to the height at which it is placed. Thus a light placed at 200 feet above the sea, and only recorded as visible 10 miles in clear weather, is manifestly of little brilliancy, as its height would permit it to be seen over 20 miles if of sufficient power. See "Table of Distances" at the end of this list.

Cuts or Sectors.--In some conditions of the atmosphere, white lights may have a reddish hue; the mariner, therefore, should not trust solely to colour where there are sectors, but verify the position by taking a bearing of the light. On either side of the line of demarcation between white and red, and also between white and yreen, there is always a small arc of uncertain colour. It should also be remembered that the edges of a sector of visibility are rarely cut off sharply, especially as seen by an observer near, and that instead of suddenly disappearing, the light frequently fades gradually away after the line given as the limit of visibility has been crossed.

Fog-Signals.-Having in view the varying distances at which a fog-signal can be heard at sea, and the occasional existence of areas in which a fog-signal is wholly inaudible, and the frequent occurrence of fog near to but not observable from a fog-signal station-

Mariners are cautioned that, whilst every endeavour will be made to start fog-signals as soon as possible after signs of fog have been observed, they should not, when approaching the land in a fog, rely implicitly upon these fog-signals, but should always use the lead, which, in nearly all cases, will give sufficient warning.

The expression "foggy weather" means that the state of the atmosphere is such as to make objects indistinct. 


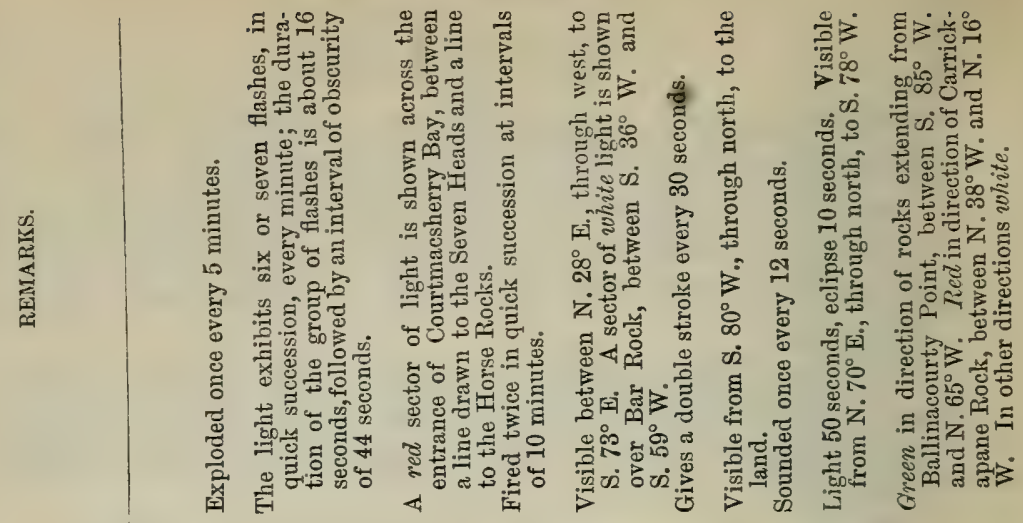

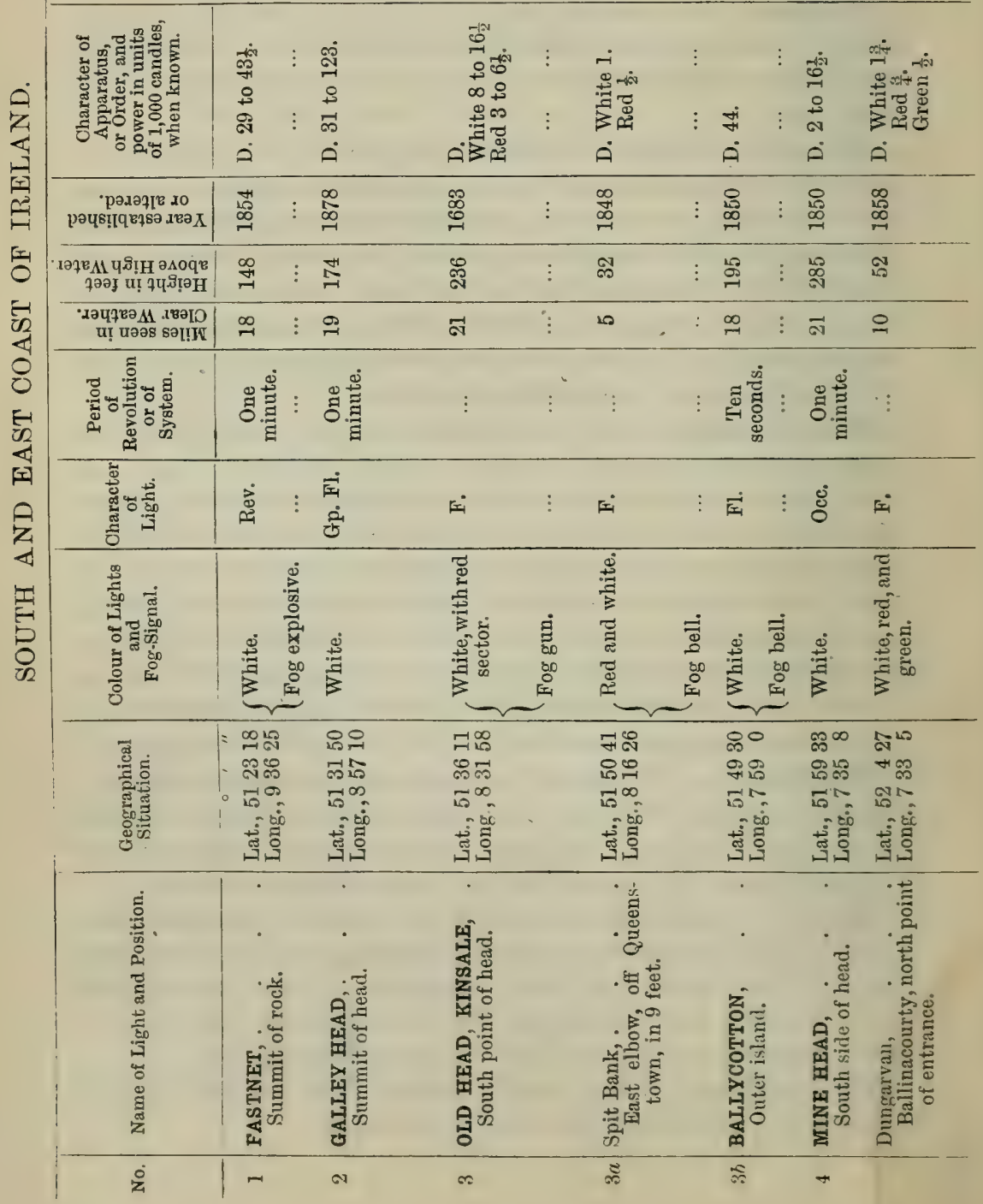


LIST OF IRISH LIGHTS
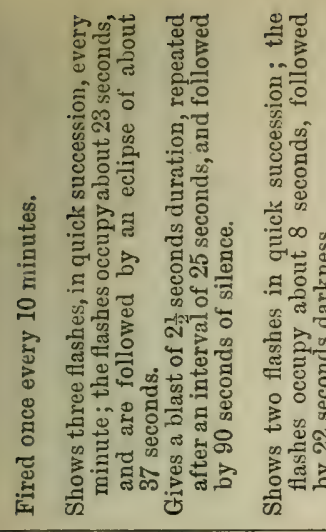

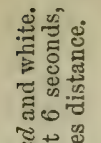

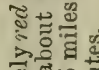

क्ष 10

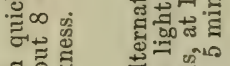

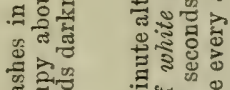

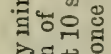

용

놇고융

हैं

迥

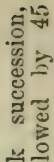

능융

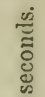

ज्ञ

吾总

- $\mathrm{\varepsilon n}^{\mathrm{E}}$

言

吾号

-is

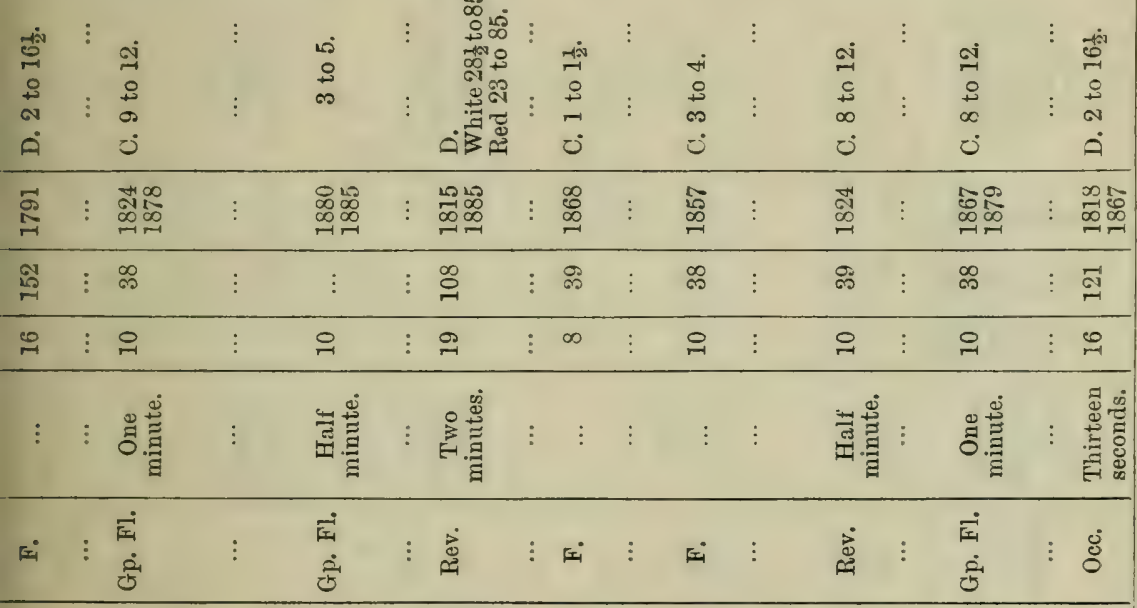

\begin{tabular}{|c|c|c|c|c|c|c|c|c|}
\hline 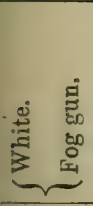 & 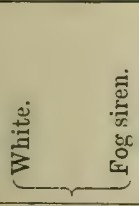 & 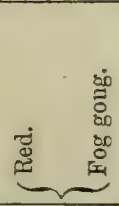 & 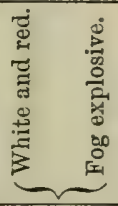 & 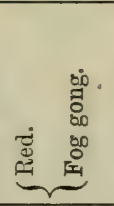 & 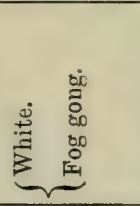 & 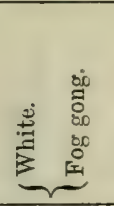 & 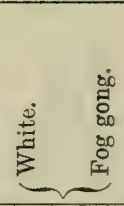 & 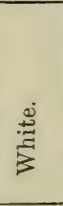 \\
\hline 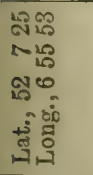 & 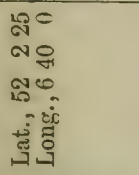 & 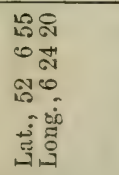 & 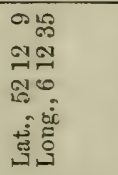 & 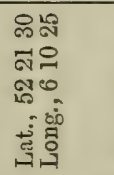 & 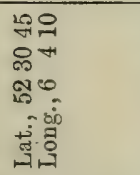 & 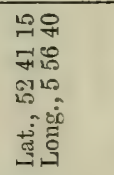 & 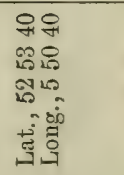 & 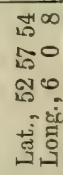 \\
\hline 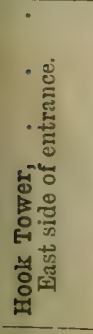 & 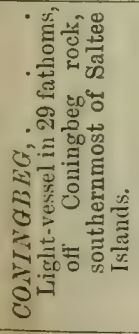 & 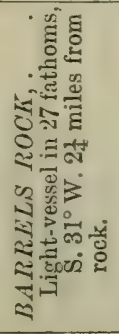 & 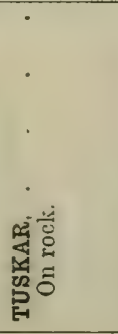 & 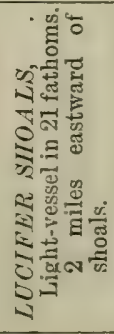 & 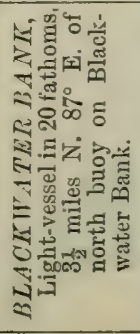 & 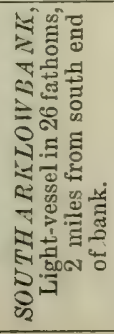 & 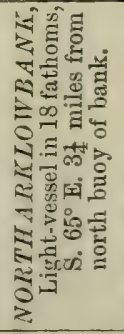 & 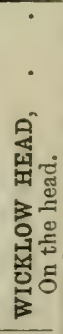 \\
\hline & * & $\infty$ & 10 & $\vec{\Sigma}$ & $i$ & $\infty$ & ${ }_{\infty}^{*}$ & $a$ \\
\hline
\end{tabular}



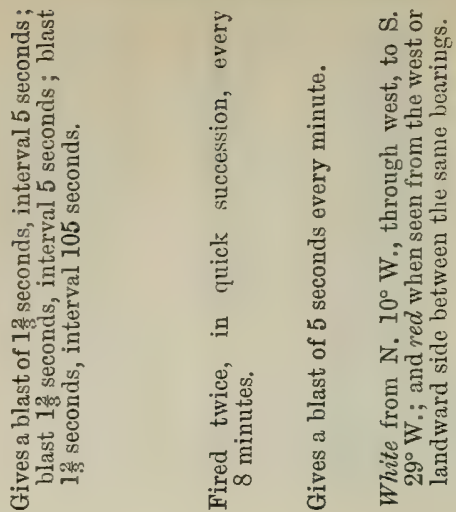

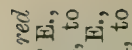

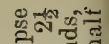
$\because \infty$ कु०

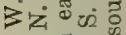

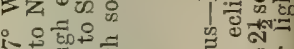

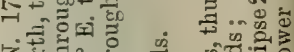
|

ठ․

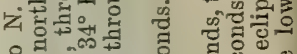

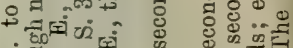
$\vec{\nabla} \approx$ घ 要, ㅎ․ㄹ on

․․‥: 政 t) 엥거

的数觉 等 .

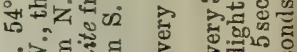

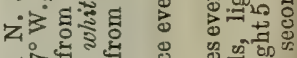

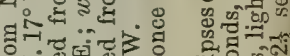

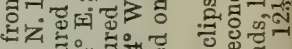

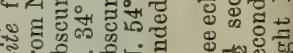

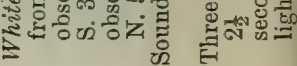

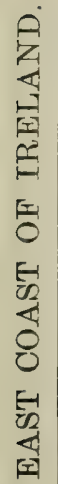

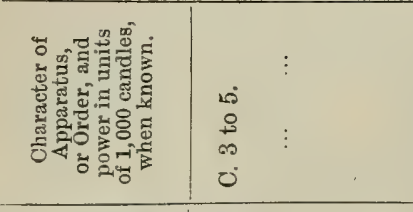

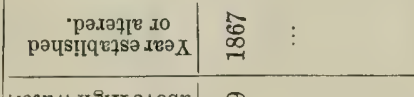

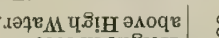

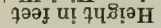

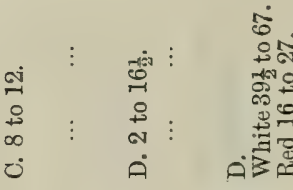

8

\begin{tabular}{|c|c|c|c|c|c|c|c|}
\hline 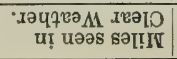 & $\infty$ & : : & 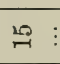 & $\infty$ & $\circ$ & $\infty$ & 29 \\
\hline 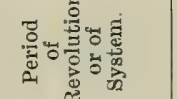 & 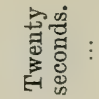 & 竞 & & 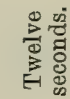 & & 列 & 㪯总 \\
\hline
\end{tabular}

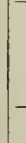

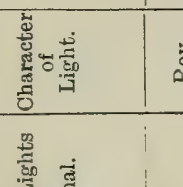

:

递: 的: 挋

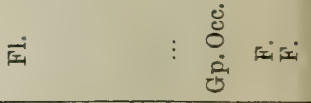

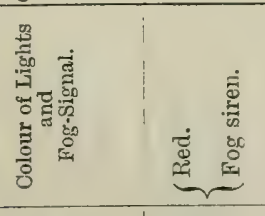

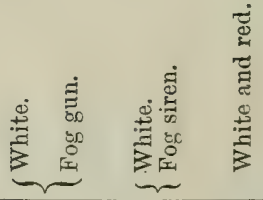

离

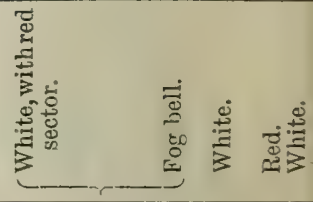

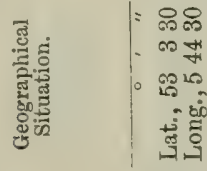

웍 윙 자영

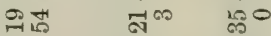

is

音高

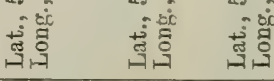

范


LIST OF IRISH LIGHTS

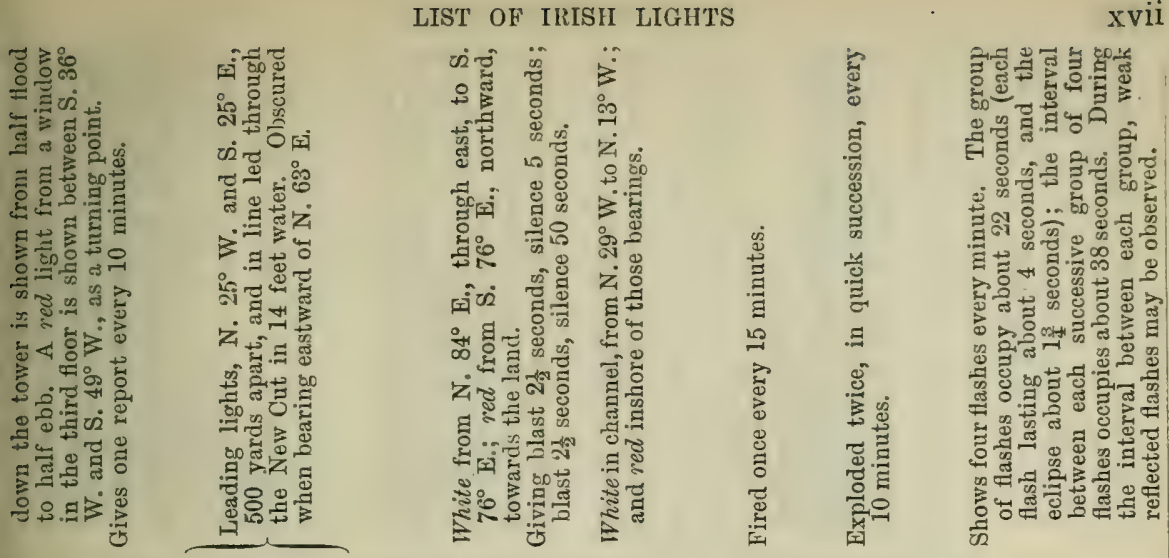

$\min _{\sim \rightarrow-1}^{\infty}$

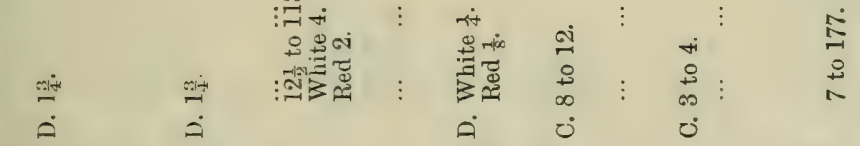

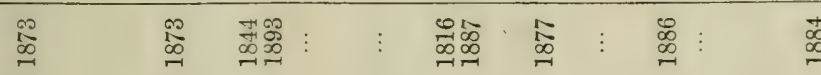

\begin{tabular}{|c|c|c|c|c|c|c|c|c|c|}
\hline$\vdots$ & 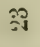 & 우 & స్త్రి & $\vdots$ & $\vdots$ & ๙ิ่ & 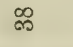 & $\stackrel{\infty}{\infty}$ & $\tilde{\mathbb{N}}$ \\
\hline$\vdots$ & 20 & 0 & $\stackrel{\leftrightarrow}{\sim}$ & $\vdots$ & $\vdots$ & 0 & 유 & 윽 & $\stackrel{0}{\sim}$ \\
\hline$\vdots$ & $\vdots$ & $\vdots$ & ○ี & $\vdots$ & $\vdots$ & $\vdots$ & 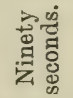 & $\vdots$ & \\
\hline 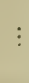 & ci & is & 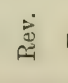 & $\dot{E}$ & $\vdots$ & $x_{i}$ & 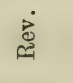 & Fis & 今े \\
\hline
\end{tabular}

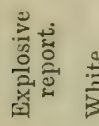

(2)

\begin{tabular}{|c|c|c|}
\hline $\begin{array}{l}\stackrel{m}{=} \\
\dot{=}\end{array}$ & 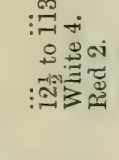 & : \\
\hline$\underset{\substack{\infty \\
\infty}}{\substack{\infty \\
\sim}}$ & 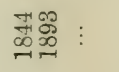 & \\
\hline 유 & స్త్ర $\quad \vdots$ & $\vdots$ \\
\hline 0 & $\stackrel{\bullet}{\sim} \quad \vdots$ & : \\
\hline
\end{tabular}

$\stackrel{\substack{\infty \\-\infty}}{\sim}$

I

$\stackrel{-1}{2}$

马.

चें

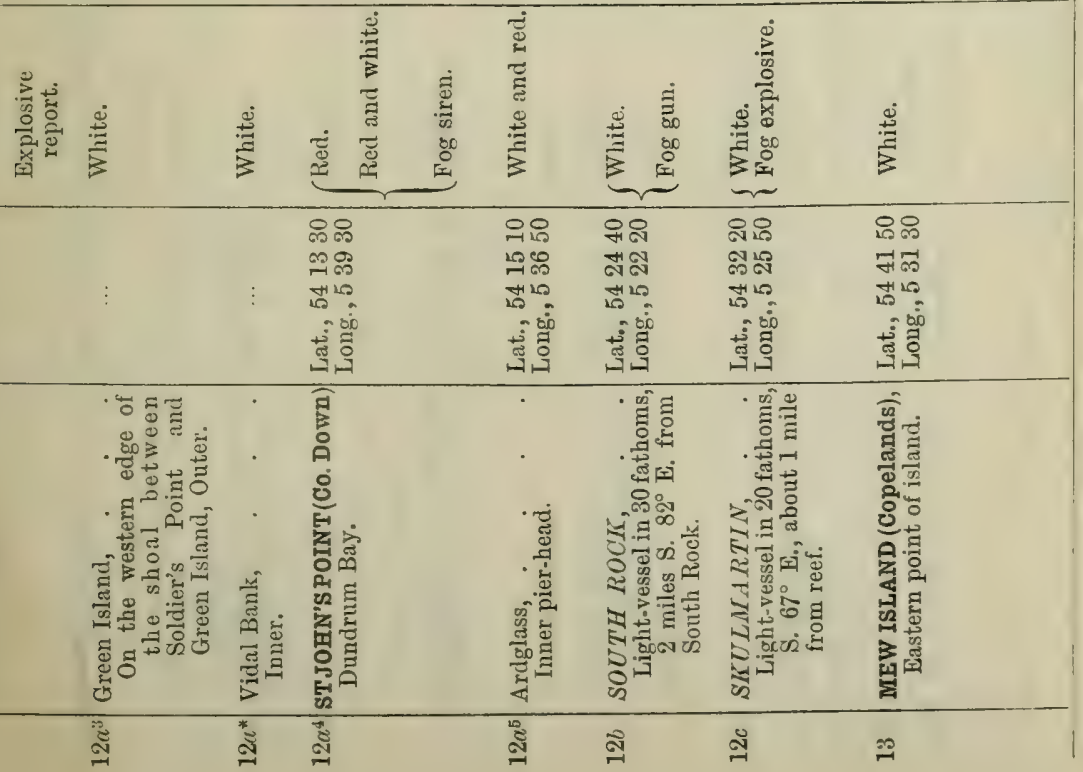




\section{$\mathrm{x}$ viii}

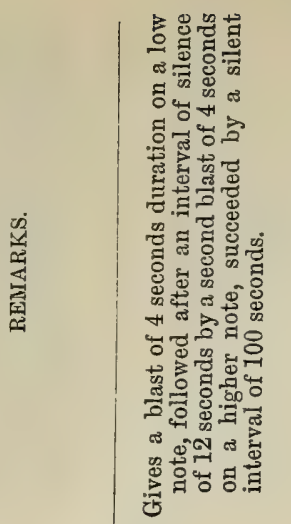

LIST OF IRISH LIGHTS

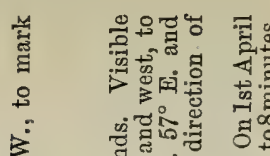

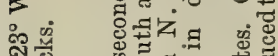

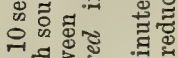

मำ

대

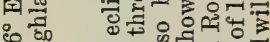

谣

मू.

뉴

t艹

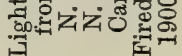

牙出

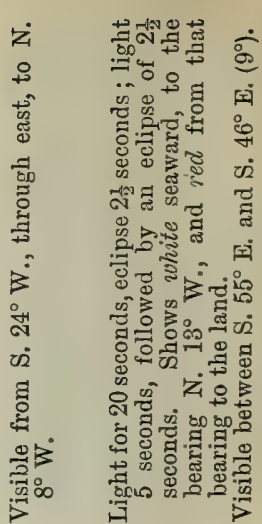

我

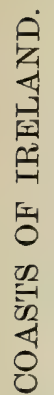

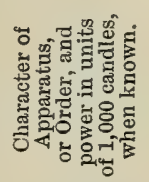


LIST OF IRISH LIGHTS

Iilitit:

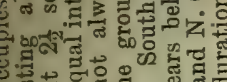

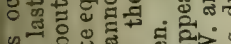

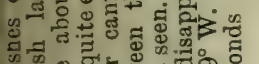

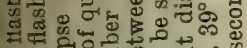

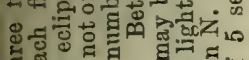
연

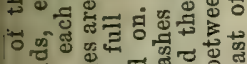

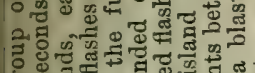

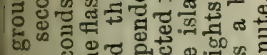

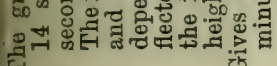

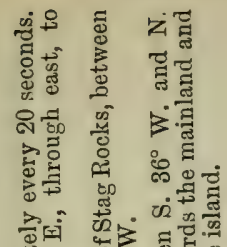

ब्ञ

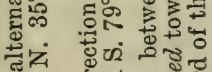

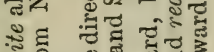

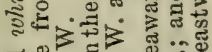

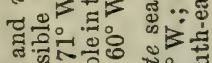

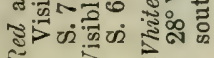

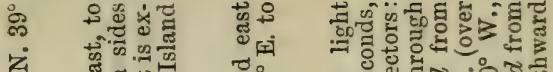
ङ

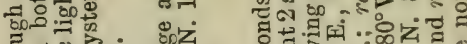

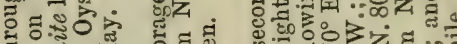
† ज地

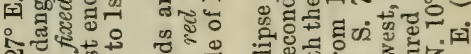
कू

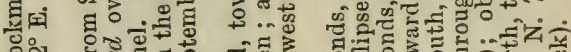

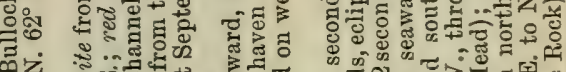

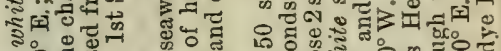

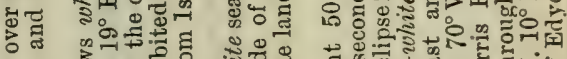

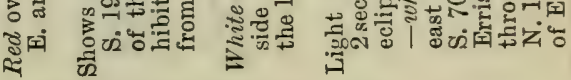

\begin{tabular}{|c|c|c|c|c|c|c|c|c|}
\hline 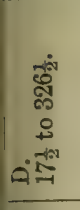 & & 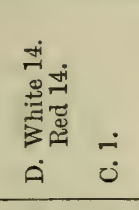 & 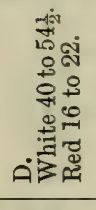 & 䨔 & 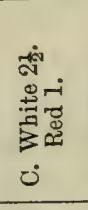 & 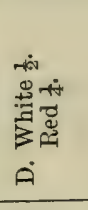 & 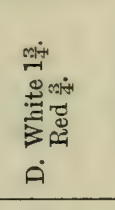 & 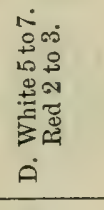 \\
\hline 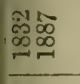 & $\vdots$ & 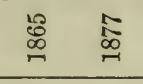 & 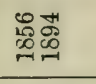 & $\overrightarrow{⿱_{9}^{\prime}}$ & 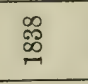 & 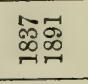 & 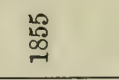 & 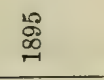 \\
\hline$\stackrel{\circ}{9}$ & $\vdots$ & 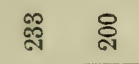 & 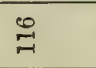 & $\infty$ & $\because$ & : & $\grave{\infty}$ & ส్టి \\
\hline$\Phi$ & $\vdots$ & สึ & 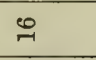 & 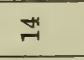 & $\Im$ & $\Rightarrow$ & 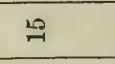 & $\vdots$ \\
\hline . & : & 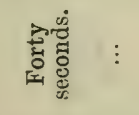 & 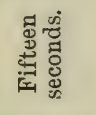 & : & : & $\vdots$ & $\vdots$ & 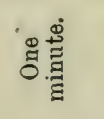 \\
\hline 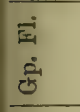 & $\vdots$ & 密 & $\vec{E}$ & E & द्ن & घi & 应 & $\begin{array}{l}\text { हू } \\
\text { हैं } \\
\text { है }\end{array}$ \\
\hline 5 & 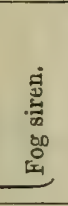 & 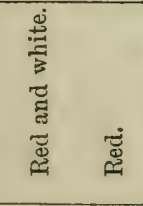 & 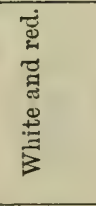 & 象 & 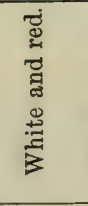 & 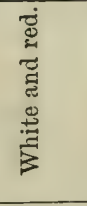 & 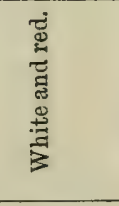 & 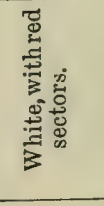 \\
\hline 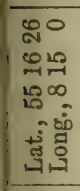 & & 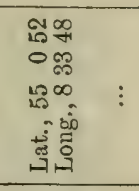 & 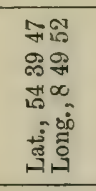 & 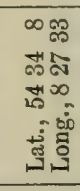 & 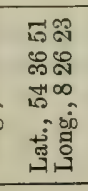 & 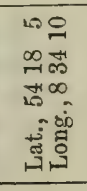 & 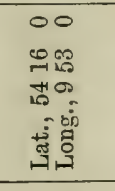 & 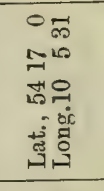 \\
\hline 9 & & 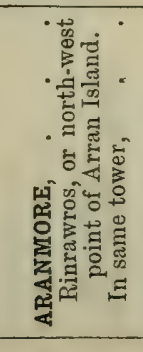 & 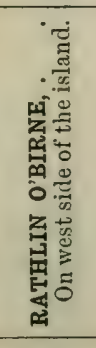 & 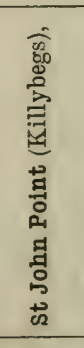 & 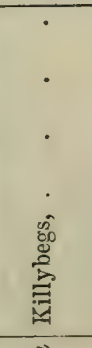 & 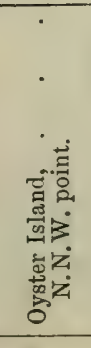 & 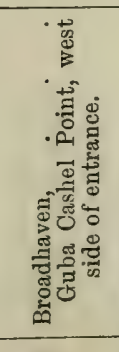 & 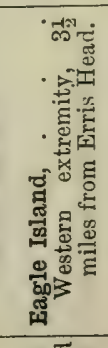 \\
\hline & & จิ & $\vec{\pi}$ & $\mathbb{*}$ & ส్ & $\approx$ & $\vec{\Delta}$ & 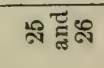 \\
\hline
\end{tabular}



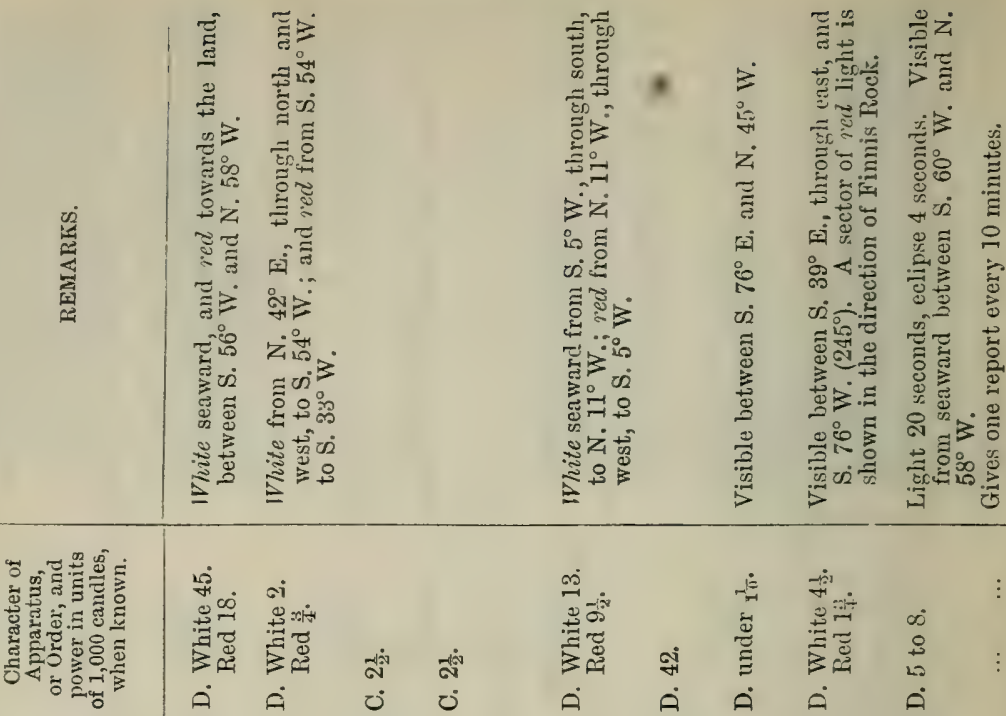

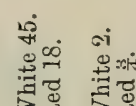

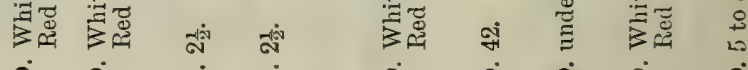

굴

рәдวา 10

$\dot{\theta} \dot{\theta}$

ठ

$\dot{\theta} \dot{A} \dot{a} \dot{0} \dot{0}$

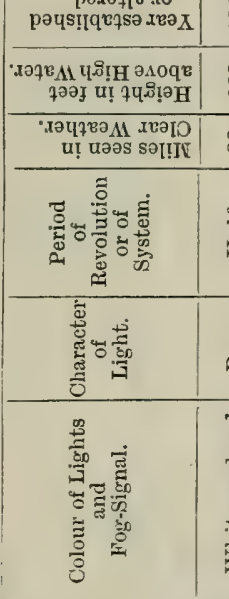

\begin{tabular}{|c|c|c|c|c|c|c|c|c|c|}
\hline 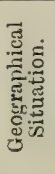 & 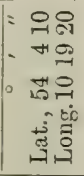 & 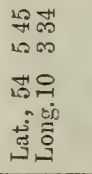 & 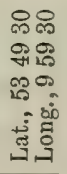 & 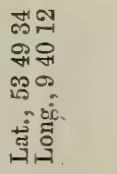 & 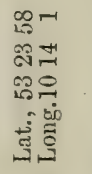 & 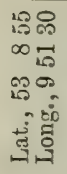 & 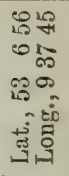 & 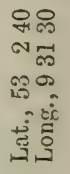 & 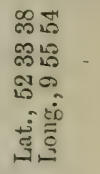 \\
\hline 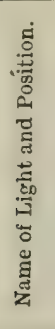 & 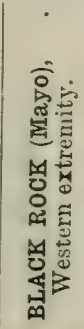 & 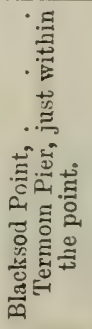 & 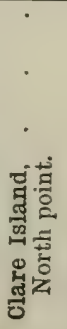 & 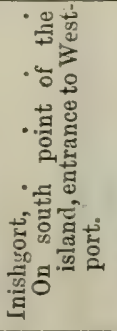 & 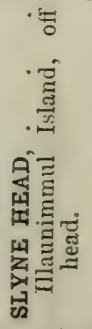 & 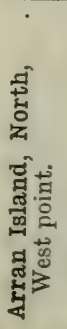 & . & 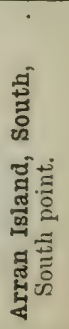 & 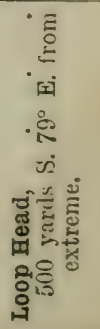 \\
\hline$\dot{z}$ & $\overleftarrow{5}$ & $\begin{array}{l}\infty \\
\text { ò }\end{array}$ & ถి & Бัँ & ल ్ㅐ & ले & $\approx$ & 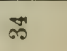 & $\%$ \\
\hline
\end{tabular}



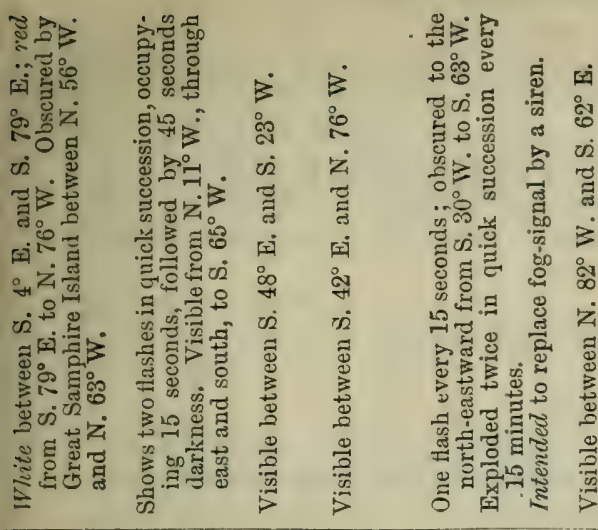

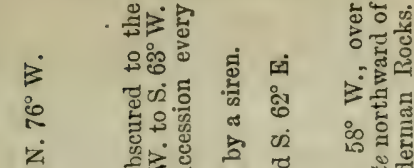

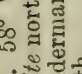

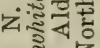

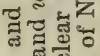

도일

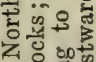

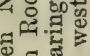

규.

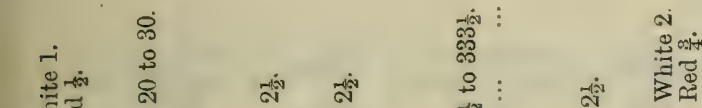

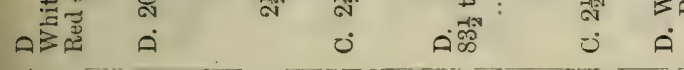

$\underset{10}{+10}$

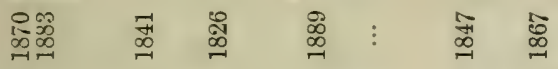

\begin{tabular}{|c|c|c|c|c|c|}
\hline 赵 & $\overrightarrow{0}$ & $\stackrel{10}{\simeq}$ & స్ & is & 8 \\
\hline จู & 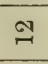 & $\stackrel{\infty}{\sim}$ & $\stackrel{\infty}{\infty}$ & $\mathbb{I}$ & 29 \\
\hline 号苛 & & & 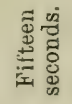 & & \\
\hline
\end{tabular}

\begin{tabular}{|c|c|c|c|c|c|c|}
\hline $\overrightarrow{c i}$ & $\begin{array}{l}\dot{\vec{x}} \\
\dot{\vec{b}}\end{array}$ & $x^{\circ}$ & 5 & $\overrightarrow{\mid \vec{x}}$ & $F \mathcal{F}^{\circ}$ & 臣 \\
\hline 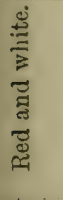 & 营 & 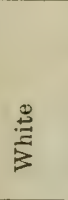 & $\stackrel{\stackrel{2}{3}}{\overrightarrow{3}}$ & 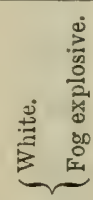 & 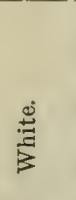 & 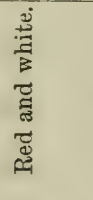 \\
\hline 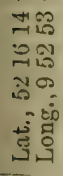 & 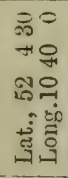 & 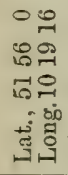 & 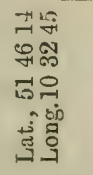 & 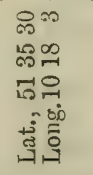 & 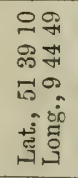 & 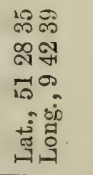 \\
\hline 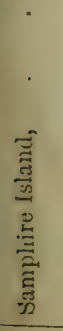 & हु & 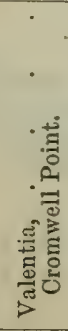 & 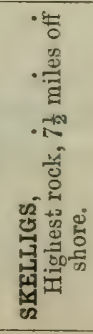 & 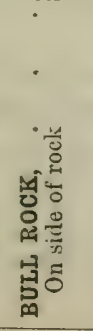 & 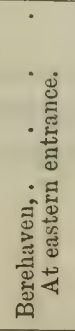 & 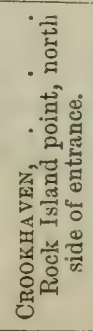 \\
\hline 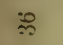 & $\widehat{x}$ & 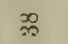 & శి & 유 & $F$ & $\underset{7}{\dddot{7}}$ \\
\hline
\end{tabular}




\section{TABLE OF DISTANCES.}

BY

ALAN STEVENSON.

TABLE OF DISTANCES AT WHCH ORJETS CAN BF SEEN AT ŚL, ACCOLD. iNg to their respective Elevations, aNd the Elevation of the Eye OF THE OBSERVER.

\begin{tabular}{|c|c|c|c|c|c|}
\hline $\begin{array}{c}\text { Heights } \\
\text { in } \\
\text { Feet. }\end{array}$ & $\begin{array}{l}\text { Distances in } \\
\text { Geographical or } \\
\text { Nautical } \\
\text { Jiles. }\end{array}$ & $\begin{array}{c}\text { Heights } \\
\text { in } \\
\text { Feet. }\end{array}$ & $\begin{array}{l}\text { Distances in } \\
\text { Geographical or } \\
\text { Nautical } \\
\text { Miles. }\end{array}$ & $\begin{array}{c}\text { IIeights } \\
\text { in } \\
\text { Feet. }\end{array}$ & $\begin{array}{l}\text { Distances in } \\
\text { Geosraphical or } \\
\text { Nautical } \\
\text { Miles. }\end{array}$ \\
\hline 5 & 2.565 & 70 & $9 \cdot 598$ & 250 & $18 \cdot 14$ \\
\hline 10 & $3 \cdot 628$ & 75 & $9 \cdot 935$ & 300 & $19 \cdot 87$ \\
\hline 15 & $4 \cdot 443$ & 80 & $10 \cdot 26$ & 350 & $21 \cdot 46$ \\
\hline 20 & $5 \cdot 130$ & 85 & $10 \cdot 57$ & 400 & $22 \cdot 94$ \\
\hline 25 & $5 \cdot 736$ & 90 & $10 \cdot 88$ & $450^{\circ}$ & $24 \cdot 33$ \\
\hline 30 & $6 \cdot 283$ & 95 & $11 \cdot 18$ & 500 & $25 \cdot 65$ \\
\hline 35 & $6 \cdot 787$ & 100 & $11 \cdot 47$ & 550 & $26 \cdot 90$ \\
\hline 40 & $7 \cdot 255$ & 110 & $12 \cdot 03$ & 600 & $28 \cdot 10$ \\
\hline 45 & $7 \cdot 696$ & 120 & 12.56 & 650 & $29 \cdot 25$ \\
\hline 50 & $8 \cdot 112$ & 130 & $13 \cdot 08$ & 700 & $30 \cdot 28$ \\
\hline 5.5 & $8 \cdot 509$ & 140 & 13.57 & 800 & $32 \cdot 45$ \\
\hline 60 & 8.886 & 150 & $14 \cdot 22$ & 900 & $34 \cdot 54$ \\
\hline 65 & $9 \cdot 249$ & 200 & $16 \cdot 22$ & 1,000 & $36 \cdot 28$ \\
\hline
\end{tabular}

Example, - A tower, 200 feet high, will be visible to an olserver whose eye is elevated 15 feet above the water 21 nautical miles; thus, from the table-

15 fect elevation, distance visible 4.44 nautical miles. 200

$$
\text { " } \frac{16.22}{20.66} \text {," }
$$




\section{OBSERVATIONS ON THE MIGRATION OF BIRDS.}

13. -It is to be hoped that the Light-Keepers will not think it too much trouble to cut off and label the wing and leg of every common bird which is killed at their station. These should be forwarded with this Schedule, and the cost of so doing will be gladly paid. All species can then be identified with certainty. Rare birds should be sent entire.

Please do not put entries for December of one year and January of another on same Schedule.

\section{NAME OF STATION,}

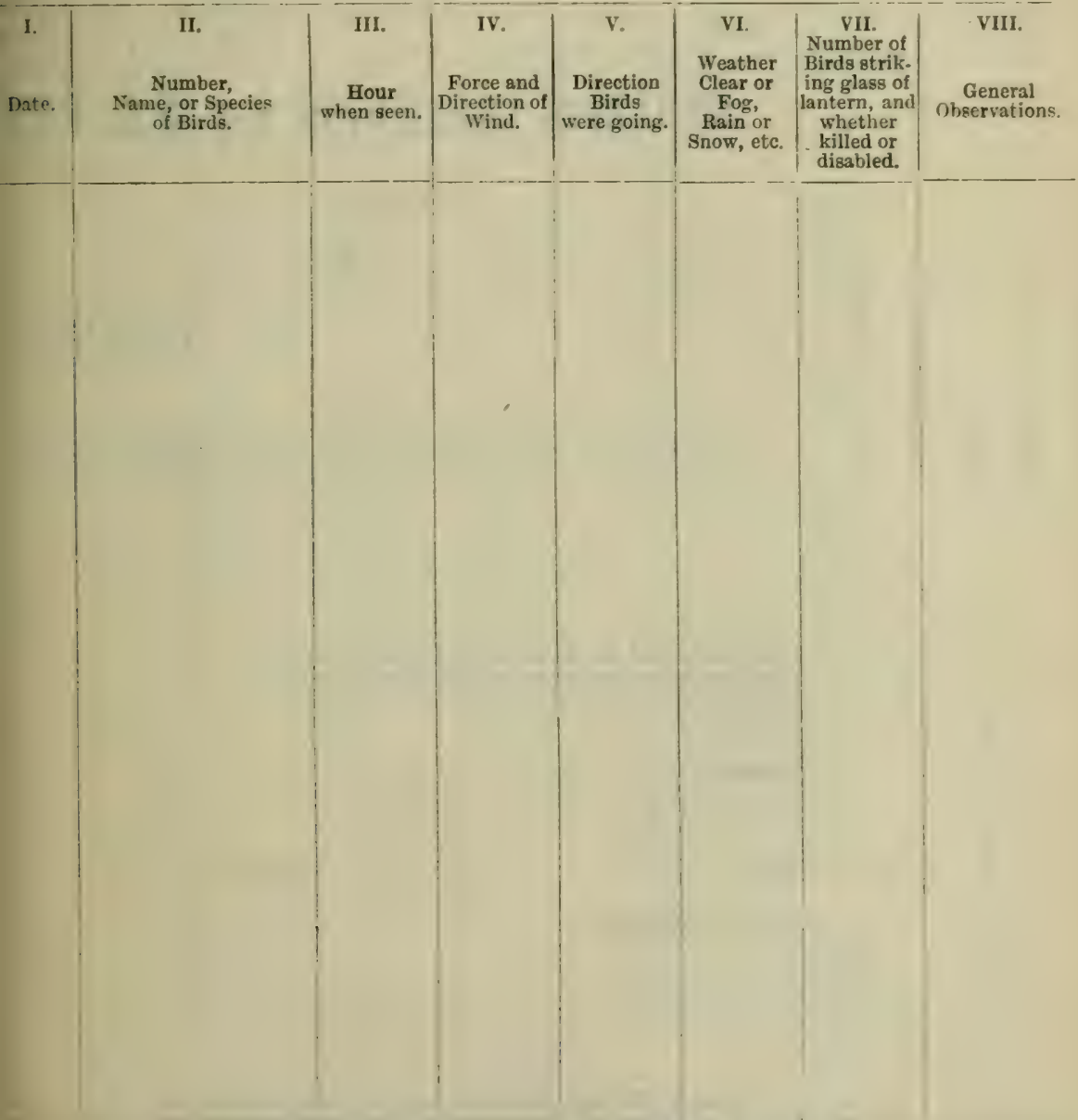

It is hopeil that the notes may extend not only to the night migration, but also have reference to any migrator. Hocks passing inland, or seen in the ricinity of the station during the day. Observers are particularly requested in noting the Time to add $\mathbf{\Delta . M .}$. or P.M., as the case may be.

If there is no Sehedule at Station, make notes on a sheet of paper, and copy into Sehedule when it arrives.

The Commissioners of Irish Lights are favourably disposed to this inquiry, provided it does not interfere with the duties of the Light-Keepers.

T.D.-When filled, please return this form to R. M. Bansixotos, Esq., Fassaroe, Bray, Co. Wicklow.

Name and Address in full of $\int$ Name, person filling in this report, Address,. 
Present Form of Envelope for Leg and Wing, and of Label (front and back) for Specimens-several of each sent to Light-kcepers with Schedules.

\section{Migration of Birds at Irish Light-Stations.}

For

\section{RICHARD M. BARRINGTON, ESq., M.A., F.L.S.}

Fassaroe,

Bray,

CO. WICKLOW.

Do not put more than one leg and wing in each envelope, and when several are full, forward the lot by post in a larger envelope.

\section{Migration of Birds at Irish Light=Stations}

Station

Sender.

Name of Bird.

Date..... of.

Mo., 1900.

How procured

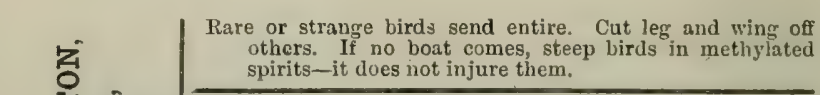

REM A R K S. 
tURe (or it may be Second Immigration)

COAST FROM WIIICH MOST HAVE BEEN SENT, and Latest Specimens have been killed, HAVE BEEN FORWARDED.

\begin{tabular}{|c|c|c|c|c|}
\hline \multirow{2}{*}{$\begin{array}{l}\text { Pate of the } \\
\text { Latest } \\
\text { Specimen } \\
\text { killed in } \\
\text { Autumn. }\end{array}$} & \multicolumn{2}{|c|}{ Spring Migration. } & \multicolumn{2}{|c|}{ Autumn Migration. } \\
\hline & $\begin{array}{l}\text { Northernmost } \\
\text { Station. }\end{array}$ & $\begin{array}{l}\text { Southernmost } \\
\text { Station. }\end{array}$ & $\begin{array}{l}\text { Northernmost } \\
\text { Station. }\end{array}$ & $\begin{array}{l}\text { Southernmost } \\
\text { Station. }\end{array}$ \\
\hline Nov. 20 & Arklow N. & Fastnet & $\begin{array}{c}\text { Blackrock } \\
\text { (Mayo) }\end{array}$ & Coningbeg \\
\hline Oct. & & & Tuskar & Fastnet \\
\hline Jan. 19 & Maidens & Rockabill & Island & \\
\hline & ahull & & & \\
\hline an. 10 & Codling Bank & Arklow S. & trahull & Fas \\
\hline Jan. 30 & Mew Island & Arklow S. & Innishtrahull & Fastnet \\
\hline Jan. & Innisht & Con & Inmishtrahull & Fastnet \\
\hline Nov. (?17) & In & $\mathrm{Fa}$ & Innishtraliul] & Fastnet \\
\hline Nov & & & & Fas \\
\hline Nov & $\begin{array}{l}\text { Blackwater } \\
\text { Bank }\end{array}$ & Co & Roc & Fas \\
\hline Nov. 7 & trahull & $\mathrm{Tu}$ & Hoo & \\
\hline Nor & & $\mathrm{C}$ & & \\
\hline & $\operatorname{InI}$ & Fas & $\mathrm{MI}$ & \\
\hline Nov. 9 & Inn & $\mathrm{Mi}$ & Rock: & \\
\hline Aug. 10 & $\mathrm{Me}$ & Hook Tower & & $\mathrm{He}$ \\
\hline Nov. 9 & Innishtr: & Fistnet & Mew Islan & Fastnet \\
\hline Sept. & Inni & $\begin{array}{l}\text { Old Head, } \\
\text { Kinsale }\end{array}$ & Innisht & Fastnet \\
\hline Out. 9 & & Hook Tower & Roc & Min \\
\hline De & & & In & $\mathrm{C}$ \\
\hline Nov. 13 & $\mathrm{Ma}$ & $\mathrm{Fa}$ & Inn & Fa \\
\hline & Ma & Mil & Tor & $\mathrm{Fa}$ \\
\hline & Inr & Tes & hull & $\mathrm{Fa}$ \\
\hline Dec & Int & $\mathrm{Co}$ & Blac & Fastnet \\
\hline $\begin{array}{l}\text { Jan. } 6 \\
\text { Dec. } 23\end{array}$ & $\begin{array}{c}\text { Innishtrahull } \\
\ldots\end{array}$ & Tuskar & $\begin{array}{c}\text { Arklow S. } \\
\text { Blackrock } \\
\text { (Mayo) }\end{array}$ & $\begin{array}{l}\text { Fastnet } \\
\text { Coningbeg }\end{array}$ \\
\hline Dec. & & & Tuskar & $\mathrm{F}$ \\
\hline Nov. 15 & & ... & & \\
\hline Jan. 12 & & & Codling Bank & Coningbeg \\
\hline & Inni & & & \\
\hline Oct. & I & Sk & & \\
\hline & Mew Island & ngbeg & & endestos \\
\hline Sept. 19 & Killybegs & Bull Rock & Slyne Head & Fastnet \\
\hline & & & & \\
\hline & $\mathrm{Ra}$ & $\begin{array}{l}\text { Blackivater } \\
\text { Bank }\end{array}$ & Innishtrahull & net \\
\hline Jan. & & & 2011 & er \\
\hline & Innishtrahull & Arklow S. & & \\
\hline $\mathrm{J}$ & Eagle Island & folver & $\begin{array}{l}\text { Ro } \\
\text { Ro }\end{array}$ & $\begin{array}{l}\text { kTor } \\
\text { net }\end{array}$ \\
\hline $\mathrm{D}$ & Innishtrahull & Fastnet & Arammore & Hook Tower \\
\hline $\begin{array}{l}\text { July (?) } 26 \\
\text { Nov. } 24\end{array}$ & $\begin{array}{l}\text { Drogheda N. } \\
\text { Eagle Island }\end{array}$ & $\begin{array}{c}\text { Coningbeg } \\
\ldots\end{array}$ & Coningbeg & $\begin{array}{l}\text { Mine Head } \\
\text { Skelliøs }\end{array}$ \\
\hline & & & & \\
\hline
\end{tabular}

$2 \pi \%$. 


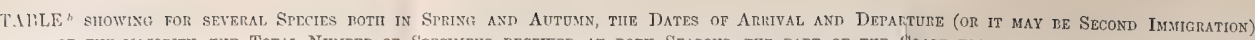
of the majority, the Total Number of Specimens received at both Seasons, tue patt of the COAst from which most Have beLN SENT,

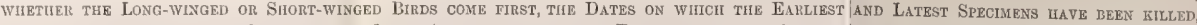

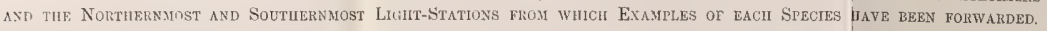

\begin{tabular}{|c|c|c|c|c|c|c|c|c|c|c|c|c|c|c|c|}
\hline \multirow{2}{*}{ 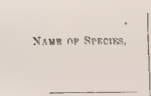 } & \multirow{2}{*}{$\begin{array}{l}\text { Date of Arrival of } \\
\text { the manjortty. }\end{array}$} & \multirow{2}{*}{ 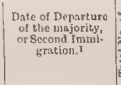 } & \multirow{2}{*}{ 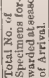 } & \multirow{2}{*}{ 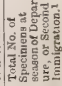 } & \multirow{2}{*}{ 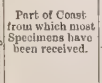 } & \multicolumn{2}{|c|}{$\begin{array}{l}\text { Whother tho Long-winged or } \\
\text { Sthort-winted Birl-s cone first. }\end{array}$} & \multirow{2}{*}{ 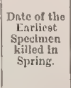 } & \multirow{2}{*}{$\begin{array}{l}\text { Dato of tho } \\
\text { thoterst } \\
\text { speciumen } \\
\text { kllied in } \\
\text { spring. }\end{array}$} & \multirow{2}{*}{ 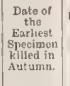 } & \multirow{2}{*}{ 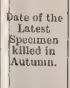 } & \multicolumn{2}{|c|}{ Spring Mrigraticn. } & \multicolumn{2}{|c|}{ Autumn Migration. } \\
\hline & & & & & & In Spriag. & In Autumin. & & & & & $\begin{array}{l}\text { Northeramost } \\
\text { Station. }\end{array}$ & $\begin{array}{l}\text { Southerinmort } \\
\text { Station. }\end{array}$ & $\begin{array}{l}\text { Northernmest } \\
\text { St:tition. }\end{array}$ & $\begin{array}{l}\text { Snuthernmost } \\
\text { Strtion. }\end{array}$ \\
\hline 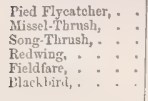 & 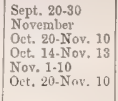 & 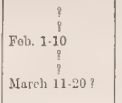 & $\mid \begin{array}{r}7 \\
7 \\
83 \\
57 \\
41 \\
120\end{array}$ & $\begin{array}{r}3 \\
31 \\
2 \\
2 \\
21\end{array}$ & $\begin{array}{l}\text { S. } \\
\text { S.E. } \\
\text { S.E. } \\
\text { E. } \\
\text { S.E. } \\
\text { S.E. }\end{array}$ & $\left|\begin{array}{c}a \\
a \\
\text { Long-winged } \\
a \\
a \\
\text { Long-wingmed }\end{array}\right|$ & 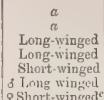 & $\begin{array}{l}\text { Feb, } 26 \\
\text { March } 5 \\
\text { April } 20 \\
\text { Fel. } 5\end{array}$ & 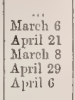 & $\begin{array}{l}\text { Ang. 7 } \\
\text { Oct. (?) } \\
\text { Sept, 3 } \\
\text { Sept. 20 } \\
\text { Oct. 16 } \\
\text { Oct. 2 }\end{array}$ & $\begin{array}{l}\text { pct. } 9 \\
\text { fan. } 19 \\
\text { an. } 10 \\
\text { an. } 30 \\
\text { anl. } 10\end{array}$ & $\begin{array}{l}\text { Maidens } \\
\text { Innishtrahtull } \\
\text { Codling Bank } \\
\text { Mew Island } \\
\text { Innislit ahtuil }\end{array}$ & $\begin{array}{l}\text { Rockabibill } \\
\text { Mino Head } \\
\text { Anklow S S } \\
\text { Arklow S. } \\
\text { Coningling }\end{array}$ & 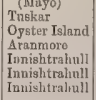 & $\begin{array}{l}\text { Fastuet } \\
\text { Fastnet } \\
\text { Fastnet } \\
\text { Fastrnet } \\
\text { Fastnet } \\
\text { Fastmet }\end{array}$ \\
\hline 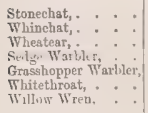 & 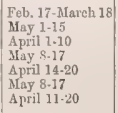 & 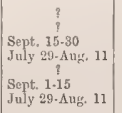 & $\begin{array}{r}9 \\
12 \\
71 \\
87 \\
8 \\
87 \\
65\end{array}$ & $\begin{array}{r}2 \\
3 \\
18 \\
55 \\
1 \\
1 \\
22 \\
17\end{array}$ & $\begin{array}{l}\text { S.E. } \\
\text { S.E. } \\
E_{1} \\
\text { S.E. } \\
\text { S.E. } \\
\text { S.E. } \\
\text { S.E. }\end{array}$ & 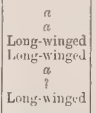 & $\begin{array}{c}a \\
a \\
\text { Short-winged } \\
\text { Lont- winged } \\
a \\
\text { Short-winged } \\
\text { Short-winged }\end{array}$ & 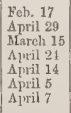 & $\begin{array}{l}\text { April 4 } \\
\text { May 25 } \\
\text { Magy 9 } \\
\text { May } 30 \\
\text { MIay } 9 \\
\text { May 28 } \\
\text { Mlay 222 }\end{array}$ & $\begin{array}{l}\text { Oct., } 20 \\
\text { Sept. } 4 \\
\text { Aug., } 5 \\
\text { July } 20 \\
\text { Aug. } \\
\text { July. } 29 \\
29\end{array}$ & $\begin{array}{l}\text { Nov. } 7 \\
\text { Nov, } 9 \\
\text { Pet. } 31 \\
\text { vov. } 9 \\
\text { kug. } 10 \\
\text { Nov. } 9 \\
\text { Beyt. 27 }\end{array}$ & 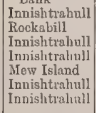 & $\begin{array}{l}\text { Thiskar } \\
\text { Coninglepg } \\
\text { Fastnet } \\
\text { Nine Head } \\
\text { Hook Tower } \\
\text { Yostnet } \\
\text { Old Ifent, }\end{array}$ & 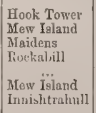 & $\begin{array}{l}\text { Fastnet } \\
\text { Tuskakar } \\
\text { Fastnet } \\
\text { Fastllict } \\
\text { Hook Tower } \\
\text { Foatret } \\
\text { Fastret }\end{array}$ \\
\hline 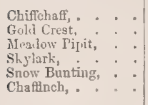 & $\begin{array}{l}\text { Apri1 8.14 } \\
\text { Oct. 1:10 } \\
\text { Oct. 21-31 } \\
\text { Oct. 21.31 } \\
\text { Oct. 4. Nov. } 6 \\
\text { Oct. 15-31 }\end{array}$ & 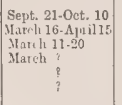 & $\begin{array}{l}16 \\
40 \\
20 \\
90 \\
19 \\
44\end{array}$ & $\begin{array}{r}6 \\
10 \\
15 \\
35 \\
14 \\
3\end{array}$ & $\begin{array}{l}\text { S.E. } \\
\text { E. } \\
\text { S.E. } \\
\text { E. } \\
\text { N. \& W. } \\
\text { S. \& S.E. }\end{array}$ & 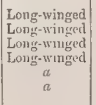 & 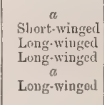 & 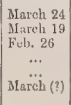 & 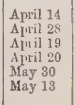 & 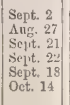 & $\begin{array}{c}\text { Pet. } 9 \\
\text { bece. } 17 \\
\text { Nov, } 13 \\
\cdots \\
\text { De. } 19\end{array}$ & 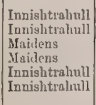 & \begin{tabular}{l}
\multicolumn{1}{l}{ Mninala } \\
Hook Toryer \\
Comingliegt \\
Fastnet \\
Mline Head \\
Tearaglt \\
Coningbeg
\end{tabular} & 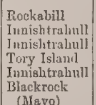 & $\begin{array}{l}\text { Mino Heud } \\
\text { Crookliaven } \\
\text { Yastuet } \\
\text { Yastnet } \\
\text { Fastret } \\
\text { Fastnet }\end{array}$ \\
\hline 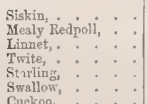 & 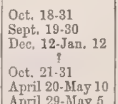 & Sept. 11-0 & $\begin{array}{r}14 \\
8 \\
7 \\
7 \\
71 \\
15 \\
10\end{array}$ & $\begin{array}{r}\cdots \\
\cdots \\
1 \\
26 \\
1 \\
1\end{array}$ & $\begin{array}{l}\text { S. } \\
\text { S. W. } \\
\text { s. \& E. } \\
\text { N. \& W. } \\
\text { S.E. } \\
\text { S. \& E. }\end{array}$ & 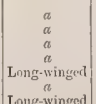 & $\begin{array}{c}a \\
a \\
a \\
a \\
a \\
\text { Lons-winget } \\
a \\
a\end{array}$ & April is & 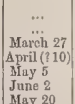 & $\begin{array}{l}\text { Oet. 9 } \\
\text { Sept, } 19 \\
\text { Oct. 26 } \\
\text { Sept. } 1 \\
\text { July } 25\end{array}$ & $\begin{array}{l}\text { Dee. 3 } \\
\text { Nov. } 15 \\
\text { Jan. } 12 \\
\text { fan. } 10 \\
\text { pot. } 5\end{array}$ & 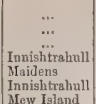 & $\begin{array}{c}\ldots . \\
\ldots . \\
\ldots . \\
\text { Coninglugg } \\
\text { Skelligs } \\
\text { Coningbar }\end{array}$ & $\begin{array}{l}\text { Tuskar } \\
\text { Codling Bank } \\
\text { Innishtrahnull } \\
\text { Inuishtituahuli }\end{array}$ & $\begin{array}{l}\text { Fastnet } \\
\text { Teasraght } \\
\text { Coningbeg } \\
\text { Tearaght } \\
\text { Fastrnet } \\
\text { Fastnot }\end{array}$ \\
\hline 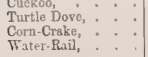 & 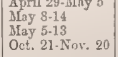 & & $\begin{array}{l}10 \\
11 \\
11 \\
32\end{array}$ & $\begin{array}{r}3 \text { (yound } \\
3 \\
2 \\
3\end{array}$ & 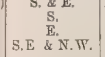 & $\begin{array}{l}\text { 8-wingod } \\
a \\
a \\
a\end{array}$ & $\begin{array}{c}a \\
a \\
a \\
a \\
\text { Long-wingred }\end{array}$ & $\begin{array}{l}\text { Aprin 18 } \\
\text { April 20 } \\
\text { April 19 } \\
\text { Mlatch } 27\end{array}$ & 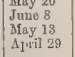 & $\begin{array}{l}\text { An. } \ldots .19 \\
\text { Sitit. } 5\end{array}$ & $\begin{array}{l}\text { sept... } 19 \\
\text { Bept. } 29 \\
\text { Pan. } 9\end{array}$ & 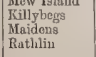 & $\begin{array}{l}\text { Commgoger } \\
\text { Fraul Rook } \\
\text { Skelliggs } \\
\text { Blackivater }\end{array}$ & $\begin{array}{l}\text { Slyno Head } \\
\text { Innisilitralurlul }\end{array}$ & $\begin{array}{l}\text { Fastnèt } \\
\text { Tuskann } \\
\text { Fastnet }\end{array}$ \\
\hline 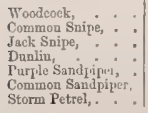 & 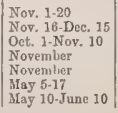 & $\left|\begin{array}{c}? \\
? \\
? \\
\text { May } \\
? \\
\text { Sept, 20-0et, 20 }\end{array}\right|$ & $\begin{array}{r}10 \\
12 \\
8 \\
12 \\
10 \\
10 \\
8 \\
18\end{array}$ & $\begin{array}{l}3 \\
3 \\
9 \\
1 \\
1 \\
2 \\
1\end{array}$ & \begin{tabular}{|}
$\mathrm{NE}, \mathrm{N}, \& \mathrm{NW}$. \\
$\mathrm{N} . \& \mathrm{~W}$. \\
S.E \\
S.E. \\
S.E. \&N.W. \\
S.E. \\
S. \& W.
\end{tabular} & $\begin{array}{l}n \\
a \\
n \\
a \\
a \\
n \\
a \\
a\end{array}$ & $\begin{array}{l}a \\
a \\
a \\
a \\
a \\
a \\
a \\
a\end{array}$ & $\mid \begin{array}{l}\text { April 6 } \\
\text { Mprareh 28 } \\
\text { April B } \\
\text { May } 7 \\
\text { April 23 } \\
\text { Blny 24 }\end{array}$ & \begin{tabular}{|l} 
May 25 \\
Apliti 23 \\
May 31 \\
May 18 \\
May 18 \\
May 17
\end{tabular} & $\begin{array}{l}\text { Oct, 26 } \\
\text { Sept. } 9 \\
\text { Sept. 28 } \\
\text { Ant. } 12 \\
\text { Oct. } 29 \\
\text { July 16 } \\
\text { July 26 }\end{array}$ & 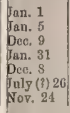 & $\begin{array}{l}\text { Innishtrahull } \\
\text { South Rock } \\
\text { Eagle Isiand } \\
\text { Innisithrahull1 } \\
\text { Drogheda N. } \\
\text { Eugle Island }\end{array}$ & $\begin{array}{l}\text { Arklow S. } \\
\text { Hook Tover } \\
\text { Coningbeg } \\
\text { Fastnet } \\
\text { Coninglugg }\end{array}$ & 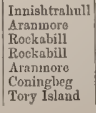 & 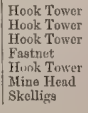 \\
\hline & & & & & & & & & & & & & & & \\
\hline
\end{tabular}




\section{A N A L Y S S}

OF THE

\section{IRISH MIGRATION REPORTS, 1881-1897.}

\section{Golden Eagle (Aquila chrysäetus, Linn.).}

"Eagles," probably referable to this species, have been reported from the Skelligs, April 1882, Clare Island, 1883 and 1884, Tearaght Rock, January 1885 and December 1887, Samphire Island, November 1887, and Aranmore, May 1889, April 1890, and September 1897. All these light-stations are situated along the Kerry, Mayo, and Donegal coast-line. There is no evidence of migration, or of an Eagle having been observed at any part of the coast remote from its breedinghaunts. It is noteworthy that since 1890 there is only one record, whereas previously to that year there are seven.

\section{SEA EAgle (Haliäetus albicilla, Linn.).}

It is possible that some of the Eagles mentioned under the foregoing head were of this species, which has now become so rare in Ireland that its occurrence is improbable. The Eagles seen at Tearaght Rock and Samphire Island in 1887, and at Aranmore in the springs of 1889 and 1890, are described as having tails wholly or partially white, but may all have been immature Golden Eagles.

Greenland Falcon (Falco candicans, J. F. Gmel.).

A rare and uncertain straggler to the Irish western sea-board, the Greenland Falcon has twice been received from light-stations, Greenland

Falcon. one example having been shot at Blackrock (Mayo) on March 10, 1884 , and another, a beautiful adult male, at the Skelligs, on September 28,1887 . The winter of $1883-84$ was signalised by a remarkable immigration of this species, which is shown by the light-keepers' reports to have visited Blackrock (Mayo) on

Sea Eagle.

Golden
Eagle.

Sea Eagle. 
Greenland November 9, Slyne Head on December" 2, and Tearaght on Falcon. December 12 ; while, as mentioned in the "Migration Report" for 1883 , p. 10, no fewer than eight specimens were obtained the same year at various points on the west coast from Donegal to Cork. In the spring of 1884 something like a return movement seems to have been noticed at the same stations. One specimen, as mentioned above, was shot at Blackrock (Mayo) on the 10th of March; two were reported to have been shot at Tearaght on March 23 and April 2 respectively; and two others were subsequently (April 7) seen at the same station, in the neighbourhood of which they may have remained during the ensuing fortnight, as one was noted there as late as April 21. From the light-keepers' descriptions it seems probable that a Greenland Falcon was again seen at the Tearaght on April 16, 1890, and one at Blackrock (Mayo) on November 23, 1891. Blackrock (Mayo), Tearaght, Slyne Head, and Skelligs are the four westernmost Irish light-stations, and it is interesting to find that, with the exception of one questionable occurrence at the Fastnet in December 1888, all the light-house records of this visitor from Arctic America are due to them. It may be, as was suggested in the "Report" fer 1887 (p. 3), that the Falcons thus occurring on the Irish coast are birds that have lost their way in following flocks of sea-fowl on their southward journey in autumn.

\section{Peregrine Falcon (Falco peregrinus, Tunstall).}

Peregrine Falcon.
The light-houses from which the Peregrine Falcon is reported are chiefly those in the vicinity of its breeding-stations, and, with one exception (Rockabill), all are situated on the north, west, and south coasts. They are the Fastnet, Kinsale, Mine Head, Dungarvan, and Hook Tower, on the south coast; Rockabill, on the east; Rathlin Island, Innishtrahull, and Tory Island, on the north; and Aranmore, Rathlin O'Birne, Killybegs, Blackrock (Mayo), Slyne Head, Arran Island (North), Tearnght, and Skelligs, on the west. The Peregrine has never been noted from a light-ship; nor from the commencement of this inquiry in 1881 to the end of 1897 had an instance been known of its striking the lautern. On September 18, 1S98, a specimen was received which had struck one of the windows of the Fastmet Light-house, and this was possibly a migrating bird. 


\section{Hoвву (F'alco subbuteo, Linn.).}

On May 23, 1890, a male Hobby was caught resting on board the Lucifer Shoals Light-ship, off the Wexford coast. It died the following day, and its skin was received. This is the only instance of the Hobby's occurrence at an Irish lightstation, but two specimens have been received in the flesh from Loftus Hall, Fethard, both picked up dead at that place, which is situated on the peninsula of Hook on the south coast of Wexford. One was found in the garden, in a very thin and starved state, on May 17, 1895; the other under a telephone wire, on April 16, 1899, rather an early date. There is no reason to doubt that both these birds were on their spring passage. The Hobby is only known in Ireland as a very rare summer visitor. Not more than ten specimens, including the above, have been obtained; and the south-eastern corner of the island is probably the usual place of arrival.

\section{Meruin (Falco cesalon, Tunstall).}

There is no evidence to show that the Merlin migrates to or from Ireland, where it is generally distributed. Only three specimens have been received from light-stations, of which one was shot (Tearaght, October 19, 1887), one caught in a house (Hook Tower, March 21, 1893), and one caught on a cliff (Hook Tower, October 24, 1895). The capture of the last mentioned may have been due to its exhaustion after a long flight, but details are not to hand to prove that this was the case. "Small Hawks," which may or may not have been Merlins, are stated to have been observed about several of the light-ships, e.g., Barrels Rock (July 1, 1891), Lucifer Shoals (February 27, 1892), Coningbeg (May 15, 1893), and Arklow North (May 21, 1896). As a regular summer visitor to Iceland, the Merlin might be expected to be occasionally seen on passage at the Irish light-stations.

\section{Kestrel (Falco tinnunculus, Linn.).}

The Kestrel is the only Hawk which is known to have struck the lantern of an Irish light-house. On the night of April 19, 1890, an adult male was killed striking at Rathlin Islaud, Co. Antrim. A Kestrel was also caught while resting on

Kestrel. 
Kestrel. board the Lucifer Shoals Light-ship, Co. Wexford, on November 27,1894 , so that the bird has been obtained on both spring and autumn migration. The number of Kestrels received up to the end of 1897 is eight, and all except two were shot. Beyond establishing the fact of its occurrence at remote rocky islets like the Tearaght, Skelligs, and Blackrock (Mayo), six of the specimens are of no special interest.

\section{Sparrow-HawK (Accipiter nisus, Linn.).}

SparrowHawk.

This species has never been received from a light-station, and it is certain that many, if not most, of the references to "Sparrow-Hawks" in light-keepers' reports apply to the Kestrel, specimens of which, labelled "Sparrow-Hawk," have been received from two stations. Most of the entries under the headings "Sparrow-Hawk" and "Hawks" are so vague as to be almost valueless, and the question whether this common Irish bird is migratory or not has yet to be determined. As negative evidence, it is of interest to note that of twelve "Hawks" forwarded at different times by light-keepers, eight are Kestrels, three Merlins, and one a Hobby, while Accipiter nisus remains so far unrepresented.

\section{SNowy OwL (Nyctea scandiaca, Linn.).}

Snowy 0wl. The only recorded occurrence of this bird at a light-station is that of November 19,1882 , at Innishtrahull, where one was shot by the principal light-keeper, and sent by him to the Museum of Science and Art, Dublin. Some particulars received from Broadhaven regarding the shooting of a specimen in Mayo, in April 1888, will be found in the Report for that year (p. 8). A statement as to another having been shot at Innishtrahull in October 1883 does not appear to have been verified. A white $\mathrm{Owl}$, possibly of this species, is also reported to have been seen, but not obtained, at Innishtrahull on January 16, 1886. That the Snowy Owl's visits should be chiefly to the north and west coasts of our island is only what we should expect from its distribution; and it is an interesting question whether our birds come to us from Arctic Europe, or, like the Greenland Falcon, from the northern parts of the American continent. 


\section{LONG-EARED OWL (Asio otus, Linn.).}

A Long-eared Owl was shot on the Tuskar Rock on the 13th of November 1887, at 11.30 A.M. The preceding three nights (November 10-12) had been marked at the Tuskar and other stations by an extraordinary rush of birds, which comprised Thrush, Blackbird, and Starling in "countless numbers," intermixed to some extent at the Tuskar with Missel-Thrush, Redwing, Meadow-Pipit, Skylark, Woodcock, and Jack Snipe, of which legs and wings were received. The Owl may have been pursuing these birds on their passage; and there is evidence of a somewhat similar incident having occurred at the Fastnet on the night of November 11, 1885, when, during a rush of Thrushes, Larks, and Starlings, a Brown Owl, with "golden colour on breast," was observed killing small birds. It will be seen that the dates of these two incidents are nearly the same, and while the description of the plumage may apply as well to the Short-eared as the Long-eared Owl, the habit of hunting by night is much more characteristic of the latter.

Under the next species it is shown that a considerable migration of Owls to the Irish coast probably takes place every year in the first half of November, and, from the instance above quoted, it appears not unlikely that a fair number of the birds reported at that season are Long-eared Owls. ${ }^{1}$

Only one instance has been reported of an Owl occurring at a light-ship, viz., on December 2, 1895, when a bird described as a "Cat-Owl" was seen on the Codling Bank ship. This was probably of the present species, to which, in Ireland, the name of "Cat-Owl" is frequently applied.

\section{Short-Eared Owh (Asio accipitrinus, Pallas).}

Although the Short-eared Owl is known to be a regular winter visitor to Ireland, it does not appear to strike the Short-eared Owl. lanterns when migrating, nor, indeed, had a specimen ever been received from a light-station until the autumn of 1899, when one, shot on the 21st of October, was sent from Aranmore.

1 This agrees with the experience of Mr Edward Williams, of Damo Street, Dublin. In oue instanco he received for preservation a Long-eared Owl which had been shot out of a flock of twelve, in autumn, in the neighbourhood of Enniskillen. Whether the remaining eleven Owls were all of the same species was not ascertained. 
Short-eared There is thus less evidence from light-houses of the migration Owl. of the Short-eared than of that of the Long-eared Owl, which, as has been shown under the foregoing heading, was once received from the Tuskar. It would be difficult to assign to either species the birds which have from time to time been reported as "Owls," and were not obtained; but it is reasonable to assume that some of those seen near light-stations at the season of passage are Short-eared Owls.

Looking to the dates at which Owls have been reported in autumn (i.e., from the end of August to end of December), we find the first half of September represented by two birds, the second half by one, each half of October by two, the first half of November by fourteen, the second half by one, and each half of December by one. The Owls noted during the first fifteen days of November are thus found to outnumber those observed during the remaining 107 days of the entire period, making it sufficiently clear that some autumnal migration takes place, which reaches its maximum in the early half of November. The birds then noticed are as follows:-

Fastnet, November 11, 1885 (see under foregoing species), Brown Owl killing small birds at night.

Old Head, Kinsale, November 10, 1884, one Brown Owl at 10 A.M. going $W$.

Mine Head, November 12, 1885, one Owl seen in daytime.

$" \quad " \quad$ November 9, 1890, two Owls flying S. at 4 P.M.

" " November 14, 1895, Barn Owl caught in a crag. [Received in flesh.]

Tuskar Rock, November 12, 1884, "Short-eared Owl" alighted at 2 P.M. ; came from $\mathrm{E}$.

Tuskar Rock, November 13, 1887, Owl shot on rock at 11.30 A.M. [Leg and wing of Long-eared Owl received.] (See under foregoing species.)

Rockabill, November 5, 1891, one Owl on rock from 10 A.Mr. to 11.30 A.M. ; went W.

Rockabill, November 6, 1891, one from 9 A.M. to 11 A.M.

" November 10, 1891, one on rock.

" November 13, 1891, one between 11 A.M. and 1 P.M.; went W. Copeland (Mew) Island, November 4, 1895, Owl on island. Slyne Head, S., November 5, 1887, one Owl on island.

The four entries from Rockabill may refer (as the lightkeeper thought) to the same bird, or may indicate an immigration past the island. In either case it is highly probable that both the Rockabill and Mew Island birds 
should be referred to the Short-eared species. The remaining birds may, in a few instances, have been Barn Owls, Short-eared Owl. as was the case with one received from Mine Head; but that most of them were either Long-eared or Short-eared is clear, since the Tawny Owl, Syrnium aluco, is unknown in Ireland.

The earliest Owl observed in autumn, not at a land-station, was reported from the Tuskar, September 18, 1881, seen at 8 A.M. The latest was that seen in Codling Bank Light-ship during the night of December 2, 1895.

In spring the earliest observation is from Rathlin O'Birne, February 12,1891, one at 3 P.M. going E.; and the latest from Mew Island, May 10, 1885; but the spring entries are neither so numerous nor so significant as those made in autumn, and no specimens were received. A "Short-eared $\mathrm{Owl}$ " is said to have been seen at Innishtrahull, where its occurrence or migration was likely, on March 16,1886, and an Owl seen at Rockabill, April 13, 1885, may well have been of the same species. Two going N.E. from the Tuskar at 11 A.M., on March 20, 1887, may have been Long-eared Owls.

\section{BARN-OWL (Strix flammea, Linn.).}

Has not been received or reported from any but landBarn-0wl. stations, and in no instance has this or any other Owl struck the lantern.

Apart from the meagre evidence supplied by the lighthouses, from one of which (Mine Head) a Barn-Owl caught in a crag was forwarded in November 1895, it is a curious fact that between the years 1891 and 1899 five birds of this species have been received from other quarters, which had all been either caught or picked up dead during the months of March, October, and November. One was caught asleep on Malin Head, October 23, 1891 ; one found dead at Fassaroe, Co. Wicklow, three miles inland, March 15, 1897; one found dead at Ballyman, Co. Dublin, three miles inland, October 24, 1897; one caught asleep in a field close to the sea at Slade, on the Hook peninsula, Co. Wexford, October 26, 1897; and another found dead at Fassaroe, November 12, 1899.

The coincidence of several of the above dates seems to suggest exhaustion after a migratory passage. 
Woodchat ShrIKe (Lanius pomeranus, Sparman).

Woodohat Is known as an Irish species on the strength of a single shrike. occurrence at Blackwater Bank Light-ship, Co. Wexford, on the night of August 16, 1893. The specimen, of which only a leg and wing were received, was a young bird, and had probably lost its way in a fog. Several "other small birds" are reported to have been around the lantern on the same and the previous night, and a Wheatear, Sedge Warbler, and Blackbird were obtained. ${ }^{1}$

[Obs.-No specimen of the Great Grey Shrike (Lanius excubitor, Linn.), which occasionally visits Ireland in autumn, has been received.

The absence of the Red-backed Shrike (Lanius collurio, Linn.) is less singular, as it has only once been obtained in the country.]

\section{Spotted Flycatcher (Muscicapa grisola, Linn.).}

Spotted

In spring the Spotted Flycatcher has only been forwarded

Flycatcher. from stations on the south and south-eâst coast, from Fastnet, Co. Cork, to Arklow North Light-ship, Co. Wicklow. It does not appear to strike the lanterns numerously, since, from 1887 to 1899 inclusive, only nine examples have been obtained on spring migration-one in April, seven in May, and one in June. The date of the earliest, killed at the Tuskar, was April 19, 1895; that of the latest, at Barrels Rock Light-ship, was June 1, 1887. The dates of the remaining seven were respectively, May 10, 16, 17, 18, 23, 26, and 28, the second fortnight in May thus furnishing two-thirds of the Spotted Flycatchers killed on spring migration. Only once (in 1893) were two specimens received during the same spring, and these were killed at adjacent stations, Arklow South and Blackwater Bank Light-ships, on consecutive nights, the 16th and 17th of May. Seven of the nine were obtained at stations off the Wexford coast.

On autumn migration the species occurs even less frequently than in spring, only five examples (including one, July 30) having been received. At this season there is no wellmarked flight-line observable as in spring. The west coast 
furnishes two specimens, and all have been obtained at very spotted different dates. The five are as follows:-

July 30,1895 , . . . . Tuskar.

September 21, 1887, . . . Coningbeg Light-ship.

October 2, 1887, . . . Tearaght.

"20, 1889, . . Blackrock (Mayo).

November 20-30 (?), 1897, . Tuskar.

As the bulk of our Spotted Flycatchers generally appear to have left us by the middle of September, it cannot be said that any of the above dates fall within the normal time of the species' departure, and the two latest are especially remarkable.

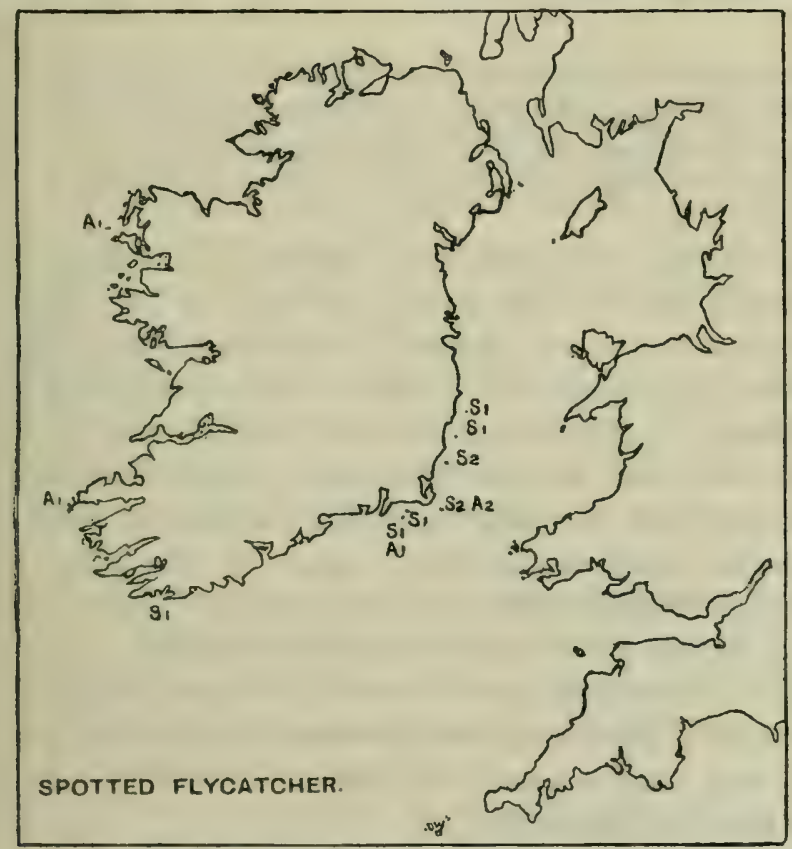

S1=0ne specimen forwarded in spring (April 19 to June 1).

A $2=$ Two specimens " $\quad$ autumn (July 30 to November 20).

All the occurrences, both in spring and autumn, have been at light-ships and island-rocks.

\section{Light-ships-}

Coningbeg,

Barrels Rock

Blackwater Bank, . . 2

Arklow South, . . 1

Arklow North, . . 1
Island-Rocks-

Fastnet, . . . 1

Tuskar, .. . . 4

Blackrock (Mayo), . , I

Tearaght, . . . 1 
Average length of wing, 3.33 inches; longest, 3.425 ; shortest, $3 \cdot 200$; difference between extremes, $0 \cdot 225$; percentage of variation, 7.

\section{Red-breasted Flycatciner (Muscicapa parva, Bechstein).}

Red-

In the Red-breasted Flycatcher we have a curious instance

breasted of a bird which, while otherwise unknown to the Irish fauna, has on as many as four occasions been received from lightstations. In no instance has it been found on the mainland. The localities and dates are-

Arklow South Light-ship, Co. Wexford, October 23, 1887.

Tearaght Rock Light-house, Co. Kerry, October 20, 1890.

Tory Island Light-house, Co. Donegal, October 28, 1894.

Blackwater Bank Light-ship, Co. Wexford, September 24, 1898.

Two of the above-mentioned stations are situated on the east coast, one on the north, and one on the west. The south coast is not yet known to have been visited, but there is reason to believe that a bird of this species was seen at the Fastnet by Mr George Dunleavy on the 16th of October 1888. The date of Mr Dunleavy's observation (see p. 8) agrees well with the other records, since three of them belong to the last half of October. Again at Blackrock (Mayo), Mr Richard Widdicombe, about the 20th of October 1889, saw (see p. 68) a bird "like a Spotted Flycatcher with a red breast." If these records be correct, we have evidence of the Red-breasted Flycatcher having visited Ireland six times, and in at least four successive Octobers, 1887-1890-but always on an island or light-ship.

All the examples were apparently immature.

Pied Flycatcher (Muscicapa atricapilla, Linn.).

Pied Fly- Has seven times been obtained at light-houses, always in autumn, and always at island-rocks.

Before the commencement of this investigation, the Pied Flycatcher had once been shot in Ireland, by Mr Robert Warren, at Moyview, Co. Sligo, April 19, 1875. Since then 
all the records have been from light-stations. The specimens sent are as follows :-

One at Tearaght Rock, September 21, 1886.

$\quad$ Fastnet, October 5, 1886.
$" \quad$ Tuskar, September 28, 1888.
Fastnet, September 30, 1888.
" Tuskar, August 7, 1890.
" Fastnet, September 8, 1896.
$\quad$ Fastnet, October 9, 1899.

The above appear to be all immature. One (Tuskar 1890) was received in flesh, and six are represented only by legs and wings.

The bird is supposed to have been seen on the Fastnet Rock on three other occasions, once in autumn (October 21, 1888) and twice in spring (April 12, 1887, and April 26, 1888). The observer in these three instances was $\mathrm{Mr}$ G. Dunleavy, from whom two of the four Fastnet specimens were received; but strict proof is still wanting of the Pied Flycatcher's occurrence at Irish light-stations in spring.

The number of autumnal occurrences of this rare species is remarkable if compared with other migrants. For instance, the following are all common summer visitors to Ireland, yet none of them have been received so often as seven times in autumn :-

Spotted Flycatcher (five times), Grasshopper Warbler (once), Chiffchaff (five times), Swallow (once), House-Martin (never), Sand-Martin (never), Swift (three times, young only), Nightjar (never), Cuckoo (three times, young only), Corn-Crake (three times), and Common Sandpiper (twice).

All the light-houses at which the Pied Flycatcher has been obtained are south of the latitude of Tralee (lat. $52^{\circ} 16^{\prime}$ ). The Fastnet, where it has occurred most frequently, is the southernmost Irish light-station $\left(51^{\circ} 23^{\prime}\right)$.

\section{GOLDEN ORIOLE (Oriolus galbula, Linn.).}

Once obtained from the Skelligs Light-house, Co. Kerry. A female, believed by the light-keeper to have been killed by Golden a Peregrine Falcon, was found dead on the rock on the 23rd of May 1899, and a leg and wing, with the tail, were forwarded. 
Water-Ouzel, or Dipper (Cinclus aquaticus, Bechstein).

Water.

Ouzel, or Dipper.

Has never struck the lantern, but it once visited the small island of Rathlin O'Birne, two miles west of Co. Donegal. One shot there on December 13, 1889, is said to have frequented a small pool for several weeks (see p. 68). This is the only Dipper received, and there is not the slightest evidence, either from the light-house schedules or otherwise, that this common species migrates to or from Ireland, or even locally in Ireland.

\section{Missel-Thrush (Turdus viscivorus, Linn.).}

Missel- There is a seeming anomaly in the facts relating to this Thrush. bird. During the seven years 1886-1892 inclusive it was caught or killed at the lanterns every year, yet no specimen has been so obtained in the seven succeeding years 18931899. It is possible that some struck and were not forwarded by the light-keepers, but the contrast between the two periods is singular.

The Missel-Thrush has struck in the months of October, November, January, February, and March. November, however, yields half the specimens received; one was forwarded in October, five in November, one in January, two in February, and one in March. Most of the above ten were obtained during "rushes" of other species, chiefly the Song-Thrush.

The stations at which the Missel-Thrush has struck are widely distributed, being situated on the coasts of Cork, Wexford, Dublin, Antrim, Donegal, and Sligo. All the five occurrences in the south (Fastnet, Hook Tower, and Tuskar) were autumnal (October and November); three on the east (Rockabill and Maidens) were in spring (February and March). The north coast proper received none, but Aranmore, the most northerly of west coast stations, sent one killed on November 30 , and Oyster Island, Co. Sligo, furnished the only example obtained in January.

- Some birds observed at Innishtrahull, August 3, 1895, were probably Missel-Thrushes, and one said to have been caught at the Tuskar, April 9, 1888, needs confirmation.

During the severe frost and snow of February 1895, immense hosts of birds took refuge in the S.W. corner of Ireland, and a 
Missel-Thrush, then found dead among many other birds on Samphire Island in Tralee Bay, is the only specimen received since 1892.

This species has never been received from a light-ship.

The measurements of the wings obtained show little variation.

Average length of wing, 6.03 ; longest, 6.20 ; shortest, 5.85 ; difference between extremes, 0.35 ; percentage of variation, 6 .

Thrush (Turdus musicus, Linn.).

The winter migration of the Thrush is one of the marked fentures of Irish ornithology. This species arrives in immense numbers on our south-east coast during October and November, and migration continues on a large scale through December, January, February, and March. It is seen passing the light-houses in considerable flocks by day, but occurs far more numerously at night, and in cloudy or foggy seasons numbers are frequently killed and disabled striking. For instance, in October 1897 the light-keeper at the Tuskar Rock (off the south-east corner of Ireland) reports "from five to six hundred Blackbirds and Thrushes killed each night from the 20th to the 23rd," and this represents only a small proportion of the great wave of Thrush migration then in progress, which can be traced during some of the same nights at the Fastnet, Mine Head, Coningbeg, Blackwater Bank, and Rockabill lights-i.e., from the coast of Cork to that of Dublin.

The mass of information received on the migration of this species is large, and the difficulty of sifting the data is increased by the fact that the light-keepers frequently confound the Thrush with the Redwing.

In this case probably the best criterion of the relative proportion in which these two species occur on migration, is the number of specimens received of each. This, counting to the end of 1899 , is-

$$
\begin{aligned}
& \text { Thrush, . . . } 118
\end{aligned}
$$

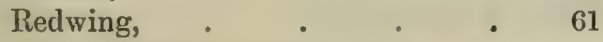

From which it appears probable that the Thrush visits us about twice as numerously as the Redwing. The year in 
Thrush. which most Thrushes were received "was 1898, when 22 were forwarded, and only 1 Redwing; next came 1891, with 18 Thrushes and 3 Redwings; and 1890, with 13 Thrushes and 4 Redwings. A remarkable rush to be mentioned under Redwing caused it to predominate greatly among the legs and wings sent in 1897, and in 1893 the only specimens received-all killed in January-were 1 Thrush and 3 Redwings. In no other years than these two has the Redwing outnumbered the Thrush, while in eleven of fourteen consecutive years (1886-1899) the Thrush preponderated over the Redwing. The numbers were equal ( 4 of each) in 1889.

Great rushes at lanterns have occurred in October, November (many), December, February, March, and April, but none are recorded in January. As these phenomena depend largely on the weather, they are not a trustworthy clue to the comparative density of the Thrush's migration at different dates. A safer method is to tabulate for each month the whole number of separately dated observations of the Thrush embodied in the "Reports" (1883-1897), and also the number of separately dated specimens ${ }^{1}$ received up to and including 1899. Thus-

Jan. Feb. Mar. April May June July Aug. Sept. Oct. Nov. Dec. Total.

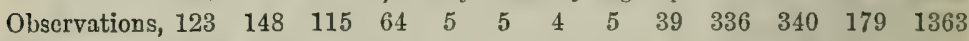

$\begin{array}{llllllllllllll}\text { Specimens, } & 12 & 17 & 10 & 4 & 0 & 1 & 0 & 0 & 3 & 24 & 29 & 15 & 115\end{array}$

These two sets of figures agree closely in their leading result-i.e., a great preponderance of both observations and specimens for October and November, November being slightly the richer in both. December shows a large diminution, its observations and specimens being about half those of November. This decrease is still further perceptible in January. February is marked by a distinct increase, and March and April by a decisive and progressive diminution, which practically reaches a vanishing point in May.

The amount of migration for each month having thus been roughly measured, it is possible, by subdividing the months in which migration occurs into shorter periods, to mark the times of its ebb and flow more clearly.

1 1.c., when two or more specimens were forwarded from the same station on tho same night, they are here counted as only one. 
The numbers in the following Table indicate specimens Thrush. received :-

Periods.

September 1-10, . . ...

, $\quad 11-20$, . . ...

, 21-30, . 3

October 1-10, . 4

" 11-20, . . 6

" 21-31, . 13

November 1-10, . 15

" $11-20$, . 9

" 21-30, . 5

December $1-10$, . 5

" $11-20$, . 8

" 21-31, . . 2
Periods.

January $1-10, \quad \cdot \quad \cdot 3$

” 11-20, . . 5

"21-31, . . 4

February 1-10, . . 11

" 11-20, . . 2

"21-28-9, . . 4

March $1-10$. 2

" $11-20, \ldots 6$

" 21-31, . . 2

April 1-10, . . 3

"11-20,

"21-30, . . I

At least 80 per cent. of the specimens striking were killed in the 4th and 1st quarters of the moon, and this rule holds good with other birds, apparently without any distinction between one species and another.

The intimate relation between the lunar phases and the number of specimens forwarded as killed striking is well shown by the statistics from 1888 to 1894 . During these seven years, out of a total of 673 birds received, only 106, or less than 16 per cent., were killed when the moon was more than half full. On examining the statistics of individual species, it was found that the proportion varied so very slightly that it may be said the rule holds good for all. Each year, therefore, the period of maximum striking changes with the lunar phases, and in arguing from specimens to dates, this has always to be borne in mind.

The figures for the above-mentioned years are as follows:-

Total Specimens killed Striking of all Species.

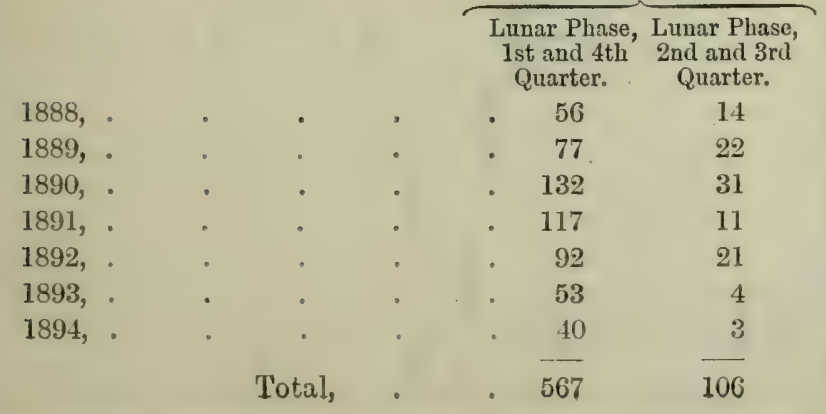




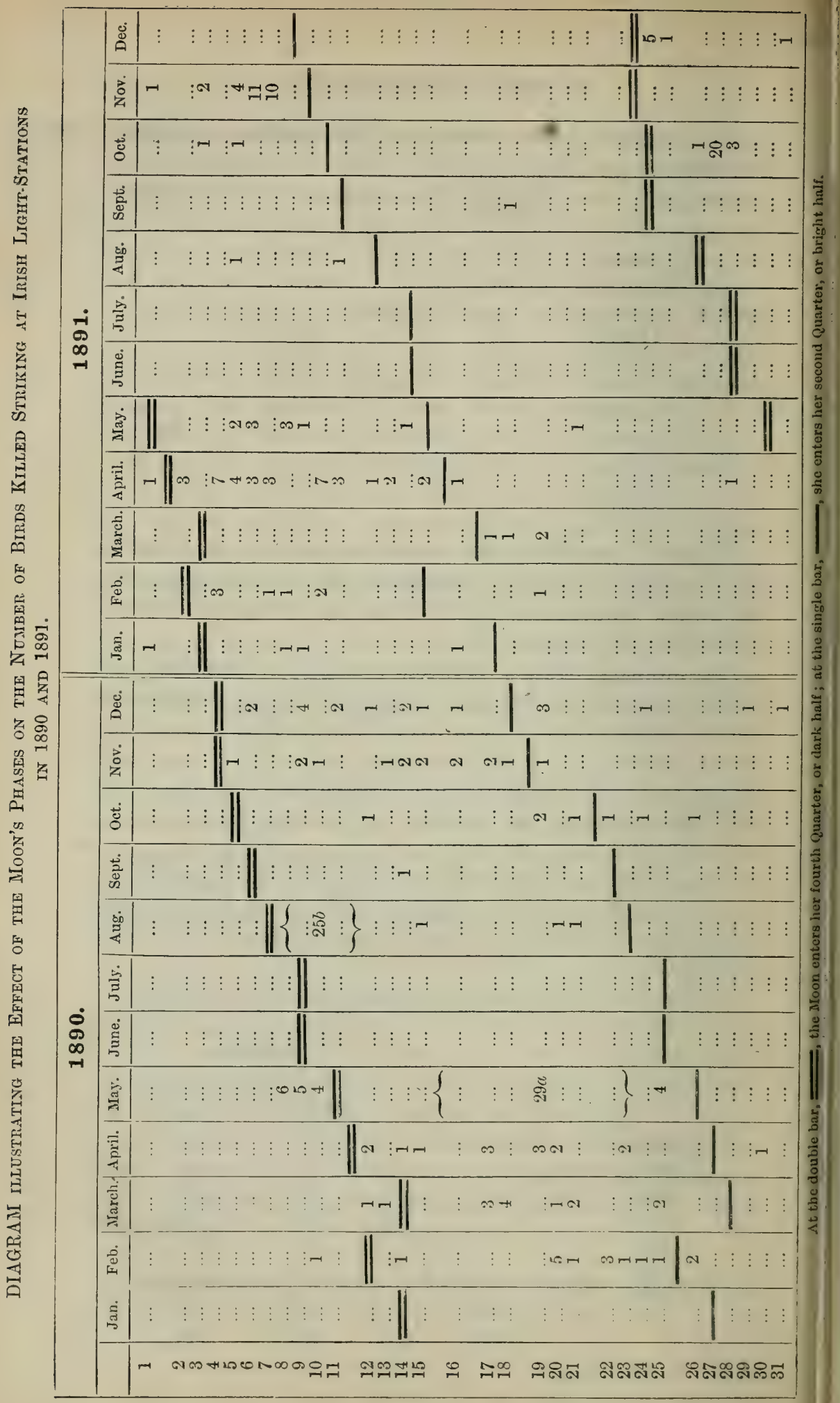


The month of maximum migration is thus shown to be from Thrush. the 20th of October to the 20th of November, during which thirty-one days 37 specimens have been received, as against 13 in the preceding thirty, and 18 in the following thirty days.

Of the large number of specimens sent in February (as compared with December, January, and March), it appears that a majority have been obtained in the first ten days of that month, and that from January 10 to February 10 is the month of greatest Thrush migration in the early part of the year.

It is apparently at a standstill from April 10 to September 20 , and is stronger during the first ten days of November than at any other time.

The Thrush strikes the lanterns on every part of the Irish coast, and its legs and wings have been received from no fewer than twenty-five stations. The number contributed by each is shown in the annexed table. From this it appears that the largest number of specimens, and also the largest number of separately dated observations, come from Blackwater Bank Light-ship, next to which rank the South Arklow Light-ship and Tuskar Rock Light-house, all these three stations lying off the eastern shore of the County Wexford, and contributing between them more than half the specimens received from the whole coast of Ireland. A line drawn from Tuskar Rock to Arklow South Light-ship-i.e., a distance of some forty mileswould probably traverse the flight-line of most of the Thrushes which migrate into Ireland. 
Thrush. TABLE sirowing the Diśribution of Turdus musicus arouxd tue Irish Coast when on Migration.

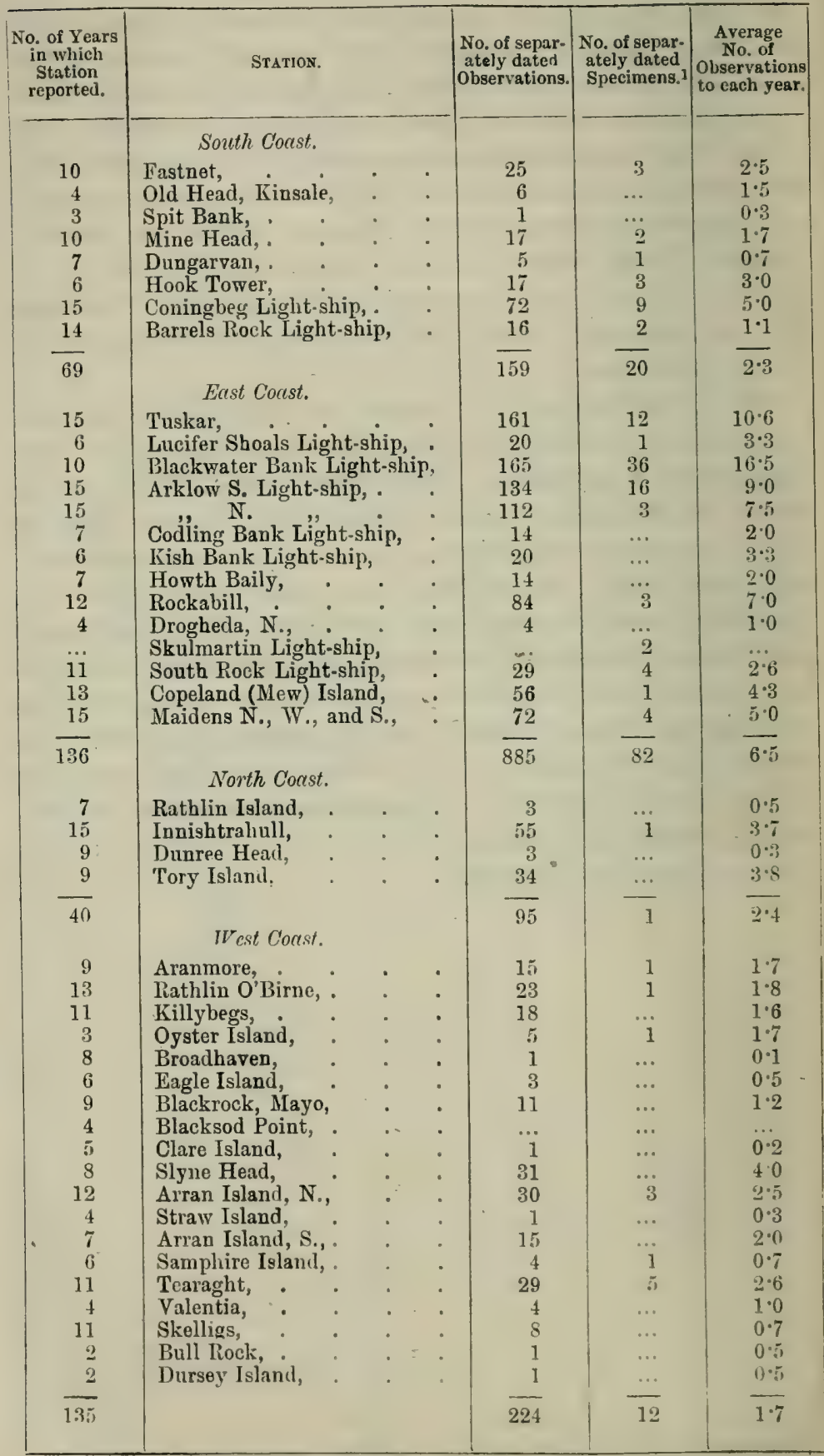

I When two or more are sent from the same station on the same date, only one is counted. 
The more northerly stations of the east coast (from lat. $53^{\circ} \mathrm{N}$. Thrush. to lat. $55^{\circ} \mathrm{N}$.) have furnished only 14 specimens, while the southerly $\left(52^{\circ} \mathrm{N}\right.$. to $53^{\circ} \mathrm{N}$.) yield 68 . Some interesting rushes are reported at the Mew Island (Co. Down) and Maidens (Co. Antrim) Light-houses on the night of February 20,1890 ; but it is plain from the lists of killed and disabled, that in these instances a great majority of the birds striking belonged to other species, notably the Lark.

The five stations on the south coast, which lie towards its eastern extremity, furnish 17 of the 20 specimens received. These are north of the 52nd parallel, while the remaining light-houses are farther south.

Only 12 specimens have been sent from the west coast, and of these the light-houses between $52^{\circ} 5^{\prime} \mathrm{N}$. and $53^{\circ} 10^{\prime} \mathrm{N}$. lat. contribute 9 ; the limits of maximum density being thus, apparently, about the same on the east and west coasts.

The north coast has forwarded only one specimen.

More than 80 per cent. of the Thrushes received from Irish light-stations were therefore obtained within a zone which lies between latitudes $52^{\circ}$ and $53^{\circ} 10^{\prime} \mathrm{N}$, the actual numbers being-

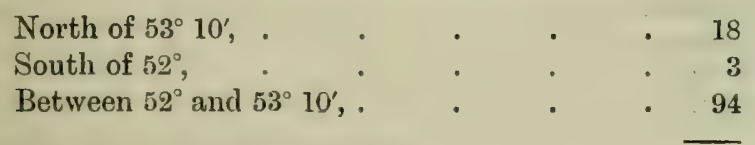

115

Seventy-three of the whole number are from light-ships, 36 from light-houses on islands, and 6 from the mainland.

A question which has not been touched on in dealing with any of the foregoing species is that of the direction of the migratory flight. On this subject the data have to be founded on observations made in the day-time, and on birds sufficiently familiar to be recognised as they fly. Consequently we are still in the dark on many points of the deepest interest. Much as our curiosity may be stimulated by the lateness of the Spotted Flycatcher's autumnal visits to some of our islandrocks, no information can be elicited from the light-keepers as to the direction in which it is then travelling; and we are left to conjecture as to whether the seven Pied 
Thrush. Flycatchers which have been killed at our southern lightstations in autumn were leaving or approaching the Irish shore. On such questions our inferences must be largely based on analogy. The Thrush, however, is one of the few species which to some extent fulfil the conditions under which direct data are obtainable; and accordingly we find in the lightkeepers' reports about two hundred records of the directions in which Thrushes have been seen migrating. These lead to a curious and suggestive result.

Briefly, this result is that all the Thrushes seen on migration at Irish light-stations are making for the land. From the first flock noted in October to the last in April, all are pushing their way to the same goal. The exceptions are so few as to be insignificant, especially as they are not more numerous in spring than in autumn. The movements may be tabulated as follows :-

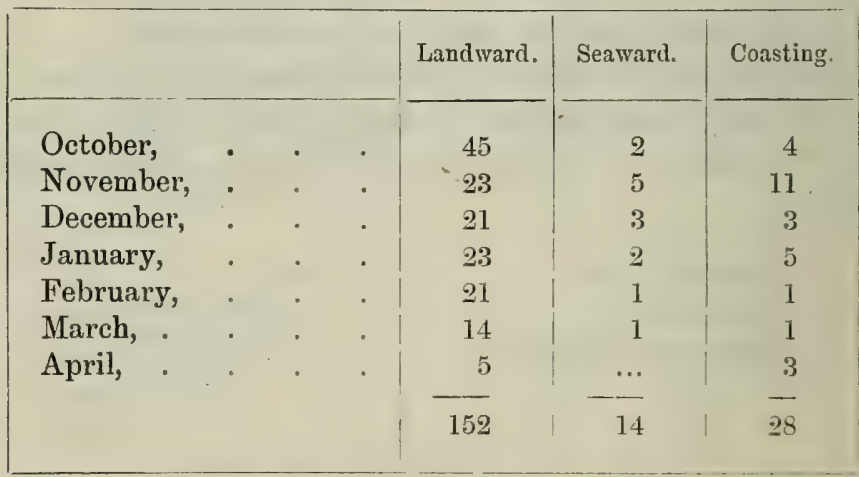

We thus find that the migration of the Thrush, so far as our light-stations indicate its course, is one continuous immigration. The birds which reach us in such vast numbers in autumn are not seen departing in spring; on the contrary, their forces seem then to be further augmented from over sea. That a considerable emigration takes place cannot be doubted, but of the times and places of the departure our information is nil.

The arrival of so many Thrushes in February is a puzzling circumstance; but it may be suggested as a possible explanation that by that time the pastures of England, and of such portions of the Continental littoral as remain green during 
the winter, are bare of herbage, and the supply of insect or molluscous food in such spots consequently at its minimum, whereas the Irish fields, under the influence of a higher winter temperature, are comparatively green even in February, especially in the south-west.

From the measurements of 94 wings obtained on migration (see Appendix, p. 622), it appears that the Thrushes which reach us early in autumn are, as a rule, longer winged birds than those which strike later. This is shown by the following figures :-

Of 50 obtained in October, November, and December-

25 earliest (Oct. 6 to Nov. 3) average in length of wing, 4.625 in.

25 latest (Nov. 5 to Dec. 25) " " " 4600 " And of 40 obtained in January, February, March, and April-

20 earliest (Jan. 4 to Feb. 9) average in length of wing, $4600 \mathrm{in}$.

20 latest (Feb. 9 to April 21) " " " " 4575,

Average length of wing, 4.6 ; longest, 4.775 ; shortest, 4.300 ; difference between extremes, $0 \cdot 475$; percentage of variation, 10 .

ReDWING (Turdus iliacus, Linn.).

Most of the Redwings received from light-stations have been Redwing. sent as Thrushes, and Turdus musicus has frequently been sent as a Redwing. Great caution has therefore to be exercised in accepting unverified statements as to either bird, and particularly as to the scarcer of the two. As was shown under the preceding species, about half as many Redwings as Thrushes have been received from light-stations, and this does not represent the full extent of the disproportion, since of the whole number of the 61 Redwings forwarded, as many as 28 struck in 1897.

This species has struck at the Rockabill Light-house as early as September 20, being three days in advance of the earliest date on which the Thrush has been obtained on autumnal migration. Like the Thrush, it occurs chiefly in October and November; but in the Redwing we find no parallel to the spring migration which was so remarkable in the Thrush. The specimens received (discarding one undated and one shot at a land-station) are distributed among the different months as follows:- 


\begin{tabular}{|c|c|c|}
\hline September, & & \\
\hline October,. & & : \\
\hline November, & & • \\
\hline December, & & . \\
\hline January, & & \\
\hline February, & & . \\
\hline March, . & & \\
\hline
\end{tabular}

The three January specimens occurred in the first ten days of that month, and therefore evidently belong to the same migration as the December birds, a migration which seems to cease about the middle of January. Ninety-seven per cent. of our Redwings may therefore be said to have struck during the antumnal influx. The two birds obtained in March struck on the 5th and 8th of that month, and represent all the evidence we possess of the spring migration.

The evidence of the autumnal movement is very fragmentary. In the years 1885,1886 , and 1889 , all the specimens forwarded were killed in October; in 1888, 1890, and 1898, none were received till November; in the winter of 1892-93 September and January were the only months in which any were sent; and during the four following winters none (except a March bird) came to hand at all. It is therefore obvious that the data are insufficient for fixing the principal time of arrival with any certainty.

Still, the following figures are of some interest:-

Before October 14,

From October 14 to November 13, Specimens received, $\quad 1$

From November 14 to December 13,

From December 14 to January 13,

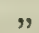

,

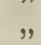

Total,
33

7

16

57

It seems as if the first inrush is followed by a lull, and this, towards midwinter, by a renewed immigration, probably of birds whose food-supply is exhausted. In mild seasons it is possible that this second migration does not take place, as the years in which we have direct evidence of it are ouly four, viz., 1887, 1890, 1892, and 1897; and since the only years in which Redwings were received between November 13 and December 13 are also 1890 and 1897 , it is probable that birds striking after November 13 are rather precursors of the later than laggards of the earlier movement: 
In connection with the above fact, it is particularly curious that while the occurrences prior to November 13 are distributed from north to south of Ireland, no birds killed after that date have been received from stations north of lat. $53^{\circ} 10^{\prime}$.

\section{Before November 13.}

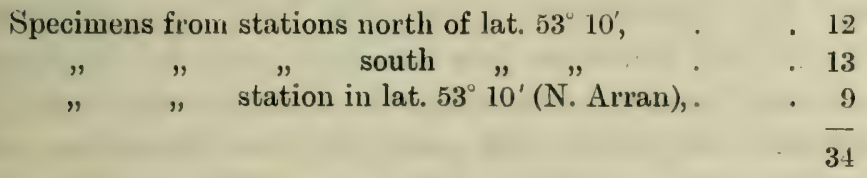

After November 13.

Specimens from stations north of lat. $53^{\circ} 10^{\prime}$, . . 0 $\Rightarrow \quad \quad " \quad$ station in lat. $53^{\circ} " 10^{\prime}$ (N. Arran), $\quad \cdot \frac{7}{23}$

This strengthens the inference that the later birds do not come direct from the north of Europe.

There is some evidence to show that the Redwing is apt to strike simultaneously over a wide area during periods of short continuance. Thus, in 1887, the first specimens received were from Tory Island and Tuskar (north-west and south-east corners of Ireland), killed on the 16th and 17th of October respectively; no more were forwarded till November 11, when one was killed striking at Barrels Rock Light-ship; and on the following night (November 12) examples were obtained at such widely remote stations as the Fastnet, Tuskar, and Innishtrahull Light-houses; after which, for six weeks, none were received. Again, in 1897, the first received were birds which had struck on the same night (October 23) at the Fastnet and Copeland Island lights; next night (October 24) Mine Head sent a specimen, and on the next (October 25) several struck on North Arran Island. Even years when only two specimens were obtained, such as 1886 and 1888, afford further illustrations of the same tendency.

liedwings seem seldom to strike except in company with other birds, and legs and wings of this species have been seut with those of the Thrush (nine times), Blackbird (five times), Starling (four times), Fieldfare, Lark, and Chaffinch (each three times), Titlark (twice), and Missel-Thrush, Stonechat, Blackcap, Greenfinch, Siskin, Waicr-Rail, Dunlin, and Wigeon (each once). 
Redwing. The two birds which struck in spring were, however, forwarded alone; and, curiously, both were from light-ships, though the Redwing's occurrences at light-ships in autumn are rare, numbering only six.

In the autumn of 1897 great numbers seem to have occurred on migration at North Arran Island, off the Galway coast. The light-keeper, on October 23rd, reported "first Blackbirds and Thrushes seen on island since the beginning of summer;" and on the nights of the 25th, 26th, and 31st of October, 1st, 2nd, 19th, and 23rd of November, and 18th, 20th, 21st, and 23rd of December, "Thrushes" (to the number of twenty-eight) were reported as killed striking, which, however, when their legs and wings were received, proved to be twenty-five Redwings and three Thrushes. This is a clearly exceptional instance of Turdus iliacus greatly outnumbering its more common congener at Irish light-stations.

Other legs and wings received from North Arran during the same period (October 23rd to December 23rd) belonged to seven Blackbirds, two Starlings, one Titlark, and one Chaffinch, making, with the twenty-five Redwings and three Thrushes, a total from this station of thirty-nine birds. Up to the 13 th of November, the proportions were nine Redwings to twelve other birds, and after that date they were sixteen Redwings to two other birds. Thus the Blackbird nearly equalled the Redwing during the earlier period, while it appears to have been totally absent in the later. This difference agrees with the view already suggested, that the earlier birds represent a strictly seasonal migration from Northern Europe, in which many species participate simultaneously, while the later immigrants are birds gradually driven westwards from their original winter retreat, and arrive in the order of their susceptibility to frost.

Comparing the number of differently dated specimens sent from various portions of the coast, in the case of Thrush and Redwing we have-

\begin{tabular}{|c|c|c|c|c|}
\hline & South Coast. & East Coast. & North Const. & West Coast. \\
\hline Inrt & $\begin{array}{r}20 \\
-\quad 8\end{array}$ & $\begin{array}{l}82 \\
20\end{array}$ & $\begin{array}{l}1 \\
2\end{array}$ & 12 \\
\hline
\end{tabular}

${ }^{1}$ Striking was almost wholly suspended during tho second and third yuarters of the moon in each month. 
The number of Redwings forwarded from the west coast is much Redwing. larger than the normal, by reason of the exceptional Arran Island rush in 1897.

The measurements of 50 wings (September to January) give the following result:-

25 earliest (Sept. 20 to Nov. 11) average in length, $4 \cdot 61$ in.

25 latest (Nov. 12 to Jan. 10) " " " 4.59 ,

Like the Thrush, the longest winged birds come first; but if we treat the autumnal migration as divisible into two, before and after November 13, a very interesting result is obtained.

Taking the specimens killed before November 13 , we find a marked superiority in length of earlier wings, thus :-

14 earliest (Sept. 20 to Oct. 26) average in length, $4.65 \mathrm{in}$.

14 latest (Oct. 27 to Nov. 12) " " $\quad 455$,

Taking the specimens killed after November 13 , we find the reverse, i.e., a marked superiority in length of later wings, thus :-

11 earliest (Nov. 19 to Dec. 20) average in length, 4.56 in.

11 latest (Dec. 20 to Jan. 10) " " 465 "

The cause which might be expected to give priority to the long wings in a seasonal rush does not operate to the same extent in the case of birds that only migrate when compelled to do so. So it is not surprising to find that in the second migration, which differs in so many respects from the earlier one, the first comers are not longer winged than the last arrivals. That they are actually shorter winged might be building too large an inference on 22 specimens; but the hypothesis naturally suggests itself that in seasons of dearth the smaller, and consequently weaker, birds are soonest forced to retreat.

Considering the number of specimens available, perhaps too much has been made of the second autumnal rush of this species; but with the view of stimulating further inquiry, the apparent characteristics of this abnormal movement may thus be summarised:-The second rush was confined to stations south of lat. $53^{\circ} 10^{\prime}$; the first rush has no such limitation. Then, many other species participated in the first autumnal 
Redwing. lush, whereas few accompanied the Redwings on the second one. Again, in the first rush, the longest winged specimens arrived earliest; in the second they arrived latest. The first rush is an annual occurrence; the second rush is not.

Average length of wing, 4.6 ; longest, 4.82 ; shortest, 4.35 ; difference between extremes, 0.47 ; percentage of variation, 10 .

The average length and percentage of variation are precisely the same as for the Thrush.

\section{FieldFare (Turdus pilaris, Linn.).}

Fieldfare. Compared with the Redwing, the Fieldfare is a conspicuous and readily recognised species, and it has been recorded at some stations with a certain degree of regularity, particularly in the north, and at Rockabill.

At Innishtrahull (the northernmost Irish light-station), Fieldfares have been observed on migration during nine out of ten consecutive autumns (1886-1895); the first birds being noted five times in October, three times in November, and once (in 1890) as late as December.

Several remarkable movements have been reported from this light-house.

In 1886 "a most extraordinary rush of Fieldfares" is noted, with heavy snow showers, wind N., on December 18th to 20 th. The light-keeper writes: "All apparently came from the Scotch coast. I never saw such a rush; the oldest people on island never saw the like. A great number left on 21st: not one to be seen after 23rd." Four western stations-Aranmore, Rathliu O'Birne, Eagle Island, E., and Arran Island, N.-also reported Fieldfares (generally in flocks) between the same dates, and this is the more significant as none were mentioned that year for any other date, on the line of coast from Innishtrahull to Tearaght. It is not stated whether this immigration at Innishtrahull took place by night or day, but none of the birds observed during this rush are referred to as striking.

In 1888 the largest incursion noted was also at Innishtiahull, and occurred on the night of November 2 ; none were killed at this station, but during the same and the next two nights, Fieldfares were killed striking at Mew Island (November 2 and 3), Blackrock, Mayo (November 2), Arran Island, S. 
(November 4), Tuskar (November 4), and Arklow S. LightFieldfare. ship (November 2), followed by one at Tearaght (November 6). Legs and wings were sent from Tearaght and Mew Island, and were the only specimens received during the year.

In 1891 a similar immigration at about the same time of year is yet more strongly attested. Numbers were reported striking the lantern at Innishtrahull on the night of October 28 (one having struck the previous night at Maidens S.); a few were next noted striking at Rockabill (November 1), while some were seen the same day at Drogheda North; and on the night of November 4 the main movement set in, when " 20 Thrushes and Fieldfares" were disabled striking at Tory Island, and Fieldfares were killed at Mew Island, Rockabill, and Arklow S. Light-ship; on the 5th, more were killed at Mew Island; on the 6 th, a dozen are reported killed striking at Fastnet; and on the 7th, three were killed at Hook Tower, one at Tearaght, some at Fastnet, and one at Arklow S. Light-ship. Five specimens (from four stations) were sent in corroboration of this rush, and no others were received until the end of January.

On November 19, 1892, again at Innishtrahull, "an enormous number of Fieldfares" are reported "striking all night; forty-six killed;" similar rushes, but comprising other birds along with the Fieldfare, occurred on the previous night (November 18) at Tory Island and Rockabill; and for three nights after the 19th, Fieldfares continued to strike at Innishtrahull, while one was received (killed November 22) from the Maidens. In this migration, as in 1886, the light-keeper stated that the birds "all came from the N., going S."

In the above instances the Fieldfare seems to have reached Ireland directly from the north, but it is probable that it follows a different route to the south-east coast occasionally. The dates on which specimens have been received from the Tuskar and Blackwater Bank stations (which furnish no fewer than 15) seldom synchronise with rushes chronicled in the north; and there are comparatively few records of the birds being observed in large numbers. Two-thirds of all the specimens forwarded, however, come from stations S. of lat. $53^{\circ}$, which seems to show that it is on this part of the coast that Fieldfares most frequently strike the light. As in the case of the Redwing, 
Fieldfare. it appears that the southern immigrants are on the whole somewhat later than the northern, for of 16 specimens received from stations $N$. of lat. $53^{\circ}, 8$ were killed before November 10 , and 8 after, while of 25 received from stations S. of that latitude, 10 were killed before November 10 , and 15 after. $^{1}$

The earliest date on which a Fieldfare has been received from a light-station in autumn is October 16 (Tory Island, Co. Donegal); the latest on autumnal migration is January 30 (Blackwater Bank Light-ship, Co. Wexford). The whole number, from October 16 to January 30 , is 41 .

The number with satisfactory data in the spring is only two; earliest, April 20 (Mew Island); latest, April 29 (Arklow S. Light-ship).

The following table shows that the principal autumnal incursion takes place in the first ten days of November:-

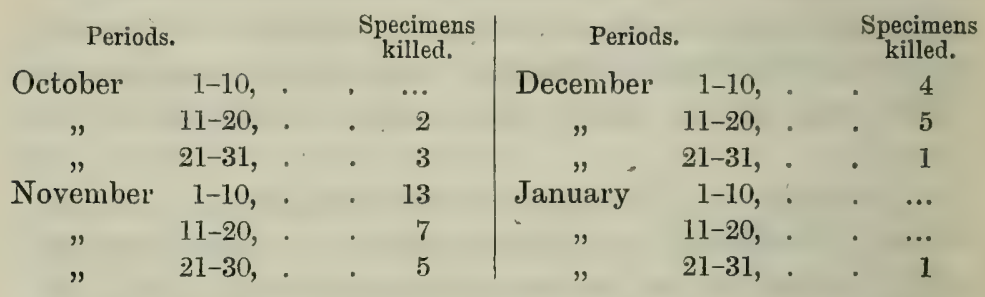

The numbers for each month are-October, 5; November, 25; December, 10 ; January, 1-total, 41.

A few are reported striking in February and March, but no specimen has been received. "Fieldfares," said to have been observed after April and before October, were probably MisselThrushes.

Fifteen are from light-ships, 28 from islands, and 3 from the mainland.

In the case of the Fieldfare, one cannot fairly argue, from the coast-distribution of the specimens killed striking, where and when most of the birds arrived, because it is evident from the observations above given that great numbers arrive on our north caasts, and yet the number of specimens forwarded (four) is insignificant. In most species they confirm the records, but in the Fieldfare this is not so.

I A specinen, shot at a south coast station in December, is omitted from this comparison. 
The fact that neither the Fieldfare nor the Redwing has in Fieldfare. more than two or three instances been forwarded in spring, corroborates the conclusion arrived at from a different class of data respecting the Thrush, viz, that departing birds are seldom observed at light-stations. The data regarding the Thrush show this to be the case by day; those regarding the Fieldfare and Redwing show that it is equally so by night.

The measurements of 33 wings obtained on autumnal migration gives a totally different result from those of the Thrush and Redwing.

17 earliest (Oct. 16 to Nov, 10) average in length, $5{ }^{\circ} 725 \mathrm{in}$.

16 latest (Nov. 13 to Jan. 30) " "

Possibly this may indicate that the males precede the females. (See Sharpe's "Handbook of British Birds," in which the measurement of the female Fieldfare's wing is given as exceeding that of the male's.) In any case, it is a departure from what seems to be the general rule, and needs explanation.

Average length of wing, 5.75 ; longest, 6.125 ; shortest, 5.425 ; difference between extremes, 0.70 ; percentage of variation, 12 .

\section{BlackBiRd (Turdus merula, Linn.).}

Both geographically and chronologically the Blackbird's maximum immigration takes place within the same limits as that of the Thrush, for of 148 specimens received, 103 were obtained in October and November, and 90 between $52^{\circ}$ and $53^{\circ} 10^{\prime} \mathrm{N}$. lat. The earliest autumnal occurrences have been on October 2 (Mine Head, Co. Waterford, and Rockabill, Co. Dublin), the latest on January 10 (Blackwater Bank Light-ship, Co. Wexford). There is a renewed migration in spring somewhat later than that of the Thrush; earliest, February 5 (Tuskar Rock, Co. Wexford); latest, April 6 (Blackwater Bank Light-ship). 120 specimens were received during the autumnal, and 24 during the vernal, period; 2 struck in summer (both at Wexford stations, July 16 and August 15) and 2 are without data-total, 148.

In point of time, the autumnal migration is more condensed than the Thrush's, since more Blackbirds than Thrushes are forwarded in October and November, and more Thrushes than Blnckbirds during the rest of the year. Subjoined are the

Blackbird. 
Blackbird. comparative numbers for each month, taking, in this case, only separately dated specimens. ${ }^{1}$

Jan. Feb. Mar. April May June July Aug. Sept. Oct. Nov. Dec. Total. $\begin{array}{llllllllllllll}\text { Blackbird, } & 2 & 9 & 9 & 3 & \ldots & \ldots & 1 & 1 & \ldots & 43 & 40 & 12 & 120\end{array}$ $\begin{array}{llllllllllllll}\text { Thrush, } & 12 & 17 & 10 & 4 & \ldots & 1 & \ldots & \ldots & 3 & 24 & 29 & 15 & 115\end{array}$

The period of densest migration for the Blackbird extends from October 15 to November 15, when 58 separately dated specimens were killed, against 25 during the remaining thirty days of October and November. If we take the whole number of specimens received (148), 75 were killed between October 15 and November 15, so that either way this interval produces more than 50 per cent. of the Blackbirds received during the entire year.

The following is the distribution of the specimens in the shorter periods already adopted for Thrush and Fieldfare. The sexes are distinguished as far as is practicable, but some of the so-called females are probably immature males :-

\begin{tabular}{|c|c|c|c|c|c|}
\hline Periods. & & $\begin{array}{l}\text { Specimens } \\
\text { Killed. }\end{array}$ & & q & $\begin{array}{c}\text { Undeterminable } \\
\text { [Legs only]. }\end{array}$ \\
\hline 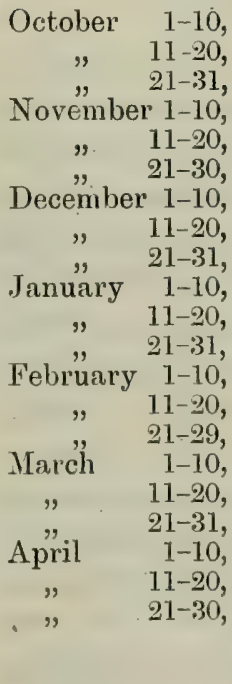 & 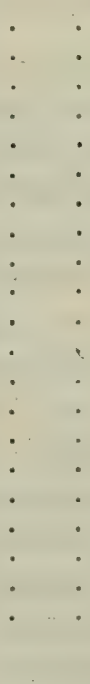 & $\begin{array}{c}10 \\
12 \\
28 \\
27 \\
15 \\
10 \\
4 \\
7 \\
4 \\
2 \\
\ldots \\
\cdots \\
1 \\
6 \\
3 \\
1 \\
7 \\
2 \\
4 \\
\ldots \\
\ldots \\
143\end{array}$ & $\begin{array}{r}3 \\
3 \\
12 \\
12 \\
10 \\
4 \\
3 \\
4 \\
2 \\
\cdots \\
\cdots \\
\cdots \\
4 \\
\cdots \\
\cdots \\
1 \\
1 \\
\cdots \\
\cdots \\
6 \\
\end{array}$ & $\begin{array}{r}7 \\
9 \\
16 \\
15 \\
4 \\
6 \\
1 \\
3 \\
2 \\
2 \\
\ldots \\
\ldots \\
\ldots \\
2 \\
3 \\
1 \\
5 \\
1 \\
4 \\
\ldots \\
\ldots \\
81\end{array}$ & $\begin{array}{c}\cdots \\
\cdots \\
\cdots \\
\cdots \\
1 \\
\cdots \\
\cdots \\
\cdots \\
\cdots \\
\cdots \\
\cdots \\
\cdots \\
\cdots \\
\cdots \\
\cdots \\
\cdots \\
\cdots \\
\cdots \\
\cdots \\
\cdots \\
2\end{array}$ \\
\hline
\end{tabular}

1 When two or more are sent from the same station on the same date, only ono is counted.

2 Two of these, one of and ono o, were found dead during hard frost. 
The spring movement does not begin until February, and is probably at its maximum about the middle of March, whereas that of the Thrush apparently begins about the middle of January, and attains its maximum in the first ten days of February.

In autumn, the adult males are in a minority to the end of October, numbering only 18 of a total of 50 ; but throughout November and December they are equal in numbers to the female and immature birds together. In the spring movement, on the other hand, the males seem to predominate during the first fortnight, while after February 20 only 2 males have been received to 14 females.

In geographical range, the distribution of the Blackbird's occurrences is very similar to that of the Thrush. The lightkeepers' observations seem to show that the Blackbird is, of the two, the more numerously observed on the south coast, and also on the southernmost portion of the west coast from Bull Rock to Tearaght; but that at nearly every station north of the Tuskar and Tearaght (which lie practically in the same latitude, $52^{\circ} 10^{\prime}$ ) the occurrences of the Thrush outnumber those of the Blackbird. To a limited extent the specimens received bear out this inference, since, if we count as one those received on the same date from the same station, the south coast furnishes 28 occurrences of the Blackbird to 20 of the Thrush, and the east coast 82 of the Thrush to 79 of the Blackbird. The annexed table gives the number of observations, and of specimens from each station: ${ }^{1}$

${ }^{1}$ In estimating geographical range, the total number of specimens available is 122. In estimating the time of arrival, it was only 120 . The explanation is that specimens bave twice been received without data as to when obtained, thongh the name of the station was given. 
Blackbird. TABLE showIxg tHE Distribution of Turdus merule AROEND THE IRISH COAST WHEN ON MITRATION.

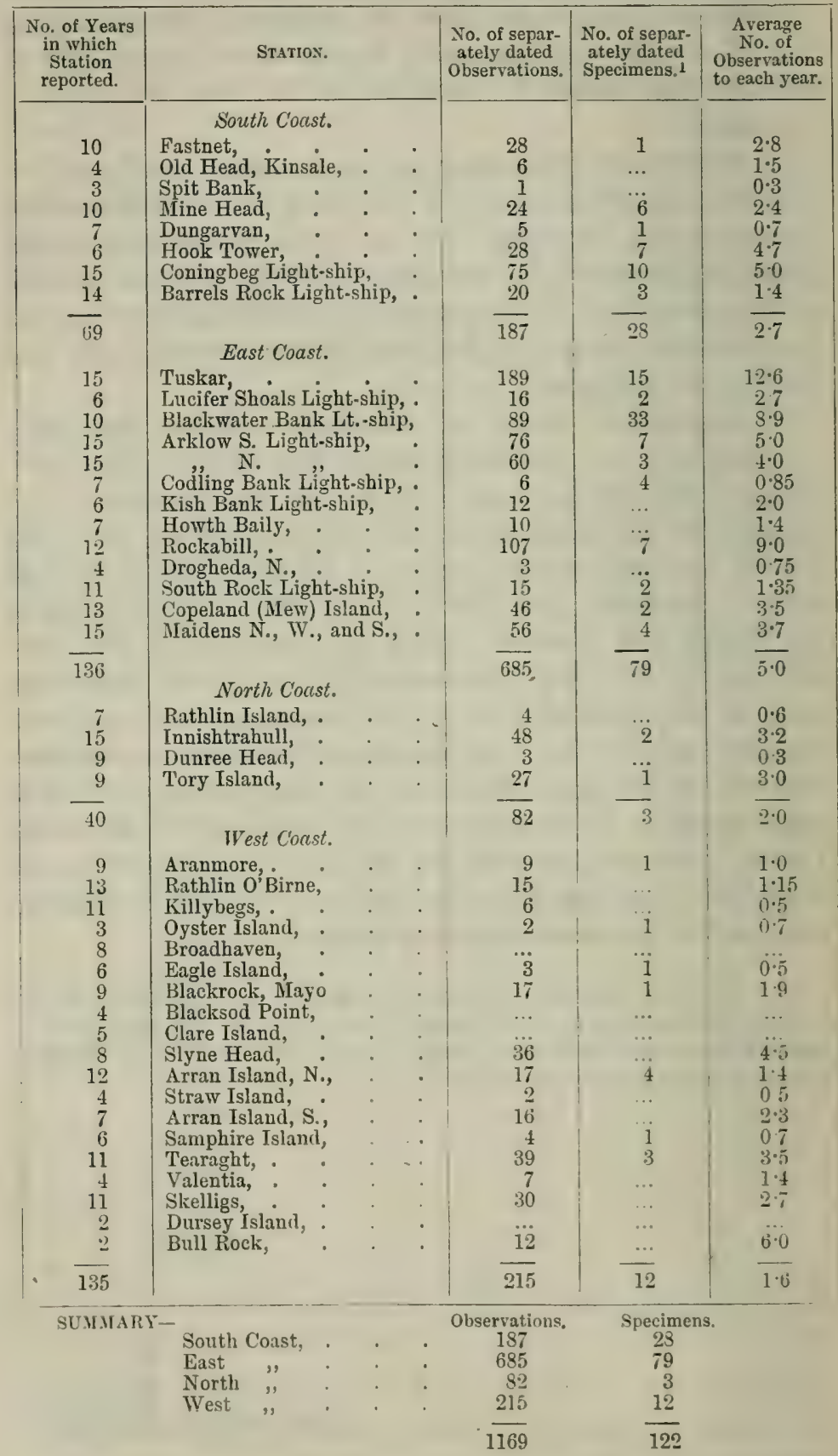

1 When two or more are sent from the same station on the same date, only one is counted. 
It will be seen at a glance from this Table that there are Blackbird. few stations from which the Blackbird has not been reported, and that specimens have been received from all parts of the coast. An overwhelming majority, however, are from the east and south. Wexford, the south-eastern county, yields twothirds of the whole number, and the birds which reach the west coast seem either to have been driven by exceptional stress of weather, or to be stragglers from among the great mass of autumnal immigrants ; for during the spring migration (February to April) none have been received from any stations on the part of the coast which lies west of Innishtrahull (Co. Donegal) in the north, and of Coningbeg (Co. Wexford) in the south.

Both in autumn and spring great rushes are sometimes reported, in which it is usual to find the Blackbird and Thrush mentioned together. These occurrences are often simultaneous at a number of stations. For instance, on the nights of October 28 and 29, 1883, there were rushes at Coningbeg Light-ship, the Tuskar Rock, and Arklow South and North Light-ships; again, on November 10 to 14, 1887, a dense rush at the Tuskar coincided with similar movements observed at the Fastnet, Coningbeg, and Barrels Rock stations on the south coast, Arklow South and Howth Baily in the east, and Slyne Head in the west, while six other stations report a few Blackbirds

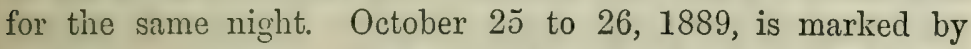
rushes at Coningbeg, Tuskar, Arklow South, Kish Bank, and New Island; November 13 to 15, 1890, by numbers striking at Hook Tower, Tuskar, Blackwater Bank, and Slyne Head, with a few at other stations; October 27, 1891, by great numbers at Hook Tower and Coningbeg Light-ship, with some at Barrels Rock, Blackwater Bank, and Arklow South Lightship, Iockabill, and Innishtrahull; and November 13 to 15 , 1893 , by a rush at eight stations, chiefly on the east coast, from Hook Tower in the south to Innishtrahull in the north.

The above instances are all autumnal, and they seem always to occur along a line in which the Tuskar occupies a more or less central position. It is otherwise in spring, where the Tuskar seems oftener than not to form the southern extremity of the line. Great spring rushes, for example, occurred at the Tuskar on March 4, 1884, February 13 to 14, 1885, and February 27 to 28,1886 ; and the observations which coincide 
Blackbird. with them elsewhere were made in the first year at Arklow North Light-ship, in the second at Arklow South and North, and in the third at Arklow South and Rockabill.

On the date of one of these spring rushes (March 4, 1886), the light-keeper at the Tuskar reports flocks (Thrushes and Blackbirds) all day passing to the W., as well as numbers killed at night; and during the rush of February 1886, at the same station, the birds are recorded as "passing N.W. at night." There is not, therefore, any reason to set them down as emigrants. In fact, the light-keepers' observations as to the direction of the Blackbird's flight bring out the same conclusion as was drawn in the case of the Thrush:-

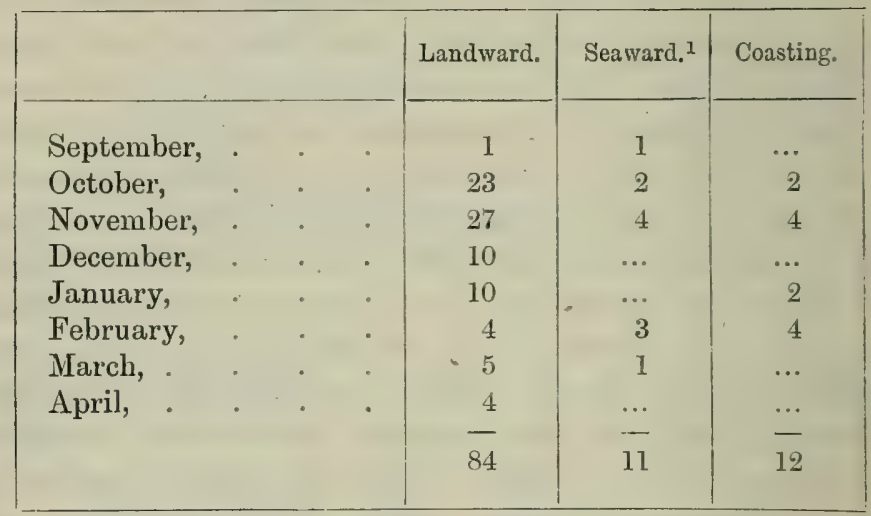

Both in autumn and spring the birds are observed arriving. Their departure is almost unobserved.

The measurements of 120 wings give the curious result, that while the shortest winged birds are the latest in spring, they are the earliest to arrive in autumn.

Of 24 obtained in January, February, March, and April-

12 in January and February average $5 \cdot 125$

12 in March and April 4.925

Of 92 in October, November, and December-

45 in October average . 4.975

47 in November and December average . . $\quad 5^{\circ} 000$

- On analysis, it is found that this result holds good only of the birds in female plumage, amongst whom in autumn a considerable number are probably immature.

${ }^{1}$ Four of the eleven seaward Hights were recorded at western stations (North and South Arran). 
Of 52 females and young birds-

25 earliest (October 2 to October 26) average . $\quad 4900$

27 latest (October 27 to December 24) " . 4. 4925

[And 2 in January,

Taking adult males-

Of 40 measured-

20 earliest (October 2 to November 7) average . $\quad 5075$

20 latest (November 8 to December 24) " . 5.062

The above figures afford some grounds for supposing that the young birds probably precede the adults in autumn, and this may perhaps explain the similar peculiarity noticed in the case of the Fieldfare.

Average length of wing, 4.97 ; longest, 5.55 ; shortest, 473 ; difference between extremes, 0.82 ; percentage of variation, $16 \frac{1}{2}$. Average length of $\hat{\delta}$ wing, 5.075 ; longest, 5.55 ; shortest, 4.80 ; difference, 0.75 . Average length of $q$ wing, $4.900 ;{ }^{1}$ longest, $5 \cdot 28$; shortest, 4.73 ; difference, 0.55 .

\section{RiNG-OuzeL (Turdus torquatus, Linn.).}

The Ring-Ouzel's migration route is peculiar, the light- Ring-ouzel. stations at which it occurs being nearly all situated either in the south, between Tearaght and Tuskar, or in the north-east, between Mew Island and Innishtrahull. From the northern stations it has been noted on spring migration only, and seven specimens received from that part of the coast (chiefly Innishtrahull) struck the lanterns at dates ranging from April 14 to May 5. At the southern stations it is observed both in spring and autumn; and here, though a large majority of the reported instances were in spring, seven of the nine south-coast specimens were forwarded in the autumn.

Isolated occurrences have been reported, in spring, from Lucifer Shoals Light-ship (east coast) and Blackrock, Mayo (west); and in autumn, from Rockabill (east) and Killybegs (west). These birds were not obtained.

The extreme dates on spring migration are-

Earliest observation,

Earliest specimen,

Latest observation,

Latest specimen,
March 4, 1887, April 3, 1891, May 11, 1886, May 5, 1896,
Blackbird. 
Ring-Ouzel. On autumn migration-

Earliest observation,

Earliest specimen,

Latest observation,

Latest specimen,

September 5, 1889, Rockabill.

September 11, 1896, Tuskar.

December 21, 1890, Tuskar.

November (? 17), 1897, Tuskar.

For March there are six observations (four from the Skelligs) but no specimens. For May, one observation and one specimen. For April, eighteen observations and seven specimens, the period of maximum immigration being apparently from the 10 th to the 20 th, as is shown below.

\begin{tabular}{|r|c|c|c|}
\hline \multicolumn{1}{|c|}{ Periods. } & Observations. & Specimens. & Coast-Distribution. \\
\hline March 1-10, & 4 & $\ldots$ & S.W. and S. \\
" 11-20, & $\ldots$ & $\ldots$ & $\ldots$ \\
" 21-31, & 2 & $\ldots$ & S.W. and S. \\
April 1-10, & 7 & 1 & S.W., S., and S.E. \\
$"$ 11-20, & 10 & 6 & S.W., S., S.E., N.E., N., \& W. \\
" 21-30, & 1 & $\ldots$ & N.' \\
May 1-11, & 1 & 1 & S. and N. \\
& 25 & - & \\
\hline
\end{tabular}

The earliest observation at a northern station is April 13 (Innishtrahull), and the earliest specimen April 14 (Mew Island), from which it appears that the birds are later in reaching the north than the south coast. Omitting the Mine Head record of May 11, 1886, as doubtful, the latest spring date for stations in the south is April 18 (Tearaght and Tuskar).

In autumn there are only seven observations and seven specimens, and most of the birds, either reported or obtained, occurred in September, and about half of them at the Tuskar.

The instances in which Ring-Ouzels have been observed by day are fairly numerous, and are reported chiefly from southwest stations, as the Tearaght and Skelligs, where it seems not unusual for solitary birds to rest on their spring journey. On one occasion a group of six, and on another " a flock," have been noted at the Skelligs; but of the remaining observations made by day (twenty in number), seventeen are of single birds only; twice, two are noted, and once three. These small numbers show that the Ring-Ouzel does not, as a rule, migrate gregariously like our other Thrushes, though individual birds often arrive at 
different stations about the same time. In 1887 one was noted at Skelligs on March 6, and one at Mine Head on March 7; one killed at Tuskar, September 21, and one caught at Fastnet, September 22. In 1888, one struck at Tuskar, April 14, and one at Hook Tower, April 15. In 1889, there were simultaneous observations at Tearaght and Skelligs, April 9; and nearly simultaneous occurrences at Tearaght and Innishtrahull, April 18 and 19. In 1890, one struck at Innishtrahull, April 13; one was found dead on Mew Island, April 14; and on the latter date a number were reported round the Tuskar lantern, four of them being killed. Thus four consecutive spring migrations furnish illustrations of the same tendency, and it would seem as if Ring-Ouzels travelled in a thinly dispersed army, with nearly the same regularity as is shown by birds which migrate in flocks.

In foggy weather this species sometimes accompanies the great masses of bewildered birds which are observed round the lanterns. In April 1891 it is enumerated as part of a dense, heterogeneous host, which for nine days swarmed "like bees" round the Tuskar light; and twice in autumn (September 19, 1895 , and September 11, 1896) it seems to have similarly occurred at the same station in mixed rushes; while it has struck at the Fastnet (October 30, 1897) amidst an assemblage comprising the Thrush, Redwing, Fieldfare, Blackbird, Chaffinch, Wheatear, Wren, Goldfinch, and Siskin (the first five species reported, the last four received). Twice, the Redstart has been received with the Ring-Ouzel (May and September 1896); the Whinchat, Willow-Wren, and Chiffchaff have each been once received with it in spring, and the Black Redstart and GoldCrest, once, in autumn.

It is remarkable that Turdus torquatus has never been received from a light-ship, and equally so that the same fact is true of the Redstart (Ruticilla phonicurus), which, as shown above, is the only bird that has been sent with the Ring-Ouzel both in spring and autumn.

In winter, birds answering to the description of the present species have occasionally been observed at southern stations; c.g., at Mine Head, December S-10, 1885; again at Mine Head, January 15, 18S7; and at Hook Tower several times in February 1894. 
Ring-Ouzel. Average length of wing, $5 \cdot 46$; longest, 5.72; shortest, $5 \cdot 12$; difference between extremes, 06 ; percentage of variation, 11 .

\section{Hedge Sparrow (Accentor modularis, Linn.).}

Hedge

Sparrow.

In only one instance is the Hedge Sparrow known to have struck at an Irish light-station, viz., at North Arran Island, September 12, 1897. The bird was received in flesh.

It is probable that some inter-migration takes place between Arran and the mainland, and doubts may well be entertained as to whether the above occurrence indicates more than a mere local flight of about nine miles.

On the Tearaght Rock, where a few Hedge Sparrows brect, successive light-keepers have observed that they are more numerous in winter than in summer, and this, again, seems evidence rather of partial than of extended migration.

On the other hand, three specimens have been forwarded from Rathlin O'Birne, of which the first two were shot as strange birds, October 18 and 21, 1895, and the third was received without data, October 7, 1896. Rathlin O'Birne (about two miles from shore) seems an unlikely spot for Hedge Sparrows to frequent.

Light-keepers have reported this species at the Tuskar (March, May, and September), Rockabill (March, May, and October), Maidens (March and October), Blackrock, Mayo (October), and Skelligs (October). Combined with the occurrences at Rathlin O'Birne, these furnish some evidence of migration, though of an unsatisfactory kind, as errors in identification are probable.

Of four wings measured, from Rathlin O'Birne, North Arran, and Tearaght, the lengths of three are identical, $2 \cdot 70$, and that of the fourth is 2.67 . Average, 2.69 ; percentage of variation, $3 \frac{1}{2}$.

\section{Robin (Erithacus rubecula, Linn.).}

Robin. Only two specimens of the Robin have been received from lightht-stations, one in spring (killed striking at Blackwater Bank Light-ship, March 13,1896) and one in autumn (killed striking at Rockabill, November 1, 1891).

Notwithstanding this remarkable paucity of proved occurrences, there is a sufficient concurrence of testimony from 
many stations to lead us to the conclusion that the Robin annually migrates in some numbers. It has been reported from four light-ships and twenty islands-the latter including the Fastnet, Tuskar, Maidens, Blackrock (Mayo), Tearaght, Skelligs, and Bull Rock-and seems to have struck the lanterns of five stations on the east coast, two on the north, one on the west, and two on the south. The instances in which it is said to have struck (inclusive of the received specimens) number twenty-two.

During December and January the Robin's reported occurrences have, with one exception, ${ }^{1}$ been from islands which it possibly frequents for food in winter, as Rathlin, Tory Island, Aranmore, Arran N. and S., Samphire, and Tearaght. In Feloruary the only station of a different character at which it has been observed is the Tuskar, where, however, there are three records of Robins during this month, the earliest on February 5, 1897. In March there is evidence of migration on a larger scale, consisting of three records from light-ships (Coningbeg, Blackwater Bank, and Arklow N.), one from Tuskar, several from Rockabill, one from Innishtrahull (stritiing), one from Eagle Island, one from Blackrock (Mayo), and one from Tearaght. [The Blackwater Bank specimen, as mentioned above, was received.] In April, two occurrences at light-ships (Blackwater Bank and Arklow N.), and three instances of Robins striting (Maidens and Innishtrahull), are noted; while a western light-keeper (Straw Island, Co. Galway) reports on April 11, 1883, "two Robins passing island for shore." The latest spring record of a Robin on Tearaght bears date April 30; the latest on North Arran, April 9 ; and a comparison of the dates of different April occurrences round the coast, shows that three-fourths of them were during the first twelve days of that month, after which we may take it that the maximum spring migration is over. In May the only notes are from Howth Baily, Rockabill, and Innishtrahull; at the first of these a bird is said to have struck on the 26th. June yields no records, and July none from the east coast, but during this month some are reported as visiting South Arran, Rathlin O'Birne, and the Bull Rock; at South Arran four are said to have been "killed" (? striking) at 9 P.M.

${ }^{1}$ At Coningbeg Light-ship, December 29, 1890. 
Robin. on July 1, 1883. The earliest evidence of autumnal migration on the east coast is at Rockabill, August 10, 1889; and during the latter half of August there are records from Barrels Rock Light-ship, Tuskar (striking), Rockabill, Maidens, and Rathlin (striking). September yields 17 occurrences and 7 instances of striking, these last being all in the E. and N.E., from Tuskar to Innishtrahull. A "great rush of birds" at the Tuskar on September 21 and 22,1892 , is said to have included Robins, with Thrushes, Larks, "Redwings," "Chiffchaffs," Wheatears, Whitethroats, Wagtails, and Swallows-a strange medley of summer and winter visitors if rightly identified. Towards the end of September the Robin begins to be more frequently noted from western stations-e.g., Slyne Head, September 21, 1S90, and Tearaght, September 29, 1890, as if re-seeking his winter quarters; and on October 8, 1894, the light-keeper on Mew Island (east coast) reports that "a Robin Redbreast has arrived here; it comes every year about this time, and roosts in the same place, under a ladder-shed." The October occurrences are but slightly more numerous than those noted in September, and the cases of striking are four, three in the S.E. (Hook Tower, Tuskar, and Blackwater Bank Light-ship) and one at the Maidens; three occurrences at the Fastnet, in different years, are recorded for dates betrveen October 20 and 27, and amongst other stations at which the bird is reported in October are Rockabill, Innishtrahull, Tory Island, Blaclirock (Mayo), Arran N., and Skelligs. The November instances, though fewer, show that migration continues throughout the month, including, as they do, one killed striking at Rockabill, November 1, 1891 [received]; "seven killed striking" at the Fastnet, November 2, 1883; one seen at the Tuskar, November 5,1886 ; one at the Skelligs ("first seen" for some years), November 9,1885 ; three passing Blackwater Bank Light-ship, November 10, 1897; a number at South Arran, November 13, 1887 ; one at North Arran ("first seen this season "), November 20, 1888; and one on deck of ArkJow North Light-ship, November 29, 1885. This is the latest clearly migrational record, except the bird seen about Coningbeg Light-ship at the curious date of December 29, 1890.

The period of the Robin's spring migration thus seems to extend from February 5 to May 26, and that of its autumn 
migration from August 10 to November 29-periods of 110 Robin. and 111 days respectively. In no single year, however, have the earliest and latest spring occurrences been farther apart than 80 days (February 24 to May 16, 1890), or the earliest and latest autumnal occurrences than 65 days (August 29 to November 2, 1883).

Dividing each month of the spring and autumn migrations into three periods, the following table gives the number of occurrences for each on the south, east, north, and west coasts respectively.

Spring Migration of the Robin.

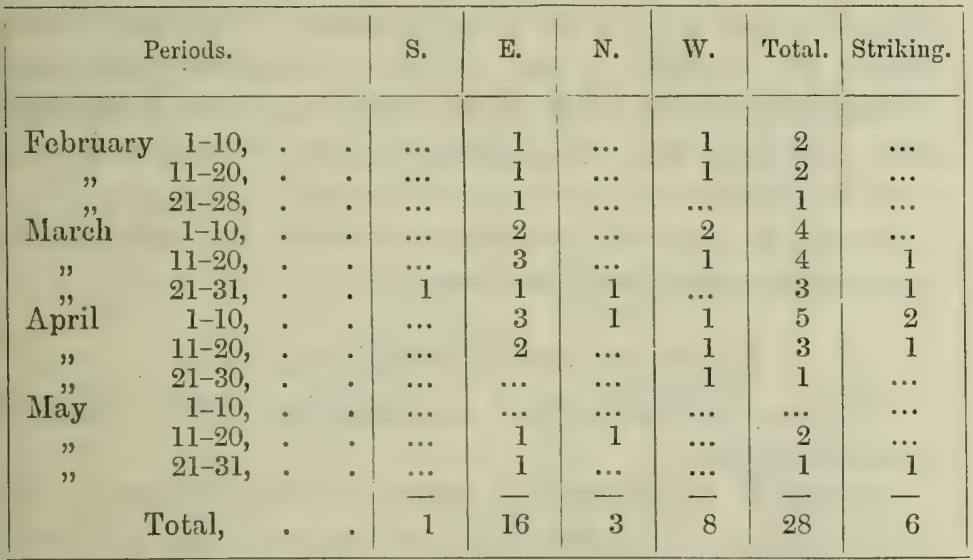

Autumn Migration of the Robin.

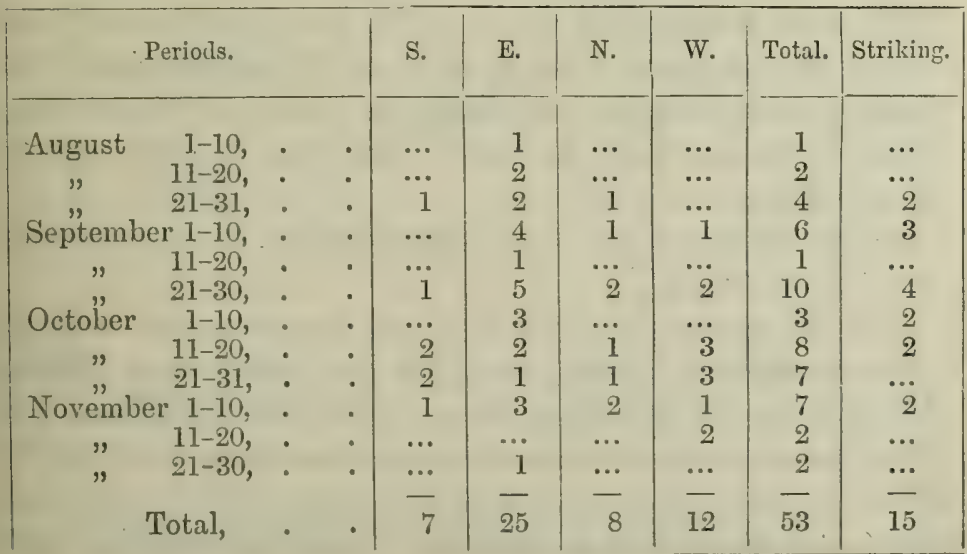


Robin. The period of maximum spring migration, according to these figures, includes the first ten days of April, and probably runs from about March 12 to April 12. The main period in autumn covers the last ten days of September, and seems to extend from September 20 to October 20.

Adding spring and autumn together, we find that of 80 occurrences during the months of regular migration, 41 are from the east coast, 20 from the west, 11 from the north, and 8 from the south. The southern occurrences are mostly in autumn, otherwise the proportions for the two seasons do not greatly vary on the different parts of the coast. No case of striking a lantern is reported during either period from the west. We may therefore take it that the western islands are reached by an overland route, and that their visitants are chiefly birds whose home is on the Irish mainland. It is at any rate clear that those islands receive an accession in winter.

Two wings received measure respectively 3.05 and 2.93 , the autumnal example being the longer.

RedstaRt (Ruticilla phoenicurus, Linn.).

Redstart. Has been obtained almost annually since 1886, chiefly on spring migration.

The case of the Redstart presents a marked contrast to that of the Robin. The latter is so common as to be universally familiar, yet the specimens received from light-stations number only two. 'The Redstart, on the contrary, is so rare that until 1885 , when its nest was first found in Ireland, it was accounted a mere straggler to our shores, yet the light-keepers have within thirteen years (1886-98) forwarded as many as 17,-four being from Ulster, nine from Leinster, three from Munster, and one from Connaught.

Of the 17 occurrences thus authenticated, 12 were in spring and 5 in autumn.

There is evidence that the bird has been observed on twelve other occasions in spring, and in a few instances in autumn; but as several of the observations were made at stations from which no specimen has been sent, and others were on dates considerably earlier or later than those of any proved occurrences, they must be treated as doubtful. Exception may be made, 
however, in favour of what is evidently the first record of a Redstart. Redstart at an Irish light-station, viz., that embodied in the "Report" for 1883, p. 8, under "General Remarks of Lightkeepers":- "Innishtrahull, April 30th. A small bird, with an orange tail, name unknown, struck, not killed." The observer was Mr W. H. James. In 1883, not enough was known of the Redstart's visits to justify a conjecture that the strange bird was Ruticilla phonicurus; but that it was so may now be considered beyond doubt, specimens having been sent from the same station, and within a few days of the same date, in three different years, on May 5, 1896, April 28, 1897, and April 26, 1898.

One remarkable fact appears on comparing the spring and autumn migrations.

Twelve specimens received in spring are all from stations in the castern half of Ireland, which includes Innishtrahull; but of five received in autumn four are from the western half.

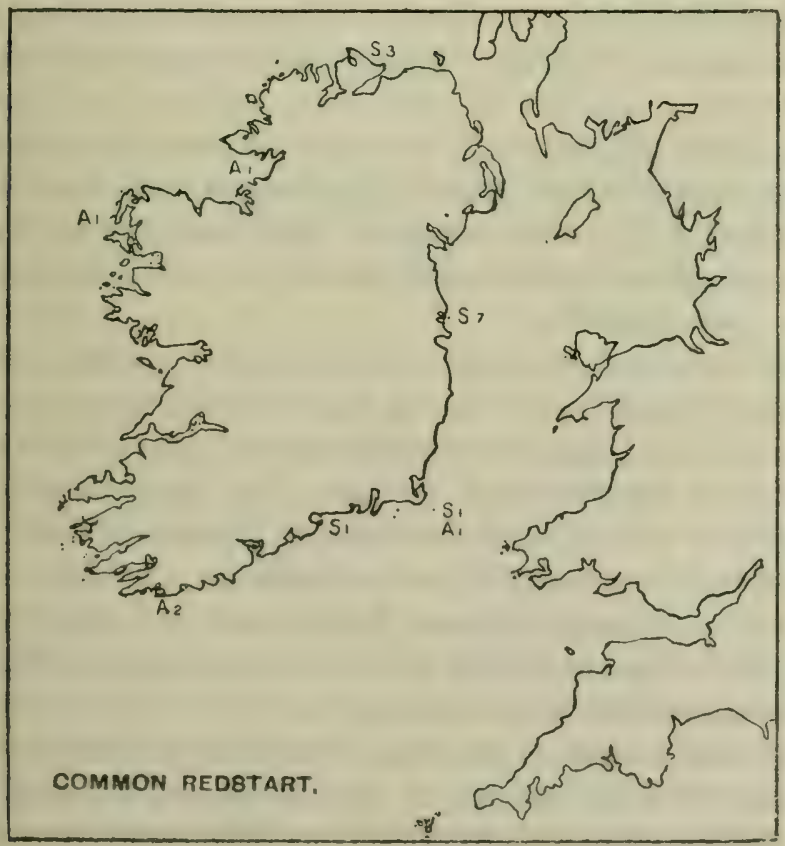

S $7=$ Seven specimenis forwarded in spring ( $\Lambda$ pril 23 to May 11 ).

A 2=Two

autumn (September 7 to November 7). 
Redstart. Seven (i.e., more than half) of the spring specimens are from Rockabill, an island off the Dublin coast, the remainder being contributed by Innishtrahull (Co. Donegal), Tuskar (Co. Wexford), and Dungarvan (Co. Waterford). Both the earliest and latest are from Rockabill.

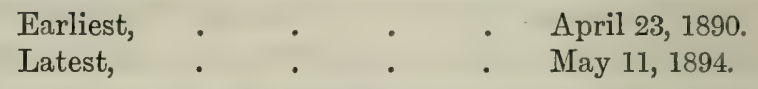

Seven were obtained in the last eight days of April, and five in the first eleven days of May. The spring movement thus seems to be characterised by more than the average punctuality, and an observance of definite flight-lines.

The autumnal instances, though only five in number, are spread over more than three times as long a period as that in which the twelve spring occurrences took place.

$\begin{array}{llll}\text { Earliest, } & \text {. } & \text {. } & \text { September 7, } 1895 \text { (Fastnet). } \\ \text { Latest, } & \text {. } & \text { - } & \text { November 7, } 1891 \text { (Killybegs). }\end{array}$

Three of the five, however, were obtained between September 7th and 13th, raising at least a presumption in favour of the earlier half of September as the time of principal autumnal movement.

At Rockabill, where, if anywhere on the Irish coast, the species should be well known, light-keepers have reportecl it as scen on July 12, 1886, August 26, 1887, and August 26, 1894. That emigration should begin towards the end of August seems prima facie probable.

The November specimen was caught in a swamp, and the date and circumstances favour the view that it was rather an exhausted straggler from abroad than a bird which had not yet set out on its autumnal voyage. The occurrence suggests comparison with that of the Spotted Flycatcher killed at the Tuskar in November 1897, and may also be parallel to the cases of the Pied Flycatcher, Lesser Whitethroat, and other "summer migrants," whose autumnal visits to our light-stations have yet to be satisfactorily explained.

- The only specimen received from an east coast station in antumn was killed striking at the Tuskar, September 11, 1896. The most westerly occurrence was at Blackrock (Mayo), where one was shot, September 13, 1891, the year in which the November bird was caught at Killybegs, also on the west coast. 
Seven (possibly 9) of the 12 received in spring, and 3 of the 5 obtained in autumn, struck the lanterns, but there has been no instance of this at a west coast station. Two of the whole number (17) are known to have been shot; and 3 were caught, from which it is probable that they were more or less exhausted.

As already remarked under Ring-Ouzel, this species has never been received from a light-ship. An interesting case of three almost simultaneous occurrences took place in 1897, when one (an adult male) struck at Dungarvan, April 27th; one at Innishtrahull, either 27 th or 28 th; and one at Rockabill on the 28th.

Of nine wings measured, average length is 3.04 ; longest, 3.12 ; shortest, 2.97 ; difference between extremes, 0.15 ; percentage of variation, 5 .

\section{Black Redstart (Ruticilla titys, Scopoli).}

Like the preceding species, the Black Redstart has been shown by this inquiry to be one of our regular visitants. It

Black Redstart. was formerly accounted a straggler, though known to be of more frequent occurrence than Ruticilla phonicurus.

The first observations of this bird reported from lightstations were in the autumn of 1883 , when it was seen at the Skelligs (October 13), Tearaght (October 27), and Dungarvan (November 13). The first specimen was sent from the Skelligs, November 13, 1884. For five consecutive years (1884-S8) examples were obtained every autumn, the whole number received during that period being 14, of which 1 occurred in spring. Since 1888, 13 further examples have been forwarded, 2 in spring, 11 in autumn. The whole number (to November 30,1899 ) is thus $27 ; 24$ in autumn, 3 in spring. The number of instances in which it seems to have been observed, but was not obtained, exceed 40 .

The Black Redstart's visits are chiefly to our south coast, inclusive of the southern extremities of the east and west. It has once been obtained on the E. coast as far north as Rockabill (November 21, 1885), but in that instance it was shot. There is evidence that on the W. coast it has three times been observed at Blackrock, Mayo, and perhaps once or twice at Slyne Head, Co. Galway; but the northernmost western station 
Black from which a specimen has been received is the Tearaght, Co. Redstart. Kerry, to which it is evidently a frequent visitor. It has struck the lantern in only three counties, Kerry, Cork, and Wexford.

The stations most favoured are apparently the Fastnet (which has sent 6 specimens), Skelligs (5), and Tuskar (5). The small strip of coast S. of lat. $52^{\circ}$ has furnished 14 , while all the rest of Ireland has only furnished 13, of which 12 were obtained between $52^{\circ}$ and $53^{\circ}$.

Total for S. ${ }^{1}$ coast,

" E. "

" "N. "

" "W. "

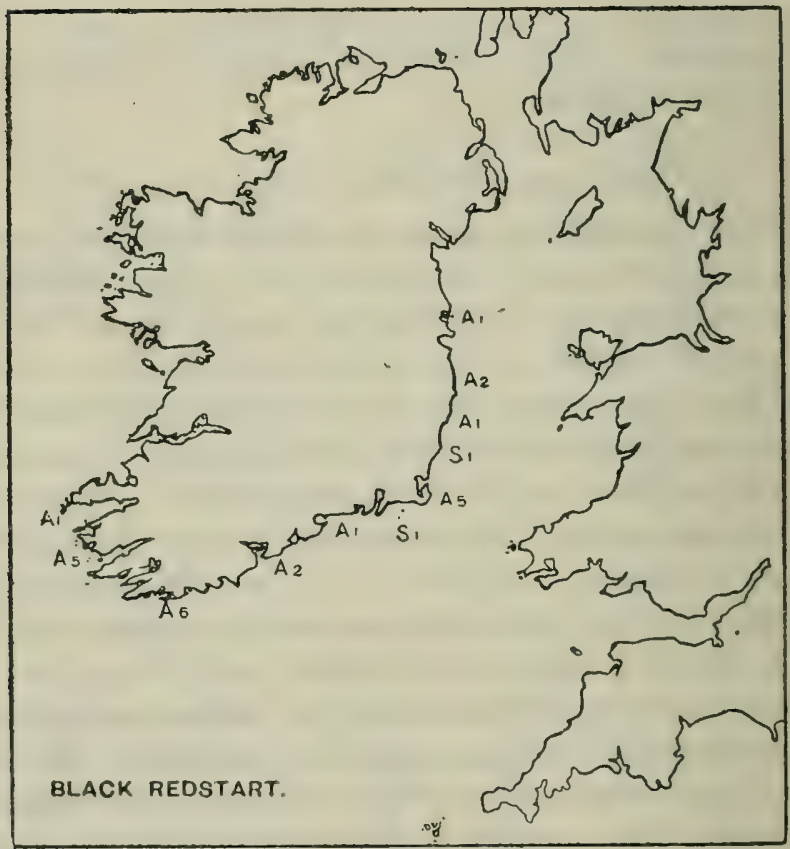

A $5=$ Five specimens forwarded in autumn (October 13 to November 21).

$\mathrm{S} 1=$ One specimen , spring (March 16 to 18).

Of 24 specimens obtained in autumn, 14 occurred in October and 10 in November.

Earliest,

October 13, 1897, November 21, 1885,

Fastnet. Rockabill.

Latest, November 21, 1885,

1 The "S. coast" extends only from Fastnet to Barrels Rock; but if from T'earaght to Tuskar were its limits, instoad of 11 there would bo 22 specimens. 
The latest date of striking is November 16, 1898 ('Tuskar), but three were shot in 1885 almost simultancously-Skelligs (November 18), Mine Head (November 18), and Rockabill (November 21).

The usual period of arrival appears to be the last fortnight of October, during which 13 specimens have been sent. Of those obtained in November, 2 were killed or found dead in the first week, 2 in the second, and 6 in the third.

The earliest reported autumnal example occurred at the Fastnet, October 1, 1888; but as the Common Redstart was sent from that station so late as October 5 in 1887, some uncertainty must be felt as to which species was observed in 1888. The next earliest was one noted at Skelligs, October 3, 1896. The latest reported arrival was at the Tearaght, November 28, 1885; unless, indeed, four birds seen at the Skelligs, January 6,1889 , can be set down as recent immigrants.

The three spring specimens were all obtained in the third week of March. Only two of them were migrating:-

One at Blackwater Bank Light-ship, March 16, 1899.

One at Coningbeg Light-ship, March 18, 1899.

The paucity of spring occurrences is similar to what has been observed of other autumnal visitants. The Redwing, Fieldfare, and Black Redstart are each represented on spring migration by two specimens. It is a curious fact that both the Black Redstarts in spring, like both the Redwings, occurred at light-ships; whereas in autumn the former species has only once, and the latter rarely, been received from that kind of station.

To what date the Black Redstart remains in this country is a question on which the Migration Reports throw little light. A specimen seems to have been observed at Blackrock (Mayo) on March 28, 1887. One is reported from Fastnet on April 12 of the same year, but it is impossible to say whether this was an early occurrence of the Common or a late one of the Black species. The same remark applies to other "Redstarts" observed in the first half of April. So-called "Black Redstarts" noted in May and July may safely be referred to R. phonicurus; and the latter seems the more likely of the two to have been seen at Tearaght, April 27, 1888.

The present species has once struck in company with the 
Red-breasted Flycatcher (Arklow S. Light-ship, October 23, 1887), once with the Ring-Ouzel and Gold-Crest (Tuskar, November 1897), and once with the Thrush, Fieldfare, Blackbird, Lark, and Jack Snipe (Tuskar, November 10, 1898). It probably often migrates in small parties of its own kind, since groups of 5, 10, and 20 have been noted from Tearaght and Skelligs, and occurrences of 2 together are frequent. Instances of simultaneous occurrence at different stations are not rare; the most noteworthy case of this happened on October 19 and 20,1887, when it was observed-for the first time that autumn-at four different island-stations:-Fastnet, 1 caught roosting, October 19 [received]; Skelligs, 1 shot, October 20 [received]; Tearaght, 10 noted, October 20,1 shot [received]; and Slyne Head, a bird probably of this species reported, also on October 20.

Females and young evidently form a large majority of the migrants, and only once has an old male been forwarded (Rockabill, November 21, 1885).

It would appear that this bird more frequently dies from exhaustion than from striking the lantern. The data as to how 27 specimens were procured are as follows:-

\begin{tabular}{|c|}
\hline Shot, \\
\hline Killed or caught striking, \\
\hline Died from exhaustion, \\
\hline Caught exhausted, \\
\hline Found dead (on island-rocks), \\
\hline Caught roosting, . \\
\hline Caught in house, \\
\hline
\end{tabular}

The data as to 15 Common Redstarts considerably differ:-

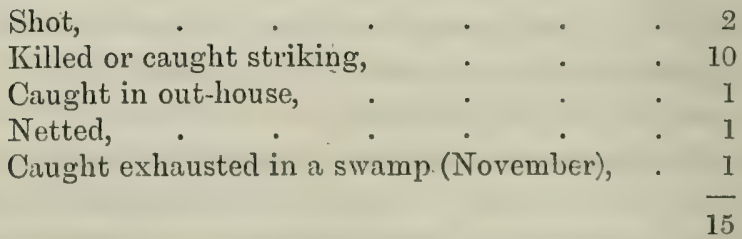

Of 22 wings measured, 13 were obtained in October, and average $3 \cdot 34$ (nearly), while 7 obtained in November average $3 \cdot 30$. The 2 obtained on spring migration both measure $3 \cdot 30$ 
exactly. The shortest wing exceeds the longest of the Common Redstart by $\cdot 05$.

Average length of wing, $3 \cdot 32$; longest, 3.55 ; shortest, $3 \cdot 17$; difference between extremes, 0.37 ; percentage of variation, $11 \frac{1}{2}$.

Stonechat (Pratincola rubicola, Linn.).

The Stonechat is very seldom correctly named by lightkeepers, who usually term the Wheatear, and sometimes the Whinchat, "Stonechat"; while the Stonechat has in most cases, when forwarded, been sent as either an "unknown bird" or a "Blackcap." The latter name is unfortunately also applied to at least three other species-the Reed Bunting, Great Titmouse, and Sylvia atricapilla.

From specimens forwarded, it appears that in spring the Stonechat has struck at the Tuskar, Blackwater Bank Lightship, Arklow North Light-ship, Kish Bank Light-ship, South Rock Light-ship, and Innishtrahull.

Earliest, February 17, 1899, Arklow North Light-ship.

Latest, April 4, 1896, Innishtrahull.

Nine examples have been obtained from the above six stations, all on the east and north coasts. Three struck in February, five in March, and one in April. Seven of the nine occurred between February 17 and March 18, a period of thirty days, which may be taken as the month of maximum spring migration. It is remarkable that as many as seven are from light-ships.

Only two have been obtained on autumn migration, both from the south coast:-
Earliest,
Latest,
October 20, 1887,
November 7, 1891,
Fastnet.
Hook Tower.

All the above (except three found dead) were killed striking.

Nine specimens (shot or trapped) have been sent in winter, and the fact that one of these was shot at Innishtrahull, January 10, 1892, during very severe weather, while five were canght in a "crib" the same day at Killybegs (both stations in Donegal), possibly indicates that some local movement had taken place.

There is no evidence as to the direction of flight. It seems

Stonechat. 
Stonechat. probable that the spring-killed examples were immigrants, since the species is more numerous in summer than in winter. For the same reason, it is natural to suppose that the two autumnal specimens were emigrants, though the fact of a departing bird striking at a land-station is not easily explained.

Several reported "Whinchats" probably belong to this species-e.g., at Innishtrahull, April 16, 1888; Blackrock (Mayo), February 15, 1889; and Codling Bank Light-ship, April 18, 1895; but unverified observations of either of these birds possess very little value.

Average length of wing, 2.64 ; longest, 2.72 ; shortest, 2.57 ; difference between extremes, 0.15 ; percentage of variation, $5 \frac{1}{2}$.

\section{Whinchat (Pratincola rubetra, Linn.).}

Whinchat. Except on migration, the Whinchat is almost unknown throughout the southern half of Ireland, while breeding locally in most of the northern counties; but of 15 specimens (spring, 12 ; autumnal, 3) received from light-stations, 11 are from the southern, and 4 from the northern half of the coast.

$$
\begin{aligned}
& \text { Earliest in spring, . } \\
& \text { Latest } \quad \text {. } \quad \text {. May 25, 1892, }
\end{aligned}
$$

both at Blackwater Bank Light-ship, Co. Wexford. With the exception of these two, all the spring examples were killed in the first half of May. Divided into weeks, the spring records are,-

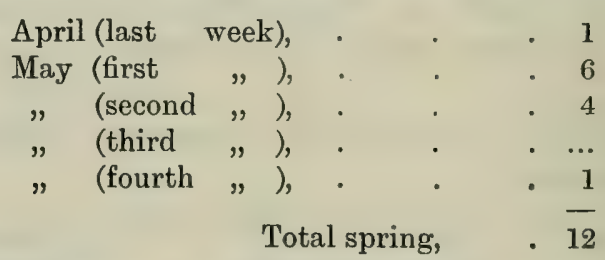

The stations whence the above were received are,-

West Coast (South Arran and Tearaght),

South Coast (Coningbeg Light-ship),

East Coast (Tuskar, Blackwater Bank Light-ship, Arklow S. Light-ship, and Rockabill).

The northernmost occurrence in spring was at Rockabill, where three were killed striking, May 4, 1889; and the northernmost occurrence on the West Coast took place almost simultaneously (May 2, 1889) at the south island of Arran. Next 
to these two, the most northerly instance in spring was at Whinchat. Arklow South Light-ship, also on May 4, 1889.

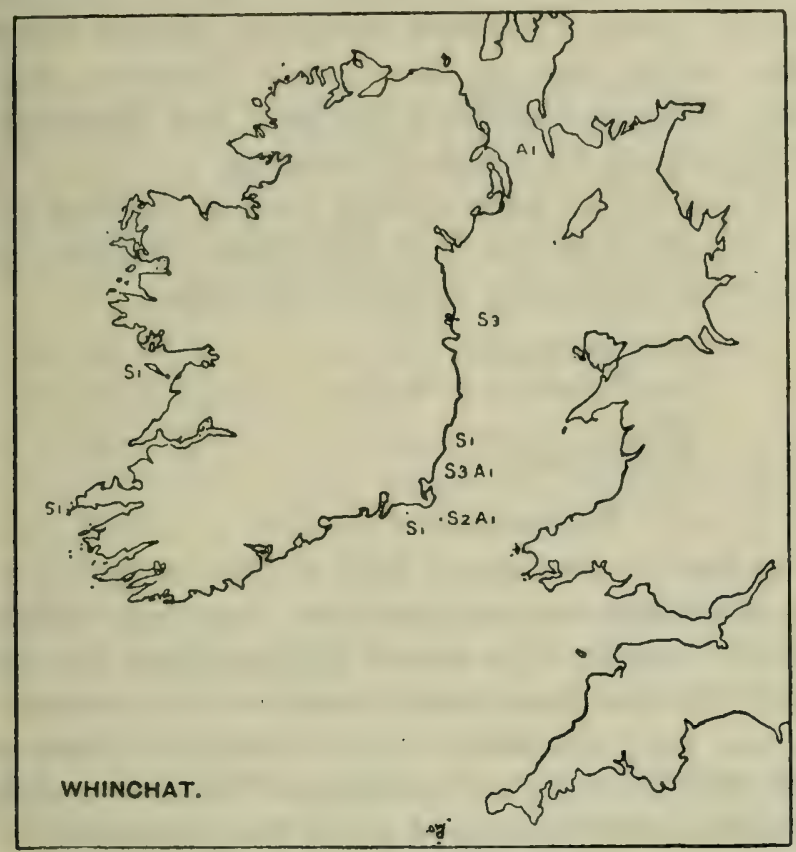

S $1=$ One specimen forwarded in spring (April 29 to May 25).

$A 1=\quad$ " $\quad$ " autumn (September 4 to November 9 ).

The autumnal occurrences, only three in number, were at Tuskar, Blackwater Bank Light-ship, and Mew Island. This last, off the Down coast, is the northernmost light-station from which the bird has been received, and the date, like that of the three most northerly instances in spring, is 1889 .

Earliest autumnal specimen, received September 4, 1889, Mew Island. Latest " " killed striking, November 9, 1890,

Blackwater Bank Light-ship.

This last was clearly exceptional, happening in a rush of birds in which a Sedge Warbler and Whitethroat were also killed. Two of the three Whinchats killed in autumn were received during the first half of September; and inasmuch as it is unusual to find either the Whitethroat or Sedge Warbler in Ireland so late as October, it is scarcely credible that the 
Whinchat. three birds killed together at Blackwater"Bank on November 9, 1890, had remained in the country to that date.

The number of normal autumnal occurrences is thus reduced to two,-a further illustration of the fact already sufficiently manifest in the cases of the Spotted Flycatcher, Redwing, Fieldfare, Common and Black Redstarts, and Stonechat, that few birds strike at the season of departure.

No Whinchat has been received from a mainland station. Six of the specimens are from light-ships, nine from islands. With few exceptions, they had struck the light.

Killed striking, .

Found dead (on light-ship),

Shot,

Without data,

Total spring and autumn,

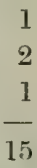

As to observed occurrences, there is little to be said except that a few of them are not improbable. The first "Whinchat" mentioned from a light-station (Tuskar, May 25, 1885)though at the time provisionally placed under Stonechat-may have been correctly named. A "Stonechat" seen at the Fastnet, May 22, 1891, was possibly a Whinchat; and Whinchats have several times been noted from Rockabill in May, when they are more likely to occur on migration than Stonechats or Wheatears. On September 19, 1895, Whinchats are mentioned amongst "very large flocks" of birds striking at the Tuskar during a N.E. wind and mist-Warblers, Wagtails, and Ring-Ouzels being also included; and while the only specimen sent on that occasion was a Yellow Wagtail, there is some probability that the Whinchat was really amongst the number.

That this bird migrates in rather mixed company is shown by the large number of other species which have been received with it. On six occasions, its associates, killed striking, have been as follows:-

.1. (Tuskar, May 9, 1888): Wheatear, Sedge Warbler, and Grasshopper Warbler.

2. (Arklow S. Lt.-ship, May 4, 1889): Sedge Warbler, Whitethroat, and Willow Wren.

3. (Rockabill, May 4, 1889): Sedge Warbler, Whitethroat, Willow Wren, House-Martin, and Cuckoo, 
4. (Blackwater Bank Lt.-ship, Nov. 9, 1891): Sedge Warbler and Whitethroat.

5. (Tuskar, Sept. 11, 1896): Ring-Ouzel, Redstart, and Chiffchaff.

6. (Blackwater Bank Lt.-ship, May 11, 1899): Sedge Warbler, Whitethroat, and Garden Warbler.

Here we have 11 species, all summer visitants, and the Yellow Wagtail above-mentioned possibly makes a twelfth. It is very remarkable that no winter visitant, "partial migrant," or bird of double passage within the British area, has struck in company with the Whinchat; and that, even on the unusual date of November 9, its associates should have been the same birds (Sedge Warbler and Whitethroat) which most commonly accompany it in spring.

The shortest Whinchat's wing received exceeds the longest Stonechat's by 0.125 inch. In all the specimens examined, the distinction given in "Saunders's Illustrated Manual" (pp. 28 and 30) holds good, the third primary being longest in the Whinchat, the fourth in the Stonechat. The legs of the two species are distinguishable by a comparison of the small feathers on the tibia, these in the Whinchat's case being dull white, and in the Stonechat's fuscous brown.

Average length of wing, 2.98 ; longest, 3.10 ; shortest, 2.85 ; difference between extremes, 0.25 ; percentage of variation, $8 \frac{1}{2}$.

WheATEAR (Saxicola cenanthe, Linn.).

The date of the earliest observed Wheatear has varied in different years from the 1st of March in 1884 to the 21st of that month in 1896 , or perhaps to the 31 st in $1883 ;{ }^{1}$ but the first arrival is generally reported between March 8 and 18 . The birds are observed passing throughout the whole of April, and in most years some have been reported in May, the latest spring date recorded being May 26 (Tearaght, 1883, and Tuskar, 1884), unless we include a bird said to have struck at Innishtrahull at the remarkable date of June 11, 1894. The spring migration has thus in some years extended over more than twelve weeks; but it may be doubted whether any of the

'There is a record, dated March 1, 1883, from Clare Island, Co. Mayo, to which some importance has been attached, in view of the meteorological conditions then prevailing (see "Digest of Migration Reports," British $\Lambda$ ssociation, Liverpool Mecting, 1896, p. 24); but the observation is isolated and uncor. roborated, the next entry being thirty days later. 
wheatear. Wheatears arriving after the third week of April remain to breed in Ireland, since these are probably en route for a more northerly summer habitat.

Slight autumnal movements have been noticed as early as July 19 (Samphire Island, 1896), and single birds have several times been reported passing light-ships and rocks between the 28th and 31st of that month. From about August 10 to the last week of September, migration seems to be fairly continuous, but, as in other cases, comparatively few specimens are sent at the season of departure. There is evidence that the Wheatear occasionally strikes up to the end of October, and in three instances it is said to have been observed between the 1st and 5 th of November (at Tearaght, Skelligs, and Innishtrahull); but a record from the Tuskar, dated December 23, 1889, is too improbable to be accepted, the specimen not having been secured.

The extreme dates on which specimens have been obtained are,-

Spring $\left\{\begin{array}{lll}\text { Earliest, } & \text { March 15, 1887, } & \text { Tuskar. } \\ \text { Latest, } & \text { May 9, 1888, } & \text { Tuskar. }\end{array}\right.$

Autumn $\left\{\begin{array}{l}\text { Earliest, August 5, 1899, Codling Bank Light-ship. } \\ \text { Latest, }\end{array}\right.$

The whole number of specimens forwarded amounts to 88, of which 71 were obtained in spring and 17 in autumn, omitting one found dead, but not freshly killed, on Tearaght, July 29, 1890. March has furnished 14 specimens; April, 55; May, 2 ; August, 8 ; September, 6 ; and October, 3.

Dividing each month of migration into three periods, the number of specimens and of reported occurrences for each ten days are as follows:-

Spring.

Periods.

$\begin{array}{crcc}\text { March } & 1-10, & \cdot & \cdot \\ " & 11-20, & \cdot & \cdot \\ \text { April } & 21-31, & \cdot & \cdot \\ " 1-10, & : & \cdot \\ " & 11-20, & \cdot & \cdot \\ \text { May } & 21-30, & \cdot & \cdot \\ " & 1-10, & \cdot & \cdot \\ " & 11-20, & \cdot & \cdot\end{array}$

Reported Specimens.
Occurrences.

\begin{tabular}{rrr}
. & 7 & $\ldots$ \\
. & 28 & 5 \\
. & 45 & 9 \\
. & 62 & 34 \\
. & 55 & 13 \\
. & 32 & 8 \\
- & 17 & 2 \\
. & 7 & $\ldots$ \\
. & 4 & $\ldots$ \\
\hline & 257 & 71
\end{tabular}


Autumn.

\begin{tabular}{|c|c|c|c|c|c|}
\hline \multicolumn{2}{|c|}{ Periods. } & & & $\begin{array}{l}\text { Reported } \\
\text { Occurrences. }\end{array}$ & Specimens. \\
\hline July & 1-10, & . & & . $\quad \ldots$ & $\ldots$ \\
\hline$"$ & 11-20, & . & & 2 & $\ldots$ \\
\hline & 21-31, & - & & 6 & ... \\
\hline August & 1-10, & . & & 7 & 2 \\
\hline$"$ & 11-20, & . & & . 16 & 2 \\
\hline & 21-31, & . & & 13 & 4 \\
\hline Septembe & r $1-10$ & . & & • 16 & 2 \\
\hline$"$ & 11-20, & . & & 18 & 2 \\
\hline & $21-30$ & . & & 21 & 2 \\
\hline October & 1-10, & . & & 8 & 1 \\
\hline$"$ & 11-20, & . & & 4 & - \\
\hline & 21-31, & . & & 3 & 2 \\
\hline Novembe & $1-10$ & . & & 3 & $\ldots$ \\
\hline$"$ & 11-20, & . & & . $\quad \ldots$ & $\ldots$ \\
\hline$"$ & 21-30, & - & · & $\cdot \quad \ldots$ & $\cdots$ \\
\hline & & & & 117 & 17 \\
\hline
\end{tabular}

From the above figures it may be concluded that the spring migration is at its maximum in the first ten days of April. There is no equally marked maximum period in autumn, the specimens being too few ; but from the light-keepers' observations it would appear probable that the latter half of September is the time of most movement.

As might be expected, the observations relating to this species range round the whole coast, as the Wheatear breeds on many of the western islands and in the vicinity of most of the lightstations; but an overwhelming majority of the specimens (83 per cent. of the whole number) have been sent from the east coast, the proportions being,-

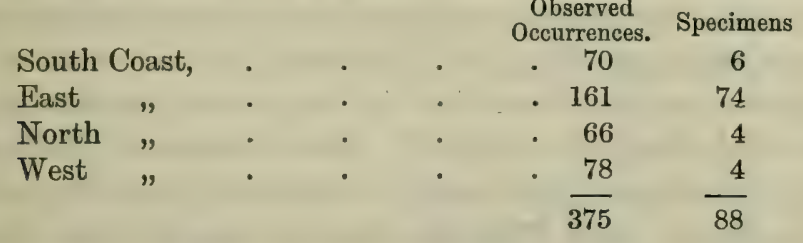

The number of light-ships on the east coast may in part account for the large number of specimens which it yields, for the Wheatear, like the Thrush, seems to strike most numerously at floating stations. Fifty-six of the examples forwarded are from light-ships, 29 from islands, and 3 from the mainland. Arklow South Light-ship has the highest 
Wheatear. record of all our stations, furnishing 23 specimens, while its neighbour light-ship, Blackwater Bank, comes second with 16 . In observations, however, Tuskar stands first, reporting more occurrences than Blackwater Bank and Arklow South Lightship together, while Innishtrahull approaches it pretty closely, the observations from these two stations being respectively 57 and 53, though Tuskar has sent only 10 specimens and Innishtrahull only 4.

At the western stations there are remarkably few references to the birds striting, and this is especially the case north of Tearaght-i.e., on the line of coast from Samphire Island to Aranmore. At these stations it is probable that most of the observations relate to birds which breed in the vicinity, and have arrived by an overland flight, when they are less likely to strike the lanterns. In a few instances, however, Wheatears have been noted striking at Aranmore, South Arran, and Blackrock (Mayo). For spring there are three such records, of which one was at Aranmore, dated May 12, 1887, and another at South Arran in 1889, when the birds were noted on several nights (between April 26 and May 1), as if passing in considerable numbers; and one specimen, killed striking April 28, was received. The third was at Blackrock (Mayo), also on April 28, 1889. It will be observed that these are late spring occurrences. In autumn there are also two instances of striking, one at Blackrock (Mayo), August 16, 1891, and one at Aranmore, September 8, 1885. These both belong to the earlier half of the autumnal migration period.

It appears unlikely that any Irish-breeding Wheatears would be seeking their summer homes at so late a date as April 2S, to say nothing of May 12 . On several of the western islands light-keepers have from time to time noted the date on which this bird "arrives to build." From Aranmore there are six such records, and they range in date from March 18 to April 3. From Slyne Head there are also six, ranging from March 17 to April 1. These afford evidence enough to show that the Wheatear is not much later in its arrival on the west coast of Ireland than elsewhere in the British Isles. This being so, it would seem to follow that the birds striking our west coast lanterns at the end of April are passing northward beyond the British area. The return of such birds might be expected 
at an early date in autumn, and the two autumnal west coast specimens are in accordance with such expectation.

The foregoing remarks are not intended to convey that the west coast constitutes a special route for the more northerly voyagers, for equally late movements are noted on other parts of the sea-board, and probably belong to the same migration. The distinguishing feature of the western stations appears to be that the Irish-breeding birds do not strike there, while the lanterns of the east are struck, we may presume, both by the Irish and by the more northward-bound migrants.

The records from Innishtrahull are interesting by reason of its position as the northernmost Irish light-station, combined with the curious fact that Wheatears are reported to have struck the light there in each of the nine months from March to November. Thirty-five cases of striking are reported from this station, while only 29 are noted from Tuskar, the station which yields the largest total number of migrational occurrences. The dates of a few Innishtrahull records (November 5, 1883; June 11, 1894; and July 20, 1894) are primâ facie somewhat improbable; but having regard to the general tenor of the evidence, and the station's geographical position, the conclusion seems to be warranted that this island is a main point of arrival and departure for birds migrating between Ireland and some more northern region, not necessarily farther away than the Outer Hebrides. An analysis of the Innishtrahull and Tuskar records (of striking birds only) yields an interesting contrast in two particulars.

(1) In spring, Tuskar has more records than Innishtrahull; in autumn, Innishtrahull has more than Tuskar-

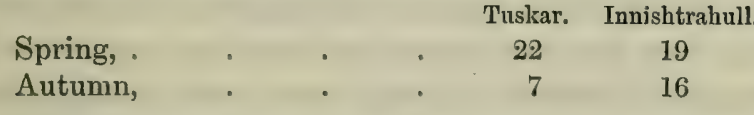

In fact, the spring records at Tuskar treble the autumnal, while at Innishtrahull the two seasons almost balance one another.

(2) In spring, most of the Tuskar birds strike before April 10 ; most of the Innishtrahull birds, after :-

Before April 10, After April 10,
Tuskar. Innishtrahull.

17

5

14 
Wheatear. In both the above points, the observations from Tuskar are representative of those from Ireland generally, while Innishtrahull witnesses proportionally more of the late spring migration, and receives a larger number of birds from over sea in autumn.

Most years have furnished instances of nearly simultaneous arrival at different parts of the coast, the more remarkable having been in $1883,1885,1888,1891$, and 1897 . In 1883, five western and south-western stations-Aranmore, Rathlin O'Birne, Slyne Head, Straw Island, and Galley Head-reported the first Wheatears between March 31 and April 5. In 1885, Tearaght, Fastnet, and Tuskar reported the bird's arrival between March 14 and 16. In 1888 it was noted between March 29 and April 1 at Mine Head, Coningbeg Light-ship, Tuskar, Blackrock (Mayo), and Slyne Head. In 1891 Tuskar reported Wheatears in extraordinary numbers from April 1 to 9 , and between those dates they were also noted arriving or striking at seven other stations, of which four east coast light-ships (Lucifer Shoals, Blackwater Bank, Arklow South, and South Rock), with Howth Baily and Innishtrahull light-houses, were struck between the nights of the 5th and 7th. Again, in 1897, the nights of March 28 to 30 are marked by Wheatears striking the lanterns at Tuskar, Blackwater Bank Light-ship, Rockabill, and Innishtrahull. Of the small group of northern stations, Innishtrahull and Rathlin have twice announced the arrival of the Wheatear simultaneously (April 28, 1883, and April 13, 1885); and in 1892 it was reported from Innishtrahull and Tory Island, the two northernmost light-houses, on April 8 and 9. These co-incident arrivals are not only interesting in themselves, but useful as corroborating the light-keepers' testimony in those instances where specimens are not forwarded.

Since the Whentear is one of the most numerous of our summer migrants, and has also a remarkably extended migration period, it is not surprising that it should have struck, at different times, in the company of a great number of different species. Those which have been killed and forwarded with it are :-

In March-Blackbird, Black Redstart, Starling, Curlew.

In April-Willow Wren, Chiffchaff, Gold-Crest, Lark, Swallow, Sand-Martin, Brambling. 
In May-Whinchat, Sedge Warbler, Grasshopper Warbler.

In August-Sedge Warbler, Willow Wren.

In September-Whitethroat, Willow Wren, Chiffchaff, Pied Wagtail, Titlark, Skylark, Quail.

In October-Ring-Ouzel, Wren, Goldfinch, Siskin.

The birds reported along with it also include the Thrush, Redwing, Fieldfare, Robin, Redstart, and Chaffinch, besides several others which are very unlikely to have been correctly identified.

Great rushes, inclusive of the Wheatear, have been reported both in spring and in autumn, such occurrences in spring being apparently limited to the east coast of Wexford (represented by the Tuskar, Blackwater Bank, and Arklow South Light-ship); while in autumn the stations from which they have been noted are the Fastnet and Tuskar. The most remarkable spring rush occurred at the last-named station, April 1 to 9, 1891. "After over twenty years' service," says the light-keeper (Mr John Hamilton), "I never saw so many birds collected together; they resembled a swarm of bees more than anything else, they were in such numbers. We could not open the balcony door, as they could not be kept from getting into the lantern." Six species of birds-Thrush, Redwing, Blackbird, Ring-Ouzel, Wheatear, and Starling-are mentioned as having been caught and identified, but it is stated that the present species was the most numerous. Legs and wings of a Wheatear, Chiffchaff, Lark, and Brambling were received. Equally curious are some of the autumnal medleys; e.g., at Tuskar, September 22, 1892, when the birds forwarded were the Wheatear, Whitethroat, Chiffchaff, Pied Wagtail, Meadow Pipit, Lark, and Quail (and Redwings and Robins were reported); and at Fastnet, October 30,1897 , when, together with the present species, a RingOuzel, two Wrens, a Goldfinch, and two Siskins were sent, and innumerable Thrushes, Redwings, Blackbirds, and Chaffinches are said to have struck and fallen into the sea.

Of 81 wings measured, 64 were obtained in spring, and average $3 \cdot 76$, which is very slightly more than the measurement given in "Saunders's Manual" (3.75) for the wing of the male bird; but the 17 obtained in autumn average 3.87 . So decided a difference strengthens the presumption that the birds which strike in autumn are largely composed of individuals breeding farther north, while of those striking in spring, only 
wheatear. a small percentage have their breeding-homes elsewhere than in Ireland.

In spring, the earlier wings have a greater average length than the later-

30 before April 7 average 379 .

30 after April $7 \quad, \quad 3 \cdot 73$.

In autumn the reverse is the case-

8 in July and August average $\mathbf{3 7 8 4}$.

9 in September and October average 3:950.

The spring figures, being based on a larger number of specimens, are more satisfactory than the autumnal ones, and it is noteworthy that of the five longest wings obtained in spring, four were received late (April 17 to May 8), notwithstanding which fact the average length of the later wings is less than that of the earlier. There is, therefore, nothing in the above figures inconsistent with the view that the longest-winged birds are journeying farther north than Ireland, and that these arrive somewhat later than most of the Irish-breeding Wheatears. It is also remarkable that none of the five longest wings above referred to occurred on the Wexford coast, from which twothirds of the whole number of specimens have been received. On the other hand, of the seven shortest wings obtained at the same season, five are from Wexford stations, and the whole seven are from the Dublin, Wicklow, and Wexford sea-board.

The wings from the west and south-west (Mayo, Galway, Kerry, and western Cork) yield, as a group, peculiarly large measurements. Only seven have been received from that part of the coast, and their average length is 3.932 , which is nearly 15 more than the average for the species. This is not due to their being principally received in autumn, for three in spring average 3.89 , which is 13 in excess of the average spring measurement, and four in autumn average 3.96 , which is 09 in excess of the average autumnal measurement.

Average length of wing, 3.78 ; longest, 4.15 ; shortest, 3.52 ; difference between extremes, 0.62 ; percentage of variation, $16 \frac{1}{2}$.

Sedge Warbler (Acroccphalus pluragmitis, Bechstein).

Sedge

Of all our summer visitants, the Sedge Warbler is the bird Warbler. which strikes most numerously at Irish light-stations, the next 
commonest being the Whitethroat, Wheatear, and Willow Wren. A table showing the number of specimens received of each of these four species, and of the Chiffchaff, at each of the two seasons of migration, is annexed :-

\begin{tabular}{|c|c|c|c|c|}
\hline Wheatear, & & $\begin{array}{c}\text { Spring. } \\
71\end{array}$ & $\begin{array}{c}\text { Autumn. } \\
18\end{array}$ & $\begin{array}{c}\text { Total. } \\
89\end{array}$ \\
\hline Sedge Warbler, & & 87 & 55 & 142 \\
\hline Whitethroat, & & 87 & 22 & 109 \\
\hline Willow Wren, & & 65 & 17 & 82 \\
\hline Chiffchaff, . & & 17 & 5 & 22 \\
\hline
\end{tabular}

From this we may fairly conclude that the total numbers in column three give a misleading idea of the Sedge Warbler's numerical superiority. On spring migration its numbers, if measured by the specimens, exactly equal those of the Whitethroat; but in autumn they nearly equal those of the Wheatear, Whitethroat, and Willow Wren added together. The Sedge Warbler is, in fact, an altogether exceptional case of a bird which strikes the lanterns at its season of departure in numbers not very far inferior to those noted at time of arrival, the proportions being about three occurrences in spring to two in autumn.

The proportions in which the above five birds have been received in different years are far from constant. Thus, during the fourteen consecutive years 1886-1899, the species most numerously received in spring has three times $(1889,1891$, and $1894)$ been the Wheatear; twice (1888 and 1892), the Sedge Warbler; three times (1886, 1890, and 1899), the Whitethroat; and four times (1887, 1896, 1897, and 1898), the Willow Wren; while in the two remaining years (1893 and 1895) the numbers for two or more species were equal. In 1890, again, the Wheatear was the least numerously received of the four predominant species; whereas in the following year (1891) its forces exceeded those of the other three added together. The variable character of these statistics proves the necessity for the extended series of annual observations before us, and the caution needed in coming to any positive conclusion from limited data. The fluctuation is, however, much less marked in autumn than in spring. The Wheatear has once, the Whitethroat once, the Willow Wren once, and the Sedge Warbler seven 
times, been the most numerously received bird at the season of departure.

None of the Warblers are distinguished with precision by the light-keepers, and in dealing with this group of birds the specimens forwarded are practically the only clue to dates of arrival or departure.

The following are the extreme dates in the Sedge Warbler's case :-

Spring, Earliest specimen, April 24, 1890, Rockabill.

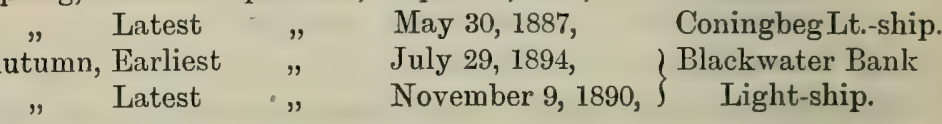

Or, discounting as abnormal the November occurrence, we may take as our latest example of the regular autumnal migration a bird killed at Tuskar, October 6, 1887.

The above figures show that the spring migration extends over thirty-seven days, the autumnal over seventy.

Dividing the thirty-seven days of spring migration into three nearly equal periods, the specimens received in each were as follows :-

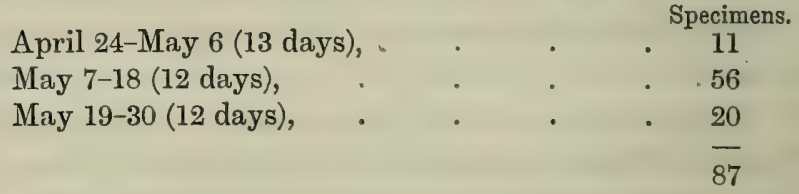

The spring movement is thus clearly at its greatest density about the 12th of May. Qnly five specimens were received in April.

Dividing the seventy days of autumnal migration into five equal periods (each of fourteen days), we find the maximum period not less strongly marked.

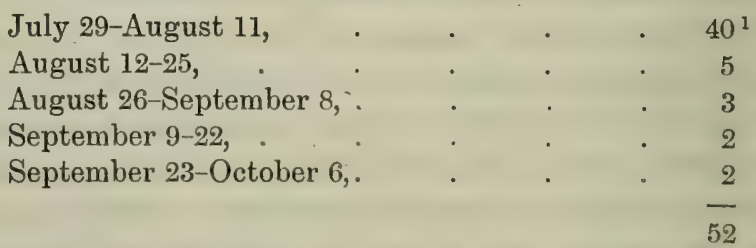

Adding the November bird, and two undated specimens, to the number killed later than the first fortnight, we obtain

i Twenty of these in one rush at Tuskar, August 10-11, 1890. 
as a net result the fact that 73 per cent. of the Sedge Warblers received in autumn were killed prior to the 12 th of August, showing a singularly early period of departure for this species.

The number of specimens contributed by each section of the coast, in spring and autumn, is as follows :-

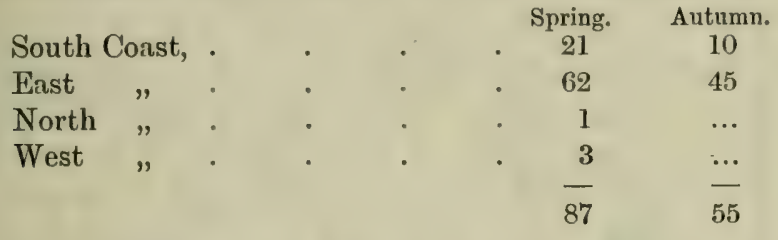

The only northern and western stations from which the Sedge Warbler has been received are Innishtrahull and Killybegs (Donegal) and the two Arran Isles (Galway). Each of these has sent one specimen. We have no autumnal examples from the north and west, and the four spring birds struck at rather late dates, between the 17 th and 24 th of May.

The spring movement does not, however, seem to include the whole of the south coast, nor the autumnal movement the whole of the east coast. The following is a synopsis of the specimens according to counties, subdivided for spring and autumn:-

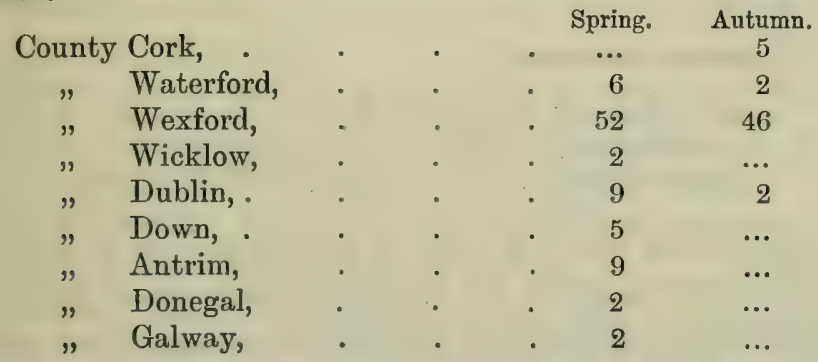

The most northerly occurrence in autumn was at Rockabill, Co. Dublin; the most southerly in spring at Mine Head, Co. Waterford. On the other hand, Innishtrahull, the northernmost Irish station, has sent a specimen in spring, and Fastnet, the southernmost, has sent several in autumn. In fact, if a line be drawn from Mine Head to South Arran, it will be found that all the Sedge Warblers received in spring were killed on, or to the north-east of that line; whereas if one be drawn from Fastnet to Rockabill, it will be found that all the 
autumnal specimens were killed on or to the south-east of that

Warbler. line. Two lines so drawn will cut one another practically at right angles, the western angle facing that portion of the coast from which the present species has not been forwarded either in spring or autumn, i.e., West Cork, Kerry, and Clare.

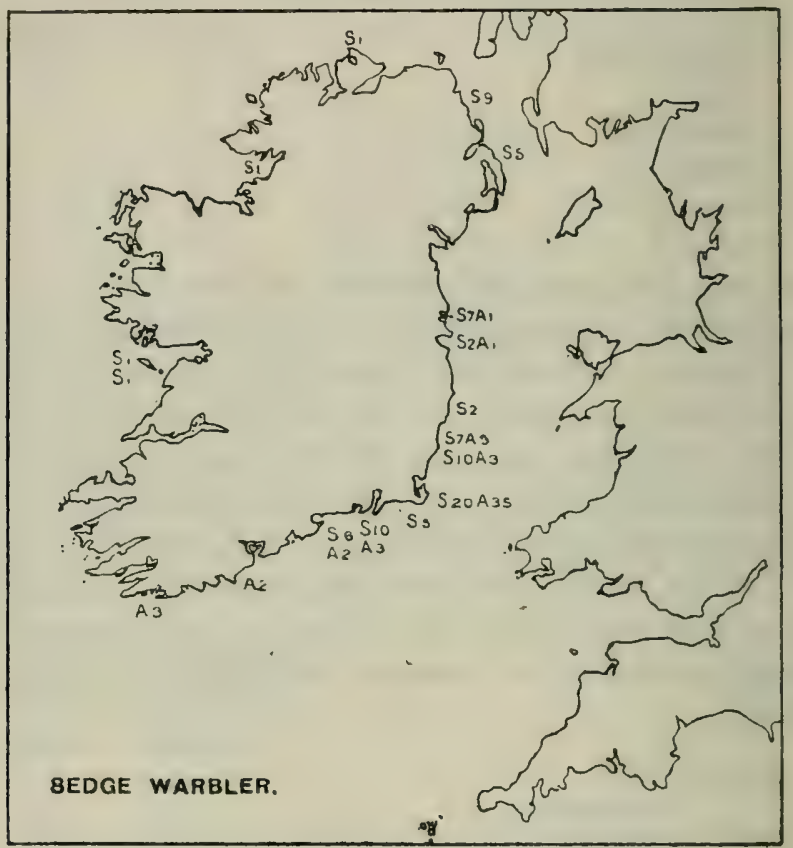

S 10=Ten specimens forwarded in spring (April 24 to May 30).

A $1=$ One specimen , , autumn (July 29 to November 9).

Partial as the Sedge Warbler is at both seasons to the southeast coast, it is not, like the Wheatear, much given to striking at light-ships. Only 32 of the specimens have been received from that kind of station, while 83 are from islands, and 27 from the mainland. This makes it the more remarkable that the bird has never been received from such stations as the Tearaght and Skelligs, from which nearly all our common summer visitants, and many rare stragglers, have been received. ${ }^{1}$

\footnotetext{
1 Tearaght alone has forwarded the Spotted, Pied, and Red-breasted Fly. catchers, Whinchat, Wheatear, Whitethroat, Lesser Whitethroat, Blackeap, Willow Wren, Yellow-browed Warbler, Woodlark, Swallow, Sand-Martin, Turtle Dove, Land-Rail, and Spotted Crake. Besides many of these, the Golden Oriole, Ring-Ouzel, and House-Martin have been sent from Skelligs.
} 
Sedge Warblers often strike simultaneously at many points along the coast. To note only some instances:-On May 9 and 10, 1886, specimens were forwarded from Mine Head, Tuskar, and Rockabill; on May 9 and 10, 1888, from Mine Head, Coninglueg Light-ship, and Tuskar; on May 8-10, 1890, from Hook Tower, Arklow South and North Light-ships, Mew Island, and Maidens; on May 23-24, 1892, from Hook Tower, Blackwater Bank Light-ship, Arklow South and North Lightships, Howth Baily, and Maidens; and on May 16-18, 1893, from Hook Tower, Mew Island, Maidens, and Killybegs. As the autumnal movement is almost limited to the Wexford coast, the coincidences are less remarkable. Rushes occurred at Tuskar and Arklow South Light-ship, August 9-10, 1888; and at Hook Tower and Tuskar, August 10-11, 1890; while several were killed at Tuskar and Blackwater Bank Light-ship, July 29-30, 1895.

The large flocks of "Warblers," "Wrens," "Flycatchers," "Titmice," etc., which are frequently reported as around the lanterns, appear to be chiefly-though by no means whollycomposed of this species, with the Whitethroat and Willow Wren, in proportions varying according to the season.

In all the great spring rushes of the present species it has been accompanied by the Whitethroat; but in its principal autumnal rushes, occurring as they do in the earlier part of August, the Whitethroat is not known to have ever participated. In September, however, the Whitethroat and Sedge Warbler are again sometimes found travelling together; and, as mentioned under Whinchat, they have struck simultaneously at so late a date as November 9 .

Altogether, the Whitethroat has been sent with the Sedge Varblex 20 times (18 spring occurrences, 2 in autumn); with the Willow Wren, 12 times (9 spring, 3 autumn); with the -Whinchat, 5 times (4 spring, 1 autumn); with the Grasshopper Warbler, 4 times (3 spring, 1 autumn); with the Blackcap, twice (1 spring, 1 autumn); with the Wheatear, twice (1 spring, 1 autumn); with the Garden Warbler, Redstart, Wren, House-Martin, Sand-Martin, Cuckoo, Ringed Plover, and Snipe, each once in spring; and with the Woodchat Shrike, Spotted Flycatcher, Chiffchaff, and Corn-Crake, once in autumn. 
The most interesting peculiarity of the Sedge Warbler is perhaps its liability to strike the lanterns in autumn, for in this particular it is, as already stated, a marked exception to the general rule.

Of our summer migrants generally it may be said that not more than 20 per cent. of their occurrences at lanterns are autumnal. This, at first sight, may appear singular, when it is borne in mind that the birds themselves, after the season of reproduction, are probably much more numerous in autumn than in spring; but three reasons present themselves, either of which may in part account for the disproportion.

1. Birds can choose their own weather for starting on a journey, not their weather for arriving. Hence they are less likely to be bewildered by fogs and storms on the coast they are quitting than on that towards which they travel.

2. The lights are always visible from the seaward side, whereas many of them are obscured either wholly or partly on the landward side.

3. Birds that migrate by night probably start in the evening, while some light remains. The earlier they set out, the less likely is it that they will strike the lanterns of the coast they are leaving, since this would only occur after dark.

Why, then, should the Sedge Warbler so far differ from the rest that 40 per cent. of the specimens are in its case autumnal?

Obviously, the first two reasons suggested above as to why birds should not strike when departing applies as well to the Sedge Warbler as to any other species. But it is not equally clear that the third does. The creature is notoriously semi-nocturnal in its habits, its song being often heard at hours when scarcely a vestige of light remains; and it may be that the "Irish Nightingale" sets out on its southward journey at a. later hour of the evening than most other migrants. This, if established, would account for its striking at the season of departure more numerously than the rest.

'From the measurements of 102 wings (55 being of birds killed in spring and 47 in autumn), it appears that at both seasons the earlier wings have a slight superiority in average length. 
In spring-

29 earliest (April 24 to May 10) average . . . 256

26 latest (May 11 to 30 ) . . . . 2.53

In autumn-

20 earliest (July 29 to August 10) average . . 2 250

26 latest (August 11 to November 9) " . . 2 248

There is, however, a much greater difference between the lengths of the spring and autumn wings than between the earliest and latest at either season.

55 in spring average $\quad . \quad . \quad . \quad . \quad 255$

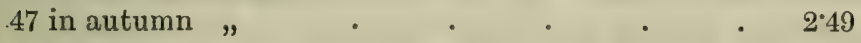

Only four specimens were weighed, and they averaged 161 grains, and varied from 144 to 175 grains, the heaviest being an autumnal specimen, while the others were obtained in spring.

Average length of wing, 2.51 ; longest, 2.70 ; shortest, 2.37 ; difference between extremes, 0.32 ; percentage of variation, 13 .

\section{Grasshopper Warbler (Locustelle noevia, Boddaert).}

Locally distributed in small numbers in Ireland, the Grass- Grasshopper hopper Warbler is seldom received from the light-stations. Warbler. The whole number of specimens forwarded within the past fourteen years amounts to nine, of which eight were obtained on spring migration and one in autumn, and all occurred in different years except two which struck at the Tuskar, April 14, 1898.

Both the earliest and latest examples in spring were killed at the Tuskar-

$\begin{array}{llllll}\text { Earliest, } & \text {. } & \ddots & . & & \text {. April 14, 1898, } \\ \text { Latest, } & . & . & . & & \text {. May 9, 1888; }\end{array}$

while the only autumnal specimen struck at Hook Tower, another Wexford Station, August 10, 1890.

Though styled by Mr Seebohm "one of the last batch of spring migrants".("British Birds," p. 342), the Grasshopper Warbler does not seem, from the Irish light-station records, to be a late bird in reaching our shores. Five of the eight specimens received in spring struck lanterns during the week ending April 20; and of the seven years in which it has been 
Grasshopper sent at that season, the Grasshopper Warbler has in three been Warbler. received before the first Whitethroat, in five before the first Sedge Tarbler, in two with the first Whitethroat, in two with the first Sedge Warbler, in two after the first Whitethroat, and in none after the first Sedge Warbler. Since it is incomparably the scarcest bird of the three, these figures admit of no other interpretation than that it is also the earliest to arrive.

As with the Sedge Warbler, the Grasshopper Warbler shows a marked predilection for the Wexford coast, all but two of the specimens having been sent from either Tuskar Rock or Hook Tower in that county. Of the two exceptions-both in spring -one was caught on board Arklow North Light-ship, Co. Wicklow, and the other killed striking at Mew Island, Co. Down. The bird's range on spring migration thus seems rarely to extend over more than the southern half of the east coast, while in autumn it has only been received from the extreme south of Co. Wexford.

Except the bird caught on Arklow North Light-ship, all the examples obtained were killed striking lanterns.

The birds which have been received with this species are :-

(In April) Whitethroat, Willow Wren, and Chiffchaff.

(In May) Wheatear, Whinchat, Sedge Warbler, Whitethroat, Willow Wren, and Cuckoo.

(In August) Sedge Warbler.

The Willow Wren appears to be its most usual fellowtraveller, having been sent with it four times. This bird has only once been forwarded alone, and, as in the Whinchat's case, all the species which have been received with it are regular summer visitants to the British area.

Average length of wing, 2457 ; longest, 2.600 ; shortest, 2.375 ; difference between extremes, 0.225 ; percentage of variation, $9 \frac{1}{2}$.

\section{Whíethroat (Sylvia cinerea, Bechstein).}

Whitethroat. That the Whitethroat is generally a little earlier than the Sedge Warbler in maling its appearance is shown by the fact that of twelve years in which specimens of both were received in spring, the Whitethroat was first in eight, the Sedge Warbler in three, and the two birds simultaneous in one. 
The dates of the earliest and latest Whitethroats received whitethroat. have been as follows:-

$\begin{array}{lll}\text { Earliest in spring, } & \text { April 5, 1889, } & \text { Copeland (Mew) Island. } \\ \text { Latest " } & \text { May 28, 1892, } & \text { Innishtrahull. } \\ \text { Earliest in autumn, } & \text { August 12, 1893, } & \text { Tuskar. } \\ \text { Latest " } & \text { November 9, 1890, } & \text { Blackwater Bank Lt.-ship. }\end{array}$

The November occurrence has already been alluded to in treating of the Whinchat and Sedge Warbler. The Whitethroat is not known to have struck in any other instance at a later date than September 27, 1888.

This bird shares with the Sedge Warbler the distinction of being the commonest species at Irish light-stations on spring migration (see p. 61). At that season 87 specimens of each have been received, of which, in the Whitethroat's case, 10 had been obtained in April and 77 in May.

The principal influx of both species is a little before the middle of May.

In the 16 days from April 5 to April 20, the specimens received were 6

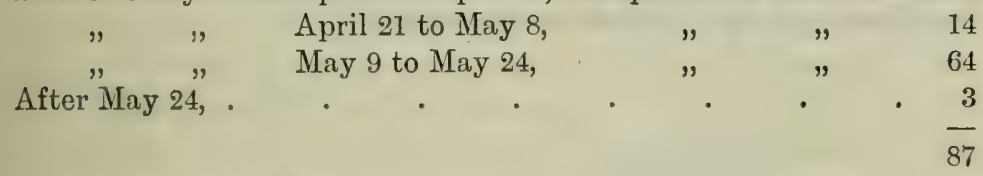

Of the 64 obtained in the third of the above periods, at least 38 , and probably 40 , struck between the 9 th and 16 th of May, while about 24 were killed between the 17 th and 24 th. The immigration would therefore appear to be at its greatest about May 12, which was also found to be the date of maximum spring migration for the Sedge Warbler.

Of the 22 birds obtained on autumn migration, 3 were killed in August and 17 (at least) in September, a leg and wing undated were received October 25, 1896, and one struck in November. August and September thus include practically. the whole period of this migration-

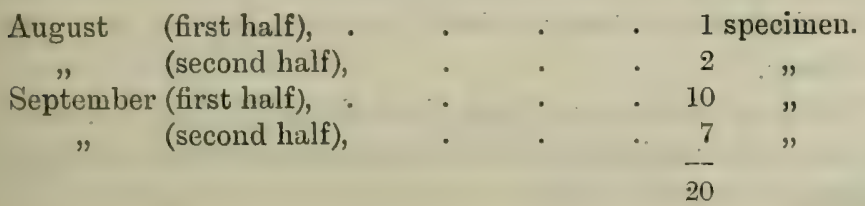


Whitethroat. The emigratory movement would seem to be at its maximum a month later than that of the Sedge Warbler, a contrast to what occurs in spring, when the date of maximum immigration is the same for both species.

The number of specimens from each section of the coast is as follows :-

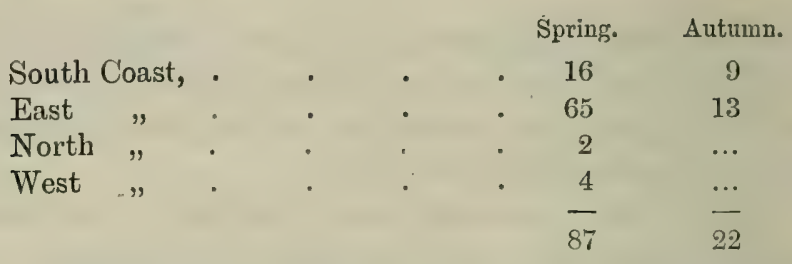

These figures are very similar to those found for the Sedge Warbler.

Grouping the specimens according to counties, we find that the Whitethroat has occurred round practically the whole coast in spring, but that in autumn, like the Sedge Warbler, it appears to be almost restricted to Cork, Waterford, and Wexford (particularly the last-named county).

\begin{tabular}{|c|c|c|c|c|c|}
\hline County & Cork, & . & . & 1 & 2 \\
\hline 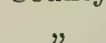 & Waterford, & . & . & 6 & 1 \\
\hline , & Wexford, & . & . & 52 & 18 \\
\hline , & Wicklow, & - & - & 2 & $\ldots$ \\
\hline " & Dublin, & • & . & 11 & . \\
\hline " & Down, . & . & - & 5 & 1 \\
\hline " & Antrim, & . & - & 4 & $\ldots$ \\
\hline " & Donegal, & - & - & 3 & .. \\
\hline "ᄆ & Galway, & . & . & 1 & . \\
\hline 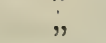 & Kerry, & . & . & 2 & .. \\
\hline
\end{tabular}

The stations from which this bird has been sent in spring include the northernmost, southernmost, and westernmost Irish islands-Innishtrahull, Fastnet, and Tearaght. At Fastnet it has also struck in the autumn, but the most northerly station from which it has been received at that season is Mew Island, Co. Down.

Thirty specimens are from light-ships, 58 from islands, and 21 from the mainland. The proportions differ at different seasons- 


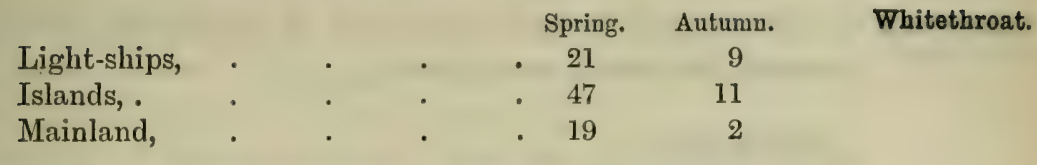

This is natural, as it appears prima facie improbable that a departing bird would strike before leaving the shore.

As evidence of simultaneous migration at different points along the coast, it may suffice to mention that on the nights of May 23-25, 1892, specimens were obtained striking at Hook Tower, Blackwater Bank Light-ship, and Arklow North Lightship; on May 14-16, 1893, at Hook Tower, Carlingford, and Killybegs; on April 28, 1897, at Hook Tower and Blackwater Bank; and on May 12, 1899, at Blackwater Bank and the Maidens; while in autumn the night of September 8, 1896, was similarly marked by Whitethroats striking at Fastnet, Coningbeg Light-ship, and Arklow South Light-ship.

In April the Whitethroat has been received in company with the Redstart, Wheatear, Sedge Warbler, Grasshopper Warbler, and Willow Wren; in May, with the Spotted Flycatcher, Whinchat, Sedge Warbler, Grasshopper Warbler, Garden Warbler, Willow Wren, House Martin, and Cuckoo; in September, with the Pied Flycatcher, Wheatear, Sedge Warbler, Willow Wren, Chiffchaff, Pied Wagtail, Titlark, Skylark, Corn-Crake, and Quail; and in November, with the Whinchat and Sedge Warbler.

The measurements of 45 wings obtained in spring show an average for that season of 2738 inches, while 20 obtained in autumn average $2 \cdot 750$.

Of the 45 obtained in spring-

$\begin{array}{llllll}24 \text { earliest average } & . & . & . & . & 2725 \\ 21 \text { latest }, & . & . & . & . & 2750\end{array}$

From this it would appear that the shortest-winged arrive first; but a division, according to months, gives a very different result,-

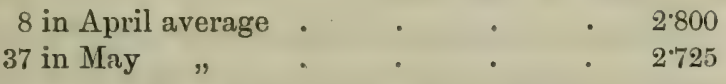

The wings obtained in the last half of May, 16 in number, show an average of 2740 , which is slightly greater than that 
Whitethroat of 21 obtained in the earlier half of the month (2.715), but decidedly below the average for April.

In autumn-

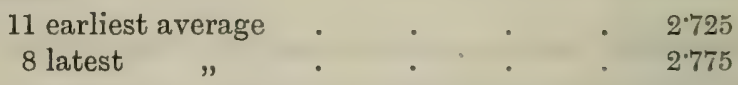

again showing some superiority in length to the later wings; but in this case the number of specimens is scarcely large enough to afford satisfactory evidence.

The weights of seven specimens (killed striking) which were received in the spring of 1899 varied from 187 to 215 grains, the heaviest being thus slightly less than half an ounce, and the lightest 12 grains heavier than the heaviest Sedge Warbler. The average weight was 200 grains.

Average length of wing, 2750 ; longest, 2.925 ; shortest, 2.625 ; difference between extremes, 0.3 ; percentage of variation, 11.

\section{Lesser Whitethroat (Sylvia curruca, Linn.).}

Lesser Whitethroat.

Two specimens from island light-stations, both stragglers on the autumnal migration, are the only examplés of this bird known to have visited Ireland.

Both occurred in October; one at our most westerly station (Tearaght), October 1, 1890, and the other at our most northerly (Innishtrahull), October 10, 1899.

With the exception of the Blackcap (a peculiar case, to be noticed subsequently), no Warbler which breeds in Ireland has ever been sent from a west coast station in autumn, and an occurrence of the Blackcap and Willow Wren together at Innishtrahull, September 27, 1892, is the only antumnal example from the north coast. The Lesser Whitethroat has straggled in autumn to the Orlineys (see "Saunder's's Manual," p. 43), and it seems not improbable that the Irish and Orcadian birds were of Continental rather than British origin.

The occurrence on the Tearaght, in October 1890, is of special interest, as during the same month three other remarkable rarities were forwarded from western light-stations-a Iellowbrowed Warbler (October 14) and Tied-breasted Flycatcher (October 20), both at the Tearaght, and a Short-toed Laxk 
(October 11) at Blackrock (Mayo). That these were Conti- Lesser nental visitors (from Europe or Asia) is evident, since none of Whitethroat. the three breed within the British Isles.

On neither of its two visits is there any evidence to show that the Lesser Whitethroat was accompanied by other birds.

The measurements of the wings were respectively 2.600 and 2.625 , and the weight of the longer-winged specimen was 150 grains.

Garden Warbler (Sylvia hortensis, Bechstein).

Although an undoubted migrant, the evidence as to the migration of this somewhat rare species is very scanty. Only

Garden Warbler. two specimens have been forwarded, one in spring and one in utumn. Both were killed on light-ships off the Wexford coast- $\begin{array}{ll}\text { Coningbeg Light-ship, } & \text { Oct. 4, } 1886 . \\ \text { Blackwater Bank Light-ship, . } & \text { May 11, } 1899 .\end{array}$

The first was travelling in company with other "small birds" which were not obtained. With the spring example were forwarded 7 Whitethroats, 3 Sedge Warblers, and a Whinchat, lilled striking on the same date; also 3 Whitethroats, 3 Sedge Warblers, and a Spotted Flycatcher, killed the previous night (May 10).

Unlike the preceding species, the Garden Warbler breeds (though only locally) in Ireland, and it is probably overlooked at the light-stations, being confounded with other Warblers which strike more numerously.

The autumnal specimen, of which only a leg and wing were forwarded, was probably immature, as the wing measured no more than 2.775 inches, and some difficulty was experienced in identifying it, but various well-known English ornithologists agree in referring it to the Garden Warbler. The Blackwater Bank bird was sent in the flesh, and its wing measures $3 \cdot 050$.

\section{Barred Warbler (Sylvia nisoria, Bechst.).}

Has once occurred at an Irish light-station.

An immature bird of this species was found wounded at Iiockabill, Co. Dublin, September 25, 1896. It was received in the flesh, and is the second example obtained in Ireland,
Barred

Warbler. 
Barred Warbler.

one having been shot in Co. Mayo by the late Dr Burkitt, September 24, 1884.

It is curious that in Scotland, as in Ireland, the Barred Warbler has been obtained twice, and that it occurred in the same years (1884 and 1896) in both countries; also, that in 1884 both the Scottish and Irish examples were shot, while in 1896 both were obtained at light-houses.

\section{BlaCKCAP (Sylvia atricapilla, Linn.).}

Blackcap.

The Blackcap is a singular instance of a spring visitant, which breeds in Ireland, but whose occurrences at Irish lightstations are chiefly autumnal.

The specimens received number eight, of which one was obtained in spring and six in autumn, while one was picked up dead on the mainland in winter.

The spring specimen was received May 23, 1892, from the Maidens Light-house, Co. Antrim. It is strange that no bird of this species has been forwarded in spring from any of our south-eastern stations.

Of the 6 autumnal specimens, 2 -struck in September, 3 in October, and 1 in November:

\begin{tabular}{|c|c|c|}
\hline ght, Co. Kerry, & & 86. \\
\hline Аауо, & & 31, 1886. \\
\hline Hook Tower, Co. Wexford, & & Nov. 7, 1891 \\
\hline ockabill, Co. Dublin, & • & Sept. 14, 1891. \\
\hline nishtrahull, Co. Donegal, & & Sept. 27, 1892. \\
\hline & & Oct. 15,1895 \\
\hline
\end{tabular}

The specimen received in winter was found dead on the 8th of December 1896, on the mainland opposite the Fastnet, and was forwarded by $\mathrm{Mr} \mathrm{E}$. Rohu, light-keeper at that station.

To analyse the September instances first. The earliest was at Rockabill, September 14, 1891. The station is on the east coast; the month is that in which it is agreed that most of the British Blackcaps depart; and the bird was apparently travelling with Sedge Warblers, since one of that species was found dead with it. A Sedge Warbler was also sent with the single specinen killed in spring. There is, therefore, every reason to consider this a case of ordinary emigration.

The second September instance was at Invishtrahull, September 27, 1892. A Willow Wren was received with this specimen. 
On no other occasion has any Irish-breeding Warbler been sent from a north coast station in autumn, and the most probable explanation of the occurrence is that these birds were travelling southwards from Scotland, and visited Ireland merely on passage.

Of the three October specimens, two occurred during the same autumn (October 1886), and both on islands off the western coast. These were forwarded alone. No other Irish-breeding Warbler has been received in autumn from the west coast, nor is it to be expected that any would choose it for a point of departure. The striking of these two birds at the Tearaght and Eagle Island light-houses in the autumn of 1886 rather suggests an influx at that season, especially when it is remembered that during the same autumn, specimens of the Pied Flycatcher were forwarded (September 21 and October 5) from the Tearaght and Fastnet. The case of this last-named bird is partly analogous, for it is a summer-visitant to Britain, yet has occurred only in autumn at Irish light-stations.

The remaining October example was killed at Blackwater Bank Lightship, October 15, 1895. This occurrence took place during a "great rush of Larks, Thrushes, Starlings, and "Warblers,'" of which many were reported as killed striking; and the other wings forwarded with the Blackcap's were those of a Thrush, Blackbird, and Skylark, all autumnal visitants.

The November bird struck at Hook Tower with a Redwing and Stonechat (November 7, 1891).

One, said to have been forwarded from the Tuskar, November 7, 1886, was not received, but the Hook Tower occurrence of the same date in 1891 renders it fairly probable that this identification was correct; though the birds reported as Blackcaps are generally Stonechats, and the name of "Blackcap" is also applied to the Great Titmouse and Reed Bunting. All the instances in which no specimens were sent have, therefore, to be treated as doubtful. Indeed, there are very slight grounds for referring any "Blackcap" observed in spring to Sylvic atricapilla.

It has long been a well-known fact that this species sometimes occurs in Ireland in winter. Thompson records 4 specimens obtained in December and 2 in January, besides 3 in November and 1 on the 1st of March, all between 1833 
Blackcap: and 1847. In subsequent years similar occurrences have been noted. Whether these were principally Irish-breeding individuals remaining through the winter, or winter immigrants, is a doubtful question; but the light-station data given above seem best to accord with the latter hypothesis, a view which is further supported by the fact of the bird being chiefly known in the Outer Hebrides, Orkneys, and Shetlands as an cuutumnal visitant ("Saunders's Manual," p. 47).

For the small number of specimens received, there is a remarkably large coast-distribution.

$\begin{array}{lllllll}\text { South Coast, } & \cdot & \cdot & \cdot & \cdot & \cdot & 2 \\ \text { East " } & \cdot & \cdot & : & : & \cdot & 3 \\ \text { North ": } & \cdot & \cdot & \cdot & \cdot & \cdot & 1 \\ \text { West " } & \cdot & \cdot & \cdot & \cdot & \cdot & 2\end{array}$

Only 1 was from a light-ship, 5 were from islands, and 1 (on migration) from the mainland. The remaining specimen was not killed at a light-station.

The other species received with the Blackcap have already been enumerated in treating of its occurrences separately.

Five wings measured show remarkably little variation, being all of lengths intermediate between those of the two Garden Warblers' wings received from light-stations.

Average length of wing, 2.84 ; longest, 2.87 ; shortest, 2.82 ; difference between extremes, 0.05 ; percentage of variation, $1 \frac{2}{3}$.

Wood Wren (Phylloscopus sibilatrix, Bechstein).

Wood Wren. Only one specimen has been received - from Blackrock (Mayo), where it was shot, May 27, 1890.

This is the only Warbler which was ever sent from Blackrock (Mayo).

That any summer migrants should turn up at this wild and remote station is sufficiently curious. It is a small, barren rock, somewhat over three acres in extent, situated nine miles from shore off the north-west section of the Connaught coast. Besides the Wood Wren, the only birds which have been received from this light-house in spring are a Greenland Falcon (shot, March 1884), a Titlark (caught striking, April 1890), and a Turtle Dove (shot, June 1857). With the exception of a Ringed Plover in July, and a Wren of unknown date, 
the other birds sent were all obtained in autumn, viz.-a Kestrel Wood Wren. (October 1890), Spotted Flycatcher (October 1889), Blackbird (November 1887), Redstart (September 1891), Gold-Crest (October 1899), Short-toed Lark (October 1890), Snow Bunting (September 1896), Chaffinch and Greenfinch (November 1887), Water-Rail (September 1898), Turnstone (November 1886), Fork-tailed Petrel (September 1892, November 1887, and its egg in August 1899), and Little Auk (December 1896). It is evident that a large proportion of these were stragglers.

The Wood Wren is so rare as an Irish-breeding bird that the scarcity of specimens is not surprising. The wing received is a short one, $2: 875$ inches.

Willow WreN (Phylloscopus trochilus, Linn.).

Of 82 specimens of the Willow Wren forwarded from light- willow stations, 65 were obtained in spring and 17 in autumn.

Wren.

Earliest in spring, April 7, 1894 (Blackwater Bank Light-ship). Latest " ".. May 22, 1887 (Coningbeg Light-ship).

Earliest in autumn, July 29, 1895 (Blackwater Bank Light-ship).

Latest " September 27, 1892 (Innishtrahull).

Of those received in spring, 44 were obtained in April, and 21 in May. The specimens whose full data are given are 63 :-

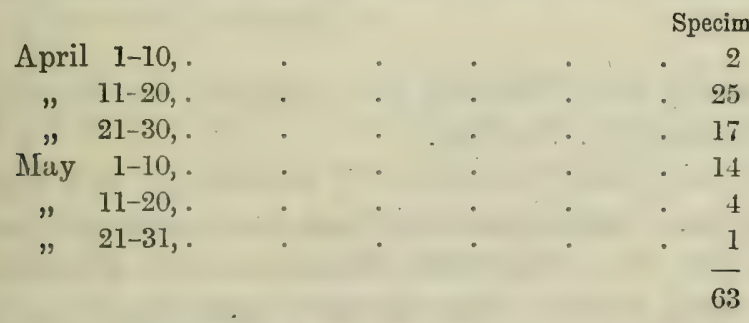

The period of greatest influx thus seems to be from April 11th to 20 th.

Of the autumnal specimens, 2 were sent at end of July, 9 in August, and 6 in September.

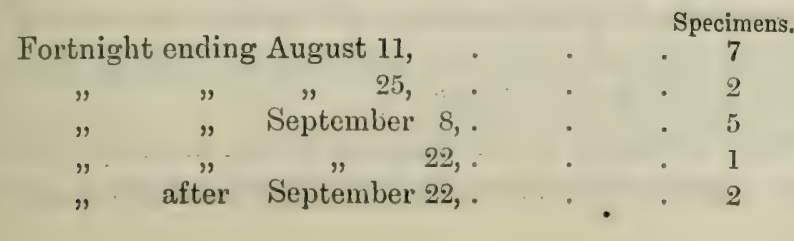


The principal exodus thus seems to accur early in August.

The coast-distribution of the specimens is as follows:-

\begin{tabular}{|c|c|c|c|c|c|c|}
\hline \multicolumn{2}{|c|}{ South Coast, } & • & & $\begin{array}{c}\text { Spring. } \\
10\end{array}$ & $\begin{array}{c}\text { Autumn. } \\
\mathbf{3}\end{array}$ & $\begin{array}{c}\text { Total. } \\
13\end{array}$ \\
\hline East & $"$ & ${ }^{-1}$ & . & 48 & 13 & 61 \\
\hline North &, & • & • & 5 & 1 & 6 \\
\hline West, & $"$ & - & • & 2 & ... & 2 \\
\hline & & & & 65 & 17 & 82 \\
\hline
\end{tabular}

It will be seen that the east coast yields 74 per cent. in spring and 76 per cent. in autumn. The 6 north coast specimens are all from Innishtrahull (Donegal), and the 2 west coast examples are both from Tearaght (Kerry). The following Table shows the distribution in counties :-

\begin{tabular}{|c|c|c|c|c|c|c|}
\hline \multirow{4}{*}{\multicolumn{3}{|c|}{$\begin{array}{l}\text { Cork, } \\
\text { Waterford, . } \\
\text { Wexford (south coast), } \\
\quad, \quad \text { (east coast), }\end{array}$}} & \multirow{2}{*}{\multicolumn{2}{|c|}{$\begin{array}{c}\text { Spring. } \\
1 \\
1\end{array}$}} & $\underset{1}{\text { Autumn. }}$ & $\begin{array}{c}\text { Total. } \\
2\end{array}$ \\
\hline & & & & & 1 & 2 \\
\hline & & & . & 8 & 1 & 9 \\
\hline & & & . & 28 & 10 & 38 \\
\hline Wicklow, & . & . & . & 2 & $\ldots$ & 2 \\
\hline Dublin, & . & . & . & 8 & 1 & 9 \\
\hline Down, & . & . & . & 4 & 1 & 5 \\
\hline Antrim, & . & . & . & 6 & 1 & 7 \\
\hline Donegal, & . & . & . & 5 & 1 & 6 \\
\hline Kerry, & . & . & - & 2 & $\cdots$ & 2 \\
\hline & & & & 65 & 17 & 82 \\
\hline
\end{tabular}

Considerably more than half the specimens at each season are therefore from Co. Wexford.

Light-ships have furnished 26, islands 42 , and mainlandstations 14. Tuskar stands highest for number of specimens, having sent 19; Blackwater Bank next, with 15; and Hook Tower third, with 8 . Thus the first three places are held by an island, a light-ship, and a mainland-station, all of which are in Co. Wexford.

Though received less numerously than either the Sedge Warbler or Whitethroat, this species sometimes occurs at the light-stations in great numbers, and in one instance (at Tuskar, April 29, 1892) the birds are said to have "looked like a snowshower in the rays of light."

When measured by the dates on which most specimens were killed striking, the time of the principal incursion seems to vary 
a good deal in different years. In 1894-the year in which the carliest specimen was received-it occurred in the first ten days of April. In 1890 the main movement would appear to have taken place between April 12th and 20th. In 1892 and 1897 it was still later-20th to 29 th.

The apparent variation in the time of influx is on examination found to be almost entirely due to the changes of the moon-the specimens forwarded being killed striking in the fourth and first quarters.

The other species received with the Willow Wren are 15 in number, of which 9 have been sent with it on spring migration only, 3 on autumnal migration only, and 3 at both periods.

In April-Redstart, Wheatear, Sedge Warbler, Grasshopper Warbler, Whitethroat, Chiffchaff, Swallow, Common Sandpiper.

In May-Ring-Ouzel, Redstart, Whinchat, Sedge Warbler, Grasshopper Warbler, Whitethroat, House-Martin, Cuckoo.

In July-Spotted Flycatcher, Sedge Warbler.

In August-Wheatear, Sedge Warbler.

In September-Wheatear, Blackcap, Whitethroat, Lark.

From the measurements of 61 wings obtained on spring migration, it appears that the longest-winged birds arrive first.

Of 30 earliest (before April 23), average length is 260 ,

Of 30 latest (after April 23), " "

a difference of 04 in favour of the earlier wings. But if the time of the immigration is divided into two equal periods of twenty-six days, the difference is more conspicuous.

Of 42 obtained in earlier period (April 7 to May 2), average is 2.6

Of 19 obtained in later period (May 2-28 ${ }^{\text {}}$ ), $2 \cdot 5$

The latest, shorter by 1 .

The measurements of 12 obtained in autumn vary in the opposite direction-

$\begin{array}{lll}6 \text { earliest (before August 20) average } & \text {. } & 2475 \\ 6 \text { latest (after August 20) } \quad 2 * 500\end{array}$

The same contrast appeared in the instances of the Wheatear and Whitethroat, but in each of these three cases the number

${ }^{1}$ A specimen was received on $\mathbf{M a y} 28,1895$, without data: 
Willow of autumnal wings measured is scarcely large enough to be satisfactory. The Sedge Warbler, with 46 wings measured, gave a different result.

The wings obtained in spring average 09 longer than those obtained in autumn.

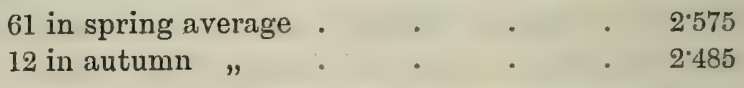

The shortest of all, however, was obtained in spring. It will be seen from the Table of Measurements (p. 639) that this wing is shorter than that of the longest winged Golden-crested Wren. The specimen was received in the flesh, and was pronounced by Mr E. Williams to be a male. Among the Chiffchaff's wings measured there are only two (one shorter and one equal) which do not exceed this diminutive Willow Wren's wing in length, and it is remarkable that all three-the short Willow Wren's and the two short Chiffchaff's wings-were sent together from the Tuskar among a number of birds killed striking on the night of April 14, 1898.

The length of the Willow Wren's wing shows a larger percentage of variation than any other species measured, except the Skylark.

Average length of wing, 2.57 ; longest, 2.85 ; shortest, 2.20 ; difference between extremes, 0.65 ; percentage of variation, 25 .

\section{Chiffchaff (Phylloscopus rufus, Bechst.).}

Chiffchaff. Though the Chiffchaff's well-known note is usually heard in Ireland some time before the end of March, the light-house returns show that only a small percentage of individuals reach us during that month; for of 16 specimens forwarded by lightkeepers in spring, only 2 were killed in March, while the remaining 14 were obtained in April.

Unfortunately the three latest spring specimens were received (April 24,1890; April 26,1892; and April 26, 1895) without date of capture, a circumstance the more to be regretted, as none of the 13 specimens with data were killed at a later date than April 14:- 
Earliest, ${ }^{1} \quad$ March 24, 1892, Blackwater Bank.

Latest, April 14, 1898, Tuskar.

That the second week of April is the time of the principal spring migration appears from the following figures:-

March (last 8 days),

April (first week), .

, (second week),

" (third or fourth week),
Specimens.

- 2

4

7

3

$\overline{16}$

In autumn only 6 specimens have been sent-

$\begin{array}{lll}\text { Earliest, } & \text { September 2, 1886, } & \text { Mine Head. } \\ \text { Latest, } & \text { October 9, 1899, } & \text { Tuskar. }\end{array}$

The principal emigration does not, apparently, take place until after September 20, as a division of the whole time of departure into periods of ten days shows that 4 of the 6 specimens were killed after that date :-

September $1-10$
$\quad, \quad 11-20$

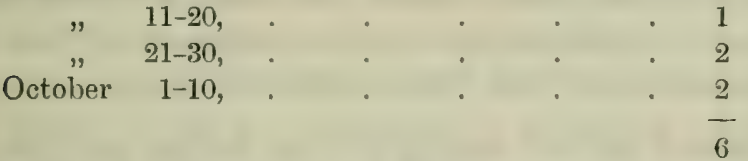

The Chiffchaff would seem, therefore, to arrive a week or ten clays earlier than the Willow Wren, and to remain a month or six weeks later.

Judging from the coast-distribution of the specimens, we may say that the Chiffehaff's occurrences at both seasons are almost limited to the enst coast :-

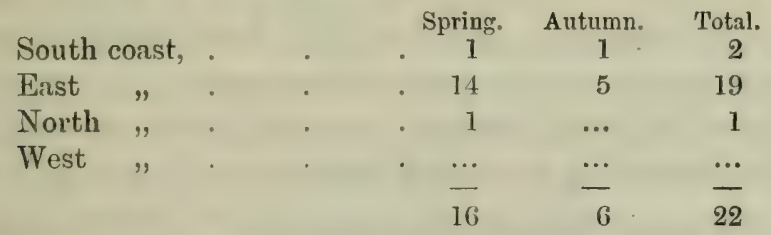

The most westerly occurrence was at Mine Head, Co. Waterford, September 2, 1886. The percentage of specimens from the east coast is 86 .

${ }^{1}$ In the year 1872 the Chiffchaff was hearl by R. M. B. at Fassaroe, Bray, on March 8, but the average earliest date in that locality for the past thirty-five years has been about March 26. 
Chiffchaff, The Chiffchaff has been received from only four counties, whereas the Willow Wren has been forwarded from nine:-

\begin{tabular}{|c|c|c|}
\hline Waterford, & $\begin{array}{c}\text { Spring. } \\
\ldots\end{array}$ & $\begin{array}{c}\text { Autumn. } \\
1\end{array}$ \\
\hline Wexford, S. coast, & 1 & $\ldots$ \\
\hline " E. coast, & 11 & 4 \\
\hline Dublin, & 3 & 1 \\
\hline Donegal, & 1 & $\cdots$ \\
\hline
\end{tabular}

At both seasons two-thirds of the specimens are from the east coast of County Wexford. As in the Sedge Warbler's, Whitethroat's, and Willow Wren's cases, Dublin comes next to Wexford in the number of specimens forwarded. The stations most favoured are Tuskar (9 specimens), Blackwater Bank (5), and Rockabill (3). Six of the 22 examples are from lightships, 13 from islands, and 3 from the mainland. These are about the same proportions as obtained for the Willow Wren.

Owing to its early arrival and late stay, the Chiffchaff frequently strikes the lanterns in company of other species, which are rather winter than summer visitants :-

In March it has been received with the Starling and Curlew.

In April with the Wheatear, Willow Wren, Sand-Martin, Meadow Pipit, Skylark, and Brambling.

In September with the Ring-Ouzel, Redstart, Whinchat, Wheatear,

Sedge Warbler, Whitethroat, Pied Wagtail, Meadow Pipit, Skylark, Corn-Crake, and Quail.

In October with the Gold-Crest and Skylark.

Its associates in striking thus belong to 17 species, of which only 3 (the Wheatear, Meadow Pipit, and Skylark) have been received with it in both spring and autumn.

Of the 16 wings obtained in spring, the 8 earliest show a decided superiority in average length-

8 earliest (before April 9) average . . 2.44

8 latest (after April 9) . . . 2 229

Of the 6 obtained in autumn, 1 was not preserved; the average length of the remaining 5 is $2 \cdot 27$, whereas the 16 spring wings average $2 \cdot 37$. A similar difference was found in the Willow Wren, 
As in the Willow Wren's case, the shortest wing was Chiffchaff. obtained on April 14, 1898, at the Tuskar light-house.

Average length of wing, 2.35 ; longest, 2.575 ; shortest, 2.150 ; difference between extremes, 0.425 ; percentage of variation, 18 .

YelLOW-BRowed WARbLer (Phylloscopues superciliosus, J. F, Gmelin).

The first and only example of this species obtained in Ireland was shot on the Tearaght Rock, Co. Kerry, on October 14, 1890, by a son of the light-keeper ( $\mathrm{Mr} \mathrm{W}$. H. James). It was forwarded in the flesh.

The Tearaght Rock, where this rare straggler occurred, is situated nine miles west of the Kerry coast, and is the most westerly of Irish islands. During the same month (October 1890) two other rare birds were sent from this station, viz., a Red-breasted Flycatcher and a Lesser Whitethroat (making the second Irish occurrence of the former and the first of the latter bird); and three days previously to the shooting of the Yellowbrowed Warbler on Tearaght, the first and only Irish specimen of the Short-toed Lark was obtained at Blackrock (Mayo), also nine miles west of the Irish mainland.

By an inadvertence, Mr James is quoted (p. 151) as saying that the weight of the Yellow-browed Warbler sent was " 1 drachm 11 scruples." The figure printed as 11 was doubtless intended for 2, which would make the weight of the bird 100 grains.

\section{Golden-CRESTED WREN (Regulus cristatus, Koch).}

Readily recognised, and well known to most light-keepers, the Gold-Crest occurs at our light-houses as an autumnal immigrant, chiefly in September and October. It again appears, but in much smaller numbers, at its departure in March and April. Fifty-six specimens have been received-46 in autumn and 10 in spring.

Earliest in spring,

Latest " ,

Earliest in autumn,

Latest " "
March 19, 1893, April 28, 1891, August 27, 1888,

December 17, 1899,
Yellow.

browed

Warbler.
Golden-

crested Wren. 
Golden-

crested Wren.

An analysis of the light-keepers' observations shows that 160 occurrences of this species are reported within the fifteen years 1883-97. The Gold-Crest has in a few instances been reported at light-stations during the months of February, May, and at South Arran as late as June, but no specimens were sent. The number of observations and of specimens for each month are compared below.

\begin{tabular}{|c|c|c|c|c|c|}
\hline & & & & $\begin{array}{l}\text { Occurrences } \\
\text { reported by } \\
\text { light-keepers. }\end{array}$ & $\begin{array}{l}\text { Specimens } \\
\text { received. }\end{array}$ \\
\hline January, & - & . & . & $\ldots$ & $\ldots$ \\
\hline February; & . & . & . & 3 & $\ldots$ \\
\hline March, & - & . & . & 12 & 4 \\
\hline April, & : & . & . & 19 & 6 \\
\hline May, & . & . & . & 1 & $\ldots$ \\
\hline June, & . & . & . & 1 & $\ldots$ \\
\hline July, & . & . & . & $\ldots$ & $\ldots$ \\
\hline August, & . & . & . & 3 & 1 \\
\hline September, & . & . & . & 37 & 18 \\
\hline October, & . & . & . & 56 & 20 \\
\hline November, & - & . & . & 24 & 6 \\
\hline \multirow[t]{2}{*}{ December, } & . & . & . & 4 & 1 \\
\hline & & & 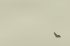 & 160 & 56 \\
\hline
\end{tabular}

Judging by this table, October is the month of maximum migration in autumn and April in spring.

The period of the autumnal influx is normally a long one, lasting in most years for two months. In 1889 it continued with little intermission from September 1 to November 15; the earliest and latest dates for that season being August 14 and December 14.

From the reported occurrences, the autumnal influx seems greatest during the first ten days of October. The dates of the specimens received yield, at first sight, a different result; but this is chiefly because one-third of the whole number were received in the autumn of 1898 , when exceptionally heavy rushes took place about the middle of September, and in the third week of October; and the schedules from which the light-keepers' observations are abstracted have not yet been analysed for that year.

Divided into periods of ten days, the autumnal migration may thus be tabulated- 


\begin{tabular}{|c|c|c|c|c|c|c|c|}
\hline & & & & & $\begin{array}{l}\text { currences } \\
\text { eported } \\
\text { ad of } 1897 .\end{array}$ & $\begin{array}{l}\text { Specimens } \\
\text { received } \\
\text { to } 1899 .\end{array}$ & $\begin{array}{l}\text { Golden- } \\
\text { crested } \\
\text { Wren. }\end{array}$ \\
\hline August & $1-10$ & . & - & . & $\cdots$ & ... & \\
\hline$"$ & 11-20, & . & - & - & 1 & ... & \\
\hline ", & 21-31, & . & . & . & 2 & 1 & \\
\hline September & $1-10$ & . & . & . & 10 & 1 & \\
\hline$"$ & 11-20, & . & . & . & 14 & 11 & \\
\hline " & $21-30$ & - & - & - & 13 & 6 & \\
\hline October & $1-10$ & - & . & . & 30 & 6 & \\
\hline$"$ & 11-20, & . & . & . & 7 & 5 & \\
\hline " & 21-31, & . & . & . & 19 & 9 & \\
\hline November & $1-10$ & . & . & . & 12 & 2 & \\
\hline$"$ & $11-20$, & . & - & - & 9 & 3 & \\
\hline & $21-30$ & - & - & . & 3 & 1 & \\
\hline December & $1-10$ & : & • & - & $\cdots$ & $\cdots$ & \\
\hline$"$ & 11-20, & . & • & - & 2 & 1 & \\
\hline \multirow[t]{2}{*}{$"$} & 21-31, & . & . & $\cdot$ & 2 & $\cdots$ & \\
\hline & & & & & 124 & 46 & \\
\hline
\end{tabular}

The spring migration seems to be more condensed, lasting in most cases from the middle of March to the middle of April:-

\begin{tabular}{|c|c|c|c|c|c|}
\hline & & & & $\begin{array}{l}\text { Occurrences } \\
\text { reported. }\end{array}$ & $\begin{array}{l}\text { Specimen } \\
\text { received }\end{array}$ \\
\hline March & $1-15$ & . & - & $\ldots$ & $\ldots$ \\
\hline$"$ & 16-31, & . & . & 12 & 4 \\
\hline April & $1-15$ & . & . & 15 & 5 \\
\hline$"$ & $16-30$ & . & - & $\frac{4}{31}$ & $\frac{1}{10}$ \\
\hline
\end{tabular}

Like most migrants, the Gold-Crest strikes chiefly on the east coast at both seasons. No specimens have been sent from west coast except in autumn, and it seems to be more frequent on the north coast in spring than in autumn, which for an autumnal immigrant is an exceptional characteristic.

The coast-distribution is shown below.

\begin{tabular}{|c|c|c|c|c|c|c|c|c|}
\hline & & & & & \multicolumn{2}{|c|}{ Observations. } & \multicolumn{2}{|c|}{ Specimens. } \\
\hline & & & & & Spring. & Autumn. & Spring. & Autumn. \\
\hline \multicolumn{2}{|c|}{ South Coast, } & - & - & . & 7 & 28 & 1 & 8 \\
\hline East & $"$ & . & . & . & 16 & 70 & 5 & 27 \\
\hline North & " & - & . & . & 9 & 9 & 4 & 2 \\
\hline West & $"$ & - & . & . & $\frac{4}{36}$ & $\frac{17}{12 t}$ & $\frac{\cdots}{10}$ & $\frac{9}{46}$ \\
\hline
\end{tabular}


Goldencrested Wren

In autumn a decided majority, both of the observations and of the specimens, are from stations south of the latitude of Dublin :-

\section{South of Dublin, North , "}

But in spring this is not so:-

\begin{tabular}{|c|c|}
\hline $\begin{array}{c}\text { Observations. } \\
74\end{array}$ & $\begin{array}{c}\text { Specimens. } \\
\mathbf{3 4}\end{array}$ \\
\hline 50 & 12 \\
\hline
\end{tabular}

Observations. Specimens.

$\begin{array}{rrr}. & 17 & 3 \\ . & 19 & 7\end{array}$

From this it would appear that if the spring movement be an emigratory one, the Gold-Crest at that season departs by a northeasterly route towards Scotland. A considerable number seem also to arrive by this route in autumn; for the light-keeper at Innishtrahull remarks (1894 "Report," p. 406) that "we have large numbers of Gold-Crests every March and October." In autumn, however, the largest influx evidently occurs farther south.

The following map shows the number of specimens from each light-station in spring and autumn.

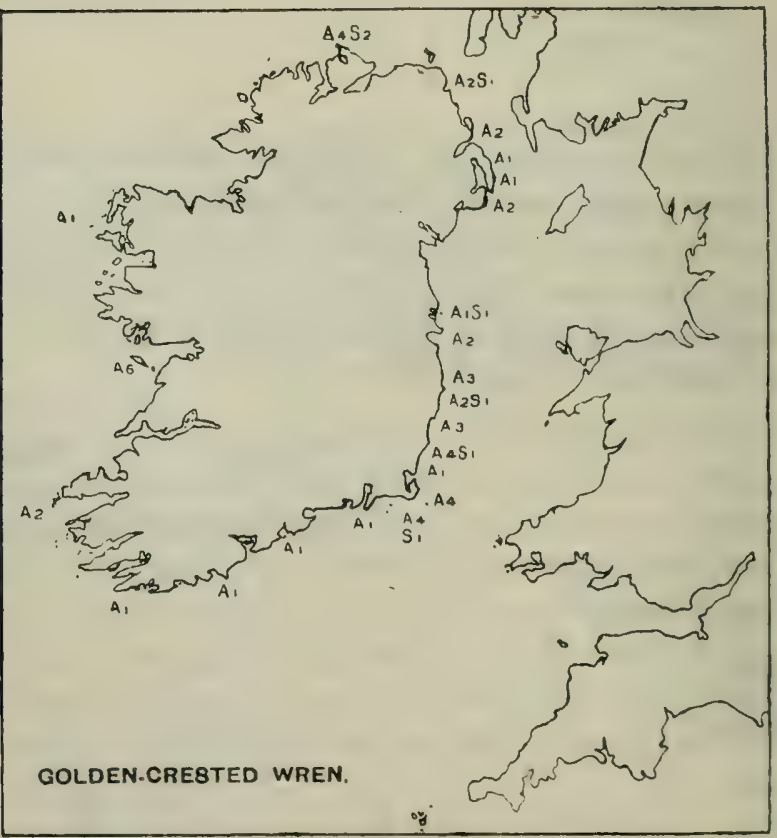

$\mathrm{S} 2=$ Two specimens forwarled in spring, March 19 to April 28.

A $4=$ Four in autumn, August 27 to December 17. 
At lanterns, the Gold-Crest appears to be more frequently caught alive than killed. In this it presents a contrast to most of the Warblers, which are oftener killed than caught:-

Goldencrested Wren.

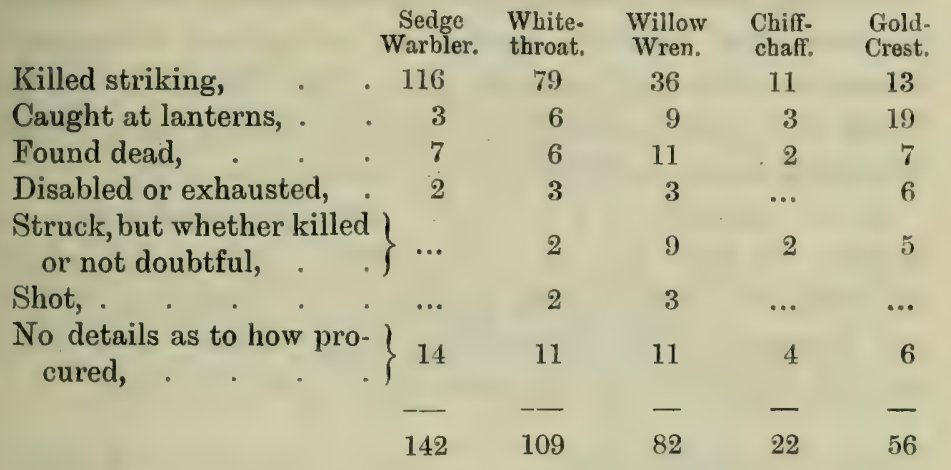

It will be seen from these figures that the number of Goldencrested Wrens caught at the lanterns almost equals the numbers of Sedge Warblers, Whitethroats, Willow Wrens, and Chiffchaffs so obtained when these are added together.

Only 2 per cent. of the Sedge Warblers forwarded are stated to have been caught; the percentage of Whitethroats is $5 \frac{1}{2}$, of Willow Wrens 11, of Chiffchaffs 14, and of Gold-Crests 34 .

On the other hand, 81 per cent. of the Sedge Warblers are stated to have been killed at the lantern; the percentage in the Whitethroat's case being 72 , in the Willow Wren's 44 , in the Chiffchaff's 50 , and in that of the present species only 23 .

It is well known that the months of September and October 1882 were marked by an extraordinary rush of Gold-Crests to the British shores, which, though its commencement is variously dated (east coast of England, August 6; east coast of Scotland, August 27; west coast of Scotland, September 27), seems everywhere in Britain to have attained its greatest density between the 7 th and 12th of October (east of England, October 7 and 12; east of Scotland, October 8 to 12; west of Scotland, October 10). It was during this period of its maximum density that the swarm extended to Ireland, where, previous to October 9th, no Gold-Crests had been noted except a few in August (6th, 9th, and 26th). On October 9th, 5 struck at Howth Baily, and 2 at Rathlin; on the 12th, a dozen at the Tuskar and 2 at Howth Baily; on the 13th, Tuskar reports 
Goldencrested

Wren.

them "continually striking all night"; while 5 struck on the same date at Rathlin; the following night the west coast was reached, 14 striking at South Arran Island; on the 15th they were noted about the lantern at Innishtrahull; and after this no more were reported, except a few isolated instances on November 30th and December 17th. The rush in Ireland thus lasted a bare week, the night of greatest density being October 13th on the east, and October 14th on the west coast. ${ }^{1}$

As an instance of a prolonged autumnal immigration into Ireland, we may take the year 1889, in which this species continued to strike during the whole of September, October, and November; the observations being chiefly from Ulster stations, especially the Maidens and Copeland Island.

Aug. 14, 1 striking at Tuskar. Sept. 1, 1 "

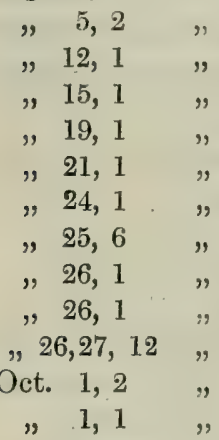

Mew Island.

Maidens.

Innishtrahull

Copeland.

S. Arran.

Maidens.

Tuskar.

Copeland.

Tuskar.

Arklow N.

Kinsale.

Kinsale.

Coningbeg.
Oct. 1, 2 striking at Maidens.

" 1, some " Copeland.

"2, some " Copeland.

" $4,1 \quad$ Maidens.

$" 16,1 \quad$ Maidens.

"20,1 " Arklow N.

$" 26,-1 \quad$ S. Arran.

" 30, $1 \quad$ \# Kish Bank.

Nov. 1-15, rushes at Rockabill.

2, 1 striking at Maidens.

"13,2 " Kish Bank.

"26,2 " Rockabill.

Dec. 14, some " Rockabill.

Another year distinguished by an interesting influx was 1898 , in which as many as 15 specimens were received, 7 of them having been killed between the 13th and 24th of September, and 7 on the nights of the 20th and 21st of October. The September rush in this instance was confined to east coast stations, Blackwater Bank sending 2 specimens, Arklow South Light-ship 1, Wicklow Head 2, and Carlingford Bar 2. The October rush seems to have begun on the northern part of the east coast, specimens being killed on October 20 at Skulmartin and South Rock Light-ships, both on the Down coast; but on

'It will be seen, by reference to the British Association's "Migration Reports" (1882, p. 1), that this celebrated rush of Regulus cristatus extended to the Faroc Islauds, where, however, the birds were not observed until 21st October. 
the following night it reached the west, and 5 starved specimens (weighing, when received, from 58 to $65 \frac{1}{2}$ grains) were caught striking at South Arran Light-house. ${ }^{1}$

The species received with the Gold-Crest are:-

In March-the Lark.

In September-the Thrush, Lark, and Starling.

In October-the Thrush, Blackbird, Chiffchaff, Wren, and Lark.

In November-the Missel-Thrush, Ring-Ouzel, Black Redstart, Lark, and Chaffinch.

The Lark has been sent with it six times, the Wren and Thrush twice, and each of the other species once.

A remarkably large proportion of the specimens forwarded appear to be males. In autumn, of 26 sent in the flesh, 20 are males and only 6 females. ${ }^{2}$ Of the remaining 20 autumnal specimens, only legs and wings are preserved; but even on the unlikely supposition that these were all female or young birds, the adult males would form nearly half the series.

From the measurements of 38 wings obtained in autumn, it appears that at that season the shorter-winged individuals arrive first:-

19 earliest (August 27 to October 1) average . 2.085

19 latest (October 2 to November 20). " . . 2'100

The few wings obtained in spring, of which eight were measured, follow the general rule (which in spring seems almost universal); i.e., that the longer-winged birds come first.

4 in March average . . . . 2 2 250

4 in April " . . . . . 2050

The spring wings slightly exceed the autumnal in length, but are too few to afford a standard.

$$
\begin{aligned}
& \text { Average of } 8 \text { in spring, . . . 2 } 2100 \\
& \text { " } 38 \text { in autumn, . . . . . . . 2093 }
\end{aligned}
$$

This may be due to the presence of immature birds in the

${ }^{1}$ The two specimens killed a night earlier on the Down coast weighed 68 and 76 grains respectively. The five from S. Arran weighed 58, 61 $\frac{1}{2}, 63,64$, and $65 \frac{1}{2}$ grains.

2 I.e., possessing the lemon-coloured crest of the female; but it is possible that some of these examples may be immature males. 
Goldencrested

Wren.

autumnal rushes, for of 20 adult males sent in the flesh at that season, the average length is $2 \cdot 106$.

It is worth remarking that these 20 adult males conform to the rule by which, as already shown, the shorter-winged specimens of the Gold-Crest arrive first in autumn.

10 earliest (September 13 to October 1) average . 2 2:100

10 latest (after October 1) " . 2‘112

Average length of wing, 2.100 ; longest, 2.225 ; shortest, 2.000 ; difference between extremes, 0.225 ; percentage of variation, $9 \frac{1}{2}$.

[Obs.--Supposed examples of the Fire-crested Wren (Regulus ignicapillus, C. L. Brehm) have repeatedly been sent from lightstations, but have always proved to be Gold-Crests. The Firecrest is not known to have ever visited Ireland.]

\section{WREN (Troglodytes parvulus, Koch).}

Wren.

The frequency with which "Wrens" are mentioned by the light-keepers might easily mislead an unwary reader into imagining that Troglodytes parvulus is one of our commonest migrants; but the small number of specimens forwarded shows that such is not the case. The name of this familiar little bird is very liberally applied by many of the keepers, who use it for all the Warbler group, and sometimes for the Gold-Crest; so that when "flocks of Wrens" are reported as flying all night about a lantern, the idea of an extensive migratory movement of the present species must not be entertained. In fact, the materials to hand are insufficient for deciding to what extent the Wren can be accounted one of our regular migrants.

Of 15 specimens received from light-stations, only 8 are known to have struck the lanterns, though some of the others may have done so. Of these 8,6 struck in autumn and 2 in spring.

The 6 obtained at lanterns in autumn are as follows:-

\begin{tabular}{|c|c|c|c|}
\hline \multicolumn{2}{|c|}{ on the South Coast, } & \multirow{3}{*}{$\begin{array}{l}\text { Fastnet, } \\
\left\{\begin{array}{l}\text { Tuskar, } \\
\text { Maidens, }\end{array}\right. \\
\left\{\begin{array}{l}\text { Eagle Island, } \\
\text { S. Arran Island, }\end{array}\right.\end{array}$} & \multirow{3}{*}{$\begin{array}{l}\text { October } 30,1897 . \\
\text { October } 16,1888 . \\
\text { November } 19,1898 . \\
\text { November } 14,188 . \\
\text { October } 21,1898 .\end{array}$} \\
\hline e East & & & \\
\hline & & & \\
\hline
\end{tabular}


The 2 obtained in spring occurred on the east coast, at the wren. same station, and nearly at the same date.

$$
\begin{array}{cccc}
\text { Maidens, } & * & * & \text { May } 8,1890 \\
" & * & \quad & 12,1899
\end{array}
$$

Of the 7 remaining specimens, which are not stated to have struck, 1 was shot on the Skelligs, where the bird is resident; another from that station is without data, as are 2 from the Tearaght, where also the species is resident; 1 was found dead on Blackrock (Mayo), where there is evidence that the Wren is often seen in winter; and 2 were received without data from Innishtrahull, both early in April. At this last-named station the light-keeper believes the bird to breed (see 1894 "Report," p. 405), but adds, "we have large numbers of them and GoldCrests every March and October, so that they must migrate about these two months, and rest here on their journey." If this information be correct, it is curious that so few specimens have been sent; and that the only 2 examples of the Wren which are known to have struck Irish lanterns in spring occurred not in March, but in May.

Like the Hedge-Sparrow, the Wren breeds on some of the bleakest islands of the west coast. At the Tearaght, Mr E. $M^{\prime}$ 'Carron (light-keeper at that station from 1882 to 1885) considers that between 60 and 100 may always be found, adding that scarcely more than 5 inhabit the same extent of ground at Mine Head (a mainland station in Co. Waterford). In some years, however, its numbers on the Tearaght have been stated to vary at different seasons; e.g., an increase is noted in the autumn of 1890 , and in January 1891 there are said to be "not so many here as in the fall." Also on the Skelligs, another breeding-station, an increase in autumn has more than once been reported; and on other western islands, as Slyne Head, the Arran Isles, and Blackrock (Mayo), the bird is more frequently noted in autumn and winter than at other seasons. Thus it is probable that, though few Wrens are killed at the lanterns, short migratory flights between the Irish mainland and our western isles are of regular occurrence.

For proof of migration on a more extensive scale we must therefore look chiefly to the evidence furnished by the east coast occurrences. These are only $t$ in number, but it is 
Wren. remarkable that as many as 3 of them are from the Antrim coast. This may mean that the Wren chooses the route between Antrim and the S.W. of Scotland as the shortest passage from Ireland to Britain-a selection not unnatural in the case of the shortest-winged British bird.

The solitary example from the Tuskar, however, shows that in some instances the bird crosses from Wales or England. The two Wrens which struck at the Fastnet light (October 30, 1897) did so during a rush of many species, caused perhaps by a sudden change of wind, and may have been blown out of their course during a local migration to some of the southern islands. If, on the contrary, they had crossed from Britain, we have here an instance of a flight of some 200 miles, performed by a bird which might be thought one of the worst adapted for long migratory journeys.

As 4 of the 6 autumnal specimens struck during the latter half of October, it may be taken as probable that this is the period of most migration.

The 2 which struck in spring occurred in the first half of May.

The Wren has never been sent from a light-ship or from a mainland station, since all the 15 specimens received, whether killed striking or otherwise, are from islands.

The following species have struck along with the Wren:-

In May - the Wheatear, Sedge Warbler, and Whitethroat.

In October-the Thrush, Blackbird, Ring-Ouzel, Gold-Crest, Lark, Siskin, and Goldfinch.

In November-the Thrush, Fieldfare, Blackbird, Lark, and Reed Bunting.

Of 12 specimens whose wings were measured, it appears that the two shortest-winged were forwarded from the Tearaght Rock, while the longest-winged example was the bird which struck at the Tuskar. The wing of this specimen equals in length the wing of a St Kilda's Wren (shot August 1884) in R. M. B.'s collection.

Average length of wing, $1 \cdot 870$; longest, 1.975 ; shortest, $1 \cdot 775$; difference between extremes, 0.200. Percentage of variation, 11 .

[Obs.-The Tree-Creeper (Certhia familiaris, Linn.), though a common Irish bird, cannot be claimed as a migrant, as there is no evidence that it has ever been observed at a light-station.] 


\section{Great Titmouse (Panus major, Limn.).}

Of very rare occurrence at light-stations.

"Titmice," like "Wrens," are often reported, but seldom sent, and there can be little doubt that in most instances the name is erroneously used. ${ }^{1}$

Four species-the Great, Blue, Coal, and Long-tailed Titmouse-are resident and common in Ireland; but of these only two (the first and the last named) have been obtained during migratory flight.

The Great Titmouse has twice been received, an interval of ten years separating its occurrences. Both were in October, at stations off the south coast (a light-ship and an island). The dates of the two are nearly coincident.

October 14, 1889, . $\quad$. Coningbeg Light-ship.
October 16, 1899, .

Both were caught alive, the one apparently exhausted and the other disabled.

On October 11, 1881, the Fastnet schedule contains an entry of "two Titmice killed, flying S., on rock" (1881 "Report," p. 16). From the coincidence of date and station, it seems not improbable that these were of the present species.

There is no evidence that either of the specimens forwarded was accompanied by other birds.

The measurements of the two wings vary considerably:Average, 2.925 ; longest, 3.050 ; shortest, 2.800 ; difference, 0.250 ; percentage of variation, $8 \frac{1}{2}$.

\section{Blue Trtmouse (Parus ceruleus, Linn.).}

The few instances in which this bird has been identified at light-stations do not entitle it to be considered a migrant,

Blue

Titmouse.

${ }^{1}$ Perhaps no other bird's name is applied more miscellaneously. In proof of this, two notes may be cited. In 1884 the light-keeper at the Tuskar, acknowledging receipt of Morris's "British Birds," writes: "I am sorry to say that all birds heretofore entered as Titmice were probably Willow or other Warblers" ("General Remarks of Light-keopers," p. 9). In 1881, on the other hand, the light-keeper on Blackrock (Mayo) reports: " 'Titmouses' seen in all weathers, and build on the rock" (1881 "Report," p. 10); here Rock-Pipits must be intended. The Gold-Crest has once been sent as a Titmouse. 
Blue

Titmouse. tional.

It has never been reported as striking.

Two specimens, both shot, have been received from a mainland station (Mine Head, Co. Waterford). One was shot December 9, 1885, and the other on March 10, 1887. Mr M'Carron, who forwarded these birds, probably considered them exceptional visitors to the locality, and he reports " one scen" on January 3, 1887, implying that such an occurrence was not usual.

A "Bluecap" is reported as seen on Rockabill, July 29, 1889, and a "Tit, small and blue," on Tearaght, April 16, 1890.

Since 1890 the species has not been mentioned.

Such is the meagre evidence as to migratory habits on the part of Parus corruleus.

[Obs.-The Coal Titmouse (Parus ater, Linn.) has never been reported or sent. "A small grey bird, not much larger than a Wren, with a black head," said to have been killed at the Tuskar, October 29, 1883, may, from the description, have belonged to this species, but the evidence is too vague to be of any value.]

\section{Long-Tailed Titmouse (Acredula caudata, Linn.).}

Long-tailed Titmouse.

Waxwing.

The only occurrence was at Innishtrahull, where two were shot out of a flock of seven, October 24, 1895. They had probably remained a fortnight on the island, as eight are reported to have been seen, October 10. Innishtrahull is six miles north of the mainland, and the light-keeper remarks that no one on the isle remembered having seen such birds before.

\section{Waxwing (Ampelis garrulus, Linn.).}

Three birds seen at Hook Tower, December 6, 1892, were probably of this species. They are described as "about the size of a Thrush, marked like a Chaffinch, with top-knots on head" (see 1892 "Report," p. 330). Waxwings are known to have visited the British islands somewhat numerously in the winter of 1892-93, and specimens were obtained in various parts of Ireland, ${ }^{1}$ chiefly in January.

\footnotetext{
${ }^{1}$ Five such instances are noticed in the Irish Naturalist, 1S93, Np. S5 and 114.
} 
Pied Wagtail (Motacilla lugubris, Temminck).

Wagtails so rarely strike the lanterns that very little evidence can be collected concerning them. As many as 272 occurrences are reported between 1883 and 1897. It is, however, in most instances quite uncertain what species was observed; and, moreover, the habits of the Pied and Grey Wagtails are consistent with their being often seen near the sea, whether migrating or otherwise, in every month of the year.

As far as the present species is concerned, 20 of the abovementioned occurrences may be set aside, being referable to either the Grey or the Yellow Wagtail. Of the remainder, 32 are mainland observations, 160 are from islands, and 60 from light-ships. The light-ship records are evidently all migrational, and worth tabulating by themselves; though it cannot be said that they all refer to the Pied Wagtail, it is at least probable that most of them do.

"Wagtails" observed at Light-ships.

\begin{tabular}{|c|c|c|c|c|c|c|c|c|c|c|c|c|c|}
\hline & Jan. & Feb. & Mar. & April & May. & June & July. & Aug. & Sept. & oct. & Nov. & Dec. & Total. \\
\hline $\begin{array}{l}\text { ngbeg Light-ship, } \\
\text { els Rock Light-ship, } \\
\text { fer Shoals, } \\
\text { kwater Bank, : } \\
\text { ow S., } \\
\text { ow N., } \\
\text { ing Bank, } \\
\text { h Rock, }\end{array}$ & $\begin{array}{l}\cdots \\
\cdots \\
\cdots \\
\cdots \\
\cdots \\
\cdots\end{array}$ & \begin{tabular}{c|c}
$\cdots$ \\
$\cdots$ \\
$\dddot{1}$ \\
$\cdots$ \\
$\cdots$ \\
$\cdots$
\end{tabular} & \begin{tabular}{c|c}
2 \\
1 \\
$\ldots$ \\
$\dddot{1}$ \\
$\dddot{1}$ \\
$\cdots$ \\
$\cdots$
\end{tabular} & $\begin{array}{c}\ldots \\
\cdots \\
\cdots \\
1 \\
4 \\
4 \\
3 \\
\cdots\end{array}$ & \begin{tabular}{l|l}
$\cdots$ \\
$\cdots$ \\
$\cdots$ \\
$\cdots$ \\
3 \\
1 \\
2 \\
$\cdots$
\end{tabular} & $\begin{array}{l}\cdots \\
\cdots \\
\cdots \\
\cdots \\
\cdots \\
\cdots \\
\cdots\end{array}$ & $\begin{array}{l}\cdots \\
\cdots \\
\cdots\end{array}$ & $\begin{array}{l}1 \\
\cdots \\
\cdots \\
\ldots \\
\ldots \\
1\end{array}$ & $\begin{array}{l}8 \\
1 \\
4 \\
4 \\
3 \\
2 \\
4 \\
2\end{array}$ & \begin{tabular}{c|c}
1 \\
$\ldots 1$ \\
$\ldots$ \\
$\cdots$ \\
$\cdots$ \\
$\ldots$ \\
$\ldots$
\end{tabular} & $\begin{array}{l}2 \\
\cdots \\
\cdots \\
2 \\
\cdots \\
\cdots \\
\cdots\end{array}$ & $\begin{array}{l}\ldots \\
\ldots \\
\ldots \\
\ldots \\
\ldots \\
\ldots \\
\cdots \\
\ldots\end{array}$ & $\begin{array}{r}14 \\
2 \\
5 \\
5 \\
14 \\
7 \\
10 \\
3\end{array}$ \\
\hline Total, & $\ldots$ & 1 & 5 & 12 & 6 & $\ldots$ & .. & 2 & 28 & 2 & 4 & $\ldots$ & 60 \\
\hline
\end{tabular}

Unless the great majority of these records refer to one species, it is evident that the period of autumnal migration is nearly the same for all, September yielding 28 occurrences, while those in the other autumnal months, added together, make less than the third part of that number.

Next to September, April appears to be the month in which Wagtails are oftenest observed at light-ships, and it is therefore probably the time of the spring passage of the commonest species.

The same results, though less marked, are borne out by a 
synopsis of all the reported occurrences (i.e., from mainland, islands, and light-ships):-

\begin{tabular}{|r|r|r|r|r|r|r|r|r|r|r|r|r|r|r|}
\hline & Jan. & Feb. & Mar. & April & May. & June & July. & Aug. & Sept. & Oct. & Nov. & Dec. & Total. \\
\hline Sonth Coast, & 2 & 2 & 5 & 3 & 2 & $\ldots$ & $\ldots$ & 3 & 17 & 4 & 3 & 3 & 44 \\
East &, & $\ldots$ & 3 & 13 & 19 & 10 & 1 & $\ldots$ & 5 & 31 & 10 & 5 & 2 & 99 \\
North n." & $\ldots$ & 1 & 3 & 3 & 8 & 1 & $\ldots$ & 1 & 1 & 3 & 2 & 2 & 25 \\
West ", & 2 & 4 & 9 & 8 & 5 & 2 & 6 & 6 & 12 & 15 & 12 & 3 & 84 \\
\hline \multicolumn{1}{|l|}{ Total, } & 4 & 10 & 30 & 33 & 25 & 4 & 6 & 15 & 61 & 32 & 22 & 10 & 252 \\
\hline
\end{tabular}

Comparing this with the light-ship table, it becomes obvious that migrational and non-migrational occurrences are here mixed together, but September still shows much the largest number of entries, while April, though very slightly ahead of either March or October, continues to hold the second place.

Only 3 specimens have been received, and of these 2 struck at the Tuskar in September, the dates being nearly coincidentSeptember 22, 1887, and September 23, 1892. The third was found dead on the Fastnet Rock, February 28, 1887. Of this specimen only the leg and wing were received, and the wing may prove to be that of a White Wagtail. September is thus the only month in which the migration of the present species is fully attested by specimens.

The tendency of birds to strike the lanterns at their season of arrival rather than of departure has been shown in the case of many of the species previously dealt with, and probably holds good in the present instance also. Indeed, if we accept the conclusion that September is the month of maximum migration in autumn, it becomes practically certain that the autumnal movement cannot be (as it is stated to be in England) a departing movement, since the season when Pied Wagtails are most numerously obscrved in Ireland (at least in the eastern counties of Leinster) is during October and November, after the principal migration.

It does not, however, follow that the birds observed in spring are departing, because those noted in autumn are arriving.

The direction of the flight has been recorded in as many as 
69 instances, 26 in spring and 43 in autumn. These confirm the conclusion arrived at in the cases of the Thrush and Blackbird, that departing birds are seldom seen. Not one of the 69 observations records a flight to the S.E.; only one, and that at a west coast island-station, records a movement to the E.; while only three-on islands of the north and west, show flights to the S. Flights to the N.E. are, with two exceptions, similarly restricted to the south coast; but there is some indication of a northuard movement in spring along the eastern shores. To this last movement belong practically all the recorded flights whose direction is not strictly landward.

The 69 observations on direction may thus be classified :-

\begin{tabular}{lcclc} 
& Landward, & Seaward. & \multicolumn{1}{c}{ Coasting. } & Total. \\
Spring, . & $\cdot 21$ & 2 (to N. and N.E.) & 3 (to N.) & 26 \\
Autumn,. & $\cdot \frac{40}{7}$ & $\frac{\ldots}{2}$ & $\frac{3}{6}$ & $\frac{1}{69}$
\end{tabular}

There is thus evidence of an influx at both seasons, though in spring it is less marked than in autumn, and it is possible that most of the migrants at this season visit us only on passage.

The bulk of the observations quoted relate to single birds or to small companies of from 2 to 9 in number. On four occasions, however, flocks are reported, and it is noteworthy that the dates of these are all in September, viz., September 5 and 9, 1884 (Arklow N. Light-ship), September 8, 1893 (Hook Tower), and September 29, 1895 (Coningbeg Light-ship), At Hook Tower the light-keeper describes the birds as "Common Grey Wagtails," by which he probably means the Pied species; he observes that "there were 8 or 9 at first, but before leaving there must have been 50 . They all left together and flew W." The westward direction favours the opinion that these Wagtails were immigrants, and in the other three instances the flocks were observed at light-ships flying directly landwards.

The subject of the direction of the Pied Wagtail's flight has been dealt with in some detail, owing to the fact that nearly all ornithologists consider this bird largely if not mainly a summer visitant to Great Britain. The proof that it visits Ireland in autumn is not vitiated by the doubt admitted to 
Pied exist as to whether some of the observations utilised relate to

Wagtail. this or to some other species; for it is at least certain that many of them refer to the Pied Wagtail, while in all cases the direction of the autumnal flights is given as landward.

Our northernmost station-Innishtrahull-possesses an exceptional record with regard to Wagtails. Of 16 occurrences noted there, 13 were in spring, and of these no fewer than 8 were in May, chiefly in the earlier half of that month. Though reported as Pied, it seems far from improbable that these were really White Wagtails, since that species has several times been obtained on the north coast of Mayo at the time of its spring passage to the North. It is possible that some of the west coast observations also relate to Motacilla alba.

The species which have been received with the Pied Wagtail are 6, but all were obtained during one rush (September 22-23, 1892, at the Tuskar):- Wheatear, Whitethroat, Chiffchaff, Titlark, Skylark, and Quail. Thrushes, Redwings, Swallows, and Robins were also reported.

[Obs.-The White Wagtail (Motacilla alba, Linn.) might be expected to occur at light-stations occasionally, and, as shown under the preceding species, there is reason to suspect that it has been several times observed at Innishtrahull, while a wing from the Fastnet (28/2/87) resembles in character that of a White Wagtail; but no certain evidence on the subject has been obtained. $\left.{ }^{1}\right]$

Grey Wagtall (Motacilla melanope, Pallas).

Grey

Wagtail.

The Grey Wagtail has twice struck, in October, i.c., at Coningbeg Light-ship, October 8, 1887, and at North Arran Island, October 19,1890 . These are the only specimens received.

"Yellow Wagtails" are reported in fourteen instances, and in most cases the Grey Wagtail is probably intended; some records at land-stations in winter are not migrational. From the Skelligs, four "Yellow Wagtails" are noted in different years (March 17, April 22, September 19, and November 10),

\footnotetext{
' I Since writing this, a special request was sent to the light-keeper at Innishtrabull to procure, if possible, one of the "Pied" Wagtails usually seen there at end of April or early in Mixy. $\Delta$ sharp luok-out was a scordingly kept, and one was captured at tho lantern on the night of $\Lambda$ pril 23, 19J0, and forwarled. It proved to be a fine ad ilt mule Motacilla alba.
} 
and it can scarcely be doubted that at least the earliest and latest of these refer to the present species. A "yellowish" example was also observed on the Tearaght, August 20, 1890; and at Barrels Rock Light-ship a "Yellow Wagtail" was seen going north, September 24, 1886. The other notes (some of which may relate to the next species) are from Kinsale (September 24), Mine Head (April 9 and June 16), Tuskar (April 14), Arklow N. Light-ship (June 10), and Rockabill (October 8). None are recorded north of the last-named station.

The bird inhabits Ireland throughout the year, but the lighthouse observations are insufficient to warrant any conclusion as to its migration.

\section{Yellow WagtaIL (Motacilla raii, Bonaparte).}

This Wagtail has three times been obtained, and in all cases from Wexford stations : a fact of considerable interest, inasmuch as all its known breeding haunts are in the northern part of our island.

The only occurrence in spring was at the Tuskar, where a fine adult male was shot, May 3, 1886.

In autumn, two specimens were received, of which both were killed within a few days of the middle of September: at Hook Tower, September 11, 1893, and at the Tuskar, September 19 , 1895.

The Hook Tower specimen struck a telephone wire; thus in only one case has this bird been obtained through striking the lantern (Tuskar, 1895), and the example so killed was immature. ${ }^{1}$

\section{Meadow-PiPIT (Anthus pratensis, Linn.).}

The Meadow-Pipit's regular spring migration seems to set in about the end of February and to continue until after the March. In autumn there is an equally marked movement from the fourth week of September to the middle of November.

1 This specimen is just in that stage when it is so difficult to distinguish II. raii from $M$. flava, and Dr Sharpe and Mr Howard Saunders both agree in stating that it may be $M$. flcva (in lit., October 30, 1899); but the Blueheaded Wagtail should not be added to the Irish list on the strength of a doubtful example. 
Meadow- In these two periods, each of about eight weeks' duration,

Pipit. 35 specimens have been sent out of a total of 39 forwarded altogether.

Earliest in spring,

Latest

Earliest in autumn,

Latest

$"$
February 26, 1891, April 19, 1890, September 21, 1887, November 13, 1887,
Maidens.

Blackrock (Mayo).

Coningbeg Light-ship.

Fifteen specimens were obtained in spring-2 in February, 10 in March, 3 in April.

\begin{tabular}{|c|c|c|c|c|c|}
\hline \multicolumn{2}{|c|}{ February 20-28, } & . & . & - & . \\
\hline March & $1-10$, . & . & • & - & - \\
\hline " & $11-20$, . & . & . & - & - \\
\hline 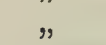 & 21-31, . & . & . & . & . \\
\hline April & $1-10$, . & . & . & . & • \\
\hline$"$ & 11-20, . & . & . & . & . \\
\hline
\end{tabular}

Twenty were obtained in autumn-4 in September, 11 in October, 5 in November.

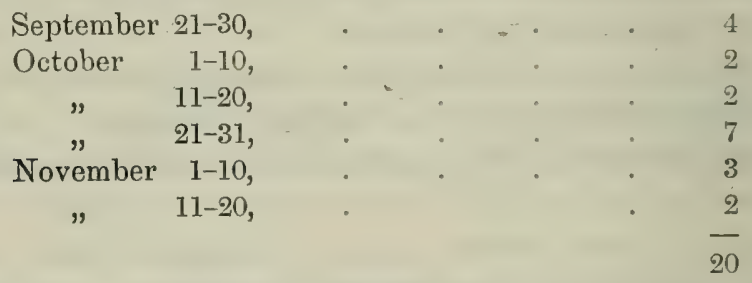

Besides these, three specimens were received in January and one in August.

The direction of the flight, whenever noted, is at both seasons almost invariably landward.

As this species, unlike most others, is obtained in nearly equal numbers in spring and autumn, the conclusion that it is an immigrant at both seasons might be expected, and the light-keepers' notes showing the landward direction go far to establish this as a fact. It is also worth noting that in at least three instances specimens received from light-ships in spring had died of exhaustion, a calamity which is much more likely to occur in the later than in the initiatory stages of a journey; and a similar case was once reported in autumn, from Arklow North Light-ship. That autumnal deaths from exhaustion are 
comparatively rare may be explained by supposing that immigrants at that season come only from the opposite coast of

Britain, while our spring visitants have had a longer and more fatiguing flight.

At both seasons a majority of the specimens is from the Wexford coast:-

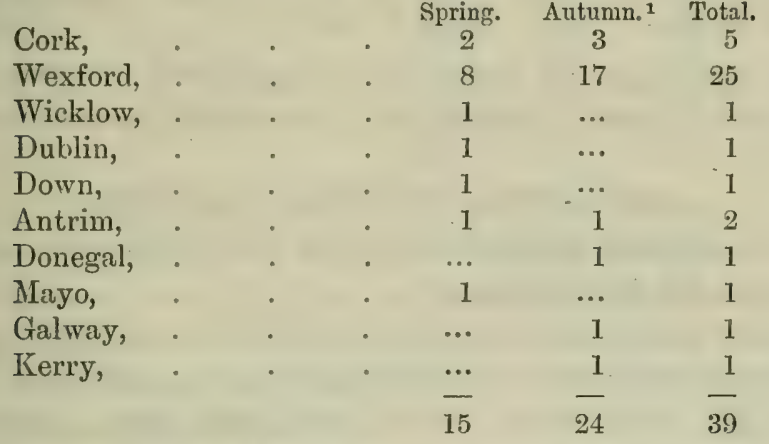

The stations which have furnished most specimens are:Coningbeg Light-ship (9), Tuskar (6), Fastnet and Blackwater Bank (5), and Lucifer Shoals Light-ship (3).

Light-ships have yielded 20; islands, 18; mainland stations, 1.

Occurrences suggestive of simultaneous migration along a consicterable coast-line may be instanced in the receipt of specimens from Fastnet and Barrels Rock Iight-ship, both killed striking on October 29, 1886; from Tuskar and Coningbeg Light-ship, on November 12 and 13, 1887; from Coningbeg Light-ship and Fastnet, November 3 and 5, 1897; from Rockabill and South Rock Light-ship, April 11, 1889; and from Fastnet, Coningbeg Light-ship, and Lucifer Shoals Light-ship, March 14-16, 1899.

Sixteen species have been forwarded as killed striking with the Titlark:-

In March-the Thrush, Lark, Reed Bunting, and Starling.

In April-the Chiffchaff.

In September-the Spotted Flycatcher, Pied Flycatcher, and Storm Petrel.

In October-the Redwing, Blackbird, Black Redstart, Chaffinch, and Starling.

In November-the Missel-Thrush, Song-Thrush, Redwing, Fieldfare, Snow-Bunting, and Brambling.

${ }^{1}$ The Jamuary and Angust stragglers are here (for convenience) grouped as autumnal migrants. 
MeadowPipit.

is $3 \cdot 165$, while that of 18 obtained in autumn is $3 \cdot 160$.

At both seasons the earlier show some superiority in length.

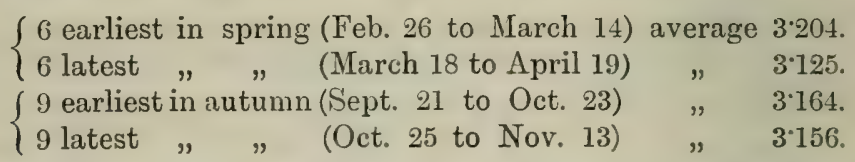

Average length of wing, $3 \cdot 17$; longest, 3.37 ; shortest, 3.00 ; difference between extremes, 0.37 ; percentage of variation, 12 .

\section{Rock-PIPIT (Anthus obscurus, Latham).}

Rock-Pipit. If this species migrates at all, we have little or no evidence of it from the light-stations.

In the second week of October 1886, two specimens were forwarded which had struck the lanterns on Rathlin O'Birne and Eagle Island West, off the north-west coast. These may have been performing a short migration southward, but no other such instances are known to have occurred, the PockPipits received from light-stations having generally been either shot or sent without data:

Skylark (Alaudd arvensis, Linn.).

skylark. This bird is more frequentiy reported by the light-keepers than any other species except the Starling.

The number of light-house observations and specimens of our four commonest winter visitants are:

\begin{tabular}{|c|c|c|c|}
\hline Starling, & . & $\begin{array}{c}\text { Observa- } \\
\text { tions. } \\
\text {. } 2040\end{array}$ & $\begin{array}{c}\text { Specimens } \\
\text { sent. } \\
80\end{array}$ \\
\hline Lark, . & . & . 1756 & 130 \\
\hline Thrush, & . & 1363 & 118 \\
\hline Blackbird, & . & . 1169 & 148 \\
\hline
\end{tabular}

Thus the Lark, coming second to the Starling in observations and second to the Blackbird specimens, has an equal claim with either of these birds to be regarded as the most numerous species on winter migration.

In order to estimate the comparative value of the observations relating to these four species, it should be borne in mind that the Starling is, for two reasons, likely to be observed in a disproportionately large number of instances. Scarcely any bird of its size is so easily recognisẹd in flight; and itṣ habit 
of ranging far, in large flocks, during the time of its sojourn with us, must frequently lead to its being noticed at lightstations when not strictly migrating. This view is corroborated by a comparison of the figures from each section of the coast.

\begin{tabular}{|c|c|c|c|c|c|c|c|}
\hline \multirow{2}{*}{\multicolumn{2}{|c|}{ Observations o }} & & \multirow{2}{*}{$\begin{array}{c}\text { Thrush. } \\
. \quad 159\end{array}$} & $\begin{array}{c}\text { Blackbird. } \\
187\end{array}$ & \multirow{2}{*}{$\begin{array}{r}\text { Lark. } \\
228\end{array}$} & \multirow{2}{*}{$\begin{array}{c}\text { Starling. } \\
\quad 388\end{array}$} \\
\hline & & & & & $\begin{array}{l}187 \\
685\end{array}$ & & \\
\hline & 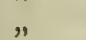 & North & " & 95 & 82 & 103 & 88 \\
\hline & $"$ & West & $"$ & 224 & 215 & 136 & 322 \\
\hline & & & & 363 & 1169 & $1756^{\circ}$ & 04 \\
\hline
\end{tabular}

Here we see that along the line of east coast stations, where migration is generally at its maximum, the Starling is less frequently noted than the Lark, while on the west coast, where there is little real migration, but much nomadic movement between the mainland and the isles, the preponderance of the Starling is strongly marked.

It therefore appears to follow that a conclusion based on the total number of observations in each of the above four cases would be erroneous, as it would place the Starling too high; and it is probable that the figures for the Thrush and Blackbird, whose occurrences at light-stations are nearly all migrational, are correspondingly low. The frequency with which these two species are reported about the lanterns, as compared with the number of times they are noted passing by day, would also lead us to suspect that they are more nocturnal on migration than the Lark, and if this is so, the large number of specimens in proportion to that of observations is readily explained.

The migration of the Lark generally begins about the middle of September. The date of the earliest observation has varied from August 28, 1897 (Coningbeg Light-ship) to October 4, 1893 (South Rock Light-ship), but has only twice fallen later than September 22. The movement becomes general early in October, and continues vigorously throughout the whole of that and the following month; after which it becomes, like that of most winter immigrants, comparatively spasmodic. The numbers of observations and specimens for each month are shown below.

Jan. Feb. Mar. April. May. June. July. Aug. Sept. Oct. Nov, Dec, Total.

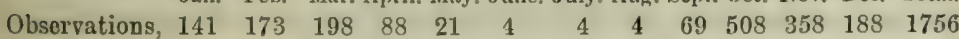
$\begin{array}{llllllllllllll}\text { Specimens, . } & 5 & 19 & 13 & 3 & \ldots & \ldots & \ldots & 1 & 6 & 38 & 27 & 14 & 126\end{array}$ 
Skylark. The solitary specimen received in August, found dead at Slyne Head, August 28, 1889, may not have been migrating, and all the September specimens were obtained in the last ten days of that month, the earliest at Blackwater Bank Lightship, September 22, 1898.

The density of the rush during October, November, and December may be compared as follows:-

\begin{tabular}{|c|c|c|c|c|c|c|c|}
\hline & & $\begin{array}{l}\text { Observa- } \\
\text { tions. }\end{array}$ & $\begin{array}{l}\text { Speci- } \\
\text { mens. }\end{array}$ & & & $\begin{array}{l}\text { Observa- } \\
\text { tions. }\end{array}$ & $\begin{array}{l}\text { Speci- } \\
\text { mens. }\end{array}$ \\
\hline October & $1-10$ & 119 & 9 & November & $21-30$ & . 88 & 8 \\
\hline$\eta$ & $11-20$, & 184 & 13 & December & 1-10, & . 67 & 1 \\
\hline$\eta$ & 21-31, & 205 & 16 & " & $11-20$ & 72 & 10 \\
\hline November & $1-10$ & 150 & 8 & " & 21-31, & 49 & 3 \\
\hline " & 11-20, & 120 & 11 & & & & \\
\hline
\end{tabular}

Throughout these three months, migration is observed every year. The period of its greatest density is fixed by both observations and specimens as October 21 to 31 .

In January the amount of migration is altogether contingent on the weather, none being noticed in mild seasons. The records for this month are of exceptional interest.

Jan. '83. '84. '85. '86. '87. '88. '89. '90. '91. '92. '93. '94. '95. '96. '97. Total.

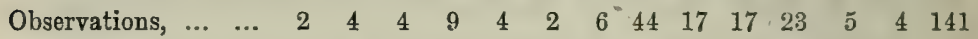
Specimens, $\ldots \ldots \begin{array}{lllllllllllllllll} & \ldots & \ldots & \ldots & \ldots & \ldots & \ldots & \ldots & \ldots & 2 & 2 & 1 & \ldots & \ldots & \ldots & 5\end{array}$

January 1892 was marked by a heavy snowstorm, which culminated on the 10 th ; in 1893 a snowstorm of considerable severity occurred on January 7 ; in 1894 similar conditions prevailed from January 4 to 7 ; and in 1895 severe weather set in towards the end of January, followed by a great snowfall early in February. In each of these four years the Reports show the renewal of the Lark's migration to have closely coincided with the advent of cold and snow. No specimens have been received in January, except in the years 1892, 1893, and 1894 , in each case after a snowstorm.

In February, on the other hand, migration is observed every year, and more specimens have been received in that month than in December. March has also never passed without records, and has furnished nearly as many specimens as December, while the observations outnumber those of February. Possibly this is really the month of principal spring migration, though fewer birds are killed, owing, it may be conjectured, to the comparative shortness of the nights. 
The April records, though few, are distributed among all the years, so that January is the only month between September and May which has in some years passed without any Larks being reported. A few observations are usually chronicled in May, but the date of the latest specimen (discounting one without data) is April 20, 1890 (Maidens).

The coast distribution of the Lark's migratory movements has already been outlined in comparing the observations relating to this species with those on the Thrush, Blackbird, and Starling. The specimens from each section of the coast are :South, 21 ; East, 98 ; North, 1; West, 6-Total, 126.

The numbers contributed by each county are :-

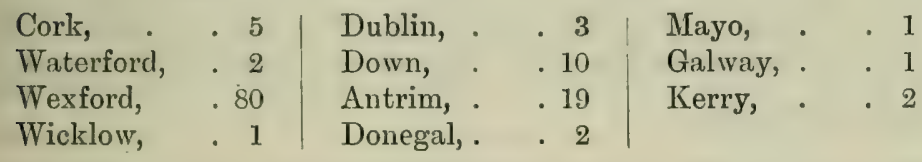

Light-ships have forwarded 57, islands 53, and mainland stations 16.

Blackwater Bank Light-ship has sent the largest number contributed by any one station-29. Next comes the Maidens, with 19, and Tuskar and Arklow South Light-ship, each with 18. Here, as in the case of the Gold-Crest, we see that the large number from Wexford is partly due to that county's numerous light-stations, since, with the exception of Blackwater Bank, no Wexford station has yielded more specimens than have been received from the Maidens, in Antrim. When we find the Tuskar and the Maidens practically equal (a very unusual circumstance), it is natural to surmise that a migration which falls with equal force on those two points is uniform along the line of the east coast. If we compare the numbers of observations furnished by the principal east coast stations, we shall find this surmise corroborated-

Tuskar, .

Codling Bank Light-ship, . 117

Blackwater Bank Light-ship, 147 Arklow South Light-ship, • 191 Arklow North Light-ship, . 193

Rockabill, . . . . 99

South Rock Light-ship, 146

Maidens, . . . . 145

Of the eight stations in this list, Tuskar and the two Arklow Light-ships alone have contributed an unbroken series of 
Skylark. reports for the fifteen years ending 1897. Rockabill and the Maidens reported in twelve of these years, South Rock Lightship in eleven, Blackwater Bank Light-ship in ten, and Codling Bank Light-ship only in seven. If we make the numbers proportional, they stand as follows :-

Tuskar,. . . . . 145

Blackwater Bank Light-ship, 220

Arklow South Light-ship, . 191

Arklow North Light-ship, . 193

Codling Bank Light-ship, . 250 Rockabill, . . • . 124 South Rock Light-ship, . 199 Maidens, . . • . 181

In this comparison the five light-ships show considerably higher figures than the three island-stations, but in other respects the observations are very uniformly distributed, and if we strike an average for each of the five counties represented by the above-mentioned eight stations, the uniformity becomes almost startling.

Wexford, 185; Wicklow, 193; Dublin, 187; Down, 199; Antrim, 181.

Thus the Lark's migration differs pronouncedly from that of the Thrush in extending along the whole of the east coast, while that of the latter bird is little observed at stations north of lat. $53^{\circ}$.

The various light-stations strongly corroborate each other's testimony with regard to this species, "rushes" being commonly reported with remarkable simultaneity along the East coast, and sometimes round the whole coast of Ireland. A large number of these simultaneous entries are furnished by lightships. The following are a few instances, in which six or more stations confirm one another's records:-

October 20-22, 1887 : Fastnet, Coningbeg Light-ship, Barrels Rock Light-ship, Tuskar, Arklow South Light-ship, Arklow North Light-ship, Maidens, Tory Island, and Slyne Hend. (On the 23rd at Blackrock, Mayo.)

January 8-10, 1892: Coningbeg Light-ship, Barrels Rock Light-ship, Blackwater Bank Light-ship, Arklow North Lightship, Codling Bank Light-ship, Drogheda North, Copeland, and Maidens.

November 13-15, 1893: Coningbeg Light-ship, Tuskar, Blackwater Bank Light-ship, Rockabill, Copeland, Maidens, Innishtraliull, and Slyne Head. 
February 3, 1897: Coningbeg Light-ship, Tuskar, Blackwater Bank Light-ship, Arklow S. Light-ship, Arklow N. Light-ship, Codling Bank Light-ship.

October 19, 1897 : Fastnet, Lucifer Shoals Light-ship, Blackwater Bank Light-ship, Arklow S. Light-ship, Arklow N. Light-ship, Codling Bank Light-ship, and South Rock Lightship.

On the night of February 20,1890, an extraordinary rush at Copeland light-house is thus described by Messrs E. M'Carron and C. Hawking:-

"Immense swarms of birds round lantern from 10 P.M. to 4 A.M. ; Larks, Blackbirds, Thrushes, and Starlings, also Curlew ; wind light S.E., misty. The air was filled with birds. The balcony outside was completely covered with killed birds; they were five or six deep all round, so to walk round would be walking on killed birds. Numbers got through the cowl into the lantern. The lantern-glass was so much soiled, both inside and out, that eight buckets of water had to be carried up next day to wash it. A labourer doing work at the light-house gathered two hundred, and 'that was not the quarter of them'; he gave a couple of buckets [of birds] to fishermen who came along. Several Curlew, Lapwing, and Golden Plover killed."

In this description there is no estimate of the proportions in which the different species occurred, but we find that on the same date a rush, which lasted for three nights, began at the -Maidens, nineteen miles to northward, and the list of killed is given as "110 Skylarks, 14 Redwings, 6 Thrushes, 11 Blackbirds, 8 Starlings, 3 Yellowhammers, 2 Lapwings "; ${ }^{1}$ from which it may fairly be inferred that Larks formed a great majority at both stations. Farther south this rush seems to have been noticed chiefly on the nights of February 22 and 23, at Arklow North and South Light-ships, and the Tuskar. At all these stations the number of birds striking is reported as large, but the Starling seems to have been more numerous than the Lark at Arklow North Light-ship, where 20 Starlings, 12 Larks, and 8 "Finches" were found on deck (the remainder of those which struck having fallen into the sea).

${ }^{1}$ The specimens forwarded were 1 Missel-Thrush, 1 Song-Thrush, 2 Blackbirds, 3 Larks, 1 Yellowhammer, 1 Starling, and 1 Lapwing. It is not im. probable that the 14 " Redwings" were wrongly identified, 
Skylark. Although this movement was noticed at the more northerly stations of the east coast (Maidens and Copeland) before it began at those further south, the direction of the flight does not appear to have been southward, but rather north-westward. At Arklow South Light-ship it was observed by day on February 23, and the light-keeper reports "continuous flocks of Starlings, Thrushes, Curlew, Larks, Blackbirds, and a few Grey Plover, going N.W."

The direction of the Lark's flight has been noted in 524 instances. We have thus a much larger quantity of evidence than in the case of the Thrush, whose direction was recorded 196 times. The result is the same in both cases.

Only 12 of the 524 observations referred to come from the west coast, where the movements are of so different a character from those noted elsewhere that it is better to confine our attention chiefly to the 512 records from the south, east, and north. Of these an overwhelming majority are landward.

\begin{tabular}{|c|c|c|c|c|c|c|}
\hline & & & & Landward. & Seaward. & Coasting. \\
\hline September & . & . & . & .13 & 1 & $\ldots$ \\
\hline October, & . & . & . & 151 & 14 & 6 \\
\hline November, & . & . & . & 103 & 8 & 5 \\
\hline December, & . & . & . & 55 & 4 & 5. \\
\hline January, & . & . & . & 44 & 2 & 2 \\
\hline February, & - & . & . & 31 & 5 & 2 \\
\hline March, . & . & . & . & 37 & 6 & 2 \\
\hline April, . & . & . & . & 11 & $\ldots$ & 1 \\
\hline May, . & . & . & . & 2 & $\ldots$ & ... \\
\hline June, . & • & - & - & ... & 1 & $\ldots$ \\
\hline July, . & . & . & . & 1 & ... & $\ldots$ \\
\hline & & & & 448 & $\overline{41}$ & $\overline{23}$ \\
\hline
\end{tabular}

Such a record clearly showis that the Lark's departure is unobserved. It must take place in spring, yet from the beginning of February to the end of May there are only 11 notes of Larks having been seen flying seawards, generally in insignificant numbers. To take these few notes as instances in which emigration has been witnessed would be unsafe, for 14 similar instances are noted in October and $S$ in November; 
while the west coast records, though only 12 in number, include 2 observations of seaward (i.e., westward) flights from Rathlin O'Birne, a station which has no land due west of it nearer than America; but the birds may have been making for the North Mayo shore, which lies about forty miles to southwest. So far, therefore, as the light-house records are concerned, we may consider ourselves still completely in the dark as to the time, route, and method of departure of the vast multitudes of Larks which are seen arriving on our shores in autumn and throughout the winter.

The list of specimens which have been sent as having struck with the Lark includes the Missel-Thrush, Song-Thrush, Redwing, Fieldfare, Blackbird, Black Redstart, Wheatear, Blackcap, Chiffchaff, Gold-Crest, Wren, Pied Wagtail, Titlark, Lapland Bunting, Reed Bunting, Chaffinch, Siskin, Linnet, Starling, Woodcock, Snipe, Jack-Snipe, Dunlin, and Storm Petrel. Of these the Thrush, Blackbird, Starling, Chaffinch, and Titlark are its most usual companions. An absentee from the list is the Greenfinch, though "Larks and Green Linnets" are often noted as passing light-ships together; while the Linnet, a still more frequently reported associate, has been received with the present species only once.

The Skylark is noted for its great variability in size, and among the wings received from Irish light-stations the longest and shortest differ by more than an inch. A remarkably large wing obtained from Arklow South Light-ship in October 1886 measured $4 \cdot 8$ inches in length, or 0.6 above the average.

Both in autumn and spring the earlier wings show the greater average length.

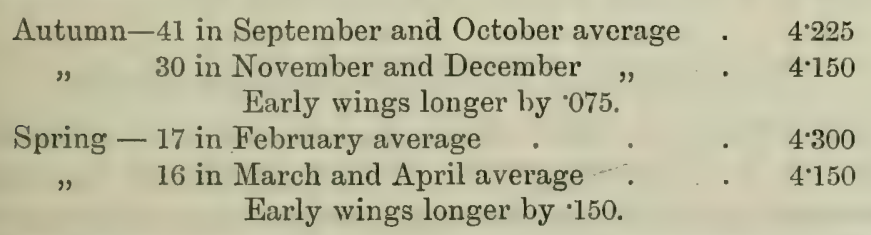

It will be seen on reference to the list of measurements (see Appendix, p. 643) that the eight longest wings were all obtained in October and February.

The average length is somewhat greater in spring than in autumn. 
Skylark.

71 in autumn (September-December) average

$4 \cdot 200$

33 in spring (February-April)

$4 \cdot 225$

The percentage of variation is the same as for the Willow Wren, and is greater than that found for any other species measured.

Average length of wing, $4 \cdot 20$; longest, $4 \cdot 80$; shortest, $3 \cdot 75$; difference between extremes, 1.05 ; percentage of variation, 25.

\section{WoODLARK (Alauda arborea, Linn.).}

Woodlark. This bird has only once been obtained at a light-station. A specimen was shot on the Tearaght rock by Mr F. Ryan, October 20, 1887. It was received in the flesh, with legs and wings of a Black Redstart, Brambling, and Greenfinch, shot the same day.

During the nine days from October 16 to 24,1887 , a large influx of many of our less regular visitants seems to have been in progress. Between those dates the birds received from the Fastnet, Tearaght, and Skelligs light-keepers include, besides the present species, 4 Black Redstarts and 4 Siskins, 2 Chaffinches, a Stonechat, Gold-Crest, Skylark, Brambling, and Greenfinch, and the only Irish specimen of the Lapland Bunting. Siskins, for which 1887 was a remarkable year, occurred chiefly at these three stations. On the east coast, the first Irish example of the Red-breasted Flycatcher and the only light-house specimen of the Stock-Dove were killed during the same period. That the Woodlark participated in this mixed autumnal rush from over sea seems much more probable than that it had merely straggled from the Irish mainland, where, as a breeding species, it is extremely rare.

\section{ShorT-TOed LaRK (Alauda brachydactyla, Leisler).}

Short-toed Lark.
On October 11, 1890, two birds supposed to be rare were shot by the light-keeper on Blackrock (Mayo), and were forwarded in the flesh. One was a Kestrel, the other a Shorttoed Lark.

- The Short-toed Lark, thus obtained, is the only bird of its species known to have visited Ireland, and is one of the greatest rarities which the light-stations have added to our fauna. Only ten occurrences in the British Isles are enumerated in 
"Saunders's Manual" (2nd edition, p. 255), and of these the Irish example is the only one which was obtained at a lightstation. It is apparently an adult bird.

The islands of the west coast were exceptionally favoured by rare birds in October 1890, as is shown by the occurrences, already mentioned, of the Yellow-browed Warbler, Lesser Whitethroat, and Red-breasted Flycatcher on Tearaght, almost simultaneously with that of the Short-toed Lark on Blackrock (Mayo). None of these four species have been obtained in Ireland except at light-stations between six and nine miles from the mainland.

\section{Snow Bunting (Plectrophenax nivalis, Linn.).}

The Snow Bunting has been reported from light-stations in every month of the year, and specimens have been obtained in every month except June and August.

In 1898 a male was sent in summer plumage, shot July 25, from Aranmore, Co. Donegal. Snow Buntings had previously been reported from the same station on June 13, 1886, and on August 18, 1883, though these were not obtained; and in 1884 two specimens in almost full summer plumage were forwarded which had been shot in the same island in the first week of May. From other west coast stations there are a few similar records. An occurrence on July 6,1897, is noted on North Arran Island, Co. Galway, and as far south as the Tearaght a specimen was shot and forwarded on May 30, 1889. With these instances in view, it seems possible that individuals may occasionally stay throughout the summer on the west coast of Ireland.

Thompson ("Natural History of Ireland," vol. i. p. 238) says that the earliest Snow Buntings noted by him (about Belfast) arrived in the middle of October 1831 and 1844, and that the latest date he had noted of their remaining was March 21, 1832. The light-house records from the east coast of Ireland (which in the case of this species are very few) are all intermediate between the above-quoted dates, the earliest being October 27 (Rockabill and Tuskar) and the latest March 18 (Tuskar), and thus corroborate Thompson's accuracy as an observer; but the north, west, and south coasts yield very different results, and show that the period of the bird's stay is normally much more prolonged than Thompson supposed. 
During sixteen consecutive years, $1882-1897$, the Snow

Bunting. Bunting's first autumnal occurrence noted by light-keepers (discounting those in July and August as possibly referable to birds which had not left us in summer) has eleven times been in September and five times in October, never later than October 10. During the same period, occurrences in spring have only been noted in fourteen years, and the latest observation was three times in March, five times in April, five times in May, and once in June. Except in 1885, when the latest observation recorded was on March 12, it has invariably been later than March 21. A list of the earliest autumnal and latest spring occurrences (omitting those in July and August) in each year is given below.

\begin{tabular}{|c|c|c|c|c|}
\hline Year. & $\begin{array}{l}\text { Earliest in } \\
\text { Autumn. }\end{array}$ & Station. & $\begin{array}{l}\text { Latest in } \\
\text { Spring. }\end{array}$ & Station. \\
\hline 1882 & October 5, & $\mathrm{Ar}$ & April 5, & Aranmore. \\
\hline 1883 & September 30 & $\left\{\begin{array}{l}\mathrm{Ar} \\
\mathrm{Te}\end{array}\right.$ & May 16 & Pathlin Island. \\
\hline 1884 & Septen & Arran Island, $\mathrm{N}$. & May 7, & Tearaght. \\
\hline 1885 & September 6, & Rathlin Island. & Mar. 12, & Aranmore. \\
\hline 1886 & September 29 & Aranmore. & June 13, & Aranmore. \\
\hline 1887 & October 1 , & Tearaght. & May 3, & Te \\
\hline 1888 & October 6, & Mine Head & Mar. 31, & krock (Мауо) \\
\hline 1889 & September 7, & Old Head, Kinsale. & May 30, & Tearaght. \\
\hline $\begin{array}{l}1890 \\
1891\end{array}$ & $\begin{array}{l}\text { September } 24, \\
\text { September } 9\end{array}$ & $\begin{array}{l}\text { Tearaght. } \\
\text { Rathlin } \mathrm{O}^{\prime}\end{array}$ & $\begin{array}{l}\text { April 10, } \\
\text { April 5. }\end{array}$ & $\begin{array}{l}\text { Tearaght. } \\
\text { Blackrock (Mayc }\end{array}$ \\
\hline & September 4 , & Inn & Mar. 25, & Tory Island. \\
\hline 3 & ber 23, & Inn & April 2 & Rathlin O'Bime. \\
\hline 4 & October 10 & Inn & May & Eagle Island. \\
\hline & September 21, & Innis & & \\
\hline 1897 & October 3 & Arran Island, N. & April 21 & Arran Isl \\
\hline & & & & \\
\hline
\end{tabular}

It will be observed that none of the occurrences in this list were on the east coast. Few in number as are the records of the Snow Bunting at eastern light-stations, they nevertheless agree with one another so remarkably as to afford very fair evidence as to the bird's usual date of arrival in that part of Ireland. This would appear to be between October 27 and November 4. There are four observations (three of them from land-stations) between November 23 and December 22, but these presumably relate to coasting birds rather than recent immigrants.

This bird, from its conspicuous coloration and coast-haunting habits, is familiar to most of the light-keepers, and is seldom 
identified wrongly. The observations from our eastern stations may fairly be contrasted with those from the north, west, and south, as indicating a later arrival in autumn and an earlier departure in spring.

The Snow Bunting undoubtedly remains on the east coast, in some years, to a later date than the light-house observations show (i.e., March 18); but if it were in the habit of remaining into May, as some are shown to do frequently on the west coast, evidence of the fact would have been forthcoming.

This species seldom strikes the lanterns. Of 34 specimens received, 21 were shot. Of the whole number, 4 were obtained in September, 7 in October, 2 in November, 4 in December, 2 in January, 2 in February, 1 in March, 6 in April, 5 in May, and 1 in July. From September to December (inclusive), 5 examples struck the lanterns, all between October 4 and November 6, a circumstance which seems to mark the period when immigration is greatest. From January to May (inclusive) 5 also struck, 1 in January, 2 in February, 1 in April, and 1 in May. It is curious that April and May are the only months in which the Snow Bunting is known to have struck the lanterns on the west coast, while February is the only spring month in which specimens have been similarly obtained on the east coast. ${ }^{1}$ For March there is one record (Innishtrahull, March 22, 1897) of this species striking, but the bird was not forwarded. The west coast examples struck respectively on North Arran Island, April 21, 1897, and at Slyne Head, May 17, 1889. The former was a beautiful male in almost perfect summer plumage, not equalled by that of any other specimen received, though seven were obtained at later dates (April 23 to July 25).

The spring specimens evidently afford no clue to the period of maximum emigration, since none struck between February 20 and April 21, during which long interval the great majority of our. Snow Buntings nust take their departure.

The extreme dates on which specimens have been obtained (discounting the July bird) are-

Earliest, . September 18, 1884, . Skelligs.

Latest, - May 30, 1889, . Tearaght.

Both from rocks off the coast of Kerry.

${ }^{1}$ At Rockabill, Fobruary 1896 and 1897, in winter plumage. 
The stations where Snow Buntings are most numerously Bunting. reported are those on the north and west coast, from Innishtrahull to Tearaght. That they are regular winter visitants to Tearaght is shown by the fact of their presence there being noted during eleven consecutive winters (1883-1893) - a more continuous record than is yielded for the same species by any other station except Innishtrahull. In four years they were observed on Tearaght as early as September, and in three they remained there till May. The reports show they are probably regular visitants to all the islands of the west and north coast. Several of the observations from Blackrock (Mayo) are interesting. Thus, in the winter of 1883-84, Snow Buntings are frequently noted from October 30 to March 30 ; in 1884-85, they are "seen every day from November 20 until middle of March"; in 1885-86, the first are noted September 8, and on January 20 the light-keeper writes: "For the last nine days the spray has been flying over rock, and the Snow Buntings never left, and how they managed to exist I cannot imagine." In 1889 one was seen on this desolate rock as late as April 27. In three out of the six years in which their arrival is noted on the Skelligs, it took place between the 11th and 18th of September.

To the south coast the Snow Bunting is a less regular visitor, but it is reported in eleven out of the sixteen years between 1882 and 1897. On the east coast it has been reported in only ten years-a paucity of records which must in part be ascribed to local and accidental causes, such as the absence of favourably situated light-stations; for it is a well-known fact that the northern part of the east coast, as far south as Dublin, is visited every winter.

The number of observations and specimens from each of the four sections of the coast is as follows :-

South Coast,
East ",
North ",
West ,

Observations, Specimens.

$\begin{array}{rr}34 & 9 \\ 20 & 4 \\ 95 & 6 \\ 232 & 15 \\ - & - \\ 381 & 34\end{array}$


As the north coast records are from only 3 stations (Rathlin, Innishtrahull, and Tory Island), while those of the west coast are contributed by 13, the north shows the higher proportion. As compared with the south and east, however, the large number of west coast observations is sufficiently striking, and affords a marked contrast to the case of any other regular migrant hitherto dealt with.

In one instance only has the Snow.Bunting been received from a light-ship (Coningbeg, October 11, 1889); and it bas only once been reported from a similar station (Arklow $\mathrm{N}$. Light-ship, February 17, 1885), but there are no light-ships on the north and west coasts.

At mainland stations, it has never been mentioned as striking; but it has struck on islands off each of the four sections of the coast.

The arrivals (not necessarily first arrivals) noted at different stations in some years coincide pretty closely. For instance:-

1882, Rathlin, Innishtrahull, and Tory Island-November 5, 7, and 9. 1885, Rathlin, Blackrock, and Skelligs-September 6, 8, and 11.

1886, Aranmore, Blackrock, Fastnet, and Tearaght-September 29, October 1,3 , and 5 .

1890, Skelligs, South Arran, Mine Head, Aranmore, and KillybegsOctober 29, November 2, 3, 4, and 6.

Seven species have been forwarded as having struck with the Snow Bunting: the Missel-Thrush, Thrush, Fieldfare, Meadow Pipit, and Brambling (Fastnet, November 11, 1891), and the Water-Rail and Purple Sandpiper (Tuskar, October 29, 1892). The association in the last-mentioned case of three characteristic Icelandic birds, unaccompanied by any of our more common migrants, is remarkable; especially as another Water-Rail struck the same night at South Arran Island, and another Purple Sandpiper at the Tearaght.

There is some ground for considering that the Snow Buntings which come to the west coast of Ireland have rather longer wings than those found on the east; for of 9 specimens obtained from stations west of longitude $8^{\circ} \mathrm{W}$., the average length of wing is 4.290 , while of 10 specimens from stations east of longitude $7^{\circ} \mathrm{W}$., the average length is $4 \cdot 235$. The average difference is thus about one-twentieth of an inch. 
Snow

Average length of wing, 4.24 ; longest, 4.80 ; shortest, 3.92 ;

Bunting. difference between extremes, 0.87 ; percentage of variation, $20 \frac{1}{2}$.

\section{LAPLAND BUNTING (Calcarius lapponica, Linn.).}

Lapland

Bunting.

A supposed "Twite" found dead with a Skylark on the Fastnet Rock, October 16, 1887, was forwarded in the flesh, and proved to be a female of the above species. This is the only Irish occurrence of the Lapland Bunting.

The week in which this bird was obtained was marked by a considerable incursion of Siskins, with several Black Redstarts and some Bramblings, at our south-western stations from Fastnet to Tearaght; at the last-named station a Woodlark was also shot at this time.

There is no evidence of Lapland Buntings having visited Ireland in the autumns of 1892 or 1893 , when such large numbers occurred in Great Britain that some instances on the Irish coast might have been expected.

\section{ReED. Bunting (Emberiza schœniclus, Linn.).}

Reed

Bunting. have been received. These are all the migrational occurrences of which there is any evidence, the Reed Bunting being unknown to most of the light-keepers, or known only as "Blackcap."

Two specimens of the above six were obtained in spring.

Earliest, March 12, 1896, Blackwater Bank Lt.-ship.

Latest, April 13, 1897, Innishtrahull.

Four were obtained in autumn.

Earliest, October 23, 1899, Blackwater Bank Lt.-ship.

Latest, November 19, 1898, $\left\{\begin{array}{c}\text { Skulmartin Rock Lt.-ship (Co. Down), } \\ \text { and Maidens W. (Co. Antrim). }\end{array}\right.$

Three of the six struck in November.

Five occurred on the east coast, from Blackwater Bank to the Maidens, and four of these were at light-ships (Blackwater, Arklow South, and Skulmartin). The remaining occurrence was on the north coast (Innishtrahull).

The Thrush, Fieldfare, Blackbird, Wren, Lark, and Brambling have struck with this species in autumn. 
Average length of wing, 3.06 ; longest, 3.12 ; shortest, 3.00 ; difference between extremes, $0 \cdot 12$; percentage of variation, 4 .

\section{CoRn Bunting (Emberiza miliaria, Linn.).}

No evidence of this species migrating can be adduced, beyond the fact that a specimen was disabled striking the Corn lantern at Tory Island, April 25, 1895. Two specimens (one shot, the other without data) have also been received from Innishtrahull, and there is evidence of individuals remaining through the summer on both those islands. These occurrences do not justify a larger inference than that the Bunting occasionally migrates between the Irish mainland and islets within a few miles of the coast.

\section{YeLLOW Bunting (Emberiza citrinella, Linn.).}

The Yellow Bunting very seldom strikes. Only six specimens have been received, all from light-ships and islands off the east coast. Of these, one struck in February, two in March, and three in November.

$\begin{array}{lll}\text { Earliest in spring, } & \text { February 20-26, 1890, } & \text { Maidens. } \\ \text { Latest } & \text { March 28, 1890, } & \text { " } \\ \text { Earliest in autumn, } & \text { November 13, 1887, } & \text { Arklow S. Lt.-ship. } \\ \text { Latest " } & \text { November 30, 1887, } & \text { Maidens. }\end{array}$

The remaining instances were at Copeland (March 7, 1898) and Tuskar (November 23, 1896).

Fifty-seven observations in fifteen years is a small number in the case of so common and conspicuous a species; and as many as fifty of these records relate either to single birds or small parties of from two to seven, generally not more than two. "Flocks" are mentioned only twice- "large flocks" at Rathlin O'Birne, November 22, 1883, and "small flocks" at Tuskar, November 20,1884; while a "rush," in which four Yellowhammers were killed striking, occurred at the Maideus in February 1890. These are the only instances in which the birds appear to have been at all numerously observed; and from the paucity of such records we may conclude that the Yellowhammer is a somewhat stationary species. 
The number of observations to each month and section of the coast are as follows :-

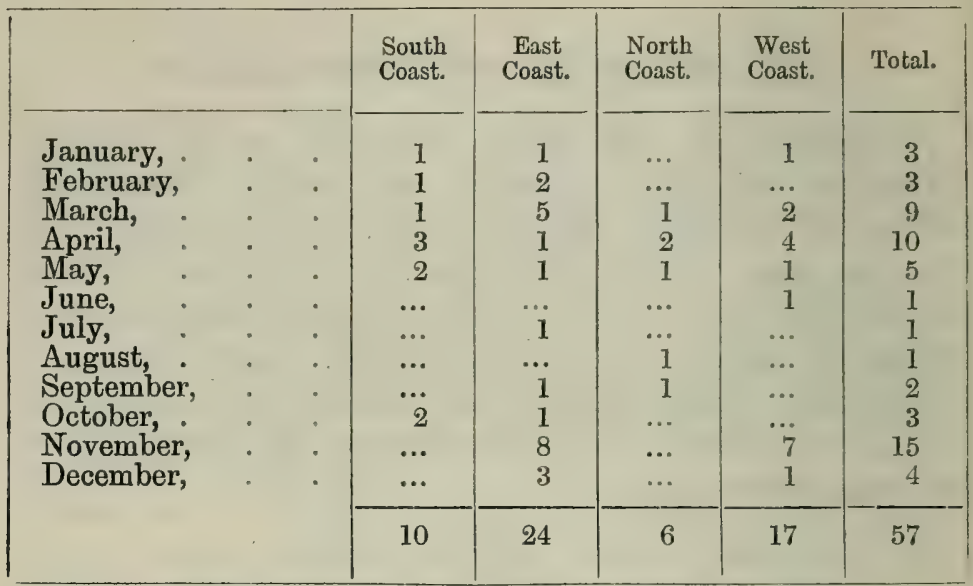

The east coast records seem to show that any intermigration which may take place between Great Britain and Ireland is probably at its maximum in March and November. This accords with what would be inferred from the few specimens received.

Several of the islands on the north and west coasts seem to be very irregularly visited, but it would be difficult to ground any inference on the records, even supposing them to be free from error, except that April has a majority of occurrences.

The direction of flight has been noted in only nine instances. Except in one case, all these flights were towards the laud.

It may be observed that the light-stations of the Ulster coast have yielded a large proportion of the specimens received of our three resident Buntings (Emberiza schoniclus, E. miliaria, and $E$. citrinella).

Ulster Coast, $\begin{array}{cc}\text { Reed } & \text { Corn } \\ \text { Bunting. } & \text { Yellow } \\ \text { Bunting. } & \text { Bunting. }\end{array}$ Total.

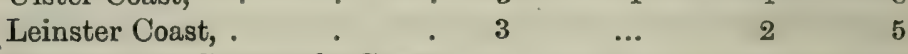

$\begin{array}{llllll}\text { Munster and Connaught Coasts, } & \ldots & \ldots & \ldots & \ldots\end{array}$

Small as the numbers are in all three cases, they yet suggest that, contrary to the usual rule, birds belonging to this group 
migrate more across the northern than the southern part of the Irish Channel. In the case of the Yellowhammer, this is corroborated by the fact that only four observations are contributed by the east coast of Wexford, while the remainder of the east coast, from Arklow North Light-ship to the Maidens, yields 20,16 of these being from stations north of Dublin.

The only occasion on which the Yellowhammer is known to have struck with other species was during the great rush at the Maidens, February 20 to 22, 1890, already referred to in treating of the Lark (p. 107). This rush was partly renewed on the 26th, and Yellowhammers are reported as killed both on that night and during the earlier period. One specimen was received, the other species forwarded being the Missel-Thrush, SongThrush, Blackbird, Meadow Pipit, Skylark, Starling, and Lapwing.

Six wings measured (of which, however, the largest belongs to a bird shot at a land-station) show considerably more variation than appeared from an equal number of wings of the Reed Bunting.

Average length of wing, 3.44 ; longest, 3.55 ; shortest, 3.22 ; difference between extremes, 0.32 ; percentage of variation, $9 \frac{1}{2}$.

\section{Chaffinch (Fringilla ccelebs, Linn.).}

The Chaffinch is a very regular migrant, arriving in large numbers on our eastern and southern shores every year about the middle of October. Its migration continues until the middle of November, after which time, in most years, it ceases to be extensively reported. The data respecting the spring movements are confusing, but, as in the case of other species, there is reason to suspect that the departing birds are not observed. Forty-seven have been received, 44 in autumn and 3 in spring.

Both the earliest and latest autumnal specimens were found dead on Blackwater Bank Light-ship:-

$\begin{array}{llll}\text { Earliest, } \quad & \quad & \quad & \quad\end{array} \quad \begin{aligned} & \text { October 14, } 1897 . \\ & \text { Latest, }\end{aligned}$

It would thus appear that there is little immigration during the 
Chaffinch. first fortnight of October, but the remaining part of that month sees the maximum autumnal influx :-

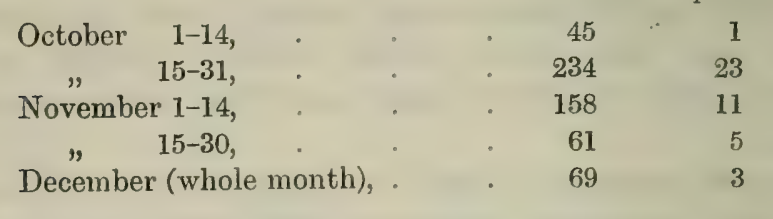

The month of greatest immigration is from October 15 th to November 14th, this period being represented by 392 observations and 34 specimens, while the remainder of October and November yields only 106 observations and 6 specimens. January and February are blank as regards specimens, and the observations for those two months are unimportant, numbering respectively only 13 and 24 .

The Chaffinches which have wintered in Ireland seem, as a rule, to leave in March. On the Tearaght, where the arrival of this species is generally recorded in October, its departure was noticed by Mr M'Carron "about March 20th," 1885, and again by $\mathrm{Mr}$ James on March 5, 1888. It is certain that these departing birds rarely, if ever, strike the light-houses, for only one specimen (a wing, sent without data from the Tuskar, received 29/3/86) has been forwarded in March. The only April specimen is also a wing without data, received with a number of other legs and wings from Innishtrahull, April 10, 1894, and which was perhaps killed in the previous autumn. The third spring specimen, and the only one with satisfactory data, was found dead on Coningbeg Light-ship on the 13th of MIay 1887-a date at which one would scarcely expect to find the Chaffinch migrating. The contrast between the small number of specimens received in spring and the large number forwarded in autumn is, in the case of this species, very exceptional. It cannot, however, be asserted that no spring migration of the Chaffinch is observed at light-stations. In March as many as 76 observations are reported, in April 54, and in May 12. The spring observations are, it is true, only one-fourth as numerous as those made in the autumn; but even this is a large proportion compared with that borne by the specimens, i.e, onefifteenth. 
If the spring records related to departing birds, the dis- Chaffinch. crepancy just alluded to would present no difficulty, for it is reasonable to suppose that birds suffer fewer fatalities in setting out than during the later stages of their journey. But when we look to the light-keepers' notes regarding direction, we find good grounds for the inference that the Chaffinches seen in spring are, like most other migrants on whom similar observations are made, not departing, but arriving.

The 186 observations as to direction which are tabulated below, are taken exclusively from the records of south and east coast stations.

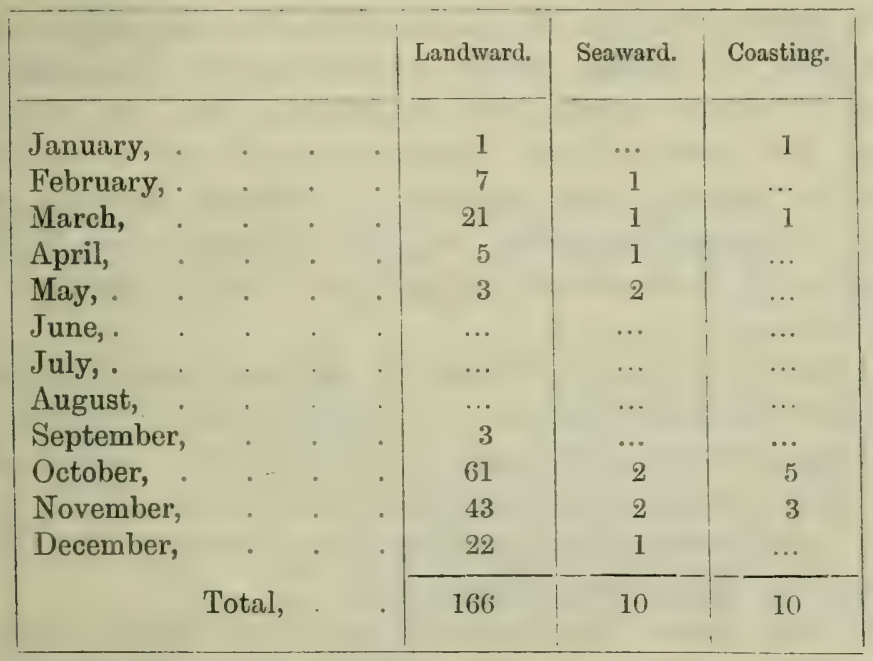

It will be seen that the proportion of seaward to landward 1lights is the same in March as in November and Decembera little less than one-twentieth.

If the above observations are accurate, they prove that an immigration of Chaffinches takes place in March, simultaneously with the departure of those which have wintered with us; and some of the light-keepers' notes are sufficiently circumstantial to add strength to this suggestion. For instance, in $1894 \mathrm{Mr}$ Wall's report from Coningbeg Light-ship runs as follows :-

"March 21st, two lighted on ship at 9 A.M. and died; wind light S.E., light haze: 25 th, four lighted on ship at 10 A.M.; 
Chaffinch. two died; wind light S.E.: 28th, two fell into the sea trying to fly on shore at 10 A.M. ; wind light E."

Here we see an instance of Chaffinches arriving on a series of days, all in a fatigued condition, some dying on the lightship's deck, and others falling exhausted into the sea, during the continuance of apparently favourable weather-a state of things scarcely compatible with the supposition that they had only just left the Irish shore; and besides, we are expressly told that the birds seen on March 28 were "trying to fly on shore."

In a number of other instances, corroborative of the above, the Chaffinches reported in spring were observed resting (in some cases dying) on the decks of various light-ships, from Coningbeg to Codling Bank. At this season they seem to occur in smaller parties than in autumn, from one to three being the numbers most frequently noted; and it is thus possible that the small number of specimens received may bear the same proportion as the autumnal ones to the number of birds observed, though not to the number of observations.

It must not, however, be taken as definitely concluded from the above, that the Chaffinch is a regular spring immigrant, as well as an autumnal immigrant, to this country. All that can be said is that the evidence points better to that than to any other interpretation, and that there is no evidence of the direct emigratory flight being observed at all.

At both seasons the south and east coast stations furnish the most observations, and if we deduct six shot birds from the number of west coast examples, the same remark applies to specimens also.

\begin{tabular}{|c|c|c|c|}
\hline \multirow{2}{*}{\multicolumn{2}{|c|}{ South Coast, }} & Observations. & Specimens. \\
\hline & & 172 & 12 \\
\hline East & $"$ & 534 & 20 \\
\hline North & $"$ & 6 & 1 \\
\hline West & $"$ & 74 & 14 \\
\hline & & 786 & 47 \\
\hline
\end{tabular}

Of the eight west coast specimens, six were obtained near its southern extremity (Tearaght and Skelligs). 
The observations and specimens from each county are as Chaffinch. follows :-

\begin{tabular}{|c|c|c|c|}
\hline & & Observations. & Specimen \\
\hline Cork, & . & 40 & 4 \\
\hline Waterford, & . & 20 & 1 \\
\hline Wexford (S. coast), & & 112 & 7 \\
\hline$" \quad$ (E. coast) & & 231 & 16 \\
\hline Wicklow, & . & 49 & 1 \\
\hline Dublin, . & . & 185 & 3 \\
\hline Louth, . & . & 4 & $\ldots$ \\
\hline Down, & . & 22 & $\ldots$ \\
\hline Antrim, . & . & 43 & $\ldots$ \\
\hline Donegal, & . & 11 & 1 \\
\hline Mayo, & . & 18 & 2 \\
\hline Galway, & . & 17 & 2 \\
\hline Kerry, & . & 34 & $4^{x}$ \\
\hline & & 786 & 41 \\
\hline
\end{tabular}

Blackwater Bank Light-ship has sent the largest number of specimens, while Tuskar comes next, and Coningbeg Lightship and Tearaght share the third place. It is evident that, unlike the Buntings, much more migration takes place across the southern than the northern part of the Channel.

As many as 18 observations of this species come from Blackrock (Mayo). All these were made in October and November, between 1886-89. In three consecutive years the date of the first arrival on this isolated rock is noted, and the coincidence of the three entries is remarkable: October 24, 1886 ; October 22, 1887 ; and October 21, 1888.

On the Tearaght Rock it has been repeatedly observed (1884, 1885, and 1886) that the Chaffinches which arrive there in autumn are principally females. On the other hand, at Drogheda North the light-keeper reports that "it is male Chaffinches which pass in winter" (1894, p. 415). At no other station has either sex been noted as predominating, and the observations on this subject are therefore too meagre to warrant any conclusion.

Twelve species have been forwarded as having struck with the Chaffinch, all during the autumnal migration. The Blackbird and Skylark have each been sent with it four times, the

${ }^{2}$ Excluding six shot. 
Chaffinch. Redwing and Starling each three times, and the Thrush, Fieldfare, Gold-Crest, Titlark, Greenfinch, Siskin, Linnet, and Dunlin, each once.

From the measurements of 40 wings obtained in autumn, it appears that the birds arriving in October have longer wings than those which arrive in November and December.

Of 23 in October, average length is $3: 38$.

Of 17 in November and December, average is $3 \cdot 34$.

The October wings are thus longer by '04, though the longest specimen measured belongs to a bird which struck late in December.

Average length of wing, 3.35 ; longest, 3.72 ; shortest, 3.17 ; difference between extremes, 0.55 ; percentage of variation, 16 .

\section{Brambling (Fringilla montifringilla, Linn.).}

Brambling. Though specimens of the Brambling have been received from eight light-stations, it is not known to have struck the lanterns at more than three-Fastnet, Tuskar, and Arklow South Lightship. From each of these, two specimens, found dead or disabled, have been sent. Four of the six so obtained struck in November, one in December, and one in April.

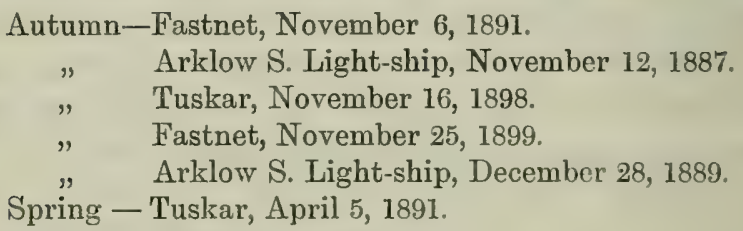

Besides these, five others have been received. Tearaght has forwarded one shot on October 20, 1887; Old Head, Kinsale, one shot on October 28, 1888; Skelligs, one shot (out of a flock of forty) on November 10, 1887; Hook Tower, one which took refuge in the light-house during severe weather in January 1894; and Innishtrahull one with incomplete data, but probably shot in April 1895.

The instances in which the "Mountain Finch" has been reportcd are few, and are limited to the stations already enumerated as having sent specimens. One occurrence is reported from the Tuskar, two from the Tearaght, two from the Skelligs (one of these at the unlikely date of May 29), and four 
from Innishtrahull. The last-mentioned station reports a "flock of Brambling on island," November 15, 1895; "two flocks," February 4, 1896; and "eight all day," March 18, 1896; but all the observations from other stations, except as regards the flock of forty seen at the Skelligs in 1887, relate to occurrences of from one to four birds only.

Many Bramblings doubtless pass unnoticed, as the lightkeepers frequently fail to recognise this species. Of the eleven specimens received, one was labelled "Flycatcher," one "Snow Bunting," and two "unknown " or "small bird." It would thus be rash to infer its absence from those parts of the coast where it has not been reported. Still, the fact that ten examples have been forwarded from stations south of lat. $52^{\circ} 41^{\prime}$, and only one from a station further north, seems to show (as in the case of the Siskin, p. 131) that this bird generally arrives on the southern and south-eastern shores of Ireland; though there is probably, in some winters, an immigration from Scotland also, to our north coast.

The earliest observation and earliest specimen in autumn are both dated October 20,1887, on which day a bird was reported at the Tuskar, and another forwarded from the Skelligs. During that winter Bramblings were more than ordinarily numerous in Ireland, and were noted or sent from four stations, all on the coasts of Wexford and Kerry. There is some evidence of their having been observed at light-stations every year from 1887 to 1891 (inclusive), and also every year from 1894 to 1899 ; but only two years (1887 and 1889) furnish instances earlier than November, which is probably the month in which most Bramblings arrive.

As March is considered the usual date for this species to depart from the British Isles, and Mr Howard Saunders considers that "by the middle of March almost all have returned to their northern breeding-grounds" ("Manual," p. 185), we have here an interesting case of a bird which has never been sent from a light-station when its spring migration must be at the maximum. A somewhat similar fact was noted of the Snow Bunting.

Nine species have been forwarded as having struck with the Brambling, each of them on one occasion only. Seven (i.e., the Missel-Thrush, Song-Thrush, Fieldfare, Black Redstart, Meadow 
Brambling. Pipit, Snow Bunting, and Reed Bunting) have struck with it in November, and two (the Chiffchaff and Skylark) in April.

Of 7 wings measured, the percentage of variation in length is somewhat greater than appeared from the measurement of 94 wings of the Thrush.

Average length of wing, 3.58 ; longest, 3.75 ; shortest, 3.37 ; difference between extremes, 0.37 ; percentage of variation, $10 \frac{1}{2}$.

\section{Tree Sparrow (Passer montanus, Linn.).}

Tree

Sparrow.

A bird of this species was once caught exhausted at the Tuskar, October 22, 1896, and was sent in the flesh. The light-keeper reports it to have come from the S.E.

Its only known breeding stations in Ireland are in County Dublin, where it is very local; but its migrational occurrence on the Wexford coast is analogous to what has been observed of other species whose breeding haunts are in more northerly districts, the most remarkable instances being the Whinchat and Yellow Wagtail.

A "Tree Sparrow" has been reported from the Tearaght, October 28, 1892, but the identification may have been erroneous.

"Sparrows" have on a few other occasions been reported from the Tuskar (March 1, 1883, and March 9, 1887), and once from Coningbeg Light-ship (October 29, 1897). These birds are as likely to have been of the present species as of the next, the evidence in favour of the House Sparrow's migration being extremely meagre.

\section{House Sparrow (Passer domesticus, Linn.).}

House

Sparrow. Dublin, on November 5, 1893, is the only specimen receiver, except from stations where the bird is resident.

The Sparrow is seldom reported from light-ships, but is said to have previously been observed passing Codling Bank (March 17, 1890). Arklow South Light-ship has once reported it in May, and Coningbeg once in October.

From the Fastnet, Tuskar, and Maidens Light-houses about six occurrences are reported, chiefly in spring; but some of the 
birds observed may have been Tree Sparrows. At Rockabill, Sparrows are noted as "unusual visitors" during a great rush of birds which occurred there in the first fortnight of November 1889 ; and large flocks have several times been reported in autumn from the western isles, to which it may be supposed that some of the mainland birds pay nomadic visits at that scason. There is, however, no reason to regard this species as a regular migrant.

\section{Hawfinch (Coccothraustes vulgaris, Pallas).}

Until 1897 no Hawfinch had been received from an Irish light-station, but in the autumn of that year three specimens were forwarded, all killed striking at stations on the Wexford coast, between October 25 and November 4. The first, a male, struck at Hook Tower, October 25; the second at Tuskar, November 1; and the third at Hook Tower, November 4.

In 1898 a fourth specimen was received, caught striking at Mine Head, Co. Waterford, on the night of November 10.

The only reported occurrence of this species was at Rockabill, where one was caught striking on the morning of April 20, 1890.

The specimens obtained are too few to prove the route usually adopted. There is, however, no evidence of any autumnal occurrence at a station north of the Tuskar.

Three were weighed, and exhibited remarkably little variation, being all slightly under 2 ounces, the lightest falling short of that weight by about 20 grains.

\section{GREENFINCH (Ligurinus chloris, Linn.).}

The migration of the Greenfinch is chiefly observed in October, November, and December, on the southern section of the east coast. Fifteen specimens have been received from light-stations, which were all killed during the last three months of the year. Some of these, however, were certainly, and others probably, shot; and only nine are known to have struck the lanterns-eight on the Leinster coast from Coningbeg to Rockabill, and the remaining example at Blackrock (Mayo).

The observations relating to the Greenfinch number 173-a little more than one-fifth the number recorded for the Chaffinch; 
Greenfinch. and the specimens (excluding shot birds of both species) are also a little more than one-fifth as many.

\begin{tabular}{|c|c|c|c|c|}
\hline Chaffin & * & & $\begin{array}{c}\text { Observations. } \\
786\end{array}$ & $\begin{array}{c}\text { Specimens. } \\
41\end{array}$ \\
\hline Greenfinch, & - & & 173 & 9 \\
\hline
\end{tabular}

From this it may be inferred as prima facic probable that the Chaffinches which visit us in autumn are about five times as numerous as the immigrant Greenfinches, but this evidence is by no means conclusive.

The period of maximum migration, measured by the observations, is approximately the same for both species, i.e., the latter half of October and earlier half of November; but in the case of the Greenfinch there is sometimes a considerable renewal in December, and four of the nine specimens which were killed striking were obtained in the latter half of that month. The rest were obtained between October 28 and November 30 , one in October, three in the earlier half of November, and one in the latter half of that month.

A few observations are on record for every month of the year. Those for the half year from August to January (inclusive) number 145, and those for the remaining half (February to July) number 28. No specimens have been received in spring. As in the case of the Chaffinch, there is some evidence of a small immigratory movement at that season, but somewhat later, Greenfinches having been noted going landwards in April from Coningbeg Light-ship (April 15, 1886), Barrels Rock Light-ship (April 29, 1887), Maidens (April 26, 1893, and April 5, 1894), and Arklow North Light-ship (April 23, 1894). In 1897 Mr J. Beahan reports from Arklow North Light-ship as follows:-

"April 20th, one Green Linnet died on deck; wind moderate S.W., clear: 27th, two died on deck; wind light N.E., clenr. June 10th, one Yellow Water-Wagtail and two Green Linnets going N.W. during forenoon; wind light S., clear: 18th, one on ship, died on deck; wind fresh N.W:, clear."

- This series of notes would show a curionsly high rate of mortality for birds sterting on their migratory journey, and as the only direction noted (on June 10) is landwards, there is little reason to doubt that all these birds were arriving, and 
that the four deaths enumerated were due to fatigue after a Greenfinch. long flight.

The whole number of observations for each month is as follows :-

Jan. Feb. March. April. May. June. July. Aug. Sept. Oct. Nov. Dec.

$\begin{array}{llllllllllll}11 & 2 & 7 & 14 & 2 & 2 & 1 & 3 & 7 & 46 & 44 & 34\end{array}$

The south coast records 38 , the east 109 , the north 5 , and the west 21 . The proportion from each section is nearly the same as in the case of the Chaffinch.

The Greenfinch, like the Chaffinch, is a frequent winter visitant to the Tearaght, where some have once been observed to remain until May 12 (1888). Shot specimens have been received in autumn from both Tearaght and Skelligs. "Green Linnets" were annually reported from the Fastnet for five consecutive autumns (1884 to 1888), sometimes as striking in numbers; but none have been noted from that station in recent years, an omission probably due to oversight, or to the birds being simply called "Linnets." The species has seldom been noted from the islands of the Galway and Mayo coasts, but in 1896 a number are said to have visited Blackrock (Mayo) with Starlings, Chaffinches, Blackbirds, and a few Thrushes, during a fortnight of very cold weather from November 5th to 18th. The Greenfinch is considered a regular winter visitant to Innishtrahull (1893 "Report," p. 357), at which station, however, there is no record of its having ever struck the lantern.

Only one specimen of the Greenfinch has been sent with other birds said to have struck during the same night. This example was found dead at Rockabill, October 28, 1886, with a Redwing, Chaffinch, and Dunlin.

Twelve wings measured exhibit very little variation in length. Though the average exceeds that of the Chaffinch by 08 , the longest Greenfinch's wing is less by '20 than the longest wing of Fringilla coelebs.

Average length of wing, 3.43 ; longest, 3.52 ; shortest, 3.32 ; difference between extremes, $0 \cdot 20$; percentage of variation, 6 .

GoLDFinch (Carduelis elegans, Stephens).

As a migrant the Goldfinch is seldom observed or obtained, Goldfinch. but small numbers apparently cross the southern part of the 
Goldinch. Channel in October, during the latter half of which month specimens have been forwarded from Blackwater Bank Lightship (found dead, October 18, 1899), Lucifer Shoals Light-ship (killed striking, October 21, 1898), and the Fastnet (killed striking, October 30, 1897). Specimens have also been sent from two mainland stations on the south coast-one found dead at Old Head, Kinsale (October 15, 1889), and another found dead at Hook Tower (November 9, 1892). A specimen shot at Mine Head in February 1886 is the only other example received.

Turning from specimens to observations, we find only eight records from the east coast-Goldfinches being once reported at Rockabill, once at Howth Baily (a mainland station), twice at Codling Bank, and four times at Arklow North Light-ship. Of these occurrences, all on the Dublin and Wicklow coast, 2 were in March, 1 in May, 3 in October, and 1 in November.

The south coast observations are nearly all from mainlandstations, affording little evidence as regards migration. On the Fastnet Rock, however, a Goldfinch is said to have been caught on November 4, 1896-a date very closely corresponding with that on which a specimen was killed striking at the same station in the following year.

On the west coast the records are comparatively numerous, but, with few exceptions, they are from islands on which the Goldfinch breeds. Out of a total of 34 west coast observations, 11 are from Aranmore and 13 from Valencia, making 24 at least from breeding-stations of the species, while 3 are from the south island of Arran, where also it is reported to remain during the spring. The remaining 7 may refer to birds which had straggled from the mainland.

The north coast yields one record, from Innishtrahull, where a Goldfinch is said to have been caught, May 6, 1895. It is remarkable that no occurrence of this finch has been noted from any light-station of the north and east coasts between Innishtrahull and Rockabill, a distance of about 160 miles.

The specimens from Blackwater Bank and Lucifer Shoals 'Light-ships were received alone, while the Fastnet specimen was forwarded with a Ring-Ouzel, a Wren, and two Sisking, obtained the same night, during a great rush of birds of various species, 
The light-keepers consider it a very rare event for a Goldfinch. Goldfinch to strike the lanterns; but, since the records and specimens from two Wexford light-ships and the Fastnet afford instances of its having been killed or caught in four consecutive autumns (1896 to 1899), the inference seems to be warranted that an annual immigration takes place.

The measurements of a large series of wings would probably show a high percentage of variation, as among five specimens received from Irish light-stations, the longest and shortest differ by one-tenth of the average length.

Average length of wing, 3.00 ; longest, 3.175 ; shortest, 2.875 ; difference between extremes, 0.30 ; percentage of variation, 10 .

\section{Siskin (Carduelis spinus, Linn.).}

The light-house investigations fully bear out the character long ascribed to this species, of an extremely erratic and irregular visitant. The autumns of 1887 and 1897 were distinguished by notable irruptions. Seven specimens were obtained in 1887, six in 1897, and only one (October 1889) in the whole remaining period, comprising the fourteen years 1884-86, 1888-96, and 1898-99.

It is curious that the Brambling should have been forwarded in eight different years, and the Siskin in only three. The latter is generally considered to be much the more frequent winter visitant, and is known to breed in many counties.

The whole number of specimens received is thus 14. All were obtained in autumn, -10 in October, 3 in November, and 1 in December.

\section{Earliest, October 9, 1897, Skelligs. \\ Latest, December 3, 1887, Tuskar.}

Nine were forwarded during the last fortnight of October, which seems to have been the period of maximum migration in both the "Siskin years." Four of the seven received in 1887, four of the six received in 1897 , and the solitary example received in 1889 , were obtained during this fortnight.

It is a singular fact that all the specimens are from southern stations south of lat. $52^{\circ} 13^{\prime}$, from Tearaght on the west coast, to 
Siskin. Tuskar on the east. The following are the numbers contributed by each:-

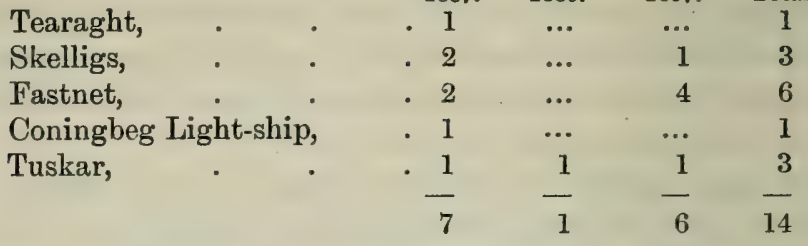

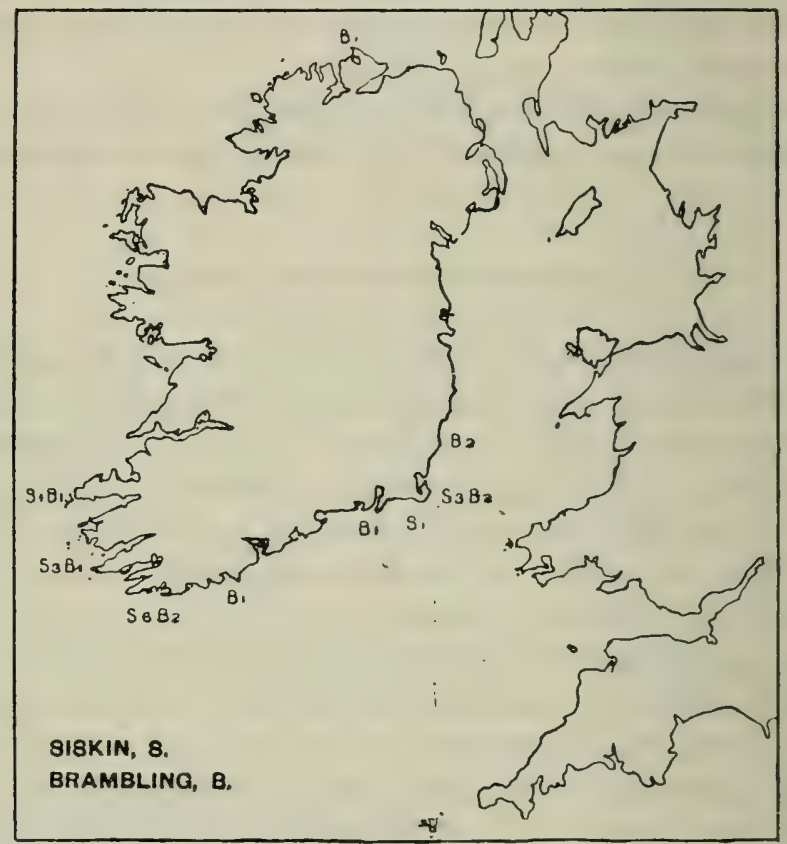

S $6=$ Six specimens of Siskin forwarded.

B 1=One specimen of Brambling forwarded.

So southerly a distribution is shown by only one other species-the Pied Flycatcher-and is particularly remarkable in the case of a northern-breeding bird like the Siskin. Like the Brambling, the Siskin seems to arrive chiefly at the southern light-stations - a very interesting fact, since both are northern species, and breed in the sub-arctic pine forests.

Two of the fourteen specimens were shot (Tearaght and Skelligs, October 19 and 24, 1887); the remaining twelve struck the lanterns, or were found dead.

Siskins were said to have been observed at Rockabill (November 7, 1887), Arklow Sonth Light-ship (April 10, 1891), and 
Codling Bank Light-ship (April.3, 1892, and October 27, siskin. 1897), but specimens were not obtained. A pair were noted at Tearaght on April 30,1889, and two birds answering to the description of this species were seen at Slyne Head, November 1, 1887. The only other observation reported is of a nonmigrational character.

If all the above observations are correct, they show that the Siskin's occurrences on migration are not so strictly confined to southern parts of our coast as the specimens would indicate. In estimating the chances of error, however, some account should be taken of the fact that scarcely any of the received specimens were correctly identified by the light-keepers. Eleven of the fourteen were sent as "unknown,"-and one as a Greenfinch. A bird sent as a Siskin turned out to be a Corn Bunting! It is therefore as well to await corroboration as to all alleged occurrences where specimens were not sent.

On October 26, 1889, a Siskin struck at the Tuskar in a rush of birds, consisting chiefly of the species which are most common on migration at that season (Thrush, Redwing; Blackbird, Lark, Starling, and Chaffinch); but in 1887, the only bird forwarded as having struck with the Siskin was a Stonechat; while in 1897 the species sent with it were the Ring-Ouzel, Wren, and Goldfinch (Fastnet, October 30), and the Hawfinch (Tuskar, November 1).

The variation in the length of the wing is large for the number of specimens.

Average length of wing, 2.85 ; longest, 3.00 ; shortest, 2.57 ; difference between extremes, 0.42 ; percentage of variation, 15 .

Mealy Redpoll (Linota linaria, Linn., var. rostrata, Coues).

This large race or sub-species of the Mealy Redpoll, whose natural habitat is Greenland, was first obtained as an Irish bird on the Tearaght Rock, Kerry, from which seven examples have been forwarded, all in autumn. They were shot on the following dates :-

$\begin{array}{ccc}\text { One, } & \text { September } 19,1889 . \\ \text { One, } & " & 20,1890 . \\ \text { Two, } & " & 25,1892 . \\ \text { One, } & \text { " } & 26,1892 . \\ \text { One, } & \text { October } & 18,1892 . \\ \text { One, } & \text { November } & 15,1893 .\end{array}$


Another, said to have been shot October 10, 1890, was not forwarded.

Dr Sharpe, who examined two of the specimens shot in 1892 , referred them to $L$. rostrata. The wing of the largest measures 3.325 inches, and that of the smallest 3.125 ; whereas the wing of the typical Linota linaria measures, according to Yarrell (4th edition), only $2 \cdot 750$, or according to "Saunders's Manual," $2: 900$.

That the west coast of Ireland is the most natural part of the British Islands to receive an immigration of birds from Greenland is sufficiently evident from its geographical position; but it is, at the same time, difficult to account for a little finch like Linota rostrata undertaking so long a flight, i.e., 900 miles.

Since 1893 no Redpolls have been received from the Tearaght. In 1898, however, one which had been shot in the first week of January was forwarded from Innishtrahull. This bird is not so large as the Tearaght examples, its wing measuring only 3.050 inches, but this is considerably in excess of the average for typical $L$. linaria.

A Mealy Redpoll is reported to have been observed on the Tearaght as late as April 22, 1893. This is the only instance in which it has been mentioned in spring. It is not, however, improbable that a "Redpole" noted on Blackrock (Mayo) on April 27, 1887, was of this species.

Considering the length of the journey which these birds may have taken, it is remarkable that none of them appear to have exhibited any signs of exhaustion, nor has a specimen ever been obtained striking the lantern.

The small percentage of variation favours the view that all the eight specimens belong to the same large race, to which two of them were referred by Dr Sharpe.

Average length of wing, 3.278 ; longest, 3.325 ; shortest, 3.050 ; difference between extremes, 0.275 ; percentage of variation, 8.

[Obs.-The Lesser Redpoll (Linota rufescens, Vieillot) has never been received from a light-station; and none of the few references to "Redpoles" (e.g., Rockabill, July 5, 1885, and April 7, 1886; and Blackrock, Mayo, April 27, 1887) can with any confidence be referred to this species.] 


\section{LINNET (Linota cannabina, Linn.).}

It is not easy to arrive at any satisfactory conclusion from the Linnet. evidence regarding the Linnet. In every Report issued since the commencement of this inquiry in 1881, "Linnets " have been mentioned with extraordinary frequency; yet not until 1890 was a single specimen of this common bird received from a light-station. A few others have since been forwarded, but the disparity between the numbers of observations and of specimens is still immense; and the question presents itself, whether we must find the clue to this disproportion in a wholesale misapplication of the name "Linnet" to various other species, or accept the alternative explanation that Linota cannabina, though migrating every year on a vast scale, very rarely kills itself against the lanterns.

There can be no doubt that the name "Linnet" is frequently applied to the Twite, and that when the epithet "Grey" is not prefixed, it sometimes signifies the Greenfinch. The Reed Bunting, though more commonly styled "Blackcap," has been sent as a Linnet, and similar mistakes are probably of occasional occurrence with regard to many species. But these are scarcely sufficient to explain the whole discrepancy.

The number of reported observations of "Linnets "-excluding all "Green Linnets," "Mountain Linnets," "Moss Linnets," "Scotch Linnets," and similar dubious items-amounts to 795 , a total slightly in excess of that recorded for the Chaffinch (786); whereas the number of specimens forwarded of the Chaffinch is 47 , and of the Linnet only 8.

If, therefore, the observations are even approximately correct, it seems to follow that we receive as large an immigration of this species as of the Chaffinch; but this is an inference which few will be disposed to accept.

The observations from three adjacent stations compare as follows :-

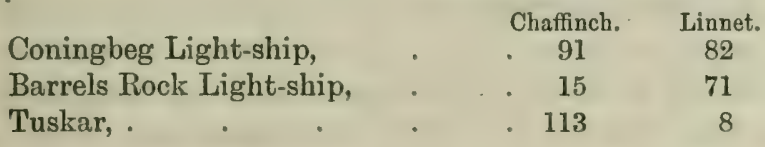

The extraordinary variation of the proportions in these three cases amounts to almost positive proof that some error has occurred, and that either Chaffinches have been largely reported 
Linnet. as "Linnets" from Barrels Rock, or Linnets as "Chaffinches" from the Tuskar. There is not the slightest ground for suspecting the truth of the latter alternative, and we may therefore conclude that the Chaffinch has, at one station at least, done extensive duty as "Linnet." As it is scarcely probable that such an error, continued over a number of years, could have been confined to one light-ship, the evidence in favour of a large immigration of Linnets into Ireland seems to be materially weakened by this conclusion.

The Tuskar observations, however, cannot be taken as quite accurate, since they would make the Linnet on migration even less frequent (as compared with the Chaffinch) than the specimens show to be the case. We should probably add to the eight observations of "Linnets" at this station, fifteen observations of "Twites," since (as will be shown under the next species) no Twite has ever been received from that part of the coast. This would make a total of twenty-three observations referable to the present species-a little more than one-sixth the number relating to the Chaffinch, and so almost proportional to the number of specimens.

It is interesting to note that all the legs and wings forwarded are from stations between Hook Tower and Codling Bank Light-ship-two from the first-named station, one from Coningbeg Light-ship, four from Blackwater Bank, and one from Codling Bank. All these were either killed striking the lanterns or died on light-ships. Their linited distribution contrasts curiously with the wide range of the reported occurrences, which are noted from every part of the coast. There is also a remarkable contrast between the present and the next species as regards their migrational distribution, for whereas the Linnet has been received only from light-stations on the south and east coasts, the Twite has been sent only from those on the north and west.

Of the eight specimens, seven occurred in autumn and winter, while one struck in spring (Hook Tower, March 27, 1892). The earliest in autumn was found dead on Blackwater Bank light-ship, October 26, 1897; the latest was found on the same light-ship's deck, January 12, 1894. Only one was obtained in October and one in November; while four were killed in December and one in January. The period from 
December 12 to January 12 has yielded five of the seven Linnet. autumnal examples.

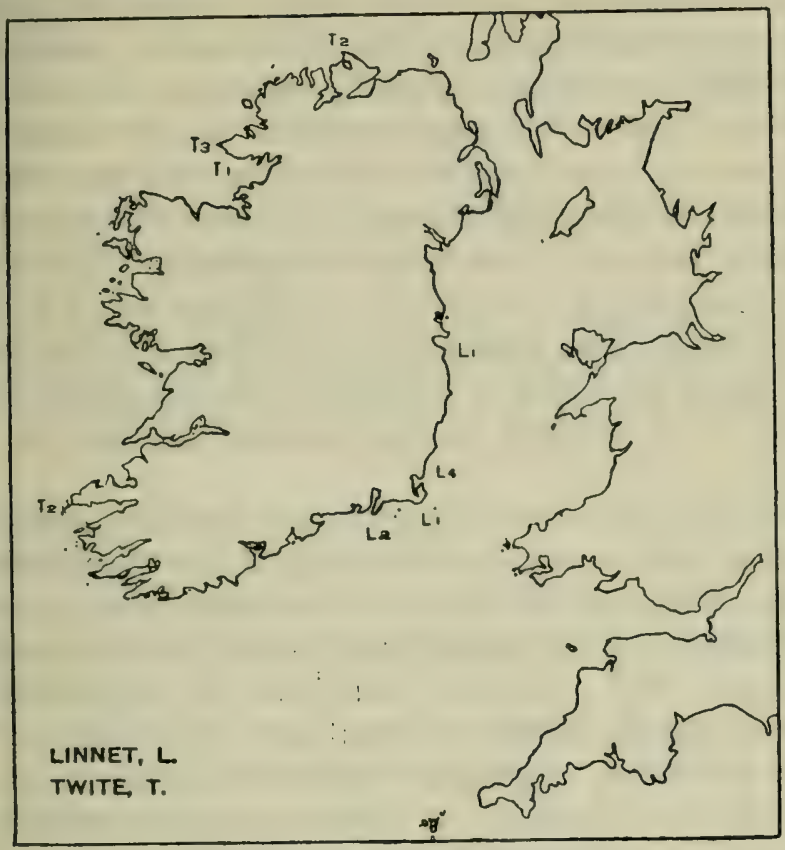

L 4=Four specimens of Linnet forwarded.

T $2=$ Two , " Twite "

On the other hand, the months which furnish the largest number of reported observations are October (187) and November (132), December coming third with 102, and March fourth with 96 .

These figures, however, possess little or no value, as there is reason to believe that errors in identification are much more numerous in the case of the Linnet than of any other species.

Of nine wings measured (including one without data, possibly shot at Mine Head) the variation is remarkably slight.

Average length of wing, $3 \cdot 136$; longest, 3.200 ; shortest, 3.050 ; difference between extremes, 0.150 ; percentage of variation, $4 \frac{1}{2}$.

Twite (Linota flavirostris, Linn.).

The only stations from which the Twite has been forwarded Twite. are Innishtrahull, Killybegs, Rathlin O'Birne, and the Tearaght; 
Twite. three of these being in Donegal, and the last in Kerry. In only one instance is it known to have been obtained through striking the lantern, i.e., at Killybegs, January 10, 1892, in extremely severe weather. On the island of Innishtrahull an example was caught, probably exhausted, on the 1st of December 1899. The other examples, six in number, may have been shot, as is stated to have been the case with one sent from the Tearaght, October 30, 1888. Of a total of 8 specimens received, 1 was killed in September, 1 in October, 3 in November, 1 in December, 1 in January, and 1 in April. The September and October birds are from the Tearaght-to which island the Twite is apparently a regular winter visitant -while those obtained in the remaining months are from Donegal.

There is no reliable evidence of the Twite's occurrence on migration outside the limited range which these eight specimens indicate, except in the case of a few observations made by Mr M'Carron on Copeland (Mew) Island in the autumns of 1889 and 1890. Between the dates of August 29 and December 22, Mr M'Carron seven times noted large or small parties of Twites, sometimes mixed with Linnets, on this island, and on November 29, 1899, his report states that "a large flock came from sea and passed towards shore." These would in all probability be immigrants from the Scottish coast.

At the Tuskar, "Twites" were somewhat frequently mentioned during the years 1887-90, but have not been noted since; while Linnets, from the date of one dubious record- "Linnets or Twites"-on October 17,1887 , cease to be noted at all until 1896, though in previous years they had several times been reported at that station. The most probable explanation is that the same birds have been differently designated by different light-keepers, and the records should either be disregarded or referred to the Linnet.

We have thus very meagre evidence of the Twite's migration, but, such as it is, it tends to show that this species crosses the northern part of the Channel into Ireland during October, November, and December, and is observed at that seasonsometimes in considerable flocks-on islands of the northern part of the coast, from Copeland to Rathlin O'Birne. It is uncertain whether the birds which visit the Tearaght in winter 
are immigrants from over sea or wanderers from the mountains of Kerry. The only station between Tearaght and Rathlin O'Birne from which the Twite has been reported is Blackrock (Mayo), where a flock is said to have appeared, October 21, 1887; but there can be no doubt that this bird and the Linnet are freely confounded, and Twites probably visit all the islands of the west coast during the autumnal migration.

The general result of the data respecting this and the previous species may thus be summarised :-

Linnet-A late autumnal immigrant to south and east coast, crossing Channel at its southern extremity.

Twite-An autumnal immigrant to north and west coast, crossing Channel at its northern extremity.

The longest wing measured is shorter by 075 than the shortest Linnet's or Mealy Redpoll's.

Average length of wing (adult), 2.92 ; longest, 2.975 ; shortest, 2.875 ; difference between extremes, 0.10 ; percentage of variation, 4 .

[Obs.-The Bullfinch (Pyrrhula europced, Vieillot) has never been received from a light-station, and it is doubtful whether this species migrates at all.

The occasional references to "Bullfinches" are in some cases undoubtedly erroneous, as in that of a series of entries from the Tuskar in 1882, where they are noted as "constantly striking" on various dates from July to October, and are described as "birds like the Green Linnet, but more white on the outside of the wing." There can be little doubt that these were Chaffinches, especially as that species was not mentioned by name from the Tuskar in 1882. Again, in April 1892, a "great rush of Chiffchaffs, Wheatears, and Bullfinches" is noted from the same station; and "Bullfinches all night, several killed," are once more reported from the Tuskar in October 1895; but reference to the notes under "Chaffinch" for those two years will show that in both cases the Tuskar omits all mention of that species. Supposed Bullfinches have been reported in about fifteen other instances [at Fastnet, Hook Tower, Coningbeg Light-ship, Arklow South Light-ship, Codling Bank Lightship, Rockabill, Maidens (twice), Innishtrahull (twice), Rathlin O'Birne, Blackrock, Mayo (twice), Slyne Head, and South 
Twite. Arran Island]; but in no case has any confirmation come to hand, though the light-keepers' attention has been specially drawn to the desirableness of obtaining some definite evidence regarding this bird. It cannot, therefore, be classed as migratory in Ireland.]

\section{Crossbill (Loxia curvirostra, Linn.).}

Crossbill. A young example of the Crossbill, the only specimen received from an Irish light-station, was caught on Coningbeg Light-ship, September 4, 1898.

A large incursion of Crossbills into Ireland is believed to have taken place in the year 1888, since which date these birds have been much more numerous in the country than formerly; and it is singular that none should have been obtained, or even observed at light-houses or light-ships, until the autumn of 1898.

The wing of the immature specimen from Coningbeg measures 3.57 inches, or 0.22 less than the average given in "Saunders's Manual" for that of an aduit bird.

\section{Starling (Sturnus vulyaris, Linn.).}

starling. The Starling is the most numerously observed, and probably the most common of all migratory birds at Irish light-stations. It has been known to strike the lanterns in every month of the year, June and the earlier half of July being the only period in which such occurrences can be considered exceptional. There is reason to believe that the south-east coast witnesses an annual movement in the last week of July, for, though it is not recorded every year, the dates of the various entries coincide so closely as to indicate that the migration is a regular one. Thus at the Tuskar, Starlings are reported as striking on July 26, 1884, July 28, 1886, July 30, 1894, and July 29, 1895. In 1895 both Blackwater Bank and Rockabill reported them on the night of July 30 , and a specimen (a bird of the year) was sent from the latter station. From Blackwater Bank a specimen was received in 1894, killed striking, July 25. As all these birds occurred at night, their direction could not be ascertained; but a few observations made by day at the same season evidently relate to arriving birds. Some were seen 
going N.W. at the Tuskar, July 27, 1894, and a similar landStarling. ward direction was taken by two which rested on Lucifer Shoals Light-ship, August 3, 1897. A flock was also reported going S.W. at the Maidens, August 1, 1885.

The July and early August observations appear to relate mainly to immature birds, but it is possible that an immigration of adults has occasionally set in as early as August 25. On that date in 1894, Starlings were reported "all night" at the Tuskar, and at the same station they were "constantly striking" on the night of August 31,1882; while on August 26, 1885, one was killed striking at Rathlin O'Birne. There is, however, no evidence as to whether these were young or old birds, as no specimens have been received in August; and the earliest September example forwarded, disabled striking at South Arran, bears date September 19, 1889.

The great autumnal inrush of Starlings takes place in October and November, and is generally at its height in the last ten days of the former month. The number of observations for each month and section of the coast are given below, and from these it will be seen that while November shows the highest total number, October is the month of most records on the east and south coasts, where the direct immigratory movement is witnessed.

\begin{tabular}{|c|c|c|c|c|c|c|c|c|c|c|c|c|c|c|}
\hline & & & & & & & & & & & & & \\
\hline & & Jan. & Feb. & Mar. & April & May. & June & July. & Aug. & Sept. & Oct. & Nov. & Dec. & Total. \\
\hline \multicolumn{2}{|c|}{ South Coast, } & 20 & 31 & 47 & 5 & 1 & 1 & 1 & 1 & 7 & 139 & 109 & 26 & 388 \\
\hline \multirow{2}{*}{$\begin{array}{l}\text { East } \\
\text { North }\end{array}$} & ," & 106 & 107 & 134 & 59 & 10 & 9 & 17 & 4 & 16 & 314 & 309 & 157 & 1242 \\
\hline & ", & 6 & 2 & 16 & 3 & 4 & $\ldots$ & $\cdots$ & $\ldots$ & $\cdots$ & 18 & 27 & 12 & 88 \\
\hline \multirow[t]{2}{*}{ West } & , , & 25 & 18 & 13 & 5 & 6 & 1 & $\ldots$ & 2 & 8 & 80 & 122 & 42 & 322 \\
\hline & & 157 & 158 & 210 & 72 & 21 & 11 & 18 & 7 & 31 & 551 & 567 & 237 & 2040 \\
\hline
\end{tabular}

In most years the autumnal movement has been strongly marked during some short period, varying from four to ten days in length, in which Starlings have been simultaneously reported as striking round the greater part of the coast. In 1883 such a period occurred from October 26th to 31st, between which dates we find notes of the birds striking at Fastnet, Kinsale, Coningbeg, Barrels Rock, Tuskar, Arklow South, Arklow North, 
Starling. Kish Bank, Rockabill, Rathlin Island, Innishtrahull, and South Arran. In 1887 the principal rush was considerably later, the nights on which most Starlings struck being from November 10 th to 15 th, and the stations which reported them between those dates were Fastnet, Mine Head, Coningbeg, Barrels Rock, Tuskar ("countless numbers" on 10th, 11th, 12th, and 14th), Arklow South, Arklow North, Rockabill, Innishtrahull, Dunree Head, Broadhaven, Blackrock (Mayo), Slyne Head, and Skelligs. In 1888 a rush prevailed all round the coast between the 4th and 10th of November, being noted at Fastnet, Barrels Rock, Tuskar, Lucifer Shoals, Blackwater Bank, Arklow South, Arklow North, Kish Bank, Copeland, Blackrock (Mayo), Slyne Head, South Arran, and Tearaght. In 1889, the period from November 11th to 18th was signalised by rushes at Coningbeg, Tuskar, Arklow South Light-ship, Kish Bank, Rockabill, South Rock Light-ship, Copeland, Maidens, and Blackrock (Mayo). In 1891, the night of October 27 was marked by Starlings striking at Coningbeg, Barrels Rock, Blackwater Bank, and Arklow South Light-ships, Rockabill, Maidens, and Innishtrahull. It would be superfluous to multiply instances further. We may take it as probable that throughout the whole period from mid-October to mid-November the immigration of Starlings is uninterruptedly in progress, and that whenever during that period the nights are dark ${ }^{1}$ and foggy round a large extent of coast, a correspondingly large number of light-house and lightship lanterns are likely to be struck by crowds of bewildered birds. It would therefore be a mistake to infer that migration is each year at its maximum on the dates of the greatest reported rushes.

Adding the observations for fifteen years ending 1897, we find that on the south and east coasts the figures for each tendays' period in October and November are as follows :-

$$
\begin{array}{ccc}
\text { October } & 1-10,42 . \\
" & 11-20, & 149 . \\
\prime & 21-31, & 262 .
\end{array}
$$

$$
\begin{array}{crc}
\text { November } & 1-10, & 208 . \\
, & 11-20, & 130 . \\
" & 21-30, & 80 .
\end{array}
$$

The specimens give a still more marked predominance to the last ten days of October; but in the case of this species

\footnotetext{
${ }^{1}$ Four $(1883$, '87, '88, and '91) of tho above rushes wero during the first and fourth quarters of the moon.
} 
they are of less value than the observations, being disproportionately few in number. The light-keepers probably consider this bird too common to be worth sending. The numbers for each of the above six periods are :-

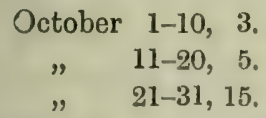

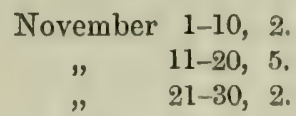

Throughout the winter, Starlings show a constant tendency to pass westwards, especially on every renewal of cold weather, and it is probably a result of this tendency that the west coast observations for November largely outnumber those for October. The flight in this direction does not always cease even when the Atlantic is reached. For example, on October 31, 1886, and again on the following day, we find the curious record of "several thousand going W." from Eagle Island, Co. Mayo-a remarkable instance of that class of movement referred to in the Preface to the same year's Report as being "apparently as reckless as that of the Lemmings." When the cold becomes intense, great multitudes throng the western islands, and numbers of the birds perish there. In February 1895 the light-keeper on Clare Island reports: "Skylarks, Starlings, and Thrushes came to island during the hard frost and snow this month, and mostly all died from hunger and cold." Corroborative details are furnished from Samphire Island, where Mr Dunleavy was then stationed. On February 7, "vast numbers of Starlings, Skylarks, Thrushes, and Redwings" were noted going S. all day, in heavy snow. "The island was literally covered with them resting on it, and at times they would darken the sky." Next day they were still going S.: "One continuous flight; they were all very exhausted, and numbers of Starlings fell. I never saw such a constant rush of birds." On the 9th, great numbers were noted resting; on the 11 th and 12th, numbers dead; on the 13th, "It is pitiful to see the hundreds of birds dead and dying all about the island, particularly Starlings; the sea is also covered with them, and Gulls feeding on them, although vast numbers of Gulls have died." A landward movement of Starlings had been noted at several east coast stations on the 28th and 29th of January previous to this great westward rush; but during the climax of the severe weather (February 
Starling. 6th to 14th), no such immigration seems to have been in progress. The bulk of the refugees had therefore probably been wintering on the Irish mainland.

The observations show that there is a spring migration in February and March, during which months a considerable number are killed at the lanterns; but, as in the case of the Thrush and Lark, there is a lack of direct evidence to show whether these night migrants are our winter guests departing, or others of the same species coming to breed. A presumption in favour of the latter hypothesis is raised by the fact that the Fieldfare and Redwing, which do not breed within our area at all, scarcely ever strike the lanterns in spring, while it is chiefly such winter visitors as the Thrush, Blackbird, Skylark, and Starling - all members of our breeding fauna - that have been sent in any appreciable number from light-stations at that season. Again, that there is an immigration of Starlings in spring seems to be established, as in the cases of the Thrush and Lark, by the notes which record the direction of the flight, when this is observed by day. These show that the flight, when seen at light-stations, is generally towards the land, in spring as well as in autumn. The directions noted on the south, east, and north coasts from January to May are as follows :-

\begin{tabular}{|c|c|c|c|c|c|c|c|}
\hline & & & & & Landward. & Seaward. & Coasting. \\
\hline January, . & . & . & . & . & 39 & 1 & 3 \\
\hline February, . & & - & $\cdot$ & - & 17 & 5 & 2 \\
\hline March, . & . & - & - & . & 19 & 9 & 6 \\
\hline April, & . & . & ${ }^{\circ}$ & . & 4 & 1 & $\cdots$ \\
\hline \multirow{2}{*}{\multicolumn{2}{|c|}{ May, }} & - & ${ }^{\circ}$ & - & 2 & $\cdots$ & $\cdots$ \\
\hline & & & & & 81 & 16 & 11 \\
\hline
\end{tabular}

The cases of the Thrush and Lark, however, are not altogether parallel to that of the Starling. In all three instances the observations seem to show that a landward movement takes place in spring, and that it is more numerousiy observed at light-stations than the seaward flight, which we know must 
occur about the same season. But in the cases of the Thrush and Lark we had practically no evidence of the seaward or emigratory flight being seen at all. This is not quite so in the instance of the present species. Fifteen seaward to 40 landward flights of the Starling are noted in February, March, and April. For the Thrush, during the same period, 2 seaward and 32 landward flights were recorded; for the Lark, 11 seaward and 79 landward. Moreover, the instances in which Starlings have been noted flying out to sea, though few in actual number, show more of the character of emigration than do similar records for either of the two other species. This is particularly the case with the records for the spring of 1887 .

In that season a remarkable movement certainly occurred on the nights of the 1st, 2nd, and 3rd of March. It was noticed at five stations-Fastnet, Mine Head, Barrels Rock, Tuskar, and Arklow South Light-ship. The daily weather charts show that at this period anti-cyclonic conditions (favourable to migration) prevailed over the British Isles, accompanied by heavy fogs at sea. The following notes were made by $\mathrm{Mr}$ Dunleavy at the Fastnet:-

"February 28th, hundreds of Starlings from 10 P.M. to 6 A.M. around light; wind light S.W., hazy; none killed or captured. March 1st, numbers from 9 P.M. to 11 P.M. heard overhead; wind light S.IV., clear; scemed to go S.: 2nd, numbers striking, 1 A.M. to 4 A.M.; hazy, wind light S., none killed: 3rd, numbers about light, 3 A.M. to 4 A.M. ; wind light S.W., hazy. While on shore from 11th to 18th February, I saw large flocks of Starlings congregating every evening about sunset, and fying $S$. The same thing occurred from 2nd to 9th March."

The notes from other stations are as follows:-

"Mine Head.-March 1st, 2nd, and 3rd, Starlings striking occasionally at night; fine, wind S. and S.E.; flocks in the fields."

"Barrels Rock Light-ship.-On night of March 1st, from 8 P.M. to 2 A.M.; and on 2 nd, from 9 P.M. to 1 A.M., flocks passing to S.E.: 9th, flocks going S. 7.30 P.M. to 9 P.M.; wind light, clear: 22nd, a few going $S$. at noon ; wind fresh W., clear."

"Tuskar.-March 2nd, fourteen on balcony, 10 P.M. to 4 A.M.; three killed striking; wind light N., hazy: 3rd, an immense number about lantern all night; calm, hazy; ten killed striking." 
Starling. "Arklow South Light-ship.-February 28th, flock going N.E., 6 P.M. March 2nd and 3rd, about lantern, midnight to 4 A.M.; two killed striking; cloudy."

Here we see strong evidence of a departing movement, proceeding southwards from Fastnet, south and south-eastwards from Barrels Rock Light-ship, and north-eastwards from Arklow South Light-ship, on the same nights; while it is shown that Starlings were also striking on those nights at Mine Head and Tuskar, on the same part of the coast-line, and presumably migrating in the same direction. The evidence adduced of the birds setting out at sunset is of particular interest, because, though we might expect this to be the case, there is very little direct information on the subject.

In the spring of 1892 there were also a few observations of departing Starlings. On February 16th, some were noted at the Tuskar going S.E. ; on February 25th, flocks at Blackwater Bank Light-ship, likewise going S.E.; on March 18th, two which had been caught striking at the Maidens during the previous night were liberated and flew N.E. There were, however, a larger number of landward movements recorded within the same period.

The above quoted notes, though meagre, point to the latter part of February and the beginning of March as the time of the Starling's departure. We may infer that this generally takes place by night. In clear weather it seems to escape detection; but during a continuous spell of fog or thick haze the birds are unable to avoid the lanterns, besides which, in such weather, they possibly fly lower, and thus are more liable to be seen or heard, even when not striking.

The migration of this species appears to be more numerously observed at the Tuskar than at any other station, and it is much more dense on the Wexford coast than further northwards. This is shown by the numbers of observations respectively noted at the eight principal east coast stations (adding to each its average proportion for any year in which it contributed no report):-

Tuskar, . . . . $265 \mid$ Codling Bank Light-ship, . 158 Blackwater Bank Light-ship, 246 Rockabill, . . . . 113 Arklow South Light-ship, . 211 South Rock Light-ship, . 47 Arklow North Light-ship, . 167 MLaidens, . . . . 63 
These figures should be contrasted with those obtained for the Starling. Skylark, in whose case the same eight stations were similarly compared, with the result that the proportion was found to be practically uniform along the whole of the east coast.

On the south coast, observations similarly diminish westward. Coningbeg Light-ship contributes 161, Fastnet 60, and Tearaght 52.

There is, however, no station of any note at which this species has not struck. Specimens, killed striking, have been received from four west coast light-houses-North and South Arran, the Tearaght, and the Bull Rock; and instances of striking have been reported from Aranmore, Blackrock (Mayo), Killybegs, Rathlin O'Birne, Oyster Island, Eagle Island, Slyne Head, and the Skelligs. In some seasons, indeed, Starlings appear to have struck somewhat numerously on the north and west coasts. Thus in the autumn of 1887, between October 16 and November 12, they were reported as striking at Innishtrahull, Dunree Head, Tory Island, Aranmore, Rathlin O'Birne, Killybegs, Blackrock (Mayo), Slyne Head, and South Arran. The light-house on the South Island of Arran appears to be struck every autumn, generally about the end of October, since such occurrences are noted in each of the nine years for which that station has sent reports. In five of those years Starlings are said to have been killed striking on either October 30 , October 31 , or November 1. As many as thirty are said to have been killed here on the night of October 20,1890. Few of our migrants strike, except at irregular intervals, on this part of the coast.

The area over which the Starling strikes is less extensive in spring than in autumn. The contrast is made apparent when we compare the county distribution of 33 specimens received in October and November with that of 20 received in February and March.

Cork,
Waterford,
Wexford,
Dublin,
Down,
Antrim,
Donegal,
Galway,
Kerry,

Oct.-Nov, Feb.-March.

\begin{tabular}{|c|c|}
\hline 6 & \\
\hline 17 & \\
\hline 2 & \\
\hline 1 & \\
\hline 1 & \\
\hline 1 & \\
\hline 2 & \\
\hline 33 & \\
\hline
\end{tabular}


starling. In April a specimen has been sent from Arklow North Light-ship, Co. Wicklow, and in May one from Codling Bank Light-ship, Co. Dublin. The total number of specimens received in the four spring months (February to May) is 26, of which 23 were from Wexford stations. The total received in the four autumnal months (September to December) is 45 , of which Wexford contributed 24 and other counties 21.

The latest specimen received in spring (with data) is the example from Codling Bank Light-ship, found dead May 5, 1899.

From the measurements of the wings, it appears that the longer-winged specimens are obtained first, at both seasons of migration.

Of 42 obtained in autumn (September-December)-

21 earliest (September 19 to October 29) average . 5.125

21 latest (October 30 to December 31) " " 5.025

Of 23 obtained in spring (February-May)-

12 earliest (February 4 to March 12) average . . 5.075

11 latest (March 13 to May 5), " . 5.050

It will be seen that the difference is much more pronounced in autumn than in spring.

Average length of wing, 5.08 ; longest, 5.40 ; shortest, 4.82 ; difference between extremes, 0.57 ; percentage of variation, $11 \frac{1}{2}$.

\section{CHough (Pyrrhocorax graculus, Linn.).}

Chough. This species is chiefly reported from stations in the vicinity of which it breeds, such as Rathlin and Tory Islands, Aranmore, Rathlin O'Birne, the Arran Isles, Tearaght, Skelligs, Bull Rock, Old Head (Kinsale), Mine Head, and Dungarvan. Pairs have occasionally been noted at Innishtrahull (April 18, 1888, August 18, 1888, and November 6, 1891), and from one to two birds on Blackrock (Mayo), March 31, 1888, October 20, 1886, and November 19, 1889. On some of the westerm islands an increase of its numbers is observed during winter. This is the case on the Tearaght, where Mr M'Carron, in 1885, reported that all except the breeding birds had gone by April 1, and $\mathrm{Mr} F$. Ryan, in 1886, made a similar observation on March 25. On Slyne Head, five seen on October 24, 1889, were noted as "the first this season"; and at the same station, on November 8, 1888, occurs the entry, "three came at night, none killed," words 
which might be taken as implying that the birds were observed about the lantern, though this is not stated. Legs and wings have been received of two shot specimens, and of one whose remains were found at a Peregrine's feeding-place-all on the west coast. On the east coast references to the Chough are very rare, and previous to 1895 consisted of two observations, of single birds only, in winter, from St John's Point, Down.

In 1895, however, a "Red-legged Jackdaw" was mentioned as having rested on the rail of Arklow North Light-ship on February 9 , going $W$. This was during a very severe spell of snow and frost (see under Starling, p. 143), and the bird may have been compelled to migrate by stress of weather; but it is remarkable that three similar instances are reported from the same station in subsequent years, viz., on June 10, 1896 ("two Red-legged Jackdaws going N.W."), April 13, 1897 ("one supposed Red-legged Jackdaw rested for a time on ship's rail, going W."), and June 22, 1897 ("two Red-legged Jackdaws going W. at 11 A.M.").

These are the only occasions on which this species has been reported from a light-ship.

As the Chough is not now known to breed in the east of Ireland, the above observations, if correct, seem to show an occasional migration across the Channel; but before any of the east coast records of this species are accepted, it is most desirable that specimens should be produced.

Although the bulk of the observations have no reference to migration, they are more frequent in November and April, and less so in September than in any other months. There are 68 for the half-year November to April, and 45 for the half-year May to October.

Jan. Feb. March. April, May, June, July. Aug. Sept. Oct. Nov, Dec. Total.

$\begin{array}{lllllllllllll}10 & 6 & 11 & 14 & 6 & 8 & 7 & 8 & 4 & 12 & 18 & 9 & 113\end{array}$

These figures corroborate the statements of the Tearaght and Slyne Head light-keepers, previously quoted, to the effect that local movements of this species take place about the beginuing of April and beginning of November.

\section{Raven (Corvus corax, Linn.).}

There is no evidence to show that the Raven is a migrant. It is frequently noted at light-stations round the western part 
Raven. of the coast, where its breeding-haunts are situated, and so large a number as thirty-six Ravens are said to have been seen together on Blackrock (Mayo) on May 23, 1882; but round the eastern side of Ireland, from Hook Tower to Rathlin, observations of this species are remarkably few, and seldom free from some suspicion of error. In two instances Ravens are said to have been observed at light-ships, one going E. from Arklow N., October 17, 1894, and one going N.E. from Coningbeg, November 18,1896 . In the case of so wide-ranging a bird, these notes would be insufficient to establish migration, even if their correctness could be ascertained.

The number of observations relating to this species does not vary much from season to season, except that such notes are fewer in June and July than at other times.

$$
\begin{array}{ccccccccccccc}
\text { Jan. } & \text { Feb. } & \text { March. } & \text { April. } & \text { May. } & \text { June. July. Aug. } & \text { Sept. } & \text { Oct. } & \text { Nov. } & \text { Dec. } & \text { Tutal. } \\
12 & 9 & 16 & 10 & 11 & 7 & 5 & 10 & 16 & 17 & 15 & 14 & 142
\end{array}
$$

\section{Hooded CRow (Corvus cornix).}

Hooded Though a cominon bird on the Irish coast, the Hooded Crow Crow. has only once been reported from the Tuskar (one going N.W., April 7, 1884), and never from the Maidens; while the only light-ships at which it has been noted are Blackwater Bank (four going N.W., March 28, 1897) and Arklow North, at which last-named station it appears to have been observed five times, generally going towards land, in the months of February, April, June, October, and November. It is possible that some of these occurrences were migrational, but the evidence is insufficient for proof, not more than five birds having been observed together on any of the occasions referred to. Still less value can be attached to notices of this bird from other stations, since nearly all, including the Fastnet, are frequently visited by it in quest of food. The number of observations recorded for each month is as follows:-

$$
\begin{array}{ccccccccccccc}
\text { Jan. } & \text { Feb. } & \text { March. April. } & \text { May. June, July. Aug. } & \text { Sept. } & \text { Oct. } & \text { Nov. } & \text { Dec. Total, } \\
7 & 14 & 21 & 41 & 11 & 10 & 11 & 12 & 12 & 23 & 18 & 22 & 202
\end{array}
$$

- From the fact of the bird being so much oftener noted in April than in any other month, it appears probable that many pairs which nest in the sea-cliff's range inland during the rest of the year. 
Rook (Corvus frugilegus, Linn.).

A spring migration of the Rook is observed at our east coast stations in March and April, during which months small parties are frequently seen flying westward past the Tuskar and the Wexford and Wicklow light-ships. In most years the beginnings of this movement have been noted between the 18th and 22nd of March, and it generally appears to cease at some date between the 17th and 22nd of April. There is also an autumnal movement, which, so far as the east coast is concerned, is less noticeable than the spring one, and is chiefly in the same direction; but, as will presently be seen, the autumnal movements sometimes noted on the west coast may even be described as phenomenal.

The number of observations for each month, on each section of the coast, is as follows :-

\begin{tabular}{|l|r|r|r|r|r|r|r|r|r|r|r|r|r|r|r|}
\hline & Jan. & Feb. & Mar. & April & May. & June & July & Aug. & Sept. & Oct. & Nov. & Dec. & Total. \\
\hline South Coast, & 2 & 2 & 15 & 19 & 3 & 3 & $\ldots$ & $\ldots$ & 3 & 4 & 9 & 9 & 69 \\
East ", & 8 & 7 & 65 & 58 & 11 & 2 & 3 & 3 & 3 & 21 & 31 & 14 & 226 \\
North ", & $\ldots$ & 1 & 5 & 11 & 5 & 9 & 5 & 4 & 5 & 7 & 7 & 7 & 66 \\
West ", & 6 & 8 & 7 & 14 & 8 & 8 & 7 & 6 & 14 & 28 & 59 & 13 & 178 \\
\hline \multicolumn{1}{|l|}{ Total, } & 16 & 18 & 92 & 102 & 27 & 22 & 15 & 13 & 25 & 60 & 106 & 43 & 539 \\
\hline
\end{tabular}

From this table, it is at once apparent that the cross-Channel movement is greatest in spring. With a view to eliminating all possibly non-migrational records, the observations from the light-ships may be taken by themselves to illustrate the same fact: ${ }^{1}$ -

Light-ship Jan. Feb. March April May June July Aug. Sept. Oct. Nov. Dec. 'Total.

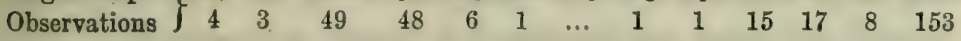

The direction of the flight has been noted in 306 instances,a larger proportion than for any other species dealt with. In 230 of these instances the direction reported is landward, in 47 it is seaward, and in 29 is more or less parallel to the coast.

${ }^{1}$ All the light-ships are situated on the Wexford, Wicklow, Dublin, and Down coast-line. Most of them are six to eight miles from shore. 
Rook. Generally speaking, it may be said that the usual direction is N. or N.E. on the south coast, N.W. on the southern part of the east coast, W. on the northern part of the east coast, and S. on the north coast. No general rule can be laid down for the west coast, the movements there being of a different character.

The flights observed on the south and east coasts, as regards direction, may conveniently be tabulated together, a decided majority of the south coast movements being at stations near its eastern extremity-Coningbeg and Barrels Rock Light-ships.

Direction noted on S. and E. Coasts.

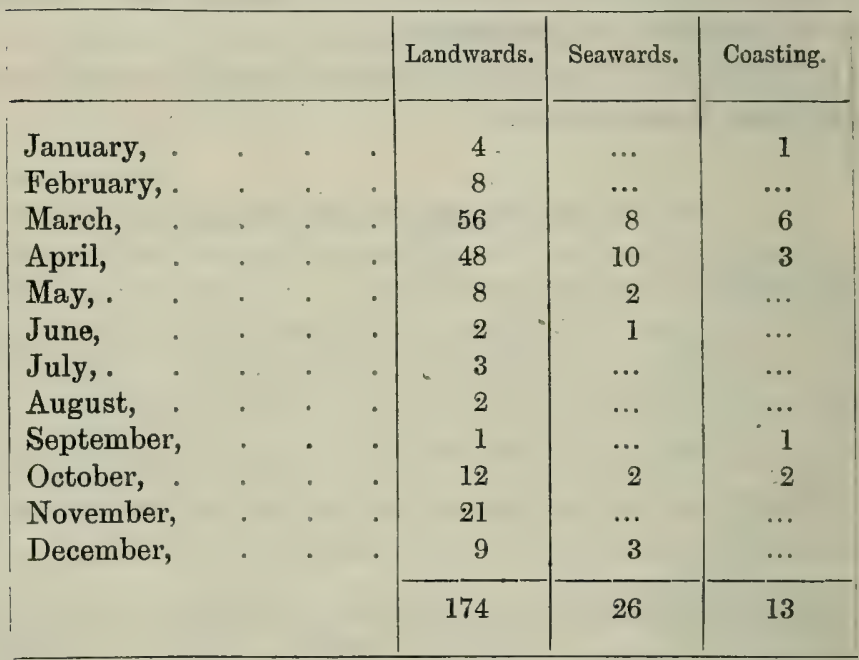

On the north coast nearly all the notes regarding direction (16 out of 21) are from Rathlin Island. Here the movements seem to be even more uniformly landward than on the south and east coasts, 19 ( 7 in spring and 12 in autumn) being towards the shore, while only 2 in spring are seawards.

On the west coast the ordinary movements are of such a nature as to defy analysis. The explanation of this is that most of the light-houses are situated on islands to which Rooks from the mainland sometimes resort, and when birds from any of these stations are reported as flying west, it is seldom clear whether they are merely passing from the mainland to the 
island, or from the island out into the Atlantic. In the follow- Rook. ing table, the movements are therefore not classified as landward or seaward, but as eastward or westward, northward or southward. It will be observed that the direction reported is generally westwards from January to September, but not during the remaining months.

Direction noted on $W$. Coast.

\begin{tabular}{|c|c|c|c|c|}
\hline & Eastward.1 ${ }^{1}$ & Westward. ${ }^{2}$ & North. & South. \\
\hline January, & $\ldots$ & 1 & $\ldots$ & $\ldots$ \\
\hline February, & $\ldots$ & 3 & $\ldots$ & $\ldots$ \\
\hline March, . & $\ldots$ & 4 & 1 & $\ldots$ \\
\hline April, . & 2 & 3 & $\ldots$ & 1 \\
\hline May, . & 1 & ... & $\ldots$ & $\ldots$ \\
\hline June, . & ... & 1 & $\ldots$ & $\ldots$ \\
\hline July, . & $\ldots$ & 2 & $\ldots$ & ... \\
\hline August, & $\ldots$ & 2 & $\ldots$ & $\ldots$ \\
\hline September, & 2 & 5 & $\ldots$ & $\ldots$ \\
\hline October, & 6 & 5 & 1 & 1 \\
\hline November, & 20 & 1 & 4 & $\ldots$ \\
\hline \multirow[t]{2}{*}{ December, } & 5 & 1 & $\ldots$ & $\ldots$ \\
\hline & 36 & 28 & 6 & 2 \\
\hline
\end{tabular}

This brings us to the subject of the exceptional movements observed at some western stations in the autumns of 1884 , 1887,1888 , and 1890 .

In November 1884 large numbers of Rooks were simultaneously noticed at the Tearaght and Skelligs-two island-stations 20 miles apart, and each 9 miles from shore-arriving in continuous flocks from the westward (i.e., from the open Atlantic), and passing in an easterly direction towards land, at a height of from 700 to 800 feet, during several consecutive days, a phenomenon which suggests the puzzling question, Where were these birds coming from? On the Tearaght, the first flock (about 60 birds) was noted on November 5, coming from the N.W.: on the 10th, " 300 in continuous flocks of from 50 down to 2 or 3 , some following far behind, and all going from W. to E.": again, on the 14th, "continuous flocks

${ }^{1}$ Including N.E. and S.E.

${ }^{2}$ Including N.W: and S.W. 
Rook. all day going E. (about 300): 15th, about 300 do.: 16th, 100, going E." A few were noted at intervals until the $25 \mathrm{th}$, all passing in the same direction. At the Skelligs a similar series of observations began on November 2, when a large flock was reported; after which, the light-keeper adds, "This flight of Rooks continued nearly every day up to the 24th inst.; sometimes they alighted on the rock." During the same period, a few Jackdaws were noted at both stations, and a young bird of that species was caught by Mr M'Carron at the Tearaght.

While this curious flight was chiefly witnessed at the Tearaght and Skelligs, there are a few indications of its having been noted on a small scale at Eagle Island and Blackrock (Mayo)-30 Rooks being reported as "flying inland" at the former station, November 14, and "10 Jackdaws, going N.E.," at the latter, November 13.

Nor are such symptoms of simultaneous movement confined to the west coast, for between November 2nd and 25th (the period during which the rush at the Skelligs and Tearaght lasted), 10 observations of Rooks passing landwards are reported from southern and eastern stations. At the Fastnet, 30 were noted on November 14; at Coningbeg Light-ship, 1 on November 15; at Barrels Rock, upwards of 60 coming from S.E., November 13; at the Tuskar, 1 on November 16, "apparently very tired, went W."; 2 at the same station on the 17 th, 1 on the 20 th, and a flock on the 24 th, were all going N.W.; so were two flocks at Arklow N. Light-ship, November 2, as well as some noted at the Maidens, November 3 and 4. The light-keeper at the Maidens adds (without giving precise dates) that "during October there was a rush of 'Crows' to this rock from the direction of Scotland."

In 1887 a similar movement occurred at the Tearaght and Skelligs, its duration at the former station being from October 21 to November 23, and at the latter from November 5 to 18. The largest rush at the Tearaght apparently took place on October 24, when the number of Rooks which passed was estimated at 300. At the Skelligs, most were noted on November 9, when flocks were reported going N.E. from 12.30 P.M. to 4 P.Mr., the first flock being believed to contain about 100 and the second about 80 birds. "These Rooks," says Mr J. Walshe (light-keeper at the Skelligs), "seem to have flown 2 
long distance, as they were apparently very tired. They came from the westward. The second flock rested about ten minutes on island." One specimen was received-a young Rook, shot on the Tearaght, November 9 . It is possible that these flocks consisted wholly of immature birds, for $\mathrm{Mr} \mathrm{M}^{\prime}$ Carron, who witnessed the occurrence at the Tearaght in 1884, remarked that those which rested lacked the "excrescence" round the base of the bill, owing to which circumstance he had at first mistaken them for Carrion Crows.

The movement of November 1887, like that of the same season in 1884, broke principally on the Kerry coast; but again, as in 1884, we find traces of it at other stations, notably at Slyne Head, where Rooks were noted on October 20 th and 27 th, and from the 4th to the 13th of November, "a flock of two hundred, with Jackdaws," being reported on this island on November 7. At Blackrock (Mayo) two were observed on October 21. On the south and east coasts we find records of one on the Fastnet Rock, which "seemed exhausted," November 8 ; and some going landwards from Coningbeg Light-ship and the Tuskar, November 10th, 18th, 24th, 25th, and 27 th.

In 1888 the autumn was again marked by records of Rooks passing western island-stations in a north-easterly direction. In that year, however, the birds were not so numerously observed as in 1884 or 1887 , nor do they seem to have been noticed passing the Tearaght. At the Skelligs, where the first flight was reported, a flock of about two hundred appeared, flying N., on November 1 . The next were observed at Blackrock (Mayo) on November 7, after which date no more seem to have occurred until the 28th of that month. On November 28th, some were reported at Slyne Head, and on November 30th and December 1st, 6th, 8th, 10th, 13th, and 14th, small parties of from two to four were seen flying N.E. at the North Island of Arran. Taken in connection with the occurrences of previous years, these records, which might otherwise have appeared insignificant, seem to show that a movement of somewhat similar nature to those witnessed at the Tearaght and Skelligs in 1884 and 1887, was in progress in 1888.

Another remarkable rush was observed at the Tearaght in November 1890, when the first flock was noted on the same day (November 5) as that on which the movement of 1884 began at 
Rook. the same station. Mr W. H. James reports: "A great flock of about 150 arrived from the west about 11 A.M., and lit on island; went $\mathrm{N}$. about 12.30 P.M.; strong breeze N.; seemed tired; a few remained, and were about light that night, several striking at 6.35 P.M." The leg and wing of an example caught striking were forwarded, and belong to an under-sized, probably immature, bird (see Appendix, p. 651). On the day after the arrival of this flock, the wind rose to a hurricane from the N.W., and Rooks, with some Jackdaws, were noted all day on the island, after which flocks were recorded at irregular but frequent intervals until the 1st of December. Mr James observed that he had never before heard of Rooks striking the lantern. Such occurrences are undoubtedly rare, only one other being recorded at an Irish light-station (Fastnet, November 24, 1897), where the light-keeper reporting the circumstance, Mr E. Rohu, speaks of it as "the first case of Crows striking that I have noticed."

The flight of 1890 was not noted from the Skelligs, but "hundreds of Crows" were reported from Slyne Head Lighthouse on the same day (November 5) as that on which the largest flock reached the Tearaght. On that day also "one Crow" was reported from North Arran. On the south coast, "thousands of Rooks" are said to have been observed on November 11th at Spit Bank, Queenstown, flying N.W.; and between the 6th and 9 th of the month flocks were noted passing in the same landward direction at three east coast stations -Blackwater Bank, Arklow South and Arklow North Lightships.

Another and an earlier instance of Rooks arriving in a fatigued condition from the ocean was described by Mr Martin Kennedy, light-keeper at Blackrock (Mayo), in 1881. Amongst other general observations on the birds visiting that station, he writes: "I have seen large flights of Rooks rest here after coming in from the sea in a S.W. direction, which seemed so fatigued that they would fall over after resting, and remain to be caught." It is not stated in what year, or at what time of year, these Rooks were seen.

- Whatever be the explanation of these occurrences, there can be no doubt of their intimate connection with the immigratory movements simultaneously observed on the south and east coasts. This appears from the fact that little or no migration 
of the Rook has been reported from southern or eastern stations in November, except in years which have been marked by some such phenomena on the west coast as those under notice. The following table, giving the number of observations in each November for the west, and also the number for the south and east coast, will suffice to establish the fact just stated.

\begin{tabular}{|c|c|c|c|c|c|c|c|}
\hline & & $\begin{array}{l}\text { West } \\
\text { Coast. }\end{array}$ & $\begin{array}{l}\text { South } \\
\text { and East } \\
\text { Const. }\end{array}$ & & & $\begin{array}{l}\text { West } \\
\text { Coast. }\end{array}$ & $\begin{array}{l}\text { South } \\
\text { and East } \\
\text { Coast. }\end{array}$ \\
\hline November & 1882 & $\ldots$ & ... & November & 1890 & 13 & 7 \\
\hline " & 1883 & ... & ... & " & 1891, & 1 & $\ldots$ \\
\hline , & 1884, & 22 & 10 & $"$ & 1892 & $\ldots$ & 1 \\
\hline$"$ & 1885 & 1 & 1 & , & 1893 & 1 & 3 \\
\hline$"$ & 1886 & $\ldots$ & $\ldots$ & " & 1894, & 1 & 2 \\
\hline$"$ & 1887 , & 14 & 7 & , & 1895 & $\ldots$ & $\ldots$ \\
\hline$"$ & 1888 & 4 & 1 & $\eta$ & 1896 & $\ldots$ & 1 \\
\hline$"$ & 1889 & $\ldots$ & 3 & " & 1897, & 2 & 4 \\
\hline
\end{tabular}

The Rook thus seems to be a nomadic rather than regular visitant in autumn, though its spring movement across the Channel is apparently regular. In only seven out of sixteen years has more than one observation of this species been reported in November from southern and eastern stations, and the only years in which the observations from such stations were at all numerous were 1884, 1887, and 1890 - the years in which the extraordinary flocks already referred to visited the Tearaght and Skelligs.

These flocks are probably part of a migrating host coming from the east, and consist of birds which have overshot their mark and flown too far to the westward. Turning back when they fail to discover any land in front of them, they naturally arrive in a state of fatigue on our west coast. The weather charts of the Meteorological Office afford no sufficient reason for supposing the birds to have been blown out of their course by storms.

Both in spring and autumn, individual Rooks are sometimes noted as arriving in a tired condition at our southern and eastern stations. Such observations have been made in spring at the Tuskar (April 15, 1891), Lucifer Shoals Light-ship (March 29, 1891), Arklow South Light-ship (April 17, 1890), Rockabill (February 28, 1889), and South Rock Light-ship (April 20, 1889). Similar notes for autumn occur in reports 
Rook. from Fastnet (November 8, 1887), Tuskar (November 16, 1884), and Rockabill (December 14, 1889); and a specimen has been forwarded which was caught on Blackwater Bank Light-ship, November 18, 1898. These facts corroborate the inference already drawn from the observations as to direction of flight, that the reported movements at both seasons are immigratory.

\section{JACKDAW (Corvus monedula, Linn.).}

Jackdaw. This species is less noted by light-keepers than any of the Corvida. There are 539 observations relating to the Rook, 202 to the Hooded Crow, 142 to the Raven, 113 to the Chough, and 67 to the Jackdaw. Of this meagre amount of information, 60 per cent. is from west coast stations-a somewhat singular fact, as the bird is less numerous in the west than in the east.

The observations for each month on each section of the coast are as follows:-

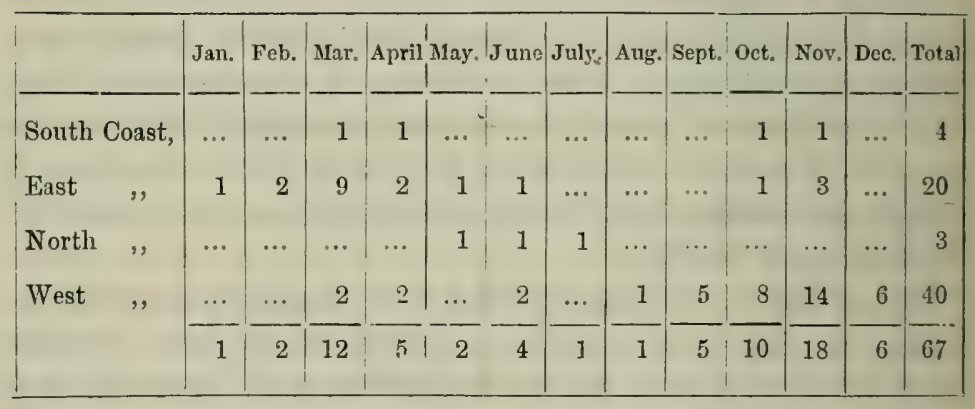

As in the case of the Rook, the west coast observations are most numerous in November, and the east coast records in March.

Only 7 observations of this species are reported from lightships-3 in March, 1 in April, 1 in October, and 2 in November. It has only once been noted from the Tuskar, in March; once from the Fastnet, in October ; twice from Rockabill, in January and March; and never from the Maidens, nor from any other station on the south or east coast than the three just mentioned, except where it is known to breed (e.\%., at Howth and the Copeland Islands). 
Thus five of the six spring occurrences at light-ships and island-rocks (which in the case of Corvus monedula are those which must be relied on to prove a cross-Channel migration) have been in March-earliest, March 9; latest, April 10. There is no note of the Rook having been observed before the Jackdaw in spring at any light-ship or island-station.

On the west coast the only spring reports are Rathlin O'Birne and Dursey Island in March, Blackrock (Mayo) on April 12 th, 1884, and 13th, 1885 .

Autumnal observations are much more numerous on the west than on the east coast. It has been shown (pp. 154 and 156) that Jackdaws accompanied the flocks of Rooks which arrived in an exhausted state at the Tearaght and Skelligs in the Novembers of 1884,1887 , and 1890. In the autumn of 1884 Daws were also somewhat frequently noted at Blackrock (Mayo), some being recorded at different dates in September, October, November, and December, generally flying N.E. or E.

Direction is noted in only 18 cases, of which 2 were on the south coast, 7 on the east, and 9 on the west. Twelve were landward, 1 seaward, and 5 coasting.

There is thus no evidence of the Jackdaw having been observed leaving Ireland, unless a solitary flock reported as flying N.E. from Arklow South Light-ship in March 1888 be considered proof of emigration at that season. There is evidence of its having been occasionally seen flying towards land, both in spring and autumn; but the information is too meagre to justify a conclusion as to whether its migrations are regular or otherwise. From the paucity of observations relating to so common a species, we may conclude that it is, in all probability, often overlooked or confounded with the Rook, whose flocks it accompanies.

\section{Magpie (Pica rustica, Scopoli).}

The Magpie is a well-known and conspicuous bird, and its non-migratory character is sufficiently evinced by the fact that it has never been reported from a light-ship, nor from such rock-stations as the Fastnet, the Tuskar, or the Maidens; though some straggle to the larger islands of the west coast, particularly in autumn.

Magpie. 
Magpie. Including mainland observations, the total number is 51 . Those which are reported from island-stations are 29 , distributed among the different months and sections of the coast, as is shown in the following table:-

\begin{tabular}{|l|c|c|c|c|c|c|c|c|c|c|c|c|c|c|}
\hline & Jan. & Feb. & Mar. & April & May. & June & July & Aug. & Sept. & Oct. & Nov. & Dec. & Total \\
\hline South Coast, & $\ldots$ & $\ldots$ & $\ldots$ & $\ldots$ & $\ldots$ & $\ldots$ & $\ldots$ & $\ldots$ & $\ldots$ & $\ldots$ & $\ldots$ & $\ldots$ & $\ldots$ \\
East &, & 1 & $\ldots$ & $\ldots$ & 1 & 2 & $\ldots$ & $\ldots$ & $\ldots$ & $\ldots$ & $\ldots$ & $\ldots$ & 1 & 5 \\
North &, & $\ldots$ & $\ldots$ & 1 & 1 & $\ldots$ & $\ldots$ & $\ldots$ & $\ldots$ & $\ldots$ & $\ldots$ & $\ldots$ & $\ldots$ & 2 \\
West $\quad$, & $\ldots$ & $\ldots$ & $\ldots$ & $\ldots$ & $\ldots$ & 1 & 1 & 2 & 3 & 4 & 9 & 2 & 22 \\
& 1 & $\ldots$ & 1 & 2 & 2 & 1 & 1 & 2 & 3 & 4 & 9 & 3 & 29 \\
\hline
\end{tabular}

During the half-year June to November, all the observations recorded (20 in number) are from islands off the west coast, viz., Aranmore, Slyne Head, North and South Arran, Samphire Island, Tearaght, Valencia, and Skelligs. This shows a tendency to scatter westwards after the rearing of the young broods. During the remaining half-year, December to May, the only records from west coast island-stations are two, both in December, from Rathlin O'Birne and Valencia.

Of the five east coast records, all save one are from Copeland (Mew) Island. As this station is only three miles from Donaghadee, and two other islands lie between it and the mainland, there is nothing remarkable in the fact of the Magpie being sometimes seen there.

There is, however, an interesting record from Rockabill, dated January 7, 1889: "Two Magpies arrived on the 'Bill,' and made several efforts to reach the mainland, but were driven back by strong wind from W., and died after four days." There was a strong west wind, and they were probably blown from shore.

The islands on the north coast from which the Magpie has been reported are Tory Island (April 9, 1892) and Innishtrahull (March 7, 1897). At the former station it was noted that the birds seen (two in number) "came from S.," i.e., from the mainland. At Innishtrahull the visits of this species seem to be very rare, for in $1889 \mathrm{Mr}$ M. J. Kennedy wrote of it: "The 
Magpie never visits this island, though they are on shore at Magpie. Malin Head." The bird observed there on March 7, 1897, is said to have "appeared very much frightened and confused," and remained on the island throughout the following day; the wind, being moderate S., can scarcely have driven this bird off shore, as was probably the case with the pair reported from Rockabill.

It may or may not be a mere coincidence that both the autumnal occurrences noted on the Tearaght took place during periods when that island was visited by great numbers of fatigued Rooks, viz., on November 18, 1884, and November 11, 1887. On the latter occasion two Magpies were observed, going $E$., in the same direction as the Rooks noted on the 9th and 12th of the same month; and Magpies were almost simultaneously reported, between November 10th and 15th, from Slyne Head and the South Island of Arran.

Attention should be drawn to the unusually large number of Magpies said to have been observed near Hook Tower, in the south of County Wexford, on October 18, 1893. Mr J. Higginbotham reports: "Magpies very numerous close to station, probably between one hundred and fifty and two mundred." So large an assemblage as this would be remarkable anywhere, but doubly so on a long and exposed promontory, such as that on which Hook Tower light-house is situated. Whether the object of the gathering was migratory or otherwise, it is of peculiar interest to find such a flock of Magpies reported from the south coast of County Wexford -the part of Ireland where, according to the testimony of contemporary writers, this bird first arrived in Ireland upwards of two hundred years ago.

[Obs.-The Jay (Garrulus glandarius, Linn.) has never been credibly reported from a light-station. The bird most commonly called "Jay" in Ireland is the Missel-Thrush.]

Swallow (Himundo rustica, Linn.).

The first trustworthy observation of the Swallow at lightSwallow. stations is usually reported between the 10th and 14th of April. In most years some "Swallows" are noted either in March or 
Swallow. in the first week of April, but it is probable that these are generally Sand-Martins, the light-keepers not distinguishing between the different species. In the following table, giving the earliest arrivals reported each year, those not later than April 7 are placed in a separate column, as less likely to refer to Hirundo rustica than to Cotile riparia.

\begin{tabular}{|c|c|c|}
\hline & Not later than April 7. & Later than April 7. \\
\hline 1882 & April 5 (Arklow S.). & $\begin{array}{l}\text { April } 18 \text { (Kish), } 21 \text { (Mine Head), } \\
24 \text { (Tuskar). }\end{array}$ \\
\hline 1883 & $\cdots \quad \ldots$ & $\begin{array}{l}\text { April } 11 \text { (Tuskar), } 15 \text { (Arklow S.), } \\
16 \text { (Rockabill). }\end{array}$ \\
\hline 1884 & March 18 (Dungarvan). & $\begin{array}{l}\text { April } 12 \text { (Dungarvan), } 13 \text { (Coning. } \\
\text { beg), } 16 \text { (Copeland), } 17 \text { (Oyster I.). }\end{array}$ \\
\hline 1885 & $\cdots \quad \cdots$ & $\begin{array}{l}\text { April } 10 \text { (Dunree Head and Killy- } \\
\text { begs), } 12 \text { (Arklow N.), } 13 \text { (Coning- } \\
\text { beg and Arklow S.), } 15 \text { (Tuskar } \\
\text { and Rockabill), } 16 \text { (Fastnet), } 17 \\
\text { (Barrels Rock and Skelligs), } 18 \\
\text { (Rathlin), } 19 \text { (Kish). }\end{array}$ \\
\hline 1886 & April 5 (Arkloiv S.). & $\begin{array}{l}\text { April } 12 \text { (Coningbeg), } 14 \text { (Mine } \\
\text { Head), } 16 \text { (Blackrock, Mayo), } 18 \\
\text { (Fastnet), } 19 \text { (Rathlin I.). }\end{array}$ \\
\hline 1887 & $\begin{array}{l}\text { March } 30 \text { (Coningbeg), April } 3 \\
\text { (Killybegs). }\end{array}$ & $\begin{array}{l}\text { April. } 9 \text { (Barrels Rock), } 10 \text { (Arklow } \\
\text { S. and Rathlin O'Birne). }\end{array}$ \\
\hline 1888 & $\begin{array}{l}\text { March } 12 \text { (Arklow S.), April.6 } \\
\text { (Rathlin I.). }\end{array}$ & $\begin{array}{l}\text { April } 14 \text { (Lucifer Shoals), } 20 \text { (Tus- } \\
\text { kar), } 21 \text { (Fastnet). }\end{array}$ \\
\hline 1889 & April 7 (Lucifer Shoals). & $\begin{array}{l}\text { April } 21 \text { (Rathlin O'Birne), } 22 \text { (Rock- } \\
\text { abill and Maidens), } 25 \text { (S. Rock). }\end{array}$ \\
\hline 1890 & March 29 (Tuskar). & $\begin{array}{l}\text { April } 10 \text { (Arklow S.), } 14 \text { (Lucifer } \\
\text { Shoals), } 17 \text { (Blackwater Bank and } \\
\text { Arklow N.). }\end{array}$ \\
\hline 1891 & April 6 (Arklow S.). & $\begin{array}{l}\text { April } 12 \text { (Tuskar), } 14 \text { (Mine Head), } \\
18 \text { (Lucifer Shoals, Blackwater } \\
\text { Bank, and Arklow N.), } 19 \text { (Barrels } \\
\text { Rock), } 20 \text { (Tearaght). }\end{array}$ \\
\hline 1892 & $\begin{array}{l}\text { April } 3 \text { (Codling Bank), } 5 \text { (Black- } \\
\text { water Bank), } 6 \text { (Coningbeg), } \\
7 \text { (Lucifer Shoals). }\end{array}$ & $\begin{array}{l}\text { April } 10 \text { (Hook Tower and Maidens), } \\
20 \text { (Arklow N.), } 23 \text { (Droghedi } \\
\text { N.). }\end{array}$ \\
\hline 1893 & $\begin{array}{l}\text { April } 5 \text { (Hook Tower), } 7 \text { (Ark- } \\
\text { low S.). }\end{array}$ & $\begin{array}{l}\text { April } 11 \text { (Barrels Rock), } 14 \text { (Black- } \\
\text { water Bank), } 16 \text { (Drogheda N.). }\end{array}$ \\
\hline 1894 & $\begin{array}{l}\text { March } 23 \text { (Arklow S.), } 27 \text { (Black - } \\
\text { water and Codling), A pril } 4 \\
\text { (S. Rock). }\end{array}$ & $\begin{array}{l}\text { April } 9 \text { (AIaidens), } 11 \text { (Hook Tower), } \\
20 \text { (Coningbeg): } 23 \text { (Arklow N.). }\end{array}$ \\
\hline 1895 & April 5 (Blackwater Bank). & $\begin{array}{l}\text { April } 10 \text { (Arklow S, and Skelligs), } \\
11 \text { (Tuskar), } 12 \text { (Barrels Rock), } \\
15 \text { (Coningbeg), } 16 \text { (Codling). }\end{array}$ \\
\hline 1896 & March 30 (Codling), 31 (Tuskar). & 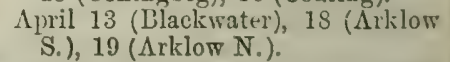 \\
\hline 1897 & $\begin{array}{l}\text { March } 19 \text { (Coningbeg), } 22 \text { (Black: } \\
\text { water and Arklow S.), } 24 \\
\text { (Arklow N.), } 29 \text { (Tuskar), } 30 \\
\text { (Lucifer Shoals), April } 4 \\
\text { (Rathlin O'Birme). }\end{array}$ & $\begin{array}{l}\text { April } 13 \text { (Blackiwater), } 14 \text { (Lucifer } \\
\text { Shoals), } 15 \text { (Skelligs), } 16 \text { (Cod- } \\
\text { ling), } 18 \text { (Arklow S.), } 19 \text { (Arklow } \\
\text { N. and Rockabill). }\end{array}$ \\
\hline
\end{tabular}


Thus in thirteen out of sixteen years, Swallows have been Swallow. noted at some of the Wexford stations (generally at light-ships) between April 10th and 14th, showing that the period between those dates usually sees the beginning of the main influx. This does not reach its maximum until the first ten days of May. The ebb and flow of the spring migration is shown in the following table, giving the number of observations for different periods. (The March observations are included, though most of them doubtless refer to the Sand-Martin.)

\begin{tabular}{|c|c|c|c|c|c|c|c|c|c|c|c|c|c|c|}
\hline & & $1-10$ & $\begin{array}{l}\text { March } \\
11-20\end{array}$ & $21-31$ & $1-10$ & $\begin{array}{l}\text { April. } \\
11-20\end{array}$ & $21-30$ & $1-10$ & $\begin{array}{l}\text { May. } \\
11-20\end{array}$ & $21-31$ & $1-10$ & $\begin{array}{l}\text { June. } \\
011-20\end{array}$ & $21-30$ & Total. \\
\hline \multicolumn{2}{|c|}{ South Const, } & .. & 2 & 2 & 4 & 27 & 40 & 47 & 42 & 22 & 10 & 6 & 3 & 205 \\
\hline East & ", & $\cdots$ & 1 & 12 & 25 & 86 & 100 & 123 & 80 & 42 & 20 & 13 & 14 & 516 \\
\hline North & $"$ & $\ldots$ & .. & $\cdots$ & 2 & 2 & 7 & 5 & 4 & 3 & 1 & 4 & 1 & 29 \\
\hline \multirow[t]{2}{*}{ West } & \multirow[t]{2}{*}{$"$} & $\cdots$ & ... & .. & 6 & 8 & 15 & 21 & 22 & 15 & 11 & 5 & 1 & 104 \\
\hline & & $\ldots$ & 3 & 14 & 37 & 123 & 162 & 196 & 148 & 82 & 42 & 28 & 19 & 854 \\
\hline
\end{tabular}

In the above table, records from light-ships, islands, and mainland-stations are included together. The same result, however, may be obtained by tabulating the light-ship records alone, as follows:-

\begin{tabular}{|c|c|c|c|c|c|c|c|c|c|c|c|c|}
\hline $1-10$ & $\begin{array}{l}\text { March } \\
11-20\end{array}$ & $21-31$ & $1-10$ & $\begin{array}{r}\text { April. } \\
11-20\end{array}$ & $21-30$ & $1-10$ & $\begin{array}{r}\text { May. } \\
11-20\end{array}$ & 21-31 & $1-10$ & $\begin{array}{l}\text { June. } \\
11-20\end{array}$ & $21-30$ & Total. \\
\hline & 2 & 11 & 23 & 80 & 111 & 137 & 100 & 42 & 21 & 11 & 12 & 550 \\
\hline
\end{tabular}

Several light-ships, as well as the Tuskar, occasionally report Swallows in July and August, and there is a record of one killed striking at Rockabill, July 11, 1884. A few immature birds may arrive later than the end of June, but the fact awaits proof, and the possibility of the Swift having been mistaken for the Swallow must not be overlooked.

Nearly all our Swallows seem to arrive on the south-east corner of the island. The eight light-stations, covering a const of about 80 miles from Coningbeg to Codling Bank, yield 
Swallow. (from March to June) 590 observations, an average of 74 to each station, while the remaining fourteen stations, extending for about 270 miles along the south and east coasts, yield only 131, an average of 9 to each station.

Fifteen specimens have been forwarded in spring, the earliest from the Skelligs (April 10, 1895), and the latest from the Tearaght (June 2, 1891). Eleven were received between April 10 and May 8, and of these 9 were from light-shipsthe only ones with satisfactory data. Two of them were killed striking (April 23, 1892, and April 16, 1895), 1 was caught on deck (April 17, 1895), 3 died on deck (May 4, 1887, May 8, 1892, and May 1, 1895), and 3 were found dead (May 7, 1886, April 30, 1890, and April 22, 1897). Coningbeg Light-ship forwarded 3, Barrels Rock 1, Blackwater Bank 2, Arklow South 1, and Codling Bank 2. These figures afford reasons for assuming that the rate of mortality among Swallows on migration is less than among any other common migratory birds.

In autumn only one specimen has been received, caught striking at the Fastnet, October 5, 1887.

At what period the autumnal movement usually begins has not been definitely ascertained. As was previously observed, Swallows are occasionally noted at all times during summer, even at such remote stations as the Tuskar and Arklow South Light-ship, each of which is seven miles from shore. These two stations contribute as many as 15 records for August, of which 5 occur between the 1 st and 10 th of the month, 5 between the 11th and 20th, and 5 between the 21st and 31st. At Coningbeg, however, which is the most distant of all our light-ships (being ten miles from shore), occurrences of this sort are comparatively rare, and there are none recorded between July 13 and August 23.

The closing days of August are marked by a slight general increase in the number of records from light-ships and islandrocks, for of a total of 25 August observations from stations so situated, 12 bear date between the 23rd and 31st of the month. It is uncertain, however, whether these should be referred mainly to the present species, or to the Sand-Martin, whose autumnal migration is said to begin earlier than that of the Swallow. 
After August, the observations recorded may be arranged in swallow. periods as follows :-

\begin{tabular}{|c|c|c|c|c|c|c|c|c|c|c|c|c|}
\hline & & & \multicolumn{3}{|c|}{ September } & \multicolumn{3}{|c|}{ October } & \multicolumn{3}{|c|}{ November } & Total. \\
\hline South & oast, & . & 10 & 22 & 24 & 21 & 8 & 1 & 3 & 1 & $\ldots$ & 90 \\
\hline East & , & - & 23 & 31 & 49 & 30 & 14 & 5 & 1 & 1 & ... & 154 \\
\hline North & , & & ... & $\therefore$ & 1 & ‥ & ... & $\cdots$ & ... & ... & ... & 1 \\
\hline \multirow[t]{2}{*}{ West } & \multirow[t]{2}{*}{ " } & & 2 & 2 & ... & 3 & 2 & 1 & 1 & 1 & 1 & 13 \\
\hline & & & 35 & 55 & 74 & 54 & 24 & 7 & 5 & 3 & 1 & 258 \\
\hline
\end{tabular}

The autumual movement is here shown to be at its maximum in the last ten days of September, and to be practically over by October 20. The statements that Swallows were observed at a north-western station (Aranmore) on November 28, 1886,and a Tuskar record, dated December 7, 1889-should both be received with caution.

Three-fifths of the autumnal observations tabulated above are from light-ships. These also point to the last ten days of September as the period when the main exodus occurs, thus:-

\begin{tabular}{|c|c|c|c|c|c|c|c|c|c|}
\hline \multicolumn{3}{|c|}{ September } & \multicolumn{3}{|c|}{ October } & \multicolumn{3}{|c|}{ November } & \multirow{2}{*}{ Total. } \\
\hline $1-10$ & $11-20$ & $21-30$ & $1-10$ & $11-20$ & $21-31$ & $1-10$ & $11-20$ & $21-30$ & \\
\hline 20 & 40 & 53 & 27 & 9 & 5 & 1 & ... & $\ldots$ & 155 \\
\hline
\end{tabular}

The autumnal observations are strikingly few compared with the spring records. The numbers for the two principal months at each season are-

Spring.

$$
\begin{aligned}
& \text { April, . . } 322 \\
& \text { May, - . } 426 \\
& \text { Total, . } \overline{748}
\end{aligned}
$$

Autumn.

September, . . 164

October, . . 85

Total, . $\overline{249}$

The eight stations from Coningbeg to Codling Bank average 27 observations in autumn to each station, whereas in spring the average was 74 to each. The remaining fourteen stations 
Swallow. of the south and east average 4 to each station in autumn, where in spring it was 9 . The eight south-eastern stations thus show a marked superiority at both seasons, but the superiority in spring is as 8 to 1 , and in autumn it is only as 3 to 1 . From this it is not necessarily to be inferred that the southeastern migration-route is less followed in autumn than in spring, for it is possible that a large proportion of the observations from other parts of the coast relate to birds which have not yet set out on their migratory journey.

There is reason to believe that, as with other species, very few of our Swallows are seen at light-stations in the act of departure.

Bearing in mind that they are far more numerous in autumn than in spring, we might have expected to find their departure a more conspicuous phenomenon than their arrival; but, as has been shown, the reverse is the case, the observations in spring being three times as numerous as in autumn. This disparity becomes still more remarkable when we compare the records of direction of flight at both seasons.

In spring, the records of direction from the south and east coasts amount to 420 , of which all but 15 are either W., N.W., N., or N.E. (the north-eastern direction being frequent at such southern stations as Coningbeg and Barrels Rock Light-ships). The most prevalent direction, N.W., is followed in 273 cases. The numbers to each of the eight points are as follows :-

\section{Direction of Flight in Spring.}

\begin{tabular}{|c|c|c|c|c|}
\hline \multicolumn{5}{|c|}{$\begin{array}{l}\text { Four laudward points } \\
\text { (From W. to N.E.). }\end{array}$} \\
\hline W., & . & . & • & 38 \\
\hline N.W., & . & & • & 273 \\
\hline N.,. & • & & • & 56 \\
\hline N.E., & • & & $\bullet$ & 38 \\
\hline
\end{tabular}

\begin{tabular}{|c|c|c|c|}
\hline \multicolumn{4}{|c|}{$\begin{array}{l}\text { Four seaward points } \\
\text { (From E. to S.W.). }\end{array}$} \\
\hline E., . & . & . & . \\
\hline S.E., & . & . & - \\
\hline S., . & . & • & - \\
\hline S.W. & • & . & . \\
\hline
\end{tabular}

This is what might have been expected, and shows that the Swallows observed at light-stations in spring are nearly all en route for their breeding-quarters.

We do not, however, find that any such overwhelming majority of those observed in autumn are flying in a contrar $y$ 
direction. The following are the records for September and swallow. October:-

\section{Direction of Flight in Autumn.}

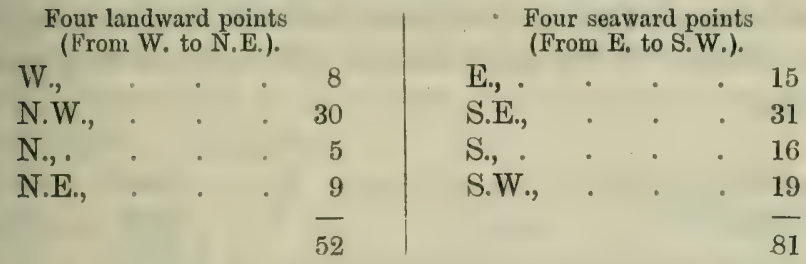

All that can be said of these figures is that they show the prevailing direction in autumn to be more or less southward. It is particularly curious that the two points towards which most flights are recorded are diametrically opposed to each other, the S.E. and the N.W.

Again, a large proportion of the observations in autumn relate to individual birds, or to small parties of from two to half a dozen. From what is known of the Swallow's halit of gathering in large flocks before setting out on the autumnal journey, it may well be doubted whether, as a general rule, these small detachments are on migration; and when we find them reported as flying N.W. or W., instead of in a southward direction, the suspicion is strengthened that they are rather making towards some rendezvous for the purpose of joining other bodies before setting out for their winter quarters.

If, however, we confine our attention to cases in which flocks of Swallows are mentioned, the evidence of an emigratory tendency is more marked. After September 5 we find only 7 instances of flocks going N.E., N., N.W., or W., while there are 26 instances of their going S.W., S., S.E., or E. Thus practically 80 per cent. of the flocks, from September 5 to the end of autumn, are departing when noted.

The net result of the observations is therefore favourable to the view that Swallows usually migrate in autumn in large flocks; but it is singular that from a series of reports extending over sixteen years, only 26 instances can be collected in which these flocks have been observed leaving our shores. The Swallow, when departing, seems, like other species, generally to evade observation. 
Swallow. For the amount of migration which must take place in September, very few fatalities are recorded. A table for the eight months from April to November (there were no fatalities in March), showing the number reported as killed, disabled, fatigued, found dead, etc., and the number for each month, may be of interest. Of the total number (67), only 16 were actually received.

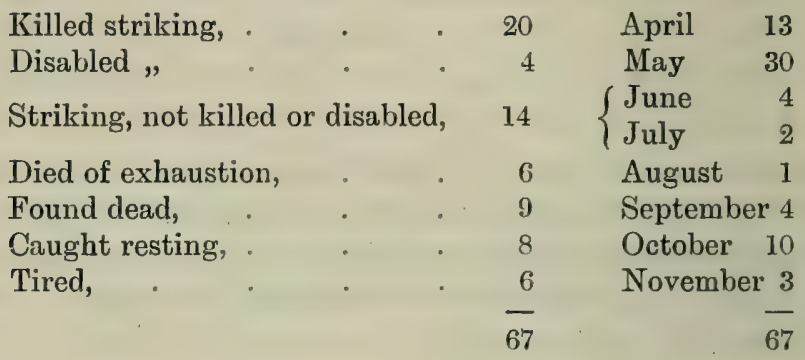

It is possible that some of these records may refer to HouseMartins, Sand-Martins, or Swifts. They show, however, that the present species, though little addicted to striking the lanterns, is still less in the habit of succumbing to exhaustion after its migratory passage, deaths from this cause being only six, while the additional instances in which Swallows are said to have shown symptoms of fatigue do not exceed the same number.

From the insignificantly small numbers (38) reported as striking, in proportion to the abundance of this species, it is a natural inference that the Swallow migrates chiefly by day, and at a sufficient speed to carry it from the beginning to the end of its journey between the morning and evening of the same day -a feat of which its well-known strength of wing makes it apparently quite capable. On the other hand, great flocks of Swallows, which seemed to be on the point of departure, have sometimes been observed in the evening at a considerable elevation in the air. There does not appear to be sufficient evidence for a decisive conclusion as to whether these birds migrate more by day than by night.

- The amount of variation in the length of the wing is small.

Average length of wing, 5.00 inches; longest, $5 \cdot 15$; shortest, 4.82 ; difference between extremes, 0.32 ; percentage of variation, $6 \frac{1}{2}$. 


\section{House-Martin (Chelidon urbica, Linn.).}

The observations on this species are of little value, as it has seldom been satisfactorily discriminated.

House-

Martin.

It has been reported 46 times (32 in spring and 14 in autumn), amounting to less than 3 observations per annum from the whole Irish coast.

Of the 14 autumnal observations, 10 have little or no migrational value, and we are reduced to the insignificant total of 4 occurrences, apart from which there is no evidence of the House-Martin's having been observed on its autumnal migration.

Light-stations have forwarded 16 examples of the Swallow, 8 of the Sand-Martin, and only 2 of the House-Martin. From its being a bird of less powerful flight than the Swallow, we might expect the Martin's rate of mortality to be higher, and we can scarcely suppose it to be lower, than that of Hirundo rustica; so that the rarity of the instances in which the present species has been obtained may fairly be considered proof of its great comparative scarcity in Ireland.

Of the two specimens forwarded, one was observed exhausted (in company with some other tired Swallows and Martins), and was shot, April 23, 1891, at the Skelligs. The other was killed striking, during a dense fog, at Rockabill, May 4, 1889.

The occurrence at Rockabill is of interest, as it happened during a rush of birds caused by a sudden descent of fog, about an hour before midnight. The light-keeper ( $M r$ John Hamilton) reports:- "The fog commenced at 11 P.M., and in about half an hour the lantern was nearly covered with birds; a great number must have been killed. We picked up several on the rock in morning." The specimens forwarded were 3 Whinchats, a Sedge Warbler, a Whitethroat, a Willow Wren, a House-Martin, and a Cuckoo. "From this sudden rush of birds," says Mr John Hamilton, "immediately after the weather got thick, I would infer that they are always migrating at this season and in autumn, but keep far from the light in clear weather. On the night mentioned it would be impossible to distinguish the light at more than a mile from the station, the weather being so thick." This appears to be a fair 
House-

Martin.

inference, and it illustrates the small degree of liability amongst the Hirundines to disasters at the lanterns, to find that a sudden fog at such a date produced only one instance of a bird of that family striking. The fog prevailed along the east coast generally, between the nights of May 3rd and 4th, and rushes somewhat similar to that at Rockabill occurred at Mew Island and Arklow South Light-ship. The whole number of specimens forwarded from these three stations for the nights in question was twenty :-

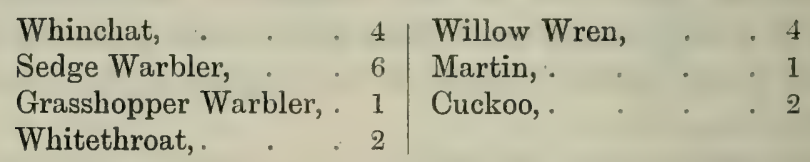

Either the Swallows and Martins must have been flying at such a height as to be almost independent of the fog, or there were few of them on the wing at the hour when it came on.

The observations of the present species are so unsatisfactory, that nothing can be inferred as to its principal migration route. The spring observations, 32 in number, are from the following seven counties :-Cork, 1; Waterford, 3; Wexford, 18; Dublin, 3; Sligo, 2; Mayo, 4 ; Kerry 1.

The only autumnal records which seem to be migrational are 4: 1 from Cork, 1 from Wexford, and 2 from Kerry.

SandSAND-Martin (Cotile riparia, Linu.).

Martin.

There is high authority for the opinion that "most of the 'early Swallows' of newspaper paragraphs are Saud-Martins," 1 and the "Swallows" observed before the end of March at lightstations may, with little hesitation, be placed in the same category; but beyond the application of this general rule, we have no adequate means of distinguishing which, or what proportion, of the "Swallows" and "Martins" of the "Migratiou Reports" belong to the species now under notice.

The number of specimens received is 8 , to 16 of the Swallow and 2 of the House-Martin. It does not seem likely that the

${ }^{1}$ Prof. A. Newton (Yarrell, 4th ed., p. 355). 
Sand-Martin is either half as numerous as the Swallow or four times as numerous as the Martin, but its numbers probably exceed those of the latter species, whose occurrences at lightstations seem particularly rare.

In 17 instances "Swallows" or "Martins" have been reported in March-once so early as the 12th of that month (Arklow South Light-ship, 1888). In accordance with what has been said above, these may be assumed to have been SandMartins. That the principal immigration is later than March appears from the dates on which specimens have been obtained. Of these, the earliest was caught on Blackwater Bank Lightship, April 3, 1899; the latest (excluding one shot, May 9, 1888, on the Tearaght) was killed striking the lantern of the same light-ship, May 6, 1891. The main influx appears to be during April, but the number of specimens is insufficient to fix its date more precisely, especially as 2 of the 8 forwarded were shot. The latter half of April, however, has yielded 3 of the 6 examples which were found dead or exhausted.

No specimen has been received in autumn, and our information as to movements at that season is nil. Those observed at light-stations have (except in two cases) been reported as "Swallows" or "Martins," and the grounds for assigning individual occurrences to the present species are too slender to lead to any conclusion. It is curious that the two instances in which the Sand-Martin has been reported by name are from western stations-Blackrock (Mayo) and Slyne Head. At the former station three are said to have been observed on October 22, 1888, and from the latter a "Sand-Martin Swallow" is reported on November 13, 1887. Both these dates are so late for the Sand-Martin that (like the November 28th and December 7th Swallows) they should be received with caution.

The evidence to hand as to the coast-distribution of this species on migration consists practically of the 17 March observations and the 8 specimens.

Of these 25 occurrences, 3 were on the south coast, 17 on the east, and 5 on the west. The county distribution is-

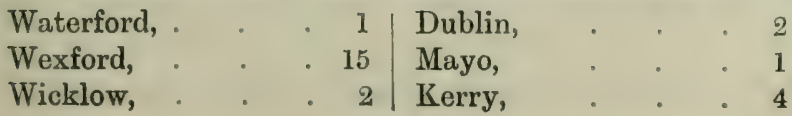


Sand- Only one of the above 25 is from a mainland-station (DunMartin. garvan), while 16 are from light-ships and 8 from islands. The four stations off the east coast of Wexford (Tuskar, Blackwater Bank, Lucifer Shoals, and Arklow South Light-ship) furnish 13, a majority of the entire number.

Of six wings measured the average length is $4 \cdot 17$ inches. The longest $(4 \cdot 27)$ is of the same length as the shorter of the two House-Martin's wings received.

\section{SwIFT (Cypselus apus, Linn.).}

Swift.

Though more frequently discriminated than the HouseMartin or Sand-Martin, the Swift is too often confounded with the Swallow to afford much material for analysis. Of 94 observations which apparently relate to this species, 44 were made in May, 25 in June, 13 in July, and 12 in August. Four other records, between September 19 and October 27, may be dismissed as too improbable for acceptance.

The earliest observations in spring are three bearing the same date,-

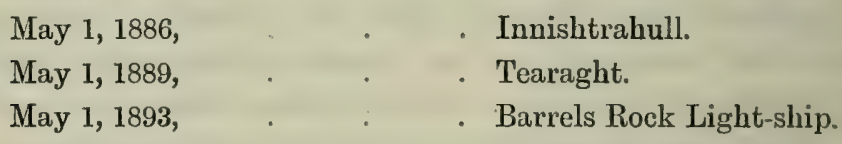

The latest in autumn are two which also bear the same date,-

August 19, 1889,

- Fastnet.

August 19, 1890,

- Hook Tower.

In some years, owing to the scarcity of observers acquainted with the species, no Swifts have been reported till June; but in twelve of the sixteen years from 1882 to 1897, the earliest occurrences noted have been between May 1st and 12th. The observations at light-ships apparently cease (as regards spring migration) about June 10. The light-ship, island, and mainland records for each ten-days' period are as follows :- 


\begin{tabular}{|c|c|c|c|c|c|}
\hline & & Light-ships. & Islands. & Mainland. & Total. \\
\hline May 1-10, & . & 4 & 8 & 3 & 15 \\
\hline$" \quad 11-20$ & . & 4 & 4 & 8 & 16 \\
\hline$" \quad 21-31$ & . & 2 & 5 & 6 & 13 \\
\hline June $1-10$, & . & 2 & 7 & 4 & 13 \\
\hline$" \quad 11-20$ & . & $\therefore$ & 6 & 2 & 8 \\
\hline$" \quad 21-30$ & . & ... & ... & 4 & 4 \\
\hline July $\quad 1-10$ & 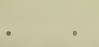 & 2 & 2 & 1 & 5 \\
\hline$" \quad 11-20$ & . & ... & $\cdots$ & 1 & 1 \\
\hline 21-31, & & $\ldots$ & 7 & $\ldots$ & 7 \\
\hline \multirow{3}{*}{$\begin{array}{l}\text { August } 1-10, \\
\Rightarrow 11-20\end{array}$} & & ... & 4 & 3 & 7 \\
\hline & . . & 1 & 3 & 1 & 5 \\
\hline & & 15 & 46 & 33 & 94 \\
\hline
\end{tabular}

Between June 20 (on which date Swifts have been reported from the Fastnet and Tuskar) and July 27, there is very little evidence of migration. A specimen, however, has been received from Blackwater Bank Light-ship, which was caught disabled on July 2, 1898; and on July 2, 1888, another example is said to have been found disabled during a fog at Blackrock (Mayo). The date on which both these occurrences happened seems too early for departure, and would be very late for arrival. The Swift ranges so far in its daily flight that it is quite conceivable that individuals may occasionally become bewildered in sea-fogs, even when not migrating.

During the last few days of July the commencement of the autumnal migration is clearly evidenced, as many as seven occurrences being reported from island-rocks between the 27 th and 31st of that month. In four of these seven instances the birds are noted as striting, viz. :-

Tuskar, one killed, July 28, 1886.

Fastnet, one disabled, July 31, 1889.

Tuskar, one killed, July 30, 1894.

Rockabill, one killed, July 30, 1895.

The Rockabill and Fastnet examples were forwarded. Both proved to be young birds; likewise the only other autumnal specimen received, which was sent without data as to how procured, from Wicklow Head Light-house, August 7, 1899.

In August-the month during which the withdrawal of the 
Swift. Swift is commonly noticed-there is only one record of its being killed at the lantern (at Hook Tower, August 9, 1890); but some were observed "flying in the rays of the light" at Fastnet, August 3,1889. The latest recorded observation for the east coast bears date August 14 (Arklow South Light-ship); for the north coast, August 12 (Innishtrahull); for the west coast, August 18 (Blackrock, Mayo); and for the south coast, August 19 (Fastnet and Hook Tower).

As Swifts, like Swallows, have frequently been observed to gather in large flocks at the season of departure, it is somewhat significant that not more than five have been reported as seen together after July 16. The bulk of the departing birds must therefore pass from our shores unseen.

There is one point in which the evidence concerning the present species is remarkably unlike what has been adduced in respect to any other. This is, that the Swift appears to strike the lanterns more frequently at its season of departure than at its time of arrival. In fact, we have no definite record of its having struck on spring migration at all, though two specimens, of which one was found dead, and the other probably shot, have been forwarded from the Tuskar (May 15, 1886, and May 22, 1887). On the other hand, there are five distinct records of Swifts killed or disabled striking between July 28 and August 9, and two of these are attested by specimens; while the example from Wicklow Head, forwarded August 7, 1889, may be a sixth instance.

As the only specimens forwarded in autumn (three in number) have been young birds, it is possible that the tendency to strike at that season is confined to the immature. It would not be surprising if birds only a few weeks, or perhaps days, out of the nest, were more liable to become confused at sea than their elders. This consideration, however, only renders more remarkable the cases of our other summer visitants, which nearly all rear considerably larger broods than the Swift, but of which, nevertheless, very few specimens are obtained in autumn in proportion to the numbers which strike in spring.

The coast-distribution of the observations relating to this species show that in May it has been more noted on the east coast than elsewhere, while in August three-fourths of the few observations chronicled are from the south and west. The 
south coast, though behind the east in May, furnishes the highest total; but some deduction should be made for the character of its stations, chiefly mainland, in the vicinity of which the Swift breeds.

\begin{tabular}{|c|c|c|c|c|c|c|}
\hline & & May. & June. & July. & August. & Total. \\
\hline South Coast, & . & 12 & 11 & 4 & 4 & 31 \\
\hline East & . & 18 & 2 & 6 & 2 & 28 \\
\hline North " & . & 9 & 4 & $\ldots$ & 1 & 14 \\
\hline \multirow[t]{2}{*}{ West } & . & 5 & 8 & 3 & 5 & 21 \\
\hline & & 44 & 25 & 13 & 12 & 94. \\
\hline
\end{tabular}

Only six specimens have been received. The wings of three adults obtained between May 15 and July 2 vary from 6.85 to 7.00 inches in length, the average being 6.92. Wings of three immature birds obtained between July 30 and August 7 vary from 6.12 to $6 \cdot 65$, the average being 6.43 . The percentage of variation in the three adults is only 2 , while in the three young examples it is 8 .

\section{Nightjar (Caprimulgus europceus, Linn.).}

This species is very seldom noted. There are, however, two records by careful observers of its having been seen or heard Nightjar. in April,-Mr M'Carron reporting one heard at Mine Head, April 20,1888; and Mr Dunleavy, one seen on the wing at Samphire Island, at 7 P.M., on April 16, 1896.

Besides the above, there are only 6 observations of the Nightjar in spring ( 4 in May and 2 in June). They are as follows :-

May 11, 1888, Tuskar, six on rock all day.

May 15, 1894, Rockabill, one on rock at noon, caught and forwarded. [Male, received.]

May 23, 1897, Tuskar, one caught exhausted. [Male, received.]

May 29, 1886, Mine Head, one heard at 2 A.M.

June 3,1888 , Tuskar, two on rock.

June 4, 1894, Hook Tower, one shot after watching it for a day or two. [Female, received.] 
Nightjar. From these notes it would appear that immigration is probably not far from its maximum about the 12th of May.

Of three July observations, two are unimportant (being at mainland-stations), and the third is only noted as a "supposed" occurrence (Fastnet, July 17, 1891).

The only evidence of the autumnal migration is a note from the Tuskar, "August 11, 1888,- - one at light all night." So little is known of the usual date of this species' departure, that even isolated records are not without interest. The departure is usually stated to take place about the middle of September. At Heligoland, however, according to Gatke, the return movement is noticed "as early as the first half of August, if the days are fine and warm."

The only light-stations which have been proved to lie in the direct migration-route of this species are the Tuskar and Rockabill, from each of which a specimen has been received. The fact that nine examples have in one year (1888) been reported from the Tuskar (six on May 11, two on June 3, and one on August 11) renders it probable that the south-east corner of Ireland is the Nightjar's usual point of arrival and departure.

\section{CucKoo (Cuculus canorus, Linn.).}

Cuckoo. Though few popular traditions are better founded than that which associates the Cuckoo's coming with the month of April, the evidence from light-stations indicates that most individuals of this species arrive in May. The total number of observations recorded for the former month is 15 , and for the latter 63 .

These are of two kinds-(a) those which record the first hearing or observing of the bird at stations whose vicinity it frequents in the breeding season, and (b) those which are essentially migrational, i.e., occurrences at light-ships or islandrocks, or striting, or reaching shore in a state of fatigue.

There are 46 of the former and 22 of the latter class, leaving 10 other spring records (nearly all in May) which are referable to neither, and may be discarded as unimportant.

The two classes of observations which have a bearing on the question of the time of arrival may be grouped in periods as follows:- 


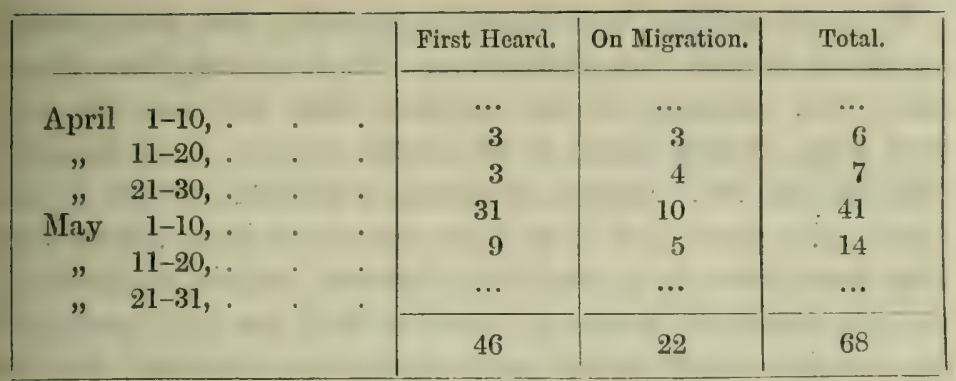

The two series above summarised may be said to commence on the same day, for the earliest date at which the Cuckoo is reported to have been heard at an Irish light-station is April 16, 1884, at Copeland (Mew) Island, and the earliest record of its occurrence on passage is April 16, 1888, at the Skelligs. Both series also end on the same day, for the latest date at which a light-keeper has noted hearing the Cuckoo for the first time is May 20, 1897, at Innishtrahull, and the latest recorded occurrence on migration was on May 20, 1890, when a female (forwarded) was killed striking at Oyster Island, Co. Sligo. Both also agree in fixing the first ten days of May as the period of maximum immigration.

They differ, however, in one respect, for it may be noticed that May has seven times as many records as April of the first hearing of the bird, and only twice as many occurrences on actual migration. The latter proportion is more to be relied on, for it is not to be expected that the earliest Cuckoos will immediately make themselves heard in exposed situations near the sea-coast; and records of this kind from light-stations will, on an average, be late. They show that until May the Cuckoo is not sufficiently numerous to occupy its outlying haunts.

The earliest annual records of hearing the Cuckoo for ench of the fourteen years $1882-95^{1}$ are as follows:-

1882, May 1, Mine Head.

1883, May 3, Ratblin Island.

1884, $\Lambda$ pril 16, Copeland (Merw) Island. $1885, \Lambda$ pril 20, Rathlin Island and Aranmore.

1886, May 7, Mine Head.

1887, May 7, Dunree Head.

1888, May 5, Dunree Head.

\author{
1889, April 28, Arran Island, S. \\ 1890, May 1, Copeland (Mew) Islaud. \\ 1S91, May 10, Mine Head and Howth \\ Baily. \\ 1892, Mlay 5, Drogheda North. \\ 1893, May 5, Howth Baily. \\ 1894, A pril 30, Drogheda North. \\ 1895, May 4, Copeland (Mew) Island.
}

Nine of the above are in the first week of May.

${ }^{1}$ In 1896 and 1897 there wero no records, except one from Innishtrahull, at the exceptionally late date of May 20, 1897. 
Cuckoo. If every station had reported regularly, the dates would no doubt exhibit less fluctuation. Of 6 records from Aranmore (Co. Donegal), 4 are between May 1st and 4 th, and of 6 from Dunree Head, in the same county, 5 are between May 1.st and 7th. Only 6 observations are from islands off the Connaught coast, and 4 of these are dated May 7 th or 8 th. That the Cuckoo is a singularly punctual bird in returning to its haunts must be known to every one who has kept account of its arrival for a number of years in the same locality, ${ }^{1}$ but the light-station records are unfortunately too meagre to show with certainty whether this punctuality is exhibited in such outlying parts of its range as the islands of the Atlantic seaboard.

Of 22 instances in which the Cuckoo has been observed on actual migration, 8 are corroborated by specimens, and in one case (Blackwater Bank Light-ship, April 29, 1899) by as many as 3 examples, killed striking on the same night. Six of the 10 specimens received in spring struck lanterns during the week ending May 5. The dates of the earliest and latest are nearly the same as in the case of the observations.

Earliest,

Latest,
April 18, 1893,

May 20, 1890,
Hook Tower (Wexford).

Oyster Island (Sligo).

The latest, as already mentioned, was a female. The sexes of two of the three birds killed on April 29, 1899, at Blackwater Bank, were also determined by $\mathrm{Mr}$ Williams, who pronounced them a male and female.

The only counties in which the Cuckoo has been reported as striking the lanterns are Wexford, Dublin, Down, and Sligo; but it has on six occasions been noted from island-rocks of the Cork and Kerry coast (Fastnet, Tearaght, and Skelligs), where it seems to rest during the spring migration. Examples have also rested at the Tuskar and Rockabill, and there is one instance recorded of a Cuckoo's alighting on a ship (Lucifer Shoals Light-ship, May 13, 1888). Of a total of 22 migrational occurrences of the species, all in spring, the distribution is as follows :- south coast, 7 ; east coast, 9 ; west coast, 6 .

Seventeen of these were south of the latitude of Dublin.

1 At Fassaroe, Co. Wicklow, it has been first heard between $\Lambda$ pril 20 th and 26 th in thirty ont of past thirty-five years, most frequently on $26 \mathrm{th}$, and never before the 15th. - R. M. B. 
Of the autumnal migration there is no evidence whatever. Cuckoo. The latest date on which an adult Cuckoo has been noted at an island-station is June 12 (Aranmore), and at a mainlandstation, July 8 (Dunree Head), this last being the only occurrence of an old Cuckoo reported during July. Between July 15 and August 8, three young examples have been forwarded, of which two were shot (Mew Island, July 15, 1890, and Aranmore, August 8, 1895); while the third was found unable to fly at the last-named station, August 8, 1898. ${ }^{1}$ These birds were not migrating when obtained; and the rule which has been found to prevail with nearly every species, viz., that the departure is unobserved, finds its most complete exemplification in the case of the Cuckoo. ${ }^{2}$

This species has oftener been forwarded alone than accompanied by others. Probably it sometimes collects in small detachments of its own kind for migration, as the three specimens which struck at Blackwater Bank Light-ship on April 29, 1899, did so within a few minutes of one another (about 11.50 P.Mr.), and no other birds seem to have been killed on that night. As mentioned under House-Martin, however, Cuckoos struck at two stations (Mew Island and Rockabill) during the fog of May 3rd and 4th, 1889, when the Whinchat, Sedge Warbler, Grasshopper Warbler, Whitethroat, Willow Wren, and House-Martin were also killed. The Cuckoo, like the Whinchat and Grasshopper Warbler, has struck only in the company of such species as are strictly summer visitants to our area.

Only nine adult wings were available for measurement. Of these the four earliest (before April 30) average 8.9, and the four latest (after April 30) 8.5. The average for the nine is intermediate between the average given in "Saunders's Manual" $(8 \cdot 50)$ and that in the 4th edition of "Yarrell" (8.75).

Average length of wing, 8.65 ; longest, 9.30 ; shortest, 7.90 ; difference between extremes, 1.40 ; percentage of variation, 16 .

1 The light-keeper says it was "found disabled, but did not strike." As its wing measures only 6.1 inches, while the average length of an adult's wing is about $8 \cdot 65$, the supposed "disablement" was probably no more than inability to fly, the quills not being sufficiently grown.

"In the "Report" for 1883 , as printed, a Cuckoo is said to have been killed striking at the Tuskar, November 2, 1883. "November" is doubtless a misprint for May. The record would otherwise be incredible, 


\section{Grate Spotted Cuckoo (Coccystes glandarius, Linn.).}

Great

Spotted Cuckoo.

Though not obtained, there is little reason to doubt that one example in nearly adult plumage was observed at the Skelligs light-house on April 30, 1897. Mr T. King's description (p. 597) is referable to no other species. The Great Spotted Cuckoo is known to have once previously visited Ireland, in 1842 (Thompson, vol. i. p. 364), and then, as on the occasion under notice, it occurred on an island off the west coast (Omey, near Clifden, Connemara) on spring migration.

\section{Hoopoe (Upupa epops, Linn.).}

Hoopoe.

Has twice been obtained, and in five other instances reported, all the best authenticated occurrences being in March or April.

An example shot at Eagle Island, E., on April 12, 1887, was forwarded, as was also the fresh skin of a Hoopoe which alighted on Barrels Rock Light-ship, March 28, 1894, and which died on board four days subsequently. The spring of 1894 seems to have been distinguished by something like an influx of the present species into Ireland, and the description of a bird, which alighted for a few moments on Codling Bank Light-ship on March 20, leaves little room for doubt that it was a Hoopoe, making two March occurrences on light-ships within eight days of each other. On April 9 of the same year another was noted from the Old Head of Kinsale. In $1888 \mathrm{Mr}$ M'Carron reported having several times observed one before April 25 in the vicinity of Mine Head. Of these five spring occurrences, three were on the south const, one on the east, and one on the west.

The other reported instances were at Rockabill, June 12, 1856, and Innishtrahull, September 15 to 24, 1894.

[Obs.-An unidentified "strange bird" seen at N. Arklow Lighti-ship, September 9, 1892, may, as suggested on p. 330, have been a Roller (Coracias garrulus, Limn.), but the description is not very exact.]

KingFisher (Alcedo ispida, Linn.).

Kingfisher. Of the two forwarded, one was found dead (supposed to have struck lantern) at Hook Tower, September 9, 1891; 
the other was found dead at Blackwater Bank Light-ship, July 20, 1898. On April 30, 1892, one is reported to have rested on Lucifer Shoals Light-ship, and afterwards flown towards the shore. The name "Kingfisher" is often misapplied in Ireland, and only a limited reliance can be placed on uncorroborated records. Some birds noted as "Kingfishers" at Blackrock (Mayo) in 18s2, were evidently misnamed.

The evidence is insufficient to prove migration. The only authenticated occurrence at a station off the mainland was in July.

[Obs. - The absence of Woodpeckers from the list of birds observed at light-stations is noteworthy, particularly as considerable incursious of the Great Spotted Woodpecker (Dendrocopus major, Linn.) took place in the autumns of 1886 and 1889.]

\section{WRyneck (Ï̈nx torquilla, Linn.).}

The Wryneck is known as an Irish bird on the strength Wryneck. of six occurrences, ${ }^{1}$ of which four have been at light-stations, viz. :-

One shot at Rathlin O'Birne, probably in October 1878. Specimen not forwarded, but credibly vouched for (see 1892 "Report," p. 308).

One killed striking at North Arran Island Light-house, October 6, 1886 ; received in flesh.

One killed striking at Rockabill, September 5, 1896; received in flesh.

One found dead at Fastnet, September 17, 1898; received in flesh.

Of two other examples obtained in Ireland, one was shot in May in Wicklow, and one in October in Waterford.

There is a close analogy between the Irish occurrences of the Wryneck and those of the Pied Flycatcher. Both species have been chiefly obtained at light-stations, and both, though summer visitants to Great Britain, are autumnal stragglers to Ireland, each having been only once taken in this country in spring. The Lesser Whitethroat (twice obtained in autumn, but never in spring) is a third instance. What becomes of these autumnal wanderers, in case they reach the 1 "The Wrynock in Ireland," by Miss Lena Gyles, Irish Naturalist, 1898, p. 16. 
Wryneck. Irish mainland safely, is a question which we have no means of answering, as none of them have been observed during the winter months.

[Obs.-A conspicuous absentee from the list of birds, of whose migration direct evidence has been adduced by the light-keepers, is the Wood-Pigeon (Columba palumbus, Linn.). A few of the "Pigeons" reported may be of this species, and isolated notes from Dungarvan, Drogheda North, Killybegs, and Slyne Head refer to "Wood-Pigeons" and "WoodQuests," but not as observed migrating. A "Wood-Pigeon" was once recorded "going to land" from the Tuskar (June 7,1889 ), and one was reported from Rockabill, March 24, 1894. These may have been either Columba palumbus or C. cences.]

\section{Stock Dove (Columba cenas, Linn.).}

stock Dove. The leg and wing of a "Pigeon" shot at the Tuskar, October 19,1887 , are the only evidence of the Stock Dove's occurrence at light-stations. It is not stated whether the bird was alone or in a flock.

\section{Rock Dove (Columba livia, J. F. Gmelin).}

Rock Dove. The observations on "Pigeons" are unsatisfactory from their vagueness, but no doubt the bulk of them refer to the Rock Dove, which does not appear to migrate.

One is said to have been caught in a fog as far as ten miles from shore, i.e., at Coningbeg Light-ship (August 19, 1895), and may have occurred at the same or other light-ships in a considerable number of instances in which it is not clear whether wild or tame "Pigeons" are intended. No specimen, however, has been received from a light-ship. One is said to have been killed striking the lantern at Rockabill, October 29 , 1897.

More than 60 per cent. of the observations are from the north and west coasts, where Rock Doves breed more numerously than elsewhere. May is the month in which it has been chiefly noted in the west, though the total number of records from all Ireland is highest in October and December:- 


\begin{tabular}{|l|r|r|r|r|r|r|r|r|r|r|r|r|r|r|r|r|}
\hline South Coast, & 4 & 3 & 8 & 6 & 2 & 3 & $\ldots$ & 1 & 3 & 10 & 3 & 7 & 50 \\
\hline East ", & 2 & 6 & 2 & 3 & 3 & 4 & 5 & 3 & 7 & 7 & 7 & 8 & 57 \\
North ", & 3 & 1 & 3 & 6 & 3 & 7 & 8 & 4 & 7 & 7 & 6 & 7 & 62 \\
West ", & 4 & 6 & 5 & 9 & 27 & 12 & 1 & 9 & 5 & 15 & 12 & 17 & 122 \\
\hline & 13 & 16 & 18 & 24 & 35 & 26 & 14 & 17 & 22 & 39 & 28 & 39 & 291 \\
\hline
\end{tabular}

Rock Dove.

On the south and east coasts a decided majority (67 out of 107) of all the observations made there, are for the half-year September to February. On the north and west they are equally numerous during that half-year and during the remaining six months, March to August, 90 being recorded in the winter half, and 94 in the summer half-year.

\section{Turtle Dove (Turtur communis, Selby).}

There is reason to believe that the Turtle Dove straggles in Turtle Dove. small numbers to Ireland every spring, arriving chiefly on the south-east coast. The first specimen received from a lightstation was from the Tuskar, shot May 12, 1886, previously to which Turtle Doves had not been mentioned in the "Migration Reports"; but the light-keeper forwarding the bird spoke of having seen one or two annually since he had been at the station. It has subsequently been either forwarded or reported nearly every year.

The whole number of occurrences, of which 14 are attested by specimens, is 23 , seventeen being on islands or at light-ships, while six were on the mainland. According to months and counties, they are as follows:-

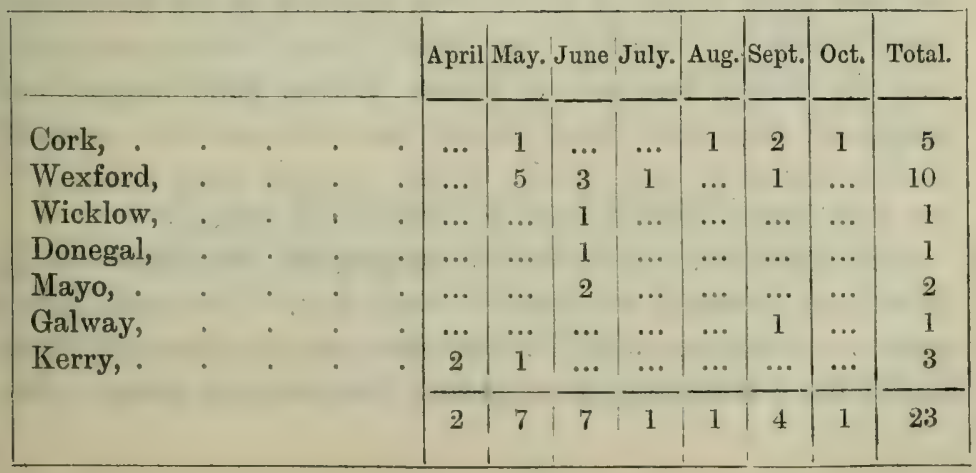


Turtle Dove. The period over which the spring migration has been proved to extend ranges from April 20 to June 8, examples having been obtained on both those dates in the same year, one on the Bull Rock (April 20, 1893) and one at Hook Tower (where it was killed against the telephone wire, June 8, 1893).

Of two specimens obtained later in June (Killybegs, June 12, 1893, and Blackrock, Mayo, June 27, 1887), the former may have been some days in the country before it was observed, and the latter had probably wandered out of its course, so that these occurrences are not necessarily evidence of late spontaneous migration. A "Dove," which rested on Coningbeg Light-ship on its north-eastward flight on July 12, 1897, may or may not have been Turtur communis.

There are thus 17 occurrences presumably referable to the spring migration, and only 6 to the autumnal. Five bear date between the 8th and 12th of May, and four of these were at Wexford stations (Tuskar and Coningbeg). The second week in May would thus seem to be the period in which immigration is most frequent.

The earliest autumnal occurrence was at the Old Head of Kinsale, where an example was shot, August 19, 1889. The latest is reported to have been caught at Berehaven Lighthouse during the latter part of October 1897. Examples are said to have been seen at the Tuskar and Fastnet on September 27,1895 , and September 28, 1896 . Of three autumnal specimens received, however, the latest was shot September 19, 1893. There is no evidence to show whether any of the birds observed or obtained in autumn were arriving or departing.

As many as 17 of the 23 occurrences were along the line of coast from Tuskar to Tearaght, while only 1 is reported from the east coast north of the Tuskar (Arklow North Light-ship, June 7, 1897). Although the Turtle Dove is a summer visitor and the Black Redstart a winter visitor, their migrational ranges on the Irish coast closely coincide, and it is curious that stragglers of both species appear to have been noticed on the west coast at Slyne Head and Blackrock (Mayo).

This Dove is not addicted to striking the lanterns. Of 14 specimens received, at least 9 were shot. One was killed against a telephone wire, 1 found dead on the Tearaght Rock, and in the 3 remaining cases precise data are not given. Two 
examples which were not forwarded are reported to have been Turtle Dove. caught.

Average length of wing, 6.99 ; longest, 7.37 ; shortest, 6.72 ; difference between extremes, $0 \cdot 65$; percentage of variation, 9 .

\section{Pallas's Sand-Grouse (Syrrhaptes paradoxus, Pallas).}

The few occurrences at Irish light-stations, which were Pallas's recorded in 1888, call for no remark, as they add almost Sand-Grouse. nothing to what is already known of the history of its irruption in that year. Since July 13, 1888, when one shot the previous day at Drogheda, North, was forwarded, the Sand-Grouse does not appear to have been observed by any light-keeper.

Red Grouse (Lagopus scoticus, Latham).

Not a migrant. In three instances Grouse have been reported Red Grouse. from light-stations on islands where they are not resident, viz., Copeland (December 22, 1894), Innishtrahull (November 1, 1883), and Blackrock, Mayo (July 11, 1884). The last-mentioned occurrence, if the information be correct, was remarkable, but the specimen was not forwarded. The bird is said to have been caught, nearly dead from exhaustion, the day after it was first observed.

Partridge (Perdix cinerea, Latham).

As in the case of the Grouse, there is no evidence of Partridge. migration.

The Partridge has once been reported from the Tearaght (May 18, 1883), and three times, probably by error, from Rockabill (May 9, 1886, October 28, 1883, and November 12, 1885). An alleged occurrence at Arklow North Light-ship, July 22,1892 , ought in all likelihood to be accredited to the Quail.

QUAIL (Coturnix communis, Bonnaterre).

Has been killed striking at Wexford light-stations in the Quail. years 1892 and 1893. Had previously been only once reported, viz., at Innishtrahull, September 11, 1882.

The instances in which specimens have been forwarded are 
Quail. 4; all were killed striking the lanterns, 3 in spring and 1 in autumn :-

One at Lucifer Shoals Light-ship,

One at the Tuskar,

April 1, 1892.1

One at Coningbeg Light-ship, September 22, 1892 .

One at Blackwater Bank Light-ship, May 14, 1893.

Mr John Hamilton, in forwarding the example killed at the Tuskar in September 1892, wrote of it as "the first of its species I have ever heard of killed striking against any lantern." This bird struck during a remarkable rush of many species, which included the Wheatear, Whitethroat, Chiffchaff, Pied Wagtail, Meadow-Pipit, and Skylark. It was forwarded in the flesh, and is an adult male.

Proof is lacking that the Quail has occurred on migration at stations other than those on the Wexford coast, but it is probable that the bird set down as a "Partridge" at Arklow North Light-ship on July 22, 1892, was of this species.

Since 1893 Quails have not been noted, and, with the exception of one uncorroborated record in 1882, all the lightstation occurrences have been in the years 1892 and $18: 3$.

\section{Corn-Crake (Crex pratensis, Bechstein).}

Corn

Both the earliest and latest observations of the Corn-Crake Crake. on spring migration are from the Tuskar:-

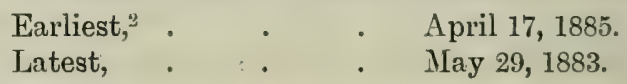

The earliest specimen was from the Tearaght, found dead April 19, 1891, at the feeding-place of a Peregrine. The latest - with data as to when killed-was shot at the Tuskar, May 13, 1885. Three examples have been found dead at later dates than this-up to June 16-but these were not ascertained to have been killed recently. There is thus no direct evidence of spring migration after May 29.

1 The leg and wing of this specimen were not forwarded until November 1 , and that date, instead of April 1 , when it is said to have been killed, is given in the "Report" for 1892, pp. 272 and 309. The light-keeper states that the bird had only one leg.

2 Discounting a very improbable record from the samo station, dated March 28,1884 . 
Some of the outlying haunts of the Corn-Crake do not appear to be always reached by the above date. The first hearing or observing of this bird on Innishtrahull-our most northerly station-has been recorded later than May 31 in four out of nine years.

Of a total of 71 observations during April, May, and June, 42 are strictly migrational, i.e., record either instances of striking the lantern, or occurrences at light-ships or rock-stations only visited on passage. Of these, 10 were in April and 32 in May, the distribution in shorter periods being-

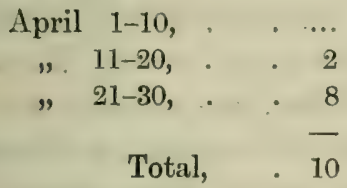

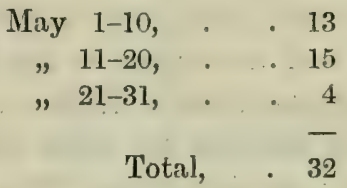

The principal immigration thus appears to be a little later than that of the Cuckoo. ${ }^{1}$ Of 11 specimens obtained in spring, 6 were killed between May 5th and 13th.

The autumnal movement is not attested by a sufficient number of occurrences to show what is the principal period of departure. The instances in which Corn-Crakes have been reported from rock-stations during the latter half of the year are 9 -and all of these are not to be relied on-2 in July, 2 in August, 4 in September, and 1 in November. Only two specimens have been sent, one killed striking at the Tuskar, September 24, 1886, the other without data.

The two July occurrences were on the 30th of that month (in different years), at Rockabill and Rathlin O'Birne. It seems improbable that these indicate the beginning of the autumnal exodus, and they yield in point of interest to the August entries, which are at any rate sufficiently singular:-

"Rockabill.-August 12, 1894, one on rock at 7 A.M.; flew ashore."

"Tuskar.-August 22, 1882, one Corn-Crake going N.W."

The possibility of error here is the more appreciable, as specimens of the Spotted Crake have twice been obtained at

${ }^{1} \Lambda$ t Fassaroe, Bray, during the past thirty-five years, the Corn-Crake has beon first heard, on an averago, three or four days later than the Cackoo. 
Corn- rock-stations in August; but owing to the scarcity of the latter

Crake. bird, and to its never having been sent from an east coast station, these occurrences cannot be confidently referred to it. If rightly placed under Land-Rail, they afford some ovidence of a hitherto unsuspected immigration of that species towards the end of summer.

The September observations are one at the Skelligs, September 1, 1897; two on consecutive nights at the Tuskar, September 23rd and 24th, 1886 ; and one from Rockabill to the following effect, sent by $\mathrm{Mr}$ H. Kelly, who, writing on October 3, 1887, says, " a few nights ago there was a great rush of Skylarks, Thrushes, Blackbirds, Snipe, and Land-Rail." A Corn-Crake's leg without data, and accompanied by legs and wings of the Wheatear, Whitethroat, Sedge Warbler, and Titlark, was received from the Tuskar, October 25, 1896, but there is no proof of either the present species or the Whitethroat having been observed on migration during that month; and a "Corn-Crake" reported from Rockabill on November 19, 1885, was, from the time of occurrence, probably a Water-Rail.

Thus there is no certain evidence of autumnal migration in any other month than September, the best attested occurrences being on September 23rd and 24th, at the Tuskar.

The Corn-Crake seems to occur much more frequently at the last-named light-station than at any other. Of 42 spring observations, as many as 17 were at the Tuskar, Rockabill coming next with 6 . Of the 9 autumnal records, 4 are from Rockabill and 3 from the Tuskar, besides which the latter station sent an undated specimen. On the west coast, the bird appears to have three times straggled to Rathlin O'Birne, and twice (in May) to Blackrock (Mayo). There is evidence that it occasionally visits the Skelligs both in spring and autumn, and the remains of three examples, eaten by Peregrines, have in different years been forwarded from the Tearaght, whither some of them may, however, have been carried by the Falcons from the adjacent island of InnishVicillane. So far as is known, only east coast lanterns have been struck, and one south coast station (Hook Tower); but a bird, which had probably been killed striking, was found dead at Mine Head, May 1, 1887.

According to counties, the 51 observations which were counted 
as migrational in endeavouring to compute the times of arrival and departure are distributed as follows :-

Corn-

Crake.

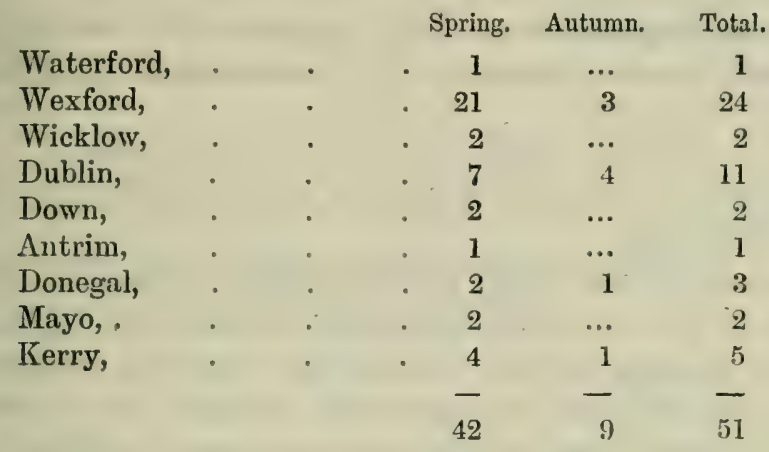

Only 3 observations are from the south coast, while 38 are from the east, and 10 from the west. The islands of the north coast, though regularly visited, afford no instance of an occurrence which can be classed as migrational.

The light-ships of the east coast furnish two interesting records of Corn-Crakes occurring in large numbers about the lanterns in spring. On May 5, 1888, Mr Wall (at Arklow South Light-ship) reports " hundreds of Corn-Crakes about light 10.30 P.M. to 12.20 A.M.; large numbers killed against glass, two fell dead on deck, several fell overboard; one caught alive and let go ; went off N.W. flying low ; weather clear, light breeze S.W." This remarkable note is confirmed by two specimens. On May 16, 1893, Mr Wall observed another and somewhat similar rush of Corn-Crakes on Arklow North Light-ship during rain; but though many were about the light from 9 P.M. to midnight, none on this occasion were killed.

The Corn-Crake has struck at the Tuskar in autumn along with the Whitethroat and Chiffchaff (September 24, 1886), but there is no evidence that it has done so in spring in the company of any other species, and possibly (as Mr Wall's observations go to show) it migrates at that season in flocks of its own kind.

Notwithstanding the doubts which are commonly expressed as to this bird's ability to migrate, it would appear to be an exceptionally powerful flier, for though it has repeatedly been killed or caught striking the lanterns, it has only once been reported as seeming exhausted (Tuskar, May 16, 1883). 
Corn- An example is said to have been shot in a wood, by the light-

Crake. keeper at the Old Head of Kinsale, on December 20, 1884.

Only eight wings were available for measurement.

Average length of wing, 5.62 ; longest, 5.95 ; shortest, 5.32 ; difference between extremes, 0.62 ; percentage of variation, 11 .

\section{SpotTed CraKe (Porzana maruetta, Leach).}

Spotted

Crake.

Has twice occurred in August, at island rock-stations off the south-west coast.

An example was caught at the Tearaght, August 21, 1887, on a ledge of rock, where it endeavoured to escape by running into a hole. Its skin was forwarded in the following October. On August 20, 1895, one was received in the flesh from the Fastnet. Though without data, it must have been caught or killed during the same month.

\section{WATER-RAIL (Rallus aquaticus, Linn.).}

Water-

Rail.

The light-house records prove this species to be much more of a migrant in Ireland than is generally supposed. The number of specimens forwarded, including one with incomplete data, is 35 , while only 13 examples of the Corn-Crake have been received; in fact, the Water-Rail is more frequently sent than any other non-passerine bird. For thirteen consecutive years (1886-98) it has been sent in the flesh every autumn.

Apart from the specimens, the evidence is meagre, as the bird is not sufficiently known to be generally recognised. Often forwarded as a "strange bird," or as a "Land-Rail," it has in isolated instances been called "Quail" and "WaterHen." Adding the observations and specimens together, however, they afford evidence of 48 occurrences-a larger number than can be cited for the Corn-Crake, if we exclude instances in which the latter bird's presence was announced by its familiar cry.

Thirty-four specimens, with data, occurred in the following months:-

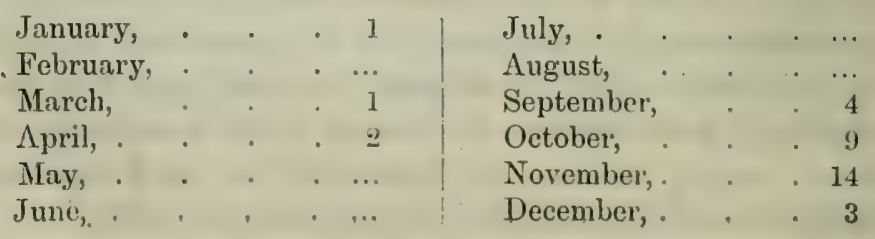


We find the autumnal migration more or less continuous from September to January, these months yielding as many as 31 instances.

\begin{tabular}{|c|c|c|}
\hline $\begin{array}{l}\text { Earliest, } \\
\text { Latest, }\end{array}$ & $\begin{array}{c}\left\{\begin{array}{l}\text { September } 5,1889, \\
\text { September } 5,1898,\end{array}\right. \\
\text { January } 9,1895,\end{array}$ & $\begin{array}{l}\text { Rathlin O'Birne. } \\
\text { Blackrock (Mayo) } \\
\text { Blacksod Point. }\end{array}$ \\
\hline
\end{tabular}

The above three records are on the north-west (1)onegal and Mayo) coast. Here the Water-Rail's occurrence on migration is frequent, but it is a barren district for most migrants.

In spring only three have been obtained.

$\begin{array}{lll}\text { Earliest, } & \text { March 27, 1897, } & \text { Rockabill. } \\ \text { Latest, } & \text { April 29, 1896, } & \text { Rathlin Island. }\end{array}$

(The intermediate occurrence being at Blackwater Bank Lightship, April 6, 1891.)

The first ten days of November have produced more specimens than any other period of equal length. This appears from the following table, in which the examples from each section of the coast on autumnal migration are placed in separate columns.

\begin{tabular}{|c|c|c|c|c|c|}
\hline & South. & East. & North. & West. & Total. \\
\hline September $1-10$, & $\cdots$ & ... & $\cdots$ & 2 & 2 \\
\hline$" \quad 11-20$, & & & $\ldots$ & $\cdots$ & \\
\hline October $\begin{array}{r}21-30, . \\
1-10\end{array}$ & $\frac{1}{2}$ & 1 & $\cdots$ & $\dddot{\jmath}$ & $\frac{2}{3}$ \\
\hline$" 11-20$, & & $\cdots$ & $\begin{array}{l}\cdots \\
\cdots\end{array}$ & & \\
\hline$" \quad 21-31,$. & 3 & 2 & 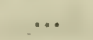 & 1 & 6 \\
\hline November $1-10$, & 3 & 4 & & 1 & 8 \\
\hline $11-20$, & $\cdots$ & 2 & 2 & 1. & 5 \\
\hline $21-30$, & $\ldots$ & $\ldots$ & 1 & $\ldots$ & 1 \\
\hline December $1-10$, & $\ldots$ & $\cdots$ & & $\ldots$ & \\
\hline$" \quad 11-20$, & $\ldots$ & $\ldots$ & 1 & $\ldots$ & 1 \\
\hline$" \quad 21-31$, & ... & $\cdots$ & $\cdots$ & 2 & 2 \\
\hline January $1-10$, & ... & $\cdots$ & $\cdots$ & 1 & 1 \\
\hline \multirow{3}{*}{$"$} & $\cdots$ & $\cdots$ & $\cdots$ & $\cdots$ & $\cdots$ \\
\hline & $\cdots$ & $\ldots$ & $\ldots$ & $\ldots$ & $\cdots$ \\
\hline & 9 & 9 & 4 & 9 & 31 \\
\hline
\end{tabular}

It would seem from the foregoing figures that migration on the south and east coast has a better defined period than on the west, the 18 specimens from the south and east having all been received between September 24 and November 19 
Water- (a period of eight weeks), while of 9 from the west, there is

Rail. a period of eighteen weeks between the earliest and latest.

Western stations have sent ten examples (including one with incomplete data) killed in autumn, whereas no other section of the coast has forwarded more than nine. The number of years in which the west coast has sent specimens in autumn is nine, while the south and east have each furnished them in only six. The north coast, with only three good lightstations, contributed specimens in three years.

These facts are very interesting when we remember the great stream of migration in other species annually witnessed on the south and east coast, and how scanty it is in the west. Many of our Water-Rails probably arrive by a route little traversed by other birds; at any rate, it has a tendency to land them on the west, and particularly on the north-west coast. The light-stations from Innishtrahull to South Arran Island have yielded one-third (11 out of 32) of the whole autumnal series. Not only so, but there is some evidence (though the wording is ambiguous) of the Water-Rail's having occurred numerously at the lantern of Tory Island light-house, in a rush of birds noted on the night of November 26, 1894. Mr E. Rohu reports, " number's of Blackbirds, Thrushes, Starlings, and Land-Rail about lantern during night; numbers struck; none killed but Land-Rail." A leg and wing of a Water-Rail were received. This account may imply that each of the four species noted was in "numbers," and if so, this is the only "rush" of Water-Rails ever reported.

Tory Island would be the most direct point of arrival for birds reaching Ireland from Iceland, where the Water-Rail is said to be partially resident.

A curious coincidence, which would corroborate the conjecture that this species visits us from Iceland, has already been noticed in dealing with the Snow Bunting. On the night of October 29, 1892, three birds were killed striking at the Tuskar-a Snow Bunting, Water-Rail, and Purple Sandpiper. This simultaneous occurrence at one station of three birds which breed in Iceland, unaccompanied, so far as is known, by any other species, is rendered more significant by the fact that another Water-Rail was killed striking on the scme night at South Arran Island, and another Purple Sandpiper at the 
Tearaght. No other example of either Rallus aquaticus or Tringa striata was forwarded that year. On the night in question a migration of both species was probably in progress, alike on our east and west coasts; and on both sections of the coast there is evidence that Snow Buntings participated in the movement, for on the Tearaght some were noted on October 30 .

An exceptionally large immigration of Water-Rails took place in November 1887, when seven were forwarded in one fortnight, chiefly killed at lanterns. These occurrences were scattered all round the coast-two on the south, two on the east, two on the north, and one on the west.

Excluding one without data, 34 specimens were received, 25 of which were killed striking. Of the 9 remaining, 2 were shot, 1 was picked up at a Peregrine's feeding-place on the Tearaght, and 6 , no doubt exhausted after migration, were caught on islands of the north and west coasts- 3 being captured in crevices of the rocks or under stones in the beach, in the months of September, November, and December.

A Water-Rail caught on Rathlin Island in December 1897 weighed slightly more than 5 ounces, but one from Copeland (Mew) Island, which had been caught striking on the night of November 10 , weighed only $2 \frac{3}{4}$ ounces.

The measurements of 26 wings obtained in autumn show that the earlier arrivals are somewhat longer winged than the later.

13 earliest (September 5 to November 6 ) average in length, 4.59 inches. 13 latest (November 8 to January 9) " " $4.56 \quad$ "

Average length of wing, 4.56 ; longest, 4.90 ; shortest, $4 \cdot 10$; difference between extremes, $\cdot 80$; percentage of variation, $17 \frac{1}{2}$.

\section{WATER-Hen (Gallinula chloropus, Linn.).}

Though the Water-Hen is a bird of sedentary habits, there are grounds for believing that a cross-channel migration occasionally takes place, chiefly in autumn. In only one instance is the Water-Hen recorded as migrating by day, i.e., at Coningbeg Light-ship, where six are reported "going N.E." at 4.30 P.M, on March 24, 1888. All the other records, at stations off the shore, relate to birds which were either killed, disabled, or rested on rocks or light-ships. Six, killed or disabled, have 
Water-Hen. been received-four in autumn and two in spring. Five of these were obtained on the east coast and one on the west.

The spring migration is based on the observation from Coningbeg Light-ship (March 24, 1888), and on the two specimens -one killed striking at Drogheda N., April 2, 1894, and one disabled striking at S. Rock Light-ship, April 10, 1889.

Of the autumnal migration, there is some evidence from east coast stations in every month from July to December:-

July 29 and 30, 1895: Tuskar, one Water-Hen on rock for a whole day.

August 23, 1892: Blackwater Bank Light-ship, one "unknown bird" about light at 2 A.M., killed striking. [Leg and wing of Water-Hen received.]

September 16, 1888: Tuskar, one found dead on rock. [Leg and wing received.]

October 29, 1897 : Codling Bank Light-ship, one in ship at 9 A.M.

November 17, 1898: Rockabill, one caught on rock. [Received in flesh.]

December 12, 1882 : Rockabill, Water-Hen noted.

The months in which specimens have been received from the east coast are thus April, August, September, and November.

On October 28, 1886, at 11.30 P.M., one struck "with tremendous force" at Rathlin O'Birne, on the west coast. In the south there are two doubtful observations from Coningbeg in October, and a specimen from Mine Head, December 2, 1896, probably not a migrant. Water-Hens are noted as newly-arrived birds at N. Arran Island (November 6, 1885) and Innishtrahull (December 16, 1882). The few remaining observations are from the mainland, or from large islands, where the species is probably resident.

Of the 18 reported occurrences, there were one each in March, July, August, and September, two in April, and four each in October, November, and December.

The specimens lead us to suppose that this species arrives chiefly on the east coast.

All the examples obtained on autumnal migration had wings of less than the average length, and may have been immature birds.

Average length of wing, 6.66 ; longest (in spring), 7.07 ; shortest (in autumu), 6.32 ; difference between extremes, 0.75 ; percentage of variation, 11 . 
Соот (Fulica atra, Linn.).

The evidence of migration consists of 5 specimens, all killed striking the lanterns in autumn-one in September, two in October, and two in November.

Earliest, September 22, 1887, Arklow South Light-ship.

Latest, November 24, 1892, Blackwater Bank Light-ship.

The other examples were killed at Dungarvan, October 26 , 1889; Mew Island, November 9, 1898; and South Arran Island, October 18, 1892. Thus 1 struck on the south coast, 3 on the east, and 1 on the west.

The Coot is occasionally noticed in winter at western stations (Aranmore, January 19, 1888, and Killybegs, November $28,1892)$, where it is regarded as uncommon.

Unlike the Water-Hen, it has never been obtained or reported in spring.

The specimens are all autumnal, but whether any of the examples forwarded at that season are adult or not is uncertain. Of four wings measured (the South Arran bird not having been preserved), the longest falls considerably short of the average given in "Saunders's Manual" for that of a full-grown Coot, viz., 8.5 inches.

Average length (from four specimens), 7.90; longest, 8.12 ; shortest, 7.65 ; difference between extremes, 0.57 ; percentage of variation, 7 .

Stone Curlew (Edicnemus scolopax, S. G. Gmelin).

This is a rare straggler to Ireland, but it appears to have been twice observed near Killybegs Light-house in the winter of 1892-93 (p. 367). The exact dates are not given in the schedules.

Ringed Plover (Agialitis hiaticola, Linn.).

This common coast-bird is seldom distinguished from the other smaller Limicolc-generally styled "Sand-Larks,"-and scarcely any evidence as to its migrations has been received. Of 8 specimens forwarded, 2 were correctly named, 1 was sent as "Dotterel," 1 as "Ball-Fowl" (? Bull-Fowl), and 4 as "unknown." There are 42 uncorroborated observations, including those in which "Dotterel" and "Sand-Plover" are

Stone

Curlew.

Ringed Plover. 
Ringed reported, and of these 29 are in the half-year March to Plover. August, and only 13 in the half-year September to February.

The Ringed Plover rarely strikes the lanterns, and of the specimens received, at least 3-probably 4-were shot. Of the remainder, 3 struck and 1 was found dead, no two having been obtained in the same month or on the coast of the same province.

One was killed striking, May 17, 1893, at the Maidens (Ulster coast).

One found dead, July 28, 1896, at Blackrock, Nayo (Connaught coast).

One caught striking, November 27, 1894, at Samphire Island (Munster coast).

One caught disabled, December 14, 1899, at Hook Tower (Leinster coast).

Its arrival "to breed" on Mew Island has been noted at dates varying from April 3 to May 16, and Ringed Plover have been reported from Coningbeg Light-ship on April 6 and May 16, in the latter instance going towards land. These notes, along with the specimen killed striking on May 17, 1893, at the Maidens, and one observation at the Tuskar on May 27, 1895, furnish all the evidence touching the spring migration.

Between August 3 and October 17, "Dotterels" or Ringed Plover are said to have been five times observed at lightships (Coningbeg and South Arklow). At South Arklow they were noted three times at night by $\mathrm{Mr}$ W. Clydesdale during the first ten days of August 1891. The specimen from Blackrock (Mayo) is the only additional evidence of migration at or near this period.

Of 4 examples weighed, 3 varied from $2 \frac{1}{4}$ to $2 \frac{1}{2}$ oz., but the weight of the specimen caught at Hook Tower, December 14, 1899 , was only $1 \frac{1}{2} \mathrm{oz}$.

Average length of wing, $5 \cdot 27$; longest, 5.42 ; shortest, $5 \cdot 10$; difference between extremes, 0.32 ; percentage of variation, 6 .

\section{Golden Plover (Charadrius pluvialis, Linn.).}

Golden

Plover.

The numbers of Golden Plover are largely augmented in autumn. It is reported to have struck the lanterns in every month from September to May, thus :-

Sept. Oct. Nov. Dec. Jau, Feb, March. April. May. Total.

$\begin{array}{llllllllll}2 & 4 & 1 & 3 & 2 & 2 & 3 & 5 & 1 & 23\end{array}$


It is frequently observed at light-stations from September to April, especially in the west and north. From May to August the observations are very few (16 out of 279 for the whole year).

\begin{tabular}{|c|c|c|c|c|c|c|c|c|c|c|c|c|c|c|}
\hline & & $J a n$. & Feb. & Mar. & April & May. & June & July. & Aug. & Sept. & Oct. & Nov. & Dec. & Total \\
\hline South & Coast, & 10 & 6 & 5 & 1 & $\ldots$ & 1 & $\ldots$ & 1 & 5 & 7 & 5 & 20 & 61 \\
\hline East & , & 5 & 9 & 6 & 8 & 1 & $\ldots$ & $\ldots$ & 2 & 1 & 7 & 7 & 6 & 52 \\
\hline North & , & 5 & 10 & 6 & 4 & 2 & 1 & 1 & 4 & .7 & 5 & 6 & 9 & 60 \\
\hline West & , & 8 & 7 & 10 & 14 & 3 & $\ldots$ & ... & $\ldots$ & 10 & 21 & 16 & 17 & 106 \\
\hline & & 28 & 32 & 27 & 27 & 6 & 2 & 1 & 7 & 23 & 40 & 34 & 52 & 279 \\
\hline
\end{tabular}

December shows the highest total number of observations, October coming second, and November third. The few records in June and July are probably not migrational, but a flock has been noted at the Maidens on August 11, 1882.

At first sight it might seem from the figures in the foregoing table that the present species arrives chiefly on the west coast, and that the east coast (contrary to the usual rule) is the least frequented route. That this is an incorrect inference becomes evident from the records of Golden Plover striking the lanterns. The coast-distribution of these is as follows :-

South, 3; East, 14 ; North, 4; West, 2--total, 23.

Thus the west coast, where the birds are most observed, is the section where they are least given to striking, while the east coast, where they are least observed, is that on which they strike most. The large number of observations from the western side of the island is due to two causes-1st, the west coast is the favoured resort of the Plover during their stay; 2nd, the movements are local, and not migrational in the larger sense.

Of eight records of this species striking in March and April, five are from light-ships on the east coast of Wexford. This shows that there is probably a spring immigration, as departing birds would not at that season be likely to start from the southeast corner of Ireland; and this inference is corroborated by the few notes which show the direction of the flight, this being 
Golden principally towards land. A flock has been reported going

Plover. N.W. at the Tuskar as late as April 21, 1886.

In autumn there is only one case of striking noted from a Wexford station, while there are four from the north-east coast-line between Mew Island and Innishtrahull; and if we analyse the total number of observations from the Tuskar and the Wexford light-ships, there is a decided preponderance of vernal over autumnal occurrences, the number for each month being,-

Jan. Feb. March. April. May. June. July. Aug. Sept. Oct. Nov, Dec.

$\begin{array}{lllllllllllll}3 & 7 & 4 & 4 & \ldots & \ldots & \ldots & 1 & 1 & 1 & \ldots & 2\end{array}$

Taking the observations from the northern extremity of the east coast, from South Rock Light-ship to Rathlin Island, we find here, on the contrary, an autumnal preponderance.

Jan. Feb. March. April. May. June. July. Aug. Sept. Oct. Nov. Dec.

$\begin{array}{llllllllllll}2 & 3 & 1 & 3 & \ldots & \ldots & \ldots & 2 & 2 & 3 & 7 & 7\end{array}$

Thus at each season the Golden Plover is most noted on that part of the east coast on which it might be expected to arrive -i.e., at the southern extremity in spring, and the northern in autumn.

There is evidence of some migration at all periods from August 11 to May 5, the autumnal movement being greatest in October, and the spring movement in April. At both seasons the principal observed movements seem to be immigratory, and from the east; but only a small proportion of the arriving birds are seen, and practically none of the departing flights are witnessed.

The light-stations at which it is reported to have struck are Fastnet, Hook Tower, Blackwater Bank, Arklow South, Arklow North, Rockabill, South Rock, Mew Island, Maidens, Innishtrahull, Tory Island, and Slyne Head. The earliest occurrence at a lantern in autumn was at the Fastnet, September 15, 1884; the latest in spring was at Innishtrahull, May 5, 1888.

Of 11 forwarded, 7 were shot, while only 4 were killed striking (two in December, one in January, and one in April); but as the light-keepers generally know this bird, which they call the "Grey Plover," their statements as to its having struck on about a score of other occasions are probably correct. 
A wing, whose measurement is given in the Appendix (p. 654) as 6.6 , proves to be imperfect, and ought not to have been included. The remainder show little variation.

Average length, $7 \cdot 44$; longest, $7 \cdot 77$; shortest, $7 \cdot 27$; difference between extremes, 0.5 ; percentage of variation, $6 \frac{1}{2}$.

\section{Grex Plover (Squatarola helvetica, Linn.).}

No evidence of migration has been received, possibly because this bird is not distinguished by the light-keepers from the Golden Plover-to which they usually apply the name of this species.

Two examples were shot at Drogheda North (a mainlandstation) in 1893-one on January 14, the other on October 9. The first had been observed two days before it was shot, and was forwarded as an unknown bird.

\section{LAPWING (Vanellus vulgaris, Bechstein).}

The Lapwing is well known, and there are probably few erroneous entries. The largest migratory movements observed take place in March.

The total number of observations is 480 , distributed as follows among the different months and sections of the coast:-

\begin{tabular}{|l|r|r|r|r|r|r|r|r|r|r|r|r|r|r|}
\hline & Jan. & Feb. & Mar. & April & May. & June & July. & Aug. & Sept. & Oct. & Nov. & Dec. & Total \\
\hline South Coast, & 8 & 11 & 22 & 1 & 2 & 1 & 4 & $\ldots$ & 5 & 17 & 20 & 22 & 113 \\
East ," & 39 & 27 & 38 & 17 & 7 & $\ldots$ & $\ldots$ & $\ldots$ & 8 & 14 & 32 & 39 & 221 \\
North ," & 7 & 11 & 6 & 5 & 2 & 4 & 1 & 3 & 6 & 5 & 4 & 7 & 61 \\
West ," & 5 & 13 & 14 & 6 & 1 & 1 & 1 & 3 & 4 & 11 & 12 & 14 & 85 \\
\hline & 59 & 62 & 80 & 29 & 12 & 6 & 6 & 6 & 23 & 47 & 68 & 82 & 480 \\
\hline
\end{tabular}

\section{Lapwing.}

In this table March and December appear practically equal, but if we deduct records made at mainland-stations, the high total for December is largely reduced. The numbers for each month then stand as follows:-

Jan, Feb. March. April. Mray. June. July. Aug. Sept, Oct. Nov. Dec.

$\begin{array}{lllllllllllll}51 & 53 & 67 & 28 & 10 & 5 & 3 & 6 & 17 & 26 & 44 & 48\end{array}$

Compared with many other species, the predominance of March in the case of the Lapwing is very remarkable, and it 
Lapwing. becomes still more conspicuous if we restrict our attention to the records of light-ships and rock-stations on the south and east coast. Eight light-ships and four island-rocks (Fastnet, Tuskar, Rockabill, and Maidens) furnish 165 observations :-

Jan. Feb. March. April. May. June. July, Aug. Sept. Oct. Nov. Dec.

$\begin{array}{llllllllllll}29 & 23 & 48 & 13 & 5 & \ldots & 1 & \ldots & 1 & 8 & 16 & 21\end{array}$

This shows an unusual state of things, for the Lapwing is much more abundant on the mainland in winter than in summer.

The spring movement seems to consist to some extent of birds on their northward passage to Scotland, for Lapwings have several times been noted going N.E. or N. (i.e., seawards) from the Maidens, almost simultaneously with the appearance of flocks at the Wexford light-ships. Thus in the spring of 1891 they are reported at Blackwater Bank Light-ship, March 18th, and going $\mathrm{N}$. at the Maidens, March 19th. In 1892, between March 16th and 18th, they are reported at Coningbeg Light-ship, Mew Island, the Maidens, and Tory Island, the movement at the Maidens being N.E. on the 16th, though on the 18th a few were seen going W. In 1894, between March 24th and 26th, occurrences of this species are noted at Coningbeg, Blackwater Bank, Arklow South Light-ship, and the Maidens, the direction being N.W. at the Wexford stations, while at the Maidens it was E. In 1887 an extensive movement was reported from a number of southern stations during the first ten days of March, when Lapwings were observed at the Tuskar on March 3rd, 6th, 7th, 8th, and 10th; at the Skelligs, March 4th and 6th; at the Fastnet, March 5th; at Coningbeg Light-ship, March 7th ; and at Barrels Rock Lightship, March 11th-in all cases going towards land. In that year there were unfortunately no spring schedules from the north-east coast. We may, however, infer from the analogous records of other years that these birds passed northward towards Scotland or the Hebrides.

There are more observations at light-ships and rock-stations during the first ten days of March than at any other period.

\begin{tabular}{|c|c|c|c|c|c|c|c|}
\hline Date. & Obs. & $\mathrm{Da}$ & & Obs. & & ate. & Obs. \\
\hline ebrua & $1-10, \quad 4$ & March & $1-10$ & 20 & April & $1-10$ & 10 \\
\hline$"$ & $11-20,7$ & . & $11-20$ & 14 & "I & 11-20, & \\
\hline " & $21-29,12$ & " & 21-31, & 14 & $"$ & $21-30$ & \\
\hline
\end{tabular}


The spring movement seems to be virtually over by April 10, Lapwing. though a Lapwing is said to have been killed at Coningbeg Light-ship on the night of May 7, 1883, and "Plovers" were reported about the lantern at South Rock Light-ship as late as May 12, 1890.

There is little evidence of autumnal migration before October. In one instance, however, a Lapwing is said to have been killed striking at the Maidens on September 12 (1884). November is the month in which occurrences at lanterns are most numerously reported, and is probably the season of principal immigration. The Lapwing is not often reported as killed at the lanterns, but is frequently noted as "plentiful in the rays of light," as if attracted by the glare and yet too wary to dash itself against the glass.

Though as many as 480 observations are recorded, only 5 specimens which are known to have struck the lanterns have been received. A shot example has also been forwarded, and two without data, making a total of 8 . Of the 5 killed striking, two were obtained in February, one in April, one in October, and one in November. All struck on the east coast, and all except the April specimen at stations north of Dublin.

Symptoms of exhaustion are occasionally noticed in the Lapwing in spring. Observations at that season are chiefly made on the southern half of the coast. A tired bird is reported from the Tearaght, March 24, 1883, and one which "did not appear to be strong" rested on Arklow South Lightship, March 26, 1894; while at the Fastnet, March 15, 1885, the light-keeper notes "two on the rock, and one drowned," the latter having apparently fallen into the water from fatigue. As there are no such entries in autumn, we may infer that the spring visitants travel a longer distance than those which come in October and November.

Average length of wing, 8.62 ; longest, 8.87 ; shortest, 8.30 ; difference between extremes, 0.57 ; percentage of variation, 7 .

\section{TuRnstone (Strepsilas interpres, Linn.).}

A bird which few of the light-keepers distinguish, and little Turnstone. reliance can be placed on uncorroborated records.

Specimens have been sent in every month except January 
Turnstone. and July, the total number received being 14, of which 8 were shot, 4 killed striking lanterns, 1 found dead, and 1 sent without data. The latest dated specimen in spring was shot at the Tuskar, June 6, 1898; the earliest in autumn was killed striking at Slyne Head, August 18, 1895. Two killed striking (September 24, 1892, and December 31, 1891) were forwarded from Hook Tower; the other struck at St John's Point, Down, February 1, 1897. The occurrences are too few to prove anything of the Turnstone's migration route. No example is known to have struck in May, the season of its northward passage. There is reason to believe that a few scattered flocks of non-breeding birds remain all the summer on rocky parts of the coast.

Four have been received from the south coast, four from the east, two from the north, and four from the west.

A pale-coloured form, killed at Hook Tower, was beautifully stuffed by Messrs Williams, and has been presented to $\mathrm{Mr}$ Whittaker, and added to his well-known collection of varieties.

Average length of wing, 6.02 ; longest, 6.25 ; shortest, 5.62 ; difference between extremes, 0.62 ; percentage of variation, 10 .

\section{Oyster-Catcher (Homatopus ostralegus, Linn.).}

Oyster.

There is a singular dearth of evidence relating to this bird as

Catcher. a migrant. Common all round the coast, and well known to the light-keepers as "Sea-Pie" (a word which is not unfrequently rendered "Sepoy"), it is scarcely ever reported from a light-ship, or as striking a lantern; and no specimen has been received.

On two occasions Sea-Pies are said to have been killed striking-one at North Arran Island, August 20, 1884, and one at Hook Tower, November 19, 1892. Some were also reported "about the light" at South Rock Light-ship, October 7, 1893, and at Samphire Island, November 27, 1894. These isolated records need corroboration.

- The only light-ship besides South Rock at which this species bas been noted is Coningbeg, where it has been reported on four occasions (three in May, one in September).

The total number of observations for each month and section 
of the coast are tabulated below. They are most numerous in September, and least so in July.

\begin{tabular}{|l|r|r|r|r|r|r|r|r|r|r|r|r|r|r|r|}
\hline South Coast, & 3 & 1 & 5 & 4 & 6 & 6 & $\ldots$ & 1 & 9 & 4 & 4 & 2 & 45 \\
\hline Fast ," & 11 & 6 & 4 & 8 & 9 & 6 & 3 & 6 & 10 & 8 & 9 & 9 & 89 \\
North ," & 3 & 1 & 1 & 3 & 2 & $\ldots$ & 3 & 2 & 1 & 1 & 1 & 2 & 20 \\
West : , & 8 & 9 & 18 & 13 & 10 & 5 & 5 & 11 & 10 & 8 & 13 & 5 & 115 \\
& -25 & 17 & 28 & 28 & 27 & 17 & 11 & 20 & 30 & 21 & 27 & 18 & 269 \\
\hline
\end{tabular}

Flocks are common from September to May. Reports of "large flocks" are exceptional during summer, but "about two hundred" were noted at Drogheda North Light-house on July 13, 1892, and there are similar records from the same station, July 30 and August 6, 1894; while both at Hook Tower and Dungarvan large flocks have been mentioned during the second week in June.

\section{Yellow-Billed Sheathbill (Chionis alba, Latham).}

A female shot at Carlingford Lough Light-house by Mr Richard Hamilton, December 2, 1892, and forwarded in the Hesh, is the only example known to have been obtained in a wild state north of the tropics (see Zoologist, 1893, pp. 28, 29).

The home of Chionis alba is the Falkland Islands and South Georgia. Differences of opinion will naturally exist as to how the intervening distance of over 7000 miles had been traversed, but it is a well-known fact that this bird has been seen at great distances from land in the southern seas. All that need be observed here is that the Sheathbill was received in perfect plumage and condition, and that (as stated on pp. 314, 315) neither Mr A. G. More, who identified the specimen, nor Mr Williams, who skinned and mounted it, could detect any trace of confinement.

\section{Grey Phalarope (Phalaropus fulicarius, Linn.).}

An irregular visitant, which has struck the lanterns on four occasions in autumn, the earliest date being August 22, and 
The Grey Phalarope's habit of swimming attracts the attenPhalarope. tion of the light-keepers, who would otherwise probably regard it as a common "Sand-Lark." Owing to this peculiarity, examples are sometimes shot and forwarded for identification, besides which a few instances are recorded in which birds believed to be of the present species were seen in the water, but were not obtained.

It occurred in the autumns of $1886,1889,1891,1892$, and 1893 ; and probably in those of 1896 and 1897. Thus:-

1886. November 13, one shot at Dungarvan. [Identified by Mr R. J. Ussher.]

1889. October, three birds, probably of this species, at Blackrock (Mayo).

"November 1, one disabled striking at Slyne Head. [Received.] 1891. October 6, one shot at Slyne Head. [Received.]

" " 9, two birds, probably Grey Phalaropes, in water at Barrels Rock Light-ship.

$" \quad$ " 11, another seen at Slyne Head.

" " 12, three at Rathlin O'Birne; two of them shot. [Received.]

$" \quad, \quad 22$, four at Killybegs, all probably shot. [Received.]

" $\quad$ "29, nine reported at Rathlin O'Birne.

1892. August 22, one killed striking at Arklow S. Light-ship. [Received.]

" November 4, one killed striking at Rockabill. [Received.]

1893. October 17, one killed striking at Slyne Head. [Received.]

1896. October 8, three reported at Skelligs.

"November 15, two " "

1897. December 27, four " "

Thus of 15 occurrences, one was in August, nine were in October, four in November, and one (not confirmed by specimen) in December.

Eleven of the above 15 records are from the west coast, which contributes 9 out of a total number of 11 specimens received. One western light-house, Slyne Head, has forwarded examples in three different years $(1889,1891$, and 1893), and two of the specimens obtained at this station had struck the Iantern.

The most noteworthy incursion of the Grey Phalarope was in October 1891, in which month seven specimens were received, all from west coast stations between Rathlin O'Birne 
and Slyne Head. This visitation was probably due to the heavy gales from the west which prevailed during the early part of the month, and which are chiefly remembered in connection with the large numbers of Petrels driven to our coasts at the same time, including two examples of Wilson's Petrel (Oceanites oceanicus, Kuhl), the first of that species known to have been obtained in Ireland. To the same series of gales we also possibly owe the visit of the first specimen of the Red-necked Phalarope (Phalaropus hyperboreus, Linn.) obtained in our island, which was shot in the earlier half of November 1891. It is remarkable that none of these visitants struck the lanterns. All the seven specimens of the Grey Phalarope forwarded from light-stations in 1891 appear to have been shot; whereas the four examples forwarded in other years $(1889,1892$, and 1893) were all either killed or disabled striking.

This species is not known to have occurred at any lightstations on the north coast, nor on the east coast except in the autumn of 1892 , when two specimens were killed striking (August 22 and November 4). The only authenticated occurrence on the south coast was that of the bird shot at Dungarvan in 1886.

Of seven wings measured, the average length is nearly 5 inches. The two longest winged examples are the birds which struck on the east coast in the autumn of 1892, the other five being from western stations.

Average length of wing, 4.99 ; longest, 5.25 ; shortest, 4.85 ; difference between extremes, 0.4 ; percentage of variation, 8 .

\section{Woopcock (Scolopax rusticula, Linn.).}

Considering the extensive immigration which annually takes place, it is strange that only ten specimens have been forwarded as killed striking in sixteen years, all between October 26 and January 1 , - one in October, seven in November, one in December, and one in January. Its nocturnal habits probably save the Woodcock from bewilderment on dark nights. It has been reported striking as early as September 21 (Killybegs, 1883), and there is a doubtful record as late as May 26 (Coningbeg Light-ship, 1884), (see Snipe). The observations for each month and section of the coast are,-

Woodcock. 
Woodcock.

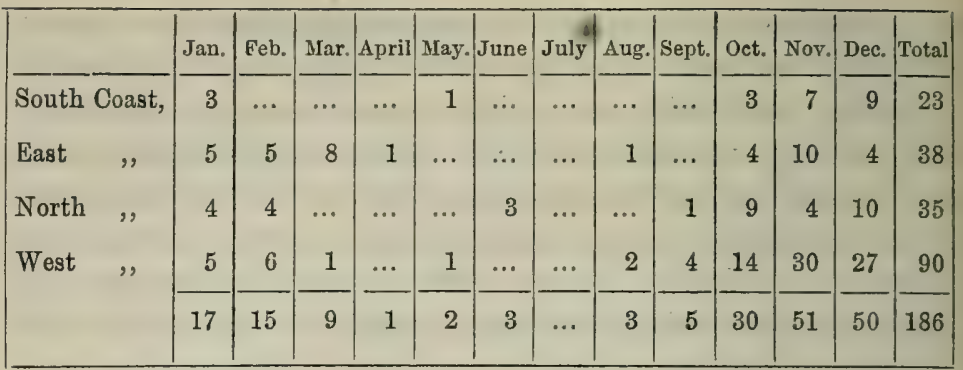

The whole number at stations north of Dublin is 126 ; at stations south of Dublin, 60. The Ulster coast shows rather more than half the records from the whole coast of Ireland,-

Munster, 41 ; Leinster, 23 ; Ulster, 98; Connaught, 24-total, 186.

Although the north and west coasts yield so large a proportion of the autumnal and winter records, they yield only two in spring (March to May), while the east coast has furnished nine.

Omitting May, June, July, and August, the map below

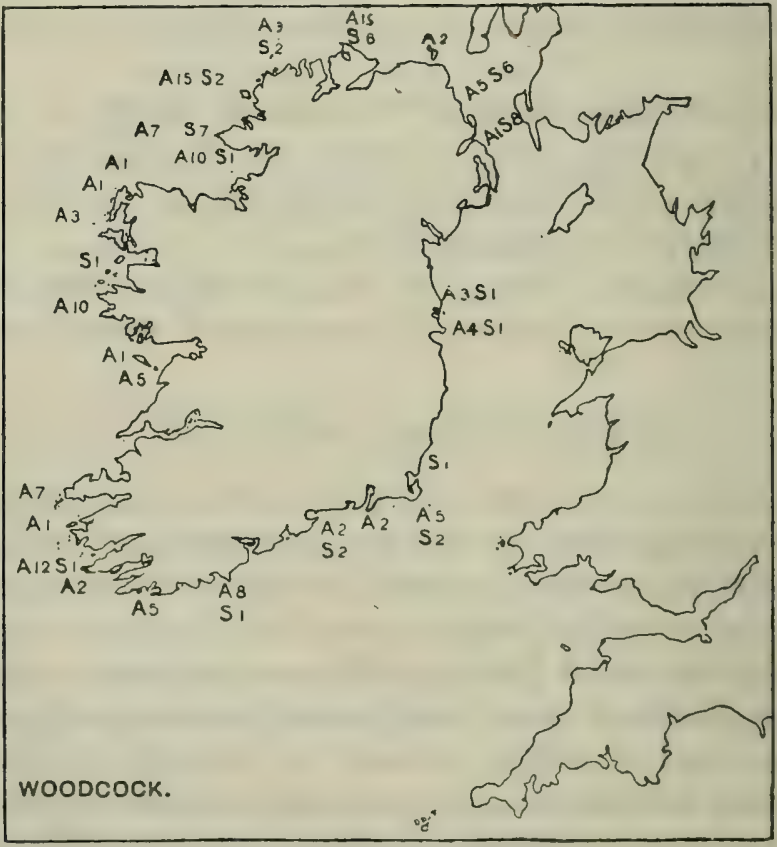

S $1=$ One observation in spring.

A $19=$ Nineteen observations in autumn. 
shows the number of spring and autumn records at each light-station-the last four months of the year counting as autumn, and the first four months as spring. Since the January migration is in nearly all cases a cold weather movement, stations appear as participating in the real spring migration which have really only received refugees from snow and frost.

There is good reason to suspect that the June and August entries are errors, ${ }^{1}$ and we have no satisfactory evidence of migration during those months.

The autumnal observations may be arranged in periods of ten days, as follows :-

\begin{tabular}{|c|c|c|c|c|c|}
\hline & South. & East. & North. & West. & Total. \\
\hline September $1-10$, . & $\ldots$ & $\ldots$ & $\ldots$ & $\ldots$ & $\ldots$ \\
\hline 11-20, . & $\ldots$ & $\ldots$ & $\ldots$ & $\ldots$ & $\ldots$ \\
\hline $21-30$, . & $\ldots$ & $\ldots$ & 1 & 4 & 5 \\
\hline October & $\ldots$ & 2 & 2 & 3 & 7 \\
\hline $11-20$. & $\ldots$ & 1 & 2 & 4 & 7 \\
\hline 21-31, . & 3 & 1 & 5 & 7 & 16 \\
\hline November $1-10$, & 3 & 2 & 1 & 14 & 20 \\
\hline \# $11-20$, . & 3 & 4 & 2 & 12 & 21 \\
\hline $21-30$, . & 1 & 3 & 2 & 4 & 10 \\
\hline December $1-10$, & 6 & 1 & 3 & 15 . & 25 \\
\hline \multirow{3}{*}{$\begin{array}{l}11-20, \\
21-31,\end{array}$} & 2 & 3 & 2 & 9 & 16 \\
\hline & 1 & $\ldots$ & 5 & 3 & 9 \\
\hline & 19 & 17 & 25 & 75 & 136 \\
\hline
\end{tabular}

The main influx seems to be from November 1 to December 10 , though in every year, except 1887, some observations are recorded for September or October.

After March 10 there is practically a cessation of occurrences at light-stations, only three being recorded for the last three weeks of that month, with one for April and two for May.

The north and west coasts receive a large proportion of the arriving birds, and the more northerly stations of the east and

${ }^{1}$ For instance, "a dozen going S.W." at Rathlin Island, June 6, 1888 and "seven" noted at Howth Baily, August 10, 1893. 
Woodcook. west receive larger numbers than do the more southerly. The stations at which most observations are recorded in autumn are,-

Innishtrahull, 26; Aranmore, 18; Rathlin O'Birne, 14; Skelligs, 13; Slyne Head and Maidens, 11-total, 82.

The statement has been made ${ }^{1}$ that Woodcocks in autumn reach the southern and western parts of Ireland before they arrive in the eastern and northern counties. It is to be regretted that the light-keepers' observations do not afford sufficient data for settling this question. So far as they go (see Table on p. 207), they prove that the earliest arrivals have been in the north and west, while the south is the latest section of the coast to be reached. The only stations from which the Woodcock has been reported in September are Innishtrahull, Aranmore, and Killybegs, all in Co. Donegal.

One has been forwarded from Blackwater Bank, January 1, 1891, and Woodcock have been "noted" three times at Coningbeg, both stations on the Wexford coast; these are the only light-ship records.

That simultaneous migration not infrequently takes place over a considerable area, is shown by the "Reports" for 1852, $1883,1884,1886,1887$, and 1888. In each of these years there was a widespread autumnal movement in November or December. In 1882 it extended round the entire coast. Woodcocks are noted at Old Head, Kinsale, on December 5th, 6 th, 7 th, 8 th, and 9 th; on the 6 th, they are also reported at Howth Baily; on the 10th, at Aranmore and Killybegs; on the 11 th, at Dungarvan and Dursey Island; on the 12th, at Howth Baily; on the 13th, at Pathlin Island; and on the 14th, at Howth Baily and the Skelligs. In 1883, between November 2nd and 4th, observations are recorded at the Fastnet, Coningbeg Light-ship, Skelligs, and Dursey Island; in 1884, between November 12th and 14th, at the Fastnet, Rockabill, and Skelligs; in 1886, between December 18th and 21st, at Innishtrahull, Aranmore, Rathlin O'Birue, and Slyne Head; in 1887, between November 11th and 16th, at the Tuskar (three times), Tory Island, Aranmore, and Slyne Head (twice); and

1 Yarrell, 4th ed., vol, iii, p. 324, etc, 
in 1888, between November 4th and 8th, at Blackrock (Mayo), Slyne Head, Tearaght, and Skelligs. We have here six instances of extensive movements, all of which took place wholly within the first and last quarters of the moon-an interesting fact; and it will be noticed that the west coast participated in each of them, while three of them were unreported on the south coast, three on the east, and three on the north.

We have no evidence that the departure of the Woodcock is noticed at light-stations. On two occasions the direction of the flight in spring has been recorded, viz., at the Tuskar, March 4, 1884, when one was observed going W., and at the Maidens on March 25 of the same year, when one is said to have flown S.W., after remaining two days on the rock. As both these flights were landward, they afford some grounds for doubting whether the individuals which are occasionally killed at the lanterns in spring are departing birds. On the other hand, they are too few to warrant any inference as to a spring immigration of the Woodcock.

Average length of wing, 7.59 ; longest, $7 \cdot 85$; shortest, $7 \cdot 22$; difference between extremes, 0.62 ; percentage of variation, 8 .

\section{Common Snipe (Gallinago coelestis, Frenzel).}

The autumnal immigration has in some years begun early in Common September. Such records as "Snipe round the light" at AranSnipe. more, September 4, 1889, and "one killed striking" at the Fastnet, September 8, 1896, are corroborated by the fact that in 1888 one killed striking at Arklow South Light-ship on September 9 was received in flesh.

The Snipe strikes in every month from September to January, and from March to May. It is not recorded as having struck in February, but is said to have occurred at Arklow South Light-ship on February $16^{\circ}, 1896$, and to have been found dead at the Tuskar during the first week of March (March 4, 1884), from which we may infer that migration is at no time totally suspended from early in September until the end of May. In 1890 one was killed striking at Arklow South Light-ship, May 25, and was forwarded in the flesh. 
Common The following table shows the number of observations for

Snipe. each month and for each section of the coast :-

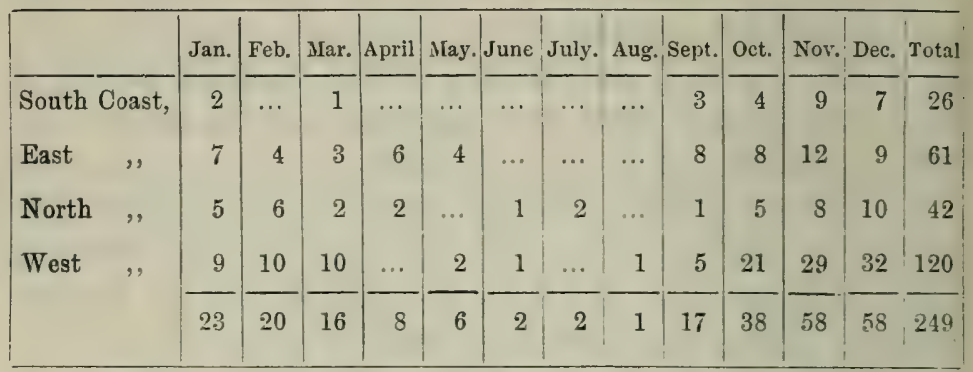

Some of the observations doubtless refer to the Jack Snipe, and, in a few instances, the Redshank. The table, however, points to the general conclusion that November and December are the months of most movement, and this is corroborated to some extent by the specimens received. Of 15 examples forwarded as killed or caught striking, three struck in September, none in October, three in November, five in December, one in January, none in February or March, one in April, and two in May.

The three spring-killed specimens forwarded (Innishtrahull, April 6, 1889; Arran Island S., May 1, 1889; and Arklow South Light-ship, May 25, 1890), if departing birds, do not coincide with the view of $\mathrm{Mr} \mathrm{H}$. Saunders, who considers that the Snipe which winter within our limits leave before or during March ("Manual," p. 573). The only two records of direction of flight in spring are landward.

"Tuskar.-April 8, 1888, two on rock; rested through night; went off west; wind light N.E., clear."

"Arklow North Light-ship.-April 25, 1891, one about ship; went north-rvest at 7 A.M.; wind light S.E., hazy."

This evidence is similar to what was found in the case of the Woodcock.

It is possible that the birds which strike in spring are on passage towards Iceland, where the Snipe is known to breed. On the night of May 1 and 2, 1889, the light-keeper at South Arran Island noted "several Snipe passing at intervals from 11 P.M. to 4 A.M.; one killed striking," and a leg and wing were forwarded. This shows that some of the late migrants move 
along the west coast, as might be expected in the event of Iceland being their destination.

Like the Woodcock, the Snipe is about twice as numerously reported from the north and west as from the south and east coasts. The six stations which yield most observations are-

Rathlin O'Birne, 36; Innishtrahull and Mew Island, 27; Slyne Head and Tearaght, 21; Aranmore, 15.

Four of these (Rathlin O'Birne, Innishtrahull, Slyne Head, and Aranmore) were also among the six which yielded the largest number of observations of Woodcock. The remaining two (Mew Island and Tearaght) are situated on the same parts of the coast as the remaining two in the Woodcock's case (Maidens and Skelligs). There would appear to be a close similarity between the flight-lines of the two species during the autumnal movement. The few spring observations tend to show that the Snipe continues throughout March to be more frequently noted on the west than on the east coast, whereas the Woodcock's occurrences after the end of February are almost confined to east coast stations. The only counties from which specimens of the Common Snipe (killed or caught striking) have been forwarded are Wexford (8), Antrim (2), Donegal (3), and Galway (2).

Unlike the Woodcock, the Snipe has frequently been noted at light-ships, and Arklow South Light-ship alone has forwarded four specimens, while Blackwater Bank has contributed two. The species has been reported at Arklow North Lightship and Lucifer Shoals. The "Woodcock" said to have been killed striking at Coningbeg, May 26, 1884, was probably a Snipe, there being no other reported instance of the Woodcock striking later than April 14.

The "Migration Reports" afford several instances of the Snipe striking on different parts of the coast at approximately the same dates. These "rushes" generally coincide in point of time with those of the Woodcock; for instance, in 1882, when the Woodcock was noted at eight stations between December 9 th and 14th, the Snipe was noted at seven between December 9 th and 16th; and in 1888, when the Woodcock was noted at four stations, all on the west coast, between November 
Common 4th and 8th, the Snipe was reported from five, of which three

Snipe. were on the east coast, between November 3 rd and 10 th.

Few specimens of the Common Snipe have been received, considering its abundance.

Average length of wing, 5.22 ; longest, 5.47 ; shortest, 5.05 ; difference between extremes, 0.42 ; percentage of variation, 8 .

\section{JACK SNIPE (Gallinago gallinula, Linn.).}

Jack

Snipe.

The only evidence of value consists of the twelve specimens forwarded which were killed or caught at lanterns. There are 25 uncorroborated observations.

Of the specimens, eight struck on the autumnal migration, one in September, three in October, three in November, and one in December.

$\begin{array}{lll}\text { Earliest, } & \text { September 28, 1886, } & \text { Rockabill. } \\ \text { Latest, } & \text { December 9, 1899, } & \text { Rockabill. }\end{array}$

Another, found decayed on the roof at Howth Baily, December 12,1892 , had probably struck during the autumn.

Three struck in spring-one in March and two in April.

$\begin{array}{lll}\text { Earliest, } & \text { March 28, 1897, } & \text { Arklow North Light-ship. } \\ \text { Latest, } & \text { April 23, 1890, } & \text { Hook Tower. }\end{array}$

With one exception (Slyne Head, October 2,1889) all twelve examples are from the east or south-east, the most southerly station being Hook Tower, and the most northerly South Rock Light-ship, so that, judging by specimens, the migration route of the Jack Snipe is far better defined than that of either the Common Snipe or Woodcock. The south coast has furnished two specimens (both from Hook Tower), while the east coast yields nine, the north none, and the west one.

The Tuskar has forwarded three specimens, all in October and November; no other station has sent more than two.

This species has been reported as striking at the Fastnet (several times), Rathlin Island (once, at the improbable date of August 9, 1S83), and Killybegs (once), but these entries were not vouched for by specimens.

Except in 1887, when three were received (killed between October 7 and November 11), no two were forwarded in the same season. It is thus impossible to draw any inference as to simultaneous movements on different parts of the coast. 
The Woodcock, Snipe, and Jack Snipe may be taken as instances of the extent to which the presence of moonlight assists birds on their migration. When the moon is more than half full (i.e., in her second or third quarter) birds seldom strike, ${ }^{1}$ whether the nights be clear or otherwise. Thus of 10 Woodcock, 15 Common Snipe, and 11 Jack Snipe which struck the lanterns on ascertained dates, the numbers which struck in the darker and in the brighter half of the lunar month respectively are as follows :-

$\begin{array}{cccccc} & \text { Woodcock. } & \text { Common Snipe. Jack Snipe. } & \text { Total } \\ \text { Moon's 1st and 4th quarter, } & 8 & 14 & 10 & 32 \\ " \text { 2nd and 3rd " } & \frac{2}{10} & \frac{1}{15} & \frac{1}{11} & -\frac{4}{36}\end{array}$

In other words, 90 per cent. were obtained within about a week of the new moon. Similar figures might be adduced with regard to nearly every species. From this we may see that without a long series of years for comparison it would be impossible to draw any fair inference as to periods of maximum migration, since the period of maximum striting varies each year according to the moon's phases.

The Jack Snipe's wing shows a larger percentage of variation in length than that of either of its allies, the Woodcock and Common Snipe.

Average length of wing, 4.45 ; longest, 4.67 ; shortest, 4.15 ; difference between extremes, 0.52 ; percentage of variation, $11 \frac{1}{2}$.

\section{Dunlin (Tringa alpina, Linn.).}

The Dunlin is one of the few species which appear to strike Dunlin. with almost equal frequency in spring and autumn.

The only reliable data are the specimens, of which 21 were killed or disabled at lanterns. Of these, 12 struck in autumn and winter (August 12 to January 31) and nine in spring (April 8 to May 31). On the autumnal migration, two (apparently immature) were obtained in August, one in September, one in October, five in November, one in December, and two in January. Of those killed on spring migration, three struck in April and six in May.

Earliest specimen, August 12, 1886, Coningbeg Light-ship.

Latest " January 31, 1897, Tuskar.

${ }^{1}$ See diagram, p. 16. 
Dnnlin. The earliest adult, however, struck on September 20, 1892, at Hook Tower; and as many as six of the twelve autumnal examples were obtained between October 28 and November 25. The three which struck in December and January did so during severe weather, and we may consider them instances of irregular movement. The normal autumnal period therefore extends over about two months, September 20 to November 25.

The spring movement lasts for about eight weeks.

$$
\begin{array}{lll}
\text { Earliest specimen, } & \text { April 8, 1894, } & \text { St John's Point, Down. } \\
\text { Latest " } & \text { May 31, 1886. } & \text { Coningbeg Light-ship. }
\end{array}
$$

That the latest example should have occurred at a south coast light-ship is of some significance, showing that this bird must have been migrating towards, not from, the Irish shore, and many which strike in spring are doubtless visitants on passage.

The Dunlin has never been sent from the north coast, and -discarding shot birds-only one example (in summer plumage), found disabled at Eagle Island, May 16, 1893, has been received from the west. Seven have been sent from the south coast (6 in autumn, 1 in spring), and 13 from the east coast (6 in autumn, 7 in spring). . The Fastnet is the southernmost, while Eagle Island and St John's Point (Down) are the northernmost stations from which this species has been received.

The number of specimens from each county is as follows:-

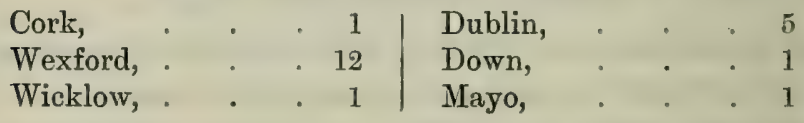

Thus of 21 birds obtained at lanterns, 18 struck on the eastern extremity of the south and the southern half of the east coast. It has not struck $\mathrm{N}$. of $54^{\circ} 14^{\prime}$.

No weight can be attached to unconfirmed observations.

Few of the species dealt with exhibit greater variation in length of wing than the Dunlin. It is equalled in this respect by the Snow Bunting, and surpassed only by the Willow Wren and Skylark.

Average length of wing, 4.54 ; longest, 4.87 ; shortest, 3.95 ; difference between extremes, 0.92 ; percentage of variation, $20 \frac{1}{2}$. 
[Obs.-No specimen of the Little Stint (Tringa minuta, Leisler) or of the Curlew Sandpiper (T. subarquata, Güldenstadt) has been received. In the "Report" for 1886, some legs and wings of the Dunlin were erroneously referred to the latter species.]

\section{Purple Sandpiper (Tringa striata, Linn.).}

The Purple Sandpiper strikes more frequently in November than in any other month. The advanced guard probably arrives in September; but the earliest received were two birds killed on October 29, 1892-one striking at the Tuskar, the other shot at the Tearaght. Some noted at Hook Tower, September 22, 1890, are the earliest reported examples.

Fourteen have been received, of which 4 were shot and 2 sent without data, while 8 struck the lanterns (6 in autumn and 2 in spring). Of the 8 birds killed striking, one (the earliest) was obtained at the Tuskar, October 29, four in November, one on December 8, and two in May. There is no direct evidence of migration from December 8 (when one was killed striking at Aranmore in 1897) to May 16, ${ }^{1}$ when one struck at Blackwater Bank Light-ship, in 1893. The second and latest spring specimen struck at the Fastnet, May $18,1888$.

Of six specimens shot or sent without data, two were forwarded in November, two in December, one in March, and one in April. There is no evidence to show that any of these were migrating.

The light-stations at which the Purple Sandpiper is known to have struck in autumn are situated in the south-east and north-west corners of Ireland. In the south-east, 2 specimens were obtained at the Tuskar lantern, and 1 at Blackwater Bank; in the north-west, 1 at Aranmore, and 2 at Rathlin O'Birne. Wexford and Donegal are thus the only counties on whose coasts this species has been proved to occur on the autumnal migration; and each has contributed three specimens at that season. The birds which struck at Donegal stations were probably immigrants from Iceland.

1 Since above was written, one was received in flesh which struck at Innishtrahull (Co. Donegal), May 7, 1900. 
Purple Sandpiper.

In spring, the only occurrences were in Cork (one at Fastnet) and in Wexford (one at Blackwater Bank). At both these points it is clear that birds might be expected to strike on their northward passage from the French or Cornish coast towards Iceland; while it is in the highest degree unlikely that birds which had wintered in Ireland would depart by southern stations in spring.

The stations from which shot specimens have been forwarded, but at which the species has not been proved to occur on passage, are Hook Tower, Eagle Island, and the Tearaght. The latest example thus obtained was shot at Eagle Island, April 7, 1886.

On the Tuskar Rock, Mr John Hamilton remarks (p. 317) that there are always seven or eight Purple Sandpipers during the winter, and in 1891 they are said to have been there up to "the latter end of May."

Average length of wing, 5.05 ; longest, 5.37 ; shortest, 4.40 ; difference between extremes, 0.97 ; percentage of variation, 19 .

\section{Кмот (Tringa canutus, Linn.).}

Knot.

The evidence is too meagre to justify any conclusion.

of 5 specimens received from light-stations, 4 were obtained on migration, viz.-

2 killed striking at Slyne Head, October 2, 1889.

1 caught on board Arklow S. Light-ship, January 14, 1888.

1 killed striking at the Tuskar, March 13, 1896.

The remaining example was shot at N. Drogheda, January 12,1893 .

The coast-distribution of the few occurrences at lanterns is somewhat similar to that of the Purple Sandpiper; and, as in the case of that species, it would seem that the bird which struck in spring had wintered further south than in Ireland.

\section{SANDERLING (Calidris arenaria, Linn.).}

Sanderling. Never distinguished by the light-keepers, and only one example (forwarded as a Sand-Lark) has been received.

This bird was killed striking at Blackwater Bank Light-ship, August 30, 1894.

The pancity of occurrences is the only noteworthy feature. 
Common SandPIPER (Totanus hypoleucus, Linn.).

The Common Sandpiper has been killed or caught striking in 9 instances, of which 7 were on spring migration-

Earliest, April 23, 1892, Blackwater Bank Light-ship,

Latest, May 17, 1886, Coningbeg Light-ship ;

while two were on the autumnal migration-

Earliest, July 16, 1893, Coningbeg Light-ship,

Latest, July (?) 26, 1888, Mine Head.

The evidence is thus meagre at both seasons, but especially so in autumn.

Of the 7 spring occurrences, only 1 was in April, while 6 were in May. These 7 examples were all obtained at stations on the Leinster coast from Coningbeg to Drogheda North. The spring migration of this Sandpiper, therefore, seems to break chiefly on the southern half of the east coast, from Wexford to Louth.

Both the autumnal specimens were obtained on the south coast, in its eastern half (counties Waterford and Wexford). There is no evidence to show in which direction the birds were migrating, and it is a significant fact that none have been sent later than July.

Though the total number received is not greater than 10 (counting one shot at Mine Head, May 5, 1888), the three years 1888, 1892, and 1893 contributed as many as 9, from which it may be inferred that this Sandpiper occurs in unequal numbers in different years. Such an inference would not be justifiable if the years in which it was obtained had been peculiarly favourable to striking; but the reverse was the case, especially as regards 1888 and 1893. The total number of specimens of all species forwarded from 1886 to 1893 are as follows:-

\begin{tabular}{|c|c|c|c|c|c|c|c|}
\hline & & & $\begin{array}{l}\text { Specimens } \\
\text { sent. }\end{array}$ & & & & $\begin{array}{l}\text { Specimens } \\
\text { sent. }\end{array}$ \\
\hline 1886 & . & . & . 111 & 1890 & . & . & . 228 \\
\hline 1887 & . & . & . 142 & 1891, & . & . & . 190 \\
\hline 1888 & . & . & . 105 & 1892 & . & . & . 166 \\
\hline 1889 & . & . & . 159 & 1893 & . & . & 94 \\
\hline
\end{tabular}

In 1893 two were killed striking on the same night (May 16) at Blackwater Bank and Drogheda North respectively, and in 
1888 two struck at approximate dates (May 6th and 8th) at the

Tuskar and Arklow North Light-ship. These coincidences are worth noting in the case of so infrequent a striker. They occurred, as such incidents usually do, in the first and last quarters of the moon.

The specimen killed at Blackwater Bank Light-ship on May 16, 1893, appears to have struck in company with a Purple Sandpiper, the light-keeper's note being "two Snipe killed striking at 10.30 P.M.," while legs and wings of a Common and Purple Sandpiper were forwarded. The only other species which have been received with this bird are the Willow Wren and Swallow (Blackwater Bank, April 23, 1892).

Average length of wing, 4.30 ; longest, 4.47 ; shortest, 4.12 ; difference between extremes, 0.35 ; percentage of variation, 8 .

\section{REDSHANK (Totanus calidris, Linn.).}

Redshank. A bird as to whose migrations the evidence of the lightstations is practically nil.

It has never been reported as striking, and only two specimens have been received, of which one was shot, and the other killed by a cat.

There are 48 observations -6 from the south, 8 from the east, 6 from the north, and 28 from the west coast-but, apart from specimens, these cannot be relied on.

[Obs.-The Greenshank (Totanus canescens, Gmel.) has occasionally been noted, but never forwarded. Among other waders which have been reported are the "Pectoral Sandpiper," "Temminck's Stint," and "Schinz's Sandpiper." These records of rare waders are unworthy of the slightest credence without specimens.]

\section{BAR-TAILED Godwit (Limosa lapponica, Linn.).}

Bar-tailed

An example, forwarded as an unknown bird, was killed strikGodwit. ing at St John's Point, Down, with a Turnstone, on the night of February 1, 1897.

There are no observations relating to this species, which, though a regular visitant on spring and autumn passage, is probably unknown to the light-keepers. 
Curlew (Numenius arquata, Linn.).

The spring migration of the Curlew, sometimes commencing Curlew. in February, is most strongly marked from the middle to the end of March. It is commonly attested by the loud cries of the birds as they pass overhead at night, and occasionally, in gloomy weather, by their occurrence at lanterns. The movement continues into April, but probably comes to an end, in most years, during the early days of that month. Frequent confusion between the Curlew and Whimbrel makes it impossible to draw a satisfactory line marking the period at which the former species ceases to pass northwards in spring; and the autumnal data, especially in August and September, are vitiated with uncertainty from the same cause. The name "Maybird" is commonly applied to the Whimbrel by the lightkeepers, and never to the Curlew - but there is reason to believe that the Whimbrel is occasionally misnamed "Curlew," and vice versâ.

A table showing the total number of observations for each month (deducting only those which there is strong reason for referring to the Whimbrel) brings out a large preponderance for March.

\begin{tabular}{|c|c|c|c|c|c|c|c|c|c|c|c|c|c|c|}
\hline & & Jan. & Feb. & Mar. & April & May. & June & July. & Aug. & Sept. & Oct. & Nov. & Dec. ' & Total \\
\hline South & Coast, & 4 & 8 & 31 & 8 & 5 & 10 & 14 & 5 & 15 & 11 & 8 & 10 & 129 \\
\hline East & , & 22 & 33 & 73 & 49 & 31 & 16 & 27 & 29 & 11 & 11 & 30 & 20 & 352 \\
\hline North & , & 7 & 4 & 5 & 5 & 2 & 3 & 3 & 4 & 7 & 7 & 15 & 8 & 70 \\
\hline \multirow[t]{2}{*}{ West } & \multirow[t]{2}{*}{ " } & 13 & 11 & 18 & 28 & 14 & 15 & 15 & 20 & 24 & 33 & 29 & 21 & 241 \\
\hline & & 46 & 56 & 127 & 90 & 52 & 44 & 59 & 58 & 57 & 62 & 82 & 59 & 792 \\
\hline
\end{tabular}

In the case of a common shore-haunting bird, such a table as the above is evidently valueless, except for the purpose of showing a large increase in the number of observations at certain seasons. It will be observed that the increase in March is strongly marked on the south and east coasts, while on the north and west it is insignificant.

If we look to the instances in which Curlews are reported as occurring about lanterns, we find that in spring such occur- 
Curlew. rences are almost confined to the east coast, and are chiefly noted at light-ships. January yields 1 , February 8, March 16, and April 6. Of 31 instances in which Curlews have been reported about the lights during those four months, 2 were on the south coast, 28 on the east (12 of which were at Blackwater Bank), and 1 (during a cold weather rush, February 7,1895 ) on the north.

In four cases only (in spring) are Curlews reported as killed or disabled striking, viz.-at Blackwater Bank Light-ship, March 24, 1892; Arklow South Light-ship, April 11, 1891 ; Rockabill, March 14, 1894; and South Rock Light-ship, March 2, 1897. One specimen (killed on the first-mentioned date at Blackwater Bank) was received.

From the above data we inay fairly assume that the Curlew migration in spring passes chiefly up the east coast of Ireland.

There was a well-marked rush in the spring of 1892, when, between March 20th and 27th, the species was reported from Blackwater Bank, Arklow South, and Arklow North Lightships, the Maidens, and Tory Island.

The autumnal records show occurrences at lanterns for every month from July to December, viz.-one in July, two in August, two in September, four in October, five in November, and one in December. Nine of these fifteen instances are reported from the east coast, and the remaining six from the west. The birds are said to have been lilled striking in five cases, of which four were on the west coast-three at South Arran Island (October 16 and November 15, 1883, and October 23,1897), and one at North Arran Island (August 22, 1884). None of these four birds, however, were forwarded; and the only specimen received in autumn, like the only one in spring, was from an east coast station-Ardglass, Co. Down-where it was killed striking, November 13, 1893.

It is clear, from the comparative paucity of records in autumn, that less migration is observed at that season on the east coast than in spring; and the reason probably is that more birds in autumn pass down the west coast, where in spring they are not reported as striking at all.

Like many species, the autumnal migration appears to be at its maximum from the middle of October to the middle of November. 
Whimbres (Numenius phocopus, Linn.).

Observations relating to the Whimbrel's spring passage are Whimbrel. numerous, particularly on the south and west coasts. Autumnal records, on the other hand, are few, perhaps owing to confusion with the Curlew. The following are the numbers for each month (from each section of the coast) from April to September. ${ }^{1}$

\begin{tabular}{|c|c|c|c|c|c|c|c|c|}
\hline & & April. & May. & June. & July. & August. & Sept. & Total. \\
\hline \multicolumn{2}{|c|}{ South Coast, } & 23 & 46 & 2 & 4 & 5 & 7 & 87 \\
\hline East & $"$ & 17 & 37 & 4 & 8 & 7 & ... & 73 \\
\hline North & $"$ & 1 & 17 & 6 & 2 & 1 & $\cdots$ & 27 \\
\hline \multirow[t]{2}{*}{ West } & \multirow[t]{2}{*}{ " } & 12 & 58 & 7 & 7 & 14 & 6 & 104 \\
\hline & & 53 & 158 & 19 & 21 & 27 & 13 & 291 \\
\hline
\end{tabular}

Comparing this table with that given for the previous species, it is evident that the Curlew prefers the east coast when going north in spring, and the Whimbrel the west coast; the Curlew travels north chiefly in March, and the Whimbrel in May.

Divided into periods of ten days, the spring occurrences are as follows :-

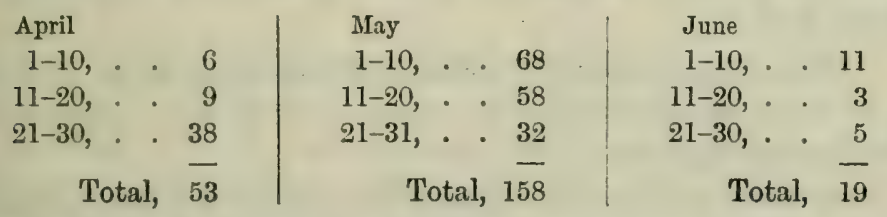

The principal movement generally sets in during the last week of April, and continues until about the middle of May. The light-stations at which the largest flocks are reported are on the Cork and Waterford coasts-Fastnet, Old Head of Kinsale, Mine Head, and Dungarvan. Conspicuous rushes were noted at one or more of these in 1884 (April 23-27 and May 5), 1885 (April 25, 26), 1887 (May 13 and 27), 1888

\footnotetext{
${ }^{1}$ A few observations for February and March are assumed to be erroneous, and
} probably refer to Curlew. 
Whimbrel. (April 28, 29, and May 6), 1889 (May 2), and 1897 (April 26-30). The flight, as might be expected, is generally northwards; but on April 28, 1897, Mr Dunleavy noted a reversal of direction on the part of the "very large flocks" then passing Dungarvan: "all that passed this day went S.W., though on previous days (26th and 27 th) it was N.E. they were flying."

There is evidence that the return migration has commenced as early as July 19 (Dungarvan, 1897); and between that date and the middle of September large numbers have repeatedly been reported at southern and south-western stations, the principal instances being,-

"Fastnet.-September 15, 1888, a flock flying S. They passed in vast numbers for two hours, flying high, with great noise."

"Fastnet.-July 27, 1889, many all night at intervals between 10.30 P.M. and 3 A.M., seemed flying S. August 20th, about fifty observed in the rays of the light between 10 P.M. and 3 A.M. (on 21st), when they went S.W."

"Samphire Island.-August 20, 1895, numbers going S.W. 9.30 and 10.30 P.M. : 22nd, going S.W. all day and night, passing at intervals in flocks of from five to ten at a time."

"Samphire Island.-August 2, 1896, numbers going S.W. from 9 P.M. to 11 P.M. : 5th, about a hundred going S.: 14th, numbers at 10 P.M.: 15th, numbers at 11 P.M. going S.W.: 17 th, at present Whimbrels appear to be very numerous, all flying S.W."

"Dungarvan.-July 19, 1897, numbers going S.W. at 10.30 P.M. : 27 th, numbers going S., 10 P.M. to 11.30 P.M. August 1st, numbers going $\mathrm{S}$. at 11.45 P.M."

The value of the observations, when unaccompanied by specimens, is in a large measure due to the fact that many of them have been repeated year after year by different light-keepers wholly independent of each other, and at different light-stations; but it is of importance to note that all the above autumnal records are contributed by one intelligent observer, $\mathrm{Mr}$ G. Dunleavy, but for whom we should be without information as to the apparent frequency with which hosts of migrating Whimbrels pass our south coast stations during August. It is remarkable that no other light-keeper at these stations noticed Whimbrels in previous or subsequent years. 
Shot specimens of the Whimbrel have been forwarded on four occasions-May 23, 1890 ; June 5, 1889; July 26, 1889 (Innishtrahull); and November 29, 1887. This last from $\mathrm{Mr}$ G. Dunleavy when at Fastnet. Only one example killed at the lantern has been received. This bird struck at Coningbeg, September 2, 1889 .

\section{Sandwich Tern (Sterna cantiaca, J. F. Gmelin).}

In the years 1882,1883 , and 1884, small parties of "Terns" were noted at Oyster Island, Co. Sligo, during the second and third weeks of April (April 9th and 12th, 1882 ; Sth and 12th, 1883 ; and 17th, 1884). As these dates would be early for any other species, the records may be referred with some confidence to the Sandwich Tern, whose only ascertained breeding-ground in Ireland is situated near the boundary of Co. Sligo.

The absence of later records is chiefly due to the fact that schedules were not sent regularly to this station.

From the rest of the Irish coast only two observations of Terns earlier than April 30 have been furnished, viz., Barrels Rock, March 8, 1890 (probably an error), and Spit Bank, April 4, 1891. In the last-mentioned instance Mr Dunleavy noted "several 'Sea-Mews' going E." These, if Terns, were most likely of the present species.

\section{Roseate Tern (Sterna Dougalli, Montagu).}

An adult male of this now very rare Irish bird was killed striking at Hook Tower, April 30, 1897. The light-keeper, Mr Barry, forwarded the specimen as an unknown bird, remarking that "it appears to be the first of its kind caught about here."

The Roseate Tern is not known to breed in Ireland at the present day, but formerly did so on islands off the Wexford, Dublin, and Down coasts.

Except the few occurrences at Oyster Island and Spit Bank which have been referred to the previous species, this is the only instance of a Tern having been recorded from an Irish light-station in April,

Sandwich

Tern. 


\section{CoMmon TERn (Sterna fluviatilis, Naumann) and}

\section{ARctic Tern (Sterna macrura, Naumann).}

Common Arctic

Tern.

In dealing with the entries in the schedules as to "Terns," it is impossible, in the absence of specimens, to separate the above two species. No example of either has been forwarded in spring. In autumn the Common Tern has been sent from Coningbeg Light-ship (killed striking, October 6, 1887) and Vidal Bank (found disabled, October 12, 1894), while the Arctic Tern has been received from Old Head of Kinsale (shot, September 19, 1889), from the Tearaght (found at Peregrines' feeding-place, October 9, 1890), and from Rathlin O'Birne (probably shot, October 10,1891). In all probability the two species associate together on passage as they do during nidification; but the Arctic Tern may be more numerous at western than at eastern stations.

The time within which these birds generally arrive is best marked by the records kept at Mew Island, Co. Down, long known as the breeding-haunt of a large colony, in which the Arctic Tern probably preponderates. The earliest date of their appearance noted at this station is May 7, 1897; the latest is May 26, 1885 . The average (of thirteen dates of arrival chronicled) is May 14. In only one year has the first appearance of the Terns at Mew Island been later than May 20; in three years it was previous to May 11; and in nine years it occurred during the ten days May 11th to 20 th.

The arrival of the Terns at this station is described as taking place during the night, and as extending over a period of nearly a fortnight. In the "Report" for 1883, Mr John Walsh writes: "They come in the night, at first in small numbers, increasing each night for ten or twelve nights, when many hundreds are to be seen"; and again in 1884, "Nay 20th, large numbers heard arriving on Mew Island during the night." In 1897 , however, they are said to have "come from the east at sunrise."

At the most northerly Irish breeding-station, Innishtrahull, the arrival of the birds is later than at Mew Island, the earliest date recorded being May 15, in 1895, and the latest May 27, in 1886. These dates are respectively seven and eight days later than those for Mew Island in the same years. The years in 
which both stations have reported are six, and in each instance Innishtrahull has been a week or more behind Mew Island, the greatest difference being seventeen days (in 1893), and the usual difference about ten days.

The earliest date at which Terns (other than the Sandwich or Roseate species) have been noted on passage at a lightstation is May 3, 1893, at Hook Tower; the latest, as regards spring migration, is June 26, 1889, at the Fastnet. The period of the spring movement thus embraces nearly the whole of May and June; but of a total of 77 observations during those months, 65 bear date between May 10 and June 10. The ten days' period of most observations is from May 11th to 20th:-

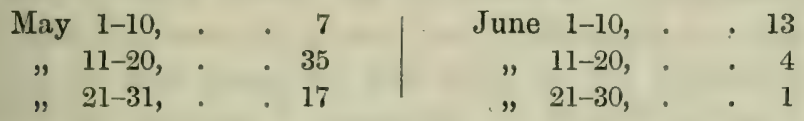

The stations at which Terns have been reported numerously on spring passage are the Fastnet, Hook Tower, Coningbeg Light-ship, Barrels Rock Light-ship, Tuskar, Drogheda North, and North Arran Island. It is therefore probable that the brunt of the migration falls on the south coast. The Fastnet and Hook Tower are the only stations at which Terns have been noted about the lanterns in spring.

The autumnal movement begins early in August and lasts late into October. There is an exceptional record for November and one (perhaps) in December, but both need corroboration. ${ }^{1}$ The dates at which the breeding-stations are abandoned vary from August 2 (Slyne Head, 1883) to September 30 (Mew Island, 1891). ${ }^{2}$ In eleven different years the departure from Mew Island is recorded as taking place in September, the emigration, like the arrival, extending over ten days or a fortnight; while in one year (1897) all the Terns had quitted this station by August 21. The evacuation of Innishtrahull was in progress in 1893 on August 15th and 16th (a month earlier than that of

1 Dungarvan, November 17, 1896, "numbers of Terns about light"; and Fastnet, December 12, 1887, "six 'Sea Mews' startled from rock by firing gun. cotton."

2In 1888 the departure from Mew Island is said to have taken place "about October 31 "; but this may havo been written from memory, and so late a date is improbable, 
Common Arctic

Tern.

Mew Island in the same year); but in 1894 (in which year the departure from Mew Island took place September 1st to 9th) the birds "commenced to leave" Innishtrahull on September 10th, and were not all gone till the 20th. The length of the stay at each breeding-station is thus seen to be irregular, and not governed by the punctuality which prevails on the spring migration.

There is reason to suppose that simultaneously with the departure from Mew Island there is generally some migration on the south coast, towards its western extremity. Thus in 1886 "Mew Gulls" are noted at the Fastnet on night of September 4, and Terns are recorded as having left Mew Island on September 11; in 1889 they are "about light" at Old Head (Kinsale), on September 1, and "nearly all have left" Mew Island by September 12; in 1894 they are again seen "at light" at old Head of Kinsale on September 3, and are chronicled as departing from Mew Island September 1st to 9 th. When only one date of departure is given at Mew Island, it may be assumed to mean that the emigration is then nearly over, and therefore the occurrences at such southerly stations as the Fastnet and Kinsale synchronise with the commencement of the exodus in the north in each of the above three years.

In 1891 Terns were noted "striking glass in immense numbers" at Hook Tower on the nights of September 7 th and 8th. The date of departure from Mew Island in that year was set down as "about September 30th," and the rush at Hook Tower probably belonged to a different migration. In connection with the other records, however, it helps to fix September as the month of the principal southward movement.

The few entries in schedules for August are chiefly of small companies noted at east coast stations (Tuskar, Lucifer Shoals, and Maidens); and there is no evidence to show that these do not relate to the Lesser Tern. There is a significant absence of east coast observations (except at Mew Island) in September, notwithstanding the annual exodus during that month from the great breeding-haunt on the Down coast.

October is characterised by the spasmodic occurrence of flocks on the west coast. In these the Arctic Tern probably predominates, as two specimens from different stations both belong to that species. On the other hand, two examples of 
the Common Tern (one killed striking, the other found disabled) have been forwarded in October from the E. and S.E. (Vidal Bank and Coningbeg Light-ship). The Tearaght has in three years $(1886,1889$, and 1890) reported or forwarded Terns Tern. in October, the latest occurrence being October 23, 1889, and at this station they have not been noted in any other month.

The number of observations for each month and each section of the coast from May to October is as follows:-

\begin{tabular}{|c|c|c|c|c|c|c|c|c|}
\hline & & May. & June. & July. & August & Sept. & Oct. & Total. \\
\hline \multicolumn{2}{|c|}{ South Coast, } & 14 & 8 & 1 & ... & 6 & 1 & 30 \\
\hline East & $"$ & 29 & 2 & 2 & 6 & 14 & 3 & 56 \\
\hline North & $"$ & 8 & 1 & $\ldots$ & 2 & 2 & $\ldots$ & 13 \\
\hline \multirow[t]{2}{*}{ West } & $"$ & 8 & 7 & 2 & 1 & 2 & 5 & 25 \\
\hline & & 59 & 18 & 5 & 9 & 24 & 9 & 124 \\
\hline
\end{tabular}

Of the 56 observations on the east coast, 36 are from Mew Island, relating to arrivals and departures at the great breedingstation. When allowance is made for this fact, it will be observed that the south-coast light-stations contribute a much larger proportion of observations on passage than the eastern.

On September 19, 1883, the principal departure from Mew Island is noted as having taken place during the night, when "some hundreds were heard leaving." In arriving, as in setting out, the birds are said to make a great noise.

\section{Lesser Tern (Sterna minuta, Linn.).}

$\Lambda$ few of the observations dealt with under the previous heading may relate to this species, whose breeding colonies are, however, much less extensive than those of the Common and Arctic Terns. One specimen of Sterna minuta has been received, disabled striking at Hook Tower, May 15, 1893. On the following night, Terns, possibly of the same species, are said to have been "numerous round the light" at this station. It is noteworthy that Hook Tower is the only Irish lightstation at which Terns are known to have been killed or 
Lesser Tern. disabled in spring, and that, of two examples forwarded, one was a Lesser, the other a Roseate Tern.

Some "Lesser Terns" reported from the Tearaght, October 3 to 7,1886 , were probably Arctic or Common. In October 1890 the wing of a supposed Lesser Tern from that station was received, and proved to be $S$. macrurce. The present species has not been obtained or reliably reported on autumnal passage.

\section{Sabine's Gull (Xema Sabinii, Joseph Sabine).}

Sabine's Gull. It is probable, as Mr Howard Saunders suggests, that a bird which was conjecturally reported as a "Hawk" from Mine Head in October 1897 (pp. 549, 550) belonged to this American species of Gull, of which about a dozen examples have been obtained on the Irish coast in autumn. It was observed during the latter part of the month, and is described by $\mathrm{Mr}$ Hawlins as " nearly all of a light grey or white, and having a black head and forked tail."

\section{BlaCK-HEAdEd GULL (Larus ridibundus, Linn.).}

Black-headed Neither the Black-headed nor any other Gull, except the Gull. Kittiwake, has been killed at a lantern, and the only example of the present species forwarded by a light-keeper was found dying in frosty weather on the Tearaght, January 1, 1891. It is therefore impossible to draw any inferences as to migration, since it is believed that the light-keepers do not distinguish this Gull from others.

\section{Common Gull (Larus canus, Linn.).}

CommonGull. As in the case of the previous species, there is no reliable evidence. One specimen has been received, found dead on Samphire Island during the very severe frost of February 1895 .

\section{Herring Gull (Lames argentatus, J. F. Gmelin).}

Herring Gull. No proof of migration has been received; but whether a regular migrant or not, the Herring Gull probably plays an important part as concerns the migration of other birds. 
Almost every year has afforded instances in which "Sea-Herring Gull. gulls" have been observed in the act of chasing and killing exhausted migrants, and the evidence amounts to cumulative proof that the carnivorous habits of the larger Gulls constitute a real peril to birds on passage. In the four years from 1894 to 1897 , as many as fifteen occurrences of this description are reported, Larks, Thrushes, and Blackbirds being generally named as the victims.

All the observations of Gulls killing small birds are from light-ships (except in the frost of 1895), showing that they seldom take the trouble to attack until the migrants are on the open sea and at a manifest disadvantage. The fullest notes are from Arklow North Light-ship, where, on October 29 and $30,1894, \mathrm{Mr}$ Stapleton reports "numbers of small birds, such as Blackbirds, Thrushes, and Larks, getting exhausted as they reach ship, are followed and eaten by Seagulls"; and in 1895, "several large Seagulls remain about ship for the winter months; and by day, when they happen to get a small bird, such as a Blackbird or Lark, worn out after a long flight, they give it chase, kill it, and eat it, feathers and all." Observations to the same effect are reported from Coningbeg, Barrels Rock, Lucifer Shoals, Arklow South, and Codling Bank Lightships.

In considering why birds migrate by night rather than by day, these predatory propensities of the Gulls must not be lost sight of. Owing to their numbers, Gulls must be a terror to birds of weak flight, and they are undoubtedly a greater peril to all species travelling across the sea than are Hawks during the overland flight. Both dangers are largely minimised by the expedient of nocturnal migration.

No specimen of Larus aryentatus has been received.

\section{Lesser Black-BACKed Gull (Larus fuscus, Linn.).}

Only about 10 occurrences of this common bird are noted, so that it must be confused with other species. In 23 instances the term "Black-backed Gull" is used without indication as to Gull. whether the present or the next species is intended. None of the observations are of interest. 
Great Black-backed Gull (Larus marinus, Linn.). Great Of the Great Black-backed or "Royal" Gull, some 77 occurBlack-backed rences are reported. They are chiefly from western stations, Gull.

as is shown by the following table:-

\begin{tabular}{|lc|c|c|c|c|c|c|c|c|c|c|c|c|c|}
\hline & Jan. & Feb. & Mar. & April & Iay. & June & July. & Aug. & Sept. & Oct. & Nov. & Dec. & Total \\
\hline South Coast, & 1 & $\ldots$ & $\ldots$ & 1 & 2 & $\ldots$ & $\ldots$ & 1 & $\ldots$ & $\ldots$ & 2 & 1 & 8 \\
East & $\prime$ & 1 & $\ldots$ & $\ldots$ & 1 & $\ldots$ & 1 & 1 & 3 & 1 & $\ldots$ & 3 & 2 & 13 \\
North &, & $\ldots$ & $\ldots$ & $\ldots$ & $\ldots$ & 1 & $\ldots$ & $\ldots$ & 2 & $\ldots$ & $\ldots$ & $\ldots$ & 1 & 4 \\
West $\quad$, & 4 & 2 & 6 & 2 & 4 & 3 & 2 & 3 & 6 & 3 & 8 & 9 & 52 \\
\hline
\end{tabular}

Two-thirds of the observations are in the half-year August to January, but the evidence is insufficient to prove an autumnal increase in numbers. Assemblages of more than 2 are considered rare, but from 5 to 10 have occasionally been noted, chiefly on the west coast, and flocks of 15 to 30 "Royal Gulls" are recorded in the following instances,-i.e., twenty on January 6, 1887, at Blackrock (Mayo); eighteen on March 15, 1893, at Rathlin O'Birne; a large number going S.E., June 29, 1892, at the Tearaght; flocks of twenty to thirty at intervals in August 1883 at Rathlin Island; thirty on November 12, 1887, at Broadhaven; and two to fifteen on December 24 and 25, 1884 , at Valentia.

Glaucous Gult (Larus glancus, O. Fabricius) and

ICELAND GULL (Larus leucopterus, Faber).

Glaucous Gull. Iceland Gull.
The Glaucous and Iceland Gulls have been generally accounted rare and accidental visitants, but the light-keepers' reports show that "Cream-coloured Gulls," belonging to one or other species, have occurred almost every year from 1881 to 1899. As the data have been generally given under "Gulls," it may be convenient to summarise them.

1881. Blackrock, Mayo, Aug.,

a "cream-coloured" or "North American Sea-Gull" about coast.

1882. April and May, one or two "North American or cream. coloured Gulls."

[1883. No observations.] 
884. Blackrock, Mayo, Oct. 11,

1885. No observations. ]

886. Blackrock, Mayo, Nov, 5 ,

five "cream-coloured Gulls."

two "cream-coloured Gulls," "about size of Iceland small Royal Gull." [Probably Iceland Gull. Gulls.]

887. Blackrock, Mayo, $\left\{\begin{array}{c}\text { Nov. } 8 \text { and } 14 \\ \text { and Dec } 24,\end{array}\left\{\begin{array}{c}\text { "Glaucous Gull" reported. The light- } \\ \text { keeper adds, "I identified subsequat }\end{array}\right.\right.$ in Dublin Museum."

$\begin{array}{ll}\text { Slyne Head, } & \text { Nov. } 7, \\ \text { Tearaght, } & \text { Dec. } 12,\end{array}$

888. Fastnet, Blackrock, Mayo, Jan. 6 ,

Fob. 10, March 13, Nov, 15, Oct. 31, Jan. 13, Feb. 16, Jan, 6, March 17, Dec. 16, Nov. 6 , one "cream-coloured Gull."

"four cream-coloured Gulls," "seemed large."

"one large Iceland Gull."

"Glaucous Gull" noted.

"Iceland Gull" noted.

"Iceland Gull" noted.

"one cream-coloured Sea-Gull."

"one cream-coloured Sea-Gull."

"one Iceland Gull" noted.

"two Iceland Gulls." one "cream-coloured or Iceland Gull." one "Iceland Gull."

Iceland Gull, shot, received in flesh. two "cream-coloured Gulls."

f Oct. 30 and fone "Iceland Gull," "very large." [Prob. \{ Nov. 6, $\{$ ably Glaucous Gull.]

Nov. 1, four "yellow-backed Gulls" on island.

Feb. 10, one "Iceland Gull" noted.

Jan. 10, one "Iceland Gull" noted, "a young bird." Feb. 2, Glaucous Gull, shot as a "large Iceland Gull," reccived in flesh.

Nov. 14, one "Iceland Gull " noted, "a young bird."

one "Iceland Gull," "young bird."

Killybegs,

",

Samphire Island,

Feb, 20,

May 10 ,

Nov..14,

895. Blackrock Point, Feb. 23,

896. Kathlin O'Birne,
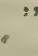

,

, s

9

,

,

,

Skelligs,

Fastuet,

Dungarvan, one Iceland Gull.

one Iceland Gull.

one Iceland Gull.

Glaucous Gull, very small, probably shot, received in flesh.

Glaucous Gull, shot, reccived in ficsh.

two "Glaucous" and one "Icoland Gull" reported.

Glaucous Gull, shot, received in flesh.
Iceland Gull, shot, received in flesh.

"Glaucous Gull" noted.

"Iceland Gull" noted.

Glaucous Gull, shot, received in flesh.

"Glaucous Gull" reported.

"Iceland Gull" reported.

Dec. 27,

Jan. 12 to 15 ,

Dec. 16,

Oct. 30 ,

Oet. 31 ,

Nov. 3,

two supposed "Ivory Gulls."

one "cream-coloured" or "supposed Arctic

Gull." 
Glaucous Gull. Iceland Gull.

1897. Rathlin O'Birne, $\left\{\begin{array}{c}\text { Jan. } 3 \\ \text { Feb. 18, }\end{array}\right\}$ one "Glaucous Gull" noted.

[1898. No specimens. Observations not yet analysed.]

$\begin{array}{cccc}\text { 1899. Spit Bank, } & \text { April 15, } & \text { Iceland Gull, shot, reccived in flesh. } \\ \text { ", } & \text { ", } & \text { April 29, } & \text { Iceland Gull, shot, received in flesh. } \\ \text { ", } & \text { May 2, } & \text { Glaucons Gull, shot, received in flesh. }\end{array}$

We have here 54 occurrences, 10 being attested by specimens-6 of the Glaucous and 4 of the Iceland Gull. Of the 44 unattested occurrences, there is some reason for assigning 13 to the Glaucous Gull, whose larger size is used as a distinguishing mark. We have thus either positive or probable evidence of the Glaucous Gull's having visited our sea-board in the winters of 1887-88, 1892-93, 1894-95, 1896-97, 1897-98, and 1898-99. Specimens have been received in four of these seasons -in February 1893, February 1895, October and November 1896, and May 1899.

While 13 unattested observations presumably refer to the Glaucous Gull, there are 20 in which there is some reason to suppose the Iceland Gull intended, but the grounds in each individual instance are very slight. Four specimens of Larus leucopterus have been forwarded-1 in December 1891, 1 in October 1896, and 2 in April 1899.

From the data, it appears probable that the two species commonly arrive about the same time on the same parts of the coast. Thus, between October 12 and November 3, 1896, Rathlin O'Birne sent 4 specimens, three of the Glaucous and one of the Iceland Gull; while between April 15 and May 2, 1899, Spit Bank forwarded 3, two of the Iceland Gull and one of the Glaucous.

Of the two, Larus glaucus has been forwarded the earlier in autumn and later in spring; but the examples are too few to establish any difference between the times of arrival and departure of the two species.

The coast-distribution of both is apparently identical, as is shown by the localities of the ten specimens.

The observations and specimens combined show 44 occurrences on the west coast and 9 on the south, to 1 on the east and none on the north. The following table exhibits the number recorded for each month. As many as 36 of the west coast occurrences are from the strip between Rathlin O'Birne and Blackrock (Mayo). 


\begin{tabular}{|lc|c|c|c|c|c|c|c|c|c|c|c|c|c|}
\hline & Jan. & Feb. & Mar. & April & May. & June & July. & Aug. & Sept. & Oct. & Nov. & Dec. & Total \\
\hline South Coast, & 2 & 2 & 1 & 2 & 1 & $\ldots$ & $\ldots$ & $\ldots$ & $\ldots$ & $\ldots$ & $\ldots$ & 1 & 9 \\
East &, & $\ldots$ & 1 & $\ldots$ & $\ldots$ & $\ldots$ & $\ldots$ & $\ldots$ & $\ldots$ & $\ldots$ & $\ldots$ & $\ldots$ & $\ldots$ & 1 \\
North &, & $\ldots$ & $\ldots$ & $\ldots$ & $\ldots$ & $\ldots$ & $\ldots$ & $\ldots$ & $\ldots$ & $\ldots$ & $\ldots$ & $\ldots$ & $\ldots$ & $\ldots$ \\
West &, & 4 & 5 & 1 & 1 & 2 & $\ldots$ & $\ldots$ & 1 & $\ldots$ & 10 & 14 & 6 & 44 \\
\hline & & 6 & 8 & 2 & 3 & 3 & $\ldots$ & $\ldots$ & 1 & $\ldots$ & 10 & 14 & 7 & 54 \\
\hline
\end{tabular}

A feature of some interest in the above table is the large proportion of south coast observations from January to May as compared with the autumnal months, in which nearly all the occurrences reported have been at western stations.

It is probable that in years in which the Glaucous and Iceland Gulls are not observed at all on the Irish mainland, they nevertheless occur at sea within 7 or 8 miles of the coast. That this is so may be inferred from the fact that during the years 1881 to 1889 all the observations of "creamcoloured Gulls" (16 in number) were from islands of the west and south-west-12 from Blackrock (Mayo), 2 from the Tearaght, 1 from Slyne Head, and 1 from the Fastnet.

All the examples obtained are in immature plumage. An approach to the "white phase" of the nearly adult Iceland Gull occurs in one of the specimens shot at Spit Bank in April 1899.

The data are insufficient for determining which is the rarer species on the Irish coast. Thompson considered the Iceland Gull the less frequent, and this appears to have been the opinion of the late A. G. More, who described the Glaucous Gull ("List of Irish Birds," 1890) as a "rare and uncertain," the Iceland Gull as a "very rare and accidental," visitant. On the other hand, Mr R. Warren, writing in 1892 (Irish Naturalist, vol. i. p. 129), states that the Iceland has occurred much more frequently than the Glaucous Gull in the vicinity of Killala Bay; and this testimony is rendered especially important by the fact that two-thirds of the "cream-coloured Gulls" reported from light-stations (thirty-six out of fifty-four) were observed within forty miles of Killala. Only two specimens of the Iceland Gull, however, have been forwarded from that part of the coast, Rathlin O'Birne to Blackrock (Mayo), while five 
Glaucous Gull.

Iceland

Gull.

examples of the Glaucous Gull have been received from lightkeepers, as well as two others from coast-guard stations, within the same district. From the whole coast-including the two last-mentioned birds-we have a total of eight Glaucous and four Iceland Gulls received between 1891 and $1899 .^{1}$

\section{KITTIWAKe (Rissa tridactyla, Linn.).}

Kittiwake. The Kittiwake is the only Gull known to have been killed striking a lantern. A specimen in immature plumage was received from the Tearaght, killed striking December 16, 1890. A young example was also caught at light, August 21, 1890, at Aranmore. Besides these two birds forwarded, a Kittiwake is reported to have been killed striking at Hook Tower, October 23, 1891; and a "Seagull" killed striking at Arklow North Light-ship, November 12, 1894, may have been of the same species. There is no satisfactory evidence of any Gull having struck in spring.

The observations relating to the Kittiwake from each section of the coast are as follows :-

\begin{tabular}{|rrr|r|r|r|r|r|r|r|r|r|r|r|r|r|r|}
\hline & & Jan. & Feb. & Mrar. & April & May. & June & July. & Aug. & Sept. & Oct. & Nov. & Dec. & Total \\
\hline South Coast, & 1 & 1 & 3 & 8 & 4 & 3 & 1 & 6 & 6 & 3 & 5 & 5 & 46 \\
East &, & $\ldots$ & $\ldots$ & $\ldots$ & 3 & 3 & 3 & 1 & 4 & 4 & 1 & $\ldots$ & 2 & 21 \\
North &, & $\ldots$ & $\ldots$ & 3 & $\ldots$ & 1 & $\ldots$ & $\ldots$ & 1 & 1 & $\ldots$ & $\ldots$ & 1 & 7 \\
West &, & 6 & 3 & 24 & 16 & 8 & 4 & 3 & 10 & 7 & 12 & 7 & 6 & 106 \\
\hline
\end{tabular}

The large proportion from the west coast is due to three light-houses situated on rocks where Kittiwakes breed-Blackrock (Mayo), Tearaght, and Skelligs-from which seventy-five observations are reported. When allowance is made for this fact, it will be seen that the migrational evidence is very scanty.

The "landing" of the birds at their western breeding-stations generally takes place between the 12th and 24th of March, but in 1883 is recorded to have occurred at the Tearaght so early

${ }^{1} \Lambda$ fifth Iceland Gull in the "white phase" has been forwarded during the present year, shot at Kingstown about March 10, 1900. 
as February 6 (possibly an error, as the spring of 1883 was Kittiwake. notoriously one of unusual backwardness with most migrants).

For ten years, 1882 to 1891, the first landing of the Kittiwakes on the west coast, when taking possession of their old nests, was recorded thus:-

\begin{tabular}{|c|c|c|c|}
\hline & Blackrock (Mayo). & Tearaght. & Skelligs. \\
\hline 1882 & No record. & No record. & March 22. \\
\hline 1883, & (1) & February 6. & No record. \\
\hline 1884, & & No record. & March 24. \\
\hline 1885, & March 31. & & March 16. \\
\hline 1886 & March 21. & March 5. & March 12. \\
\hline 1887, & No record. & No record. & March 14. \\
\hline 1888, & March 6. & No record. & March 4. \\
\hline 1889, & March 11. & March 14. & March 14. \\
\hline 1890 & No record. & March 27. & No record. \\
\hline 1891, & March 23. & March 22. & $"$ \\
\hline
\end{tabular}

In the years 1888,1889 , and 1891, the records from different stations corroborate each other closely, and show that the dates of landing may vary from March 4th and 6th in one year to March 22nd and 23rd in another.

Though the nests are appropriated thus early in the year, laying does not commence until nearly the end of May. In 1883, eggs were first noted at the Tearaght ("only two found among hundreds of nests") on May 24 ; in 1885, at Skelligs, "Kittiwakes commenced laying" on June 6.

The searcity of young birds of the previous year about the breeding-stations in summer has long been noted. The late A. G. More was of opinion that the young Kittiwakes went far out to sea in May and June, and this was confirmed by the Rockall Expedition of $1896 .{ }^{1}$

The departure of the mass of the breeding birds generally takes place in August. At the Tearaght, in 1893, it is said to have occurred on July 15th ; in 1883, "about September 1st." At the Skelligs, Kittiwakes are recorded in 1882 as departing on August 26th; in 1883, August 15th to 28th. In 1885 the Tearaght light-keeper, Mr M'Carron, observes that "the Kittiwake remains long after the Puffin, Razorbill, and Guillemot are gone, but leaves before the Stormy Petrel." Though most

1 "Report on the Ornithology of the Rockall Expedition," by Harvie-Brown and Barrington, Trans. Roy. Irish Acad, vol. xxxi. part iii., pp. 66 and 71. 
Kittiwake. of the birds depart, some remain about these rocks throughout the winter.

Direction of flight is seldom given, but there is fragmentary evidence of a northward movement in April, and of a southward (or perhaps south-westward) one in September, October, and November. Thus in 1888 Kittiwakes were noted going $\mathrm{N}$. at Slyne Head almost daily from April 4th to 14th, and at Fastnet going N.W. on April 28th; while on May 3rd flocks of "Gulls" (probably the same species) were going N. all day at North Arran Island. The southward or south-westward movement in autumn has been reported from Dungarvan, Blackrock (Mayo), Slyne Head, and the Skelligs, but only on a few occasions. Some important flights were noted at Dungarvan by $\mathrm{Mr}$ Dunleavy on September 9 and October 9, 1897; on the former date, "Kittiwakes going W., flying very high in one continuous flock, about one hundred yards wide and about a mile in length;" on the latter, "thousands of Kittiwakes going S.W."

It is probable that many of the flocks of "Gulls" observed in early summer are composed of Kittiwakes, but the records cannot be discriminated. May is the month in which flocks of Gulls are most frequently noted, the observations of such gatherings for each month being as follows :-

Jan. Feb. March, April, May, June, July. Aug. Sept. Oct. Nov. Dec.

$\begin{array}{llllllllllll}11 & 10 & 32 & 39 & 45 & 29 & 17 & 26 & 30 & 35 & 41 & 25\end{array}$

Great Skua (Megalestris catarhactes, Linn.), Pomatorinne Skua (Stercorarius pomatortinus, Temminck), and RicharDson's SkUA (Stercorarius crepidatus, J. F. Gmelin).

Great Skua. Pomatorhine
Skua. Richardson's Skua. 
it "the largest I have ever seen, and very dark in colour." It Great skua. was noted chasing a "Grey Gull" (probably Herring Gull). Pomatorhine

The evidence is not sufficient to justify any inferences as to Richardson's migration.

\section{Buffon's SkuA (Stercorarius parasiticus, Linn.).}

An example of this species, which rarely visits the Irish Buffon's coast, has been received from Samphire Island, where it was Skua. shot in the autumn of 1893.

[Obs.-The Great Shearwater (Puffinus gravis, O'Reilly), a rare straggler to Irish waters, is believed to have been observed by Mr F. Ryan close to the Tearaght Rock on September 21, 1887, but was not obtained. It is not improbable that this species ${ }^{1}$ may, like the Fulmar, be met with every summer in limited numbers off the west coast of Ireland, seldom approaching land, however, nearer than 20 miles.]

\section{Manx Shearwater (Puffinus angiorum, Temminck).}

Unlike most web-footed birds, Shearwaters and Petrels Manx strike the lanterns with some frequency. The instances in Shearwater. which the Manx Shearwater is reported as striking, or as found disabled, amount to 35 ; and seven examples have been forwarded,-five killed striking, one caught (probably disabled at lantern), and one stunned. With this bird nocturnal habits do not prevent occasional bewilderment at night.

The total number of observations of this species (usually called "Mackerel Cock" by the light-keepers) is 319. The number for each month and section of the coast is as shown below :-

\begin{tabular}{|ll|r|rr|r|r|r|r|r|r|r|r|r|r|r|r|}
\hline & & Jan. & Feb. & Mar. & April & May. & June & July. & Aug. & Sept. & Oct. & Nov. & Dec. & Total \\
\hline South Coast, & $\ldots$ & 6 & 17 & 25 & 25 & 19 & 16 & 6 & 9 & 3 & 1 & 6 & 133 \\
East &, & $\ldots$ & $\ldots$ & 19 & 25 & 32 & 21 & 6 & 5 & 3 & 2 & $\ldots$ & $\ldots$ & 113 \\
North &, & $\ldots$ & $\ldots$ & 2 & 2 & $\ldots$ & $\ldots$ & $\ldots$ & 1 & $\ldots$ & $\ldots$ & $\ldots$ & $\ldots$ & 5 \\
West &, & 1 & 3 & 10 & 9 & 8 & 6 & 6 & 12 & 3 & 6 & 4 & $\ldots$ & 68 \\
\hline
\end{tabular}

1 "Peport on the Ornithology of the Rockall Expedition," op. cit., p. 235. 
The half-year from March to August yields 272 observations Shearwater. averaging 45 per month; the half-year from September to February yields 50, averaging 8 per month. The east and north coasts furnish none earlier than March or later than October; but the south has records for every month, except January, and the west for every month except December.

The instances in which the birds are said to have struck the lanterns tend to show that May and August are the months of principal migration:-

\begin{tabular}{|l|r|r|r|r|r|r|r|r|r|r|r|r|r|}
\hline & Jan. & Feb. & Mar. & April & May. & June & July. & Aug. & Sept. & Oct. & Nov. Dec. \\
\hline Instances, &. & $\ldots$ & $\ldots$ & 2 & $\frac{1}{4}$ & 14 & 4 & $\ldots$ & 10 & 1 & $\ldots$ & $\ldots$ & $\ldots$ \\
Specimens sent, & $\ldots$ & $\ldots$ & $\ldots$ & 1 & 5 & $\ldots$ & $\ldots$ & 1 & $\ldots$ & $\ldots$ & $\ldots$ & $\ldots$ \\
\hline
\end{tabular}

The chief spring migration appears, therefore, to extend from March 2 to June 14; and the chief autumn migration from August 2 to September 1.

It may be of interest to compare the above with records of the same bird's arrival at its breeding-stations, which is generally announced by its nocturnal cry. Such notes are furnished from five light-houses-Howth. Baily, Rathlin Island, Aranmore, Tearaght, and Skelligs. The extreme dates from each are as follows :-

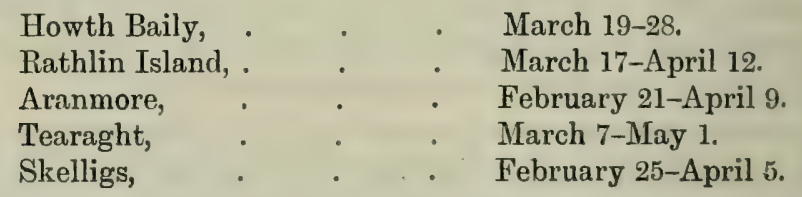

Three of these stations also furnish notes as to the last date at which the bird has been heard:-

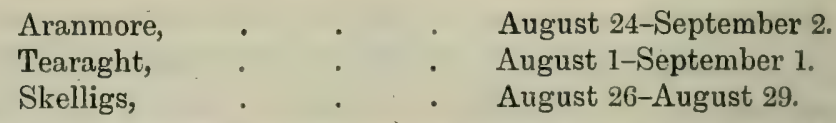

The usual period is apparently from the last week of March to the last week of August. This is not inconsistent with a large augmentation of the numbers during May; at the same time, it is possible that many of the migrants observed at that season are bound for higher latitudes.

The stations from which the largest numbers of observations have been forwarded are:- Barrels Rock Light-ship (70), 
Arklow North Light-ship (42), Arklow South Light-ship (33), Coningbeg Light-ship (28), Skelligs-a breeding-station of the species - (21), Tearaght-a breeding - station - (20), Howth Baily-in the vicinity of a breeding-station-(19), Aranmore - a breeding-station-(15), Hook Tower (14). There are not more than seven records from any other station.

The light-ship observations of this species are so numerous, in proportion to those furnished from islands and the mainland, that they merit a separate analysis. They show a great preponderance of vernal over autumnal records. According to months, they are as follows:-

\begin{tabular}{|l|r|r|r|r|r|r|r|r|r|r|r|r|r|}
\hline & Jan. & Feb. & Mar. & April & May. & June & July. & Aug. & Sept. & Oct. & Nov. & Dec. \\
\hline Coningbeg, &.$\ldots$ & $\ldots$ & 4 & 5 & 7 & 3 & 2 & 2 & 5 & $\ldots$ & $\ldots$ & $\ldots$ \\
Barrels Rock, & $\ldots$ & $\ldots$ & 6 & 11 & 12 & 10 & 13 & 7 & 1 & 1 & 3 & 1 & 5 \\
Arklow S., & $\ldots$ & $\ldots$ & $\ldots$ & 5 & 4 & 12 & 7 & 1 & 3 & 1 & $\ldots$ & $\ldots$ & $\ldots$ \\
Arklow N., & $\ldots$ & $\ldots$ & $\ldots$ & 5 & 10 & 13 & 9 & 3 & 1 & $\ldots$ & 1 & $\ldots$ & $\ldots$ \\
Other light-ships, & $\ldots$ & $\ldots$ & 3 & 4 & 3 & 1 & $\ldots$ & $\ldots$ & $\ldots$ & $\ldots$ & $\ldots$ & $\ldots$ \\
\hline
\end{tabular}

Allowing for some errors, there is enough corroboration here to show that the Manx Shearwater is much more numerously seen at light-ships from March to June than during the rest of the year. This period corresponds with that of the spring migration, as shown by the records, already quoted, of birds killed striking at that season,-earliest, March 2, 1885, at the Skelligs; latest, June 14, 1892, at Blackrock (Mayo). Specimens killed striking have been received in spring from Old Head (Kinsale), Mine Head, Coningbeg Light-ship, Howth Baily, and Slyne Head. None were forwarded in June, but the Mine Head example struck as late as May 27.

The fact that the Manx Shearwater is not recorded as heard at its breeding-stations later than September 2, combined with the fact that it has not been reported as striking the lantern later than September 1, may be accepted as evidence that August is the month of principal autumnal migration. During that month one specimen has been received, found stunned in the balcony of Howth Baily light-house, August 2, 1891," 
Fork-tailed Petrel (Oceanodroma leucorrhoa, Vieillot).

Fork-tailed Petrel.

This interesting species, formerly accounted one of our rare and accidental visitors, has been ascertained by the lightkeepers to breed on two wild and rocky islets off the west coast, Tearaght and Blackrock (Mayo). At the former station its egg was first found in 1886, and other eggs (with the birds caught on them) were forwarded in each of the two following years. From the latter station only one egg has been forwarded, a much incubated one, received August 13, 1899.

That this Petrel occurs annually at our western and southwestern stations is probable, from the fact that during the fourteen years 1886-1899 it has been either forwarded or reported in nine.

The only evidence as to the time of spring migration is an example from the Fastnet, caught at lantern May 5, 1896.

In autumn, four specimens with satisfactory data have been received-one from Eagle Island West, caught at lantern in second week of October 1886; one from Berehaven, killed striking October 28, 1897 ; one from Blackrock (Mayo), caught in yard, November 15, 1887 ; and one from Old Head, Kinsale, which struck the lantern November 20, 1895. A skin without data was sent from Blackrock (Mayo), September 9, 1892, but this bird may have been shot, and there is no direct evidence of migration in September.

Large Petrels, probably of this species, were seen about the Skelligs from October 14th to 18th, 1891. This is the only uncorroborated observation.

Thus the stations from which the Fork-tailed Petrel has been noted are all situated on the western and south-western seaboard between Eagle Island and Kinsale, the west coast proper yielding nine occurrences, and the south coast (Fastnet and Kinsale) two. The earliest and latest occurrences were the two on the south coast (May 5 at Fastnet, November 20 at Old Head, Kinsale).

\section{Storm Petrel (Procellaria pelagica, Linn.).}

Storm The Storm Petrel occurs numerously on migration at both

Petrel. seasons, especially on the south and west coast.

Nineteen 
specimens, killed or caught at lanterns, have been forwarded, of which one was obtained in spring (Eagle Island, E., May $24,1886)$ and eighteen in autumn; earliest at North Arran, July 26, 1898; latest at Arklow North Light-ship, November $24,1892$.

The observations for each month are as follows:-

\begin{tabular}{|lr|r|r|r|r|r|r|r|r|r|r|r|r|r|}
\hline & Jan. & Feb. & Mar. & April & Iay. & June & July. & Aug. & Sept. & Oct. & Nov. & Dec. & Total \\
\hline South Coast, & $\ldots$ & $\ldots$ & $\ldots$ & 3 & 28 & 14 & 16 & 13 & 30 & 27 & 11 & 2 & 144 \\
East &, & 1 & $\ldots$ & $\ldots$ & 1 & 7 & 6 & 5 & 13 & 9 & 15 & 8 & $\ldots$ & 65 \\
North &, & 1 & $\ldots$ & $\ldots$ & $\ldots$ & $\ldots$ & 1 & 2 & 2 & 2 & 1 & $\ldots$ & $\ldots$ & 9 \\
West & $\ldots$ & $\ldots$ & $\ldots$ & 2 & 7 & 15 & 14 & 13 & 6 & 11 & 13 & 5 & 2 & 88 \\
& 2 & $\ldots$ & 2 & 11 & 50 & 35 & 36 & 34 & 52 & 56 & 24 & 4 & 306 \\
\hline
\end{tabular}

The months of principal migration thus seem to be May, September, and October. More strictly, the maximum movement in spring, according to the observations, is from May 10 to June 10 , and in autumn from September 20 to October 20.

\begin{tabular}{|c|c|c|c|}
\hline \multicolumn{2}{|c|}{ SPRING. } & \multicolumn{2}{|c|}{ AUTUMN. } \\
\hline & Observations. & & Observations \\
\hline April 10-May 10, & 20 & July 20-Aug. 20, & 43 \\
\hline May 10-June 10, & 63 & Aug. 20-Sept. 20, & 36 \\
\hline June 10-July 10, & 16 & Sept. 20-Oct. 20, & 70 \\
\hline & & Oct. 20-Nov. 20, & 31 \\
\hline
\end{tabular}

The observations from different stations corroborate one another so strongly that their general accuracy cannot be doubted, though the specimens would yield a totally different conclusion as regards the autumnal movement. Two examples were sent in July, six in August, two in September, one in October, and seven in November. The disproportionately large numbers towards the beginning and close of the period of migration may be partly accidental, since the total (18) is not sufficiently large to eliminate the element of chance, and four of the November specimens were sent in 1891. Nevertheless, it can in some degree be explained by a tendency on the lightkeepers' part to forward the first specimen of a common bird 
Storm which strikes, while omitting to send later ones. The observa-

Petrel. tions record few instances of Petrels striking lanterns on the east coast prior to November, though on the west coast striking is frequent from about the end of July. In accordance with this fact, the nine specimens received between July 20 and September 20 are all from north and west coast stations, Rathlin Island to Skelligs; while of nine sent later (September 21 to November 24), eight are from south-east and east coast stations, between Hook Tower and South Rock Light-ship. From the light-keepers' reports it appears that many strike the lanterns at westerly stations in September and October, though so few have been forwarded during those months that in the case of a less familiar species the observations would have to be discredited.

The largest rush of Storm Petrels noted at lanterns in any year took place on the nights of the 27 th and 28 th of July 1889 , as is shown by the corroborative reports of three south-western stations-Fastnet, Tearaght, and Bull Rock. At the Fastnet, "hundreds appeared about the light on July 27th; several were captured and let off again ; wind light N.W., misty." At the Tearaght, "July 27 th and 28 th, immense numbers of Petrels all night round the light ; one ikilled, several caught; fog, rain." At the Bull Rock, writing on July 29th, forwarding some moths caught during a fog the previous night, the light-keeper adds, "A large number of Storm Petrels made several attempts to enter the lantern at the same time."

It is worth noting that so nocturnal a bird as the Storm Petrel is as much influenced as other species by the presence or absence of moonlight, and rarely strikes except in the fourth and first Quarters. The large rush above referred to occurred at the Fastnet and Tearaght on the night of New Moon; and of 17 specimens, the date of whose striking is definitely ascertained, 13 struck in the dark half, and the remaining four on dates coincident with a change of moon from dark to bright half, or vice versâ. Two examples were picked up dead at Hook Tower in the second Quarter, but the date on which they were killed is not certain.

The amount of variation in the lengths of the wing is small. Average, 4.75 ; longest, 5.00 ; shortest, 4.55 ; difference between extremes, 0.45 ; percentage of variation, $9 \frac{1}{2}$. 
Razorbill (Alca torda, Linn.) and

Common Guiliemot (Uria troile, Linn.).

These two species, under the name of "Mur," are frequently confounded with one another by the light-keepers, who occasionally misname them "Puffin." None of the birds belonging Razorbill. to this family (Alcido) are known to strike the lanterns. Consequently precise data respecting their movements are extremely scanty, and but for the observations contributed from two principal breeding-stations-the Tearaght and Skelligs - would be practically nil. Thousands breed at these stations, and there are ample opportunities of distinguishing them.

The notes at these two Kerry localities show that the Guillemot usually arrives in their vicinity for purposes of nidification during January, while the Razorbill is seldom observed to do so before March. The dates of the earliest observation of each species at Tearaght or Skelligs during the twelve years 1882-93 (there are no records from either station since the latter year) are quoted below, the dates of the first landing on rock being also quoted when such are available.

\begin{tabular}{|c|c|c|c|}
\hline \multicolumn{2}{|c|}{ GUILLEMот. } & \multicolumn{2}{|c|}{ RazorbiLL. } \\
\hline $\begin{array}{l}\text { First Noted. } \\
\text { Feb. } 21 \text { (T.). }{ }^{1} \\
\text { Jan. } 20 \text { (T..). } \\
\text { Jan. } 28 \text { (T.). } \\
\text { Jan. } 28 \text { (T.). } \\
\text { Jan. } 28 \text { (S.). } \\
\text { Jan. } 28 \text { (T.). } \\
\text { Jan. } 29 \text { (T.). } \\
\text { Jan. } 23 \text { (S.). } \\
\text { Jan. } 1 \text { (T.). } \\
\text { Jan. } 7 \text { (S.). } \\
\text { Jan. } 30 \text { (T.). } \\
\text { Jan. } 17 \text { (T.). }\end{array}$ & $\begin{array}{l}\text { First Landed. } \\
\text { Feb. } \ldots \\
\text { Feb. } 19 \\
\text { Fe (T.). } \\
\text { Jan. } 28 \text { (S.). } \\
\text { Feb. } 6 \text { (T.). } \\
\text { Jan. } 30 \text { (S.). } \\
\text { Jan. } 31 \text { (T.). } \\
\text { Jan. } 7 \text { (S.). } \\
\text { Jan. } 30 \text { (T.). } \\
. . .\end{array}$ & $\begin{array}{l}\text { First Noted. } \\
\text { March } 28 \text { (S.). } \\
\text { March } 19 \text { (T.). } \\
\text { March } 23 \text { (T.). } \\
\text { March } 12 \text { (T.). } \\
\text { March } 12 \text { (S.). } \\
\text { March } 3 \text { (T.). } \\
\text { March } 3 \text { (S.). } \\
\text { March } 1 \text { (S.) } \\
\text { Jan. } 1 \text { (T.). } \\
\text { Feb. } 26 \text { (S.). } \\
\text { Feb. } \quad 28 \text { (T.). }\end{array}$ & 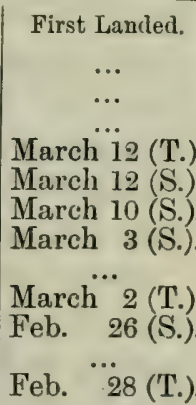 \\
\hline
\end{tabular}

The uniformity of these records warrants the inference that the Razorbill is generally a full month later than the Guillemot in occupying its breeding-ground. ${ }^{2}$

1 The letters (T.) and (S.) indicate Tearaght and Skelligs.

2 As the Razorbill in winter plumage is white-throated, and therefore especially liable to be mistaken for the Guillemot, this inference would scarcely be justified were it not that many of the Tearaght records are from Mr M'Carron, who is well acquainted with the difference between "White-throated" and "Black. throated " Razorbills. 
Razorbill. On the other hand, the departure of the two is nearly

Guillemot. coincident. In most years it is noted as commencing in July, and as over before the middle of August. When any difference is recorded, it has the effect of making the Razorbill a little later in leaving than the Guillemot.

\begin{tabular}{|c|c|c|c|c|}
\hline & \multicolumn{2}{|c|}{ GUILLEMOT. } & \multicolumn{2}{|c|}{ RAZORBILL. } \\
\hline $\begin{array}{l}1882, \\
1883, \\
1884, \\
1885, \\
1886, \\
1887, \\
1888, \\
1889, \\
1890, \\
1891, \\
1892, \\
1893,\end{array}$ & $\begin{array}{c}\text { Noted as Leaving. } \\
\text { Aug. } 1 \text { (S.). } \\
\text { Aug. } 1 \text { (T.). } \\
\text { July } 20 \text { (T. }(\mathrm{S} \text {. }) . \\
\text { July } 20 \text { (S.). } \\
\ldots \\
\ldots \\
\ldots \\
\text { July } 10 \text { (S.). } \\
\ldots \\
\ldots \\
\text { July } 10 \text { (T.). } \\
\text { July } 1 \text { (T.). }\end{array}$ & 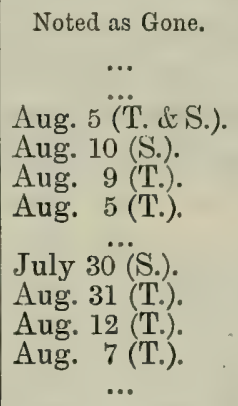 & $\begin{array}{c}\text { Noted as Leaving. } \\
\text { Aug. } 1 \text { (S.). } \\
\text { Aug. } 10 \text { (T.). } \\
\text { July } 31 \text { (T.). } \\
\text { July } 13 \text { (T.). } \\
\ldots \\
\ldots \\
\ldots \\
\text { July } 10 \text { (S.). } \\
\text { July } 15 \text { (T.). } \\
\text { July } 8 \text { (T.). } \\
\text { uly } \ldots \text { (T.). }\end{array}$ & $\begin{array}{c}\text { Noted as Gone. } \\
\qquad . . . \\
\text { Aug. } \ddot{14} \text { (T.). } \\
\text { Aug. } 10 \text { (S.). } \\
\text { Aug. } 9 \text { (T.). } \\
\text { Aug. } 5 \text { (T.). } \\
\text {... } \\
\text { July } 30 \text { (S.). } \\
\text { Aug. } 31 \text { (T.). } \\
\text { Aug. } 12 \text { (T.). } \\
\text { Aug. } 7 \text { (T.). } \\
. . .\end{array}$ \\
\hline
\end{tabular}

The only years in which different dates are given for the departure of each species at the same station are 1883, 1884, and 1893, and in all these the Guillemot's departure is noted from the Tearaght as commencing earlier than the Razorbill's - the greatest difference being eleven days in 1884, and the least four days in 1893. In 1885 the Razorbill's departure is reported as commencing at the Tearaght before that of the Guillemot is noted at the Skelligs, but the observations, being from different stations, are of little value as a standard.

Comparing the total number of observations of Guillemot and Razorbill respectively from Irish light-stations for each month, we find, assuming most of the entries to be correct, that the former species is most numerous in January and August, the latter in March and August.

$\begin{array}{lccccccccccccr} & \text { Jan. } & \text { Feb. } & \text { Mar. April. May. June. July. } & \text { Aug. Sept. } & \text { Oct. } & \text { Nov. Dec. Total. } \\ \text { Guillemot, } & 21 & 18 & 13 & 15 & 8 & 10 & 16 & 21 & 4 & 8 & 3 & 7 & 144 \\ \text { Razorbill, } & 11 & 10 & 39 & 25 & 13 & 9 & 25 & 29 & 12 & 11 & 12 & 13 & 209\end{array}$

The coast-distribution of these records is of no interest, and would be misleading, as they depend on the movements of the few light-keepers who endeavour to distinguish the Razorbill from the Guillemot. The observations disclose no difference 
between the distribution of the two species. Young Razorbills are constantly noted throughout the winter.

As might be expected, "Murs" are chiefly noted at lightships, where the observations are numerous at all seasons.

The few specimens forwarded were shot, with the exception of one--a Guillemot-found on the deck of Blackwater Bank Light-ship, December 26, 1897.

The notes on direction are few, but show a northward tendency in spring and southward in autumn.

\section{Black Guillemot (Uria grylle, Linn.).}

Four specimens have been received, all shot in winter, November 4 to February 15, and all at stations in the northern Black Guillemot. half of Ireland-Dundalk, Green Island (Co. Down), Innishtrahull, and Killybegs. One was shot in November, two in December, and one in February. All were in the mottled plumage of winter, which attracted the attention of the lightkeepers, who failed to recognise the species, and forwarded the birds as "unknown."

The instances in which the bird is reported are only threeFastnet, April 5, 1889; Howth Baily, March 23-25, 1892 ; and Tearaght, February 23, 1897.

We may perhaps assume that the Black Guillemot is commonly overlooked, since it has never been reported during the half-year May to October, the latest spring record being April 5, and the earliest in autumn, November 4.

\section{LitTLE AuK (Mergulus alle, Linn.).}

Three have been forwarded, all from stations in the northern half of Ireland.

One from Vidal Bank (Down), caught at the mouth of a river, November 27, 1890.

Remains of one from Tory Island, found May 1895.

One from Blackrock (Mayo), found uninjured near lighthouse, received December 17, 1896.

Mr M'Carron believes that he has observed the Little Auk at the Tearaght (December 21, 1883, and January 9, 188 \pm ) and at Mine Head (March 28, 1886). 


\section{Puffin (Fratercula arctica, Linn.).}

Puffin. The term "Puffin" is so vaguely applied that the observations on "Sea-Parrots"-which in nearly all cases refer to the present species-are almost the only ones worth attending to. Of these there are 140-128 in the half-year March to August, and 12 in the half-year September to February. They extend round the whole coast, but are most numerous in the S. and S.W. (from Barrels Rock Light-ship to Tearaght).

\begin{tabular}{|rr|r|r|r|r|r|r|r|r|r|r|r|r|r|}
\hline & Jan. & Feb. & Jar. & April & May. & June & July & Aug. & Sept. & Oct. & Nov. & Dec. & Total \\
\hline South Coast, & $\ldots$ & $\ldots$ & 8 & 12 & 21 & 8 & 2 & $\ldots$ & $\ldots$ & 1 & $\ldots$ & $\ldots$ & 52 \\
East & $\ldots$ & $\ldots$ & 1 & 1 & 15 & 7 & 5 & 3 & 1 & $\ldots$ & $\ldots$ & 1 & 1 & 35 \\
North & $\ldots$ & 1 & $\ldots$ & $\ldots$ & 3 & 1 & $\ldots$ & $\ldots$ & $\ldots$ & $\ldots$ & $\ldots$ & $\ldots$ & 1 & 6 \\
West &, & $\ldots$ & 1 & 13 & 14 & 2 & 1 & 3 & 8 & 1 & 3 & $\ldots$ & 1 & 47 \\
\hline
\end{tabular}

Of the twenty-two March observations, twenty-one are later than March 20, while of the nine August observations none are later than August 20. Thus the period of the Puffin's stay may be fixed as not exceeding five months' duration, 21st March to 20th August.

On the Tearaght its arrival has been noted in ten of the eleven years 1882-1892, and has varied from March 23 (in 1884 and 1885) to April 1 (in 1882, 1883, and 1892). Dates of departure from the same station have been noted in seven years, but in some of these years the date given is apparently that of the commencement of the emigration, in others of its conclusion. The earliest date at which adult birds are reported as leaving is August 1 (1884), and the latest date at which any are noted as still remaining is August 20 (1883). We may conclude that the Puffin is punctual in its arrival and departure, coming in the last week of March, and leaving during the first fortnight of August, a few exceptionally lingering into the third week of that month.

Specimens have been forwarded in October (Fastnet, October 30, 1888, killed by Hawk) and December (Tearaght, December 8, 1890, "picked up"), but none have been obtained on migration. 
Great Northern Diver (Colymbus glacialis, Linn.).

The Great Northern Diver is doubtless confounded with the lied-throated species, which is not mentioned by name in the reports, whereas "Northern" or "Great Northern Divers" Great Northern Diver. have been noted in 131 instances-52 of these being on the authority of one light-keeper, Mr G. Dunleavy, while stationed successively at the Fastnet, Spit Bank, Drogheda North, Samphire Island, and Dungarvan light-houses.

The half-year November to April yields 100 observations to 31 in the half-year May to October; but in other respects the data (tabulated below) are insufficient to warrant any conclusion.

\begin{tabular}{|c|c|c|c|c|c|c|c|c|c|c|c|c|c|c|}
\hline & & Jan. & Feb. & Mar. & April & May. & June & July & Aug. & Sept. & Oct. & Nov. & Dec. & Total. \\
\hline South & Coast, & 9 & 1 & 8 & 5 & 2 & $\ldots$ & $\ldots$ & $\ldots$ & 2 & $\ldots$ & 3 & 5 & 35 \\
\hline East & , & 3 & 2 & 1 & 7 & 3 & 2 & ... & 2 & $\ldots$ & 5 & 1 & 6 & 32 \\
\hline North & ," & $\ldots$ & $\cdots$ & $\ldots$ & $\ldots$ & $\ldots$ & 1 & $\ldots$ & $\therefore$ & 1. & $\ldots$ & $\ldots$ & 1 & 3 \\
\hline West & , & 9 & 4 & 7 & 7 & 2 & 3 & 1 & 1 & ... & 6 & 13 & 8 & 61 \\
\hline & & 21 & 7 & 16 & 19 & 7 & 6 & 1 & 3 & 3 & 11 & 17 & 20 & 131 \\
\hline
\end{tabular}

The solitary July occurrence (probably an error) was reported from the Tearaght, July 5, 1893.

The direction of flight has been noted only nine timestwice in spring (March 9 to May 9) and seven times in autumn and winter (September 22 to February 9). In the two former instances the direction was northward, in six of the seven latter it was southward; but the only movement of any magnitude was that reported from Arklow North Light-ship in 1894, when, on October 16th, and again on October 26th and 27th, "flocks" were noted "going S.W. all day."

No Diver has been reported as striking the lantern, nor have the light-keepers forwarded any specimen.

That Colymbus glacialis moves northward along the west coast in considerable numbers in the end of May and early in June is confirmed by the fact that numbers are met with at that time between Achill Island and the mainland in the small inland sea which opens into Blacksod Bay at the Bull's Mouth 
Great on the north, and into Clew Bay on the south. Here as many

Northern as thirty were seen in one day, chiefly in pairs, by R. M. B. in
Diver. 1894. This annual migration has been noted by $\mathrm{Mr}$ J. R. Sheridan of Achill.

Sclatonian or Horned Grebe (Podicipes auritus, Linn.).

Sclavonian or Horned Grebe.
Eared or Black-necked Grebe.
Two very handsome specimens, both adults, in full breeding plumage, were shot by Mr Thomas Wilson, coastguard, in Blacksod Bay, Co. Mayo, on April 15, 1895, and were forwarded in the flesh by the light-keeper there. They are said to have been shot out of a flock of six.

EAREd or Black-Necked GreBe (Podicipes nigricollis, C. L. Brehm).

One has been received-in winter plumage-shot at Killybegs, February 6, 1893.

LitTle Grebe or Dabchick (Podicipcs fuviatilis, Tunstall).

Little Grebe or Dabchick.
Though common in Ireland, the Little Grebe has very rarely been noticed at light-stations. Three have been received, of which one was shot (Berehaven, December 25, 1898), while two were killed striking (Slyne Head, November 16, 1889, and Hook Tower, November 7, 1892). Another is said to have been killed striking at Hook Tower, November 1, 1892, but the light-keeper did not forward it. Slyne Head lantern is 115 feet above the sea-level and Hook Tower 152 feet, so that these birds, of apparently weak powers of flight, were at a considerable elevation, and must have been flying with much velocity at the time.

This is the only Grebe which has struck the lanterns, and the evidence points to some migration during November, but only on a small scale.

[Obs.-The Great Crested Grebe (Podicipes cristatus, Linn.) is not known to have occurred at a light-station. A "Grebe" reported at Innishtrahull, May 3, 1884, may have belonged to that species.] 
Cormorant (Phalacrocorax carbo, Linn.) and

Shag (Phalacrocorax graculus, Linn.).

Two birds seldom distinguished by the light-keepers. Neither Cormorant. the direction of flight, noted in 70 instances, nor the character of the entries in schedules, nor the number of monthly records, justify any conclusion as to the migration of either or both species. Out of 368 observations, only 19 expressly refer to the "Green Cormorant," by which the Shag is probably meant. The term "Crested Cormorant," occasionally used, is doubtless applied to both when breeding.

At several east coast stations (Tuskar, Rockabill, and Mew Island) it has been noticed that Cormorants are plentiful from September or October to April, during which month they probably repair to their breeding-haunts. But a comparison of the total number of observations for each month shows little fluctuation between one season and another, the largest number belonging to December, and the smallest to February.

\begin{tabular}{|c|c|c|c|c|c|c|c|c|c|c|c|c|c|c|}
\hline & & Jan. & Feb. & Mar. & $\Lambda$ pril & IIay. & June & July. & Aug. & Sept. & Oct. & Nov. & Dec. & Total \\
\hline South & oast, & 14 & 7 & 7 & 16 & 11 & 8 & 10 & 3 & 7 & 3 & 12 & 14 & 112 \\
\hline East & ", & 2 & ... & 1 & 6 & 11 & 3 & 3 & 8 & 9 & 8 & 13 & 9 & 73 \\
\hline North & , & 4 & 2 & 1 & 1 & 1 & 3 & 4 & 7 & 4 & 4 & 2 & 11 & 44 \\
\hline \multirow[t]{2}{*}{ West } & \multirow[t]{2}{*}{$"$} & 10 & 7 & 8 & 19 & 12 & 8 & 10 & 7 & 13 & 19 & 14 & 12 & 139 \\
\hline & & 30 & 16 & 17 & 42 & 35 & 22 & 27 & 25 & 33 & 34 & 41 & 46 & 368 \\
\hline
\end{tabular}

GanNet (Sula bassana, Linn.).

The observations are numerous, amounting to 1268 , and Gannet. these include as many as 580 in which the direction of flight is recorded. This is an unusual proportion, and is due to the fact that this large bird generally takes a definite courseswerves but little to the right or left, and can be seen a long distance away, coming towards or going from the observer.

The spring migration is chiefly observed in April, but flocks have been noted going N.E. as early as January 2 (Lucifer Shoals, 1889, and Blackwater Bank, 1891); while northward 
Gannet. movements on an extensive scale have been reported from Slyne Head-on the west coast-on January 9 and 13, 1888.

From January to April the number of observations increases monthly, after which it diminishes from April to July. There is a slight increase again in September, and a considerable one in October, which is the month of the principal autumnal movement.

The following are the numbers for each month:-

\begin{tabular}{|l|r|r|r|r|r|r|r|r|r|r|r|r|r|r|r|}
\hline & Jan. & Feb. & Mar. & April & May. & June & July. & Aug. & Sept. & Oct. & Nov. & Dec. & Tutal \\
\hline South Coast, & 26 & 24 & 40 & 38 & 52 & 27 & 25 & 15 & 19 & 24 & 21 & 31 & 342 \\
East ," & 10 & 28 & 70 & 131 & 90 & 28 & 22 & 28 & 33 & 45 & 12 & 7 & 504 \\
North ", & 1 & 4 & 12 & 16 & 16 & 7 & 6 & 5 & 7 & 9 & 2 & 1 & 86 \\
West ," & 20 & 37 & 50 & 41 & 24 & 21 & 15 & 17 & 27 & 57 & 17 & 10 & 336 \\
\hline & & 57 & 93 & 172 & 226 & 182 & 83 & 68 & 65 & 86 & 135 & 52 & 49 & 1268 \\
\hline
\end{tabular}

The direction of flight is generally more or less parallel to the coast-line-that is to say, at east and west coast stations it is either northward or southward, and at south and north coast stations it is either eastward or westward.

In spring, the movement is northward along the east and west coasts, and westward along the south and north coasts.

During the six months from January 1 to June 30, the northward and southward movements at east and west coast stations compare as follows :-

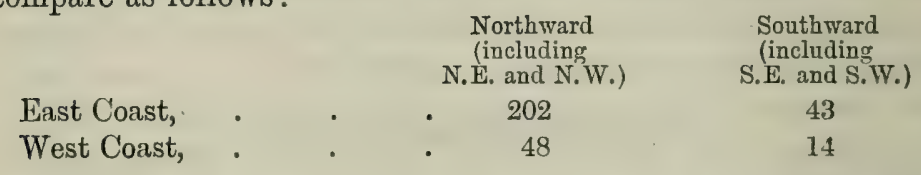

During the same period, the eastward and westward movements at south and north coast stations compare thus:-

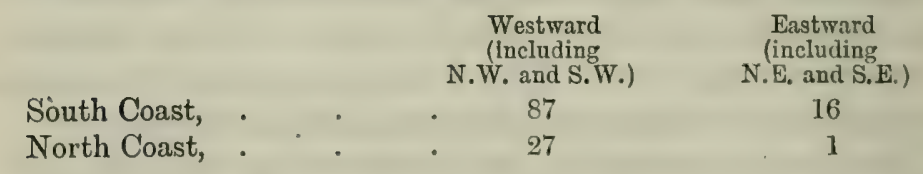

Thus the spring migration is shown to be strongly northwards up the east coast (202 to 43), and strongly westwards 
along the south coast ( 87 to 16). It is less numerously Gannet. observed at north and west coast stations, but is nevertheless distinctly westwards at the former (27 to 1 ) and northwards at the latter (48 to 14).

The westerly direction along the south coast in spring may partly be explained by the fact that the Gannet's Irish breedingstations (the Little Skellig and Bull Rock) are situated at the south-west corner of our island; but this does not account for the uniformly westward movement in spring along the north coast. It may be due to birds coming up the east coast turning to the left on their way to St Kilda and Iceland, past Rathlin Island and Innishtrahull.

In the autumn, we find little evidence of anything like a return migration. On the east and west coasts the directions recorded during the six months from July to December are as follows:-

\begin{tabular}{|c|c|c|c|}
\hline & & $\begin{array}{c}\text { Northward } \\
\text { (including } \\
\text { N.E. and N.W.). }\end{array}$ & $\begin{array}{l}\text { Southward } \\
\text { (including } \\
\text { S.E. and S.W.). }\end{array}$ \\
\hline East Coast, & $\cdot$ & 34 & 35 \\
\hline West Coast & • & 12 & 20 \\
\hline
\end{tabular}

If there is any southward movement here indicated, it is only along the west coast; and this is consistent with the results of the table of observations on p. 250, where the west coast shows a considerable increase in the number of Gannets noted during October, while the remaining sections show only a slight increase at that season.

The records of direction for the last six months of the year on the south and north coasts, are still more barren than those on the east and west:-

N.W. and S.W.

South Coast, . . . 19

North Coast, . . . 3
Eastward

(including

N.E. and S.E.).

18

1

Here the westward and eastward flights just balance each other, so that there is no evidence of migration.

That some large movements are witnessed on the west coast in autumn, is illustrated by the Tearaght light-keeper's report for 1884, where $\mathrm{Mr}$ M'Carron states that on October 13, "two hundred and ten passed S.W. between 8 and 9 A.M. Great numbers had passed before I commenced and after I left off 
counting. All young birds, flying low, and in flocks of from thirty to two or three ; calm, misty." On October 18 of the same year the Skelligs light-keeper reports, "Gannets for the last few days wheeling in flocks, and seeming inclined to take a southerly direction"; and on the 20th, "twenty going south. None perched on the Lesser Skellig after this date."

These two nearly simultaneous reports corroborate one another in the important particular of making the birds fly south and south-west, rather than east, from the southern extremity of the west coast. If this be the general rule, it explains the lack of evidence showing an eastward movement along the south coast in autumn.

The date of first landing on the Little Skellig for nidification has been noted in four years, and varies from February 6, 1886, to February 28, 1885. In three of the four years the date was in the fourth week of February.

The date on which it has last been seen on the same rock has likewise been noted in four years, varying from September 26, 1886, to November 7, 1887. The September date seems unusually early, but occurred in the same year with the early landing in spring. The date of departure from the Bull Rock is once recorded, October 26, 1897.

It is probable that the few specimens forwarded were all shot; but there is one record (p. 259) of a Gannet striking a lantern, and falling disabled into the sea (Arklow South Lightship, April 10, 1891); and a yet more singular fate befel a bird of this species at North Arran Island on February 27, 1897, when "one going N.W. at noon," in bright sunlight, struck the light-house balcony and was killed-the only instance on record of a bird killed striking an Irish light-house in daytime (p. 614).

\section{Heron (Ardea cinerea, Linn.).}

Heron. Probably a non-migratory species in Ireland, since it is very seldom noted from light-ships, or from islands not frequented for fishing. When flying it looks large, and is readily recognised, and few passing a light-station should escape being observed. There are only four records from light-ships (Coningbeg and Barrels Rock), in January, July, September, and November respectively. There are four from the Tuskar, in 
March, August, September, and October; one from the Fastnet, in December; one from the Maidens, in May; and four from Blackrock (Mayo) of which two were in September, one in April, and one in June.

The direction of flight has been recorded in very few instances, and shows no uniformity at any season. At Blackrock (Mayo), a Heron flying westwards on September 2, 1896, was watched with a telescope until it disappeared on the western horizon. Where this bird was bound for cannot be suggested-the nearest land to the west being America. The only other September note from the same station is of a bird flying south-east (September 27, 1884).

Of a total of 209 observations, a large proportion belong to the three autumnal months (September to November):-

$\begin{array}{llllll}\text { Spring (March-May), } & \cdot & \cdot & \cdot & \cdot & 34 \\ \text { Summer (June-August), } & \cdot & \cdot & \cdot & : & 58 \\ \text { Autumn (Sept.-Nov.), } & \cdot & \cdot & \cdot & \cdot & 80 \\ \text { Winter (Dec.-Feb.), } & \cdot & \cdot & \cdot & \cdot & \mathbf{3 7} \\ & & & & & 209\end{array}$

As the birds would be away from shore breeding in spring, and augmented in force by the young in autumn, this fluctuation does not afford grounds for suspecting any seasonal influx, in the absence of direct evidence.

\section{Bittern (Botaurus stellaris, Linn.).}

One reported occurrence and one specimen constitute all the evidence from light-stations regarding this once fairly common Irish bird.

An example is said to have been shot by the light-keeper at Old Head, Kinsale, on February 15, 1883. Ten years later, on August 27, 1893, a Bittern was caught in a pool among the rocks at Slyne Head, and was sent in the flesh. This bird was doubtless in an exhausted condition after its migratory flight, and must have been a recent immigrant. It was much emaciated. August is an early month for such an occurrence.

White-Fronted Goose (Anser albifrons, Scopoli).

The different species of Geese are not discriminated. Most of the observations probably refer to the White-fronted, Brent,

Bittern. 
White-

fronted

Goose. and Barnacle Goose. The name "Barnacle" is applied both to the true Barnacle and to the Brent, and a White-fronted Goose has been seut as a "Baruacle," so there is great confusion in the minds of some light-keepers.

The following are the numbers of observations relating to "Wild Geese" (omitting "Barnacles") for each month and section of the coast:-

\begin{tabular}{|l|r|r|r|r|r|r|r|r|r|r|r|r|r|r|}
\hline & Jan & Feb. & Mar. & April & May & June & July & Aug. & Sept. & Oct. & Nov. & Dec. & Total \\
\hline South Coast, & 4 & 1 & $\ldots$ & 3 & $\ldots$ & $\ldots$ & $\ldots$ & 1 & $\ldots$ & 3 & 7 & 4 & 23 \\
East , & 2 & 3 & 2 & 3 & 1 & 2 & 1 & $\ldots$ & 1 & 6 & 3 & 6 & 30 \\
North ," & 9 & 2 & 4 & 3 & 3 & 1 & $\ldots$ & 4 & 3 & 17 & 9 & 5 & 60 \\
West ," & 10 & 7 & 5 & 6 & 2 & $\ldots$ & 1 & 1 & 2 & 29 & 14 & 13 & 90 \\
\hline & 25 & 13 & 11 & 15 & 6 & 3 & 2 & 6 & 6 & 55 & 33 & 28 & 203 \\
\hline
\end{tabular}

The few records in summer may all refer to the Brent Goose, of which an example has been sent in July (see under Brent Goose).

The uncertainty as to what species is referred to in almost every instance makes it undesirable to pay much attention to the above figures. October is the month of most records, and comparatively few occur during the first ten days of that month.

The spring observations are much fewer than the autumnal, but the only specimen of the White-fronted Goose received from a light-station was shot on May 3, 1887, at Rathlin O'Birne.

The records of direction of flight, on being analysed, bring out no difference between those relating to "Barnacles" and those on "Wild Geese" generally. As might be expected, the direction is generally southward (including S.E. and S.W.) throughout the autumnal months, including January. The months in which the northward (including N.E. and N.W.) direction is shown to predominate are March and April. For all 'Geese, including "Barnacles," the direction notes for each month are-

Northward,

Jan, Feb. March, April. May. June. July. Aug. Sept. Oct. Nov, Dec.

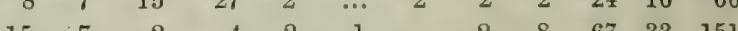


Here is seen a southward tendency from September to whiteJanuary, an equipoise in February, and a northward tendency in the two following months. By May the evidence of migration is practically at an end.

These observations are placed under White-fronted Goose, because it is the commonest Irish species.

[Obs.-The Grey-Lag (Anser cinereus, Mayer), Bean ( $A$. segetum, J. F. Gmelin), and Pink-footed Goose (A. brachyrhynchus, Baillon) are winter visitants (the last-named very rare), on whose movements the "Migration Reports" throw no light.]

\section{Barnacle Goose (Bernicla leucopsis, Bechstein).}

The name Barnacle is commonly misapplied by the light- Barnacle keepers to the Brent Goose, and it is impossible to distinguish, Goose. in most cases, to which bird individual observations relate.

The Barnacle Goose has been forwarded from one stationAranmore-where it was shot on December 31, 1897. This island is frequented during winter by Barnacles, a fact which is proved by the description of their feeding in large flocks "on the brows of the cliffs," as they have been noted doing so as late as April 19 (p. 193). The extreme dates at which "Barnacles" have been reported from Aranmore are-

Earliest in autumn,
Latest in spring,

There are no grounds for stating that here, more than elsewhere, Bernicla leucopsis and B. brenta are distinguished from each other.

The geographical situation of Aranmore, near the northern extremity of the west coast, favours the view that it is in the lirect migration route of a species whose principal known breeding-stations are stated to be on the east coast of Greenland.

\section{Brent Goose (Bernicla brenta, Pallas).}

As the Brent Goose is more common than the Barnacle, Brent Goose. it is fair to conclude that a large majority of the so-called "Barnacles" reported by light-keepers are of the first-named species. In only fifteen instances have "Brent Geese" been mentioned by name, while "Barnacles" have been reported in 
Brent Goose. three hundred and eighteen ; but of four so-called "Barnacles" shot and forwarded, two were Bernicla brenta and one Anser albifrons, while the true Bernicia leucopsis was sent only once. Besides having twice been sent as a "Barnacle," the Brent was once forwarded as an unknown bird, so that three specimens altogether have been received.

That this species occasionally occurs in summer is proved by the fact that one example was shot and forwarded from Rathlin O'Birne on July 10, 1887. "Barnacles" have also been reported flying northwards from Dunree Head, Co. Donegal, on August 1,1883 , and it is not improbable that these, as well as two "Wild Geese" noted going S.W. from Innishtrahull on June 28, 1894, were Brent Geese.

From 1882 to 1891 inclusive, there were records for August or September in every year except 1887. These were nearly all from north-western stations, Aranmore, Rathlin O'Birne, and Oyster Island; and the direction reported was in every instance southward. Of late years the reports from this group of stations have been comparatively meagre, and there is no record of "Barnacles" earlier than October in any year after 1891, except one from Arklow North Light-ship, September 21, 1894.

An overwhelming majority of the whole number of observations on "Barnacles" is from the north and west coasts, while the south yields practically none.

\begin{tabular}{|l|r|r|r|r|r|r|r|r|r|r|r|r|r|}
\hline & Jan. & Feb. & Mrar. & April & Nay. & June & July & Aug. & Sept. & Oct. & Nov. & Dec. & Total \\
\hline South Coast, & $\ldots$ & 1 & $\ldots$ & $\ldots$ & $\ldots$ & $\ldots$ & $\ldots$ & $\ldots$ & $\ldots$ & $\ldots$ & 2 & $\ldots$ & 3 \\
East,, & $\ldots$ & $\ldots$ & 2 & 1 & $\ldots$ & $\ldots$ & $\ldots$ & 2 & 2 & 8 & 12 & 7 & 34 \\
North,, & 5 & 9 & 9 & 5 & 1 & $\ldots$ & $\ldots$ & 1 & $\ldots$ & 18 & 13 & 5 & 66 \\
West,, & 12 & 13 & 21 & 18 & 5 & $\ldots$ & 1 & $\ldots$ & 10 & 64 & 52 & 34 & 230 \\
\hline
\end{tabular}

The period of densest immigration is in the last ten days of October:-

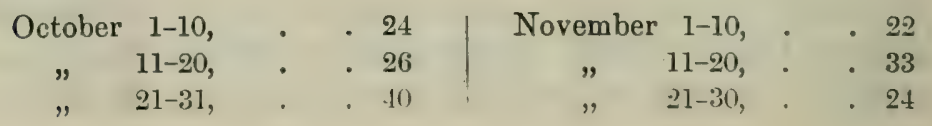


Departure is chiefly witnessed in March and April, as the Brent Goose. direction records show :-

Jan, Feb. March. A pril, May. June. July. Aug. Sept. Oct. Nov, Dec.

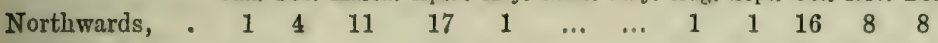

Southwards, $\quad \begin{array}{lllllllllllll}4 & 3 & \ldots & 2 & \ldots & \ldots & \ldots & 1 & 7 & 40 & 20 & 9\end{array}$

Sea-haunting birds, whose flight is along the coast rather than between land and sea, are more readily observed on their departing migration than land-birds, as the above figures show, when compared with those for other species.

Some very interesting observations, which apparently relate to the departure of the Brent Goose in spring, were made by $\mathrm{Mr}$ Dunleavy at Samphire Island in 1895. On February 4 "Barnacle Geese" were very numerous at that station; on February 13 and March 17 large flocks passed N.; on March 24, "these birds are getting scarce"; more flocks were noted as passing $\mathrm{N}$. on six different dates up to April 19, and on that day "thousands going N.W. from 7 P.M. to 7.30 P.M., in one continuous string, single file, flying high and making a great noise. I suspect they were migrating, as I never saw them go the same course all the season." On the 21st, several flocks were noted going N. at 7 P.M., and on May 9 is the entry "Barnacle have left; none seen since April 21st." The return of the "Barnacles" to this station was noted by Mr Dunleavy on October 7, and a specimen shot and forwarded on November 19 proved to be a Brent Goose, to which species it is therefore probable that the foregoing observations should be referred.

In the spring of 1896, the last flock was noted going $\mathrm{N}$. from Samphire Island on April 8, a fortnight earlier than in 1895, which was a very backward season, owing to the severe weather experienced in February; but at more northerly stations, such as Aranmore and Innishtrahull, "Barnacles" have in several years been noted in May. The latest spring record is from North Arran Island, May 18, 1885.

Three specimens of Bernicla brenta received were all shot:at Drogheda North, October 11, 1892; Samphire Island, November 19, 1895; and Rathlin O'Birne, July 10, 1887.

Bewick's Swan (Cygnus Bewicki, Yarrell).

To this species probably belong most of the migratory Swans Bewick's observed at Irish light-stations, for the Whooper (Cygnus

Swan. 
musicus, Bechstein) is a much scarcer visitant; but some of Swan.

the observations undoubtedly relate to the Mute Swan (Cygnus olor, Gmelin), which is resident in a wild state on several of our lakes and rivers. In two instances "Black Swans" have been noted (1883, p. 39, and 1895, p. 495), but as these must have been escaped birds, they are excluded from consideration.

All the observations on Swans, other than Black, may be grouped as follows (those in the summer months, italicised below, must relate to the Mute Swan):-

\begin{tabular}{|c|c|c|c|}
\hline Coast. & Station. & $\begin{array}{c}\text { No. of } \\
\text { records. }\end{array} \mid$ & Months in which noted. \\
\hline $\begin{array}{l}\text { South } \\
\text { East } \\
\text { North }\end{array}$ & $\begin{array}{l}\text { Coningbeg Light-ship, } \\
\text { Drogheda North, } \\
\text { \{ Rathlin Island, } \\
\text { Lough Sivilly, } \\
\left\{\begin{array}{l}\text { Aranmore, } \\
\text { Rathlin O'Birne, } \\
\text { Killybegs, } \\
\text { Oyster Island, } \\
\text { Broadhaven, } \\
\text { Blacksod Point, }\end{array}\right.\end{array}$ & $\begin{array}{r}1 \\
5 \\
1 \\
1 \\
1 \\
10 \\
\\
1 \\
1 \\
2 \\
1 \\
24\end{array}$ & $\begin{array}{l}\text { December. } \\
\text { January, Narch, May, July, December. } \\
\text { November. } \\
\text { June. } \\
\text { December. } \\
\text { January (2), March (1), April (1), } \\
\text { November (3), December (3). } \\
\text { December. } \\
\text { December. } \\
\text { January and December. } \\
\text { Date not given; earlier in winter } \\
\text { than February } 23 .\end{array}$ \\
\hline
\end{tabular}

As all the east coast records come from one station, which has twice noted Swans in summer (May $2 S$ and July 22), it is probable that these all refer to the Mute Swan, likewise the solitary record from Lough Swilly in June.

Of the remaining eighteen records, sixteen are from the norther'n section of the west coast, between Aranmore (Donegal) and Blacksod Point (Mayo). The earliest in autumn and the latest in spring are both from Rathlin O'Birne, the station yielding the largest number of Swan occurrences.

Earliest in autumn, November 1, 1896.

Latest in spring, April 21, 1897.

December shows eight records; November, four; January thiree; February, one (probably); March, one; and April, one.

The largest number reported in one flock is thirty, from Broadhaven, January 21, 1897. In other cases the companies range from two to eleven, from two to six birds being noted in twelve instances, and from seven to eleven in five. 
Direction has been noted twelve times in the autumnal and winter months (November to Jantuary), and was southward in nine, northward in three. It has been twice noted in spring (March 7 and April 21), and was northward on both occasions, from Rathlin O'Birne.

[Obs.-As the occurrences of the Mute Swan (Cygnus olor, Gmelin), mentioned under the previous heading, have no claim to be considered migrational, they do not call for separate notice.]

\section{Common Sheldrake (Tadorna cornute, S. G. Gmelin).}

Perhaps more likely to be correctly identified than any other species of Duck except the Common Scoter; but the only specimen received was sent as an unknown bird, from St John's Point, Co. Down, June 28, 1895, without data as to how obtained.

The observations number only twenty-seven, distributed almost equally round the coast, and including one or more for every month except July (twenty from November to April, seven from May to October). Flocks are mentioned only twice; and the only occurrence at lanterns is a rather improbable record from the Tuskar, of "seven Sheldrakes killed striking" on the night of November 14, 1882-improbable because of the largeness of the number, in the case of a species not elsewhere reported as striking at all.

\section{Wild Duck (Anas boscas, Linn.).}

The observations are of little value, since no specimen has been received, though light-keepers have forwarded examples of the Wigeon and Scaup, etc., and specimens sent as "Wild Duck" have proved to be Teal and Scoter.

[Obs.-The Gadwall (Anas strepcra, Linn.), Pintail (Dafila ccutc, Linn.), and Shoveller (Spatula clypeata, Linn.) are onitted, as no specimens have been forwarded, and there is no reliable testimony concerning any of them.]

\section{TeAL (Nettion creccc, Linn.).}

One has been forwarded, disabled at lantern, Oyster Island, Co. Sligo, on the night of October 22, 1890.

Wild Duck.

Common Sheldrake.

wick's

Swan. 
Teal.

Another, from Samphire Island, was found dead during frosty weather, February 12, 1895.

With these exceptions, there is no trustworthy information.

WIGEON (Mareca penelope, Linn.).

Wigeon. One (sent as a Duck) was killed striking at the Maidens, October 19, 1889; another (sent as a Teal) was found killed near the light-house at Mine Head, December 13, 1885.

There are 38 observations, all probably of little value-18 from east coast, 9 from west, 8 from south, and 3 from north.

Earliest record in autumn, September 14, 1886 (Dungarvan).

Latest " in spring, April 6, 1897 (Codling Bank Light-ship).

Scaup (Fuligula marila, Linn.).

Scaup. Three have been received, of which two were shot (Innishtrahull, October 15, 1888, and Drogheda North, February 2S, 1894); while the third was found dead, along with a Teal, on rocks at high-water mark on Samphire Island, February 12, 1895. These three examples were sent respectively as a "Pochard," "Rock Wigeon," and "Shovel - bill." Reliable observations on the different species of the genus Fuligula are not to be expected.

[Obs.-Neither the Pochard (Fuligula ferina, Linn.) nor the Tufted Duck (Fuligula cristata, Leach) has been received from a light-station.]

\section{GoLDEN-Eye (Clangula glaucion, Linn.).}

Golden-Eye. Never mentioned by name in the report of any light-keeper. The only specimen received was a female, shot at Aranmore, March 18, 1899.

\section{LONG-TAILED DUCK (Harelda glacialis, Iinn.).}

Long-tailed Duck.
The only light-station records are in 1896 and 1899. In the former year three examples were forwarded-two shot out of a "flock of about a dozen" at Inishgort, Co. Mayo, on January 18th and 19th, and one shot at Rathlin O'Birne, October 16. Another, said to have been shot the same year at Innishtrahull, on September 15 (an unusually early date), was not forwarded. 
In 1899 a fine old male was shot on November 13 at Dundalk. Long-tailed All the above records are from the northern half of Ireland.

\section{Eider Duck (Somateria mollissima, Linn.).}

The Eider has been observed in a few instances at Rathlin Island, Innishtrahull, and (probably) Killybegs.

At Rathlin Island three were reported on April 3, 1886, and seventeen on April 16 of the same year, the light-keeper adding that " the Eider Duck was seen here sixteen years ago."

At Innishtrahull two (accurately described as "white with black on top of head") were noted as "rare visitors" on February 2, 1890; and on November 5 of that year three were reported from the same station.

At Killybegs "two rather large white Ducks, never seen here before," noted as going S. on February 8, 1894, were probably of this species.

A record from Rockabill of "Eider Duck and young," on June 5, 1886, may be dismissed as erroneous.

No specimen has been received.

Common Scoter (EEdemia nigra, Linn.).

The Scoter strikes more frequently than other Duck, and six examples killed at lanterns have been forwarded-one in October, two in November, one probably in February, and two in April. The two which were killed in November are from the Maidens, the remaining four from Wexford stations (Hook Tower, Lucifer Shoals, and Blackwater Bank).

The earliest observation of "Black Ducks" in autumn is of a large flock at Drogheda North, September 27, 1891; the latest in spring is of a flock going E. at Lucifer Shoals Lightship, May 16, 1890. The total number of observations is only 23 (of which 16 were at east coast stations), but Scoters are no doubt often reported as "Wild Ducks."

Four records in April and May are all from Wexford lightships, viz. :-

Lucifer Shoals, April 17, 1888, flock of Black Duck flying low. May 16, 1890, flock of Black Duck going $\mathrm{E}$.

Blackwater Bank, April 15, 1891, flock of Wild Duck at 11 P.M. going N.E.; three killed striking. [Legs and wings of two Common Scoters received.]

Blackwater Bank, April 15, 1894, flock of Black Duck going N.E. 
These occurrences apparently indicate migration in a northeastward direction past the Wexford coast.

Surf-Scoter (Edemia perspicillata, Linn.):

Surf-Scoter. On November 5, 1888, Mr Dunleavy, while stationed at the Fastnet, shot an immature bird of this American species (the third obtained in Ireland at that time) in Crookhaven Harbour, Co. Cork. It was forwarded in the flesh.

The two previous examples (recorded by Thompson and Sir R. Payne-Gallwey respectively) were shot off the east coast of Ireland, in Belfast and Dublin Bays. Three additional specimens have since been obtained on the west coast.

Red-breasted Merganser (Mergus serrator, Linn.).

Red-breasted Mentioned occasionally by a few light-keepers, but none of Merganser. the observations are of interest. Of eighteen records, sixteen are from mainland-stations and the remaining two from Oyster Island, Sligo, which is only one mile from shore. There is no proof that the bird has been recognised on migration. A female, probably shot, was received from Killybegs, December $24,1891$. 


\section{ANALYSIS-PART II.}

Some of the Principal Points of Interest-Some General Remarts - Various Tables - Bats and Insects at Light-houses-Recipe for Preserving Wings, \&c.

IT may be assumed that almost every land-bird killed striking at an island light-house or light-ship at night, some miles from shore, or even at a mainland-station on an exposed headland, or seen passing over the sea in the day-time, is in an abnormal situation, and would not be there unless on the special business of migration. Hence this phenomenon can be most frequently and most conveniently witnessed in a country, well supplied with light-stations. At an inland locality one cannot be nearly so certain that a bird is migrating. The brilliant lights which save thousands of human lives by warning our vessels of danger, attract, on the other hand, thousands upon thousands of winged voyagers, numbers of whom, when bewildered by the glare on dark nights, fly oftentimes against the lanterns with great force, and are killed striking.

The Table on $\mathrm{p}$. xxv shows in a convenient form many of the conclusions arrived at concerning some of our well-known birds, but the letterpress under each species in the Analysis ought also to be consulted.

One interesting result of this investigation is the fact that in every species of which a sufficient number of wings were measured, the longer-winged examples arrived first in spring.

In the autumn the same law holds good in nine cases out of fourteen, the apparent exceptions being the Fieldfare, Wheatear, Whitethroat, Willow-Wren, and Gold-Crest. In the Blackbird, in which the sexes can be partially distinguished by their wings, the longer-winged males come first in autumn; but the reverse is apparently the case with the females. This latter inference 
is, however, neutralised by the fact that some of the supposed wings of females may have been those of immature males.

It has long been remarked that in certain birds the males arrive first in spring; it is also known that in several species the males have the longest wings.

Professor Newton, in his "Dictionary of Birds," p. 557, states that it has been suspected that where there is any difference in the size of birds of the same species, particularly in the dimensions of their wings, the individuals which perform the most extensive journeys are naturally those with the longest and broadest remiges, and the Wheatear and Willow-Wren are cited as examples.

The Irish specimens of these two species show that as a whole the longer-winged arrive first in spring, but from this it is not necessarily to be inferred that our Irish breeding Wheatears are not the earliest to arrive, as some very longwinged specimens arrived late. The whole subject of wing measurements in connection with migration is of the greatest interest, and further data are being collected.

The close connection between lunar darkness and the number of birds killed striking has already been demonstrated under Thrush on pp. 15 and 16 and elsewhere. It does not imply that there is less migration during moonlight, but it proves that the birds avoid the lanterns at that time.

The number of birds killed striking in the autumn considerably exceeds the deaths from a similar cause in spring. This may be due either to the longer autumnal nights, or to the greater number of birds in the autumnal rushes, or to the fact that many of them are young and inexperienced, or, what is most probable, to a combination of all three causes.

Neither the wings nor the statistics afford any sufficient clue to enable one to determine positively in any given species whether the young birds precede the old ones or not. This is a question which the collection of a large number of specimens in the flesh (and not wings merely), in successive years, and during all stages of the migratory rush, might assist in deciding, but not conclusively, since it could be objected that even if the young were accompanied by their parents in the first rush, the latter might escape altogether. There is one point in favour of the supposition that the old birds are in 
the van of the advancing army in autumn-viz., that in the majority of cases the longer-winged birds come first, but see p. 35.

It has been demonstrated by this inquiry that the islands off our west coast, and the Atlantic seaboard generally, are the last refuge of thousands of starving land-birds in hard winters.

The question why so many birds, of apparently feeble flight, should select the night-time for travelling over sea has not yet been satisfactorily answered; but it is worth while considering whether these voyagers do not thereby greatly diminish one of the chief perils of migration, namely, destruction by Gulls (see p. 229) at sea, and near shore by Hawks of various species.

The height at which birds fly is another problem regarding which widely different opinions are held. An attempt was made to ascertain whether the elevation of a light-house lantern above the sea-level had any effect on the number of birds killed striking. No conclusion of any value was arrived at, since the question was complicated by various other considerations, especially the locality of the light-station and character of the light. It is well known that fixed lights are more fatal than revolving or intermittent ones, and white light is believed to be more destructive than red. If birds travelled at a very great height in the day-time they would not be seen at all, and the schedules would not contain any diurnal records. When direction is indicated, these records are in the great majority of cases landwards. One way of accounting for the comparative scarcity of seaward movements, is to assume that departing birds ascend to a great height and so escape observation, and that they then descend gradually when approaching land. Arriving birds are more likely to strike than those departing, because, among other reasons, many lights are partially obscured at the landward side.

That some birds fly with great speed is proved by the force with which they strike the lanterns, the thick glass of which is occasionally smashed by such heavy species as the Ducks, where weight, added to velocity, results in a tremendous blow being given, the keel of the breast-bone being occasionally flattened at the same time (see pp. 57, 194, 380, etc.).

So far as can be determined, it is the force and not the direction of the wind which hastens or delays the departure of birds. 
They travel when the wind is blowing from different points of the compass. It is obvious this must of necessity happen when the cyclonic or anticyclonic system is of moderate dimensions, and is not moving in the same direction as the birds.

When travelling in a direct line, birds, according to the "law of storms," must often encounter winds blowing from directly opposite quarters. It has been said that it is the weather at the starting-point which affects the date of departure, but none of the collected data prove this, since it is impossible to identify any particular individuals throughout the entire journey. If the Redwings are noticed leaving Scandinavia, and again observed within a day or two arriving in Ireland, we must assume they are the same birds, otherwise, for the purposes of this argument, the coincidence would be valueless.

If we look at the dates on which birds are killed striking, and make allowance for the variation caused by the lunar phases, a remarkable regularity in the period at which the majority arrive is shown. Possibly, therefore, the bulk of each species also departs from other countries on the journey to Ireland about the same time each year, unless the meteorological conditions are of a very exceptional type.

\section{Migration Routes (Spring).}

Though these cannot be fixed with certainty, the different coast-distribution of various species on migration suggests that they follow different lines, and to some extent they can be arranged accordingly.

Four main groups present themselves, to one or other of which nearly all our summer visitants can be assigned.

First, the group with a widely-diffused migration route, striking at stations from S.W. to N. of Ireland, i.e., to the right of a line GF, drawn from Tearaght to Innishtrahull (see map on opposite page). This may be called the General Type. The birds which belong to it are the Ring-Ouzel, Whitethroat, Willow-Wren, Swallow, Cuckoo, and Corn-Crake.

Second, the group with a south-eastern distribution, occurring at light-stations to the right of a line $\mathrm{CD}$, drawn from Mine Head to Mew Island. This may be called the South-Eastern Type. It contains eleven species (seven of which, printed in 
italics, are not known to have struck outside Co. Wexford), viz.,-Hobby, Whinchat, Grasshopper Warbler, Garden Warbler, Yellow Wagtail, Swift, Nightjar, Quail, Common Sandpiper, Rosecte Tern, Lesser Tern. The seven Wexford species form an extreme South-Eastern group.

\section{SPRING MIGRATION.}

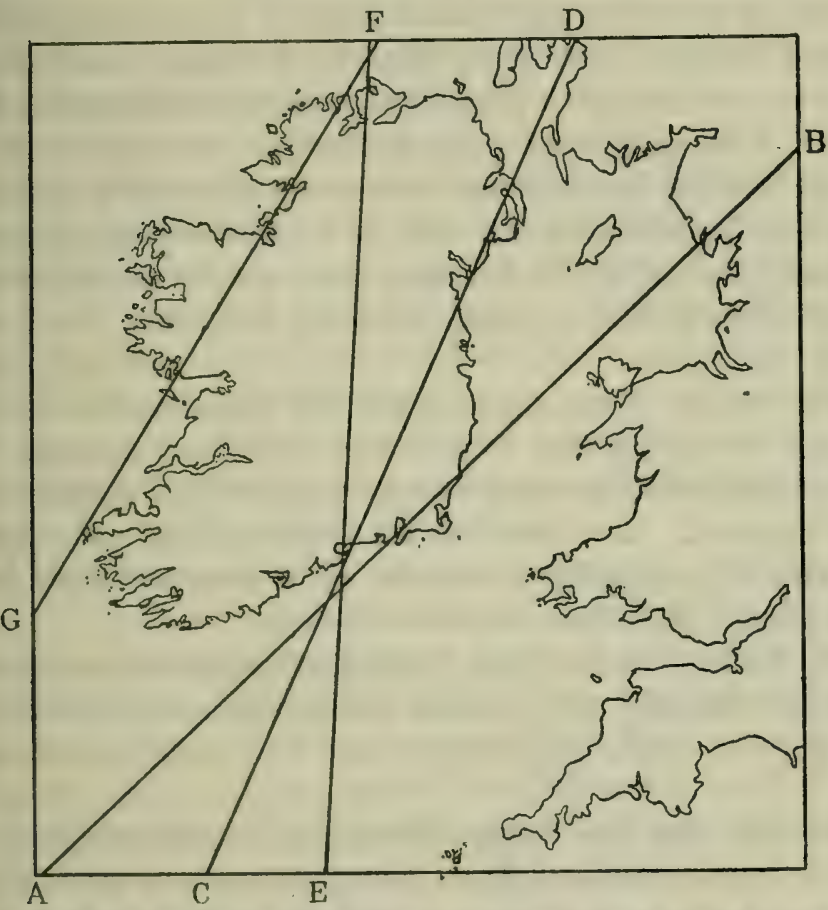

AB. The Hobby, Carden Warbler, Yellow Wagtail, Swift, Quail, Roseate Tern, and Lesser Tern only received from stations $\mathrm{S}$. E. of this line.

CD. The Whinchat, Grasshopper Warbler, Nightjar, and Common Sandpiper only received from stations S.E. of this line.

EF. The Common Redatart and Chiffchaff not received from any station W. of this line.

GF. The Willow. Wren, Swallow, Ring-Ouzel, and Corn-Crake not received from any station W. of this live.

Third, the group with an eastern distribution, occurring at light-stations to the right of a line EF, drawn from Mine Head to Innishtrahull. Its most typical members are the Redstart and Chiffchaff. The Sedge Warbler, though it has occasionally struck at stations on the west coast (N. Arran and Killybegs), probably belongs to this Eastern Type, since it has not been received from any Munster station south or west of Mine Head.

Fourth, the group with a southern distribution, occurring at light-stations to the right of a line drawn from Tearaght to 
Arklow N. Light-ship. The Golden Oriole, though received only from the Skelligs, should probably be referred to the Southern Type, along with the Spotted Flycatcher, SandMartin, and Turtle-Dove. The last named has straggled to western stations in early summer, but did not strike there.

The Wheatear does not fall into any group, as its occurrence at western stations is regular and normal. The only occurrences of the Blackcap and Wood-Warbler in spring were at the Maidens and Blackrock (Mayo) respectively, and therefore they cannot be grouped, nor can the Sandwich, Common, and Arctic Terns, of which no specimens were received in spring at all.

It may be seen from the map of Europe that the series of stations favoured by the Southern group are those which would naturally be reached by birds travelling N.W. from the French coast.

The Eastern Type stations, on the other hand, would be reached by immigrants from Great Britain in general; and the South-Eastern by those who select the Welsh coast as their starting-point. The route of the General Type can only be explained by supposing that some of its members come direct from France, and others viâ Great Britain.

The birds of the extreme South-Eastern group (confined to Wexford stations) may contain some which rightly belong to the Southern Type, within whose pale their small strip of coast lies.

The fact that the Sedge Warbler has never been received from a station south of Mine Head, militates to some extent against the theory that every bird breeds in the northernmost part of its range, as it suggests that the Sedge Warblers which breed in the south-west corner of Ireland arrive on a part of the coast somewhat farther north than their nesting localities. The Sedge Warbler occurs so numerously at Irish lanterus from Mine Head northwards, that it is fair to conclude it would have been forwarded from the Fastnet or Skelligs, if those stations lay in its route.

The Whimbrel prefers the west coast of Ireland, going N. in spring; the Curlew, the east coast. The Lapwing also selects the east coast at the same season; the Gannet goes up both the east and west coasts early in the year, but its return from the northward is chiefly observed at western stations. 
The fact that the Whinchat and Yellow Wagtail, which breed only in the N. and N.W. of Ireland, should be limited to southern stations at the season of arrival is noteworthy.

In the map showing "Spring Migration" (p. 267), no attempt has been made to lay out any route, and the lines drawn across Ireland merely indicate the limits of certain species as received from light-stations. These are curiously suggestive of direction, and as if the main body of birds came from the S.E., with a front extending from S.W. to N.E.

An attempt was made to draw a few similar lines for the autumnal immigrants, but owing to various causes it was not sufficiently successful to merit illustration. Maps showing the coast-distribution have been given in the text under Spotted Flycatcher, Common Redstart, Black Redstart, Whinchat, Sedge Warbler, Golden-crested Wren, Siskin and Brambling, Linnet and Twite, and Woodcock.

The points of arrival of the various species dealt with in the Analysis will be found in the text under each individual species, as far as the light-stations indicate them.

In Ireland it would be difficult to ascertain whether the birds to arrive first in spring are our own breeding birds or those proceeding farther north. Most of our spring immigrants come to stay, and the fact that the longer-winged examples are in the van is no proof that they belong to the Northern Type. In the case of the Wheatear, some of the very longest-winged specimens came late; but, taken as a whole, the earlier wings of the Wheatear have a greater average length than the later.

Judging by specimens, it is not true to say that the earlier immigrants are first obtained in the S.W. of Ireland either in spring or autumn, though in a few species it holds good.

There are grounds for believing that such White Wagtails as approach Ireland on their northward journey in spring pass up the west coast like the Whimbrel, both species being preceded by what may turn out to be a northern race of Wheatears.

\section{Migration Routes (Autuma).}

If a census were taken, it would probably be found that the bird population of Ireland was greatest in the late autumn. 
The spring migration is comparatively hurried; but in the autumn, birds linger on their southward journey, and as the young birds are then added to the advancing army, it is much more numerous, and, probably owing to ignorance and lack of discipline in the young, has a much more widespread and irregular front-hence the migration routes at this season are ill-defined.

It is true in the main to say that the arrival of Arctic birds ceases after the middle of November, but it cannot be said that it is universally true, for some of our later immigrants are probably Arctic birds which have stopped at a half-way house.

The departure of birds is so little observed, that it is difficult to say whether they retrace their steps along the same line in autumn by which they reached us in spring; but many birds have struck at our most southerly station, the Fastnet, in autumn which have not struck so far south in spring (see Table, p. xxv).

Whether the Waders-Ducks, Gulls, and Divers-travel direct $\mathrm{N}$. and $\mathrm{S}$. in the autumn, and strike the route of the Passeres at right angles, is a question which the records do not enable us to answer.

Such vague inquiries lead to no direct result. It would be well if both interrogations and research were confined to one species at a time, especially when investigating in bird migration.

The East coast receives the bulk of the immigrants in autumn, as it does in spring; but, as might be expected, the direction of flight in autumn is south-west rather than northwest, and consequently certain light-stations which receive none of the spring immigrants receive a fair proportion of the autumnal ones.

Northern stations lying west of Innishtrahull are shut out of the flight-line of our spring immigrants (though Innishtrahull itself has sent examples of many of them). This remark does not necessarily apply to the Wheatear, which no doubt passes Tory Island and Aranmore on passage towards Iceland or. Greenland; but no other species among the birds usually accounted "summer visitants" is known to have struck at either of those stations. The probable explanation is that they do not lie in the landward route of any bird flying WV. or N.W.

Among our autumual immigrants, the following have struck 
at either Tory Island or Aranmore:-Thrush, Redwing, Fieldfare, Blackbird, Skylark, Water-Rail, Woodcock, Snipe, and Purple Sandpiper-enough to show a marked difference between the spring and autumnal movements. The Water-Rail and Purple Sandpiper may reach this part of the coast by a direct southward flight, but it is probable that the others are flying S.W. from Scotland or Northern Europe.

All the above-named birds have likewise been received from the Tuskar, which is at the opposite angle of the coast from Tory Island, and have also been forwarded from the south (Woodcock, Snipe, and Purple Sandpiper from Hook Tower, the rest from the Fastnet). The Purple Sandpiper has not been forwarded from any eastern stations lying between Wexford and Donegal, but the migration route of the remaining eight species practically includes the whole Irish coast. The numbers arriving, except in the case of the Water-Rail, are much greater on the $\mathrm{E}$. than on the W. side of the island.

Three species-the Gold-Crest, Meadow Pipit, and Starling -have been received in autumn from stations ranging round the south, east, and north-east coasts from Fastnet to Innishtrahull, but not from Tory Island or Aranmore. Starlings, however, are reported as striking numerously at Tory Island in the autumns of $1887,1891,1892,1894$, and 1895; and there are records of both Gold-Crests and Starlings striking at Aranmore, though no specimens were forwarded. It is, therefore, probable that the same south-westward direction is taken by these three species, and that the whole of the Irish coast is included within their route, like that of the other autumnal immigrants already noticed.

The autumnal immigration from the north-east thus comprises ten species, which flow into Ireland at all points from N. to S. :-

Thrush.

Fieldfare.

Redwing.

Blackbird.
Gold-Crest. Meadow Pipit. Skylark.
Starling.

Woodcock.

Common Snipe.

But, as was shown in dealing with these species separately, the Thrush, Blickbird, Gold-Crest, Meadow Fipit, and Starling occur far more densely towards the southern extremity of the Channel, while the Lark's migration seems uniform from north 
to south, and the Fieldfare, Snipe, and Woodcock, if the observations are to be relied on, arrive most numerously in the north.

Judging by the "Migration Reports," the earliest Woodcock arrive in Donegal (see p. 208). It has often been alleged that it first appears at our western and south-western stations in the autumn, - an ingenious gentleman once seriously suggested that this was due to the fact that the Scandinavian Scolopax rusticula started from Norway with its bill pointed direct for Ireland, but that by the time it reached the spot where Ireland ought to be, that island, owing to the earth's rotation, had moved several miles from W. to E., and the Woodcock found itself out in the Atlantic, the shores of Kerry and Connemara fast receding from its view on the eastern horizon. The bird then had a race to catch up Ireland, and landed in an exhausted condition on our western coast.

The early Redwings are evenly distributed, like the Lark; the later cross the southern half of the Channel with the bulk of the Thrushes and Blackbirds.

A second group of autumnal immigrants reaches us from the east, of which no specimens have been forwarded in autumn from stations north of Rockabill (lat. $53^{\circ} 36^{\prime}$ ) in the eastern half of Ireland, or of Blackrock, Mayo (lat. $54^{\circ} 4^{\prime}$ ), in the western half (and at this last-named station their occurrences at lantern have been rare). This group comprises the Chaffinch, Greenfinch, Linnet, Jack Snipe, and Dunlin. The migrational limits of these five species on the south and east coast, as defined by the specimens, is very similar, viz. :-

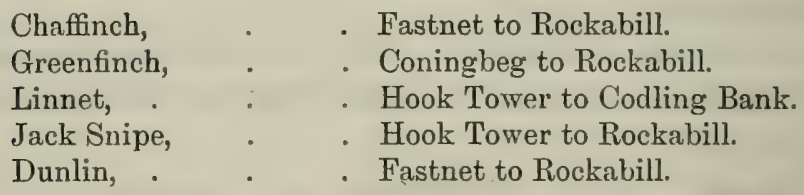

On the west coast, the Greenfinch has been caught at lanterus as far north as Blackrock (Mayo), and the Chaffinch is reported to have struck at the same station, from which a shot specimen was sent in corroboration. The records as to both species striking at this station were in November 1887, and may be considered exceptional. 
The limits of the above-mentioned five birds suggest that they reach us by a route nearly due west from the Welsh coast, though in the case of the Jack Snipe it is difficult to understand such a course being adopted.

The Goldfinch may probably be referred to the above group, though rarely forwarded.

Thirdly, there is a group which favours the south coast. Its constituents are all more or less erratic visitants:-

Pied Flycatcher.

Black Redstart.

Brambling.

Siskin.

The coast-line from Tearaght to Arklow South Light-ship has furnished 52 examples of these four species in autumn. Stations north of that limit have sent only three specimens (Black Redstarts), all shot. The Brambling and Siskin occur in such uncertain numbers from year to year that we may regard their visits to our south coast light-stations as the result of hard weather, which drives them from their accustomed winter retreats elsewhere. If they came to us direct from the north of Europe, they might be expected to occur chiefly at north-easterly stations, as the Fieldfare does.

It is very remarkable that the autumnal immigration of such northern species as the Jack Snipe, Siskin, and Brambling, is apparently confined to the southern half of Ireland, if we are to judge by specimens killed striking.

Fourthly, there is a small group with a tendency to strike on the north-west:-

Snow Bunting.

Twite.
Water-Rail.

Purple Sandpiper.

The migration of the Twite is very scantily attested. The other three species breed in Iceland, and their occurrence on our north-western sea-board is what we might expect. None of the three Icelandic birds are confined to the N.W., and on one occasion they all struck together at the Tuskar-October $29,1892$.

Fifthly, there are a few species whose visits to the west coast require that they should be grouped apart. The most interesting is the 
of the large race (var. rostrata) which-breeds in Greenland. The others are the

Greenland Falcon. Snowy Owl. Glaucous Gull.
Iceland Gull.

Barnacle Goose.

Surf-Scoter.

All these species are known to breed on the western side of the Atlantic (chiefly in Greenland), and only two of them-the Snowy Owl and Glaucous Gull-on the eastern side, or in Iceland. It is, therefore, not improbable that examples of all reach Ireland from the western continent. No bird of this group has ever been noted as striking the lanterns. Except the Mealy Redpoll, they all belong to orders which scarcely ever strike.

\section{Return Movements.}

Of these we can say little or nothing. From innumerable points of view the observations recorded tend to one conclusion, that nearly all the movements noted at light-stations are immigratory, emigration being unobserved.

This conclusion is principally grounded on-

(a) The records of direction of flight.

(b) The paucity of specimens at season of departure.

(c) The southerly stations at which some "winter visitants" strike in spring.

(d) The abnormally late dates (for departing birds) at which "winter visitants" bave struck.

(e) The frequent deaths from exhaustion reported at "season of departure."

( $f$ ) The fact that some species (as the Thrush) show greater average length of wing in autumn than in spring.

Direction of Flight.-Accumulated evidence that this is landward at both seasons of chief observed migration is given in the cases of Turdus musicus, Turdus morula, Motcoilla largubris, Anthus pratensis, Alanda arvonsis, Fringilla calcbs, Sturnus vulgaris, and Corvus frugilegus. These are the only land-birds whose direction had been noted in more than a few instances, except Hirundo rustica, which is sometimes (but not frequently) seen departing. There are other species, as Limurinus chloris, Scolopax rusticula, and Gallinayo calestis, whose recorded direc- 
tions in spring, though few, point the same way as those of the eight first-mentioned.

Pancity of Specimens at Season of Departure.-This is specially noticeable in the case of birds which are wholly absent at one season. "Summer migrants" are vastly more numerous when leaving than when arriving, considering the number of young reared; but they strike the lanterns three times as numerously in spring as in autumn (see Table G, p. 279). "Winter migrants," counting only those species of which none breed with us, strike ten times as numerously in autumn as in spring (see Table H, p. 280). "Partial winter migrants," of which some either stay or come to breed, strike'three times as numerously in autumn as in spring (see Table J, p. 280).

Southerly Stations struck in Spring.-The principal instances are among Limicoline birds (Jack Snipe, Dunlin, Purple Sandpiper), which cannot be southward-bound in spring, and are probably going northwards to Iceland or the Arctic regions. The Jack Snipe has been sent in spring from Hook Tower, the Dunlin from Coningbeg Light-ship, and the Purple Sandpiper from the Fastnet (all on the south coast).

Late Dates of striking in Spring.-Some species which have rarely or never been known to strike during their normal period of departure, have nevertheless done so after the departing movement may be considered at an end. Thus the bulk of our Snow Buntings must leave us in March or early April, yet the only dates of striking in spring (later than February 20) are April 21 and May 17. The emigration of the Brambling is believed to be completed by the middle of March (Saunders's "Manual"), yet the only spring specimens from light-stations were in April. The Chaffinches which winter in Ireland are not usually seen after March, but of three sent in spring, the only one with data was found dead on a south-coast light-ship on May 13. The Common Snipe is stated by Mr H. Saunders to leave before or during March; no specimens have been sent in either February or March, but three, killed striking, have been forwarded between April 6 and May 25. The evidence of the dates thus corroborates that of the stations, tending to show that the occurrences under notice are referable to a different movement from that of our departing birds. 
Deaths from Exhaustion at "Season of Departure."-These are principally noticed under Chaffinch and Greenfinch. The cases cited (pp. 121, 122, and 128) are the more significant, as the wind is stated to have been light.

Wing Measurements in Autumn longer than in Spring.On an average, this peculiarity is found to prevail in the Thrush, and in a comparatively slight degree in the Blackbird and Starling. If the migrants were the same individuals at each season, we might rather expect the opposite rule from the intermixture of young birds in the autumnal rushes.

The following appended tables may be of some use in estimating general results :-

A.-Nearly all birds migrate in some part or other of their range, but the following have not been proved by the lightkeepers to migrate to or from Ireland.

Sparrow-Hawk.

Hen-Harrier.

Barn-Owl (?).

Dipper.

*Hedge-Sparrow.

Tree-Creeper.

Blue Titmouse.

Coal Titmouse.

*Long-tailed Titmouse.
*Rock-Pipit.

*Corn Bunting.

*House-Sparrow.

Lesser Bedpoll.

Bullfinch.

Chough (?).

Raven.

Hooded Crow (?).

Magpie.
Jay.

*Kingfisher.

Rock-Dove.

Red Grouse.

Pheasant.

Partridge.

Cormorant (?).

Shag (?).

Heron.

* The few species marked with an asterisk have been killed or disabled at lanterns under circumstances which possibly indicate mere local movements.

B. - Birds which, though shown to migrate, probably do so on a small scale in proportion to their numbers.

Robin.

Wren.

Great Titmouse.
Reed-Bunting.

Yellowhammer.

Linnet.
Twite.

Water-Hen.

Coot.

C.-Birds which most frequently strike the lanterns, showing number of specimens of each received. There are a few examples of some species in this list which cannot properly be allocated either to spring or autumn, hence the totals occasionally differ slightly from those in the tables for these seasons. 


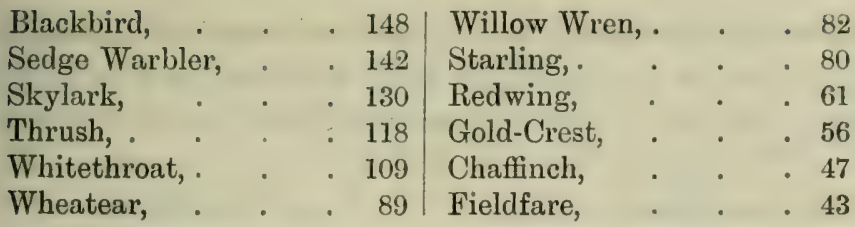

Every species of which as many as forty specimens have been received is named in above list. It will be observed that all belong to the order Passeres.

D.-Some birds which, though known to migrate regularly, have not been forwarded from light-stations.

\author{
Oyster-Catcher. \\ Little Stint. \\ Curlew Sandpiper. \\ Greenshank. \\ Sandwich Tern. \\ Pomatorhine Skua. \\ Richardson's Skua. \\ Great Northern Diver. \\ Red-throated Diver.
}

Great-crested Grebe (?).

Grey-leg Goose.

Bean Goose.

Wild Duck.

Shoveller.

Pintail.

Pochard.

Tufted Duck.

It will be noted that none of the above belong to the order Passeres. The only orders represented are Limicola, Gavice, Pygopodes, and Anseres. Only one summer visitant, the very local Sandwich Tern, belongs to this group, while there are sixteen winter visitants - i.e., eleven that do not breed in Ireland at all, or breed very sparingly, and five which, while breeding in limited numbers, are largely reinforced in the winter months.

In the remaining orders-including Passeres, the largest and most important of all-every bird which is known to be a regular immigrant at any season has been received from a light-station.

These facts are important in estimating the weight of the ncgative evidence as to a species being migratory or otherwise, in instances where it has not been forwarded.

Such evidence is strong in the case of a passerine bird, because among the Passeres we have the greatest cumulative proof that species which migrate are addicted to striking the lanterns.

So strong is the testimony in the case of this large order, 
that if we look from regular to irregular (Passerine) visitants, we find only twelve species which have not been sent from lightstations, while there are thirteen which have been forwarded.

Forwarded.
*Woodchat Shrike.
Pied Flycatcher.
*Red-breasted Flycatcher.
Golden Oriole.
*Lesser Whitethroat.
Barred Warbler.
*Yellow-browed Warbler.
White Wagtail.
Wood-Lark.
*Short-toed Lark.
*Lapland Bunting.
Mealy Redpoll.
Crossbill.

Not Forwarded.

Great Grey Shrike.

Red-backed Shrike.

White's Thrush.

Rufous Warbler.

Icterine Warbler.

Waxwing.

Two-barred Crossbill.

Serin.

Ortolan.

Rose-coloured Starling.

Carrion Crow.

Purple Martin.

* Those marked with an asterisk have been received only from light-stations. Nearly all the birds in the right-hand column are very rare stragglers to Ireland, and six of them have been obtained only once.

It may therefore be concluded that any passerine bird resident in Ireland, which has never been received from a light-station is little given to migration.

This is the case with the following-

\begin{tabular}{l|l|l} 
Tree-Creeper. & $\begin{array}{l}\text { Bullfinch. } \\
\text { Coal Titmouse. } \\
\text { Lesser Redpoll. }\end{array}$ & $\begin{array}{l}\text { Magpie. } \\
\text { Jay. }\end{array}$
\end{tabular}

In the case of non-passerine birds we cannot argue with the same confidence. Among the Limicole only a few species are addicted to striking, though all are known to be migratory. Negative evidence in this order would therefore be valueless.

E.-Birds which, though formerly classed as "residents," are proved by their frequent occurrence at light-stations to be habitual migrants-

Missel-Thrush.

Song-Thrush.

Blackbird.

Golden-crested Wren.
Meadow Pipit:

Skylark.

Chaffinch.
Greenfinch.

Rook.

Water-Rail.

while the Robin, Wren, Great Titmouse, Pied and Grey Waytails, Goldfinch, Limnet, Twite, Water-Hen, Coot, and Little 
Grebe may be named as instances of "resident" species which are shown to migrate to a certain extent.

F.-Birds which light-keepers have added to the Irish List-

Woodchat Shrike.

Red-breasted Flycatcher.

Lesser Whitethroat.

Yellow-browed Warbler.

Short-toed Lark.
Lapland Bunting.

Mealy Redpoll (Greenland form, var. rostrata).

Yellow-billed Sheathbill.

The Pied Flycatcher and Wryneck are rare stragglers whose ascertained occurrences in Ireland have been chiefly at lightstations. All the light-house records of the above ten species, amounting to twenty-eight occurrences, were in autumn.

G.-Birds found in Ireland only in summer months, showing comparative numbers forwarded from light-stations in spring and autumn.

\begin{tabular}{|c|c|c|c|}
\hline & \multirow{2}{*}{ Spring. } & \multirow{2}{*}{$\begin{array}{c}\text { Autumn } \\
5\end{array}$} \\
\hline Spotted Flycatcher, & & & \\
\hline Ring-Ouzel, & . & 8 & 7 \\
\hline Common Redstart, & . & 12 & 5 \\
\hline Whinchat, & . & 12 & 3 \\
\hline Wheatear, & . & 71 & 18 \\
\hline Sedge Warbler, & . & 87 & 55 \\
\hline Grasshopper Warbler, & . & 8 & 1 \\
\hline Whitethroat, & . & 87 & 22 \\
\hline Wood-Warbler, & . & 1 & $\ldots$ \\
\hline Willow Wren, . & . & 65 & 17 \\
\hline Chiffchaff, & . & 16 & 6 \\
\hline Garden-Warbler, & . & 1 & 1 \\
\hline Yellow Wagtail, & . & 1 & 2 \\
\hline Swallow, & . & 15 & 1 \\
\hline House-Martin, . & . & 2 & $\ldots$ \\
\hline Sand-Martin, . & . & 8 & $\ldots$ \\
\hline Swift, . & . & 3 & 3 \\
\hline Nightjar, & . & 3 & \\
\hline Cuckoo, & . & 10 & 3 \\
\hline Turtle Dove, . & . & 11 & 3 \\
\hline Corn-Crake, & . & 11 & 2 \\
\hline Common Sandpiper, & . & 7 & 2 \\
\hline Common Tern, . & . & $\ldots$ & 2 \\
\hline Arctic Tern, & . & $\ldots$ & 3 \\
\hline Lesser Tern, . & & 1 & $\ldots$ \\
\hline Roseate Tern, . & & 1 & $\ldots$ \\
\hline & & 450 & 161 \\
\hline
\end{tabular}


Nearly three times as many specimens received in spring as in autumn. But for the exceptional case of the Sedge Warbler, the figures would be 363 in spring, 106 in autumn. The Cuckoo has never struck the lanterns on autumnal migration.

H.-Birds found in Ireland only in winter months, showing comparative numbers forwarded in spring and autumn.

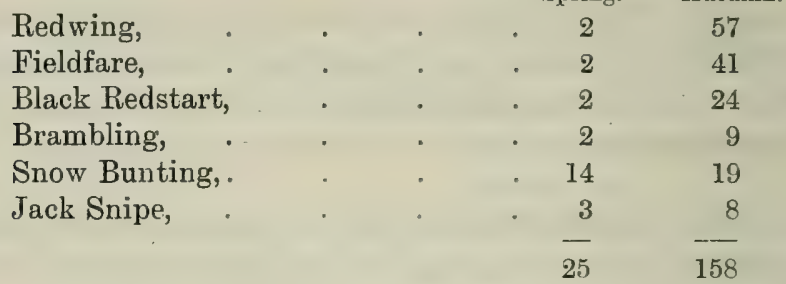

-nearly seven times as many specimens in autumn as in spring. Omitting the Snow Bunting, specimeus of which were chiefly shot, the figures would be 11 in spring, 139 in autumn.

J.-Birds found in Ireland throughout the year, but more numerous in winter, showing comparative numbers forwarded in spring and autumn

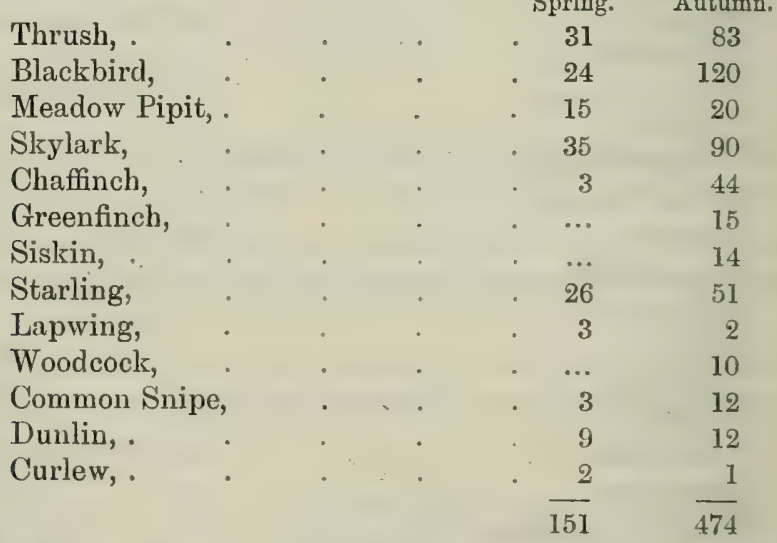

- more than three times as many in autumn as in spring. Compare this with preceding table $(\mathrm{H})$, and it is seen that the winter visitants who wholly absent themselves in summer, strike much less numerously in spring than those whose numbers 
merely diminish in the breeding season. Hypothetically, this can be explained by the suggestion that there is a spring immigration of the latter group of species (Thrush, Blackbird, Meadow Pipit, etc.) simultaneous with the departure of the winter visitants; while the Redwing, Fieldfare, Black Redstart, and Brambling, being all emigrants, scarcely ever strike the lanterns at that season.

K.-Birds, the direction of whose flight has been generally noted as landwards both in spring and autumn.

Thrush.

Blackbird.

Pied Wagtail.

Meadow Pipit.

Skylark.

Chaffinch.
Starling.

Rook.

As all these species are found in Ireland throughout the year, it is possible that a second immigration takes place.

There are also exceptional records of Corn-Crakes flying landwards in autumn, as there are of Woodcock and Snipe in spring. Corn-Crakes have occasionally been found wintering in Ireland, but immigration in autumn has never hitherto been suspected. In confirmation of the landward direction of so many species at their supposed season of departure, we have evidence of some (as the Chaffinch and Greenfinch) dying on light-ships of exhaustion in spring, when the weather was not stormy.

L.-Birds whose departing flights have in some instances been witnessed by light-keepers.

Among land-birds these are extremely few-

Starling. I Swallow. | Lapwing.

The Starling's departure seems to have been noticed under abnormal meteorological conditions. Twenty-six flocks of Swallows have been seen flying seawards in autumn-a small number for so common a bird. The Lapwing is hardly a case in point, since it is simultaneously seen arriving at the southern and departing at the northern extremity of the east coast in spring, and is therefore, in the case of these observations, to be regarded as a bird of passage rather than an emigrant.

Among aquatic birds (Gannet, Swans, Geese, etc.) observations of return movements are comparatively frequent. 
M.--Summer visitants which have been killed at lightstations at abnormally late dates in autumn:-

Spotted Flycatcher, November 20, 1897, Tuskar.

$\begin{array}{llcl}\text { Ring-Ouzel, } & & (? 17), 1897, \text { Tuskar. } \\ \text { Common Redstart, } & " & 7,1891 \text {, Killybegs. } \\ \text { Whinchat, } & " & 9,1890, \text { Blackwater Bank. } \\ \text { Sedge Warbler, } & " & 9,1890, \quad " \\ \text { Whitethroat, } & " & 9,1890, \text { " } \\ \text { Blackcap, } & " & 7,1891, \text { Hook Tower. " }\end{array}$

N.-Birds which, though summer visitants to Great Britain, have occurred at Irish light-stations only in autumn.

Woodchat Shrike (once).

Pied Flycatcher (seven times).

Lesser Whitethroat (twice).
Wryneck (four times).

Spotted Crake (twice).

The Blackcap's occurrences at light-stations have been chiefly autumnal, and there is reason to suspect an irregular immigration at that season. The visits of these birds are probably akin to those of the Red-breasted Flycatcher, Yellow-browed Warbler, Barred Warbler, Lapland Bunting; and Short-toed Lark-all in autumn.

O.-Birds which have been noted flying westwards from the extreme west into the Atlantic:-

Starling, from Eagle Island, E., October 31, 1884 ("a thousand"), also October 31 and November 1, 1886 ("thousands"); and from Blackrock (Mayo), November 16, 1887 ("about sixty").

Rook, from Slyne Head, October 21, 1889, "large flocks."

Heron, from Blackrock (Mayo), September 2, 1896.

Also "Linnets" (a term too vaguely used to be accepted with confidence), from Eagle Island, September 12, 18s4. Blackbirds and other species have occasionally been noted going west from the Arran Isles and from Rathlin O'Birne, but these records are less curious than the above from Eagle Island and Blackrock. What the object of these movements can be it is difficult to conceive; it may be that sometimes there is a reckless. western impulse. We know that islands off our west const are the last refuge of many species during hard weather, but the occasional autumnal rushes out on to the Atlantic Ocenn do not appear to be associated with any special meteorological condition. 
Much has been written on the routes taken during migration, and fanciful aerial roadways have been sketched along the coast, up river-valleys, through mountain passes, and other imaginary lines. When, however, the author is pinned to a particular species, there is often very little for such a speculator to build upon, except the theory of least resistance.

In the works of some prolific writers on migration, there are general statements which it is impossible to grapple with. A more precise indication of the individual species referred to in each case would be necessary to enable one to do so.

There are some points which the reader must bear in mind when studying the foregoing Analysis, and the Annual Reports which follow. The element of uncertainty attaches itself to every record made by an untrained observer,-and, as the lightkeepers are not skilled ornithologists, care has been taken not to attach too much importance to any particular statement. When, however, entries are corroborated by specimens or by independent testimony year after year at several stations, then the utility of accumulating what at one time appeared to be useless statistics is more clearly shown.

This is one reason why many trifling notes swell the size of the Annual Reports. These were printed in order to see whether, if repeated for many years, they might be of any practical value.

One item occasionally omitted (though inserted by the lightkeepers) was the time at which birds were seen passing. Some observers appeared to make entries only at particular hours when they happened to be in the light-house tower, or passing to and fro from their dwellings, and conclusions based on such data were not reliable.

A natural tendency to forward only uncommon varieties which were killed striking prevents the figures showing the relative proportion of the various species of birds killed at lanterns from being strictly accurate, but it is in the main correct, and a request now printed at the top of each schedule (see p. xxiii) to send the leg and wing of every common bird killed striking will, it is to be hoped, remedy this defect. ${ }^{1}$ Whether there was a tendency to forward the first specimen of each common species killed during the season and to omit

1 The column for the direction of flight was first added in 1884 . 
some of those obtained subsequently, is not certain, but at any rate there is a possibility it might sometimes have been done.

In the Analysis there are several tables, and in them different words have occasionally been used to express the same ideathus, "table of occurrences," "table of observations," "table of records," "table of reported occurrences," and "table of observed occurrences," are identical. An occurrence, observation, or record, signifies a particular date on which a particular species was noted at a particular station, whether the number seen was large or small, or observed many times during the day or only once.

The arrangement of the Analysis is the same as that of the Reports, which were commenced several years ago, and which chiefly followed the fourth edition of Yarrell. The nomenclature is that of Saunders's "Manual of British Birds."

The great problems of the origin of the migratory impulse and how birds find their way, are outside the scope of this work.

\section{BATS.}

Bats have been reported on several occasions from some of our most out-lying stations (Fastnet, Rockabill, Blackrock (Mayo), and Tearaght), as well as from two light-ships (Lucifer Shoals and Arklow South). Three were forwarded, and belonged to the three following species:-

Plecotus auritus (Long-eared Bat), Tearaght, November 4, 1891.

Vesperugo pipistrellus (Pipistrelle or Common Bat), Arklow South Light-ship, September 21, 1898.

Vespertilio Daubentonii (Daubenton's Bat), Lucifer Shoals Lightship, April 24, 1891.

The Long-eared and Daubenton's Bats were caught, the Pipistrelle found dead. Bats have never been reported as striking the lantern.

\section{INSECTS.}

Among insects forwarded, the most interesting was a Locust (Locusta cinerascens), caught at South Arran Island in August 1898 (see Irish Naturalist, 1899, p. 249). The 
Death's Head Moth (Acherontia atropos) has been received from Coningbeg Light-ship, ten miles from shore, and about a dozen times from mainland-stations.

\section{Recipe for Preserving Legs and Wings.}

Brush every leg and wing over on both sides with a broad, flat, soft brush, which has been dipped in a solution composed of half a pint of spirits of wine and $2 \frac{1}{2}$ drachms of corrosive sublimate, then mount them like botanical specimens (of course without gum or paste) on sheets of stiff paper, with the original labels pasted or pinned in corner.

\section{ERRATUm.}

The entry in the 1893 "Report," p. 369, of a Grey Phalarope at Arklow South Light-ship is a repetition by mistake of a similar entry for 1892 . 



\section{REPORTS}

ON TIIE

\section{MIGRATION OF BIRDS}

AS OLSELVED AT

LIGHTHOUSES \& LIGHTSHIPS

ON

\section{THE IRISH COAST,}

1888-1897

INCLUSIVE. 



\section{8}

A 
List of Light Stations.

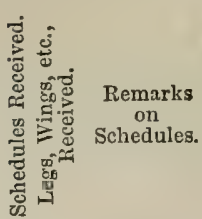

1. Fastnet, Co. Cork

48 excellent.

क.

Names of Observers.

4. Mine Head, Waterford,

2 14 rery good $x-\{$ Ed. Marron and

5. *Coningbeg Lt.-ship, Wexford, 410 excellent.

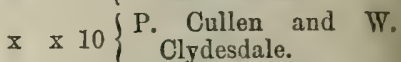

6. Barrels Rock Lt.-ship, do., 10 good.

7. Tuskar Rock,

do.,

626 excellent.

o x 4 Charles $\mathrm{I}^{\prime}$ Cabe.

7a. Lucifer Shoals Lt.-ship, do., 21 good.

7b. Blackwater Bank Lt.-ship, do., 20 fair.

8. Arklow Sth. Lt.-ship, Wicklow, 213 very good.

8. *Arklow North Lt.-ship, do., 31 good.

10. Kish Bank Lt.-ship, Dublin, ,.. 10 fair.

11. Howth Baily, do., ... 11 fair.

$12 \alpha$. St John's Point, Down, ......... 10 fair.

12b. South Rock Lt.-ship, do., ..... 10 fair.

13. Copeland (Mew) Island, do., ... 15 very good.

14. *Maidens South, Antrim, ........ 10 good.

15. Rathlin Island, do., ….... I 0 poor.

16. Innishtrahull, Donegal, ........ 31 very good.

17. Dunree Head, do., ........ 20 fair.

20. Aranmore, do., ........ 27 very good.

21. Rathlin O'Birne, do., ........ 20 very good.

24. Broadhaven, Mayo,............. 10 good.

${ }_{7}$ P. Corish, E. M'Kenna,

Page.

× $\quad$ × 9 Michael Anser.

$x$ × 6 John Murphy.

$x \times 7\{$ A. B. Wall and P.

$x \quad 8\{$ William Daly and

$x \quad x \quad 8\{$ James Toomey.

- x $7\left\{\begin{array}{c}\text { Michael Cunniam and } \\ \text { J. Pinston. }\end{array}\right.$

$x \quad 0-R$. Armstrong.

o $x$ - Edward Rohu.

x $\quad 03\left\{\begin{array}{c}\text { Thomas Cooney and } \\ \text { Henry Thompson. }\end{array}\right.$

o $\quad \mathrm{x} 3$ Ed. M'Carron.

$x \quad 0 \quad 5 \quad$ B. Sole and J. Corish.

$\mathrm{x} \quad 0 \quad 6$ Patrick Keenan.

$\mathrm{x} \times 6$ M. J. Kennedy.

$x x-$ Jervis Brownell.

$\begin{array}{llll}\mathbf{x} & \mathbf{x} & 5 & \text { Thomas Fortune. }\end{array}$

27. Blackrock, do., ............ 2 0 very good. $x \quad x \quad 9\left\{\begin{array}{l}\text { Edward Rohu and } \\ \text { Richard Widdicombo }\end{array}\right.$

31. Slyne Head, S., Galway,........ 3 1 excellent. $\quad$ x $\quad x \quad 3\left\{\begin{array}{c}\text { Richard Widdicombe, } \\ \text { P. D'Arcy, and F. } \\ \text { M.aguire. }\end{array}\right.$

32. Arran Island, N., do., ....... 3 o very gool. $x \quad x \quad 9\left\{\begin{array}{r}\text { H. Williams, J. O’Don- } \\ \text { nell, and J. Watson. }\end{array}\right.$

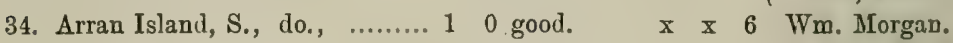

37. Tearaght, Kerry, .............. 311 excellent. $\quad x \quad x \quad 9\{$ F. Ryan, W. H. James,

39. Skelligs, do., ............... 2 0 very good. $x \quad x \quad 9$ James Walsh.

Hook Tower sent 2 specimens, Crookhaven 1, Kinsale 1, Drogheda E. and W. 1, and Green Island 1.

Legs, Wings, etc., received, 105.

$0=$ No reply.

$\mathrm{x}=$ Schedules returned partly or wholly filled.

Spring, replios received from 23 stations. Autumn, replies received from 22 stations. 


\section{LEGS, WINGS, ETC., RECEIVED.}

\section{Species. How Received. How Procured. Date. Name of Station.}

Spotted Flycatcher, Rec'd. in flesh, Killed st., ${ }^{1}$. $18 / 5$ mo., Coningbeg Lt.-ship.

Pied Flycatcher, .

Dead on rock, $30 / 9$ mo., Fastnet.

" " . Leg, wing, tail, Shot, . . 28/9 mo., Tuskar.

Missel Thrush, . Leg and wing, Killed st., . 30/11 mo., A ranmore.

Thrush,

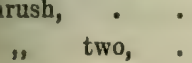

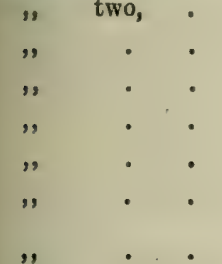

$$
\begin{aligned}
& \text {, } \quad \text {. } 18 / 1 \text { mo., Coningbeg Lt.-ship. } \\
& \text {, . 7/ } 2 \mathrm{mo} ., \quad \text {, ", } \\
& \text {, . 16/10 mo., Tuskar. } \\
& \text {, . 17/ } 1 \text { mo., Arklow S. Lt. ship. } \\
& \text { " . 11/ } 3 \text { mo., " ", } \\
& \text {, } \quad \text { 9/11 mo., Copeland (Mew) Island. } \\
& \text {, } \quad \text { 30/11 mo., Aranmore. } \\
& \left\{\begin{array}{c}
\text { Caught at } \\
\text { lantern, } .
\end{array}\right\} 6 / 11 \text { mo., Tearaght. }
\end{aligned}
$$

\begin{tabular}{|c|c|c|c|c|c|}
\hline$"$ & - & - Leg and wing, & Killed st., & 9/11 mo., & Copeland (Mew) Island. \\
\hline , & - & " & $"$ & 6/11 mo., & Tearaght. \\
\hline ieldfare, & - & - & & 2/11 mo., & Copeland (Mew) Island. \\
\hline$"$ & $\cdot$ & $"$ & $\left\{\begin{array}{c}\text { Caught at } \\
\text { lantern, }\end{array}\right.$ & 6/11 mo., & Tearaght. \\
\hline
\end{tabular}

Redwing, . . Leg, wing, head, Shot, . . 16/2 mo., Mine Head.

Blackbird, . - Leg, . . Killed st., - 18/3 mo., Coningbeg Lt. ship.

" two, . Legsand wings, " . 16/10 mo., Tuskar.

" . . Leg and wing, " . 29/11 mo., Aranmore.

Ring-Ouzel, - Rec'd, in flesh, Found dead, 15/ 4 mo., Hook Tower.

" " two, . Legsand wings, Killed st., . $29 / 9$ mo., Tuskar.

Black Redstart, two, Rec'd. in flesh, $\left\{\begin{array}{c}\text { Caught in } \\ \text { house, }\end{array}\right\} 28 / 10$ mo., Fastnet.

Killed st., . 9/ 5 mo., Tuskar.

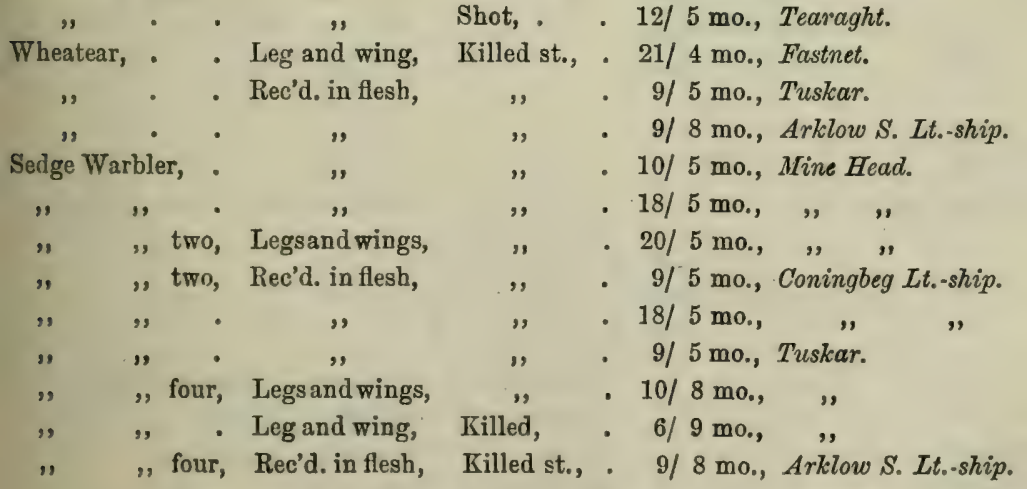

1 Killed st. $=$ Killed striking lantern. 


\section{LEgs, Wings, ETC, RECEIVED-continued.}

Species. How Received, How Procured. Date. Name of Station.

Grasshopper
Warbler, . . Rec'd. in flesb, Killed st., . 9/ 5 mo., Tuskar.

Whitethroat, three, Legsand wings, , , . 10/5 mo., Mine Head.

". two, . . Rec'd. in flesh, Killed, . 11/ 9 mo., Hook Tower.

" . . Leg and wing, Killed st., . $31 / 8$ mo., Tuskar.

, . . " Killed by cat, $22 / 9 \mathrm{mo}$, ,

" . " Killed st., . $27 / 9 \mathrm{mo.,}$,

" . . Rec'd. in flesh, Shot, . . 12/ 5 mo., Tearaght.

Willow Wren, . Leg and wing, Killed st., . $10 / 5 \mathrm{mo}$, Mine Head.

, " . ", Shot, . . 26/4 mo., Tearaght.

Golden-crested Wren, Rec'd. in flesh, $\left\{\begin{array}{c}\text { Caught at } \\ \text { lantern, . }\end{array}\right\} 1 / 10 \mathrm{mo}$, Crookhaven.

\begin{tabular}{|c|c|c|c|}
\hline ," & & $"$ & ", \\
\hline " & & $1 "$ & , \\
\hline , & & " & ," \\
\hline Wren,. & $\theta^{\circ}$ & - & Leg and wing, \\
\hline Meadow-I & Pipit, & , & ," \\
\hline " & " & • & , \\
\hline SkJlark, & - & - & ", \\
\hline " & - & - & , \\
\hline ", & - & - & ", \\
\hline ", & - & - & , \\
\hline
\end{tabular}

Killed st.; . $8 / 4$ mo., Coningbeg Lt. ship. ? 16/10 mo., Tuskar.

Killed s+., . $27 / 8$ mo, Copeland (MIew) Island.

Snow Bunting, · Rec'd. in flesh, Shot, - . 31/10 mc, Tearaght.

Brambling, . . " " . . 28/10 mo., Kinsale.

Twite, . . Leg and wing, , . . 30/10 mo., Tearaght.

Chough, . . Rec'd. inflesh, ", . 2/11 mo., Slyne Head, S.

Sand-Martin, . Leg and wing, " . . 9/5 mo., Tearaght.

Turtle Dove, . Rec'd, in flesh, " . . 19/5 mo., Tuskar.

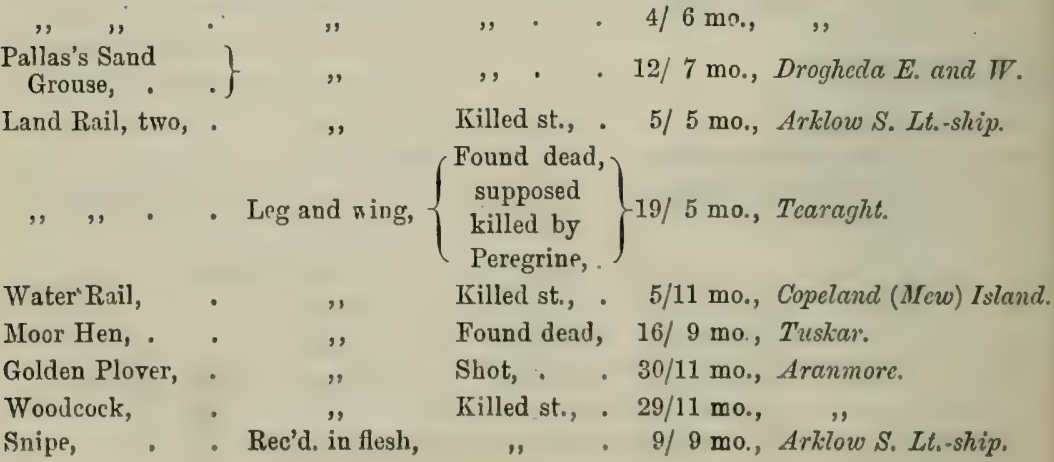




\section{LEgS, WiNgs, ETC., RECEIVED-continued.}
Species.
How Received.
How Procured.
Date.
Name of Station.

Snipe, - . Rec'd. in flesh, Struck rigging, 9/11 mo., Arklow S. Lt. ship.

" . . Leg and wing, Caught st., . 30/11 mo., Aranmore.

Jack Snipe, . . " " Shot, . 12/11 mo., ",

Purple Sandpiper, Leg, wing, bill, Found dead, 18/5 mo., Fastnet.

Kinot, . . Leg and wing, $\left\{\begin{array}{c}\text { Caught on } \\ \text { deck, }\end{array}\right\} 14 / 1$ mo., Arklow S. Lt. ship.

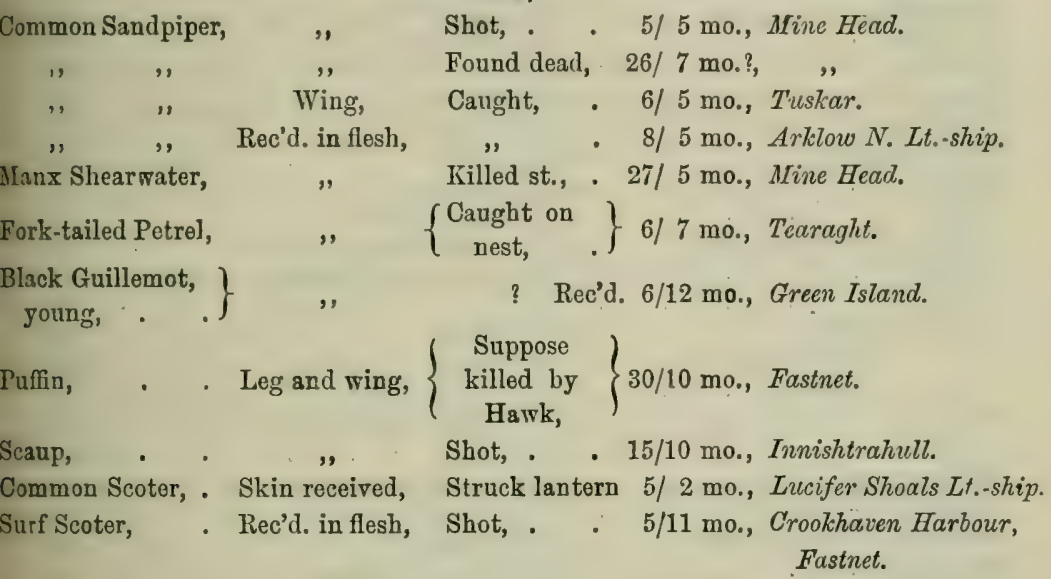




\section{INDEX.}

Bald Coot,

PAGE

Birds not identified, $\quad 57$

Blackbird, . • . . . 15

Black Guillemot, . . . . 50

Black Redstart, . . . . 19

Brambling, . • . . . 29

Bullfinch, • • • • • 31

Bunting, Snow, . . . . 27

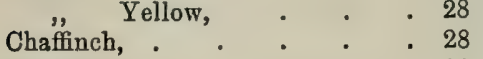

Chiffchaff, . . . . . 22

Chough, . . . . . 35

Cormorant, . . . . 52

Corn-Crake, . . . . 41

Crow, Hooded, . . . . 36

Cuckoo, . . . . . 39

Curlew, · • . • . 46

"Diver, Great Northern," . . 52

"Ducks," . . . . . . 56

Fieldfare, . . . . . 14

Flycatcher, Pied, - - 9

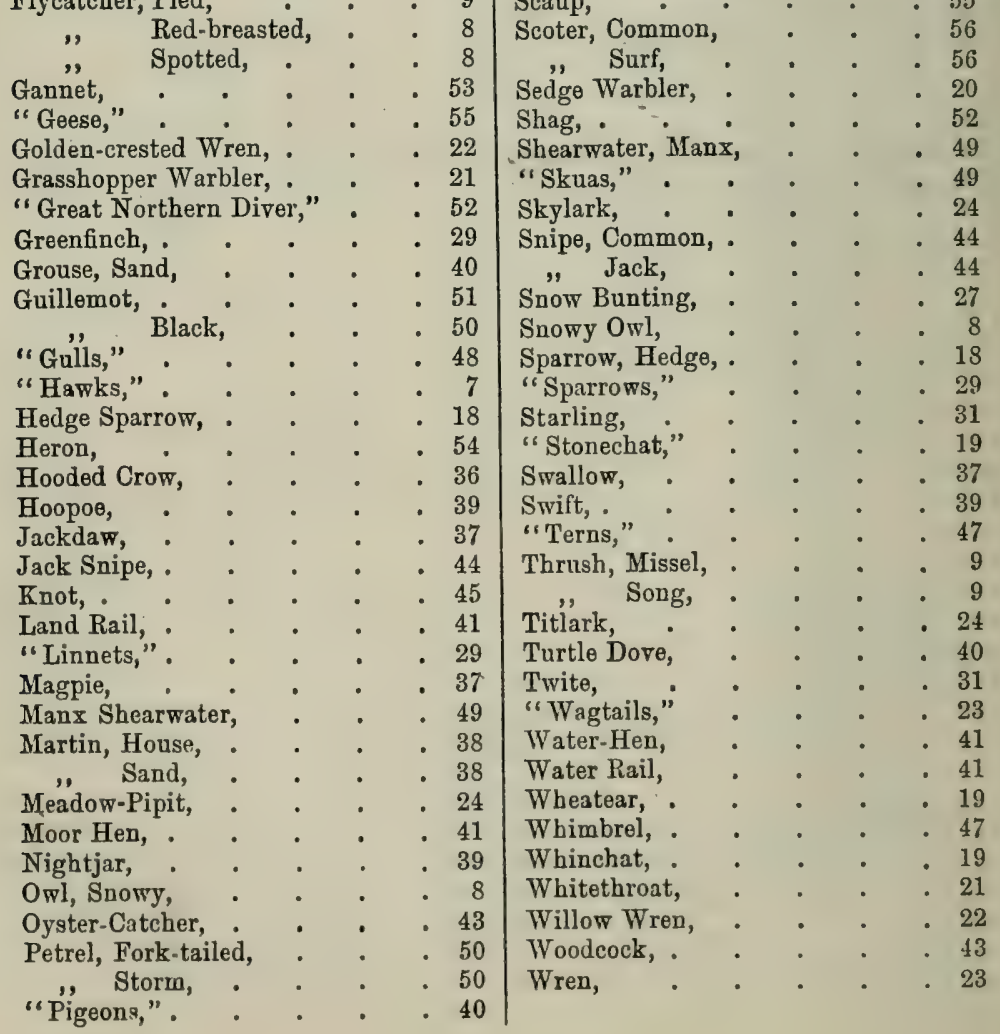

Plover, Golden, . . . . 42

"Green, . . . . 42

," Grey, • . . . 42

,, Ringed, . . . . 42

Puffin, . . . . 51

Rail, Land, . $\quad$. $\quad$ • $\quad$. 41

"Water, . . . . 41

Raven, . . . . . 35

Razorbill, • . . . . 51

Redshank, . . . . . 46

Redstart, . . . . . 18

, Black, . . . . 19

Redwing, • • • . . 13

Ring-Ouzel, . . . . 17

Robin, . . . . . 18

Rook, . . . . . . 36

Sand Grouse, . • • . 40

"Sand Larks," . . . . 45

Sandpiper, Common, . . . 45

. Purple, . . . 45

Scaup, . . . . . 55

Scoter, Common, . . . 56

"’ • • • 50

Shag, . . . . . 52

Shearwater, Manx, • • 49

"Skuas," -

Skylark, • • • • • 24

Snipe, Common, • • • • 44

"Jack, • • • . 44

Snow Bunting, • • • • 27

Sparrow, Hedge, . • . . 18

"Sparrows," • . . . . 29

Starling, . • • . 31

"Stonechat," • • • . 19

Swallow, • • • $\cdot 37$

Swift, , * $\cdot \cdot \cdot \cdot 39$

Thrush, Missel, . . . . 9

Titlark, . . 24

Turtle Dore, • • • . 40

Twite, • • • . . 31

"Wagtails," • • • . 23

Water-Hen, • • • . 41

Water Rail, • • • • 41

Whimbrel, . . . . . 47

Whinchat, . . . . 19

Whitethroat, . . . . 21

Willow Wren, • • • . 22

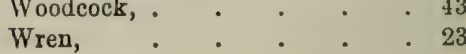




\section{"Hawks."}

Fastnet.-May 9th, one Sparrow Hawk on rock ; very light in colour; wind moderate S.E., gloomy: 12th, one "Kite" on rock at 7 A.M. ; wind light E.S.E., clear. June 1st, one large Hawk on rock at 2 P.M. ; foggy. September 26th, one Sparrow Hawk on rock all day : 30 th, one "Osprey or Sea Hawk" flying N.E.; clear, gentle breeze N.E. October 17th, one "Falcon Hawk" about rock. December 5th, 1 P.M., a large Hawk, supposed to be an Osprey, on rock; when started flew S.W.; weather misty, gentle breeze W.S.W. "It was larger and lighter in colour than any Sea Hawk I have ever seen; it was almost white, or a very light grey, and very shy, so I could not get close to observe it better.-GEorae Dunleavy." [Probably Greenland Falcon.-R. M. B.]

Mine Head.-June 18th, "Small Blue Hawk." October 14th, one Hawk going S.E. November 5th, one Sparrow Hawk. December 1st, one Hawk going S.E.

Coningbeg Light-ship.-May 27th, 9 A.M., one Sparrow Hawk on ship.

Tuskar.-February 4th, one Sparrow Hawk on rock at 7.30 A.M. ; left at 8 A.M. March 20th, one Sparrow Hawk on rock resting; left at 8 A.M.in north-westerly direction: 23rd, one Hawk going N.W. 7 A.Mr. April 30th, one Hawk on rock. September 22nd, one Sparrow Hawk going W. 5 A.M. October 16th, one Hawk at light all night: 21st, one Hawk going W. November 16th, one Hawk going W. 8 A.M.: 18th, one Hawk on rock; went off W. 8 A.M. : 20th, one Hawk going W. 9 A.M.

Blackwater Bank Light-ship.-February 7th, 7 A.M., one Hawk going N.W.

Arklow South Light-ship. — November 8th, "9 A.M., one Sparrow Hawk fighting with two Gulls, Gulls chased Hawk; he went N.W."

Arklow North Light-ship.-June 2nd, one Sparrow Hawk at ship ; went N.E.

Innishtrahull.-April 26th, 9 A.M., one Peregrine hovering about. December 20th, 2 P.M., one Merlin Hawk on island.

Dunvee Head.-January 25th, one Hawk going S.E. December 15th, one Sparrow Hawk going E.

Aranmore.-The Kestrel always remains here, also the Falcon. 
Broadhaven.-June 18th, one Sparrow Hawk going E. at noon.

Blackrock, Mayo.-March 15th, 10 A.Mr., one Sparrow Hawk on rock: 30 th, one Falcon about rock during day. October 21st, two Falcon Hawks seen. November 1st, two Falcon Hawks on rock all day.

Slyne Head, South.-November 13th, one Kestrel.

Arran Island, North.-May 27th, 2 P.M., two Sparrow Hawks on rock. June 1st, one Peregrine Falcon on rock at noon: 28th, 11 A.M., two Peregrine Falcons hovering over the rock. November 26th, 3 P.M., one Hawk about station: 27 th, one Hawk chasing Linnets; killed one.

Tearaght.-August 26th, pair of Peregrine Hawks about all day. November 6th, 11 A.M., one "Grey Hawk (Hen Harrier) seen.-W. H. JAMES."

Skelligs.-January 1st to February 16th, two Peregrine Falcons about. The Peregrine is resident and breeds on the island. October 1st to 31st, two. December, two Peregrines all the month.

SNowy OwL (Nyctea scandiaca, Linn.).

From Broadhaven John A. Murray writes :- "A Snow Owl was shot by Mr Gallagher of Corlough in April, I think; the bird weighed $6 \mathrm{lbs}$. He shot a Sand Grouse at the same time. Both were sent to Mr Knox of Kingstown." (See More's "List of Irish Birds in the Science and Art Museum, Dublin," p. 8, 2nd edition.)

Spotted Flycatcher (Muscicapa grisola, Linn.).

Coningbeg Light-ship.-[May 18th, Spotted Flycatcher killed striking; received in flesh. Entry in schedule on May 16th, "several small birds about light at night; fresh breeze S.W., clear ; several killed striking."]

Arklow South Light-ship.-May 11th, one Flycatcher on deck at 9 A.M., not seen at station for thirteen years-[? Muscicapa grisola.-R. M. B.]; light haze, calm.

Red-Breasted Flycatcher (Muscicapa parva, Bechst.).

Fastnet.-October 16th, noon, "one Red-breasted Flycatcher (supposed), marked same as Pied Flycatcher; very pale pink 
tinge on breast; smaller and plumper; gloomy, gentle breeze W.S.W. I have seen the same sort of bird before--GEonGE Dunleavy."

\section{Pied Flycatcher (Muscicapa atricapilla, Linn.).}

Fastnet.-April 26th, 9 A.M. to noon, two Pied Flycatchers on rock; clear, wind light S.W. "Seemed to be feeding on midges, of which there were many on rock.-George DUNLEavy." September 30th, 4 P.M., one found dead on rock, supposed to have died from exhaustion; clear, gentle breeze N.E. [Received in flesh.] October 21st, "one on rock 7 A.M., left for shore when disturbed; misty, rain, moderate breeze S.E.-GEoRGE DUNLEAVY."

Tuskar.-September 28th, "one small bird, name not known, on rock all day; calm, dense fog; shot and forwarded.-P. CoRIsH." [Leg, wing, and tail of Pied Flycatcher received.]

\section{Missel Throsh (Turdus viscivorus, Linn.).}

Tuskar.-April 9th, "one caught at light at midnight; as it was uninjured, I gave it its liberty next morning;" clear, light breeze N.E.

Aranmore.-November 30th, "six Fieldfares killed;" overcast, moderate breeze E. [Leg and wing of Missel Thrush received.]

Arran Island, South.-October 31st, 1 A.M., "two Missel Thrushes" disabled, going W.; misty, light breeze S.

\section{Thrush (Turdus musicus, Linn.).}

Fastnet.-October 16th, 1 P.M., one on rock; gloomy, gentle breeze S.W.

Mine Head.-February 11th, Thrushes left about this time. March 11th, Thrushes about lantern. October 10th, 8 A.M., two seen; foggy.

Coningbeg Light-ship.-January 1st, 9 A.M. to noon, three; rain, fresh breeze S.: 18th, several at light; overcast, moderate breeze S.E. [Leg and wing received]: 19th, one at light; overcast, moderate breeze S.E. February 6th, one "Redwing Thrush" on ship at 9 A.M.; killed; Starling and "Redwing Thrushes" about light from 8 P.M. to 7.30 A.M. on 7 th, 
several killed; wind light W., overcast-[Legs and wings of two Thrushes received]: Sth, several at light; one killed; overcast, gentle breeze N.W. March 10 th, flock at light; remained till 4 A.M. on 11th; gloomy, with rain. April 14th, several at light; gloomy, moderate breeze W.

Barrels Rock Light-ship.-October 23rd, three "Mountain Thrushes" going N.; clear, gentle breeze S.W.

Tuskar.-January 11th, four on rock 10 P.M.; overcast, light breeze S.E. ; left during day: 16th, one, and 17th, two at light; clear: 19th, numbers at light all night with other birds; two killed; overcast. February 8th, one killed; very clear, moderate breeze N.W.: 13th, one going N.W. at 2 P.M. ; thick snow, moderate breeze E.: 17 th, several at light from 3 A.M. to 6 A.M. ; three killed; clear, light breeze N. March 10th, a few at lamp, with great numbers of Starlings; three killed; rain, gentle breeze S.W. to S.E. : 31st, two seen going N.W. at 6 A.M. April 10th, five at light all night; two killed; overcast, gentle breeze W.: 11th, 12th, 13th, and 14th, some Blackbirds, Thrushes, and Starlings; a great rush from midnight to 3 A.M. on the 12th; showers, fresh breeze W.; numbers killed. October 7th, one on rock all day; gale N.W.: 9th, 8 P.M. to morning of 10 th, great rush, with Blackbirds, Larks, Starlings, etc.; clear, light breeze N.E. : 16th, two on rock all day; another rush at night; two killed-[Leg and wing received]. November 3rd, one going W.; four at light at night: 7th, Thrushes on rock all day; overcast, strong breeze S.E.

Lucifer Shoals Light-ship.-March, Thrushes and Starlings at lantern; three killed; fell on board. October 23rd, Thrushes going N.W., some rested on ship; clear, wind light S.W. : 26th, some killed striking; hazy, wind fresh S.W.: 27th, Thrushes about ship all day, "some flew to land; some were killed at

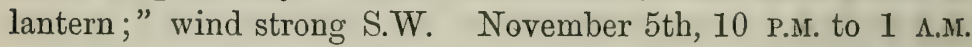
on 6th, several about lantern; three killed; wind fresh S.E.

Blackwater Bank Light-ship.-October 9th, four killed; overcast, light breeze N.W. November 10th, 1 P.M., "one lit on board;" overcast, rain, fresh gale S.E.

Arklow South Light-ship.-January 16th, "two at light; one killed at 9 P.M.;" gloomy, moderate breeze E.: 17th, 9 P.M. to 4 A.M., two killed striking; gloomy, moderate breeze 
S.E. [Leg and wing received]: 18th, one about light at 10 P.M. ; gloomy : 19th, four about light. February 18th, 2 A.M. to 4 A.M., large numbers at light; several killed; snow, wind light N.W. March 8th, 8 P.M. to midnight, large numbers about light; some killed; fell overboard; rain, strong breeze S.W.: 9th, a flock going N.W., flying low; gloomy, moderate gale S.W.: 11th, four killed-[Leg and wing received]: 17th, Thrushes at light; light breeze N.E.: 1Sth, midnight to 4 A.M., Thrushes about light; several killed; fell on board; clear, light breeze N.E. April 12th, 1.20 A.M., Thrushes and Starlings about light; large numbers killed; rain, moderate breeze N.W. November 2nd, Thrushes, Blackbirds, and Larks at light, 5 P.M. to 4 A.M.; several killed; showery, strong breeze N.E.: 7th, 9 A.M., one on deck. December 3rd, 8 P.M. to 10 P.M., a few about light; none killed; hazy, rain, fresh breeze S.W.: 5th, 9 P.M. to 11 P.M., two at light; fog.

Arklow North Light-ship. - February 16th, some at light (see under Starling): 19th, some going N.W. (see under Starling). September 19 th, one killed on deck; wind light S. November 3rd, 8 P.M. to midnight, Thrushes at lamp, many going overboard: 5th, midnight, Thrushes at light; sleet, strong breeze S.E.: 7th, do., many striking and going overboard; showers, moderate gale S.E.

Kish Bank Light-ship.-October 9th, 9 P.M., two at lantern; hazy. November 4 th, one at 1 P.M.; clear, strong breeze S.E.: 12th, three at 3 P.M. going N.W.; gale S.S.E.

South Rock Light-ship.-March 9th, two at light at midnight; killed; hazy, rain, fresh breeze S.W.: 10th, thirteen killed at night: 13th, one found on deck at daylight; killed against rigging; clear, wind fresh E. April 5th, 8 P.M., six Thrushes going N.W.

Copeland (Mew) Island.-October 17th, "Blackbirds and Thrushes are residents here. In misty or foggy weather, when other birds are flying about the lantern, our Blackbirds and Thrushes are up too, and some of them get killed against the glass." November 5th, Thrushes at lantern all night; some killed; wind N.E.: 9th, Blackbirds and Thrushes about light all night; two Thrushes killed-[Legs and wings of Thrush and Redwing received]: 27th, 28th, and 29th, Thrushes, Starlings, and Lapwings striking; a few of each killed. 
Rathlin Island.-May 11th, 4 P.M., a large flock of Thrushes going N.E.; clear, moderate breeze N.E. "They build on the island."

Innishtrahull.-January 15th, "one Common Thrush" striking, not injured, 1 A.M.; hazy, gentle breeze E.; "birds are very scarce in this locality this winter; not a Thrush to be seen from the middle of November (1887) until this date (January 16, 1888); Blackbirds and Thrushes seem to be coming back again, as I saw about two dozen this evening": 16 th, seven on island all day; hazy, moderate breeze E. Narch 24th, 10 P.M to 1 A.M., three striking; clear, fresh breeze E.N.E. November 2nd, one striking lantern at midnight, not disabled; rain, strong breeze N.E.: 5th and 6th, numbers striking; nine killed; hazy, fresh gale E.S.E.

Aranmore.-March 19th, "Mountain Thrushes" still on island. November 10th, a few going N.E. at 9 A.M. ; overcast and misty, moderate gale S.E.: 30th, 3 A.M., Thrushes at light; eight killed - [Leg and wing received]; overcast, moderate breeze $\mathrm{E}$.

Rathlin O'Birne.-January 3rd, 6 A.Mr., two Thrushes remained a few days; rain, moderate gale S. February 10 th, 11th, 12th, 13th, and 14th, immense numbers migrating S.W., in all cases in company with Blackbirds, Fieldfares, Starlings, and Linnets; sometimes rested only for a few minutes on island; snow. September 20th, 2 P.M., three Thrushes seen; wind light S.; first seen on island.

Blackrock, Mayo.-October 21st, two on rock all day; gloomy, wind N.E. : 23 rd to 28 th, several on rock. November 1st, several on rock all day; clear and cloudy, wind N.W.: 2nd, several on rock all day; one killed, several caught; blue sky and cloudy, wind N.: 3rd to 9 th, several on rock; some caught.

Slyne Head, South.-January 13th, two at 2 P.M.; gentle breeze S.E. : 19th, one. February 13 th, numbers on island all day; snow, wind fresh S. to N. March 2nd to 12th, two on island. April 6th and 7th, one on island; clear. November 6th, twelve killed striking; gloomy, strong breeze E.: 7th, Thrushes about all day; gloomy, fresh gale E.: 8th, Thrushes at night; none killed; gloomy, fresh gale E.: 27th, two going $\mathbf{E}$.

Arran Island, N.-April 9th, three going S. at 2 A.M.; clear, gentle breeze N. November 26th, 8 A.M., twenty Thrushes 
about station, some almost too weak to fly; clear, moderate breeze W.N.W.: 27th, several seen at 8 A.M.; clear, gentle breeze E.: 29th, 9 A.M., several seen; hazy, fresh breeze E. December 1st, two at station at 8 A.M.: 9 th, 3 P.M., two at station; clear, gentle breeze E.: 13th, 3 A.M. to 7 A.M., four at light; struck several times, but were not killed; clear, moderate gale $\mathrm{S}$.

Arran Island, S.-October 31st, Thrushes going W. all night; three killed; misty, gentle breeze S. November 1st, four about all night; two killed; clear, moderate breeze S.E.: 2nd, three going S. at night; struck; hazy, light breeze W.: 3rd, flocks at light all night; moderate breeze S.W., misty: 4th, five going S.W. at 3 A.M.; three killed; clear, gentle breeze N.E.: 5th, midnight, three struck going S.W.; clear, gentle breeze N.E.

Tearaght,-March 20th, Thrushes left. November 2nd, two seen at 10 A.M. ; clear, fresh breeze N.: 4th, Thrushes about all day; clear, moderate breeze E.: 6th, one at lamp, not killed; cloudy; two killed later on-[Legs and wings of Thrush and Redwing received]: 26th, several all day; clear, squally, showers, strong breeze S.S.W.

Skelligs.-May 9th, two Thrushes on island all day; mist and fog, moderate breeze W. November 5th, 10 A.M., "two Mountain Thrushes" on rock; moderate breeze E.

\section{REDWING (Turdus iliacus, Linn.).}

Fiastnet.-November 27th, 3 A.M., one caught at lantern; overcast: 28th, several about light all night; clear, gentle breeze E.

Mine Head.-February 3rd, two Thrushes, "sides red": 16th, one shot. [Leg and wing and head of Redwing received.]

Barrels Rock Light-ship.-November 11th, small flock going N. at 10 P.M. ; two rested on ship.

Tuskar.-January 18th, 5 A.M., one killed at light; clear, fresh breeze S.E. November 6th, one found dead; overcast, moderate gale E. : 12 th, one at light at 1 A.M.; overcast, fresh gale S.S.E.; three birds striking through the night; if killed fell in sea.

Copeland (Mew) Island.-November 9th, "two Thrushes" killed striking. [Leg and wing of Thrush and Redwing received.] 
Slyne Head, South.-February 13th, numbers of Redwing on island all day; snow, fresh breeze, variable.

Tearaght.-November 6th, 4 A.M., "two Thrushes" killed striking. [Leg and wing of Thrush and Redwing received.]

Skelligs.-April 24th, two Redwing on island all day; showers, strong breeze N.N.E.

FieldFare (Turdus pilaris, Linn.).

Tuskar:-January 15th, two found dead on rock; clear, fresh breeze N.E.: 19th, numbers at light, with Thrushes, Blackbirds, Larks, and Starlings ; two killed and one disabled; overcast, fresh breeze S.E. March 28th, one going N. November 4th, one found killed; clear, strong breeze S.E.

Arklow South Light-ship.--November 2nd, one Fieldfare found dead; showery, strong breeze N.E.

Copeland (Mew) Island.-November 2nd, several killed against glass; strong wind with rain; several small birds striking-[Leg and wing of Fieldfare received]: 3rd, birds at light all night; Fieldfare killed; wind N.E., strong.

Innishtrahull.-November 3rd, one striking at midnight, not disabled; rain, strong breeze N.E.: 3rd, eighty to one hundred on island at 9 A.M.; "this rush of birds arrived on night of 2nd;" hazy, moderate gale $\mathrm{E}$.

Rathlin O'Birne.-February 10th, 11th, 12th, 13th, and 14th, " immense numbers of Thrushes, Fieldfares, Starlings, Linnets, and Blackbirds during these dates, their flight being invariably to the S.W.; heavy snow on shore; sometimes rested only for a few minutes on island."

Blackrock, Mayo-October 21st, one on rock; wind N.E. November 1st, two on rock all day; wind N.W.: 2nd, several on rock; three killed.

Arran Island, S.-October 31st, six Fieldfares going W.; two killed striking; rain, gentle breeze S. November 2 nd, six going S. at night; struck lantern; hazy, gentle breeze W.: 3rd, flocks at lantern all night; moderate breeze S.W., misty: 4th, six goïng S.W.; four killed, 3 A.M. ; wind N.E.

Tearaght.-November 6th, one killed, 4 A.Mr; overcast, showery, fresh breeze E. [Leg and wing received]: 7 th, 9 A.M., flock observed; misty, fresh breeze E. 


\section{BlaCkBIRD (Turdus merula, Linn.).}

Fastnet.-September 28th, one female on rock at 1 P.M.; wind light N.W. October 21 st, one male on rock at 7 A.M.; left for shore when disturbed; misty, rain, moderate breeze S.E. November 2nd, two males and two females at light at 10 P.I. ; clear, moderate breeze N.N.E. ; captured by assistant.

Mine Head.-February 11th, one male caught at glass: 12th, "all left about this time, except a few." December 14th, 10 A.M., five observed.

Coningbeg Light-ship.-January 13th, one at light at 10 P.M.; overcast, light breeze E.: 18th, several at light; overcast, moderate breeze S.E. March 10th, flock at light from 10 P.M. to midnight; gloomy and rain, light airs, variable: 11th, flock at light, midnight to 4 A.M.; gloomy and rain, fresh breeze S.E.: 18th, several at light, 6 A.M.; one killed-[Leg received]; one seen at 3 P.M. April 14th, several at light, 10 P.M. to midnight; moderate breeze W.

Barrels Rock Light-ship.-November 28th, eight going N.W. in morning; weather variable. December 1st, three going $\mathrm{N}$. at 10 A,M.; clear, moderate breeze W.

Tuskar.-January 11th, 10 P.M., three on rock, left during day; overcast, wind light S.E.: 19th, numbers at light all night; one hen killed; overcast, fresh breeze S.E. February 17 th, several at light from 3 A.M. to 6 A.M.; one caught; overcast, gentle breeze N. March 10th, a few at lamp all night; two killed; rain, wind variable. April 12th, a great rush of Blackbirds, Thrushes, and Starlings midnight to 3 A.M.; showery, fresh breeze W.; numbers killed: 14th, Blackbirds at light; some killed; overcast and showery, moderate breeze S.E. August $3 \mathrm{rd}$, one on balcony at 4 A.M. October 9th, from 8 P.M. great rush; eight killed: 16th, three on rock all day, a rush at night; wind light S., overcast; two killed-[Legs and wings received]. November 2nd, midnight to 4 A.Mr., four at light; one killed; clear, showery, moderate gale N.E. : 3rd, three at lamp from 8 P.M. ; overcast.

Blackwater Bank Light-ship.-February 14th, two killed: 24th, one going S.E. 7 A.M. ; clear, fresh breeze N.E.

Arklow South Light-ship.-January 13th, one about light at 2 A.M. ; weather variable. November 2 nd, 5 P.M. to 4 A.M., 
Blackbirds at light; two cocks killed; showery, strong breeze N.E. : 9th, Blackbirds at light at 9 P.M. ; one killed against rigging; hazy, wind $\mathrm{S}$. by $\mathrm{E}$.

Arklow North Light-ship.-March 11th, two Blackbirds killed striking (see under Starling). November 1st, one killed; sleet, strong breeze N.E.

South Rock Light-ship.-March 10th, fourteen killed striking; hazy and fog, wind moderate S.E.

Copeland (Mew) Istand.-Letter dated September 20th : " It is strange how plentiful Blackbirds and Hedge Sparrows are on Mew Island; a great part of the island is covered over with ferns." October 17th, Blackbirds and Thrushes are residents. November 5th, Blackbirds at light all night; one killed; wind strong N.E.

Maidens South.-March 9th, one at lantern at 4 A.M., not killed; gloomy, moderate breeze S.W.

Rathlin Island.-May 6th, 7 A.M., "one flock going W.; they build on island every year;" fresh breeze N.W.

Innishtrahull.-January 8th, one male seen 2 P.M.; misty, moderate gale W.: 15th, one striking, not injured, 3 A.M. ; hazy, wind light E. : 16th, four on island; males and females, more seen in evening; hazy, moderate breeze $\mathrm{E}$. March 16 th, numbers striking at 11 P.M.; fifteen disabled; light breeze S.: 24th, five striking 10 P.M. to 1 A.M.; clear, fresh breeze N.E. October 18th, one male on island, 1 P.M. ; hazy, fresh breeze S.E. November 5th and 6th, numbers striking; four killed; hazy, fresh gale S.E.

Dunree Head.-November 29th, 10 A.M., two going E.; showery, strong breeze E.

Aranmore.-November 10th, four going N.E. 9 A.M.; overcast, moderate gale S.E. : 29th, ten at light; five killed; overcast, moderate breeze E. [Leg and wing received.]

Rathlin O'Birne.-February 10th, 11th, 12th, 13th, and 14th, "numbers going S.W.; heavy snow on shore; sometimes rested only for a few minutes on island" (see Fieldfare): 23rd, one seen at 10 A.M. October 20 th, two at 2 P.M.; misty, gentle breèze N.E.; "first observed."

Blackrock, Mayo.-March 12th, one on rock 9 A.M. ; clear, wind light W. October 23rd to 28th, Blackbirds on rock. November 1st, several on rock all day; clear, wind N.W. : 2nd, 
do., two killed; wind variable: 3rd to 9 th, several on rock; some caught.

Slyne Head, S.-January 9th, 2.30 P.M., two observed; gloomy, showers: 13th, two seen: 16th, do.; gloomy, light breeze E. February 13th, do.; snow, fresh breeze, variable. March 2nd, 3rd, 4th, 5th, 6th, 10th, and 12th, do. November 6th, one female killed striking; gloomy, strong breeze E. : 7th, do.; moderate gale E.: 8th, Blackbirds came at night; none killed; fresh gale E. : 28th, one on island all day; gloomy, light breeze E. December 16th, one on island.

Arran Island, S.-October 31st, four disabled 1 A.M. going W. ; misty, light breeze S. November 1st, five going W. 2 A.M. ; three killed; rain, light breeze S.E.: 2nd, four going W. at 11 P.M.; one disabled; hazy, light breeze S.E.: 3rd, flocks at light; moderate breeze S.W., misty: 5th, two going S.W. at 11 P.M. struck; clear, light breeze N.E.

Tearaght.-March 20th, Blackbirds left. October 19th, one female observed: 26th, one observed; gale W.: 30th, one. November 2nd, noon, six; clear, fresh breeze N.: 4th, Blackbirds about all day; clear, moderate breeze E.: 6th, one female killed 4 A.M.; overcast, fresh breeze E.: 7 th, flock seen at 9 A.M.; misty, fresh breeze E. December 4 th, one cock observed: 5th, Blackbirds about all day; fog, moderate breeze S.

Skelligs.-January 3rd, 10 A.M., five Blackbirds landed; overcast, showers. April 24th, three on island all day; showers, strong breeze N.N.E. October 4 th to 17 th, several about.

\section{RING-Ouzeis (Turdus torquatus, Linn.).}

Hook Tower.-April 1õth, a bird killed striking, forwarded. [Ring-Ouzel received in flesh.]

Tuskar-April 14th, one killed striking; overcast and showery, moderate breeze S. September 29th, two killed at lantern; wind N.E. [Legs and wings received]. October 9th, one Ring-Ouzel at light 2 A.M. ; clear, light breeze N.E.

Blackrock, Mayo.-April 18th, one on rock during day; showery, light air N.W.

Skelligs.-March 6th, "flock of Ring-Ouzels all day; misty, detached clouds, light breeze N.E." 


\section{Hedge Sparrow (Accentor modularis, Linn.).}

Mine Head.-February 11th, one seen.

Copeland (Mew) Island.--September 20th:- "It is strange how plentiful Blackbirds and Hedge Sparrows are on Mew Island. A great part of the island is covered with ferns."

\section{RoBIN (Erithacus rubecula, Linn.).}

Fastnet.-September 28th, one on rock at 1 P.M.; clear, light breeze N.W.

Tuskar--October 16th, one at lantern all night; showery, light breeze $\mathrm{S}$.

Copeland (Mew) Island.- "The Robin and Wren are neighbours of ours here."

Tory Island.-January 30th, one Robin 10 A.Mr; moderate breeze N.W.

Broadhaven.-April 7th, one Redbreast 3 P.M. ; very clear, strong breeze N.

Blackrock, Mayo.-March 12th, 9 A.M., one on rock; clear, light breeze W. "Very seldom seen on rock."

Arran Island, N.-November 20th, one; remained at lighthouse; first seen this season; clear, fresh breeze N.W.: 26th, one observed 9 A.M. ; clear, moderate breeze N.W. December 1st, one at 1 A.M.; clear, strong breeze S.W.: 8th, one at noon; clear, light breeze N.W.: 15th, one observed 10 A.M. ; clear, moderate breeze N.E.

\section{Redstart (Ruticilla phcenicurus, Linn.).}

Fastnet.-October 16th, one "Redstart" on rock in company with Titlark 1 P.M.; gloomy, light breeze S.W.: 17th, one "Common Redstart" about rock; gloomy, moderate breeze S.: 21st, one Redstart on rock 7 A:M. ; left for shore when disturbed; misty, rain, moderate breeze S.E.: $22 \mathrm{nd}$, one at 10 A.M.; clear, moderate breeze S.E.: 24th, two at 9 A.M. ; clear, light breeze S.-George Dunleavy.

Tuskar:-April 30th, four Redstarts on rock with Wheatears, Pipits, Whitethroats, and Swallows; as morning was misty, could not see which way they went; rain, overcast, wind light S. May 8th, one Redstart on rock all day; clear, calm. June 7th, 
two "Redstarts" on rock all day. November 12th, two all day; overcast, rain, fresh gale S.E.-PATRICK CoRISH.

\section{Black Redstart (Ruticilla titys, Scopoli).}

Fastnet-October 1st, one male Black Redstart on rock; clear, light breeze N.E.: 28th, two on rock 8 A.M.; hazy and rain, gale S.W.; they sought shelter in house and died. [Received in flesh.]

Tearaght.-April 27th, one Black Redstart seen on rock.

\section{"Stonechat."}

Coningbeg Light-ship.-March 23rd, 11 A.M., one Stonechat on ship; clear, moderate breeze $\mathrm{N}$.

Tuskar.-April 25th, one Stonechat all day; clear, moderate gale E. September 22nd, one on rock all day.

Slyne Head, S.-March 31st, one Stonechat all day; light breeze N.E., cloudy; first seen this year. April 1st, one: 7th, several on island; clear, light breeze N.W.; several here all month since the 4th (April). [? Wheatear.-R. M. B.]

Arran Island, N.-May 21st, four "Stone Checkers" remaining on rock; gloomy.

Tearaght.-November 21st, two Stonechats 12.30 P.M. ; clear, showery, fresh breeze N.W.

Whinchat (Saxicola rubetra, Linn.).

Tuskar.-May 9th, "Warblers" at light from 9 P.M.; some killed-[Sedge Warbler and Grasshopper Warbler, Wheatear, and Whinchat received in flesh]; clear, light breeze N.E.

Innishtrahull.-April 16th, midnight, one Whinchat striking lantern glass; cloudy, fresh breeze S.E.

Slyne Head, S.-April 1st, one on island; cloudy, light breeze N.E. : 7th, one all day.

Tearaght.-May 12th, Whinchat shot. [Received in flesh.]

Wheatear (Saxicola oenanthe, Linn.).

Fastnet.-April 21st, three at light 10 P.M.; one killed; misty and rain; strong breeze S.E. [Leg and wing received]. August 10th, two young Wheatears on rock at 11 A.M.; fog; 9 P.M. to 11 P.M., large numbers at light; none killed; drizzling 
rain, light breeze S.W. : 18th, 3 A.M., a rush of Wheatears going S.; clear, light breeze S.E. September 25 th, one on rock; wind S.E.: 27 th, one at light 9 P.M.; misty, strong breeze S.E. : 28th, several at light 8 P.M. to 11 P.M. ; misty and rain.

Mine Head.-April 1st, first Wheatear seen: 4th, a few. "Not plentiful this year."

Coningbeg Light-ship.-March 29th, one about ship at 7.30 A.M. ; showers, moderate breeze N.E.

Tuskar.-March 29th, two at light at 3.30 A.Ir. ; rain, moderate breeze E. April 3rd, a few at light: 4 th, one at light at 3 A.M.; rain, moderate breeze N.W.: 30th, Wheatears in numbers on rock; " as morning was misty, I could not see which way they went;" overcast and rain, light breeze S. May 6th, one on rock 9 A.M.; fog: 7 th, two; fog: 8 th, several all day; clear, calm: 9 th, numbers killed at light from 9 P.II. [Received in flesh]; rain, light breeze N.E.: 10th, "Warblers and Wheatears" in numbers; fog, light breeze N.E. August 11th, Wheatears at light. September 3rd, 4th, 9th, and 11th, one noted each day.

Arklow South Light-ship.-August 9th, several small birds killed striking midnight to 3 A.M. [Three Sedge Warblers and one Wheatear received]; hazy, rain, light breeze S.W.

Innishtrahull.-September 4th, three striking 9 P.M.; not injured; light breeze S.W.

Blackrock, Mayo.-April 1st, one on rock at 9 A.M.; clear, light breeze N.E.

Slyne Head, S.-April 3rd, one all day; wind light N.E.; cloudy: 4th, two on island all day, "male and female": 7th, several; clear, light breeze N.W. April, several here all month since 4 th.

Tcaraght.-April 26th, Wheatears seen. October 21st, one; light breeze S.E.

Skelligs.-March 18th, several all day; clear, light breeze S.E.; "breeds on the island." November 5th, 10 A.M.; eight; showery, moderate breeze E.

Sedge Warbleir (Acrocephalus schonobcenus, Linn.).

Mine Head.-May 10th, one killed striking-[Received in flesh]: same date, "Reed Warbler caught striking": 18th, one 
killed striking-[Received in flesh]: 20th, two killed at light. [Legs and wings received.]

Hook Tower.-About August 15th, some killed; two sent to Mr R. J. Ussher.

Coningbeg Light-ship.-May 9th, 10th, and 11th, several small birds killed; fog, light breeze E. [Legs and wings of two Sedge Warblers received]: 12th and 16th, do.; clear: 18th, one killed striking-[Received in flesh]. October 4th, one on ship all day; clear, fresh breeze W.

Tuskar.-May 9th, "Warblers at light; numbers killed"[Sedge Warbler received in flesh]; rain, light breeze N.E. August 10th, several Warblers all night; four killed-[Legs and wings of four Sedge Warblers received]. September 7th, "one Warbler found dead on balcony." [Leg and wing Sedge Warbler, dated 6th, received.]

Athlow South Light-ship.-August 9th, several small birds killed-[Four Sedge Warblers and one Wheatear received in flesh]; hazy, rain, light breeze S.W.

Grasshopper Warbler (Acrocephalus navius, Bodd.).

Tuskar.-May 9tb, "Warblers and Wheatears at light from 9 P.M. ; wind light N.E., rain, and clear; numbers killed." [Sedge Warbler, Grasshopper Warbler, Wheatear, and Whinchat received in flesh.]

\section{Whitethroat (Sylvia rufa, Bodd.).}

Mine Head.-May 10th, small birds striking-[Legs and wings of three Whitethroats received]: 18th, two killed striking. [Legs and wings received.]

Hook Tower.-September 11th, one killed striking. [Received in flesh.]

Tuskar-April 14th, Whitethroats at light midnight to 3 A.M.; some killed; overcast and showery, moderate breeze S.E. : 30th, Whitethroats on rock; "as morning was misty, I could not see which way they went." May 5th, one on rock all day: 15th, Whitethroats at light from 11 P.M.; a few killed; overcast, moderate breeze S.E. August 31st, one found dead at 6 A.Mr. [Leg and wing received]. September 
9th, one on rock all day; overcast: "10th, one at noon: 12th, one at light: 22nd, one killed by cat-[Leg and wing received] : 16th, one; overcast, moderate breeze E.: 27 th, one killed striking; strong breeze S.E., overcast. [Leg and wing received.]

Tearaght.-May 12th, one shot-[Received in flesh]: 14th, several.

\section{Willow Wren (Phylloscopus trochilus, Linn.).}

Mine Head.-May 10th, small birds striking and in rays; three Whitethroats and Sedge Warbler killed; "Reed Warbler" caught striking. [Sedge Warbler in flesh, and legs and wings of Whitethroats and Willow Wren received.]

Arklow North Light-ship.-September 11th, one "Sallypicker" caught at 2 A.M. ; clear, light breeze N.W.

Tearaght.-April 26th, one "Chiffchaff" shot. [Leg and wing of Willow Wren received.]

\section{Chiffchaff (Phylloscopus collybita, Vieill).}

Tuskar.-April 14th, Larks, Whitethroats, and "Chiffchaffs" about light from midnight to 3 A.M. ; some of each kind killed; overcast, showery, wind moderate S.E.

Innishtrahull.-May 5th, two "Chiffchaffs" striking at 10 P.M. ; not injured ; misty, light breeze S.W.

\section{GOLDEN-CRESTED Wren (Regulus cristatus, Koch).}

Crookhaven.-October 2nd, "I forward a little bird caught at light; it is the second of same description which $I$ have seen in this locality during the last five years." [Gold-Crest received in flesh.]

Coningbeg Light-ship.-April 7th and 8th, several small birds at light; one killed; gloomy, light breeze N.E. [Gold-Crest received in flesh.]

Tuskar.-September 11th, one at light 11 P.M.; clear. October 9th, two "Firecrests" killed at light-[a Gold-Crest received in flesh on 16th]: 10th, one at light from 8 P.M.; clear, light breeze $\mathrm{N}$. 
Copeland (Mew) Island.-August 27th. [Golden-crested Wren killed striking; received in flesh.]

Innishtrafull.-September 16th, one striking at 1 A.M.; clear, wind light S.: 17th, four striking 1 A.M. to 3 A.M. ; clear, light breeze S.W.

WrEN (Troglodytes parvulus, Koch).

Tuskar:-October 10th, 1 P.M., one on rock; clear, light breeze S.W.: 16th, one on rock all day-[Leg and wing received; killed striking night of $16 \mathrm{th}]$; overcast, light breeze S.: 22nd, one all day; misty.

Copeland (Mew) Island.-November, "the Wren is plentiful here."

Innishtrahull.-December 22nd, one on island at 3 P.M.; clear, wind light S.E.: 25th, one at 11 A.M.; clear, gale S.

Rathlin O'Birne.-March 2nd, one Wren on island during winter. September 15th, 10 A.M., two on island; not observed after 22nd January 1889.

Blackrock, Mayo.-October 21st, one seen; gloomy, wind N.E.: 22nd, one all day; cloudy, S.E.: also on 23rd, 28th, and November 1st.

Slyne Head, S.- "During January four Wrens, and in March two Wrens, on island." April 3rd and 6th, two seen. December 16 th, one on rock all day.

Arran Island, N.-November 30th, December 4th and 12 th, one about station.

Skelligs.-Resident; breeds on the island.

"Wagtails."

Mine Head.-January 31st, one "Water Wagtail" seen.

Coningbeg Light-ship.-September 25th, one Wagtail about ship 9.30 A.M. ; light haze, moderate breeze E.: 30th, one going N. at 10 A.M. ; clear, fresh breeze N.E.

Tussicar-March 17th, one Wagtail at light; clear. April 14th, "one Yellow Wagtail" at light from midnight to 3 A.M. ; overcast, moderate breeze S.E. October 4 th, one at 9 A.M. ; clear, strong breeze N.W.: 21st, one on rock.

Innishtrahull.-May 5th, one "Pied Wagtail" striking, not injured, 10 P.M.; misty, light breeze S.W. 
Slyne Head, S.-February 13th, "one Grey Wagtail" on rock all day; snow. March 12 th, one Wagtail all day.

Tearaght.-October 1st, two Wagtails observed; remained on island for several days.

Meadow-Pipit (Anthus pratensis, Linn.).

Fastnet.-March 24th, one on rock all day. October 12th to December 8 th, one or two seen at intervals.

Coningbeg Light-ship.-March 14th, several small birds about light at night; wind moderate W.; gloomy, rain; several killed -[Leg and wing Titlark received]: 16th, 25th, 27th, 28th, and 29th, one noted each day. April 3rd, 10 A.M., two going N.E.; one killed; clear: 6th, one going N.E. October 7th, one about ship. Tuskar.-March 27th and 29th, April 1st and 19th, one seen each day on rock: 30 th, "Pipits" on rock. September 28th, "one small bird, name not known," on rock all day; shot and forwarded-[Leg and wing Titlark received]; calm, thick fog. October 7 th, one all day; clear, moderate gale N.W.

Arklow North Light-ship.-May 7th, Titlarks at lantern at midnight; misty.

Kish Bank Light-ship.-December 20th, two about deck at noon.

Copeland (Mew) Island.-November, "Pipits are plentiful here."

Rathlin O'Birne.-February 26th, 3 P.M., five Titlarks going E.

Blackrock, Mayo.-October 21st, several Titlarks.

slyne Head, S.-March, "some Titlarks here all month."

Arran Island, N.-April 15th, five seen. June 5th, three nests of young Titlarks reared on rock. [? Rock Pipits.R. M. B.]

Arran Island, S.-November 4th, Titlarks going S.W. at 3 A.M.; three disabled; clear, light breeze N.E.

Skelligs.-May 9th, "resident; breeds on island."

\section{SKYLARK (Alauda arvensis, Linn.).}

Fiastnet.-October 21st, one at rock at 7 A.M.; one captured at 3 P.M. completely exhausted; died-[Leg and wing received]; misty, rain, moderate breeze S.E.

Mine Head.-December 20th, 4 P.M., a ferw Skylarks. 
Coningbeg Light-ship._March 20th, four Larks going N.E.; clear, fresh breeze N.E.: 22nd and 23rd, several passing N.E. during day. April 21st, three going N. September 22nd, two going N.; haze, light breeze E.: 28th, several about ship; weather variable. October 6th, three going $\mathrm{N}$.

Barrels Rock light-ship.-October 17th, small flock going N.W. November 1st, flocks going N.W. at 3 P.M.; one rested on ship.

Tuskar--January 9th, one on rock 2 P.M.: 19th, Larks at light all night; one killed; overcast, fresh breeze S.E. February 5th, one on balcony at daylight: 6th, two found killed on rock; cloudy, light breeze W.: 8th, one killed in morning; very clear, moderate breeze N.W. March 9th, one at light at 5 A.M.; mist and showers, moderate gale S.W.: 29 th, one on rock. April 14th, Larks about light, midnight to 3 A.M. ; some killed; passing showers, moderate breeze S.E. September 29th, one at light during night. October 5th, one seen: 9th, great rush of Larks from 8 P.M.; five killed; clear, light breeze N.E.: 10th, Larks at light from 8 P.M.; none killed: 16th, Larks at light all night; one killed. [Leg and wing received.]

Lucifer Shoals Light-ship.-October 21st, several flocks going N.W. from 10 A.M. to 4 P.M., flying low; clear, wind moderate S.E.: 23rd, Larks going N.W. all day; wind light S.W. : 26th, Larks striking from 9 P.M. to midnight; some killed; hazy, wind fresh S.W.: 27th, Larks and Thrushes about all day; some flew to land; some killed at light; hazy, wind strong S.W. November 9th, one about ship.

Blackwater Bank Light-ship.-February 9th, one found dead on deck: 28th, two going N.W. October 9th, four killed; overcașt, light breeze N.W.: 19th, one going N.W.: 20th, 24th, 28th, and November 1st, one or two noted going N.W. each day: 4th, one killed striking; hazy : 9th, one going N.W.

Arklow South Light-ship.-March 11th, large numbers at light from 2 A.M. to 6 A.M.; many striking, fell overboard; twelve caught; rain, moderate breeze S.E. [Leg and wing received]: 17th, Thrushes, Larks, and Starlings at light, midnight to 4 A.M. ; several striking fell overboard; clear, light breeze N.E. September 29th, two at 7 A.Mr. October 18th, flock flying low to N.W. November 2nd, 5 P.M. to 4 A.M., 
Thrushes, Blackbirds, and Larks at light; showery, strong breeze N.E. : 6th, several flocks going N.W., flying high, from 8 A.M. to noon; gloomy, light breeze E. : 7 th, flock going N.W., flying low: 12 th, two about ship: 17 th, one : 28 th, several at light, 8 P.M. to midnight; none killed.

Arklow North Light-ship.-January 1st, 3rd, and 5th, Larks and Starlings about lantern at midnight; wind S. February 16 th, some at midnight. March 7th, numbers of Larks and Starlings about lantern during first watch; none killed; gale S.W., misty, rain : 11th, one killed striking. October 6th, two going N.W. at noon; one caught. November 1st, Larks going N.W. all day: 2nd, flocks going N.N.W. all day; four killed on deck; sleet, moderate breeze N.E.: 3rd, 8 P.M. to midnight, Larks at lantern, many going overboard; rain, moderate gale E. : 5th, Larks at lantern at midnight; sleet, strong breeze S.E.: 7th, do., many going overboard; showers, moderate gale S.E. : 8th, Larks going N.W. at noon; showers, moderate gale S.E.

Kish Bank Light-ship.-October 9th, seven at lantern at 9 P.M.; hazy. November 4th, two at lantern at 8 P.M.; rain, moderate gale S.E.: 12 th, eight going N.W. December 14 th, two about deck 9 A.M.; went N.W.: 29th, two small flocks going N.W.: 30th, 4 P.M., flock going N.W.

Howth Baily.-October 9th, several striking, 11 P.M.; fog. [Leg and wing received.]

South Rock Light-ship.-January 14th, 11 P.M., two at light; one killed; clear, moderate breeze E. March 10th, eight killed striking; hazy and fog, wind moderate S.E.: 11th, two dozen flying to land; clear, wind moderate N.E.: 20th, one found dead on deck at daylight, killed against the rigging; clear, wind fresh N.E. : 21st, one at light all night, killed against rigging; hazy.

Copeland (Mew) Island.-October 9th and 17th, one killed striking. November 2nd, plentiful all night at lantern from 6 P.M. till midnight: $27 \mathrm{th}, 28 \mathrm{th}$, and 29th, Skylarks striking; one killed on 28th.

Maidens South.-January 14th, Skylarks at lantern at night; not killed; gloomy: 17th and 18th, two killed striking each night. February 5th, three killed. March 1st, one at lantern 8.30 P.M.: 2nd, two at lautern 1 A.M.: 8th, one going S.W. 
8 4.M.: 10th, nine killed striking at night; clear, light breeze S. : 20 th, 9 A.M., one going $\mathrm{N}$.

Rathlin.-June 10 th, a dozen Larks going E. 1 A.M.; did not strike; fog, wind light S.E.

Innishtrahull.-March 24th, 10 P.M. to 1 A.M., nine striking, four killed; clear, fresh breeze N.E. April 14th, two striking 11 P.M. ; mist, fresh breeze S.E.

Broadhaven.-April 1st, Skylarks numerous; "very plentiful this season."

Blackrock, Mayo.-March 11th, three disabled 3.30 A:M.

Slyne Head, S.-February 13th, numbers of Skylarks on island all day; snow. March 12th, 19th, and 24th, one noted each day.

Arran Island, N.-May 24th, four going S. 10 A.M.

Arran Island, S.-May 6th, 11 P.M., three going N.W.; one killed striking; misty, moderate breeze S.W.: 10th, two killed striking.

Tearaght.-November 6th, one killed 1 A.M.; overcast, showery, fresh breeze E.

Snow Bunting (Plectrophanes nivalis, Linn.).

Fastnet.-October 18th, one on rock at 3 P.M.

Mine Head.-October 6th, one seen.

Innishtrahull.-October 18th, twelve on island at noon.

Aranmore.-October, "Snow Bunting to be seen daily passing back and forward."

Rathlin O'Birne.-December 15th, thirty on island at 9 A.M.; "flocks came until end of January."

Blackrock, Mayo.-March 15th, one on rock; gale N.E.; "it is remarkable that so few Snow Bunting have visited rock this year": 31st, two. October 21st, one "Snowbird (male)"; gloomy, wind N.E.: 23rd to 28th, one "Snowbird" on rock. November 10th, one "female Snowbird."

Slyne Head, S.-March 30th, one Snow Bunting on island.

Arran Island, N.-November 22nd, three seen; fresh gale S.W. December 3rd, several about rock all day; misty, fresh breeze S.W.

Tcaraght.-March 29th, one seen on rock. October 31st, one shot; fresh breeze N.W. [Received in flesh]. November 4th and 10 th, one seen. 


\section{Yellow Bunting (Emberiza citrinella, Linn.).}

Fastnet.-March 16th, one seen on rock; clear and frosty, strong breeze N.E.

Mine Head.-January, "Yellow Bunting and all the other common species plentiful this month." February 11th, one.

Slyne Head, S.-March 19th, one on island all day. April 4 th and 15th, two (male and female) on island all day.

Arran Island, N.-June 15th, "one Ortolan seen; remained on rock for some days." [Possibly Yellow Bunting.-R. M. B.]

Tearaght.-October 28th, one Bunting observed; strong gale S.W. [Probably Yellow Bunting.-R. M. B.]

\section{Chaffinch (Fringilla coelebs, Linn.).}

Fastnet.-September 28th, several at light, with a few Wheatears, 8 P.M. to 11 P.M. ; misty, wind light N.W.: 29th, Chaffinches left for mainland at noon. October 16th, one on rock at 9 A.M. : 22 nd, one caught 9 A.M. : 24 th, three.

Mine Head.-February 11th, one Chaffinch seen.

Coningbeg Light-ship.- September 27th, two about ship at noon; clear, moderate breeze S.E. October 5th, one about ship all day: 19th, several about day and night; hazy, moderate breeze S.E.

Barrels Roch Light-ship.-November 3rd, large flock at 11 A.M. going N.W.; rain, fresh breeze E.

Tuskar.-January 20th, noon, "bird like a Chaffinch" about rock. February 3rd, one at 10 A.M. March 23rd and 27th, one. April 6th, one going. W.: 7th, two seen: 8th, one (killed by cat): 17th, 18th, and 19th, one all day: 27 th, one at light 11 P.Mr; clear, light breeze W. October 9th, rush of Chaffinches from 8 P.M.; clear, light breeze N.E.: 15th, one on rock: 16th, one killed striking: 19th, 20th, 21st, and 22nd, one seen : 30 th, one (killed by cat). November 4th, one : 5th, 6 th, and 7th, Chaffinches on rock all day; weather gloomy, wind S.E.

Blackwater Bank Light-ship.-October 17th, one going S.E.: 18th, one perched in boat 5 P.M. : 21st, two found dead on deck; clear, light breeze S.E. : 29 th, one at light 6 P.M.

Arklow South Light-ship.-November 4th, one going W.N.W. : 7 th, one on deck. 
Blackrock, Mayo.-October 21st, several on rock all day; gloomy, wind N.E.: 22nd, two on rock all day; clear, wind S. to S.E. November 8 th, six on rock all day; gloomy, wind S.E. to E. : 9 th, do.

Slyne Head, S.-January 19 th, one at noon. February 13 th, numbers on island all day; snow, fresh breeze. March 19th, four all day; misty.

Tearaght.--March 5th, Chaffinches left. November 7th, one observed 9 A.M. ; misty and showers, fresh breeze E.

Brambling (Fringilla montifringilla, Linn.).

Old Head, Kinsale-October 28th, Mountain Finch shot. [Brambling received in flesh.]

\section{"SPARROWS."}

Broadhaven.-June 3rd, flocks of Sparrows at station all day.

GreEnTINCH (Coccothraustes chloris, Linn.).

Fastnet.-September 29th, one on rock at noon, left for mainland; gloomy, moderate breeze S.E.

Mine Head.-February 11th, Greenfinches left.

Arlilow North Light-ship.-August 11th, numbers of small birds at lantern; "one Green Linnet" killed midnight; rain, strong breeze S.W.

St John's Point, Down.-December 30th, large flock Greenfinches about station during day.

Copcland (Mcw) Island.-October 28th, "one came into dwelling-house, the only one observed."

Tearaght.-March 28th, Greenfinches left, except one pair which remained till the 12th May. December 23rd, one observed noon; squally, passing showers.

\section{"LinNets."}

Fastnct.-October 24th, "four Grey Linnets" flying S.W.: 29th, five do. going S.W. noon; clear, moderate breeze S.W.

Coningbeg Light-ship.-April 1st, 10 A.M., flock of Linnets going N.E.; 11. A.M., do. 
Barrels Rock Light-ship.-October 18th, small flock of Linnets going N.W.; clear, fresh breeze S.E. November 5th, small flock going N.W. noon; one killed by Gull; rain, strong breeze S.E. : 8th, five going N.W. 4 P.M.; gloomy, moderate gale S.E. December 12th, small flocks going N. from 9 A.M. to 10 A.M. ; clear, light breeze S.W.

Lucifer Shoals Light-ship.-March 27th, four Linnets going N.W. 11 A.M.: 31st, several flocks of Linnets going N.W.; clear, moderate breeze N.E.

Arklow South Light-ship.-May 12th, one Cock Grey Linnet on deck at 10 A.M.; went to land; calm, light breeze. November 14th, 9 A.M., two going N.W., flying low.

South Rock Light-ship.-March 8th, one at light 6.30 A.M. May 9th, one going N.W. at 10 A.M.

Maidens South.-January 22nd, 10 A.Mr, two Linnets going W.

Innishtrahull.-January 11th, 12th, and 13th, four Linnets on island; wind S.W. August 30th, "nine Scotch Linnets" on island; clear, wind strong N.W. October 18th, eighteen Grey Linnets on island at 1 P:M. ; fresh breeze S.E

Rathlin O'Birne.-February 10th, 11th; 12th, 13th, and 14th, "immense numbers of birds, consisting of Thrushes, Fieldfares, Starlings, Linnets, and Blackbirds, seen during these dates; their flight was invariably to the S.W.; sometimes rested only for a few minutes on the island; heavy snow on shore." October 28th, fifty Linnets going W. 8 A.M.; squalls and hail, strong breeze W.; two killed striking. December 10th, fifty alighted 8 A.M.; clear, strong breeze S.E.; remained till 14 thh.

Broadhaven.-April 5th, three flocks going S. noon; clear, moderate gale N:E.

Blackrock, Mayo.-October 21st, "three Cock Grey Linnets seen"; gloomy, wind N.E.

Slyne Head, S.-February 13th, Grey Linnets on island all day; snow, strong breeze, variable. December 15th, large flock of Linnets on island at 9 A.M. (first seen); clear, light breeze N.E. : 15 th, small flock.

- Arran Island, N.-November 26th, six Linnets about rock at 3 P.M. ; clear, fresh breeze S.: 27 th, twenty Linnets 10 A.M.; clear, light breeze E.: 30 th, flock at noon. December 8th, two Grey Linnets at station: 12th, flock of Linnets going N. : 15th, ten Linnets at station, went $\mathrm{N}$. 
Arran Island, S.-November 1st, five Grey Linnets at 3 A.M.; two caught; clear, light breeze S.E.: 2nd, several flocks going W.; hazy, wind W.: 5 th, four Grey Linnets at 2 A.M.; two killed; light breeze E.

Tearaght.-September 8 th, flock of Linnets and Twites about all day. October 23rd, 9 A.M., one flock (thirty birds) Grey Linnets; cloudy and misty, light breeze S.E.

TwITE (Linota flavirostris, Linn.).

Tuskar.-January 8th, one about rock at 10 A.M. March 31st, four going N.W.; wind strong N.E.

Tearaght.-February 20th, "Twites have all left by this date." September 8th and 9th, flock of Twites and Linnets about all day; clear, light breeze N.E. October 30th, Twite shot at 2 P.M. [Leg and wing received]; clear, showery, moderate breeze W.

\section{"Bullfinch."}

Blackrock, Mayo.-November 11th, one on rock all day; gloomy, wind S.W. to S.E.

Starling (Sturnus vulgaris, Linn.).

Fastnet.-October 16th, one on rock: 17 th, one on rock, probably same bird: 18th, two: 19 th and 21st, four. November 4 th, three all day.

Mine Head.-February 6th, several at lantern. March 11th, Starlings at glass all night; several killed; wind and rain: 28 th and $29 \mathrm{th}$, large flocks.

Coningbeg Light-ship.-January 2nd, six going N.E. 9 A.м.: 7 th, flock going N.E. at 8 A.M. : 10 th, one at light at 10 P.M. February 6th, several killed from 8 P.M. to midnight; overcast, wind N.W.: 7th, two killed: 24th, one going N. March 10th, Starlings at light from 10 P.M. to midnight; several fell overboard; rain, wind light, variable: 11th, midnight to 4 A.M., do.; gloomy and rain, fresh breeze S.E. April 3rd, 11 A.M., one going N.E. October 19th, one about ship all day.

Barrels Rock Light-ship._-October 18th, small flock going N.: 19th, Starling going N.: 20th, one going N.: 21st and 22nd, several going $\mathrm{N}$. November 4 th, Hock passing N.; showery, fresh breeze S.E.: 5 th and 7 th, Starlings going N. 1 A.M. to 
3 A.M. ; clear, moderate breeze S.E. : 11 th, 8 P.M. to midnight, Starlings passing in a northerly direction; clear, fresh breeze S.E.: 28th, Starlings passing N. 9 P.M. to midnight; clear, moderate breeze S.E. December 8th, three at light at 8 P.M.

Tuskar:-January 12th and 13th, one disabled: 15th, one killed at light: 19th, Starlings, with Thrushes, Blackbirds, Fieldfares, and Larks, in numbers at light all night; overcast, fresh breeze S.E. February 5th, one at light 10.30 P.1r.: 6th, large numbers at light; five killed; some must have fallen into sea; light breeze N.W.: 9 th, one at light: 11 th and 17 th, some at light. March 9th, three at light at 5 A.M. : 10 th, 7 P.M. to daylight on 11th, great numbers about light; great flocks resting on balcony at night, and also a few Blackbirds and Thrushes; rain, light breeze W.S.W. to S.E.: 17th, Starlings in numbers at light from 10 P.M. ; fresh rush at midnight; clear, wind N.E.: 20 th, ten on balcony j A.M.; clear, fresh breeze N.E. : 29th, Starlings at light, with Thrushes, Blackbirds, and two Wheatears (principally Starlings), 3.30 A.M.; three Starlings killed; rain, moderate breeze E.: 30 th, one going N.W. 6 A.M. April 3rd, one at light 2.30 A.M. ; after 2.30 A.M. a rush of Starlings and a few Wheatears; some Starlings killed striking; dark, fresh breeze N.: 4 th, three at light 3 A.M.: 6 th, six Starlings and a few small birds at light 3.20 A.M.: 7 th, two at light 10 P.M. : 10th, ten at light all night; four killed striking: 11th, twenty at light; three killed: 12th, numbers at light, with Blackbirds and Thrushes, midnight to 3 A.M.; many killed; this was a great rush; overcast, clear, fresh breeze W.: 13 th and 14th, a few at light in early morning. October 9th, great rush from 8 P.M., with Blackbirds, Thrushes, Chaffinches, and Larks; six Starlings killed; clear, light breeze N.E. : 10th, Starlings at light; none killed; clear, light breeze N.: 12th, do.; clear and showery, moderate breeze W.: 16th, one all day; Starlings at light at night; two killed: 19th, three on rock all day: 20th, large flock going N.W. at 8 A.M. : 21st, three on rock: 22 nd, four going N.E.: $23 \mathrm{rd}$, two on rock, died; "drinking salt-water kills them": 24 th, one : 31st, twenty-four going W. at 9 A.M. November 1st, six going W. 10 A.M. : 2nd, five at light; one killed, early morning: 4 th, 5th, 6th, 7th, 8th, 9 th, 10 th, and 11 th, Starlings daily on rock: 15 th, six Starlings going W. 11 A.A. 
Lucifer Shoals Light-ship.-October 22nd, several going N.W. flying high, 7 A.M. to 5 P.M. ; clear, wind light S.E.: 23rd, Starlings going N.W. all day; several rested on ship; clear, wind light S.W.: 24th, flocks going N.W.: 26th, Starlings striking 9 P.M. to midnight; seven killed; hazy, wind fresh S.W. : 29 th, several at lantern from 6 P.M. to 5 A.M. ; five killed. November 3rd, two about ship all day; one found dead: 8th and 10th, two going N.W.; rested on ship.

Blackwater Bank Light-ship.-February 4th, Starlings at light; six disabled; overcast: 5th, two killed striking: 6th, four killed striking. October 9th, two killed: 16th, one got into lantern through open door 6 A.M.: 19th, one seen: 21st, seven on ship all day; two found dead on deck, others went off N.W. : 31st, large flocks going N.W. 11 A.M.; clear, moderate breeze S.W. November 4th, four killed striking.

Arklow South Light-ship.-January 15th, one going N.W. February 18th, numbers at light; several killed, 2 A.Mr. to 4 A.Mr. ; snow, light breeze N.W. March 8th, Starlings at light 8 P.M. to midnight; several fell overboard; rain, strong breeze S.W.: 12 th, ten found dead on deck: 17th, Starlings at light: 18th, midnight to 4 A.M., several fell overboard; clear, light breeze N.E. April 12 th, numbers killed at light midnight to 3.30 A.M. ; rain, light breeze W.N.W. September 25th, one about ship. November 3rd, 7 P.M., several at light; came from S.E.; two killed; showery, fresh breeze S.E. : 4th, 8 P.M. to 4 A.M., several; rain, fresh breeze S.E. by S.: 6 th, several flocks, 8 A.M. to noon, flying high to N.W.; gloomy, light breeze E. : 7th, one on deck: 10 th, do.

Arklow North Light-ship.-January 1st, 3rd, and 5th, Larks about lantern at midnight; wind strong to gale S., showers. February 16th, Starlings, Larks, and Thrushes about lantern at midnight; wind light N.N.W.; overcast: 19th, two flocks of Starlings and Thrushes going N.W. at noon; gale N.E., snow. March 7th, number at lantern; gale S.W.: 11th, Starlings, Larks, and Blackbirds about lantern at midnight; wind light, variable, hazy, rain; ten Starlings, two Blackbirds, and one Lark killed striking. May 5th, some about lantern at midnight; hazy, fresh breeze S.W.: 28th, two at midnight, found dead. November 1st, flock going N.W.: 2nd, flocks going N.W. all day; sleet, moderate gale N.E. : 3rd, some at lantern, 8 P.M. 
to midnight, some going overboard; rain, moderate gale $\mathrm{E}$ : 5th, do, at midnight: 7 th, do., many striking and falling overboard; showers, moderate gale S.E.: Sth, flocks going N.W. at noon; showers, moderate gale S.E.; three killed striking.

Kish Bank Light-ship.-October 7th, a flock at lantern; four rilled 9 P.M. November 4th, 8 P.Mr, nine at lantern; rain. December 11th, several flocks going N.W. 11 A.M. ; cloudy, rain, fresh gale $\mathrm{S}$.

Howth Baily.-March 11th, large number of birds, chiefly Starlings, from 2 A.M. to 4 A.M. ; many killed, all Starlings; strong breeze E., fog and haze. May 12th, two Starlings have taken up their abode in ventilator of tower; apparently going to build.

South Rock Light-ship.-January 11th, two killed. March 10th, twenty-four killed striking; fog, wind moderate S.E.: 12 th, one caught 6 A.M. April 14th, twelve found killed. May 11 th, two seen in rigging; afterwards killed.

Copeland (Mevo) Island.-November 4th, Starlings at glass all night; several killed; wind strong N.E. : 5th, some at glass all night; some killed; wind strong N.E. : 9th, do., five killed: 27 th, 28th, and 29th, do., a few killed each night.

Maidens South.-January 4th; four going S. March 10th, two killed striking.

Innishtrahull.-November 2nd, one at midnight: 17th, two disabled striking; full gale N.W.

Rathlin O'Birne.-February 10th, 11th, 12th, 13th, and 14th, "immense numbers of Starlings, Thrushes, Fieldfares, Blackbirds, and Linnets during these dates, their flight being invariably to the S.W.; sometimes rested only for a few minutes on island; heavy snow on shore." November 22nd, thirty-six going Wr. at 9 A.M. ; rain; moderate gale W.

Blackrock, Mayo.-October 21st, two on rock; gloomy, wind N.E. November 1st, 2nd, 3rd, 9th, and 11th, fifty to one hundred Starlings on rock.

Slyne Head, S.-January, two on island during month. February 13th, numbers on island all day; snow, fresh breeze, variable. March 12 th, two do.: 19 th, one with broken wing on island. April 6th, one. October 30th and 31st, large flocks on island; showery, moderate gale S.W. November 3rd, do. : Sth, some at light: 10th, five at 10 A.M. : 28th, large flocks on island; wind light E. December 16 th and 17 th, a few. 
Arran Island, N.-April 12th, seven going S. November 27th, flock going S.W. 7.30 A.M. : 28th, flock at station; remained over 29th. December 1st, flock of Starlings going N.E. : 2nd, two on rock: 9 th, ten: 12 th, twenty going S.W.

Arran Island, S.-October 31st, four lilled striking; misty. November 1st, seven killed during night: 3rd, flocks at light all night; misty, moderate breeze S.W.: 4th, nine killed: 5th, several going S.W. 2 A.M. ; one caught and one got down chimney into bedroom.

Tearaght.-March 26th, Starlings left. October 25th, one seen. November 2 nd, eight: 6 th, two killed 4 A.M. ; overcast, fresh breeze E.: 26th, about thirty; squally; remained on island.

Slielligs.-October 20th to 23rd, large flock about; gloomy, moderate breeze S.E.

\section{Chough (Pyrrhocorax graculus, Linn.).}

Mine Hexd.-April 4th, ten flying about station in the breeding season. November 12th, fourteen seen 3 P.M.

St John's Point, Down.-November 30th, one Chough about station during day. December 16 th, one perched on rocks at 1 P.M.

Innishtrahull.-April 18th, two hovering about island 11 A.M. August 18th, two on island 1 P.I.; misty, wind light E.

Aranmore.-The Chough always remains here.

Blackrock, Mayo.-March 31st, one about rock.

Slyne Head, S.-November 2nd, one shot by keeper 8 A.M. [Received in flesh]: 4th, five about all day: 5th, eleven: 8 th, three came at night, none killed; gloomy, fresh gale E.

Arran Island, N.-November 21st, "six Crows with red feet" hovering about at 2 P.M. ; clear, fresh gale N.

Tearaght.-_"Two Choughs remain always."

Skelligs.-February 16th to 19th, two about; resident, breed on island.

\section{RAVEN (Corvus corax, Linn.).}

Mine Head.-January 1st, two about station every day this week; did not breed in their usual place this year or last year-['86 and '87.-L. M. B.]. October 13th, two seen. 
Dunree Head.-February 29th, two seen. April 5th, four going N.W. November 10th, two. December 15th and 23rd, two.

Broadhaven.-April 1st, two seen; they breed here.

Blackrock, Mayo--February 26th, 1 P.M., three going E. March 31st, "two small Ravens round rock," noon. June 25th, two Ravens about at 1 P.M.

Slyne Head, S.-November 4th, two about all day.

Skelligs.-January 24th, four observed. May 9th, two on island all day. December 3rd, five on island all day; fog and rain, strong breeze S.W.

Hooded Crow (Corvus cornix, Linn.).

Fastnet.-March 18th, six grey-backed Crows; left for Cape Clear. These birds often visit the rock.

Mine Head.-March 24th, ten or twelve about station; they build on the cliffs. December 12th, five: 17th, four.

Aranmore.-The Hooded Crow always remains here.

Blackrock, Mayo.-April 26th, one about rock at noon.

Arran Island, N.-April 3rd, three seen. December 2nd, "two Carrion Crows" about rock.

Tearaght.-October 1st, three Hooded Crows always remain. November 28th, two "Carrion Crows."

Slielligs.-January 16th to 28th, two Hooded Crows about. February 1st to 16th, do.; resident, breeds on island. October 4th to 17 th, six about. December 11 th, two all day.

RooK (Corvus frugilegus, Linn.).

Coningbeg Light-ship.-March 19th, 11 A.M., "two Crows" going N.E.: 20th, one going N.E. 11 A.M. April 3rd, 9 A.M., one on ship: 7 th, one going N.E. 7 A.M. ; clear, light breeze N.E.

Tuskar.-March 26th, one Crow going N.W.: 29th, one going N.W. April 1st, five going E.: 18th, three going S.W. May 3rd, four going W.: 8th, one going W.

Maidens South.-March 21st, 11 A.M., three Crows going N.E. Arklow North Light-ship.-February 14th, five Crows going N.W. at noon; strong breeze N.E., snow.

St John's Point, Dou'n.-November 13th, flock of Crows going N. at 11 A.M.

Rathlin Island.-April 1st, "large flock black Crows" going $\mathrm{S}$. 
Innishtrahull. - April 8th, two Crows on island; light breeze S.E.

Rathlin O'Birnc.-September 2nd, ten Rooks going W. 8 A.M., first arrival; misty, fresh breeze W.

Broadhaven.-April 1st, flock of Crows going W.

Blackrock, Mayo.-November 7th, thirteen Crows passed rock going N.E.

Slyne Head, S.-March 25th, one Crow on island. April, one Crow comes here occasionally. November 2Sth, several on rock.

Arran Island, N.--November 30th, four Crows going N.E. December 1st, two on rock: 6th, one going N.E. : Sth, two about station: 10th, 13th, and 14th, two going N.E.

Slielligs.-November 1st, large flock of Crows, about two hundred, going N. 10 A.M.; clear, showery, strong breeze N.N.E.

\section{JACKDAW (Corvus monedula, Linn.).}

Coningbeg Light-ship._-March 19th, noon, four going N.E.; overcast, strong breeze N.E.

Lucifer Shoals Light-ship.-April 10th, three going S.W. 11 A.M., flying very low; clear, wind light N.W.

Rathlin O'Birne.-October 29th, four on island; remained till November 6th.

Magpie (Pica rustica, Scop.).

Mine Head.-October 5th, five going N.E. 3 P.M.; clear. December 4th, two Magpies, 10 A.M. : 15th, three, 9 P.M.

Rathlin O'Birne.-December 18th, one going W. at 2 P.M.; "never observed this time of year on this island;" misty, fresh breeze W.

\section{SWALlow (Hirundo rustica, Linn.).}

Fastnct.-April 23rd, one about rock; fresh breeze S.E. May 7th, one, 6 P.M.; dense fog: 26th, one. June 5th, Swallows at light 10 P.M. ; fog, light breeze S.E October 10 th, several young Swallows about rock chasing Hies to 5 P.M.; clear, light breeze $\mathrm{N}$. 
Coningbeg Light-ship.-April 21st, five" going N. May 11th, two about ship: 14 th, one going N.E. June 1st, noon, several about ship; fog, light breeze S.E. October 1st, several during day; clear, moderate breeze N.W.

Tuskar.-April 20th, one at 3 P.M., the first seen; gloomy, light breeze N.W.: 28th, one going N.: 30 th, Swallows about rock. May 27th, four Swallows constantly about rock from 27 th to 7 th of June. October 4th, one going N.W.: 21st, one.

Lucifer Shoals Light-ship.-April 14th, three going N.W. 2 P.M. : 15th, one going N.W.

Blackwater Bank Light-ship.-October 22nd, one caught on deck 11 P.M. ; clear, light breeze S.W.

Arklow South Light-ship.-March 12th, 2.30 P.M., flock of "Swallows" going S.W., flying high; clear, wind light N.E. April 22nd, one going N.W.: 30th, ten going N.W. noon; rain. May 2 nd, two flocks going N.W. in afternoon: 5 th, one about ship: 19th, one going N.W. August 8th, one going N.W. September 27th, flock going S.E.; light breeze S.E., hazy.

Arklow North Light-ship.-May 16th, one going N.W. 2 P.I. September 21st, four going N.W. 10 A.II.; hazy, moderate breeze N.E. October 3rd, two going N.W.; strong breeze E.

South Rock Light-ship.-May 10th, one going N.W.

Rathlin Island.-April 6th, a good many going E.; gale N.W.

Aranmore.-May 26th, 1 P.M., saw first Swallow; misty, light breeze N.E.

Blackrock, Mayo.-May 10th, one flying round rock.

Tearaght.--May 13th, several flying about.

Hodse-Martin (Chelidon urbica, Linn.).

Tcaraght. - October 27th, several "Swifts and Martins" remained around island for several dajs; mist and rain, fresh gale S.W.

Sand Martin (Cotile riparia, Linn.).

Blackinock, MIayo.-Octaber 22nd, three on rock all day; gloomy, wind S.E.

I'caraght.-May 9 th, one shot-[Leg and wing received]: 11 th, two seen. 


\section{SwiFt (Cypselus apus, Linn.).}

Coningbeg Light-ship.-June 2nd, one "Black Swallow" 6 P.M. ; fog.

Innishtrahull.-May 21st, one at noon : 23rd, three.

Broadhaven.--June 8th, one going E. : 20th, one going S.

Blackrock, Nicyjo.-June 18th, one going N.E. July 2nd, one found disabled 8.30 A.M. ; fog, moderate breeze S.W.

Arran Isiand, $N$.-June 10 th, two seen.

Tcaraght.-July 29th, one. October 25th, one "Swallow (Swift)" seen 9 A.M. ; misty, moderate gale S.W.: 27 th, several Swifts and Martins about island for several days.

\section{Nightjar (Caprimulgus europaus, Linn.).}

Iine Head.-April 20th, one heard.

Tuskar:-May 11th, six on rock all day; hazy, calm. June 3rd, two on rock all day. August 11th, one at light all wight.

Cuck0o (Cuculus canorus, Linn.).

IFine Head.-May 13th, Cuckoo first heard.

Coningbeg Light-ship.-April 30th, one killed striking 11 P.M.; rain, moderate gale S.W.

Tuskar.-May 10th, one on balcony 1 A.M.; one at light 11 P.M.

Lucifer Shocls Light-ship.-May 13th, a Cuckoo rested at 4 A.M., and afterwards flew N.W. towards land; wind light N.E., clear.-J ANes BYrNe, in lit., April 1889.

Howth Baily.-May 14th, a Cuckoo found dead.

Dunree Head.-May 5th, one going E. 10 A.M.; "first seen this month": 16th, two going N.E. 11 A.M.: 25th, one going W. 10 A.Mr. : 30 th, one going E. ; "last heard this year."

Aranmore.-June 12th, one seen 3 P.M.

Tearaght.-April 26th, one on rock.

Skelligs.-April 16th, one shot on island; misty, fresh breeze S.W.

\section{Hoopoe (Upupa epops, Linn.).}

Minc IIcad.-April 25th, "observed several times in neighbourhood; one shot by Mr Fitzgerald at Seaview." 
"Pigeons."

Fastnet.-October 16th, "two small Blue Pigeons" on rock: 17th, one Pigeon on rock; "this was a Rock Pigeon, and larger than the two seen yesterday": 19 th, one on rock.

Mine Head.-January 1st, flocks of Rock Pigeons in the fields every day during month ; they build near station.

Coningbeg Light-ship.-June 2nd, 6 P.M., one pigeon.

Arkilow North Light-ship.- September 9th, one on deck 4 P.M. ; flew off N.W.

Innishtrahull.-June 20th to 28th, four Pigeons on island each day; clear, wind variable: 30 th, one on island.

Dunree Head.-January 14th, two going E. July 9th, six going N.E. Six to twelve noted at intervals during year up to December. "Pigeons are about the caves here winter and summer."

Aranmore.-September and October, some seen daily.

Rathlin O'Birne.-October 31st, 10 A.Mr., ten on island; first seen in flock.

Slyne Head, S.-January 9th, four aboutisland. March 21st, five on rocks west of the island.

Arran Island, N.-May 26th, three Wild Pigeons on rock 2 P.M. : 29 th, one : 31 st, six or seven.

Tearaght.-November 9 th, three seen 11 A.M.; remain.

Turtle Dove (Turtur communis, Selby).

Tuskar--May 19th, one shot-[Received in flesh]. June 4th, two on rock 3 P.M. ; one shot. [Received in flesh.]

Blackrock, Mayo.-June 3rd, one on rock during day; fog.

SANd Grouse (Syrrhaptes paradoxus, Pallas).

Fastnet.-See under "Birds not Identified," p. 57.

Drogheda, E. and W.-July 13th, "I send you per same post a Sand Grouse which I shot at 4 P.I. yesterday; there were about ten or twelve in the flock, three of which I killed. It was the second time I observed them yesterday." [Received in flesh.]

Broadhaven.- "A bird was shot in April, I think, by $\mathrm{Mr}$ Gallagher of Corlough, who called it a Sand Grouse. It had 
no claws, but the foot resembled that of a rat, I am informed. A Snow Owl was shot the same time. Both were sent to $\mathrm{Mr}$ Knox of Kingstown." (See More's "List of Irish Birds in the -Science and Art Museum, Dublin," p. 8, 2nd edition.)

CorN-Crake (Crex pratensis, Bechst.).

Tuskar.-April 30th, two Land Rails on rock 4.30 A.M. ; rain, wind light S. May 6 th, one at 9 A.M.; fog: 10 th, one on balcony at 1 A.M. : 11th, six on rock all day; hazy, calm.

Arklow South Light-ship.-May 5th, "hundreds of Corn-Crakes about light 10.30 P.Mr. to 12.20 A.M. ; large numbers killed against glass, two fell dead on deck, several fell overboard; one caught alive and let go; went off N.W. flying low; weather clear, light breeze S.W.-A. B. WALL." [Two received in flesh.]

Innishtrahull.-July 13th, 6.30 P.M., one heard on island.

Tearaght.-May 19th, remains of Land Rail found, probably killed by Peregrine. [Leg and wing received.]

\section{WATER RAIL (Rallus aquaticus, Linn.).}

Fastnet.-November 4th, 11 P.M., one killed striking; "from description given by R. Lyons, assistant, I take it to be a Water Rail; I was ashore at the time."

Copeland (Mew) Island.-November 5th, "two Quail killed against glass;" wind strong N.E. [Leg and wing Water Rail received].

Tearaght.-April 26th, one Water Rail seen on rock.

WATER-HeN (Gallinula chloropus, Linn.).

Coningbeg Light-ship.-March 24th, "six Water-Hens going N.E." 4.30 P.M. ; clear, light breeze N.E. October 3rd, "one small Water-Hen" on ship during day; showery, strong breeze N.E. [Possibly Water Rail.-R. M. B.]

Tuskar.-September 16th, one found dead on rock; clear, light breeze N. [Leg and wing received.]

\section{BALD Соот (Fulica atra, Linn.).}

Aranmore.-January 19th, "one male Coot caught" near station 10 A.M. ; overcast, moderate gale E. 
Ringed Plover (Aigialitis hiaticula, Linn.).

Coningbeg Light-ship.-April 6th, "three Ringed Dotterels" round ship. September 24 th, seven "Dotterels" flying W.

Broadhaven.-April 10th, 3 P.M., three " Little Ringed Dotterel feeding."

Golden Plover (Charadrius pluvialis, Linn.).

Mine Head.-December 18th, three seen 5 P.M.

Arklow South Light-ship.-January 14th, "one Grey Plover" on deck; gloomy, N.E.

Arklow North Light-ship.-March 1st, "two Grey Plover" going N.W. at 10 A.M. ; strong breeze E., snow.

St John's Point, Down.- "Considerable quantities of Golden Plover come down from the mountains during frosty weather."

Maidens South.-January 17th, thirteen Golden Plover 11 A.M. flying S.W., very high. February 29th, two at lantern 9 P.M. ; cloudy, moderate breeze N.E.

Innishtrahull.-May 5th, 10 P.M. to midnight, a few at light; misty, light breeze S.W. August 5th, noon, two going N.E. September 24th, two seen: 25th; two. November 29th, one disabled striking at midnight.

Aranmore.-September 20th, flock observed; they remain on island all winter. November 30th, noon, one shot. [Leg and wing received.]

Rathlin O'Birne.-January 30th, five on island; remained till February 1st. November 1st, eighteen going E.; three shot. December 3rd, fifteen on island (came from mainland).

Blackrock, Mayo.-May 26th, noon, one in summer plumage on rock.

Tearaght.-November 6th, one going W.

Green Plover (Vanellus vulgaris, Linn.).

Nine Head.-None seen in January, and very few observed through the spring. November 24th, four "Plover." December 13th, six.

Coningbeg Light-ship.-March 7th, flock of Lapwings at light 10.30 P.M. ; hazy : 27 th, one going N.E.

Tuskar:-March 16th, three on rock all day. April 8th, one stayed all night. 
St John's Point, Down.- "There are large quantities of Lapwing always about here."

Copeland (Hev) Istand.-November 2nd, one killed striking; wind strong N.E., rain: 27th, Lapwings striking, together with Starlings and Thrushes; a few of each killed.

Naidens South.-January 17th, thirteen Golden and twentythree Green Plover flying very high, going S.W.

Innishtrahull.-September 25th, thirteen "Peewits " on island. Aranmore.-February 10th, one shot. July 2nd, two seen on island. October, "Plover to be seen daily."

Rathlin O'Birne.-September 2nd, two seen 3 P.I.; remained on island till 15 th.

Blackrock, Mayo-March 11th, one on rock.

Oyster-Catcher (Hocmatopus ostralegus, Linn.).

Ferstuct.-April 2Sth, six flying N.E. 3 P.n. September 5th, two seen. November 14th, two on rock.

Coningbeg Light-ship.-May 14th, several seen 9 P.M.

Tuskar.-January 19th, one on rock; went off N.W.

Copeland (Mew) Island.-November, Oyster-Catchers are plentiful here.

Innishtrahull.-April 4th, seven on island. November 17 th, nineteen on island; remained over night.

Tory Island.-January 15th, Oyster-Catchers seen.

Aranmore.- "The Seapie always remains on south end of island."

Broadhaven.-April 17th, two.

Slyne Head, S.-January, Seapies about every day. March, some Seapies here all month. April, Seapies come here to feed at low water, and go away again.

Arren Istand, N.-May 11th, three on rock. November 22nd, six on island.

Tearaght.-November 25th, two observed.

Slielligs.-March 23rd, two landed at noon. May 9th, one all day.

Woodcock (Seolopax rusticula, Linn.).

Tuslar:-February 13th, one flying S.W. 1 P.Ir. ; thick snow, moderate breeze $\mathrm{E}$. 
Rathlin Island.-June 6th, " a dozen Woodcocks going S.W. 5 P.M. ; foggy, light breeze S.W. These birds are not often seen in the island.-PATRICK KEENAN."

Arannore.-January 28th, "Woodcock shot"; clear, strong breeze N.E. Woodcock remain here all winter. November 29th, one killed striking at 3 A.M. ; wind moderate E., overcast. [Leg and wing received.]

Blackrock, Mayo. - November 8th, one on rock all day; gloomy, wind S.E. : 9 th, do.

Slyne Head, S.-November 7th, one killed striking; gale E.

Tearaght.-November 4th, 11 A.M., one seen; wind light E.

Shelligs.-October 27th, one lighted at 8 A.M.; overcast, moderate breeze S. November 6th, two killed striking, going W.; gloomy, fresh breeze S.E.: 7th, two shot; gloomy, gale S.E.

\section{Common Snipe (Gallinago colestis, Frenzel) and} JACK SNIPE (G. gallinula, Linn.).

Mine Head.-October 25th, two Snipe seen 6 P.M. ; weather clear. November 28th, one. December 16th, one seen.

Tuskar:-January 8th, one Snipe on rock 5 A.M.; thick fog, moderate breeze S.W. April 8th, two on rock; rested through night; went off west; clear, wind light N.E. November 3rd, one Snipe found dead; overcast, moderate gale $\mathrm{E}$.

Arklow South Light-ship.-September 9th, 9 P.M., two Snipe striking; one killed, one disabled; moderate breeze N.E. [Common Snipe received in flesh]. November 9th, one Snipe at light 9 P.M. ; subsequently killed striking rigging. [Common Snipe received in flesh.]

Arlilow North Light-ship.-November 5th, one Snipe killed on deck; sleet showers, strong breeze S.E.

Copeland (Mew) Istand.-November, Snipe are plentiful here. Innishtrahull.-January 16th, 11 A.M., three Snipe on island; hazy, moderate breeze $\mathrm{E}$.

Aranmore-February 2nd, 8 A.M., shot one Snipe; they remain here all winter. November 12 th, Jack Snipe shot[Leg and wing of Jack Snipe received]: 30th, one Snipe caught striking 3.15 A.I.; overcast, moderate breeze E. [Leg and wing of Common Snipe received.] 
Slyne Head, S.-March 31st, one Snipe on island all day; wind light N.E. November 6th, one killed striking; gloomy, fresh breeze E.: 10th, one Snipe seen 10 A.r. : 28th, one on rock all day; weather gloomy, light breeze E. December 10th, one on rock all day.

Tearaght.-October 21st, one seen 2.30 A.Mr; cloudy and gloomy, light breeze S.E. November 10th, one Snipe seen 11 A.M. ; clear, fresh breeze S.E. December 5th, 11 A.M., two.

\section{Purple Sandpiper (Tringa striata, Linn.).}

Fastnet.-May 18th, midnight to 1 A.M., several Sand Larks about light; one killed. [Leg, wing, and bill of Purple Sandpiper received.]

Kмот (Tringa canutus, Linn.).

Arklow South Light-ship.-January 14th, one "Grey Plover" on deck at 5 A.M. ; wind light N.E., gloomy. [Leg and wing of Knot received.]

Common SANDPIPER (Totanus hypoleucus, Linn.).

Mine Head.-May 5th, Strand Lark shot feeding in stream[Leg and wing of Common Sandpiper received]. July ? 26th, one found killed; fog previous night. [Leg and wing received.]

Tuskar.-May 6th, one struck. [Wing received.]

Arklow North Light-ship.-May 8th, one Common Sandpiper caught at lantern at 4 A.M. ; wind light E. [Received in flesh.]

\section{"SAND LARKS."}

Fastnet.-May 22nd, six Sand Larks on small rock. August 16th, four. October 20th, six: 29th, two. November 28th, three. December 5th, four.

Tuskiar.-January 12th, one Sandpiper killed by cat: 14th, and February 9th, Sandpipers on rock all day: 14th, two. April 20th, one shot. May 11th, two "Sanderlings" on rock all day. September 22nd, ten Sandpipers all day.

Copeland (Mew) Island.-November, "Strand Larks are common here." 
Broadhaven.-April 10th, three "Sanderlings" feeding.

Blackrock, Mayo.-November 10th, one Sand Lark on rock all day.

Slyne Head, S.-January, "Sand Larks about every day." March, "some here all months." April, a number seen up to the 12 th, none observed since.

Arran Island, N.-November 24th, 11 A.Mr., Sand Larks about shore: 25 th, do.

Tearaght.-November 25th, noon, one observed: 26th, two.

Redinank (Totanus calidris, Linn.).

Aranmore.-The Redshank always remains on south end of island.

Broadhaven.-May 15th, 1 P.II., one seen.

Slyne Head, S.--January, Redshanks about every day.

Arran Island, N.-November 24th and 25th, Redshanks about shore.

CURLEW (Numenius arquata, Linn.).

Fastnet.-August 15th, 11 P.M., several hèard flying N.

Coningbeg Light-ship.-March 21st, a flock over ship at 10.30 P.M. ; clear, light breeze N.W. September 23rd, several flying N.E.: $29 \mathrm{th}$, several flying over ship. October 13th, 7 P.M., several going N.E.

Tuskar.-March 26th, four going E. May 3rd, one going W.: 7th, two on rock all day: 14th, two going S.E. noon. August 11th, one at light all night. September 28th, one on rock 10 A.M.; dense fog, calm.

Arklow North Light-ship.-April 12th, noon, flock going S.E.

Howth Baily.-Narch 16th, large flocks of Curlew all day, remaining in neighbourhood; wind variable, snow.

South Rock Light-ship.-January 19th, two at lantern at midnight. April 6th, midnight, three going N.W.

Copcland (Mow) Island.-November, "Curlew are plentiful."

Maidens South.-March 21st, one going N.

Imnishtrahull.-August 24th, "seven young Curlews" on island through the day.

Dunree Head. - January 6th, seven going S.E.

Aranmore.-September, a few about; very plentiful on south side of island. October, Curlew to be seen daily. 
Rathlin O'Birne.-January 20th, fifteen on island; "the only large flock seen this year."

Broadhaven.-May 4th, five seen.

Blackrock, Mayo.-March 31st, one shot.

Slyne Head, S.-April 15th, three on island.

Arran Island, N.-November 23rd, ten on island.

Tearaght.-December 4th, one seen.

Whimbrel (Numenius phoopus, Linn.).

Fastnet.-April 2Sth, 10 P.Mr. to 11 P.Mr., great numbers of Whimbrel going N.E.; hazy, moderate breeze (heard only). May 6th, numbers flying $\mathrm{N}$.; dense fog, moderate breeze W.: 7th, several seen 11 P.Mr.; dense fog. August 18th, one going W. September 15th, 2 A.M. to 4 A.M., a flock flying S.; gloomy, wind light S.E. "They passed in vast numbers for two hours, flying high, with great noise."

IIine Head.-April 29th, a great number of "young Curlew" passing with much noise at 10 P.M. ; rain; heard several times through night. [Whimbrel probably.-R. M. B.]

Coningbeg Light-ship.-May 9th, two killed striking; rain, moderate breeze E.: 15th, several going N.W. (apparently Whimbrels): 16th, four going N.E. 7.30 P.M., and at 9 P.M. several going N.E.; clear, fresh breeze S.W.: 27 th, 8 P.M., several going N.E. ; clear, light breeze S.W.

Tushict.-May 6th, 1 A.M. to 2.30 A.Mr., "May birds" at light; fog; 9 A.M., "May birds" on rock.

Brocellaven.-May 8th, twenty feeding at 4 A.M. "Not as numerous as last season."

Blackrock, Mayo.-May 18th, 7 P.M., three "May birds" on rock.

\section{"TERns."}

Fastnet.-June 1st, 1 1.M., several "Sea Mews" around light: 3rd, one going S.W. August 11th, several at light 1 A.M. September 4th, several at light 2 A.M.

Tuskin:-August 11th, one "Blackheaded Mew" at light.

Copeland (1Mew) Island.-October 31st, "Mews are all gone about this date. These birds are very plentiful in summer here, and breed." 
Rathlin O'Birne.-Terns breed on rocks outside island. Arran Island, N.--May 17th, flock of Terns round rock.

\section{"GULLS."}

Fastnet.-February 23rd, one large Iceland Gull hovering about rock at 4 P.I.; frosty. March 30th, numbers of Kittiwakes feeding. April 25th, numbers of Grey Gulls flying S.E. : 28th, large flocks of Kittiwakes flying N.W. May 26th, two flocks "large White Gulls" going S.E. November 28th, a flock of Kittiwakes.

Mine Head.-January 29th, "a small cream-coloured Gull, short neck, straight red bill, tips of wings black," seen.

Coningbeg Light-ship.-Herring Gulls, a few Blackbacks, and small Common Gulls daily in vicinity of ship during May and June; also through February, March, and April.

Lucifer Shoals Light-ship.-December 16th, "Grey Gulls" about ship all day.

Kish Bank Light-ship.-October 9th, a flock of Gulls going S. November 1st, flocks about all day: 11th, do. December $26 \mathrm{th}$, do.

Howth Baily.-September 19th, large numbers of Sea Gulls follow the "Hopper" barges daily at all seasons in the neighbourhood of this station. These barges come out from Dublin to discharge mud, and one carries the rubbish swept off the streets.

St John's Point, Down.-October 12th and 19th, flocks of Herring Gulls during day.

Copeland (Mew) Island.-October 28th, Herring Gulls seen from time to time.

Dunree Head.-August 10th, numbers seen. September 18th, do.

Tory Island.-January 10th, large numbers of Sea Gulls.

Aranmore.-April 20th, Kittiwakes in great numbers on rocks and water. July, Gulls numerous every day throughout month; they breed here. August, do.

-Rathlin O'Birne.-Royal Gulls, Terns, and Sandpipers breed on rocks outside island.

Broadhaven.-June 16th, flock of Kittiwakes about all day.

Blackrock, Mayo.-February 10th, one Iceland Gull about rock; gloomy, gale N.W.; Kittiwakes about, one disabled. 
March 6th, Kittiwakes returned to their nesting ledges on rock: 13th, one Iceland Gull about rock; gloomy, fresh breeze E.N.E. October 21st and 22nd, "Gulls and Didleens or small Gulls" about rock all day: 23 rd to $28 \mathrm{th}$, do., going S.; small Gulls and Gannets when passing all go S. November 12th, a few large Gulls and one "Royal Gull" about.

Slyne Head, S-January, a number of Gulls about every day. February, about twenty large Sea Gulls around island up to the 15 th of March, only two after that date. March 27th, great numbers of Kittiwakes going N. all day: do. on 28th, 30 th, and 31st. April 4th, Kittiwakes going N. in numbers: 5th and 6th, do. not so numerous on 6th; no large Gulls after Sth: one flock Kittiwakes going S. on 6th: 8th, Kittiwakes in flocks going N.: 11th, $12 \mathrm{th}, 13 \mathrm{th}, 14 \mathrm{th}$, do.: 15th, numbers feeding on the water.

Arran Istand, N.-May 3rd, flocks of Gulls going N. all day: 7 th, flocks feeding. November 23rd, fifty Sea Gulls about shore: 27th, two Royal Gulls about rock, first seen for a long time. December 7th, three Royal Gulls going S.E. : 8th, several Gulls about station.

Tearaght.-March 4th, Kittiwakes arrived. October 1st, Gulls of several sorts around rock all day: 13th, great numbers of sea-fowl about all day; squally, fresh breeze S.W.

Shelligs.-March 4th, Kittiwakes first landed on rock. December 19th, large flock feeding.

\section{"SKUAS."}

Fustnet.-August 9th, one Skua Gull at noon going W. "I often see them close to mainland chasing other Gulls." Aranmore.-July 30th, 8.30 P.M., two Skua Gulls going S.

Manx Shearwater (Puffinus anglorum, Temminck).

Festnet.-March 16th, large flocks in company with Puffins, Cruillemots, and Razorbills feeding about rock; clear and frosty, strong breeze N.E. "More or less abundant through summer months." July 12th, numbers feeding about all day.

Mine Head. - May 27th, one killed striking at 11 P.M. [Received in flesh]: 31st, heard several times.

Coningbeg Light-ship.-May 29th, great flock in company with Puffins, etc., daily throughout May and June. 
Aranmore.-February 21st, "Manx Shearwater heard about cliffs to-night; clear, fresh breeze S.E. - Thomas Fortune." July, seen daily; they breed here. August, do.; less numerous after 22nd; finally disappeared at end of month.

Slyne Head, S.-March 30th, numbers going N. all day; wind variable.

Skelligs.-March 1st, first heard 11 P.M.

Fork-tailed Petrel (Cymochorea lencorrhoa, Vieill).

Tearaght.-July 6th, Fork-tailed Petrel found hatching; bird and egg forwarded. [Received.-R. M. B.]

\section{Storm Petrel (Procellaria pelagica, Linn.).}

Fastnet.-August 11th, about twenty striking midnight to 2 A.M., none killed; rain, light breeze W.S.W. September 4th, 2 A.M., Storm Petrels at light; rain, wind W.N.W.

Coningbeg Light-ship.-May 17th, one about ship; clear, fresh breeze S.W.: 18th, two do.: 21st, do.: 23rd, 25th, 29th, 30th, and 31st, several seen. June 3rd, 4th, 5th, 6th, 7th, and 8 th, do. December 7th, one on ship; hazy, moderate breeze S.W.

Barrels Rock Light-ship.-November 6th, 2 P.M. to 5 P.M., one about ship; rain, strong breeze S.E. : 12th, two about all day; rain, gale S.E.

Tuskar,-May 10th, one at light 11 P.M. ; fog, light breeze N.E.

Lucifer Shoals Light-ship.-October 28th, one about ship all day; clear, wind strong S.W.

Innishtrahull. - September 3rd, one striking, not injured, 9 P.M. " The Petrel is a rare visitor in the North Channel; I have not seen one on the North coast for the past ten years.M. J. KenNeDY."

Rathlin O'Birne.-November 4th, 9 A.M., one killed striking; misty, strong breeze $\mathrm{E}$.

Blackrock, Mayo.-May 13th, 12.30 A.Mr., one striking; gloomy, wind $\mathrm{N}$. June 2 nd, one at light 1.30 A.n.; ; showery, fresh breeze E.: 5th, one at light 11.30 P.M. ; misty.

- Tearaght.-April 28th, Storm Petrel arrived.

Black GullLemot (Uria grylle, Linn.).

Green Island.-[December 6th, young Black Guillemot received in flesh.] 
RAzorbill and GuIllemot (Alca torda, Linn., and Uria troile, Linn.).

Fastnet.-March 16th, large flocks feeding about all day; more or less abundant through summer months: 30th, large numbers of Razorbills feeding in morning. November 28th, a flock of Razorbills going S.E.

Mine Head.-January 29th, "young Razorbills" numerous on water. June 18th, Guillemots and Razorbills about.

Lucifer. Shoals Light-ship.-December 16th, "Murs" about all day.

Howth Baily.-May 10th, one Razorbill [Possibly Manx Shearwater.-R. M. B.] disabled striking at midnight, but recovered and flew away; calm, clear.

Copeland (Mew) Istand. - Young Razorbills plentiful in September, October, and November; saw two with their young one. November Sth, Razorbill found killed.

Innishtrahull.-April 7th and 8th, numbers of Guillemots and Razorbills fishing near island. June 16th, numbers of Guillemots in vicinity of island.

Aranmore.-February 21st, numbers of Guillemots about cliffs all day. March 8th, Razorbills in flocks all day. April 20th, Guillemots and Razorbills in great numbers in water. July, Guillemots to be seen daily on cliffs and on water; they breed here. August, do. less numerous after 22nd.; none to be seen towards end of month.

Broadhaven.-June 16th, twenty Guillemots fishing 1 P.M.

Blackrock, Mayo.-March 11th, flocks of "Auks and Razorbills" going W. during day; cloudy, passing showers, strong breeze N.W.

Tearaght.-January 29th, Guillemots arrived. March 4th, Razorbills arrived.

Skelligs.-January 30th, Guillemots first landed on rock. March 3̈rd, Razorbills do. December 19th, young Razorbill feeding.

Puffin (Fratercula arctica, Linn.).

Festnet.-March 16th, large flocks seen all day. More or less abundant through summer months. October 30th, dead bird found on rock, supposed killed by hawk. [Leg and wing of Puffin received.] 
Dunree Head.-August 29th, twenty-five going W. September 23rd, great numbers going W. ; weather gloomy, light breeze S.S.W.

Blackrock, Mayo.-April 26th, a few Puffins on rock during day; first appearance this year; clear, light breeze N.E. October 21st, upwards of twenty Puffins going S.; wind N.E. : 23rd to 28th, Puffins going S.

Slyne Head, S.-March 1st, flocks going N. all day: 20th, flocks going W.: 27th, 28th, 30th, 31st, great numbers going $\mathrm{N}$; ; snow on 27 th and 28th, with rising wind. April 1st, Puffins from daylight to noon: 2nd, Puffins going N.: 4th, do. all day, fifty to one hundred in each flock: 6 th, do., not numerous: 7th, Puffins in flocks going N. all day: Sth, flocks going N. all day, one flock going S.: 9 th, numbers going N.: 10th, do.: 11th, $12 \mathrm{th}, 13 \mathrm{th}, 14 \mathrm{th}$, and $15 \mathrm{th}$, do.

Arran Island, N.-April 28th, flocks going N. all day. June 3rd, large flocks going $N$. all day.

Tearaght.-March 29th, several on water. April 5th, Puffins came on rock in large numbers. November 1st, about twelve going $\mathrm{S}$.

Skelligs.-March 27th, Puffins first landed on rock.

\section{"Great Northern Diver."}

Aranmore-December, seen daily.

Rathlin O'Bime.-November 15th, one seen under cliff, remained about five days; first ever seen here; hail, moderate gale S.W.

Broadhaven.-May 20th, three observed.

Cormorant (Phalacrocorax carbo, Linn.) and Shag ( $P$.graculus, Linn.).

Fastnet.-March 17th, four large brown Cormorants seen: more or less abundant through summer months: 20th, two large Green Cormorants fishing at noon: 26th, two Brown Cormorants on rock. May 5th and 23rd, four to eight. December 20th, one "White-breasted Cormorant" on rock.

MFine Hcad.-February 6th, three dozen Cormorants about all day.

Coningbeg Light-ship.-One to two at intervals from January to May. 
Dunree Hecd.-[One or two dozen Cormorants are reported to have been seen every week or two from January to December at this station. The light-keeper says: "These Cormorants come to the Head every evening, and go away every morning to feed."-R. M. B.]

Aranmore.-April 20th, Cormorants in great numbers on rocks and water. July, seen daily; they breed here. August, seen regularly.

Broadthaven.-April 27th, fifty Cormorants fishing: 30th, twenty Green Cormorants.

Blackrock, Mayo.-October 23rd to 28th, Cormorants about rock.

Slyne Head, S.-March, "some Cormorants here all months."

Gannet (Sula bassana, Linn.).

Fustnet.-February 27th to March 9th, large flocks going N.W. daily. May 23rd, several flocks going N.W., "about onethird were last year's birds." June 13th, twenty-five, four last year's birds, going W. July 12 th, numbers flying W. all day. August 14th, numbers fishing about rock. October 16th, three do.: 17th, four do.

Coningbeg Light-ship._January, several seen. February, a few.

Barrels Rock Light-ship.-December 9th, three going W.

Tuskar.-October 21st, ten about rock.

Lucifer Shoals Light-ship.-February 10th, several flocks going N.E. 2.20 A.M. [P.M. ?], flying low : 11th, one flock going N.E.: 16th, several do.: 27 th and 28th, several; all these birds recorded as going N.E. March 26th, two flocks going N.E. April 5th, two flocks going N.E.: 6th, 7th, 9th, 11th, 12th, 16th, flocks going N.E., all flying low. December 11th, several going N.E., flying very low: 12 th and 15th, flocks of Gannets going N.E.

Blachwater Bank Light-ship.-February 2nd, eight Gannets going N.E.: 26th, four birds going N.E. October 11th, 13th, and 15th, three to six do.

Arklow South Light-ship.-March 24th, several Gannets going N.E., flying low. April 26th, seven going N.E. July 16th, two do. September 27 th, flock going N.E.

Arklow North Light-ship.-February 22nd, several Gannets 
going N.E. at noon; gale E., snow. March 29th, several flocks going N. April 8th, several flocks going N.E. May 13th, eight Gannets going S.W.: 20th, flocks going N.E. and S.W.

Kish Bank Light-ship.-October 14th, five Gannets going N.

Copeland (Mew) Island.-October 1st, Gannets are to be seen every month since I came here; plentiful in September.

Dunree Head.-July 2nd, Gannets going S.

Aranmore.-July, Gannets seen every day. August, do.

Blackrock, Mayo.-January 29th, about thirty going N.: from 1st February till 1st March there was a constant migration, all going N.: after 1st March very few observed going N., but they remained fishing round locality. October 21 st and 22 nd, Gannet about rock all day: "Small Gulls and Gannets when passing all go S. direction."

Slyne Head, S.-January 9th, Gannets going N. all day at intervals : 13th, Gannets in numbers going N. all day. February 8th, 9 th, 10th, 11th, and 12th, numbers going $\mathrm{N}$. at intervals all day: 13th, do.; not so numerous. March 1st, numbers going $\mathrm{N}$. as the preceding days: 12 th, numbers going $\mathrm{N}$. all day: 19th, do.: 20th, do.: 27th, great numbers going $\mathrm{N}$. all day: 28th, 29th, 30th, April 1st, 2nd, 3rd, 7th, and 8th, do.: 9 th, 10th, 11th, 12th, 13th, 14th, and 15th, a few going N. all day.

Arran Island, $N$.-June 8th, flocks fishing round rock all day.

Tearaght.-February 2nd, Gannets (old birds) going N. from daylight to 2 P.M.: 3rd, do.: 17th, do. March 14th, Gannets going $\mathrm{N}$. (old birds). October 1st, some Gannets round rock all day.

Skelligs.-February 22nd, Gannets first landed on Little Skellig.

\section{Heron (Ardea cinerea, Linn.).}

Mine Head.-February 13th, two passing to the S.; great fall of snow. April 8th, one passing N.E.

Copeland (Mew) Island.-October 1st, three or four Herons are frequently seen on the marshy flats of this island.

Rathlin O'Birne.-February 3rd, "three Cranes" going W.; came back again in a few days.

Broadhaven.-April 13th, Heron observed; very numerous at all times. 
"GEESE"

Lucifer Shoals Light-ship. - December 19th, a flock of "Barnacles" too numerous to count going N.W. at 3 P.M.; sometimes very low, and then rising in a body; clear, wind strong S.S.W.

St John's Point, Down.-October 24th, ten Brent Geese going S.W. at 9 A.M.; wind moderate S.W.: 30 th, twenty going S.W. at 12.30 P.M. December 3rd, flock Brent Geese going S.W.

Innishtrahull.-January 6th, two Wild Geese going S.W.: 12th, two on island: 13th, two going N.E. October 13th, 11.30 A.M., twenty-one Brent Geese going S.W.; drizzling rain, strong breeze N.: 31st, 12 P.M., six Barnacle Geese going $\mathrm{W}$.

Aranmore. - January 16th, large flocks of "Barnacles" feeding on island all day. Barnacles remain here all winter; they arrive in November and leave in the middle of May. May 13th, Barnacles still on island. September 10th, twentyfour Barnacles going $\mathrm{S}$. The Barnacles remain on island till late in spring, and may be observed daily; flocks of eighty and more are frequently to be seen. October, Barnacles to be seen daily.

Rathlin O'Birne. - January 10th, one Barnacle observed; stayed until 18th, "having lost the flock." March 2nd, Barnacles were observed migrating on November 3rd going S., and have not been seen passing since on return northwards. October 3rd, five Barnacles going S.W.; one shot by keeper: 18th, three Barnacles returned to mainland. November 28th, 11 A.M., three "Wild Geese" going S.W.; "seldom seen here ": 30th, Barnacles going S.W. 9 A.M.; one shot by keeper.

Slyne Head, S.-March 19th, fifteen Barnacles stopped on rocks all day: 24th, three flying round. November 27th, eleven Barnacles going $\mathrm{E}$.

Arran Island, N.-November 27th, 3 P.M., twelve Wild Geese going N.E.; two do. going S.

\section{SCAUP (Fuligula marila, Linn.).}

Innishtrahull.—October 15th, one "Pochard shot, supposed to be a male," at 1 P.M. in creek on island; wind moderate W. clear. [Leg and wing of Scaup received.] 
Common Scoter (Edemia nigra, Linn.).

Lucifer Shoals Light-ship. - February 5th, "specimen of Duck," struck the lantern at 10.30 P.M., flying in a S.E. direction; wind moderate W., and clear at the time. [Skin of immature Scoter received.]

\section{SURF Scoter (Edemia perspicillata, Linn.).}

Fastnet.-November 5th, "shot a species of Duck or Widgeon in Crookhaven Harbour." [Immature male Surf Scoter received in flesh.]

\section{"Ducks."}

Coningbeg Light-ship.-April 5th, two "Wild Ducks" going N.N.E. at 6 A.M.

Tuskar.-November 4th, six "Ducks" going S.E.: 20th, three Scoters swimming abuut rock: 21st, four Scoters swimming about all day. "These birds answer the description given of 'Scoter' in Morris's 'British Birds." I have never seen them before."

Lucifer Shoals Light-ship.-April 17th, flock of Black Ducks flying low in line 10.30 A.M. December 27th, one flock of Ducks going N.W.

Arlolow North Light-ship.-August 9th, flock of Ducks flying E. noon; weather cloudy, calm. September 19th, flock of Ducks going E. October 1st, six Ducks going E. : 30th, large flock of Ducks going N.; showers, gale S.W.

St John's Point, Down.-October 18th, two flocks of Widgeon going W. at 10 A.M.; fresh breeze S. November Sth, flock of Widgeon going S.W. at 8.20 A.Mr. ; strong gale S.E. December 3rd, several pair Mergansers about shore during day; gale S.W., overcast, rain : 7th, large flock Widgeon going W.: 16th, flock of Pochards going S.W.

Maidens South.-April Sth, "I particularly wish to state that during the months of October, November, and December 1888, great flocks of what I call White-breasted Divers passed the rock, as a rule always flying to windward; they closely resemble Wild Duck.-B. SouE."

Rathlin O'Birne.-January 20th, 9 A.M., three Wild Duck 
(Teal) on large pool. November 1st, do.; left on 5th, and returned on 18th.

Blackrock, Mayo.-February 28th, 10.30 A.M., large flock of Widgeon going $\mathbf{N}$.

Slyne Head, N.-November 1st, two Teal Duck (male and female) struck lantern at 3 A.M., breaking a pane of glass N. side; strong wind, showery and squally. They were sent by keeper to Irish Lights Office.

\section{BiRdS NOT IDENTIFIED.}

Fiastnet.-May 22nd, 6 P.M., " a strange bird (species unknown) on rock for a few minutes, then left for shore; weather clear, light breeze N.W. About size of a Dove, but shaped like a Gull; very small head. Colour-head and neck, light brown ; breast, grey ; back, black ; most of tail white; could not see if it was web-footed or not; it flew something like a Hawk"-[Possibly a Sand Grouse.-R. M. B.]. October 10th, 2 P.M., one small bird (species unknown) about rock, "size and shape of House Swallow, but tail not so forked; head, breast, back, and tail black, underneath dull white"; weather clear, light breeze $\mathrm{N}$.

Aranmore.-June 27 th, "observed a strange bird near station, of handsome plumage; could not discern the colours; in size and mode of flying resembled a Magpie; flew northwards 6 A.M. ; misty."

Arren Island, N.-December 4th, several small birds-" about the size of a Lark, with reddish head, black and grey spotted wings, white breast, yellow legs, tail rather long-about station all day. I never saw any like them."

Tearaght.-October 27th, 11 A.MI., "one small bird with yellow tail." 

1889 
List of Light Stations.

1. Fastnet, Co. Cork,

2 excellent.

3. Old Head, Kinsale, Co. Cork, 29 good. 3a.Spit Bank, do, 1 good.

4. Mine Head, Waterford,......... 10 good.

5. Dungarvan, do., ......... 11 poor.

5. *Coningbeg Lt.-ship, Wexford, 54 excellent.

7. Tuskar Rock, do., 38 excellent.

$7 a$.Lucifer Shoals Lt.-ship, do., $\quad 14$ good.

7b. Blackwater Bank Lt. -ship, do., 14 good.

8. Arklow Sth. Lt.-ship, Wicklow, 323 very good.

8.*Arklow North Lt.-ship, do., 20 very good.

10. Kish Bank Lt.-ship, Dublin,... 12 good.

12. Rockabill, do., ... 512 excellent.

12b. South Rock Lt.-ship, Down, ... 25 very good.

13. Copeland (Mew) Island, do., ... 513 excellent. 14. *Maidens South, Antrim,....... 518 excellent.

14. ,N North, do., ........ 11 poor.

16. Innishtrahull, Donegal, ........ 310 excellent.

17. Dunree Head, do., ........ 10 poor.

20. Aranmore, do, ....... 10 good.

21. Rathlin O'Birne, do., ........ 23 good.

22. Killybegs, do., $\quad . . . . . .110$ good.

24. Broadhaven, Mayo,............ 10 poor.

27. Blackrock, do., ............. 22 very good.

31. Slyne Head, S., Galway, ,...... 413 very goot.

32. Arran Island, N., do., ........ 10 good.

34. Arran Island, S., do., ........ 17 good.

37. Tearaght, Korry, ............... 516 excellent. 39. Skelligs, do.,

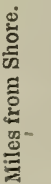

Names of Observers.
William Maginn

$\mathbf{x}$ - F. Ryan.

o $\mathbf{x}$ - George Dunleavy.

$x$ - Henry Williams.

o $x$ - H. Higginbotham.

x $\times 10\left\{\begin{array}{c}\text { P. Cullen and } W . \\ \text { Clydesdale. }\end{array}\right.$

x $\quad$ × 7 J. M. Leary.

$x \quad 09$ James Byrne and $\begin{array}{lllll}x & 0 & 6 & \text { P. King and J. Murphy. }\end{array}$ x $x \quad 7\{$ P. Clancy and A. B.

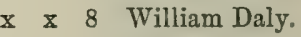

- $\quad x \quad 7$ Michael Cunniam.

$x=5\left\{\begin{array}{l}\text { John Hamilton and M. } \\ \text { Polly. }\end{array}\right.$

x 3 Thomas Coonty and Henry Thompson.

$x \quad x \quad 3\left\{\begin{array}{l}\text { E. M'Carron and James } \\ \text { Twobig. }\end{array}\right.$ $x \quad x \quad$ B. Sole and J. Kelly. $x \quad 5 \quad$ Patrick Keenan and $\mathrm{x}$ x 6 M. J. Kennedy.

$\mathrm{x} 0$ - Jervis Brownell.

- $\mathrm{x} 5$ Thomas Furtune.

x $\quad 0 \quad 2\left\{\begin{array}{l}\text { James Macginley and } \\ \text { J }\end{array}\right.$ J. A. Miurray.

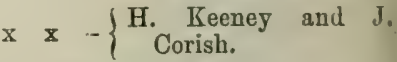
$x$ o John Murray.

x $\quad x \quad 9$ Richard Widdicombe. $x \quad x \quad$ P. D'Arcy and $F$. x $\quad 0 \quad 9\{$ John O'Donncll aud - James Watson.

$x \quad 0 \quad 6$ W. Morgan.

$x \quad x \quad 9\{$ W. H. James and Ben. $x \quad y$ jamin Jeffers

$x$ o 9 James Walsh.

Wicklow Head sent 2 specimens.

Legs, Wings, etc., received, 159.

$o=$ No reply. $\mathrm{x}=$ Schedules returned partly or wholly filled. Spring, replics received from 25 stations. dutumn, replies received from 19 stations. 


\section{Legs, Wings, etc., Received.}

\section{Species. How Received. How Procured. Date. Name of Station.}

Peregrine Falcon, Rec'd, in flesh, Shot, . . 10/2 mo., Slyne Head, S. Iiestrel's Eggs, three, $\left\{\begin{array}{c}\text { From nest on } \\ \text { cliff, }\end{array}\right\} 12 / 6$ mo., Wicklow Head. Spotted Flycatcher, \}Recd. in flesh, Prob. shot, Rec'd.20/10 mo, Blackrock, Mrayo. young, Water-Ouzel

Missel-Thrusb, .
$"$

"
Shot, . 13/12 mo., Rathlin O'Bime.

$\left\{\begin{array}{c}\text { Caught at } \\ \text { lantern, }\end{array}\right\} 6 / 3$ mo., Rockabill.
Thrush,

,

,

Reclwing,

39

,

Fieldfare,

39

,

Blackbird,

Lingr.Ouzel,

Redstart,

Stonechat;

Whinchat,

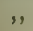

three,
Leg and wing,

Wing,

Leg and wings, Shot, . 20/10 mo., T'earaght.

Leg and wing, Killed st., . 26/10 mo., Tuskar.

",

,

,

,

Rec'd. in flesh, ",

Leg and wing,

,

,

,

Rec'd. in flesh, $\left\{\begin{array}{c}\text { Caught in } \\ \text { garden, }\end{array}\right\} 30 / 4$ mo., Rockabill.

,

Legsand wings,

Leg and wing,

Rec'd. in flesb,

Legs and wings,

Leg and wing,

five, Rec'd. in flesh,

Killed st., . 15/11 mo., Maidens S.

,, . 26/10 mo., Tuskar.

, : $\quad 3 / 10$ mo., Maidens $S$.

Caught st., . 3/10 mo., Innishtrahull.

Disabled st., 19/4 mo.,

". . 14/5 mo., Arklow S. Lt. ship.

,. 4/ 5 mo., Rockabill.

Killed st., . $2 / 5$ mo., Arran Island, $S$.

$\left\{\begin{array}{c}\text { Caught and } \\ \text { killed st., }\end{array}\right\}$ 6/ 4 mo., Arklow S. Lt. ship.

Killed st., - $28 / 3$ mo., South Rock Lt. ship.

Dead on deck, ?/ 4 mo., BlackwaterBankLt..Sh.

", , 18/11 mo., Arklow S. Lt.-ship.

? Rec'd. 4/ 9 mo., Copeland (Mow) Island.

, $\quad$. 6/ 4 mo., Lucifer Shoals Lt.-ship.

Dead on deck, $7 / 4$ mo., Blackwater Bank Lt. sh.

$\left\{\begin{array}{c}\text { Caught at } \\ \text { lantern, }\end{array}\right\} 9 / 4$ mo.,

Died on board, 21/-4 mo.,

tbree,

,

Legs, wings, tail $\left\{\begin{array}{c}\text { Killed ag'nst } \\ \text { rigging, . . }\end{array}\right\} 28 / 3$ mo., South Rock Lt. ship.

Leg and wing, Dead on deck, 23/ 4 mo.,

Killed st., - 19/ 8 mo., Maidens $S$.

,

,

,
,
,

Found dead,

28/ 4 mo., Arran Island, S.

Seclge Warbler,

Found dead, 4/ 8 mo., Old Head, Kinsale.

in

1 Killed st.$=$ Killed striking lantern. 


\section{Legs, Wings, eTC., Received-continued.}

Species. How Received. How Procured. Date. Name of Station.

Sedge Warbler, . Rec'd. in flesh, Killed st., - 3/ 5 mo., Tuskar.

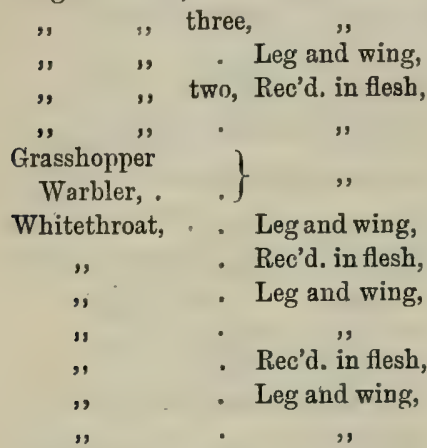

Willow Wren, . Rec'd. in flesh,

, " . Leg and wing,

" " $\quad$ two, Rec'd. in flesh,

, , . Leg and wing,

Chiffchaff," . . Rec'd. in flesh,

," . . Leg and wing,

Wren,. . . Rec'd. in flesh,

", . 14/ 5 mo., Arklow S. Lt. ship.

, . 4/ 5 mo., Rockabill.

" $\quad$ - 7/ 5 mo., Copeland (Mow) Island.

". $\quad 22 / 5$ mo., Arran Island, $S$.

, $\quad 7 / 5$ mo., Copeland (Mew) Island.

Shot, . 17/ 7 mo, Old Head, Kinsale.

Killed st., - 14/5 mo., Arklow S. Lt. ship.

, . 4/ 5 mo., Rockabill.

," $\quad 5 / 4$ mo., Copeland (Merv) Island.

? $\quad 7 / 5 \mathrm{mo}$.,

? Rec'd. 4/ 9 mo.,

Killed st., . 21/ 5 mo., Arran Island, S.

, Prob. 4/ 5 mo., Arklow S. Lt. ship.

". 4/ 5 mo., Rockabill.

? . 7/ 5 mo., Copeland (How) Island.

Caught, . $19 / 8$ mo., Maidens $S$.

Caught st., . 5/5-mo., Innishtrahull.

Killed, - $8 / 4$ mo., Lucifer Shoals Lt.-ship.

Dead on deck, 7/ 4 mo., Blackwater BankLt. sh.

Killed st., . 11/ 4 mo., Rockabill.

Found dead, ?/?/89, Blackrock, Mayo.

". . " ? 15/10/89? Tearaght.

Golden-crested Wren, , $\quad$ At lantern, . 26/9 mo., Kinsale.

Killed st., . 9/ 4 mo., Coningbeg Lt. ship.

$\begin{array}{lll}" & \text { " } & \text { Leg and wing, } \\ " & \text { " } \\ ", & \text { Rec'd. in flesh, }\end{array}$

Great Titmouse, . Leg and wing,

Meadow-Pipit, . ,

" " $"$ " $\quad$ "

Rock-Pipit, . . ,

Skylark, . . ,

Caught, . 30/10 mo., Kish Bank Lt.-ship.

Caught st., . 12/ 9 mo., Innishtrahull.

Disabled, . 19/9 ro., Arran Island, S.

Caught, . 14/10 mo., Coningbeg Lt.ship.

Killed st., . 11/ 4 mo., Rockabill.

, Prob. $11 / 4$ mo., South Rock Lt. slip.

, . 22/10 mo., Maidens $S$.

Killed on rock, 20/10 mo., Tearaght.

Killed st., . 26/10 mo., Tuskar.

",

?/?/89, Arklow S. Lt. ship).

" pale variety, Rec'd. in flesh,

Dead on deck, 16/11 mo., ", ",

Killed st., . 26/9 mo., Maidens $S$.

" . . Leg and wing,

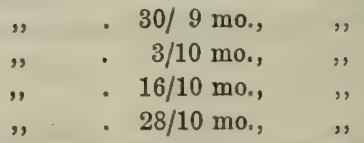

$\begin{array}{ll}\text { Snow Bunting, * Rec'd. in flesh, Shot, . } & \text { Found dead, } 28 / 8 \mathrm{mc} ., \text { Slyne Head, S. } \\ \text { 19/9 mo., Kinsale. }\end{array}$

Caught on deck, 11/10 mo., Coningbeg Lt. ship. 
LEGS, Wings, ETC., ReCEIVED-continued.

Species. How Received. How Procured. Date. Name of Station.

Snow Bunting, . Rec'd. in flesh, Shot, . . 27/ 3 mo., Slyne Head, S.

Leg and wing, Killed st., . 17/ 5 mo., ", ,"
Rec'd, in flesh, Shot, . . 23/ 4 mo., Tearaght.

$\left\{\begin{array}{c}\text { Rec'd. in flesb, } \\ \text { in spirits, }\end{array}\right\}$, . . 30/ 5 mo., ,"

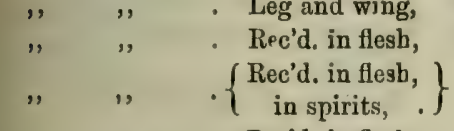

, , . . Rec'd. in flesb,

Corn Bunting, . Rec'd. in flesh,

Chaffinch, . . Leg and wing, two, . Rec'd. in flesh, Brambling, .

House Sparrow,

Dead on deck, 28/12 mo., Arklow S. Lt. ship.
" $\quad\left\{\begin{array}{c}\text { Caught in } \\ \text { light-house } \\ \text { kitchen, . }\end{array}\right\} 4 / 12$ mo., Copeland (Mow) Island.

", Lag and wing,
Greenfinch, young, Rec'd. in flesh,

Killed by dog, $1 / 6$ mo., Slyne Head, S.

, . 20/9 mo., .,

, . 1/ 7 mo., Innishtrahull.

Killed st., ' 26/10 mo., Tuskar.

Shot, . 15/10 mo., Tearaght.

". . Leg and wing,

Goldfinch, . . Wing, . .

Siskin, . . Rec'd. in flesh,

Mealy Redpole, .

Twile, young,

Starling,

Leg and wing,

? 2/10 mo., Tearaght.

? 19/10 mo., ,"

Found, . 15/10 mo., Old Head, Kinsale.

Killed st., . 26/10 mo., Tuskar.

Shot, . . 19/9 mo., Tearaght.

Killed, . 1/ 9 mo., ,

$\begin{array}{cc} & \text { Killed st., . } 26 / 10 \text { mo., Tuskar. } \\ \text { Wing, . . } & \text { ? } 2 / 89, \text { Arklow S. Lt. ship. }\end{array}$

Leg and wing, Killed st., . 23/ 2 mo., ,, ," , 13/11 mo., Maidens $S$. ,. $\quad 19 / 9$ mo., Arran Island, S.

Found killed, 19/10 mo., Tearaght.

Shot, . $29 / 7$ mo., Innishtrahull.

Killed st., - 4/ 5 mo., Rockabill.

Picked up dead, 19/ 4 mo,, Blackwater Bank Lt.-sh.

Rec'd. in flesb, Found stunned, $31 / 7$ mo., Fastnet.
$?$
7/ 8 mo., Wicklow Hcad.

Killed st., . $5 / 5$ mo., Rockabill.

,

$\{$ Killed ag'nst $\}$

3/ 5 mo., Copeland (New) Island.

Rock Dove,

,

$\{$ glass, . $\}$

Leg and wing,

Shot, .

Rec'd. $5 / 9$ mo., Fastnet.

Shot, . . 19/ 8 mo., Old Head, Kinsale.
wing, tail, Picked up, . 25/ 5 mo., Tearaght.

Leg, wing, tail, Picked up, 25/ 5 mo., Tearaght.
Rec'd. in flesh, Found disabled, 6/ 5 mo., Maidens S.

Picked up at d. in flesh, Found.

Feathers, $\left\{\begin{array}{c}\text { Picked up at } \\ \text { Hawks' } \\ \text { feeding-place }\end{array}\right\} 8 / 6$ mo., Tearaght.

Water-Rail,

Killed st., - 5/ 9 mo., Rathlin O'Birne.

Ioor-Hen, .

Rec'd. in flesh,

Disabled st., $10 / 4 \mathrm{mo}$, South Rock Lt.-ship.

Coot, .

Leg and wing,

Killed st., . 26/10 mo., Dungarvan. 


\section{Legs, Wings, ETC., ReCEIVED-continued.}

Species. How Received. How Procured, Date. Name of Station.

Turnstone, . . Rec'd. in fiesh, Shot, . . $10 / 3$ mo., Innishtrahull.

Grey Phalarope, . $\quad$ ". Disabled st., 1/11 mo., Slyne Head, S

Woodcock, . Wing, . . Killed st., . 26/10 mo., Innishtrahull.

Snipe, . . Leg and wing, " . 6/ 4 mo.,

" . . " Killed, . 2/ 5 mo., Arran Island, S.

Jack Snipe,. . Rec'd. in flesh, $\left\{\begin{array}{c}\text { Dead on } \\ \text { balcony, }\end{array}\right\} 2 / 10$ mo., Slyne Head, s.

Dunlin, . Leg and wing, $\left\{\begin{array}{c}\text { Caught on } \\ \text { deck, }\end{array}\right\} 12 / 11$ mo., Kish Bank Lt.-ships.

Knot, two, . Rec'd. in flesh, $\left\{\begin{array}{c}\text { Dead on } \\ \text { balcony, . }\end{array}\right\} 2 / 10$ mo., Slyne Head, S.

Redshank, . . Leg and wing, Shot, . . 20/8 mo., , , ,

Whimbrel, . . is Killed st., . $2 / 9$ mo., Coningbeg Lt.-ship.

, . . " " Shot, . 26/ 7 mo., Innishtrahull.

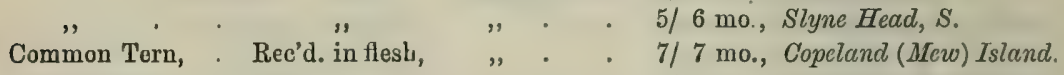

Aretic Tern, . Skin, . . . . . $19 / 9$ mo., Old Head, Kinsale.

Manx Shearwater, Leg and wing, Killed st., , $22 / 5$ mo., ", ",

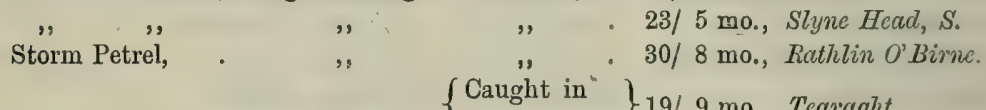

Little Grebe, . Rec'd, in flesh, Killed st., . 16/11 mo., Slyne Head, s'

Wigeon, . . Leg and wing, ", . 19/10 mo., Maidens S.

Common Scoter, . Tongue and wing,. , , . ?/11 mo., Maidens $N$. 
I NDEX.

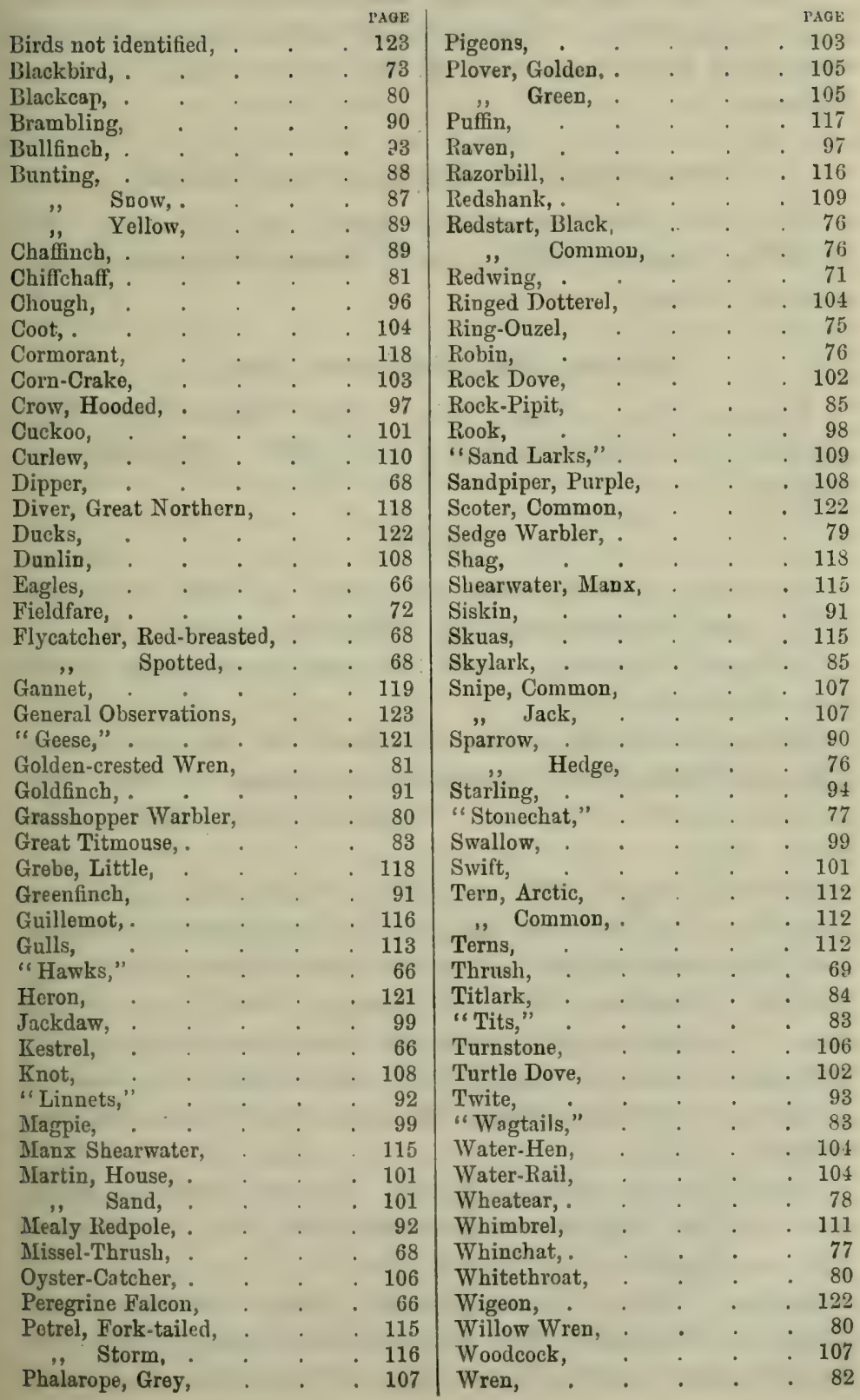




\section{EAGLes.}

Aranmore-May 4th, a large Eagle and two Falcons hovering over the station. "This Eagle had a white band on the tail and white ball [? band.-R. M. B.] on each wing.-THomas ForTune."

Peregrine Falcon (Falco peregrinus, Tunstall).

Slyne Head, S.-February 10th, Hawk shot at 10 A.M. ; "saw it lift a Puffin out of the sea." [Female Peregrine Falcon received in flesh.]

Kestrel (Falco tinnunculus, Linn.).

Wicklow Head.-June 12th, "three Hawk's eggs sent; obtained from their nests in a steep cliff." [Kestrel's eggs received.]

\section{HawKS.}

Mine Head.-March 20th, one going E.: 26th, two going S.W. April 4th, one going N.E. May 3rd, two going S.

Coningbeg Light-ship.-April 22nd, one on the ship. Gulls were chasing this bird.

Tuskar Rock,-May 24th, one Hawk on the rock. June 18th, one Hawk going towards land at sunrise. October 16th, one large Hawk on the rock. November 3rd, one Hawk on the rock.

Rockabill.-April 10th, one Falcon, very large: 26th, one going W. July 29th, one large black Hawk chasing the Seafowl; flew towards land. August 13th, one Falcon on the rock; flew W. November 23rd, one Sparrow Hawk going W. at noon. "I have caught a Sparrow Hawk in a ship's rigging 600 miles from the nearest land, and small birds, such as Linnets and Sparrows, 200 and 300 miles off.-John Hayilton." [Where?-R. M. B.]

South Rock Light-ship.-August 21st, one Sparrow Hawk rested on the ship for one hour, and flew N.W. September 28th, one Sparrow Hawk flew to land.

Copeland (Mew) Island.-October 311st, a Sparrow Hawk flying E. November 3rd, Sparrow Hawk seen: 20th, one Sparrow Hawk seen in the morning: 23rd, one on the island: 
24th, a Sparrow Hawk about the island. December 14th and 15th, a Sparrow Hawk flying about.

Maidens South.-May 28th, one Hawk rested on the rock for about an hour, and flew S.

Innishtrahull.-March 15th, one Merlin Hawk on the island. April 6th, one Merlin Hawk: 23rd, 30th, and May 11th, do. July 31st and August 9th, one Merlin. Septenber 23rd, two Buzzards hovering over the island at 1 P.M. ; wind light S.E., clear.

Aranmore.-Falcon and Sparrow Hawk always about this station.

Rathlin O'Birne.-April 1st, one Hawk on the island, killed a Seapie. July 15th, two Hawks on island, larger than the Hawks previously observed.

Broadhaven.--Sparrow Hawks often observed at this station.

Blackrock, Mayo.-March 19th, one Falcon round the rock. April 5th, one Falcon Hawk about the rock in the morning, and also all day on the 6th April: 28th, two Falcons about all day. May 20th, three Falcons flying about the rock. November 15th, one Fantail Falcon on the rock: 17th, two Falcons about the rock.

Slyne Head, S.-March 20th, one Falcon. April 7th, one Goshawk on the island at 11 A.M. ; wind light E., gloomy: 10th, a large dark-brown Hawk on the island: 30th, two Common Hawks on the island.

Arran Island, N.-April 11th, one Sparrow Hawk (first noticed this season). May 7th, one White Falcon (supposed) pitched on dwelling, and afterwards flew N.E. at 5 P.M.; wind light S., rain. "This bird was larger than the Common Hawk, with white body and wings, and a slate-coloured back. It seemed to be very fatigued, and was followed by a number of small birds.-John O'Donnell." [Probably a Hen Harrier.R. M. B.] May 8th, one Hawk going E. at 6 P.M.

Tecraght.-February 24th, one brown Hawk on the island. March 9th, three Peregrine Falcons over the rock. April 24th and 25th, a pair of Peregrine Falcons all day. May 3rd, one small brown Hawk: 24th, one Kestrel about. September 1st, two Kestrels all day: 15th, one Kestrel and one Peregrine about all day: 18th, one Peregrine. October 2nd, one Merlin about during the day: 4th, one Sparrow Hawk about all day. 
December 4th, one Peregrine all day on the rock. A Peregrine Hawk was observed to attack a large Herring Gull and kill it, and take it up the island.

Bull Rock,-Hawk seen during fog on night of July 28th.

Spotted Flycatcher (Muscicapa grisola, Linn.).

Tuskar Rock,-August 30th, one "Flycatcher" on rock all day.

Blackrock, Mayo.-October 20th, one Spotted Flycatcher[Received in flesh]. "I knew it was a Flycatcher of some sort, as I saw it catching flies; I saw another like it the same day with a red breast.-Richard Widdicombe." [Possibly a Redbreasted Flycatcher.-R. M. B.]

\section{"Red-breasted Flycatcher."}

Frestnet.-March 2nd, "one Pied Flycatcher remained two days on the rock; I observed it closely. It was much darker than the ordinary Pied Flycatcher; it had. a dull-red breast, resembling a young Grey Linnet; perhaps it may have been a Red-breasted Flycatcher; it kept low down on the rock in pursuit of flies; sky clear, wind moderate S.S.E.-GEorGE Dunleavy."

Water-Ouzel or Dipper (Cinclus aquaticus, Bechst.).

Rathlin O'Birne-December 13th, Water-Ouzel shot[Received in flesh]. "This bird was for some weeks on the island, and was very shy; it used to resort to a little pool of water, wading through it."

\section{Missel-Thrush (Turdus viscivomu, Linn.).}

Rockubill.-March 6th, a bird caught at lantern at 9.30 P.M.; wind E., heavy rain-[Missel-Thrush received in flesh]. One Wheatear caught at same time, and let go; flew towards shore.

Aranmore.-April 27th, "Nest of Missel-Thrush found near the station, with eggs hatched, a few days ago; the old birds are a very fine pair; they are the first I have ever met with; the foundation of the nest was sticks and heather lined with wool and moss.-Thomas Fortune." 
Thrush (Turdus musicus, Linn.).

Old Head, Kinsale.-October 21st, a large rush of Thrushes, Redwings, Blackbirds, Starling, and Chaffinches; thunder and lightning.

Spit Bank.-December 30th, numbers observed on shore for the last month.

Coningbeg Light-ship.-October 25th, flocks about light. November 16th, some about light (see under Blackbird).

Tuskar Rock.--October 3rd, eight round the light: 26th, two round the light-[Leg and wing received]; great rush of other birds (see under Siskin). November 2nd, three all night round the lantern; gale E. : 12 th, six Thrushes at light at 10 P.M. December 1st, two do.: 3rd and 8th, two or three all day on rock.

Blackwater Bank Light-ship.-March 1st, Thrushes, Blackbirds, and Starling killed striking; snow.

Arklow South Light-ship.-February 22nd and 23rd, several Starling and Thrushes about the light-[Leg and wing of Thrush received]. October 25th, several Thrushes and Stares about the lantern; some killed, fell overboard; wind light E.: 26th, Blackbirds, Thrushes, and Larks about the light; some killed, fell overboard; wind fresh E., gloomy: 28th, Thrushes and Stares at lantern; Thrush killed. November 11th, Thrushes and Stares about the light; wind light E.N.E., hazy: 14th, Thrushes and Stares do.; wind light W.S.W., hazy; some killed: 18th, Thrushes struck lantern; wind light S., haze-[Wing received, undated]. December 14th, several Thrushes about light; wind moderate W.S.W., misty, rain; four killed.

Arklow North Light-ship.-February 10th, Thrushes and Stares about the ship and flying N.W.; eight killed; gale N.E.: 22nd, Thrushes, Blackbirds, Larks, and Starlings about the light; wind moderate N.; sleet and rain. September 25th and 26th, Larks, Thrushes, and Starlings about the light; wind fresh S.W., hazy, rain. October 2nd, 3rd, and 5th, many land birds about the light; seven Thrushes killed; wind high, cloudy to rain: 24th, 26th, and 27th, Larks, Stares, and Thrushes about the lantern; many killed; wind moderate E., cloudy.

Kish Bunk Light-ship.-October 20th, one on deck: 25th, 
many Thrushes and Blackbirds about the light; two caught and three killed. November 11th, five Stares, three Blackbirds, and two Thrushes about the ship during the morning: 13th, Thrushes about the light: 17th, several Thrushes and Skylarks about the lantern; hazy.

Rockabill.-January 11th, two Thrushes killed striking; wind fresh from the south. April 7th, one all day about the rock. September 5th, numbers of Thrushes and other birds this week (see note under Blackbird). November, great rushes of Thrushes and other birds (see under Sparrow).

South Rock Light-ship.-March 8th, one Thrush about the lantern at 3 A,M.; wind light N.W.

Copeland (Mew) Island.-October 2nd, Thrushes and Blackbirds striking; breeze strong N.E., misty; one killed: 19th, Thrushes and Skylarks about the light; fresh gale, clear: 26th, several Thrushes killed striking. November 3rd, Skylarks and Thrushes striking lantern; wind S.W., moderate: 13th, Lapwings, Starlings, Blackbirds, and Thrushes about all night; fog: 17th, Fieldfares, Thrushes, and Starlings fiying through the rays : 20 th, do. (see under Starling). December 28th, Thrushes and Starlings about the lantern.

Maidens South.-February 3rd, Thrushes and Skylarks about the lantern; left at daybreak for the land; strong gale N. October 2nd, a number of Thrushes and Starlings round the lantern from 9 P.M. to midnight; wind moderate S.W., clear: 3rd, a number of Thrushes, Blackbirds, and Larks round the light all night; two Blackbirds and ten Larks killed; wind moderate E.: 19th, a Thrush and two Hedge Sparrows on the rock at 11.30 A.M.; gale S.E.: 24th, flocks of small birds like Thrushes and Starlings passing west all day at intervals; wind N.E., light. November 5th, a flock of Thrushes and Blackbirds going west: 14th, flocks of Starlings, Thrushes, Blackbirds, and other small birds passing S.W. at 10.30 A.M. ; wind light S.W. December 21st, several Blackbirds and Thrushes round the lantern; wind strong S.E.; none striking.

Maidens North.-October 16th and 17th, Thrushes passing (see under Blackbird).

Innishtrahull.-January 7 th and 8 th, one about each day; gale S.E. February 22nd, one killed striking: 27th, two Thrushes and 
a Redwing struck the glass (the Thrushes killed); wind fresh S.E., snow. March 3rd, two Thrushes and a Blackbird struck the glass; wind fresh S.E. July 11th, a Thrush seen. October 3rd, one caught at the lantern: 20th, numbers of Thrushes and Redwings striking all night; gale $\mathrm{E}$, hazy; seven Thrushes killed.

Dunsee Head.-January 27 th, twenty going E. ; wind strong S.E., clear.

Aranmore.-October 13th, one near station: 19th, two at the light, disabled.

Rathlin O'Birne.-February 10th to 13th, flocks of Rooks, Starlings, and Thrushes on the island during snow.

Slyne Head, S.-September 30th, two about island. October 20th, Blackbirds, Thrushes, and Linnets all day on island: 22nd and 23rd, Thrushes all day about the island.

Tearaght.-October 19th, one seen: 20th, twelve-[Leg and wing received, shot]: 22nd, some. December 4th, Thrushes and Blackbirds all day on the island; gale S.E.

Slclligs.-April 14th, two all day on the rock; wind light S.E.

\section{REDWING (Turdus iliacus, Linn.).}

Fastuct.-February 27th, one flew into dwelling; caught and let go.

Old Head, Kinsale.-October 21st, a large rush of Redwings, Thrushes, Blackbirds, Starlings, and Chaffinches; night heavy, thunder and lightning.

Spit Bank.-December 30th, six going S.W.; "observed for the last month large numbers of Redwings, Thrushes, Blackbirds, and Fieldfares on shore."

Coningbey Light-ship.-November 20th, one "Mountain Thrush" [Pessibly Redwing.-R. M. B.] on ship at 9 A.M.

Tuskar Rock-October 26th, two Thrushes round light at 12.30 A.M. [Leg and wing of Redwing and Thrush received]; great rush of birds (see under Siskin). November 24th, one flying towards land. December 29th, three at light.

Rockabill.-November, great rushes of Redwings and other birds (see under Sparrow). December 1st, four on rock all day; wind S.E., strong, gloomy. 
Copeland (Mew) Island.-October 20th, about half a dozen killed striking; wind S.E., fresh gale.

Maidens South.-October 14th, numbers of Redwings and Skylarks at light; wind light S.W.; one Redwing killed-[Leg and wing received]: 17th, flocks of Larks and Redwings passing west all day; gloomy, wind light S.E. : 19th, several Redwings and Skylarks round the light; Redwing killed-[Leg and wing received]; gale S.E. : 20 th, two all day on the rock; one killed at night striking-[Leg and wing received]: 22nd, Skylarks and Redwings round the lantern during the night; wind strong N.E. November 3rd, one Redwing about the rock all day. December 1st, a flock of Larks and Redwings going west: 27th, two Redwings at the lantern glass at midnight; wind strong S.E.

Maidens North.-October 16th and 17th, Redwings passing (see under Blackbird).

Innishtrahull.-February 27th, two Thrushes and a Redwing struck glass; wind fresh S.E., snow. April 20th, one "Mountain Thrush" on island. October 20th, numbers of Thrushes and Redwings striking all night; gale E., hazy; ten Redwings killed.

Blackrock, Mayo.-October, a number of Redwings all the month about the rock: 23rd, two killed striking. November 14th, one about all day; misty: 15 th, two on the rock; wind strong S., misty to rain: 21 st and 24 th, one about the rock.

\section{FIELDFARE (Turdus pilaris, Linn.).}

Spit Bank.-December 30th, numbers of Fieldfares observed on shore during last month (see note under Redwing).

Tushar Rock-October 12th, one round the light ali night. November 21st, one round the lantern at 11 P.M. ; gale S.

Blackvoter Bank Light-ship.-April [? day], Fieldfare found dead on deck. [Leg and wing received.]

Arklow South Light-ship.-November 18th, one found dead on deck; wind light S., haze. [Received in flesh.]

Rockabill.-February 22nd, numbers of Fieldfares going W. at 11 A.M.

Copeland (Mew) Island.-November 13th, Fieldfares round the lantern; fog: 17th, Fieldfares, Thrushes, and Starlings flying through the rays: 20th, do. (see under Starling). 
Maidens Sonth.-January 9th, Fieldfares and Starlings about the light; wind moderate N.W.: 29th, Larks and Fieldfares about the lantern; none killed; wind moderate S.W., cloudy. February 12th, Blackbirds, Fieldfares, and Starlings striking through the night; none killed; wind moderate W., cloudy: 18th, Fieldfares and Starlings about the lantern; a Starling killed; wind moderate W. November 15 th, several Fieldfares round the light; one killed striking-[Received in flesh]; wind S.W., cloudy. December 30th, three Fieldfares going S.W.

Maidens North.-October 16th and 17th, Fieldfares passing (see under Blackbird).

Innishtrahull.-October 20th, five at light all night; gale $\mathrm{E}$.

Blackrock, Mayo.-November 14th, five all day: 15th, two on rock; wind strong S.: 16th, two about rock; wind fresh N.W.; misty to rain.

Tearaght.-January 14 th, one at 2 P.M.; wind strong S. October 20 th, one about rock.

\section{BLACKBIRD (Turdus merula, Linn.).}

Fastnet.-February 23rd, one female on rock; flew to shore.

Old Hoad, Kinsale.-October 21st, large rush of Blackbirds, Thrushes, Starlings, Redwings, and Chaffinches; night heavy, thunder and lightning.

Spit Bank-December 30th (see under Redwing).

Dungarvan.-October 26th, one caught striking, and let go again.

Coningbey Light-ship. - October 25th, flocks Blackbirds, Thrushes, and Larks about light from 9 P.M. to midnight; many killed and fell overboard; wind moderate E.S.E., gloomy. November 11 th and 12th, some about light: 16th, Blackbirds and Thrushes about light at night; wind light E., cloudy.

Tuskar Rock,-October 5th, two at light: 6th, one killed striking: 12th, Blackbirds all night round the lantern: 26th[Leg and wing of Blackbird killed striking, received]; great rush of birds (see Siskin). November 2nd, two at the light: 23rd, two do. December 1st, twelve at lantern at 11 P.M.: 15 th, one on the rock.

Blackwater Bank Light-ship.-March 1st and 2nd, Blackbirds, Starlings, and Thrushes killed striking; snow. 
Arklow South Light-ship.-October 26th, Blackbirds, Thrushes, and Stares about lantern; some killed, fell overboard; wind fresh E., gloomy. November 18th, Blackbirds about the light.

Arklow North Light-ship. - February 22nd, Blackbirds, Thrushes, Larks, and Starlings about the lantern; two Blackbirds killed; sleet and rain. April 8th, Blackbirds, Larks, and Stares going N.W.; wind fresh N.E., gloomy; one Blackbird killed. May 1st, one at lantern. October 18th, three killed striking; wind moderate S., rain. November 17th, two killed striking; wind light S.W., hazy.

Kish Bank Light-ship.-October 25th, many Thrushes and Blackbirds about the light; two caught, and three killed. November 11th, three Blackbirds about the ship during the morning.

Rockabill.-January 11th, one killed striking. April 18th, one hen bird all day on the rock; calm. September 5th, "very thick weather during past few days, and a great many birds in consequence-Blackbirds, Thrushes, Larks, Willow Warblers, Woodpeckers, Whitethroats, and two Swifts; we caught a fine Blackbird with a white breast." November 15th, great rushes of birds, including Blackbirds, during the last fortnight (see full note under Sparrow).

South Rock Light-ship.-March 8th, one at lantern at 3 A.Mr.

Copeiand (Mew) Island.-July 4th, Blackbirds breed, and some thirty or forty birds are always on the island. October 2nd, Thrushes and Blackbirds striking at 4 A.Mr; breeze strong N.E., misty: 3rd, one struck at midnight: 25th, Blackbirds and Starlings striking; strong breeze W., rain: 26th, Blackbirds, Larks, and Starlings about light; strong breeze. November 13th, a rush of birds this night; Blackbirds, Thrushes, Starlings, and Lapwings round the light; fog: 25th, Blackbirds are plentiful on the island now.

Maidens South.-February 12th, Blackbirds, Fieldfares, and Starlings striking throughout the night; none killed; cloudy, wind moderate W. July 5th, two Blackbirds on the rock at sunrise; flew to the W. October 3rd, a number of Thrushes, Blackbirds, and Larks round the light all night; two Blackbirds and ten Larks killed; wind moderate E. [Leg and wing of Blackbird received]: 25th, a Blackbird on the rock 
at noon. November 5th, a flock of Thrushes and Blackbirds at 9.50 A.M. going W.: 12 th, three Blackbirds on rock at 11 A.M.: 14th, flocks of Starlings, Blackbirds, Thrushes, and other small birds passing S.W. December 21st, several Blackbirds and Thrushes round the lantern; wind strong S.E.; none striking.

Maidens North.- "The migration of Blackbirds, Thrushes, Redwings, and Fieldfare passed here on the 16th and 17th October."

Innishtrahull._January 6th, male and female Blackbirds about in the forenoon; first seen since the beginning of November; wind light S.W. March 3rd, two Common Thrushes and a Blackbird struck the glass; wind fresh S.E. July 11th, one seen; female. October 3rd, one female Thrush caught striking - [Leg and wing of Blackbird received]. December 5th, two Blackbirds at noon.

Aranmore.-October 13th, one near the station: 19th, one at light, disabled.

Rathlin O'Birne.-January 3rd, four on island.

Broadhaven.-Frequently observed at this station.

Blackrock, Mayo.-October, two all the month on the rock. November 14th, one all day: 15th, one on rock: 17th, one: 19th and 20th, two about rock.

Slyne Head, S.-September 30th, one all day. October 20th, Blackbirds, Thrushes, and Linnets all day on the island: 25th, one on island.

Tearaght.-October 22nd, several females on rock.

Skelligs.-March 3rd, two females on rock.

\section{RING-OUZEL (Turdus torquatus, Linn.).}

Fustnct. -April 9th, "I have been informed by a country-man that a pair of 'White Blackbirds' breed in a wood belonging to $\mathrm{Mr}$ Hungerford, about four miles from our shore dwellings; he says they nest there every year, so I presume they must be Ring-Ouzels.-GEORGE DuNLeavy."

Rockabill.-September 5th, a fine Blackbird with a white breast caught this week.

Innishtrahull.-April 19th, two Ring-Ouzels striking the glass at midnight; both caught; wind light S.W., rain. [Leg and wing received.] 
Tearaght.-April 9th, one on rock: 15th, one: 18th, one.

Skelligs.-March 24th, one on rock. April 9th, two: 11th, one.

HedGe SparRow (Accentor moduiaris, Linn.).

Copcland (Mew) Island.-November 25th, one. December 29 th, one.

Maidens South.-October 19th, two on rock.

RoBIN (Erithacus rubecula, Linn.).

Tuskar Rock,-September 6th, one at light.

Rockabill.-April 2nd, two have been about the rock for the past fortnight, and during the winter there is scarcely a day without a Robin on the rock: 26th, one. August 10th, one perched on rock.

Copeland (Mew) Island.-Septernber 23rd, one. November 2nd, one: 25th, one. December 29th, the Robin still on the island.

Maidens South.-September 4th, one on rock: 5 th, one.

Innishtrahull.-March 28th, one striking the glass; wind light W. April 6th, two, and two Chiffchaffs striking; wind strong E., haze.

Arran Island, N.-April 5th, two seen: 9th, one.

Tearaght.-February 8th, one noticed at 11 A.M.

Bull Rock.-One in July.

Redstart (Ruticilla phoenicurus, Linn.).

Rockabill.-April 30th, two all day on the rock; one caught in a piece of garden netting-[Received in flesh]; wind S.E., fresh; the other flew W. There was a Black Redstart on the rock at the time the Redstart was killed. May 5th, one Redstart on rock (see under Cuckoo).

\section{Black Redstart (Ruticilla titys, Scopoli).}

Oid Head, Kinsale-February 27th, one close to station. October 19th, one seen. These birds were observed on and off until December 27 th.

Rockabill.-May 1st, one all day on rock.

Tearaght.-November 16 th, one on rock.

Skelligs.-January 6th, four Redstarts on rock. 
"STONEchat."

Tuskar Rock:-August 11th, one all day: 22nd, three all night; grale N.W.: 28th, 29th, and 30th, Stonechats and Warblers on the rock every day; left for the shore on the 30th.

Rockabill._-"Stonechats build on the rock, and the birds are very tame." April 28th, two all day. July 22nd, two rested at 8 A.M. August 20th, two on the rock.

South Rock light-ship.-March 28th, two strange birds killed striking at 5 A.M. going N.W.; wind light S.W., rain-[Stonechat received in flesh; also leg, wing, and tail of Wheatear]. November 10th, 11th, and 12th, Starlings, "Stonechats," and Larks about the light each night; wind light S., gloomy.

Copeland (Merv) Island.-June 21st, one Stonechat. September 12 th, one. October 6 th, one. November 13 th, Stonechats seen.

Maidens South.-April 7th, three. September 15th and 16th, one: 18 th, one all day. October 6 th, two.

Ruthlin O'Birne.-March 22nd, three on the island.

Killybegs. - April 14th, two; they nest and remain till autumn. October 19th, last seen to-day.

Bleckrock, Mayo.-April 28th, two struck the lantern at 11 P.M.

Slyne Head, S.-April 1st to 7th, several arrived to build.

Arren Island, S-April 26th, Stonechats and Skylarks round the light all night. May 1st, tlocks of Stonechats passing all night; one killed. [Possibly these were Wheatears, as one was killed striking on April 28th, and sent as a "Stonechat."]

\section{Whinchat (Pratincola mubtra, Linn.).}

Tuskar Rock-August 22nd, one.

Aiklow South Light-ship.-May 4th, from 10 P.M. to 4 A.M. on Jth, several small birds about lantern; wind light S.E., haze and rain; six killed striking. [One Whinchat, three Sedge Warblers, Whitethroat, and Willow Wren received in flesh.]

Rockituill.-May 4th, rush of birds during fog (see under Cuckoo). [Legs and wings of three Whinchats received, killed striking.]

Copeland (Ntow) Island.-September 4th-[Leg and wing of Whinchat received]. 
Blackrock, Mayo.-February 15th to 23rd, a Whinchat (male) about the rock.

Arran Island, S.-May 2nd, strange birds about the light at night going S.; wind S., heavy rain; one sent in flesh. [Male Whinchat received.]

\section{Wheatear (Saxicola cenanthe, Linn.).}

Old Head, Kinsale.-March 17th, several seen to-day.

Tuskar Rock-May 5th, two on rock at 4 A.M. : 7th, one: 9th, Wheatears all day on the rock; wind moderate S.E., overcast: 13th, Wheatears and Warblers on the rock all day; wind light N., clear. August 7th, one: 18th, several at light; wind light S.W.: 20th, one all day. December 23rd, one all day on the rock; wind moderate S.W.

Lucifer Shoals Light-ship.-April 6th, several birds about the light at 2 A.M.; three killed striking. [Legs and wings of Wheatears received.]

Blackwater Bank Light-ship.-April 7th, several at midnight going N.W.; eight killed; wind light E.N.E. [Leg and wing received.]

Arklow South Light-ship.-April 6th, several small birds about lantern between midnight and 2 A.M. ; wind light N.E., hazy; some struck and caught-[Five Wheatears received in flesh]: 8th, numbers of small birds about light from 1 A.M. to 3 A.M. ; wind moderate $\mathrm{N}$. to $\mathrm{E}$., light haze: 9 th, two small birds caught at lantern at 3 A.M. ; wind light N.E., light haze-[Wheatear received in flesh]: 21st, three birds sent; " had them on board some days [date of capture not given, possibly 6th]; there were numbers at light." [Three Wheatears received in flesh.]

Rockabill.-May 5th, Wheatear caught (see under MisselThrush).

South Roch Light-ship.-March 28th, two strange birds killed striking at 5 A.M. going N.W.; wind light S.W., rain - [Legs and wings of Wheatear received; also Stonechat in flesh]. April 23rd, "Stonechat" found dead on deck at 5 A.M. [Leg and wing of Wheatear received.]

Copeland (Mcv) Island.-April 18th, one; a few remain all summer. July 10th, one young. Wheatear seen.

Maidens South.-August 19th, small bird, unknown, caught striking; and two "Chaffinches," one struck, at 11.30 P.M. ; 
wind moderate N.E., gloomy, rain-[Legs and wings of Willow Wren and Wheatear received]. October 11th, six during the forenoon; flew in a S.W. direction.

Innishtrahuli.-April 19th, one striking at midnight: 30th, two striking. May 6th, two at light. June 3rd, young Wheatears on the island; the birds breed here. August 19th, two striking at midnight: 30 th, two striking the glass at 2 A.M. September 3rd, one striking, not injured: $27 \mathrm{th}$, two at glass during night. October 1st, one on the island.

Blackrock, Mayo.-April 8th, two on rock.

Arran Island, S.-March 24th, one on rock. April 28th, one Stonechat killed striking at 3 A.M. ; clear. [Leg and wing of Wheatear received.]

Tearaght.-April 14th, several about the island. October 19th, one.

Skelligs.-May 16th, Wheatears breeding here.

SEDGE WARBler (Acrocephalus phragmitis, Bechst.).

Old Head, Kinsale.-August 4th-[Leg and wing received]; also on September 6th.

Coningbeg Light-ship.-May 14th, one on the ship.

Tuskar Rock.-May 3rd, "Chiffchaff" killed striking-[Sedge Warbler received in flesh]: 9th, Warblers all day on the rock; wind moderate S.E., overcast: 10 th, three all day : 13 th, Wheatears and Warblers on the rock all day. June 4th, one "Warbler" round the light all night. August 4th, one all night: 18th, several, with Wheatears; two killed: 27 th, several on rock: 28th, 29th, and 30th, Warblers and Stonechats on the rock every day; left for shore on the 30 th. September 7 th, one all day.

Arklow South Light-ship.-May 4th, three Sedge Warblers killed striking-[Received in flesh]-(see under Whinchat).

Rockabill.-May 4th, great rush of birds at night (see under Cuckoo)-[Leg and wing of Sedge Warbler received, killed striking]. July 25th, three Sedge Warblers rested and flew to land. August 19th, two Willow Warblers pitched on the rock.

Copeland (Mew) Island.-April 5th, about a dozen Sedge Warblers and Whitethroats killed striking, and many small birds observed about the lantern. May 3rd, birds about lantern (see under Cuckoo). [Two Sedge Warblers received in flesh.] 
Arran Island, S.-May 22nd, Hocks of strange birds going N.W. at 11 A.M. ; wind light S.W., misty; one killed striking [Sedge Warbler received in flesh.]

Grasshopper Warbler (Locustella navia, Bodd.).

Coppland (Mew) Island.-May 3rd, birds about lanteru (see under Cuckoo). [Grasshopper Warbler received in flesh.]

Whitethroat (Sylvia cinerea, Bechst.).

Old Head, Kinsale.-July 17 th, bird shot. [Leg and wing of Whitethroat received.]

Arklow South Light-ship.-May 4th, one killed striking[Received in flesh]-(see under Whinchat).

Rockabill.-May 4th, rush of birds during fog (see under Cuckoo-[Legs and wings of Whitethroat received]. September 5 th, numbers of birds, including Whitethroats, this week (see under Blackbird).

Copeland (Mew) Island.-April 5th, about one dozen Whitethroats and Sedge Warblers killed striking; a great number of small birds in rays all night; weather thick-[Leg and wing of Whitethroat received]. May 3rd, birds about light (see under Cuckoo): 7 th-[Whitethroat received in flesh]. September 4th-[Leg and wing of Whitethroat received].

Arran Island, S.-May 21st, flocks of "Thorn Linnets" going N.W. at 3 A.M. ; wind light S.W., misty; one killed. [Leg and wing of Whitethroat received.]

\section{"BlackCAP."}

Killybegs.-The "Blackcap" nests, and remains through the summer, and on till autumn. [Stonechat?-R. M. B.]

Arran Island, N.-April 15th, two "Blackcaps" about the station. [Stonechats?-R. M. B.]

\section{Willow Wren (Phylloscopues trochilus, Linn.).}

Arkiow Sonth Light-ship.-May 4th, small birds about the light-[Willow Wren received in flesh]-(see under Whinchat).

Rockabill.-April 21st, one "Woodpecker" all day about rock; wind strong W. September 5th, "very thick wenther during past few days, and a great many birds in consequence- 
Blackbirds, Thrushes, Larks, Willow Warblers, Woodpeckers, Whitethroats, and two Sivifts. We caught a fine Blackbirl with a white breast." ["Woodpeckers" are possibly "Sallypeckers," a name sometimes applied to Chiffchaffs and Willow Wrens.-R. M. B.] May 4 th, great rush of birds at night (see under Cuckoo)-[Leg and wing of Willow Wren received]. September 5th, numbers of birds, including Willow Warblers, this week (see under Blackbird).

Copeland (Mow) Island.-May 3rd, birds about light (see under Cuckoo); two Willow Wrens killed striking. [Received in flesh.] Maidens South.-August 19th, a small bird, unknown, caught striking at 11.30 P.M. ; and two Chaffinches, one struck; wind moderate N.E., gloomy, rain. [Legs and wings of Willow Wren and Wheatear received.]

Innishtrahull.-May 5th, "Chiffchaff" caught striking at midnight; wind light N.W. ; rain and fog. [Leg and wing of Willow Wren received.]

\section{Chiffchaff (Phylloscopus rufus, Bechst.).}

Tuskar Rock.-May 5th, two on rock at 4 A.M.; wind light S.E., overcast: $6 \mathrm{th}$, nine killed striking; wind light $\mathrm{N}$., fog: 9th, Chiffchaffs all day on the rock; wind light N., overcast: 15th, one. [Probably some of these were Sedge Warblers (see under this head).]

Lueifer Shools Light-ship.-April 8th, several small birds about the lantern. [Chiffchaff received in flesh.]

Blackwater Bank Light-ship.-April 7th, one killed striking. [Leg and wing received.]

Rockabill.-April 11th, one Chiffchaff killed striking. [Leg and wing received.]

Innishtrahuil.-March 28th, a "Chiffchaff" striking the glass. April 6th, two striking.

\section{Golden-Crested Wren (Regulus cristatus, Koch).}

Old Head, Kinsale.-September 26th and 27th, twelve struck lantern, one caught-[Received in flesh]; remained round the lamp both nights. October 1st, some at the light; two struck, but were not killed; cloudy.

Coningbeg Light-ship.-April 11th, one found dead-[Received 
in flesh]; wind light N.E. October 1st, one on ship during day, killed; wind N.E., clear.

Tuskar Rock.-August 14th, one at light. September 24th, one do.: 26th, one found dead on the rock at 4 P.M.; wind strong W.

Blackwater Bank Light-ship.-April 7th, four killed striking; wind light N.E.

Arklow North Light-ship.-September 26th, one killed; wind fresh S.W. October 20th, many land birds about the light; Wren [? Gold-Crest-R. M. B.] killed, and others fell overboard.

Kish Bank Light-ship.-October 30th, a very small bird caught about ship at 2 P.M. ; wind fresh W., clear-[Leg and wing Gold-Crest received]. November 13th, two small Wrens about the ship; wind light S., clear.

Rockabill.-November 15th, great rushes of birds, including Golden Wrens, during last fortnight (see under Sparrow): 26th, two Golden Wrens all day. December 14th, Gold-Crests flying round the light, tired; wind fresh W., fog.

Copeland (Mew) Isiand.--September 1st, one caught at lantern: 15th, one do.: 25th, six about light; wind N., clear. October 1st and 2nd, Gold-Crests about the light at midnight.

Maidens South.-September 5th, two at light, one killed; wind light N., fog: 21st, one at the lantern. October 1st, two at light at midnight: 4 th, one found dead : 16th, one at lantern. November 2nd, one at lantern.

Innishtrahuil.-September 12th, one caught at lantern at midnight; wind light W., clear. [Leg and wing received.]

Arran Island, S.-September 19th, one disabled-[Received in flesh]. October 26th, one on rock; wind N.E.

\section{WREN (Troglodytes parvulus, Koch).}

Tuskar Rock.-October 6th, two on rock: 14th, one. December 25 th, one all day.

Rockabill.-April 16th, one all day.

Copeland (Mero) Island.-July 29th, one. In winter and the early spring these little birds are plentiful. September 23rd, one. October 10th, about ten. November 25th, a few "Common Wrens" on the island now. December 12th, a Common Wren seen.

Maidens South-May 1st, two at lantern, flew N. August 
30th, one "Common Wren" on rock. September 4th, a Wren all day: 24th, a brown Wren on rock: 30 th, one do. at the lantern glass at midnight; wind light N.E., gloomy. October 12 th, one brown Wren on rock: $25 \mathrm{tb}$, a Wren at noon.

Innishtrahull-October 26th, two on island.

Rathlin O'Birne.-May 30th, two on island (first noticed since December).

Killybegs.-Wren nests, and remains through the summer, and on till autumn.

Blackrock, Mayo.-March 24th, one all day; strong gale S. October, three or four brown Wrens all the month about the rock. November 14 th, 19 th, and 20 th, several brown Wrens all day on the rock; gale S.E.: 21st and 24th, several. [Wren found dead, received in flesh; sent without date.]

Slyne Head.-Two Common Wrens are to be seen almost daily.

Arran Island, N.-April 30th, one Wren (first noticed for some time). May 5th, one.

Arran Island, S.-April 17th, one Wren struck the lantern at 1 A.M. ; wind S., cloudy.

Tearaght.-Common Wren seen here at all times; it nests on the island. [One killed later on, received in flesh.]

Skelligs.-Wrens breed here.

Great Titmouse (Parus major, Linn.).

Coningbey Light-ship. October 14th, one Great Tit caught at 1 P.M. ; wind moderate S., clear. [Leg and wing received.]

\section{"Tits."}

Rockabill.-July 29th, one Bluecap [? Blue Tit.-R. M. B.] on the rock at 3 P.M. ; wind moderate S.E.

\section{"Wagtails."}

Mine Head.-April 7th, three Grey Wagtails: 9th, one Yellow Wagtail.

Tuskar Rock.-September 2nd and 4th, Wagtail each day on rock; overcast. December 10 th, one; wind fresh N.W.

Copeland (Mew) Island.-September 23rd, one.

Maidens South.-February 14th, one Pied Wagtail on rock for two days; went N. April 10th, one Pied Wagtail during 
the forenoon; flew west. September 12th, one Pied Wagtail on the rock; flew west. October 3rd, a Grey Wagtail at noon. December 25th, one Pied Wagtail at 10.30 A.M.

Innishtrahull._May 9tb, five Pied Wagtails; rarely seen at this station; wind light E., rain.

Ruthlin O'Birne.-May 10th, one Wagtail; stayed to 14th.

Killybegs. - The Wagtail nests, and remains till autumn.

Blackrock, Mayo.-March 15th and 16th, one Grey Wagtail; wind fresh S.W.

Slyne Head, S.-October 10th, two Wagtails on the island.

Arran Island, N.-May 15th, one Wagtail at noon.

Skelligs.-March 17th, one Yellow Wagtail; stayed several days; wind light $\mathrm{E}$.

Titlark or Meadow-Pipit (Anthus pratensis, Linn.).

Fastnet.-March 11th, one all day.

Coningbeg Light-ship.- September 24th, two Larks going N.E. : 29th, two do.: 30th, two round ship. October 25th, flocks (see under Blackbird). November 15th, one.

Arklow South Light-ship.-April 6th and 10th, one.

Arklow North Light-ship.-April 6th, two: 11th, Larks, Stares, and Titlarks about the light; two Titlarks killed; gale N.E., misty, rain. October 2nd, 3rd, and 5th, many land birds about the light; seven Thrushes and three Titlarks killed; wind high, cloudy, with rain.

Kish Bank Light-ship.-October 9th, two going N.W. November 13 th, two on deck.

Rockabill.-April 8th, one all day: 11th, one killed striking. [Leg and wing received.]

South Rock Light-ship.-April 11th, one "Cuckoo's Nurse" flying about ship; killed striking at 11 P.M. ; wind moderate N.E., clear. [Leg and wing of Titlark received.]

Copeland (Nerv) Island.-November 25th, a few on island.

DIaidens South.-October 22nd, one killed striking-[Leg and wing received]: 31st, three all day. November 6th, 10th, and 11 th, one or two.

Innishtrahull.-June 3rd, Titlarks breed here.

Rathlin O'Birne.-April 5th, eight; they breed here, and remain all winter. [? Rock-Pipits.-R. M. B.] 
Blackrock, Mayo.-March, Titlarks always here; two species, light grey and dark-[Probably Meadow and Rock Pipits.R. M. B.] October and November, several.

Skelligs.-Titlarks breed here. [? Rock-Pipit.-R. M. B.]

Bull Rock.-Two noted.

Rock-PipIT (Anthus obscurus, Lath.).

Slyne Head, S.-Rock Tits breed here, and remain.

Tcaraght.- "The Rock-Pipit breeds on this island:" [October 20th, leg and wing of Rock-Pipit received, killed on rock.]

\section{SKYLARK (Alauda arvensis, Linn.).}

Tuskar Rock.-October 16th, a flock going N.W.: 26th, great rush of various sorts of birds between 8 P.M. and 4 A.M. [Leg and wing of Skylark, killed striking, received]. December 23rd, two all day: 29 th, one at light at 2 A.M.

Coningbeg Light-ship.-October 25th, flocks about light, 9 P.M. to midnight (see under Blackbird).

Blackwater Bank Light-ship.-March 3rd, two on deck.

Arklow South Light-ship.-January 26th, several at light; four killed. February 10th, several flocks going W.; snow and rain: 11th, one on deck: 23rd, Larks, Starlings, and Thrushes about the lantern. October 26th, Blackbirds, Thrushes, and Larks about light; wind fresh E., gloomy. November 16th, one on deck. [Skylark, pale in colour, received in flesh.] [Undated leg and wing received, with schedule dated November 18th.]

Arklow North Light-ship.-February 10th, flocks about ship in the afternoon; sleet and rain: 19th, Stares and Larks going N.W. at noon; wind light W., gloomy; four Larks killed: 22nd, Larks, Stares, and Thrushes about light; wind moderate N.; two Blackbirds killed. April 8th, Blackbirds, Larks, and Stares going N.W. in the early morning; wind fresh N.E.; one Lark caught: 11th, Larks, Stares, and Titlarks about light; gale N.E., misty, rain. September 26th, Larks, Thrushes, and Starlings about the light; wind fresh S.W., hazy, rain. October 15th, Skylarks and Starlings going N.W. at noon; wind fresh S.W.: 24th, 26th, and 27th, Larks, Starlings, and Thrushes about lantern; wind moderate E., cloudy; many killed. 
Kish Bank Light-ship.-November 12th, two about ship: 28th, several Thrushes and Skylarks about lantern; wind moderate S.W., hazy.

Rockabill.-September 5th, numbers of Larks and other birds this week (see under Blackbird).

South Rock Light-ship.-March 8th, two at 3 A.M. : 15th, five about ship at 6 A.M.: 19th, one: $23 \mathrm{rd}$ and $24 \mathrm{th}$, some; one killed: 28th, one at 3 A.M. September 19th and 24th, two killed striking. October 13th, four going N.W. November 10th, 11th, and 12th, Starlings, Stonechats, and Larks about light each night; wind S., gloomy: 27th, a flock going W. December 31st, three going N.W.

Copeland (Mew) Island.-October 2nd, some killed striking; strong breeze, misty: 18th, several killed; wind S.E., moderate gale: 19th, Thrushes and Skylarks about the light; fresh gale S.E. : 26th, Blackbirds, Larks, and Starlings about the light. November 3rd, Skylarks and Thrushes striking lantern; wind moderate S.W.: 13th, Skylarks at light; fog: 23rd, one do. December 1st, some small birds, apparently "Larks," flying W. in the forenoon: 22nd, from 12 to 1 A.M. several at light; gale S.E.

Maidens South.-January 2nd, a flock at lantern; one killed: 28th, Larks and Fieldfares at lantern. February 3rd, Thrushes and Skylarks at lantern; left at daybreak for the land; N. gale. March 1st, two Skylarks at lantern; one killed: 20th, numbers at lantern, three killed; wind strong N.E. : $27 \mathrm{th}$, three about rock: $28 \mathrm{th}$, two found dead. September 2nd, a number of Chaffinches and Larks at light from 9 P.M. to 11 P.M.: 26th, numbers of small birds at light; Skylark killed striking-[Leg and wing received]: 30th, several Skylarks at lantern; two killed-[Leg and wing of one received]. October 3rd, several flocks passing at intervals during day, and a number of Thrushes, Blackbirds, and Larks at lantern at night; two Blackbirds and ten Larks killed striking; wind moderate E. [Legs and wings of three Larks received]: 5th, flocks of small birds like Skylarks passing W. all the forenoon; wind light N., cloudy: 14th, numbers of Skylarks and Redwings about light all night; wind light S.W., cloudy: 16th, several Skylarks round the light-[Leg and wing received]: 17th, flocks of Larks and Redwings passing W. all day; wind light S.E., gloomy: 19th, several Redwings and Skylarks at 
light all night; gale S.E.: 22nd, Skylarks and Redwings at lantern; Skylark killed; wind strong N.E.: 23rd, flocks of Skylarks passing W. at intervals all day; flying high; wind N.E., cloudy; one found dead: 28th, Linnets and Larks all night at light; wind light S.W.; a lark killed-[Leg and wing received]. November 4th, two Skylarks at noon: 11th, four at light at 3 A.M.; a large flock of Starlings and Skylarks rested for an hour on the rock and flew W.: 12th, a Skylark on the rock: 15th, six going S.W.: 20th, two at light; one killed. December 1st, a flock of Larks and Redwings going W. at 10.30 A.M.: 2nd, a flock of Larks and Linnets going N.W. at 9 A.M. ; gale S. : 5th, flocks of Larks and Linnets going S.E. at intervals during day; wind moderate S.: 23rd, two Skylarks flying W.

Maidens North.-April 4th, some killed striking; E. gale.

Innishtrahull.-January 23rd, one struck lantern. February 24th, two do. at 2 A.M.; wind light W.S.W. March 28th, four Skylarks and a Chiffchaff striking; wind moderate S.W. April 6th, four Skylarks striking; wind strong E. May 6th, one at the light; calm and fog. September 23rd, one striking glass; wind light N., clear. December 3rd, three seen.

Rathlin O'Birne.-March 19th, seven on island.

Killybegs.-Skylarks nest and remain until autumn. May 12th, one at lantern.

Broadhaven.-Skylarks frequently observed.

Blackrock, Mayo.-April 6th, one about rock. October, one on rock all the month. November 15 th, one on rock.

Slyne Head, S.-August 28th, one found dead. [Leg and wing received.]

Arran Island, S.-April 17th, one struck lantern: 26th, Skylarks and Stonechats round light all night.

Tearaght.-November 11th, one Lark struck the light. December 8th, one on rock.

SNow Bunring (Plectrophenax nivalis, Linn.).

Old Head, Kinsale.-September 7th, two close to station; gale N.W.: 19th, one shot-[Received in flesh]. October 15th, eight. November 4 th, four.

Coningbeg Light-ship.—October 11th, one "Chaffinch" caught 
on deck at 10 A.M. ; wind light W.N.W., clear. [Leg and wing of Snow Bunting received.]

Innishtrahull.-January 23rd, twenty-seven throughout the day, male and female birds. May 1st, two on island, one nearly all white. October 4th, nine; gale N., squally; they have just arrived. December 10th, a large number on the island; N.W. gale, squally.

Aranmore.-September 21st, one near station: strong N.W. gale. October 9th, one; strong S.W. gale. November 17th, six; wind moderate S. December, Snow Buntings, Linnets, and Bernacle Geese are the only birds observed this month.

Killybegs.-November 28th and 29th, eighteen; the birds rested; wind moderate N.W.

Blackrock, Mayo.-March 11th, twelve here since last month. April 27th, one about the rock; wind strong S.W. October, from half a dozen to a dozen on the rock nearly the whole month. November 21st, one all day; S.E. gale.

Slyne Head, S.-March 27th, " a small bird shot; two of the keepers have been nearly four years at this station, and never saw one like it. I suppose it to be a Snow Bunting "- - [Snow Bunting received in flesh]. April 25th, five all day; wind fresh N. ; three remained a week. May 17th, one killed striking at 5 A.M. [Leg and wing received]; wind light S.E., clear. November 28th, ten on island in the morning (first seen this season); wind light N.W., hail: 29th, eight. December 9th, six at 8 A.M. landed on island; W. gale.

Arran Island, N.-A pril 5th, twelve about island : 18th, four : 28th, twenty seen; wind light S.W. May 3rd, six about station; wind moderate S.E.

Tearaght.-Auril 23rd, one pair on rock; W. gale; one shot -[Received in flesh]. May 30th, one shot-[Received in Hesh]. September 20th, one shot; wind N.W. strong, squally[Received in flesh]. "I can find no account of its being seen in this locality at such an early date before." October 4th, two: 29 th, one: 31 st, one all day on the rock.

\section{Bunting (Emberiza miliaria, Linn.).}

Innishtrahull.-July 1st, a small bird shot on the island at 4 P.M. ; wind moderate W.N.W., hazy; two of these birds were here since spring: [Bunting received in flesh.] 
YelLow Bunting (Emberiza citrinella, Linn.).

Fastnet.-May 6th, one on rock.

South Rock Lright-ship.-September 4th, one about ship.

Broadhaven.-Frequently observed.

\section{Chaffinch (Fringilla ccelebs, Linn.).}

Old Head, Kinsale.-October 21st, a large rush of Chaffinches, Thrushes, Blackbirds, Starlings, and Redwings; night heavy, thunder and lightning.

Mine Head.-May 12th, one going S.E.

Dungarvan.-October 26th, two killed striking.

Coningbeg Light-ship.-March 10th and 11th, one going N.E. each day: 13th, one on ship at 6 P.M. : 15th, one going N.E.: 16th, one on ship. April 18th, one about ship at 5 A.r. October 6th, one going N.E.: 21st, several about light from 10 P.M. to midnight; wind moderate N.E. November 17th, two on ship and several about light; wind S.E., haze: 18th, one dead on ship; wind light $\mathrm{S}$.

Tuskar.-October 26th, great rush of various sorts of birds between 8 P.M. and 4 A.M. [ $[\mathrm{Leg}$ and wing of Chaffinch, killed striking, received]. November 10th, one all day. December 1st, one at light: 10th, one on rock.

Blackwater Bank Light-ship.-March 15th, five on deck at 8 A.M. ; went to N.W.: 1Sth, twelve went N.W. at 10 A.I. ; wind light S.W. April 2nd, one round ship at noon: 5th, several small birds, like Chaffinches, flying round the lantern.

Arklow South Light-ship.-April 5th, two flocks flying low to N.E.; wind light N.E. October 18th, several about ship in the afternoon; wind strong S.E., rain: 21st, one on deck.

Arklow North Light-ship.-February 27th, four on deck at noon; wind N., snow and sleet. April 13th, four on deck at noon; wind strong E. October 10th, a flock at noon; wind light W.: 22nd, many land birds; four Finches caught on deck; wind fresh N.E.

Kish Bank Light-ship.-September 7th, one rested on deck at 2 P.I. ; wind light S.E., clear: 24th, two on deck; wind strong N.E. October 17th, three about ship: 19th, two on deck. November 13th, two about ship in the morning; wind light S., clear : 23rd, one on ship. 
Rockabill.-November 15th, great rushes of birds, including Chaffinches, during last fortnight (see under Sparrow): 27th, 29 th, and 30th, twelve about rock all day; wind N.W., strong; Chaffinches are more numerous this season than last. December 6 th, 7 th, and 8th, many all day about the rock: 14 th, Chaffinches at light; wind fresh W., fog: 15th, 16th, and 17th, some all day on the rock; wind moderate to strong W., gloomy.

Copeland (Mew) Island.-November 2nd, one on island: 13th, some: 25 th, the few which were on the island have left. December 14th, a few about to-day : 16th, one about the island to-day.

Maidens South.-August 28th and 29th, two about rock. September 2nd, a number, with Larks, at light; gloomy, wind light S.E. : 3rd, two : 4th, a number, with Larks, on rock all day : 9 th, two during the night: 17 th, two on rock: 18 th, a Stonechat and a Chaffinch all day; the Chaffinch killed striking; squally: 29th, two flew S.W.

Blackrock, Mayo.--October, from thirty to fifty about during the month; left about 27th: 23rd, two caught at lantern. November 14th, several all day: 15th, several: 17th, two: 19 th and 20th, two all day.

Slyne Head, S.-October 12th, thirteen on island.

Tearaght.-September 25th, one shot. October 15th, two shot, out of flock on the island-[Received in flesh]: 20th, several at light.

Brambling (Fringilla montifringilla, Linn.).

Arklow South Light-ship.-December 28th, one "Flycatcher" found dead on deck at 11 P.M.; wind light S.E., gloomy. [Brambling received in flesh.]

Tearaght.-December 14th, three "Mountain Finches" on the rock; wind fresh S.W.

Sparrow (Passer domesticus, Linn.).

Rockabill.-November 15th, "great rushes of birds visiting and passing over the station the last ten or twelve days; a number killed striking; Chaffinches, Green Linnets, Song Thrushes, Redwings, Golden Wrens, Sparrows (unusual visitors), Starlings, Blackbirds, Grey Linnets, and Curlews," 
Copeland (Mew) Island.-December 4th, a Sparrow caught in the lighthouse kitchen-[Dark-coloured Sparrow received in flesh]: 6 th, several about the dwellings.

Killybegs.-Sparrows nest, and remain until autumn.

Broadhaven.-Sparrows numerous here.

Slyne Head, S.-May 27th, one on island. June 1st, one on rock; killed by dog. [Leg and wing received.]

GREENFINCH (Ligurinus chloris, Linn.).

Arklow South Light-ship.-November 17th, one about ship.

Rockabill.-November 15th, great rushes of birds and some Green Linnets (see full note under Sparrow): 29th and 30th, many all day; they have been numerous since November 1st, more so than last year. December 8th, some all day: 14th, some about light (see under Linnet).

Copeland (Merv) Island.-November 28th, one struck kitchen window in the forenoon; wind strong N.W. December 12th, some: $22 \mathrm{nd}$, a large flock this morning, also two Grey Linnets.

Maidens South.-October 21st, three going N.W. November 6th, one: 11th, three. December 14th, five on rock.

Tearaght.-January 13th, one. October 2nd, small bird forwarded-[Greenfinch (young) received in flesh]: 19th, two Green Linnets at 2.30 P.M. [Leg and wing received.]

GoLdfinch (Carduelis elegans, Steph.).

Fastnet.- "I have no recollection of ever seeing a Goldfinch striking lantern" (see under Bullfinch).

Old Head, Kinsale.-October 15th, thirty seen close to the station-[Wing Goldfinch received, marked "found October 16th "]: 29th, I saw more birds here this month than I did for the past twelve; none of them were rare. Goldfinches were very plentiful for a few days.

Mine Head.-March 17th, two going N.W. at 11 A.M.; clear: 31st, two going W. at 2 P.M. ; clear. April 3rd, two going N.

\section{SISKIN (Carduelis spinus, Linn.).}

Tuskar:-October 26th, great rush of birds between 8 P.M. and 4 A.M., various sorts killed striking. [Siskin received in flesh.] 
Tearaght.-April 30th, a pair of Siskins on the island at 11 A.M. ; wind light S.E.

\section{Mealy Redpole (Linota linaria, Linn.).}

Tearaght.-September 19th, a small bird shot at 4 P.II. ; fresh breeze N.W. [Mealy Redpole received in flesh.]

\section{"Linnets."}

Fastnet.- "I have often seen the common Grey Linnet and Twite strike, but have no recollection of ever seeing any killed by so doing.-GEORGE DUNLEavy."

Spit Bank:-December 26th, a flock of Grey Linnets going S.W.

Coningbeg Light-ship.-March 15th, several noticed going in different directions at 11 A.M. October 20th, flocks of Linnets going N. 9 A.M. to 10 A.M.; wind moderate N.E., rain. November 23rd, several going N.E.

Lucifer Shoals Light-ship.-March 16th, one Grey Linnet going towards shore.

Arklow South Light-ship.-February 10th, several flocks going W.; snow. April 5th, one Grey Linnet about the ship in the morning; haze.

Artilow North Light-ship.-February 10th, flocks about ship; sleet and snow. December 21st, one Grey Linnet about ship.

Rockabill.-November 15th, great rush of birds, including Grey Linnets, during last fortnight (see under Sparrow). December 4th, large flock of Grey Linnets going S.W.: 14th, Grey and Green Linnets flying round the light; wind fresh W., fog: 15th, 16th, and 17th, Linnets all day on the rock.

South Rock Light-ship.-October 13th, a large flock going N.W. at noon. December 10th, a flock of Grey Linnets going W. at 5 P.M.; wind strong N.W.; birds tired: 20th, a flock going W. at 8 A.M.

- Copeiand (Mcw) Island.-July 1st and 4th, a flock. November 29 th, one. December 26th, a flock of Limnets going towards the mainland froin the Scottish coast: 22nd, two Grey Linnets.

Maidens South.-October 28th, Linnets and Larks about the light; wind light S.W. December 2nd, a flock of Larks and Linnets going N.W. at 9 A.M. : 5th, flocks of Larks and Linnets 
going S.E. at intervals during the day; S.W. gale: 12th, three Grey Linnets on rock.

Aranmore.-September 21st, large flocks of Linnets all day near the station: 23rd, flocks all day. December, Snow Buntings, Linnets, and Bernacle Geese, the only birds observed this month.

Slyne Head, S.- January 22nd, a flock about island. Linnets on the island daily during July. October 20 th and 23rd, Blackbirds, Thrushes, and Linnets all day.

Arran Island, N.-March 9th, one Grey Linnet for some time on island. April 22nd, ten Grey Linnets about station. May 2nd, two Linnets going E. : 19th, six Linnets about island.

Tcaraght.-January, Linnets all the month. September 26th, numbers of Linnets all day; wind moderate N.W.

\section{TwITE (Linota flavirostris, Linn.).}

Fustnet.- "I have often seen the common Grey Linnet and Twite strike, but have no recollection of ever seeing any killed by so doing."

Tuskar. - September 14th, several going W. at noon. October 8th, two on rock.

Copeland (Mew) Island.-August 29th, a few. September 23rd, twenty or thirty. October 10 th, about fifty. November 25th, the Twites have all left the island: 29th, a large flock came from sea and passed towards shore; wind fresh N.W., clear. December 22nd, a flock on island this morning.

Imishtrahull.-August 31st and September 1st, a Twite on island. October 14th, numbers do.; wind light S., clear.

Tearaght.-A pair of Twites are supposed to have nested here this season, as they were observed building. September 1st, about twenty Twites all day about the rock; wind light $\mathrm{E}$., gloomy-[Leg and wing received] : 22nd, five on rock: 26th, numbers all day.

\section{BUllfinch (Pyrrhula europoea, Vieill).}

Fustnet.-April 9th, "I have never seen a Bullfinch to my knowledge. I have no recollection of ever seeing a Goldfinch striking lantern, but I often have seen the common Grey Linnet and Twite strike, but have no recollection of ever seeing any killed by so doing.--George DùnLeavy." 
Rockabill.-April 11th, male and female Bullfinch all day on the rock; rain, wind fresh N.E.

Innishtrahull.-December 3rd, one Bullfinch in the lighthouse garden; wind fresh S., clear. Very rare, the only one noticed during the present keeper's tenure.

\section{StaRLiNg (Sturnus vulgaris, Linn.).}

Fastnet.-February 25th, one at 11 P.M.

Old Head, Kinsale.-October 21st, a large rush of Starlings, Thrushes, Blackbirds, Chaffinches, and Redwings; night heavy thunder and lightning.

Mine Head.-March 13th, two flocks going E.

Coningbey Light-ship.-February 25th, 26th, and 27th, about ship at night; wind E., sky overcast. March 6 th and 7 th, two about the light: 15th, one on ship. November 11 th and 12th, Starlings and Blackbirds about light; wind S.E., gloomy: 13th, several about light.

Tuskar.-May 4th, two killed striking. October 1st, three going N.: 3rd, ten at light: 5 th, five at light: 10 th, some going W. at noon: 26th, great rush of birds at night, various sorts killed striking between 8 P.M. and 4 A.M. [Les and wing of Starling received]. November 6th, a flock going W.: 12th and 21st, three at light: $22 \mathrm{nd}$, five do. December 1st, four at light: 4 th, a flock going W.: 8 th, two all day: 15 th, sixteen on rock: $28 \mathrm{th}$, three do.: $29 \mathrm{th}$, two at light.

Lucifer Shoals Light-ship.-March 15th, two going W.

Blackwater Bank Light-ship.-March 1st, Starlings, Blackbirds, and Thrushes killed striking; snow : 15th, three on deck in the morning, went N.W.: 28th, two killed striking.

Arklow South light-ship.-February 10th, several flocks of Starlings going W.; snow and rain : 22nd, several at light: $23 \mathrm{rd}$, some killed striking-[Leg and wing received]. October $12 \mathrm{th}$, several flocks flying low to N.W.: $25 \mathrm{th}$, Stares and Thrushes at lantern; some killed, fell overboard; wind light E. : 26th, Blackbirds, Thrushes, and Starlings about the lantern; some killed, fell overboard; wind fresh E., gloomy: 2Sth, Thrushes and Starlings about the lantern; wind fresh N.E. November 11th, 13th, 14th, 17th, and 1Sth, Starlings about the lantern; wind light N.E. and S.W., hazy and overeast. December 14th, 
one ou deck: 27th, some going N.W. in daytime, and about light; wind S.E., gloomy.

Arklow North Light-ship.-February 10th, flocks about ship: 11th, flocks of Starlings and Thrushes about ship; eight killed; some flew N.W.; N.E. gale: 19th, Starlings and Larks going N.W.; wind light W., gloomy : 22nd, Starlings, Larks, Thrushes, and Blackbirds about light; sleet and rain. April 8th, Starlings, Blackbirds, and Larks going N.W.; wind N.E., gloomy: 11th, Starlings, Larks, and Titlarks about light; N.E. gale, misty, rain: 24th, Starlings and Larks about the light; one Stare killed. September 25th and 26th, Starlings, Larks, and Thrushes about light; wind fresh S.W., hazy, rain. October 13th, some going N.W.: 15th, de., with Larks: 18th, three killed striking: 19 th, some going N.W. at 8 A.M. : 24th, 26th, and 27th, Starlings, Larks, and Thrushes about the lantern; wind moderate E., cloudy.

Kish Bank Light-ship.-October 19th, two Starlings on deck: 20th, five Starlings round ship: 27th, many going N.W. at 11 A.M. ; N.E. gale. November 11th, five about ship: 13th, some about light: 24 th, two on ship.

Rockabill.-January 11th, many round light; twelve killed; wind fresh, cloudy. July 18 th, one killed striking. These birds are always about in foggy weather. November, great rushes of birds (see under Sparrow): 17th and 18th, several going W. during these days; wind S.E., gloomy. December 10th, some going W.: 14th, Starling at light; wind fresh W., fog.

South Rock Light-ship. - March 15th, four about ship. October 15th, twenty going N.W. November 10th, 11th, and 12th, Starlings, Stonechats, and Larks about the light each night; wind light S., gloomy.

Copcland (Mezv) Island.-July 1st, Starlings always on the island, the young observed to-day. October 25th, Starlings and Blackbirds striking; strong breeze W., rain: 26th, some about light. November 12th, Starlings striking: 13th, a rush of birds this night; Blackbirds, Thrushes, Lapwings, and Starlings round the light; fog: 17 th, 18 th, 19 th, and 20 th, Starlings about lantern ench night; Fieldfares, Thrushes, and Starlings flying through the rays. December $28 t h$, Thrushes and Starlings about lantern.

Muidens South.-January 9th, Starlings and Fieldfares about linteru. February 12th, Blackbirds, Fieldfares, and Starlings 
striking throughout the night; none killed; wind moderate W.: 18th, Fieldfares and Starlings about lantern; a Starling killed; wind moderate W. March $27 \mathrm{th}$, four striking at midnight. October 2nd, a large number of Thrushes and Starlings round lantern from 9 P.M. to midnight; wind moderate S., clear: 24th, flocks of small birds like Thrushes and Starlings passing W. all day; wind light N.E. November 11th, a large flock of Starlings and Skylarks rested for an hour on the rock and flew to the W.; wind light W.: 13th, a number of Starlings and small birds round the lantern from 6.30 P.M. to midnight; two Starlings killed-[Leg and wing of one received]: 14th, flocks of Starlings, Thrushes, Blackbirds, and other small birds passing S.W. at 10 A.M. ; wind light S.W.: 19th, two on rock.

Maidens North.-April 4th, a small flock; some killed striking; E. gale.

Innishtrahull.-October 20th, two about light; E. gale.

Rathlin O'Birne.-January 23rd, two; one struck lantern. February 9th, flocks on island; N. gale, snow: and from 10th to 13 th, while the snow lasted.

Killybegs.-April 20th, one killed striking.

Blackrock, Mayo.-March 21st, one all day; N.E. gale. October 27th, about forty going E. at 7 A.M. ; wind moderate N.E. (cloudy to rain): 29 th, thirty about rock all day. Novernber 10th, a flock all day; about forty: 14th, twenty to thirty Starlings went E. at 4 P.M. ; misty: 15th, thirty all day: 16th, fifty about rock: 19 th and 20th, twelve; S.E. gale: 21st, ten: 24th, eighty all day about the rock; S. gale.

Slyne Head, S.-May 6th, one. October 25th, flocks at 3 P.M. ; wind moderate S.E. November 1st, flocks on island all day; storm from W.

Arran Island, S.-September 19th, Starling disabled striking. [Leg and wing received.]

Tearaght.-January, flocks all the month on island. October 19th, two young Starlings on island-[Leg and wing of one found killed received]: 20th, three. November 5th, flocks going S.; wind fresh N.W. December 4th, flocks all day about rock.

CHovgh (Pyrrhocorax graculus, Linn.).

Fastnct.-April 9th, Jackdaws and Choughs breed near shore 
dwellings. Choughs are very numerous on north side of Crookhaven Harbour.

IIne Head.-January 30th, two. April 25th, four going N.W. May 4 th, five going E. : 17th, one going N.

Aranmore.-Choughs always about this station.

Blackrock, Mayo.-November 19th and 20th, two on rock all day; S.E. gale (Crows with red legs).

Slyne Head, S.-October 24th, five (first this season) flying S.E.

Tearaght.-April 18th, two and some Hooded Crows all day about the rock. The Chough breeds on the island. July 31st, five about rock. September 14th, four all day: 22nd, two: 26 th, two.

Skelligs.-January, two throughout the month; breed here, and also on Dursey Island.

Bull Rock:-Choughs come on rock during winter, but are on Dursey Island all the year round.

\section{RAVEN (Corvus corax, Linn.).}

Fastnet.-March 27th, two on rock.

Mine Head.-April 24th, two going S.E. May 16th and 19th, two.

Dunvee Head.-January 23rd and 25th, two.

Aranmore.-Ravens always about.

Broadhaven.-Ravens frequently observed.

Tecrecight.-February 13th, three all day: 24th, four about rock. July 6th, one. September 15th, six Ravens all day: 17 th and 18 th, two.

Slielligs.-April 11th, ten all day on the rock; wind light S.E. : two on the 29th: and two on May 16 th.

Bull Rock.-August 8th, one, about three weeks since.

\section{Hooded Crow (Corvus cornix, Linn.).}

Fustuet.-April 20th, two were seen every day since the 12 th. Rockabill.-February 16th, one on rock.

Innishtrahull.-April 7th, nest found in the cliff; six eggs. June 7 th, a young one seen.

Rathlin O'Birne.-May 31st, four "Grey Crows." (None of these birds have built here since 1886.) 
Blackrock, Mayo.-April 4th, two "Grey-backed Ravens" about rock; gale N.W. : 28th, two do. during the day.

Slyne Head, S.-April 15th, one Hooded Crow.

Tearaght.-April 18th, two Choughs and some Hooded Crows on rock. Hooded Crows breed on the island. October 2nd, six : 17th, eight on island.

Skelligs.-May 16th, four all day.

Rook (Corvus frugilegus, Linn.).

Tuskar.-July 9th, one going W. November 24 th, two going towards land.

Blackwater Bank Light-ship.-April 6th, two "Crows" going N.W.

Arklow South Light-ship.-March 13th, a flock going E.; N.W. gale.

Kish Bank Light-ship.-October 20th, four going N.

Rockabill.-February 28th, several "Crows" going S.W.; birds seemed tired, and rested for a while; wind E., showery. April 15th, two Rooks going S.W.: 17th, one going N.: 22nd, five going W. July 16th, four "Crows" going W. December 13th, five "Crows" going W.: 14th, very large number of "Crows" going S.W. at 11 A.M.; wind S., cloudy; appeared very tired, rested for some time on the rock.

South Rock Light-ship.-April 15th, eight "Crows" going N.E. (these birds are very seldom seen): 20th, two "Crows" going N.W., seemed very tired. December 19th, seven "Crows" going N.W.

Copeland (Mew) Island.-June 21st, a few always about the dwellings. October 14th, a number of "Crows" about island. November 5th, one dozen "Crows" coming from the direction of the Scottish coast, and going towards the shore: 29th, several "Crows" on island.

Maidens South.-May 14th, four going E.

Spit Bank:-December 21st, ten Rooks going S.W.: 22nd, twenty do. : 26th, forty going S.W. at noon.

Ininishtrahull.-June 21st, one on island; a rare visitor. July 29th, one "Carrion Crow" shot. [Leg and wing of Rook received.]

Rathlin O'Birnc.-February 10th to 13th, flocks of Rooks, with Starlings and Thrushes, on the island during the snow. 
June 27th, eighteen Rooks: 30 th, fifty came from the S.E. July 30 th, twenty on island.

Broadhaven_- "Crows" often seen.

Slyne Head, S.-April 13th, three "Common Crows" going N.W.: 14th, seven going W. October 10th, three on island: 12th, eleven "Crows" going W.: 21st, large flocks of "Crous" going $W$.; clear, wind fresh N.E.; some rested on the dome of the lantern: 22nd, Thrushes, Crows, and Linnets all day on the rock; wind moderate N.E., clear: $23 \mathrm{rd}$, do.

Arran Island, N.-April 8th, two. May 4th, do.

\section{JACKDAW (Corvus monedula, Linn.).}

Spit Banl:-December 28th, "numerous about Queenstown." Rathlin O'Birne.-March 30th, five came from shore, and remained till April 2nd.

\section{Magpie (Pica rustica, Scop.).}

Fustnet.-April 9th, "I have never seen Magpies at any distance from shore in numbers.-GEo. Dunleavy."

Mine Head.-February 4th, two seen. March 11th, 18th, and 28th, one or two seen.

Rochabill.-January 7th, two Magpies arrived on the "Bill," and made several attempts to reach the mainland, but were driven back by strong wind from W., and died after four days.

Copeland (Mcw) Island.-December 16th, one on island.

Innishtrahull.- "The Magpie never visits this island, though they are on shore at Malin Head."

\section{SWALLOW (Hirundo rustica, Linn.).}

Fustnet.-May 4th, two (first this year); left for the shore when the fog lifted. May 23rd, one about rock.

Mine Head.-May 8th, four going N.E.

Coningbeg Light-ship.-May 5th, a flock going N.: 6th, do.: $13 \mathrm{th}, 14 \mathrm{th}, 15 \mathrm{th}, 19 \mathrm{th}, 21 \mathrm{st}$, and $24 \mathrm{th}$, one to four seen each day. June 2nd, four. September 13th, four going N.E.

Tuskar.-May 5th, five on rock at 4 A.M.; wind light S.E.: Sth, Swallows going towards shore in the morning; two killed striking in the afternoon; fog: 9 th, one found dead: 12th, 
some about all day: 18th, two: 22nd, one. June 3rd, 11th, and 13th, one each day: 16th, three going towards land at sunrise: 20 th, two going N.W. July 4 th, four round the rock at noon: 5th, two flying towards shore. December 7 th, one on the rock at 8 A.M. ; wind strong N.-J. M. LEARY.

Lucifer Shoals Light-ship.-April 7th, two.

Coningbeg Light-ship.-September 24th, two on ship. October 1st, two going N.E. : 2nd, one on ship.

Arklow South Light-ship.-May 6th and 7th, Swallows flying low to the N.W.; calm; fog and haze both days: 13th, two flying N.W.: 18th, Swallows flying singly N.W., low, in the morning; wind light. June 29th, two.

Arklow North Light-ship.-May 4th, three going N.W. at 1 P.M. : 5 th and 6th, Swallows all day going N.E.; wind light. September 2Sth, a flock going N.W. at noon; wind fresh N.W. October 31st, some caught on deck; wind moderate-W.

Rockabill.-April 22nd, one going W. at 11 A.Mr; the first this year.

South Roch Light-ship.-April 25th, one rested on the ship at 4.40 A.II. ; flew N.W. May 9 th, forty going N.W. at 10.30 A.Ir.; wind light S.S.E.; fog and rain: 14th, one. June 3rd, one. July 20th, two going E.

Copeland (Mew) Island.-May 4th, a few noticed to-day. July 10th, young Swallow found dead.

Maidens North.-May 2nd, a great number of Swallows going N.W. at noon; gale S.

Maidens South.-April 22nd, two at noon flying round the rock; first this year ; wind light N., bright and clear. May 7th. Sth, 9th, 13th, and 14th, two Swallows daily. June, Swallows were the only land birds observed this month. August 28th, one rested, and flew $\mathrm{S}$.

Aranmore.-May 6th, one Swallow; first seen this year.

Rathlin O'Birne.-April 21st, ten about island; wind light S.W.; only stayed a few hours.

Slyne Head, S.-April 29th, one; wind light S.E.; first noticed this year. May 2 nd, six going W. at 4 P.x. ; wind S., rain: 3rd and 12th, one. June 5th and 6th, Swallows about.

Tecreaght.-May 3rd, one at 4 P.Mr.; wind light S. July 30 th, one. 


\section{House-Martin (Chelidon urbica, Linn.).}

Old Head, Kinsale.-May 1st, several.

Lucifer Shoals Light-ship.-May 15th, several about the light, one fell on deck; calm.

Rockabill.-May 4th, great rush of birds during fog (see under Cuckoo)-[Leg and wing of House-Martin received]; killed striking.

Innishtrahull.-July 26th, one Martin about the lighthouse at noon; gale $\mathrm{N}$., clear (the only one noticed since the light-keeper joined this station in 1885). August 8th, one. September 10 th, one.

Blackrock, Mayo.-May 3rd, one at 11 A.M.; wind strong S.E.: 25 th, one caught in dwelling.

Tearaght.-October 24th, four about on rock.

SANd-MarTin (Cotile riparia, Linn.).

Blackwater Bank Light-ship.-April 19th, several small birds about the lantern; one killed. [Leg and wing of Sand-Martin received.]

\section{SwIFT (Cypselus apus, Linn.).}

Fastnet.-June 9th, two about shore dwellings: 20th, six. July 27 th, one: 30 th, three: 31 st, five at 4 A.M.; wind moderate S.W., misty; four observed sleeping on rock, and one disabled striking-[Received in flesh]. I do not recollect seeing so many since I came here as this season. August 3rd, several Swifts flying in the rays of the light at 2 A.M.; gale S.W., rain: 19th, one about rock.

Wicklow Head.-August 7th, "A bird sent, nobody about here seems to know what kind it is." [Swift received in flesh.] Innishtrahull.-May 6th, two Swifts about the station at 5 P.M.; calm. June 7th, one at noon; wind N.W., clear: 10th, one: 17 th, two.

Aranmore.-May 10th, one Swift.

Broadhaven.-August 2nd, two Swifts.

Tearaght-May 1st, two going N.

Cuckoo (Cuculus canorus, Linn.).

Old Head, Kinscle.-May 3rd, one ; seemed very tired ; wind strong S., fog. 
Arklow South Light-ship.-May 6th, two round the ship at 6 A.M. ; wind light S.E.

Rockabill.-May 5th, one killed striking at 2.30 A.M. during a dense fog-[Received in flesh]; several Whitethroats were killed the same night. "The fog commenced at 11 P.M., and in about half an hour the lantern was nearly covered with birds-a great number of them must have been killed. We picked up several on the rock in morning. Next day, on the rock, I saw two Spotted Corn-Crakes, one Redstart, several Whinchats, Reed and Willow Warblers, one Grey Plover, one Curlew, and other small birds which I was unable to identify. From this sudden rush of birds immediately after the weather got thick, I would infer that they are always migrating at this season and in autumn, but keep far from the light in clear weather. On the night mentioned, it would be impossible to distinguish the light at more than a mile from the station, the weather being so thick.-JoHN Hamilton."

Copeland (Mew) Island.-May 3rd, Cuckoo killed against glass-[Received in flesh]; small birds also about lantern during night; some killed striking; weather thick-[Grasshopper Warbler, two Sedge Warblers, Whitethroat, and two Willow Wrens received in flesh]: 4th, Cuckoo heard on Copeland Island to-day; shows that a number arrived last night.

Innishtrahull.-May 10th, one heard at 1 P.Mr.; wind strong S.E., clear. First heard for the last three years.

Arran Island, N.-May 7th, Cuckoo first heard.

Arran Island, S.-April 28th, Cuckoos frequently on island from this date.

Rock Dove (Columba livia, Gmel.).

Copeland (Mew) Island.-August 27th, a Rock Pigeon shot. [Leg and wing of Rock Dove received.]

\section{Turtle Dove (Turtur communis, Selby).}

Fastnct.-September 5th, "leg and wing of a small Dove sent." "[Leg and wing of Turtle Dove received.]

Old Head, Kinsale.-August 19th, one shot; gale N., rain. [Leg and wing received.]

Tearaght.-May 25th, one Turtle Dove picked up dead among the rocks. [Leg, wing, and tail received.] 


\section{Pigeons.}

Mine Head.-March 10th, three Pigeons going S.W. April 1st, thirteen going S.W.

Coningbeg Light-ship.-September 13th, one Pigeon on ship; caught; apparently tame.

Tuskar.-June 7th, one Wood Pigeon going to land; wind strong N.E., clear.

Arklow South Light-ship.-August 5th, two on ship. October 12th, one, with silver ring round right leg.

Rockabill.-May 2nd, one very large white Pigeon (neck inclined to yellow) on rock, and flew W.; wind S.E., fresh. July 7th, two Carrier Pigeons on rock. August 4th, one darkbrown Pigeon rested and flew towards shore. October 17th, the gas-maker caught a Carrier Pigeon here, with a brass ring, marked " 29 " on each leg.

Copeland (Mew) Island.-November 19th, one Pigeon rested on gas-house: 23rd, one going towards shore; came from the direction of the Scottish coast : 24th, six "Wild Pigeons."

Maidens North.-October 9th, a flock going S.

IIcidens South.-August 16th, two Rock Pigeons all day.

Innishtrahull.-July 3rd, 4th, and 6th, two Rock Pigeons each day; hazy: 26th, two young Rock Pigeons.

Dunree Head.-January 7th, six Pigeons going S.E.

Aranmore.-Rock Pigeons always about.

Rathlin O'Birne.-July 10th, two, like Ringdoves.

Broadhaven.-Rock Doves often observed.

Slyne Head, S.-April 30th, four Pigeons going S.E. May 9th, one Woodguest going W.

Arran Island, N.-May 12th, 13th, 14th, and 20th, several Pigeons.

Arran Island, S.-May 19th, one Rock Pigeon.

Tecraght.-February 8th, four Rock Pigeons. Rock Pigeons breed here; there are generally three or four pairs of them. December 8th and 14th, eight all day.

Slelligs.-June 3rd, two Rock Pigeons all day.

Corn-Crake (Crex pratensis, Bechst.).

Tuskar.-May 5th, one on rock at 4 A.Mr; wind light S.E.: 14th, one at noon; wind light S.W. 
Rockcibill.-May 5th, two Spotted Corn-Crakes-[? Porzana marnetta.-R. M. B.]—on rock (see under Cuckoo). "It may interest you to know that I caught alive, on Eagle Island, Mayo, April 30th, 1880, a Spotted Corn-Crake. The wind had been blowing strong from the N.W. for some time."

Maidens South.-May 6th, one found disabled. [Received in flesh.]

Innishtrahull.-May 16th, one heard at midnight. July 29 th, two heard.

Rathiin O'Birne.-June 21st, two heard at twilight; wind light $N$. (Rare occurrence here-the birds remained until July 2nd.)

Blackrock, Mayo.-May 12th, one all day on rock; wind light S.E.

Tearaght.-June 8th, "feathers of Corn-Crake sent, picked up at Peregrine's feeding-place." [Received.]

WATER-RAIL (Rallus aquaticus, Linn.).

Rathlin O'Birne.-September 5th, a bird going W.; struck with tremendous force at midnight. [Water-Rail received in flesh.]

WATER-HeN (Galiinula chloropus, Linn.).

South Rock Light-ship.-April 10th, one Water-Hen disabled. "The only one seen here for the last three years." [Received in flesh.]

Соот (Fulica atro, Linn.).

Dungarvan.-October 26th, one killed striking (first of the kind) at 4 A.M. ; wind fresh N.E. [Leg and wing received.]

Ringed Dotterel (Aigialitis hiaticula, Linn.).

Coningbeg Light-ship.-May 16th, ten going N.E.

Innishtrahull.-March 6th, three on the island. July 16th, a "Dotterel" at noon.

Rathlin O'Birne.-April 1Sth, four "Ringed Plover" on the island at 1 A.M. ; wind strong S.W., cloudy. (These birds often come in wild weather.) "Ping Plover build on island, and lay their eggs on little stones." 
Golden Plover (Charadrius pluvialis, Linn.).

Mine Head.-January 29th, six going E.

Arlilow South Light-ship.-February 10th, a flock flying E.

Arklow North Light-ship.-February 13th, "Plover" going N.W., and many birds at the lantern; eight killed [? Were these "Plover."-R.: M. B.]; wind light S.W., rain. October 18th, a flock going $\mathrm{N}$.

Rockabill.-May 5th, one "Grey Plover" on rock (see under Cuckoo).

South Rock Light-ship.-December 6th and 7th, large flocks of Golden Plover going W. early each day.

Copeland (Mew) Island.-November 13th, great rush of Lapwing and other birds; also some Golden Plover.

Maidens South.-November 13th, a number of Curlew and Golden Plover passing the lantern; wind light S.W.

Innishtrahull.-August 3rd, one flying E.

Rathlin O'Birne.-April 29th, four "Grey Plover"; one shot.

Killybegs.-Golden Plover always seen in October, November, and December. December 5th, fifteen going N.E.

\section{Green Plover (Vanellus vulgaris, Bechst.).}

Rockabill.-December 5th, one flying to shore.

South Roch Light-ship.-November 27th, flock of "Plover" going $W$.

Copeland (Mew) Island.-April 18th, several at intervals during the summer. September 14th, thirty. November 3rd, twenty about to-day: 13th, "Lapwing, Starlings, Blackbirds, and Thrushes very plentiful in rays from 5 P.Mr. to 7 P.M. ; also small birds; hundreds may be seen at the same time; also some Golden Plover; thick haze. Birds still plentiful at 8 P.Mr, not striking, among them being Whimbrel, Curlew (not many), Skylarks, Fieldfares, and others which I could not distinguish. Lapwing seemed vory plentiful, in flocks of from about half a dozen to three dozen, passing to the N.W., and sometimes seeming a mile distant through the broad clear beans of the light. Though they all appeared to be going in the same direction, yet there were great numbers wheeling round about the lantern with the other birds. They were plentiful up to 3 A.M. or 4 A.M. I observed only one, a Starling, 
killed next morning.-Edward M'CARron." 24th, ten Lapwings on island: 25th, two seen in the rays of the light: 27th, a flock flying towards shore from the Scottish coast: 29th, Lapwings on the island to-day. December 5th, some about: 22nd, one dozen : 29th, large flocks about these days.

Maidens North-December 25th, a flock of "Green Plover" going N.W. These birds are observed from October to December.

Maidens South.-January 9th, 10th, and 11th, Green Plover heard each night; gloomy, and wind variable. Also on the nights of the 23rd, 24th, and 25th. December 28th, a flock of Lapwings going W. at 11 A.M.

Innishtrahull.-June 28th, three "Lapwings" on island.

Aranmore.-August 29th, a large flock of "Plover" going S. October 13th, a flock of "Plover" near the station.

Rathlin O'Birne.-April 9th, six Green Plover coming from shore; one shot. These birds are mostly seen in the spring; rare in winter.

Killybegs.-Green Plover always seen in. October, November, and December.

Slyne Head, S.-November 29th, one Lapwing on island; wind strong S.W. The first noticed on these rocks by present keepers.

Tearaght.-November 30th, one Lapwing on island at 9 A.Mr.; wind strong $\mathrm{S}$.

\section{TuRnstone (Strepsilas interpres, Linn.).}

Innishtrchull.-March 10th, a small bird shot. "I have always named them "Sand Larks'; they are resident here all the year, and breed on the island; they never strike lantern." [Turnstone received in flesh.] August 30th, fourteen Turnstones on the island. "These birds have now returned after an absence of about two and a half months; they will remain during the winter.-M. J. KENNEDY."

Oyster-Catcher (Homatopus ostralegus, Linn.).

Spit Bank.-December 22nd, ten feeding.

Tuskar-May 16th, two on rock.

Copeland (Mew) Island-December 16th, Oyster-Catchers always plentiful. 
Maidens South.-April 5th and 6th, two Seapies on rock.

Innishtrahull.-January 4th, seven "Seapies." July 3rd, eleven on the rocks throughout the day: 16th, one.

Aranmore.-July, Seapies about every day.

Rathlin O'Birne.-Seapies are on the island in great numbers, and nest on the west side; they remain all the year.

Killybegs.-Seapies always here.

Broadhaven.-Oyster-Catchers numerous.

Slyne Head, S.-May 27th, Seapies eggs found on the island. Oyster-Catchers about the island throughout the year.

Arran Island, N.-April 7th, twelve about island.

Tearaght.-April 14th, a pair at noon.

Skelligs.-April 11th, 26th, and 29th, two all day.

Grey Phalarope (Phalaropus fulicarius, Linn.).

Blackrock, Mayo.-October, there were three little birds about the size of a Sand Lark, and the same colour, feeding on the water the last week of the month. [Probably Grey Phalaropes.--R. M. B.]

Styne Head, S.-November 1st, one Phalarope found disabled striking-[Received in flesh]; gale W., hail.

Woodcock (Scolopax rusticula, Linn.).

Fastnct.-April 9th, Woodcock rare on shore this season (see under Snipe).

Mrcidens North.-March 5th, one at 11.45 P.M. November Sth, one killed striking at midnight; wind strong S.W.

Innishtrahull.-February 10 th, one on the island at 2 P.M.; snow. October 10th, one on island: 26th, one Woodcock killed striking at 4 A.I. ; wind moderate S.E., clear. [Wing received.] Aranmore.-August 30th, one on island. October 9th, many Woodcock on the island.

Rethlin O'Bime.-January 18th, two on island; gale W. February 9th, one shot; gale $N$., snow.

Blackrock, Mayo._October 26th, one on rock; wind light N.E.

Common Snipe (Gallinago coelestis, Frenzel) and JACK SNIPE (G. gallinula, Linn.).

Fastnet.-April 9th, Woodcock and Snipe very rare on shore this season, but Jack Snipe very numerous. 
Tuskar.-November 16th, one going W.; wind moderate N.E. Arlilow North Light-ship.-October 19th, one Snipe killed, found on deck; wind strong S.E.

Rockabill.-January 28th, one Snipe found dead.

Copeland (Mew) Island.-May 16th, a few. Only few remain; plentiful in winter, none in August. September 15th, Snipe commencing to return. November 25th, a few on the island. December 29th, some do.

Innishtrahull.-March 3rd, three Jack Snipe and a Common Snipe on the island; wind fresh S.E. April 6th, one Common Snipe killed striking; wind fresh E., misty. [Leg and wing received.]

Aranmore.-September 4th, Snipe round the light; wind light S.E., foggy. October 9 th, many on island.

Rathlin O'Birne.-Snipe come to the island about the commencement of October, and remain until the middle of February.

Slyne Head, S.-March 16th, one Jack Snipe on the island at 10 A.M. ; wind strong N.W., gloomy. October 2nd, one Jack Snipe found dead on balcony; wind light $\mathrm{E}$. [Received in flesh]. December 11th, two Common Snipe on island.

Arran Island, S.-May 1st, 11 P.M. to 4 A.M., several Snipe passing at intervals; one killed striking. [Leg and wing received.]

Tearaght.-February 18th and 24th, a few Snipe about in the early part of the day. November. 1st, one on the rock; gale N.W.: 16th, one large Snipe on the rock at 2 P.M; wind moderate N.E. December 25 th and 27th, several Snipe on rock.

Dunlin (Tringa alpina, Linn.).

Kish Bank Light-ship.-November 12th, one "Stare" caught on deck at noon; wind light S., gloomy (sending wing and leg). [Leg and wing of Dunlin received.]

Purple SandPIPer (Tringa striata, Linn.).

Tuskar.-December 7 th, one on rock at 4 P.M.

Кнот (Tringa canutus, Linn.).

Tuskar:-July 14th, one "Knot" on rock at noon. [Probably an error.-R. M. B.] 
Slyne Head, S.-October 2nd, two Knots killed striking; wind light E., rain. [Received in flesh.]

$$
\text { "SAND LARKs," ETC. }
$$

Fastnet.-February 9th, seven on rock: 23rd, two, March 27th, six. April 14th, thirty-seven on rock: 15th, ten. May 22 nd, three on rock: 23 rd, six about rock: 24 th, eighteen all day. July 27th, a large flock of Sand Larks at 11 P.M. going S.E. : 31st, three going S.E. at noon.

Coningbeg Light-ship.-February 28th, one on ship. March 16 th, one on ship. April 19th, three about the light; wind moderate S.W., gloomy. September 2nd, a flock of "Sandpipers" going S.W.: 26th, two going W.

Tuskar.-November 26th, ten "Sandpipers" on rock.

Rockabill.-November 11th, "Two kinds of Sandpipers build their nests-[Probably some error.-R. M. B.]-here, and seemingly never leave.-Joнn Hamilton." November 19th, a flock of Sandpipers on rock.

Copeland (Mew) Island.-December 16th, flocks about rock.

Maidens South -February 25th, four. During fine weather they remain for days. May 6th, two.

Rathlin O'Birne.-April 23rd, twenty Sand Larks about the dwellings at 7 A.M.; wind strong N.W. (These birds come about the houses when the surf is high.) "There are three species of Sand Larks; one (the Ringed Plover) builds its nest on small stones; another species is grey, and is always about the rocks-[? Purple Sandpiper.-R. M. B.]; and the largest of all is black on the back, with 'red' legs, and white under the wings-[? Turnstone.-R. M. B.]. Never more than two of the latter seen together." "Sandpipers always here."

Killybegs.-Sand Larks always here.

Blackrock, Mayo.-November 21st, several Sand Larks.

Slyne Head, S.-Sand Larks always here.

Tearaght.-January 13th, one Sand Lark. October 24th, one. December 16th and 18th, Sand Larks all day.

REDShank (Totanus cailidris, Linn.).

Copcland (Mev) Island.-November 5th, Redshanks always about. December 29th, Redshanks, in pairs, constantly round the rocks. 
Maidens South.-August 6th, one Redshank came down through the cowl of the light-room during the night; wind light.

Killybegs.-Redshanks always here.

Slyne Head, S.-August 20th, one "Turnstone" killed; leg and wing sent-[Leg and wing of Redshank received]. "Turnstones" are noted as "residents, but not in large numbers."

CuRlew (Numenius arquata, Linn.).

Spit Bank.-December 20th, twenty Curlew feeding.

Coningbeg Light-ship.-January 4th, several over ship at midnight; wind light W., fog. March 14th, one going N.W.

Tuskar.-July 20th, one going W. September 28th, one going $W$.

Arklow South Light-ship.-April 9th, several Curlew going E., high; wind light N.E.

Rockabill.-February 18th, several Curlews going W. April 20th, two going W.; wind strong S.W. July 11th, two going S.W. August 5th, two going W.: 13th, a flock going W.: 23rd, two young Curlews going W. November, great rushes of birds (see under Sparrow) : 25th, two Curlews going S.W.

South Rock Light-ship.-March 2nd, one Curlew killed striking, 1.30 A.M. ; wind light S.E.

Copcland (Mew) Island.-Curlew to and fro all summer; one shot August 26th, and one caught in a trap on August 28th. November 3rd, small flocks about, and many seen on the Copelands: 13th, Curlews about the light; fog: 22nd, several flying about the rays; wind S., fog: 29 th, some on island. December 22nd, a flock on island.

Maidens South.--January 9th, 10th, and 11th, Curlew heard each night; wind variable, gloomy: also on the nights of the 23rd, 24th, and 25th, and March 13th, 14th, and 15th; apparently they came from the direction of the Scottish coast. July 5 th to $22 \mathrm{nd}$, flocks of Curlew heard several nights; weather gloomy. August 16th, five flying W. November 13th, a number of Curlew and Golden Plover passing the lantern; wind light S.W.

Aranmore.-September 2nd, ten going S.

Rathlin O'Birm.-March 22nd, Curlew frequent island, and always come at dusk from mainland, and generally leave at 
daybreak. June 4 th to 17 th, between fourteen and thirty Curlew on the island each day. July 4th, fifteen Curlew on the island, and large flocks came on and off until the middle of the month.

Killybegs.-Curlew always here.

Broadhaven.-Curlew frequently seen.

Slyne Head, S.-April 30th, one on island. May 2nd, seven Curlew going E.: 12th, one on island. June 20th, 22nd, and 25th, small flocks seen. Curlew on the island during July and August. October 25th, one. November 1st, one. December 18th, two. Curlew are noted as being very numerous about Slyne Head this season.

Arran Island, N.-April 7th, five about island.

Tearaght.-One noted April 9th, September 26th, October 1st and 30th, and December 6th.

\section{Whimbrel (Numenius phoopus, Linn.).}

Festnet,- "May 2nd, a rush of Whimbrel for three hours, going N.E. ; wind S.W., misty, rain. They seemed in vast numbers, and flew high in a continuous stream from 11 P.M. on 2nd to 2 A.M. on the 3rd. Saw several on shore during the last week in April; shot some; they were in fine condition and plumage. May 5th, many Whimbrel going N.E. 1 A.M. ; wind light S.W., misty; one captured at lantern. July 27 th, many all night at intervals between 10.30 P.M. and 3 A.M., seemed flying S.; wind light N.W., misty. August 20th, about fifty observed in the rays of the light between 10 P.M. and 3 A.M. on 21st, when they went S.W.; wind light S.W., hazy.-George Dunleavy."

Old Head, Kinsale.-May 7th, twelve at 8 A.M. going N. 10 th, eight going N. September 15th, two going S.

Coningbeg Light-ship.-May 1st, ten going N.; wind moderate S.E.: 4th, a flock going N. at 10 P.M. ; wind light S., fog. September 2nd, Whimbrel killed striking. [Leg and wing received.]

South Rock Light-ship.-April 27th, several flocks going N.W. between 9 A.M. and 11 A.M. : 30 th, a number of small birds and Whimbrel flying about the light.

Copcland (Mew) Island.-May 3rd, "Curlew" (Whimbrel) flying about in flocks, and making a great noise. November 13th, birds very plentiful this night; Whimbrel about light; fog. 
Maidens South.-May 19th and 20th, a flock heard passing each night.

Innishtrahull.-May 12th, 13th, and 14th, from three to five young Curlew each day on the island; hazy. July 26th, eleven young Curlew on the island; gale N., clear; two shot - [Leg and wing of one Whimbrel received]: 29th, twenty young Curlew on the island at 11 A.M.; wind light S.E., clear.

Aranmore.-Arrived first week in May.

Rathlin O'Birne.-May 16th, eighteen; left in evening: 20th, five, and some seen on and off till June 2nd. Whimbrel are seen here in flocks of from five to ten during May and June, but I never observed them later.

Broadhaven.-May 6th, Whimbrel arrived in large flocks.

STyne Head, S.-May 12th, one "Maybird" on the island: 28th and 30th, one Whimbrel each day. June 5th, two "Maybirds"; one shot. [Leg and wing of Whimbrel received.]

Arran Island, N.-May 7th, six about the station (first noticed this season); wind light S. : 16th, forty about island.

Arran Island, S.-April 29th and 30th, flocks of Whimbrel going S. May 4th, Whimbrel going S. all night; wind light E., showery: 5th, flocks of Whimbrel passing S. at 10 A.M.; wind W., clear. ["South," at this station, is probably an error. -R. M. B.]

Common Tern (Sterna fluviatilis, Naum.).

Copeland (Merv) Island.-July Tth, Common Tern shot. [Received in flesh.]

\section{Arctic Tern (Sterna macrura, Naum.).}

old Head, Kinsale.-September 1st, six Terns flying round light; one shot. [Skin of Arctic Tern received, labelled "Sept. 19th, shot on balcony."]

\section{Terns.}

Fistnet.-May 27th, a number of "Sea Merws" about light from 11 P.M. to midnight; wind moderate N.W., misty. June 26th, several "Sea Mews" going N.E.

Oll Head, Kinsale.-September 1st, six about light; one shot. 
Copeland (Mew) Island.-Miny 14th, "Sea Mews" arrived this morning; wind light S., misty. About five hundred are on the island during the summer. Eggs about 1st June, young birds about 1st July. The eggs are taken in great numbers by the people visiting the island, and laying continues until about the 20th August. The birds are beginning to get scarce, since the establishment of the light-house in 1884. September 12th, nearly all the Mews have left the island. October 1st, all gone.

Maidens South.-August 31st, three Terns, one at 10 P.Mr.

Rathlin O'Birne.-Terns built in increasing numbers this year, on a small island close by. They arrive about 3rd June, and remain until end of July; I always observe they are more plentiful in foggy weather.

Tearaght.-October 23rd, flocks of Terns, Kittiwakes, and Gulls all day.

\section{GULLS.}

Fastnct.-February 4th to 9th, thousands of Gulls and liazorbills feeding about the rock: 20th, many; also Puffins, liazorbills, Guillemots, and a number of Gannets. March 4th, many Kittiwakes. April 11th to 14th, do. August 1st and 19th, several Common Gulls.

Spit Bank. - November 26th, twelve Great Black-backed Gulls flew past light-house going N.E. in one flock; I never saw more than two or three together before; wind light N.W. December 20th, two Lesser Black-backed Gulls and numbers of Kittiwakes and Common Gulls feeding on bank: 22nd,-numbers of Kittiwake, two Lesser and four Great Black-backed Gulls feeding on bank: 24th and 27th, numbers of Kittiwakes.

Coningbeg Light-ship.-Many Herring Gulls, Kittiwakes, and Black-backed Gulls seen during the months of May, June, July, August, and September. "Small Common Gulls" noted during September.

Arklow South Light-ship.-October 20th, two Gulls fighting for a dead bird at 2.20 P.M.

Rockabill.-April 18th and 21st, many Gulls : 23rd to 26th, Kittiwakes numerous. July 19 th and 20 th, flocks of Blackheaded Gulls fishing all day; these birds are not common at this station: 28th, do. August 10th, Black-headed Gulls 
fishing all day: 12th to 18th, many Kittiwakes, Herring Gulls, and Black-headed Gulls about the rock. November 11th, the Gulls which had taken up their residence on the "Bill" have all deserted us : 22nd, a few Gulls fishing.

Copeland (Mew) Island.-June 21st, large flocks Kittiwakes during the summer, but no breeding-place near. Also a good number of Herring Gulls, and occasionally a few common Gulls. September 15th, Kittiwakes began to leave on September 1st. November 25th, scarcely a Gull is to be seen: 29 th, some "Royal" Gulls about the island. December 2nd, a Kittiwake seen to-day going S.; one or two Royal Gulls during December.

Maidens North.-March 1st, many Herring Gulls.

Innishtrahull.-March, "Common Gulls, Great Black-backed, Small Black-backed, Herring, and Kittiwake Gulls are residents throughout the year."

Aranmore.-June 10th, one "Ivory Gull" flying S. Greater and Lesser Black-backed Gulls and Herring Gulls breed here in large numbers. July, Gulls about every day. November 18th, six Black-backed Gulls going N.E.

Rathlin O'Birne.-Inmense flocks of "Common Gulls" are round the island at all seasons, but more especially in spring and summer. They nest on the rocks to the west of the island.

Blackrock, Mayo.-March 11th, a number of small Gulls all day about the rock, apparently commencing to nest (the light-keeper calls these birds "Didleens") - [Kittiwakes.R. M. B.]; two Royal Gulls about the rock: 25th, a great number of "Didleens" about the rock. April, two Royal Gulls about the rock every day. May, numbers of "Didleen Gulls" and two Royal Gulls about the rock each day. October, Gulls about all the month. November 15th, one cream-coloured Sea Gull on the rock all day; wind strong S., misty to rain [perhaps an Tceland Gull.-R. M. B.].

Slyne Head, S.-May 16th, eight Kittiwake Gulls arrived to build. Gulls round the island throughout the year.

Tearaght.-February 16th, several different species of Gulls about the island all day. March 14th, first Kittiwakes for the season. July 27 th, six Kittiwakes round the light. September 14th and 15th, several Royal Gulls and some young Herring 
Gulls. October 23rd, several Gulls and Kittiwakes: 31st, one cream-coloured Gull all day about the rock; wind strong S.W. December 4th, Peregrine killing Herring Gull (see under Hawk).

Skelligs.-March 14th, Kittiwakes first appeared.

Bull Rock, Kerry.-August 8th, large numbers of Kittiwakes still on rock.

\section{SKUAS.}

Rockabill. - July 27th, several "Skuas fishing"; wind moderate W., gloomy. These birds seldom visit this station.

Manx Shearwater (Puffinus anglorum, Temminck).

Fastnet.-April 5th, several to-day, passing one at a time, going W.: 9th, three going N.W.; "I think they must breed near shore dwellings on Crookhaven side of the harbour, as I often hear their cry at night": 29th, Shearwaters, Puffins, Razorbills, and Guillemots fishing in large numbers.

Old Head, Kinsale.-May 22nd, one killed striking at 1.30 A.M.; several seen about light. [Leg and wing received.]

Coningber Light-ship.-Many seen daily during the months of May, June, July, August, and September.

Rockabill.-July 30th, several seen fishing all day; not often seen.

South Rock Light-ship.-April 24th, five "Mackerel cocks." J une 4th, two do.

Aranmore.-July, many throughout the month. September 1st and 2nd, Manx Shearwaters about and passing all night. These birds were here this year in great numbers, and were last heard on September 2nd.

Slyne Head, S.-May 23rd, two Manx Shearwaters killed striking; wind fresh S.W., rain. [Leg and wing sent.]

Fork-tailed Petrel (Oceanodroma lencorrhoa, Vieill).

Old Head, Kinsale.-March 27th, "I got four Fork-tailed Petrels' eggs at Tearaght altogether; one in '86, which I sent to Mr Ussher; two in '87, one of which I sent to Mr More (it was unfortunately broken in transit), the other to you; and one in '88, which I sent to you with the bird-it was very much hatched" [Francis Ryan in lit. to R. M. B.] 


\section{Storm Petrel (Procellaria pelagica, Linn.).}

Fostnet.-Hundreds appeared about the light on July 27th; several captured and let off again; wind light N.W., misty. August 4th, three seen flying in the rays of the light at 11 P.M.; misty.

Coningbeg Light-ship.-May 12th, one in the afternoon: 18th, one: 22nd and 23rd, four Storm Petrels during day; wind light W., clear: 29th, five about the ship: 30th, fourteen at 10.30 A.M.; wind fresh S.W., clear: 31st, several during the day; wind fresh S.W., clear. June 1st and 2nd, several about ship. July 20th, nine about ship; wind light S.W.: 24th and 25th, several : 28th to August 8th, one daily. September 13th, one : 15th, nine: 16th, one in lantern at 8 A.M. : 24 th, one on ship: 17th, flock about ship. October 7th, several about; gale, clear.

South Rock Light-ship.-August 20th, two about ship (first noticed this year).

Rathlin O'Birne.-June 14th, first observed. Build in large numbers, and some of the eggs were observed to be of a bluer colour than others. August 30th, one struck at midnight. [Leg and wing received.]

Tearaght.-May 1st, several at 11 P.M. ; two caught: 23rd and 24 th, one about lantern. June 24 th and July 3rd, Petrels about the lantern each night; two caught: 27 th and $28 \mathrm{th}$, immense numbers of Petrels all night round the light; one killed, several caught; fog; rain. September 19th, one caught in rabbit trap. [Leg and wing received.]

Bull Rock.-July 29th, some Moths forwarded caught at light during a fog last night. A large number of Storm Petrels made several attempts to enter the lantern at the same time.

Razorbill and Gulllemot (Alca torda, Linn., and Uria troile, Linn.).

Fastnet.-February 4th to 9 th, thousands of Razorbills feeding; no Puffins observed: 20th, first Guillemots observed this year; also Puffins. March 4th, many Kittiwakes and Razorbills. April 5th, one small black diver, name unknown, observed near shore fishing, all black, with a white mark on each wing, black, sharp-pointed bill, and red legs; "I often see one, but never 
more at a time"-[Black Guillemot.-R. M. B.]: 12th, Pazorbills in large numbers: 13th, about fifty: 29th, Razorbills, Guillemots, Puffins, and Shearwaters in large numbers. May 25th, about fifty Razorbills. June 3rd, three Guillemots, the first seen for some time. July 10th, Guillemots numerous: 12th, one Razorbill and a young one about rock: 26th, several Razorbills : 30th, three Razorbills and young ones. August 8th and 17th, several Razorbills and their young.

Coningbeg Light-ship.-January 9th, several flocks of "Murs."

Rockabill.-May 14th, numbers about. July 28th, Razorbills and Guillemots fishing all day. August 14th to 24th, Razorbills very numerous.

Copcland (Mew) Island.-Razorbills and Guillemots are observed both summer and winter.

Maidens South.-April, large flocks fishing.

Innishtrahull.-April 21st, Puffins and Razorbills fishing.

Aranmore.-Guillemots and Razorbills left about August 6th.

Blackrock, MIayo.-March 11th, two flocks of Razorbills or Guillemots going N.: 25th, great numbers of Razorbills. April 7th, a flock of Puffins or Guillemots going N., but too high to distinguish them. May, Razorbills and Guillemots daily. November, Guillemots and Razorbills going S. all the month.

Tearaght.-February 17 th, fifty Guillemots about rock; wind moderate; first for the season. These birds breed here in large numbers; also Razorbills and Puffins. March 10th, first Razorbills for the season. July 31st, Guillemots and Razorbills leaving the rock. October 23rd, flocks of Razorbills noted.

Skelligs.-January 23rd, Guillemots about rock; first this year. March 1st, Razorbills about rock; first this year. July 10th, Guillemots and Pazorbills commencing to leave, as their young are fledged; nearly all had left by the 30th of July.

Bull Rock.-Razorbills left third week in July; Guillemots second week in July.

Puffin (Fratercula arctica, Linn.).

Fastnet.-February 20th, hundreds all day; also Razorbills and Guillemots and many Gannets ; first Puffins observed this year. April 29th, Puffins, Razorbills, Guillemots, and Shearwaters fishing in large numbers. 
Coningbey Light-ship.-March 24th, a flock going N.E.; large flocks daily during May, June, July, August, and September.

Rockabill.-May 14th, numerous Puffins. July 26th, several. August 10th, Puffins all day.

Copeland (Mew) Island.-May 13th, one found dead on the rocks. July 27 th, do. September 4 th, large flocks passing to the E. October 6th, one young bird washed ashore dead: 8th, an old bird also washed ashore dead.

Killybegs.-March 30th, three; first noticed this year. August 1st, last noticed to-day.

Blackrock, Mayo.-A pril 7th, a flock of Puffins or Guillemots going N., but too high to distinguish them: 16th, several Puffins arrived to nest.

Tearaght.-March 15th, first Puffins: 23rd, a great rush in the afternoon; wind strong W. July 27th, one Parrot round the lantern at 11 P.M.

Skelligs.-March 25th, first appeared.

Bull Rock.-Left last week in July.

Great Northern Diver (Colymbus glaciaiis, Linn.).

Fastnet.-April 5th, one seen fishing off shore, in splendid plumage; rare to observe them so late.

LITTLE GREBE (Podiceps fuviatilis, Tunstall).

Slyne Head, S.-November 16th, small bird killed striking at 11 P.M. ; wind light E., cloudy. [Little Grebe received in flesh.]

Cormorant (Phalacrocorax carbo, Linn.) and

SHAG ( $P$. graculus, Linn.).

Fastnet.-February 21st, several green and brown; one or two noted occasionally in this month and April. May 1st, two large-crested Cormorants: 5th, small Green Cormorant; wind moderate; this was the smallest Cormorant I ever saw : 23rd, several fishing. June 18th, one Green Cormorant: 19th, five Cormorants. July 28th, four Brown Cormorants.

Spit Bank.-December 20th, eight Cormorants : 23rd, several about harbour.

Mine Head.-March 16th, four going S. April 6th, three going $\mathrm{S}$. 
Coningbeg Light-ship.-April 7th, one about ship: 8th, one going N.E. A few noted constantly during May: 26th, thirteen going S.S.W. June 1st, one going S.W.: 2nd, 5th, 8 th, and 9 th, one about ship. July 10 th to 15 th, from one to three Cormorants: 26 th, two going N.E.: 30 th, one. September 12th, two: 17th and 30th, one.

Rockabill.-April 9th, several crested Cormorants: 18th, two: 27th, May 14th, and July 17th, Cormorants noted. August 10 th to 24 th, Cormorants very numerous. November 20th, Cormorants. (These birds are not as numerous as last winter, probably owing to the mild season.) December 11th, three: 12th, four.

Copeland (Mew) Island.-Cormorants always to be seen.

Dunvee Head.-A few noted twice in January going $\mathrm{N}$.

Aranmore.-Black and Green Cormorants always about.

Rathlin O'Birne.-Cormorants always here.

Killybegs.-Observed at all times.

Broadhaven.-Cormorants, Black and Green, very numerous this season.

Blackrock, Mayo.-Numbers of Cormorants, crested and not crested, always about.

Slynie Head, S.-Cormorants always plentiful.

Arran Island, S.-May 4th, Cormorants passing all day in numbers, going W.

Tearaght.-Cormorants seem to have increased at this station since last year.

\section{Gannet (Sula bassana, Linn.).}

Fustnet.-February 20th, many. March 28th, several. Several during April going W. May, odd ones noted; several on 23rd: thirteen going N.W. on 24th. June, several throughout month: 12 th, "fourteen, two of them this year's birds, all black, all going W.": 14th, "four, three of them this year's birds." Numerous at end of month. July 10th, numerous. August, constantly noted: 20th, "two, this year's birds": 22nd, "two, last year's birds": 23rd, "a hundred, several were this year's birds ; some lying on the water gorged."

old Head, Kinsale.-March 1st, several going W. : 3rd, forty going W.

Coningbeg Light-ship.-Many from June to September. 
Lucifer Shoals Light-ship.-January 2nd, three flocks of Gannets going N.E.: 4th, several going N.: 8th, a flock going N.E.

Blackwater Bank Light-ship.-March 25th, four going N.E. : 29th, three do. April 1st, five Gannets going N.E. : 15th, nine going N.E.

Arklow South Light-ship.-April 6th, a flock going N.E.: 10th, a flock going N.E.

Kish Bank Light-ship.—September 6th, three going N.

Rockabill-April 5th and 6th, several going S.: 25th, five going S.: 26th, numerous Gannets: 27th, several going S. 29th, several going S. July 15th, Gannets going S. all day : 31st, several going S. all day. August 12th, one Spotted Gannet going S. December 3rd, two going S.

South Rock Light-ship.-March 2nd, six going N.E. April 15th, ten going N.E.: 16th, thirteen going N.E. : 20th, a flock : 24 th, five going N.E. ; also five going S.W.: 29 th, a flock going N.E.

Copeland (Mow) Island.-May 13th, Gannets always seen. November 28th, some young birds about.

Maidens North.-June 8th, six Gannets going S.E.

Maidens South.-April, large flocks.

Innishtrahull.-March 14th, three. April 6th, a number. July 18th, a young bird fishing.

Aranmore.-July, Gannets noticed every day. September 27 th, a great number. October 9 th, numbers.

Rathlin O'Birne.-Not so plentiful as last year.

Killybegs.-March 26th, two going S.; first seen this year.

Blackrock, Mayo.-March 11th, Gannet going N. each day since the 1st of the month. April, numbers about, and flocks going N. during the early part of the month. May, Gannet fishing round the rock every day. October, Gannets noticed all the month. November, Gannets going S. all the month.

Slyne Head, S.-Few this year.

Tearaght.-June 12th, twenty old and young birds: also on $16 \mathrm{th}, 18 \mathrm{th}, 20 \mathrm{th}$, and $22 \mathrm{nd}$. September 14th, 15th, and 17th, Gannets, old and young, fishing.

Skelligs.-January 3rd, five seen, flew W.

Bull Rock.-August 8th, the colony of Gannets has not decreased in numbers during the last five years. About one 
thousand of them may be seen on the W. side of the rock during the months of June and July. About fifty or sixty Gamnets, nearly all black, have been seen. Gannets live on W. side of rock. All others on N.E. and S. More Sen-Parrots live on N. side. Kittiwakes on E. and S.

\section{Heron (Ardea cinerea, Linn.).}

Fastnet.-July 31st, one flying S.

Spit Bank:-December 20th, seven feeding on bank: 22 nd seventeen: 24th, nine. "They frequent the Spit Bank at low water every day."

Copeland (Mew) Island.-August 1st, one or two seen from time to time throughout the year. November $3 \mathrm{rd}$, some always about. December 22nd, many to-day.

Innishtrahull.-June to December, one to four noted occasionally.

Aranmore.-September 23rd, one at station.

Rathlin O'Birne._."Cranes" frequent the island.

Broadhaven.-Herons plentiful here.

Slyne Head, S.-October 12th and 2öth, one "Crane" on island.

\section{"GeEse.}

Arlilow North Light-ship.-February 10th, flocks of Geese about ship in the afternoon; sleet and snow.

South Rock Light-ship.-October 13th, a flock of Wild Geese going N.W.

Copeland (Mev) Island.-December 30th, about two hundred birds like Geese going N.

Innishtrahull.-January 23rd, four Barnacle going S.W. March 5th, thirteen: 14th, eighteen Barnacle Geese going N.E.; wind fresh. April 3rd, nine Barnacle going N.E. October 4th, five about island: 24th, seventeen Barnacle Geese going S.W. November 19th, three Brent Geese about island.

Aranmore.-Barnacle Geese left about first week in May. September 1st, a large flock of Barnacle going S. October 21st and 29th, Barnacle in flocks all day, going S. Novemher 18th, flocks of Barnacle passing and repassing during the early morning. December, Snow Buntings, Linnets, and Barnacle Geese are the only birds observed this month. 
Rathlin O'Birne.-February 20th, three Barnacle going N.; the last observed.

Killybegs.-March 5th, four Wild Geese going N. October 14th and 27th, a few Wild Geese. These bixds remain on the uninhabited island of Inishduff throughout the year, but, except in frosty weather, they are rarely seen at Killybegs. November 26th, one hundred Wild Geese going S.

Slyne Head, S-January 7th, thirteen Barnacle on the adjacent island, eleven on small rock. December 2nd, eight Barnacle going N.E. : 25th, twenty-four going S.E.

Tearaght.-December 10th, Barnacle going E.; gale N.W.

\section{WIGEON (Mareca penelope, Linn.).}

Maidens South,-October 19th, a "Teal" killed striking west side of lantern at 11 P.M. ; gale E. [Leg and wing of Wigeon received.]

Common Scoter (Edemia nigra, Linn.).

Maidens North.-November (?), a bird killed at night. [Wing and tongue of Common Scoter received.]

\section{Ducks.}

Fastnet-April 9th, "Dippers or Dip Jacks," as they are called by the country people, are very numerous in Crookhaven Harbour; I think they breed here.

Coningbeg Light-ship.-February 27th, nine about light at 4.30 A.M. ; wind N.E., overcast. September 26 th, one flock Wild Duck going S.E. November 15th, one Teal noted : 26th, nine Wild Duck about light at 2 A.M. ; wind moderate N.W., clear.

Tuskar.-November 8th, three going towards shore.

Lucifer Shoals Light-ship.-January 3rd, two flocks going W.

Arklow North Light-ship.-February 10th, flocks about ship.

Rockabill.-November 15th, a great many Wild Duck said to be on Church Island at present; I often hear them at night passing.

Copeland (Mew) Island.-April 4th, two seen to-day. A small number frequent the island; these birds bred here formerly. December 9th, a flock of Wild Duck flying about the island.

Maidens South.-January 14th, five White-breasted Diver's 
about all day, resembling Ducks, and having white breasts: 31st, a flock of White-breasted Divers going W. Many of these birds are about during the months of November and December.

Slyne Head, S.-May 24th, one Sheldrake about the island.

\section{BIRDS NOT IDENTIFIED.}

Copeland (MLcv) Island.-November 24th, shortly after sumrise a small bird perched on the window; back and head dark brown, breast dirty white; seemed fatigued, and uttered a loud, hard chirrup; flew towards the shore with a bounding flight.

Maidens South. - November 30th, a small bird on the rock at 2 P.Mr. ; green on the back, bright yellow on breast and legs.

Innishtrahull.--July 13th, at 11 A.M., two birds larger than a Blackbird, apparently of a very dark colour, with short pointed wings, which were beating the air very rapidly with a loud whirr (which first drew my attention), flew very fast towards the N.E. They were keeping close together and in line, only about six yards from the ground, and were out of sight in about half a minute. I never saw birds flying so fast.

Rathlin O'Birne.-May 23rd, a strange bird on the island; appeared very tired. Colour-dirty grey on the back, white breast. Wings very long for size of bird. In size somewhat larger than a Woodcock, and had a somewhat similar flight. It only flew a short distance, and was going S.E. for shore.

Killybegs.-December 8th, one "Hollinhawk" (local name), a large bird with a white breast, black wings and back, observed resting on the water.

\section{General Observations.}

Fustnet.-April 9th, " there have been no birds killed striking or otherwise since I commenced to fill in schedule on the 30th November last."

Aranmore.-June, a Long-eared Bat caught in lantern; first I have ever seen.

Blackrock, Mayjo._-"Two Bats about rock all summer; left about September." 

1890

$$
0
$$

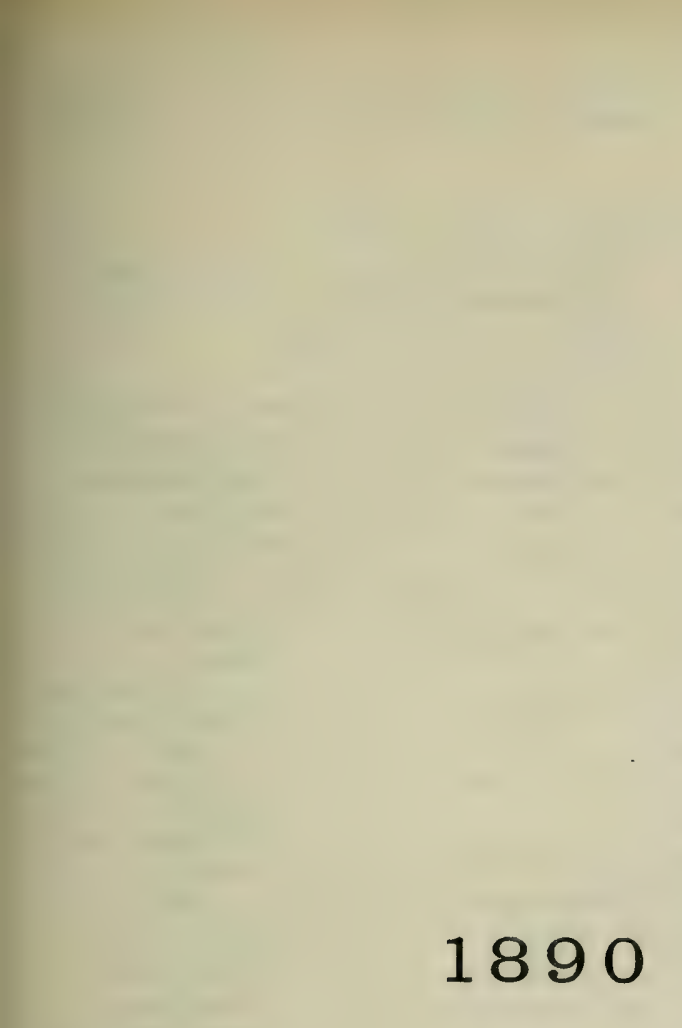

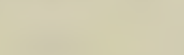

.

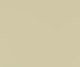




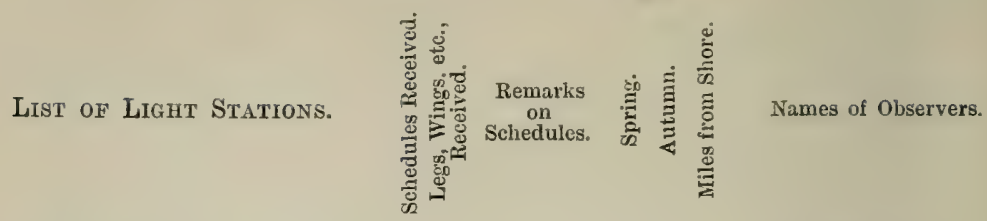

3a.Spit Bank, Cork, ............... 40 excellent. $\quad$ x $x$ - George Dunleavy.

4. Mine Head, Waterlord,........ 20 good. $\quad x \quad x-$ Henry Williams.

5a.Hook Tower, Wexford,........ 321 excellent. $\mathrm{x}$ x - Daniel Hawkins.

5. ${ }^{*}$ Coningbeg Lt.-ship, Wexford, 12 poor. o $\quad x 10$ Peter King.

6. Barrels Rock Lt.-ship, do., 15 good. $\quad x \quad$ o $4\left\{\begin{array}{c}\text { Charles M'Cabe and } \\ \text { Ed. Broad. }\end{array}\right.$

7. Tuskar Rock, do., 355 very good. $\times \quad \times \quad 7\left\{\begin{array}{c}\text { John Hamilton, P. } \\ \text { Corish, and J. MI. } \\ \text { Leary. }\end{array}\right.$

7a.Lucifer Shoals Lt.-ship, do., 36 very good. $\quad x \quad$ x $9\left\{\begin{array}{c}\text { James Byrne } \\ \text { Michael Anser. }\end{array}\right.$ and

7b. Blackwater Bank Lt.-ship, do., 315 very good. $\times \quad \times \quad 6 \int_{1}^{\text {P. } \begin{array}{l}\text { Cullen, Daniel } \\ \text { Durphy. }\end{array}}$

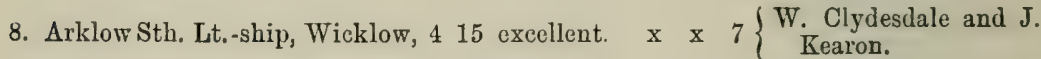

8. *Arklow North Lt.-ship, do., 410 excellent. $\quad$ x $\quad$ x 8 A. B. Wall.

9a.Codling Bank Lt.-ship, Dublin, 10 poor. $\quad$ x $\quad 0 \quad 7$ Joseph Oxford.

10. Kish Bank Lt.-ship, do, 11 poor. $\quad$ x 0.7 Michael Cunniam.

11. Howth Baily, do., 20 very good. $x$ x - R. Armstrong.

12b. South Rock Lt.-ship, Down, ... 23 good. $\quad$ x $\times 3\left\{\begin{array}{c}\text { Thomas Cooney, Pat- } \\ \text { rick Clancy, and } \\ \text { Henry Thompson. }\end{array}\right.$

13. Copeland (Mew) Island, do., .. $3 \quad 6$ very good. $x \quad x \quad z\left\{\begin{array}{c}\text { E. M M Carron and } C . \\ \text { Hawkins. }\end{array}\right.$

14. ${ }^{*}$ Maidens South, Antrim, ....... 228 good. $\quad$ x $\quad$ x $5\left\{\begin{array}{c}\text { B. Sole and Francis } \\ \text { Maguire. }\end{array}\right.$

14. Maidens North, do., ........ 17 poor. 17 x 5 Patrick Keenan.

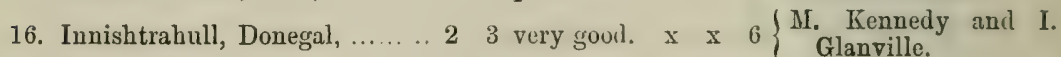

17. Dunreo Head, do, 10 good. $x$. $x$.

20. Aranmore, do., ....... 2 1 very good. $x \quad x \quad 5$ Thomas Fortune.

22. Killybegs, do., …....2 2 good. $\mathrm{x} \times-\left\{\begin{array}{c}\text { Hugh Keeney and } J \\ \text { Corish. }\end{array}\right.$

23. Oyster Island, South, Sligo,... 144 good. $\quad$ o $\quad x \quad 1 \quad$ J. F. Connell.

31. Slyue Head, S., Galway,....... 3 0 very good. $x \quad x \quad 3$ P. D'Arcy.

32. Arran Island, N., do., ....... 2 1 good. $\quad$ × $\quad x \quad 9$ Michael Barry.

34. Arran Island, S., do., ....... 1 0 very good. 0 x 6 J. C. MacGinley

37. Tearaght, Kerry, .............. 624 excellent. $\quad x \quad x \quad 9 \quad$ W. H. James.

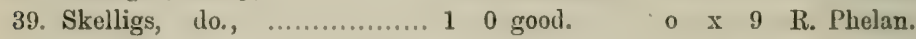

Old Head, Kinsale, sent 1 specimen, Rockabill 11, Vidal Bank 1, Rathlin Island 2, and Blackrock, Mayo, 4.

Legs, Wings, etc., received, 228.

$0=$ No reply.

$\mathrm{x}=$ Schedules returned partly or wholly filled.

Spring, replics reccived from 22 stations. Autumn, replies received from 24 stations. 
Legs, Wings, etc., Received.

Species. How Received. How Procured. Date. Name of Station.

Hobby, . . Skin, . . $\left\{\begin{array}{c}\text { Rested, and } \\ \text { died on board }\end{array}\right\} 23 / 5$ mo., Lucifor Shoals Lt. ship.

Kestrel, . . Leg and wing, Killed st., ${ }^{1}$. $19 / 4$ mo., Rathlin Island.

". Rec'd. in flesh, Shot, . 11/10 mo., Blackrock, MIayo.

Spotted Flycatcher, Rec'd. in spirits, ,, Rec'd. 23/ 5 mo., Tuskar.

lied-breasted " Rec'd. in flesh, " . 20/10 mo., Tearaght.

Pied ", , , . . 7/8 mo., Tuskcor.

Missel-Thrush, . Leg and wing, , . . 16/12 mo., Hook Tower.

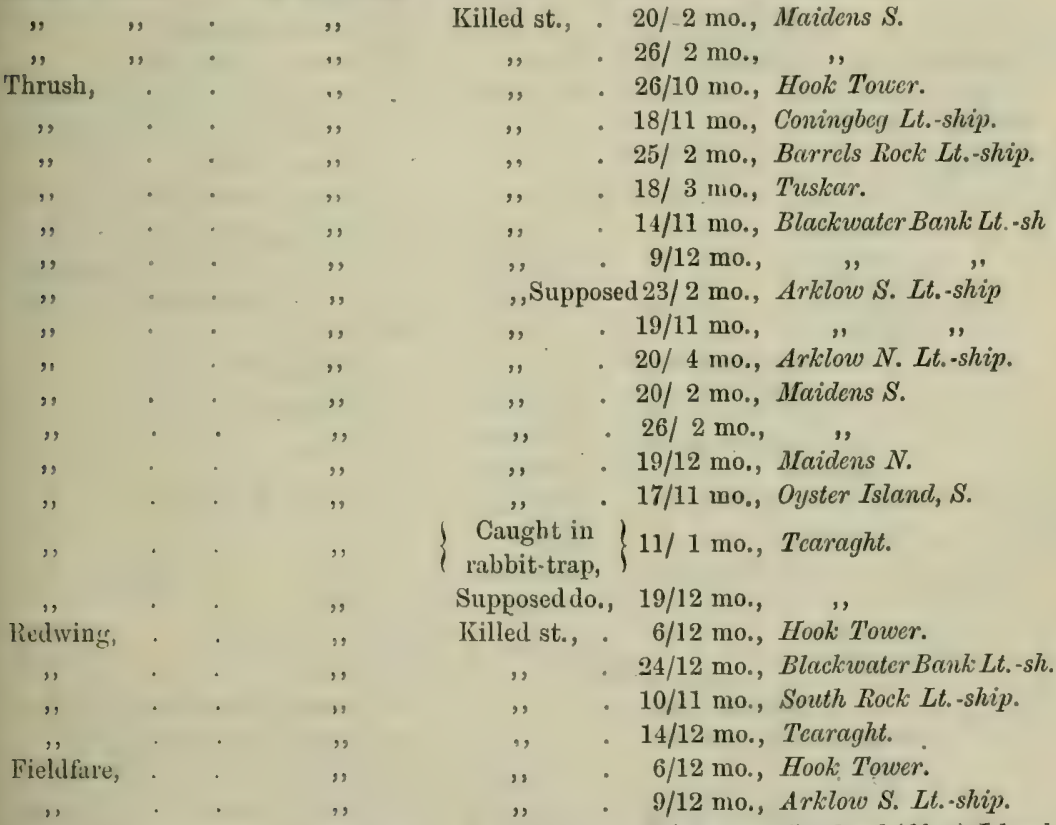

Found killed, 20/4 mo., Copeland (Mcw) Island.

Killed, . 19/12 mo., Maidens $N$.

" . . . " n

" . $\quad, \quad$,

Blackbird, 8/12 mo., Tearaght.

$\left\{\begin{array}{c}\text { Disabled by } \\ \text { Sparrow- } \\ \text { hawk }\end{array}\right\} 26 / 10$ mo., Hook Tower.

Killed st., . 24/ 2 mo., Barrels Rock. Lt.-ship.

two, , ,

" $\quad$. $17 / 3$ mo., Lucifer Shocts Lt. ship.

,. 13/11 mo., Blackwater Bank Lt. sh.

", Supposed 23/2 mo., Avklow S. Lt. ship.

1 Killed st. $=$ Killed striking lantern. 


\section{Legs, Wings, ETC., ReCEIVED-continued.}

Species. How Received. How Procured. Date. Name of Station.

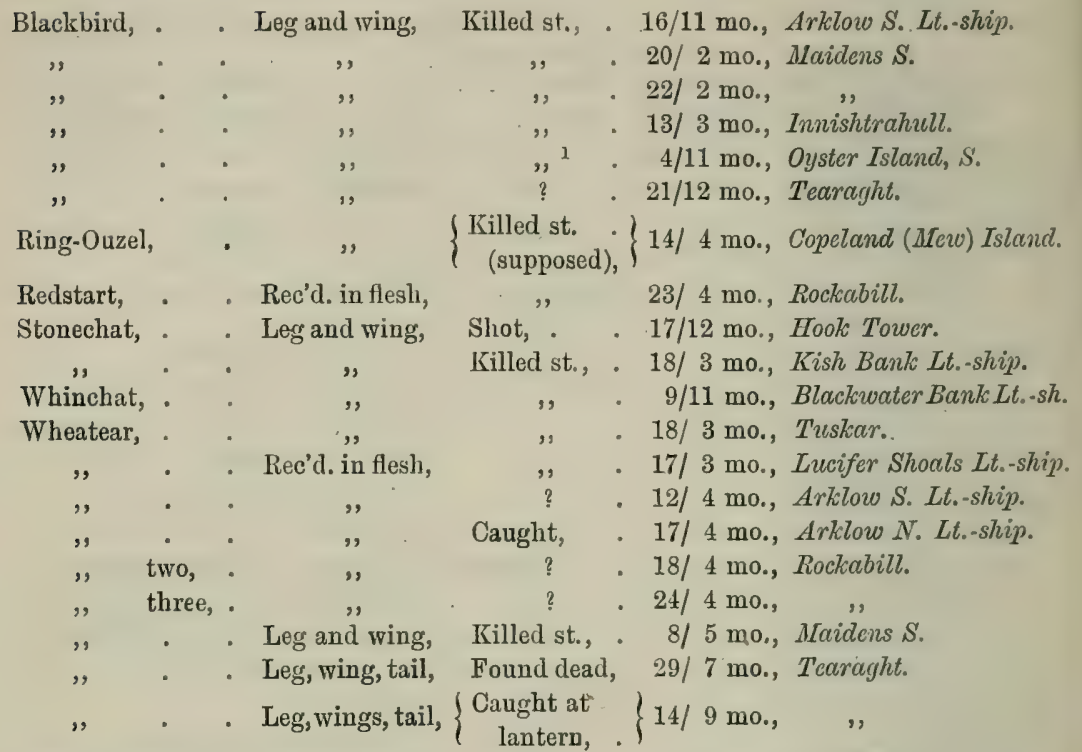

Sedge Warbler, . Leg and wing, Killed st., . 8/ 5 mo., Hook Towor.

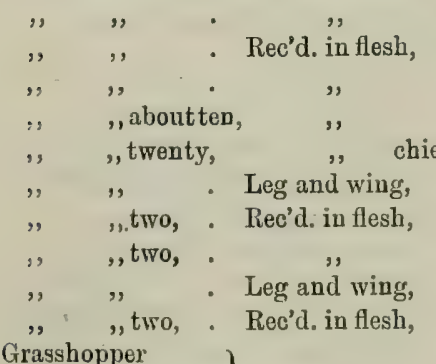

$\left.\begin{array}{l}\text { Grasshopper } \\ \text { Warbler, . . }\end{array}\right\}$

Whitethroat, • Leg and wing,

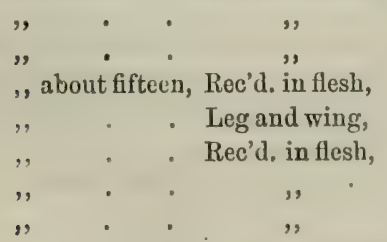

Killed, . 10/ 5 mo., ",

Killed st., . $20 / 5$ mo., ,

. 10/ 8 mo., ",

16/-23/5 mo., Tuskar.

8/-11/8 mo., , ,

9/11 mo., Blackwater Bank Lt.-sh.

25/ 5 mo., Arklow S. Lt.-ship.

9/ 5 mo., Arklow N. Lt.-ship.

8/ 5 mo., Copeland (Mcw) Island.

9/ 5 mo., Maidens $S$.

- 10/ 8 mo., Hook Tower.

Caught on deck,19/ 4 mo., Arklow N. Ll -ship).

Killed st., . $8 / 5$ mo., Hook Tower.

Killed, : 10/5 mo., ,"

Found dead, 10/ 5 mo., Barrels Rock Lt.-ship.

Killed st., 16/-23/5 mo., Tuskar.

". $\quad$ 9/11 mo., Blackwater Bank Lt. - sh.
$" . \quad . \quad 8 / 5$ mo., Arklow N. Lt. -ship.
Caught st., . $20 / 5$ mo., Copeland (Hew) Island.

I Supposed killed striking some time before. 


\section{Legs, Wings, eTC, Received-continued.}

Species. How Received. How Procured. Date. Name of Station.

Lesser Whitethroat, Roc'd. in flesh, .Shot, . . '1/10 mo., Tearaght.

Yellow-browed

Warbler, . . $\}$

Wool Wren, . Leg, wing, tail, " . . 27/ 5 mo., Blackrock, Mrayo.

Willow Wren, . Rec'd. inflesh, ," . . 8/ 5 mo., Old Head, Kinsale.

" " two . Legsand wings, Killed st., . 12/ 4 mo., Hook Tower.

" $\quad . \quad\left\{\begin{array}{c}\text { Rec'd. in flesh, } \\ \text { in spirits, }\end{array}\right\}$ Shot; . . 23/5 mo., Tuskar.

" "three, Rec'd. in flesh, Killed st., . 11/ 8 mo., ,"

" " ". Leg and wing, ", 15/ 4 no., Blackwater BankLt.-sh.

" ", two, . Rec'd. in flesh, Dead on deck, 17/ 4 mo,, Arklow N. Lt.-ship.

" . . " ? . 18/4 mo., Rockabill.

" . . . " ? . 24/ 4 mo., ,"

" " . Log and wing, Found killed, 24/4 mo., Copeland (Mew) Island.

" " . Rec'd. in flesh, Killed st., . 9/5 mo., Mraidens $S$.

Chiffchaff, . . " ? . 24/4 mo., Rockabill.

$\left.\begin{array}{l}\text { Golden-crested } \\ \text { Wren, . }\end{array}\right\}$ Leg and wing, $\left\{\begin{array}{c}\text { Picked up } \\ \text { alive, }\end{array}\right\} 15 / 11$ mo., Coningbeg Lt.-ship.

Leg and wing, _, . 21/ 3 mo., Maidens $S$.

". . " " " . 25/3 mo., ,

". . Rec'd. in flesh, $\left\{\begin{array}{r}\text { Caught at } \\ \text { lantern, }\end{array}.\right\} 21 / 10$ mo., Tcaraght.

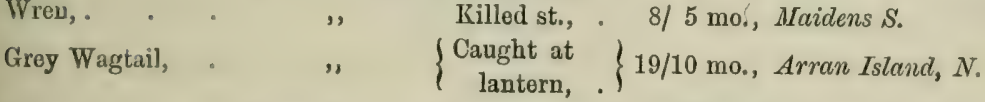

Titlark, . Leg and wing, Died on deck, $\left\{\begin{array}{c}27 / 3 \text { mo. } \\ \text { probably, }\end{array}\right\}$ Lucifer Shoals Lt. ship.

Legsand wings, " Rec'd. 19/ 8 mo.,
Wing, . Killed st., . 20/ or $26 / 2$, Mcidens $S$.

Rec'd. in flesh, $\left\{\begin{array}{c}\text { Caught at } \\ \text { lantern, }\end{array}\right\} 19 / 4$ mo., Blackrock, Mrayo.

Skylark, . . Leg and wing, Killed, . 24/10 mo, Hook Tower.

" . . . Killed st., . 14/11 mo., Blackwater Bank Lt. sh.

, ". $17 / 11$ mo., " $\quad$ " $\quad "$,

Killod, Supposed 23/2 mo., Arklow S. Lt. ship.

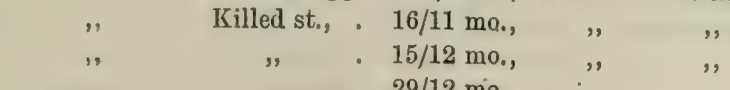

Wing, . . " " $\quad$. 12/10 mo, Arklow N. Lt. ship.

Leg and wing, $\quad$ ", . 12/12 mo., South Rock Lt. ship.

" $\quad$. $\quad 10 / 2$ mo., Maidens $S$.

" $\quad$. 14/ 2 mo., ,"

"three, . . Legs and wings, ", 20/-22/2 mo., ", 


\section{Legs, Wings, ETC., Received-continued.}

Species, How Received, How Procured. Date. Name of Station.

Skylark, . . Leg and wing, Killed st., . 12/3 mo., Maidens S.

Yellow Bunting, . Leg and wing, Killed st., 20/or26/2mo., Maidens S.

"I

Chaffinch, "

Greenfinch, .

Mealy Redpole, .

Starling,

$$
\text { " }
$$

,

$$
\text { is }
$$

$$
3
$$$$
\text { , }
$$$$
\text { , }
$$

Chough,

Rook, .

Jackdaw,

Swallow,

$$
\text { "s }
$$

Cuckoo,

,

,

Turtle Dove,
Found dead, 28/3 mo., ",

Leg and wings,

Leg and wing,

Rec'd. in flesh,

Leg and wing,

"'
",
",
",

,

,

,3

9)

,

Rec'd. in flesh

,

9

,

,

Shot, . 17/12 mo., Hoole Tower.

, . . $20 / 9$ mo., Tearaght.

Killed st., - 18/ 3 mo., Tuskar.

," . 20/ 2 mo., Maidcns S.

" . 19/12 mo., , $\quad N$.

" . 31/12 mo., Tearaght.

? $\left\{\begin{array}{c}\text { With letter } \\ \text { dated } 19 / 3\end{array}\right\}$

Caught st., . 5/11 mo., ,

Shot, . 2/12 sent, ,

$\left\{\begin{array}{c}\text { Caught on } \\ \text { island, }\end{array}\right\} 13 / 5$ mo., Innishtrahull.

Caught, . 18/5 mo., Tearaght.

Killed st., . $20 / 5$ mo., Oyster Island, S.

Shot, . - 8/5 mo., Tuskar.

Killed, . 23/ 2 mo., Barrels Rock Lt. -ship.

" . 15/11 mo., Blackwater Bank Lt. sh.

„, Supposed 23/ 2 mo., Arklow S. Lt. ship.

$\left\{\begin{array}{c}\text { Found dead } \\ \text { on deck, }\end{array}\right\} 30 / 4$ mo., Barrels Rock Lt. -ship.

Struck mast, $10 / 5$ mo., Blackwater Bank Lts.sh.

Shot, . , 15/ 7 mo., Copeland (Mew) Island.

Water-Rail, $\cdot\left\{\begin{array}{c}\text { Beak and } \\ \text { feathers, }\end{array} .\left\{\begin{array}{c}\text { Found at } \\ \text { Peregrine's } \\ \text { feeding-place }\end{array}\right\} 9 / 10 \mathrm{mo}\right.$, Tearaght.

Golden Plover, . Leg and wing, Killed st., . 11/12 mo., Maidens $N$.

Green Plover, . ", " . 22/ 2 mo., " $S$.

Woodeock, . " " . $9 / 11 \mathrm{mo}_{0}, \quad, \quad N$.

Common Snipe, . Rec'd, in flesh, ", : 25/ 5 mo., Arklow S. Ll. ship.

, " . Leg and wing, " , . "

Jack Snipe, . , , ,

Killed, - $9 / 12$ mo., Maidens $N$.

Killed st., . 11/12 mo.,

Killed, . 23/ 4 mo., Hook Tower.

Dunlin, two, . Legsand wings,

Killed st., . 15/11 mo., ,"

Rec'd. in flesh, Found dead, 25/5 mo., Arklow S. Llo-ship.

,

$"$

,

18/ 4 mo., Rockabill.

Purple Sandpiper, Leg and wing, Shot, . . 14/11 mo., Hook Towcr. 
LEGS, Wings, ETC., RECEIVED-continued.
Species.
How Received.
How Procured.
Date.
Name of Station. Purple Sandpiper, Leg and wing, $\quad$ ?
Whimbrel, . .
",

". Wing, . $\left\{\begin{array}{c}\text { Picked up at } \\ \text { Peregrine's } \\ \text { feeding-place }\end{array}\right\} 2 / 9$ mo., Tearrght.

Arctic Tern, . ", . . " ", 9/10 mo., ,

Kittiwake, . Rec'd. in flesh, $\left\{\begin{array}{c}\text { Caught at } \\ \text { light, }\end{array}\right\} 21 / 8$ mo., Aranmore.

, . . Leg and wing, $\left\{\begin{array}{r}\text { Killed at } \\ \text { lantern, . }\end{array}\right\} 16 / 12$ mo., Tearaght.

Storm Petrel, . „ $\quad\left\{\begin{array}{c}\text { Caught on } \\ \text { deck, }\end{array}\right\} 17 / 11$ mo., Blackwatcr Bank Lt. sh.

" ". Rec'd. in flesh, Caught, . 20/10 mo., South Rock Lto-ship.

" " two,. $\quad\left\{\begin{array}{c}\text { Caught at } \\ \text { lantern, } .\end{array}\right\} 15 / 8$ mo., Killybegs.

" " . " Caught st., . $20 / 8 \mathrm{mo.}$, Rathlin Island.

I.ittle Auk, . $\quad\left\{\begin{array}{c}\text { Caught in } \\ \text { mouth of } \\ \text { river, }\end{array}\right\} 27 / 11$ mo., Vidal Bank.

Puffin, young, . Leg and wing, Picked up, . 8/12 mo., Tearaght.

Teal, . . . ", Disabled st., 22/10 mo., Oyster Island, S. 
I N D E X.

Auk, Little,

PAGE

Birds not identified,

Blackbird,

"Blackeap,"

Brambling,

"Bullfinch,"

Bunting, Corn, .

, Snow, .

Chaffinch

Yellow,

Chiffehaff; .

Chough,

Cormorant,

Corn-Crake,

Crow, Hooded,

Cuckoo,

Curlew,

Diver, Great Northern,

"Ducks,"

Duulin.

Eagles,

Fieldfare

Flycatcher, Pied

"Gannet, " .

General Observations,

Golden-crested Wren,

Goldfinch, .

Grasshopper Warbler,

Greenfinch,

Greenland Falcon,

Grouse, Red,

Guillemot.

"Gulls,"

Hawfinch,

"Hawks,"

Heron,

Hobby,

Jackdaw,

Kestrel,

Kittiwake Gull,

Lark, Short-toed,

"Linnets,"

Magpic,

Manx Shearwater,

Martin, House, Sand,

Mealy Redpole,

Missel-Thrush,

Owls,

Oyster-Catcher,

Partridge,

Peregrine Falcon,
189

195

142

150

161

164

159

159

159

160

152

169

190

176

169

174

182

190

194

180

133

141

135

135

135

191

193

196

152

162

149

162

133

176

188

185

161

134

192

133

171

133

185

159

162

172

187

173

173

162

135

135

179

176

133
PAQE

Petrel, Fork-tailed, . . . 187

, Storm, . . . . 187

"Pigeons," . . . 174

Plover, Golden, . . . . 176

,"Green, . . . . 177

, Ringed, . . . 176

Puffin, . . . . . . 190

Raven, . . . 169

Razorbill, . . . . . 188

Redshank, . . . . . 182

Redstart, Black, . . . 147

, Common, . . . 146

Redwing, . . . . . 140

Ring-Ouzel, . . . . 145

Robin, . . . . 146

Rock-Pipit, . . . . 155

Rook, .. . . . 169

"Sand Larks," . . . . . 181

Sandpiper, Purple, . . . . 181

Sedge Warbler, . . . . 148

Shag, . . . . . 190

Skylark, . . . . . 155

Snipe, Common, . . . . 180

, Jack, . . . . 180

Spąrow-Hawk, . . . . 134

,. Hedge, . . 146

"Sparrows," . . . . 161

Starling, . . . . . 164

Stonechat, . . . 147

Swallow, . . . . . . 172

"Swans," . . . . . . 194

Swift, . . . . 174

Teal, . . . . 194

Tern, Arctic, . . . . 184

,. Common, . . . 184

Thrush, . . . . 136

Titlark, . . . . . 151

"Tits," . . . . . 153

Turnstone, . . . . 178

T'urtle Dove, . . . . . 174

"Twite,". . . . . 164

Wagtail, Grey, . . . . 153

"Wagtails," . . . . . 153

Water-Rail, . . . 176

Wheatear, . . . . 147

Whimbrel, . . . . 183

Whinchat, $\quad . \quad . \quad . \quad 147$

Whitethroat, Common, . . 150

," Lesser, . . . 150

filow Wren, . 151

Woodeock, . . . . 179

Wood Wren, . . . . . 151

Wren, $\quad . \quad 153$

Yellow-browed Warbler, . . 150 


\section{EAGLes.}

Aranmore.-April 2nd to 29th, "two Eagles with white band on tail and white ball on wings.--Thomas Fortune."

Greenland Falcon (Falco candicans, Gmel.).

Tearaght.-April 16th, one "Jer-Falcon" observed to S.E. towards some other islands at 4 P.M. ; wind light N.E., detached cloud, mist.

\section{Peregrine Falcon (Falco peregrimus, Tunstall).}

Mine Head.-April 13th, two Peregrines about cliffs: 21st, two.

Hook Tower.-March 11th, one Peregrine Falcon seen frequently in the autumn; they breed in the cliffs near Bagganbun, about four miles off.

Aranmore--January and February, Falcon Hawks seen occasionally, and constantly in July and August. December, one pair of Falcons occasionally.

Tearaght.-August 31st, four Peregrines at 10 A.M. ; wind light S.W. September 28th, two all day. December 27th, two all day. "Two or three Woodcock were seen lately, but not shot; the Peregrine was seen to seize one and carry it towards another island, and another day to seize another brown bird, sort not known, which he dropped in the sea when a Herring Gull chased him, and the Gull got it."

\section{Новву (Falco subbuteo, Linn.).}

Lucifer Shoals Light-ship.-May 23rd, one Hawk rested at noon; wind light S.E., clear; died on board next day.-J J JMES BYRnE. [Skin of Hobby received.]

\section{Kestreu (Falco tinnunculus, Linn.).}

Hook Tower:-January 22nd, one about station. March 3rd, two: 12th, two all day. April 1st, and September Sth and 24th, one. October 8th, two.

Rathlin Island.-April 19th. [Leg and wing of Kestrel received, killed striking at 10 P.M.]

Aranmore.-January and February, Kestrels seen occasionally, and constantly in July and August. 
Blackrock, Mayjo.-October, "I am sending you two birds shot on the 11th inst., as I thought they were strange ones.RichaRd Widdicombe." [Kestrel and Short-toed Lark received in flesh.]

Arran Island, N.-July 28th, one Kestrel going S. August 2nd, two on rock: 6th, two going E. September 8th, one on rock.

Tecoraght.-July 31st and August 11th, one. August 31st, four Peregrines and one Kestrel at 10 A.M.; wind light S.W. December 30th, one Kestrel.

\section{Sparrow-Hawk (Accipiter nisus, Linn.).}

Mine Head.-October 26th, saw a Sparrow-Hawk pounce on a young Blackbird: 29th, two going $\mathrm{S}$.

Hook Tower.-October 26th and November 1st, one.

Arklow North Light-ship.-October 16th, "one large Hawk, Sparrow-Hawk," came from W. at 8.30 A.M. ; rested on mainmast and went S.E. ; gale N.W., clear.

Copeland (Merv) Island.-November 7th, a small Hawk, perhaps a Sparrow-Hawk, observed on island: 9th, SparrowHawk on island.

Oyster Island, S.-October 28th, one going W.

Tearaght.-October 7th and November 16th, one SparrowHawk.

\section{"Hawks."}

Mine Head.-March 8th, 15th, and April 1st, 22nd, and 25th, one or two noted.

Tuskar.-March 11th, one Hawk killing small bird on the rock : 22nd and 29th, one on rock. April 7th, one flying W. at 10 A.M. ; gale N.: 19th, one large Hawk on the rock at 7 A.M. ; wind light S.E. October 27th, Hawk shot.

Lucifer Shoals Light-ship.-March 22nd, one following a Chaffinch at 6.30 A.M.; wind light S.W., clear. September 21st, one about ship at 5 P.M. following a small bird; wind light 'W., clear.

Arllow South Light-ship.-March 28th, one about ship at 7 P.M. ; wind S., fog. June 11th, one going N.

Copcland (Mcw) Island.-November 11th, a large Hawk on west part of island at noon. 
Innishtrahull. - March 25th, and April 4th and 29th, a "Merlin Hawk" on island.

Slyne Head, S.-March 26th, large mottled grey and white Hawk ("hooded") going N.E. at 9.30 A.M.; gale W., clear. April 6th, one Common Hawk going E. : 8th, two do. going E. 25th, one large Hawk going E. at 2 P.M.; flew from island; strong breeze N.W., clear; Sen Parrot found killed by large Hawk at same time. August 1st, one Hawk going N.E. 2nd, one Common Hawk going E. October 18th, one Common Hawk on island: 22nd, one do.

Arran Island, N.-May 15th, one Hawk going E. November 27th, one Hawk and one hundred Linnets going $W$. at 10 A.M. ; wind light E., snow.

Shelligs.-October 1st, one large Hawk going W.; wind strong W.

\section{OWLS,}

Mine Head.-November 9th, two Owls flying S. at 4 P.M.; wind light $\mathrm{N}$, clear.

Maidens South.--March 12th, one Qwl going S.W. at 11 A.M.; fresh breeze W., gloomy.

Spotted Flycatcher (Muscicapa grisola, Linn.).

Tuskar.-[May 23rd, Spotted Flycatcher received in flesh, in spirits; shot.]

Red-breasted Flycatcher (Muscicapa parva, Bechst.).

Tearaght.-October 20th, one small bird shot at 11 A.м.; wind light N., blue sky, detached cloud. [Red-breasted Flycatcher received in flesh.]

Pied Flycatcher (Muscicapa atricapilla, Linn.).

Tuskar:-August 7th, a bird shot and sent. [Pied Flycatcher received in flesh.]

\section{Missel-Throsh (Turdus viscivorus, Linn.).}

Hook Towcr.-December 16th, one shot; not a usual visitor at this station-[Leg and wing received]. A few seen during the latter part of this month.

Rockibill.-March, great rushes of Missel-Thrushes and other birds (see under Blackbird). 
Maidens South.-February 20th to 22nd, great rushes of Thrushes and other birds (see full note under Common Thrush) -[Leg and wing of Missel-Thrush received]: 26th, Thrushes about light. [Leg and wing of Missel-Thrush received.]

\section{Thrush (Turdus musicus, Linn.).}

Mine Head.-October 21st, six going E. ; two killed.

Hook Tower:-October 16th, Song Thrushes about lantern; gale N.W.: 26th, one Song Thrush killed striking; gale N.W. [Leg and wing received]. November 17th, many round light; wind moderate S.W., misty; two killed. December 15th, Thrushes and Blackbirds round light all night; one Thrush killed; wind fresh N.W. Many seen daily during latter part of month; frost.

Coningbeg Light-ship.-November 15th, about half a dozen round lantern; one killed striking; wind light S.W., clear: 18th, many round the light; three killed; wind light S.TW. [Leg and wing received]. December 5th, 9th, and 14th, many round light; some killed; wind moderate to. fresh E., cloudy. The birds left at daybreak.

Barrels Tiock Light-ship.-February 22nd, some round light: 23rd, 24th, 25th, and 26th, some killed striking ; wind moderate to fresh N.E. [Leg and wing received.]

Tuskar.-February 19th, a flock at light; some killed; wind strong S.E. : 21st, do., with Starling: 22nd, two killed striking; wind light S.E., overcast. March 11th, Thrushes at the light all night; wind fresh S.W.: 17th, five all night: 18th, Thrush killed striking-[Leg and wing received]. October 15th, several going W.; wind strong N.W.: 18th, one; gale N.W.: 20th, 21st, and 23rd, large number of Thrushes, Blackbirds, Starlings, and Redwings round light each night; seemed to be mostly this year's birds; wind light N., clear. November 4th, 7 th, and 10th, great rushes (see under Starling): 1.4th, great numbers, with other birds, all night, striking, several killed; gale S., fog.

Livifer Shoals Light-ship.-March 15th, several, with Blackbirds, round lantern at midnight; wind light S.W., clear; none struck. October 23rd and November 5th, some going N.W. : 16th, some about lantern; calm, fog. December 15th, one at 10 P.M. ; died on deck; wind moderate N.E. 
Blachater Bunk Liyht-ship.-April 5th, several: 20th, six about light 10.30 1.M. to midnight; wind fresh S.W., gloomy. November $7 \mathrm{th}$, flocks going N.W. between 10 A.M. and 2 1'.Mr.; wind strong N.W.: 10th, several Thrushes, Blackbirds, and Starlings about light from 10 P.M. to midnight; several killed; strong gale S., rain: 11th, six Thrushes about light 10 P.M. to midnight; two killed; strong breeze W., clear: 13th, 14th, 15th, and 16th (see under Blackbird)-[Leg and wing of Thrush killed on 14th received]: 17th, several (see under Lark) : 18th and 19th, four about light. December 9th, flock going W.: 10th, Blackbirds, Thrushes, Larks, and Starlings about light from 7 P.M. to daylight; went N.W.; wind moderate S., hazy; ninteen killed, three disabled-[Leg and wing of Thrush received]: 11th, a flock (see under Blackbird): 12th, several flocks, with Larks and Linnets, going N.E.: 14th, flocks going N. at 11 A.M. : 16th, a few at light, with Blackbirds; five birds killed: 20 th, flock going W.: 24 th, some about light (see under Starling) : 29th, one flock going N.W.: 30th, two flocks of Thrushes going S.W.; gale E.

Arklow South Light-ship.-February 19th, four killed striking between 8 P.M. and midnight: 22nd, one killed striking: 23rd, continuous flocks of Thrushes and other birds going N.IV. and striking (see under Starling). [April 3rd, Leg and wing of Thrush received, found in ball at masthead; believed to have been killed on February 23rd.] October 13th, several Thrushes, Blackbirds, and Larks; seven killed; wind moderate S.W., clear; "the first birds seen since June": 17th and 18th, one or two about ship all day: 19th, Starlings, Thrushes, and Blackbirds about light 8 P.M. to midnight; wind light N.N.E., clear; a great many killed. November 10 th and 11th, several at night; gale S.; several killed striking fell overboard, two on deck: 13th, one about ship: 19th, a few small birds about light; one killed on deck, several fell overboard-[Leg and wing of Thrush received]: 29th, some going N.W. December 2nd, 3rd, 4th, 5th, 6th, and 7th, several about light (see under Starling): 9th, a few about lantern; wind light S.E., clear: 12 th, one killed striking at 1.30 A.M.: 13th, one killed striking at 2 A.M.: 16th, several Thrushes and Blackbirds about lantern during night; wind light E., clear; several killed striking: 17th and 18th, one noted: 20th, some going 
N.W. during day: 31st, Starling and Thrushes going N.E. during day.

Arklow North Light-ship.-April 20th, several about light midnight to 4 A.Mr; one killed striking-[Leg and wing of Thrush received]. October 19th, Thrushes, Larks, Starlings, Blackbirds, and "various kinds" about light from 8 P.M. to midnight; wind light N.E., gloomy; several struck and fell overboard. December 22nd, several, with Skylarks, about light from 4 A.Mr., also during day: 31 st, three rested.

Kish Bank Light-ship.-March 18th, several, with Larks, about light; Thrush and Lark killed (see under Lark).

Howth Buily.-October 22nd, several, with Larks, at 10 P.M., struck but not killed. November 8th, a few all day: 10th, rush at night (see under Blackbird): 16th, some all day, remaining.

Rockcuill.-March, great rushes of Thrushes and other birds during early part of month; numbers killed striking east side of lantern.

South Rock Light-ship.-March 12th, several, with Larks, about light; gloomy. November 10th (see under Redwing). December 11th, flocks, with Larks, about light at 9.30 P.M.; about twenty killed and fell overboard; fresh breeze S.E., dark: 12th, flocks, with Starlings and Larks, about light at 11 P.M.; about thirty killed and fell overboard; wind light S., hazy: 13th and 14th, flocks, with Larks, about light: 18th, flocks of Green Plover, Thrushes, and Curlew about light at 8 P.M.; Thrushes killed in great numbers, and fell overboard; did not get one; strong breeze S.E., hazy and sleet: 20th, a flock going N.W. at noon.

Copelend (Mow) Island.-January 27th, some through rays of light at 10 P.M. ; hazy. February 14th, numbers, with Blackbirds, round lantern: 17th, numbers: 20th, remarkable rush of birds, including Thrushes (see full notes under Lark): 22nd, large numbers round light: 25th, some striking. April 20th, all the Thrushes left islaud. October 10th, Thrush on island: 13̣th, one. December 11th, 12th, and 13th, Thrushes killed striking (see full note under Lark): 19th, some, with Larks and Blackbirds, about light and striking; wind light S.E.

Mailens South.-February 14th, some round light; hazy: 20th, 21st, and 22nd, "great rushes of birds, chiefly Thrushes, Blackbirds, liedwing, Curlew, Lapwing, Starling, Skylarks, and 
Yellowhanmers; one hundred and ten Skylarks, fourteen liedwing, six Thrushes, eleven Blackbirds, eight Starlings, three Yellowhammers, two Lapwings killed-[Leg and wing of Thrush received]-Bradley Sole": 26th, Thrushes, Blackbirds, Redwing, Curlew, and other small birds about light all night; weather gloomy; one Thrush, three Redwing, two Blackbirds, and one Yellowhammer killed - [Leg and wing of Thrush received]-(see also under Missel-Thrush). March 12 th, some round light; wind light W., gloomy. December

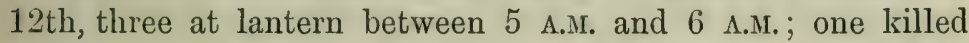
striking: 18th, nine on rock at 3 A.M. ; flew to land; gale S.E., snow.

Maidens North.-November 17th, large flocks, with Blackbirds, passed lantern going E. at 10 P.M.; fresh breeze W.; one of each killed. December 19th, one killed at 8 P.M. going N.E. [Leg and wing of Thrush received.]

Innishtrahull.-March 13th, two on island; gale S.W. December 9th, two struck glass at midnight; one disabled: 12th, one struck: 19th, a few, with Blackbirds and Fieldfares, on island. "These birds are very scarce this winter."

Aranmore.-January, February, and March, not very numerous. November 1st, three. December, a few seen daily.

Killybegs.-February 17th, one killed striking. March 12th, do. November 20 th, two at lantern at 10.30 P.M.

Oyster Island, S.-November 14th, one going S.W.: 17 th, one killed striking at 1 A.M. going S.E.-[Leg and wing received]. December 23rd and 27th, some all day.

Slyne Hcad, S.-October 17th, one; first this year; fresh breeze N.W. November 13th, Thrushes, Blackbirds, and Starlings on island all night; scores killed striking of each kind; strong breeze S.W., misty; Linnets and Chaffinches on island all day. "Thrushes every day to the end of month."

Arran Island, N.-November 14th, flocks at light; thirtytwo killed striking: 15th, Thrushes and Blackbirds all day. December 31st, about five hundred Thrushes, Blackbirds, I'lover, and Wrens here all day on account of the heavy frost and snow; two Starlings struck; nearly all the birds left next day on account of thaw.

Arren Island, S.-October 21st, twelve; two killed. They remain all the year. 
Tectroyltt.-January 11th, one all day-[Leg and wing of Thrush received; "caught in rabbit-trap."] October 20th, some, with Larks, flying through rays of light, 10 p.x. to midnight; four Thrushes struck; none killed: 23rd, four all day. November 10th, flocks of Thrushes (see full note under Starling): 23rd and 24th, Thrushes and Blackbirds all day; wind fresh S.W. November and December, Thrushes, Blackbirds, Fieldfares, Starlings, etc., in large numbers on island: 19th, intense frost and snow on mainland, one supposed to be killed in rabbit-trap. [Leg and wing received.]

Sliciligs.-November 20 th and 21st, flocks, with other birds, on rock. December 16 th to 26 th, numbers on rock; weather generally gloomy and misty: $27 \mathrm{th}$, Thrushes and Redwings left during night.

REDWInG (Turdus iliacus, Linn.).

Hook Tower:-February 18th, a number at lantern; one killed. March 3rd, some all day. October 16th, some at lantern; gale N.W. December 6th, one killed-striking-[Leg and wing received]. During latter part of December a great many Redwings, Song Thrushes, and a few Blackbirds and Fieldfares seen daily round here, owing to the severe frost.

Tuskar.-October 20th, 21st, and 23rd, a number with other birds round light, seemed mostly this year's birds; wind light N., clear. November 4th and 7th, a number with other birds passing N.W. all day; some killed on 4th.

Blackwater Bank Light-ship.-December 24th, "Thrushes" with other birds abont light; wind moderate N. [Leg and wing of Redwing received; killed striking.]

Rockabill.-March, great rushes of birds, including Redwings, during early part of month; great numbers killed against east side of lantern. "We collected a hamperful" (see under Blackbird).

South Rock Light-ship.-November 10th, large flocks about light at 11 P.M.; gale S., rain; killed in great numbers and fell overboard, one got on deck. [Leg and wing of Redwing received.]

Maidens South.-February 13th, numbers, with Larks, at light: 20th, 21st, 22nd, and 26th, great rushes of birds (see full notes under Thrush); seventeen Redwings killed. March 10th, one on rock.

Innishtrahull.-March 13th, two struck at 1 A.M.; gale S.W. 
Oyster Island, S.-December 27th, some all day.

Arran Island, N.-October 10th, two "Mountain Thrushes" killed striking at midnight. [Possibly Redwing.]

Tearaght.-October 21st, one at 9 A.M.; rush of birds preceding night (see under Blackbird). November 10th, flocks (see full note under Starling). December 14th, one killed striking at 10.30 P.M. ; wind light S.E., blue sky-[Leg and wing received]: 31st, two struck; hail and snow.

Skelligs.-December 16 th to 26 th, numbers on rock; weather generally gloomy and misty; one killed striking on 21st: 27 th, Thrushes and Redwing left during night.

\section{FieldFare (Turdus pilaris, Linn.).}

Hook Tover,-February 18th, some at light; some canght. March 3rd, some all day. November 15th, six Blackbirds and a Fieldfare killed striking; wind light S.W. Many birds round the light. December 6th, one killed striking-[Leg and wing received]: 9 th, one do.; wind light N.E. A few seen daily during latter part of month; severe frost.

Arklow South Light-ship.-December 9th, one killed striking at 6.30 A.M. ; wind light N.E.; the first seen-[Leg and wing received]: 20th, some with other birds going N.W. during day.

Kish Bank Light-ship.-March 18th, one "Mountain Thrush" (? Fieldfare) killed striking at 1 A.M.

Copcland (Mow) Island.-April 20th, one found killed; several on island. [Leg and wing received.]

Maidens South.-January 20th, eleven on rock; gale W.; were very much exhausted; attempted several times to reach mainland.

Mfaidens North.-December 19th, one Blackbird killed striking at 8 P.M. [Leg and wing of small Fieldfare received.]

Innishtrahull.-December 19th, a few, with Blackbirds and Thrushes, on island. "These birds are very scarce this winter."

Oyster Island, S.-December 27th, some on island all day.

Arran Island, S.-December 15th, twenty-five "Fairfields" on island at noon, first seen this year; wind light N.: 24th, eighteen on island; wind light N.E.

Tcaraght.-November and December, numbers on island; frost and snow on mainland. December 8th-[ Leg and wing of Fieldfare received]. 
BlackBird (Turdus merula, Linn.).

Mine Head.-March 30th, four flying W. October 20th, twelve flying $\mathrm{S}$.

Hook Tower.-February 15th, some at light; one killed. March 3rd, some all day. October 26th, one disabled by Sparrow-Hawk-[Leg and wing received]. November 14th, three killed striking; gale S.W.: 15th, six killed striking; wind light S.W.; many birds round the light. December 6 th, one "female" killed striking; gale S.E. [Possibly Fieldfare]: 15th, some at light; wind fresh N.W. A few seen daily during latter part of month; severe frost.

Coningbeg Light-ship.-November 6th, one cock flying N.E. December 14th, many at light: 28th, several round the ship; flew to land; wind light N.E.

Barrels Rock Light-ship. - February 21st, some at light. Blackbirds round the light on the 22nd, 23rd, 24th, 25th, and 26th; some killed; wind moderate to fresh E. to N.E. [I.eg and wing received.]

Tuskar.-February 25tlı, some at lantern; gale N.E. March 11th, many striking all night; wind fresh S.W.: $22 \mathrm{nd}$, two at light: 24th, two do. October 16th, great rush of Blackbirds, male and female, fine large birds; several killed; strong gale N.W., showery: 20th, 21st, 23rd, numbers with Thrushes, Starlings, and Redwings round light,-birds seemed mostly this year's; wind light $\mathrm{N}$, clear: 27 th, one. November 4 th and 7th, numbers with other birds passing N.W. all day: 14th, Blackbirds, Thrushes, Starlings, and Larks about light all night, great numbers killed; gale S., fog and rain.

Lucifer Shoals Jight-ship.-March 15th, several, with Thrushes, round lantern at midnight; clear, none struck: 17th, several Blackbirds round lantern at 9 P.M. ; wind light S.W., sleet[Legs and wings of two received]. November 15th, one on ship, flew to land: 16th, several, with Thrushes and Starlings, at midnight; fog. December 16th, one killed at lantern.

Blackwater Bank Light-ship. - April 5th, several, with Thrushes, about light from 10.30 P.M. to midnight; wind moderate S.W.: 16th, six about light: 17th, two do. November 7 th, flocks going N.W. between 10 A.M. and 2 P.M.; strong breeze N.W.; clear: 10th, several about light, some killed; strong gale S. : 13th, several, with Thrushes, alout light 
10 P.M. to midnight; wind light S.W., clear; six killed-[Leg and wing of Blackbird received]: 14th, several, with Thrushes, Larks, and Starlings, about light midnight to 4 A.Mr.; wind light S.W. to S.E., gloomy; many killed: 15th, flocks, with Thrushes and Starlings, about light 10 P.M. to midnight; wind light S.E., gloomy; many killed: 16th, flocks, with Thrushes and Starlings, about light midnight to 4 A.M. ; fresh breeze S.E., rain; many killed. December 10th, some about light with other birds all night, went N.W.; several birds killed, hazy-[Leg and wing of Blackbird received] : 11th, three flocks during day going N.W. ; strong breeze S.E., hazy,-Blackbirds, Thrushes, Starlings, and four Larks from 6 P.M. to daylight about light; seven killed; birds left at daylight and went N.W.; calm: 16th, some, with Thrushes, at light at 7 r.M. ; wind moderate S.E., gloomy; five killed : 24 th, some about light (see under Starling).

Arklow South Light-ship.-February 23rd, continuous flocks Starlings, Blackbirds, etc, going N.W.; some striking (see full note under Starling). April 3rd, one found in ball at masthead; believed to have been killed February 23rd-[Leg and wing received]. October 13th, several Thrushes, Blackbirds, and Larks; seven killed; wind moderate S.W., clear; "the first birds seen since June": 19th, a number, with Starlings and Thrushes, 8 P.M. to midnight; wind light N.E., clear; a great many birds killed: 20th and 21st, one noted. November 5th, several going N.W. in the forenoon; strong breeze N.W., clear: 15th, one about ship - [Leg and wing received; killed striking on 16th]: 21 st and $25 \mathrm{th}$, one or two going N.W.: 29th, some, with Thrushes, going N.W. December 2nd to 7 th, several at light: 9 th, a few about, lantern: 16th, several, with Thrushes, at lantern, some killed; clear: 20th, some going N.W. (see full notes under Starling): 22ud, flocks, with Larks, going N.W. during day.

Arlilow North Light-ship.-October 19th, rush of birds about light, Blackbirds, etc. (see under Starling). November 3rd, one, and a Yellowhammer on ship at 8.30 A.M. ; wind moderate S.W., rain.

Houth Baily.-November 10th, flocks, with Thrushes, from 8 Г.м. to midnight; several striking and some killerl; gale S.W., haze and rain: 16th, some all day, remaining. 
Rockabill. - "Some great rushes of Blackbirds, Thrushes, Redwings, Starlings, Missel-Thrushes, Chaffinches; Grey and Green Linnets, and Curlew during the early part of March; great numbers were killed striking against the $\mathrm{E}$. side of lantern; we collected a hamperful.-JoHn Hamiton." (Letters, April 23rd and May 16th.)

South Rock Light-ship.-March 24th, one found killed; fresh breeze S.E.: 27 th, one found killed at midnight; fresh breeze S.W. April 13th, flocks about light; sixty killed striking, and fell overboard; wind light S.E., clear, rain.

Copeland (Merv) Island.-February 14th, numbers of birds flying round lantern during first part of night; mostly Blackbirds and Thrushes; wind light S.E., misty: 17th, numerous about light; wind E., misty: 20th, "immense swarms" of Blackbirds and other birds (see full note under Lark) : 22nd, large numbers of Blackbirds and Thrushes round lantern at 10.30 P.M. ; wind light S.W., misty: 25th, large numbers, with Thrushes and Starlings, striling; wind light E., misty. April 20th, Blackbirds still plentiful on island. May 9 th, four or five Blackbirds' nests found. November 9 th, one caught: 13th, several flying round light; misty. December 8th, one, with white feather in tail, found killed: 9 th, plentiful up to 5 A.M. ; calm and hazy: 12 th and 13th, some killed striking.

Maidens South.-January 19th, three on rock; hurricane from W., gloomy. February 14th, some at light; hazy: 20th, 21st, and 22nd, great rushes of Blackbirds and other birds (see full note under Thrush); eleven Blackbirds killed--[Legs and wings of two received]: 26th, some at light; two killed. March 12th, Blackbirds, Thrushes, and Larks round light; wind light W., gloomy: 21st, some about light; cloudy: 28th, one all day. October 22nd, one killed striking; misty. November 11th, one going S.W.: 13th, one at lantern. December 12 th, one do.

Maidens North.--November 17th, large flocks Thrushes and Blackbirds passing lantern going E. at 9.45 P.M.; fresh breeze W., misty; one of each killed. December 19th, one killed striking.

Innishtrahull.-March 10th, one on island: 13th, four, and two Redwings striking lantern at 1 A.M., one killed; gale S.WT. 
[Leg and wing of Blackbird received] ; six on island; gale S.W.: 16 th, one and one Skylark struck at 1 A.M. November 12th, one struck at 4 A.M. December 19th, a few, with Thrushes and Fieldfares, on island. "These birds are very scarce this winter." Aranmore.-January,February, and March, not very numerous. Novernber 1st, two. December, a few seen daily.

Killybegs.-November 20th, one at lantern.

Oyster Island, S.-November 4th, one disabled striking at 2 A.M. ; wind strong S. [Leg and wing received]. December $23 \mathrm{rd}$, some on island; frosty.

Slyne Head, S.-November 7th, one female; gale N.W. : 13th, Thrushes, Blackbirds, and Starlings on island all night; scores killed striking of each kind; strong breeze S.W., misty.

Arran Island, N.-November 5th, one on island: 15 th, some on island. December 31st, numbers all day; frost and snow (see full note under Thrush).

Arran Island, S.-October 22nd, fifteen going E., five killed; wind light N.E., misty; they breed on island.

Tcaraght.-October 20th, several Blackbirds, Thrushes, Starlings, and Larks round light; four Thrushes struck, none killed; wind light $\mathrm{N}$. (see also under Lark) : 21st, one noted. November 10 th, great flocks Starlings, Blackbirds, etc. (see full note under Starling): 23rd and 24th, some, with Thrushes, all day; fresh breeze S.W. Numbers here during November and December; intense frost and snow on mainland. December 21st, one. [Leg and wing received.]

Skelligs.-November 20 th and 21st, flocks, with Starlings and Thrushes, on rock at 10 A.M.; fresh breeze N.E., gloomy. December 16th to 26th, large number Thrushes, Redwings, Blackbirds, and Starlings on rock; wind variable, weather generally gloomy and misty : 27th, Tnrushes and Redwings left during night, ouly Starlings and Blackbirds remain; fresh breeze E, gloomy.

\section{RING-OdzeL (Turdus torquatus, Linn.).}

Hook Tower.-April 17th, three Ouzels flying about at 2 P.M., one male and two females. One bird had a well-defined white mark on the throat. They stayed about two days. A farmer in the neighbourhood told me that the Ouzels flew into his kitchen and could easily have been caught. 
Tuskar,-April 1st, one Ring-Ouzel flying E. at 9 A.Mr.; wind light S.: 14th, Ring-Ouzels round the light; wind strong S.E ; four killed striking.

Copeland (Mew) Island.-April 14th, Ring-Ouzel found dead at base of tower, killed striking; another found wounded previous night; weather thick, wind S.E. [Leg and wing of Ring-Ouzel received]. "The Ring-Ouzel visited us this spring. It is somewhat remarkable. Several were killed. A wounded one was on the island about a fortnight."

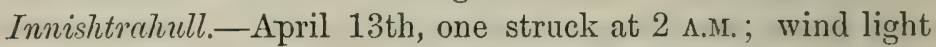
S.E.

Hedge Sparrow (Accentor modularis, Linn.).

Copeland (Mew) Island-January 31st, Hedge Sparrow noted. November 27th, Hedge Sparrow on island.

Maidens South.-March 26th, two on rock at 10 A.M.

Tearaght.-September 23rd, "four Black Wrens (Hedge Sparrows)" at 10 A.M. ; wind light N.W.

Robin (Erithacus rubecula, Linn.).

Coningber Light-ship.-December 29th, one Robin about ship

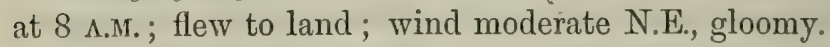

Tuskar:-February 24th, one on rock all day; wind moderate N.E.

Arklow North Light-ship.-March 18 th, one on deck at 9 A.M.; wind light S.E. April 19th, one at 8 A.M. (Several small birds about light on nights preceding both above dates.)

Rockabill.-May 16th, "a Robin and Wren on rock."

Copeland (Mew) Island.--January 21st, one found killed in gas-yard. September 12 th, one on island for last few days. November 9th, Robin still on island.

Slyne IIcad, S.-September 21st, one on island all day; strong breeze N.W. November 10 th, one on island.

Arran Island, N.-October 27th, one on island.

Arran Island, S.-December 15 th, one remains on island.

Tecrarlt.-Deptember 29th, one at 11 A.M.; fresh breeze W.

Redstart (Ruticilla phonicurus, Linn.).

Tockibill.-April 23rd, Redstart found dead; must have been killed striking-[Common liedstart received]. "A heautiful male Redstart on the rock during the past few days." 
Black Redstart (Ruticilla titys, Scopoli).

Tearaght.-October 11th, one Blackstart; fresh breeze S.W.

Stonechat (Pratincola rubicola, Linn.).

Hook Tower.-December 17th, one shot. [Leg and wing received.]

Barrels Rock Light-ship. - February 17th, a small flock remained some time on the ship, and flew to the N.E.; wind moderate S.E., clear : 22nd, three flying N.E.

Kish Bank Light-ship.-March 17th, small bird disabled striking at 11 P.M. ; fresh breeze S.W., cloudy : 18th, several of the same sort about lantern at 11 P.M. ; wind light N.E.; one disabled striking. [Leg and wing of Stonechat received.]

South Rock Light-ship. - March 29th, one Stonechat about ship.

Copreland. (ITew) Island.-November 27th, a pair on island.

Killybegs.-March 31st,'one flitting about broken-down walls; first olserved this year. October 5th, last Stonechat observed this year.

Slyne Head, S.-March 19th, several arrived to breed on island; wind light N.: 28th, scores of Stonechats and Linnets on island all day; wind moderate S.W., cloudy. [Probably Wheatears.-R. M. B.]

Arran Island, N.--" Stonechatters" breed here.

\section{Whinchat (Pratincola mebetra, Linn.).}

Mine Head.-April 16th, two Whinchats flying S.

Blrchwater Bank Light-ship.-November 9th, several small birds about light 11 P.M. till midnight; fresh breeze N.N.W., clear; three killed. [Leg and wing of Whinchat received. See also under Whitethroat and Sedge Warbler.]

\section{Wheatear (Saxicola conanthe, Linn.).}

Mine Hcad.-March 26th, two about station. April 26th, four flying $\mathrm{S}$.

Hook Tower.-March 12th, two about rocks: 16th, five. September 13th, two about rocks. "Wheatears come here about the middle of March, but there were not many this spring."

Tusliar.-March 17th, one all night: [18th, Leg and wing 
received; killed striking]: 29th, two all day on rock. April 14 th to 19 th, two or three frequently on rock.

Lucifer Shouls Light-ship.-March 17th, one small bird killed striking at midnight; wind moderate S.W., showers. [Wheatear received in flesh.]

Blackwater Bank Light-ship.-April 16th, two on ship.

Arklow South Light-ship.-April 12th, a few small birds about lantern at 11 P.M. ; wind light S.W., clear-[Wheatear received in flesh]: 19th, one bird same as that sent on 12 th died on deck.

Arklow North Light-ship.-April 17th, several small birds at midnight to 3 A.M.; one "Chitchat" caught; also several "Tits and Chaffinches" about ship 9 A.M. to 5 P.M.; wind light N.E.; several struck fell overboard, three dead on deck. [Wheatear and two Willow Wrens received in flesh; Wheatear was labelled "Chitchat."]

Rockabill.-[April 18th, two, and 24th, three Wheatears received in flesh.]

South Rock Light-ship.-March 20th, one dead on deck (see under Starling). April 14th, twelve at light at 1 A.M.; four killed striking; wind light S.E.

Copeland (Mew) Island.-April 2nd, first observed this year: 18th, one found killed. May 6th, several on island: 9th, a few. August 10th and 19th, two.

Maidens South.-[May, Sth, leg and wing of Wheatear killed striking received; seems large.]

Innishtrchull.-March 2Sth, two at noon, first arrivals; wind light S.W. April 4th, nine: 13th, one struck glass at 2 4.M. May 9 th and 13 th, one do. each night. June 7 th, young Wheatears on island.

Aranmore.-March 26th, two seen.

Terraght.-March 29th, first for season at noon; wind light S. July 29 th, one "Whinchat" found dead, apparently killed striking some time ago-[Leg, wing, and tail of Wheatear received]. September 14 th, one, and 15 th, two, caught at lantern-[Leg, wingss, and tail reccived]: 17th, 18th, and following days, Wheatears all day.

Sedge Warblel: (Acrocephlelus phrergmitis, Bechst.).

Hook Tourr.-May Sth, one killed striking; wind moderate 
S.E. [Leg and wing received]: 10th-[Leg and wing received]: 20th, a small bird killed against lantern at night - [Sedge Warbler received in flesh]. August 10th, six Sedge Warblers and one Grasshopper Warbler killed striking; wind moderate S.E., misty. [One Sedge Warbler received in flesh.]

Tuskur.-April 13th, one "Warbler" at light killed striking, and one in daytime on rock: 17th, two "Warblers" found dead. [May 16th to $23 \mathrm{rd}$, about ten received in Hesh; killed striking.] August 8th to 11th, twenty killed striking. [Received in flesh.]

Blucliwuter Banki Light-ship,-April 17th and 18th, several Selge Warblers about light between 10 P.M. and midnight; wind moderate N.E., gloomy. November 9th, several small birds about light 11 P.M. to midnight; fresh breeze N.W., clear; three killed. [Legs and wings of Sedge Warbler, Whinchat, and Whitethroat received.]

Arklow South Light-ship.-April 17th, one "Sallypicker" about ship: 18th, several "Sallypickers" about lautern from 8 P.M. till midnight; wind moderate N.E., hazy : 19th, two do. about ship: 20th, one do. caught at lantern. May 25th, two "Sallypickers" and one Snipe killed striking; wind light N.E., hazy-[two Sedge Warblers received in flesh]. October 1Sth, one "Sallypicker" about ship all day.

Arklow North Light-ship.-May 9th, a few small birds about light from 2 A.M. to 4 A.M.; wind light N.E., rain; two killed striking. [Two Sedge Warblers received in Hesh.]

Copeland (MIew) Island.-May 8th, three small birds killed agrainst glass. [Leg and wing of Sedge Warbler received.]

Muidens South.-May 9th, two Sedge Warblers killed striking. [Received in flesh.]

Grassiiopper Warbler (Locustella navia, Bodd.).

Hook Tower.-August 10th, one Grasshopper Warbler killed striking; wind moderate S.E., misty. [Received in flesh.]

Arliow North Light-ship.-April 19th, one "Wren" canght on deck at 10 А.M. ; died in cabin; wind light S., gloomy -[Grasshopper Warbler received in flesh]. May Sth, one Grasshopper Warbler on deck at 8.50 A.M. ; wind light N.E., clear. 
Whi'éminoat (Sylvia cinerea, Bechst.).

Hool Tower--May Sth, one killed striking-[Leg and wing received]: 10th-[Leg and wing of one killed received].

Barrels Rock Light-ship.-May 10th, one found dead. [Leg and wing received.]

Tuskar.-May 16th to 23rd, about fifteen Whitethroats killed striking. [Received in flesh.]

Blackwater Bank Light-ship.-November 9th, several small birds 11 P.M. to midnight; fresh breeze N.W., clear; three killed. [Leg and wing of Whitethroat received. See also under Whinchat and Sedge Warbler.]

Arklow North Light-ship.-May 8th, several small birds about light at 10 P.I.; wind light N.E., light haze. [Whitethroat received in flesh.]

Rockctill.-May 16th, "small bird sent; six of the same species killed last night; wind S., foggy." [Whitethroat received in flesh.]

Copeland (Mew) Island.-May 19th, small birds striking glass and flying through rays until midnight; rain and thick haze. One came in through lantern door-a Whitethroat. There were a great many of these flying through rays; I suppose forty or fifty-[Whitethroat received in flesh]. October 12th, small bird like Whitethroat against glass about 3 A.M.

Lesser Whitethroat (Sylvia curruca, Linn.).

Tcarcught.-October 1st, a small bird, supposed to be "Lesser Whitethroat" shot at 4.15 P.Mr.; blue sky-[Lesser Whitethroat received in flesh]. "It was not observed by any one before that evening, and was then hopping about the yard, and flew to some rocks; seemed to be looking for food. We knew the bird to be a peculiar one-W. H. JAMES."

\section{"Blackcap."}

Thuslicur.-February 22nd, one Blackcap all day on rock; overcast; 'wind light S.E. : also on the 25th, wind strong N.E.

Yellow-Browed Warbleir (Phylloscopus supcriciliosus, Gmel.).

Tearayht.-October 14th, "I forward a very small bird shot by my son at 10.45 A.M. ; wind light N.N.W., blue sky, detached 
clond. It was first observed on a marsh mallow bush[Lavaterce crborec grows near summit of Tearaght liockI. M. B.] - as if seeking for insects; it then flew to some rocks, where it was shot. The only bird I can find in books to answer it is the Dalmatian regnulus. I weighed it, and it only weighed 1 drachm 11 scruples. It is the smallest bird I ever saw. I put it in spirits at once after getting it.-W. H. J MMES." [Yellow-browed Warbler received in flesh. Mr James is to be congratulated on having added two birds to the Irish list in 1890.- R. M. B.]

Wood Wren (Phylloscopus sibilatrix, Bechst.).

Blackrock, Mayo.-May 27th, "a bird shot on rock, never saw one like it before.-Ricinnd Widdiconbe." [Leg, wing, and tail of Wood Wren received.]

\section{Willow Wren (Phylloscopus trochilus, Linn.).}

Old Head, Kinsale.-[May Sth, Willow Wren received in flesh, shot.]

Hook Tower.-A pril 12th, Chiffchaffs round the light all night; ten killed striking; wind light S.E., cloudy-[Legs and wings of two Willow Wrens received]: 13th, five or more Chiffchaffs flying about all day. [Probably Willow Wrens.-R. M. B.]

Lucifer Shoals Light-ship.-May 17th, several "Sallypickers" about lantern at midnight; one died on deck; one rested inside lantern and left at daylight; wind moderate S.W., thick rain.

Tuskar. - [May 23rd, Willow Wren received in flesh in spirits, shot.] [August 11th, three killed striking, received in flesh.]

Blackwater Bank Light-ship.-April 15th, several small birds about light from 9 P.M. to midnight; three killed; wind moderate N.E., gloomy. [Leg and wing of Willow Wren received.]

Arlilow North Light-ship.-April 16th and 17th, small birds about light and ship, three dead on deck (see full note under Wheatear). [Two Willow Wreus and one Wheatear received in flesh.]

Rockabill.-[April 18th and 24th, a Willow Wren received in flesh each day.] 
Copelend (Mew) Istand.-April 24th, Willow Wren found killed-[Leg and wing received]. August 20th, Willow Wren on island.

Mcidens Sonth.-May 9th, one killed striking. [Received in flesh.]

Ciifffchaff (Phylloscopus mufus, Bechst.).

Rockabill.-[April 24th, Chiffchaff received in flesh.]

Innishtrahull.-May 9th, two Chiflchaffs striking glass at 1 A.M. ; wind light E., hazy: 12th, do. ; wind light W.

GOLDEN-CRESTED Wren (Regulus cristatus, Koch).

Mine Head.-April 29th, two at 8 A.M. ; wind light S.W.

Coningbeg Light-ship. - November 15th, one Gold-Crest picked up on deck alive; wind light S.W. [Leg and wing received.]

Arklow North Light-stip.-October 19th, "various kinds" of birds about light 8 P.M. to midnight; wind. N.N.E., gloomy. [Golden-crested Wren received in flesh; killed striking at 10 P.M.]

Howth Baily.-October 21st, one Gold-Crest.

Copcland (Mov) Island.-September 12th, Gold-Crest caught against glass at 7 P.M. ; calm, gloomy.

Maidens South.-March 21st, three Golden-crested Wrens, with Blackbirds and Larks, about light all night; wind moderate W., cloudy; one Gold-Crest and one Lark killed -[Leg and wing of Gold-Crest received]: 25th, small birds round light; fresh breeze S.W., cloudy; one Gold-Crest killed striking. [Leg and wing received.]

Slyne Head, S.-October 22nd, one killed striking; the first seen here; wind light S.W., cloudy.

Arran Island, N.--November 8th, one "Golden Wreu" on island at 3 P.M.; strong breeze W.

Tearaght.-October 8th, one caught at lantern at 4 A.м. ; wind light S.E., misty : 21st, one "Firecrest supposed" caught at lantern; wind light N.E. [Gold-Crest received in flesh] : 25th, four at 10 A.M.; fresh breeze N.W., squalls. November 14 th, one "Firecrest supposed" at 11.30 A.M. ; wind light N.: 15th, one do. in morning. 


\section{WREN (Troglodytes parvulus, Koch).}

Hook Tover.-March 16th, two common. Wrens. They breed here. December 6th, one Wren on the rocks.

Tuskar:-April 12th, one on rock at 10 A.M. ; wind light S.

Arklow North Light-ship.-May 1st, one about ship.

Rockcabill.-May 16th, "a Robin and Wren at present on the rock."

South Rock Light-ship.-May 22nd, one Wren killed striking at 3 A.M. ; wind light S.W.

Copeland (Mew) Island.-April 21st, one on island. October 12th, common Wren caught against glass about 10 P.M.; haze : 13th, one on island.

Maidcns South.-May Sth, one killed striking. [Received in flesh.]

Innishtrahull.-December 9th, one on island.

Killybegs.-October 13th, "more plentiful than usual."

Slyne Head, S.-October 22nd, one on island all day.

Arran Island, $N$.-December 31st, a large number of Wrens all day; frost and snow (see full note under Thrush).

Tearaght.-“A number here this fall."

\section{"Tits."}

Maidens South,-November 18th, one "Tit" pitched on rock. Tearaght.-April 16th, one Tit, "small and blue," seen.

\section{"WAGTAILS."}

Hook Tower:-December 7th, two to four Pied Wagtails daily. Arklow South Light-ship.-April 23rd, one Water Wagtail going N.W.; strong breeze N.W.

Copelend (NIew) Island.-September 30th, Wagtail on island. MIaidens South.-March 17th, one Pied Wagtail on rock.

Innishtrchull.-May 11th, one Pied Wagtail on island. Arcnmore.-April 26th, one Wagtail at 7 A.M., remained. Slyne Head, S.-August 25th, one Wagtail on island. September 12 th, November 10 th and 15th, two do. Arran Islant, N.-October 27th, two Wagtails on island.

Grey Wagtail (Motacilla melanope, Pallas).

Arren Island, N.-October 19th, " a bird caught at lantern 
at midnight; calm, misty; another escaped." [Grey Wagtail received in flesh.]

Arran Island, S.-November 30th, two at 9 A.Mr.; gale S.W.

Tearaght. - August 20th, one Wagtail (yellowish) seen. September 30th, one Grey Wagtail all day; gale S.W.

Skelligs.-November 10th, one Yellow and two Grey Wagtails at 2 P.M. ; fresh breeze N.; remained till dusk.

\section{TitLaRK (Anthus pratensis, Linn.).}

Hook Tover.--September 12th, a few seen all the year.

Tusker.-March 13th, one at the lantern: 16th, three on rock. April 2nd and 3rd, a few on rock.

Lucifer Shoals Light-ship.-March 21st, several flocks "Bog Larks" going N.W.; wind light W.: 26th, 27th, and 29th, several flocks "Bog Larks" going N.W. each day; wind moderate N.E.; one died on deck-[Leg and wing of Titlark received]. [Legs and wings of Titlark received on August 19th.] September 21st, one Titlark got into lantern during night, and died. November 6th, one going N.W.; fell into water going to land.

Arlilow South Light-ship.-April 21st, several about lantern. Arklow North Light-ship.-April 14th, one on deck at 9 A.II.

Kish Bank Light-ship.-March 28th, two about ship all day; went N.W. April 12th, four about ship; went N.W.

Howth Baily.-March 17th, "Larks (Tits)," midnight to 4 A.M. ; wind light S.W., snow; several striking. November 8th, flocks of about twenty Chaffinches, with Titlarks, from noon to 4 P.M., remaining.

Copeland (Mew) Island.-April 18th, one found killed. Titlarks always here. May 6th, nest found.

Maidens South.-February 20th to 26th, great rushes of birds (see full note under Thrush). [Wing of Meadow-Pipit received.]

Innishtrahull.-June 7th, young ones seen on island.

Blackrock, Mayo.-April 19th, one caught at lantern[Received in flesh]. Nay 27th, "the Titlarks" [Possibly RockPipits.-R.M.B.] "here were off the rock from the beginning of December till early in February; I never saw them banished before, and I am eighteen years on rock and islands. The Wrens were also banished, and I have seen none since."

Arran Island, S.-November 3rd, five Titlarks and ten Skylarks in yard all day; common on island; strong gale S.W. 
Tearaglet.-October 10th, 11th, and 12 th, one or two each day. "There were a number of Titlarks and Wrens here this fall."

Rock-PIPIT (Anthus obscurus, Lath.).

Hook Tower.- " A few to be seen all the year round. Rock and Meadow Pipits frequent this place; the former are the most numerous."

Tuskar--March 30th, six on the rock; wind light N.E.

Aranmore.-January, February, and March, Rock-Pipits seen occasionally.

\section{SKylark (Alauda arvensis, Linn.).}

Hook Tover:-October 24th, many round light; wind fresh W.; one killed-[Leg and wing received]. November 28th, some all day; wind fresh N., snow. December 9th, three killed striking; wind light N.E. : 12th, some round light; one killed. Larks breed here, and a number are killed against lantern in autumn; they were numerous about the end of December (see under Linnet).

Coningbcg Light-ship.-January 11th, one on ship. December 2nd, ten flying S.W.: 17th, several flocks flying to the land at 11 A.M. ; wind light E., cloudy.

Tusliar.-February 23rd, two killed striking: 25th and 26th, one on rock; wind strong N.E. March 11th and 12th, Skylarks striking during the night; wind fresh S.W.: 17th, three at lantern: 22nd, two about light. November 13th, two killed: 14th, Larks, with other birds, about light all night; great numbers of birds killed; gale S., fog, rain.

Lucifer Shoals Light-ship.-November 3rd, one about ship: 10th, two going N.W. December 18th, one rested; gale S.; died next day.

Blaclivater Bank Light-ship.-November 13th, three going N.W.: 14th, several about light, with Blackbirds, etc.; gloomy; many birds killed-[Leg and wing of Skylark received]: 15th, three going N.W.: 17th, several, with Thrushes, about light midnight to 4 A.M. ; wind light S.E., gloomy; one Lark killed -[Leg and wing received]: 18th, three about light: 19th, two do.: 20 th, three going N.W.: 21st, one dead on deck, four going N.IV. December 10th, some about light all night, with other birds; went N.W. ; hazy; several birds killed (see under 
Thrush): 11th, two flocks going N.W. during day; two caught on deck: 12th, flocks going N.E.: 14th, flocks, with Thrushes, going N.; wind moderate S.E., clear-[Leg and wing received; killed striking] : 24th, several Larks, and other birds, about light at 6 P.M.; some killed; went W. at daylight: 30 th, a flock going S.W.; gale E.

Artilow South Light-ship.-February 23rd, continuous flocks, with other birds, going N.W., and some striking (see full note under Starling); one found on ball at mast-head on April 3rd, believed to have been killed February 23rd-[Leg and wing received]. October 13 th, several, with Blackbirds and Thrushes, seven birds killed; wind moderate S.W., clear; "the first birds seen since June": 14th, a few about lantern at midnight: 30 th, flock going W. November 4 th and 5 th, two flocks going W. each day: 10 th, 11 th, 13 th, and 16th, one or two flocks each day going N.W-[Leg and wing of Skylark received]: 20 th and 25th, one going N.W.: 2Sth, great flock going N.W. at 10 A.Ir. ; strong breeze N.E., snow showers : 29th, great flock going N.W. at 8.45 A.M. and 11 A.M.; wind light S.E., clear. December 2nd to 7th, several about light with other birds; a few birds striking each night: 9 th, a few Larks, Thrushes, Blackbirds, and Plover about lantern; wind light S.E., clear: 14th, a few do.; wind light W.: 15th, one killed striking at 6.30 A.Mr; wind light N.W., clear: 20th, some going N.W. [Leg and wing received] : 21st, flocks going N.W. during day; wind light S.E. ; 22nd, flocks going N.W. : 25th, flock going E. at 10 A.M.; wind light S.W., light rain: 27th, a few going S.W.; snow showers: 29th, several about lantern; one Lark killed striking-[Leg and wing of Skylark received].

Arklow North Light-ship.-February 22nd, great number of birds at lantern; several Larks killed (see under Starling). October 12 th, several small birds 9 p.M. to midnight; wind light S.W., cloudy; one Lark found dead on deck-[Wing received]: 19th, Larks and other birds about light $S$ P.Mr. to midnight; several struck; gloomy: 21st, several flocks going W. and N.IW. 9 A.M. to 4 r.M.; flying high; wind light N.E.: 22nd, one: $2 S$ th, several flocks with Starlings going N.W. at 8 A.M., gloomy. November 3rd, flock going N.W. December 19th, several flocks small birds going N.W. during day; wind light N.W., clear; one Skylark caught in evening: 20th, flocks of small 
birds of various linds going W. during day (see under Linnet); one Skylark caught on deck: 21st, flock going N.W. in evening; one on deck: 22nd, several about light and about ship during day; one caught: 24 th, several about light 4.30 P.I. to midnight; two killed striking: 30 th, several flocks going N.W. during day; a Sea-gull killed and ate a Lark; gale S.E.: 31 st, one on ship; went N.W.

Codling Bank Light-ship.-March 9th, several going N.W. and N.E. noon and 6 P.M.; fresh breeze N.W.: 10th, several, with Linnets, going S.E.: 21st, several going N. April 4th, two going N.W.: 20th, ten going N.: 25th, five going N.W.

Kish Bank Light-ship.-March 17th, one killed striking at 11 P.M. going N.W.; cloudy, rain. 18th, several, with Thrushes, about lantern at 11 P.м.; one Thrush and Lark killed; wind moderate N.E., cloudy : 22nd, several flocks going N.W. during day.

Howth Baily.-October 22nd, several, with Thrushes, striking at 10 P.M., not killed: 23rd, several, with Chaffinches, at 7 P.M. ; a few struck. November 5th, two flocks (supposed Larks) going $\mathrm{N}$.

South Roch Lightt-ship.-March 12th, several, with Thrushes, about lantern from $S$ P.M. to midnight; fresh breeze S.W., gloomy: 16th, one about light. May 19th, two round light at midnight. November 7 th, four going S.E. December 11th, 12 th, 13th, and 14th, flocks about light (see under Thrush). [Leg and wing of Skylark received; killed striking on 12th.]

Copeland (Mew) Island.-February 17th, Larks, Blackbirds, and Thrushes about light; wind E., misty: 20th, "immense swarms of birds round lantern from 10 P.M. to 4 A.M.; Larks, Blackbirds, Thrushes, and Starlings, also Curlew; wind light S.E., misty. The air was filled with birds. The balcony outside was completely covered with killed birds; they were five or six deep all round, so to walk round would be walking on killed birds. Numbers got through the cowl into the lantern. The lantern-glass was so much soiled, both inside and out, that eight buckets of water had to be carried up next day to wash it. A labourer doing work at the lighthouse gathered two hundred, and 'that was not the quarter of them'; he gave a couple of buckets to fishermen who came along. Several Curlew, Lapwing, and Golden Plover killed.-CharLes 
Hawnins and Edward M“Carron." December 9th, 1 A.M., birds flying against glass pretty frequently, Skylarks chiefly; large birds in the distance passing through rays; caught a Snipe, partly injured on balcony; wind N.E., calm and hazy (see Green Plover): 11th and 12th, birds striking all night; Skylarks, Thrushes, Starlings, and Lapwing plentiful in the distance through the rays; Larks and Thrushes killed on the 11th ; Blackbirds killed on 12th; wind moderate S.E., hazy: 13th, birds still plentiful about lantern; same kinds killed as on previous nights; weather still hazy: 19th, some Larks, Thrushes, and Blackbirds at light, striking; wind light S.E.

Maidens South.-January 23rd, two going W. February 10th, some, with Starlings and other birds, about light at 8.30 P.M. ; one Lark killed-[Leg and wind received]: 13th, numbers, with Redwings, at light: 14th, Larks, Thrushes, and Blackbirds round light; wind moderate S.W., hazy; one Lark killed-[Leg and wing received]: 20th, 21st, and 22ud, great rushes of birds (see full notes under Thrush); one hundred and ten Skylarks killed-[Legs and wings of three received]. March 12th, some at light; gloomy; five killed striking-[Leg and wing received]: 20 th, some around light; two killed-[Leg and wing received]: 21st, some about light; one killed-[Leg and wing received]: 25th, Skylarks and other small birds all night round light; fresh breeze S.W., cloudy; three Larks and one Gold-Crest killed-[Leg and wing of Skylark received]: 28th, two seen. April 20th, one lilled striking-[Leg and wing received]. October 22nd, three Larks and one Blackbird killed striking at 6 A.M.; wind moderate N.W., misty. December 10th, four Larks at lantern at 3 A.x.; one killed: 18th, one caught inside lantern at 8 P.M.

Innishtrahull.-March 16 th, one struck at 1 A.M., not injured : 20th, two struck, not injured, at 1 A.M.: 21st, two striking lantern at 1 A.M. December 9 th, one disabled striking at 4 A.M.

. Killybegs.-February 17th, one killed striking. March 15th, one struck at midnight. September 5th, one struck at 10 P.x. October 21st, two at lantern. November 20th, one do.

Slyne Houd, S.-April 20th, one killed striking at 11 P.M.

Arran Island, N.-Larks breed on island.

Arran Island, S.-November 3rd, common on island. 
Tearaght.-September 22nd, one seen. Oetober 20th, Larks and Thrushes flying through rays of light from 10 P.M. to midnight; wind light N.W.: 21st, several: 30 th, two seen. December 26 th and 27 th, one or two.

SHORT-TOED LARK (Alauda brachydactyla, Leisler).

Blackrock, Mayo.-October, "I am sending you two birds I shot on the 11th inst., as I thought they were strange ones. -Richard Widdicombe." [Short-toed Lark and Kestrel received in flesh.]

Snow Bunting (Plectrophenax nivalis, Linn.).

Iine Head.-November 3rd, one; wind fresh N.W.

Hook Tover.-November 28th, Snow Buntings about all day; wind fresh $\mathrm{N}$., snow. December 7 th, twenty about rocks; wind strong S.E.

Innishtrahull.-March 6th, "Snow Bunting and Turnstone the only regular visitors."

Aranmore.-January, February, and March, flocks of about forty seen occasionally. November 4th, four. December, a few seen daily.

Killybegs.-February 7th, two rested: 28th, three going N.IV. March 31st, one at 7 A.M., seemed tired. November 6th, three going N.: 19th, two seen.

Slyne Head, S.-April 6th, three on island. October 17th, one first seen; fresh breeze N.W., misty: 25th, three on island.

Arran Island, S.-November 2nd, three perched on wall; gale W., squally ; first seen this year.

Tearaght.-January 10th, February 7th, and April 10th, one or two seen. September 24 th, and October 20 th to 30 th, one or two noted. November 5th, two.

Skelligs.-October 29th, one at 4 P.M. on rock.

Conn Bunting (Emberiza miliaria, Linn.).

Innishtrahull.-April 2nd, one on island; wind light S.E.

YelLow Bunting (Émberiza citrinella, Linn.).

Aiklow North Light-ship.-November 3rd, one rested on ship. 
Houth Baily.-November 10th, flock of about twenty small birds, chiefly Yellowhammers, remained in neighbourhood; wind moderate W., clear.

Maidens South.-January 13th, one on rock. February 20th, 21st, 22nd, and 26th, great rushes of birds, including Yellowhammers (see full note under Thrush); four Yellowhammers killed striking-[Leg and wing received]. March 19th, one all day: 28th, one found dead. [Leg and wing received.]

Arran Island, N.-November 27th, two all day; snow.

Chaffinch (Fringilla ccelebs, Linn.).

Iine Hcad.-April 20th, three at 8 P.M.; wind light S. W.

Hook Tower.-October 19th, one about the station.

Coningbeg Light-ship.-November 4th, two on ship; gale N.W.

Tuskar.-February 24th, March 4th and 20th, one each day on rock. March 28th, two round light at 11 P.M. October 28th, flocks, with Starlings, going W. all day; four birds killed: 30th, several on rock: 31st, some on rock; one killed. November 4th and 7th, great number of "Finches" and other birds passing N.W. all day; several killed on 4th: 8th, some on rock all day; gale S.: 12 th, two flocks going W. at 9 A.M.; one killed; wind light S.W., clear.

Lucifer Shoals Light-ship.-March 22nd, Hawk following a Chaffinch.

Arklow South Light-slip.-November 4th, one about ship: 5 th, five noted: 11th, one: 13th, two about ship: 15th and 23rd, one about ship: 27th, one going N.W.; snow. December 20th, some going N.W. during day.

Arklow North Light-ship.-February 22nd, eight "Finches" killed striking (see full note under Starling). March 27th, several about ship at 9 A.r. to 4 P.M.; wind light S.W., hazy: 28th, several do. from 5 A.M. to 6 P.M.; fog: 30 th, one Chaffinch on mizen-boom at 5.40 A.м. April 17 th, several about ship (see undèr Wheatear). October 20th, one on deck. November 3rd, one, went N.W. December Sth, two on deck, went N.W.: 15th, one do.: 20th, flocks going W. during day, and some about ship; wind light N.E., light haze.

Kish Bant Light-ship.-April 17th, three round ship all day. 
May 1st, two going N.W.: 9th, three round ship at midnight; hazy.

Howth Bcily.-October 23rd, several, with Larks, at 7 P.M. ; a few struck; clear : 28 th, flocks, supposed to be Chaffinches, going N.; fog. November 8th, flocks of about twenty, with Titlarks, from noon to 4 P.M., remaining: 16 th, flocks, with Starlings, Rooks, and some Blackbirds and Thrushes, all day, remaining; wind light S.W.

Rockabill.-March, great rushes of Chaffinches and other birds during early part of March (see full note under Blackbird).

South Rock Light-ship.-November 11th, about fifty going N.W. at noon; wind fresh S.W., clear.

Copcland (Mew) Island.-January 31st and December 11th, one seen.

Maidens South-March 13th, one on rock all day.

Slyne Head, S.-November 13th, some on island all day.

Arran Island, S.-November 12th, common on island.

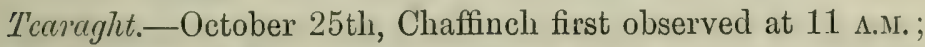
fresh breeze N.W., squalls - [Leg and wing received]. November 2nd, one; gale N.W., squalls: 5th, flock observed: 10th, great flocks Starlings and other birds, including Chaffinches, at 8 A.M. December 6th, flock all day.

\section{Brambling (Fringilla montifringilla, Linn.).}

Innishtrahull.-February 25th, 26th, and 27th, Mountain Finch (supposed) on island each day; rare visitor here.

Tearaght.-October 26th, one Mountain Finch at noon; strong gale N.W., squalls.

\section{"SPARrows."}

Codling Bunl: Light-ship.-March 17th, several "Sparrows" going N.W.

Dunrec Hecul.-July 16th, sixteen "Sparrows" going E.

HAWFinch (Coccothraustes vulgaris, Pallas).

Rockictill.-April 20th, "caught at lantern at 1 o'clock in the morning, a beautifully marked bird, with a very large head and remarkably strong bill. I have him in a cage ; he appears very tame, and eats hempseed. I think he is a Hawfinch.-JoHN HaMilToN." 


\section{Greenfinch (Ligurinus chloris, Linn.).}

Hook Tower.-December 17th, one shot. [Leg and wing received.]

Lucifer Shouls Light-ship.-November 1st, three rested on ship and flew N.W.

Rockctitl.-March, great rushes of Grey and Green Linnets, etc., during early part of March (see full note under Blackbird). Arenmore.-January, February, and March, Grey and Green Linnets in flocks seen occasionally.

Killybegs.-January 9th, one killed striking at 10 P.M. "About this time flocks are seen generally in the morning."

Tearaght.-January 8th, flocks of ten to twenty all day; strong gale N.W. December 4th, flock all day; strong breeze N.E. : 16 th, two.

GoLdFinch (Carduelis elegans, Steph.).

Arklow North Light-ship.-October 19th, two Goldfinches came from S.E.; rested on ship twenty minutes; went N.W. at 11.15 A.M. ; wind light $\mathrm{N}$.

Aranmore.-January, February, and March, Goldfinches seen occasionally; they always remain. July and August, Goldfinches constantly seen.

Arran Island, N.-December 23rd, five Goldfinches on island.

Mealy Redpole (Linota linaria, Linn.).

Tearaght.-September 20th, two Mealy Redpoles all day on island; fresh breeze N., blue sky; one shot-[Received in flesh]. October 10 th, one Mealy Redpole shot; wind moderate S.E.

\section{"LINNETS."}

Hook Tower.-Linnets were plentiful this autumn. October 8th, 9th, and 11th, some flying west. November 28th, some noted. December 12th, some about light; one killed. Sliylarks and Linnets (Twites) were numerous about the end of December, but I could not see any indication of flight in any particular direction, as they appeared almost daily in quest of food. I may except two or three flocks of Linnets (common) on the 8 th, 9 th, and 11 th October, which took a westerly direction. 
Barrels liock Light-ship.-March 13th, two Grey Linnets flying north: 16th and 17th, a few do.

Lucifor Shoals Light-ship. - March 14th, one flock going N.W.: 16th, several flocks all the forenoon going N.W.; wind fresh N.W., clear. October 27th, three flocks going N.W., flying very low; wind N.: 31st, several flocks going N.W. during day, skimming the water; wind moderate N.W. November 5th, several flocks Linnets and Thrushes going N.W.; strong breeze N.W. Lecember 18th, one rested and died; gale S.

Blackwater Bank Light-ship.-March 30th, one Grey Linnet going N.W. April 16th, two Linnets on ship. November 12th, flocks going N.W.; fresh breeze S.W. : 18th, two lighted on ship. December 12th, flocks going N.E.

Arklow North Light-ship.-April 3rd, several going N.W., flying high, noon to 2 P.M.; wind light S., clear: 12th, one Grey Linnet on deck. October 23rd, flock going N., flying low. December 20th, flocks, with Chaffinches and various small birds, going W. during day; wind light N.E.; a Skylark, Starling, Grey Linnet, and some Chaffinches about ship all day.

Codling Bank Light-ship.-March 10th, several, with Larks, going S.E. April 6th, several going N.W. at 11 A.M. : 21st, one fell on the water.

Rockabill.-Great rushes of Grey and Green Linnets and other birds during early part of March (see full note under Blackbird).

South Tiock Light-ship.-December 15th, large flocks going N.W. at 10 A.M. ; several hundreds; fresh breeze N.E., clear: 20th, large flock going N.W. at noon; wind light S.E., clear.

Copeland (Meiv) Island.-September 1st, one Grey Linnet noted: 18th, about a dozen, with Twites, on island.

Maidens South.-March 31st, flock of Grey Linnets going N. November 9th, one Linnet going S.W.: 18th, one Linnet and one "Tit" pitched on rock.

Arcanmore.-January, February, and March, Grey and Green Linnets, in flocks, seen occasionally. July and August, Linnets constantly noted.

Killybegs - October 3rd, twenty-three came from S.W., and rested close to station: 5 th, thirty-five noted.

Slyne Hccul, S.-March 28th, numbers on island all day; wind moderate S.W., cloudy. July 10th, fifteen on island. "Very 
few birds struck lantern; Linnets and Curlew the most numerous on island." August 1st, 2nd, 15th, and September 12 th, a few noted. November 2 nd, seven; gale N.IV. : 5 th, some: 13 th, great rush of birds; Linnets on island all day (see full note under Thrush): 15th, some all day.

Arran Island, N.-August 29th, about a hundred Grey Limnets, young birds, going N.W. at 9 A.M. November 27th, one hundred Linnets going W.; snow.

Arran Island, S.-October 21st, twenty-five on wall; first flock seen; wind light N.E. December 27 th, large flocks during day; strong breeze E.

\section{"TWITE."}

Hook Tover.-December, Twites numerous at end of month.

Tuskir.-February 5th, one flying N.W. March 6th, one flying W.: 11th, one do. : 18th, two on rock all day.

Copeland (Mew) Island.-September 19th, a dozen came on island.

Innishtrahull.-November 16th, numbers on island.

\section{"Bullfinch."}

Arklow South Light-ship.-October 20th, one going E. 11 d.M.

Starling (Sturnus vulgaris, Linn.).

Mine Head.-March 17th, a flock passing S. October 24th, a flock going $\mathrm{N}$ : November 20 th, a flock going $\mathrm{E}$.

Hook Tower.-Danuary 22nd, large flock at 9 A.M. Starlings were very numerous at this station up to the latter part of February; a few pairs remained to breed. October 12th, many Hying W. all day; wind light S.W. November 26th, numerous Hocks about all day; snow. December 6th, several killed striking; gale S.E., rain. Thousands left early in December.

Coningber Light-ship.-November 15th, a small flock round light; one killed striking: 26th and 27tb, a few flying $\mathrm{N}$. December כ̌th, many round light; some killed: a quantity on 9 th and 14th, and some on 2Sth and 31st; wind generally E.

Barrels Rock Light-ship.-February 20th, a flock flying N.: 21st, some round the light: 22 nd, a few passing during the day. Starlings round the light on the 23rd, 24th, 25th, and 26th; 
some killed striking; wind moderate E.-[Leg and wing received]. March 5th, a few passing throughout night; wind moderate N.W.

Tusliar.-January 7th, one at lantern: 21st, Starling round light; wind S.E. February 22nd, 23rd, 25th, and 26th, Starlings day and night; some killed. March 9th, many round light; gale S.W.: 10th, a flock flying W.: 11th, 12th, and 13th, many striking: 17 th, a few at light: 18 th, one killed striking[Leg and wing received]: 22nd, two about lantern; one killed striking : 24th, two about light: 28th, one at light. . April 17th, Starlings round light all night; wind strong N.E.: 19th, two at light. October 20th, 21st, and 23rd, numbers, with Thrushes, etc., round light each night; wind light N., clear; "seemed mostly this year's birds": 24th, a flock going W.; strong breeze W.: 26th and 27th, two Starlings noted: 28th, flocks, with Chaffinches, all day going W.; four killed; wind light N. : 29th, great numbers at intervals during the day going W.; five killed at night; gale W., misty: 31st, flocks going W: during day; three killed at night; wind light W. November 4 th and 7th, great numbers, with Blackbirds, Thrushes, Finches, and Redwings, passing all day going N.W.; several killed on 4th: 9th, great number going N.W. all day; two killed: 10th, some, with Thrushes and Blackbirds, constantly day and night going N.W.; gale S.; numbers blown into the sea, young and old: 13th, flock going N.W.: 14th, Blackbirds, Thrushes, Starlings, and Larks about light all night; great numbers killed; gale S., fog and rain.

Lucifer Shoals Light-ship.-March 13th, two flocks going N. October 23rd, 28th, 29th, 30th, and November 8th, flocks during day going N.W.: 16th, several, with Blackbirds and Thrushes, at midnight; fog.

Blackwater Bank Light-ship.-March 9th, two dead on deck: 11th, three killed striking: 13th, two do. April 12th, four about light. November 7 th, flocks going N.W.during day : 10 th, several, with Thrushes and Blackbirds, about light and killed; strong gale S., rain: 12th, flocks going N.W. at 11 A.M.; fresh breeze S.W.: 14th, 15th, and 16th, numbers about light (see under Blackbird)-[Leg and wing of Starling received]: 20th, flock going N.W. at 11 A.M. December 10th, Blackbirds, Thrushes, Larks, and Starlings about light all night; several killed: 11th, some at light all night: 24th, about forty birds, Starlings, 
Blackbirds, Thrushes, and Larks about light at 6 P.Mr.; some killed and disabled; wind moderate N., clear and cloudy; went W. at daylight: 30 th, some going S.W.; E. gale.

Arklow South Light-ship.-February 22nd, one killed striking: 23rd, continuous flocks, with Thrushes, Curlew, Larks, Blackbirds, and a few Grey Plover, going N.W. ; ten Starlings, Larks, Blackbirds, and Thrushes killed and fell overboard; wind light N.W., overcast. March 16th, flock going N. April 3rd, one found in ball at masthead, supposed to have been killed striking on February 23rd-[Leg and wing received]. October 19th, Starlings, Thrushes, and Blackbirds about lantern from 8 P.M. to midnight; wind light N.E., clear; eight killed striking fell on deck and a great many overboard : 24th, flock going W.: 28th, two going W. November 1st, flocks going N.W.: one or two flocks passing N.W. during day on 2 nd, 6th, 8 th, 12th, 13th, 16th, 18th, and 27 th: several flocks on 10 th, and great flocks on 28 th and 29 th ; snow shower on 28 th. December 2 nd, 3rd, 4 th, 5 th, 6 th, and 7 th, several Starlings, Thrushes, Blackbirds, and Larks about lantern during night; weather variable; a few birds nightly striking lantern, but all falling overboard: 10 th and 12 th, a few about lantern : 20th, Starlings, Fieldfares, Larks, Curlew, Chaffinches, Blackbirds, and Thrushes going N.W. during day; wind moderate N.E., hazy: 28th, several flocks during day going E. and N.IV.: 29th, several, with Larks, about lantern at 4 A.M. ; wind light S.E. : 30 th, small numbers going N.W. during day, flying low ; fresh breeze S.E. : 31st, some, with Thrushes, going N.E. during day; fresh breeze S.E.

Arklow North Light-ship.-February 22nd, great quantity of land birds at lantern at midnight; calm, hazy; twenty Starlings, twelve Larks, eight Finches killed striking, dozens fell overboard. March 21st, one about light. October 19th, rush of birds (see under Thrush); "Starling dead on deck": 22nd, one on ship: 28th, several flocks, with Larks, going N.W. : 31st, flocks going N.W. November 1st, several about light; some killed, fell overboard; strong breeze S.TV.: 4th, flocks going N.WV. duriug day; fresh breeze W.; several about light at night: 6th, several flocks going N.W. dluring day; two rested; gale S.IV., rain: Sth, several flocks going N.W.; two on deck. December 13th, several flocks going N.W. during day; fresh breeze S., gloomy: 15 th and 16 th, several about light; wind fresh N.E.: 
20th, one about ship: 28 th, several about light 5 P.M. to 4 А.M. ; wind S.E., gloomy: 31st, one rested on ship.

Howth Baily.-October 24th, large flock going N.W. at 1 P.M. ; wind W.: 26th and 27th, flocks all day remaining: 28th, large flocks, supposed to be Starlings, Mountain Thrushes, and Chaffinches going N. all day; wind light W., haze and fog. November 11th, thirty going N.W. at 4 P.M. : 16th, flocks with other birds all day remaining.

Rockabill.-Great rushes of Starlings and other birds during early part of March; great numbers killed striking east side of lantern (see full note under Blackbird).

South Rock Light-ship.-March 16th, several at midnight, one killed striking; clear: 18th, several about light at 3.30 A.M. ; one killed striking; wind light S.W., sleet showers: 20th, one found dead on deck. May 19th, one at light. December 12th, flocks Thrushes, Starlings, and Larks about light at 11 P.M.; about thirty killed and fell overboard; wind light S., hazy.

Copeland (Mcw) Island.-February 20th, remarkable rush of Starlings and other birds (see full note under Lark): 25th, numbers of Starlings striking; wind light E, misty. March 11th, 10 P.M., "Starlings striking glass for last couple of hours, but not plentiful": 17th, striking at 4 A.r. April 13th, flying in rays of light; drizzling rain. May 9th, breeding here. September 17 th, several seen. November 13 th, some at lantern at 9 P.M.; misty. December 9th, some do. from 3 A.M. to 5 A.M.; wind light S.E.: 11 th and 12 th, birds striking all night; Starlings plentiful in the distance through the rays.

Maidens South.-February 10th, some abont light: 20th, 21st, and 22nd, great rushes of birds, including Starlings (see full note under Thrush); eight Starlings killed striking-[Leg and wing received]. March 16th, two at light: 20th, some, with Larks, round light; one Starling and two Larks killed; wind light $\mathrm{N}$. October 30 th, eight going W. at 9 A.M. December 18th, one hundred going W.; gale S.E., snow.

Haidens North.-December 8th, large flocks going W. at 4 P.M. ; strong breeze E.: 19th, one killed striking at 8 P.M. [Leg and wing received.]

Innishtrctull.-March 20th, one and two Skylarks striking glass at 1 A.M. ; wind N. December 19th, nineteen on island; first seen this winter; wind light N.E., clear. 
Aranmore.-November 10th, a flock going S.E. at 11 A.M.

Killybers.-October 8th, twenty-four Starlings going N.E. at 3 P.M.: 9th, large flocks began to roost at night among the reeds in an adjacent bog. November 18th, one at lantern.

Oyster Island, S.-October 25th, twenty going S.W. at 3 P.M. November 15th, do. December 7 th, one disabled striking. "Starlings are resident, they breed in ventilators of lighthouse."

Slyne Head, S.-October 28th and 31st, large flocks on island all day. November $2 \mathrm{nd}, 5$ th, and $10 \mathrm{th}$, flocks on island: 13th, Thrushes, Blackbirds, and Starlings on island all night; scores killed striking of each kind; strong breeze S.W., misty: 16th, flock on island; Starlings every day to end of month.

Arran Island, N.-October 28th, flocks came this day for the first time this winter, and almost every day afterwards for the whole winter. December 31st, two struck lantern.

Arran Island, S.-October 4th, twenty on island at 9 A.M. ; first seen in autumn; fresh breeze S.W., gloomy: 20th, a hundred on island at 2 P.M. ; wind light N.W., misty. "Immense flocks during day and evening, thirty killed striking." November 8th, large flock on island at 8 A.M.; twenty-five killed striking; strong breeze W., cloudy.

Tearaght.-October 20th, several round light: 27th, about thirty at 10 A.M.; strong breeze N., hail showers. November 10th, great flocks, with Crows, Blackbirds, Redwings, Thrushes, and Chaffinches, at 8 A.M.; the Crows flying S.; moderate breeze S.E., blue sky; twelve Ravens at 7 A.M.: 12th, large flock, new arrivals all day; freeh breeze S.W., rain. November and December, large numbers on island; intense frost and snow on mainland: 31st, two; and two Redwings struck; wind light E., snow; one Starling killed-[Leg and wing received]. There have been a great many Starlings, Blackbirds, Thrushes, Fieldfares, Larks, and other birds here during November and December, owing probably to the inteuse frost and snow ou mainland. There appeared to be a great rush about November 5 th to 10 th.

Slelligs.-November 16th, flock of from fifty to sixty on rock

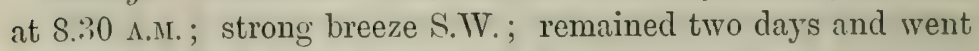
S.E.: 20 th and 21st, flocks, with Blackbirds and Thrushes, on rock at 10 A.M.; fresh breeze N.E, gloomy (see under Black- 
bird). December 16 th to 31 st, a number on rock; wind variable, weather generally gloomy and misty.

\section{CHOUGH (Pyrrhocorax graculus, Linn.).}

Ballycotton.-January 1st to 7th, a few about island.

Mine Head.-March 8th and 12th, two observed.

Aranmore.-January, February, and March, occasionally seen. July and August, constantly. December, occasionally.

Arran Island, S.-See note under Jackdaw.

Tearaght.-[Leg and wing of Chough received with letter, dated 19/3/90.] July 10th, three. August 31st, two. September 28th, two. November 27 th, seven Choughs all day.

\section{RAven (Corvus corax, Linn.).}

Spit Bank, Quecnstown.-January 23rd, three going N.E.

Mine Head.-March 28th, two Ravens flying S.W.

Dunree Head.-August 16th, two going S.W.

Aranmorc.-July and August, constantly seen. December, one pair occasionally.

Tearaght.-January 11th, seven all day, fresh breeze S.W.; fog. August 31st, eight; and three Hooded Crows at 6 P.M.; wind light S.W. October 10th, five going S.E. November 10th, twelve at 7 A.M. (see under Starling). December 9th, eight at 8 A.M.

\section{HOODED CRow (Corvus cornix, Linn.).}

Mine Hcad.-March 13th and 18th, two Grey Crows noted.

Aranmorc.-January, February, and March, seen occasionally. March 26th, nesting near station.

Slyne Hcad, S.-April 1st, 10th, and 16th, one to four noted.

Arran Island, N.-July Sth, 20th, and August 21st, one or two noted.

Tcaraght.-August 31st, three; and eight Ravens at 6 P.M. September 28 th, two all day. October 12 th, ten at 9 A.M. ; wind S.IV., squally: 20th, eight: 31st, three all day. December 30th, six.

\section{Rook (Corvus frugilegus, Linn.).}

Spit Bank, Quecnstoun.-March 14th, Rooks passing at intervals between 7 A.M. and 9 A.M., flying very low to the S.IW. 
April 25th, several passing. June 18th, 20th, and 21st, a few passing to the $N$. October $22 \mathrm{nd}$, a large flock flying S.W. at 4 P.M. November 11th, thousands of Rooks flying N.W. in the afternoon; wind fresh N.W.

Hook Tower.-March 10th, three going N. coming from seawards, flying high, at 10 A.M.; gale W. April 17th, five flying inland. May 1st, a few passing inland during the day. Numerous flights of Rooks on fine days; these I believe to be local migrants, as they always come from inland and return in the same direction.

Coningbeg Light-ship.-December 4th, one "Crow" flying N.E.

Barrels Rock Light-ship.-March 17th, one "Crow" flying N.

Tuskar.-February 9th, one "Crow" flying N.W. March 16th, two flying W.: 19 th and 20th, two flying N.W. April 1st, two flying W.: 17th, twenty Crows flying E.

Blackwater Bani Light-ship.-March 24th, two "Crows" going N.W. at 10 A.M. November 8th, flocks of Rooks going N.W. at 11 A.M. : 25th, flock going N.W. at 9.30 A.M.

Arklow South Light-ship.-April 17th, one Rook lit on ship at 6 P.M.; seemed completely tired; wind light N.E., thick haze. November 9th, ten "Crows" going N.W. at 10 A.M., and five going N.W. during day. December 16 th, one flock going N.E. at 10 A.M. ; flying low.

Arklow North Light-ship.-November 1st, flock of "Crows" going N.W. at noon; flying low: 6th, flock of "Crows" gुoing N.W. at 9 A.M.

Kish Bank Light-ship.-Warch 11th, one "Crow" lighted on ship at noon; flew N.W.

Howth Baily.-November 16th, flocks all clay, remaining.

Copcland (Mcw) Island.-May 9th, several on island.

Maidens South.-December 10th, two "Crows" on roof of dwelling.

Aranmore.-January and February, occasionally seen.

Slyne Head, S.-August 11th, six "Common Crows" going N.W. September 12th, five Crows going W. at 11 A.M. October 22nd, three on island. November 3rd, two Crows at 10 A.M. : 5 th, hundreds of Crows going N.W. at 11 A.M.; wind light, moderate N.W.: 9th, large flock going E. at noon: 10th, five on island: 12th, three all day. 
Arran Island, N.-May 18th, one noted. June 28th, two. September 3rd, three common Crows going N.W.: Sth and 9th, two or three on rock: 10th, six going E. November 5th, one "Crow" on island.

Arran Island, S-December 14th, twenty Crows going W. at 2 P.M. ; wind moderate S.E., misty, "only once observed."

Tearaght.-November 5th, a great flock of "Carrion Crows (Rooks)," about one hundred and fifty arrived about 11 A.M. from the W. and lit on island, went N. about 12.30 P.M. ; strong breeze N., blue sky, detached cloud; seemed tired, a few remained and were about light that night, several striking at 6.35 P.M. ; moderate breeze N., gloomy; one caught-[Leg and wing received]: 6 th, Crows about all day, ten or twelve Jackdaws with them; wind W. to hurricane N.W., fog, mist, rain : 9th, one at 10 A.M. ; wind moderate N.: 10th, great flocks of Starlings, Crows, etc., at 8 A.M., the Crows flying S.; wind moderate S.E., blue sky, detached cloud: 16th, thirty-six Crows going N. at 11 A.M.; wind light S.W., blue sky, detached cloud: 25th, a flock flying about 80 feet high at 10 A.Mr.; strong breeze N.E., blue sky, showers, hail: 28th, large flock all day; wind light E. December 1st, large flock Rooks all day; wind moderate S., fog, rain. "Since [until ?] I joined this station, I never saw such a lot of Crows, nor heard of them striking lantern. There were some Jackdaws amongst them.-W. H. JAMES."

\section{JACKDAW (Corves monedula, Linn.).}

Spit Bank, Quccnstown.-April 13th, three. They are very plentiful in Queenstown, but are rarely seen so far from the town as this.

Innishtrchull.-May 23rd, five on island at 9.30 A.M.; wind light E., clear.

Arran Island, N.-August 28th, two going E. at 2 P.м.; wind light $\mathrm{E}$.

Arran Island, S.-November 18th, two "Choughs or Jackdaws" on crags at 1 P.M.; wind moderate S.W., misty. "Build on cliffs here."

Tcaraght.-November 5th and 6th (see full notes, important, under Rook). December 2nd, "I forward leg and wing of a Jackdaw shot near dwellings." [Received.] 
Magpie (Pica rustica, Scop.).

Mine Head.-March 11th, one at 9 A.M.; wind moderate W., clear.

Hook Tower.-November 14th, two about the rocks; gale S.W., overcast.

Dunree Head.--June 20th, one going N.E. at 4.10 P.M.; gale S.W., cloudy.

Arran Island, S.-November 4th, two on garden wall at 9 A.M. ; strong breeze N.W., squally.

SWALLOW (Hirundo restica, Linn.).

Hook Tower.-April 21st, five hovering all day; wind light N.E., clear. May 10th, ten about all day.

Barrels Rock Light-ship.-April 30th, one found dead on the deck. [Leg and wing received.]

Tuskar.-March 29th, one flying N. at 6 A.M.; wind light N.W. April 3rd, one on the rock at 10 A.M.; wind light E.: 4th, one at 4 P.M.: 14th and 15th, Swallows on the rock in the early morning; wind fresh from the E.: 18th, one at daylight.

Lucifer Shoals Light-ship.-April 14th, two going N.W.: 15th, several flocks during day going N.W.: 16th, two flocks going N.W.: 17th, two going N.W.: 19th and 20th, several during day going N.W.: 21st, 22nd, and 27th, a few going N.W.; all "flying low," or "skimming the water." May 18th, one round ship. July 14th, one going N.W.

Blackwater Bante Light-ship.-April 17th, four going N.W. at 10 A.M.; wind moderate N.E., gloomy.

Arklow South Light-ship.-April 10th, flock going N.W. at 11.30 A.M., flying low; fresh breeze N.E, clear: 15th, one flying about ship at 7 P.M.: 30 th, one going N.W. at noon. May 6th, one about ship at 11 A.M.: 12 th, two going N.W. at 11 A.M.: 20th, two about ship at 9 P.M.

Arklow North Light-ship.-April 17th, several Swallow's passing high towards N.W. 6 A.M. and 4 P.M.; wind light N.E., light haze: 21st, one going N.W. at 5 P.M., flying low : 22nd, one going N.W. at 1.30 P.M., flying low. May 1st, one about ship: 6th, two going N.E. at 11 A.M., flying low: 10th, one about ship at 3 P.M. August 11th, two going S.E. at 1 P.M. 
Kish Bank Light-ship.-April 29th, two Swallows going N. at 4 P.ur. May 8th, two round ship. June 17 th, two going N. at 6 P.M. : 25th, two going N.W.

Houth Buily.-July 27th, flocks: 28th, 29 th, and 30th, some all day; wind moderate and fresh. September 11th, several all day, remaining; wind light W.: 27th, large flocks all day, remaining; wind light W.: 28th, a few. October 3rd, some; gale S.W.: 4 th and 5th, some all day; wind moderate W.

South Rock Light-ship.-May 7th, two at 11.30 A.M. going N.W., rested on ship for an hour: 11th, one round light at midnight; hazy: 12 th, two flying round light at 1.30 A.M.; wind light N.E., clear: 17 th, three round ship at 8 A.M. August 31st, one going N.E. at noon.

Copeland (Mew) Island.-May 2nd, some observed.

Innishtrahull.-May 13th, one caught on islaud at 10 A.M. [Leg and wing received.]

Dunice Hoad.-April 28th, six about eliffs at 4 P.M.; first arrivals; fresh breeze S.E., elear. June 6th, Swallows about station at 11 A.M., going N.; strong breeze N.W.: 14th, six about cliffs at 11 A.M. July, Swallows left this month.

Aranmore.-June 4 th, four on island at 10 A.Mr.

Slyne Head, S.-MIay Sth, two on island at 8 A.M.; first seen this year; wind light N.E., showery: 9th, two: 17th, three: 19th, two; "Swallows very scarce this year": 24 th, two. June 28th, one at 10 A.M.

Arran Island, N.-May 12th, three flying W. at 5 P.M. Jume 15th, two on rock at 9 A.M. August 8th, one.

Tecurceght.-May 18th, one caught at 5 P.M.; wind fresh S.E., mist, rain-[Received in flesh]. "It seems to be a scarce visitor" here, as any of that species are either Swift or Martin."

\section{House-Martin (Chelidon urbica, Linn.).}

Hook Tower.-May 10th, two "Martins" about all day; wind moderate N.E.: $14 t h$ and 15 th, a few House-Martins and Common Swifts flying about all day.

\section{- Sand-Martin (Cotile riparia, Linn.).}

Lucifcr Shoals Light-ship-August 10th, one "Martin" astern of ship at 7 P.M. 
Innishtraluull.-June 15th, two Martins about island at noon; wind light W., hazy.

Tearaght.-March 30th "and following days," one Martin at 2.30 P.M.; wind light S.W., overcast. May 19th, six Martins and Swifts all day; fresh breeze S.E., mist, rain. September 4th, one Martin at 7 A.M.

\section{Swift (Cypselus apus, Linn.).}

Hook Tower.-May 14th and 15th, a few House-Martins and Common Swifts Hying about all day. August 9th, several Swifts all day; one killed; clear, wind fresh E.: 19th, four during the day.

Innishtrahull.-May 11th, three on island at 11 A.M.; first arrivals; wind light S.E., hazy.

Tearaght.-May 19th, a few (see under Martin). August 9 th, one at 10 A.M.; also next day.

\section{CucKoo (Cuculus canorus, Linn.).}

Blackwater Bant Light-ship.-May 10th, "a bird struck the mizen-mast at 11 P.M." [Cuckoo received in flesh.]

Copeland (Mew) Island.-May 1st, Cuckoo heard. July 15th, shot a young Cuckoo. [Received in flesh.]

Dunree Head.-May 4th, Cuckoo first heard, perched on tree at 3 P.M.; fresh breeze E.

Aranmore.-May 2nd, one Cuckoo heard at 9 A.M. July, constantly observed.

Oyster Island, S.-May 20th, a bird killed striking at night. [Cuckoo received in flesh.]

\section{TURTLE Dove (Turtur communis, Selby).}

T'usliar.-May 8th, one Turtle Dove shot on the rock. [Received in the flesh.]

\section{"Pigeons."}

Mine Head.-March 23rd, four. October 30th, a flock of Wood Pigeons flying S. at 4 P.I. December 15th, a flock of Pigeons flying S. at 2 P.M.

Hook Tower.-A few Pigeons breed round here, but they never leave. 
Tuskar.-February 11th, one arrived. April 8th, one Pigeon Hying S.E. at noon; wind strong N.

Blachwater Banli Light-ship.-April 12th, six about light at midnight, two killed; wind light S., gloomy.

Arlilow South Light-ship.-December 20th, one caught at lantern at 10.30 P.M.; wind light N.E.

Arklow North Light-ship.-April 14th, one Carrier Pigeon, "slate colour, large red circle round eyes." May 8th, a Carrier Pigeon rested on mainmast at 6.30 P.M., caught, came from S.E. ; light breeze N.E.; marks on ring on left leg, "No. 25, 1889," on ring on right leg, "H. C., 1889." December 20th, large flock going W. at 10 A.Mr, flying low, rose high when over ship, came from E.; wind light N.E.

Rockabill.-April 22nd, a beautiful Carrier Pigeon pitched on the rock, and after resting a while flew towards Dublin; strong breeze W.

South Rock Light-ship.-July 22nd, one Wood Pigeon or Blue Dove flying round ship at 8 A.M.

Copeland (Mew) Island.-July 22nd, Carrier Pigeon about chimney top, caught and let go. December 8th, Pigeon on island, appeared to be tame.

Innishtrahull.-April 29th, one Rock Pigeon on island.

Dunree Head.-July 10th, ten flying about cliffs. August 20th, flock going W. September 10th, October 4th, and November 21st, ten to twelve noted going S.W. each day.

Aranmore.-January, February, and March, Rock Pigeons seen occasionally. " Rock Pigeons always remain." October, "very plentiful."

Slyne Head, S.-May 17th, two going $\mathrm{E}$.

Arran Island, N.-May 21st, six Wild Pigeons going E. at 9 A.M.; fresh breeze S.E., rain: 29th, four Rock Pigeons at \pm P.M. June 6 th and 7 th, ten: 16th, three: 21st, twentyfour.

Arran Island, S.-October 31st, two on crag near lighthouse; one shot. December 18th, three on island.

Tearaght. - March 12th, twelve Rock Pigeons all day; wind moderate W. August 14th, two. October 3rd, ten: 29 th, ten. November 17th, "about four dark-coloured Pigeons" all day; fresh breeze S.E. December 3rd, ten: 20th, about twenty. 
Red Grouse (Lagopus scoticus, Latham).

Aranmore.-March 24th, one Grouse shot at 4 P.M.; strong breeze S.E., squally, with rain.

Partridge (Perdix cinerea, Latham).

Mine Head.-November 6th, twelve Partridges flying N. at 4 P.M. ; gale S., fog.

Corn-Crake (Crex pratènsis, Bechst.).

Innishtrahull.- May 24th, one heard on island at 9 P.Ir.; fresh breeze $\mathrm{E}$.

Hook Tower.-May 17th, one Land-Rail killed against lantern.

Water-Rail (Rallus aquaticus, Linn.).

I'earaght.-October 9th, beak and feathers of Water-Tiail found at Peregrine's feeding-place. [Received.].

Ringed Plover (AEgialitis hiaticula, Linn.).

Spit Bank, Queenstown.-July 2nd, about twenty feeding on the bank. October 19th, two all day.

Hook Tower.-November 28th, three all day.

Copeland (Mew) Island.-May 16th, observed a pair. The eggs of these birds were found on the island in 1888, but none could be discovered in 1889 .

Innishtrahull.-June 8th and 9th. (See note under Dunlin.)

Killybegs._- "Sand Plover observed almost daily."

Arran Island, S.-November 15th, four in lighthouse park at 8 A.M.; strong breeze S.; very scarce.

Golden Plover (Charadrius pluvialis, Linn.).

Mine Head.-October 18th, about fifty Grey Plover [? Golden] at 1.P.M. November 27th, 28th, and 29th, Golden Plover observed passing each day. December $20 t h$, twenty flying $N$.

Hool Tower.-May 14th, none were seen during the winter, and are said to come here seldom except in a hard winter, about December.

Arklow South Light-ship. - February 23rd, a few "Grey 
Plover" (see full note under Starling). December 9th, some (see under Skylark).

South Rock Light-ship.-November 6th, large flocks of "Grey Plover," about sixty in number, at 9 A.M.

Copeland (Mew) Island.-February 20th, great rush of birds (see under Lark).

Maidons North.-[December 11th, leg and wing of Golden Plover received; killed striking.]

Innishtrahull.-December 19th, numbers of "Grey Plover" hovering about light from 4 A.M. to 7 A.M., none injured; S.E. gale, sleet.

Aranmore.-January, February, and March, "Grey Plover" seen occasionally. September 30th, a flock of "Grey Plover" on island; gale S.W. October, very plentiful. November. 6th, flocks of Plover all day, remained; strong breeze S., squally. December, about in flocks.

Killybegs.-January 26th, forty Golden Plover going S.E. March 2nd, six going S.: 10th, eight going N. September 6th, one going N.: 18th, two going N.: 24 th, two at 10 A.M. October 13th, three going S.W.: 14th, thirty-five going N. at 3 P.M.; wind moderate N.W. November 26th, flocks of Green and Golden Plover in neighbouring marshes; frosty weather. December 10th, eight Golden Plover going $\mathrm{N}$.

Oyster Island, S.-December 7th, twenty on island: 12th, thirty going $\mathrm{S}$.

\section{Green Plover (Vanellus vulgaris, Bechst.).}

Minc Head.-November 26th, fourteen flying S.: 27 th, twelve. Hook Tower.-February 2nd, thirty Lapwings about all day. Green Plover were here in great numbers during the winter, but left about the middle of February. May 13th, two. November 28th, many.

Coningbeg Light-ship.-December 31st, two flocks of Green Plover flying towards land at $8.30 \mathrm{~A}$.M.; wind fresh E., snow.

Tuskar.-April 2nd, one Lapwing on the rock at 7 P.M.: 14th, one left for the land at 8 A.M.; wind strong S.E., gloomy.

South Roch Light-ship.-May 11th, two Plover and one Swallow round light at midnight; wind light S.E., hazy: 12th, two Plover at midnight; wind light N.W. November 
9th, three about ship at 6.30 P.M. December 1.8th, flocks, with Thrushes and Curlew (see under Thrush).

Copeland (Mew) Island.-February 20th, great rush of birds, including several Plover (see under Lark): 22nd, number of "Peeweeps" round lantern first part of night. May 6th, a Lapwing observed: 9 th, a pair on island: 17 th, a few about. September 17th, several. October 1st, Lapwing to and fro. November 13th, several flying in rays of light at 8.30 P.M.; wind S., dense fog. December 9th, Lapwing, Blackbirds, Starling, and Larks plentiful up to 5 A.I.; still, calm, and hazy: 11th, plentiful in rays of light (see under Lark).

Maidens South.-February 20th, 21st, and 22nd, great rushes of birds, two Lapwings killed striking (see full note under Thrush). [Leg and wing of Green Plover received.]

Innishtrahull.-March 10th, one on island at noon, first seen all winter; strong breeze S.W., fog. April 29th, one on island.

Dunree Hecud.-December 20th, fifty going E, and flocks flying about all day; wind moderate $\mathrm{E}$.

Aranmore-April 28th, two near station. December 4th, Grey and Green Plover about in flocks.

Killybegs.-Spring, "Green Plover observed almost daily." October 10th, five at 3 P.M. November 26th, flocks (see note under Golden Plover).

Oyster Island, S.-November 14th, thirty going N.; wind light S.E., showery. December 23rd, some on island all day; wind light E., frosty. "Green Plover are very numerous this winter."

Arran Island, $N$.-December 31st, numbers of Plover and other birds on account of frost.

Arran Island, S.-October 25th, four going E., one shot; snow showers. December 23rd, four, appeared young birds.

Tearaght.-December 30th, one; wind fresh E.

Skelligs.-December 24th, two on rock; fresh breeze N.E., mist.

TuRnstone (Strepsilas interpres, Linn.).

Hook Tower.-March 10th, five about shore all day: 16th, six. Angust 19th, thirty on rocks all day. September 22nd, four. November 28th, eight. 
Innishtrichull._- Snow Buntings and Turnstones the only regular residents."

\section{Oyster-Catcher (Howatopus ostralegus, Linn.).}

Hook Tower.-January 22nd, these birds are seen daily at this station. September 8th, ten all day. Oyster-Catchers here all the year round, but not numerous in autumn; never more than one flock seen, the most together being about forty or fifty.

Tuskar.-April 3rd, two Seapies at 10 A.M.

Howth Buily.-September 10th, several Seapies all day.

Copcland (Hew) Islend.-May 9th, plentiful, and always here. Arcanmore. - January, February, and March, Seapie seen occasionally; and constantly in July, August, September, and October.

Killybegs._-Seapie observed almost daily.

Arran Island, N.-Flocks of Sand Larks and Seapies constantly on rock.

Teureght._January 12th, four Seapies all day; gale S.

Woodcock (Scolopax rusticula, Linn.).

Mine Head.-November 13th, one flying N. at noon.

MLeidens North. - November 9th, one going S.W.; killed striking at 11.30 P.M.; strong breeze N.E., misty. [Leg and wing received.]

Innishtrahull.-December 27th and 28th, one on island each day ; fresh breeze S.E.

Aranmore.-January, February, and March, Woodcock seen occasionally. September 30 th, two at 1 P.M. October and December, very plentiful.

Arran Island, S.-December 2nd, one on island at 3 P.M. ; first seen this year; gale N.E., misty.

Tearaght.-December 10th, one at 12.30 P.M.; wind moderate E. : 31st, one at 11 A.M. "Two or three Woodcock were seen lately but not shot. The Peregrine was seen to seize one and carry it towards another island to the N., and another day to seize another brown bird, sort not known, which he dropped in the sea when a Herring Gull chased him, and the Gull got it."

Skclligs.-December 16th, one shot on rock; fresh breeze E. 
Common Snipe (Gallinago ccelestis, Frenzel) and

JACK SNIPE (G. gallinula, Linn.).

Mine Head.-March 16th, one Snipe flying E. November 12th, four flying to the W.: 30th, seven flying W. December 28th, three flying. S.

Hook Tower.-April 21st, one Jack Snipe killed. [Leg and wing received.]

Tuskar:-April 19th, one Jack Snipe killed striking; wind moderate S.W.

Arklow South Light-ship.-May 25th, one Snipe killed striking at 9 A.M.; wind moderate N.E. ; hazy, showers. [Received in flesh.]

Copeland (Mew) Island.-May 6th, the "heather bleat" of the Snipe heard; though several Snipe are on island, no nest could be found: 17th, Snipe still heard overhead and in every direction. December 9th, Snipe partly injured, caught on balcony (see note under Lark).

Maidens North.-December 9th-[Leg and wing of Snipe received, "killed"]: 11th, one killed striking at 9.30 P.M. going N.W.; gale S.E., rain. [Leg and wing received.]

Arcumore.-January, February, and March, seen occasionally. October and December, very plentiful.

Slyne Head, S.-November 14th, two Snipe on island at 1 P.M. ; strong breeze N.W., showers. "A few Snipe almost daily."

Arran Island, N.-November 27th, two on island all day; snow.

Tearaght.-March 29th, one Jack Snipe at noon. December 2nd, one large Snipe at noon; wind moderate S.E., log: 31st, four Snipe at 8 A.M.; fresh breeze E.

Skelligs.-December 14th, one large Snipe shot on rock at 4 P.M. ; fresh breeze E.

\section{DunLin (Tringa alpina, Linn.).}

Hook Tower. - October 19th, six on the rocks all day: 26 th, twenty to thirty on the rocks. November 15th, two killed striking; wind light S.W. [Legs and wings received]: 17th, Dunlin round the light; wind moderate S.W.; one killed. 
Arlklow South Light-ship.-[May 25th, Dunlin received in flesh, found dead.]

Rockabill.-[April 18th, Dunlin received in flesh.]

Innishtrahull.-June 8th and 9th, "observed a very pretty bird pairing with the Ringed Dotterel, either a Sanderling or Dunlin; the plumage very much resembled that of a Sanderling on the back, but it was black under the breast like a Dunlin; bill about two inches long, black; legs black; back and wings much brighter and prettier than the Dunlin. I failed to find their nest. I never saw birds so different in plumage pairing before.-M. J. KENNEDY."

\section{Purple SANdpiper (Tringa striata, Linn.).}

Hook Tower.-January 22nd, four Purple Sandpipers all day on the rocks. These birds are seen daily at this station during the winter. March 16th, twenty about the rocks; wind fresh W. September 22nd, five, and four Turnstones, all day; wind light N.W. October 19th, twenty all day; wind light N. November 14th, several; one shot; gale S.W. [Leg and wing received.]

Tearaght.-December 28th, "several Sand Larks at 3 P.M.; wind light E." [Leg aud wing of Purple Sandpiper received.]

\section{"SAND LARKs."}

Spit Bant, Qucenstown.-October 12th, a large flock of Sand Larks going N.E. at 5 P.M.

Fine Head.-November 8th, three flying N. at noon.

Maidens South.-January 28th, five all day.

Aranmore.-January, February, and March, "Sea Larks" seen occasionally.

Killybegs.-Sand Larks observed almost daily. November 3rd, large number of "Strand Larks" all day; strong breeze W., foggy.

Arran Island, N.-Flocks of Sand Larks and Seapies constantly on rock.

Tearaght,-January 11th and 12th, one or two Sand Lark; wind strong to a gale. November 9th, one Sandpiper. December 17th, three Sand Larks: 2Sth, several Sand Larks at 3 P.M.; wind light E. (Probably Purple Sandpiper, which see.) 


\section{Redshank (Totanus calidris, Linn.).}

Hook Tower.-October 19th, two on the rocks all day. Arklow South Light-ship.-November 15th, one going S.E.

Innishtrahull. - November 12th to 14th, twenty-one on island each day, "an unusual number to be together here."

Killybegs.-Observed almost daily.

Oyster Island, S.-November 25th, ten going S.E.; squally. December 7 th, three seen.

Slyne Head, S.-August 2nd, three on island.

\section{CURLEW (Numenius arquata, Linn.).}

Spit Bank, Quecnstown.-January 11th, a large flock flying W., high. March 6th, a large flock flying high to the S.W. July 6th, thirty on the bank. October 15th, five: 30th, numbers feeding.

Mine Head.-March 14th, two flying N.W. April 19th, four flying $\mathrm{N}$.

Hook Tower.-February 2nd, about fifty all, day. October 19th, forty. Curlew here all the year round.

Tuskar.-March 11th and 12th, great numbers, whistling; wind fresh S.W.: 20th, one. April 3rd and 4th, two: 19th, four.

Lucifer Shoals Light-ship.-March 11th, one around ship at 10 P.M. ; wind moderate N.W. : 14th, one all night.

Blackwater Bank Light-ship.-March 6th, two flying round ship at 8 P.M. April 19th, flocks going N.W. up to 11 P.M.: 20th, flock going NW. at 10.30 P.I. ; fresh breeze S.IW., gloomy.

Arklow South Light-ship.-February 23rd, flocks going N.W. (see full note under Starling). April 12th, one about lantern at 11 P.M. December 20th, some going N.W. (see note under Starling).

Artilow North Light-ship.-April 15th, flock going N.E. at 9.40 P.M. : 29th, one going N.W. May 8th, flock going S.W., flying high, at 10 P.M. July 16th, one over ship. August 8th, several going S.W. at 11 P.M. ; wind light S.E. : 9th, flock going W. at 9.45 P.M.

Howth Baily.-October 26th, flocks Curlew and Starling all day remaining; strong breeze N.W. November 8th, flock at 5 P.M. along the shore. 
Rockubill.-March, great rushes of birds (see under Blackbird).

South Rock Light-ship.-May 6th, two going N.E. December 18th, rush of birds, including Curlew (see under Thrush).

Copelend (IIew) Island.-February 20th, remarkable rush of Curlew and other birds (see full note under Lark): 22nd, some seen in rays of lantern; misty: 25 th, some flying past light. May 17th, during the past week about a dozen Curlew or Whimbrel on island. August 10th, Curlew calling at night and flying about by day.

Maidens South.-February 20th, 21st, 22nd, and 26th, great rushes of birds (see full notes under Thrush). March 7th, numbers of Curlew heard passing through the night; gloomy and showery: 11th, Curlew heard passing: 12th, passing at night: 16th, heard all night.

Dunree Head.-September 28th, seven going N.E. Octoher 24th, twenty-four going N.W. November 7th, six going E.

Aranmore.-January, February, and March, Curlew seen occasionally. September 30th, a flock going S.E. at 2 P.M. ; gale S.W. October and December, very plentiful.

Killybegs.-Observed almost daily.

Slyne Head, S.-March 31st, two going E. at 3 P.M. April 10th, one do. going E. : 25th, two do.; 27th, six on island. May 17th, two: 25th, seven going E. July 2nd, five going E. : 7th, three do.; "Curlew very numerous this year." August 1st, nineteen going S.W.: 2nd, five on isiand. September 21st, two do. October 17th, 19th, and 25th, one to five noted. November 5th, 14th, and 16th, a few.

Arran Island, N.-May 20th, six going W. August 16th, sixteen on rock all day.

Arran Island, S.-October 28th, fifty going N.W. November 30th, fifteen lighting on crag near lighthouse at 10 A.M.; large flocks passing; gale S.W., foggy.

Tecrerght.-December 4 th, one at noon; strong breeze N.E.

Shelligs.-December 24th, one at 9 A,M. ; fresh breeze N.E.

Whimbrel (Numenius phocopus, Linn.).

Spit Banl; Queenstown.-April 20th, Whimbrel heard at 1 A.M. May $11 \mathrm{th}$, some going $\mathrm{W}$. in the afternoon; also heard at night: 31st, two large flocks going $\mathbf{E}$. at 9 P.M. 
Hook Tower-May 4th, 5th, and 6th, passing and hovering round the lantern; wind moderate S.E.

Lucifer Shoals Light-ship.-August 10th, "four Curlew, young May birds," going N. at 2 P.M. ; calm.

South Roch Light-ship.-August 2nd, ten going N.W. at 10 А.м. : $3 \mathrm{rd}$, large flock going N.W. at 8 A.M.; wind light N.W.: 7 th and 12th, large flocks passing all day N.W.: 22nd, large flocks, about twenty in number, going N.W. at 6 A.Mr. ; wind light S.W., showery. "Above flocks of Whimbrel largest ever seen here.-Henry Thompson."

Copeland (Mew) Island.-May 17th (see under Curlew).

Innishtrahull.-May 23rd, six "young Curlew" on island at 6 P.M. ; wind moderate S.E., clear; two shot. [Leg and wing of Whimbrel received.]

Slyne Head, S.-May 14th, one May bird on island at 11 A.M.; first seen this year; gale W.: 15th, two; gale S.W.; "May birds scarce."

Tearaght.-September 2nd, "wing of Curlew picked up at Peregrine's feeding-place." [Leg and wing of Whimbrel received.]

Arctic Tern (Sterna macrura, Naum.).

Tearaght.-October 9th, wing of supposed Lesser Tern picked up at Peregrine's feeding-place. [Wing of Arctic Tern received.]

\section{TERNS.}

Barrels Rock Light-ship.-March Sth, flocks of Sea Mews passing all day N.W.; fresh breeze W.

Lucifer Shocls Light-ship.-August 10th, "three Kittiwakes -black caps with forked tails, don't know their name," round ship at 7 P.M. ; calm.

Copeland (Mew) Island.-May 12th, "Mews arrived this morning; were not again seen till next morning, when they were not so plentiful; were not seen during the day; next morning they were again observed, but up to the 17th were not plentiful. Probably those observed in the morning arrived during the night, and were merely passing on to their final destination. June 20th, some Mews' eggs found: 30th, the Mews' eggs, which are laid on the level ground unprotected 
and unhidden, are picked up as soon as they are laid. Boys come out from the mainland purposely to gather them; one boy gathered fourteen dozen one afternoon.-EDward M'CARron." August 10th, a very few young Mews may be seen. September 1st, Mews still here: 12th, nearly all gone: 18th, a few still on island (see also under Crane): 20th, only a few lately here, but this evening some two or three hundred were on the island. October 1st, Mews all gone.

Slyne Head, S.-May 19th, "Perrs" arrived to build on adjacent island.

\section{KitTiwaKe GUlL (Rissa tridactyla, Linn.).}

Aranmore.-August 21st, one caught at light at 1 A.M.; wind light E., gloomy, squally. [Young Kittiwake received in flesh.]

Tearaght.-March 27th, Kittiwakes landed at 6 A.M.; wind light S.W., misty, passing showers, hail. April 3rd, great numbers all day; fresh breeze S.W. August 1st, all sea birds nearly gone, except Kittiwake. Some few remained till about the first week in September. December, Kittiwakes, old and young, about rock during month: 16th, one young Kittiwake killed at lantern at 11 P.M. ; wind light E. [Leg and wing received.]

\section{"GULLS."}

Spit Bank, Queenstown.-January 3rd, several Grey Gulls all day, and on 6th. Herring Gulls and Common Gulls feeding on sprats in the afternoon of the 11th: 13th, a large flock of Herring Gulls, also one Iceland Gull and several Common Gulls fishing. February 16th, two Iceland Gulls fishing near the lighthouse; wind fresh S.S.E., gloomy. One of these birds was much smaller than the other and lighter in colour. March 22nd and 28th, numbers of Common Gulls on the bank: 30th, numbers of Kittiwakes. April 1st and 3rd, Kittiwakes numerous: 5th, two Herring Gulls were observed to chase and strike a small Grey Gull, which fell dead on the water: 12th and 13th, many small Grey Gulls and Herring Gulls about the harbour: 25th, numbers of Kittiwakes feeding. May 11th, about two hundred Kittiwakes: 30th, about thirty Kittiwakes and some Common Gulls feeding. June 8th, 
numbers of Kittiwakes: 18th and 22nd, several Common Gulls. July 2nd, fifty Common Gulls on the bank. At intervals during October many Kittiwakes and Common Gulls noted. November 29th, some hundreds of Kittiwakes.

Hook Tower:-Common Gulls, Kittiwakes, and Black-headed Gulls daily seen during the early part of the year. April 26th, many Herring Gulls and Kittiwakes on the water all day; gale N. Numbers of Gulls noted September 3rd, 19th, and 30th. November 26th, many Common Gulls, Herring Gulls, and Kittiwakes to be seen all the year round. Gulls build in cliffs about four miles off.

Lucifer Shoals Light-ship.--March 24th, several Gulls and Puffins about ship at noon.

Arklow South Light-ship.-November, great number of small Common Gulls, also Herring Gulls and a few Black-Backs, and a few "Skua Gulls."

Codling Bank Light-ship._April, "Gulls about the ship daily." Howth Baily.-August 3rd, large flocks Gulls all day: 25th to $28 \mathrm{th}$, large flocks Gulls remaining. October 24th, large flocks Gulls of various descriptions, and Razorbills and Guillemots, from noon to 3 P.M., appeared to be feeding on sprats; wind moderate W., clear: 27th, immense flocks of Gulls.

Copeland (Mew) Island.-July 1st, Kittiwake Gulls very plentiful. August 9th (see under Razorbill): 20th, Kittiwake Gulls plentiful. October 1st, Kittiwake Gulls still about island: 10th, Skua Gull shot by visitor: 13th, Gulls plentiful about island. November 20th, during autumn and up to the present Poyal Gulls may be seen daily, sometimes as many as a dozen together.

Maidens South.-Tanuary 8th, 12th, 14th, 18th, and 22nd, Black-backed Gulls-one to three-seen near rock.

Innishtrahull.-November 1st, two Skuas near island at 2 P.M. ; they were chasing all other Gulls near them.

Dunree Head.-October 8th, great numbers of Gulls and Puffins on water at 3 P.M. ; fresh breeze S.E.

Aranmore-January and February, Gulls, both Black-backed and Common, seen occasionally during these months. July and August, Lesser and Greater Black-backed and Herring Gulls seen constantly. October, same species seen daily. A few Common Gulls always remain. 
Slyne Head, S.-January 6th, one cream-coloured or Iceland Gull flying about island at 3 P.M.; strong breeze S.W.; shot, fell into sea, and was lost.

Tearaght.-October 20th, Common Gulls noted, also Skua at 2 P.M.; wind light N. December 27th, "eight or ten Cormorants or Shags, two Royal (Great Black-backed) Gulls, Herring Gulls, Kittiwakes, old and young, several Gannets, fishing about rock during month." A Herring Gull chasing a Hawk (see under Woodcock).

\section{Manx Shearwater (Pufinus anglorum, Temminck).}

Hook Tower:-April 26th, about six all day on the sea; gale N. September 3rd, a number of Shearwaters all day; wind strong W.: 19th, a number; gale S.E. : 30th, do.; gale S.E.

Barrels Rock Light-ship.-March 8th, small flocks passing all day to the W.; wind fresh W.: 10th, 11th, and 20th, odd birds passing, principally towards the $\mathrm{W}$.

Lucifer Shoals Light-ship.-March 9th, twelve "Mackerel Cock" going W.; strong breeze N.W.

Aranmore.-March 16th, some noted. April, Shearwaters in large numbers daily. July, seen daily. None observed after the 24th of August.

Tearaght.-May 1st, first heard at 10 P.M. ; generally heard every night up to August.

Fork-tailed Petrel (Occanodroma leucorrhoa, Vieill).

Tearaght.-October 17th, "no Fork-tailed Petrels seen, but they are said to breed on the next island."

\section{Storm Petrel (Procellaria pelagica, Linn.).}

Lucifer Shoals Light-ship.-May 18th, one "Petrel" round ship; wind light S. September 21st, one Storm Petrel in wake of ship; wind S.W. October 26th, one "Petrel" about all day.

Blackwater Bank Light-ship.-November 17th, one caught on deck at 6 A.M. and another at 5 P.M. ; wind moderate S.W., gloomy. [Leg and wing received.]

Arklow South Light-ship.-November 12th, one about ship at 1.30 P.M. 
Arklow North Light-ship.-August 11th, one round ship at 1.30 P.M. ; calm, fog.

South Rock Light-ship.-October 20th, a "Mother Carey's Chicken" caught. [Storm Petrel received in flesh.]

Killybegs.-August 15th, two caught at lantern at 9 P.M. ; a wet, hazy night. [Received in flesh.]

Rathlin Island. - [August 20th, Storm Petrel received in flesh, caught striking.]

Slyne Head, S.-October 25th, one found disabled at 8 A.M. ; strong breeze N.W. ; heavy gale next day; first seen here for two years.

Tearaght.-April 19th, one, the first seen, at 10 P.M.; overcast, misty. "Storm Petrels were very numerous around light this season in foggy weather." May 25th, several from 10 P.xI. to 4 A.Mr. striking lantern, none killed; fog. July 4 th, great numbers from 11 P.M. to 2.30 A.M. striking lantern, none killed; fog: 10th, 17th, and 18th, great numbers all night; misty. September 16th, several at 1 A.M. at lantern; mist. October 9th, several around lantern all night, all young birds: 12th, several between 9 P.M. and 11 P.M. November 3rd, a young one at 11 A.M.; squally: 9 th, another do. at 2 P.M.

\section{Razorbill (Alca tord $\alpha$, Linn.) and GuILlemot} (Uria troile, Linn.).

Spit Bank, Queenstown.-January 6th, one Razorbill feeding wind strong S.W.; first noticed for some time: 11th, two fishing: 15th, one Guillemot on the water; wind strong S.W.: 17th, three and two Razorbills: 27th, many Guillemots about the harbour all day (probably come in for refuge); weather severe for some time past: 30th, several Razorbills, last year's birds, all day about the harbour. April 6th, four Razorbills: 13th, one Guillemot: 27 th, one Razorbill. October 17 th, one Razorbill on the water close to the lighthouse; 22nd, one. November 12th, two Puffins and a Razorbill: 29th and December 3rd, a few Razorbills fishing.

Hook Tower.-March 9th, several Razorbills all day. April 21 st, small flocks do. passing all day to the S.E. : 26th, Razorbills on the water. September 19th, a number. December 12th, thirty Guillemots seen daily. Razorbills build in cliffs about 
four miles off. They are not nearly so numerous here as on the N.W. coast, where I have seen them scattered over the water for miles.

Barrels Rock Light-ship.-February 28th, a large flock of Guillemots flying W. at 3 P.M. March 4 th, a flock flying in the same direction.

Arlilow South Light-ship. -November, great flocks of "Razorbill Puffin" daily about ship.

Codling Bank Light-ship.-March 16th, several "Murs" going S.E. April, "Murs about the ship daily."

Howth Baily.-September 25th, several Razorbills all day, remaining: 27 th, some all day: 28th, four. October 24th, flocks (see under Gulls).

Copcland (Mew) Island.-May 9th, Razorbills heard [? R. M. B.] on water. August 9th, numbers of Guillemots, Razorbills, Kittiwakes, Gulls, and Gannet after fry: 19th, Razorbills plentiful; a few young ones of this year among them. September 1st, young Razorbills heard daily on the water during the last fortnight.

Innishtrahull.-March 25th, seven Guillemots near station.

Aranmore.-April, Razorbills and Guillemots in large numbers daily. July and August, Guillemots and Razorbills seen constantly. September, no Razorbills or Guillemots; all other sea-fowl mentioned in July to be seen daily.

Tearaght.-January 1st to 8th, Guillemots and Razorbills, old and young, first seen on water round rock; wind fresh N.E.: 31st, Guillemots first landed on rock, and continued to come each morning up to February 28th. March 2nd, several Razorbills landed at 7 A.M. : 27th, Guillemots landed at 6 A.M. "Razorbills began to leave about July 15th." Guillemots, Razorbills, and Puffins all left before end of August. October 20th, flock of Razorbills and Common Gulls. December 3rd, one supposed Razorbill heard on rocks near lighthouse at 8 A.M. : 11th, young Razorbills fishing all day.

LITTLE AUK (Mergulus alle, Linn.).

Vidal Bank. - November 27th, "a bird caught at the mouth of a freshwater river." [Little Auk received in flesh.] 
Puffin (Fratercula arctica, Linn.).

Spit Bank, Queenstown.-January 20th, four; first noticed this season; six seen on the following day. November 12 th, two.

Hoole Tower.-March 9th, several. April 21st, small flocks passing all day to the S.E. : 26th, some seen. September 19 th, a number. Puffins build in cliffs about four miles off.

Barrels Rock Light-ship.-March 21st, a few "Parrots" flying to the W.; first seen; wind light W., clear. A small flock on the 23rd passing in the same direction.

Lucifer Shoals Light-ship.-March 24th, several (see under Gull).

Arklow South Light-ship.-November, "Puffins about station daily."

Codling Bank Light-ship.-April 1st, 14th, 18th, and 22nd, eight to fourteen noted going N.E.

Dunree Head.-May 5th, several. October 8th, a number (see under Gull).

Killybegs.-March 28th, first observed this year.

Slyne Head, S.-April 25th, one-Sea Parrot found killed by large Hawk (see under Hawk).

Tearaght.-February 28th, one Puffin (Sea Parrot) at 11 P.II., did not land. March 26th, first landed at 5 P.M.; gale S.E., mist, rain. All left before end of August. December 8th, young Puffin picked up. [Leg and wing received.]

\section{"Great Northern Diver."}

Spit Bank, Queenstown.-January 19 th to $22 \mathrm{nd}$, one or two near station. November 29 th and December 1st, one in the harbour each day.

Aranmore.-January, February, and March, seen occasionally.

Oyster Istand, S.-October 28th; two shot; male and female. November 14th, three seen; one male shot. December 11th, three noted.

Cormorant (Phalacrocorax carbo, Linn.) and Shag ( $P$.graculus, Linn.).

Spit Bank, Qucenstown. - January 6th to 22nd, several Cormorants at intervals : 23rd, twenty-seven Green Cormorants 
in one flock flying W.; and many Cormorants and Shags about the harbour all day.

Hook Tover:-Cormorants here all the year round; they breed in cliffs about four miles off.

Coningbeg Light-ship.--January 5th, one Cormorant about light at midnight; strong breeze S.W., light haze: 11th, one do.; wind moderate W., clear.

Tuskar:-January, a succession of heavy gales this month. The Green Cormorant (Shag) appears to be a hardier bird than P. carbo.

Howth Baily.-September 11th, several Cormorants all day, remaining: 27th, some. November 18 th, several going E.

Copeland (Mev) Island.-May 17th, Cormorants which have been here all the year left during the last six or seven weeks. September 18th, not observed for a long time. November 20th, always about.

Dunree Head.-August 8th, nine Cormorants going N.W.: 19th, twenty-three going N.E. October 30th, ten going N.E. December 10th, twenty-four going $\mathrm{N}$.

Aranmore.-January, February, and March, Green and Black Cormorants seen occasionally. "They are always here."

Killybegs.-Cormorants observed almost daily.

Tearaght.-December 27th, eight or ten Cormorants or Shags during month.

\section{Gannet (Sula bassana, Linn.).}

Hook Tower.-March 31st and April 1st, two to four flying S.E. Very scarce here this spring, only a few pairs seen, generally flying S.E.

Barrels Rock Light-ship.-February 28th, one flying E. March 4th, one flying W.: 18th and 20th, odd Gannets passing all day, chiefly to the W.

Incifer Shoals Light-ship.-March 9th, several flocks going W.: 10th, flock going S.W.: 21st, several flocks going S.W. April 16th, five flocks going N.E.: 17th, three flocks going N.E. : 24 th to 30 th, several flocks going N.E.

Blackwater Bank Light-ship.-March 10th, five going N.E.: 16th, do.: 29th, flock of thirty-one going N.E. "Gannets passing $N$. in small flocks from 10 th to 20 th of April." December 12 th, seven going N.E. 
Arklow South Light-ship.-November, "a few Gannets seen." Arklow North Light-ship._-March 14th, large flock going N.E.: 29th, large flocks going N.E.: 30th, several going N.E.: 31st, large numbers going N.E. April 12th, 21st, and 22nd, several going N.E. : 27 th, flock going N.E. : 30 th, three Gannets going S.W. July 11th, two going S.W. August 6th, 7th, and 9th, several noted: 10th, flock going S.W. October 9th, 10th, and 11th, several going S.W. during day.

Codling Bank Light-ship.-March 14th, six going S.W.: 30th, fourteen going N. April 1st, thirteen going N.E.: 3rd, 6th, 11 th, 13 th, 18 th, and $23 r d$, six to fourteen each day going $N$.: 15 th, four going S.E.

Kish Bank Light-ship.-April 30th, three going S.E.

Howth Baily.-July 27th, several remaining. September 25th, several going S.

South Rock Light-ship.-April 16th, twenty-one going N.

Copeland (Mew) Island.-May 6th, several: 9th, always to and fro. August 9th, numbers about: 20th, plentiful. September 20 th, several.

Innishtrahull.-April 13th, nine going N.W. December 12th, one Gannet fishing near station, "a "late visitor."

Killybegs.-February 23rd, one Gannet going N.W.; first observed this year. March 11th, two fishing.

Arran Island, S.-December 22nd, five fishing.

\section{Heron (Ardea cinerea, Linn.).}

Spit Bank, Queenstown.-April 19th, eleven; the first noticed for a long time; they were very light in colour, two being almost white. Herons are from time to time observed in large numbers at this station; as many as twenty birds may be seen feeding on the bank at one time: 21 st, some: 27 th, one. June 2nd, one: 18th, five: 21st, one. July 2nd, 4th, and 6 th, one to three. October 12 th and 15 th, five to seven: Herons noted 16th, 18th, and 22nd. November 29th, twentyfour.

Copeland (Mew) Island.-September 18th, "yesterday several 'Cranes' came to the island pursued by the Mews. I think their absence during last summer was owing to the annoyance they would be subjected to by these Mews." 
Innishtrahull.-June 6th and 7th, a large Heron on rocks.

Aranmore.-December 4th, one going S.E.

Slyne Hecud, S.-March 27th and 31st, July 26th, August 19th, and September 2nd, one to two "Cranes" noted.

Arran Island, N.-July 12th, 15th, and August 4th, two to six "Cranes" all day.

Arran Island, S.-November 10th, six "Cranes" fishing.

\section{"GEESE."}

Spit Bank, Qucenstown.-January 9th, three large Wild Geese going W.

Hook Tower.-One flock of Geese heard passing overhead at night about the latter part of November. "Not many noticed since I came here."

Tuskar--November, great many Barnacle and Duck remain in Wexford Bay during the winter.

Lucifer Shoals Light-ship.-November 14th, two flocks of Barnacle close to ship all day; gale S.: 15th, three flocks Barnacle about ship until evening: 16th, two flocks do. going W. at 3 P.M. ; lighted close to ship, and flew to land.

Howth Baily.-October 25th, about thirty Barnacle going N.

South Rock Light-ship.-July 3rd, fifteen Wild Geese going N.W. at $S$ P.M. ; wind moderate N., clear.

Copeland (Mew) Istand.-December 9th, heard Barnacle flying overhead.

Maidens South.-October 16th, eight Barnacle going W.; appeared fatigued; strong gale N.W. November 19th, twentytwo Barnacle going S. : 26th, forty or fifcy Barnacle going S.

Innishtrahull.-April 13th, a large flock of Barnacle or Brent Geese going N.E.; flying very high; "never saw so many in a flock, there must have been three or four hundred." Novernber 5th, eighteen Barnacle Geese going W.

Aranmore.-January, Barnacle seen daily in flocks of from twenty to one hundred passing and repassing. April 10th, sixty going S.; gale S.: 19th, large flocks feeding on brows of cliffs near station: 28th, flocks going N.E. September 20th, twenty going S. October, Barnacle seen daily passing S. December, Barnacle daily passing and repassing.

Killybegs. - February 22nd, ten Wild Geese going N.W. December 4 th, five going S.E. : 26th, four going S.E. 
Oyster Island, S.-October 24th, several flocks of Barnacle going N.W.; three shot: 26th, six large flocks Barnacle going $\mathrm{N}$; ; squalls: 28th, twelve large flocks going $\mathrm{N}$.; six shot. November 3rd, one flock Wild Geese going N.: 5th, 6th, 7th, and 8th, flocks of Barnacle going N. and S.; several shot; strong breeze W., squalls: 11th, flocks going S. at 11.30 A.M.; strong breeze S., mist and rain: 17th, thirty Barnacle going S.: 24th, several flocks going N.; strong breeze N.W.: 25th, Wigeon and Barnacle going N.; squally. December 1st, fifteen Barnacle going S.; strong breeze S.W., rain: 6th, one Barnacle killed striking at 1 A.M. going N.W.; wind moderate N.E., overcast. "This bird broke two panes of glass, was alone, and in very poor condition." "Barnacle generally arrive here in October and leave in December:"

Slyne Head, S.-October 17th, twelve Barnacle flew round island at 11 A.M. ; the first this year; fresh breeze N.W., misty. November, flock of Barnacle seen on adjacent island almost every day during month.

Arran Island, S.-November 25th, two Barnacle going N.E. at 8 A.M.; first seen this year; strong gale N.E., hail showers: 28th, eighteen going E. at 4 P.M. December 20th, seven going W. at 3 P.M.

"SWANS."

Oyster Island, S.-December 23rd, four Swans going S.E.; wind light $\mathrm{E}$, frosty.

\section{Teal (Nettion crecca, Linn.).}

Oyster Island, S.-October 22nd, one "Wild Duck" going S.E. at 3.30 A.M.; disabled striking; wind light N.W., drizzling rain; a young bird. [Leg and wing of Teal received.]

Arran Island, S.-December 30th, two Teal on lake near lighthouse; remained a short time; strong gale $\mathrm{E}$.

\section{"DuCKs."}

Spit Bank, Qucenstown.-January 5th, sixteen Ducks flying N.E. November 1st, about fifty Ducks going S.W.: 29th, nine large Ducks feeding. December 3rd, three Wrigeon and four Teal on the water : 4th, "I understand that Wild Ducks have been pretty numerous to the $\mathrm{N}$. of Queenstown." 
Tuslar:-February 26th and 27th, three Scoters about the rock. November, "Great many Barnacle and Duck remain in Wexford Bay during the winter."

Lucifer Shoals Light-ship.-January 22nd, two Wild Ducks struck lantern at midnight; fell on deck; strong breeze S.W., rain. May 16 th, one flock of Black Duck going E. at 5 P.M.; wind moderate S., rain.

Arklow North Light-ship.-August 3rd, flock of Wild Ducks going S.W. at 2 P.M. ; wind light S.W., clear.

Copcland (Mew) Island.-January 24th, Wild Duck flying through the rays of light at 8 P.I. ; strong gale S., heavy rain: $26 \mathrm{th}$, twenty round island: $28 \mathrm{th}$, flock flying over island.

Innishtrchull.-February 2nd, two Eider Duck in water in vicinity of station at 2 P.M.; white with black on top of head; strong breeze W.; rare visitors here. November 5th, three Eider Duck near island at 11 A.M.; gale N.; "one of these was a very pretty bird."

Oyster Island, S.-October 28th, five flocks Wigeon going $\mathrm{N}$. at noon. November $14 \mathrm{th}$, three flocks Wigeon going N.

\section{BIRDS NOT IDENTIFIED.}

Spit Bank, Queenstown.-January 9th, one small Diver on the water, about the size of a Puffin; in colour, black, with white bars on the wing; and again on the 13th. [Black Guillemot.R. M. B.]

Copeland (Mew) Island.-April 18th, forty birds found killed on dome of lighthouse; no doubt killed against weathercock on February 20th, during the great rush of that night. May 6th, small bird like Whitethroat on island. Two birds, resembling Wigeon when flying, with white patch on wings, on the passage between Donaghadee and Mew Island.

Slyne Head, S.-October 18th, "a brownish-black bird as large as a Hawk, with white ring round neck, and one feather protruding from centre of tail about four inches, passed over island going E.; wind light N.E., rainy and misty. It was very daring, coming within a few yards, and giving a few turns over our heads; flight very easy, flew towards shore. It was seen on shore for a week after. Great numbers of Black Pollock on coast at the time. Description of bird by people on shore agrees with mine, except that they make the centre feather of 
tail much longer, ten to twelve inches." [Buffon's Skua?R. M. B.]

Arren Island, N.-October 26th, "two birds about the size of a Skylark on island; yellow heads and necks, under wings white, with slate coloured backs, and tail of black and white feathers," seen at 1 P.M. ; strong gale N., hail showers, snow.

Tearaght.-April 18th, one small yellow bird, "not known," at 1 P.Mr. September 5th, one small bird, black with white tail, not identified. November 1st, small bird not identified, brown and blue on back, and white breast, at 12.30 P.Mr.; fresh breeze S.W., fog.

\section{General Observations.}

Barrels Roch Light-ship.-June 5th, no land birds of any description passed here lately. Sea birds very scarce for the time of year.

Tuskar.-April 5th, I shot an Otter on the rock last month. Very few Warblers killed at light this spring, owing to the weather.

Rockabili._- "During twenty years at lighthouses I have never known of a Bat being killed striking.-JOHN HAMILTon."

Aranmore.-May and June, "all the species mentioned for January and February are to be seen, except Snipe, Woodcock, and Barnacle, also Grey Plover." "No birds struck lantern during the whole year, except the Kittiwake."

Tearaght.-March 2nd, "sea birds first made their appearance and began to land on rock, and are very busy. Come always early in the morning, and leave about 10 A.M." "No birds observed in June except the ordinary sea birds." "All sea birds nearly gone by 1st of August, except Kittiwake." "Few birds strike this lantern, owing to its being a revolving one." 
1891 
List of Light Stations.

Names of Observers.

1. Fastnet, Co. Cork,

18 good.

x $\quad x \quad 8$ Hamilton Kennedy.

3a. Spit Bank,

20 very good.

4. Mine Head, Waterford,

20 good.

$x$ o - George Dunleary.

$x$ o Henry Williams.

5 a. Hook Tower, Wexford, ........ 236 very good.

5. *Coningbeg Lt.-ship, Wexford, 22 good.

$0 x-$ W. H. James.

6. Barrels Rock Lt.-ship, do., ... 55 excellent.

$x \quad \times 10$ Peter King.

7. Tuskar Rock,

do., ... 27 very good.

z $x .4\{$ James Beahan and

$7 \alpha$. Lucifer Shoals Lt.-ship, do., ...2 4 good.

$\mathrm{x} \quad \mathrm{x} 7$ John Hamilton.

7b. Blackwater Bank Lt.-ship, do., 427 excellent. $\quad x \quad \times \quad 6\left\{\begin{array}{c}\text { Patrick Cullen and } \\ \text { Daniel Dunn. }\end{array}\right.$

8. Arklow Sth. Lt.-ship, Wicklow, 627 excellent. $\quad x \quad x \quad 7\left\{\begin{array}{c}\text { W. Clydesdale and J. } \\ \text { Kearon. }\end{array}\right.$

8.*Arklow North Lt.-ship, do., $4 \quad 6$ excellent. $\quad x \quad x \quad 8\left\{\begin{array}{c}\text { John Penston and } \\ \text { Alfred Wall. }\end{array}\right.$

11. Howth Baily, Dublin, ........ 35 excellent. $\mathrm{x}$ x - Edward M Carron.

12. Rockabill, do., ........ 28 very good. $x \quad x \quad 5 \quad$ Edward M'Kenna.

12a.Drogheda, North, ............. 10 very good. o $\mathrm{x}$ - George Dunleavy.

12b. South Rock Lt.-ship, Down, ... 210 poor.

x $\quad x \quad 3\left\{\begin{array}{c}\text { Patrick Clancy and } \mathrm{H} \text {. } \\ \text { Thompson. }\end{array}\right.$

13. Copeland (Mew) Island, do., ... 344 very good. $x \quad x \quad 3 \quad$ R. Armstrong.

14. *Maidens South, Antrim,........ 44 very good. $\quad \mathrm{x} \quad \mathrm{x} \quad 5 \quad$ Francis Maguire.

16. Innishtrahull, Donegal, ........ 3 0 very good. $x \quad x \quad 6\left\{\begin{array}{c}\text { M. S. Kennedy and } \\ \text { George Gillespie. }\end{array}\right.$

17. Dunree Head, do., ........ 1 o poor. $\quad \mathbf{x}$ - Jervis Brownell.

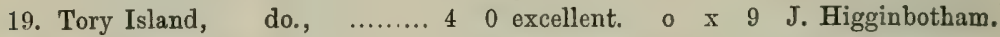

21. Rathlin O'Birne, do., ........ 34 very good. $x \quad x \quad 2$ John Murray.

22. Killybegs,

do., $\quad . . . . . .228$ good.

$\mathrm{x} \quad 0-\left\{\begin{array}{l}\text { Joseph Corish and Jobn } \\ \text { Kennedy. }\end{array}\right.$

27. Blackrock, Mayo, .............. 3 1 very good. х $\quad$ x 9 Richard Widdicombe.

31. Slyne Head, S., Galway, ........ 31 very good. $x \quad x \quad 3 \quad$ P. D'Arcy.

32. Arran Island, N., do., ........ 1 l 0 good. $\quad 0 \quad x \quad 9$ Michael Barry.

34. Arran Island, S., do., ........ 1 1 0 good. $\quad 0 \quad x \quad 6 \quad$ J. C. MacGinley.

37. Tearaght, Kerry, .............. 415 very good. $x \quad x \quad 9\left\{\begin{array}{c}W . H . \text { James and } \\ \text { Charles Hawkins }\end{array}\right.$

39. Skelligs, do., .............. 34 poor. $\quad$ x $\quad$ x 9 Robert Phelan.

Galley Head sent 1 specimen; Oyster Island, S., 3.

Legs, Wings, etc., received, 190.

$0=$ No reply.

Spring, replies received from 23 stations. $\mathrm{x}=$ Schedules returned wholly or partly filled.

Autumn, replies received from 25 stations. 


\section{Legs, Wings, etc., Received.}

Species. How Received. How Procured. Date, Name of Station.

Kestrel, . . Rec'd. in flesh, Shot, . 6/12 mo, T'earaght.

" • . " , . . 23/4 mo., Skelligs.

Missel-Thrush, . Leg and wing, Killed st., ${ }^{1}$. 6/11 mo., Fastnet.

\begin{tabular}{|c|c|c|}
\hline ,", & , & . \\
\hline Thrush, & - & • \\
\hline , & • & - \\
\hline , & - & - \\
\hline ", & two, & . \\
\hline , & · & - \\
\hline ", & - & . \\
\hline , & - & - \\
\hline " & - & - \\
\hline ," & - & • \\
\hline ", & - & . \\
\hline " & - & - \\
\hline , & . & - \\
\hline ", & - & . \\
\hline , & . & - \\
\hline
\end{tabular}

". $\quad$. Rec'd. in flesh,

Redwing,

Fieldfare,

, two,

Blackbird,

six, . Legs and wings,

$" \quad$. . Leg and wing,

,$\quad$. . Legsand wings,

, . . .

, . . Leg and wing,

two, . ,

- .

", two, . Rec'd. in flesh,

". . . Leg and wing,

" three, Legsand wings,

Ring-Ouzel, . Skin, .

Robin,

Redstart,
Leg and wing, Rec'd, in flesh,
6/11 mo., Hook Tover.

". $\quad$. 19/ 1 mo., Oyster Island, S.

6/11 mo., Fiastnet.

". 27/10 mo., Hook Tower.

,

". 28/10 mo., Barrels Rock Lt.-ship.

? $\quad 19 / 3 \mathrm{mo}$, Lucifer Shoals Lt. ship.

Killed st., . $2 / 4$ mo., Blackwater BankLt.-sh.

" . $3 / 11 \mathrm{mo}$, , , " ,

," 24/12 mo., , ", ",

", . 16/ 1 mo., Arklow S. Lt. ship.

, . 4/ 2 mo.,

7/. 2 mo.,

8/ 2 mo.,

$10 / 2 \mathrm{mo}$,

- 27/10 mo., Rockabill.

,, . $8 / 1$ mo., South Rock Lt. ship.

", 4/ 4 mo., , ", ,

Found dead, 5/11 mo., ,, ,,

Killed st., . 7/11 mo, Hook Tower.

? $\quad 5 / 3$ mo., Arklow S. Lt. stip

Killed st., . 27/10 mo., Rockabill.

,. . 6/11 mo., Fastnet.

? $\quad 28 / 4$ mo., Arklow S. Lt.-ship.

? . 4/11 mo., ", ",

Killed st., . 5/11 mo., Copeland (Mew) Island.

", . 7/11 mo., Tearaght.

", 7/11 mo., Fastnet.

". 27/10 mo., Hook Tower.

". 27/10 mo., Barrels Rock Lt.-ship.

? . 19/ 3 mo., Lucifer Shoals Lt. ship.

Killed st., . $2 / 4$ mo., Blackwater BankLt. sh.

" 6/4 mo., ," ",

? . 27/10 mo., Arklow S. Lt. ship.

Killed st., . 27/10 mo., Rockabill.

", . 4/ 4 mo., South Rock Lt.-ship.

,. 6/11 mo,, Copeland (Mev) Island,

" . 7/11 mo., Tearaght.

Shot, . 3/ 4 mo., Fostnet.

Killed st., - 1/11 mo., Rockabill.

? $\quad 5 / 5$ mo., Tuskar.

1 Killed st. $=$ Killed striking lantern. 


\section{Legs, Wings, etc., Received-continued.}
Species.
How Received.
How Procured.
Date.
Name of Station.

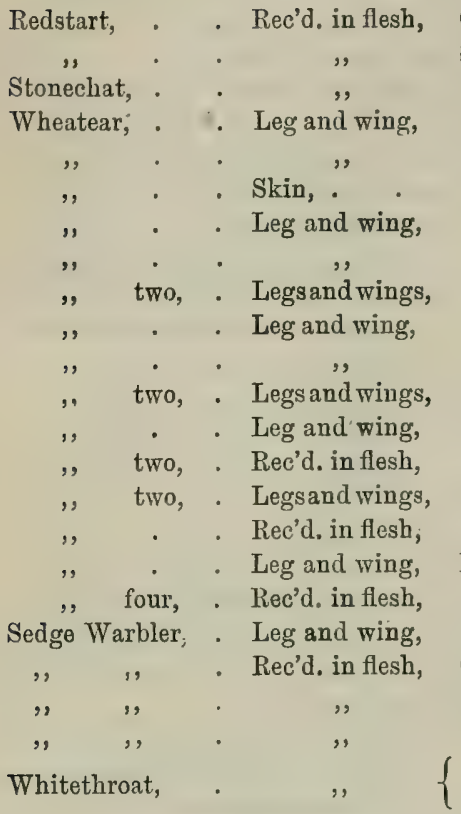

Caught, . 7/11 mo., Killybegs.

Shot, . 13/9 mo., Blackrock, Mayo.

Killed st., . 7/11 mo., Hook Tower.

Found dead, 17/ 3 mo, Coningbeg Lt.-ship.

Killed st., . 1-9/4 mo., Tuskar.

" $\quad$. $5 / 4$ mo., Lucifer Shoals Lt.-ship.

, . 2/ 4 mo., BlackwaterBankLt.-sh.

,

4 mo., ", ,

, . 10/4 mo.,

, . 18/9 mo.,

, . $3 / 10 \mathrm{mo.}$,

Killed, - $7 / 4$ mo., Arklow S. Lt.-ship.

10/ 4 mo., , , ,

- 12/ 4 mo., ,, ,,

Killed, . 13/ 4 mo., ",

", . 11/ 4 mo., Arklow N. Lt. ship.

Killed st., . $10 / 4$ mo., Howth Baily.

", . $4 / 4$ mo., South Rock Lt.-ship.

Killed, . 6/5 mo., Bleckwater Bank Lt.-sh.

Caught, . 14/ 9 mo., Rockabill.

Killed st., : 6/ 5 mo., Maidens $S$.

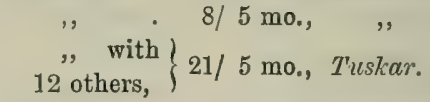

Leg and wing, Killed st., - 5/ 5 mo, Blackwater BankiLt. sh.

$\begin{array}{lll}" \quad & \cdot & \text { Leg and wing, } \\ " \quad & \cdot \quad & \text {. } \\ " & \text { Rec'd. in flesh, }\end{array}$

Found dead,

9/ 5 mo.,

Killed st., .

5/ 5 mo., Howth Baily.

,, $\quad$ 8/ $5 \mathrm{mo} .$, Iridens $S$.

Blackcap, . . ,

,. 7/11 mo., Hook Tower.

, $\cdot$, ,

Caught, . 14/9 mo., Rockabill.

Willow Wren, . Leg and wing,

Killed st., . 16/ 4 mo., Blackwater Bant:Lt.-sh.

Found dead, 15/ 5 mo., " "

" " . Rec'd. in flesh, Killed st., . $8 / 5$ mo., Maidens $S$.

Chiffchaff, . . Leg and wing,

,

, . 5/ 4 mo., Tuskar.

" $\quad$ 10/ 4 mo., Blackwater Bank Lt. sh.

". . Rec'd. in flesh, Golden-crested Wren, ,

Caught, ' 11/ 4 mo., Howth Baily.

Killed st., . 6/11 mo., Hook Tower.

$\begin{array}{crr}, & \text { ", } & \text { ", } \\ \text {," } & \text {, } & \text { Wing,. }\end{array}$

Killed, $\quad$. $11 / 4$ mo., Arklow N. Lt.-slip.
. $28 / 4$ mo., Rockabill.

Killed st., . ? mo., Tearaght.

Wren,. . . Leg and wing,

Titlark, . . ,

,

,

,

1/ $1 \mathrm{mo.}$,

Killed st., . 6/11 mo., Fastnet.

? $\quad 22 / 1$ mo., Hook Tower.

Found dead, 18/ 3 mo., Coningbeg Lt.ship.

Caught, . 27/ 2 mo., Arklozv N. Lt. ship. 


\section{LEGS, WINGS, ETC., Received—continued.}

Species. How Received. How Procured. Date. Name of Station.

Rock-Pipit, .

Skylark,

"four,

,

,

,

,

,

,

.

Snow Bunting,

, , , four,

Chaffinch,

,

,

two

", .

Starling,

Swallow,

House-Martin,

Sand-Martin,

" "

Kingfisher,

Rock-Dove,

Turtle Dove,

Land-Rail,

Water-Rail,
Leg and wing,

,

Legsand wings,

Leg and wing,

,

,

,

,"

Wing, .

Leg and wing,

Rec'd. in flesh,

Killed, 10/4 mo., ", ,

Found on roof, 18/4 mo., Howth Baily.

Found dead, 21/12 mo,, Copeland (Mew) Island.

Killed st., . $7 / 11$ mo., Tearaght.

, . 6/11 mo., Fastnet.

Shot, . 6/10 mo., Hook Tower.

$\left\{\begin{array}{l}\text { with } 4 \\ \text { others, }\end{array}\right\}$

15/12 mo., ,, ,

Killed st., - 27/10 mo, Barrels Rock Lt. ship.

Died on deck, 17/11 mo., Blackwater Bank Lt.-sh.

Legsand wings,

Killed st., . 28/10 mo., Tearaght.

Wing, .

Leg and wing,

, . 7/11 mo., ,"

,, 6/11 mo., Fastnet.

,, . 5/ $4 \mathrm{mo.,}$ Tuskar.

" . 27/10 mo., Hook Tower.

,, 27/10 mo., Barrels Rock Lt.-ship.

, . 1/ 4 mo., Blackwater Bank Lt.-sh.

, . $3 / 11 \mathrm{mo}$,

, . 24/12 mo.,

4/ 2 mo., Arklow "s. Lt. "ship"

Killed, . $7 / 4$ mo., , ,

,

,

,

,

"

Rec'd. in flesh,

Leg and wing,

"?

10/ 4 mo.

$27 / 10$ mo.,

Killed st., - 24/12 mo.,

25/12 mo.,

,

"

11/ 4 mo., Arklow N. Lt.-ship.

", . 27/10 mo., Rockabill.

Picked up, . $2 / 6$ mo., Tearaght.

Shot, . 23/4 mo., Skelligs.

,

,

,

Rec'd. in flesh,

,

Leg and wing,

Rec'd, in flesb,

Wing,

Rec'd. in flesh,
, . 23/4 mo., ,"

Killed st., . 6/ 5 mo., Blackwater BankLt. sh.

Caught, . 26/4 mo., Arklow N. Lt. -ship.

Found dead, 9/ 9 mo., Hook Tower.

Shot, . . 14/12 mo.,

". . 23/ $4 \mathrm{mo}$, , Tearaght,

Found, . 19/4 mo.,

Caught, . 27/10 mo., Galley Head. 


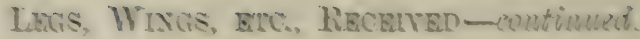

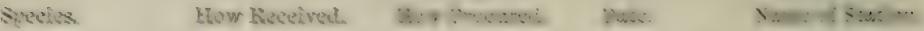

\begin{tabular}{|c|c|c|c|c|}
\hline Wwter-Busil, & - Ree'it in thesh. & Kilted st., & . $\quad 5 / 11 \mathrm{mo}$, & EFwe Tourer. \\
\hline 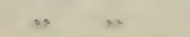 & . & ? & 25/ 9 ma. & Bumnts Euete $I$ b. whig. \\
\hline " & - Les and wies, & Killed st., & (i) 4 man, & 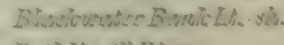 \\
\hline$=$ & $=$ & Cisught. & $23,1 \geq \tan$ & Bustubin (Y Birmos. \\
\hline$\Rightarrow$ & - & $\therefore$ s.ate. & $21 / 12$ mo, & Aibughers. \\
\hline Golden Flover. & " & Killed st.., & 9/ $1 \mathrm{mec}$ & 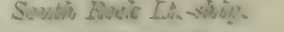 \\
\hline liteen Plover, & . Wirg: . & 1 & IO/ $8 \mathrm{men}$, & Qugstare Iswava, s. \\
\hline Turvstome. & - Bee'ul. in tlesh. & Shot. & - 11/12 me, & Howt Twers. \\
\hline$\rightarrow$ & . leg onit s:m? & $\begin{array}{l}\text { hulled } 3 t-1 \\
\text { tern, }\end{array}$ & $81 / 12$ mach, & \\
\hline
\end{tabular}

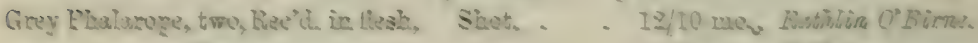

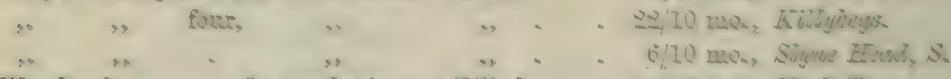

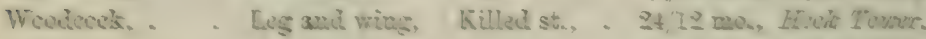

$\rightarrow=$

a

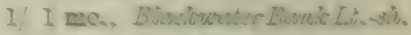

Saripe,

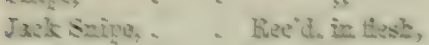

Dualion,

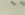

Aretie Tern, "Leg and wing,

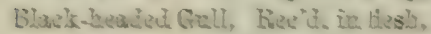

\section{Deeland Guth.}

\section{Manx Sleangrater.}

Starma Petrelt.

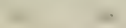

2. 2

-. $\quad \cdots$

$\therefore \quad$ is

Cemponas sioter. a. . Qt/T2 ma, How Towor.

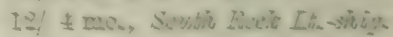

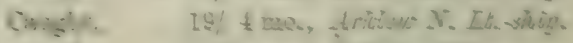

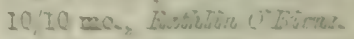

\section{Find ipte:}

Sliot.

6,12 me. Kingens.

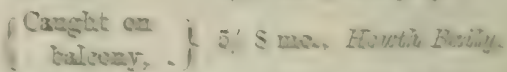

Eieksd un, - it, II me, Elow Fownr.

$=$ m. IT/II mo.

"x

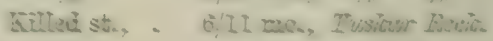

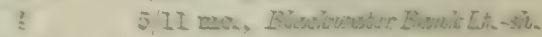

Killai st., - II! \& eac.. Sistivigs. -. $\quad 5 / 20$ mes. Fitel Fiverr.

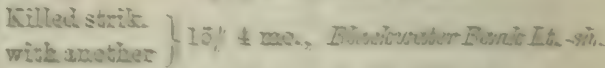

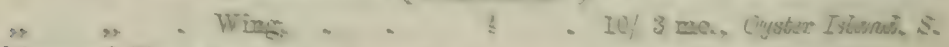

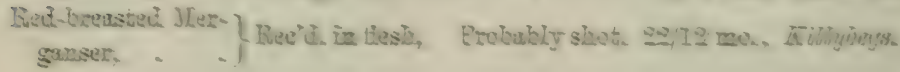

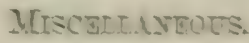

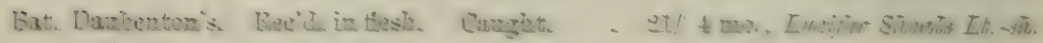




\section{N I) EX.}

lixt, Daulontori's,

pess

205

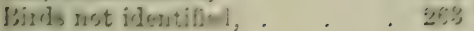

li.scklis 1,

Blackesp,

Brambling,

liuntira, ismmen,

, Snc, , Yellow,

Cinatirnets,

Chistibafi, .

C:sught

Cormstant,

Corte-Crake,

Crow, $\mathrm{Hos}+\mathrm{se}$

Curcios

Ciurles:

Jiser, fires: Northorn.

"Juarks,"

J) unlio,

Falece, Greculand,

Fir? ifare.

Porecrine,

"Wipoatrihers,"

risunet,

"resens,"

Cieneral o aervations,

Gishlis-armet 1 Wros,

ri,llifwat, .

Grestivot

Coillems:

Gull, P'ack-hesis:

, In-1,nel,

$\therefore$ Gull ,"

"Hawks,"

Heron,

Jo-klaw,

$\therefore$ Jar,"

I.ested,

His gritace.

"Linzets,"

Zarrity

Manx Shearwater,

Xastin, Heces:

, Susal,

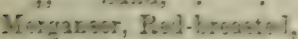

Misot-Tir.t.

Migutjar,

Gwis,

Oyeter-Cotwer,

P'etre. So.rmu
Hhaturope, Grey, . . 2 212

"Pigesas," . . 260

l'isver, fislden,. . . 2:8

$\because$ Given, . . 24\%

, Iingel, . . . $2 \div 2$

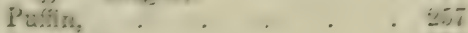

liaven, . . . 2 235

leavor:ill, . . . . 20;

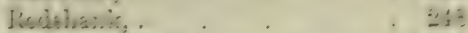

Polstart, Hldok, . . 217

. Conctosen, . . 217

l'eiwit:. . . . 211

Itiar-0.2. . . 216

icon, . . . . . 216

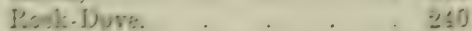

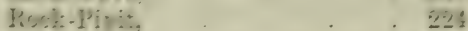

list, . . 230

"4... I Larks," . .

Saulifin, l'ueple, . . . 247

Sust: Clommon. . . 202

sielge Watble... . . , 210

Sheg, . . . . 250

Shearwater, MLanx, . . 254

Bickin, . . . . . $\$ 10$

Ginglask, . . . 208

Erire, Conmes. . . 230

"Jack, . . . DAe

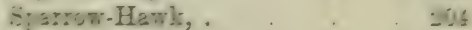

Sicrow, Hruse, . . . E;?

Staring; . . . . 201

G:oveclist. . . . 217

Swellsw, . . . . 2. 25

Swift, . . . . 21:

Ters, Arotir, .

. Cbmusn,. . . . 252

Thrubl, . . .

Titlatk, . . . . .

"Tils," . . . . . 5

Turnbicse, . . . . 245

Tartle Dove, . . . . $\$ 41$

$\therefore$ Twite. . . . . . . . . . .

s. Wagtails." . . . . . . . . .

Water-Hin, . . . . 35

Weter-llail. . . . . . . .

Whes:exr.. . . . 218

Whimbrel, . . 25

whinckat. . . . . 216

Whitethreat, . . . . 220

Willsw Wres. . . . .

Woslerek, . . 146

Wyos. .0 .0 .21 
Greenland Falcon (Falco candicans, J. F. Gmel.).

Blackrock, Mayo.-November 23rd, "a White Hawk, something larger than the Game Hawk. It was perched on the rock. When it started, it flew away towards Achill Head." [Probably a Greenland Falcon.-R. M. B.]

\section{Peregrine Falcon (Falco peregrinus, Tunstall).}

Fastnet.-May 10th, one Peregrine hovering at 8 A.M.; wind N.E., clear. "Peregrines have been here all winter, and carcases of birds they have killed have been found on rock." September 9 th, one Peregrine at noon.

Mine Head.-February 28th, one Peregrine Falcon found dead in a field near lighthouse. March $12 \mathrm{th}$, one do. at 1 P.Mr. going E. April 14th and 18th, one do. noted. June 21st, one Peregrine seen.

Tearaght.-March 6th, one. April 6th, two Peregrines remain to breed. November 5th, two Hawks, Peregrine, and Kestrel.

Skelligs.-March 9th, two Peregrines, male and female; they breed on rock.

Kestreu (Falco tinnunculus, Linn.).

Mine Head.-May 21st, two at 8 A.M. going N.

Rathlin O'Birne.-December 17th, one.

Tearaght.-February 10th and July 30th, one Kestrel. November 5th, two Hawks, Peregrine, and Kestrel. December 6th, a Hawk shot and sent. [Kestrel received in flesh.]

Shelligs.-April 23rd, a Hawk shot at 7 P.M. on rock; strong breeze E. [Kestrel, stuffed by keeper, received]. October 21st, one Kestrel.

Sparrow-HawK (Accipiter nisus, Linn.).

Mine Head.-January Sth, two Sparrow-Hawks going $\mathrm{N}$. Junè 10th, one.

Hook Tower:-October 23rd and November 21st, one or two Sparrow-Hawks seen.

Howth Baily.-August 2nd, one Sparrow-Hawk: also noted on 16 th, September 8 th, and November 17 th. 
Innishtrahull.-August 15th, two Sparrow-Hawks hovering; wind moderate N.W. September 20th, two.

Rathlin O'Birne. - Sparrow-Hawk noted, February 7th, August 5th, and December 27th.

Slyne Head, S.-March 26th, one on island.

Arran Island, N.-Sparrow-Hawk seen here from February 21st to March 1st.

Tearaght.-April 1st, one at 2 P.M.

HAWKs.

Bullycotton.-March 20th, "there are always small Hawks, Starling, Linnets, etc., here."

Coningbeg Light-ship.-March 27th, a Hawk going S.E., flew about ship for a few minutes at 2.30 P.M. ; fresh breeze N.W., clear.

Barrels Rock Light-ship.-July 1st, one small Hawk about ship from 4 A.M. to 8.30 A.M. ; wind light S.W., clear. November 5th, one Hawk chasing a small bird: 24th, one Hawk going N.E.

Lucifer Shoals Light-ship.-July 29th, one "Lorey Hawk" flying about ship at 10.30 A.M. October 14th, one "Lorey Hawk" and Lark around ship at 4 P.M. ; wind gale S.W., clear. "The Hawk caught the Lark and thought to come on board with it; we beat him off; he was exhausted, and he let go the bird and flew in for shore."

Blackwater Bank Light-ship.-March 23rd, one Hawk about ship chasing Linnet at 6 A.M.; clear.

Arklow South Light-ship. - June 7th, one Hawk at 10.30 A.M.

Rockabill.-October 25th, one Hawk going N.: 26th, one Hawk on rock; wind gale N.E.: 29th, one Hawk on rock all day; wind light E. : 30th, one Hawk; wind light S.E.

Copeland (Mew) Island. - November 5th, "several birds striking, a few killed; a Hawk seen to seize a bird in the rays of the light at 11 P.M."

Dunree Head.-April 14th, one Hawk going W.

Tory Island.-November 5th, one Hawk in cliffs: 21st, one Hawk caught a Dotterel and killed it at 4 P.M. "I have noticed Hawks always seem to prefer such birds as Dotterel, Sand 
Larks, etc., to a Thrush, Blackbird, or Starling, as I have often seen the Hawk pick out one of these birds even when the others were plentiful all round." December 6th, 9 th, and 13 th, one seen: 20 th, one caught and killed a Dotterel at 9 A.I., near station.

Blackrock, Mayo.-March 30th, one large Hawk, grey on back and white underneath, at 12.20 A.M. going N. April 5th, two Falcon Hawks, one white underneath and grey on back, about rock: 22nd, one Grey Falcon Hawk. June, Falcon Hawks come here at intervals; don't breed here. September 13th, small Hawk at 1 P.M.: 16th, one "Falcon Hawk (Game)."

Slyne Head, S.-March 21st, two Hawks all day on island; gale W.: 28th, one Common Hawk on island. April 4th, one Common Hawk going N.W.: 12th, one do. on island. July 15th and 28th and October 12th, one do. noted.

Arran Island, S.-September 5th, one Hawk at 8 A.Mr. chasing birds on island (very scarce here).

Tearaght.-February 1st, one Brown Hawk at 10 A.M.; "name not known": 3rd, seen again: 17th, one male Hawk (greyish) all day: 23rd, two Hawks (one bluish grey, the other brown) at 12.30 P.M. April 1st and 19th, one small Spotted Hawk all day. October 26th, one Hawk on island.

Shelligs._August 3rd, one "Hen Harrier" feeding on a Puffin at 2 P.M. on rock.

\section{OWLS.}

Hook Tover.-September 12th, one Owl at 5 P.M. ; wind light E., blue sky, clouds.

Howth Buily.-May 26th, one Owl in fields. July 30th, a large Owl near station, coming out of a rabbit-hole. August 14th, two seen in the evening.

Rockctbili.-November 5th, one Owl on rock from 10 A.M. to 11.30 A.M.; went W.; wind light W., gloomy: 6th, one Owl from 9 A.M. to 11 A.M.; wind light W., gloomy; "I think this is the same Owl that was on rock yesterday": 10th, one on rock: 13th, one between 11 A.M. and 1 P.M. ; went W.

Rathlin O'Birne.--February 12th, one Owl at 3 P.x. going E. ; wind light N.W., blue sky. October 25th, one Owl at noon on island; wind moderate S., clear. 


\section{"Flycatchers."}

Copeland (Mow) Island.-April 13th, Flycateher, 10 P.мr. to 12 P.M., perched on lantern sash; wind light S., clear.

Tathlin O'Birne.-September 11th, two Flycatchers on island at 11 A.M.

\section{Missel-Thrush (Turdus viscivorus, Linn.).}

Frastnet.-November 6th, five Thrushes ("Warblers") killed striking; wind light E., very dark. [Leg and wing of MisselThrush received.]

Spit Bank, Quecnstowon.-May 11th, "I was shown to-day a Fieldfare's nest containing five young birds; it was in a Plum tree in $\mathrm{Mr}$ O'Connell's garden at Ballydonal, on the north side of Queenstown Island." [Probably Missel-Thrush.-R. M. B.]

Hook Tower.-November 6th, one Missel-Thrush at 10.30 P.M. [Leg and wing received.]

Howth Baily.-July 12th, on this day, and during five or six weeks afterwards, large birds like Fieldfares, but not the same colour on back, were near station. [Probably MisselThrush.-R. M. B.]

Oyster Island, S. - January 19th, Missel-Thrush killed striking. [Leg and wing received.]

\section{Throsh (Turdus musicus, Linn.).}

Fastnet.-November 5th, several, with "Redwings," all night hovering round light; wind light E., gloomy: 6th, three dozen "Redwings" killed striking, going S.W.; wind light E., very dark-[Leg and wing of Thrush received]: 7th, "Redwings" (?) hovering round light.

IFine Head.-January 11th, eighteen Thrushes going S. at 9 A.M.; one killed.

Hook Tower.-October 27th, great rush of Thrushes and other birds all night round lantern, going S.E. to N.E.; wind strong N.E., overcast-[Leg and wing received]. November 7th, five "Song Thrushes" killed striking; wind light S. W., gloomy.

Coningbeg Light-ship.-March 10th, flocks (see under Linnet). October $27 \mathrm{th}$, Thrushes all night flying round lantern; left at 4.30 A.Mr. for land; wind fresh E. November 3rd, 4th, 5th, 6th, 
7th, 8th, and 9th, Thrushes, Blackbirds, and Starlings all night; numbers struck, fell overboard; wind moderate E., 3rd to 6th.

Barrels Rock Light-ship.-October 27th and 28th, various birds about light (see under Blackbird); killed night of 28th[Leg and wing of Thrush received]. November 2 nd, one Thrush at 9.5 A.M.; killed; overcast.

Tuskar:-April 1st to 9th, great number of Thrushes and other birds all night round light; going N.IV. at daylight; great number killed striking (see under Wheatear). November 16th, great number of Thrushes and other birds all night round light; wind fresh S., fog and rain; numbers killed, male and female, young birds: 17th, a few on rock all day; fog and rain: 18th to 25th, Thrushes going W.; a few killed, male and female. December 4th to 20th, great numbers of Thrushes and other birds all night round light; wind strong $\mathrm{E}$. and variable; many killed, male and female, young and old: 21st to 30th, flocks passing all day going W.; some on rock: 31st, Thrushes all night round light.

Lucifer Shoals Light-ship.-February 3rd, one Thrush killed striking at midnight; fell overboard; wind light W., fog: 10th, one killed striking at 2 A.M.; fell on board; wind light W.S.W., clear. March 19th-[Legs and wings of two Thrushes received]. April 3rd, one killed striking.

Blackwater Bank Light-ship.-January 3rd, flock going N.; wind S.W. March 20th, one about light: 31st, four do.; one killed. April 1st, six about light-[Leg and wing received]: 4th, flock going N. October 26th, flock about light; gale; two killed: 28th, flock going N.W. November 1st, four: 2nd and 3rd, several about light-[Leg and wing received]: 5th, 6th, and 7 th, several about light. December 22nd, six about light; two killed: 24th, several do. [Leg and wing received]: 25th, several about light.

Arklow South Light-ship.-January 1st, some, with Starlings, about lantern: 16th, one killed-[Leg and wing received]; wind moderate N.E., clear. February 4th, Thrushes, Larks, and Starlings about light; wind light W., overcast; several killed; fell on deck and overboard-[Leg and wing received]: 6th, a few small birds about light at midnight; and "several small birds about light from midnight to 4 A.M. on 7 th; wind light S.W., gloomy; one killed and one disabled, Thrushes"; one 
Thrush about light at 8.30 P.M., killed; wind light S.W. [Legs and wings of one killed striking on 7 th, and one on 8th, received]: 10 th, numbers of small birds at light; some striking (see under Lark)-[Leg and wing of Thrush received]. March 5th, one about lantern at 2 A.M.; killed striking; clear. October 2Sth, Thrushes during day going N.W. November 1st, one at 2 A.M. about ship, killed: 5th, Thrushes and Blackbirds during night about light; wind light N.N.E., clear; one Thrush killed.

Arklow North Light-ship.-February 5th, six about lantern; fog; several killed striking: 7th, four do.; some killed. May 6 th, several do.; fog; one killed; some fell overboard: 8 th, a few about light. October 27th, Thrushes and Larks about light; several killed. November 2nd, large number of Thrushes and other birds about light; went N.W. (see under Skylark); and one Thrush at 2 P.M., floating dead by ship, ebb tide: 22nd, one Thrush about light: 24th, four do.: 30 th, one killed striking; wind strong S.W., rain. December 20th, one Thrush about ship.

Rockabill.-October 10th, one going N.W. and two on rock: 27 th, several round light; gale E.; six killed striking- [Leg and wing received]. November 1st, countless numbers of Thrushes and other birds at lantern at night; nine Thrushes killed (see under Blackbird); wind moderate E. : 2nd, several at lantern: 4th, sixteen going W. in daytime, and five killed striking: 6 th, several at lantern: 8 th, five all day.

Drogheda.-November 25th, a few going S.W.

South Rock Light-ship.-January 8th, flock of about twenty about light at 8 P.M.; one killed striking; clear-[Leg and wing received]. April 4th, several, with Blackbirds, about light from 9 P.M. to midnight; three killed-[Thrush and two Blackbirds received in flesh]. [November 5th, Leg and wing of Thrush received; found dead.]

Copeland (IIew) Island.-May 12th, Thrushes and other birds found dead in gutter of dome of lantern (see under Woodcock). November 6th, "a few Larks and Thrushes striking; one killed; wind light W., overcast, sleet": 30 th, a few Thrushes on island. December 7th, do.

Maidens South.-January 3rd, four, and three Starlings, at lantern at 6 A.M.; misty; Thrushes about rock during day. 
February 3rd, five at lantern; one killed; misty, rain: 4th, two at lantern at 3 A.M. : 5th, one killed striking at 2 A.M.; clear: 9th, three Thrushes and three Larks at lantern at 1 A.Mr; wind light S.W., clear; two Larks killed striking. April 8th, one: 9 th, a few at lantern: 10 th, two at lantern. October $28 \mathrm{th}$, three do.; left at daylight. November 2nd, one at lantern: 6th, a number of Thrushes, Blackbirds, and Larks at lantern all night; gloomy; left at daybreak. December 22nd, two at lautern.

Innishtrahull.-January 9th, numbers on island (see under Fieldfare). October 5th, one on island at 3 P.M.; gale S.E., cloudy; first arrival: 26th, Thrushes (see under Redwing). December 8th, one just arrived; gale S.W.: 20th, several just arrived; strong breeze N.W.

Dunvee Head.-January 16th, numbers going E. at 11 A.r.; wind fresh N.W.

Tory Island.-October 28th, two at lantern. November 3rd, a few at lantern: 4th, Thrushes (see under Larks): 5th, Thrushes, one Blackbird, and Fieldfare round lantern from midnight to morning; wind light S. to S.E., haze; àbout thirty struck; seven killed: 6th, several Thrushes, Blackbirds, etc., round station; probably the disabled ones: 10th, "no Thrushes are to be found on island at any other time during year." [Probably some of the Thrushes noted at this station were Redwings (see under Redwing)]: 28th and 29th, one. December 1st, two, one disabled, during night: $3 \mathrm{rd}$, three: $7 \mathrm{th}$, "Thrushes at lantern from 4 A.M. to 7 A.M." (see under Redwing); very plentiful round station this morning: 12th, "several round light."

Rathlin O'Bine.-January 16th, from three to ten on island during season. October 10th, some all day. November 23rd, six.

Killybers.-February 5th, one at 11 P.M. killed striking. March 7 th to 13 th, very plentiful; and 28 th (see under Cormorant); "natives of the place."

Blackrock, Mlayo.-October 16th, one about rock; gale N., hail.

Slyne Hecul, S.-January 3rd, seven all day. October 3rd, five killed striking at 11 P.Mr.; gale S.W. November 7th, seven all day; five lilled striking; wind light S.W. December, Thrushes on island every day. 
Arran Island, N.--January 2nd, 3rd, and 4th, a few.

Arran Isand, S.-October 2nd, two; wind fresh N.W.; first seen this year.

T'caraght.-Numbers during winter 1890-91 (see under Fieldfare). March 8th, one. October 29th, twenty. November 26 th, twenty on island; wind fresh N.W. December 15 th to 31st, a number on island (see under Blackbird).

Slielligs.-October 28th, two Thrushes and one Redwing on rock; wind fresh S.E.

\section{REDWING (Turdus itiacus, Linn.).}

Hook Tover:-November 7th, two killed striking; wind light S.W., gloomy: [Leg and wing received.]

Tuslar:-April 1st to 9th, great rush of Redwings and other birds round light all night; going N.W. at daylight; great number killed striking (see under Wheatear). November 16th, a few all day on rock: 29 th, two.

Arklow South Light-ship.-[March 5th, Leg and wing of Redwing received.]

Howth Baily.-November 15th, one found killed on balcony. Several about station during November and December.

Rockabill.-October 26th, one killed: 27th, one killed striking - [Leg and wing received]. November 10th, three all day on rock.

Drogheda.-November 24th, a number about fields: 25th, number all day going S.W.; clear and frosty. December 11th, several going S.W.

Innishtrahull.-April 7th, two striking lantern at 1 A.M. October 26th and 27th, Redwings, Blackbirds, and Thrushes striking lantern glass each night about 2 A.M.; wind fresh to a gale N.E. ; some killed; numbers on island.

Tory Island.-November 4th, rush of birds, including Redwing (see under "Larks"): 5th, one Thrush (Redwing) at 10.30 P.M., disabled striking; wind light S.W., clear; first caught: 12th, "Thrushes" from 12.15 A.M. to 4 A.M. round lantern; strong breeze W., clear moonlight; one Redwing killed: 13th, a great many Thrushes and other birds round lantern; only two killed--Redwings (see under Starling). December 2nd, two Thrushes (Redwings) at station: 7th, 
"Thrushes" at lantern from 4 A.Mr. to 7.30 A.M.; one Redwing killed: 12th, Redwing killed striking (see under Thrush).

Rathlin O'Bime.-March 9th, five at 11 A.M., remained; gale $\mathrm{W}$.

Tearaght.-October 26 th, ten on island; gale S.E.

Skelligs.-October 28th, one on rock (see under Thrush).

Fieldfare (Turdus pilaris, Linn.).

Fastnet.-November 6th, one dozen killed striking; wind light E., very dark-[Leg and wing received]: 7th, a number round light.

Hook Tower.-November 7th, three killed striking; wind light S.W., gloomy; Thrushes, Redwings, Blackbirds, Starlings, and one Chaffinch also killed striking.

Tuskar.-November 16th, Fieldfares and other birds all night round light; numbers killed; wind fresh S., fog and rain: 21st, some at midnight round light: $29 \mathrm{th}$, one on rock.

Arklow South Light-ship.-April 29th, one killed striking at 2 A.M.; wind moderate S.W., clear-[Leg and wing received]. November 4th, Fieldfare and other birds during morning about light; clear; one killed-[Leg and wing received]: 6th, various birds during night about light; wind moderate N.W., clear; one Fieldfare killed: 7th, Fieldfare killed striking; clear (see under Blackbird).

Rockabill.-November 1st, great rush of birds (see under Blackbird); a few Fieldfares at lantern: 4th, eight at 10 A.M. going W.; wind moderate N.E., gloomy; four killed striking.

Drogheda.-November 1st, six going S.W.: 10th, large flocks about fields.

Copcland (Mcw) Island.-November 4th, some birds striking; a Fieldfare killed: 5th, several birds striking; a few killed. [Legs and wings of two Fieldfares rèceived.]

Maidens South.-February 15th, one on rock at 7 A.N.; flew to land. October 27 th, one about lantern.

Innishtrahull.-January 9th, seven Starlings and numbers of Common Thrushes and Fieldfares on island during day; wind light W. October 28th, numbers of Fieldfare striking lantern at 12.30 A.M., and many on island ; wind strong S.E.

Tory Island.-November 4th, rush of birds, Fieldfares in- 
cluded (see under Lark): 5th, birds round light (see under Thrush): 12th, Fieldfare round lantern from 12.15 A.M. to 4 A.M. ; clear moonlight: 23rd, one going S.W.; appeared wounded.

Rathlin O'Birne.-January 19th, four on island during season. November 25th, four all day.

Killybegs.-January, "large flocks through this month, which was unusual." March 7th to 13th, Fieldfares very plentiful (see under Golden Plover).

Arran Island, S.-October 18th, two at 8 A.M.; first seen this year; wind moderate $S$. November 18th, twenty on island.

Tearaght.-_ A great many Starlings, Blackbirds, Thrushes, Fieldfares, Larks, and other birds visited this place during November and December '90 and January '91, owing, I think, to the intense frost and snow on the mainland." November 7th, one killed striking. [Leg and wing received.]

BlackBIRd (Turdus merula, Linn.).

Fastnet.-November 7th, one killed striking; wind light S.W., very dark. [Leg and wing received.]

Mine Head.-January 14th, seven on fields; one killed.

Hook Tower.-October 27th, great rush of Blackbirds and other birds round lantern going S.E. to N.E.; wind strong N.E., overcast-[Legs and wings of five males and one female received]. November 7 th, three, one male, two females, killed striking; wind light S.W., gloomy.

Coningbeg Light-ship.-April 6th, very large numbers of Starlings, Blackbirds, and small birds at 10.30 P.N. round lantern; went away about 4 A.M. ; wind fresh N.E.; numbers killed. October 27th, Blackbirds, Thrushes, and Starlings in great numbers all night round lantern; left at 4.30 A.M. for land; wind fresh E. November 3rd, 4th, 5th, 6th, 7th, 8th, and 9th, Blackbirds, Starlings, and Thrushes all night round lantern; numbers struck and fell overboard.

Barrels Rock Light-ship. - October 27th, several birds of various kinds about ship during this and following night; some killed and some fell overboard; fresh breeze S.E. [Leg and wing of Blackbird received.] (See also under Chaffinch and Starling.) 
Truskar:-April 1st to 9th, great rush of Blackbirds and other birds round light all night; going N.W. at daylight; great numbers killed striking (see under Wheatear). November 16th, many all night round light; numbers killed striking; fog: 18 th to 25 th, Blackbirds on rock; great numbers on latter date. December 12th to $20 \mathrm{th}$, some Blackbirds and other birds at night round light: 21st to 30th, Blackbirds and other birds passing.

Lucifer Shoals Light-ship.-February 3rd, two killed, fell overboard; fog. [March 19th, Legs and wings of Blackbirds received]: 29th, two at midnight; one died on deck, caught the other.

Blackwater Bank Light-ship.-January 7th, flock about light from 10 P.M. to midnight; gloomy. [April 2nd, Legs and wings of Blackbirds received, killed striking]: 6th, four at 9 P.M. about light; hazy-[Leg and wing received]. October 27th, flocks all night round light. November 2 nd and 5th, some about light. December 7 th, two do.

Arklow South Light-ship.-January 2nd, some, with Larks and Starlings, about lantern; seven Larks disabled; one male Blackbird killed striking, fell overboard: 12th, two going N.W. February 5th, two disabled. May 2nd, some about lantern. October 27th, Blackbirds during night; wind fresh E. ; male and female killed-[Legs and wings of two received]: 28th, some during day going N.W.: 29th, one female about deck. November 4th, some about light during morning: 5th, Blackbirds and Thrushes about light: 7th, several, with Larks, about light; one Blackbird, one Lark, and one Fieldfare killed striking: 8th, several going N.W.

Arklow North Light-ship.-November 2nd, a large number, with other birds, about light.

Howth Baily.-July 26th, two noted. October 30th, some, and several in the winter.

Rockabill.-October 10th, five going N.W., and two on rock: 11th, one going N.W.: 13th, two on rock: 16th, one going TV.: 22 nd, three all day on rock: $23 r d$, two on rock: $2 \pm$ th, one on rock: 27 th, one killed striking-[Leg and wing received]: 31st, filteen going W. November 1st, countless numbers of Blackbirds, Thrushes, Starlings, and a few Fieldfares, also Lark, three Wrens, and one Redbreast at glass of lantern at 9 P.M. to 
4 A.II; sixteen Blackbirds, nine Thrushes, twenty-one Starlings, and one Redbreast killed striking: 2nd, several at lantern : 4th, fifteen going. W., three killed striking: 6th, Blackbirds, Thrushes, and Starlings at lantern, fifteen killed: 8th, two on rock.

Drogheila.-November 24 th, some about fields : 25 th, numbers going S.W.

South Rock Light-ship.-April 4th, several Thrushes and Blackbirds about light; two Blackbirds killed striking[Two received in flesh]-(see under Thrush).

Copeland (Mew) Istand.-March 5th, several on the island. April 5th and 6th, some, with Starlings, striking lantern; gale S.E.: 7th, several striking from 10 P.M. to midnight; clear: 10tb, several striking; hazy: 27th, several breed on island. May $12 \mathrm{th}$, some, with other birds, found dead in gutter of dome of lantern; must have been killed striking during the spring (see under Woodcock): 1Sth, several nests found. September 28th, several all day. October 14th and 20th, several. November 3rd, some killed striking: 4th, one killed: [6th, Leg and wing of Blackbird received, killed striking]. A few noted on island at intervals from November 17th to December 31st.

Maidens South.-April 11th, three at lantern. November 1st, two do. at 2 A.M. : 6 th, numbers of Blackbirds, Thrushes, and Larks flying round lantern; gloomy; left at daybreak.

Innishtratull.-October 26th and 27th, some, with other birds, round light on island (see under Redwing). December 14th, one just arrived: 20th, several on island.

Dunrce Head.-January 9th, one. March 26th, one; gale, snow.

Tory Island.-November 3rd, some round light; one male caught: 5th, one at lantern: 6th, several (see under Thrush): 10th, "no Blackbirds are to be found on island at any other time of the year": 13th, great rush of several species, Blackbird included (see under Starling). December 2nd, one; first seen since middle of last month.

Rathlin O'Birne.- January $17 \mathrm{th}$, three to four on island during season. October 18 th, some seen at noon. November 23rd, seven all day.

Killybergs.-March 7th to 13th, and 28th, Blackbirds plentiful; native of the place (see under Cormorant). 
Blackrock, Mayo.-March 27th, one female all day on rock.

Slyne Head, S.-January 3rd, three seen: 15th, four. October 3rd, three killed striking at 11 P.M.; gale S.W. December, Blackbirds on island every day.

Arran Island, N.-January 2nd, 3rd, and 4th, a few on island.

Arran Island, S.-September 10th, two remain and build on island; no trees here. November 10th, seven on island, and several round light; three killed.

Tearaght.-Numbers during winter 1890-91 (see under Fieldfare). March 9th, one female all day. October 29th, twenty at 10 A.M.; wind moderate E. [November 7th, Legs and wings of three received, killed striking]: 26th, twenty. December 15th, fifty, also fifty Thrushes, one Snipe all day on island; strong breeze S.W., rain and mist; remained to end of month.

Skelligs.-January 1st and 2nd, Blackbirds and Starlings still on rock; left on 3rd (see under Starling). October 26th, ten at $10 \mathrm{A.M}$ : 28th, a hundred to a hundred and fifty, males and females, at 1.30 P.M. on rock; wind fresh S.E.

Ring-OuzeL (Turdus torquatus, Linn.).

Fastnet.-April 3rd, one shot; "not having seen any like it before." [Skin received.]

Tuskar.-April 1st to 9th, great rush of Ring-Ouzel and other birds round light all night; going N.W. at daylight; great number killed striking (see under Wheatear): 10th, one killed striking at 11 P.Mr. ; wind light S.E., cloudy. December 21 st, two at midnight; caught one and let it go again.

\section{Robin (Erithacus rubecula, Linn.).}

Rockabill.-November 1st, one killed striking-[Leg and wing of Robin received]; great rush of birds (see under Blackbird).

Copeland (Mew) Island.-October 18th, one all day: 30th, do. November $17 \mathrm{th}$, one on island.

Maidens South.-April 9th, two killed striking at 2 A.M.: 11th, two at lantern at 10 P.M., one killed.

Blackrock, Mayo.-October 16th, one Robin Redbreast all day about rock; gale $\mathrm{N}$., hail showers.

T'earaght.-October 30th, one Robin Redbreast. 
Redstart (Ruticilla phonicurus, Linn.).

Truskar:-[May 5th, Redstart received in flesh.]

Killybegs._November 7th, one caught in a swamp. [Received in flesh.]

Blackrock, Mayo.-September 1.3th, one shot. [Received in flesh.]

\section{Black Redstart (Ruticilla titys, Scopoli).}

Blackrock, Mayo.- "November 14th, a small bird, slatecoloured back and breast, reddish tail; used to fly with head upwards for about two yards into the air after insects.-J. Trant."

\section{Stonechat (Pratincola rubicola, Linn.)}

Fastnet.-May 22nd, one on rock. September 7th and 9th, one all day.

Hook Tower.-September 12th, some all day. November 7th, one killed striking at 11 P.M.; gloomy. [Received in flesh.]

Arlilou South Light-ship.-April 6th, one on ship: 10th, one "Chitchat" on ship; Stonechats same day.

Houth Baily.-April 10th, one killed striking; misty; one or two occasionally seen through the summer. October 7 th, one. "During snow and frosty weather, about half a dozen might be seen on the banks at the station."

Maidens South.-April 6th, one: 7th, one all day. September 2nd, two all day: 10 th and 16th, one do.

Killybegs.-March 26th, one at 11 A.M. (first observed this year). April 5th, two: 7 th, one killed striking at 3 A.M.

Blackrock, Mayo.-April 19th, one all day: 22nd, one going N.E. May 3rd and 6th, one all day: 10th, several do. August 16th, one about rock and one at lantern: $27 \mathrm{th}$, and September 6 th and 12th, two or three about rock: 13 th and 20th, two noted.

Slyne Head, S.-March 19th, six all day; wind light N.E.; arrived to build, same date as '90: 26th, large number on island; strong gale W.

Skelligs.-March 16th, one on rock; gale N.E. 
Whinchat (Pratincola rubetra, Linn.).

Hook Tower.-October 19th, three at 10 A.M.; wind light N.W.

Wheatear (Saxicola onanthe, Linn.).

Mine Head.-March 28th, one about station. April 9th, one: 23rd, two.

Hook Tower:-September 12th, Wheatears all day.

Coningbeg Light-ship.-March 17th, one "Whitetail" found killed; fresh breeze E., clear. [Leg and wing of Wheatear received.]

Tuskar-April 1st, great number of Wheatears, Thrushes, Redwings, Starling, Blackbirds, and Ring-Ouzels; Wheatears most numerous; strong breeze S., showery. "We had a tremendous rush of all the above-mentioned species from the 1 st to the 9th. After over twenty years' service at lighthouses round the Irish coast, I never saw so many birds collected together; they resembled a swarm of bees more than anything else, they were in such numbers. We could not open the balcony door, as they could not be kept from getting into the lantern. A great number were killed, but as the lighthouse is on the N.W. side of the rock, and the wind S.E., they nearly all fell into the sea when killed. I caught several of the species I have identified, but let them off again. At daylight they all Hew away N.W.-John HAmilton." [Leg and wing of Wheatear, etc., received.]

Lncifer Shoals Light-ship.-April 5th, one "small bird" killed striking at 2 A.M.; wind moderate N.W. [Skin of Wheatear received.]

Blackwater Bank Light-ship.-[April 2nd, Leg and wing of Wheatear received, killed striking]: 6 th, three at 9 P.M. about light-[Leg and wing received]: 10 th, flock at 1 A.M. about light; gloomy; three killed-[Legs and wings of two received]. September 18th, three at 8 P.xr. about light; one killed-[Leg and wing received]. October 3rd, one found dead. [Leg and wing received.]

Arklow South Light-ship.-April 7th, "two small birds killed on deck"-[Legs and wings of two Wheatears received]: [10th, 
Leg and wing of Wheatear received]: [12th, two received in flesh]: 13th, several small birds from midnight till 4 A.M.; wind fresh S.W., rain; two fell on deck and several overboard[Legs and wings of two Wheatears received]: 21st, one about ship: 23rd and 24th, one.

Arklow North Light-ship.-April 11th, a large number of various kinds of birds about light; one small bird killed striking; several fell overboard-[Golden-crested Wren and Wheatear received in flesh]: 19th, one white-tail small bird caught on deck at 1.30 P.M.; died; wind light S.E., haze: 20th and 22nd, one small Wheatear about ship: 27th, one white-tail about ship between 4 A.M. and 8 A.M. ; went N.W.

Howth Baily.-April 5th, one (first this year); one or two afterwards, but they do not remain here during summer: [10th, Leg and wing received; killed striking].

South Rock Light-ship.-April 5th, several Starlings and Wheatears about light at 2 A.M.; two killed striking; fresh breeze S.E. [Four killed striking received in flesh.]

Innishtrahull.-Narch 21st, one (first arrival). April 6th and 7 th, two at 1 A.M. striking lantern glass; gale S.E. September 3rd, four on island.

Rathlin O'Birne.-March 11th, numbers; wind strong S. [Unusually early if correct.-R. M. B.] They breed here.

Blackrock, Mayo.-April 26th, one. May 10th, several.

Tearaght.-March 8th, one at 3.45 P.M.; wind light N.E. April 3rd, one at 2 A.Mr. at lantern. November 4th, one killed.

\section{Sedge Warbler (Acrocephalus phragmitis, Bechst.).}

Blackwater Bank Light-ship.-May 6th, several small birds about light from 10 P.M. to midnight; one killed. [Leg and wing of Sedge Warbler received.]

Rockabill.-September 14th, one found dead. [Received in flesh.]

Maidens South. - [May 6th, Sedge Warbler received in flesh; killed striking: 8th, one received in flesh; killed striking.]

Tearaght.-May 9th, one "Reed Warbler" at 4 P.M.; wind light N.E. : 26th, one "Reed Warbler" all day. 
Whitethroat (Sylvia cinerea, Bechst.).

Tuskcur-[ May 21st, Whitethroat received in flesh; killed striking with twelve others.]

Blackwater Bank Light-ship.-May 5th, one "Sedge Warbler" killed striking at 10 P.M. [Leg and wing of Whitethroat received]: 9 th, "one small bird dead on deck" at 9 A.M. ; clear. [Leg and wing of Whitethroat received.]

Howth Baily.-May 5th, one found killed on balcony. [Received in flesh.]

Maidens South.-[May 8th, Whitethroat received in flesh; killed striking at 1 A.M. on 6 th.]

Blackrock, Mayo.-May 22nd, one all day.

BlackCAP (Sylvia atricapilla, Linn.).

Hook Tower.-November 7th, one at 10.30 P.M. killed striking; wind light S.W., gloomy. [Received in flesh.]

Tuskar.-November 25th, one: 28 th, one on rock at 1 P.M.; wind strong N.E.

Rockabill.-September 14th, one found dead. [Received in flesh.]

Willow Wren (Phylloscopus trochilus, Linn.).

Barrels Rock Light-ship.-April 25th, "one Wren of a green colour on deck." [? Wood Wren.-R. M. B.]

Lucifer Shocls Light-ship.-April 18th, several "Sallypickers" round lantern the whole night.

Blackwater Bank Light-ship.-April 16th, flock of "Wrens" at 10 P.M. about light; wind light N.W., clear; four killed striking-[Leg and wing of Willow Wren received]: 26th, four "Wrens" at 11 A.M. going N.N.W.; wind light S.; "remained on board ship for about an hour before leaving for shore." May 15th, "one small bird dead on deck" at 9 A.M.; clear. [Leg and wing of Willow Wren received.]

Aiklow South Light-ship.--MIay 6th, several "Sallypickers" from 9 P.M. to midnight; fog; one killed, fell overboard.

Arklow North Light-ship.-October 30th, one "Sallypicker."

Maidens South.-[May Sth, Willow Wren received in flesh; killed striking.] 
Chiffohaff (Phylloscopus rufus, Bechst.).

Tuskar.-April 5th, immense rush of birds (see under Wheatear). [Leg and wing of Chiffchaff received; killed striking.]

Blackwater Bank Light-ship.-April 10th, flock of unknown small birds at 10 P.M. about light; wind light S.W., gloomy; six killed. [Leg and wing of Chiffchaff received.]

Howth Baily.-April 11th, one caught on lantern glass at 4 A.M. [Received in flesh.]

Innishtrahull.-May 6th, one striking at 1 A.M. ; wind fresh S. rain. October 29 th, one (see under "Larks").

Golden-CRested Wren (Regulus cristatus, Koch).

Fastnet.-September 7th, one at 10 A.M. "flew in at kitchen window"; wind fresh E., fog. November 7th, one killed at 9 P.M. ; very dark.

Hook Tower.-November 6th, one killed striking-[Received in flesh]: 7th, four caught at lantern at 8 P.M.; wind light S.W., gloomy: 23rd, several small birds round light, supposed to be Gold-Crests.

Tuskar-A -A pril 10th, two "Firecrests" all day on rock.

Arklow North Light-ship. -April 11th, one killed striking[Received in flesh]-(see under Wheatear).

Rockabill.-April 28 th, two at 8 A.M. on rock; wind moderate N.W. ; one killed. [Received in flesh.]

Maidens South.-April 11th, two at 10 P.M. at lantern; wind light $\mathrm{S}$.

Innishtrahull.-October 15th, one at 1 A.M. at lantern glass; strong breeze S.W.

Rathlin O'Birne.-February 15th, one at 2 P.M. going S.E.

Tearaght.- ? [One killed striking; wing received.]

WREN (Troglodytes parvulus, Koch).

Mine Head.-June 19th, two at 8 A.M.; clear.

Tusliar:-April 10th, one, and two "Firecrests" all day on rock; wind light S.E.

Lucifer Shoals Light-ship.-April 18th, two going N.W. rested on ship at 4 A.M.; calm, clear.

Arklow South Light-ship.-November 2nd, one during day about ship. 
Arklow North Light-ship.-April 27th, one about ship.

Howth Baily.-April 17th; one Common Wren inside lantern flying round dioptric apparatus.

Rockabill.-October 23rd and 24th, one on rock: 29 th, two all day: 30th, one. November 1st, great rush of birds (see under Blackbird); three Wrens at lantern: 7th, 8th, 9th, 10th, 12 th, and 13th, from one to four all day on rock.

Copeland (Mew) Island.-April 9th, one at night striking; wind light S.E., unusual transparency: 10th, Wrens and other birds striking lantern at night, some disabled; thick haze. October 2nd, one killed striking at 10 P.M. : 20 th and 30 th, one all day. November 19 th and 29th, and December 31st, one.

Tory Island.-November 5th, four Common Wrens in field at 8.30 A.M. (first seen); wind light S., gloomy. December 6th, one on cliff: 13 th, one.

Rathlin O'Birne.-April, Wrens remain and breed here. September 28th, one on island.

Slyne Head, S.-March 28th, one Common Wren on island; strong breeze N. September 23rd, two Common Wrens all day. October 12 th, one all day.

Arran Island, S.-November 2nd, one at 9 A.M. chased by Hawk into lighthouse; wind fresh S.E., cloudy.

Tearaght.-January 1st, one at 2 P.M. ; wind light E. [Leg and wing received]. "Not so many here as in the fall."

Skelligs.-October 21st, one disabled.

"TITs."

Maidens South.-April 7th, a Tit all day on rock; wind light N.E.

\section{"WagtaIls."}

Mine Head.-January 23rd, one "Yellow Wagtail" about station at 4 P.M. May 26th, two Wagtails at 8 A.M.

Arklow South Light-ship.-March 21st, one Water Wagtail at 9.30 A.M. going N.W. September 11 th, one at 5.30 A.M. and one at 6 P.M. about ship. November 7 th, Wagtails during day going N.W. : 16th, two at 11 A.M. going N.W.; wind light N.E.

Mrcidens South.-September 10th, two on rock. October 3rd, one at lantern at 4 A.M. : 27 th, one at 11 A.M. going S.W. 
Innishtrahull.-May 2nd, three "Pied Wagtail" at 10.30 A.M. on island; wind fresh N.W.

Tory Island.-November 12th, one Wagtail at 8 A.M.; first seen.

Rathlin O'Birne.-November 29th, one at noon.

Killybegs.-February 21st, two, first observed, remain here. Not always noted, as they frequent the place.

Blackrock, Mayo.-August 27th, three "Grey Wagtails," one male, two female, at 9 A.Mr going N.E.; wind light S.W.

Slyne Head, S.-July 12th, two Wagtails at 8 A.M. September 7 th, two at 7 A.M. November 17 th, two all day. December 4 th, two.

Arran Island, S.-October 22nd, two at 10 A.M. on wall. Seldom seen.

Slielligs.-April 22nd, one male "Yellow Wagtail" at 3 P.M. on rock; wind fresh $\mathrm{E}$.

Titlark (Anthus pratensis, Linn.).

Frestnet.-November 6th, one killed striking. [Leg and wing received.]

Hook Tower.- [Leg and wing of Meadow Pipit received January 22nd.]

Coningbeg Light-ship.-March 18th, one Lark found on deck. [Leg and wing of Meadow Pipit received.]

Arklow South Light-ship.-March 16th, one going N.W.: 18th, several going N.W. July 13th, one at 11 P.M. about lantern.

Arklow North Light-ship.-February 27th, one caught on upper deck-[Leg and wing received]. April 27th, one about ship; went N.W. May 3rd, one at 5 A.M.; flew N.W. October 20 th, one at 2 P.M. about ship; fell overboard.

Houth Baily. - November 19th, Titlarks are the only resident land birds here; I find them much the same all the year round.

Copeland (Mew) Istand.-April 27th, several breeding on the island. May 18th, nests found.

Maidens South.-September 10th, one on rock. October 7 th, two going S.W. : 15th and 17th, one: 22 nd, two going W.: 27 th and 29 th, one or two on rock. November 4 th and 5 th, nne: 30 th, one or two noted. 
Innishtrahull.-January 5th, one found; killed striking. August 15th, one killed.

Rathlin O'Birne.-January 24th, some on island during season.

Killybegs.-March 28th, some; are natives of the place (see under Cormorant).

Blaclerock, Mayo.-March and April, always here. June, Titlarks breeding about rock. September 27 th, one all day. October, here always.

Arran Island, N.-March, "during this month Titlarks are common here."

Tcaraght.- "January, not so many Pipits (Titlarks) and Wrens here as there were in the fall." October 26th, fifty on island; gale S.E. November 4th, a hundred all day; one killed; wind light E. : 21st to 27 th, several noted.

Rock-PiPIT (Anthus obscurus, Lath.).

Hook Tower. - [Leg and wing of Rock-Pipit received January 22nd.]

Tuskar.-April 17th, two all day.

SKYLARK (Alauda arvensis, Linn.).

Hook Tower.-October 26th, one killed striking; strong breeze N.E. [Leg and wing received]: 27th, great rush of Larks and other birds round lantern all night, going S.E. to N.E.; strong breeze N.E., overcast-[Legs and wings of four received]. November 6th, one at 8 P.M., killed striking: 16th, "Sand Larks" all day; wind light N.E. [Leg and wing of Skylark received.]

Coningbeg Light-ship.-April 10th, three Larks resting on ship; hazy. November 16th, some at 2 A.M. going N.E.

Barrels Rock Light-ship.-February 15th, one going S.IV. May 4th, three going N. October 23rd, "some Larks, apparently Skylarks," flying past at 8 A.Mr. going N.W.

Tuskar-[April 5th (?), Leg and wing of Skylark received, killed striking; immense rush of birds at this time, but Larks not mentioned (see under Wheatear)]: 10th, two at 11 P.I. round light. November 16 th, Larks and other birds all night round light; wind fresh S.; numbers killed. December 4 th to 20 th, great numbers, with other birds, all night round light; many killed. 
Lucifer Shoals Light-ship.-April 18th, one. October 14th, Lark caught by Hawk (see under Hawk).

Blackwater Bank Light-ship.-January 3rd, flock going N.: 12 th, two on ship. April 14th, some at 10 P.M. about light. November 2nd, 3rd, 5th, 6th, and 7th, some about light. December 25th, some about light from midnight to 7 A.M.; wind light $\mathrm{S}$.

Arklow South Light-ship. - January 2nd, seven disabled striking (see full note under Blackbird). February 4th, rush of birds at light (see full note under Thrush) - [ [Leg and wing of Lark received]: 5th, several at 11.10 A.M. : 10th, lots of small birds about light from 1 A.M. to 6 A.M. ; wind light W., overcast; three killed striking fell on deck, several fell overboard; one Lark killed - [Leg and wing received]: 19th, several small birds about light at 5 A.M. ; haze; two Larks in ship at 11 A.M.; one killed-[Leg and wing received]. April 6th, one in ship: 10th, some about light-[Leg and wing of Skylark received]. October 15th, one about ship: 22nd, several: 25th, several about light. November 7th, several Blackbirds and Larks about light; wind light S.W., clear; Blackbird, Lark, and Fieldfare killed striking: 16th, several about lantern; rain.

Arklow North Light-ship.-January 2nd, one about ship; large numbers about light at 7 P.M.; wind light W., foggy; some killed striking, some caught alive: 6th, one dead on deck. February 5th and 7th, a few about lantern: 21st, several about light; wind light S.: 23rd, one on deck, caught: 26th, one on deck. October 27th, one rested on ship; gloomy; some, with Thrushes, about light, many killed: 28th, several: 29th and 31st, one on deck. November 1st, two do.: 2nd, large number, with other birds, about light from 4 A.M. to 7 A.M.; went N.W.; wind light N.E., light haze; none killed: 29th, one going N.IV.

Houth Baily.-[April 18th, one found on roof of dwelling, "probably killed previous winter"; wing received.] November 25 th, one caught at lantern.

Rockabill.-April 29th, three all day; five at 10 A.M. going N.W. May 3rd, three on rock. June 1st, six going IV. October 13th, 16th, 17th, 22nd, 27th, and 30th, three to four noted. November 1st, one at lantern (see under Blackbird): 9 th, one on rock: 10 th and 12 th, three to five all day.

Copeland (Mev) Island.-May 12th, some found dead in 
dome of lantern (see under Woodcock). November 6th, a ferw striking; sleet. [December 21st, Skylark found dead; leg and wing received.]

Maidens South.-January 2nd, seven at lantern at 2 A.M.; misty; flew W. to land at daylight. February 9 th, three at lantern at 1 A.M. ; two killed striking: 15 th, two at lantern at 2 A.M.; one killed striking: 20 th, five at lantern at 5 A.M.; foggy: 24 th, two on rock. April 8th, three at lantern: 9th, about twenty Larks and Thrushes all night round lantern; wind moderate S.E.: 10th, three at lantern; one killed: 11th, three do.; two killed. October 1st, 3rd, 8th, 22nd, 27th, 29th, and 30th, two to four noted, chiefly at lantern. November 1st, one killed striking: 2nd, four round lantern, one killed: 5th, three going S.W.: 6 th, a number round lantern; left at daybreak: 7 th, four and one Starling at lantern; one killed, caught three. December 22nd, two at lantern: 23rd, two at 2 A.M. killed.

Innishtrahull.-February 5th, two struck lantern at 4 A.M. April 7th, one striking lantern at 1 A.Mr.; wind moderate E. May 7th, one Skylark striking lantern at 1 A.I. August 24th, two "hatching on island." October 29th, two "Lairks" and a Chiffchaff caught on lantern glass at 9 P.M. ; wind light E.

Tory Island.-November 4th, Larks, Thrushes, Green Plover, Redwing, and Fieldfare from 12.10 A.M. to daylight round lantern; wind light S.E., gloomy ; ten killed; no Plover struck; again from sunset to midnight; twenty Thrushes and Fieldfare disabled: 12th, flock going S.: 13th, great rush of birds (see under Starling). December 7th, Larks and Thrushes from 4 A.M. to 7.30 A.M. at lantern; wind moderate N.E.; two Larks disabled; very dark morning; birds very numerous: 12th, several round light.

Rathlin O'Birne.-March 11th, numbers; they breed here. October 25th, some on island at noon.

Killybegs.-February 5th, two at 10 P.M. March 7 th to 13 th, very plentiful (see under Cormorant). April 1st, one at 1 A.M. killed striking. Not always noted, as they frequent the place.

Blactrock, MLayo.-April 6th, one all day on rock. October 16th, two about rock; gale $\mathrm{N}$.

Tearaght.-Numbers during winter of 1890-91 (see under Fieldfare). November 7 th, one killed striking. [Leg and wing received.] 


\section{SNow Buntivg (Plectrophenax nivalis, Linn.).}

Fastnet.-November 6th, one killed striking. [Received in flesh.]

Hook Tower:-October 6th, one shot-[Received in flesh]: 22nd, three all day: 23rd, one. November 26th, flock of twenty. "Large flocks of Snow Buntings seen for the next week; again on December 2nd, and several other days. The people say they did not see such a lot of these birds for several years ; it must be owing to such severe weather." December 15th, five shot. [Four received in flesh.]

Howth Baily.-November 23rd, several flying W.

Innishtrahull.-December 4th, eight on island, just arrived; wind light N.E., gloomy : 6th, a large flock.

Tory Island.-November 6th, one; first seen: 7th, one: 14 th and 15th, flocks of from forty to seventy going S.E.; one flock noted each day; calm: 15th, seven going S.E. : 21 st, twenty to thirty at 1 P.I.; came from N., and lighted at station; wind moderate $\mathrm{N}$. (these were nearly white in plumage): 22nd, two: 23rd, large flock going S.E.; wind light W.: 26th and 28th, some at station. December 1st, 2nd, 3rd, 5th, and 7th, a few noted: 10th, 13th (flocks), 17th (flocks), nearly white in plumage: 19th, 22nd, (flocks) at station, "as usual."

Rathlin O'Birne.-March 3rd, six at noon; remained. September 9 th, twelve. October 7 th, one. December 27 th, one.

Blackrock, Mayo.-March 19th, "about fifty remained here all winter": 22nd, two: 30th and 31st, and April 1st, four all day: 5th, two. September 20th, one all day: 27th, and October 1st to 16th, a number; wind fresh and gales, hail showers.

Slyne Head, S.-February 3rd, one on island. March 5th, five all day; gale W.: 26th, five came from W.; gale W., snow. April 1st, four. October 8th, one; gale S.E.; first seen. November 28th, five.

Arran Island, S.-November 3rd, three on island; wind fresh ; first seen this year.

Tearaght.-October 26th, some noted.

S7ielligs.-September 12 th, three on rock at 11 A.M.; wind light, fog: 23rd, seven; wind strong S.E., fog. 
Yellow Bunting (Emberiza citrinella, Linn.).

Coningbeg Light-ship.-April 10th, three resting on ship; went away for land: $19 \mathrm{th}$, two do.: $20 \mathrm{th}$, three do.

Killybegs.-April 2nd, one at 10 A.M. resting.

Tearaght.-June 18th, one for several days ; " a rare visitant."

Common Bunting (Emberiza miliaria, Linn.).

Innishtrahull.-January 17th, two Common Buntings in lighthouse garden at 10 A.M., one shot; wind light S.E., clear. "The first Bunting I have seen here during the winter months except the Snow Bunting."

Chaffinch (Fringilla, coelebs, Linn.).

Hook Tower.-October 27 th, two round lantern; wind strong N.E. November 7th, one killed striking; wind light S.W., gloomy.

Coningbeg Light-ship.-April 21st, three at noon. October $26 \mathrm{th}$, one rested on ship, left for land; wind strong N.E. : 30th, two do.; wind fresh S.E. November 13 th and 14th, some all night (see under Linnet).

Barrels Rock Light-ship. - October 27th, several birds of various kinds about ship during this and following night; some killed; several fell overboard-[Leg and wing of Chaffinch received]_-(see also under Blackbird and Starling). November 2nd, odd Chaffinches during day going N.E.

Tuskar.-April 19th, two on rock. November 25th, great number, with other birds, going W. during day.

Lucifer Shoals Light-ship.-February 20th, one going N.W. rested, and left next morning going W.

Blachwater Bank Light-ship.-November 17th, one died on deck; wind moderate W. [Leg and wing received.]

Arklow South Light-ship.-March 20th, one going N.IV.; wind fresh N.: 28th, one on ship. April 6th and 10th, one do. August 27th, two at 5 A.M. October 13th, one on ship. November 2nd, two during day. December 20th, one on ship.

Arklow North Light-ship.-October 18th, one on deck: 30th, two.

Howth Baily.-November 21st, one at station. 
Rockabill.-October 10th, three on rock: 11th, two going N.W.: 13th, three on rock; strong gale: 16 th, two going W.; gale S.W.: 17 th, one on rock: 20 th, two do.; gale S.W. : 22 nd, 23rd, and 24th, two to four on rock: $25 \mathrm{th}$, "one Hawk and one Chaffinch" at 1 P.M. going N.: 26th and 27th, eight to nine on rock, and one at lantern at night: 29 th and 30 th, several on rock. November 3 rd to 12 th, several all day on rock; wind variable: 13 th, four; went W.

Maidens South.-April 2nd, one on rock; gale S.E. October 18th, three alighted at 9 A.M. December 20th and 23rd, two on rock.

Tory Island.-October 31st, one all day. November 5th, one (male), probably the same as on 31st; they are plentiful on island, but no others at station: 8th, eight on corn-stacks on island: 16th, one struck during night: 26th, one all day. December 14th, one.

Slyne Head, S.-July 28th, five going N.W. ; wind light N.

Tearaght.-[October 28th, legs and wings of two Chaffinches received, killed striking]: $29 \mathrm{th}$, ten noted. [November 7 th, wing of Chaffinch received, killed striking]: 21st, fifty at noon; wind variable : $23 \mathrm{rd}$, some all day on island.

Skelligs.-October 30th, sixty going E. ; wind fresh S.E.

Brambling (Fringilla montifringilla, Linn.).

Fastnet.-November 6th, one "Snow Bunting"killed striking; wind light E., very dark. [Leg and wing of Brambling received.]

Tuskar. - April 5th, immense rush of birds (see under Wheatear). [Leg and wing of Brambling received, killed striking.]

Greenfinch (Coccothraustes chloris, Linn.).

Tuskar:-November 25th, a great number, with other birds, going W. during day; gale N.E., clear; two Greenfinches killed. Blackwater Bank Light-ship.-December 21st, one at 11 А.M. resting on ship.

Arklow North Light-ship.-April 26th, one about ship.

Howth Baily.-December 25th, one Greenfinch.

Rockabill.-November 5th, one on rock all day.

Tearaght.-April 23rd, one at 10.30 A.M. ; wind fresh E. 
GoLdFinch (Carduetis elegans, Steph.).

Mine Head.-April 29th, two at 1 P.M. going E.

Tearaght.-November 21st, one at noon; wind variable; "could not get it."

\section{Siskin (Carduelis spinus, Linn.).}

Arklow South Light-ship.-April 10th, Siskins and other birds about light; wind light S.E.

\section{House Sparrow (Passer domesticus, Linn.).}

Killybegs.-March 28th, native of the place.

\section{"LinNets."}

Ballycotton.--March 20th, Linnets always here.

Coningbey Light-ship.-March 10th, several flocks of Linnets, Thrushes, and Starlings going N.W. at 11 A.M. ; strong gale N.E.: 21st, small flock of Linnets going N.W.; wind moderate N. November 13th, Linnets, Chaffinches, and Starlings all night round lantern and on board ship; some killed striking; strong breeze S.W.; a number remained on board and died: 14th, do.; numbers killed, others went towards Irish land: 16th, some at 2 A.M. going N.E.

Barrels Rock Light-ship.-February 25th, one Grey Linnet going N.: 28th, one do. about ship all day. March 2nd, two Linnets going N. April 14th, one Grey Linnet: 23rd, two do. going N. October Sth, twenty-five passed going S.E.

Lucifer Shoals Light-ship.-February 8th, one Linnet going N.W:, flying for land. March 8th, four going N.W.

Blackwater Bank Light-ship.-January 17th, one Linnet about ship. March 23rd, Linnet chased by Hawk (see under Hawk).

Arklow North Light-ship. - April 18th, one red-breasted Linnet about ship, went N.IV. October 29th, one cock Grey Linnet caught on upper deck. November 23rd, one do. going N.'.'.

South Rock Light-ship.-November 23rd, one Linnet around ship.

Copeland (Mew) Island.-September 24th, flock of twenty "Grey Linnets" remaining: 28th, flocks remaining all day. October 24th, several all day. 
Maidens South.-April 17th, two Grey Limnets going WV.: 19 th, one on rock. September 16th, three Linnets going W. October 1st, 2 nd, 7 th, and 17 th, a few going W. and S.W.

Tory Island.-November 5th, flock of Grey Linnets flying N. : 15th, flock of Linnets, with Redbreasts, at 7.50 A.M. going S.L. : 23rd, flock of Grey Linnets at station: 26th, flock of Linnets at noon going S.E. December 10th, two large flocks Grey Linnets at 10 A.M. going S.E.; gale N.W.: 13th, 17th, and 22nd, flocks of do.

Rathlin O'Birne.-April 7th, flocks going S: at 11 A.M. August 16th, flocks going E. October 17th, flocks hovering at noon.

Slyne Head, S.-March 22nd, large flock at 8 A.M. going N.W.: 28th, five going E. : 30 th, scores of Linnets at 8 A.M. on island; wind light N.E. April 20th, ten. June 22nd, large flock all day. July 2nd and 28th, some all day. September 7 th and 23rd, large lock; wind light S.E. November 7th, flock all day.

Arran Island, S.-September 8th, thirty-six at 7 A.M. ; first seen this year: $22 n d$, forty on wall; wind light N.E.

Tcaraght.-October 26th, twenty on island; wind moderate S.E. November 21 st, ten at noon: $23 \mathrm{rd}$, some all day: 27 th, fifty.

\section{"Twite."}

Coningbeg Light-ship.-April 26th, two Twites at 2 P.M.: 27 th, one.

StARLING (Sturnus vulgaris, Linn.).

Fastnet.-November 6th, some round light; very dark.

Ballycotton.-March 20th, Starlings always here.

Hook Tower--October 22nd, immense flock: 27 th, great rush, with other birds, round lantern all night, going S.E. to N.E.; wind strong N.E., overcast--[Leg and wing received]. November 6th, four at, 8 P.M. : 7th, nineteen killed striking; wind light S.W., gloomy: 16 th, large flocks for several days : $23 \mathrm{rd}$, one at lantern.

Coningbey Light-ship.-March 10th, flocks going N.W. at 11 A.M. : 11th, flock going N.IV.; wind light N., snow showers; two rested on ship: 26th, four or five round light; went away before daylight. April 6th, very large numbers of Starlings, Blackbirds, and small birds at 10.30 P.M. flying round lantern; 
went away about 4 A.M.; wind fresh N.E.; numbers killed: 16th, six at 11 P.M. round lantern. October 27th and 28th, great numbers all night round lantern; left at 4.30 A.M. for land; wind fresh E., overcast: 30th, six rested on ship. November 1st, two remained on board: 3rd, 4th, 5th, 6th, 7th, 8th, and 9th, Starlings, Blackbirds, and Thrushes all night flying round; numbers struck and fell overboard: 13th, Starlings, Chaffinches, and Linnets all night flying round and on board ship; several killed striking; numbers remained ou board and died; strong breeze S.W., showery: 14th, do. all night; went for the Irish land; wind moderate S., rain: 19th, flocks of Starlings at 2 P.M. going for the land.

Barrels Rock Light-ship.-February 27 th, five at 5 P.M. going E. April 9th, three at 5 P.M. going N. October 26th, about twenty at 7 A.M. : 27 th, several birds of various kinds about ship during this and following night; some killed; several fell overboard[Leg and wing of Starling received]_(see also under Chaffinch and Blackbird). November 1st, small flock at 9 A.M. going N.E.: 16th, large flock at 8 A.Mr. December 30th, one going S.W.

Tuskar.-April 1st to 9th, great rush, with other birds, round light all night, going N.W. at daylight; great number killed striking (see under Wheatear): 13th, four round light at 4 A.M. November 18th to 25th, some going W.; a few killed. December 4 th to 20th, great numbers of Starlings and other birds all night round light; many killed: 21st to 30th, some, with other birds, in flocks passing W. all day: 31st, some round light all night.

Lucifer Shouls Light-ship.-April 3rd, several at 1 A.M. ; ten killed: 10th, two rested: 18th, two.

Blackwater Bank Light-ship. - January 5th, flocks going N.W. : 10th, three going N.: 22nd, six about light. March 14th, six from 2 to 4 A.M. about light: 31 st, three about light; clear; one killed. April 1st, flock from 11 P.Mr. to 12 P.Mr. about light[Leg and wing received]: 7th, flock at 3 P.M.: 10 th and 14th, some at 10 P.M. about light. September 13th, flocks at 1 P.M. going N.W. October 27th, flocks all night; some killed: 29th, flocks at 4 P.M. November 2 nd and 3rd, flocks about light[Leg and wing received]: 5th, 6th, and 7th, some about light: 15th, two resting on ship: 16th, flock going N.W. December 
$22 \mathrm{nd}, 24 \mathrm{th}$, and $25 \mathrm{th}$, some about light; some killed. [Leg and wing received.]

Arklow South Light-ship.-January 1st, some, with Thrushes, about lantern: 2nd, some, with Blackbirds and Larks: 15th, flock going E.: 19th, two. February 4th, some at light[Leg and wing received]: 5th, one in ship: 26th, flock at 11 P.M. about lantern; haze. March 13th, one killed striking at 11 P.M., clear: 23rd, two about ship. April 3rd, two about light: 4th, four do.: 6 th, one going N.W.: [7th, Leg and wing received]: 10th, some about light-[Leg and wing received]. October 13 th, flock at 9 A.M. going N.W.: 18th, five going N.W.: 20th, flock going N.W.: 26th, two about deck at 9 A.M.: 27 th, several about light; fresh breeze $\mathrm{E}_{\text {。 }}$, overcast; seven killed[Leg and wing received]: 28th and 30th, some going N.W. November 2nd, one killed: 3rd, 4th, and 7th, one do.: 20th, flock going N.W.: 23rd, do. December 17th, do.: 22nd, two at night about light: 24 th, sixteen going W. at 11 A.M. ; several at night about light; many killed-[Leg and wing received]: 25th, flock at 9 A.M. going N.W. [Leg and wing received.]

Arklow North Light-ship.-January 1st, one going N.W. at 10 A.M. March 4th and 5th, a few about light. April 11th, birds about light (see Wheatear); one Starling killed striking[Received in flesh]. October 25th and 26th, a few about light: 29th, one rested on mast; went N.W. November 2nd, some, with Larks and other birds, about light: 24 th, two: 28 th, six about light.

Howth Baily.-April 10th, some striking glass from 8 P.M. to 4 A.M.; several killed; misty, strong breeze S.E. May 2 nd, a few building in ventilator holes under balcony; always here.

Rockabill.-October 27th, five at 11 P.M. at lantern; gale E.; three killed-[Leg and wing received]: 28th, flock at 4 P.M. going W. : 29th, flock going W. ; five all day on rock : 30 th and 31st, a few went W. November 1st, countless numbers of Starlings and other birds from 9 P.M. to 4 A.M. at Iantern; twenty-one Starlings killed (see under Blackbird): 4th, eleven going W.; one killed striking: 6th, several at lantern: 7th, nine going $W$.; one killed: 10th, eight all day on rock; one killed.

Drogheda.-November 1st, a large flock going W.: 10th, 
large flocks about fields: 25 th, numbers going S.W. December 11 th and 24th, several do.

South Rock Light-ship.-April 5th, several, with Wheatears. November 22nd, one about lantern; clear.

Copeland (Mew) Island. - March 5th, flocks apparently remaining on the island to breed. April 5th and 6th, some, with Blackbirds, at night; some disabled; gale S.E., misty: 10th, several striking at night; thick haze : 27 th, many breeding on island. May 12th, some found dead on dome of lantern (see under Woodcock). September 6th, large flocks all day, remaining: 24th, flocks remaining. November 11th, several flocks: 13th, large flocks. December 5th and 8th, a flock noted: 13th, flock going W.: 16th, 21st, 22nd, and 24th, some seen on island.

Maidens South.-January 2nd, four at lantern-sash: 3rd, three; misty. October 8th, 15th, 20th, 22nd, 27th, 28th, 30th, and November 4th, 5th, and 7th, a few noted, from one to twenty, generally going W. or S.W.

Innishtrahull.-January 9 th, seven on island, with Fieldfares and Thrushes. May 24th, two. October 27th, some striking (see under Redwing).

Tory Island.-October 28th, twenty to thirty. November 3rd, one caught at lantern at 9 P.M. : 6th, several flocks going S.W., twenty to a hundred in each : 8th, flocks on island: 10 th, flock (two hundred) going S.E. at 9 A.M., flying high: 12th, some on island "as usual": 13th, "a great many birds round lantern from 4 A.M. to daylight; many struck, but only two killed (Redwings); the birds were Starling, Thrushes, Blackbirds, and Larks; wind S.E.; flocks of Starlings going N. by day: 21st, very large flocks all day going to mainland: 29th, one at station. December 12th, one disabled striking at night: 19th, flock going S.E., flying high.

Rathlin O'Bime.-January 14th, flocks during season on island. October 23rd, eight.

Killybegs.-March 7th to 13th, very plentiful: 28th, natives of the place (see under Cormorant).

Biackrock, Mayo.-October 16th, two all day about rock.

Slyne Head, S.-January 3rd, twenty-five on island: 7th, and February 3rd, flock all day: 12th, five. October 15th and November 7 th, flocks all day on island; ten killed on 7 th. December, some on island every day. 
Arran Island, N.- "No birds except Starlings seen here from January 4th to February 21st."

Arran Island, S.-October 5th, eighteen at 2 P.M. going N.W.; gale S.W.; first seen this year: 31st, twenty-four all night on island; ten killed striking; wind strong S.E. November 23rd, two at 9 A.M. ; wind light S.; not seen since October 31st.

Tearaght.-Numbers during winter 1890-91 (see under Fieldfare). October 30 th, a flock.

Skelligs.-January 1st and 2nd, Starlings and Blackbirds still on rock; left on 3rd; last seen at 3 P.M.; wind light. March 17 th, twenty on rock. September 29 th, fifty at 3 P.M. going E.: wind strong S.W.

\section{Снобgh (Pyrrhocorax graculus, Linn.).}

Mine Head.-During April, May, and June, three to five noted at intervals.

Innishtrchull.-November 6th, two on island; wind fresh S.W.

Rathlin O'Birne.-April, two. They remain and breed here. August 26th, two.

Arran Island, S.-August 17th, "five Jackdaw (Choughs)" at 10 A.M. on crag. (Build on island.)

Tearnght.-February 3rd, four; strong breeze S.E. April 6 th, three.

RAVEN (Corvus corax, Linn.).

Dunree Head.-March 15th, two going S.W. April 16th, two going S.W. May 16th, two going N.E.; gale N.W. June 10th, three going S.W.

Tory Island.-November 5th, two on the cliffs.

Rathlin O'Birne.-December 17th, two all day on island.

Tearaght.-February 1st, ten at 11.30 A.M.; strong breeze S.W. December 18th, four all day on island; wind light S.E., fog.

Hooded CRow (Corvus cornix, Linn.).

Fastnet.-May 17th, Crows (Greybacks) on rock.

Iine Head.-April 5th, two Grey Crows noted: 18th, four: 29 th, three.

Tory Island.-November 27th, one Hooded Crow at 11 A.N.; 
first seen; three later on going to mainland; strong breeze S.W. December 9 th, one Grey Crow going S.E.: 14th, two going S.: 19th, two remain on island.

Slyne Head, S.-February 3rd, five Grey Crows going W.; strong breeze S.W. March 28th, two do. at 10 A.M. going E. : 31st, five going E. April 12th to 20th, three to four on island.

Arran Island, S.-August 12th, four "Grey Crows" on island; gale.

Tearaght.-April 6th, three Hooded Crows.

Rook (Corvus frugilegus, Linn.).

Spit Bank, Queenstown-February 21st, large numbers going N.E. March 21st, several do. April 6th, one. "This bird made a peculiar noise similar to the cry of a goose."

Coningbeg Light-ship.-March 25th, three Crows at 4.30 P.M. going N.; "went for the land at 6 P.Mr."; fresh breeze N.W., clear.

Barrels Roch Light-ship.-April 10th, one "Crow" going N.; wind light S.E.: 14th, one "Crow" rested on ship at 9 A.M. going N.; wind light $\mathrm{N}$.

Tuskar.-April 15th, large flock of "Crows" at 5 A.M. going N.W.; wind light N.W.; "seemed very tired": 16th, ten do. at noon going E. ; wind light N.W.

Lucifer Shoals Light-ship.-March 29th, two "Black Crows" at 11.20 A.M.; seemed tired.

Arklow South Light-ship. - March 21st, one "Crow" at 11 A.M. going N.W.: 24th, one going N.W. April 6th, two "Crows" going N.W.; calm.

Arklow North Light-ship.-April 19th, one "Crow" at 6 P.M. going S.E.; wind light S.E. December 2nd, one at 10 A.Mr. going N.W. ; wind light W.

Maidens South.-February 21st, one Crow going S. at noon; misty. December 23rd, one at 3 P.M.

Tory Island. - February 25th, two Rooks during day. December 19th, two "Common Crows" at 11.15 A.M.; strong breeze S.W.; seldom seen.

Rathlin O'Birne.-August 7th, twelve Rooks at 8 A.M. going W. 
Killybegs.-April 21st, four "Crows" going S. May 10th, one going $\mathrm{E}$.

Slyne Head, S.-January 3rd, five "Crows." April 4th, two "Common Crows" going N.W. September 7th, seven on island. November 16th, twelve Crows at 2 P.M. going N.

Arran Island, N.- "Common Crow" seen here from February 21st to March 1st.

Tearaght. - January 29th, flocks of Rooks, more or less, several times since November 5 th (see full note, November 5th, 1890); six or eight still remain: 27 th, seven on island all day.

JACKDAW (Corvus monedula, Linn.).

Howth Baily.-March 23rd, Daws come here in February every year, are more plentiful in March, and remain till after the breeding season. They breed in the cliffs N.E. of the station. There are often thirty or thirty-five at the feedingplace of the poultry belonging to the station.

MaGPIE (Pica rustica, Scop.).

IFine Head. - March 18th to June 25th, one or two at intervals.

Arran Island, S.-August 30th, two Magpies at 7 A.M. perched on wall; gale S.W.; seldom seen here.

$$
\text { "JAY." }
$$

Arklow North Light-ship.-April 24th, one "Jay" at 7 A.M. about ship; wind light N.E., clear; went N.E.

\section{SWALlow (Hirundo rustica, Linn.).}

Fastnet-April 22nd, seen while on shore. May 24th, one all day. November 6 th, one disabled striking at night; wind light $\mathrm{E}$.

Mine Head.-April 14th, one going E., and two to eight at intervals to June 23rd.

Coningbeg Light-ship.-April 26th, two at 2 P.M.: 27th, one or two.

Barrels Rock Light-ship.-April 19th, nine going N.; wind light S.E.: 21st, odd Swallows during day going N.: 23rd, one 
about ship: 24th, seven going N.: 26th, a few during day going $\mathrm{N}$; ; wind light S.E.: $27 \mathrm{th}$, Swallows in twos and threes all day going N.; wind light S.E. (on 26th and 27th they were " of a small species, some flying about ship at dusk"): 28 th, small flocks during day going N.; wind light N.W.: 29th and 30th, odd ones all day going N.; wind S.W. July 1st, one going S.: 13th, four "dark" ones at noon going S.: 15th, two going N.E.

Tuskar-April 12th, two at noon going N.W.; wind light S.E. (the first seen this year): 14th, one at 5 A.M. killed striking; wind light N., showery: 20th, four going N.W. June 12th, "Swallows passing west every day; they very often rest with us for a few hours, then resume their journey."

Lucifer Shoals Light-ship.-April 18th, one. September 23rd, one. October 16th; two about ship: 19th, one going N.W.

Blackwater Bank Light-ship.-April 18th, two going N.E.: 19th, six going N.; wind light E.: 25th, three going N.E.: 26th, two going N.E. May 2nd, three going N.W.: 6th, flocks at 10.30 P.M. going N.W.; wind light S.W., gloomy; two killed striking. September 10 th, flocks at 10 A.M. going S.W. October 10th, flock going S.; wind fresh S.W:

Arklow South Light-ship.-April 6th, one in ship: 14th and 15 th, one: 18 th, three: 21 st, two at 7 P.M. roosting in enginehouse; hazy: 22nd, two going N.W.: 26th, two going N.W. May 3rd, two going N.W.: 12th, two going N.W.: 13th, one going N.E.: 27 th, great numbers from 8 A.M. to 1 P.M.: 28 th, several from 8.15 A.M. to 4 P.M.: 29 th, numbers from 9 A.M. to 3 P.M.: 31st, two. June 4th, 8th, 10th, 12 th, and 25 th, one or two noted. July 12th, one going S.E.: 16th, one going S.E. August 23rd, one going S.: 24th, several going N.W.; wind light S.W.: 30th, one going W. September 26th, 27th, and 29 th, one to five noted. October 11th, two going S.W.; strong breeze S., rain: 31st, two about ship.

Arlilow North Light-ship.-April 18th, several : 21st, several, flying low: 25 th, one: 27 th, one.

Housth Baily.-April 25th, some observed. September Sth, "some still here."

Rockabill.-September 20th, eight going E. : 25th, thirty going E. ; wind light S.E.: 29th, seven going E. October 1st, three on rock. 
Copeland (Mew) Island.-May 18th, Swallow's nest found.

Mraidens South.-May 4th, one going W. June 15th, two going S. September 1st, two flying round rock; gale W.: 3rd, seven at noon going S.; wind fresh S.E. : 6th, one going S.

Innishtrahull.-April 26th, one on island; wind light S., clear ; " a very early visitor." June 18th, two about island.

Dunree Head.-May 18th, two going E.; first arrival : 29th, eight going N. Swallows left latter end of September.

Killybegs.-April 25th, "saw first Swallow."

Slyne Head, S.-May 28th, two on island. June 5th and 7th, a few noted.

Tearaght.-April 20th, one; wind fresh S.E. [June 2nd, Leg and wing of Swallow received, picked up.] July 12th, two all day: 14th, one. November 4th, one.

Skclligs.-April 23rd, thirty Swallows and three Martins at 6 P.M. on rock; strong breeze E. ; seemed very exhausted; shot one of each description. [Legs and wings of Swallow and House-Martin received.]

House-Martin (Chelidon urbica, Linn.).

Howth Baily.-April 25th, Martins observed; they breed every year on the cliffs under lighthouse, east side. August 20th, "still here."

Blackrock, Mayo._May 6th, one "House-Martin Swallow about rock": 10th, two do. all day about rock: $22 \mathrm{nd}$, one do. all day. June 9 th, one do. August 17th, one do. about rock. [Possibly a pair bred on rock this year.-R. M. B.]

Skelligs.-April 23rd, thirty Swallows and three Martins on rock at 6 P.M.; seemed very exhausted; shot one of each species; strong breeze E., cloudy, gloomy, passing showers. [Legs and wings of Swallow and House-Martin received.]

\section{Sand-Martin (Cotile riparia, Linn.).}

Coningbeg Light-ship.-April 18th, two Martins rested on ship : 20th, four Martins do.: 25th, three Martins or Swallows lighted on ship; left for land. May 22nd, one Martin.

Blackwater Bank Light-ship.-May 6th, flocks of "Swallows" at 10.30 P.M. going N.W.; wind light S.W., gloomy; two killed. [Leg and wing of Sand-Martin received.] 
Arklow North Light-ship.-April 18th, one Martin caught: 26th, one Martin caught on deck at 10.15 A.M. [Received in flesh]: 27 th, one.

Maidens South.-June 21st, "two Swallows (Martins)" going W.: 28th, "two Swallows (Martins)" at noon. July 2nd, two Martins going S.W.: 13th, one Martin going S.

Blackrock, Mayo.-April 20th, three Swallows with brownish backs and white underneath (smaller than a House-Martin Swallow) all day; wind S.E. [Probably Sand-Martins.R. M. B.]

Tearaght.-June 5th, several Martins all day.

\section{SwIFT (Cypselus apus, Linn.).}

Mine Head.-June 22nd, four going $\mathrm{E}$.

Blackrock, Mayo.-June 5th, one Black Swallow (Swift) about rock; first this year; wind fresh E. August 18th, two Swifts (Black Swallows) about rock.

Tearaght.-June 7th, one "Swift Swallow" at 4 P.M. July 8th, one Swift picked up dead.

NightJaR (Caprimulgus europaeus, Linn.).

Fastnet.-July 17th, Nightjar (supposed) at 11 P.M.; wind E., gloomy.

Cuckoo (Cuculus canorus, Linn.).

Mine Head.-May 10th, one going S. June 28th, one Cuckoo going $\mathrm{E}$.

Howth Baily.-May 10th, first heard this year; remained in neighbourhood during summer.

Dunree Head.-May 13th, one going W.; first heard.

Skelligs.-April 23rd, one at 6.30 P.M.

KInGFisher (Alcedo ispida, Linn.).

Hook Tower:-September 9th, a Kingfisher found alongside lighthouse in the morning; probably killed striking during dense fog at night; strong breeze S. [Received in flesh.]

Rock-Dove (Columba livia, Gmel.).

Hooli Tower.-December 14th, one Rock Pigeon shot at 12 P.M. [Leg and wing of Rock-Dove received.] 
TurTle Dove (Turtur communis, Selby).

T'earaght.-April 23rd, one shot at 2.30 P.M.; wind fresh E. [Received in flesh.]

\section{"Pigenns."}

Mine Hcad.-April 18th, three going W.: 21st, four Pigeons going S. May 12th, three going W. June 18th, three going $\mathrm{E}$.

Tuskar.-November 28th, one "Dove" shot; fell into the sea and was lost; wind strong N.E.

Arklow North Light-ship.-February 19th, one Pigeon flying round. April 11th, one do. going N.W.

Maidens South.-February 9th, one "tame Pigeon pitched on roof" at 11 A.M.; flew W. to the land: 19th, one "dun-coloured Pigeon on balcony" at 2 A.M.; flew W. to the land; foggy. March 24th, one "Blue Mottled Pigeon" rested about an hour; went S. September 4th, Blue Pigeon pitched on roof of dwelling at noon; flew from the N.; shot.

Dunree Head. - February 10th, ten Pigeons going S.E. March 8th, fourteen going E. June 28th, six going N.E. September 4th, ten going W. December 21st, twenty-seven going N.W.

Tory Island.-November 11th, three going N.E.

Rathlin O'Birne.-August 19th, two on island.

Slyne Head, S.-June 7th, one going W.

Arran Island, S.-September 28th, seven on crag, feeding; strong gale S.W.; two shot.

Tearaght.-February 2nd, twelve to sixteen Rock Pigeons all day. October 26th, ten Pigeons on island; gale S.E. December 18th, ten do.

CoRn-Crake (Crex pratensis, Bechst.).

Spit Bank, Queenstown.-April 29th, Corn-Crakes first heard this year.

Mine Head.-May 10th, three; wind light N.E. July 10th, two going $\mathrm{N}$.

Arklow North Light-ship.-April 25th, one at 6 A.M.; rested five minutes on ship and went N.W.; wind light S.E., hazy.

Copcland (Mcw) Island.-April 26th, one lying in the grass; wind light $\mathrm{S}$. 
Innishtrahull.-May 8th, two on island; wind strong breeze S.E.

Rathlin O'Bime.-May 12th, one on island; wind light N.W.; seldom seen.

Tearaght.-April 19th, wing of Land-Rail picked up on island. [Received.]

WATER-RaIL (Rallus aquaticus, Linn.).

Fostnet.-November 6th, one disabled striking; very dark.

Galley Head.-October 27th, one caught about midnight in the lantern; "never seen here before." [Received in flesh.]

Hools Tower.-November 5th, one killed striking. [Received in flesh.]

Barrels Rock Light-ship. - [September 25th, Water-Rail received in flesh.]

Blackwater Bank Light-ship. - April 6th, two "unknown birds" at 9 P.M. about light. [Leg and wing of Water-Rail received.]

Rathlin O'Birne-December 23rd, Water-Rail caught; "it was pecking about on the beach at noon, and ran under a stone." [Leg and wing received.]

Killybegs.-[December 21st, Water-Rail shot. Leg and wing received.]

Blackrock, Mayo.-November 5th, "small bird with long legs of a dark brown colour; can run very fast-Water-Hen I used to call them." [Possibly Water-Rail.]

WATER-HEN (Gallinula chloropus, Linn.).

Arran Island, S.-September 18th, two "Water-Hen" on lake; they never leave it.

RINGed Plover (Afgialitis hiaticula, Linn.).

Arklow South Light-ship.-August 3rd, several at 9.45 P.M. about ship; wind light N.W.: 5th and 10th, several about ship from 9 P.M. to 10 P.M.; wind light W.

Innishtrahull.-January 9th, "eleven Dotterel (ringed)" on island; wind light W. June 21st, two young Dotterel on island. July 16th, four Dotterel at 8 A.M. 
Golden Plover (Charadrius pluvialis, Linn.).

Mine Head.-March 10th, flock going S.; four shot: 14th, twelve going W. April 9th, one going N.

Hook Tower.-October 12th, flock of "Grey Plover" all day; gale S.W.

Blackwater Bank Light-ship.-January 1st, a flock going N.W.; haze: 2nd, flock of "Grey Plover" going N., hazy.

Arklow South Light-ship.-April 6th, several "Grey Plover" at 8.50 P.M. about light; wind light N.E., light haze.

Arklow North Light-ship.-February 26th, "Grey Plover" about ship.

South Rock Light-ship.-January 9th, flock of about fifty going N.W. at 7.30 P.M. ; calm, dark; one killed striking. [Leg and wing received.]

Copeland (Mew) Island.-December 21st, flocks of Green and Golden Plover on island all day; wind light W., frosty.

Innishtrahull.-April 11th, two going S.E. December 28th, three on island, just arrived; gale S.E., gloomy.

Tory Island.-November 29th, one "Grey Plover" shot at lake; strong breeze N.W.

Rathlin O'Birne.-March 19th, three shot at 1 P.M. "Very few this season." October 6th, two on island; gale W.: 15th, three on marsh; wind fresh S.W.

Killybegs.-January 5th, some at 10 A.M. going N.; frosty: up to 11th, continuous flocks. March 7th to 13th, "Golden Plover very plentiful; as also Lapwing, Fieldfares, Starling, Thrushes, Blackbirds, and Skylarks-owing to the heavy frost. No Wild Geese observed, though they usually come in frosty weather." April 4th, twenty-two Golden Plover going S.: 26th to May 3rd, large flocks near station.

Arran Island, S.-September 15th, two going S.E.; gale N.W.; one shot; very scarce.

Green Plover (Vanellus vulgaris, Bechst.).

Spit Bank, Queenstown.-March 21st, two "Lapwing Plover" going N.E.

IIine Head.-March 10th, ten going E. March 14th, six going W. July 20th, one at 4 A.M. going E.: 27th, one going W. 
Hook Tower. - October 17th, large flocks Plover; wind moderate W.

Barrels Rock Light-ship.-February 26th, two going E.; hazy : 27th, flocks of Plover, 4 P.M. to 5 P.M., going N.W.; wind light S.E., gloomy: 28th, one large flock of Plover at 5 P.M. going N.W.; wind moderate W. March 2nd, small flock at 10.30 A.M. going N.W.

Blackwater Bank Light-ship.-January 16th, flock passed over ship at 10 P.M. going N. March 18th, one "Lapwing" at 3 A.M. about light; wind fresh N.E. December 24th, flock passed over ship going $\mathrm{N}$. at midnight; wind light S.E., gloomy.

Arklow South Light-ship. - February 20th, one "Plover" going N.W. April 10th, flock Green Plover at 8.40 P.Mr. about light; wind light S.E. May 2nd, a few Plover from 10 P.M. to midnight about lantern ; wind light W., clear. December 25th, four flocks Green Plover going S.W.

Howth Baily. - November 25th, great numbers of Green Plover flying in rays of light. Flocks through the fields in December.

Drogheda.-December 21st, three "Lapwing Plover" at 2 P.M. going S.S.W.; fog and frost: 24th, six "Lapwing" at noon going S.W.

Copeland (Mew) Island.-September 6th, large flocks all day, remaining; wind strong W., clear: 28th, a flock remain. October 5th, one: 13 th, twelve all day; gale S.E. November 5th, 19th, 21st, 24th, and 26th, a flock of Green Plover noted about island: 30th, large flocks all day. December 5th, flocks on isle: 7th, Lapwing all day : 21st, flocks of Green and Golden Plover on island all day; frosty.

Maidens South.-March 19th, fifteen going N. April 1st, two going $\mathrm{S}$.

Innishtrahull.-February 25th, 26th, and 27th, two on island. June 18th, one at 11 A.M.

Tory Island.-November 4th, rush of Green Plover and other birds (see under Skylark) from 12.10 A.x. to daylight. December 22nd, three going S.E.; first seen.

Rathlin O'Birne.-March 23rd, two on island; remained a month. September 4th and October 13th, two all day: 22nd, one. Killyberg.-MIarch 7 th to 13 th, very plentiful (see under Golden Plover). May 4th, hatching on adjacent moor and hill. 
Oyster Island, S. - [March 10th, Wing of Green Plover received.]

Arran Island, S.-August 20th, five going N.E; gale S.W.; first observed this year.

Tearaght.-January 2nd, one at noon; wind light S.W.

Turnstone (Strepsilas interpres, Linn.).

Hook Tower:-November 23rd, one shot. December 11th, one shot-[Received in flesh]: 31st, one killed striking; wind moderate S.W. [Leg and wing received].

Tuskar.-June 12th, "we had a flock (six) of Turnstones, beautifully marked, feeding among the Purple Sandpipers during the latter end of May."

Innishtrahull.-August 8th, nine at 4 P.I. on island; wind fresh S.W. "Several Turnstones on island all winter."

\section{Oyster-Catcher (Homatopus ostralegus, Linn.).}

Hook Tower.-October 18th, several Seapies; wind moderate W.

Tuskar:-April 17th, twelve on rock.

Drogheda.-September 28th, numbers all day feeding on strand. "Seapies are here in large numbers all the year round, and to be seen every day."

Copeland (Mew) Island. - March 5th, flocks, apparently remaining on island to breed. April 26th, May 24th, and September 6th, large flocks of Seapies remaining: 24 th, twenty all day: 28th, forty. October 5th, 14th, and 17th, flocks. November 5th and 11th, some: 21st and 26th, flocks: 30 th, large flocks. December 7th, large flocks of sea birds on island all day, including Seapies: 8th, a flock: 13th, about thirty: 31st, large flocks.

Innishtrahull._"Seapie all the summer; build on island." "Seapie on island all winter."

Rathlin O'Birne. - January 28th, flock during season. September 2nd, some on island all day. November 10th, twenty all day.

Killybegs.-March 28th, are natives of the place (see under Cormorant).

Blackrock, Mayo.-May 10th, three all day about rock. 
Slyne Head, S.-Always round island.

Arran Island, S.-October 29th, twenty-eight on rocks; three shot by keeper.

Tearaght.-March 12th, a pair; breed on island.

Skelligs.-March 8th, two on rock.

Grey Phalarope (Phalaropus fulicarius, Linn.).

Barrels Rock Light-ship.-October 9th, two, apparently Sea Larks, drifting. [Possibly Grey Phalaropes.-R. M. B.]

Rathiin O'Birne.-October 12th, three Phalaropes at 1 P.Mr. on water; "never saw birds of the kind before; shot two;" gale S. [Two Grey Phalaropes received in flesh]: 29th, nine at 4 P.M. on water; wind light S.E.

Killybegs. - October 22nd, four ; "rare in this country." [Four received in flesh.]

Slyne Head, S.-October 6th, one shot swimming on small pool on island; gale S.W.; "never noticed any like it before" -[Received in flesh]: 11th, another seen.

Woodcock (Scolopax musticula, Linn.).

Mine Head.-January 21st, one going N.

Hook Tower.-October 27th, one killed striking at 12.50 A.M. coming from S.E.; wind strong E., hazy. December 24th, one killed striking; wind light N.E. [Leg and wing received.]

Blackwater Bank Light-ship.-[January 1st, Leg and wing of Woodcock received, killed striking.]

Copeland (Mew) Island.-May 12th, "one hundred and fifty birds found dead in eave gutter of dome of lantern; Blackbirds, Thrushes, Larks, Starlings, and one Woodcock. These birds must have been killed during the spring by striking against the dome and cowl of lantern."

Innishtrahull.-November 4th, one on island; first arrival.

Rathlin O'Birne.-February 22nd, one killed. October 23rd, one on island.

Tearaght.-November 14th, one on islạnd.

Common Snipe (Gallinago colestis, Frenzel) and JACK SNipe (G. gallinula, Linn.).

Fostnet.-September 9th, one Jack Snipe killed striking at midnight; wind light S., fog. 
Hook Tower:-November 25th, one Snipe at 10 A.M.; wind fresh N.W. December 24th, one Snipe killed striking. [Leg and wing received.]

Barrels Rock Light-ship.-August 14th, one Snipe (apparently) at 6 A.M. going N.; wind fresh W.

Lacifer Shoals Light-ship.-September 13th, one Snipe at 10.30 P.M. lighted, and left for the shore; hazy.

Arklow North Light-ship.-April 25th, one Snipe about ship; went N.W. at 7 A.M. ; wind light S.E., hazy.

South Rock Light-ship.-A pril 12th, Jack Snipe killed striking. [Received in flesh.]

Copeland (Mew) Island.-April 26th, a few Snipe remaining.

Innishtrahull.-December 7th, four Jack Snipe on island; just arrived; wind light S.W.: 31st, two Snipe on island.

Tory Island.-October 31st, one Snipe; first seen; wind light S.E. November 7th, one in field: 8th, one going N.

Rathlin O'Birne.-February 24th, Snipe on island. August 23rd, three do. on island. September 18th, one do. killed striking glass. October 13th, one on marsh: 15th, eight Snipe on island; wind fresh E.: 28th, two.

Slyne Head, S.-January 1st, three Snipe on island. March 5 th, three. November 28 th, three all day; gale W. Snipe on island every day during December.

Arran Island, S.-November 30th, one Jack Snipe; first seen this year.

Tearaght.-January 23rd, one Jack Snipe. February 6th one do. December 15th to 31st, one Snipe on island (see under Blackbird).

\section{DUNLiN (Tringa alpina, Linn.).}

Arklow North Light-ship.-April 19th, "Sand Snipe" at 10 A.M. on deck ; caught and died ; wind light S.E., hazy. [Dunlin received in flesh.]

PURPle SANDPIPER (Tringa striata, Linn.).

Tuskar.-Purple Sandpiper during the latter end of May.

$$
\text { "SAND LARKs." }
$$

Fastnet.-July 30th, one "Sand Lark" going E.

Barrels Rock Light-ship.-October 16th, about twenty going N.W.; gale W. 
Lucifer Shoals Light-ship.-April 18th, one going N.W.; left for the shore after resting.

Droghecla. - December 18th, large flocks on strand: 19th, Sand Larks and "Sand Plover" in numbers on strand; frosty. "These birds are here in large nnmbers from December to March."

Copeland (Mew) Island.-March 4th and 5th, flocks all day on island. November 13th and 24th, Sand Larks.

Rathlin O'Birne.-February 15th, they breed here. September 24 th, some on island all day; gale W. November Sth, numbers all day on island; gale S.W.

Killybegs.-March 28th, Sand Larks and "Sand Plover"; natives of the place (see under Cormorant).

Blackrock, Mayo.-March 29th, several Sand Larks or Rock Larks on rock.

Slyne Head, S._- "Strand Larks" always round island.

Arran Island, N.-March, "during this month Sand Larks are common here."

Aman Island, S.-September 2nd, twenty-three "Strand Larks" in lighthouse park; strong gale S.W. (Leave shore in stormy weather.)

\section{Redshank (Totanus calidris, Linn.).}

Hook Tower.-January 15th, one Redshank shot; "very hard to get near; saw only two of this kind."

Innishtrahull.-Some on island all winter.

Rathlin O'Birne.-March 30th, five on island during season.

Arran Island, S.-October 19th, six; strong gale S.W.; very plentiful about shore.

\section{CURLEW (Numenius arquata, Linn.).}

Fastnet. - July 28th, three going N.W. September 7th, several at 9 P.M. hovering round light; wind fresh E, fog: 9 th, several at 11 P.M.; wind light S.E., fog.

Spit Bank, Qucenstown.-February 23rd, five going S.W. March 1st, three going S.W.: 17th, three going S.W.; gale E.: 20th, numbers heard at 10 P.M. going S.W.; "seemed from the noise they made to be very numerous and flying high": 27 th, three going N. April 10th, numbers feeding on bank. July 8th, some on bank: 23rd, eight do. 
Hook Tower.-September 9th, several Curlew all day.

Barrels Rock Light-ship.-April 29th, four at 10 A.M. going N. July 1st, two at 3 P.M. going S.

Blackwater Bank Light-ship.-March 14th, three about light: 23rd, ten at 6 A.M. going N. April 1st, flock at 11 P.M. about light: 10 th, flock at 10 P.M. about light: 12 th, flock at 9 P.M. about light: 17 th, flock at 7 P.M. going N.E.

Arklow South Light-ship.-February 9th, several about light at 8 P.M. March 21st, several at 8 P.M.; wind light N.E. April 11th, several; two disabled and fell overboard. July 26th, several.

Arklow North Light-ship. - January 7th, flock flying low, going N.W. March 6th, flock at 9 P.I. going N.E., high; "sure sign of rainy weather"; wind light N.W., cloudy. May 12th, flock at 9 P.M. going N.W., flying high; wind light N.: 13th, flock going N.W. July 23rd, large flock at 6 P.M. flying over ship, going N.W. August 3rd and 20th, large flocks. October 31st, large flock at 8 P.M.

Howth Baily.-November 23rd, several flying in rays of light at 6 P.M. December 5th, large flock near station. Flocks in fields during December.

Rockabill.-May 20th, fifteen going N.W.: 26th, two going W. June 3rd, five going $\mathrm{S}$.

Drogheda.-December, "Curlew about here during the winter months, but not in great numbers."

Copeland (Mew) Island.-May 24th, several on island. November 5th, some : $17 \mathrm{th}$, immense flocks; wind light N.W., clear : $26 \mathrm{th}$, flocks. December $7 \mathrm{th}$, large flocks of sea birds on island all day, including Curlew; gale N.: 31st, large flocks on island.

Maidens South.-March 23rd, two at 8 A.M. going W. June 18th, three going N.: 24th, four going S. July 7th, four going S.W. September 4th, three going S.W.

Innishtrahull.-July 22nd, three on island. A few Curlew during November.

Dunree Head.-December 7th, twenty at 10 A.M. going E.

Tory Island.-November 5th, twenty-one in field: 7th, forty to sixty going S.W., flying high: 8th, flocks on island, and some going S.W.: 11th and 12th, flocks on island: 13 th, flocks, with Starlings, going N.; coming from shore: 21st, "Curlew always on island": 26th, flock at noon going S.W. December 
5th, three going S.W.: 17th, about a hundred going S.E.; these birds have been scarce lately on island.

Rathlin O'Birne.-March 27th and September 6th, flocks on island. October 23rd, Curlew on island at 4 P.M. November 13 th, sixteen all day.

Killybegs.-March 28th, Curlew are natives of the place (see under Cormorant).

Blackrock, Mayo.-March 29th to April 1st, one about rock: 14th, one: 22nd, one. August 16th, sixteen going S.W.: 18th, four going S.W.: 27th, one about rock. September $12 \mathrm{th}$, some passed light at night, 9.30 P.M., going S.; foggy : 20th, three all day. October 1 st to 15 th, three about rock; gales every day.

Slyne Head, S.-February 12th, two on island: 15th, ten going S.E. March 5th, 22nd, and 28th, a few noted. April 1st, 7th, 12th, 16th, May 29th, June 23rd, July 2nd, August, September 13th, October 7th, 8th, and November 16th, a few noted; from one to ten.

Arran Island, N.- "A few on island, which have come in from Connemara."

Arran Island, S. - August 15th, eighteen feeding (very plentiful).

Tearaght.-January 3rd, two all day: 6th, one. March 14th, one.

Skelligs.-July 28th, five going E.: 29th, two going E.

\section{Whimbrel (Numenius phceopus, Linn.).}

Fastnet.-May 13th, nine at noon going N.E.

Spit Bank, Quecnstown.-March 17th, one going N.E. " 1 consider it strange to see Whimbrel so early; it was flying high;" three Curlew also noted. April 28th, number heard at 11 P.M., flying high, going N.E. May Sth, a large flock at 5 P.M. going N.; gale N.E.: 16th, seventeen at 4 P.M., feeding: $22 \mathrm{nd}$, two going N.E.

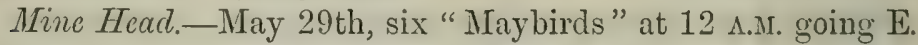

Blackwater Bank Light-ship.-May 2nd, flock at 6 P.M. going N.W.

Arklow South Light-ship. - May 20th, twenty-seven going N.E.: 26th, several at $S$ r.M. going N.W.; wind light N.WY.

Maidens South.-May 11th, two Curlew or Maybirds going 
N.: 19th, two going W. July 2nd, four going S.W.: 14th, two on rock; one shot. [No specimen received; possibly Curlew, as date unusual.-R. M. B.]

Rathlin O'Birne-May 30th, numbers at 3 P.M. on island; fresh breeze S.

Killybegs.-May 24th, flocks observed every day during the month up to this date: 27 th, two going N.W., flying very high : 29th, one going N.W., flying very high.

Blackrock, Mayo.-September 6th, two about rock.

Slyne Head, S.-May 29th, two on island.

\section{Arctic Tern (Sterna macrura, Naum.).}

Tuskar.-June 12th, "we had a great number of Arctic Terns here during the latter end of May, but they have all left now."

Rathlin O'Birne.-May 23rd, numbers of Terns at 6 A.M.; strong breeze S. They breed here. October 12th, "the Terns breed here in July and are gone about the 1st of August; a flock of about two hundred visited here on the 10th, which is unusual, so I forward legs and wings-[Leg and wing of Arctic Tern received]. The Sandwich Tern, with black feet and beak, do not breed here."

\section{Terns.}

Spit Bank, Queenstown.-April 4th, several "Sea Mews" at 11 P.Mr. going E. July 10th, three "Sea Mews" about lighthouse.

Hook Tower.-September 9th, Terns striking glass in immense numbers for the past two nights; dense fog, wind moderate to strong S.S.E. to S.S.W. and S.; none killed.

Copeland (Mew) Island.-May 12th, several "Mews" at 4 A.M. remaining; wind S.E., clear: 18th, large flocks have arrived on island to breed. June 11th, large numbers. No "Mew's" eggs found up to this date. July 4th, large quantities of eggs are now on the island, and the birds are hatching. Keepers do not allow any one to take the eggs, by order of the Commissioners of Irish Lights. September 6th, "Mews" still on island; have hatched and reared a large number of young birds this season; left island about the $30 \mathrm{th}$.

Innishtrahull.-May 20th, numbers of Sea Mew hovering about; "they build on island." 
Slyne Head, S.-May, "Perrs building on adjacent island." [Probably Terns.]

BlaCK-HEAdED GULL (Larus ridibundus, Linn.).

Tearaght.-January 1st, one small Gull picked up dying on the road at 11 A.M. ; wind light E., clear and frosty; "the day before was thick with snow showers in the evening"-[Blackheaded Gull received in flesh]; "another, apparently of the same species, was observed on rocks under dwellings, it had red legs": 3rd, "one small Gull at 10 A.M."

ICELAND Gult (Lanus leucopterus, Faber).

Killybegs.-December 16th, Iceland Gull shot. [Received in flesh.]

\section{"GULLS."}

Spit Bank, Queenstown.-January 30th, numbers of Common Gulls at noon fishing; wind light S.W. February 25th, numbers of various species about harbour. March 13th, numbers of Common Gulls all day: 17th, one Iceland Gull at noon, hovering; gale E., gloomy. "This bird had beautiful creám-coloured plumage." April 6th, about fifty Common and Kittiwake Gulls at noon feeding close to lighthouse: 8th, several Common Gulls: 10th, numbers of Gulls feeding. May 4th, fourteen large Grey Gulls at 8 P.M. going S.W., "flying high and all in a cluster": 10th, about a hundred Herring Gulls. July 25th, numbers of Common Gulls feeding. August 4th, five young Kittiwakes (last year's birds) fishing.

Hook Tower:-November 16th, Gulls of several kinds for several days: 23rd, one Kittiwake Gull at 10 P.м. killed striking; wind light N.W., overcast, gloomy. December 16th, one "Black-headed Gull"; strong breeze N.E.

Barrels Rock Light-ship.-February 6th, "these birds are continually about ship, and were very tame during the cold weather; they would alight on rail, and could be easily caught." July 14th, Gulls, Murs, and Gannets drifting with tide, feeding on fish, probably herring fry. August 21st, seven Blackheaded Gulls at 4 P.M. going E.; "a small kind." October 17th, about two hundred large and small Gulls during day, drifting; apparently feeding on fry: 19 th and 20 th, large flocks drifting: 23rd, two hundred do. November 6th, Gulls numerous: 14th, 
about a hundred: 28 th, do. December 7 th, do. : 30th, a lot of small Gulls all day about ship.

Tuskar:-April 14th, Gulls all day round rock.

Blackwater Bank Light-ship.-October 25th, flock of Gulls at 11 A.M.: 27 th and 30 th, several flocks playing a short distance from ship. "Birds remaining about ship for the night, leave for the Irish land at daylight." "Common Gull seen almost daily during November."

Arklow South Light-ship.-February, flocks. April, a few daily. May 27th, one Skua Gull going N.E. "Lots of Gulls passing and near ship during this month." June, July, August, and September, Gulls and a few Skua Gulls passing ship daily.

Hovth Baily.-Sea Gulls always here; they feed on the refuse which the barge "Eblana" brings from Dublin and discharges in the bay. The "Eblana" makes three or four trips a week. The Sea Gulls seem to be on the look-out for her, because as soon as she shows round the Baily Point, they come on in hundreds to meet her. They may be seen hurrying on two miles off, a proof of the distance they can see objects. They accompany the barge to the discharging ground, where they remain feeding on the refuse.

Rockibill.-June 26th, twelve Sea Gulls building on small rock. [Kittiwakes.-R. M. B.]

Dunree Head.-November 4th, Gulls and Puffins in great numbers lying on water fishing; wind light $\mathrm{N}$.

Tory Island.-December 6th, large flocks of Gulls.

Rathlin O'Binene-April 3rd, all the different species of Gulls remain here during season. November 14th, thirteen "Royal Gulls" all day: 29th, numbers of Kittiwakes all day after fry.

Blackrock, Mayo._March 23rd, a number of "Didleen Gulls" came on rock to build for first time this year; Didleens, odd large Grey Gulls, large Didleens, and two Royal Gulls around rock every day this month. June, "no large Gulls on this rock; they are always about it." August, Gulls every day. September 12th, a great number of Herring Gulls all day. October, Gulls here every day, especially two Royal and three large "Terrin" Gulls: 10th, "two small Gulls, smaller than a Didleen, black on back. I never saw birds like them before; they were among the Didleens." [Could these have been Sooty Terns?-R. M. B.] 
Slyne Head, S.-Gulls always round island.

Tearaght.-March 22nd, Kittiwakes at 5 A.M.; wind moderate N.W.; first landed; left about August 12th. October 29th, a hundred Kittiwakes. November 5th, five hundred Herring Gulls and Kittiwakes all day on water: 6th, two cream-coloured Gulls at 2 P.M. on water; wind light E. "These Gulls seem rare."

Skelligs.-October 14th, numbers of Kittiwakes and Shearwaters (see under Manx Shearwater).

\section{Manx Shearwater (Puffinus anglorum, Temminck).}

Hook Tower.-August 22nd, one caught at 11 P.M. ; gale S.E.

Barrels Rock Light-ship.-April 12th, some (first seen) all day going N.; wind moderate S.E. "Shearwaters and Parrots daily flying and swimming past in various directions after 12th of this month." October Sth, about a hundred and fifty "Mackerel Cocks" during day going E.: 11th, about fifty do. November 8th, about twenty Manx Shearwaters, apparently feeding.

Blachwater Bante Light-ship.-April 11th, one "Mackerel Cock" at 10 A.M. going N.E.

Arklow South Light-ship.-Some daily passing ship in June, July, August, and September.

Howth Baily.-March 28th, first heard from cliffs N.E. of station. April 2nd and 9th, heard again: 11th, about a dozen flying W. July 6th, a dozen. August 2nd, one found partly stunned on balcony; had probably struck lantern: 5th, one caught on balcony-[Received in flesh]. "The noise these birds made in the cliffs during the end of March and April was very attractive; every dark, calm night their strange loud chorus was kept up. We searched the bank in the daytime in which we supposed them to be in the nighttime, but could find no trace of them. We could see them in the afternoons both flying and diving along the coast."

Skelligs.-August 11th, two and some Storm Petrels stunned striking (see under Storm Petrel). October 14th, upwards of three or four hundred about rock. They were following a lot of Kittiwakes, and all seemed to be feeding on sprat. The Shearwater disappeared on the 26th, all but a few. 


\section{Storir Petrel (Procellaria pelagica, Linn.).}

Hook Tower.-October 13th, two at 10.30 A.M.; gale S.E.: 15 th and 16th, great numbers all day; gale S.E. November 14th, one picked up-[Wing received]: 17th, another do. [Wing received.]

Barrels Rock Light-ship.-August 8th, two to four near ship; wind fresh S.W. October 13th, 14th, and 15th, three to sixteen near ship; strong gale each day.

Thshar.-[November 6th, one received in flesh, killed striking.]

Blackwater Bank Light-ship. - October 22nd, three about ship; wind light: 23rd, two; wind light, but a gale on 26 th. November 5th, flock from 8 P.M. to 4 A.M. on deck; wind light, gloomy; one killed. [Leg and wing received.]

Arklow South Light-ship.-One or two seen about ship on July 31st, August 3rd, 11th, 14th, and 18th, September 27th and 28th, October 12th, 13th, and 14th: 16th, several during day about ship; whole gale S.W.: 18th, several do.

Rathlin O'Birne.-June 10th, they breed here.

Tearaght.-May 4th, one (first seen this year): 20th, one. June 6th, Petrels all night; wind light S.E.; none killed. "I did not see the Forked-tailed Petrel while on the Tearaght.W. H. JAMES."

Sliclligs.-August 11th, six and two Shearwaters at 12.30 A.M., strong breeze W., rain, mist; stunned, recovered after a short time; large numbers of these breed on rock-[Leg and wing of Storm Petrel received]. "In reply to query about Petrels, I did not notice any Petrel about the rock during September, but on October 14th I saw about two hundred of them in small flocks, about twenty to thirty in each flock. They were a little larger than Storm Petrel, and of a different colour-back, black; breast, light grey, nearly white; under wings, light grey, but darker than breast; very restless, not remaining more than five minutes on water, then flying a few yards. They flew very fast, and kept very close together; each flock kept separate; I did not notice any of them diving They remained until the 18 th; weather very rough; wind $\mathrm{S}$. to N.W.-Robert J. Phelan." [Possibly Fork-tailed Petrels.

$-\mathrm{R}, \mathrm{M} . \mathrm{B}$.] 
Razorbill (Alca torda, Linn.) and GuILlemot (Uria troile, Linn.).

Spit Bank, Queenstown.-January 30th, three Razorbills at noon fishing; wind light S.W., clear. March 3rd, one do. April 19th, eleven: 20th, numbers. May 1st, numbers of Guillemots all day. July 23rd, Razorbill and her young one seen.

Barrels Rock Light-ship.-February 11th, large flocks of "Murs" all day: 12th, large flocks do.: 21st, flocks do. March 4th, "Murs and Gannets" all day. July 20th, flocks of "Murs," ten to twelve, going E.: 29th, flocks of from twenty to thirty do. at sunset going E. August 4th, flocks of from fifteen to twenty do. after sunset going E.: 6th, flocks of from twenty-five to thirty do. after sunset going E. : 17th, 18th, and 19th, large flocks all day drifting; wind fresh W., clear. October 19th, 23rd, and 28th, flocks of "Murs" all day drifting past. November"6th, Gulls, "Murs," and Gannets all day, apparently after small fish. December 15th, a few "Murs" going $\mathrm{E}$.

Arklow South Light-ship.-February, great flocks' of Gannet, Puffin, Razorbill, Herring Gull, and small Common Gull during this month.

Howth Baily.-May 11th, Guillemots, Razorbills, old and young, diving. October 2nd, young Razorbills (of this year) heard on the water. "At this time of year I heard these birds round the coast everywhere I have been.-EDWard M'CARron." November 19th, "young" Razorbills, not of this year, observed frequently diving close to the station. [Probably old birds which have assumed winter plumage.-R. M. B.]

Killybegs.-April 3rd, one Razorbill found uninjured in lighthouse yard this morning; it was not heard to strike.

Blackrock, Mayo.-April 6th, Razorbills and Guillemots came on rock for building; the first this year. June, breeding. August 9th, all Razorbills and Guillemots gone.

Tearaght.-February 2nd, Guillemots at 6 A.M. ; first landed ; wind moderate S.W.: 27th, Razorbills at 6 A.M. ; first landed. Razorbills, with their young, leaving the island on July Sth; all left about August 12th; also Puffins, Guillemots, and Kittiwakes.

Skelligs.-January 7th, large flocks of Guillemots on rock at 
7 A.M.; strong breeze S.E., gloomy; "visiting daily, and remaining on rock for a few hours." February 26th, large numbers Razorbills on rock at 6.30 A.M. ; visiting daily for a few hours.

\section{Puffin (Fratercula arctica, Linn.).}

Barrels Rock Light-ship.-April 6th, three "Sea Parrots"; first seen this season: 7th, several during day: "Parrots and Shearwaters daily swimming and flying past in various directions after 12th of month": 21st, small flocks of "Parrots" during day.

Tuskar.-April 14th, all day round rock.

Blackwater. Bank Light-ship.-During April, several flocks going N.E. November, seen almost daily.

Arklow South Light-ship.-February, flocks. April, daily about ship. May, "lots of Puffins passing and near ship during this month." June, July, August, and September, passing ship daily.

Dunree Head.-November 4th, numbers on water.

Rathtin O'Birne.-August 21st, flocks all day going N.E.; wind fresh S.W.

Blackrock, Mayo.-April 14th, came to rock for first time. June, "Puffins, Razorbills, Guillemots, Didleens, Cormorants, and Titlarks breeding about rock since they came." August, Puffins went away from 2nd to 8th.

Arran Istand, N.-March, "during this month Puffins are common here."

Tearaght.-March 28th, Puffins on water: 31st, first landed at 4.30 P.M.; left about August 12th.

Black Guillemot (Uria grylle, Linn.).

Tearaght.-February 23rd, one small Black Diver, with white patches on wings, close to rock. [Probably Black Guillemot.]

\section{"Great Northern Diver."}

Spit Bank, Qucenstown.-One or two seen January 12th, 18th, 28th, February 26th, March 3rd and 22nd.

Howth Baily.-April 18th, one Northern Diver; and on one or two occasions afterwards, diving.

Drogheda.-December 25th, several "Small Northern Divers" all day, fishing in river: 31st, three Great Northern Divers all day.

Tearaght.-March 5th, two Northern Divers all day. 
Cormorant (Phalacrocorax carbo, Linn.) and

Shag ( $P$. graculus, Linn.).

Spit Ban7, Queenstown.-One or two Cormorants noted January 28th, April 29th, July 8th, and August 4th. February 3rd, four "Green Cormorants." March 9th, three "Brown Cormorants."

Barrels Rock Light-ship.-One or two Cormorants noted on February 19th, May 3rd, August 10th, November 20th, and December 6th and 7th.

Blackwater Bank Light-ship.-October 30th, flock of Cormorants going N.E.

Arklow South Light-ship.-November 21st, two Green Cormorants about ship: 27th, one Black Cormorant going S.W.

Howth Baily. - April 2nd, a few Cormorants always to be seen diving, except during the breeding season. During the winter and early spring flocks of these birds leave Lambay and Ireland's Eye every morning and cross Dublin Bay torwards the Kingstown and Dalkey coasts, and return every evening. I never saw Cormorants of such a large size as these; they do not breed on Howth.

Drogheda. - December 25th, thrèe Cormorants fishing in river: 31 st, six do.

Copeland (Mew) Island.-May 19th and 20th, some Cormorants round island. October 17 th, about eight going S. WV.

Dunree Head.-January 22nd, twenty-one Cormorants going N. February 24th, sixteen going N.IW. June 21st, eight going S.E. July 8th, ten going N.: 23rd, thirty-one going N.W.; the greatest number ever seen together. August 25th, twentysix going N. September 18th, fifteen going N.W.: 29tb, twenty-one going N.E.

Rathlin O'Birne. - January 19th, twenty Cormorants on island during season; four with white spots under or behind the wings. November 19th, seven'all day.

Killybegs.-March 28th, "Cormorants, Seapie, Curlew, Wild Duck, Seagulls, Sand Larks, Sand Plover, Lapwing, Titlarks, Sparrows, Thrushes, Blackbirds, Starlings, and Linnets are natives of the place, and may be seen nearly every day."

Blackirock, MIayo.-March, Cormorants always here. April, round rock all month. June, breeding about rock. August, seen daily. October, always here. 
Slyne Head, S.-Always round island.

Skelligs.-March 23rd, one "Cormorant" (white head and neck), "first of this description I have ever seen," at 11 A.M. on rock.

Gannet (Sula bassana, Linn.).

Fastnet.-July 17th, large flocks going N.W.

Barrels Rock Light-ship.-February 6th, two going N.E.: 18th, 27th, 28th, and March 2nd, small flocks all day going W. April 18th, seven going W.: 20th, small flocks during day going W. : 25th, seven going W.: 28th, small flocks during day going W. Also noted May 1st and June 12th, going W.: 13th and 14th, flocks going W. (about half of them young birds of a dark colour). July 8th, flocks, white and dark grey, during day: 18th, some going E., dark grey and white: 20 th, four going W., white: 26th, four going W., three white, one dark: 27th, nine going E., eight white, one dark. August 2nd and 13th, two or three going W. October 9 th and 12th, a few, white and grey, going W.: 20th, Gannets, Gulls, and Murs drifting during day: 23rd, about ten white and grey. November 3rd and 6th, numerous Gannets. December 7th and 11th, a few, two "black and white": 14th, several, "black and white": 18th, large flock going $\mathrm{S}$.

Tuskar:-April 14th, some all day round rock.

Lucifer Shoals Light-ship.-February 17th, 18th, and 19th, several flocks of Gannet going N.E. at noon, "in twelves and tens each flock."

Blackwater Bank Light-ship.-January 2nd, one flock going N.E.: 18th, six Gannets going N.E. March 15th, Gannets in flocks of four and six going N.E.: 16th and 21st, Gannet going N.E. "During April several flocks of Gannet passed almost daily going N.E." May 5th, flocks going N.E. September 15th, five going N.E. October 20th, six going N.E. : 21st, three going N.E.

Arklow South Light-ship.-February, "great flocks during this month." April, "great flocks going N.": 10th, two at night about light, one disabled and fell overboard. May, "lots of Gannet passing." June, July, August, and September, passing daily.

Arklow North Light-ship. - February 23rd, several large flocks going N.E. : 24th and 25th, several large flocks. April 16th, 17th, 19th, 25th, and 26th, several going N.E. May 1st, flock going N.E. : 4th, several flocks going N.E. 
Copeland (Mew) Island.-April 4th and 6th, several fishing. May $12 \mathrm{th}, 16 \mathrm{th}, 19 \mathrm{th}$, and $20 \mathrm{th}$, several round island. June $11 \mathrm{th}$, flocks every day during month up to this date. December 4th, a few fishing around island.

Innishtrahull.-February 25th, three fishing.

Rathlin O'Birne.-April 3rd, numbers during season. August 29th, six going $\mathrm{S}$.

Killybegs.-February 12th, one at noon fishing; first observed this year. March 28th, numbers fishing round Head.

Blackrock, Mayo.-March 19th, continual flocks going N. for the last fortnight and all the month, and fishing round rock every day. April, fishing round rock all month: 27th, two flocks (seventeen and eighteen) at 3 P.M. going S.W. September 12 th, going S. all day at intervals. October 1 st to 15 th, Gannets going S.E. every day; gales.

Arran Island, N.-March, common here during month.

Tearaght.-February 6th, eighteen going S.W. to N.W. "Some going daily to the N."

Skelligs.-March 3rd, flocks round rock.

Bull Rock.-June 2nd, "there are from a hundred to a hundred and ten pairs (certainly a hundred pairs) building this year on Bull Rock."

\section{Heron (Ardea cinerea, Linn.).}

Spit Bank, Queenstown.-One to four noted March 12th, April Sth and 10th, May 10th, July 24th and 25th, and ten on July 8th.

Howth Baily.-August 15th, one going N.E.

Copeland (Mew) Island.-One to three noted September 24th and 28th, October 31st, November 19th, 29th, and 30th, December 13th and 24th. A few on November 5th, 13th, and 26th. Several on October 5th, 14th, and 22 nd.

Tory Island--One or two noted November 11th, 13th, 21st, and 26th. December 17th, two going E.

Rathlin O'Birne.-August 11th, one "Stork" at 10 A.Mr. on island; wind light S.W.

Slyne Head, S.-January 1st, one "Crane" on island: 16th, and March 21st, one do. going S.E. : 30th, one on island. April 14th and September 3rd, one going S.E.

Arran Island, S.-November 4th, two "Cranes" fishing in pools near shore. 
Tearaght.-May 18th, "one Heron (Crane)" going S.E. Skelligs.-July 26th, three Herons going towards mainland.

\section{"Geese."}

IFine Head.-April 10th, six "Wild Geese" going E.

Barrels Rock Light-ship.-December 22nd, one Wild Goose going $\mathrm{S}$.

Arklow South Light-ship.-December 19th, one flock Wild Geese going N.W.

Howth Baily.-November 16th, about thirty "Barnacle" going N.E.: 21st, a flock going N.E.

South Rock Light-ship._March 22nd, three Geese going S.E.

Maidens South.-March 8th, three Barnacle going W. April 9th, heard a number of Barnacle passing lantern at 11 P.M. October 14th and 23rd, two to three do. going S. December 19th, ten going W.: 21st, two at 5.30 P.M. pitched on dome of lantern; remained for about an hour and flew S.

Innishtrahull.-February 16th, seven Barnacle on island. March 6th, three Brent Geese on island: 7th, four do. October 30th, seven Barnacle Geese going S.W.; first arrival here. December 14th, a flock of do. flying S.W.: 24th, flock do. going $\mathrm{S}$.

Tory Island.-October 28th, seven Barnacle came from $\mathrm{N}$. and lit on island. November 6th, five do. going S.W.; flying high: 15th, four do. going N.W.: 16th, flocks do. from 11 P.M. to 2 A.M. going S.E; full moon, eclipse, none struck: 17th, seven going S.E.: 23rd, Barnacle and Duck heard at lake close to lighthouse at $12.30 \mathrm{~A}, \mathrm{M}$.

Rathlin O'Bime.-January 12th, six Barnacle at noon. "Very few this year." September 21st, eight do. going W. October 1st, flocks do. going S.: 21st, some do. going S.: 22nd, thirteen on marsh: 23rd, two "Geese" at 1 P.M. on marsh. December 7 th, four "Land Barnacle" on marsh: 12th, twelve "Geese" going W.; gale S.E., snow.

Killybegs.-March 7th to 13th, "no Wild Geese observed, though they usually come in frosty weather."

Slyne Head, S.-October 8th, twenty-four Barnacle going S.E; f first seen this year: 17th, large flock do. all day flying round islands. December, Barnacle seen off adjacent islands almost daily. 
Arran Island, N.-February or March, "a few Wild Geese were seen going in the direction of Clare."

\section{Common Scoter (Edemia nigra, Linn.).}

Hook Tower.-October 5th, "Black Scoter" killed striking, and picked up at foot of tower at 12.30 P.M.; gale S. [Common Scoter received in fiesh.]

Blachwater Bank Light-ship.-April 15th, flock of Wild Duck at 11 P.M. going N.E.; wind light N.W., clear; three killed striking. [Legs and wings of two Common Scoters, male and female, received.]

Oyster Island, S.-[March 10th, wing of Common Scoter received.]

Red-breasted Merganser (Mergus serrator, Linn.).

Killybegs.-[December 22nd, female Merganser received in flesh. Probably shot.]

\section{"DucKs."}

Spit Bank, Queenstown.-February 14th, forty "large Duck" on water: 17th, three Teal going- N.E.: 27th, seven Duck going S.W. March 3rd, five Duck going N.E.

Barrels Rock Light-ship.-February 7th, one Wild Duck from noon to sunset, swimming. "This bird had a brown head and breast, wings tipped with the same colour, and a grey back and wings. The head was large in proportion to the rest of the body."

Tuskar.-April 19th, flock of Wild Duck going S.E. November 28th, twelve Duck going W.; gale N.E.

Blackwater Bank Light-ship.-November 2nd, one Wild Duck at 11 A.M. about ship.

Arklow South Light-ship.-September 21st, one Wild Duck going W.; wind fresh N. November 20th, one do. going N.E. December 13th, one do. going S.W.

Droghecla.-September 27th, a large flock of Black Duck on water, about three hundred yards from shore. October 15th, "heard the cry of Wigeon passing WV." November 1st, thirteen large Duck inside of the bar: 26th and 27th, "Golden-headed Wigeon" in large flocks going W.; frosty,-_"These birds frequent the feeding-beds every night during the winter 
months; the beds are about half a mile from this station": 30th, three Duck and one Mallard on river. December 20th, a large flock of Black Duck on water; frosty.

Copeland (MCw) Island.-March 5th and April 26th, one Wild Duck: 24th, a Wild Drake seen, and two Muscovy Ducks. December 6th, a flock of Duck on the island.

Innistrahull.-November 14th, one Wild Duck on sea.

Tory Island.-November 11th, flock of Wild Duck on lake: 23rd, Duck and Barnacle heard at lake close to lighthouse at 12.30 A.M.; clear.

Rathlin O'Birne.-September 13th, one Duck on island. November 21st, one Wigeon on marsh.

Slyne Hcad, S.-April 9th, two Wild Duck going N.W.

Arran Island, N.- "I have seen Wild Duck on a small island called the 'Branack' near this station."

Arran Island, S.-November 21st, six Wild Duck at 8 A.M. on lake. They frequent it in cold weather.

\section{Birds Not IDENTIFIED.}

Hook Tower.-November 23rd, several small birds round light; supposed to be Gold-Crests.

Arklow South Light-ship.-August 28th, a flock of grey birds, a little larger than Thrushes, going S.E.; wind fresh N.W., showery. September 7th, a brownish bird, long black bill, legs, and claws, struck lantern; wind light S.W., fog.

Houth Baily.-July 18 th, a round short bird, size of Puffin, with some white about wings, short neck, and short round straight bill, seen on the water close to station. November 20th, "noticed a peculiar bird on the sea to-day; had a slightly turned-up white bill, white throat and breast, brownish colour on back, with a number of white spots."

Blackrock, Mayjo.-May 22nd, two small strange brownish birds, about the size of a Grey linnet, about rock at 2 P.M.; had a chirrup like a Wren; fired at them, but could not see them after; wind N. to light W., gloomy. August 19 th to 22nd, "a strange bird, about the size of a Wagtail, white streak above the eyes and white underneath, grey like a Skylark on back, and spotted"; wind N.: 29th, "a bird like a Sand Lark, only it had a long tail and bill, about rock; wind light S.W." : 30th, "a 
bird about the size of a Pigeon, slate colour, had round-shaped wings, about rock at 2 P.M. ; strong gale S., rain."

Tearaght.- "A large bird with a white head, supposed to be an Eagle, was observed by one of my sons passing Tearaght, going W.; I forget date."

\section{General Observations.}

Fastnet.- "On the night of November 6th, large flock of Moths round light."

Spit Bank, Queenstown.- - No birds strike this lantern; it does not seem to be in the track of birds migrating." "No birds seen from May 22nd to July 8th, only a stray Gull now and again." August 7th, "very few birds about here for some time back."

Hook Tower.-November, "a great many birds strike this lantern." December, "I did not see so many birds striking lantern since I was stationed on Tuskar Rock in 1875 and 1876 as I have seen here during the autumn migration."

Barrels Rock Light-ship.-February 6th, "no land birds of any description seen since January 27th."

Arklow North Light-ship.-March, "very few birds indeed up to the present." May, "no small birds of any kind from 10 th to 22nd." "Very few entries between May 12 th and October 18th; birds never so scarce as they have been this year up to latter date."

Howth Baily.-July 26th, "no birds about lantern this summer, and very few of any kind about station." November 19th, "Titlarks are the only resident land birds here; I find them much the same all round the coast."

Rockabill.-October, "there have been very few birds seen at this station."

South Rock Light-ship.- "No birds seen this fall."

Copeland (Mew) Island.-May, "one hundred and fifty birds found dead in eave gutter of dome of lantern-Blackbirds, Thrushes, Larks, Starlings, and one Woodcock; these birds must have been killed during the spring by striking against the dome and cowl of lantern." December, "no large 'rushes' of birds observed during autumn or winter striking against lantern; weather has been very free from fog this winter, perhaps that is the reason the birds have not been striking." 
Maidens South.-March, never observed fewer birds about lighthouse than this year.

Innishtrahull.-March, "birds of all common kinds are very scarce this winter."

Tory Island. - "Up to October 28th, no birds were observed." November 10th, "during the nights of $3 \mathrm{rd}, 4 \mathrm{th}$, and 5 th, the birds were plentiful round light; the nights were very dark; scarcely any birds at lantern since."

Blackrock, Mayo.-August 18th, one Bat at night about rock. October, "birds very scarce, owing to stormy weather."

Slyne Head, S.- "No notes taken from April 27th to May 28th." "No birds of note during August except Curlew." October 17th, "up to this birds have been very scarce." "No strange birds this year except Grey Phalarope."

Arran Islancl, N.- "No birds seen here, except Starlings, from January 4th to February 21st." "No night migrations here; no birds striking lantern."

Tcaraght.-January, "no sea-birds have landed here as yet this season. I think such birds as visit here on migration come generally at night, and leave about same time, as we seldom see them coming or going away." "No birds killed at lantern for the winter months." November 4th, "Long-eared Bat flew into one of the houses." [Received in flesh.]

\section{Daubenton's Bat (Vespertilio Daubentonii, Leisler).}

Lucifer Shoals Light-ship.-April 21st, Bat caught at 7.30 P.M., "flying low about ship, striking man on watch; it died the next day." [Daubenton's Bat received in flesh : sent as a bird.] 

1892 


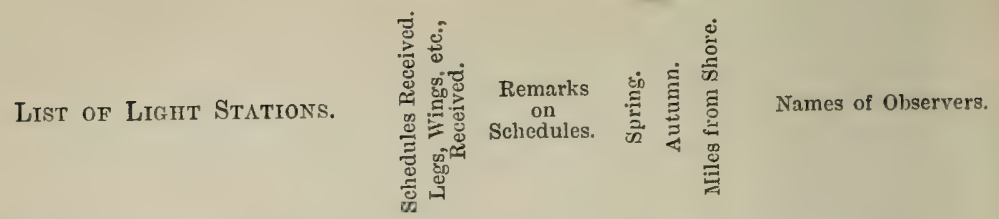

4. Mine Head, Waterford,

10 good.

$5 a$. Hook Tower, Wexford,........ 428 excellent.

$0 \quad x-$ H. Kelly.

5. ${ }^{*}$ Coningbeg Lt.-ship, Wexford, 20 good.

$\mathrm{x} x-$ W. H. James.

6. Barrels Rock Lt.-ship, do., 4 o very good. $x \quad x \quad 4\left\{\begin{array}{c}\text { J. Beahan, Ed. Broad, } \\ \text { and T. Succan. }\end{array}\right.$

7. Tuskar Rock, do., 113 very good. $x \quad 0 \quad 7$ John Hamilton.

7 a.Lucifer Shoals Lt.-ship, do., 11 good. $\quad x \quad$ o 9 John Byrne.

7b. Blackwater Bank Lt.-ship, do., 440 excellent. $\quad x \quad x-\left\{\begin{array}{c}\text { Patrick Cullen and } \\ \text { Daniel Dunn. }\end{array}\right.$

8. Arklow Sth. Lt.-ship, Wicklow, $5 \quad 7$ excellent. $\quad \mathrm{x} \quad \mathrm{x} \quad 7\left\{_{\left(\begin{array}{l}\text { Wearon, and Ed. } \\ \text { Broad. }\end{array}\right.}^{\text {Clydesdale, J. }}\right.$

8. Arklow North Lt.-ship, do., 39 excellent. $\quad x \quad x \quad 8\left\{\begin{array}{l}\text { J. Pinston and Alfred } \\ \text { Wall. }\end{array}\right.$

9. Codling Bank Lt.-ship, Dublin, 34 very good. $x \quad x \quad-\left\{\begin{array}{l}\text { Alfred Wall, W. Clydes- } \\ \text { dale, and H. Thomp- } \\ \text { son. }\end{array}\right.$

11. Howth Baily, do., 27 excellent. $x \mathrm{x}$ - Edward MI'Carron.

12. Rockabill, do., 18 good. $0 \quad x \quad 5$ H. Kennedy.

12a.Drogheda, North, Meath, ...... 64 excellent. $\quad \mathrm{x} \quad \mathrm{x}$ - George Dunleavy.

12b. South Rock Lt.-ship, Down,... 12 poor. $\quad$ x $\quad$ o 3 Patrick Clancy.

13. Copeland (Mew) Island, do., .. 5 - 1 very good. $\times \quad x-\left\{\begin{array}{l}\text { R. Armstrong, W. } \\ \text { Butler, M. Polly, } \\ \text { R. Lyons, and B. C. } \\ \text { Kennedy. }\end{array}\right.$

14. Maidens South, Antrim, ,....... $4 \quad 6$ very good. $x \quad x \quad 5$ Francis Maguire.

16. Innishtrabull, Donegal, ....... 311 very good. $x \quad x \quad 6$ George Gillespic.

19. Tory Island, do., ….... 4 0 excellent. $\quad x \quad x \quad 9 \quad J$. Higginbotham.

21. Rathlin O'Birne, do., ….... 22 good. $\quad x \quad 0 \quad 2$ John Miurray.

22. Killybegs, do., ....... 27 very good, o $x$ - John Kennedy.

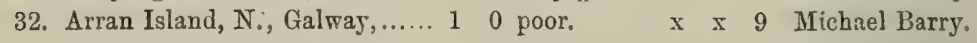

34. Arran Island, S., do., $\ldots . . .12$ very good, o 1 x 6 J. C. MacGinley.

37. Tearaght, Kerry,............. 410 excellent. $\quad$ x $\quad$ x 9 Charles Hawkins.

The following Stations sent no Schedules, but forwarded specimens:-Carlingford Lough sent a Sheathbill (Chionis alba); Lough Swilly, Donegal, a Gannet; Blackrock, Majo, a Fork-tailed Petrel.

Legs, Wings, etc., recoived, 166.

$0=$ No reply.

$\mathrm{x}=$ Schedules returned partly or wholly filled.

Spring, replies received from 19 stations, Autumn, replies received from 19 stations. 


\section{Legs, Wings, hTc, Received.}

Species. How Received. How Procured. Date. Name of Station.

Kestrel, .
Spotted Flycatcher,
Missel-Thrush, . Thrush,

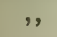

,

,

,

,

,

,

\section{Redwing,}

Fieldfare,

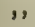

,

Blackbird,

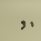

,

,

,

,

,

,

,

,

.

(n)

(n)

(1)

(n)

". tivo, . Legsand wings,

., . . Leg and wing,

Hedge Sparrow, . Rec'd. in flesh,

Stonechat, .

WV
Rec'd. in flesh,

Leg and wing,

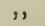

,

,

,

,

,

,

,

,

Wing,

Leg and wing,

,9

,

Wing,. .

Leg and wing,$$
\text { , }
$$

two, . Legsand wings,

tivo,

Leg and wing,

,

,

,

five, .

,

,

Leg and wing,

,

"?

Leg and wing,

Rec'd. in flesh,
Shot, .

27/ 3 mo., Tearaght.

Caughtondeck, 26/ 5 mo., Arklow N. Lt. ship.

Killed st., ${ }^{1}$. 23/11 mo., Hook Tower.

" . $30 / 1$ mo., Blackwater Bank Lt. sh

", 20/3 mo., , ",

". 23/3 mo,, ", ",

, . 18/10 mo., ", ",

, . 25/11 mo., ", ",

". 13/12 mo., ", ",

? 29/10 mo., Arklow S. Lt. ship.

Killed st., . 23/ 9 mo., Arklow N. Lt. ship.

". 20/9 mo., Rockabill.

, $\quad$. $30 / 1$ mo., Blackwater Bank Lt. sh.

Killed, - 22/11 mo., Maidens $S$.

? Rec'd. 27/12 mo., Innishtrahull.

Picked up dead, 13/10 mo., Hook Tover.

Killed st., . 19/10 mo,, ," ,

". 22/12 mo., , . .,

" $\quad$ 26/ 3 mo., Blackwater Bank Lt.-sh.

?

$22 / 5$ mo.,

Killed st., . 24/10 mo.,

" . 25/10 mo.,

13/12 mo.,

24/12 mo, ,

- 17/10 mo., Arklow S. Lt.-stip.

- 11/11 mo., Arklozv N. Lt. slip.

18/11

9/11 mo., Codling Bank Lt.-ship.

10/11 mo., ", ",

$25 / 11 \mathrm{mo}$,

2/10 mo., Rockabill.

27/10 mo., ,"

22/11 mo., ,

15/11 mo., Tearaght.

Caught, . 13/ $3 \mathrm{mo}$,

Shot, . . 14/ 1 mo., Innishtraluull.

Caught in crib, $10 / 1$ mo., Killybegs.

Killed st., . $25 / 5$ mo., Bluckwater Bank Lt. sh.

". 26/ 3 mo., Hook Tower.

" . 29/4 mo., Tuskar.

! 23/ 9 mo., ,,

Killed st., - $26 / 3$ mo, Blackwater Bankit. $-s h$. , $\quad$. 29/ 9 mo., Arklow N. Lt.-ship.

1 Killed st. = Killed striking lantern. 


\section{LEGS, Wings, ETC., RECEIVED-continued.}

Species. How Received. How Procured, Date. Name of Station.

Sedge Warbler, two, Rec'd. in flesh, Killled st., , 24/ 5 mo., Hook Tower.

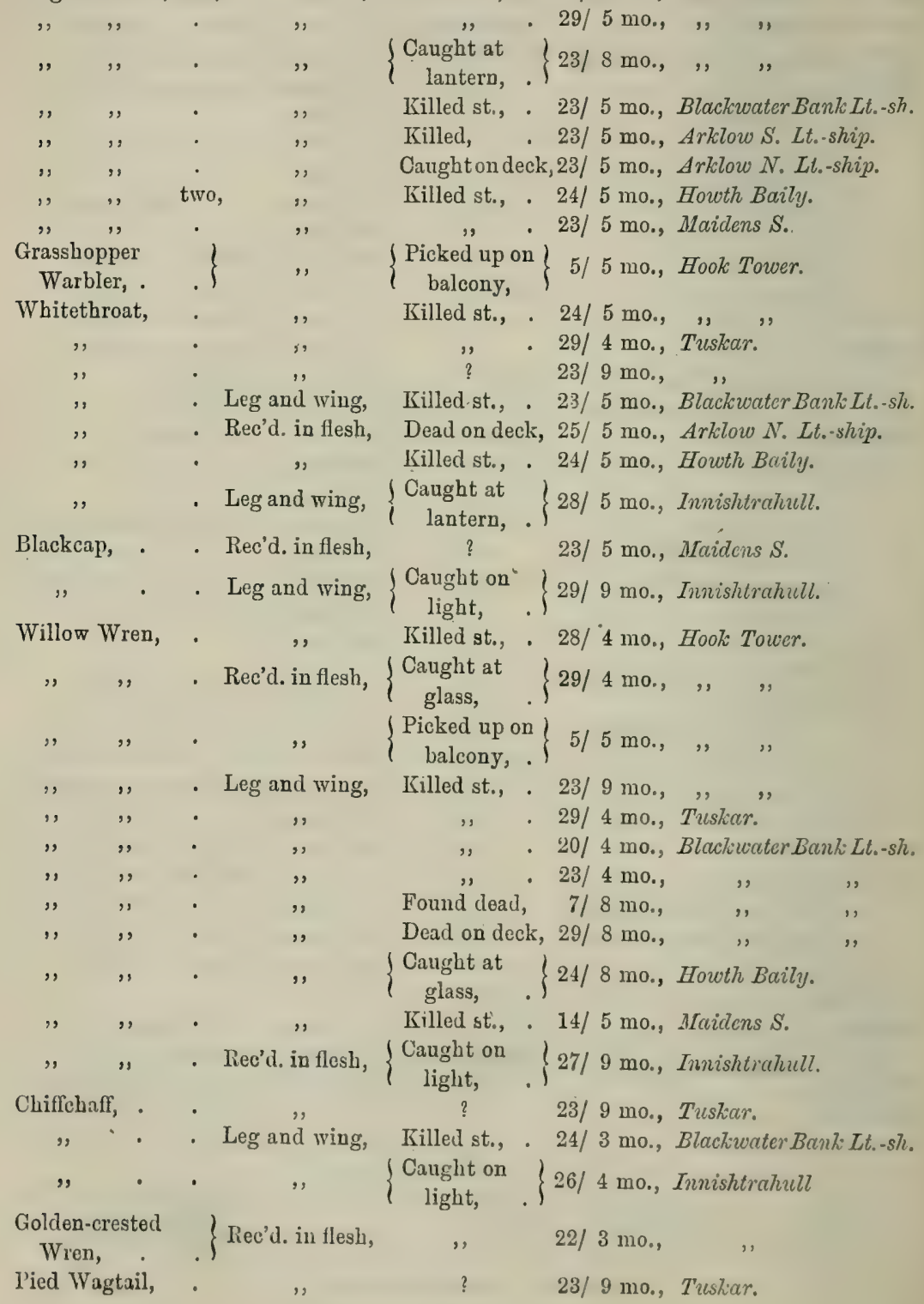


LEGS, WINGS, ETC., RECEIVED-continued.

Species. How Received. How Procured. Date. Name of Station.

Meadow-Pipit, . ! ? 23/9 mo., Tuskar.

" Log and wing,

Dead on deck, $10 / 1$ mo., Blackwater Bank Lt. sht.

Killed st., . 17/10 mo.,

Got by one of $\{27 / 12$ mo., Innishtrahull.

Rock-Pipit, . $\cdot \begin{gathered}\text { Rec'd. in flesh } \\ \text { in spirits, }\end{gathered}$

Killed st., . 26/ 2 mo., Hook Tower.

Skylark, . . Leg and wing,

",

,

",

Rec'd. in flesh,

Leg and wing,

Killed st., . $27 / 2$ mo., Blackwater Bank Lt. sh.

\begin{tabular}{|c|c|c|c|}
\hline ", & . 25/10 mo., & , & , \\
\hline "' & - $15 / 11$ mo., & ," & "I \\
\hline , & - 22/11 mo., & ", & "' \\
\hline " & - $13 / 12 \mathrm{mo}$, & , & ", \\
\hline
\end{tabular}

Found ondeck, 16/12 mo., Arklow S. Lt. -ship.

$\left\{\begin{array}{c}\text { Leg and white } \\ \text { wing, }\end{array}\right\}$

two, - Legsand wings,

$\begin{array}{lll}" \text { two, - Legsand wings, } & \\ , \quad \text {. Leg and wing, }\end{array}$

Snow Bunting, .

," ,

Corn Bunting,

Chaffinch,

,

9

Goldfinch, . . Rec'd. in flesh,

Mealy Redpoles, two

,

,

Twite

,

,

Starling,

9

,

s)

,

Swallow,
Killed st., . 22/11 mo., Rockabill.

.$\quad \quad$. $21 / 1$ mo., South Rock Lt. ship.
Shot, . $\quad$. $25 / 3$ mo., Copeland (Mew) Island.
1/11 mo., Tearaght.

Killed st., . 29/10 mo., Tuskar.

", . 9/11 mo., Innishtrahull.

$1 \quad 27 / 12$ mo., ",

Caught on deck, 23/10 mo., Blackwater Bank $L t_{0}-s /$.

Dead on deck, 10/11 mo., Arklow N. Lt. ship.

Killed st., - 24/10 mo., Rockabill.

Shot, . 1/11 mo., Tearaght.

Picked updead, 9/11 mo., Hook Tower.

Shot, . 25/9 mo., Tearaght.

$$
\text { , . . 26/9 mo., ,, }
$$$$
\text { ", . 18/10 mo., ," }
$$

Killed st., . $27 / 3$ mo., Hook Tower.

Dead on deck, 11/12 mo., Blackwater Bank $L t_{\text {. }}$ sh.

\section{Leg and wing,}

Rec'd. in flesh, $\left\{\begin{array}{c}\text { Caught at } \\ \text { lantern, }\end{array}\right\} 10 / 1$ mo., Killybegs.
Leg and wing, Killed st., . $5 / 3$ mo., Hook Tower

" . 27/ 3 mo., , , ,

" . 27/ 2 mo., Blackwater Bank Lt. sh.

". 24/ 3 mo.,

,2. 13/12 mo.,

" . 26/10 mo., Arklow S. Lt.-ship.

? Rec'd. 27/12 mo., Innishtrahull.

Killed st., .. $23 / 4$ mo., Blachwater Bank Lt. sh. Deadon board, 8/ 5 mo., Codling Bank Lt.-ship. 


\section{LEGS, WINGS, ETC., RECEIVED-continued.}

\section{Species. How Received, How Procured, Date. Name of Station.}

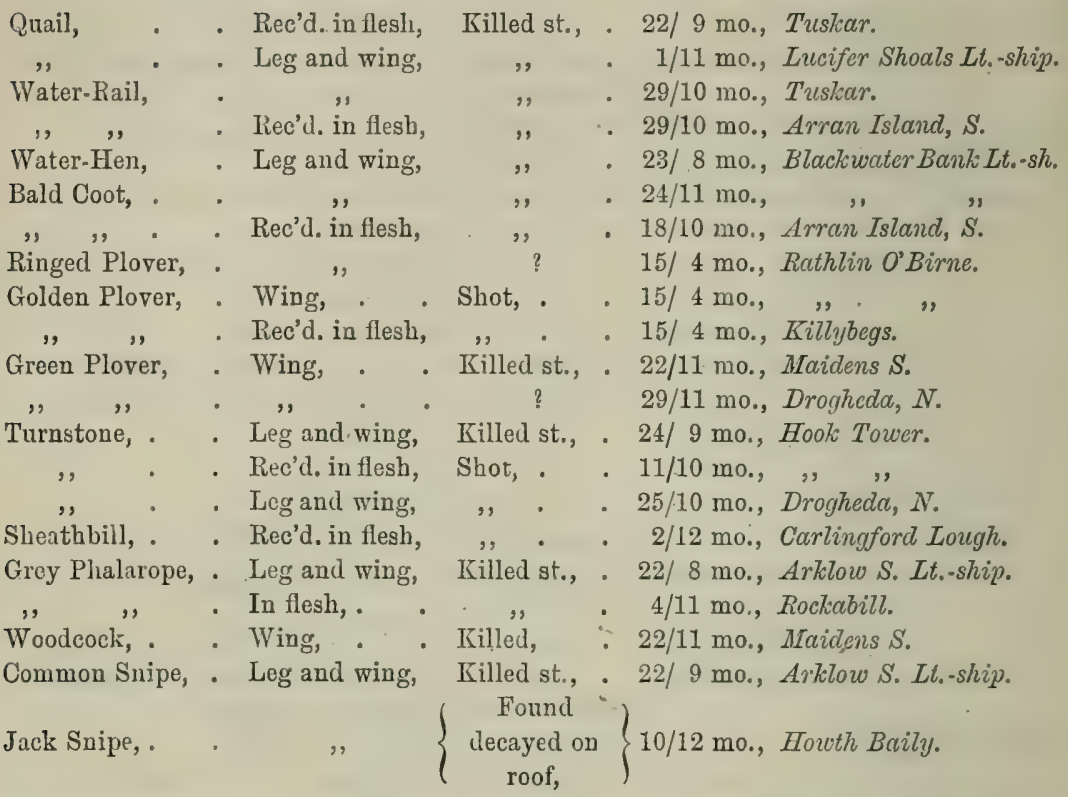

Dunlin, . . _ Killed st., . $20 / 9 \mathrm{mo}$, Hook Tower.

". . Rec'd. in flesh, $\left\{\begin{array}{l}\text { Found dead } \\ \text { on balcony, }\end{array}\right\} 26 / 12$ mo., , , ,

Purple Sandpiper, Leg and wing, Killed st, . 29/10 mo., Tuskar.

" ", "Shot, . . 29/10 mo., Tearaght.

Common Sandpiper, „, Killed st., . 23/4 mo., Blackwater Bank Lt. -sh.

, , , ,

$\left\{\begin{array}{l}\text { Found dead } \\ \text { on balcony, }\end{array}\right\} 5 / 5$ mo., Howth Baily.

Curlew,

Killed st., . $24 / 3$ mo., Blackwater BankLt. sh.

Fork-tailed Petrel, Skin received, ? 9/ 9 mo., Blackrock, BLayo.

Storm Petrel, . Rec'd. in flesh, $\left\{\begin{array}{c}\text { Flew on } \\ \text { board and } \\ \text { died, }\end{array}\right\} 28 / 11$ mo., Arklow N. Lt. ship.

Guillemot, . . N Shot, . . 23/ 3 mo., Howth Baily.

Little Grebe, . $\quad, \quad\left\{\begin{array}{c}\text { Picked up } \\ \text { dead, }\end{array}\right\} 7 / 11$ mo., Hook Tower.

Gannet, ‘ . " Shot, . . 4/10 mo., Lough Swilly.

Brent Goose, . " " . . . 11/10 mo., Drogheda, N.

Common Scoter, . Head, . . " . . 29/11 mo., ;, 


\section{N D E X.}

\begin{tabular}{|c|c|c|c|c|c|c|c|c|c|}
\hline & & & & $\mathbf{P A}$ & & & & & PAGR \\
\hline Birds not identi & ified, & - & & . 330 & Petrel, Storm, & - & . & . & 323 \\
\hline ird, . & $\cdot$ & & & - 281 & "Pigeons," & . & . & . & 09 \\
\hline ap, . & - & & & . 288 & Plover, Golden, & & . & . & 310 \\
\hline oose, & - & & & - 327 & Green, & - & - & • & \\
\hline $\begin{array}{l}\text { Bullfinch," } \\
\text { unting, Corn, }\end{array}$ & · & & & - 300 & Ringed, & & - & - & \\
\hline $\begin{array}{c}\text { anting, Corn, } \\
\text {," Snow, }\end{array}$ & & • & & $\begin{array}{l}\text { · } 296 \\
\text {. } 295\end{array}$ & Puffin, & • & . & - & \\
\hline$"$ Yellow & & & & - 296 & Quail, & . & . & • & 309 \\
\hline Chaffinch, . & - & - & & . 296 & Raven, . & - & • & . & 304 \\
\hline aff, . & . & & & . 2 & Razorbill, . & . & . & . & 24 \\
\hline Chough, & . & & & - 30 & Redshank, . & - & . & . & 18 \\
\hline Common Scoter, & & & & - 3 & $\mathrm{ng}$, . & - & . & . & - \\
\hline Coot, Bald, & 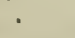 & & & - 31 & Ouzel, & . & . & . & . \\
\hline ant, & • & & & - 32 & Robin, & - & - & . & \\
\hline ke, & - & - & & - 30 & Rock-Pipit, & - & - & - & . \\
\hline Hooded, & $\cdot$ & & & - 30 & Rook, & - & · & - & - \\
\hline $\begin{array}{l}\text { uckoo, : } \\
\text { urlew, : }\end{array}$ & : & & & $\begin{array}{l}\cdot 308 \\
: \quad 318\end{array}$ & "Sand Larks," . & & - & . & \\
\hline ver, & - & & & . 325 & Sandpiper, Comn & mon, & · & • & . \\
\hline $\mathrm{ks}, "$ & - & • & & - 32 & Sedge Warbler, & le, & - & - & . \\
\hline Dunlin, . & . & . & & . 316 & Shag, & & . & • & \\
\hline Fieldfare, . & - & - & & . 280 & Sheathbill, Yello & ow-bil & illed, & · & \\
\hline$\cdot$ & - & - & & . 32 & Siskin, & • & - & . & $\begin{array}{l}314 \\
\cdot \quad 298\end{array}$ \\
\hline 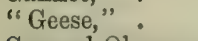 & & & & . 327 & Skylark, . & & . & . & \\
\hline Observa & ations, & & & . 330 & Snipe, Conmmon, & & . & . & . \\
\hline ested T & $\mathrm{Wr}$ & & & - 28 & ', Jack, & & - & . & \\
\hline$\cdot 1$ & - & & & . 29 & $\begin{array}{l}\text { Sparrow-Hawk, } \\
\text { Hedge, }\end{array}$ & & $\dot{.}$ & : & : \\
\hline per Wa & arb] & & & - 28 & ", House, . & & . & : & . 2 \\
\hline nch, & & - & & - $\quad 2$ & Tree, & & . & . & . 297 \\
\hline $\begin{array}{l}\text { Phalarope, } \\
\text { mot, Blac] }\end{array}$ & & : & & $\begin{array}{l}31 \\
: \quad 32\end{array}$ & Spotted Flycatch & her, & . & . & - 276 \\
\hline mot, Blac & imon, & • & & $\begin{array}{l}02 \\
. \quad 32 \\
\end{array}$ & r. & . & . & . & \\
\hline "Gulls," . & . & - & • & 32 & $a t$, . & . & . & . & . \\
\hline "Hawks," & . & - & & 275 & "Swans," . & • & $\dot{.}$ & · & $\cdot 3$ \\
\hline Heron, & . & . & & 32 & Swift, & 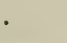 & . & - & - 30 \\
\hline Jackdaw, . & - & - & & 30 & Ter & • & - & • & \\
\hline $1, \quad$. & - & . & & . & , . & 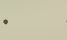 & . & - & - \\
\hline Kin & . & . & & - & Titlark, . & 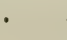 & - & . & \\
\hline Grebe, & $\dot{.}$ & . & & $\begin{array}{l}298 \\
\cdot \quad 325\end{array}$ & "Turnstone, & - & : & . & $\begin{array}{l}\cdot 31 \\
\cdot \quad 30\end{array}$ \\
\hline [ag] & - & . & & . 30 & "Wagtails," & & . & - & \\
\hline rwate & & . & & . 3 & Pied, & & - & . & \\
\hline$\pi$ & - & - & & - & en, & . & - & . & \\
\hline pole, & : & - & & $\cdot \begin{array}{l}2 ! \\
0\end{array}$ & & • & & - & $2 \varepsilon$ \\
\hline l-Thrush, & & & & - 27 & & • & . & - & 32 \\
\hline Owl, Snowy, & & & & . 27 & & . & & & \\
\hline & & & & - 27 & en, & & & & \\
\hline Oyster-Catcher, & & • & & 31 & Woo & & & · & \\
\hline "Partridge," & & • & & . 30 & "Wood Warbler, & & . & . & \\
\hline er & & & & 2 & $W_{1}$ & & . & & \\
\hline$k-t_{2}$ & & & & 32 & Wryneck, & & & . & 308 \\
\hline
\end{tabular}


Peregrine Falcon (Falco peregrinus, Tunstall).

Mine Head.-November 10th, a Peregrine Falcon observed close to lighthouse.

Hook Tower.-October 4th, "a pair of Peregrines build on a cliff about four miles from here; we got the eggs."

Rockctill.-October 17th, Peregrine hovering at daylight; strong breeze E., rain.

Tory Island.-April 12th, "a Hawk swooped amongst a flock of Grey Plover, and carried off one" (see under Golden Plover): 13th, Hawk again near station to-day at noon. October 27th, a large Hawk going S.E.

Rathlin O'Birne.-June 17th, one Falcon going S. at noon.

Killybegs.-October 24th, one Falcon Hawk remained all day.

Tcaraght.-February 15th, Peregrine seen. April 6th, do. at noon. August 7th, two Peregrines on island. September 9th, three do. December 31st, two do.

\section{MerLin (Falco cesalon, Tunstall).}

T'ustar.-October 29th, "a beautiful Merlin seen a few days ago."

Lucifer Shoals Light-ship.-February 27th, Merlin or Hobby Hawk observed at 4.50 P.II. ; wind light E., flew round the ship; seemed inclined to rest, then flew for the land.

Killybegs.-November 20th, a Merlin Hawk all day, apparently an old bird.

Kestreu (Falco tinnunculus, Linn.).

Howth Baily.-August 10th, four Kestrels about the station: breed on cliffs : 20 th, still about station.

Drogheda, N.-May 10th, one Kestrel Hawk going N.: 16th, one do.

Tearaght.-March 27th, a Hawk shot-[Kestrel received in flesh]. April 8th, Kestrel noted.

Sparrow-Hawk (Accipiter nisus, Linn.).

Hook Tower:-March 30th, one at 10 A.M. October th, Sparrow-Hawk seen chasing Linnets. 
Drogheda. -June 8th, one going N. October 25th, two about station.

Copcland (Mew) Island.-November 7th, a Iawk on island, small species (Sparrow-Hawk).

Innishtrahull.-April 12th, one Sparrow-Hawk. July 19th, two do.

Rathlin O'Birne.-April 3rd, one. May 22nd, one "coursing" at 8 A.M. July 18 th, one going S. at noon.

Killybegs.-November 20 th, two all day.

Tearaght.-May 20th, Sparrow-Hawk seen. October 11th, one going N.: 18th, one on island for two days.

\section{"Hawks," Етс.}

Blackuater Bank Light-ship.-May 22nd, one Hawk from 9 P.M. to midnight about light; wind fresh S.W. (several Sedge Warblers at same time): 24 th, two Hawlis about light from 11 P.Ir. to midnight; wind light S.W., gloomy and rain (also Sedge Warblers).

Arlilow South Light-ship.-May 26th, two Hawks at 3.30 A.II. about ship; wind light S.W., fog. August 4th, one going N.W. at 9 A.M. ; wind light $\mathrm{N}$.

Drogheda.-June 19th, one "Kite" going S.

Maidens South.-September 11th, one "Hawk or Falcon" going W.; had small bird in talons: 13th, one Hawk (dark colour) going S.W.

Innishtrahull.-January 5th, one large Hawk flying round island; gale N.W.: 16th, one very large Hawk, with "white feathers round eyes," flying over island at 11 A.M. ; gale S.E., gloomy-[Possibly female Hen-Harrier.-R. M. B.] August 1st, a very large Hawk at 4 P.M.

Tory Island.-March 31st, one pair Brown Hawks breed on east end of island.

Arran Island, N.--December Sth, one Hark and six liavens hovering over station, and alighting occasionally on Brannock Island.

Arran Island, S.-September 30th, two Hawks at 4 P.Mr.; one rested on cowl of tower, the other attacked a Titlark which took refuge in coal-house.

Tecrayht.-December 31st, "Hawks here nearly always." 


\section{Snowy OwL (Nyctea scandiaca, Linn.).}

Innishtrahull, in lit. 24/3/92.-A Snowy Owl was shot on this island by the principal light-keeper in 1882 or 1883, and he sent it to the Museum in Dublin (see More's "List of Irish Birds," second edition, p. 8).

\section{OWLS.}

Hook Tower.-October 6th, one Brown Owl at 4 P.M.; wind fresh N.W.

Houth Baily.-October 3rd, a large Owl flying about in the evening.

Spotted Flycatcher (Muscicapa grisola, Linn.).

Arklow North Light-ship.-May 26th, one small bird caught on deck at 8 A.M.; wind light S.E., fog; died. [Spotted Flycatcher received in flesh.]

\section{Missel-Thrush (Turdus viscivorus, Linn.).,}

Hook Tower.-November 23rd, one Missel-Thrush killed striking; strong breeze S.E. [Leg and wing received.]

\section{Thrush (Turdus musicus, Linn.).}

Mine Head.-October 15th, one going W.; wind fresh E. November 19th, one at 11 P.M. flying round light.

Hook Tover.-October 26th, one killed striking.

Coningbeg Light-ship.-January 10th, large flocks of Thrushes, Larks, and Starlings going N. from 7 A.M. to 3 P.M.; wind fresh N.E., snowstorms. December 13 th, several at 10.30 P.M. ; six killed striking.

Barrels Roch Light-ship. - January 10th, great rush of Thrushes, Starlings, Larks, and other birds going N. during day; wind fresh N.E., hail and snow showers.

Tuskar.-September 21st and 22nd, great rush of Thrushes and other birds (see interesting note under Chiffchaff). October $29 \mathrm{th}$, Thrushes often occur.

Lucifer Shoals Light-ship.-February 19th, two at noon about ship ; gale E. : 20th, several flocks all day going N.W.; strong gale E., snow : 27 th, two flying for shore at 1 P.M. 
Blackwater Bank Light-ship.-January 9th, flocks of Thrushes and Larks going N.W.; wind fresh N.W.: 10th, flocks of Thrushes and Larks going N.W.; snow : 30th, several Thrushes about light all night; one or two killed striking-[Leg and wing received]. March 20th, several Thrushes and Larks about light; one killed; wind light N.E., clear-[Leg and wing received]: 23rd, flock about light from 9.30 P.M. to 10.15 P.M.; wind moderate N.E., clear; one killed striking-[Leg and wing received]. October 17 th and 18 th, several about light; one killed striking-[Leg and wing received]: 24th, 25th, 26th, and 27th, Thrushes about light: 29th, November 1st, 18th, 21 st, 24 th, and 25 th, several about light; three killed on 25 th -[Leg and wing received]. December 12th, 13th, and 14th, flock of Thrushes, Larks, Blackbirds, and Starlings about light from 7 P.M. to 7 A.M.; wind moderate S.W.; rain and fog. On 14th about eighty birds killed striking; sixteen Thrushes and a few others picked up on deck, the rest fell overboard. [Leg and wing of Thrush received, killed on 13th.]

Arklow South Light-ship.-January 9 th and 11th, flocks going N.W., snow: 29th, one killed striking at 11.30 P.M. ; wind moderate S.W., clear: 31st, several at 7.30 A.M. going N.W., calm, rain. March 16th, 17th, and 26th, about light during night; some killed striking. October 29th, various kinds of birds about light at 1 A.M.; fresh breeze S.W., showery; one killed-[Leg and wing of Thrush received]. December 13th, numbers of birds about light during night; wind moderate S.W , rain; several killed striking; three Thrushes found dead.

Arklow North Light-ship.-January 8th, several about light all night; wind N.W., snow: 9 th and 10th, Thrushes going N.W. during day. February 19th, Thrushes about ship; snow, strong breeze E.; "fell into water and were drowned": 20th, two rested on ship; strong breeze S.E., snow; went overboard. March 27th, Thrushes about lantern all night; sleet and snow; several birds killed: 29th, two about lantern; several birds killed and went overboard. August 16th, four at 10 P.M. about lantern; strong breeze N.W., rain; struck, none killed: 17th, two Thrushes and several small birds at 11 A.M. going S.E.: 21st, several Thrushes, Linnets, and small birds about lantern at 10 P.M. ; wind moderate S.W., fog; two birds killed. September $22 \mathrm{nd}$, several birds about light during night; wind light 
N.E, clear; two struck, one, a Thrush, not killed: 23rd, one caught and one found dead on deck-[Leg and wing received]. November 11th, Thrushes, Blackbirds, and Starlings from 8 P.M. to midnight about light; wind moderate $\mathrm{S}$., gloomy; numbers killed striking: 23rd, Thrushes, Blackbirds, and Starlings from 7 P.M. to midnight about light; wind light, variable, rain; several killed: 24th, several, with Blackbirds and Larks, about light.

Codling Bank Light-ship.-January 8th, several flocks, with Starlings, during day going N.W.; strong breeze N.W., snow: 9th, several flocks, with Larks, going N.W.; snow showers: 10th, several large flocks, with Larks, going N.W.; clear. October 25th, flock at 7 A.M. going N.W.; wind fresh E. November 6th, one going N.: 11th, 23rd, 24th, and 25th, several (see under Starling).

Howth Baily.-March 11th, some at station (see under Blackbird): 25th, one against lantern glass at 4 A.M. October 17 th, one caught on balcony.

Roclicubill.-September 20th, one killed striking; gale E., rain. October 17th, one killed striking; strong breeze E. 'November $22 n d$, Thrushes at night (see under Blackbird).

Droghecla, $N$.-January 8 th to 10 th, great rush S. of many species, including Thrush (see under Golden Plover); heavy frost and snow.

Copeland (Mew) Island.-January 8th and 9th, some, with Blackbirds and Larks, on island in a weak state: 11th and 15th, several noted. February 24th, some at light: 26 th and 27 th, some on island, and some striking at night. March 17th, Thrushes and other birds striking at night; wind S., fog: 18th, some noted on rays of light: $20 \mathrm{th}$, some on island.

Maidens South.-January 7th, some going S.E. (see under Skylark); one died on rock: 9th, four going S.W.; fresh breeze N., snow. February 10th, one at lantern at 2 A.II.: 21st and 25th, a few going W.: 27th, six at lantern all night; three killed striking: 2Sth, one, and one Blackbird and two Larks on rock; 'wind light E., clear; went W. at noon: 29th, one at lantern; went W. at daylight. March 6th, two going S.W.: 15th, one at lantern; clear: 16th, one went W. at 10 A.M. : 17th, nine, with Larks, all night round lantern; strong breeze S.E.: 19th, four at lantern at midnight; fresh breeze S.E. : 25 th, some do. 
November 21st, rush of Thrushes, "G. Plover," Blackbirds, and Larks flying round lantern from 7 P.M. to midnight; strong breeze S.E.; gloomy : 22nd, Thrushes, Blackbirds, Larks, Green Plover from 7 P.M. to 9 P.M. flying round lantern; strong breeze S.E., gloomy (one Woodcock, one Green Plover, one Fieldfare killed): 23rd, Thrushes, "G. Plover," Blackbirds, and Chaffinches from 6 P.M. to 2 A.M. flying round lantern; wind light S.; Blackbird caught: 24th, some, in rush of various species (see under Green Plover). December 4th, some going S.W.; gale N., heavy show.

Innishtrahull.-January 11th, many on island, with other birds (see under Snipe). February 27 th to 29 th, several killed striking. September 29th, one. October 23rd, a few (see under Blackbird).

Tory Island. - February 23rd, one struck. March 3rd, great numbers, with Blackbirds and other birds, striking; one Thrush killed: 20th and 21st, great numbers of Thrushes, Fieldfares, a few Blackbirds and Starling, striking on N.E. side of lantern from 7 P.M. to 5 A.M., some Larks amongst them. April 9th, Thrushes have all left island. October 27 th, two at lantern. November 14th, some, with Blackbirds, at lantern from 4 A.M. to 6.30 A.Mr; four Thrushes struck, one killed; one male Blackbird killed; wind moderate S.E., rain: 18th, from 8 P.M. to 6 A.M. on 19th, a very great number of Thrushes, Fieldfare, and some Blackbirds round light; twenty-five Thrushes and two hen Blackbirds picked up at daylight; strong breeze S.E., thick, rain: 21st and 22nd (night and early morning), a great number of birds round light, some Starlings amongst them.

Arran Island, N.-July, about twenty here the greater part of this month (see under Blackbird).

Arran Island, S.-October 15th, five seen; strong breeze N.E.

T'carccyht.-January 1st to 10 th, great flocks on island; frost and snow. February 19 th and 27th, numbers noted. October 15th, thirty on island; wind moderate E.: 19th, about forty do.; wind light E. December 11th, a flock; gale N.W.

REDWING (Turdus iliacus, Linn.).

Hook Toucr:-March 25th to 27th, great rush of birds, chiefly Starlings; three Redwings killed on 27 th. 
Tuskar.-September 21st and 22nd, great rush of Thrushes, Larks, Redwings, Chiffchaffs, Wheatears, Whitethroats, Wagtails, Swallows, and Robins (see under Chiffchaff).

Arklow South Light-ship.-December 24th, various kinds of birds about light; one Mountain Thrush killed striking[Possibly Redwing]; fresh breeze S.W.

Rockabill.-September 20th, one killed striking; gale E., rain-[Leg and wing received]. October 27th, Redwings all night; some killed; strong breeze S., fog. November 18th, great rush of Redwings, Fieldfares, and Starlings going $\mathrm{N}$.; gale S., rain. "The greatest flight of birds seen here for the season."

Drogheda, $N$.-January 8 th, great rush of birds all day going S.; heavy frost and snow ; ten species noted (see under Golden Plover); one Redwing killed. "This migration continued until the 10 th, when a thaw set in."

Tory Island.-February 29th, one "Mountain Thrush" disabled striking at 5 A.m. [Possibly Redwing].

Tearaght.-January 1 st to 4 th, and 8 th, 9 th, and 10th, Pedwings noted; frost and snow. February 20th, some noted. November 20 th, several on island; strong gale S.: 25 th, several.

\section{FieldFare (Turdus pilaris, Linn.).}

Mine Head.-November 5th, six going S.; wind light E. December 20th, flock near lighthouse.

Blackwater Bank Light-ship.-[January 30th, leg and wing of Fieldfare received; killed striking.]

Howth Baily.-January 10th, large flock Fieldfares about station; snow.

Rockabill.-November 18th, Fieldfares, Starlings, and Redwings all night going $N$.; gale $S_{\text {., }}$ rain; killed, and mostly all blown into the sea. "The greatest flight of birds seen for the season."

Maidens South.-January 8th, one at lantern; gale N.W., snowstorm. February 24th, one at lantern. November 22nd, several species of birds round lantern at night (see under Thrush); one Fieldfare killed-[Wing received]. December 4th, three going S.W.; snow: 5 th, one do.; gale $\mathrm{N}$., heavy snow. 
Innishtrahull.-November 19th and 20th, an enormous number of Fieldfares striking all night; strong breeze S.E., drizzle; forty-six killed: 21st, Fieldfares striking all night; gale S.E., drizzle, misty; five killed, two disabled: 22nd, four killed-[Leg and wing received on December 27th]; "Fieldfares all came from the $\mathrm{N}$., going S."

Tory Island.-March 20th and 21st, great numbers of birds, chiefly Thrushes and Fieldfares, striking on N.E. side. November 18th and 19th, great rush of Thrushes and Fieldfares; strong breeze S.E., rain.

\section{BLACKBIRD (Turdus merula, Linn.).}

Mine Head.-November 20th, two at 11.30 P.M. going W.; one disabled.

Hook Tower.-February 27th, two at 9 A.M. March 25th to 27 th, great rush of Starlings and other birds; three female Blackbirds killed on $27 \mathrm{th}$. October 13 th, one female picked up dead[Leg and wing received]: 15th, one at 10 A.M., and some round light all night: 16th, some noted at 10 A.M.; strong breeze N.E.: 19th, one female killed striking; wind light N.E. [Leg and wing received]: 26th and 27th, one killed striking. November 10th, one female all day. [December 22nd, Leg and wing received, killed striking.]

Coningbeg Light-ship.-October 24th, two Blackbirds at 8 P.M. flying round; wind fresh E.S.E. : 26 th, a few at 8.30 P.M. flying round; gale S.

Tuskar.-February 21st, flock going S.E.; wind light S.E.; Blackbirds common here.

Lucifer Shoals Light-ship.-February 27th, one at 1 P.Mr. flying for shore.

Blachucater Bank Light-ship.-March 26th, Blackbirds, Starlings, Wheatears, aud Curlews about lantern; about a hundred birds killed striking; wind light S.W. [Leg and wing of Blackbird received]. [May 22nd, Wing of Blackbird received.] October 24 th, a few about light ; wind light E.; one killed striking-[Leg and wing received]: 25th, four do.; one killed striking; clear-[Leg and wing received]. November 1st, several about light: 24th, flocks. December 12th, 13th, and 14th, rush of Thrushes, Larks, Blackbirds, and Starlings; at least two Blackbirds killed striking-[Leg and wing received]: 
24th, flock about light all night; strong breeze S.E.; six killed - [Legs and wings of two received].

Arklow South Light-ship.-February 13th, one at 10 P.M. about light; calm. March 26th, several about light; nine birds killed; probably some were Blackbirds. October 17th, Blackbirds and other birds at 7.30 A.MI. ; struck light; wind fresh N.E., clear-[Legs and wings of two Blackbirds received]. December 13th, numbers of birds during night; one Blackbird and three Thrushes killed striking: 14th, one found on deck killed: 17th, several birds of various kinds about light during night; wind fresh S.W., light haze ; one Blackbird killed: 24th, various kinds of birds about light; one Blackbird and one "Mountain Thrush" killed striking; fresh breeze S.W.

Arklow North Light-ship.-January 18th, two at 8 A.M.; flew towards land at noon. March 27th, Blackbirds, Thrushes, and Curlew about lantern all night; sleet and snow, wind N.E.; several birds killed. November 11th, numbers, with Thrushes and Starlings-[Leg and wing received]: 18th, two about light; one hen killed striking-[Leg and wing received]: 23rd, numbers (see under Thrush) : 24th, several Larks, Thrushes, Blackbirds, and Starlings about light; wind light variable, rain; one or two hen Blackbirds killed striking; several birds fell overboard: 2ōth, several from 9 P.M. to midnight; one hen killed striking.

Codling Bank Light-ship.-November 11th, 23rd, 24th, and 25th, several, with Starlings and Thrushes, about light each night; wind light and moderate S. and S.S.W. [Legs and wings of three Blackbirds received, killed striking on 9 th, 10th, and 25th.]

Howth Baily.-March 11th, Blackbirds and Thrushes at station; frost and snow. October 3rd, two young Blackbirds about the banks. November 19th, one caught against glass.

Rockabill.-September 21st, one killed striking; wind light E. October 2nd, several all day and night; one killed striking-[Leg and wing received]: $27 \mathrm{th}$, some all night; strong breeze S., fog-[Legs and wings of two received]. November 9th, several, with Starlings, all night hovering; some disabled; wind S., rain: 22nd, several Blackbirds, Thrushes, Starlings, and Larks all night; some disabled and killed; wind fresh S.W. [Leg and wing of Blackbird received.] 
Drogheda, $N$.-January 8th, great rush all day going S., with nine other species (see under Golden Plover).

Copeland (Mew) Island.-January 4th, 5th, and 6th, several all day, remaining: 8th, Blackbirds, Thrushes, etc., all day, remaining; some very weak; strong gale N.E., severe snowstorm: 9th, some Blackbirds, Thrushes, and Larks on island in a weak state: 10 th, 11 th, 15 th, 17 th, and 22 nd, February 3rd, 10th, and 17th, Blackbirds noted: 24th, birds round light all nïght, including Blackbirds, Thrushes, and Starlings: 26th and 27th, March 5th, 10th, 17th, 18th, 20th, and 25th, some noted. April 3rd, several pairing. October 18th and 19th, some on island. November 23rd, some on island all day.

Maidens South,-January 7th, Blackbirds, with Larks and other species, going S.E. ; gale N.W to N.: 9th, one going S.W.; snow. February 27 th, three at lantern : 28th, one; wind light E., clear. March 19th, two (cock and hen) caught on balcony at 10 P.M. ; fresh breeze S.E.; let go in the morning, and flew S.; others at lantern: 20th, one caught on balcony; let go at daylight; flew S.: 25th, some at lantern; one caught. November 2nd, one going S.; gale S.E. : 21st and 22nd, rush of Thrushes, Blackbirds, and other birds: 23rd, some, with Thrushes and other birds, round lantern; one caught; let go and flew W.: 24th, rush of Blackbirds, Plover, etc., from 7 P.M. to 11 P.M.; wind fresh S.E., gloomy. December 4th and 5th, some going S.W.; snow.

Innishtrahull.-January 11th, numbers of Blackbirds, Thrushes, and Snipe; wind moderate N.N.W. February 27th to 29th, several striking, with Thrushes and Larks; some killed. September 30th, two on island. October 23rd, four, and seven Thrushes, on island; strong breeze N., snow; fresh arrivals. November 19th and 20th, five striking, three killed: 22nd, some striking all night, one killed; gale $\mathrm{E}$.

Tory Island.-February 26th, one male at station. March 2nd, female killed striking: 3rd and 4th, midnight to 5.30 A.M., great numbers of Blackbirds, Thrushes, Skylarks, and Starlings striking lantern; some disabled, one Thrush killed; wind light S.E., gloomy: 20th and 21st, a few, with many Thrushes. April 9th, Blackbirds have all left island. November 14 th, some, with Thrushes, at lantern: 18th to 19 th, 
rush of Thrushes and Fieldfares, with some Blackbirds; two hen Blackbirds killed.

Arran Island, N.-April, six going towards Clare at 5 P.M.; wind light W., foggy; two killed striking. July, some Blackbirds and Thrushes here the greater part of the month; a flock of about sixty-[Some error here, perhaps Missel-Thrushes]seen on the 14th and 20th, going in the direction of Slyne Head.

Arran Island, S.-October 31st, two struck light; they breed here.

Tearaght.-January 5 th to 10 th, numbers; frost and snow: 17th, a number. February 19th and 27th, some. April 6th, five going E. at 8 A.M. [November 15th, Leg and wing of Blackbird received, killed striking.] December 1st, flock on island: 11 th, some do. ; gale N.W.

RiNG-Ouzel (Turdus torquatus, Linn.).

Lucifer Shoals Light-ship.-April 9th, one "black bird with a large white ring round his neck about an inch thick; he was about the size of a Blackbird; never saw one like it before; he rested and flew to S.W."

Killybegs.-November 30th, one Ring-Ouzel, "an old bird I think," going S. at 1 P.M.; fresh breeze N.W.

HedGe Sparrow (Accentor modularis, Linn.).

Howth Baily.-December 14th, one observed.

Tearaght.-January 15 th and February 25th, numbers of Hedge Sparrows noted. [March 13th, Hedge Sparrow caught; received in flesh.] May 15th, four going S. at 6 P.M.; strong breeze N.W. September 28th, two on island. October 18th, four do. December 25th, a number; wind light $\mathrm{E}$.

\section{Roвì (Erithacus ?'ubecula, Linn.).}

Tuskcur.-September 21st and 22nd, great rush of Robins, with Thrushes, Larks, Redwings, Chiffchaffs, Wheatears, Whitethroats, Wagtails, Swallows, and other birds (see under Chiftchaff); wind moderate E., gloomy.

Howth Bcily._May 26th, one struck lantern at 11.30 P.M., and was caught on balcony. 
Copelend (Mew) Island.--January 24th, "a Robin Redbreast has been on island for several weeks."

Maidens South.-August 24th, one on rock all day; wind light $\mathrm{N}$.

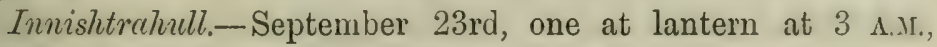
killed; wind moderate S., gloomy.

T'araght.-April 30th, one Robin Redbreast at 10 A.M.; wind moderate $\mathrm{S}$.

\section{Stonechat (Pratincola rubicola, Linn.).}

Copeland (Mew), Island.-April 3rd, a few "Stone-chatters" pairing.

Maidens South.-August 23rd, two Stonechats on rock all day; wind light N.: 24th, five do.: 28 th, two do. September 11 th and 20 th, two. December 5 th, three going S.W. at 10 A.M.; gale N.W., heavy snow.

Innishtrahull.-January 10 th, four on island at 11 A.M. ; gale N.E. : [14th, one received in flesh; shot].

Rathlin O'Birne.-June 3rd, ten on island.

Killybegs. -January 10th, "five small birds caught in crib"[Five Stonechats received]. October 4th, one; "very late in the year to see one of these birds here."

Tearaght.-February 20th, a number. April 25th, twenty at 8 A.M. ; wind light N.W. August 2nd, some on island. November 10 th, several.

\section{Whinchat (Pratincola rubetra, Linn.).}

Blachuater Bank Light-ship.-May 25th, several "small birds" about light from midnight to 3 A.M.; wind moderate S.W.; one killed striking. [Leg and wing of Whinchat received.]

\section{Wheatear (Saxicola cenanthe, Linn.).}

Hook Tower:-March 19th, one at 10 A.M. ; first seen; fresh breeze S.E., blue sky: 25th, Wheatears, with Larks, about lantern at night; great rush of birds at this time, chiefly Starlings; one Wheatear picked up dead next morning[Leg and wing received]. June 18th, one. September 22nd, two, and one Swallow, at lantern at 8 P.M. : 24 th, one at light. 
Tuskar-April 29th, great rush of birds, including Wheatears, this night (see under Willow Wren)-[Leg and wing of Wheatear received]. September 21st and 22nd, great rush of Wheatears and other birds (see under Chiffchaff). [Wheatear received.]

Blackwater Bank Light-ship,-March 25th, Wheatears about light all night; wind light S.W.; one killed striking: 26th, about a hundred birds killed striking; Curlew, Starling, Blackbird, and Wheatear noted-[Leg and wing of Wheatear received]. May 10th, one.

Arklow North Light-ship.-[September 29th, Wheatear received in flesh, killed striking.]

Codling Bank Light-ship.-May 5th, two during day.

Howth Baily.-March 25th, first observed this year. August 19th, small bird, like Wheatear, flying about inside lantern. September 1st, Wheatears against glass from 1.30 A.M. till morning: 28th, a few still about the station.

Rockabill.-September 20th, Wheatear all night; gale E., rain.

Drogheda, N.-April 28th, two; first seen this season. May 5 th and 10 th, numbers all day about rabbit-warren; Wheatears observed more or less every day since April 28th. "I think these birds are breeding in rabbit-holes, as I saw several go in." Several young Wheatears about warren towards end of June and in July.

Innishtrahull.-April 8th, two; first arrival; wind light S.E.: 24th, four. September 18th, five on lantern glass at 2 A.M. ; two killed striking; fresh breeze W.

Tory Island.-April 9th, two: 10th, in pairs on island: 13 th, numerous to-day.

Rathlin O'Birne.-March 11th, seven at noon; wind light S.E.

Sedge Warbler (Acrocephalus phragmitis, Bechst.).

Mine Head.-October 15th, one Thrush and three Sedge Warblers at 8.30 P.M. ; kept flying round the light.

Hook Tower.-May 5th, one Sedge Warbler and one Willow Wren killed at lantern; fresh breeze N.E.: 24th, two killed striking; wind S.E., fog and rain-[Received in flesh]: [29th, Sedge Warbler received in flesh, killed striking]. August 22nd, one at 11.30 P.M.; gale S.E. : $23 r$ d, one caught at lantern at 
11.30 P.M.; wiud light S.E. [Received in flesh]. September 23rd, one killed striking.

Blackwater Bank Light-ship.--May 17th, four about light from 11 P.м. to midnight: 22nd, 23rd, and 24th, several about light; four killed striking on 23rd; wind moderate S.W. [Leg and wing received.]

Arklow South Light-ship.-May 23rd, one "Wren" about light at 2 A.M. ; killed; wind light S.W., clear. [Sedge Warbler received in flesh.]

Arklow North Light-ship.-May 23rd, one small bird at 4 P.M. on deck; caught, and died; wind fresh S.W., fog. [Sedge Warbler received in flesh.]

Howth Baily.-[May 24th, two Sedge Warblers received in flesh, killed striking.]

Maidens South.-May 23rd, one killed striking at 2 A.M.; wind S.W., gloomy-[Received in flesh]. August 24th, one "Warbler" on rock all day; killed at 1 A.M.; wind light $\mathrm{N}$.

Grasshopper Warbler (Locustella novia, Bodd.).

Hook Tower.-May 5th, "Sedge Warbler" (supposed) picked up on balcony. [Grasshopper Warbler received in flesh.]

\section{Whitethroat (Sylvia cinerea, Bechst.).}

Hook Tower.-May 24th, four killed striking; wind S.E., fog and rain. [One received in flesh.]

Tuskar, - April 29th, great rush of birds, chiefly Willow Wrens; one supposed Whitethroat sent, killed striking[Received in flesh]. September 23rd-[Whitethroat received in flesh]-(see under Chiffchaff).

Blackwater Banti Light-ship.-[May 23rd, Leg and wing of Whitethroat received, killed striking.]

Arlilow North Light-ship.-May 25th, one small bird at 9 A.M. dead on deck. [Whitethroat received in flesh.]

Howth Baily.-April 5th, "a little bird like a Whitethroat observed at noon; small birds in rays of light during preceding night." May 24th-[Whitethroat received in flesh, killed striking].

Maidens South.-April 27th, one at 3 A.M., killed striking.

Innishtrahull.-May 28th, three birds killed; one caught at 
glass; sent-[Leg and wing of Whitethroat received.] "One or two Whitethroats are seen here, but they are scarce."

BLACKCAP (Sylvia atricapilla, Linn.).

Maidens South.-[May 23rd, Blackcap received in flesh.]

Innishtrahull.-September 27th, a small bird, and leg and wing of another sent, both caught at lantern. [Willow Wren received in flesh, with leg and wing of Blackcap.]

\section{"WOOD WARBLER."}

Codling Bank Light-ship.-May 10th, one "Wood Warbler" at 9.45 A.M. on ship; calm, light haze.

WiLlow Wren (Phylloscopus trochilus, Linn.).

Hook Tower.-April 28th, one Willow Wren caught at lantern; stroug breeze S. [Leg and wing of Willow IVren received]: 29th, a "Chiffchaff" caugh亡 at glass at 3.30 A.M. ; wind light S.E., rain-[Willow Wren received in flesh]. May 5th, one killed at lantern: 8th, one picked up on balcony. [Received in flesh.]

Tuskar.-April 29th, "great rush of Chiffchaffs, Wheatears, and [Bullinches?-R. M. B.] at night; the first-named very numerous; looked like a snow shower in the rays of light." "Leg and wing of Chiffchaff sent." [Leg and wing of Willow Wren received.]

Lucifor Shoals Light-ship.-April 27th, several "Sallypickers" at midnight (one in lantern); wind fresh N.E. : left for the shore.

Blackwater Bank Light-ship.-April 20th and 21st, "Sedge Warblers" about light; wind fresh S.W., rain; one killed striking-[Leg and wing of Willow Wren received]: 23rd, "Wrens" about light all night; wind light S.WV., rain-[Leg and wing of Willow Wren received, killed striking]. Angust 7 th, one "small bird" found dead on deck at 8 A.M. ; wind light S.E., rain-[Leg and wing of Willow Wren received]: 29th, one unknown bird found dead on deck at $S$ A.M. ; wind fresh S.W., rain. [Leg and wing of Willow Wren received.]

Arklow South Light-ship.-April 10th, one Sallypicker at 
9 A.M. going N.W. May 12th, one Sallypicker about ship during day.

Howth Baily.-August 24th, small birds round lantern; Willow Wren caught against glass-[Leg and wing received]. Great many moths flying through rays and against glass; wind N.W., drizzling rain.

Maidens South.-[May 14th, Legs and wings of Willow Wren received, killed striking.]

Innishtrahull.-September 27 th, a small bird, and leg and wing of another sent, both caught on light. [Willow Wren received in flesh, and leg and wing of Blackcap.]

\section{Chiffchaff (Phylloscopus rufus, Bechst.).}

Hook Tower.-September 23rd, one Sedge Warbler and one Chiffchaff killed striking; wind light S.W. [Leg and wing of Chiffchaff received.]

Arklow South Light-ship.-March 25th, flock of "Sallypickers" about ship at 6 A.M. ; wind light.

Tuskar:-[September 23rd, Chiffchaff received in flesh. "We had a great rush of birds here during the last two nights, Thrushes, Larks, Redwings, Chiffchaffs, Wheatears, Whitethroats, Wagtails (I have very seldom seen the latter flying round light), Swallows, and Robins; wind moderate E., gloomy."]

Blackuater Bank Light-ship.-March 24th, three "Golden Wrens" about light from 8 P.M. to daylight; wind light N.E.; one killed striking. [Leg and wing of Chiffchaff received.]

Innishtrahull.-[April 26th, Leg and wing of Chiffchaff received ; caught at lantern.]

Golden-Crested Wren (Regulus cristatus, Koch).

Hinc Head.-November 10th, one struck at 8 P.M., not killed. December 20th, one.

Tusliar.-February 24th, "Firecrest" at 2 P.M. on rock; wind light S.E., misty.

Arklow South Light-ship.-September 4th, one "Golden Wren" at 11 A.M. about ship; wind light N.W.

Maidens South.-March 25th, one "Golden Wren" at lantern.

Innishtrahull.-March 22nd, a bird caught on the light at 10 P.M. ; wind light. N. ; never seen here before, supposed to be a Firecrest. [Golden-crested Wren received in flesh.] 
WREN (Troglodytes parvulus, Koch).

Barrels Rock Light-ship.-March 25th, one Wren at 9 A.M. about ship.

Tuskar.-January 21st, Wren all day on rock; wind light N.W., clear.

Rockabill.-October 17th, a Wren noted.

Copeland (Mew) Island.-February 10th, a Wren on island. March 5th, 18th, 20th, and October 19th, do.

Maidens South.-March 20 th, one on rock at 7 A.M.; wind fresh S.E. May 7th, one all day.

Tearaght.-February 15th, a number noted. April 30th, five. July 20th, Wrens noted.

\section{Pied Wagtail (Motacilla lugubris; Temminck).}

Tuskar.-September 23rd, one "White Wagtail" sent in flesh-[Pied Wagtail received ?] Great rush of birds during last two nights (see under Chiffchaff), including Wagtails. "I have very seldom seen the latter flying round light. I heard from one of the men who was on shore, that the roofs of our dwellings were covered with Wagtails for a couple of days last week."

\section{"Wagtails."}

Barrels Rock light-ship.-March 17th, one at 5 P.M. about ship; wind light S.W.

Arklow South Light-ship.-May 4th and 8th, one going N.W. at 1 P.M.

Arklow North Light-ship.-May 8th, Water Wagtail about ship at 9.30 A.M.; haze.

Howth Baily.-September 21st, one perched on railing in the morning, seemed tired. October Sth, one near station: 18th, one.

Drogheda, N.-October 25th, seven Water Wagtails going S.W.; wind light E., clear and frosty.

Maidens South.-February 24th, one on rock for an hour; flew N.E. October 4th, two going W. at 11 A.M.

Tory Island.-February 23rd, one at station since 20th; only one seen on island. March 18th, three on island; "never" come near light; one of these is as dark in colour as a Swallow, and 
but that he is with other Wagtails, one would doubt as to what he is ": 20 th, three, including black one, on island. April 14th, two at station at 8.15 A.M.; snow.

Rathlin O'Bine.-April 24th, one all day on island. June 14th, one do.

Arran Island, N.-February, three noted; one disabled striking.

\section{- Titlark (Anthus pratensis, Linn.).}

T'uskar:-September 21st and 22nd, great rush of birds (see under Chiffchaff). [Meadow Pipit received.]

Blackwater Bank Light-ship.-January 10th, one "small bird" dead on deck at 11 A.M. ; wind fresh N.E., snow showers-[Leg and wing of Titlark received]. October 17th, "Larks about light at night; wind light N.E. ; one killed striking." [Leg and wing of Titlark received.]

Arklow South Light-ship.-March 21st, two going N.W. September 11th, one going S.W.: 21st, several at 9 P.M. about light; wind light N.E. : 22nd, a flock going N.W. at 10 A.M.; wind light $\mathrm{E}$.

Codling Bank Light-ship.-January 9th, one caught alive on deck.

Maidens South-August 19th, two all day. November 16th to 26 th, one or two at intervals.

Innishtrahull._" Several on island all the year."

Tory Island.- "Titlarks are always to be seen at station."

Rathlin O'Birne._-"Titlarks at all times."

Arran Island, S.-September 30th, Titlark attacked by Hawk; took refuge in coal-house.

Tearaght.-January 1 st to 7 th, and 26th, Titlarks noted. April 6th, some going E. July 20th, "there are a few on island all the summer." October 18th, Titlarks chasing Mealy Redpole (see under Mealy Redpole). December 17th, flock on island; fresh breeze S.

Rock-PIPIT (Anthus obscurus, Lath.).

Innishtrahull.-December 7th, one "killed at glass"; wind light N.E, showery: [27th, Rock-Pipit received in flesh in spirits, got by one of the islanders].

Tearaight.-April 20th, twenty at 9 A.M. 
SKYLARK (Alauda arvensis, Linn.).

Hook Tower. - February 8th, large flocks of Larks and "Linnets": 26th, one killed striking; wind light S.E., overcast -[Leg and wing received]-(see also under Starling). March 25th, Wheatears, Larks, Starlings, and Blackbirds about lantern at 10 P.M.; wind light E., gloomy; one Wheatear, Lark, and Starling picked up dead next morning; great rush of birds at this time (see under Starling)- [Leg and wing of Skylark received, killed striking]: [27th, Leg and wing of Skylark received, killed striking]. September 21st, Larks, some killed - [Leg and wing of Skylark received, killed striking]. November 10th, one Lark killed striking.

Coningbeg Light-ship.-January 9th, two "Larks" lighted on ship at 10 A.M. ; wind fresh N.E. : 10th, large flocks Thrushes, Larks, and Starlings from 7 A.M. to 3 P.M. going N.; wind N.E., snow showers: 12 th, five Larks at 5 P.M. lighted on ship; wind light N.E.; flew for the land at daylight. October 13th, two Larks at 10 A.M. flying for land; wind fresh N.E.

Barrels Rock Light-ship.-January 10th, great rush, principally Starlings, Linnets, Larks, and Thrùshes, going N. (see under Starling).

Tuskar.-[September 23rd, Skylark received in flesh (see under Chiffchaff).]

Blackwater Bank Light-ship.-January 9th, flocks of Larks going N.W.; wind fresh N.W.: 10th, flocks going N.W.; wind fresh N.E., snow: 18th and 19th, flock all night about light; one killed: 30 th, several about light all night. February 27 th, several about light at night; three killed striking-[Leg and wing of Skylark received]. March 16th, several about light from 9 P.M. to 11.30 P.M., when it cleared, and the birds left: 20th, "several Larks and Thrushes about light; wind light N.E., clear; one killed striking." October 13th, 14th, and 18th, Larks about light: 25th, Larks about light; wind fresh E., clear; one killed striking- $[\mathrm{Leg}$ and wing of Skylark received]: 26th, Larks, Starling, and Thrushes about light from 1 A.M. to 6 A.M. ; wind light S.E.; many killed; flocks of Larks from 9 A.M. to 3 P.M. going N.Wr.: 27 th, four about light: 30 th, flock of Larks going N.N.W. at 10 A.M.; wind light W., clear. November 6 th and 8 th, flocks going N.; clear: 
15th, 18th, 22nd, 23rd, and 24th, flocks about light. December $12 \mathrm{th}, 13 \mathrm{th}$, and 14th, rush of birds ; numbers killed (see under Thrush). [Legs and wings of three Larks received, killed striking on November 15th and 22nd and December 13th. Skylarks and Titlarks are both probably meant by Lark at this station (see under Titlark, October 17th).]

Arklow South Light-ship.-January 11th, 18th, 19th, 20th, 23rd, 24th, 25th, and 29th, "Larks" noted going N.W. and about lantern; wind variable: 31st, several going N.W. February 4 th and 19th, March 1st, 4th, 18th, 19th, 22nd, 24th, and 26th, Larks noted. October 15th and 27th, one noted: 28th, two "Larks" all day about ship. November 12th, two Larks going N.E. December 16 th, one "Linnet" found on deck at 7.30 A.M. [Leg and wing of Skylark received.]

Arklow North Light-ship.-January 6th, many flocks at 2 P.Mr. going N.W.; wind N.W.; "three about the deck": 8th, several about lantern all night; wind N.W., snow; "two killed and two caught on deck": 9th, two Skylarks died on deck: 10th, "Larks" going N.W. February 15th and 17th, one about ship: 19th, several about ship from noon to 5 P.M. ; strong breeze E., snow; "Skylarks fell into water and were drowned": 27th, several about ship. September 20th, one caught on deck between 1 P.M. and 2 P.M. November 24th, several, with Blackbirds and other birds, about light.

Codling Bank Light-ship.-January 8th, several about light; snow showers: 9th, several flocks, with Thrushes, going N.W.; strong breeze N.E.; Skylark killed and eaten by Gull (see under Gulls); four Thrushes, six Skylarks, and one Grey Liunet about ship; gale $\mathrm{N}$., clear: 10th, several large flocks of Larks and Thrushes during day going N.W.; wind moderate N.E : 17th, 18th, 19th, and 20th, Skylarks noted; several flocks : 21st, one Skylark at 10.30 A.M. close to ship; killed and eaten by Gulls. April 3rd, two Larks on ship. October 25th, seven at 11 A.Mr. going N.W. November 10th, several flocks from 10 A.M. to 11 A.M. going in various directions.

Rocliabill.-September 21st, some at 9 P.M. killed; wind light E., misty: 22nd, large flocks all night; several killed; wind light E. October 3rd, several all night; many killed; wind light S.W. November 22nd, Larks and other birds all night; wind fresh S.W.; some disabled and killed-[Leg and wing of 
Skylark received] : 23rd, some, with Starlings and other birds, all night.

Drogheda, N.-January 8th, great rush all day (see under Golden Plover).

South Rock Light-ship.-January 17th, one: 18th, several about lantern from 8 P.M. to midnight: 20 th, several about lantern from 8 P.M. to midnight; wind light S.W.: 21st, two killed. [Legs and wings of two Skylarks received.]

Copeland (Mew) Island. - January 9th, some on island in a weak state: 10 th and 11 th, several. February 26 th, several Larks killed striking; wind light S.E., misty. March 18th, some in rays of light: 24th, Larks and Starlings striking all night; wind light W; none killed: 25th, two striking. [Leg and wing of Skylark received.]

Maidens South.-January 7th, "about a hundred Larks, and some Thrushes, Blackbirds, Starlings, Tits, and six Plover, going S.E. noon to 4 P.M.; gale N.W. to N., snow; three Tits (Titlarks?) and one Thrush perished on rock": Sth, six killed striking; strong gale N.W., snowstorm: 9 th and 18th, a few noted: 19th, two killed striking: 24th, three going S.W. February 11th, five going W.: 27th, six killed striking; wind moderate E. : 28th, two on rock: 29th, three at lantern; went W. at daylight. March 6th and 16th, a few going S.W.: 17th, some, with Thrushes, round lantern: 18th, 19th, 20th, and 25th, a few Larks; one killed striking on 19th; one caught on 20th. April 2nd, fifteen going W.; wind light S.: 3rd, Larks at lantern; fog. September 20th, two killed striking; wind light N.E., clear: 21st, four at lantern. October 3rd, five killed striking. Novenber 1.6th, one, and one Starling, caught: 21st and 22nd, rush of birds, including Lark (see under Thrush): 24th, rush of Larks and other birds (see under Green Plover) : 25th, four going W. December 4 th and 5th, Larks going S.W.; snow; one killed striking.

Innishtrahull.-February 27 th to 29 th, several Skylarks, Blackbirds, and Thrushes striking glass; some killed. May 13th, six killed striking at midnight. September 3rd, eight at 4 A.Mr; three struck, not killed; gale N.: 12 th, ten on lantern at 1.30 A.M. ; wind light S.W. "Skylarks breed on island." November 19th and 20th, nine striking at night; five killed. December 17th, two killed striking; gale S.W.: 19th, three lilled 
striking; wind light S.: 24 th, three at 2 A.M. on glass; not injured.

Tory Island.-March 3rd and 4th, rush of Larks and other birds (see under Blackbird): 17th, Larks plentiful at station and on island to-day: 20th and 21st, great numbers of birds, chiefly Thrushes, striking on N.E. side; some Larks amongst them: 29th, large flocks going S.W.; numerous on island. April 10th, plentiful: 13th, in pairs, numerous. November 14th, Larks and Starlings at lantern from 4 A.M. to 6.30 A.M., and from 6 P.M. to 9 P.M.; several Starlings struck, none killed: 23rd, large flocks all day going S.W.; wind light S., haze; two struck at midnight.

Rathlin O'Birne.-March 2nd, nine noted. May 8th, eight.

Killybegs.-October 10th, a number going E. at 10 A.M. : 27th, two killed striking; wind light S.E. November 9th, a few going N.E.

Tearaght.-April 25th, "three "Larks" at 8 A.M. October 27 th, five Skylarks on island-[Leg and wing of Skylark received, shot]. "There are only four or five on island; they were together."

Snow Bunting (Plectrophenax nivalis, Linn.).

IFine Head.-December 4th, two going S.; strong breeze N.W., snow showers.

Hook Tower.-March 8th, flocks from beginning of January, with Starlings and other birds. December 5th, a flock; wind fresh N.E. ; first seen since spring.

Tuskar:-October 29th, Snow Bunting killed striking; first seen this year. [Leg and wing received.]

Innishtrahull.-September 4th, a very large flock at 2 P.M.; wind light N.W. "Large flock on island all winter." October 24 th, two struck, one killed, at 11 P.M.; wind light N., snow. [Leg and wing received November 9th, killed striking.]

Tory Island.-February 16th, flock all day; wind $\mathrm{N}$., snow : 20th and 21st, flocks on island: 28th, to March 2nd, numbers about: 13 th, they have left station: 17 th, one female caught, supposed to have been hurt during night: 19th, large numbers; "do not seem as light in colour as those up to 13 th of month": 22nd, flock going S.E.: 25th, a flock, light in colour, same as those here up to 13 th ; one or two were nearly white. October 
24 th, one ; first seen: 27 th, ten going S.E. at noon. November 23rd, some.

Rathlin O'Birne.-February 6th, two all day; fresh breeze S.W.

Killybergs.-October 10th, one male at station: 11th, two, male and female: 21st, a few. November 14th, "sixty Buntings" going S. at noon, mostly young birds; wind light N.W.: 20th, flock going S.; strong gale S.E.

Arran Island, S.-October 7 th, two on wall at 1 P.M.; strong breeze N.W.

Tearaght.-September 20th, six on island; went next day: 25 th, two at noon; wind light W.; left at once. October 30th, two. November 10th, five. December 21st, five.

Corn Bunting (Emberiza miliaria, Linn.).

Innishtrahull.-[December 27th, Leg and wing of Corn Bunting received.]

YELLow Bunting (Emberiza citrinella, Linn.).

Blackwater Bank Light-ship.-May 7th, two Yellowhammers noted.

Tory Island.-March 15th, four Yellowhammers on island -two male, two female; wind light S.E., clear; first seen on island for past twelve months. April 13th, two on road.

Rathlin O'Birne.-April 26th, some all day on island; wind light N.W.

ChafFinch (Fingilla coelebs, Linn.).

Hook Tower:-October 18th, one; wind light N.E.

Coningbeg Light-ship.-February 10th, one on board all day; wind light N., clear. March 17th, about thirty at 2 P.M. April 9th, one on ship; wind light N.E.: 26th, one do.: "appeared weary"; wind light N.W. September 22nd, one killed striking; wind light E. October 18th, three at noon on ship ; went for the land; wind moderate N.E.: 14 th and 17 th, "Finches" noted with Starlings: 27th, "Finches."

Blachucater Bank Light-ship.-October 23rd, one caught at 3 P.M. [Leg and wing received] : 26th, two on ship. November 2nd, two at 4 P.M. on ship: 8th, two going $N$. 
Arklow South Light-ship.-March 21st, one about ship. at 4 P.M.: 30th, one do. April 1st, three going N.E.: 3rd, one do.: 5th, one about ship: 7th, one going N.W. at 11.30 A.M. November 11th, two about ship.

Arklow North Light-ship.-November 5th and 6th, one on deck : 10th, one dead on deck. [Leg and wing received.]

Codling Bank Light-ship.-April 4th, two in ship: 7th, one do. May 2nd, two going N.E. November 1st, two rested for fifteen minutes; went N.W.: 5th, two about ship : 6th, several at 10 A.M.: 7th, one going N.W.: 23rd, one about ship.

Houth Baily.-October 28th, one against glass at 9 P.M. November 10 th and 15 th, some about station.

Rockabill.-October 24th, one at midnight killed striking; strong breeze N., clear. [Leg and wing received.]

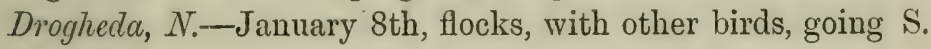
all day; ten species noted (see under Golden Plover).

Maidens South.-February 25th, two going W. March 18th, three on rock; went W. April 6th, two. November 23rd, five during day going S.W.; fresh breeze S.E., gloomy; some also at lantern during night: 26th, one; went W. December 4th, five going S.W. at 8 A.M.; strong breeze N.W., snow : 5th, three do.

Tory Island.-March 20th, 22nd, and 24th, male Chaffinch at station. April 11th, 13th, and 14th, one at station: 17th, three going S.E. ; wind light N. October 27 th, one disabled at lantern; fresh breeze S.W., rain. November 22nd, five to twenty in flocks round station all day: $23 \mathrm{rd}$, some do.

Tearaght.-January 17 th and February 20th, numbers noted. September 20th, two on island. October 26th and 27th, some on island; gale S.W.; "remained some time." November 1st, flock on island; one shot-[Leg and wing received]. December 7 th, flocks on island.

\section{"Tree SParrow."}

Tearaght.-October 28th, one Tree Sparrow on island; wind S. November 1st, one do.; strong breeze S.

SPARrow (Passer domesticus, Linn.).

Hook Tower.-April 12th, one House Sparrow at 9 A.M. ; first observed; wind light E. 
Drogheda, $N$.-June 2nd, numbers all day about station; wind W.; "first seen about here since winter months."

Maidens South.-April 10th, two at 8 A.M. on roof of house; went E. ; fresh breeze N.E.

\section{GREENHINCH (Ligurinus chloris, Linn.).}

Howth Baily.-October 29th, one struck lantern at 7.30 P.M., and was caught on balcony.

Drogheda, N.-January 8th, some, with numbers of other birds, going S. all day (see under Golden Plover).

Tearaght.-January 26th, numbers ; strong breeze S.W.

GoLdFinch (Carduelis elegans, Steph.).

Hook Tower.-November 9th, one picked up dead. [Received in flesh.]

Killybegs.-November 11th, ten going S. at 11 A.I.; wind light S., clear; " the largest number ever seen together."

Siskin (Carduelis spinus, Linn.).

Codling Bank Light-ship.-April 3rd, one.

Drogheda, N.-June 12th, two at 7 P.M. in Mornington House wood; wind fresh N.E.

Mealy Redpole (Linota linaria, Linn.).

Tearaght.-September 25th, two "Redcaps" shot on island; they were together, clinging to little weeds, picking the seed: wind moderate W., gloomy-[Two Mealy Redpoles received in flesh]: 26th, one by itself, shot-[Received in flesh]. October 18th, two Mealy Redpoles observed at 9 A.M. ; wind light E., blue sky; one shot "while perched on a little rock after being chased all over the island by Titlarks; these Redpoles were of a greyer or lighter colour than those shot on September 25th -Charles Hawhins;" wind light E. [Received in flesh. No apparent difference in colour.-R. MI. B.]: 28th, two Redpoles on island in the morning; wind moderate to strong S., misty.

LinNeT, (Linota cannabina, Linn.).

Hook Tower.-February 8th, large flocks, with Larks, all day; wind light N.W. [March 27th, Wing received; killed striking.] 
From July 14th small numbers seen about. October 4th, flock at 11 A.M. chased by Sparrow-Hawk.

Coningbeg Light-ship. - March 17th, about twenty-five at 11 A.M. going N.W.; wind light S.W. April 3rd, one on ship. October 23rd, large numbers at 10 A.M. going for the land; wind light N.W.: 26th, half a dozen going N.E.; strong breeze S. ; "looked dead beat; saw the Gulls killing some": 27th, 30th, and 31st, several flocks going N.E.

Barrels Roch Light-ship. - January 10th, rush of birds, principally Starlings, Linnets, Larks, Thrushes, etc., going $\mathrm{N}$. March 17th, one at 6 P.M. about ship; fog.

Blackwater Bank Light-ship.-January 19th, one about ship; flew N.: 21st, two going N.W. May 9th, two noted. October 25th, flock going N.W.; wind fresh E. November 11th, three about light. December 11th, one dead on deck at 4 P.M.; fresh breeze N.W., clear. [Leg and wing received.]

Arklow North Light-ship.-August 21st, some, and some Thrushes, about lantern.

Codling Bank Light-ship.-January 9th, one caught; gale N. November 1st, flock going N.W.: 5th and 6th, one Linnet noted: 9th, one about ship.

Howth Baily.-November 10th and 15th, some about station. Rockabill.-October 17 th, one caught at night; strong breeze E., rain.

Drogheda, N.-January 8th, flocks, with other birds, going S. all day (see under Golden Plover).

Maidens South.-April 3rd, one going S.W. November 23rd, three going S.W. December 4th, three do.; snow : 21 st, three going S.W.

Tory Island.-April 10th, large flocks of Grey Linnets going S.E. from 8 A.M. to 10 A.M. ; wind light E.; four flocks observed coming in from W. and flying S.E. to mainland; some flocks settled on island: 11 th, flocks round station up to 9 A.M.: 13 th, flock going S.E. at 9 A.M. ; fresh breeze N.E., hail ("I think I never saw a Grey Linnet strike lantern"): 17th, flocks round station. October 27 th, six at 8 A.M. ; wind light S.W.: 28 th, a flock. [Possibly Twites.-R. M. B.]

Arran Island, N. - March, ten noted; snow. June, "no birds seen on island this month save a flock of Linnets, which were here for several days. August, on island almost every 
day this month. October 18th, twenty going $\mathbf{N}$.; wind light E., foggy; eight struck glass and were disabled.

Arran Island, S.-September 5th, twenty perched on wall at 9 A.M. ; fresh breeze S.W.; first flock observed: 22 nd, immense flock going N.E. at 10 A.M. ; wind light E. ; "apparently coming from inland." October 17 th, very plentiful.

Tearaght.-February 19th, a number; strong breeze E.; snow. May 10 th, ten at 4 P.M. ; wind light S. July 20th, four going S.E. September 28th, a number on island; wind N.E. October 18th, several. November 20th, and December 7 th, 17 th, and 31 st, some.

\section{TwITE (Linota flavirostris, Linn.).}

Killybegs.-January 10th, a "Grey Linnet" sent-[Twite received]. October 8th, twenty-seven Twites going $\mathrm{E}$. at 10 A.M.; fresh breeze N.W.; apparently young birds: 10th, flocks going E. at 10 A.M.; fresh breeze N.: 11th and 21st, flocks going $\mathrm{E}$.

\section{"BULlFinch."}

Hook Tower.-January 10th, one at 3 P.M.; wind fresh N.E.

Tuskar.-April 29th, great rush of "Chiffchaffs, Wheatears, and Bullfinches." [No Bullfinch has ever been received by me from any Irish light-station.-R. M. B.]

STARLING (Sturnus vulgaris, Linn.).

Mine Head.-October 13th, four at 8 P.M. going IV.; one killed: 19 th, three: 24 th, two at 9 P.M.; one struck. November 19th, five at 11 P.M. round light. December 8th, four at 7 P.M. going $W_{\text {. }}$; one disabled.

Hook Tower.- "From the beginning of January immense flocks of Starlings, Plover, Larks, Snow Buntings, and other birds about, owing to the severe cold. Some were seen going farther south from this." March 5th, one Starling killed striking; wind moderate S.E. [Leg and wing received]: 24th, Starlings striking from 10 P.M. to morning; eight killed; wind light S.E., gloomy: 25th, large flocks flying from S. to N. at 9 A.M.; wind light E., gloomy; one picked up dead next morning: 27th, immense numbers of Starlings striking lantern from 9 P.Mr. to morning; several killed; also three female Blackbirds 
and three Redwings killed-[Leg and wing of Starling received]. There were large numbers of Starlings, Wheatears, Larks, Blackbirds, and Redwings striking from 25th to morning of 27 th ; wind chiefly light E. June 14th, a flock at 8.30 P.M. July 14th, flocks of Starling, Plover, and Curlew seen. October 4th, 15th, 16th, 18th, 20th, and 26th, Starlings noted; two killed striking on last date.

Coningbeg Light-ship.-January 10th, large flocks of Thrushes, Larks, and Starlings from 7 A.M. to 3 P.M. going N.; wind N.E., snow showers: 12th and 13th, a few on ship in the evening; flew for land next morning. February 13th, two noted: 19th, several large flocks, with some Green Plover and small birds, from 8 A.M. to 5 P.M.; strong gale E., heavy snow; "trying to get to land, blown to leeward with the gale." March 25th, great numbers round lantern; several killed; wind light N.E.: 26th, five at 10 A.M. going N.W. "very much exhausted." October 13th, a few at 8 P.Mr.; left about midnight; strong breeze N.E.: 14th and 17th, some Starlings and "Finches" 8 P.M. to midnight: 18 th, nine at 4 P.M. ; went for the land: 24 th, 25 th, and 26th, a few noted in the evenings. December 13th, Starlings round light.

Barrels Rock Light-ship.-January 8th and 18th, a few noted: 10th, "about a thousand common birds, principally Starlings, Limets, Larks, Thrushes, etc., during day going N.; wind fresh N.E., hail and snow showers." March 19th, a small flock at 9 A.M. going N.E. December 9th, one on board: 29th, two noted.

Tuskar:-January 8th to 20th, Starlings night and day going W.; wind N. ; two killed striking: 27th, two killed striking. February 9 th to 13 th, some round light: 16th, some going S.E. : 28th, flock of Lapwing and Starling at 11 A.Mr. going W. October 29 th, flocks passing day and night; some will remain with us till Narch or April. Starling and Purple Sandpipers are our only companions during the winter.

Blachwater Bank Light-ship.-January 4th, one at 11 P.M.; killed striking: 8th, 9th, and 10th, flocks going N.W.: 30th, one caught at light. February 19th, flocks going N.W.: 20th, three about light: 25 th, flocks at 8 A.M. going S.E.: 27 th, several about light from midnight to 6 A.M.; two killed striking - [Leg and wing received]. March 24th, 
25th, and 26th, several about light; many killed striking[Leg and wing received]. October 13th, 14th, and 26th, some about light: 27 th, flocks going N.W.: 28 th, flock going N. at 8 A.M. : 29 th, several about light from 1 A.M. to 5 A.M.; three killed; and flock going $N$. at 11 A.M. November 2nd, 6th, 8th, 15th, 21st, 23rd, 24th, and December 7 th and 10th, flocks about light going N. or N.W.: 12th, 13th, and 14th, rush of birds; numbers killed, chiefly Thrushes. [Leg and wing of Starling received, killed striking on 13 th.]

Arklow South Light-ship.-January 8th, 9th, and 11th, some going N.W., snow. February 25th, one: 26th, two on ship: 27th, one going N.W. March 23rd, one killed striking; clear: 25th and 26th, flocks about light. April 1st and 4th, one noted. October 13th, a large flock going W. at 10 A.M. ; wind fresh N.E. ; first seen: 14th and 28th, one noted: [26th, Leg and wing received, killed striking]: 19th and 31st, and November 1st, 2nd, 3rd, and 17th, flocks noted going N.W.: 18th, several birds of various kinds about light; wind S.E. to W., heavy rain; none killed (see under Fieldfare, Rockabill station): 19th, large flocks during day going $\mathrm{N}$. December 3rd, one killed.

Arklow North Light-ship.-Januàry 9th and 10th, numbers during day; snow showers; two caught on deck: 30th, one caught inside lantern. February 12 th, one rested on mizzenboom: 16th, several about light: 20 th, two rested at 10 P.M.; strong breeze S.E., snow; went overboard: 25 th, one on mast; went N.W. March 29th, one. April 3rd, one about ship. November 2nd, 4th, and 5th, flocks going N.W.: 11th, 23rd, and 24th, numbers of Thrushes, Blackbirds, and Starlings at light; several killed.

Codling Bank Light-ship.-January 8th, flocks, with Thrushes, going N.W.: 10th, one on ship. November 11th, several, with Blackbirds and Thrushes, from 8 P.n. to midnight about light; wind light S.W., gloomy; many killed and disabled: 23rd, 24th, and 25th, several Blackbirds, Thrushes, and Starlings about light at night, with other birds on last two dates ; one killed striking; wind light and moderate S.W., haze and rain.

Howth Baily.-October 17th, some struck lantern at 11 P.M.; one caught. December 13th, one struck lantern.

Rockabill.-October 14th, several all night; gale E, rain: 
17th, several all night: 27 th, Starlings all night; some killed. November 9 th, several, with Blackbirds, at light; some disabled: 18th, greatest rush of season, Fieldfares, Starlings, and Redwings noted (see under Fieldfare): 22nd, rush of Blackbirds, Thrushes, Starlings, and Larks : 23rd, Starlings and Larks all night; some disabled; fresh breeze. S.W.

Drogheda, N.-January 7th, large flocks all day; snow: 8th, rush all day going $\mathrm{S}$; t ten species, including Starling, noted (see under Golden Plover). June 14th, about a hundred on warren at 4 A.M., mostly young birds (see Hook Tower, same date): 22nd, five, all young birds, going $\mathrm{N}$.; flying low, and resting every hundred yards or so: 23rd, large flock, mostly young birds. July 10 th and 13th, a large flock going $N$.; all seemed this year's birds. November 21st, two large flocks all day. December 7 th, a large flock about station.

South Rock Light-ship.-January 18th, a flock going N.W. at 10 A.M. ; wind light S.E. : 20 th, two round ship.

Copeland (Mew) Island.-January 10th, flocks all day: 14th, 20 th, and 24th, some noted. Constantly noted during February and March on island and round light, and striking. April 2nd, flock all day, remaining; pairing; wind light S. October 7th, 18th, and 19th, some noted. December 4th, flock of thirty: 19th, large flocks, remaining; wind light W.

Maidens South.-January 7th, some going S.E., with Larks and other birds: 8 th, three killed striking; strong gale N.W., snow: 24th, one at lantern at 2 A.M.; clear. March 17th, two caught on baleony at 11 P.M.; let go in the morning, flew N.E.: 18th, 19th, and 25th, some noted, and two caught. November 2nd and 3rd, a few going S. and S.W.: 16th, one Starling and one Lark caught on balcony at 4 A.M. ; wind light W., clear; let go at daylight, went W.: 24th, rush of "G. Plover" and other birds (see under Green Plover).

Innishtrahull.-May 28th, six on island. October 18th, some do. November 22nd, three killed striking; gale S.E. December 24th, six all night. [Leg and wing received on 27th.]

Tory Island.-March 3rd and 4th, great rush of Blackbirds, Thrushes, Larks, and Starlings ; some disabled: 13th, numerous on island: 19th, flocks do.: 20th and 21st, some striking on N.E. side (see under Thrush). April 9th, all have left island. 
November 14th, some, with Larks, at lantern: 21st and 22nd, rush of birds, some Starlings amongst them: 23rd, large flocks on island: some noted between 24 th and 28 th; the only birds about island.

Killybegs.-October 11th, large flock going E. November 2nd, very large flocks all day, remaining.

Arran Island, N.-January 10th, a few, with a few "Crows," going towards Co. Clare. May 4th, 9th, 15th, and 20th, some all day going $\mathrm{N}$. November, a few going $\mathrm{S}$.

Arran Island, S-October 10th, Starlings feeding on crag; first flock observed; four killed previous night. November 1st, three struck light; a great quantity on island.

Tearaght.-January and February, hundreds noted. October 4th, two: 19th, one. November 1st, flock on island: 5th, some noted. December 1st, a flock.

Chough (Pyrrhocorax graculus, Linn.).

Tory Isiand.-March 2nd, two "Red-leg Jackdaws" on island; wind light S.E; first seen : 26th, two, paired to breed in cliffs.

Rathlin O'Birne.-April 7th, two; they breed here. June 10th, two.

Killybegs.-November 28th, six going S.W.; strong gale S.W.; seldom seen here.

Tearaght.-July 28th, "seven Choughs (Crows)." August 7 th, ten on island. October 1st, ten; "seem to stop here for some days": 25 th, flock going S.E. November 20 th, seven.

\section{RAVEN (Corvus corax, Linn.).}

Howth Baily.-March 26th, two observed at station.

Tory Island.-March 26th, two paired to breed in cliff's.

Rathlin O'Birne.-February 23rd, two at noon; gale S.L. July 25 th, two on island.

Arran Island, N.-December 8th, six Ravens and one Hawk near station.

HOODED CRow (Corvus cornix, Linn.).

Hook Tower.-April 10th, two; wind E.

Innishtrahull._"Two Black-hooded Crows build on island." 
I'ory Island.-February 20th, one; wind E., snow. March 26th, two paired to breed. April 13th, two nest on cliffs.

Arran Istand, N.-March, three Crows, spotted on neck, large species. [Possibly Hooded Crows.-R. M. B.]

Tearaght.-October 19th, four; remained some time. November 12 th, four.

\section{Rook (Corvus frugilegus, Linn.).}

Tuskar.-January 7th, six "Crows" at 2 P.M. going W.; "seemed fatigued"; wind light N.: 26th, "Crow" at noon on rock; fog.

Arklow South Light-ship._June 14th, one "Crow" going N.E. Arklow North Light-ship.-April 3rd, one Crow going N.E.

Drogheda, N.-April 25th, large flock going N., flying very high; strong breeze N. October 28th, about two hundred going N., flying high. November $24 \mathrm{th}$, great numbers all day about station. December 13th, flocks of Gulls and Rooks.

Maidens South-March 20th, one Crow going S.W.: 24th, two going W: April 3rd, one going. W.; fog.

Tory Island.-March 15th, one Common Crow going S.; lighted on top of lantern, and flew to mainland.

Rathlin O'Birne.-March 4th, forty going W.; fresh breeze S. July 21st, flocks of "Crows" going W. at 8 A.M.; wind light $\mathrm{N}$.

Arran Island, N.-January 10th, twelve "Crows" going towards Co. Clare. In March, "three, spotted on neck, large species"-[Possibly Hooded Crows.-R. M. B.] September, "no birds except a flock of Crows, which came nearly every day from Innishmore in the forenoon, and went back about sunset." Arran Island, S.-October 30th, forty Rooks passing to mainland.

Tearaght.-January 24th, four Rooks; wind light N.W. February 20th, twenty "Common Crows"; gale E., heavy snow. May 10th and August 2nd, five. December 21st, a flock on island.

\section{JACKDAW (Corvus monedula, Linn.).}

Houth Baily.-March 26th, a great many breed close by in the cliffs.

Copeland (Mew) Island.-May 24th, a few remaining. 
Arran Island, S.-September 2nd, four; they build on islaud. Tearaght.-October 25th, two; wind light E. November 12 th, six at noon; gale $\mathrm{N}$.

Magpie (Pica rustica, Scop.).

Copeland (Mew) Island.-May 10th, two at 5 A.M. going W.; wind light $\mathrm{S}$.

Tory Island.-April 9th, two on island at 10.30 A.M. ; came from S.; first seen; wind light S.E.

Arran Island, S.-September 10th, four Magpies on wall at 3 P.M.; wind light N.W.; rarely seen here.

SWALLOW (Hirundo rustica, Linn.).

Hook Tower.-April 10th, several about at 3 P.M.; wind E., blue sky. May 4th, three at 6 P.M.; fresh breeze N.E.: 6th, two. September 20th, Swallows and Swifts in great numbers all day; wind moderate S.E., mist, rain; Swallows taking their departure to the S.: 21st, Swallows and Maybirds at 9 A.M.; strong breeze N.E.: 22nd, one at lantern at 8 P.M.; not killed; wind light $\mathrm{E}$.

Coningbeg Light-ship.-April 6th; two going N.; wind light N.E. : 26 th, three flying for the land: 27 th, one do. September 18th, one on ship: $22 \mathrm{nd}$, one flying round deck. October 6th, one at 4 P.M.; wind fresh $\mathrm{N}$.

Barrels Rock Light-ship.-May 6th, some seen: 7th, ten noted; two lighted on board and remained till next day: 9th, some going N.; wind light S.E.: 21st, two at noon going $N_{\text {. : }}$ 23rd, four about ship; "left at dusk": 25th, one lighted on ship. June 17th, a flock going S.E. during forenoon ; rain.

Tuskar.-September 21st and 22nd, great rush of birds, including Sivallows (see under Chiffchaff). "Just before the last gale, about a week ago, I noticed large flocks of Swallows flying W.; they must have had some warning of the approaching storm, and were turning back." October 29th, "Swallows passing in small flocks till within a week ago."

Lucifer Shoals Light-ship.-April 7th, two going N.W.; wind light N.E. May 4th, several round ship; wind fresh N.E.: 13th, several flocks going W.; wind light S.W., rain. August 16th, Swallows from 8 A.M. till noon about ship; wind moderate S.E. 
Blackwater Bank Light-ship.-April 5th, one going N.; wind light S.W., thick haze: 23rd, several about light; wind light S.W., rain-[Leg and wing received]: 26th and 28th, several going W. and N.W. May 5th, several going N.W. all day; wind light N.E.: 7th, do.: 8th, 9th, and 10th, a few do.: 13th, flocks do.

Arklow South Light-ship.-May 2nd, several going N.W.: 3rd, 5th, 6th, 7th, and 10th, several going N.W. during day: 13th, two: 14th, several going W.: 19th, 27th, and June 9th, one to three noted going N.W.: 10th, three going S.: 14th, four going S. September 23rd, several going S.E.: 26th, several going N.W.: 29th, one going S.W.

Arklow North Light-ship.-April 20th, several going N.W.; wind light S.W., clear; first seen this year. May 7th, several going N.W.: 9 th, several flocks from 9 A.M. to 5 P.M. going N.W.; wind light S., flying low: 10th, several flocks from 6.30 P.M. to 7.30 P.M. about ship; several rested on main rigging: 11th, six going N. August 28th, several at 11 P.M. about lantern; clear, hazy at intervals; wind light S.W.; one killed striking.

Codling Bank Light-ship.-April 3rd, two going N.W.; calm, clear. Through April and up to May 18th, Swallows constantly noted, from one to four at a time, generally going N.W. and W.N.W.; sometimes about ship; one died on ship. May 8th - [Leg and wing received]-several noted about light same night; clear.

Howth Baily.-August 4th, "fine clear night; a great many moths, flies, and small winged insects on the lantern glass; birds-Swallows, I think-were flying about through the rays, catching the moths or flies-EDWARD M'CARRoN": 27th, small birds flying about lantern; "a great many birds flying about at a great height, seemingly Swallows, perhaps assembling on the eve of their departure." September 28th, Swallows still about the station.

Rockabill.-September 21st, one at noon. October 1st, one all day.

Drogheda, N.-April 23rd, several; first seen this season: 30th, numbers. May 8th, some all day: 9th, numbers: 17th, several, with Swifts: 26th, twenty going N.W. in a flock. June 2nd, two: 6 th, three. 
Maidens South.-April 10th, two going W.: 12th, two going S.W. : 23rd, two going W.: 24 th and 25th, three, and one going S.W. and W.: 26th, one going W.

Innishtrahull.-June 12th, four at noon; strong breeze N.

\section{"Martin."}

Hook Tower.-April 2nd, three "Martins" at 10 P.M.

Lucifer" Shoals Light-ship.-May 17th, several Martins; wind fresh W.

\section{SwIFT (Cypselus apus, Linn.).}

Hook 'Tower.-September 20th, Swallows and "Swifts" in great numbers all day.

Drogheda, N.-May 12th, one going N.: 17th, several: 18th, several about river: 20th, numbers going $\mathrm{N}$. all day; gale N.W.: 21st, dozens of Swifts: 22nd, several. June 23rd, three.

Cuckoo (Cuculus canorus, Linn.).

Howth Baily.-May 8th, first heard.

Drogheda, N.-May 5th, first heard.

\section{WRYNECK (Iÿnx torquilla, Linn.).}

Innishtrahull, in lit. 24/3/92, 26/4/92,31/5/92.- "A Wryneck was shot on Rathlin O'Birne in 1878 by the principal lightkeeper there, John Tottenham, who stuffed it, but I find on inquiry it went to loss. I think it was in the month of October. I was there then, but we did not know it was a Wryneck. The principal keeper on North Arran-[Thomas Fortume.-R. M. B.] - got one (see 'Migration Report,' 1886, p. 39), and I knew, when I saw it, it was the same lind.-George Gillespie" [who was on North Arran as assistant-keeper in October 1886.R. M. B.].

KiNGFisher (Alcedo ispida, Linn.).

Licifer Shoals Light-ship.-April 30th, one Kingfisher at noon going N.W.; wind light S.W.; "rested, and left for the shore."

Drogheda, N.-November 24th, these birds frequent the streams about Mornington House. 
"Pigenons."

Hook Tower:-February 15th, seven Rock Pigeons. March 6 th, 7 th, and 8 th, seven or eight do.

Drogheda, N.-May 20th, one small Blue Pigeon going N.W.

Copeland (Mew) Island.-November 24th, a white Pigeon perched on dome of lighthouse at sunrise, then flew towards mainland.

Maidens South.-February 28th, one Blue Pigeon going N.E.

Arran Island, S.--September 24th, fifteen Wild Pigeons on crag; not common here.

Tearaght.- "Rock Pigeons remain here during winter."

"PARtridge."

Arklow North Light-ship-July 22nd, "one Partridge flying around ship from 3.30 A.M. to 4 A.M.; calm, fog."

\section{QUAIL (Coturnix communis, Bonn.).}

Tuskar.-September 22nd and 23rd, great rush of - birds at night (see under Chiffchaff). [One Quail received in flesh, killed striking.]

Lucifer Shoals Light-ship.-[November 1st, Leg and wing of Quail received, killed striking.]

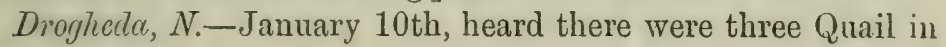
rabbit-warren.

Conn-Crake (Crex pratensis, Bechst.).

Tuskar:-April 30th, a Land-Rail on the rock to-day; the first this year.

Drogheda, N.-May 15th, Corn-Crake heard in fields near lighthouse.

Innishtrahull.-June 12th, one Corn-Crake on island at 10 A.M. ; strong breeze N.

Rathlin O'Birne.-May 6th, one Corn-Crake on island at 6 P.M.; wind light N.E.

WATER-RAIL (Rallus aquaticus, Linn.).

Tuskar:-[October 29th, Leg and wing of Water-Rail received, killed striking.] 
Killybegs.-November 29th, one Water-Rail all day; strong gale N.W.

Arran Island, S.-October 29th, Water-Rail struck light at 3 A.M. going S.E.; strong breeze N.W., squalls. [Received in flesh.]

WATER-HeN (Gallinula chloropus, Linn.).

Blackwater Bank Light-ship.-August 23rd, one "unknown bird" about light at 2 A.M., killed striking; calm, rain. [Leg and wing of Water-Hen received.]

\section{BALD CоOT (Fulica atra, Linn.).}

Blackwater Bank Light-ship.-November 24th, one Bald Coot killed striking at 8 P.M.; wind moderate S.E., rain. [Leg and wing received.]

Killybegs.-November 28th, one Bald Coot at 2 P.M.; strong gale S.W.; "not seen one for past twelve months."

Arran Island, S.-October 18th, Bald Coot struck light at 2.30 A.M. going N.E. ; wind light N.E. ; clear. [Received in flesh.]

\section{Ringed Plover (Agialitis hiaticula, Linn.).}

Drogheda, N.-May 13th, Sand Plover's egg picked up among gravel a little above high-water mark on bank of river. [Ringed Plover's egg received.]

Copeland (Mew) Island.-April 3rd, a few "Ring Plover" arrived to breed; wind light S.E.

Innishtrahull.-July 5th, one "young Dotterel" on island; "breed on island."

Tory Island.-February 16th, "Ring Plover" all day, thirty to fifty in flocks ; wind N., snow : 20th, flocks of Grey and Ring Plover on island.

Rathlin O'Birne.-March 14th, two Dotterels. April 15th, two Dotterels at noon; wind moderate N.E. [Ringed Plover received in flesh.]

Golden Plover (Charadrius pluvialis, Linn.).

Mine Head.-October 24th, flock seen going E. December 5th, flock going S. : 8th, flock. 
Hook Tower.-February 19th, flocks of Golden and Lapwing Plover all day; gale W., snow. September 20th, four "Grey Plover." November 14th, one do. found dead.

Barrels Rock Light-ship.-March 7th, one "Grey Plover" going N.E. .

Blackwater Bank Light-ship.-September 22nd, several Golden Plover about light from 8 P.M. to 11 P.M. ; wind light S.E.

Arklow South Light-ship.-February 22nd, flock of "Grey Plover" going E. March 24th, two do. about light.

Drogheda, N.-January 8th, continuous flocks of Golden Plover, Lapwings, Starlings, Redwings, Thrushes, Blackbirds, Larks, Linnets, Chaffinches, and Greenfinches all day going S.; heavy frost and snow; one Redwing killed. "This migration continued until the 10 th, when a thaw set in. Very few birds killed, as they did not rest on their way past here, and all flew very high with the exception of small birds and Lapwing." February 27th, four.

Maidens South.-August 23rd, six Golden Plover going S.W.

Innishtrahull.-February 13th, one on island: 20th, three. June 12th, two.

Tory Island.-February 20th, flocks of Grey and Ring Plover on island; snow: 29th, to March 2nd, Golden Plover noted on island. April 12th, large flock of "Grey Plover" lighted on island about 11.30 A.M.; in a few minutes a Hawk swooped amongst them and carried off one; strong breeze N.E.: 16th, flocks of "Grey Plover" on island; snow.

Rathlin O'Birne.-April 15th, one Golden Plover at noon; shot-[Wing received]: 20th, twelve. May 17th, eighteen.

Killybegs. - [April 15th, Golden Plover shot; received in flesh.] Arran Island, S.-October 23rd, five "Grey Plover" going N.E.; wind light N.; first seen this year.

\section{Green Plover (Vanellus vulgaris, Bechst.).}

Mine Head.-October 25th, flock going E. November 2nd, flock going E. : 15th, and December 14th, flock going W.

Hook Tower:-January and February, large flocks Plover, Curlew, Starling, and other birds about during frost. February 19th, flocks of Golden and Lapwing Plover all day; gale W., snow: 28th, eight Lapwings. March 4th, one. June 18th, Lapwing Plover and Curlew for several days. July 14th, flocks. 
October 20th, large flocks Lapwing Plover all day; wind light N.W.

Coningbeg Light-ship.-February 19th, Green Plover, with large flocks of Starlings and other birds "trying to get to land"; strong gale E., heavy snow. March 17 th, flock of about twenty.

Tuskar.-February 24th, flock of Lapwing at noon going S.E.; one shot: $28 \mathrm{th}$, flock going W.

Lucifer Shocls Light-ship.-March 8th, a flock of Green Plover at 1.30 P.M. going $\mathrm{N}$.

Blackwater Bank Light-ship.-January 4th, four Lapwing going N.W. November 18th, flock of Plover going N.W. December 21st, flock of Plover going N.

Arklow South Light-ship.-December 24th, several kinds of birds, including Green Plover, about light during night; wind moderate S.E.

Codling Bank Light-ship.-December 31st, eight going N.W.

Howth Baily.-January 24th, a number of Lapwing flying over light at 6 P.M. February 22nd, a flock.

Drogheda, N.-January 8th, rush all day going S. (see under Golden Plover). February 25th, seven going N.E.: 27th, ten do. October 23rd, twenty-three going S.; frosty; first seen this season. November 23rd, two large flocks going $\mathrm{N}$. at noon; wind light S.: [29th, Wing received]. December 5th, nine going $\mathrm{W}$.; one shot: 27 th, eleven going $\mathrm{N}$.

Copeland (Mew) Island.-January 3rd, large tlock Lapwing: gale N., hail and snow: 7th and 8th, flocks of Plover all day; gales and snow: 9th, large flocks of Curlew, Seapies, Lapwing, and Sand Larks: 14th and 15th, Plover on island: 21th, a flock of eighteen Lapwing going S.; "Lapwing frequent the island all the year round." February 2nd, 6th, 14th, and 20th, Lapwing noted. March 17th, flocks striking at night; wind S.: 20th, four. December 4th, six; snow : 27 th, large flocks all day; heavy frost.

Maidens South,-January 7th, six Plover going S.E., with Larks and other birds. February 23rd, ten Green Plover at noon going N.E.; gale S.E. March $16 \mathrm{th}$, fifty Green Plover at no.on going N.E.; strong breeze S.: 18th, nine going W.: 26th, twenty going E. November 21st and 23rd, "G. Plover" noted in rush of birds (see under Thrush): 22ud, Green Plover at 
lantern-[One killed striking, wing received]: 24th, rush of "G. Plover," Larks, Thrushes, Blackbirds, and Starlings round lantern from 7 P.M. to 11 P.M. ; fresh breeze S.E., gloomy.

Innishtrahull.-January 1st, one Lapwing Plover on island; gale N.N.W. February 8th, five io. June 4th, August 10th, and October 11th, three on island.

Tory Island.-February 20th, one Lapwing going E. ; snow; first seen this year: 21st, Plover at station : 22nd, one Lapwing going E. March 14th, one do.: 18th, one heard flying round lantern: 24th, Plover near station.

Rathlin O'Birne.-February 14th, April 19th, and June 30th, two or three noted.

Killybegs. - November 8th, a very large flock of Green Plover feeding on marsh all day; mostly young birds; gale S.W.

Arran Isand, S.-September 1st, twenty-eight Green Plover at 7 A.Ir. going S.E.; strong breeze S.W.; first seen this year.

\section{TuRnstone (Strepsilas interpres, Linn.).}

Hook Tower.-February 16th, several; gale E. : 27th, four; wind light S.E. September 24 th, one Turnstone killed striking at 9.30 P.M. ; wind S., drizzling rain-[Leg and wing received]. October 11th, flocks all day; wind moderate N.W.; one shot, "of a lighter colour than usual at this time." [Received in flesh.]

Drogheda, N.-October 25th. [Leg and wing of Turnstone received, shot on strand.]

Innishtrahull._July 23rd, six on island at noon.

\section{Oyster-Catcher (Hcematopus ostralegus, Linn.).}

Hook Tower.-February 16th, several Seapies; gale E.; generally on the rocks during day. March 9th, Seapies and Curlew about at all times. October 11th, flocks, with Turnstones, all day. November 19th, one Seapie killed striking; wind light $\mathrm{N}$. [Leg and wing not sent. If correctly named, the only reported instance of such an occurrence on Irish coast to date.-R. M. B.]

Howth Baily.-February 14th, shot a pair.

Droghecla, N.-April 22nd, two Seapies; the first seen for some weeks: 26th, Seapie heard at 10 P.M. on strand; "seemed 
to be a number from the noise"; wind light S.W.: 28th, twelve. May 20th, a large flock; gale N.W.: 27th, about a hundred. June 3rd, seven : 6th, seventeen going S.E.: 8th, large flock all day about strand; "numerous here every day now." July 13th, about two hundred. November 21st, large flocks all day.

Copeland (Mew) Island.-January 1st, about sixty Seapies; gale N.: 2nd, 3rd, and 4th, large flock: 7th, 8th, and 9th, flocks all day, remaining; weather very cold and severe; gales: 10th, 20th, and 26th, flocks noted. February 14th, Seapies all day: 20th, some noted. November 24th, large flocks feeding. December 19 th and 27 th, do. remaining.

Innishtrahull.- "Seapie off and on all the year."

Rathlin O'Birne.-February 29th, seven on rock. May 12th, eleven.

Arvan Island, S.-November 6th, often seen.

YeLLOW-BILIED Shenthbill (Chionis alba, Latham).

Carlingford Lough Light-house, in lit. December.2nd.-I am sending per parcel post to-day a. white bird, larger than a Pigeon, I shot at lighthouse.-Richard Hamilon-[Yellowbilled Sheathbill, female, received in flesh]. [In answer to further inquiry, the following particulars were communicated in a letter dated December 9th :] - "At 8.30 A.M. on the 2nd inst. I was at the Blockhouse (a small island about $\$ 00$ yards from the lighthouse) shooting duck, and saw the bird walking about on the highest part of it, which is not more than 10 feet high. I first took it for a tame Pigeon, as it seemed to take no notice of me, but observed that it walked differently, at about an angle of $45^{\circ}$, and was not pecking at anything; so I fired at it, and was surprised to see it go off. It took a half-circle from the rock, and again alighted a few yards from the water. I again fired at about forty yards; still the bird stood steady, as if not touched; so I sent the dog for it, and when about two yards distant it again took to flight, and seemed quite strong, but fell in the water about fifty yards from the rock. I picked it up with the boat" (see also Zoologist, 1893, pp. 28, 29). [The above is the only hitherto recorded occurrence of the Sheathbill, in a wild state, north of the tropics. The bird was received by me in perfect plumage and condition. The late $\mathrm{Mr} \mathrm{A}$. G. 
More, who first identified the specimen, could detect no trace of confinement in its plumage, and neither could Mr Williams, who skinned and mounted it.-R. M. B.]

\section{Grey Phalarope (Phalaropus fulicarius, Linn.).}

Arklow South Light-ship.-August 22nd, one "Sand Lark" killed striking; wind light S.E., fog- $[\mathrm{Leg}$ and wing of Grey Phalarope received]; "several about light during night."

Rockabill.-November 4th, Phalarope found dead after striking: [Leg and wings of Grey Phalarope received.]

\section{Woodcock (Scolopax rusticula, Linn.).}

Hovth Baily.-March 30th, a Woodcock perched on bank at 4 P.M.

Copeland (Mew) Island.-January 10th, several Woodcock on island; gale N.E., frost and snow: 11th, a few; frost: 15th, one shot. February 8th and 21st, and March 4th, 5th, and 13th, one noted.

Maidens South.-Nóvember 22nd, several kinds of birds round lantern at night (see under Thrush); one Woodcock killed. [Wing received.]

Innishtrahull.-January 12th, two on island; fresh breeze N., gloomy: 26th, one. October 9th, two on island at 11 A.M.; strong breeze N.W., showers; "the first arrival": 24th, one struck glass at 11 P.M., killed; wind light N., snow. December 7 th, four all day on island.

Rathlin O'Birne.-March 9th, two on island; strong gale N.

Killybegs.-October 1st, one going E. at 11 A.M. ; wind moderate N. : 20 th, one do. November 24 th, one going W.; "seldom seen here except in snowy weather."

Arran Island, S.-October 19th, two going N.E. at 4.30 P.M. ; wind light N.E., clear; first seen this year.

Common Snipe (Gallinago coelestis, Frenzel).

Arklow South Light-ship.-Deptember 22nd, three Snipe at 8 P.M. going S.W.; wind light N.E., clear; one killed striking. [Leg and wing received.]

Copeland (Mew) Island.-January 4th, several Snipe on island; 
strong breeze N., hail and snow: 5th, 6th, 7th, and 8th, several; weather very severe and stormy: 9 th, $10 \mathrm{th}, 11 \mathrm{th}, 22 \mathrm{nd}, 24 \mathrm{th}$, and 26th, Snipe noted. "From one to two dozen on island all the winter." Snipe noted in February and March. March 17th, "a few passing through rays of light to-night; wind S., fog;" number's of other birds striking. October 25th, some on island. November 24 th, several all day. December 4 th, several; gale N.W., snow: 13 th and 19th, some: 27 th, several; heavy frost.

Innishtrahull.-January 11th, "a great many Snipe, Thrushes, and Blackbirds on island." February 3rd, " a very large Snipe" on island.at 3 P.M. ; "never saw so large a one;" wind moderàte N., showery.

Tory Island.-February 19th, Snipe in great numbers on island; cold snowy weather. March 4th, Snipe still numerous.

Rathlin O'Birne.-February 20th, one Snipe on island at 4 P.M. ; gale N.E. June 26th, three.

Killybegs.-October 26th, three killed striking at 10.40 P.Mr; strong gale N.E., rain. November 20th, six renain; gale S.E.; "Snipe breed near lighthouse."

Tearaght.-February 20th, two Snipe; gale E. ; heavy snow. December 7 th, two for a couple of days.

\section{JACK SNIPE (Gallinago gallinula, Linn.).}

Hook Tower.-May 24th, two killed striking; wind S.E., fog and rain.

Howth Baily.-December $12 \mathrm{ch}-[$ Leg and wing received of Jack Suipe, found decayed on roof].

Innishtrahull.-February 28th, a large number "J. Snipe" on island; several shot.

Killybegs.-October 3rd, one at 4 A.M. killed striking; wind moderate N.W. ; clear.

Arran Island, S.-November 5th, three going N.E. at 4 P.M. ; strong breeze S.W.; very scarce here.

\section{Dunlin (Tringa alpina, Linn.).}

Hook Tower:-September 20th, one Dunlin picked up dead[Leg and wing received]. December 26th, one "Curlew Sandpiper or Common Sandpiper" found dead on balcony. [Dunlin received in flesh.] 


\section{Purple Sandpiper (Tringa striata, Linn.).}

Tuskar:-[October 29th, Leg and wing of Purple Sandpiper received, killed striking.] "Purple Sandpiper remain here during the winter, and become so tame that they come up to the door in bad weather; some of them get washed away by the sea, but must soon be reinforced, for their number always appears the same-about seven or eight.—Јонм Hamiton."

Tearaght.-October 29th, a "strange bird shot; supposed to be some kind of Sandpiper"; wind N.W., showers. [Leg and wing of Purple Sandpiper received.]

Copcland (Mew) Island.-December 27th, flocks of "Sandpipers" remaining; heavy frost. [? Purple Sandpipers.R. M. B.]

Common SANDPIPER (Totanus hypoleucus, Linn.).

Blacliveater Bank Light-ship.-April 23rd, "Sand Larks" about light all night; wind light S.W., rain. [Leg and wing of Common Sandpiper received.]

Howth Baily.-May 5th, "Strand Lark" found killed on balcony." [Leg and wing of Common Sandpiper received.]

\section{"SAND LARKS."}

Blackucater Bank Light-ship.--September 23rd, several "Sand Larks."

Droghede, N.-May 18th, about fifty "Sand Plover" going N.E.; strong gale W.; first seen since March. November 24th, a large flock of "Sand Plover" on strand. December 14th, "I have only seen one flock (on the 24th ult.) of the little bird called by the natives 'Sand Plover.'”

Copeland (New) Island.-January 4th, flocks of "Sand Larks" all day, remain; hail and snow : 9th, flocks of Curlew, Seapies, Lapwing, and Sand Larks: 17th, "Sand Larks" frequent the island nearly all the year round.

Tory Island.-March 24th, "Strand Larks" near station.

Arran Island, S.-November 7th, eighteen "Strand Larks" in lighthouse park at noon; wind light S.; very seldom here.

Tearaght.-April Sth, "Sand Larks" observed on rock. 
ReDshank (Totanus calidris, Linn.).

Barrels Rock Light-ship.-June 14th, one Redshank on board during the day.

Drogheda, $N$.-April 22nd, two.

Innishtrahull.-_ "Redshanks on and off island all the year."

Killybegs.-November 27 th, four all day; seen very often in winter.

CuRLew (Numenius arquata, Linn.).

Hook Tower.-January and February, large flocks during frost. February 5th, flocks at all times: 8th, two flocks going N.W. March 9th, about at all times. April 27th, six noted. May 6th and June 18th, Curlew about several days. July 14 th, flocks seen. October 20 th, large flocks all day. December 4th, large flock.

Tuskar.-February 27th, flock going N.W.; wind light S.E.

Lucifer Shouls Light-ship.-A Aril 6th, flock going N.E. May 13th, one Curlew-[Whimbrel?-R. M. B.]-lighted on deck: "it was disabled, and not able to fly farther": 17 th, a flock at 11 P.M. round ship; wind fresh N.W.

Blackwater Bank Light-ship.-March 24th, about light all night; wind light N.E.; one killed striking-[Leg and wing received]: 25th, all night about light; went S.E.: 26th, several: with Starlings, Blackbirds, and Wheatears, from 8.30 P.M. till midnight; wind light S.W., light haze; about a hundred birds killed striking; weather cleared at midnight and birds left. September 15 th, three at 10 P.M. going N.W. November 13 th, flock going N. at 10 P.M.

Arklow South Light-ship.-March 20th, two at 11 P.M. about light. June 24th, one going N.W. August 19th, two going N.W. : 31st, large flock going S.W.; wind fresh N.W.

Arkilow North Light-ship. - February 21st, flock at 9 P.M. going N.W.; wind fresh S.E. March 27th, Curlew all night about lantern; sleet and snow, wind N.E. May 14 th, two goilig N.W.: 17th, several going N.W.: 19th, flock going N.W.: 21st, four going N.W. July 10th, four do.: 26th, flock going S.W., flying low, close by ship.

Coulling bunl: Light-ship.-April 5th and 6th, several going in various directions at night. May 10th, several going N.W. 
Howth Baily.-January 15th, some near station. February 17 th, about thirty do. March 10 th, some noted.

Droghoda, N.-April 22nd, one "Jack Curlew": 28th, three Curlew. May 22nd, one going N. June 3rd, about forty feeding: 21st, five going N.W.: 23rd, several flocks from noon to 3 P.M. going S. November 4th, about a hundred feeding. December 7 th, two large flocks going N.E.; flying high and in two compact bodies: 13 th, three large flocks going N.E. at 3.30 P.M. ; wind light N.W.

Copeland (Mew) Island.-January 2nd, 3rd, 4th, and 5̆th, large flocks: 6th, 7th, and 8th, flocks all day, remaining; weather very cold and severe, gales: 9th, large flocks Curlew, Seapies, Lapwing, and Sand Larks all day, remaining; fresh breeze N., frost and snow: 10th, 14th, 20th, 22nd, and 26th, Curlew noted; "they frequent the island all the year round." February 2nd, 14th, 20th, and 21st, March 4th, 10th, 17th, 20th, and 24th, Curlew noted. July 26th, several Curlews and Terns flying in rays of light, none struck; hazy. August 23rd, immense flocks, remaining all day; weather warm and fine. October 7th, large flock going S.: 25th, large flocks on rocks. November 9 th, about eighty going W.: 22nd, a flock feeding: 24th, large flocks. December 13th, large flocks, remaining: 27 th, do.; heavy frost.

Maidens South.-March 17th, heard Curlew passing at midnight: 19th, heard them pass; going N.E.: 25th, some flying round lantern and passing. April 3rd, some passing N.E.: 10th, a few do. July 8th and 9th, some going S.W. and W. August 18th and 19th, passing S.W. at midnight: 23rd and 25th, Curlew going S.W. December 17th, ten going do.

Innishtrahull.-January 11th, eight on island. May 2Sth, two all day.

Tory Islend.-March 13th, numerous on island: 19th and 26th, flocks all day on island. April 9th, all have left.

Rathlin O'Birne.-February 11th, seven on island. July 13th, flock all day.

Killybergs.-November 21st, several seen nearly every day. Arran Island, S.-September 14th, twenty-eight going S.W. ; first flock since Maybirds went. November 10th, some going S.E. ; plentiful now.

Tearaght.-January 30th, four. April 8th and June 2nd, 
two noted. June 10th, two and one Maybird rested on island. July 31st, one; passed S. next day. December 17th, four; did not remain long.

\section{Whimbrel (Numenius phooopus, Linn.).}

Hook Tover:-September 21st, Swallows and Maybirds at 9 A.M. ; strong breeze N.E.

Coningbeg Light-ship.-April 8th, a "Maybird" (supposed) at 10 P.M. going for land.

Tuskar.-April 30th, a Maybird or small Curlew on the rock.

Blackwater Bank Light-ship.-May 17th, six at 11.30 P.N. about light.

Codling Bank Light-ship._-May 9th, several going N.W.

Drogficla, N.-April 25th, three Whimbrel at 2 P.M. going N.E.; first seen: 26th, one going N.; flying high and fast: 29th, three going N.W.: 30th, one going S.E. May 6th, a large flock at 4 A.Mr. going N.E; w wind light E. : 8th, Whimbrel all day about banks of river: $10 \mathrm{th}$, several all day feeding; wind light E.: 12th, twenty-seven going N.E.; "more or less of these bircls seen every day since April 25th": 16th, fifteen at 7.30 P.x. going N.; gale N.W. : 22nd, seven : 26th, three going N.; flying very high and fast. June 8th, one going N.E.

Maidens South.-April 17th and 18th, a few "Maybirds" going $\mathrm{N}$. in the evening; fresh breeze N. May Sth, two on rock. June 16th, three.

Innishtrahull._June 17th, five Whimbrel on island; wind light $\mathrm{N}$.

Rathlin O'Birne.-May 2nd, flocks on island; strong breeze N.E.

Tearaght.-April Sth, five Maybirds noted. June 10th, one.

\section{Terns.}

Hook Tower.-August 23rd, "several birds, I think Terns, were flying all round light." September 20th, numbers round light; fresh breeze E., fog and rain: 24 th, Terns round light; none struck.

Blachwuter bunli Light-ship. — August 21st, several birds known as "Slirs" about light from 10 r... to midnight; wind 
moderate S.W., gloomy; and again next night from 10.30 P.M. to midnight; wind light S., gloomy. [Probably Terns.R. M. B.]

Droghcda, N.-May 13th, three flying about river: 17th, numbers all day fishing: 18 th, hundreds do.: 20th, numbers.

Copcland (Mow) Island.-May 11th, a few Mews; wind moderate S.E., hazy; "annual immigration of Mews to this island ": 24th, large numbers all day. June 7th, some Mews' eggs found. July 26th, several Curlew and Terns flying in rays of light; none struck; hazy. September 5th, Mews still on island; several young unable to fly: 11th, "annual emigration of Mews from this island during the past fortnight."

Innishtrahull.-May 22nd, a number of Sea Mew at noon; wind fresh S.E. "A large number of Tern build on the island, stopping only the summer months."

Rathlin O'Birne.-June 1st; fifty Terus on the island. "The Terus had great difficulty in bringing out their young last year, owing to storms and very unfavourable weather. They came here twice this season, remained one day each time. It seems they have decided it is not a favourable place for bringing out their young, as they have deserted the island."

\section{"GULLS."}

Mince Head.-November 19th, two Sliua Gulls observed near lighthouse.

Coningbeg Light-ship.-Oetober 26th, Gulls killing Linnets.

Barrels Rock Light-ship.-January 21st and 23rd, a lot of large and small Gulls near ship during day; wind moderate W.: 26th, 27th, 28th, and 30th, large and small Gulls noted. November 15 th, 16th, 17th, 22nd, 24th, 26th, and 30 th, numbers noted feeding. December, numbers noted throughout month, of various sizes, drifting, feeding, etc.

Blackwater Bant, Light-ship.-January, "the common Gull seen almost daily." May, do. December, Gulls daily.

Arlelow South Light-ship.-August 18th, large flocks Gulls drifting past.

Codling Banl: Light-ship.-Tanuary 9th, a Seagull caught a Skylark flying close to ship and ate it: 21st, three Seagulls attacked, killed, and ate a Skylark at 10.30 A.M. close to ship; 
wind moderate S.W. April, a few Gulls daily. May, flocks of Herring and small Gulls during this month. November, a few Gulls daily.

Rockabill.-September 22nd, "to-day Gulls and Kittiwakes left the Bill, a large rock adjoining, which they come to in hundreds in April or May."

Drogheda, N.-April 29th, large flocks of Kittiwakes at 5 A.M. passing in continuous flocks for over three-quarters of an hour, flying very low, almost skimming the ground; strong breeze S.E. May 1st, about two hundred Gulls fishing on river, mostly last year's birds: 6 th, numbers of Kittiwales and Black-headed Gulls fishing on river at noon: 20th, numbers of Kittiwake Gulls and Terns all day fishing about river; gale N.W. June 4th, seven Great Black-backed Gulls at 4 A.M. going W.; all last year's birds. July Sth, numbers of Kittiwake Gulls. December 7th, great numbers of various kinds of Gulls all day; frost: 13th, large flocks: 14th, several large flocks of Kittiwakes going E.; flying very high.

Innishtrahull.-May 16th, large flocks all day round island. "There are only four kinds of Gulls here-the Common Gull, the Herring Gull, the Kittiwake, and the Black-backed or Royal Gull."

Rathlin O'Birne.-May 30th, seven Royal Gulls all day. June 12th, ten do.; squally; strong breeze S.

Killybegs.-October 30th, one Iceland Gull, very large bird[Glaucous Gull ?-R. MI. B.]-remained about station; fresh breeze W. November 6th, one Iceland Gull going E. at noon; wind light S.W.; "a very large bird, of a dark cream colour"[Glaucous Gull?-R. M. B.].

Tearaght.-January 24th, numbers of Royal Gulls; wind moderate N.W. April 6th and 8th, Kittiwakes noted at 6 A.MI. May 2Sth, Royal Gulls going S. June 29th, large number Royal Gulls going S.E. at noon. August 2nd, Royal Gulls round the rocks after fry; wind moderate N. October $22 \mathrm{nd}$, flock of Kittiwakes going S.W., flying low and near the water; wind moderate N. November 1st, four "Yellow-backed Gulls" on island-[Glaucous Gulls?-R. M. B.]; strong breeze S.: 12th, flock of Kittiwakes flying S.: 20th, a large number of Herring Gulls; gale S.; Gulls of various linds round island continuously: 23rd, flock of Kittiwakes on water. 
Manx Siearwater (Puffinus anglorum, Temminck).

Hook Tower:-April 22nd, one Shearwater going N.W. August 22 nd, one caught at 11.30 P.M. ; gale S.E. : 23rd, another caught at same hour.

Barrels Rock Light-ship.-March 20th, one going S.E.; wind moderate E. ; first seen. May 10th, about seventy "Mackerel Cocks"; wind light E.: 20th, 24th, 26th, 27th, and 28th, a few do. noted.

Lucifer Shoals Light-ship.-May 15th and 16th, several "Mackerel Cock" about ship during the day.

Arlilow South Light-ship.-June 8th, small flocks of Shearwaters all day going in various directions: 13 th and 17 th, do. August 19th, odd ones noted.

Codling Bant Light-ship.-May, flocks of Manx Shearwaters about station during this month.

Howth Baily.-March 14th, Manx Shearwater struck glass and was caught on balcony; snowing; wind light and variable. May 26th, one struck lantern at 11.40 P.M. September 20th, no Shearwater heard since August.

Tearaght.-April 8th, Shearwaters noted: 30 th, "Shearwaters heard at night." May 28th, more Shearwaters.

Fork-tailed Petrel (Cymochorca ieucorrhoa, Vieill).

Blachrock, Mayo.-September 9th, Fork-tailed Petrel sent. [Skin received.]

\section{Stora Petrel (Procellaria pelagica, Linn.).}

Blachwater Bank Light-ship.-November 23rd, one at 6.30 A.M. on deck; "let this bird go at daylight."

Arklow South Light-ship.-August 30th, one going S.E.; strong breeze $\mathrm{S}$.

Arklow North Light-ship.-May 30th, one Mother Carey's Chicken in water alongside ship; wind fresh S.W. November 24th, one Mother Carey's Chicken flew on board at 5.30 A.M. ; wind light; died: [2Sth, Storm Petrel received in flesh].

Codling Bank Light-ship.-January Sth, one about ship. May 18th, one do. 
Rathlin O'Birne.-June 23rd, numbers breed here.

Tearaght.-June 8th, numbers going E. at 10 A.M. ; wind light S.E. : 15th, great numbers going E. at $S$ P.I.; wind light N.E. September 22nd, great numbers at night striking glass, none killed; wind light S.E., overcast.

\section{Razorbill (Alca torda, Linn.),}

Common Gullemot (Uria troile, Linn.), and

Black Gulluenot (U. grylle, Linn.).

Hook Tower.-February 21st, Guillemots on water. March 21st, flocks Guillemots passing at all times: 30 th, flocks of Razorbills passing W. at all hours every day. April 22nd, large quantities of Razorbills and Guillemots fishing. May 1st, Razorbills passing every day.

Barrels Rock Light-ship.-January 4th, several small flocks of "Murs" going N.W.: 15th, to February 3rd, "Murs" noted at frequent intervals, generally going W. May 13th, 15th, and 17th, "Murs" during day. "Murs" constantly noted during June and July. November 22nd, thirty "Murs." A few flocks noted at intervals on several days up to end of December.

Arklow South Light-ship.-August 18th, large flocks of "Murs" drifting past during day. October 19th, several flocks.

Codling Banti Light-ship.-May, flocks of Razorbills about station.

Howth Baily.-March 23rd, Black Guillemot, Lesser Guillemot, and young Razorbill on water; shot the Guillemot, believing it to be rare-[Common Guillemot received in flesh]: 25th, Black Guillemot on water: 28th, young Guillemot on water. September 20th, young Guillemot heard on the water: 25 th, several do.; throat and sides of head white. October 18 th, Razorbills and Guillemots diving.

Tearaght.-January 30th, "Guillemots come in during the night, and fly off to N.WV. in the morning." February 6th, a number at 7.30 A.M. April, Razorbills at 6 A.M. July 10 th, Razorbills and Guillemots going away to W. and N.W.: 20th, no Razorbills seen to-day: 2Sth, very few Guillemots to be seen. August 7th, Razorbills and Guillemots left here. 


\section{Puffin (Fratercula aretica, Linn.).}

Barrels Rock Light-ship.-March 15th, two "Sea Parrots" going E; first seen: 16th, a few, and some noted every month up to July 19 th.

Codling Bank Light-ship.-April, great flocks of Puffins passing station daily. May, flocks about station during this month. November, a few "Puffins" daily near ship during this month.

Innishtrahuil.-January 10th, great flocks "Puffins" flying W. all day. May 21st, large flocks all day flying S:W.

Tory Island.-March 13th, "Puffins appeared in small flocks": 26th, plentiful on cliffs to-day.

Rathlin O'Birne.-March 16th, flocks of Puffins going W. at noon. June 21st, flocks going W. July 10th, flocks all day going $\mathrm{W}$.

Killybegs.-November 22nd, three Puffins all day; gale E., fog; rarely seen at this time of year.

Tcaraght.-April 1st and 2nd, Sea Parrots or Puffins going E. : 8th, Puffins going E. at 6 A.M. August 7th, nearly all have left.

\section{DIVER.}

Hook Tower.-April 2nd, one "Northern Diver" all day.

Rathlin O'Birne.-February 28th, Northern Diver fishing at noon.

Killybegs.-October 31st, one Northern Diver at noon; appeared exhausted after arrival. November 7th, one Great Northern Diver remains; "this bird remains here for the winter."

Tearaght.-July 28th, "Brael or large Diver" on rock at noon; wind light $\mathrm{E}$.

LitTle Grebe (Podicipes fluviatilis, Tunstall).

Hoo\% Tover.-November 1st, one "Dabchick" killed striking; wind light N.E.: 7th, "Little Grebe" (supposed) picked up in lighthouse yard, probably killed striking; wind light N.W. [Received in flesh.]

Cormorant (Phalacrocorax carbo, Linn.) and SHAG (P. graculus, Linn.).

Hook Tower.-February 6th, Cormorants about at all times. Houth Baily.-August 23rd, no Cormorants have been 
observed all summer, but an odd one may now be seen. September 15th, Cormorants noted. December 14th, Cormorants continually passing towards Clontarf, Kingstown, and Dalkey each morning before sunrise, and returning each evening to Lambay.

Drogheda, N.- "Cormorants seen almost every day of the year."

Rathlin O'Birne.-March 23rd, five; always here. May 31st, forty fishing all day; wind light $\mathrm{S}$.

Kiilybegs.-November 22nd, twelve Cormorants; gale E.; two white-breasted Cormorants all day.

Arran Island, S.-September 28th, twenty Cormorants; build in cliffs opposite.

Gainet (Sula bassana, Linn.).

Hook Tower.-February 20th, six going S.; first seen this year. March 21st, Gannets passing at all times.

Barrels Rock Light-ship.- January and February, one to three noted at intervals, generally going W. March 20th, seven going N.W.: 24th, small flocks: 25th, and April 26th, a few going N.E.: noted almost every day during May, generally going W. June 16th, several going E.: 27th, four at 10.30 A.M. going W. July 6th, four going S.IV.: 19th, several, white and grey, going W., and a few at intervals to end of month. November and December, a few at intervals.

Lucifer Shoals Light-ship.-May 5th and 6th, several flocks going N.E.

Blackwater Bank Light-ship.-March 22nd, several flocks going N.E. May, about ship almost daily.

Arklow South Light-ship.-June 18th, small flock going N.E. August 17th, small flocks going N.E.: 20th, five going S.TV.: 27th, five going S.W.; four white, one black.

Arklou North Light-ship.-April 21st and 22nd, several going N.E. May 6th, large flock going N.E.: 19th, large flock going N.E.: 22nd, several going N.E.: 26th, two black, one white, going N.E. 27 th and 28th, several do.: 29th, several: 30th, six going N.E. August 20th and 21st, flock noted.

Codling Bant: Light-ship.-April, great flocks passing station daily. May, flocks about station. November, a few daily near ship. 
Drogheda, N.-May 20th, seven ; first seen this season.

Copeland (Mcw) Island.-February 3rd, eight. April 24th, several. May 11th, Gamnets all day. September 5th, several. October 5th, a few.

Lough Swilly.-October 4th, young Gannet shot. [Received in flesh.]

Tory Island.-April 16th, numerous near station; not many seen up to this.

Rathlin O'Birne.-March 20th, four always here.

Tcaraght.-January 24th, two. April 9th, some going S.E. July 28th, twenty going E. October 11th, several going $N$. November 20th, six on island; strong gale S.

HERon (Ardea cinerea, Linn.).

Howth Baily.-September 29th, two observed.

Drogheda, N.-May 14th, one going N.W.; first seen for some time. During June, one or two at intervals.

Copeland (Mew) Island.-January 7th, one. December 19th, a few.

Maidens South.-May 25th, one Crane going N.W.

Tory Island.-April 9th, two going E. October 28th, two do.

Rathlin O'Birne.-July 3rd, three all day on island.

Aiman Isiand, S.-October 25th, Cranes often seen fishing in pools.

Tearaght.-June 2nd, "one Crane (Heron)" at noon. September 22nd, one do.

Brent Goose (Bernicla brenta, Pallas).

Droghecla, $N$.-October 11th, a bird, supposed to be a Barnacle, at 2 P.M. resting on bank of river; wind light $\mathrm{N}$.; shot and sent. [Brent Goose received in flesh.]

\section{"GEese."}

Hool Tower:-October 12th, one Wild Goose at 6 P.Mr. going W. December Tth, large flock Wild Geese at 7.30 A.Mr. going S. ; wind fresh N.

Barrels Rock Light-ship.-January 13th, three Wild Geese going N.W., flying high. 
Drogheda, N.-October 27th, two Wild Geese going S.; strong breeze S. November 2nd, seven do. going N.W.

Copeland (Mow) Istand.-January 7th, large flock of Wild Geese, about sixty, going S., flying high; gale N.E., weather very severe.

Maidens South -December 17th, fifteen Barnacle going S.W.

Innishtrahull.-October 3rd, sixteen Barnacle Geese going S.W. : 6th, eleven do. on island: 27 th and 28th, flocks of Barnacle all day going $\mathrm{S}$.

Tory Island.-February 16th, two Wild Geese going E, flying high; snow. October 17th, a flock of Barnacle (seven) passed over island; first seen; wind N.: 23rd, Barnacle on lake; strong breeze N., snow: 25th, seven do. on island. November 22nd, large flocks of Barnacle, from six to thirty, going S.W.; strong breeze S.E.

Rathlin O'Birne.-February 9th, three Barnacle on island. March 6th, thirty Barnacle going E.; strong breeze S.: 28th, twenty-six going $\mathrm{E}$.

Killybegs.-October 13th, twenty Wild Geese going S.E.; wind light N.E.: 16th, seven very large Geese going S.E.: 20th, several flocks of Geese going S.E. from 10 A.M. to 12 noon, flying very high; wind moderate N.W.: 28th, seven flocks of Geese at intervals from 8 A.M. to 3 P.M. going E., flying very high; wind moderate S.: 30 th, two Wild Geese; fresh breeze W. ; very large, remained all day. November 3rd, thirteen Wild Geese going S., flying high; strong breeze S.: 1Sth, seven going S.E., flying high; gale S.: 23rd, thirteen Barnacle going S.E.; wind light S.E.; these birds remain all winter on a small island-Inishduff -about four miles from station.

Arran Island, S.-October 2nd, twenty-eight Barnacle going N.W. ; wind moderate N. ; first flock seen this year: 4th, thirty Barnacle going N.E. ; "hardly ever rest here."

\section{"SWANS."}

Còningbery Light-ship.-December 27th, six Swans at 10 A.м. going S.W., "flying low and strong"; wind light S.

Drogheda, N.-May 28th, one Swan going W.; wind light N.E., misty. December 12th, one Swan going N.W.; wind light $N$., clear; "it came right in from the sea, and seemed 
fatigued; it was not pure white, but light grey on the back, probably a young bird of the second or third year."

\section{Common Scoter (Edemia nigra, Linn.).}

Droghecta, $N$.-November 29th, one Black Duck on river at 3 P.M. ; wind light W., clear; shot-[Head of Common Scoter received]. December 14 th, the Black Duck are in large numbers, but rarely approach nearer to the land than a quarter of a mile, where they remain in large flocks, feeding on the water.

\section{"Ducks."}

Hook Tower. - January and February, Wigeon and Duck observed going up the harbour, as if they came from the S. February 22nd, four Black Scoters at 11 A.M. going E.; gale S.E. March 1st, seven do. going E. April 8th, six Wild Ducks going E. at 6 A.M. November 24th, one Wild Duck going N.

Barrels Rock Light-ship.-March 28th, about thirty Wild Ducks going S.E.; wind fresh N.W., hail.

Lucifer Shouls Light-ship.-March 1st, several Wild Ducks the whole night round ship; flying round lantern; wind moderate N.E., clear.

Blackwater Bank Light-ship.-April 30th, flock of Wild Duck going W. November 16th, flock of do. going S.W.

Arklow South Light-ship.-August 22nd, seven Wild Ducks going S.W. December 29th, large flock of Wild Duck going N.E. ; wind fresh S., clear.

Codling Bank Light-ship.-November 28th, one flock of Wild Duck going W.

Drogheda, N. - January 27th, four "Saw-bill" Ducks (probably Merganser) fishing on river. March 3rd, seven "Saw-bills" and four Sheldrake all day fishing. May, "have been told that Sheldrakes used to build on this rabbit-warren." June 4th, one Mallard going N.E. October 14th, two Mallard and three Ducks going N. November 1st, a large flock of Golden-headed Wigeon going N.W.; wind light N.W.: 22nd, about a hundred Ducks on strand; gale S. December 4th, sixteen Ducks and Mallard on strand; snow: 5th, three small flocks of Wigeon going W.; frosty: 10th, two large flocks of Duck going $\mathrm{N}$.; strong breeze W. 
Copeland (Mew) Island.-January 1st, twenty Wild Ducks on island; gale N.: 4th, 5th, and 6th, flocks Wild Duck on island; weather very cold : 14 th, about fourteen : 15 th to 25 th, twelve to twenty Teal on island. February 2nd, a flock of Duck on island: 10th, a flock of twelve Teal.

Innishtrahull.-January 10th, three Wild Ducks round island all day.

Tory Island.-February 29th to March 2nd, Wild Duck in large numbers on island; weather very cold and dry. March 18 th, one on lake; very scarce.

Rathlin O'Birne.-February 25th, one Sheldrake fishing: 27 th, one Wigeon on pond at noon.

Killybegs. - October 13th, four Black Ducks going W. November 26th, seven Ducks passing; "they breed near station."

Arran Island, S.-November 2nd, two Wild Ducks on lake.

Tearaght.-October 19th, flock of Wild Duck going N.

\section{Birds Not IdENTIFIEd.}

Hook Tower.-December 6th, three birds about the size of a Thrush, marked like a Chaffinch, with top-knots on head, at 10 A.M. ; wind fresh N.W., blue sky. [Probably Waxwings.R. M. B.]

Arklow North Light-ship.-September 9th, a strange bird, the size of a Thrush, head and neck white, blue breast, bronze coloured wings with white feathers, at 6.40 A.M. ; flew S.E.; calm, clear. [Possibly Roller.-R. M. B.]

Innishtrahull.-February 8th, a strange black bird like a Jackdaw, but smaller; black legs and bill, nearly same make as a Blackbird: 29th, a small bird of the Duck species, light coloured, with top-knot a little larger than a Lapwing, dives often.

Tearaght.-February 20th, "bird resembling Golden Oriole on island, could not capture it."

\section{General Observations.}

Tuskar.-April 30th, "birds have been very scarce this spring, I suppose owing to our not having much fog; still a dark cloudy night, when the light is visible a long way off, attracts 
most birds, though they do not get killed in such numbers, as they only hover round the light. In foggy weather they strike the lantern glass like a bullet from a rifle."

Lucifer Shocls Light-ship.- "Birds very scarce this year."

Codling Bank Light-ship._- "Birds not very plentiful about this station."

Howth Baily. - February, "migration of birds is scarcely noticeable here, and the station being built on such a narrow point, there is not room for land birds to be about. Even in foggy weather very few birds come near the lighthouse."

Drogheda, N.-May 13th, two Bats in the evening, flying close to station; wind light S.W.; first seen here. "The past season has been the worst ever known for birds." June 9th, three Bats flying about station at 10 P.M. December 14th, "so far this has been a very poor season for birds, although the weather has been very severe for the last fortnight."

Tory Island.-March 31st to April 4th, a marked absence of all kinds of birds about station or on island. October 28th to November 14 th, no birds at station. November 24th to 28th, wild stormy weather, no birds of any kind except Starlings about island.

Killybegs.-November, "no birds killed striking this month."

Tcceraght.-January 23rd, Long-eared Bat received (probably that caught 4/11/91). 

1893 
List of Ligrit StAtions.

4. Mine Head, Waterford,........ 10 poor. $\quad$ x $0-$ H. Kelly.

5a.Hook Tower, Wexford, ........ 419 excellent. $\mathrm{x} \times \mathrm{x}$ - J. Higginbotham.

5. ${ }^{*}$ Coningbeg Lt.-ship, Wexford, 23 very good. $x \times 10\left\{\begin{array}{c}\text { P. King, J. Doyle, } \\ \text { and A. B. Wall. }\end{array}\right.$

6. Barrels Rock Lt.-ship, do., $\ldots 3 \quad 1$ excellent. $\quad$ x $\quad 0 \quad 4\left\{\begin{array}{c}\text { James Beahan and } \\ \text { T. Luccan. }\end{array}\right.$

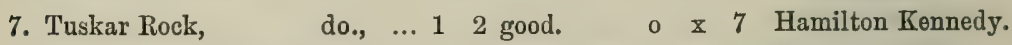

7b. Blackwater Bank Lt.-ship, do., 216 very good. $x \quad x-\left\{\begin{array}{c}\text { Patrick Cullen and } \\ \text { Daniel Dunn. }\end{array}\right.$

8. Arklow Sth. Lt. ship, Wicklow, 35 very good. $x \quad x \quad 7\left\{\begin{array}{c}\text { E. Broad, J. Kearon, } \\ \text { and N. Burdge. }\end{array}\right.$

8. Arklow North Lt.-ship, do., 20 very good. $x \quad x \quad 8\left\{\begin{array}{c}\text { A. B. Wall and } J . \\ \text { Penston. }\end{array}\right.$

9a.Codling Bank Lt.-ship, do., 22 very good, $\mathrm{x} \times \mathbf{x}-\left\{\begin{array}{c}\text { W. Clydesdalo and } \mathrm{H} . \\ \text { Thompson. }\end{array}\right.$

11. Howth Baily, Dublin, .......... 32 excellent. $\quad \mathbf{x} \quad \mathbf{x}-\left\{\begin{array}{c}\text { Edward M M Carron and } \\ \text { H. L. Murphy. }\end{array}\right.$

12. Rockabill, do., ........ 2 2 1 very good. 0 x 5 C. Hawkins.

12a. Drogheda, North, Meath, ..... 36 excellent. $\mathrm{x}$ x - George Dunleavy.

$12 \alpha^{*}$. Vidal Bank, Down, .......... 10 very good. o $x$ - M. Polly.

12b. South Rock Lt.-ship, Down, ... 1 0 fair. o $\quad$ x 3 John Kearon.

13. Copeland (Mew) Island, do., .. 41 excellent. $\quad x \quad x-$ R. Armstrong.

14a. Maidens South, Antrim, ........ 27 very good. $x \quad x \quad 5$ Francis Maguire.

16. Innishtrahull, Donegal, ........ 36 very good. $\quad x \quad x \quad 6$ George Gillespie.

21. Rathlin O'Birne, do., ....... 10 fair. $\quad \mathrm{x} \quad 0 \quad 2$ John Murray.

22. Killybegs, do., ….... 26 very good. $x \quad x-J o h n$ Kennedy.

30. Slyne Head, N., Galway, ...... 12 fair. $0 \quad x$ - John Harrison.

37. Tearaght, Kerry, ............... $3 \quad 1$ very good. $x$ o 99 Charles Hawkins.

The following Stations sent no Schedules, but forwarded specimens:-Old Head, Kinsale, sent four live Peregrine Falcons and a Manx Shearwater; Ballycotton scnt two Black Redstarts (on different dates) and a Golden-crested Wren; Carlingford Bar, the Leg and Wing of a Whitethroat; Ardglass, a Curlew; Eagle Island, W., a Dunlin; Slyne Head, S., a Bittern; Arran Island, N., a Dunlin; and Bull Rock, the Leg and Wing of a Turtlo Dove.

Legs, Wings, etc, received, 94.

$0=$ No reply.

$\mathrm{x}=$ Schedules returned partly or wholly filled.

Spring, replics received from 16 stations. Autumn replies received from 17 stations. 


\section{Legs, Wings, etc., Received.}

Species. How Received. How Procured. Date. Name of Station.

$\left.\begin{array}{c}\text { PeregrinoFalcons, } \\ \text { four, }\end{array}\right\} \quad$ Alive, $\quad\left\{\begin{array}{c}\text { Taken from } \\ \text { nest, }\end{array}\right\}\left\{\begin{array}{c}\text { 3rd week } \\ / 7 \text { mo., }\end{array}\right\}$ Old Head, Kinsale. Merlin, - . Rec'd. in flesh, Caughtin house, 21/ 3 mo., Near Hook Tower.

Woodchat Shrike, Leg and wing, Killed at lantern, 16/ 8 mo., Blackwater Bank Lt. sh.

Spotted Flycatcher,

\begin{tabular}{|c|c|c|}
\hline & , & ", \\
\hline Thrush, & - & , \\
\hline Redwing, & . & , \\
\hline ," & - & ," \\
\hline & - & , \\
\hline Fieldfare, & . & , \\
\hline Blackbird, & • & ", \\
\hline Black Redst & & Rec'd. in flesh, \\
\hline Wheatear," & & Leg and wing, \\
\hline ", & & $\{$ and tail \\
\hline
\end{tabular}

Sedge Warbler, . Rec'd. inflesh,

:,, two,

, , ?

, , . Leg and wing,

, , . . ,

, , . Rec'd, in flesh,

, , . Leg and wing,

,, ,, Rec'd, in flesh,

Whitethroat, . Leg and wing,

Rec'd. in flesh,

,

,

Leg and wing,

",

Rec'd. in flesh,

Leg and wing,

Willow Wren,

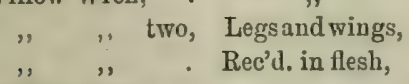

Golden-crested

Wren,

, ,

, ,

Leg and wing,
Rec'd. in flesh,

Found dead,

' "'

17/ 5 mo., Blackwater Bank Lt. sh.

$8 / 1$ mo., Hook Tower.

" 9/ 1 mo., ", "

, . 10/ 1 mo., Blackwater Bank Lt. sh.

". 10/ 1 mo., Arklow S. Lt.-ship.

". 13/11 mo., Blackwater Bank Lt. .sh.

," 10/ 1 mo., ",

, 15/8 mo., ," ",

Shot, . . 23/10 mo., Ballycotton.

" . 28/10 mo., ",

Killed st., - 15/ 8 mo., Blackwater Bank Lt. -sh.

$$
\text { , 18/4 mo., Maidens, } S \text {. }
$$

? Sent $29 / 4 \mathrm{mo}$, Hook Tower.

At lantern, . 15/ 5 mo., ," ,"

Killed st., . 18/ 5 mo., " "

? . 16/ 8 mo., Blackwater Bank Lt. sh.

Found stunned, 13/ 8 mo., Howth Baily.

? $\quad 27 / 5$ mo., Copeland (Mrew) Island,

Killed st., . 17/ 5 mo., MFaidens, $S$.

? . 24/ 5 mo., Innishtrahull.

Killed st., . 17/ 5 mo., Killybegs.

? Rec'd. 25/ 2 mo., Hook Tower.

Killed st., . 19/ 4 mo., ,, ,,

" . 14/ 5 mo., ", ,"

Killed atlantern, 18/ 5 mo., " "

Killed st., . 12/ 8 mo., Tuskar.

", . 14/ 5 mo., Carlingford Bar.

Killed, . 5/ 5 mo, Maidens $S$.

Killed st., - 4/ 5 mo., Innishtrahull.

". 16/ 5 mo., Killybegs.

. $\quad 19 / 4$ mo., Hook Tower.

, . 18/4 mo., Maidens $S$.

" . 21/ $4 \mathrm{mo}$, ,

? Sent 23/10 mo., Ballycotton.

Found ondeck, 10/10 mo., Coningbeg Lt.-ship.

Killed st., - 3/9 mo, Tuskar.

1 Killed st.=Killed striking lantern. 


\section{Legs, Wings, ETC., Received—continued.}

Species. How Received. How Procured. Date. Name of Station.

Golden-crested Wren,

, , ,

,$\quad$,

, , ,

Yellow Wagtail, . Rec'd. in flesh, $\left\{\begin{array}{c}\text { Killedagainst } \\ \text { telephone } \\ \text { wire, }\end{array}\right\} 11 / 9$ mo., Hook Tower.

Skylark,

,"

Snow Bunting, . Wings,

House Sparrow, . Leg and wing,

Mealy Redpole, .

Twite,

Starling,

Cuckoo,

Turtle Dove,

$\begin{array}{cc},, & , \\ , " & , \\ \text { Quail, } & \end{array}$

"

Water-Rail,

Ringed Plover,

Grey Plover,

," ,

Turnstone, .

Grey" Phalarope, .

Snipe,

Jack Snipe,
Leg and wing, Found dead, 15/9 mo., Blackwater BankLt. sh.

Rec'd. in flesh, Killed st., . 14/ 9 mo., Arklow S. Lt. ship.

$\left\{\begin{array}{c}\text { Caught in } \\ \text { out-office, }\end{array}\right\} 13 / 9$ mo., Rockabill.

Skin, . Caught, . 19/3 mo., Innishtrahull.

Leg and wing, Killed, . 17/ 1 mo., Blackwater Bante Lt. sh.

Killed st., . $10 / 1$ mo., Arklow S. Lt.-ship.

Rec'd. in flesh,

Leg and.wing, Died on ship, 7/11 mo., Codling Bank Lt.-ship.

Killed st., . 16/10 mo., Bĺackwater-BankLt. sh.

Rec'd. in flesh, $\left\{\begin{array}{c}\text { Picked up. } \\ \text { dead, }\end{array}\right\}$ 18/ 4 mo., Hook Tower.

$\left\{\begin{array}{c}\text { Killed at } \\ \text { lantern, . }\end{array}\right\} 14 / 5$ mo., , ,

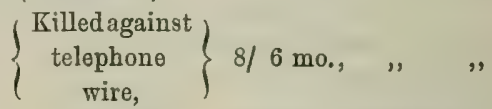

? $\quad 12 / 6 \mathrm{mo}$, Killybegs.

Leg and wing, Shot, . . $19 / 9$ mo., Slyne Head, $N$.

Killed on rock, 20/ 4 mo., Bull Rock.

Killed st., . 14/ 5 mo., Coningbeg Lt. ship.

$\cdot$,

,

,

"

Rec'd, in Hesh,

"

Leg and wing,

Shot, . 2/ 1 mo., Drogheda, $N$.

Killed st., . 17/ 5 mo., Mfaidens $S$.

Shot, : . 14/ 1 mo., Drogheda, $N$.

". - 9/10 mo., ", ",

? Rec'd. 24/ 5 mo., Innishtrahull.

Dead on deck, $22 / 8$ mo., Arklow S. Lt. ship.

Killed st., . 17/10 mo., Slyne Head, $N$.

Killed st., 13/-14/11 mo., Blackwater Bank Lt. sh.

$$
\text { . }\left\{\begin{array}{c}
2 / 11 \text { mo., } \\
\text { Rec'd. } \\
4 / 4 / 91
\end{array}\right\} \text { Hook Tower. }
$$




\section{LEgS, Wings, etc, ReceIved-continued.}

Species. How Received. How Procured. Date. . Name of Station.

Dunliv, . . - Leg and wing, ? . 25/ 2 mo., Hook Tower.

$\left\{\begin{array}{c}\text { Found dead } \\ \text { on deck, }\end{array}\right\} 6 / 5$ mo., Blackwater Bank Lt. sh.

". . . $\left\{\begin{array}{c}\text { Leg, wing, } \\ \text { and bill, }\end{array}\right\}$ Killed st., . $10 / 5$ mo., Howth Baily.

," . Rec'd. in flesh, Caught alive, 16/ 5 mo., Eagle Island, $W$.

Purple S ndpiper, Leg and wing, Killed st., . 16/5 mo., Blackwater Bank Lt. sh.

Knot, . . Rec'd. in flesh, Shot, . . 12/1 mo., Drogheda, N.

Common Sandpiper, Leg and wing, Killed st., . 16/ 7 mo., Coningbeg Lt.-ship.

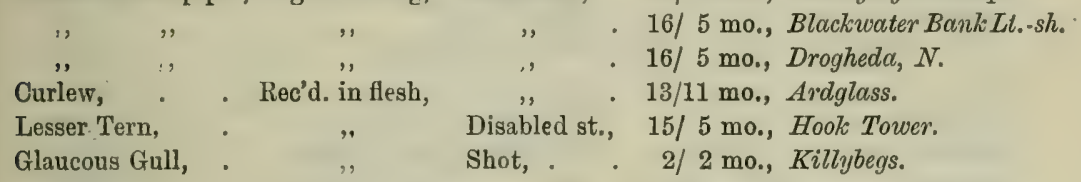

Manx Shearwater, $\quad$ :. Caught, $\quad\left\{\begin{array}{l}\text { Rec'd. with } \\ \text { letter, dated } \\ 25 / 4 \text { mo., }\end{array}\right\}$ old Head, Kinsale.

Black Guillemot, $\quad$.. Shot, . . 15/ 2 mo., Killybegs.

Eared Grebe, . " . 6/ 2 mo., ,

Bittern, . . . Caughtin pool, $27 / 8$ mo., Slyne Head, $S$. 


\section{INDEX.}

Birds not identified, .

PAGE

Bittern,

Blackbird,

"Bullfinch,"

Bunting, Snow,

"Yellow,

Chaffinch,

Chough,

Cormorant,

Corn-Crake,

Crow, Hooded,

Cuckoo,

Curlew,

"Stone, . $\quad 372$

Diver,

"Ducks," . . . . . 380

Dunlin, . . . . . 370

Fieldfare, . . . . . 343

Flycatcher, Spotted, . . . 340

Gannet,

"Geese," .

General Observations,

Golden-crested Wren,

Goldfinch,

Grebe, Eared,

Greenfinch,

Guillemot, Black,

" Common, .

Gulls,

Heron,

Jackdaw,

Kestrel,

Knot,

"Linnets,"

Magpie,

Manx Shearwater,

Martin, House, .

Mealy Redpole, .

Merlin,

Missel-Thrush,

Nightjar, .

Oyster-Catcher, .

Peregrine Falcon,

Petrel, Storm, .

Phalarope, Grey,

358

"Pigeons,"

PAGE

Plover, Golden,

366

367

368

367

367

377

Puffin,

Grey,

Quail,

366

Raven,

361

Razorbill, . . . . . 376

Redshank, . . . . 372

Redstart, Black, . . . 346

Redwing, . . . . . 342

Robin, . . . . . 345

Rock-Pipit, : . . 352

Rook, . . . . 362

"Sand Larks," . . . . 371

Sandpiper, Common, . . . 371

") Purple, . . . 371

Sedge Warbler,. . . 347

Shag, . . . . 378

Shrike, Woodchat, . . . 340

Skylark, . . . . . 352

Snipe, Common, : . $\quad 370$

", Jack, . . . . 370

Sparrow-Hawk, . . . . 339

Sparrow, Hedge, ․ . . 345

" House, . . . 357

Starling, . . . . . 359

Stonechat, . . . 346

Swallow, . . . . 363

"Swans," . . . . . 380

Swift, . . . . . 365

Tern, Lesser, . . . . 373

Terns, . . . . . 373

Thrush, . . . . 340

Titlark, $: 351$

Turnstone, . . . . 368

Turtle Dove, . . . . 365

Twite, . . . . . 359

"Wagtails," . . . . 350

Wagtail, Yellow, . . . 350

Water-Rail, . . . 366

Wheatear,. . . . . 346

Whimbrel, . . . . 373

Whinchat,. . . . 346

Whitethroat, . . . 348

Willow Wren, . $\quad 348$

376 Woodcock, . . . 369

369 Wren, . . . . . 350 
Peregrine Falcon (Falco peregrinus, Tunstall).

Old Head, Kinsale.-July, four young Peregrine Falcons received alive, taken from the nest some time before.

Tearaght.-February 28th, "Falcon Hawk" on island; gale S. March 6th, three "Falcon Hawks" at noon: 8th, three Peregrine Hawlss on island: 25th, one do. April 4th, two.

\section{MerLin (Falco oesalon, Gmel.).}

Hook Tower:-March 21st, a Hawk sent, caught in house by a gardener at Loftus Hall. [Female Merlin received in flesh.]

Kestrel (Falco tinnunculus, Linn.).

Howth Baily.-February 21st, one. April 10th, observed several times; breeds in cliffs every summer. June 10th, breeding. October 7 th, one.

Innishtrahull.-July $2 \mathrm{nd}$, one round station.

Tearaght.-February 20th, one noted. April 24th, one on island at noon.

SPARRow-HawK (Accipiter nisus, Linn.).

Drogheda, $N$ :-April 16th, one going S.

Innishtrahull.-July 2nd, "Sparrow-Hawks come and go." December 22nd, one stopped on island.

Rathlin O'Birne. - February 11th, one "Sparrow-Hawk" lovering at noon. April 21st, one "Sparrow-Hawk" hovering.

Tecurcught.-February 20th, two, and one Kestrel on island.

\section{"HAWKS."}

Hook Tover:-September 21st, small Hawk at station watching tame Pigeon: 26th, two going N.W. at daylight; gale N.W. October 5th, three going N.E. at 11 A.Mr; wind light W.: 10th, three at station: 18th, Hawk and Raven fighting in air at station at 2 P.M. ; wind light N.; Hawk flew off first.

Coningbeg Light-ship.-May 15th, one small Hawk at 1 A.M.

Copeland (Mew) Island.--September 27th, a large Hawk on island.

Tearaght.-April 4th, Hawks nearly always here. 
Woodchat SHRIKe (Lanius pomeranus, Sparrman).

Blackwater Bank Light-ship.-August 16th, several small birds about light from 9 P.M. to daylight; one killed; wind moderate S.W., rain and fog. [Leg and wing of young Woodchat Skrike received, labelled "the first of this species killed at this station.-P. Cullen and D. Dunn." Agrees exactly with a young male from Seville, July 9th, 1869, E. Mus. Howard Saunders.-R. M. B.]

Spotted Flycatcher (Muscicapa grisola, Linn.).

Blackwater" Bank Light-ship.-May 17th, one "small bird" found dead at 9 A.M. ; wind light S.E., clear. [Leg and wing of Spotted Flycatcher received.]

Arklow South Light-ship.-[May 16th, Spotted Flycatcher found dead on deck. Leg and wing received.]

Missel-Thrush (Turdus viscivorus, Linn.).

Howth Baily.-June 20th, some birds like Fieldfares, only more grey, are here this summer again; they may be young Missel-Thrushes. July 30th, these birds are now gone.

\section{Throsh (Turdus musicus, Linn.).}

Hook Tower.-- [January 8th, Leg and wing of Thrush received, killed striking.] April 16th, Larks, Thrushes, and Warblers round light; wind fresh S.W., fog. October 8th, Starlings, Larks, and Thrushes about light; "first autumn observation of birds round lantern;" two Thrushes and one Blackbird killed; drizzling rain: 19th, some, with Fieldfares, Blackbirds, and Larks, round light; one killed striking: 20th, one.

Coningbeg Light-ship.-October 17th, flocks: 20th, two at light. November 13th and 14th, Thrushes, with Larks, Blackbirds, and Starlings, at lantern; some killed: 16th, numbers of birds, including Thrushes; several killed (see under Skylark).

Tuskar:-September 23rd, Thrushes and Blackbirds all night round light; some killed; wind S.W., fog. October 5th, Thrushes, with Blackbirds and Larks, round light all night. November 10th, Thrushes all night round light; wind N.W.: 13th, Blackbirds, Thrushes, and Larks round light: 15th, do.; largest rush for season. 
Blackwater Bonk Light-ship.-February 26th, flock going N.W. at 11 A.M.; wind moderate N.W. March 7th, flock about light at 10 P.M. ; wind light N.W. October 31st, flocks, with Blackbirds and Starlings, going N.W. November 5th, flocks, with Larks and other birds: 7th, a flock: 8th, flocks Linnets and Thrushes: 10th, some: 12th, Thrushes about light: 13 th and 14th, numbers of birds about light; some were Thrushes; many birds killed (see full note under Blackbird): 24th, a flock: 29th, Thrushes about light from 8 P.M. to 10 P.M.; strong breeze S.W.: 30 th, Thrushes about light from 6.50 P.M. to 10 P.M. ; fresh breeze N.E.

Arklow South Liyht-ship.-February 6th, several Thrushes about light during night; one killed striking; wind light S.W. December 5th, "Thrushes and various other birds about light during night; wind moderate S.W., gloomy; one Thrush and one 'Finch' found on deck killed": 19th, several flocks of Starlings, Thrushes, Linnets, and "Finches" going N. during day; strong breeze S.W.

Arklow North Light-ship.-January 6th, several flocks of birds going N.W. from noon to 4 P.M., flying high; Thrushes and Starlings about light from 8 P.Mr. to midnight: 7th, flocks going N.W.; strong breeze S.E., sleet; four Thrushes on upper deck for some hours; several birds about light at night; some killed, fell overboard: 8th, 9th, and 11th, Thrushes about light; wind variable. October 17 th, some about ship, with several other species, going N.W. (see full note under Linnet). December 28th, several; some striking at 11 P.M.; wind moderate S.W., hazy, rain ; two killed.

Rockabill.-September 11th, four on rock in the morning; wind N.E. October 1st, four at 6 A.M.; wind light W.: 23rd, five, and ten Starlings at lantern; some striking. December 22nd and 25th, Blackbirds and Thrushes round lantern; a few struck.

Copeland (Mew) Island.-January 8th, some here all day; strong breeze E. October 7th, some Thrushes and Lapwing here at night; wind light S.E., drizzle and haze; a few killed. November 13th, rush of Blackbirds, Thrushes, and Larks; large numbers striking, a few killed.

Maidens South.-February 6th, rush, with Larks (twenty) from 8 P.M. to 2 A.M. round lantern; strong breeze S.W., clear. 
March 6th, rush of Thrushes, Larks, Blackbirds, and Curlew from 9 P.Mr. to 3 A.M. round lantern; Curlew going N.E.; wind light W., clear: 7th, rush of Thrushes, Larks, etc., from 9 P.M. to 3 A.M. round lantern; wind moderate N.W., clear. April 13th, rush of Larks, Thrushes, and other birds round light: 17th, "Thrushes, etc.", round lantern from 10 P.M. to 1 A.M.; fresh breeze S.E.: 18th, some round lantern from 9 P.M. to 2 A.M.; wind light S. October 7 th, some, with Larks, round lantern; misty. November 13th, rush of Larks, Thrushes, and other birds; light breeze S.E., misty.

Innishtrahull.-January 14th, four struck at 10 P.M., one killed; fresh breeze W., foggy. November 14th, rush of Thrushes and other birds (see full note under Blackbird).

Slyne Head, N.-November 6th, Thrushes, Starlings, and Blackbirds about lantern all night; "several lit at lantern;" hazy. December 21st, fifteen on island.

\section{REDWING. (Turdus iliacus, Linn.).}

Hook Tower-- [January 9th, Leg and wing of Redwing received, killed striking.] October 17th, two "Mountain Thrushes" at lantern from 9 P.M. to 11 P.M. ; wind light $N$. [Perhaps Redwings.-R. M. B.]

Backwater Bank Light-ship.-[January 10th, Leg and wing of Redwing received, killed striking.]

Arklow South Light-ship.-January, several birds of various kinds about light during night of 9 th and morning of 10 th ; a few killed striking; wind light S.E. [Leg and wing of Skylark and of Redwing received.]

Rockabill.-October 17th, four Redwings on rock at 6 A.Mr.; wind light N.E. November 15th, Redwings and other birds at lantern from midnight to 4 A.M.; fresh breeze S.E., misty; some of each kind killed.

Innishtrahull.-April 10th, one caught striking at 11 P.M.; wind light W., rain: 14th, one killed striking at 10.30 P.M.; fresh breeze S.W., rain. October 7th, five "Thrushes" (Redwings) stopped on island; first arrival; wind light S.W. November 14th (see full note under Blackbird).

Tearaght.-February 10th, a flock; gale N.W. March 3rd, flock all day on island; strong breeze S.W., misty. 
Fieldfare (Turdus pilaris, Linn.).

Hook Tower.-October 19th, Fieldfares, Thrushes, Blackbirds, and Larks round light from 1 A.M. to 4 A.M. ; wind light N., clear; one Fieldfare and one Blackbird wounded, one Thrush and two Lark's killed.

Tuskar:-November 12th and 13th, Fieldfares, Starlings, and Chaffinches (several) all night round light; wind W.; several killed.

Rockabill.-November 15th, Fieldfares and other birds at lantern from midnight to 4 A.M., some of each kind killed; fresh breeze S.E., misty.

Blackwater Bank Light-ship.-November 13th and 14th, numbers of birds round lantern (see under Blackbird). [Leg and wing of Fieldfare received.]

Copeland (Mew) Island.-October 4th, flocks of Fieldfares from 9 P.M. to midnight, several struck; wind light W., night calm, gloomy.

Innishtrahull.-November 9th, three on island; first arrival ; wind light S.E., clear: 14th, rush of Fieldfares and other birds (see full note under Blackbird).

Rathlin O'Birne.-March 12th, seven on island at 10 A.M.; strong breeze S.W., cloudy.

Tcaraght.-March 1st, several Fieldfares and flock of Ravens on island in the morning; gale $\mathrm{W}$.

\section{Blackbird (Turdus merula, Linn.).}

Hook Tower.-October 8th, Starlings, Larks, and Thrushes about light; first birds round lantern this autumn; one male Blackbird killed: 19th, some, with Fieldfares and other birds, about light; one Blackbird wounded: 20th, one male killed at lantern. November 13th, 14th, and 15th, "Wild Duck, Blackbird, Chaffinches, Grey and Green Linnets at lantern." "Blackbirds are very rarely to be seen here."

Coningbeg Light-ship.-November 13th and 14th, some killed striking: 16th, rush of Larks and other birds, including Blackbird.

Tuskar. - September 23rd, Thrushes and Blackbirds all night round light. October 5th, Blackbirds, Thrushes, and Larks all night round light; several killed, mostly Blackbirds; wind 
S.W., fog. November 10th, some all night round light; wind N.W.: 13th, Blackbirds, Thrushes, and Larks all night round light; several killed; wind S.W.: 15th, do.; wind W., fog; largest rush for season.

Blackwater Bant Light-ship.-[January 10th, Leg and wing of Blackbird received, killed striking.] February 18th, flocks, with Larks, about light from 8 P.M. to midnight; wind moderate S.W. August 15th-[Leg and wing of Blackird received, killed striking]. October 16th, two about ship; one killed: 19th, several, with Larks, about ship from 8 P.M. to daylight; five killed: 31st, several flocks, with Thrushes and Starlings, going N.W. from 8.30 A.M. to 10 A.M.; wind moderate N.E. November 12th, flock about light; fresh breeze E. : 13th and 14th, "several Blackbirds, Thrushes, Larks, Chaffinches, Snipe, Starling, and two Storm Petrels about light from 6.30 P.M. to daylight; forty birds killed and two disabled "-[Leg and wing of Fieldfare and Snipe received]; wind S.E., gloomy: 25th, flock going W. at 2.45 P.M.

Arklow South Light-ship.-January 12th, "one killed during night."

Arklow North Light-ship. - January 7th, flocks of birds, including Blackbirds, going N.W. from 10 A.M. to 4 P.M.; strong breeze S.E., sleet; several birds about light at night, some killed and fell overboard. July 17th, one hen Blackbird killed striking at 12.30 A.M.; wind moderate N.W. October 17th, some about ship (see full note under Linnet).

Codling Bank Light-ship.-October 7th, several going N.W. in the forenoon; wind light $\mathrm{N}$.

Rockabill.-September 10th, two on rock in the morning; strong breeze E. October 17th, four at 6 A.M.; wind light N.E.: 31st, ten, with other birds; none striking (see full note under Greenfinch). November 2nd, some noted: 3rd, flock going W. at noon; strong breeze W.: 15th, Blackbirds and other birds at lantern from midnight to 4 A.M.; some of each kind killed; wind fresh S.E., misty. December 22nd, ten, and some Thrushes, round lantern at midnight; four struck: 25th, Blackbirds and Thrushes round lantern at 8 P.M. ; fresh breeze N.W., blue sky; two struck glass; some on rock in the morning: 31st, ten round lantern at midnight; wind light N.W. 
Copeland (Mcw) Islend.-January 4th, some here all day; wind light S.W., frost: 8th, some. April 1st, several, evidently going to breed here. October 7th, some at night; wind light S.E., drizzle; a few killed. November 13th, some, with Thrushes and Larks, from 8 P.M. to midnight; wind light S.E.; large numbers striking, a few killed. Blackbirds frequent the island all the autumn and winter.

Maidens South.-March 6th, rush of Thrushes, Larks, Blackbirds, and Curlew. April 18th, "Blackbirds, etc.," round lantern from 9 P.M. to 2 A.M.; wind moderate S. October 7th, some, with Larks and Thrushes, at lantern. November 13th, rush of Larks, Thrushes, Blackbirds, and other birds: 14th, two Blackbirds on rock.

Innishtrahull.-November 14th, " the last three nights a great number of birds have been killed at the lantern: on the 11th, eighteen were killed and a large number got away without injury : on the 12th, twenty-three, and a good many not injured: on the 13th, fifty-nine, and some not injured; some more disabled. The greater part of all these birds were Blackbirds, Thrushes, Fieldfares, and Skylarks, some five or six Starlings, and five Snow Bunting, the others were about equal in numbers; weather gloomy and hazy.-Geo. GilLespie." "The usual number of Thrushes (Redwing, Fieldfare, and Garden), Blackbirds, Green Linnets, Snow Bunting, Wrens, etc., visited the island.during the quarter."

Rathlin O'Birne.-March 10th, three on island at 9 A.M.; fresh breeze N.W.

Slyne Head, $N$.-November 6 th, some all night about lantern; hazy: 11th, do.; two females killed; wind E., hazy. December 19th, 20th, and 21st, one on island all day.

Tearaght.-March 3rd, five on island all day; strong breeze S.W.

Hedge: Sparrow (Accentor modularis, Linn.).

Rockabill.-October 31st, twenty at lantern and on rock, with other birds.

Tearaght.-July 21st, six on rock at noon; wind light N.W.

RoBin (Erithacus rubecula, Linn.).

Hook Tower.-October 17th, one disabled at lantern at 11 P.Mr.; wind moderate $\mathrm{N}$., clear. 
Howth Buily. - March 8th, one about station to-day. November 1st and December 12th, one at station.

Rockabill.-October 21st, two Robin Redbreasts on rock at 11 A.M.; strong breeze S.W.

Copeland (Mew) Island.-January 1st and 4th, one seen on island all day; gale E., frost: 30th, one. February 25th, one.

Tearaght.-January 31st, two on isiand, with a ferw Larks and Starlings. March 5th, two on island; wind light N.W.

\section{Black Redstart (Ruticilla titys, Scopoli).}

Ballycotton.-October 23rd, unknown bird sent, shot-[Black Redstart received in flesh]: 28th, "Black Redstart shot at 12.30 P.M.; we sighted it the day after shooting the other; the first one shot appeared cold and tired, the second full of energy." [Received in flesh.]

Slyne Head, N.-November 11th, two Redstarts all day on island. December 21st, one do. [Probably Black Redstarts.R. M. B.]

Stonechat (Pratincola rubicola, Linn.):

Maidens South.-March 8th, two on rock all day; wind light W. April 13th, Larks, Thrushes, Stonechats, and Warblers round light: 14th, three; wind light W.: 17th, Stonechats and other birds round lantern from 10 P.M. to 1 A.M. ; fresh breeze S.E., rain.

Rathlin O'Birne. - March 2nd, numbers of Stonechats on island all day; wind moderate S., fog. April 2nd, sixteen all day; fresh breeze S.W.

Tearaght.-March 6th, five Stonechats on island at noon; wind light $\mathrm{N}$ : 25 th, seven at 8 A.II.; wind light S.W., misty.

\section{Whinchat (Pratincola rubetra, Linn.).}

Tuskar:-August 12th, Whinchat noted (see under Whitethroat): 28th, one on rock at noon; wind light S.W., hazy.

Wheatear (Saxicola conanthe, Linn.).

Tuskar.-September 10th, three on rock at 8 A.I. ; wind S.W., gloomy.

Blackwater Bank Light-ship. - April 12th, one on deck; wind light N.E.: 22nd, several about light from 9 P... to 
midnight. August 15th, several "small birds" about light all night; wind light S.W., fog; one killed. [Leg and wing of Wheatear received.]

Arlilow South Light-ship.-April 11th, several small birds about light from 10 P.x. to 11 P.M. ; wind light N.E., light haze; one Wheatear killed. August 12th, several about light; fog; one caught.

Houth Baily.-March 19th, first seen this year. September 13th, two or three near station.

Drogheda, N.-April 12th, three; first seen this season. July 12 th, five young ones about station; rare here this season. September 27th, two.

Maidens South.-April 18th, "Stonechat" killed striking at 10 P.I. ; wind moderate S. [Leg, wing, and tail of Wheatear received.]

Innishtrahull.-April 1st, ten on island: 13th, two killed striking at 2 A.M. : 1Sth, three struck at 3 A.M. ; strong breeze S.E. : 23rd, thirty on island; wind light N.W. September 4th, one struck at 11 P.M.: 13 th, two struck at 11 P.M.; fog. "Wheatears hatch on island."

Tecraght.-March 24th, five on island; strong breeze S.E.

\section{Sedge IVARbler (Acrocephalus phragmitis, Bechstein).}

Hook Tower.-April 29th, "Warbler" sent-[Sedge Warbler received in flesh]. May 14th and 15th, "Warblers" killed at lantern; five or six from 11 P.M. to 1.30 A.M.; wind S.E., gloomy, fog-[Two Sedge Warblers and one Whitethroat received in flesh]: 18th, three Warblers picked up dead at base of tower; wind S. [Sedge Warbler and Whitethroat received.]

Blackicater Bank Light-ship.--[August 16th, Leg and wing of Sedge Warbler received.]

Houth Buily.-August 12th, fog to-night; Willow Wren found stumned-[Len and wing of Sedge Warbler received]; small birds flying through rays of light.

Copeland (MLew) Island.-May 16th, a bird found dead on balcony of lighthouse, species not known: 17th, several birds flying in rays of light; appear to be same species as that killed previous night. • [May 27th, Sedge Warbler received in flesh; perhaps killed on 16th.] 
Mciidens South.-[May 17th, Leg and wing of Sedge Warbler received, killed striking.]

Innishtrahull.-[May 24th, Sedge Warbler received in flesh.] Killybegs. - [May 17th, Sedge Warbler received in flesh, killed striking.]

Whitethroat (Sylvia cinerea, Bechstein).

Hook Tower:-[February 25th, Leg and wing of Whitethroat received; date when killed not given.] April 19th, two "Warblers" killed striking at night; wind light S.W., fog[Whitethroat and Willow Wren received in flesh]. May 14th and 15th, "Warblers" killed at lantern; five or six from 11 P.Mr. to 1.30 A.M. ; wind S.E., gloomy, fog-[Whitethroat and two Sedge Warblers received in flesh]: 18th, three Warblers picked up dead at base of tower; wind S. [Whitethroat and Sedge Warbler received.]

Tuskar-[August 12th, Leg and wing of a Whitethroat, killed striking, received.]

Howth Baily.-April 20th, Whitethroat found killed on balcony.

Carlingford Bar.-[May 14th, Leg and wing of Whitethroat received, killed striking.]

Maidens South.-May 5th, twenty Whitethroats and small birds ; seven killed between 10 P.M. and 2 A.M. ; wind light S.E., misty-[Whitethroat received in flesh]: 6th, three at sash at 11 P.M. ; wind light S.E.

Innishtrahull-May 4th, one killed striking at 2 A.Mr.; wind moderate S.E. [Leg and wing received on $24 \mathrm{th}$; possibly above]: Sth, seven on island at noon; strong breeze S.E., gloomy : 17 th, two struck at 1 A.M.; strong breeze S.E., fog.

Killybegs.-[May 16th, Whitethroat received in flesh, killed striking.]

WiLLOW WREN (Phylloscopus trochilus, Linn.).

Hook Touer.-April 19th, two "Warblers" killed striking; fog. [Willow Wren and Whitethroat received in flesh.]

Barrels Rock Light-ship.-MIay 14th, six "Sallypickers or Wrens" lighted on board during forenoon, then flew for shore; wind light E, light haze.

Mrcidens Sonth.-April 1Sth, two small green birds killed 
striking at 10 P.M.; wind moderate S. [Legs and wings of two Willow Wrens received]: 21st, "Warbler or Willow Wren" killed striking at 1 A.M. ; wind light E. ; misty-[Willow Wren received in flesh]. May 3rd, two Willow Wrens at sash at 11 P.M. ; wind light S.E., misty.

Innishtrahull.-[May 24th, Willow Wren received in flesh.] October 14th, one "Willow Warbler" stopped on island; wind moderate S.W., fog.

Golden-CREsted Wren (Regulus cristatus, Koch).

Ballycotton.-[October 23rd, Golden-crested Wren received in flesh.]

Coningbeg Light-ship. - October 10th, small bird found on deck. [Golden-crested Wren received in flesh.]

Tuskar.-September 3rd, one at 11 P.M. killed striking; wind light W., fog. [Leg and wing received.]

Blachwater Bank Light-ship.-September 15th, one found dead; wind moderate S.W. [Leg and wing received.]

Artilow South Light-ship.-September 15th, "several very small birds about light during night; wind light S.W., dark but clear; two killed, name not known." [Golden-crested Wreu received in flesh, labelled "Little bird killed on night of 14th.]

Houth Baily.-September 2nd, Golden Wren caught at lantern at 11.30 P.M.; calm, haze: 9th, another caught at 10 P.M.; wind moderate N.E., clear: 12 th, one caught at lantern at 4 A.M.; calm, haze (strong breeze from the E. for some days previously): 17th, one caught at lantern at 12.15 A.M.; strong breeze W. October 8th, one caught at 11.30 P.I. November 14th, one caught at 10 P.M.

Rockabill.-September 10th, two on rock in the morning; strong breeze E. [One caught in out-office, sent on 15th, received in flesh.]

Copeland (Mew) Island. - October 4th, flocks of Goldencrested Wrens from 9 P.M. to midnight; fifteen struck, not disabled; night calm; wind light W., gloomy.

Innishtrahull.-March 19th, "Fire or Gold Crest caught"[Skin of Golden-crested Wren received]. November 20th, one Gold-Crest caught on lantern at 11 r.M.; fresh breeze N.E., hazy. 
WREN (Troglodytes parvuius, Koch):

Hook Tover.-October 16th, Common Wren disabled at 9.30 P.M.; wind light W., haze: 17 th, one at station, probably the same.

Coningbeg Light-ship.-October 19th and 20th, one Wren noted.

Codling Bant Light-ship.-October 5th, one in ship.

Rockabill.-September 28th, two on rock at 9 A.M.; fresh, breeze S.W.

Drogheda, N.-December 1st, one Common Wren on balcony of lighthouse at 4.15 P.M.; rarely seen about here; wind moderate N.E., clear and frosty.

Copeland (Mew) Island.--December 3rd, a Wren on island to-day.

Maidens South.-March 8th, one on rock at 8 A.M.: 9th, one at noon. April 14th, one. November 14th, one on rock.

Innishtrahull.-December, "the usual number of Wrens visited the island during the quarter."

Slyne Hcad, N.-December 21st, two Common Wrens on island all day.

Tearaght.-January 17th, four on island; gale N. March 18th, a few: 30th, and April 24th, do.; these birds frequent the island.

Yellow Wagtail (Motacilla Raii, Bonaparte).

Hoot Tower.-September 11th, unknown bird killed against telephone wire. [Yellow Wagtail received in flesh.]

\section{"WAgTAILS."}

Hook Tower.-May 12th, one Common Wagtail at station at 4 P.M. ; wind light S.E. ; first seen here. September Sth, a large flock of "Common Grey Wagtails" collected on the banks or cliffs round station from 9 A.Mr. to about 3 P.M. "There were eight or nine at first, but before leaving there must have been fifty; about ten or twelve of them appeared more marked in colour of plumage than the others. They allowed us to approach quite close. They all left together, and flew off TT.; weather clear, gale N.IV.-J. Higrinbotidus." September 23rd, two "Grey 
Wagtails" at station at 1 P.M.; gale N.: 25th, two "Grey Wagtails" going N. at 9 A.M.; fresh breeze W. October 3rd, two pairs of "Grey Wagtails" noted.

Tuskar:-August 28th, "White Wagtail" at 10 A.M.; wind light S.W.

Arklow South Light-ship.-April 23rd, two going N.IV. at 11 A.M.

Arklow North Light-ship.-May 5th, Water Wagtail on deck at 6 A.M.; wind light S.W., clear; went N.W. in half an hour.

Howth Baily.-August 29th, Wagtails in garden. September 13th, three about station.. November 1st, one at station.

Maidens South.-March 8th, two on rock at 8 A.M.; flew W.; wind light S.W.: 10th, two at 7 A.Mr.; flew W. April 24th, two; flew W. November 3rd, one on rock all day: 14th, one rested and flew W.

Innishtrahull.-April 1st, one Pied Wagtail on island. October 4th, one do. stopped on island.

Rathlin O'Birne.-April 18th, two Wagtails all day; fresh breeze S.

Tcaraght.-March 8th, two "Willy Wagtails" on island; wind light N.E., fog.

\section{TitLark (Anthus pratensis, Linn.).}

Hook Tower:-September, about station every day.

Coningbeg Light-ship.-December 14th, one on deck; flew N.E.

Tuskar.-September 9th, one killed striking.

Arklow South Light-ship.-August 16th, several about light; one killed.

Arllow North Light-ship.-October 17th, some, with other species, about ship or going N.W. (see full note under Linnet).

Rockabill.-September 15th, twenty on rock; misty. October 31st, some, with other birds, at lantern and on rock.

Copeland (Mcw) Istand.-April 30th, a number have nests on the island at present; eggs in some, and young birds in others. Maidens South-October 30th, three on rock; flew W.

Innishtrchull.-February 12th, four at glass at 9 P.M. ; snow. May 1Sth, four Meadow Pipits struck at 11.30 P.Mr.; fresh breeze S.E., fog. September 11 th, two do. at glass at 1 A.M.; 
misty: 13th, three "Pipits" at glass at 10.40 P.M.; fog. "Meadow Pipits hatch on island."

Tearaght.-January 1st, numbers on island in the morning; gale S.E. March 30th, twenty noted; wind moderate S. April 24 th, they frequent the island. July 21st, "Titlarks numerous to-day; some always here"; wind light N.W.

Rock-PiPit (Anthus obscurus, Lath.).

Hook Tower--September, Rock-Pipits about station every day.

Tearaght.-March 8th, one on island; fog.

SKYLARK (Alauda arvensis, Linn.).

Hook Tower.-April 16th, Larks, Thrushes, Warblers, and Swallows round light all night; wind fresh S.T., fog; one IVarbler killed. September 29th, large flocks of Larks all day about station; gale W. October 5th, one killed striking at 11 P.M.; clear: 8th, Larks, with Starlings and other birds, about light: 12 th, 13 th, and 14th, numerous round, station; two killed: 17.th, one Skylark killed at 8 P.Ir.; clear: 18th, large flocks Larks near station: 19th, two, and one Thrush, killed striking.

Coningbeg Light-ship.-November 12th, a few flocks of Larks, Linnets, and Starlings going N.W. for land during day; strong breeze S.E.: 13th and 14th, several, with Thrushes, Blackbirds, and Starlings, flying round lantern from 6 P.M. to daylight, when they flew towards land; wind S.E. and N.E. ; about a dozen of each killed: 16th, numbers of Larks, Linnets, Thrushes, Blackbirds, and Starlings flying round at 7 P.x. ; strong breeze S., haze and rain; several killed; birds went away in the morning. December 23rd, several flocks of Skylarks going S.W.; wind light W., clear.

Barrels Roch Light-ship.-January 7th, two Larks on board at 11 A.M.

Tusken:-October 5th, Larks round light all night; wind S.W., fog. November 13th, do.: 15th, do.; largest rush for season.

Blachuceter Bunk Light-ship._-Janmary 17th, several Larks about light from 9 P.M. to midnight; wind moderate N.IW.; three killed-[Leg and wing of Skylark received]: 22nd, Hock 
going N.W. at 1.30 P.M. February 5th, three about light: 18th, flocks, with Blackbirds, about light: 21st, two on deck; went N.E.: 28th, flock about light from 8 P.Mr. to 11 P.Mr; strong breeze S.W. October 19th, Blackbirds and Larks about ship. November 5th, several flocks of Larks, Chaffinches, Linnets, and Thrushes from daylight to 2 P.M. going N.W.; wind moderate N.W.: 12th, Larks about light; fresh breeze E.: 13 th and 14th, some at light (see under Blackbird); many birds killed: 24th, Larks noted: 27th, flock going $N$. at 11 A.M.: 29th, Larks noted.

Arklow South Light-ship.-January 9th, one going N.; several birds of various kinds about light on night of 9 th and morning of 10th; a few killed striking; wind light S.E. [Leg and wing of Skylark and of Redwing received]: 12th, Skylarks going S.E. December 25th, two flocks going N.W.

Arklow North Light-ship.-January 7 th, several flocks Larks and other biras going N.W. from 10 A.M. to 4 P.M.; strong breeze S.E., sleet; two Skylarks on upper deck caught alive; several birds about light at night; some killed, fell overboard: Sth, several flocks of Skylarks going N.W. from noon to 4 P.M.; strong breeze S.E., rain: 8th and 9th, Skylarks about light: 13th and 19th, one going N.W. March 5th, flock going N.W.: 6th, six going N.W.: 14th, one about ship. October 9th, several going N.W.: 17th, Larks about ship (see full note under Linuet).

Codling Bunk Light-ship.--January 3rd, flock at 3.30 P.Mr.: th, great flocks of Larks all day: 5th, 6th, and 7th, great flocks noted: Sth, some on ship: 12th, several at midday. Flocks of Larks noted all through October in daytime going in various directions, but generally W.N.W.; none noted about light. November 2nd, great numbers: 4 th, Larks going N.W.

Fockabill.-October 31st, some about light. November 2nd, some noted: 15 th, Skylarks at lantern from midnight to 4 A.M.; fresh breeze S.E., misty; some killed: 30th, flock going W. December 4 th, two on rock.

South Rock Light-ship.-October 4th, several about light; one struck: 5th, several during day going W.: 7th, several flocks Larks groing W. during day, and several flocks about light; wind light N.E.; three struck: Sth, 9th, 10th, 12th, and 13th, Larks going W.: 16th, 17th, and 19th, Larks going 
W. during day: 18th and 19th, about light; wind variable, clear. December 3rd, several Larks going N.W. at 11 A.M.: 4th, a few going N.W. at 10 A.M. : 14th, several going N.W.

Copeland (Mew) Island.-October 7th, large numbers from midnight to 6 A.M.; wind light S.E., drizzle; large number killed and disabled. November 13th, rush of Blackbirds, Thrushes, and Larks ; numbers striking, a few killed.

Maidens South.-January 4th, one killed at 4 d.M. February 6 th, twenty at lantern: 13th, seven round lantern at midnight; one killed. March 6th and 7th, Thrushes, Larks, and other birds round lantern. April 13th, Larks, Thrushes, Stonechats, and Warblers round lantern from 10 P.M. to 2 A.M.; wind light S.W., clear: 17th, Larks round lantern at night; fresh breeze S.E., rain. October 7th, Larks, Thrushes, and Blackbirds flying at lantern from midnight to 4 A.M. ; six Larks killed; wind moderate N.E., misty: 8th, Larks going W.: 24th, nine going S.W.: 30th, November 3rd and 7th, a few going W.: 13th, a rush of Larks, Thrushes, Blackbirds, Green Plover, and Starlings flying round lantern from midnight to $5 \mathrm{~A}$..I.; wind light S.E., misty: 14th, three Larks on rock.

Innishtrahull.-February 12th; one Skylark at glass; snow. March 11th, five struck at 1 A.M.; four killed; gale S.TV., showery. April 11th, two killed striking at 1.30 A.1.; wind moderate S.W., drizzle: 18th, five struck at 3 A.M.; strong breeze S.E., misty, "Skylarks hatch on island." November 14th, great rush of Skylarks and other birds the last three nights (see full note under Blackbird).

Rathlin O'Birne.-March 2nd, numbers on island; wind S., fog.

Slyne Head, N.-November 6th, birds about light all night; Skylarks and Linnets from 10 P.M. to 4 A.M.; seven Larks killed; hazy: 14th, Skylarks on island all day.

Tecrerght.-January 31st, "five Larks, twenty Starlings, and two Robins on island in the morning; striking, none killed." February 10th, Larks striking. March 18th, flock round lantern at 'midnight ; some striking; misty.

Snow Bunting (Plectrophenax nivalis, Limn.).

Hook Toure--Septemlier 29th, ten; the first this season; remained a short time, and had hardly any white feathers, being 
quite grey in colour; gale W. October 3rd, six; strong breeze W.: 18th, white Snow Buntings at 2 1.M. ; wind light N.; first white ones.-J. HigginвothaM.

Tuskar.-October 27th, some on rock; wind W., foggy.

Rockabill. - November 4th, four on rock; gale N.E.

Droghcda, $N$.-November 27th, large flock; strong gale N.W.

Maidens South.-November 3rd, two "Snow birds" on rock; flew W. ; wind light $\mathrm{S}$.

Innishtrahull.-January 18th, two struck at 8 P.M.; one killed; wind light S.W., drizzle-[Wings of Snow Bunting received May 24th, perhaps those of above]. September 23rd, "thirteen coming from the N." at 4 P.Mr. g gale N.W., hail: 27th, "five coming from the N." at noon; wind moderate N.W. October 27th, eighteen stopped on island; strong breeze N.W., rain. November 14 th, great rush of birds last three nights, chiefly Blackbirds; five Snow Buntings noted.

Rathlin O'Birne.-April 2nd, one all day; fresh breeze S.W.

Killybogs.-December 31st, fourteen "Bunting," all young birds; wind light N.E. [Snow Bunting?-R. M. B.]

Slyne Hcad, N.-November Sth, eleven all day on island; wind N.E., clear, frost. December 10th, 11th, and 12th, some all day.

Tecuraght.-January 17th, ten; gale N. February 28th, ten; gale $\mathrm{S}$.

Yellow Bunting (Emberiza citrinella, Linn.).

Rockicill.-November 5th, two at 10 A.M.; went W.; fresh breeze N.E.

Teceraght.-April 10th, two on island; wind moderate $\mathrm{E}$.

Chaffinch (Fringiilla, coelebs, Linn.).

Hook Tover:-October 19th, one at station; wind light $\mathrm{N}$. November 13th, 14th, and 15th, "Wild Duck, Blackbird, Chaffinches, Grey and Green Linnets at lantern."

Coninglery Lights-ship.-October 19th, one about deck; wind light S.W. November 19th, two, and two Green Linnets settled on ship at 10 A.Mr., and remained all day; gale N.E.

Tushar.-September 27 th, all night round light. Novembur 12 th and 13th, several round light all night.

Blrchuter Banti Light-ship.-CSeveral, with Linnets and two 
Blackbirds, from 11 P.x. on October 16th to 6 A.M. on the 17th, about ship; wind variable, rain; one bird killed. November 5th, flocks of Larks, Chaffinches, and other birds going N.W.: 13th and 14th, numbers of birds about light, some were Chaffinches; many birds killed (see full note under Blackbird).

Arklow South Light-ship.-February 3rd, several about ship at 10 A.M.; wind light S.W. November 12th, various small birds during day going N.W.; two Chaffinches rested on ship.

Arklow North Light-ship.-At intervals during March one noted about ship; also on May 16th, and October 11th and 17 th.

Codling Bank Light-ship.-October 4th, flocks between 10 A.M. and 4 P.M.: 5 th, flocks going N.W.: 6th, flocks going W. from 10 A.M. to noon; wind moderate N.: 9th, flocks noted between 9 A.M. and noon : 14th, great flocks of Chaffinches going N.W. from 9.40 A.M. to 11 A.M.; wind light E. : 15th, 17th, 18th, 19th, 20 th, 28th, and 30 th, Chaffinches noted, always between 9 A.Mr. and 2 P.M.; wind variable. (Direction of flight not always entered, but when given was W.N.W.) November 3rd, great numbers of Chaffinches: 4th and 6th, Chaffinches going N.W.

Howth Baily.-January 18th, Chaffinches about station since the beginning of month. October 5th, one struck and was caught at 7 P.M.: 6th, one caught at glass at 7 P.II. : 12 th, one struck at 8 P.M., caught. November 29th, two in daytime. December 4 th, four.

Rockabill.-September 20 th, fifteen on rock at 10 d.M. ; fresh breeze N.W. October 13th, thirty on rock; fresh breeze S.W.: 31st, fifty at lantern and on rock, with other birds, some striking. November 2nd, some noted: 15th, Chaffinches and other birds at lantern from midnight to 4 A.Mr.; some of each kind killed; fresh breeze S.E., misty. December 14th, fifteen on rock in the morning.

South Rock Light-ship.-October 6th, several going W. at 9 A:M. ; wind light N.W.

Maidens South.-April 26th, two at 4 A.M. ; flew W.; foggy. October 8th and 30th, November 7 th and 14th, two or three noted on rock or going $W$.

Slyne Itcal, $N$ - -November 11th, female killed striking. 


\section{House Spartiow (Passer domesticus, Linn.).}

Codling Bank Light-ship.-[November 5th, Leg and wing of House Sparrow received, found dead on ship.]

Drogheda, N.-May 30th, some hundreds of House Sparrows about dwelling-house all day; it is very unusual to see so many about here; wind light N., clear.

Tearaght.-April 5th, two "Sparrows" on island; wind light $\mathrm{S}$.

\section{GreENFInCH (Iigurinus chloris, Linn.).}

Hook Tower:-November 13th, 14th, and 15th, Green Linnets at lantern (see under Chaftinch).

Coningbeg Light-ship.-November 19th, two and two Chaffinches on ship all day; gale N.E. December 3rd, four on ship at 8.30 A.M. "Gave them some food; did not see them next day."

Arklow South Light-ship.-April 4th, one going S.W.

Rockibill.-October 9th, twenty at 5 A.M. round lantern: 31st, fifty, with other birds, at lantern and on rock from 2 A.M. to noon. November 2nd, some noted: 15th, Greenfinches and other birds at lantern from midnight to 4 A.M.; some of each kind killed; fresh breeze S.E., misty. December 9th, a few on rock at noon; flew W.: 12th, flock in the morning; flew W.: 14th, twenty on rock in the morning.

South Rock Light-ship.-October 9th, "G. Linnets" going W. during day; wind moderate S.E. November 2Sth, one going N.W. December 3rd, "G. Linnets" going N.W.

Innishtrahull-December, "the usual number of Green Linnets visited the island during the quarter."

GoLDFINCH (Carduelis elegans, Steph.).

Arklow North Light-ship.-October 17th, Goldfinch amongst birds noted about shjp or going N.W. (see full note under Linnet).

Codling Bank Light-ship.-November 6th, "Chaffinches and four Goldfinches going N.W. and on deck;" fresh breeze N.E.

Rockabill.-October 29th, one on rock at 10 A.M.; strong breeze N.W.

Mealy Redpole (Linota linaria, Linn.).

Tearaght.-April 22nd, one on island; wind light E., overcast. November 15th, one shot. [Received in flesh.] 


\section{“LINNETS."}

Hook Tower.-September 19th, large flocks of Grey Linnets going N. at 9 A.M. ; fresh breeze N.W.: 23rd, Linnets at station during day in flocks of twelve to twenty; weather cold: 26th, large flocks at station; gale N.W. October 1st, do. between 7 A.M. and 10 A.M. ; wind light N.; all Grey Linnets : 5th, large flocks all day about station; wind light W.: 18th, large flocks near station. November 13th, 14th, and 15th, Grey Linnets at lantern.

Coningbeg Light-ship.-November 4 th and 6th, several flocks of Linnets and Starlings going N. between 10 A.M. and 3 P.M.; wind fresh N.E.; "going for the land": 12th, flocks of Larks, Linnets, and Starlings going N.W.: 16th, numbers of Larks, Linnets, and other birds round light. December 23rd, flock of Grey Linnets going W.

Blackwater Bank Light-ship.-September 27th, six going W. October 16th, some, with Chaffinches, about ship. November 5th, flocks going N.W.: 7th, two flocks going N.W.: 8th, several flocks, with Thrushes, from-11 A.M. to midnight going N.W.; fresh breeze N.E. ; one bird killed.

Arklow South Light-ship.-October 21st, Linnets and "Finches" going N.W. November 20th, a large flock of Grey Linnets going N.W. at 9 A.M. ; strong breeze N.E., hail showers. December 19th, Linnets noted, with Thrushes and other birds, going $\mathrm{N}$.

Arklow North Light-ship.-October 9th, flock going N.W. at 9 A.M.; wind N.: 14th, several flocks going N.W.; wind light S.W.: 16th, several flocks going N.W.: 17th, several flocks, also "Chaffinch, Titlarks, Goldfinch, Blackbirds, Thrushes, Larks, Starlings, etc., about ship all forenoon or going N.W.;" wind light variable, hazy, cloudy and rain. "These birds kept flying to N.W. and back again, lighting on rigging and about ship until 1 o'clock, when they all flew to N.W."

Howth Baily.-October 25th, flock came from S.E., and went N.W.

South Rock Light-ship.-October 7th, some going W. during day; wind light N.W.: 18th, Linnets about light during night; wind light N.E., clear. November 21st, several going N.E.; 
wind moderate N.W.: 27 th, several going N.W.; wind light S.W. December 5th, three going N.W.

Maidens South.-March 8th, three going W.: 21st, two do. October Sth, three do. November 4th, nine Grey Linnets going S. : 7th, two do. going S.W.

Slyne Head, N.-November 6th, some at night, with Larks, Starlings, and other birds: 7 th, Linnets on island; wind E.

Tearcght.-Jauuary 1st, twenty on island; gale S.E. April 24 th, five do. July 15 th, flock on rock; rain.

TwITE (Linota flavirostris, Linn.).

Codling Bank Light-ship.-[November 11th, Leg and wing of Twite received; died on ship.]

Houth Baily.-November 13th, one about station: 20th, flocks do.

\section{"Bullfinch."}

Coningbeg Light-ship.-December 3rd, six "Bullfinches"[Chaffinches?-R. M. B.]-and four Green Linnets on ship at 8.30 A.M.; wind moderate N.W., clear; "gave them some food."

StARLing (Sturnus vulgaris, Linn.).

Mine Head.-February 9th, five at 10 P.M.; strong gale W.; two killed: 27 th, two at 8.20 P.M.; one struck.

Hook Tower.--September 19th, hundreds going N.E. at 9 A.M.; fresh breeze N.W., clear; first this autumn: 23rd, large flocks; gale N. October 4th, large flocks going N.E.; strong breeze W.: 8 th, first birds round lantern this autumn ; Starlings, Blackbirds, Larks, and Thrushes; one male Blackbird killed, and two Thrushes; rain: 12th, 13th, and 14th, Starlings numerous: 18th, large flocks near station, seventy or eighty yards long: 20th, four killed at lantern.

Coningber Light-ship.-October 17th, flocks. November 4th and 6th, flocks going N.; wind fresh N.E.: 9th, a few round light: 12th, flocks going N.W.; strong breeze S.E.: 13th and 14th, Starlings at lanteru; about a dozen killed: 16th, numbers, with Larks and other birds, at 7 P.M. ; some killed: 23rd, a few round lantern.

Tusliar,-October 11th, some going N.W. at noon; wind 
N.W. November 12th and 13th, some round light; several killed; wind W.

Blackwater Bank Light-ship.-September 30th, flock going N. October 17th, flock about ship from 8 P.M. to 9 P.M.; one killed striking-[Leg and wing received, dated 16th, probably same]: 27th, flock going N.W.: 31st, flocks do. November 7th, 9th, $10 \mathrm{th}, 14 \mathrm{th}, 21 \mathrm{st}$, and 30th, Starlings noted, generally in flocks - and going in a northerly direction, or about light. December 31st, flock going $\mathrm{N}$.

Arklow South Light-ship.-January 7th and 8th, very large flocks going N. during day; fresh breeze S.E. October $17 \mathrm{th}$, several flocks of birds going N.W. during day; wind light N.W., rain; four Starlings disabled, one died. November 5th, a few about light: 6 th, small flocks going $N$. during day; some about light: 7th, odd Starlings and small birds going N. during day: 13th and 14th, "numbers of small birds about light during night; several struck, but fell overboard; most of them Starlings": 27th and 29th, flocks going N.W. during day. December 19th, flocks going $\mathrm{N}$.

Arklow North Light-ship.-January 6th, Starlings about light: 7th, flocks going N.W. ; strong breeze S.E. ; several birds about light. October 17th, Starlings about light (see full note under Linnet).

Codling Bank Light-ship.-January 5th, 6th, and 7th, great flocks of Larks and Starlings; fresh breeze S.E.: on 7th, one Starling passed with string and piece of paper attached: Sth, Starling and Larks on ship, etc. October 17th, Starlings going N.W. between 10 A.M. and 12 noon: 24th, some going W.: 30th, some noted. November 3rd, do.: 4th, some going N.W.

Houth Baily.-February 15th, Starlings commenced to build in ventilator holes of tower: 23rd, Starling struck lantern glass at 4 A.M., and was caught on balcony. August 9th, great thunderstorm from 7 P.M. to 11 P.M.; Starling against glass at 11.30 P.M. October 19 th, one struck at 2.30 A.M.

Rockibill.-October 23rd, ten (see under Thrush). November 5 th; three noted; went W. December 14th, twenty on rock; Hew W.: 31st, ten at midnight; some killed striking; wind light N.W.

Droghceda, N.-January 4th, hundreds near station: 6 th, two large flocks. February 23rd, about filty going S.IV. April 
30th, fifty near station. June 1st, a large flock near station, seemed mostly young birds. July 5th, a large flock near station all day; all young birds of this year. October 3rd, hundreds near station. November 10th, large numbers all day. They are here all the year, in greater or less numbers.

Vidal Bank.-November 4th, a large flock passing light at 4.30 P.M. going S.; wind light S.E., clear; one killed against glass : 8th, thirty here: 24 th and 29 th, a large number.

Copcland (Mew) Island.-January 4th, a flock all day; frost. February 22nd, flocks here all day. April 1st, some: 5th, flock, evidently going to breed on island. September 5th, large flocks all day; wind light S.: 18th, do.: 27th, some. October 3rd, flock here: 9th and 19th, flocks here all day.

Maidens South.-January 6th, seven going S.W. October 30th, twenty going W. November 3rd, a few do.: 13th, rush of Larks, Thrushes, Blackbirds, Green Plover, and Starlings.

Innishtrahull.-January 22nd, three struck at 10 P.M.; one killed; gale S.E., hazy. March 12th, one killed striking at 2 A.M. ; gale N.W., snow. May 29th, a flock on island at noon; wind light $\mathrm{N}$. November 14th, great rush last three days (see full note under Blackbird).

Slyne Head, N.-November 6th, Starlings, Thrushes, and Blackbirds about lantern all night; hazy: 19th, some about at 10 A.M. December 10 th, 11 th, and 1.2th, some all day.

Tearaght.-January 31st, twenty, with a few Larks and Robins, noted.

Chodgh (Pyrrhocorax graculus, Linn.).

liathlin O'Birne.-March 12th, two on island all day.

Tearaght._July 6 th, seven on rock: 7 th, some all day.

Raven (Corvus corax, Linn.).

Hook Tower:-October 10th, two at station: 18th, Raven and Hawk fighting.

Rockabill.-October 31st, ten Ravens-[Some error.-R. M. B.] -with other birds. December 4th, two on rock: 9 th, one.

Drogheda, N.--January 15th, one going N.E.

Rathlin O'Birne.-March 12th, two on island.

T'earaght.-March 1st, "several Fieldfares and flock of Ravens on island in the morning; gale W." 


\section{Hooded Crow (Corvus cornix, Linn.).}

Hool Tower.-October 4th, two Grey Crows at station.

Innishtrahull.- " Four build on the island."

Tearaght.-March 5th and 25th, four. July 6 th, six on rock: 7 th, some all day.

\section{Roor (Corvus frugilegus, Linn.).}

Hook Tower.-September 23rd, large flocks of "Common Crows about station every day."

Coningbeg Light-ship.-October 25th, one "Crow" rested on ship at 3 P.M. ; wind fresh N.W., clear.

Arklow South Light-ship.-May 4th, one "Crow" going S.E. at 8 A.M.

Arklow North Light-ship.-March 30th, six "Crows" going N.W. October 12th, large flock going $\mathrm{N}$. at 11 A.Mr.; wind moderate N.W.

Codling Bank Light-ship.-October 12th, "Crows" going W.; wind moderate N.W.: 23rd, some noted: 24th and 26th, great flocks going W. during day: 27th, two flocks going N.W.; wind moderate N.W.: 30th, and November 2nd, "Crows" noted.

Rockabill.-November 26th, four on rock; gale N.

Maidens South.-March 21st, April 26th, and May 4th, three "Crows" noted going W. October 1st, two going W. November 3rd, one noted.

Imnishtrahull.-November 14th, large flock of "Crows"; wind light E., hazy; stopped eight or nine days on the island; unusual visitors.

Slyne Hearl, N.-November 4th, abont two hundred "Crows" flying W. from 9 A.M. to 11 A.M. ; clear.

Tearaght.-April 24th, a few "Crows" noted; these birds frequent the island.

\section{JACKDAW (Corvus monedula, Linn.).}

Howth Baily. - March 21st, about fifty along the cliffs. April 10th, May 16th, and November 13th, Daws noted.

Copcland (Mcuc) Island.-April 24th, several all day; they breed here. 


\section{MagPIE (Pica rustica; Scop.).}

Hook Towcr.-September 20th, one at 8 A.M. at station; went E. October 6th, four going S.E. at 10 A.M.; wind light N.: 18th, twenty to thirty noted at 10 A.M.; "Magpies very numerous close to station, probably between one hundred and fifty and two hundred-J. Higginвotham": 19th, twelve going N.E. at 9 A.M. ; wind light N.

Slyne Hcad, N.-November 7th, seven on island at 10 A.M. ; wind $\mathrm{E}$. : 9 th, seven at noon; wind $\mathrm{E}$, clear, frost.

T'earaght.-July 10th, one on rock, killed by keeper; wind light N.W., clouds, rain.

\section{SWALLOW (Hirundo rustica, Linn.).}

Hook Tower.-April 5th, two; wind light E., clear; first this season: $16 \mathrm{th}$, Swallows round light all night; fresh breeze S.W., fog. May 2nd, "large numbers; heavy rain; none seen for past three weeks, remarkably numerous to-day." October 18th, five at 10 A.M.; wind light N., clear; none here since spring till to-day.

Coningbeg Iight-ship.-May 11th, three small flocks going N.E. September, several rested one day on ship at 5 P.M. going S.W.; wind light S.W., fog.

Barrels Rock Light-ship.-April 11th, three flying low. June 20th, four flying low, going N. July 2nd, ten going W.: 12th, four about ship.

Tuskar:-August 10th, Swallows at 10 A.M. going S.E. ; wind N.W. : 12 th, Swallows all day: 28 th, several at 3 P.M. going S. September 7th, flocks going S.E.; wind N.W. October 17th, several at 10 A.M. going E. ; wind N.W., rain.

Blackwater Bank Light-ship.-April 14th, several going N.W. from 8 A.M. to 4 P.Mr; wind light, variable: 15 th, 17 th, and 20 th, several going N.W. between 9 A.M. and 4 P.M. ; wind light S.W. May 2nd and 3rd, several going N.W. in daytime; and on 3rd from 8 P.x. to midnight about light; fog: 4th, several from midnight to 4 A.ur. about light; fog. September $3 \mathrm{rd}$, flock going E. at 11 A.M.; wind light S.E.: 4th, flock going S.E. at 10 A.M. ; wind light S.W.

Arlilow South Light-ship.-April 7th and 11th, several going N. during day; wind light N.E.: 16th, several going N.W. 
during day; wind light S.W.: 21st, 24th, and 25th, several going N.W. May 1st and 3rd, some going N.W. during day: 4th, several small flocks going N.W. during day; wind light S.W., fog: 5th, several Swallows going N.W.: 25th, a large flock going $\mathrm{N}$.; wind light N.W.: 26th, some going N. during day. August 2nd and 7th, one noted going S.E.

Arklow North Light-ship.-May 2nd, several going N.W.; fresh breeze S.W.: 4 th, several on deck at 4 A.Mr.; wind moderate S.W., thick haze; flew N.W. after resting; several going N.W. at 5 A.M. and 6 P.M.: 14th, two going N.W.: 15th, one do.: 16th, flock going N.W. at 6 P.Mr; wind light S.E. : 26th, two going N.W. October 13th, several flocks going N.E. at 2 P.Mr.; fresh breeze N.W.

Codling Bant Light-ship. - October 4th, three Swallows noted.

Howth Baily.-May 10th, birds like Swallows flying in rays of light, snapping at moths.

Drogheda, N.-April 16th, three; first seen this season. May 28th, four. June 26th, great numbers flying about station from 2 P.I. to 8 P.M.; wind fresh to gale S., rain. July 12th, numbers, all young birds, about station at 11 A.M.; several lighted on dome of lighthouse; wind light N.E., clear.

Copeland (Mew) Island.-May 14th, five all day; wind light N.E, hazy.

Maidens South.-April 20th, one "Stwallow Martin" going S.IV. at 11 A.M.; wind light E.; first seen this spring: 23rd, three going W. May 4th, two do.: 5th, five do.

Innishtrahull.-April 23rd, six on island at noon; wind moderate N.W., clear; first arrivals. June 15th, a large number all day; wind light S.E., clear.

Tearaght.-April 23rd, one; wind light S.

\section{House-Martin (Chelidon urbica, Linn.).}

Howth Baily.-April 23rd, House-Martins first observed this yeàr. August 6th, Moths very plentiful to-night, and birds, supposed to be House-Martins, catching them in the rays of the light: 7th, Moths plentiful again at night, and small birds after them: Sth, great numbers of Moths at night round lantern glass and windows of dwellings; small birds snapping them off 
windows: 29th, some couple of hundred House-Martins on telephone wires, supposed to be preparing to migrate. October 1st, none observed for the last ten days. "When the Starlings finished breeding in the ventilator holes of tower this year, the House-Martins carried out their breeding operations in the same ventilator holes."

\section{SwIFT (Cypselus apus, Linn.).}

Barrels Rock Light-ship. - May 1st, two Tits and two "Black Swallows" about ship in the forenoon: 11th, two do, about ship at noon: 13th, one "Iarge Black Swallow" about ship.

Howth Baily.-May 16th, some Swifts observed.

Droghcda, $N$.-May 28th, two near station. July 9 th, large numbers all day; wind S.W., rain.

NightJaR (Caprimulgus europceus, Linn.).

Houth Baily.-July 30th, Goat-Suckers plentiful this month on the Hill of Howth.

\section{Cucroo (Cucules canorus, Linn.).}

Ilool: Tower:-April 18th, one picked up dead, probahly struck lantern during night-[Received in Hesh]. May 9th, first heard: 14th, one killed at lantern at 10 P.M.; wind moderate S.E. [Received in flesh.]

Howth Baily.-May 5th, first heard.

Copcland. (Mev) Island.-May 11th, first heard this year.

I'caraght.-May 7th, one on island; gale S.

\section{Turtle Dove (Turtur communis, Selby).}

Hook Tower:-June 8th, one killed against the telephone wire, a mile from station-[Received in flesh]. Four birds exactly similar were seen for six or seven days past at Fethard.

Coningbery Light-ship.-May 11th, one Dove alighted on ship, then flew to land.

Killybergs.-[June 12th, Turtle Dove received in flesh.]

Styne Hecu, N.-[September 19th, Leg and wing of Turtle Dove received, shot.] 
Bull Rock - [April 20th, Leg and wing of Turtle Dove received, killed on rock.]

\section{"Pighons."}

Mine Head.-January 12 th and February 20th, flock of Wild Pigeons noted.

Coningbeg Light-ship.-October 20th, one Wild Pigeon about ship ; caught; it died on $23 \mathrm{rd}$.

Arlilow South Light-ship.-July 20th, two Pigeons of a bluish colour rested on ship at 9 A.M., and flew S.W.

Rockabill.-October 31st, one Pigeon among birds noted at lantern and on rock. November 5th, one Pock Pigeon remained forty-eight hours: $26 \mathrm{th}$, one Pigeon on rock.

South Rock Light-ship.-December 13th, one Pigeon about ship.

Maidens South.-February 14th, one Blue Pigeon rested on roof.

Innishtrahull.-November 1st, one Carrier Pigeon stopped on island; shot it; strong breeze N.W., rain.

Tecraght.-January 14 th, ten Pigeons round island; gale N.

QuaIL (Coturnix communis, Bonn.).

Coningbeg Light-ship.-May 14th or 15th, two Quail, one killed striking; calm, hazy. [Leg and wing received.]

Blackuater Bant Light-ship.-May 14th, one Quail killed striking at 11 P.x.; wind light S., gloomy. [Leg and wing received.]

Corn-Crake (Crex pratensis, Bechst.).

Liklon North Light-ship. - May 16th, a large number of Corn-Crakes about light from 9 P.M. to midnight; wind light S.S.E., rain; none killed.

Innishtrahull.-May 24th, six Land-Rails on island at 2 P.M.; strong breeze S.W.; " they hatch on island."

\section{WATER-RAIL (Rallus aquatious, Linn.).}

Burrels Rock Light-ship.-[October 21st, Leg and wing of Water-Rail received; found dead on deck.] 
Stone Curlew (Gidicnemus scolopax, S. G. Gmelin).

Killybegs.-February, "I have twice seen a very curious bird here, it is about the size of a Woodcock, back brown, head and part of neck white, but bill short and thick, very long legrs and large eyes; it frequented an open level piece of land.-JoHN Kennedy." [Probably Stone Curlew.-R. M. B.]

\section{Ringed Plover (Aigialitis hiaticula, Linn:).}

Drogheda, N.-January 2nd, several "Ball Fowl" on bank of river; shot one. [Leg and wing of Ringed Plover received.]

Copeland (Mew) Island.-April 23rd, they breed on island. May 13th, three noted.

Maidens South.-[May 17th, Ringed Plover received in flesh, killed striking.]

Innishtrahull.-April 23rd, ten "Dotterel" on island; wind moderate N.W. June 20th, young Dotterels noted; "they hatch on island." December 30th, six "Ring Dotterel " stopped on island.

Rethlin O'Birne.-March 12th, seven "Dotterels" on island all day; gale W., overcast.

Golden Plover (Charadrius pluvialis, Linn.).

Blachivater Bank Light-ship.-November 17th, flock of "Grey Plover" going E.; strong breeze N.W.

Droghede, N.-October 22nd, five Golden Plover going N.E.

Innishtrahull. - February 15th, five Golden Plover on island.

Fiathlin O'Birne.-February 20th, six going E. March 19th, four all day.

Killybeys. - November 3rd, ten going E.; rain : 20th, twentythree going $\mathrm{N}$., flying very high.

Grey Plover (Squatarola helvetica, Linn.).

Dirughele, N.-January 12th, one grey bird like a Plover resting on Sloblands; "never observed one like it before": 14 th, one unknown bird on Sloblands; gale N.W., snow 
showers; "same sort as that seen on 12 th inst." ; shot-[Grey Plover received in flesh]. October 9th, one Grey Plover shot on Sloblands; wind light N. [Leg and wing received.]

\section{Green Plover (Vanellus vulgaris, Bechst.).}

Hook Tower.-September 5th, from thirty to forty going W. wind light S.E.: 7 th, twelve at station: 23rd, large flocks near station; gale N.: 24th, large flocks going N.W. between 9 A.M. and 11 A.M. ; wind light N., weather very cold: 26th, large flocks going N.W. from 8 A.M. to noon; wind moderate N.W. October 11th, large flocks going N.E.; wind moderate W.: 12th, 13th, and 14th, numerous round station: 18th, large flocks do.

Arklow South Light-ship.-January 2nd, a very large flock going S.; wind light E., snow showers. November 11th, two going N.W.: 15th, odd Plover about the light from 8 P.M. to midnight ; wind moderate S.E.

Drogheda, N.-September 27th, five Plover going W.; first seen this season. October 3rd, about fifty going $N$.; wind moderate W. December 24th, fifty going S.; wind moderate $\mathrm{S}$.

Copeland (Mew) Island.-January 4th, large flocks all day; frost : 7th, here all day; gale E., heavy snow showers. October 7th, Thrushes and Lapwings at night; a few killed; Lapwing frequent the island all the autumn and winter.

Maidens South.-March 3rd, nine "G. Plover" going N.E.: 9th, fifteen going N.E. October 24th, ten going W.: 29th, Green Plover passing W. at midnight; fresh breeze N.W., clear. November 13th, rush of Larks and other birds, including Green Plover; wind light S.E., misty.

Innishtrahull.-June 8th, seven on island; wind light N.E.

Rathlin O'Birne. - February 25th, two all day; wind moderate S.E.

Killybegs.-November 29 th, eleven going S.; gale S.W.

Turnstone (Strepsilas interpres, Linn.).

Droghcela, $N$-October 9 th, a large flock on strand; one shot. [Leg and wing received.] 
Innishtrahull. - [May 24th, Leg and wing of Turnstone received.] "Turnstones frequent the island."

\section{Oyster-Catcher (Homatopus ostralegus, Linn.).}

Hook Tower.--September, "about station every day."

Howth Baily. - August 31st, four. September 3rd, three along the rocks. October 6 th, two do.

Drogheda, N.-February 9 th, some on strand; strong gale W. August 16th, numbers; "they will be about here for some months to come."

South Rock Light-ship.-October 7th, Seapies about light; wind light N.E., clear.

Copeland (Mew) Island.-January 4th and 7th, flocks all day; frost and snow. September 5th, large flock all day: 18th, immense flocks of Curlew and Seapies; wind moderate W.: 27 th, some noted. October 3rd, flocks here: 5th and 6th, large flocks of Seapies and Curlew here; wind light W. and N.W.: 19th, flocks all day; Seapies frequent the island all the autumn and winter.

Innishtrahull._-"They frequent the island."

Rathlin O'Birne.-February 5th, ten all day. March 5th, eleven.

Tearaght.-July 5th, four "Seapoys" on rock.

Grey Phalarope (Phalaropus fulicarius, Linn.).

Ailow South Light-ship.-[August 22nd, Leg and wing of Grey Phalarope received, found dead on deck.]

Siyne Head, N. - [October 17th, Leg and wing of Grey Phalarope received, killed striking.]

WoodCock (Scolopax rusticula, Linn.).

Howth Baily.-August 10th, seven came near station for a few minutes and flew off again.

Innishtratull.-January 6th, four on island; gale N.W., snow. October 24th, December 5th, 18th, and 30th, one on island.

Killyboys.-December 19th, one here.

Slyne Head, N.-December 6th, two. 
Common Snipe (Gallinago coelestis, Frenzel) and JACK SNipe (G. gallinula, Linn.).

Hook Tower:-November 2nd, "a bird like Snipe." [Leg and wing of Jack Snipe received.]

Blackwater Bank Light-ship.-November 13th and 14th, rush of birds; Snipe noted about light. [Leg and wing of one Snipe and one Fieldfare killed striking received.]

Copeland (MLew) Island.-January 4th, some Snipe here; frost: 15 th, a large number on island: 30 th, some. September 1st, several here: 18 th, some all day: $27 \mathrm{th}$, Snipe frequent the island all the autumn and winter.

Innishtrahull.- "Snipe and Jack Snipe here all the winter." October 13th, four going S.W. stopped on island. December 1st, eight on island; fresh breeze N., snow.

Rathlin O'Birne.-February 27 th, numbers of Snipe feeding all day; fresh breeze N.E. March 25th, three.

Siyne Head, N.-November 9th, four Snipe on island; frost: 14th, four do.: 19th, Snipe about island at 10 A.M. ; one struck at 11 P.M.; killed. December 16th, six on island: 19th and 20th, some do.

\section{DUNLIN (Tringa alpina, Linn.).}

Hook Tower:-[February 25th, Leg and wing of Dunlin received.]

Blackwater Bank Light-ship.-May 6th, one "Sandpiper" found dead on deck at 8 A.M.; wind light S.E., clear. [Leg and wing of Dunlin received.]

Howth Boily.-May 10th, a Strand Lark killed against lantern--[Leg, wing, and bill of Dunlin received]. November 9th, Strand Larks along the rocks: 25th, a few do.

Eagle Island, W.-May 16th, a bird caught injured at base of tower; wind moderate S.E.; heavy rain, with thunder. [Dunłin received in flesh, in summer plumage.]

slyne Houl, N.-December 21st, one "Dunney" (Dunlin ?) on island.

Liran Island, N-November 24th, a bird sent. [Dunlin received in $\mathrm{Hlesh}$.] 


\section{Purple Sandpiper (Tringa striata, Linn.).}

Blackuvater Bank Light-ship.—May 16th, two "Snipe" killed striking at 10.30 P.M. ; wind light S.E., rain. [Leg and wing of Purple Sandpiper and Common Sandpiper received.]

\section{KNoт (Tringa canutus, Linn.).}

Droghedre, N.-January 12th, a large flock of "Strand Plover" about Sloblands; shot four-[Knot received in flesh]: 19th, about a thousand Strand Plover or Knots on strand; strong breeze N.W.; common here during winter. February 8th, some thousands of Knots on strand; fresh breeze W. April 1st, a large flock of Knot going S.; wind moderate S.W. December 23rd, a very large flock about station; fresh breeze W., clear.

\section{Common Sandpiper (Totanus hypoleucus, Linn.).}

Coningbeg Light-ship_July 16th, two "small sea-birds" about light at 2 A.Ir.; wind light, rain; one killed striking. [Leg and wing of Cummon Sandpiper received.]

Blackweater Bank Light-ship.-May 16th, two Snipe killed striking at 10.30 P.M. ; wind light E.S.E., rain. [Leg and wing of Common Sandpiper and Purple Sandpiper received.]

Drogheda, N.-[May 16th, Leg and wing of Common Sandpiper received, killed striking.]

\section{"SAND LARKs."}

Arlilow North Light-ship.-July 12th, one Sand Lark about ship.

Droykcela, 1 .-January 13th, two large flocks about banks of river. September 16th, seven.

Copeland (New) Island.-A April 5th, flocks of Sandpipers here; wind light S.E. September 5th, several all day; wind light S., fog: 18th, they frequent the island all the autumn and winter.

Innishtrahull._" Strand Larks frequent the island."

Rietllin O'Bime.-March 22nd, four on island. April 10th, seven all day. 


\section{Redshank (Totanus calidris, Linn.).}

Innishtrahull._-"Redshank frequent the island."

\section{CURLEW (Numenius arquata, Linn.).}

Hook Tower.-September, "about station every day."

Barrels Rock Light-ship.-July 8th, four flocks going N.W., Hying high; wind light S.E.: 19th, three flocks going S.E., flying low; fresh breeze S.W.

Arklow South Light-ship.-May 4th, one going N.W.

Arklow North Light-ship.-March 2nd, flock going N.; fog, calm: 3rd, flock going N.W.: 9th, flock going N.W. May 28th, two going $\mathrm{N}$.

Codling Bank Light-ship.-January 7th, Curlew going W. at night.

Howth Baily.-November 12th, about forty along the coast. December 10th, still in flocks round shore.

Drogheda, N.-May 31st, four. July 10th, nine going W.; fresh breeze S.

Vidal Bank,-November Sth, about twenty going S.; fresh breeze N.E.: 13th, about fifty passed station going S.; wind moderate S.E. : 14th, six going S.; wind moderate N.: 29 th, fifty going S.; gale W.

Ardglass.-November 13th, bird struck glass at 5.30 A.x.; strong breeze S.E. [Curlew received in flesh.]

Copeland (Mew) Island.-January 4th, large flocks all day; frost: 7 th, do.; heavy snow: 30 th, some. September 5th, large flocks: 18th, immense flocks of Curlew and Seapies on this and neighbouring islands; wind moderate W. : 27 th, flocks. October 3rd, do.: 5th and 6th, large flocks Curlew and Seapies round island; wind light W. and N.W., weather fine. December 30th and 31st, immense flocks of Curlew round island all day; wind light N.W. Curlew frequent the island all the autumn and winter.

Maidens South.-March 3rd, two going N.E.: 5th, eight going N.E.: 6th, Curlew going N.E. : 9th, five do. April 12th, Curlew at intervals going N.E. : 13th, a few going N.E.: 17th and 18th, Curlew during night flying N.E.: 24th, heard passing $N$. at 11 1.M. : 25th, Curlew heard passing N. at 9 P.x. to midnight; wind moderate $\mathrm{N}$, clear. 
Innishtratull.- "Curlew come and go in flocks from the mainland."

Rathlin O'Birne.-February 3rd, fourteen all day. March 2nd, numbers on island all day; wind moderate S., fog.

Tearaght.-January 14th, five round island; gale N. June 13 th, two.

\section{WhIMBReL (Numenius phocopus, Linn.).}

Blachwater Bank Light-ship.-May 14th, flock of Whimbrel about light at 10.30 P.M. ; wind light S.E.

Howth Baily.-March 5th, a flock noted.

Droghede, $N$.-June 27th, two on river bank; "first and only ones seen this season; cannot account for their not being seen this year." July 6th, six going S.W. and flying very high; wind light S.E. : 12 th, a large flock going N.E.

Maidens South.-May 3rd, four Maybirds going N.E.; wind light S.E. : 6 th, three do.

\section{Lesser Tern (Sterna minuta, Linn.).}

Hook Touer.-May 15th, one very small Tern disabled at lantern at 1.30 A.M. ; wind S.E., fog. [Lesser Tern received in flesh.]

\section{Terns.}

Hool: Tover.-May 3rd, Common Tern heard flying round light at 9 P.M., probably five or six in number; wind S.W., dense fog: 16th, Terns numerous all night round light; wind S.E., light rain; none killed.

Drogheda, N.-September 15th and 16th, numbers of Puffins, Terns, and Kittiwakes fishing on river: 18th, large numbers feeding: 19th, thousands of Kittiwakes, Terns, and Puffins feeding on river from 3 P.M. to 5 P.M.

Copeland (Mew) Island.-May 8th, a few Seamews at 10 A.M.; wind light S.E.: $11 \mathrm{th}$, several. June $4 \mathrm{th}$, an immense number of News on island at this date, and a great number of eggs. September 11th and 16th, still on island: 18th, none: 20th, Mews have left.

Innishtrahull.-May 25th, a large number of Seamews; strong breeze N.W. : 30th, a large number of Arctic Terns; wind light 
N.E. ; first seen. 'July 14th, a large number of young Tern on island. August 15th and 16th, Tern leaving island all day; wind light S.E., clear. "A large number of Arctic Tern hatch on the island."

Glaucous Gull (Larus glaucus, O. Fabricius).

Killybegs.-February 2nd, a bird, supposed to be "a large specimen of the Iceland Gull," shot fishing at 3 P.M.; fresh breeze S.W., fog. [Immature Glaucous Gull received in flesh.]

\section{GULLS.}

Hoole Tower. - September, "Common Gulls about station every day."

Barrels Rock Light-ship. - January 3rd, about a hundred Gulls and a few Gannets: 7th, about a hundred Gulls about the ship. April 1st to 4th, a few large Gulls about ship during day; "Gulls" and "Common Gulls" constantly noted up to May 15th. April 28th, about twenty Black-headed Guils and forty Murs during day drifting S.W. May 10th, about a hundred large and small Gulls during day going W. and drifting, blackwinged and grey; wind light N.E. June 16th and 19th, Gulls drifting: June 28th, a few Gulls and some Murs going E. during day. July 4th, about twelve Black-headed Gulls during day: 24th, large Gulls during day: 30th, a large number of Gulls, Murs, and Mackerel Cock, and about thirty Gannet going in various directions and drifting, feeding on fry, etc.; wind light N.W., clear. August 9th, about two hundred.

Corlling Bants Light-ship.-January, a few Gulls; Herring and small Gulls near ship during the month. October, great numbers small Gulls during this month.

Howth Baily.-April 23rd, Royal Gulls flying about. October 1st, "Seagulls always plentiful." December 13th, Kittiwake Gull found killed.

Drogheda, N.-January 7th, numbers of Grey Gulls: 20th, two large Black-backed Gulls. February 9th, numbers of Gulls: 10th, four Great Black-backed Gulls; one Iceland Gull going N.; strong gale N.W., squally; "I have heard that several have been seen near Drogheda this winter, but this is the first I have 
seen." September 19th, thousands of Kittiwakes, Terns, and Puffins fishing on river from 3 P.M. to 5 P.M.; wind W.: 21st, eight Great Black-backed Gulls fishing; also numbers of Common Gulls and several Grey Gulls.

Vidal Bank.-November 14th, two Royal Gulls and several common ones'fishing: 17th, several Gulls.

Innishtrahull.-March, two; "for part of the winter 1893-94 the Gulls were very scarce."

Rathlin O'Birne.-March 15th, eighteen Royal Gulls on island all day; gale W., overcast.

Killybegs._January 10th, one Iceland Gull all day, a young bird; gale S.E., gloomy. November 14th, one Iceland Gull, young bird, going S.; wind light N.E.

Tearaght.-March 30th, Kittiwakes on rock during night; went S.W. June 19th, four "White-backed Gulls" going N. in the morning; wind light E., clear; "round island some time": 30th, Kittiwakes here since February; very numerous to-day. "They left on the 15th of July; a few remained longer, but the mass went on above date."

Manx Shearwater (Puffinus angloinu, Temminck).

Old Head, Kinsale.-[Manx Shearwater caught; received in flesh, with letter dated April 25th.]

Hook Tower.-May 10th, one picked up dead at base of tower; night clear, wind N.E.: 14th, one killed striking at midnight; wind moderate S.E., gloomy.

Barrels Rock Light-ship.-April 13th, four "Mackerel Cocks" noted. June 24th, two "Skirweathers" noted. July 25th, "Mackerel Cocks" during day; fresh breeze N.W.: 27th, two "Skirweathers" noted: 28th, about twenty "Mackerel Cocks": 30th, numbers: 31st, about twenty. August 1st, thirty "Mackerel Cocks."

Arklow South Light-ship.-March 29th, two Manx Shearwaters going N.E. May 9th, several going in various directions: 13th, a flock of Gannets and Shearwaters: 28th, small flocks of Manx Shearwaters going in various directions: 29th, several flocks.

Howth Baily.-March 19th, Shearwater heard at night, and again on 21st: 31st, heard every fine night now. April 16th, 
scveral flying over the land from towards the station at 8.30 P.M.; fog; one found wounded at bottom of tower next morning. May 10th, Shearwaters keeping up a great chorus to-night; one stunned striking; night very calm; a great many moths on glass: 16th, fog at night; two found on balcony next morning; one of them flew away. June 20th, Shearwaters not so much heard now : 25th, Shearwaters about station: 30 th, scarcely heard now.

Rockabill.-October 20th, two Shearwaters near rock.

Tearaght.-March 28th, heard round rock from 8 P.I. to midnight; strong breeze S.E. April 24th, heard on water at 10 P.M.; wind light N.E. June 30 th, on rock at night; gale S. July 31st, numbers of Shearwaters heard all night round island.

\section{Storm Petrel (Procellaria pelagica, Linn.).}

Blackwater Bank Light-ship.-August 3rd, one all day about ship; fresh breeze S.W. : 4th, one. November 13th and 14th, numbers of birds about light; two Storm Petrels noted; many birds killed (see full note under Blackbird).

Arklow South Light-ship.-September 29th, one Petrel about ship.

\section{Black Guillemot. (Uria grylle, Linn.).}

Killybegs.-February 15th, one unknown bird shot feeding. [Black Guillemot received in flesh.]

RAzorbill (Alca torda, Linn.) and Guillemot (Uria troile, Linn.).

Barrels Roch Light-ship.-January 1st, about seventy "Murs" and a few Gulls drifting and flying low: 4th, four flocks of "Murs." April 2nd, 5th, 6th, 8th, 9th, 10th, 11th, 12th, 13th, 15th, 24th, and 28th, "Murs" noted; generally from six to forty at a time, and about ship or drifting. May 4th, six flocks of "Murs" going S.E.; wind light S.W.: 12th, several flocks of "Murs" going S.E. and N.W. during day: 14th, "Murs" noted: 15th, about fifty large flocks of "Murs" going S.E. and N.W. [Possibly from and to Saltees.-R. M. B.] during day; wind light W. June 18th and 19th, "Murs" noted: 23rd, about 
twenty "Murs" and six "Parrots" during day, flying low: 24th, 26th, 27th, 28th, 30th, "Murs" noted; and constantly up to August 9th.

Rockabill.-October 25th, fifty "Razorbills or Guillemots" going S.; gale N.W. November 5th, Razorbills going S.

Drogheda, $N$.-September 20th, several young Guillemots, all this year's birds, fishing in river; very unusual to see them about here; wind moderate W., clear.

Tearaght.-January 17th, Guillemots noted. February 28th, Razorbills on rocks in the morning, also more Guillemots; gale S. March 5th, considerable numbers of Razorbills and Guillemots on rocks in the morning, but they leave at daylight. March 19th, flock of Razorbills and flock of Guillemots on rocks in the morning; went S.W. at daylight: 30 th, on rock during night. June 30th, here since February; very numerous to-day. The mass of Guillemots left on July 1st, and of Razorbills on the 5th; a few of each kind remained longer.

\section{Puffin (Fratercula arctica, Linn.).}

Barrels Rock Light-ship.-From April 2nd to August 3rd, "Parrots" noted at frequent intervals drifting past ship, generally a few at a time

Rockabill.-November 5th, flock of "Puffins" going S.: 29th, twenty "Sea Parrots" going N.E. at noon.

Drogheda, N.-September 15th and 16th, numbers of Puffins, Terns, and Kittiwakes fishing on river all day; "unusual to see these birds in such numbers here, must be after fry"; wind light W., clear: 19th, thousands of Kittiwakes, Terns, and Puffins fishing.

Tearaght.-March 26th, a few Puffins on rocks; they leave at daylight; wind light S.E. : 30th, some on rock during night. Jume 30th, here since February, very numerous to-day. The mass of Puffins left on July 27th, a few remained longer.

\section{DIVER.}

Innishtrcchull.-December 15th, one Northern Diver outside island.

Kellybegs-December 29th, one Northern Diver; "this bird remains for the winter." 
Tearaght.-June 9th, five "Common Divers" going N.: 24th, one Great Northern Diver on rock at 4 A.M.; gale N.W. July 5th, two Common Divers on rock.

EARed Grebe (Podicipes nigricollis, C. L. Brehm).

Killybegs. - February 6th, a bird, supposed to be a Grebe, shot fishing; strong breeze S., clear. [Eared Grebe received in flesh.]

CoRmorant (Phalacrocorax carbo, Linn.) and SHAG ( $P$.graculus, Linn.).

Howth Baily.-August 29th, Cormorants going towards the S.W. every morning, and returning in the evening. October 1st, Cormorants always plentiful.

Drogheda, N.-September 16th and 19th, several Cormorants fishing.

Vidal Bank.-November, two or three fishing at intervals.

Innishtrahull.-October 30th, a "White Cormorant" was observed off the island; wind fresh N., hail.

Rathlin O'Birne.-April 7th, ten Cormorants on island; these have a very white spot between the wing and tail; fresh breeze N.E.

Gannet (Sula bassana, Linn.).

Barrels Rock Light-ship.-January 3rd, 4th, 5th, and 7th, Gannets noted. April 3rd, four going W.; white in colour: 5th, seven going E.; white: 7th, four, grey and white, going W.: 12th, three, grey, going E.: 19th, eight about ship, black and white. May 6th, about forty going S.W.: 7th, twenty going S.W.: 9th, ten going S.W.: 14th, twelve, "white and black wings," going S.W. June 15th, two going W. July 30th, thirty. August 9th, six at 6 P.M.

Arklow South Light-ship.-March 17th, odd Gannets: 20th and 21st, large flocks: 22nd, small flocks going in various directions. May 13th, "flock of Gannets and Shearwaters going S.W."

Arklow North Light-ship. - January 31st, several flocks Gaunets going N.E. and S.W. March 20th, several flocks going 
N.E. : 21st, large flocks going N.E. : 26th, several flocks going N.E. : 27 th, seven Gannets going N.E.

Howth Baily.-August 17th, two dozen Gannets diving.

Rockabill.-October 20th, five went N. November 29th, ten Gannets going N.E.

Copeland (Mcw) Island.-April 5th, a few: 30th, twelve. May 9th, several. September 8th, do.: 17th, some: 26 th and 27th, several. October 2nd and 3rd, thirty: 7 th and 9th, several.

Rathlin O'Birne.-February 28th, numbers of Gannets going W. all day; fresh breeze S.W.

Tearaght.-January 14th, a number round island; gale $\mathrm{N}$. March 18th, four going S.W.: 19th, flock going S. : 30th, ten. April 23rd, twenty going W. June 1st and 9th, several going S. July 21st, flock going $\mathrm{S}$.

\section{Heron (Ardea cinerea, Linn.).}

Drogheda, N.-July 5th, two very large Herons going N. September 18th, six fishing.

Copeland (Mew) Island.-April 30th, one. June 4th, five going N.W. September 11th, several fishing: 26th, October 7 th, 8 th, and 19th, do. They frequent the island all the autumn and winter.

Tecraght.-June 13th, one on island; misty: 24th, one on rock. July 10th, one all day.

\section{BITTERN (Botaurus stellaris, Linn.).}

Slyne Head, S.-August 27th, " a Bittern caught at noon; it was standing on a stone in the centre of a pool at the bottom of a narrow creek in the rocks, as if it were fishing." [Bittern received in flesh.]

\section{"GeEsE."}

Droghecla, $N$.--February 21st, a large flock of Geese going S.; fresh breeze N.

Vidal Bank:-November 6th, several flocks of Barnacle in the Lough; fresh breeze S.E.: 12th, Barnacle and Wild Duck all day: 17th, Barnacle up the Lough, flew past light; strong gale N.: 29th, Barnacle still in Lough; gale.W. 
Copeland (Mew) Island.-October 30th, two Wild Geese going S. ; wind light $\mathrm{N}$.

Innishtrahull.-January 26th, one Brent Goose shot; came in from $\mathrm{N}$.; strong breeze N.W. October 8th, two Wild Geese going S.W.: 9th, twelve do. going S.W.; wind light S.W.: 13th, six do. on island. December 26th, three going N.W.

Rathlin O'Birne.-February 8th, thirteen Barnacle feeding; gale N.W.: 14th, four do. going S.; gale N.W.: 17th, seven "White-fronted Geese" going S.; strong breeze S.W. March 7th, seven do. going S.: 28th, eleven Barnacle going W.; fresh breeze S.E., squalls.

Killybegs.-January 20th, twenty Barnacle going S.; shot three; strong breeze N.W.: 24th, one White-fronted Goose going S.; shot it; gale S.E. February 18th, two Geese, one white and one grey, the white (a male bird) seems to have once been tame. November 10th, thirteen Barnacle going S.E. December 8th, nine Wild Geese going S.; storm from W.

Slyne Head, N.-November 14th, about thirty Brent Geese on neighbouring islands all day. December 14th, Brent Geese flying about island.

"SWANs."

Drogheda, N.-January 20th, a very large Swan going S.E. March 20th, two Swans going S.; fresh breeze S.E., clear.

\section{"Ducks."}

Hook Tower.-November 10th, "Wild Drake broke a pane of 7/16 plate glass in lantern; bird of course killed": 13th, "Wild Duck," Blackbird, Chaffinches, Grey and Green Linnets, at lantern: 14th and 15th, "same as 13th."

Arklow South Light-ship.-March 18th, one Wild Duck going N. May 22nd, one Wild Duck going E.

Coclling Bank Light-ship.-October 10th, six Wild Ducks going N.E. : 16th, one Wild Drake going N.E.

Droghede, $N$.-January 2 nd, seven Wigeon going N.E.: 3rd, seven Merganser Duck fishing: 7th, about a hundred Duck on north shore; strong gale S.E., snow: 13th, five large Wigeon going W. February 22nd, several hundreds of Duck and Mallards on water; strong gale N.E. July 6th, one "Saw-bill 
Wigeon" going S.E. ; "I thought it very curious to see one at this time of year": 9th, a large flock of Duck, about a hundred, going S., flying low and very irregularly; "was surprised to see Duck in such numbers at this season"; wind light S.W., rain. September 17.th, a large flock of young Duck going N.E., observed to leave feeding-beds to W. of station; wind light N.W., clear; these birds heard off and on every night for the last month. October 1st, a large flock of Scoter Duck on water.

Vidal Bank.-November 6th, a flock of Wild Duck passed the light; fresh breeze S.E., clear: 10th, fifteen Teal here; wind light N.E., frost; about twenty-three Teal and Wigeon going up the Lough: 12th, Wild Duck and Barnacle all day: 17th, several Wild Duck flew past the light; strong gale N., heavy showers: 18th, four "Scale-Drake" remaining all day; strong gale N.E., snowstorm: 19th, "Scale-Drake," Barnacle, and Wild Duck still in the Lough; strong breeze N., frosty; "Scale-Drake only visit here in very hard weather, as also do the Shell-Drake and Barnacle": 29th, Wild Duck still in Lough; gale W.

Copeland (Mew) Island.-January 7th, a flock of Wild Duck going S.; gale E., snow : 15th, a flock feeding. April 27th, two Wild Ducks; appear to be going to breed on island. May 3rd, two. December 9th, seven.

Innishtrahull._- No Duck have been here this year."

Slyne Head, N.-November 16th, "Wild Ducks flying to W.; returned to mainland."

\section{BIRDS NOT IDENTIFIED.}

Hook Tower.- "October 21st, a bird seen as dark as a hen Blackbird and slightly larger; shape of Corn-Crake or Quail; clark bill and legs-bill as long as a Snipe's; probably hurt at lantern during night; got quite close to it, but could not catch it."

Droghecla, N.-January 11th, two Turkey-headed Divers (local name) at mouth of river; "shot one, but it drifted out to sea; they have been very scarce this year": 16th, "about ten days ago a man shot a bird on the river, but would not part with it. It was the size of a Common Wigeon, with a bluish-grey bill like a Duck, but soft like the Surf Scoter's 
that I sent from Crookhaven. The legs were placed very far behind, and formed like the legs of the same bird; the colour was a bright mottled-brown, turning black towards the head; the lower portion of the throat and breast was white."

\section{General Observations.}

Hools Tower.-May 14th, "to-night has been remarkable for large number of Moths round lantern from" sunset to 1 A.M." July and August, " a marked absence of all birds in vicinity of station. As there are no trees or bushes near to build in, the small birds usually seen about lighthouses on the mainland are absent here."

Tuskar.-December, "no birds observed this month; weather very stormy."

Blackwater Bank Light-ship._- On the 12th, 13th, 14th, and 15th of August the sea was actually alive with sea-birds. I attributed this to a great quantity of fog that was passing at the time." "During the latter part of October, and almost daily during November, large flocks of small birds-such as Blackbirds, Thrushes, Chaffinches, etc.-were seen flying towards the land, and almost invariably between the points of N.E. and W. These birds did not come close enough to distinguish their species."

Arklow North Light-ship.-January 19th, large white Butterfly in cabin at 4.30 P.M. ; wind moderate W., clear. It flew about cabin for four days, and died on the 24 th.

Howth Baily. - August 6th, 7th, and 8th, Moths very plentiful each night round lantern, also noted round windows of dwellings; small birds (supposed to be House-Martins) catching them in rays of the light: 9th, great thunderstorm from 7 P.M. till 11 P.M.; Moths not plentiful to-night. December, "there are very few birds of any kind down about the station, and migration is scarcely observable, except the arrival and departure annually of some birds, such as the Wheatear, Swallow, Martin, Cuckoo, etc."

Drogheda, N.-January 16th, no Fieldfare or Redwing observed this year, notwithstanding all the severe frost, nor many small birds, only those resident in the place, and no flocks of Skylarks, as in other severe seasons. April 3rd, "birds very scarce about here this spring:" 
Maidens South.- "A lot of birds get killed that I never see, particularly during a strong E. wind; they rebound off the lantern and fall into the sea." "Never observed fewer birds passing than this year."

Innishtrahull.-March, "more birds killed at the light this year than for â number of years."

Killybegs.-April, " no birds killed striking this winter." 

1894

$$
4
$$

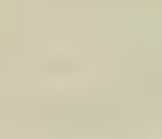

$2+$

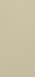

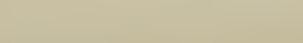


List of Light Statrons.
Names of Obscrvers.

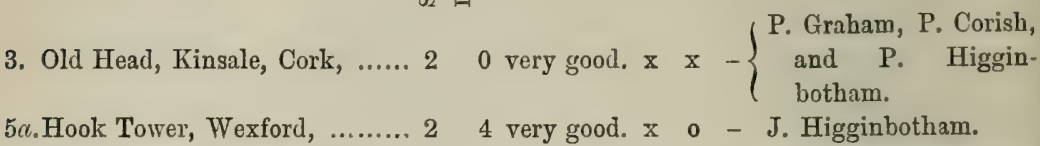
5. *Coningbeg Lt.-ship, Wexford, 43 excellent. $x \times 10\left\{\begin{array}{c}\text { A. B. Wall, J. Doyle, } \\ \text { and J. Godkin. }\end{array}\right.$

6. Barrels Rock Lt.-ship, do., 41 excellent. $\times \quad \times 4\left\{\begin{array}{c}\text { James Beahan and } \\ \text { Thomas Luccan. }\end{array}\right.$ 7. Tuskar Rock, do., 16 good. $\quad 0 \quad x \quad 7 \quad$ H. Kennedy.

76. Blackwater Bank Lt.-ship, do., 417 excellent. $\quad x \quad x \quad 6\left\{\begin{array}{c}\text { P. Cullen and Daniel } \\ \text { Dunn. }\end{array}\right.$

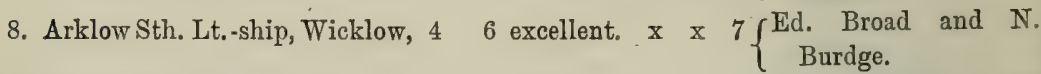

8. *Arklow North Lt.-ship, do., 31 excellent. $\quad x \quad x \quad 8\left\{\begin{array}{c}\text { John Pinstoz and } \\ \text { Thomas Stapleton. }\end{array}\right.$

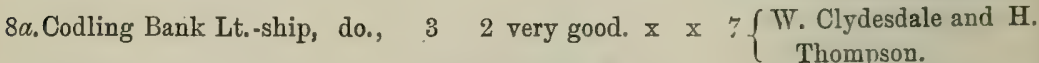

12. Rockabill, Dublin, ............. $3 \quad 7$ very good. $x \quad x \quad 5$ Charles Hawkins.

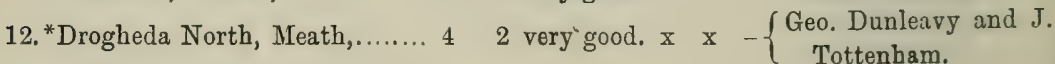

12a.St John's Point, Down, ........ 11 fair. $\quad$ x o - Edward Rohu.

12b. South Rock Lt.-ship, do., ...... 30 good. $\quad$ x $\quad x \quad 3 \quad$ J. Kearon.

13. Copeland (Mew) Island, do., ... 3 0 very good. $x \quad x \quad 3 \quad$ R. Armstrong.

14. Maidens South, Antrim,....... 11 good. $\quad x \quad 0 \quad 5$ fFrancis Maguire ant

16. Innishtrahull, Donegal, ........ $3 \quad 7$ very good. $x \quad$ x 6 G. Gillespie.

19. Tory Island, do., ......... 1.2 good. $\quad$ o $\quad x \quad 9$ Edward Rohu.

21. Rathlin O'Birne, do., ......... 2 o very good. $x \quad x \quad 2\left\{\begin{array}{c}\text { John Murray and Johu } \\ \text { Kennedy. }\end{array}\right.$

22. Killybegs, do., ......... I 0 good. o $x$ - John Kennedy.

25. Eagle Island, E., Mayo,....... 1 1 fair. $\quad \mathrm{x} \quad \mathrm{x} \quad 1$ Joseph Corish.

29. Clare Island, do., ........ 1 fair. $\quad x \quad x \quad 4$ K. Kerr.

30. Slyne Head, N., Galway, ...... 1 0 fair. $\quad x \quad 0 \quad 3$ John Harrison.

36. Samphire Island, Kerry, ....... 2 very good. o $x \quad \frac{1}{2}$ George Dunleavy.

40. Bull Rock, Cork,.............. $1 \quad 0$ good. $\quad x \quad \circ 5\left\{\begin{array}{c}\text { John O'Donnell and J. } \\ \text { Connell. }\end{array}\right.$

Lucifer Shoals Light-ship sent a Kestrtl, and Vidal Bank a Common Tern.

Legs, wings, etc, received, 64 .

$0=$ No reply.

$\mathrm{x}=$ Schedules returned partly or wholly filled.

Spring, replies received from 20 stations, Autumn, replies received from 19 stations. 


\section{Legs, Wings, etc., Received.}

Species. How Received. How Procured. Date. Name of Station.

liestrel, . Rec'd. in flesh, $\left\{\begin{array}{c}\text { Caught on } \\ \text { board, }\end{array}\right\} 27 / 11$ mo., Lucifer Shocls Lt.-ship.

$\left.\begin{array}{c}\text { Red-breasted Fly- } \\ \text { catcher, . }\end{array}\right\}$ Leg and wing, Killed st., ${ }^{1}$. 28/10 mo., Tory Island.

Thrush,

", . 26/11 mo., Coningbeg Lt. -ship.

$\begin{array}{llll}" & \cdot & \cdot & \text { " } \\ , & \cdot & \cdot & \text { ", } \\ \text { " } & \cdot & \cdot & ,\end{array}$

Redwing, . . , ,

Blackbird, . . , ,

" $\quad$. 24/11 mo., Coningbeg Lt. ship.

" $\quad$ " . 3/10 mo., Blackwater Bank Lt. sh.

,

". $\quad 2 / 11 \mathrm{mo}$.

" $\quad\left\{\begin{array}{c}\text { Found killed } \\ \text { on deck, }\end{array}\right\} 9 / 11$ mo., Arklow S. Lt. ship.

$\left\{\begin{array}{c}\text { Killed ag'nst } \\ \text { lantern, . }\end{array}\right\} 26 / 11$ mo., Rockabill.

Common Redstart, Rec'd. in flesh,

$\begin{array}{rrr}? & 4 / 5 \mathrm{mo}, \quad, \\ \text { Caught, } & 11 / 5 \mathrm{mo.},\end{array}$

Wheatear, . . Leg and wing,

Killed st., . $7 / 4$ mo., Blackwater Bank Lt.sh.

Rec'd. in flesh, $\left\{\begin{array}{c}\text { Found dead } \\ \text { on rock, }\end{array}\right\} 5 / 4$ mo., Rockabill.

," two, . Legs and wings,

? Rec'd.10/ 4 mo., Innishtrahull.

SedgoWarbler, four, Rec'd. in flesh, Killed st., . 31/ 7 mo., Tuskar.

\section{," $"$. Leg and wing,}

Whitethroat, . Rec'd. in flesh,

. Leg and wing,

Willow Wren,

, , 3 ,

Chiffchaff," , , ,

Golden-crested Wren, Rec'd. in flesb,

", ", two, ",$$
\text { W }
$$$$
\text { C }
$$$$
\text { , }
$$$$
\text { , }
$$$$
9
$$

Chaffinch, - * " . . Wing, Brambling, . Linnet,

$$
\begin{aligned}
& \text { 6/ } 9 \text { mo., " } " \\
& \text { " Rec'd. 6/ } 9 \text { mo., Blackwater Bank Lt. steskar. }
\end{aligned}
$$

Killed st., . 25/ 9 mo., Blackuater Bank Lt.-ste.

$$
\begin{aligned}
& \text { " i } / 4 \text { mo., ", ", } \\
& \text { " . 27/8 mo., ", ", }
\end{aligned}
$$

Died in ship, 17/ 5 mo., Codling Bank Lt.-ship.

Killed st., . 3/ 4 mo., Hook Tower.

$\left.\begin{array}{c}\text { Caught at } \\ \text { light, }\end{array}\right\} 2 / 10$ mo., Arklow N. Lt. -ship.

$$
\text { ? } 8 / 10 \text { mo., Maidens, South. }
$$

? Rec'd. 11/ 4 mo., Innishtrahull.

? Rec'd. 10/ 4 mo.,

Killed st., . 26/11 mo, Coningbeg Lt. ship.

" . 25/9 mo., Blackwater Bank Lt. -sh.

" . $4 / 10 \mathrm{mo}$,

" . 5/ 1 mo., Arklow S. Lt. ship.

Died on board, 11/11 mo.,

? Rec'd, 10/ 4 mo., Innishtrahull.

Rec'd. in flesh, Died in house, 7/ 1 mo., Hook Touter. Leg and wing, Dead on deck, 12/ 1 mo., Blackwater Bank It. -sh. 


\section{Legs, Wings, etC., Received-continued.}

species.

'Iwite,

Starling,

Nightjar,

Hoopoe,

Water-Rail,

Water-Hen,

Ringed Plover,

Golden Plover,

Green Plover,

Woodcock, .

Snipe,

Dunlin,

, young

$$
,
$$

,

Sanderling, .

Common Tern,

Scaup,
How Received, How Procured.

Date.

Name of Station.

\section{Wing, . ? 11/ 4 mо., Innishtrahull.}

Leg and wing, Killed st.. . 25/ 7 mo., Blackwater Bank Lt.-sh.

Rec'd. in flesh, Shot, . . 4/ 6 mo., Hook Tower.

Caught, . 13/ 5 mo., Rockabill.

Skin, . . Died on board, 28/ 3 mo., Barrels Rock Lt,-ship.

Leg and wing, Killed st., . 26/11 mo., Tory Island.

$\{$ Found dead,

$\left\{\begin{array}{c}\text { supposed } \\ \text { killed st., }\end{array}\right\} 2 / 4 \mathrm{mo}$, Drogheda North.

$\left\{\begin{array}{c}\text { Caught at } \\ \text { lantern, }\end{array}\right\} 27 / 11$ mo., Samphire Island.

Prob.shot, Rec'd.10/ 1 mo., Hook Tower.

Killed st., . 6/ 4 mo., Blackwater Bank Lt. sh.

Wing, . . ,, . 28/11 mo., Samphire Island.

Leg and wing, $\quad$.. $\quad$. 5/ 1 mo., Blackwater Bank Lt.-sh.

$\left\{\begin{array}{c}\text { Killed ag'nst } \\ \text { lantern, }\end{array}\right\}$ 5/ 1 mo., Arklow S. Lt.-ship.

Disabled st., $23 / 8 \mathrm{mo}$., , , ,

Rec'd. in flesh, $\left\{\begin{array}{c}\text { Killed at } \\ \text { lantern, }\end{array}\right\} 25 / 11$ mo., Rockabill.

. Leg and wing, Killed st., . $8 / 4$ mo., St John's Point, Down.

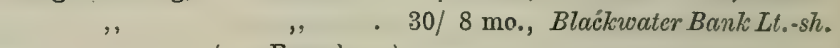
Rec'd. in flesh, $\left\{\begin{array}{c}\text { Found } \\ \text { injured near } \\ \text { light-house, }\end{array}\right\} 12 / 10$ mo., Vidal Bank.

-Wing, . . Shot, . 28/2 mo., Drogheda North. 


\section{N D E X.}

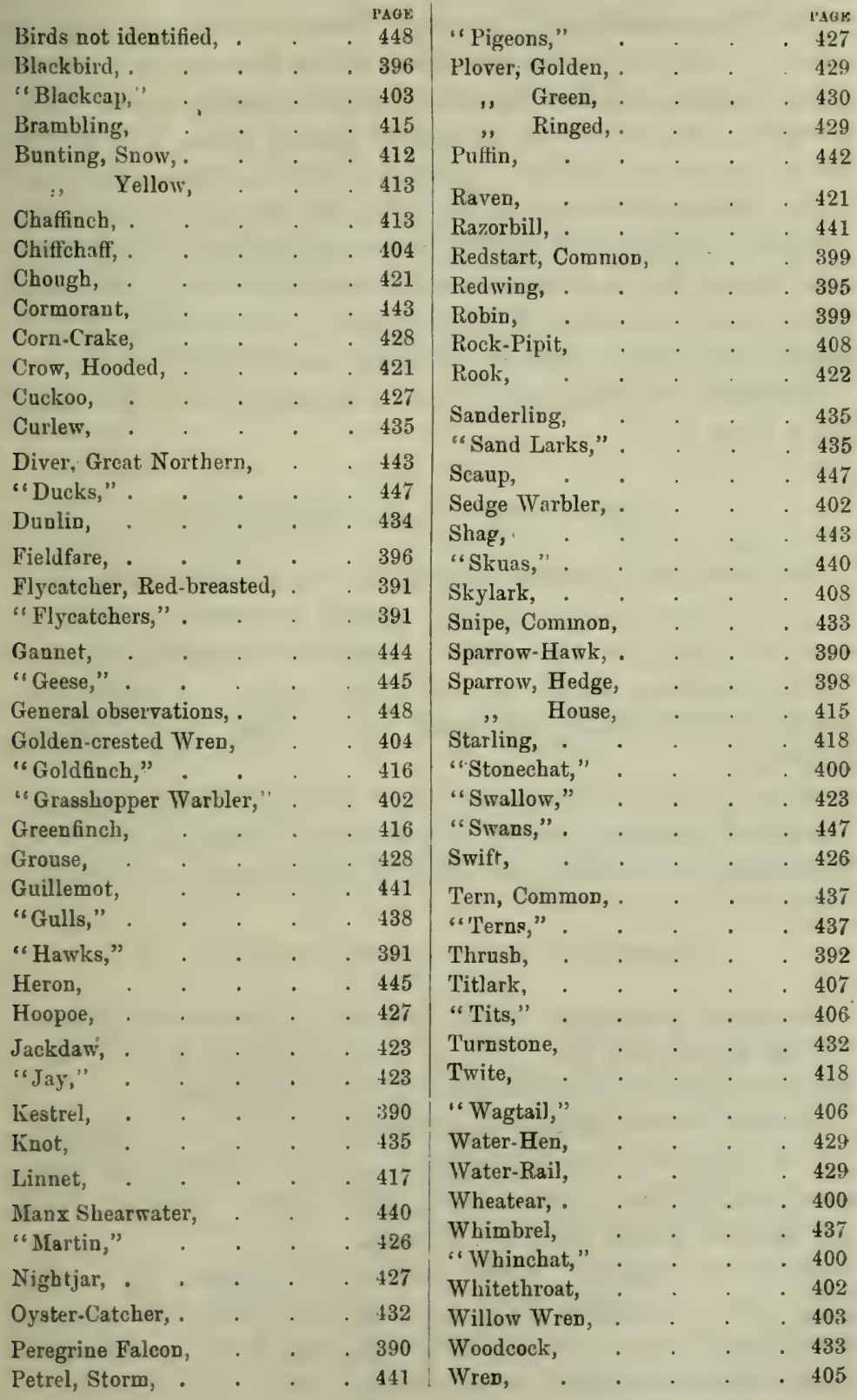




\section{Peregrine Falcon (Falco peregrinus, Tunstall).}

Old Head, Kinsale.- "Two large Hawks build every year in cliffs." "The pair of Falcons noted above have built in cliffs, according to local tradition, for the past hundred years. The present caretaker of the mountain grazing farm here is the fourth generation that has regularly robbed the young from the nest. His father, who died last year, told me that about thirty years ago they failed to build one season, the hen having died, but before the next season came round, the cock bird, after being absent for some time, returned provided with a new mate.-P. Corish." [No doubt Peregrines.-R. M. B.]

Rockabill.-October 22nd, one Peregrine Hawk on rock; wind light S.E.

\section{Kestrel (Falco tinnunculus, Linn:).}

Lucifer Shoals Light-ship.-November 27th, "Hawk, supposed to be common Sparrow-Hawk, caught on board, came from eastward, died on the 30th." [Kestrel received in flesh.] "There was one caught on board in October; he stayed two days, and then left; the crew say he was of a different species."

Rathlin O'Birne.-February 4th, "Sparrow-Hawk" hovering [Probably Kestrel.-R. M. B.] at noon; fresh breeze S.W. March 16th, one Kestrel on island at noon; wind moderate S.

Sparrow-Hawk (Accipiter nisus, Linn.).

Coningbeg Light-ship.-May 18th, one Sparrow-Hawk about ship at 11.35 A.M., flew N.W. at 12.15 P.M., chased by a large number of Gulls; wind moderate E.N.E., light haze.

Arklow North Light-ship.-September 30th, one SparrowHawk going W. between 10 and 11 A.M.; "seemed to have come from Wales;" wind light S.W., clear. October 15th, one. Sparrow-Hawk going W. at noon.

Rockabill.-January 20th, one Sparrow-Hawk on rock; gale N.W. February 28th, one Sparrow-Hawk on rock at 7 A.M. ; strong breeze to gale S.IV. October 27 th, one SparrowHawk and two Pigeons in the morning; wind moderate S.W. 
Innishtrchull.-May 14th, one Sparrow-Hawk at 11 A.M.; strong breeze E.N.E., misty. June 20th, one Sparrow-Hawk at 10 A.M.; fresh breeze N.W., rain. July 16th, one SparrowHawk at 4 P.M.; strong breeze W., rain.

Bull Roch.-January 30th, one Sparrow-Hawk going S.E. at 3 P.M.

\section{"HawKs."}

Barrels Rock Light-ship.-April 7th, one Hawk going N., flying low; wind light E.N.E. June 12th, one Hawk lighted on board for a few minutes at 9 A.M., and flew N.

Tuskar:-October 19th, "Hawks" [? R. M. B.] and other birds round light all night; strong breeze E., rain (see note under Blackbird).

Blackwater Bank Light-ship.-April 10th, one Hawk about light at 2 A.M.; fresh breeze S.

Copeland (Mew) Island.-February 20th, a Hawk caught at sunset, came into gas-house; wind light S.W., clear.

\section{Red-breasted Flycatcher (Muscicapa parva, Bechst.).}

Tory Island.-October 27 th and 28th, very great quantities of Redwing, Thrushes, Fieldfares, Larks, Blackbirds, and Starlings ; also one "Willow Wren (not sure)" about lantern during night; numbers killed, others disabled; wind light E.S.E. to S., overcast. Leg and wing of "Willow Wren" forwarded.E. RoHu. [Leg and wing of Red-breasted Flycatcher received.]

\section{"Flycatchers."}

Rockccill.-May 6th, flock of "Flycatchers" going W. at 10 A.M.; wind moderate W., clear: 8th, twenty on rock at 10 A.M.; strong breeze S.W., cloudy: 10th, twenty "Spotted Flycatchers" on rock at 9 P.M.; "striking, not killed;" strong breeze S.IV., passing showers: 16th, "Flycatchers" on rock at noon; fresh breeze E., fog, rain. August 18th, large number of "Flycatchers" and Wheatears on rock at noon; wind moderate N.W.; some struck at midnight. September 24th, great numbers round lantern, and striking (see under Redwing). October 11th, some (see under Skylark): 13th, flock going W. at noon; wind light N.E. 


\section{Thrush (Turdus musicus, Linn.).}

Hook Tower:-April Sth and 9th, Thrushes round light; wind light and moderate S.S.E., haze and rain; two killed.

Coningbeg Light-ship.-January 5th, "Thrushes, Stares, Linnets, and Skylarks" about light at 11 P.Mr.; snow; several killed: 6th, some Thrushes (see under Skylark). September 22nd, several birds, large and small, about light from 8 P.Ir. to 10.30 P.M.; several killed striking; Thrush dead on deck; fresh breeze E.S.E., rain. November 26th, several Thrushes and Skylarks about light from 6 P.M. to 2 A.M.; wind moderate N.E.; Thrush killed-[Leg and wing received]: 27th, several Thrushes at night: $30 \mathrm{th}$, four at night; wind light E.S.E. December 6th, six about light at 9 P.M.; wind light S.W.

Barrels Rock Light-ship.-April 12th, "one Thrush found dead at sunrise."

Tusliar.-October 20th, flocks going W. at night (see under Starling). November 28th, some all night; wind light E., misty ; some killed.

Blackwater Bank Light-ship.-January 4th, flocks of Thrushes and other birds going N.W.; snow: 6th, numbers at light (see full note under Skylark). March 5th, four Thrushes about light from 8 P.M. to midnight; strong breeze W.S.W., clear: 8th, several Thrushes, Larks, Blackbirds, and Starlings about light from 10 P.M. to midnight; fresh breeze S.W., rain; two Thrushes and two Starlings killed-- [Leg and wing of Thrush received]: 9th, two Thrushes about light at night; gale S.W., rain: 29th, flock of Thrushes and Starlings about light from 10 P.M. to daylight. April 3rd, some going N.WT. during day; fog. September 23rd, several Thrushes about light 9 P.Mr. to midnight; fresh breeze N.E., overcast; one killed striking-[Leg and wing received]: 24 th, several Thrushes and Larks about light 8 P.M. to midnight; wind moderate E.N.E., gloomy: 25th, Thrushes, Larks, and Sedge Warblers about light, midnight to 5 A.M.; fresh breeze E.N.E., gloomy; one Lark and one "Sedge Warbler" (Whitethroat, which see) killed striking. October 3rd, several Thrushes, Larks, Blackbirds, and Starlings about light 1 to 4 A.M.; wind moderate S.S.E., overcast; several killed, fell overboard; and again from 
10.30 P.M. to midnight; wind light N.E. ; one Blackbird killed: 5th, several Thrushes and Larks about light 9 P.M. to midnight; one Thrush killed; wind moderate E.N.E., overcast; and again from 10.30 P.M. to midnight on 6th; wind light E.; "two killed": 7th, several Thrushes and Blackbirds about light from 1 to 4 A.M. ; wind light N.E., overcast; two killed: 8th, Thrushes, Blackbirds, and Larks about light 11 P.M. to midnight; three killed; wind light S.W., overcast: 11 th and 13th, several (see under Blackbird): 17th, flock of Thrushes going W. at 3 P.M.; wind moderate N.E.: 20th, several Blackbirds and Thrushes about light from 8 P.M. to 11 P.M. ; strong breeze E.S.E., rain; three killed: 26th, flock of Thrushes going N.W. at 11. A.M.; wind moderate W.S.W., rain: 31st, and November 2nd, several about light; gale S.W. [Leg and wing of Thrush received; killed striking]: Sth, flock of Thrushes going N.W. at 11 A.M.; wind moderate W.N.W., clear: 9th, several (see under Blackbird): 17th, flock of Thrushes going N.W. at 11 A.M. ; gale S.S.W., rain: 21st, several Thrushes and Blackbirds from 8 P.M. to 11 P.M.; strong breeze S.W., clear; two killed: 22nd, six Thrushes about light; wind moderate S.W., overcast; two killed: 23rd, several Thrushes and Blackbirds from 9 P.M. to midnight; wind moderate E.N.E., overcast; six killed: 24th, several Thrushes and Blackbirds from midnight to 6 A.M.; wind moderate N.E., overcast; ten killed; and from 6 to 8 P.M., four killed: 26th and 27th, several (see under Skylark). December 2nd, several Thrushes and Blackbirds about light from 9 P.M. to midnight; fresh breeze S.: 16th, flock of Thrushes at night: 21st, a flock from 6 P.M. to 6.30 P.M.; gale S.W.

Arklow South Light-ship.-February 7th, one at 8.15 P.M. fell on deck; killed striking; fresh breeze W.S.W. April 8th, one Thrush and six "Sallypickers" at 6.30 A.M. found on deck killed; wind light N.E. October 5 th, several small birds about light from 8 P.M. to midnight; wind light N.N.E., light haze; one Thrush killed striking: 30th, Thrushes and other birds about light during night; wind S., rain one Thrush killed. November 2nd, several flocks of birds like Thrushes, Larks, and Linnets going N.W. from 8 A.M. till noon; wind moderate S.W.; and several birds about light during night; one Thrush disabled; fresh breeze S.S.W.: 3rd, flocks like Larks and Thrushes (see under Skylark) : 4th, a great many flocks of birds of various 
kinds, Thrushes, Larks, and others, going W. during day ; fresh breeze S.W., gloomy: 9th, Thrushes round light (see under Blackbird)-[Leg and wing of Thrush found killed on deck received; sent as "Mountain Thrush"].

Arklow North Light-ship.-January 4th to 6th, many flocks (see under Skylark). October 5th, 11th, and 18th, several (see full note under Skylark): 21st, several Thrushes and Blackbirds round light from 9 P.M. to 3 A.M.; strong breeze S.E., showery; one Blackbird killed: 29 th and 31st, flocks (see full notes under Skylark). November 2nd and 9th, several (see under Skylark); eight Thrushes and four Blackbirds going N.W. at 5 A.M. ; wind moderate S.W., rain; one disabled: 25th, several Thrushes about lantern at 10 P.M.; one killed striking; wind moderate S.E., gloomy. December 1st, several Thrushes and Blackbirds round light from 6 P.M. to 5 A.M. ; two Thrushes killed striking, several disabled and fell overboard; wind light. S.E.

Codling Bank Light-ship.-April 8th, one Thrush killed striking at 1 A.M. ; wind light S.W., fog. October 31st, Thrushes and Blackbirds flying about light at 3 A.Mr, ; about sixty struck and fell overboard; fresh breeze S.W., fog and rain.

Rockabill.-January 2nd, ten Thrushes round lantern at midnight; fresh breeze E., gloomy; none struck. September 26th, four round lantern in morning; wind light N. October 11th, a flock at lantern (see under Skylark): 20th, two at lantern at 2.30 A.M. ; strong breeze E.

South Rock Light-ship.-February 7th, one going E. at 11 A.M. ; gale S.W.: 8th, one killed striking at 11 P.M. ; fresh breeze S.W., clear. October 7th, several (see Skylark): 30th, some about light (see Chaffinch). November 24th, a few about light at 3 A.M. ; one killed striking; wind light E., clear: 26th, several Thrushes and Blackbirds about light; wind light E., clear.

Copeland (Mew) Island.-February 10th, a few all day remaining; gale N.W. March 5th, several; "Thrushes breed on isle." October 8th and 27th, several. November 25th, large nurnbers (see notes under Blackbird).

South Maidens.-April 10th, one Thrush at lantern, 10 P.M., with other birds.

Innishtrahull.-November 25th and 26th, immense numbers of Thrushes and Blacklirds at the light on both these nights 
from 9 P.M. to 6 А.M.; eighty or ninety killed ; wind moderate S.E., foggy. December 15th, Thrushes on island at 9 A.M.; gale N.W., hail showers; four killed: 24th, Thrushes and Blackbirds on island at noon; wind light N.W., misty, rain; nine killed and three disabled.

Tory Island.-October 26th, 27th, and 28th, great rush (see under Redwing). November 26th, numbers; Water Rail killed striking same night.

Rathlin O'Birne-March 12th, Thrushes on island at noon; strong gale W., hail.

Slyne Head, N.-January 10th, about a hundred Thrushes all day.

Samphire Island.-November 19th, three Thrushes going S.W. at 12.30 P.Mr. ; wind moderate S.W.; and several about light from 10 to 11 P.M. ; wind moderate S.W., rain.

Bull Rock.-January 3rd, Thrushes on rock all day; one killed striking; wind light E., gloomy : 13th, eight on rock all day: 25th, five at 10 A.M.; fresh breeze W., clear. February 8th, four all day ; wind light W., clear.

\section{REDWING (Turdus iliacus, Linn.).}

Codling Bank Light-ship.-[March 8th, leg and wing of Redwing received, killed striking against lantern; sent as "Thrush."]

Rockabill.-January 2nd, four Redwings round lantern at midnight; fresh breeze E., gloomy. September 24th, three Redwings, a number of Skylarks, and great numbers of Flycatchers round lantern during night, many striking; wind moderate N.E., overcast. October 2nd, 3rd, and 11th, some at lantern (see under Skylark).

Tory Island.-October 10th, " numbers of Redwing, etc., about lantern during night, misty": "26th and 27th, numbers of Redwing, Thrushes, Fieldfares, Blackbirds, and Starlings about lantern during night, some disabled; gale E., overcast and rain: 27 th and 28th, very great numbers of Redwings, Thrushes, Fieldfares, Larks, Blackbirds, and Starlings, also one "Willow Wren" [Leg and wing of Red-breasted Flycatcher received] about lantern during night; numbers killed, others disabled; wind light E.S.E. to S., overcast. 
FieldFARE (Turdus pilaris, Linn.).

Rockabill.-October 27th, numbers of Fieldfares (see note under Chaffinch).

Drogheda North.-May 25th, three Fieldfares feeding on burrow at 4 P.M. ; strong breeze N. "Thought it strange to see these birds at this time of year."

Innishtrahull.-October 15th, flock of Fieldfares going W. at 2 P.M. ; wind moderate N.E., clear.

Tory Island.-October 26th, 27th, and 28th, great numbers (see under Redwing).

\section{BlaCkBird (Turdus merula, Linn.).}

Old Head, Kinsale.-January 12th, one Blackbird about hill all day; strong breeze S.W.

Coningbeg Light-ship.-October 9th, a few about light at 10 P.M.; one cock killed striking; wind moderate S.W., rain. November 23rd, several birds of various kinds about light from 8 P.M. to midnight; two hen Blackbirds killed striking; wind moderate N.E., gloomy: 24th, several Blackbirds and Starlings about light from 6 P.M. to 2 A.M.; some killed, fell overboard; fresh breeze E. [Leg and wing of female Blackbird received.]

Tuskar.-October 19th,Starlings, Blackbirds, Hawks [? R. M. B.] round light all night; strong breeze E., rain: 20th, flocks at night (see under Starling): 22nd, Starlings and Blackbirds all night; some killed; "all male Blackbirds;" wind moderate N.E., showery. November 21st, flock of Blackbirds all night, some killed; wind moderate S.W., misty ; 2Sth, Blackbirds and Thrushes all night, some killed; some females observed among: Blackbirds; wind light, misty.

Blackwater Bank Light-ship.-January 3rd and 4th, flocks going N.W. during day; strong breeze S.E., snow: 6th, numbers (see full note under Skylark). March 8th and October 3rd, 7th, and 8th, several (see full notes under Thrush) - [Leg and wing of Blackbird received, killed striking on 3rd]: 11th, several Blackbirds and Thrushes about light from 7 P.Mr. to midnight; eight killed; wind light S.IV., rain: 13th, several flocks with Thrushes going N.W. from 9 A.M. to 4 P.M.; wind light N.W.: 
20th, several (see under Thrush): 31st, and November 2nd, several Blackbirds and Thrushes about light at night; gale and fresh breeze S.W.; eleven killed on 2nd-[Legs and wings of Blackbird and Thrush received]: 9th, several Blackbirds and Thrushes about light from 1 A.M. to 4 A.M.; wind moderate S.W., rain; twelve killed: 21st, $23 \mathrm{rd}$, and 24th, several (see under Thrush): 26th and 27th, some at light (see under Skylark). December 2nd, several about light: 21st, flock of Blackbirds and Thrushes from 6 P.M. to 6.30 P.M. ; gale S.W.

Arklow South Light-ship.-January 7th, "some Blackbirds and Larks" going N.W. during day; wind light W., clear. October 9th, two Blackbirds struck light at 2 A.M.; wind light S.W., clear. November 9th, Blackbirds and Thrushes about light from 2 A.M. till 7 ; several struck but fell overboard; wind moderate S.W., rain. [Leg and wing of Blackbird received, found killed on deck.]

Arklow North Light-ship.-October 11th, several at light striking; calm, haze: 21st, several round light; one killed; strong breeze E., showery: 29th, Gulls chasing small birds, including Blackbirds (see full note under Skylark). November 9th, several, two caught. December 1st, several, with Thrushes, striking.

Codling Bank Light-ship.-October 31st, numbers striking (see under Thrush). November 9th, Larks and Blackbirds going in various directions; wind light.

Rockabill.-January 2nd, twenty Blackbirds round lantern at midnight; fresh breeze E., gloomy; none struck. March 16th, some round lantern at 4 A.M. ; wind light N.W., went E. in the morning. September 24th, great numbers (see under Robin). October 2nd and 3rd, numbers at night; two killed (see under Skylark) : 8th, one on rock at noon; wind light S.E. : 9 th, two on rock: 11th, flock at lantern (see full note under Skylark): 20th, numbers at lantern at midnight; strong breeze E., clear: $22 \mathrm{nd}$, four on rock: $24 \mathrm{th}$, four. November 26th, two birds killed at light. [Legs and wings of two female Blackbirds received.]

South Rock Light-ship.-October 11th and 12th, 21st and 27 th, Blackbirds about light (see under Skylark). November 26th, several about light; clear: 30th, two about light at 10 P.M. ; one killed; wind light N.W., gloomy. December 3rd, 
4 th, and 5 th, some about light; wind variable: 25 th, several about light at 2.30 A.M. ; wind W., clear.

Copeland (Mew) Island.-February 10th, several Blackbirds, all day, remaining; gale N.W. March 5th and 20th, several; "Blackbirds breed on isle." October 8th, several Blackbirds, Thrushes, and Larks from 10 P.M. to 5 A.M.; some killed and disabled; wind moderate S.E., misty: 27th, birds striking lantern from midnight to 4 A.M. ; a few Blackbirds, Thrushes, and Starlings killed; strong breeze S., dark and squally. November 25th, large numbers Blackbirds, Thrushes, and Larks striking, some killed; fresh breeze S.E., gloomy.

Maidens South.-March 30th, one Blackbird.

Innishtrahull.-November 25th and 26th, immense numbers of Blackbirds at light; and December 24th, some noted (see full notes under Thrush).

Tory Island.-October 26th, 27th, and 28th, great rush (see under Redwing). November 26th, numbers of Blackbirds and other birds striking (see full note under Water Rail).

Eagle Island, E.-October 17th, one Blackbird, seen on island, first observed.

Slyne Head, N.-January 10th, fifty Blackbirds, all day.

Samphire Island.-October 23rd, one female Blackbird at 3 A.M.; caught at lantern; gale S.W., rain. November 8th, several Blackbirds about light at 11 P.M.; gale N.W., rain.

Bull Rock.-January 3rd, Blackbirds all day on rock; wind light E., gloorny: 13th, four all day; wind moderate S.W., clear. February 8th, two all day: 20th, and March 1st, two on rock.

\section{"Hedge Sparrows."}

Rockabill.-March 16th, four "Hedge Sparrows" on rock at 4 A.M.; wind light N.W. May 15th, two on rock at noon; strong breeze N.E, haze, rain. October 4th and 5th, Hedge Sparrows and Skylarks round lantern at uight, some striking; sèveral Larks killed; wind moderate N.E. and fresh breeze E., misty.

Drogheda North.-June 12th, two "Hedge Sparrows" about station at 1. P.M.; stroug breeze N., showery. "Never saw any about station before." 


\section{RoBin (Erithacus mbecula, Linn.).}

Coningbeg Light-ship.-March 26th, one Robin lighted on ship at 4 P.M.; wind light S.E.

Blackwater Bank Light-ship.-April 4th, one Robin about deck from 4 P.M. to sunset; wind light N.E., hazy. October 7th, one Robir about light 1 A.M. to 4 A.M.; wind light N.E., overcast.

Rockabill.-August 17th, one Robin on rock at 8 A.M.; wind moderate N.W., overcast: 26 th, two Redbreasts on rock at noon; fresh breeze E, overcast. September 24th, six Redbreasts and great numbers of Blackbirds round lantern during night; many striking; wind moderate N.E., overcast.

Copeland (Mew) Island.-February 4th, a Robin all day; wind light S.W. March 15th, one all day. October 8th, "a Robin Redbreast has arrived here, it comes every year about this time and roosts in the same place, under a laddershed, and in daytime sits often on a wall opposite our door and sings cheerily. I presume it is the same bird that has come here for several years."

Innishtrahull.-May 17th, one Robin at 2 P.M.; wind light N.E., gloomy. September 25 th, one at 2 P.M.; wind light S.E., rain. October 6th, one on island at 2 P.M. ; wind moderate S.E., gloomy.

Tory Island.-October 19th, one Redbreast about station at 6 P.M.; strong breeze E., clear.

Common Redstart (Ruticilla phonicurus, Linn.).

Old Head, Kinsale.-April 4th, Redstarts all day on hill; wind light E.: 30th, two Redstarts all day; fresh breeze N.E. May 1st, one Black Redstart at 10 A.M.; wind moderate N.E. : 2nd, two Redstarts going N.W.; wind moderate N.W. September 17th, two Black Redstarts all day; wind light S.E. : 19th, one Redstart all day; wind light E.: 21st, two at 10 A.Ir. : 23rd, one Redstart about station all day; wind light N.E. [Redstarts recorded at this station were probably all $R$. phocnicumus, and are therefore put under that species, but no specimen was sent.-R. M. B.]

Rockabill.-May 4th and 11th, birds sent supposed to be "hen Black Starts, and rare"-[Two female Common Redstarts 
received]. May 15th, two "Black Starts" on rock at noon; strong breeze E.N.E., haze, rain. August 26th, one "Red Start" on rock at noon; fresh breeze E., overcast.

\section{"STONECHAT."}

Old Head, Kinsale.-March 28th, one Stonechat on hill; wind moderate E. May 14th, one at 11 A.M.; wind light $\mathrm{N}$. September 18th, two all day; wind moderate E.

Tuskar:-September 2nd, numbers of small birds, Stonechats, etc., round light (see under Willow Wren).

Codling Bank Light-ship.-April 12th, one on ship at 6 A.M.; calm, light haze.

Rockabill.-March 20th, four at noon; wind light S., overcast. September 26th, two round lantern in morning; wind light $\mathrm{N}$. October 2nd and $3 \mathrm{rd}$, two at lantern (see under Skylark).

Maidens South.-April 2nd, one noted: 3rd, one at 4 A.Mr. caught on balcony; wind light N.E., misty: 4th, one noted: 7th, one at lantern (see under Skylarks): 14th, one on rock all day; strong breeze E., clear.

Ruthlin O'Birne.-March 19th, Stonechats on island all day; wind light $\mathrm{S}$.

\section{"WhINCHAT."}

Old Head Kinsale.-September 4th, Whinchat on hill all day; wind light N.E.

Rockabill.-May 15th, two at noon; strong breeze N.E., rain.

\section{Wheatear (Saxicola cenanthe, Limn.).}

Old Hcad, Kinsale-March 23rd, one Wheatear at 10 r.M.; fresh breeze E.: 27th, two all night; wind moderate E.: 28th, one. April 4th, some all day on hill; wind light E.: Sth and 14th, two. Jume 10th, two at 2 P.M.; fresh breeze N.T.: 11th, one, and 12th, two, about station all day. August 22nd, one at 10 P.M.; wind light S., fog and rain: 23rd, one all night; wind light E.: 30th, two ou balcony at 10 r.s.; wind light E., fog. September 16th, Wheatears and "Warblers" at light at 
midnight; wind moderate E.: 17th, one Wheatear and three "Warblers" on hill all day: 18th, 19th, 21st, and 29th, some on hill.

Tustiar.-July 31st, Wheatears all night (see under Sedge Warbler at this station). August 25th, "Wheatears, Jack Snipe, Titlarks, all night; several killed; wind light W., misty."

Blackucater Bank Light-ship.-April 7th, "strange birds like Blackcaps going N.W. from 5 A.M. to 8 A.M.," and "strange birds like Bluecaps" about light from 8 P.M. on 7 th to daylight on Sth; leg and wing of one forwarded-[Leg and wing of Wheatear received]-(see also full notes under Willow Wren): Sth and 9th, "strange birds like Bluecaps" about light from 10 P.M. to daylight; seven killed, three disabled; wind light to moderate S.E., clear.

Codling Bank Light-ship.-April 3rd, one Wheatear on ship at 10 A.M.; wind light E., fog.

Rockabill.-[April 5th, Wheatear received in flesh, "found dead on rocks."] May Sth, twenty on rock at 10 A.Mr.; strong breeze S.W., cloudy. August 16th, two Wheatears and two Curlew on rock at 6 A.M.; flew ashore; strong breeze N.W.: 1Sth, number on rock (see under "Flycatchers"): 25th, four

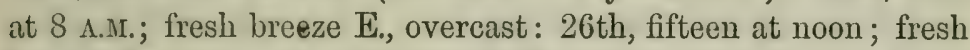
breeze E., overcast. October 11th, ten at lantern (see under Skylark).

Droghede North.-May 6th, one Wheatear at 2 P.M.; fresh breeze W., clear; first seen this season: 12th and 17th, two noted: 25 th and 31st, several all day about burrow. August 10 th, one on burrow.

St John's Point, Down.-April 2nd, one Wheatear; wind easterly, misty: 8th, two between 10 P.M. and 12 P.M.; wind moderate S., rain.

Innishtrahull.-March 24th, one "stopped on island;" wind light S.E., hazy: 26th, four; wind light S.S.E., clear. [A pril 10th, legs and wings of two Wheatears received.] May 10th, one ; gale W., rain. June 11th, one disabled, striking at 11 P.M.; fresh breeze N.W., gloomy. July 20th, two disabled at 3 A.M.; wind light W., fog. August 12th, three disabled at 2 A.Mr.; gale W., fog. September 4 th, two striking at 4 A.M.; wind light N.E., rain : 24th, two disabled at 11 P.M.; wind light N.E., rain. 
Rathlin O'Birne.-March 27th, Wheatears on island all day; wind moderate S.E.

Eagle Island, East.-March 25th, Wheatears first observed and remain. They breed on island.

Slyne Head, N.-March 17th, one female Wheatear: 18th, one male and female Wheatear.

SEDGE WARBLER (Acrocephalus phragmitis, Bechst.).

Old Head, Kinsale.-May 20th, two "Warblers" at midnight; wind moderate N.E. September 3rd, one "Warbler" about light; wind light E.: 16th, "Warblers" at midnight; wind moderate E.: 17th, three "Warblers" all day on hill; wind light S.E. [Were all these Sedge Warblers ?-R. M. B.]

Tuskar.-July 31st,"Willow Wrens, Whitethroats, Wheatears, all night; wind moderate E., fog; several killed; four forwarded, am not aware of their names "-[Four Sedge Warblers received in flesh]. September 2nd, three sorts of "Warblers" noted. (Perhaps some were Sedge Warblers, see full note under Willow Wren at this station.) [6th, Sedge Warbler received in flesh.]

Blackwater Bank Light-ship.-April 28th, several Swallows and Sedge Warblers about light from 9 P.M. to midnight; wind light S.W., overcast; two "Warblers" killed-[Leg and wing of Sedge Warbler received.] May 15th, one Sedge Warbler lighted on ship at 6.30 P.M.; wind light, variable, showery. September 23rd, several Sedge Warblers about light 9 P.M. to midnight; fresh breeze N.E., overcast: 25th (see full note under Thrush). October 8th, three Sedge Warblers, 11 P.M. to midnight; wind light S.W., overcast.

\section{"GRASSHOPPER WARBLER."}

Truskar.-September 2nd, "Grasshopper" and other "Warblers" noted at 2 A.M. (see full note under Willow Wren at this station).

Whitethroat (Sylvia cinerca, Bechst.).

Old Head, Kinsalc.-September 20th, one Whitethroat at 10 P.M.; wind light E. 
T'uskar. - July 31st, some at night (see under Sedge Warbler at this station). September 1st, several Whitethroats killed; wind light N., clear: [6th, Whitethroat received in flesh].

Blackwater Bank Light-ship.-September 25th, one "Sedge Warbler" killed striking--[Leg and wing of Whitethroat received]-(see full note under Thrush).

\section{"Blackcap."}

Maidens South.-April 14th, one "Blackcap" on rock all day; strong breeze E., clear.

\section{WILLOW WREN (Phylloscopus trochilus, Linn.).}

Hook Tower.-April 6th, "Willow Wrens from 9 P.M. on 5th to daylight on 6th; fresh breeze N.E., haze; nine killed": 7th, three from 9 P.M. to 12 P.M. killed; wind moderate E., haze: Sth, five picked up dead at daylight; wind moderate E., fog: 9th, Willow Wrens or Sallypickers round light; three killed; wind moderate S.E., rain: 30 th, one killed during night.

Coningbeg Light-ship.-April 5th, about a dozen "Reed Warblers" about ship at 9 P.M.; went away at daylight; wind moderate N.E., haze: 6th, half-a-dozen "Reed Warblers" about ship at 8.30 P.M.; wind light N.E., haze; two killed striking: 7th, several "Reed Warblers" about lantern at 8.30 P.M.; wind light E., haze; went away about 5 A.M. : 14th, a few "Reed Warblers" about lantern at 8 P.M.; wind moderate W., clear. [Possibly all Willow Wrens. See records under Hook Tower and Blackwater Bank.-R. M. B.]

Tuskar.-July 31st, "Willow Wrens" at night (see under Sedge Warbler at this station). September 2nd, "Willow Wrens" hovering round light at 2 A.M. ; some striking and disabled; also "Stonechats," "Warblers," "Grasshopper Warblers," and "Willow Warblers" at the same hour; wind light N., hazy.

Blackwater Bank Light-slip.-March 28th, flock of "Wrens" going N. at 9 A.Mr.; wind light N.E. April 7th, "flock of Swallows, Wrens, and strange birds like Blackcaps" going N.W. from 5 A.M. to 8 A.M.; wind moderate E., rain: 7 th and 8th, "flock of Chaffunches, Wrens, and strange birds like 
Bluecaps about light from 8 P.M. to daylight; wind moderate to light N.E. to S.E., light rain; ten killed, four disabled" [Leg and wing of Willow Wren received. See also under Wheatear]: 12th, flock of "Wrens" and other birds about ship from 4 A.M. to 7 A.M.; wind light W., light rain. August $27 \mathrm{th}$, flock of "Wrens" about light 8 P.M. to 11 P.M.; wind light N.E., gloomy. [Leg and wing of Willow Wren received, killed striking.]

Arklow South Light-ship. - April 8th, "six Sallypickers" found on deck killed (see Thrush). May 16th, one Green Wren [Probably Willow Wren.-R. M. B.] and two Larks rested on ship all day.

Codling Bank Light-ship.-May 10th, two "Wood Warblers" on ship during day; wind moderate W., clear: 12th, "Wood Warblers" on ship: 18th, one, and 19th, two on ship during day. A bird died on ship on 17th-[Leg and wing of Willow Wren received]. "Several small birds, same size, only different colours, have been on ship during this month, and went for the land."

South Rock Light-ship.-October 7th, one "Sallypicker" killed; calm, clear. [Possibly a Willow Wren or Cbiffchaff. -R. M. B.]

Innishtrahull.-April 24th, two "Willow Warblers" killed striking at 11 P.M.; gale S.E., rain: 28th, one "Willow Warbler" disabled at 8 P.M.; wind light N.W., rain.

\section{Chiffohaff (Phylloscopus rufus, Bechst.).}

Old Head, Kinsale.-May 22nd, three Chiffchaffs on wall at noon; wind light N.W. September 25th, a Chiffchaff on hill at noon; wind moderate $\mathrm{E}$., passing showers.

Hook Tower.-[April 3rd, Chiffchaff killed striking, received in flesh.]

Rockctbill.-March 20th, ten Chiffchaffs on rock at noon; wind light S., overcast.

Golden-Crested Wren (Regulus cristatus, Koch).

Old Hcad, Kinsale.-August 28th, a Gold-Crest on balcony at midnight; wind light N.E. 
Arklow South Light-ship.-March 19th, one "Golden Wren" and one Starling rested on ship at 8.30 A.M.; wind light.

Arklow North Light-ship.-September 24th, one Goldencrested Wren flying round light at 10.15 P.M., killed striking one of ship's stays; wind light S.E., clear. October $2 \mathrm{nd}$, small bird, name unknown, caught flying round light at 10.30 P.M.; calm, light haze, lived a week in cabin. [Golden-crested Wren received in flesh.]

Rockabill.-August 25th, one Gold-Crest on rock at 8 A.M.; fresh breeze E., gloomy. September 26th, one round lantern; clear. October 11th, three at lantern (see under Skylark).

Maidens South.-October 8th, "a Wren sent; unable to identify it." [Gold-Crest received in flesh.]

Innishtrahull.-April 10th, "two birds forwarded; I think one is a Fire-Crest and the other a Gold-Crest; I think one must have been killed last November"-[Two Golden-Crested Wrens received in flesh]. June 23rd, "numbers every March and October" (see full note under Wren).

\section{WREN (Troglodytes parvulus, Koch).}

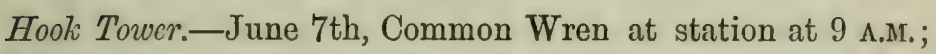
calm, clear.

Arklow South Light-ship.-March 23rd, one "Wren" rested on ship; wind light N.E.

Rockcbill.-September 26th, four "Wrens" round lantern in morning; wind light $\mathrm{N}$. October 20th, three at lantern at midnight; strong breeze $\mathrm{E}$.

Copeland (Mew) Island.-February 4th, a Wren all day, remaining; wind light S.W. March 15th, several all day: 20th, two: 28th, one. November 25th, a Wren on "isle at present; comes every year ; is it same bird?"

Maidens South.-April 4th, one Wren on rock at 7 A.M.: 5th, one on rock at 6 A.M.: 7 th and 8 th, one noted: 10 th, one: 11th, one on rock all day: 15 th, one at 6 A.M. on rock all day; wind light S., clear.

Innishtrahull.-[April 10th, Leg of Wren received]: 25th, one "Jenny Wren" disabled striking at 4 A.M.; gale S., rain. June 23rd, one "Jenny Wren" noted at 2 P.M. ; wind moderate W., rain. "I think this one built here, but we have large numbers 
of them and Gold-Crests every March and October, so that they must migrate about these two months, and rest here on their journey.-GEORGE GILLESPIE."

Tory Island.-September 23rd, one Common Wren caught at Lloyd's Signal Station.

Eagle Island, East.-October 17th, one Wren seen on island.

Bull Rock.-January 9th, two Wrens on rock at 9.30 A.M.; wind moderate S., gloomy. February 20th, one at noon; wind moderate E., clear.

\section{"Tits."}

Codling Bank Light-ship.-April 12th, "one Wood Tit" on ship at 6 A.M.; calm, light haze: 13th, "Tits" on ship (see under Titlark).

Maidens South.-March 24th, one Tit on rock, flew W.; wind light S.E.: 25th, one: 26th, three: 28th, three: 29th, four: 30 th and 31st, two on rock. April 2nd, 4th, 7th, 10th, and 15th, one to three "Tits" noted.

\section{"WAGTAIL."}

Old Head, Kinsale-April 1st, one Wagtail in garden at noon; wind light S.W. September 24th, a "Yellow Wagtail" about cliff at 2 P.M.; wind light $\mathrm{E}$.

Coningbeg Light-ship.-August 28th, Wagtail flying round ship at 6 A.M.; went N. at 8 A.M. ; wind E., clear. October 3rd, "one Water Wagtail landed on ship, chased by Gulls," at 2 P.M.; wind light S.E., clear: 4th, one at 7 A.M., going N.E.; wind light N.E.

Arklow South Light-ship.-April 8th, one Wagtail about ship (see under Snipe).

Codling Bank Light-ship.-March 23rd, several Wagtails about ship 9 A.M.; wind light S., hazy.

Rockabill.-May 15th, one "Willie Wagtail" on rock at 4 P.N.; strong breeze N.E., overcast.

Drogheda North.-May 9th, four "Water Wagtails" close to station at 6.30 P.nr.; strong breeze W., squally; first seen about: here for a long time. August 5th, two "Water Wagtails" close to station. 
South Rock Light-ship.-August 30th, one Wagtail going W. at 10 A.M.; wind light N.W., clear.

Maidens South.-March 24th, one Wagtail on rock, flew W.; wind light S.E.: 26th, four: 27th, three noted. April 7th, two, and 15th, one, on rock.

Innishtrahull.-March 6th, one Pied Wagtail "stopped on island ;" wind light E.S.E., clear: 10th, three do.; gale W.S.W., hail. April 16th, four at 9 A.M.; fresh breeze E., misty. May 30th, one at 9 A.M.; wind light E., clear.

Tithark (Anthus pratensis, Linn.).

Coningbeg Light-ship.-October 15th, Titlarks and Skylarks about ship at 6.30 A.M. ; fresh breeze N.E., clear.

Tuskar.-August 25th, "Wheatears, Jack Snipe, Titlarks all night; several killed; wind light W., misty."

Arklow North Light-ship.-March 5th, several going N.W. (see under Skylark): 11th, some Titlarks going N.W. 10 A.M. to 2 P.M.; strong breeze N.W. : 19th, two lighted on ship at 5 P.M., flew N.W.; calm, clear. April 23rd, several at noon, about ship till 1.30 P.M., going W.; wind light S., clear. September 23rd, several Titlarks on deck from 7.20 A.M. to noon, one died; wind light S.E., clear. November 4 th, two about ship from 10 to 11 A.M. : 26th, Titlarks and Linnets going S.W. during forenoon.

Codling Bank Light-ship.-March 25th, one Titlark going N.W.; wind light S.E. : 28th, three on ship ; calm, hazy. April 6th, several on ship at 5 A.M.; wind moderate E., clear: 8th, one killed striking at 2 A.M. ; wind light S.W., fog: 11th, one on ship at 5 A.M. ; calm, light haze. May $3 \mathrm{rd}$ and 4 th, some noted during day: 12th, Titlarks in ship during day; wind moderate N.W., clear: 13th, "Tits" in ship during day; wind moderate S.W., rain.

Rockccbill.-January 17th, five Titlarks on rock at 8 A.M. ; wind moderate S.W. June 10th, some on rock at noon; strong breeze N.W.

South Rock Light-ship.-October 2nd, two going N.W.; wind moderate $\mathrm{S}$.

Copeland (Mew) Island.- "Titlarks breed on island." September 25th, several striking (see note under Skylark). 
Eagle Island, East.-(See note under Snow Bunting.) Titlarks [Rock Pipits? - R. M. B.] breed on island.

\section{Rock-PIPIt (Anthus obscurus, Lath.).}

Hook Tower--January, "over a dozen dead Rock-Pipits picked up; birds have been dying in hundreds" (see full note under Chaffinch at this station).

Innishtrahull -June 5th, two Rock-Pipits disabled at 1 A.M.; wind light N.E., gloomy. July 8th, one disabled at 10 P.Mr.; wind light S.E., rain. August 29th, three disabled at 3 A.M. ; wind light N.W., fog.

Samplive Island.-October 7th, four Rock-Pipits on island all day. "I have seen this species on island every day since I came here on September 8th."

SkYLARK (Alauda arvensis, Linn.).

Old Head, Kinsale.-February 13th and 24th, Larks in garden all day; wind light. March 21st, four Larks all day; wind light S.: 25th, one-Skylark at midnight; wind moderate $\mathrm{E}$.

Hook Tower. - January 8th, Skylarks (see note under Chaffinch). April 8th and 9th, Larks round light; wind light S.E., haze and rain; two killed.

Coningbeg Light-ship.-January 5th, two Skylarks about ship; snow, wind moderate S.E.; one caught (see also under Thrush): 6th, "Larks, Thrushes, Stares, and Linnets about light; several killed striking glass of lantern and perishing in the snow;" large flock Skylarks and Linnets about ship at 3.30 P.N.; four Larks and four red-breasted Linnets caught; another large flock going N.W. at 7 P.M. ; wind light N., clear; some killed striking, some caught: 7th, large flock Skylarks about ship, two caught; wind moderate W., clear; six red-breasted Linnets and Larks found dead on deck. October 8th, large flock of Skylarks going N.E. at 7 P.M. ; calm; several "small birds" about light from 9 P.M. to 11 P.M. : 12 th, several Skylarks and Starlings about light from 8 P.M. to 6 A.M.; wind light S.: 13th, a few Skylarks about ship at 10 A.M.: 15 th, several abont ship at 6.30 A.M., two killed; fresh breeze N.E., clear; flock noted at 
2 P.M. : 19th, six Skylarks going N.E. : 20th, several flocks Skylarks and Starlings going N.E. from 7 A.M. to 2 P.M., flying low; fresh breeze S.E. November 26th, Thrushes and Skylarks about light (see under Thrush); Lark killed-[Leg and wing of Skylark received]. December 10th, flock of Skylarks going N.W. ; "small birds" about light and on previous night.

Barrels Rocki Iightship.-February 23rd, one Skylark and one Chaffinch going $\mathrm{N}$. on board during forenoon; cloud and rain. March 11th, four Skylarks and five Linnets lit on board at 11 A.M, going $\mathrm{N}$.

Tuskar.-November 21st, flock of Larks all night; some killed; wind moderate S.W., misty.

Blackwater Bank Light-ship.-January 5th, flocks (see note under Starling): 6th, great numbers of Larks, Starlings, Thrushes, Blackbirds, and Lapwings about light from 8 P.Mr. to midnight; snow, wind variable; a great many which were killed and disabled fell overboard: 7th, flocks of Larks and Starlings going N.W. from 9 A.M. to noon; wind light S.W., clear. March 8th, several (see under Thrush). September 14th, two Larks lighted on ship at 2 P.M.; wind light N.E., hazy: 24th and 25th, several (see under Thrush) - [Leg and wing of Lark received]. October 3rd, several (see under Thrush): 4th, several Larks about light, midnight to 4 A.M. ; wind moderate N.E.; two killed striking-[Leg and wing received]: 5th, 6th, and 8th, several (see under Thrush): 16th, flock of Larks going N.W. at 10 A.M. ; fresh breeze N.E. November 18th, flocks of Larks, Linnets, and Starlings going N.W. from 8 A.M. to 9.30 A.M. ; fresh breeze S.W.: 26th, Larks, Thrushes, and Blackbirds about light from 10 P.M. to midnight; wind moderate N.E., overcast; and from 9 P.M. to midnight on 27th; wind light N.W.; two Larks killed. December 25th, flock of Larks going N.W. at 2 P.M.; wind light N.W.

Arklow South Light-ship.-January 5th, numerous small birds about light during night; several Larks killed and four caught; a lot struck and fell overboard-[Leg and wing of Skylark received]-(see also under Dunlin); wind variable, snow: 7 th, some going N.W. (see under Blackbird): 8th, seven Larks rested on ship at 3 P.M. ; strong breeze S.E., rain; flew N.W.: 15th, odd Larks going N.W. during day. February 20th, "one Lark at 10 A.M. ; wind light S.E.; Seagulls chasing 
it." March 23rd, two Larks. April 8th, one (see under Snipe). May 16th, two Larks rested on ship at 8 A.M.; remained all day; wind light $\mathrm{E}$, haze, rain: 17th, two Larks on ship. September 24th, Larks about the light during night. October 3rd and 22nd, one rested on ship going N.: 26th, flocks going W.: 29th, one flock of Larks going N.W. at 11 A M.; gale W., clear. November 2nd, flocks like Larks going N.W.: 3rd, four flocks of birds like Larks and Thrushes going W.; gale S.W.: 4th, flocks going. W. (see under Thrush).

Arklow North Light-ship. - January 4th and 5th, many flocks of Larks, Thrushes, and other birds about lantern from 5 P.M. to 12 P.M.; strong breeze S.E., snow showers; ten killed and disabled on 4th, four on 5 th; on 6 th from midnight till 8 A.M., six killed and disabled; "several flocks" from 10 A.M. to 12 A.M. on 6th about ship, going N.W. at intervals; wind moderate S., clear: 28th, several flocks Larks and Linnets going W. from 8 A.M. to dusk; strong breeze N.W.: snow showers; 29th, one "Woodlark" about deck[Possibly Skylark.-R. M. B.]. March 5th, severál with Titlarks going N.W. at 2 P.M.; strong breeze W., rain. October 5th, several with Thrushes round light; wind light S.E., haze; none struck: 11th, several Larks, Blackbirds, and Thrushes round light from 9 P.M. to 5 A.M.; several killed and wounded; calm, haze: 18th, flocks of Larks and Thrushes going W. from 9 A.M. to 4 P.M. ; wind light E., clear: 19th, Lark died on deck: 29 th and 30th, several Grey Linnets and Skylarks going N.W. during day; three Larks eaught; wind fresh S., showery; "numbers of small birds such as Blackbirds, Thrushes, and Larks, getting exhausted as they reach ship, are followed and eaten by Seagulls-Thomas StAPLEToN": 31st, several flocks of Larks and Thrushes going W. during day; fresh breeze S. November 2nd, several Larks and Thrushes about lantern at midnight; wind moderate S.W.: 9th, several Larks, Blackbirds, and Thrushes about ship from 2 A.M. to 4 A.M.; many killed, two Blackbirds caught; fresh breeze S.W., rain.

Codling Bank Light-ship.-October 23rd, flocks going N.W. during day; gale S.E., haze and rain. November 3rd, 4th, 5th, 6th, 7th, and 8th, great flocks of Larks going N.W. during day: 9th, Larks and Blackbirds going in various directions from 
10 A.M. to 11 A.M.; wind moderate S.W.: 10 th, flocks going N.W. from 11 A.M. to 12 noon; wind moderate W. : 16th, Larks going N.W.: 21st, flock going N.W. at 10 A.M.; wind moderate S.W.: 26 th, one great flock going N.W. at 9 A.M. ; wind light N.

Rockabill.-January 27th, five on rock; gale W.; two struck. May 18th, twenty on rock at noon; fresh breeze E., blue sky. September 24th, some at lantern (see under Redwing). October 2nd, numbers of Skylarks, Blackbirds, a few Redwings, and two Stonechats round lantern; some striking; four Larks killed; wind light E., misty: 3rd, Larks, Blackbirds, Redwings, and two Stonechats round lantern; wind moderate S.; two Blackbirds killed: 4th and 5th, a great number of Skylarks round lantern; several killed striking; wind moderate N.E., misty: 7th, twenty noted: 11th, "Larks, Blackbirds, Redwings, Thrushes, Flycatchers, and two Lapwings, three GoldCrests, ten Wheatears, and two Curlew at lantern, 2 A.M. to 6 A.M. ; wind light E., misty; some striking": 20th, number of Skylarks at midnight; strong breeze E., clear: 24th, four: 27th, Larks noted (see under Chaffinch).

South Rock Light-ship.-February 17th, one at 10 A.M.; wind moderate N. April 7th, several with Linnets about light; wind moderate E., gloomy: 8th, a few about light. September 24th, October 1st, 3rd, 4th, 5th, and 6th, several about light; wind light to moderate, variable, clear; one killed striking on 6th: 7th, several with Thrushes about light from 8 P.M. to 12 P.M.; calm, clear: Sth, a flock going N.W. at 10 A.M. ; wind light S.: 11 th and 12 th, Larks and Blackbirds about light from 8 P.M. to 12 P.M. ; wind light S.W.: 13th, flocks going N.W. during day; wind light W.: 17 th, three going E. at 11 A.M.; wind light N.W.: 19th, several going N.W. at 11 A.M. : 20th, several about light; fresh breeze E., clear: 21st, a few with Blackbirds about light at 10 P.M. : 24th and 25th, Larks about light: 27th, Larks, Starlings, and Blackbirds about light; two killed; fresh breeze S.E., clear: 28th, flocks of Larks going W. during day; wind mocierate S.W.: 29th, several about light; clear: 30 th, flocks going E. during day (see also under Chaffinch). November 10th, flocks going W. during day; wind moderate S.W.: 28th, several going WV. during day: 29th, several going N.W. December $2 \mathrm{nd}, 3 \mathrm{rd}, 4 \mathrm{th}$, and 5 th, some about light: $16 \mathrm{th}$, one going N.W. 
Copeland (Mew) Island.-September 25th, "Sky and Tit Larks" from midnight to 5 A.M.; several striking, and some killed; wind moderate E., light haze. October 8th, several; and November 25th, large numbers (see notes under Blackbird).

Maidens South.-March 26th, 28th, and 30th, a few seen. April 2nd, seven going W.: 3rd, four at 3 A.M.: three killed striking; wind light N.E., misty : 6 th, twelve noted: 7 th, seven Larks, three Starlings, one Stonechat at lantern at 11 P.M.; two Larks killed; wind light E., gloomy: 10th, three Larks, two Starlings, one Thrush at lantern at 10 P.M.; wind moderate S.E., drizzling: 12th, ten going S.W.

Innishtrahull.-September 12th, two at 2 P.M.; wind light N., rain: 28th, four at 4 P.M.; wind moderate S.E., gloomy. December 8th, eight on island at 3 P.M.; wind moderate S.W., misty.

Tory Island.-October 27th and 28th, great rush at night (see under Redwing).

Eagle Island, East.-October 17th, three Skylarks on island.

\section{Snow Bunting (Plectrophenax nivalis, Linn.).}

Rockabill.-October 27th, two (see under Chaffinch).

Drogheda North.-December 17th, flock at 11 A.M.

Innishtrahull,-October 10th, flock on island at 10 A.I., first arrival ; wind light N.W., rain.

Tory Island.-October 13 th, two about island at 2 P.M. ; wind moderate W., foggy.

Rathlin O'Birne.-February 16th, twelve on island at 4 P.M.; wind moderate $\mathrm{N}$., overcast.

Killybegs.-January 4th, ten "Bunting"-[Possibly Snow Bunting:-R. M. B.] —all day remain about station. February 27th, six "Bunting" all day, remain, young birds; gale S.W.

Eagle Island, East.-May 8th, last Snow Bunting observed. "Snow Buntings, Titlarks, Sandlarks, Seagulls, Cormorants, and Gannet to be seen every day in winter. The only birds which breed on the island are the Sand Plover, Titlark, Wheatear, and a pair of Seapies, also a pair of Martins in ventilator of lighthouse. No flocks of birds going in any particular direction observed.-JOSEPH CORISH." 


\section{Yellow Bunting (Emberiza citrinella, Linn.).}

Coningbeg Light-ship.-October 4th, two about ship at 10 A.II.; flew N.E. at 4 P.M.; light haze.

Arklow North Light-ship.-March 19th, four about ship at 6 P.Mr.; flew N.W.; calm, clear.

Codliny Bant Light-ship.-April 1st, one on ship at 6 A.M.; calm, fog.

Rockabill.-March 24th, one or two on rock at 8 A.M.; wind light E.

Chaffinch (Fringilla ccelebs, Linn.).

Hook Tower. - January 8th, "during the past four days Chaffinches, Greenfinches, and Grey Linnets have been round here dying in hundreds. The Skylarks appear better able to find something to eat, as I got none of them dead. [The Chaffinch is one of the hardiest of our birds, and the Skylark one of the first to feel the effect of frost and snow.-R. M. B.] I picked up over a dozen dead Rock Pipits. The Starlings also died in scores. I got seven Grey Plover killed against glass (a rare bird to strike), and four Lapwing." [A leg and wing of one of the "Grey" Plover, "not one of the lantern killed ones, but exactly the same," was received two days later, and proved to belong to the Golden Plover.-R. M. B.] "I fancy little importance can be attached to the direction the birds struck from on that night, as, owing to the quantity of snow which fell, the birds made for the sea-coast, where the snow soonest thaws, in thousands, and were in fields on the north side of station, and after our fog-gun was fired every ten minutes the birds rose and made circuits round tower and lantern, some of them striking and getting killed. The Common Crows and even the Starlings were eating the dead birds, but made no attempt to kill them.-J. HigGinBothaм."

Coningbeg Light-ship.-March 21st, two lighted on ship at 9 A.M. and died; wind light S.E., light haze: 25th, four lighted on ship at 10 A.M.; two died; wind light S.E.: 28th, two fell in the sea trying to fly on shore at 10 A.M.; wind light E. September 12th, two about ship at 2 P.M.: 14th, one about ship at 11 A.M.; flew N.E. at noon; wind light S.E.: 26th, 
one about ship; flew N.E. at 4 P.M.; wind moderate N.E., clear. October 16th, two about ship at 2 P.Mr.; wind N.E. December 4th, two about ship at 2 P.M.; wind light N.E., clear.

Barrels Rock Light-ship.-February 23rd, "one Skylark and one Chaffinch on board for a short time during forenoon, going N." April 1st, two on board for a few minutes.

Tustar:-October 20th, "Finches" at night (see note under Starling).

Blackwater Bank Light-ship.-February 18th, flock going N.W. at 8 A.M.; wind moderate E., clear. March 14th, six going N.W. at 11 A.M.; wind moderate S.W.: 23rd, one going N.W. at 3 P.M.: 27 th, flock going N. at 11 A.M.; wind light E.N.E.: 28th, flock going N.W. at 10.30 A.Mr; wind light N.E.: 30th, one about deck from 3 P.M. to sunset; calm, clear. April 6th, one about deck from 3 P.M. to sunset; wind moderate N.E., clear: 7th and 8th, Chaffinches and other birds about light (see under Willow Wren): 12th, some about ship (see note under Swallow).

Arklow South Light-ship.-March 25th, two going N.W. at 8 A.M.; wind light S.E.: 26th, one rested on ship at 10 A.M.; wind light E.: 27 th, one rested on ship at 7 A.M.; wind light E., gloomy: 29th, one noted. October 3rd, one rested on ship at 11 A.M. going N.; wind light S.E., clear: 13th, one "flying about and lighting on ship" at noon; wind light W., clear. [November 11th, wing and foot of Chaffinch received, rested on ship and died.]

Arklow North Light-ship.-March 19th, two about ship from 4 P.M. to 6 P.M.; flew N.W., calm, clear. November 26th, some at 11 A.M., going W.; wind light N.E.

Codling Bank Light-ship.-March 22nd, several going N.W. at 11 A.M.; calm : 24th, several going N.W. at 9 A.M.: 26th, one on ship at 1 P.M.; calm, light haze: 31 st, two on ship at 8 A.M.; wind light S.W. April 5th, one on ship at 4 P.M. November 15th, one on ship at noon; fresh breeze S.W.: 24th, one on ship at 11 A.M. ; wind moderate S.E.: 27th, one about ship at 11 A.M. ; wind light E.

Rockabill.-January 10th, a number on rock at noou; flew N.; gale S.W.: 27th, some at 9 A.M.; gale W. March 16th, some at 4 A.M.; wind light N. W. May 15 th, five at noon; strong breeze N.E. October 9th, twenty in the morning; wind fresh to strong breeze S., misty: 13th, great number on rock; wind 
light N.E., clear: 20th, numbers at lantern at midnight; strong breeze E.: 22nd and 23rd, some on rock; wind light S.E.: 24th, numbers of Chaffinches and flock of Starlings at lantern and on rock; gale S.: 27th, Chaffinches, two Greenfinches, flock Starlings, two Snow Buntings, Larks, and a number of Fieldfare round light and on rock next day; misty, wind moderate, variable.

Drogheda North. - November 8th, two male Chaffinches going W. at 10 A.M.; strong breeze N., clear. "I notice it is male Chaffinches which pass light-houses in winter.J. Tottenhan." December 7th, flock going W. at 2 P.M.; wind moderate S.W., misty: 27 th, three at noon.

South Rock Light-ship.-October 18th, one about ship at 10 A.M. ; wind light N.W., rain: 30th, Chaffinches, Thrushes, and Larks about light during night; two killed; strong breeze S.E., rain.

Copeland (Mew) Island.-March 5th, several all day, remaining; wind light S.W., gloomy.

Mraidens South.-March 24th, one on rock flew W.; wind light S.E., misty. From one to four noted on rock on 27 th, 29th, 31st, and April 4th, 8th, 10th, 11th, 12th: 13th, three Chaffinches, two Crows going S.W. at 9 A.M.; fresh breeze S.E. : 14th, two on rock all day; strong breeze E., clear.

Innishtrahull.-[April 10th, wing of Chaffinch received.] November 14th, two on island at 3 P.M. ; gale S.W., rain.

BRAMBLING (Fringilla montifringilla, Linn.).

Hook Tower.-January 8th, "a small bird came into the house during hard weather on 6th, appeared quite tame, and lived in a cage till 7th." [Brambling received in flesh.]

Sparrow (Passer domesticus, Linn.).

Rockcubill.-May 15th, five "Sparrows" on rock at 5 P.M.; strong breeze N.E., rain.

Drogheda North.-May 18th, a large flock of House Sparrows about station at noon; strong breeze N.E.; "these birds have appeared about station the last few days, they are rarely seen 
down from the farm-houses." June 12th, numbers all day about station; strong breeze N., showery.

South Maidens.--March 28th, one Sparrow, "the first Sparrow ever seen on the rock;" wind light S., misty.

\section{GreENFINCH (Ligurinus chloris, Linn.).}

Hook Tower.-January 8th, "during the past four days Greenfinches and other birds have been round here dying in hundreds" (see full note under Chaffinch at this station).

Arklow North Light-ship.-January 29th, several, and one "Woodlark" from 9 A.M. until dusk, on and about deck all day. April 23rd, several about ship at 11 A.M. going W.; wind moderate S.E., rain. September 23rd, two from 7 A.M. to noon, one died; wind light S.E., clear. October 14th, one Green Linnet on deck at 12 P.M.; calm, clear; remained feeding on deck: 19th, several small birds about ship all day; some Green Linnets and a Lark died on deck; wind light N.E., clear: 25th, several on deck all day; some remained all night; three caught; fresh breeze S.W., clear. November '25th, several about lantern from 1 A.M. to 4 A.M. ; one killed striking; wind moderate S., gloomy: 26th, "Green Linnets and Chaffinches" going W. at 11 A.M. ; wind light N.E.

Rockabill.-January 10th, numbers on rock at noon; gale S.W. ; flew N. October 13th, some; wind light N.E. : 23rd, ten at 8 A.Mr; wind light S.E., clear: 27 th, two about light (see under Chaffinch).

Drogheda North.-November 20th, "Green Linnets" going W. at 2 P.M., clear.

Maidens South.-March 25th, 27th, 28th, one. April 5th, three going W.; wind light E. : 8th, two: 10th, one.

\section{"GoldFinch."}

Arklow North Light-ship._-March 3rd, several flocks of Goldfinches going N.IV. at 8 A.Mr. f fresh breeze W.S.IV., clear: 5th, several flocks of Linnets and Goldfinches going N. W. from 11 A.M. till noon; fresh breeze S.W., hazy and rain. [Flocks of Goldfinches are so rare, that I have put name in inverted commas. -R. M. B.] 


\section{Linnet (Linota cannabina, Linn.).}

Hook Tower.-January 8th, "during the past four days Grey Linnets and other birds have been round here dying in hundreds" (see full note under Chaffinch at this station).

Coningbeg Light-ship.-J January 5th, "one cock Linnet (Redbreast) and Skylark" caught on upper deck; wind moderate S.E., snow (see also under Thrush): 6th, some about light (see under Skylark). October 13th, two "Grey. Linnets" about ship at 10 A.M.; gloomy: 17th, "Redbreasted Linnet" about ship at 1 P.M.; went N.E. at 2 P.M.; wind light N.E.

Barrels Rock Light-ship.-March 11th, five Linnets lit on board for a short time at 11 A.M. going N.; showery. November 18th, two large flocks going S.W. at 11 A.M., flying low; fresh breeze S.

Blackwater Bank Light-ship.-_January 5th, flocks going N.W. with Starlings and Larks: 12th, one Linnet found dead on deck at 9 A.M.; wind light W.S.W., clear-[Leg and wing of Linnet received]. February 28th, two going N. at 11 A.M. fresh breeze N.W., clear. March 5th, two going N.W. at 8 A.M. : 9th, flock going N.W. at 3 P.M. : 10 th, flock going N.W. at 11 A.M.; fresh breeze S.W. : 22 nd, one about deck from 8 A.M. to noon; wind light S.E., clear. April 12th, Linnets about ship (see note under Swallow). September 13th, one Linnet lighted on ship at 11 A.M.; wind light N.E., hazy. November 18th, flocks going N.W.

Arklow South Light-ship.-March 9th, five "Grey Linnets" going N.W. at 4 P.M. ; wind moderate W., showery; some about light after dark: 17th, one "Grey Linnet" going N. at 4 P.M. : 18th, three going N.W. at 9 A.M. ; wind light W.: 21st, two going N.W. at 8 A.M.; wind light S., gloomy : 23rd, one rested on ship: 27 th, one rested on ship at 7 A.M. September 20 th, two going S.E. ; wind light N.W. October 5th, a flock of Linnets going N.E. at 5 P.M. ; wind N.E. : 26 th, several flocks with Larks going W. during day; wind light S. November 2nd, Hocks like Linnets (see under Thrush).

Arklow North Light-ship.-January 28th, several flocks going W. all day. March 3rd, several flocks going N.W. at 10 A.M.; strong breeze W.S.W.: 5th, several flocks (see under 
Goldfinch): 10th, several going N.W. at 7 A.n.; wind light S.W. November 15th, several flocks going N.W. ; fresh breeze S.W. : 26th, some going S.W.

Drogheda North.-August 6th, "Grey Linnets and Swallows" going N. (see under Swallow).

South Rock Light-ship.-April 3rd, two Linnets going N.W. at 9 A.M. ; fog: 4 th, two going N.W. at 9 A.M. ; wind light E., fog : 7 th, some about light; gloomy : 11th, several Linnets going N.W. at 1 P.M. ; wind light E. : 19th, several going N.W. at 11 A.M.; wind light E. September 1st, one going W.: 23rd, several going W. at 10 A.M. ; wind light E., clear.

Maidens South.-March 28th, 29th, and 31st, from two to five "Grey Linnets" noted. April 6th, three going S.W.; wind moderate $\mathrm{E}:$ 11th, one noted.

Innishtrahull.-October 12th, flock of Grey Linnets going $\mathrm{E}$. at 11 A.M. ; wind moderate S.S.W., misty.

Eagle Island, East.-June 15th, two resting on island. October 15th, flocks flying about station.

Bull Rock.-January 6th, Linnets on rock all day; wind N.E., a little snow. February 14th, fifty Linnets on rock all day; wind moderate S.W., gloomy.

TwITE (Linota flavirostris, Linn.).

Innishtrahull.-[April 11th, wing of Twite received.]

\section{StARLING (Sturnus vulgaris, Linn.).}

Old Head, Kinsale.-January 4th, a flock of Starlings about hill all day; strong breeze E.: 24th, some going N.W. at 10 A.M. February 2Sth, four all day; gale S.W. March 15 th, three at noon; wind moderate N.W. November 5th, seven going N.W. at 2 P.N.; wind light N.W.: 24th, five going N.W. at 10 A.M.

Hook Tower.-January, Starlings and other birds died in scores. "The Common Crows and even the Starlings were eating the dead birds, picking them up, but made no attempt to kill them." (See full note under Chaffinch at this station.) April 12th, two round light at 3 A.M.; one killed, one disabled; wind light $\mathrm{N}$, clear. 
Coningbeg Light-ship. - January 5th, several about light (see under Thrush): 6th, several (see under Skylark). September 29th, two flocks noted going N.; wind moderate E., clear. October 12th, some about light all night: 15th, two large flocks going N. at 8 A.M.; two flocks at 2 P.M.: 18th, flock going N.E.: 20th, several flocks going N.E.: 24th, Starlings about ship at 10 A.M., flying low. November 24th, several (see under Blackbird). December 8th, several noted.

Barrels Rock Light-ship.-November 24th, two flocks going N.W. at 2 P.M., flying high; wind moderate to fresh $\mathrm{E}$.

Tuskar.-July 27th, several going N.W. at 6 P.M.; wind light N.W.: 30 th, Starling all night round light; fresh breeze N.E., misty. August 25th, Starlings all night. October 19th, some all night round light; strong breeze E., rain : 20th, flocks of Starlings, Blackbirds, Thrushes, Finches, etc., going W.; numbers killed; gale $\mathrm{E}$, rain, thunder and lightning. November 21 st, some Starlings killed at night.

Blackwater Bank Light-ship.-January 3rd, flocks of Starlings and Blackbirds going N.W. during day; strong breeze S.E., clear: 4th, flocks, with Blackbirds and Thrushes, going N.W. from 9 A.M. to noon; strong breeze E., snow showers: 5th, flocks, with Larks and Linnets, going N.W. from 9 A.M. to 4 P.M.; wind E., snow: 6th, great rush: and 7th, flocks (see under Skylark). February 11th, flock about light all night; strong gale S.W. March 8th, several about light; two killed striking: 9th, four about light: 29th, flock about light. July 25th, two about light at 10 P.M.; wind light S.E., thunder; one killed striking-[Leg and wing of Starling received]. October 3rd, several (see full note under Thrush). November 10 th, flock going N.W. at 9 A.M.: 15th, two flocks going N.W.; wind moderate to fresh S.W.: 18th, flocks going N.W. in morning: 24th and 30th, flock going N.W.

Arklow South Light-ship.-January 6th, flocks of Starlings and other small birds during day going N.W., overcast: 10th, two rested on ship. February 18th, one about ship at 10 A.M.; seemed tired. March 19th, one rested; also a Golden-Crested Wren. October 2nd, one rested on ship at 10 A.M. going N.W.; wind light S., clear: 18th and 19th, several flocks of Starlings and "other small birds" going W. 
and N.W. during these two days; fresh breeze N.E., clear; one Starling rested on ship.

Arklow North Light-ship.-October 1st, three young Starlings on deck all day.

Codling Bank Light-ship.-April 12th, one on ship at 6 A.M.; calm, light haze. October 24th, large flock going N.W. at 9 A.M.; gale S.W., fog. November 7 th and 8th, great llocks Larks and Starlings during forenoon going N.W.: 10th, flocks going N.W.: 24th, one on ship: 26th, one killed striking; wind moderate $\mathrm{E}$., gloomy: 28th, several about light; wind light N.W.

Rockabill.-March 16th, some round lantern at 4 A.M.; flew $\mathrm{E}$. in the morning; wind light N.W. October 8th, one on rock at noon; wind light S.E.: 23rd, flock at 8 A.M.: 24 th and 27 th, a flock (see under Chaffinch). November 2nd, flock going W. at noon; wind moderate S.W., clear.

Drogheda North.-April 4th, about thirty going S.W. at 10 A.M.; calm. May 2nd, a large flock going N.W. at noon; wind moderate N.W.: 12th, three Starlings rested at 5 A.M., and flew N. June 13th, a large flock going N. at'5 A.M. July 20th, some hundreds about station all day, nearly all young birds; wind light S.W., clear.

South Rock Light-ship.-February 18th, several about light at 2 A.M.; wind moderate S.E., clear. October 9th, one about deck at 11 A.M.; fresh breeze S.W., hazy : 23rd, flock going N.W. at 10 A.M. : 24th, some about light: 26th, one on deck during day: 27th, several going N.W. at 10 A.M.; fresh breeze E.; also during night at lanter'n. December 27th, one going N.W.

Copeland (Mew) Island.-February 7th, large flock all day, remaining; gale W. March 10th, flocks all day, remaining: 20th, flock. "Starlings breed on isle." They frequent this island all the summer months, and are to be seen every day. October 27th, some striking, midnight to 4 A.M.: dark and squally.

Maidens South.-March 24th, six Starlings and one Crow going W. at 8 A.M.; wind light S.E.: 26th, ten noted. April 7th and 10 th, a few at lantern.

Innishtrahull.-October 5th, six on island at 11 A.M.; wind moderate S.E., gloomy: 8 th, one disabled at 4 A.M.; wind light S., misty. 
Tory Island.-October 26th, 27th, and 28th, great rush (see under Redwing). November 26th, numbers; Water Rail killed striking same night.

Rathlin O'Birne.-January 5th, Starlings all day on island; fresh breeze S.E., snow.

Eagle Island, East.- "November 7th to 15th, large flocks of Starlings came from the land; after feeding a short time, returned again."

Clare Island.-October 20th, a dozen Starlings flying about station; the first seen this season.

Slyne Head, N.-January 10th, hundreds of Starlings on island all day; wind S.E., snow.

Samphire Island.-October 22nd, several about light at 11 P.M.; gale S.E., cloudy. November 16th, twenty going S.W. at 1 P.M., flying very high and scattered; strong breeze S.W. December 3rd, one on island; strong gale S.E.

Bull Rock.-January 3rd, Starlings on rock all day; wind light E., gloomy : 9 th, thirty on rock at 9 A.M.: 25 th, twenty on rock at 10 A.M. ; fresh breeze W., clear : 28th, one disabled.

Chodgh (Pyrrhocorax graculus, Linn.).

Rathlin O'Bime-March 28th, two Choughs going W. at noon; wind moderate S.E., blue sky, misty.

Bull Rock.-January 6th, Choughs on rock all day; wind N.E., a little snow: 22 nd, ten on rock all day; wind moderate N., hail.

Raven (Corvus corax, Linn.).

Arklow North Light-ship.-October 17th, one Raven going E. at noon; wind moderate N.E., clear.

\section{Hooded Crow (Corvus cornix, Linn.).}

Rockabill.-February 28th, six Hooded Crows on rock at 7 A.M. ; strong breeze to gale S.W. May 16th, two "Crows" on rock at noon.

Copeland (Mew) Island.-February 7th, four Hooded Crows all day, remaining; gale $\mathrm{W}$. 
Rook (Corvus frugilegus, Linn.).

Hool. Tower.-January, "birds dying in hundreds; Common Crows were eating the dead birds" (see full note under Chaffinch at this station). April 30th, twenty or thirty "Common Crows" going E. at 2 P.M.; fresh breeze N.E.

Coningbeg Light-ship.-March 4th, one going N.E. at 10 A.M. ; clear. April 2nd, six going N.E. at 6 A.M.; two lighted on ship to rest: 17th, two flocks of Crows going for the land at 6 A.M.; calm, clear: 19th, flock of Crows going for the land at 8 A.M.; wind light S.E.

Barrels Rock Light-ship.-April 1st, one lighted on board for a few minutes: 28th, one lighted on board, and afterwards flew to land.

Blackwater Bank Light-ship.-March 4th, one going N. at 11 A.M.; strong breeze N.W., clear: 11th, one going N.W. at 11 A.M. ; gale W. : 17th, six going N.W. at 11 A.M. ; wind light S.W., clear: 24th, flock going S. at 8 A.M. ; wind moderate E., clear. April 3rd, flock going N.E. at 2 P.M.; wind light N.E., fog: 13th, flock going N.E. at 33 P.M.; wind moderate S.W., clear.

Arklow South Light-ship.-March 8th, four going N.W. at 11 A.M.; wind moderate W.: 23rd, three noted during day: 29th, seven going N.W.

Arklow North Light-ship.-March 2nd, large flocks going N.W. at 9 A.M.; strong breeze W., clear. April 22nd, a flock going to the N.W.; fresh breeze S., clear. September 30th, two going W. about 11 A.M.; "seemed to have come from Wales." October 22nd, one Crow going W.; wind light S.E.: 28th, three going N.W. during day. December 5th, two going N.W. during forenoon; wind light S.W.

Codling Bank Lightship.-March 24th, some going N.W. at 9 A.M. : 25th and 29th, one going N.W. April 2nd, flock going W. at 3 P.M. ; wind light S.W., fog. May 2nd, one going N.W. November 16th, seven Crows going N.W. at 11 A.M.; fresh breeze S.W.: 19th, one going N.W. at 10 A.M.; fresh breeze S.W.

Rockabill.-January 20th, four Rooks on rock; gale N.W. 
Drogheda North.-May 21st, hundreds of Rooks about rabbit burrow at noon; wind light N.E., clear.

Maidens South.-March 24th, one going W. at 8 A.M. : 25th and $27 \mathrm{th}$, three Crows noted going W.: 30th, one. April 3rd, four going S.W. at 7 A.M.: 6 th, 7 th, and 12 th, three to four: 13th, two going S.W. at 9 A.M.

Innishtrahuill.-August 30 th, two at 10 A.M. ; wind moderate N.W. September 29th, three at 11 A.M.; wind moderate S.E. October 21st, fourteen going S. at 11 A.M.; strong. breeze E., gloomy.

Rathlin O'Birne.-March 31st, Crows going W. at 8 A.M.; wind light S.E.

Eagle Island, East.--December 18th, two Crows at 11 A.M. rested on island, then went for the land.

Samplire Island.-November 19th, great numbers of Rooks going S.W. from 8 A.M. to 9 A.M. ; fresh breeze S.W., rain ; "flying in flocks of from three to ten at intervals, and flying with short, quick flaps of the wings, then soaring, without any motion of the wings, wheeling suddenly about, and again proceeding with short, quick flaps, but making no cawing sound as Rooks usually do."

\section{JACKDAW (Corvus monedula, Linn.).}

Arklow North Light-ship.-November 24th, Jackdaw about ship at 1 P.M. ; flew W. that night; wind moderate S.E.

Copcland (Mew) Island.-February 5th, several at noon, remaining; wind light W. March 28th, a few. June 11th, large numbers on isle; build and breed on small Copeland Isle.

$$
\text { "JAY." }
$$

Maidens South.-April 12th, one "Jay" at lantern at 10 P.Mr.; wind moderate S.E. [Missel Thrush ?--R. M. B.]

\section{SWALLOW (Hirundo rustica, Linn.).}

Old Head, Kinsale.-June 11th, three all day; fresh breeze N.W. September 5th, one going N.W. at noon; wind light N.E.: 23rd, two all day; wind light N.E.

Hook Tower.-April 11th, three round light at 2 A.M., first 
seen this year; wind light S., fog; five at 10 A.M.; wind light N.E., haze: 17th, plentiful all day; wind, variable. May 10th, over a hundred on telephone wires at 2 P.M.; wind light N., clear.

Coningbeg Light-ship.-April 20th, three going N.E. at 2 P.M.; wind light S.W., light haze; "stopped at ship for about one minute": 27th, about twenty "going N.W. for the land" at 10 A.M.; wind moderate S.W., clear: 28th, about ten going N.E. at 2 P.M.; wind light W.: 29th, three going N.E. at 4 P.M.; wind light W. May 1st, two going N.E. at 10 A.M.: 2nd, several about ship during day, making for land; wind moderate, clear: $3 \mathrm{rd}$, several going $\mathrm{N}$. during day : 4th, some going N.W., clear: 11th, several about ship; wind light S.E.: 12th, two about ship, went N.W.: 17th, two about ship; wind light N.E., fog; remained on board all night, went N.W. June 4th, some going N.E. at noon; wind light E., fog; two about ship at 4 P.M., clear. September 25th, several going S.E. during day; fresh breeze N.E., clear: 27th, one Martin and Swallow about ship at 4 P.M. ; caught and let go, this year's birds; wind light N.E., clear; some going S.W. from 12 to 6 P.Mr.: 28th, several about ship from noon to 5 P.M.: 30 th, large flock going S.E. at 7 A.M., flying high ; wind light S.E.; four going S.E. at 10 A.M., flying low.

Barrels Rock Light-ship.-May 1st, a few during day; wind moderate N.W., showery: 2nd, a large flock going N. at 7 A.M.; wind moderate W., showery: 3rd, several flocks: 4th, four during day: 12 th, a flock going N.W. at 9 A.Mr; wind moderate N., clear: 29 th, one lit on board at 1 P.M.

Tuskar.-September 1st, one killed; wind light N., clear.

Blackwater Bank Light-ship.-March 27th, flock going N.W. at 3 P.M. ; wind light N.E., clear. April 1st, flock going N. at 10 A.M.; wind light S.W.: 3rd, flock Swallows and Thrushes going N.W. between 10 A.M. and 3 P.M.; wind variable, fog: 7 th, flock Swallows and other birds going N.W. between 5 A.M. and 8 A.M.; wind moderate E., rain: 12th, "flock of Swallows, Linnets, Chaffinches, and one Pigeon from 4 A.M. to 7 A.M. about ship; wind light W, light rain": 17th, flock going N.W. at 9 A.M. ; wind light W.: 25th, three going N.W. at 10 A.M. ; strong breeze S.W.: 26th, six going N.W. at 4 P.M.: 28th, several about light from 9 P.M. to midnight; wind light S.W., 
overcast. Mny 4th, flocks going N.W. 10 A.M. to 2 P.M.; fresh

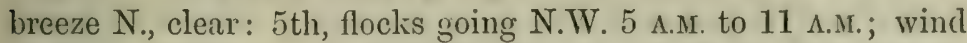
moderate N.W., clear: 14th, flocks going N.W. 9 A.M. to noon; fresh breeze S., clear: 15th, flocks going N.W. 1 P.Mr. to 7 P.M.; wind light, variable, showery. Angust 31st, one going N.W. at 11 1.n.; wind light N. W., clear. September 15th, flock going S.E. at 11 A.M.; wind light N.E., clear: 21 st, flock going S.E. at 10 A.M.; wind moderate. S.E., gloomy : 24th, flock going S.E. at 9 A.M.; fresh breeze N.E., overcast.

Arklow South Light-ship.-March 23rd, one going N.W. at 4 P.M. ; wind light N.E., gloomy; first seen this spring. April 18th, one "Martin or Sivallow" going N.W. at 2 P.M.; wind moderate N.E., clear: 27 th, one going N.W. at 7 P.M.; wind light N.E., clear. May 1st to 12th, "Swallows all day going N.W.; wind and weather variable; a large number passed." June 15th, one going N.W. at 9 A.M. ; wind moderate N.E., rain. September 17th, odd Swallows going S. during day; wind light S.E., gloomy; first seen going S.: 18th, small flocks going S. during day; wind light E., gloomy : 25th, 30th, and October 1st, small flocks going S.E. during day.

Artilow North Light-ship.-April 23rd, several going W. at noon; wind light S., clear. September 27th, several going S.E. from noon to 5 P.M.; wind moderate S.E., light haze.

Codling Bank Light-ship.-March 27th, one going N.W. at 9 A.M.; calm, light haze : 30 th, one on ship at 5 A.M.; wind S., fog. April 7 th, three flying about ship at 7 A.Mr.; wind light N.E., hazy: 19th, one going N.W. at 11 A.M. May 2nd, 3rd, 4th, 5th, 6th, 7th, and Sth, Swallows and flocks of Swallows going W.N.W. during day; wind variable: 13th, Swallows going W.N.W. during day; wind moderate S.S.W., rain: 15th, 16th, and 17th, several during day, going N.W. on 17th : 24th, one going W. at 11 A.M.; wind moderate N.E., clear.

Rocluctill.-May Sth, six on rock at 10 A.M.; strong breeze S.W., cloudy.

Droghedla North.-May 12th, one flying about station from 1. P.M. to 6 P.M.; wind moderate W., clear; first seen this season : 15 th, several all day flying about station; strong breeze N.E., cloudy and rain: 21st, 22nd, and 24th, numbers all day flying about; wind variable, clear; "very numerous every day": 29th, numbers of Swallows and about twenty Swifts going N.W. 
at 2 P.M.; wind light S.W., showery. June 12th, numbers of Swallows flying about station from 2 P.M. to 7 P.M.; fresh breeze N., showery. August 6th, great numbers of Swallows going N. at 4 P.M.; "flying very scattered and making a great noise, they were accompanied by a number of Grey Linnets;" wind moderate W., clear.

South Rock Light-ship.-April 4th, one going N.W. at 9 A.M.; wind light E., fog: 8th, one going N.W. at 11 A.M.; wind light S.E., hazy. October 8th, two going E. at 9 A.M.; wind light S., hazy.

Maidens South.-April 9th, four Swallows going W. at noon; wind moderate S., rain: $11 \mathrm{th}$, two going W.; wind light S.E.

Killybegs.-April 23rd, two old birds remain for the summer; wind moderate S.E., clear: 27 th, six ; wind light S., clear.

Eagle Island, East.-May 11th, first Swallow of the year.

Clare Island.-May 15th, "two Swallows at noon; these were the first seen this season."

\section{"Martin."}

Coningbeg Light-ship.-September 27th, one Martin and one Swallow about ship at 4 P.M.; caught and let go; this year's birds; wind light N.E., clear.

Arklow South Light-ship.-April 17th, one Martin going N.W. at noon; wind light W.S.W., clear.

Eagle Island, East.- "A pair of Martins breed in ventilator of light-house."

SwIFT (Cypselus apus, Linn.).

Hook Tower.-May 2nd, one Swift round tower at 7 P.M.; wind moderate N.W., clear.

Tuskar.-July 30th, "Swift killed striking glass at 12 A.M.;" fresh breeze N.E., misty.

- Arklow South Light-ship.-May 16th, odd Swifts going N. during day; wind light $\mathrm{E}$., haze, rain: 21st, two going $\mathrm{N}$.; wind moderate N.E.

Drogheda North.-May 29th, about twenty Swifts going N.W. 
Nightjar (Caprimulgus europoeus, Linn.).

Hook Tower.-June 4th, "a strange bird shot after watching it for a day or so; one of the men says it is a Night or Moth Hawk, and that he saw them along the Mediterranean ports. -J. Higginbotram." [Female Nightjar received in flesh.]

Rockabill.-May 15th, one Nightjar on rock at noon; caught it; strong breeze E.N.E, haze, rain.-Charles Hawkins. [Received in flesh.]

\section{Cuckoo (Cuculus canorus, Linn.).}

Droghcda North.-April 30th, one Cuckoo heard in Beauly Wood at 6 A.Mr.; calm, clear; first heard this season. May 10th, one heard at 11 "P.M.": 17th, one Cuckoo going W. at 5 P.M. ; gale N.E., clear.

\section{Hoopoe (Upupa epops, Linn.).}

Old Head, Kinsale.-April 9th and 10th, one Hoopoe on hill all day; wind moderate S., weather variable.

Barrels Rock Light-ship.-March 28th, "a bird lit on board and died four days afterwards. When approached its crown became erect and very handsome, and it used to make a hissing noise at the same time.-J. BeaHAN." [Fresh skin of Hoopoe received on April 10th.]

Codling Bank Light-ship.-March 20th, " a bird seen on ship at noon, about the size of a Redshank, dark yellow or ochre colour and black across tail and back, with large top-knot on head the same as a Cockatoo; only stopped for a moment, as one of the crew tried to catch it; went N.E.; calm, clear. -W. Clydesdale."

Innishtrahull.-September 15th, "one Hoopoe at 8 A.M.; a rare visitor; stopped until 24th.-GEorge GILLESPIE."

\section{"Pigeons."}

Old Head, Kinsale.-November 17th, three going N.E. at noon; gale S.W., overcast, rain.

Hook Tower.-January 10th, "we have at station now a Pigeon that was taken from a nest in cliffs near station 
last August, and reared by hand; it is quite tame, going with the fowls at station and roosting amongst them."

Blackwater Bank Light-ship.-April 12th, one about ship (see note under Swallow).

Rockabill.-March 20th, one Carrier Pigeon on rock at 8 A.M.; wind light S., overcast; remained on rock two days: 24 th, Wood Pigeon on rock at 8 A.Mr; wind light E. June 5th, one Carrier Pigeon on rock at 4 A.M. ; wind moderate N.E., fog, rain. "This Pigeon remained on rock two months." October 9th, one Rock Pigeon on rock: 27th, two Pigeons in the morning. November 2nd, Rock Pigeon at noon; wind moderate S.W.: 8th, one Carrier Pigeon noted.

Drogheda North.-July 12th, three Rock Pigeons going S.E. at 4 P.M. ; wind moderate W., clear. August 4th, about fifty Woodquests going $\mathrm{N}$. at 2 P.M.; wind moderate W., cloudy.

Maidens South.-March 28th, two Blue Pigeons noted.

Tory Island. - October 21st, three Pigeons going E. at 10 A.M. ; wind light W.

Bull Rock.-January 5th, three Pigeons on rock at 10 A.II.; gale E., clear. February 12 th, three on rock at 10 A.M. ; strong breeze N.W., hail.

Grouse (Lagopus scoticus, Lath.).

Copeland (Mew) Island. - December 22nd, large flock of Grouse all day, remaining; storm N.E., clear.

\section{Conn-Crake (Crex pratensis, Bechst.).}

Hook Tower.-May 13th, one at 10 A.M. ; killed striking wire; wind light S., rain.

Rockabill.-May 15th, one on rock at 4 P.M.; strong breeze N.E., overcast. August 12th, one on rock at 7 A.M. ; flew ashore; strong breeze W., gloomy.

Droghecta North. - May Sth, one heard close to station at 10 P.M.; fresh breeze W.; first heard this season.

Innishtrahull.-June 18th, one Land Rail at 3 1.M. ; wind light S.S.W., clear. "Annual visitors; first arrival noticel: breed here." 


\section{Water-Rail (Rallus aquaticus, Linn.).}

Tory Island.-November 26th, "numbers of Blackbirds, Thrushes, Starlings, and Land-Rail about lantern during night; numbers struck, none killed but Land-Rail; wind light S., gloomy." [Leg and wing of Water-Rail received.]

Rathlin O'Birne.-February 26th, Water Rail on island at noon; strong gale S.W.

\section{WATER-Hen (Gallinula chloropus, Linn.).}

Drogheda North.-April 2nd, one Water-Hen found dead at 6 A.M. ; wind light S.E., fog; supposed to have been killed striking. [Leg and wing of Water-Hen received.]

\section{Ringed Plover (Agialitis hiaticula, Linn.).}

Droghede North.-May 22nd, seven "Sand Plover" feeding: on river bank at 6 P.M. ; wind light S.E., clear.

Copcland (Mow) Island.-June 11th, four "Ring Plovers" all day, remaining; wind light N.W., clear.

Innishtrahull.-February 12th, eight "Ring Dotterel" stopped on island; wind moderate S.E., hazy.

Rathlin O'Birne.-February 20th, six "Dotterels" on island at noon ; wind light E., overcast.

Eagle Island, East.- "Sand Plover breed on island."

Samphire Island.-November 27th, numbers of Curlew, Seapie, and Ring Dotterel about light from 8 P.M. to 11 P.M.; wind light S.E., fog ; one Ring Dotterel caught, the only one that came near the glass. [Leg and wing of Ringed Plover received.]

Golden Plover (Charadrius pluvialis, Linn.).

Old Head, Kinsale.-January 6th, three "Grey Plover" going N.W. at 4 P.M. ; wind light N.E. : 7th, six "Grey Plover" going N.W. at 2 P.M. ; wind moderate S.W:

Hook Tower:-January, "seven Grey Plover killed against glass, a rare bird to strike. A leg and wing of one, not one of the lantern killed ones, but exactly the same, forwarded "- [Leg and wing of Golden Plover received] - (see full note under Chaffinch at this station). 
Coningbeg Light-ship._-January 6th, "several flocks Grey Plover during the day going N.E.;" snow: 7th, flock "Grey Plover" going N.E. at 11 A.M. ; wind moderate S.W. August 30th, "Grey Plover" going N. at 2 P.M., flying low; wind E., clear.

Arklow North Light-ship.-October 9th, "Grey Plover" round light; wind light E, clear : 23rd, flock of Golden Plover going N.W. at 11 A.M. ; one pitched on deck; gale S.E., rain.

Codling Bank Light-ship.-November 17th, two Golden Plover going S.W. at 10 A.M. ; strong breeze S.W.

Innishtrahull.-January 5th, two stopped on island; strong breeze S., snow. October 24th, four on island at noon; gale S.E.

Tory Island.-October 13th, flock about island during day; wind moderate W., foggy.

Rathlin O'Birne.-January 5th, Golden Plover on island all day; fresh breeze S.E., snow. March 30th, some all day; wind moderate S.E. October 7th, eighteen going S.E. during day, apparently young birds; wind moderate S.E., clear: 27 th, ten going S. at 10 A.M. ; wind light N.E., clear. November 10th, twenty-three, old and young, going N.E. at 2 P.M. ; gale S.W., hail: 27 th, seven going N.E. at noon.

Killybegs.--January 10th, one going E.; strong breeze S. February 14th, forty, mostly young birds, remained all day; wind light S.E., misty. April 6th, four young birds, remained all day; fresh breeze E.S.E.

Eagle Island, East.-October 14th, one resting on island.

\section{Green Plover (Vanellus vulgaris, Bechst.).}

Old Head, Kinsale.-January 3rd, three going N. at 10 A.M. ; strong breeze E., blue sky. "On the evening of the 4th, Grey and Green Plover in countless numbers began to arrive with the snow showers, they remained all night, and up to noon next day, but the ground getting covered with the heavy fall, they all left as suddenly as they came." March 2nd, one going N.W. at noon ; strong breeze N.W.: 11th, two going N.E. at 11 A.M. ; gale N.W. November 26th, one on hill at 11 A.M. ; wind light E.

Hook Tower.-January, "four killed striking" (see full note under Chaffinch at this station). 
Coningbeg light-ship.-January 5th, two flocks "Plover" going N.E.; wind moderate E., snow. March 24th, three going for Saltee Island at 11 A.M. ; wind light E.

Blackwater Bank Light-ship.-January 2nd, two about light at 7 P.M. ; fresh breeze S.E., clear: 6th, great numbers of Lapwing, etc., about light; many killed and disabled (see full note under Skylark). March 26th, flock "Plover" going N.W. at 2 P.M. ; wind S.E. April 6th, flock of "Plover" about light at 10 P.M. ; wind light N.E., clear. [Leg and wing of Green Plover received, killed striking.]

Arklow South Light-ship.-March 26th, one Green Plover rested on ship at 11 A.M. ; "remained all day, did not appear to be strong;" wind light E, gloomy.

Arklow North Light-ship. -January 9th, several flocks going S.W. from 9 A.M. to 3 P.M. ; these flocks were small and scattered. October 20th, two flocks of Lapwing going N.W. at noon, flying high and scattered; wind light E., showery: $28 \mathrm{th}$, flocks going N.W. during day; fresh breeze S. December 5th, four Lapwing going N.W. during forenoon; wind light S.W.

Codling Bank Light-ship.-November 30th, several about light at night; wind light $\mathrm{E}$.

Rockabill.-October 5th, two "Peeweeps going W. at noon; remained on rock a while;" fresh breeze E: 11th, rush of birds, one or two Lapwings noted (see under Skylark).

Drogheda North.-March 5th, thirteen going W. at 4 P.M.; gale W. December 26th, Lapwing going W. all day; wind moderate N., clear.

South Rock Light-ship.-April 8th, a few Larks and Plover about light at 11 P.M. ; calm, hazy.

Copeland (Mew) Island.-Green Plover frequent this island all the summer months.

Maidens South.-Narch 24th, thirty-five going E. at 10 A.M.; wind light S.E. April 3rd, seven at 5 A.M.

Innishtrahull.-January 5th, three Lapwing and two Golden Plover stopped on island; strong breeze S., snow. September 15th, one Lapwing at 4 P.M. ; wind light N.W., gloomy.

Rathlin O'Birne.-January 30th, six on island at 8 A.M. ; strong gale W., hail. March 23rd, twelve going E. at 4 P.M. ; wind light S. December 16th, six going N. at 1 P.M. ; wind light S.E., gloomy. 
Killybergs.-March 8th, thirty Green Plover all day, remain; strong breeze S.W., cloudy.

Slyne Head, N.-January 12th, four all day. March 17th, fourteen.

Bull Rock--January 5th, four on rock at 10 A.Mr. ; gale E., clear. March 1st, five on rock at 10 A...I. ; fresh breeze W., gloomy.

Turnstone (Strepsilas interpres, Linn.).

Drogheda North.-August 7th, five Turnstones on river bank at 2 P.M.; first seen for some time; fresh breeze IV., showery.

Samplire Island.-November 15th, a large flock of Turnstones going N. at 2 P.M. ; strong gale W., sleet.

\section{Oyster-Catcier (Homatopus ostralegus, Linn.).}

Coningbeg Light-ship.-September 6th, Oyster-Catcher about ship at 2 P.M. ; went N. ; wind N.W., clear.

Rockcubill. - February 1st, six Seapie at 8 A.Ms.; wind moderate S.W. September 24th, one at noon; "first seen this autumn;" wind moderate N., overcast.

Drogheda North.-July 30th, large flocks of Seapie all day on banks of river; wind light S.E., clear. August 6th, a large flock going S.E. at 2 P.M.; wind moderate W.: 9 th, great numbers on strand.

Copcland (Mew) Island.-March 10th, flocks all day, remaining; fresh breeze W.: 28th, flocks. Seapies frequent this island all the summer months. November 25th, flocks daily round isle.

Rathlin O'Birnc.- January 27th, twenty-four on island all day; strong gale N.W.

Eagle Island, East.- " A pair breed on island."

Samphire Island.-October Sth, six going N.E. at 3 P.M.; fresh breeze S.W., clear: 9 th, two on E. end of island at 3 P.M. ; strong breeze S.W. November 10th, six Seapie and numbers of Curlew feeding on rocks on mainland at 2 P.Mr. ; fresh breeze N.W.: 18th, numbers feeding, and 27 th, numbers about light; wind light S.E., fog. 
Woodcock (Scolopax rusticula, Linn.).

Old Hocul, Kinsale.-January 5th, one on hill at 2 P.M.; wind moderate N.E., snow.

Innishtrchull.-November 18th, three on island at 11 A.M.; gale $\mathrm{S}$., rain.

Tory Island.-October 15th, one about island at noon;

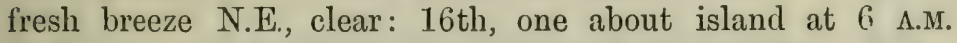
$23 \mathrm{rd}$, one found killed, having struck iron railings during night.

Rathlin O'Birne.-January 6th, six on island at noon; strong breeze S.E., snow. October 29 th, one going S. at 2 P.M.; " came from the north;" wind light S.E., showers. November 21st, two going E. at noon; gale S.S.E., gloomy.

Killybegs.-February 6th, one at 1 P.M. ; remains in vicinity; gale S.W., gloomy.

Samplire Island.-November 28th, one struck lantern with great force on north side at 4 A.M., killed; wind moderate S.E., foggy: [Wing of Woodcock received.]

Conmon Snipe (Gallinago ceelestis, Frenzel) and JaCK SNipe (G. gallinula, Linn.).

Old Hcad, Kinsale.-January 1st, one Snipe on hill at noon; wind light N.E.: 14th, one at noon; wind light N.W. October $19 \mathrm{th}$, one at noon; wind moderate N.E. November 26th, one at 11 A.M. ; wind light E.

Tuskar.-August 25th, Wheatears, Jack Snipe, and Titlarks all night; several killed; wind light W., misty.

Blachwater Bank Light-ship.-January 6th, great rush of birds; three Snipe found dead at 9 A.M. - [ [Leg and wing of Common Snipe received, killed striking]-(see under Lark).

Ar7low South Light-ship.-April 8th, "one Snipe, one Lark, and one Wagtail flying about and lighting on ship in the afternoon;" wind light N.E., hazy.

Rockabill.-February 6th, one Snipe going N. at noon ; strong breeze S.W., overcast.

Copcland (Mew) Island.-February 1st, several Snipe all day; wind moderate N.W. March 20th, several all day. "Snipe 
breed on isle. They frequent this island all the summer." November 25th, a good number of Snipe on isle.

Innishtrahull.-January 3rd, ten Snipe, "stopped on island;" fresh breeze S.W., rain. February 12th, seven, "stopped on island;" wind moderate S.E., hazy. November 10th, three on island at 2 P.Mr; first arrival; strong breeze S.W., hail showers. December 28th, two on island at 2 P.M. ; strong gale $W$.

Tory Island.-October 13th, "twelve Snipe in flock about island at 11 A.M. ;" wind moderate W., foggy.

Rathlin O'Birne.-January 5th, Snipe on island all day; fresh breeze S.E., snow. October 2nd, tbree Snipe going S. at 11 A.M. ; fresh breeze S.E., showers: 4th, six going S. at 9 A.M. ; fresh breeze S.E., clear: 26th, four came from the N.; remained on island all day; fresh breeze N.W., clear. November 22nd, five going S. at 1 P.M. ; fresh breeze S.W., clear. December 5th, six going $\mathrm{E}$. at noon; wind light E., gloomy; "these birds remain till evening": 7 th, five going S.E. at 2 P.M. ; wind light S.W., clear: 22nd, one Jack Snipe going N. at 9 A.M. ; hurricane W., clear; " remained part of day."

Killybegs.-January 21st, eleven Suipe going S. at different times during day; gale W., clear. March 25th, four going S. at noon; wind light E., misty: 26th, one killed, striking at midnight, young birds; wind light $\mathrm{E}_{\text {. }}$ misty.

Eagle Island, East.-October 14th, one Snipe resting on island.

Slyne Head, $N$--January $12 \mathrm{th}$, eleven Snipe all day.

\section{DUNLin (Tringa alpina, Linn.).}

Old Head, Kinsale.-September 13th, two Dunlin on rocks at 10 A.M. ; wind light E., overcast.

Arlolow South Light-ship.-January 5th, numerous small birds about light during night; a bird not kuown killed against lantern-[Leg and wing of Dunlin received]; rind vilriable, snow. August 23rd, several small birds flying about light during night; wind light N.E., rain; oue disabled striking. [Leg and wing of young Dunlin received.]

Rockabill.-November 25th, bird killed at lantern, supposed - to be rare. [Dunlin received in Hlesh.] 
St John's Point, Down.-April 8th, one "Sand Lark" at 11 P.M. about lantern; killed striking; wind moderate S., rain. [Leg and wing of Dunlin received.]

KNот (Tringa canutus, Linn.).

Sumplire Island.-December 11th, a large flock of Knots going S. at 3 P.M.; wind light N.W.

SANDERLing (Calidris arenaria, Linn.).

Blackwater Bank-August 30th, flock of Sand Larks at 10.30 P.M.; wind light E.N.E., clear and cloudy. [Leg and wing of Sanderling received; killed striking.]

"SAND LARKS."

Coningbeg Light-ship.-March 22nd, two "Sandpipers" at 10 A.M.

Barrels Rock Light-ship.-April 3rd, a number of "supposed Sea Larks " going N. at noon; wind light E.

Arklow North Light-ship.-October 1st, one Sand Lark all day on deck; seemed disabled; died.

Rockabill.-February 22nd, flock of Sand Larks on rock at 9 A.M.; wind light N.E.

Copeland (Mew) Island.- "Sand Larks frequent this island all the summer months."

Rathlin O'Birne.-January 24th, Sand Larks on island all day; gale S.W.

Eagle Island, East. -Sand Larks every day in winter.

\section{CURLEW (Numenius arquata, Linn.).}

Old Head, Kinsale.-March 4th, a flock at 10 A.M.; wind moderate N.W.: 6th, three going N.E. at 4 P.M.; wind moderate $\mathrm{N}$.

Hook Tower:-April 12th, Curlew round light from 2 A.M. to 5 A.M. ; wind light N., clear.

Coningbeg Light-ship.-January 6th, large flock going N.E. over ship. December 4th, one going S.W.

Tuskar.-July 27th, several going S.E. at 8 A.M. August 20th, several going S.E. at 9 A.M.; "lighted on rock; were never known to do so before;" wind moderate W., clear. 
Blackwater Bant Light-ship.-February 27th, Hock going N. at 10 P.M. ; passed over ship; wind moderate S.W. April 2nd, flock at 4 P.M. going S.W.; wind light S.W., clear: 14th, flock going N. at 4 P.M. ; strong breeze S.W., clear. October 8th, Curlew passed over ship going S.E. at 11 P.x.; wind light S.W., overcast.

Arklow South Light-ship.-March 19th, three going S.E. at 8 A.M. : 23rd, two going S.E.; wind light N.E.

Arklow North Light-ship.-January 10th, observed Curlew Hying and whistling round lantern between 10 P.M. and 11 P.M. ; wind moderate S.W., dark and clear. October 9th, "two Curlew, and Grey Plover, and small birds" round light at night; wind light E., clear; none struck.

Codling Bants Light-ship.-March 23rd, several going W. at 4 P.N. ; wind light S., hazy. May 4th, one noted: 9 th, several on ship during day; wind moderate S.W., clear.

Rockctbill.-February 6th, two going N. at noon; strong breeze S.W. August 16th, two on rock at 6 A.M.: 17th, two going N.; wind moderate N.W. October 11th, two at lantern; wind light E., misty.

Drogheda North.-May 31st, one going W.; calm, clear. June 27 th, three going $N$. at 8 P.M.; wind light E. July 22nd, three going W.; wind light S.W.

Copeland (Mow) Island.-March 10th, flocks all day, remaining; fresh breeze W.: 28th, flocks of Curlew and Seapies all day, remaining; wind light S.E. Curlew frequent this island all the summer months. November 25th, flocks daily round isle.

Maidens South.-March 26th, Curlew passing at 11 P.M.: 27 th, passing from 10 P.M. to midnight: 2Sth, passing all night at intervals: 29th, passing from 9 P.M. to 11 P.M., apparently going $N$. each of these nights. April 4th, six going $N$. at 8 A.M.; wind light N.E., foggy: 5th, four going N.: 9th, five going $\mathrm{N}$. at noon; wind moderate $\mathrm{S}$., rain: 11th, some going N.: 12th, some passing N. at night: 13th, four going N. at 6 ì.nr.; strong breeze E.: 19th, a few going N. at 6 A.M. and 4 1...r.; wind variable, clear: 20 th, three going N. at 5 r.M.; wind moderate S.E., misty.

Rathlin O'Birne.-January 17 th, flocks on island at 4 P.M. ; wind moderate S.W. February 23rd, some on island; gale N.W. 
Samplire Island.-October 13th, a large flock resting on rocks at 6 P.мr.; calm, elear. November 10th, numbers feeding on rocks of mainland: 18th, numbers of Curlew and Seapie feeding, at 2 P.M. : 27th, numbers of Curlew, Seapie, and Ring Dotterel about light from 8 P.M. to 11 P.M.; wind light S.E., fog.

\section{Whimbrel (Numenius phocopus, Linn.).}

Coningbeg Light-ship.-May 1st, five "Maybirds" and two Swallows "going N.E. for the land" at 10 A.M.; wind light N.E.

Blachwater Bank Light-ship.-April 28th, flock of Whimbrel passed over ship going $\mathrm{N}$. at 10 P.Mr; wind light S.W., overcast. May 4th, flocks passed over ship at 10 P.M.; wind moderate N., clear.

Drogheda North.-May 6th, four going N.E. at 1 P.M.; fresh breeze W., clear; first seen this season: 9th, two going W. at 6 P.M.; strong breeze W.: 11th, seven going W., flying very high: 22nd, three going E. July 9th, three going N.E. at 2 P.M. ; wind light S.E. : 13th, seven going W. at 6 P.M.

Killybegs.-May 4th, "thirty-seven Maybirds all day; will remain for three or four weeks; young birds very tame; fresh breeze N.W.-JoHn Kennedy."

Eayle Islend, East.-May 20th, Maybirds; first observed, and remain.

\section{Common Tern (Sterna fluviatilis, Naum.).}

Vidal Bank.-October 12th, "bird found injured near lighthouse, never saw one of the kind before." [Common Tern received in flesh.]

\section{"Terns."}

Old. Head, Kinsale.-September 3rd, one Tern about light all night; wind light $\mathrm{E}$.

Hool Tower:-May 14th and 15th, "flocks of 'Perrs' or 'Mews' all day near tower, flying high; these birds build on a small islaud at entrance to Fethard, six miles east of us." June 7th to 13th, Common Terns have been off point at station in thousands, also Puffins, Shearwaters, Razorbills, etc. 
Rockabill.-August 28th, "some Mews (Gulls) observed several days."

Drogheda North.-June 4th, great numbers of Terns going N.E.; "it took these from 11.45 P.M. to midnight to pass station, they were in one continuous flock, and making a great noiseJohn Dunleavy;". wind light E., fog and rain. July 15th, one "Sea Mew" going N.; wind light W., clear : 21st, numbers of "Sea Mew" about river all day; wind light W.

St John's Point, Down.-May 5th, two "Greater Tern" going E. at 3 P.M. ; wind moderate W., gloomy.

Copeland (Mew) Island.-May 11th, "Mews" arrived to-day at 3 A.M.; come here to breed; wind light W., clear. June 4th, "Mews" have commenced to lay eggs. September 9th, the last of the "Mews" have taken their departure, they have been gradually decreasing in numbers since the 1st of September, but some were delayed as their young were not able to fly on the earlier date. October 7 th, one Mew or Tern; wind light E., clear.

Innishtrahull.-May 26th, Tern at 8 A.M. ; gale N., rain; first arrival, annual visitors, build here. September 10th, Tern commenced to leave on this date, all left about the 20 th.

\section{"GulLs."}

Coningbeg Light-ship. - May 18th, young Sparrow Hawk chased by Gulls. August 26th, one Black-headed Gull lighted on ship at 4 P.M.; "bleeding from breast, apparently shot;" clear. September 11th, large numbers on water.

Barrels Rock Light-ship.-January 15th to 21st, Gulls constantly noted. February, Gulls in large numbers. March, Gulls noted several times. April, Gulls almost daily. May and June, constantly. November, Gulls several times. December, Gulls constantly. [The Gulls at this station are entered as "large and small," "drifting, feeding, and flying about ship."]

Blachwater Bank Light-ship.- "Gulls about ship daily during January and February, and March and April." "Gulls are constant visitors."

Arklow South Light-ship.-January 25th, small flocks of small Gulls going in various directions during day. February 20th, Gulls chasing a Lark at $10 \Lambda, M$. 
Arklow North Light-ship.-October 29th and 30th, Gulls chasing and eating small birds (see full note under Skylark). November 12th, one Seagull about ship at 6 P.M. ; killed striking, fell on.board; gale N.W., clear.

Codling Bank Light-ship._March and April, " a few Herring Gulls, Black Backs, and small Common Gulls about station during these months." May, "number of Puffins, Gulls, and Gannet passing and about ship this month." November, "Herring and small Gulls about station each month, also a few Black-back Gulls."

Rockabill.-February 1st, four Royal Gulls on rock. June 15th, great number of "H. Gulls" on the water. August 26th, Royal Gulls, Herring Gulls, etc., seen all round the place on the sea and on the rocks. November 2nd, flocks of Herring Gulls going E. from 10 A.M. to 4 P.Mr. wind moderate S.W., clear.

Drogheda North.-August 6th, numbers of Kittiwake and other Gulls : 9th, great numbers of Gulls and Seapies on strand.

Rathlin O'Birne.-November 1st, one Iceland Gull going N.E. ; young bird, wind fresh S.E., gloomy: 3rd, one Iceland Gull, young bird, going N.; fresh breeze S.E., gloomy: 30th, one Iceland Gull, young bird, going N.; wind moderate N.W., clear. December 2nd, one Iceland Gull, young bird, going E-JoHn KENNEDY.

Killybegs.-February 20th, one Iceland Gull all day, old bird; wind light E., misty. May 10th, one Iceland Gull all day; apparently wounded; strong breeze W. "Never saw one so late in the year before.-JoHn KENNEDY."

Eagle Island, East.-Gulls daily in winter.

Clare Island.-March 20th, large number of Sea Gulls, "resorting to cliffs here, apparently pairing."

Samphire Island.-October 7th, thousands of Herring, Kittiwake, and Common Gulls, Razorbills, Puffins, and Mackerel Cock feeding on fry in the bay all day; calm, clear: 11th, great numbers of Gulls and Gannet fishing in bay: 13th, immense numbers of Gulls, Cormorants, Puffins, Razorbills, and Guillemots feeding on fry all day; calm, clear; the bay was actually swarming with them, the noise they made was deafening. November 9th, two Greater Plack-backed Gulls: 1tth, one Iceland Gull going N.W.; gale W., snow showers: 23rd, tẃo Great Black-backed Gulls. 
Bull Rock:-March 7th, Kittiwakes on rock. "Kittiwakes build on this rock" (see note under Razorbill). "Herring and Royal Gulls build on adjacent rocks, they are residents."

\section{"SKUAS."}

Samphire Island.-October 26th, one large Skua Gull going N.W. at 3 P.M. ; wind light E., rain. "The largest one I ever saw, and very dark in colour, it gave chase to a Grey Gull for a short distance."

Manx Shearwater (Puffinus anglonum, Temminck).

Hook Tower.-April 24th, Manx Shearwater at 4 P.M. driven on to land by violence of S.W. gale: 30 th, twenty to forty on sea near station; fresh breeze N.E. June 7 th to 13 th, Shearwaters off point at station.

Coningbeg Light-ship. - September 1st, Manx Shearwater going W. at 11 P.M.; wind N.E.; one disabled, striking; fell on deck: 15th, six going N.F., flying low; wind light N.E.

Barrels Rock Light-ship.-February 11th, some "Mackerel Cocks ;" gale S.W.: 25th, about a hundred "Mackerel Cocks," flying low; strong breeze S.W. : 26th, several large flocks going W. during forenoon: 27th, a few large flocks. April 14th, 21st, and 25th, a few noted during day. May 31st, some. June 1 st to 10 th, numbers noted during day: $17 \mathrm{th}, 18 \mathrm{th}$, and $23 \mathrm{rd}$, some.

Blackwater Bank Light-ship.—"Gulls daily about ship in large numbers during April, also Shearwaters."

Arklow South Light-ship.-March 12th, odd Manx Shearwaters going in various directions during day; wind moderate S.W.; first seen : 13th and 16th, odd ones during day. April 10th, several: 25th, several "Mackerel Cock" flying about; gale S.W., sleet. May 14th, several Manx Shearwaters apparently after small fish: 17th, 18 th, 19th, and 21st, some noted during day. June 19th, several "Mackerel Cock" flying about ship during day.

Droghecla North.-June 17th, large numbers fishing.

St John's Point, Doun.-April Sth and 9th, numbers of Manx Shearwaters going N.E. during day; wind fresh to strong S. 
Samphire Island.-October 7th, great numbers "Mackerel Cock" feeding in the bay.

\section{Stork Petrel (Procellaria pelagica, Linn.).}

Blackwater Bank Light-ship.-August 14th and 15th, two Stormy Petrels about ship from 3 P.M. on 14th to 6 P.M. on 15th; wind moderate N.W., showery.

Arklow North Light-ship.-September 28th, one Stormy Petrel on ship's deck at 2 A.M.; wind moderate E., light haze; caught, and let go next day.

RAzorbill (Alca torda, Linn.), and

GuIllemot (Uria troile, Linn.).

Hook Tower.-June 7th to 13th, Razorbills off point at station.

Barrels Rock Light-ship.-January 17th, "Murs" noted : 31st, four "Murs." February, "Murs" noted several times. March 3rd, a large number of "Murs" during day, flying low : 8th, ten noted. April, "Murs" noted several times. May, Murs constantly noted. June, large numbers almost daily. November 20th and 21st, several flocks of Murs going S.E., flying low: 27th, a few Murs going N.E. during day. December 1st, three flocks; numbers noted between 12th and 22nd: 31st, a few.

Rockabill.-October 12th, flock of Guillemots going $\mathrm{S}$. in the morning; wind light S.E., clear: 24th, Guillemots going S. at 9 A.M.; gale S.

Drogheda North.-June 17th, large numbers (see full note under Gannet).

Rathlin O'Birne.-October 14th, a large number of Guillemots going N.E. all day ; wind light S.E., gloomy : 30th, two "Black Guillemots, male and female," going S., fishing round island all forenoon; wind moderate W., clear.

Eagle Islend, East.-March 28th, Razorbills first seen on the water.

Samplirre Island.-October 7th and 13th, immense numbers (see under Gull).

Skelligs.- "Guillemots cannot be got here sooner than the end of March or 15th of April. I never saw them on the 
rocks during the winter months at any of these west outlying stations.-William Maginn."

Bull Rock.-February 22nd, "twenty Puffins (Razorbills)" going $N$. at 1 P.M.; wind light S., clear: 28th, "twenty Puffins (Razorbills)" fishing close to rock at 3 P.M. March 5th, "Puffins (Razorbills and Guillemots)" on rock at 7 A.M.: 6th, "Sea Parrots, Guillemots," on rock at 7 A.M.: 7 th, forty Razorbills on rock at 7 A.M.: 13th, "a hundred Puffins (Parrots and Guillemots)" on rock at 7 A.M.; wind moderate W., gloomy. "Razorbills, Guillemots, Sea Parrots, and Kittiwakes build on this rock. They number several hundred of each species. They arrive about February 20th, and leave on or about the 1st of August." [Species ill defined here.-R. M. B.]

\section{PuFfiN (Fratercula arctica, Linn.).}

Hook Tower.-June 7 th to 13th, Puffins off point at station.

Barrels Rock Light-ship.-April 4th, three "Parrots" noted during day; the first seen this year: $10 \mathrm{th}$, eight, and 11th, fifty drifting during day; Parrots noted constantly during month. May 9th, 10th, 11th, 28th, 29th, and 30th, Parrots noted. June, Parrots almost daily.

Blackwater Bank Light-ship.-Puffins about ship daily during March. "Puffins are constant visitors." June 7th, first observed the Puffins with young.

Codling Bank Light-ship.-May, "number of Puffins, Gulls, and Gannet passing and about ship this month."

Rockabill.-February 20th, flocks of "Sea Parrots" going N. at 10 A.M. ; wind light S.W. [Puffins?-R. M. B.] October 24th, Puffins going S. at 9 A.M.; gale S.

Drogheda North.-June 17th, large numbers.

Rathlin O'Birne.-March 25th, Puffins going N. at noon; fresh breeze S.E., blue sky, misty.

Eagle Island, East.-April 2nd, Puffins first observed. October 6th, last Puffin observed.

Clare Island.-April 13th, large numbers of Puffins "resorted to cliffs this morning." August 1st, "the Puffins that came here in April have now left the cliffs."

Samphire Island.-October 7th and 13th, numbers fishing. 
Bull Rock.-[Sea Parrots, Razorbills, and Guillemots appear to be all classed as "Puffins" at this station; they are all said to build on rock. See full notes under Razorbill and Guillemot.-R..M. B.]

\section{Great Northern Diver (Colymbus glacialis, Linn.).}

Arklow North Light-ship.--October 16th, several flocks going S.W. all day; wind moderate N.E., clear : 26 th and 27 th, flocks going S.W. all day.

Rockabill.-June, Divers during latter part of month.

Drogheda North.-January 11th, two fishing on river; strong breeze S.W.

Rathlin O'Birne.-November 14th, one going S.; gale S.W., hail showers.

Samplire Island.-November 14th, one fishing close to island at 3 P.M.; gale W., snow showers: 21st, one fishing close to island at 2 P.M.; strong gale S.W. clear. December 16th, one going N.W. at 2 P.M.; fresh breeze W.

\section{Cormorant (Phalacrocorax carbo, Linn.), and} ShaG ( $P$. graculus, Linn.).

Barrels Rock Light-ship.-January 16th, three "Black Shag" noted; fresh breeze S.W.: 23rd, one: 25th, two: 28th, one. February 10th, two. December 14th, one Cormorant at ship.

Codling Bank Light-ship.-May 14th, one Cormorant: 21st, one: $22 \mathrm{nd}$, two. November $12 \mathrm{th}$, one: $16 \mathrm{th}$, two.

Rockabill.-June 15th, five Cormorants on the water.

Rathlin O'Birne--January 12th, twelve Cormorants going E. at noon; fresh breeze S.W. February 10th, some going E; strong gale W. November 12th, one White-breasted Cormorant going $\mathrm{S}$.

Eagle Island, East.-Cormorants every day in winter.

Clare Island.-March 20th, twelve Cormorants "resorting to cliffs here, apparently pairing."

Samplire Island.-October 13th, great numbers: 17th, a flock of thirty Cormorants going N.W.; calm, clear. November 10th, numbers fishing about bay all day; fresh breeze to gale N.W.; "more or less seen every day, but in unusual 
numbers to-day." December 20th, two large Green-crested Cormorants.

Bull Rock.-January 11th, six Cormorants fishing round rock all day. February 15th, three.

\section{Gannet (Sula bassana, Linn.).}

Hook Tower.-April 7th, Gannets numerous all day; first this year; wind moderate E., haze: 30th, four.

Coningbeg Light-ship.-May 13th, several flocks going S.W.: 14th, several flocks going S.W.: 16th, several going E. September 17th, large flocks and "large shoals of mackerel": 24th, large number. December 5th, several going N.E.

Barrels Rock Light-ship.-January 15th, 17th, 21st, 22nd, and 28th, a few. February, a few constantly noted. March 2nd, 10th, and 12th, a few. April, a few almost daily going chiefly W. May 3rd, some: 6th and 7th, several flocks, apparently feeding on fry: 8th, a few: 10th and 12th, a number: 25th to 30 th, a few almost daily. June, a few almost daily; noted as being of a "grey colour," from 13 th to 25 th. November 17 th twenty: 18th, 19th, and 21st, some. December, constantly noted; a large flock going W. on 25th. They are generally entered as about ship, or going W.

Blackwater Bank Light-ship.- " Gannet passing and repassing daily during April."

Arklow South Light-ship.-February 20th, six. March 16th, small flocks going S.W. during day: 18th, flock going S.W.: 22nd, small flocks going S.W. during forenoon; calm. April 8th, one going S.W. at 10 A.M.: 12 th, two flocks going S.W.: 18th, one going N.E. May 14th, several, apparently after small fish: 16th, small flocks going S.W. during day; wind light E. October 4th and 6th, one going S.W.: 13th, six going $\mathrm{S}$.

Arklow North light-ship.-September 25th, several Hocks going S.W. during day; wind light E., clear. October 26th and 27th, flocks going S.W. all day.

Codling Bank Light-ship.-March and April, several flocks about station during these months. May, "number of Puffins, Gulls, and Gannet about ship, and passing this month."

Rockabill.-May 16th, six going N. at nooll; fresh breeze E., 
fog, rain. June, "Gannets, Gulls, and Divers during latter part of month." October 10th, flock going N.E. at noon; wind light N.E., misty : 23rd, flock going N.E. at noon; wind light S.E.

Drogheda North.-June 10th, about fifty fishing: 17th, large numbers of Gannet, Puffins, Guillemots, Razorbills, and Shearwaters fishing. "These birds have not been observed in such numbers about here for years."

St John's Point, Down.-April 1st to 8th, numbers seen passing N.E. during day; wind easterly, misty.

Copeland (Mew) Island.-February 15th, several all day, remaining. May 20th, about twenty. June 17th, several diving for fish.

Rathlin O'Birne.-March 21st, numbers all day. October 12th, a large number going N.; old and young; fishing. November 6th, thirteen going S.

Eagle Island, East.-Gannet every day in winter.

Samphire Island.-October 11th, great numbers fishing.

Bull Rock.-January 1st, three fishing round rock: 8 th, 11th, 15 th, 18th, 28th, February 2nd, 5th, and 10th, from three to twelve noted: $22 \mathrm{nd}$, eight going N.W.: 25th, thirty fishing round rock all day. March 6th, some: 12th, large numbers on rock. "Gannet build on this rock, and remain nearly the whole year round."

\section{Heron (Ardea cinerea, Linn.).}

Coningbeg Light-ship.-November 11th, one going N., flying low ; wind moderate N.W.

Drogheda North.-May 22nd, five fishing on river bank: 30th, two. June 18th, two large Herons. August 5th, three going N.W.

Copeland (Mcw) Island. - February 1st, several all day. March 10 th and 12th, several all day, "remaining."

Eagle Island, East.-May 24th, one "Crane" went S.E. June 4th, one "Crane" going S.E.

\section{"GeEse."}

Old Head, Kinsale.-January 30th, one Wild Goose going E. Arklow North Light-ship.-September 21st, four Barnacle going N.E., flying very high. 
Copeland (Mew) Island.-May 13th, four Wild Geese on isle; "have never seen Geese here before at this season;" wind light W., clear. December 22nd, large flock of Barnacle going N.W.; storm from N.E., clear.

Maidens South.-January 8th, eight Barnacle going W.; strong breeze S.E., gloomy.

Innishtrahull.-May 28th, three Wild Geese going S.W.; gale N., rain. June 28th, two Wild Geese going S.W.; wind light S.W., misty. August 4th, two Wild Geese; wind light S.W., rain. October 7th, three going S.W.: 18th, ten going S.; fresh breeze N.E., rain. November 5th, eight going S.W.; gale S.W., rain.

Tory Island.-October 19th, flock of Greylags going S.; fresh breeze E., clear.

Rathlin O'Birne.-March 4th, four Barnacle on island; gale N., hail. October 20th, two Barnacle going N.E. November 17th, nine White-fronted Geese going S., flying very high: 18th, four White-fronted Geese going E. December $27 \mathrm{th}$, two Wild Geese going. $\mathrm{N}$.

Killybegs.-January 29th, thirteen Wild Geese going W., flying very high; hail. March 12th, nine very large Grey Geese going N.; gale W., hail showers. April 14th, ten Barnacle going W.; gale S.E., rain.

Eagle Island, East.-October 16th, forty Barnacle going N.E.: 19th, two Barnacle going N.E.

Clare Island.-October 16th, about a hundred Wild Geese passed here to-day, flying N.; wind N.E., clear: 20th, about thirty in two flocks passed at noon, flying S.; gale N.E., overcast, rain.

Samphire Island.-October 16th, about fifty Barnacle going W.: 25th, nineteen going S.; strong gale N.W., showers: 26th, about forty "Barnacle Geese" going N.: 27th, nine "Barnacle Geese" going S.: 28th, some hundreds groing S.; fresh breeze W. "These birds seem to be very numerous about here, in fact are to be seen in more or less numbers nearly every day from 16th October to 16th November." November 18th, some hundreds feeding on water close to island. December 11th, great numbers feeding in bay all day; wind light N.W., clear. 


\section{"Swans."}

Drogheda North.-July 22nd, six Swans going S.W. at 6 P.M.; wind light S.W., clear; "flying very low and scattered."

Rathlin O'Birne.-December 11th, two White Swans going S. at 1 P.M. ; "I think old birds ;" wind light S., clear : 12th, five White Swans going N. about noon; "I think old birds;" strong breeze S., rain.

\section{Scaup (Fuligula marila, Linn.).}

Drogheda North.-February 8th, three "Rock Wigeon " feeding on river at 2 P.M.; gale N.W., clear: 28 th, four "Rock Wigeon" feeding on river at 2 P.M. ; gale S.W., cloudy; shot one, a male bird, and sent wing. [Wing of Scaup received.] March 31st, one " Rock Wigeon" going S. " These birds are to be seen here occasionally.

\section{"DUCKs."}

Old Head, Kinsale.-September 9th, six Ducks going E.; calm : 22nd, four going $\mathrm{E}_{\text {.; }}$ gale $\mathrm{E}$., overcast.

Coningbeg Light-ship.-January 4th, flock of Wild Duck going W., flying low; fresh breeze S.E., snow showers.

Barrels Rock Light-ship.-December 26th, two flocks of Wild Duck going W.; wind moderate N., gloomy.

Blackwater Bank Light-ship.-April 15th, flock of Black Duck going N.E. ; fresh breeze S.E., clear.

Arklow South Light-ship.-January 19th, a very large flock of Wild Duck going S.E. at noon; fresh breeze S.W., overcast: 25th, one Wild Duck going S.W.

Drogheda North.-January 20th, one Sheldrake going N.; and five large Duck going S.; gale W. February 20th, one male and two female Sheldrake going N.; wind light S.W.

Copeland (Mew) Island.-February 28th, a Sheldrake caught at noon, "drake was wounded;" wind moderate S.W., clear; flock Wild Duck all day. March 10th, a Wigeon found dead at 4 P.M. ; fresh breeze W. "A few Wild Duck breed on isle." May 13th, a few Wild Ducks all day, remaining. June 3rd and 11th, two large Wild Ducks; "I think building here." 
November 25th, flocks Wild Duck, Seapies, and Curlew daily round isle.

Tory Island.-October 16th, thirteen Wild Duck going S.: 25th, three Teal on lake; gale S.E.

Rathlin O'Bime.-November 16th, two Teal, male and female, going S.; wind S.E., clear.

Killybegs.-February 8th, two White Duck going S.; rather large, never seen here before; strong breeze W., clear, showers.

Samphire Island.-October 18th, one Duck going W.; calm, showers: 27th and 28th, two or three Mallards and Ducks going N. November 5th, about thirty Mallard and Duck going S.; strong gale S.W., rain.

\section{BiRds NOT IDENTIFIED.}

Hook Tower.-February 25th, "a bird, size and colour of hen Blackbird, but having a white breast distinctly marked, was seen on one or two occasions in vicinity of station.-J. HiGG1sвотнам." [Possibly Ring Ouzel.-R. M. B.]

Codling Bank Light-ship.-April 18th, "one strange bird heard, not seen, from 2 A.M. to 3 A.M., going W.; fresh breeze N.E., clear. This bird made a strange noise similar to a person laughing, giving a haw, haw, haw every minute."

Drogheda North.-August 8th, "a strange bird the size of a Redbreast, and much the same colour on back and wings, but all the under part of a deep red colour, seen close to station at 4 P.M." [Possibly Common Redstart.-R. M. B.]

South Rock Light-ship.-April 22nd, "one Cuckoo's nurse" going N.W. at 11 A.M. [Titlark?-R. M. B.]

Clare Island.-May 22nd, "a bird resembling a Duck, with white wings, neck shorter, flew round station and then away to the S."

\section{"General Observations."}

Old Head, Kinsale.- "Though a fixed light, very few birds strike the lantern at night, and in the case of an odd one doing so it is generally during the prevalence of E. and S.E. winds, when they fall to leeward and drop into the sea. All through the summer months there was no marked movement noticed, only a few Wheatears, Swallows, and an odd Whinchat about 
the hill." November, "owing to mildness of season birds very scarce, only an odd flock of Starlings to be noted."

Drogheda North.-June 12th, "several Bats flying about station at 9 P.M.; wind moderate N., gloomy ; first seen for a long time."

St John's Point, Down.- "This light being red, revolving, and dark landward, very few birds are found to strike. For the five years I have been here, I have not noticed anything in the movements of birds worth recording." 

1895

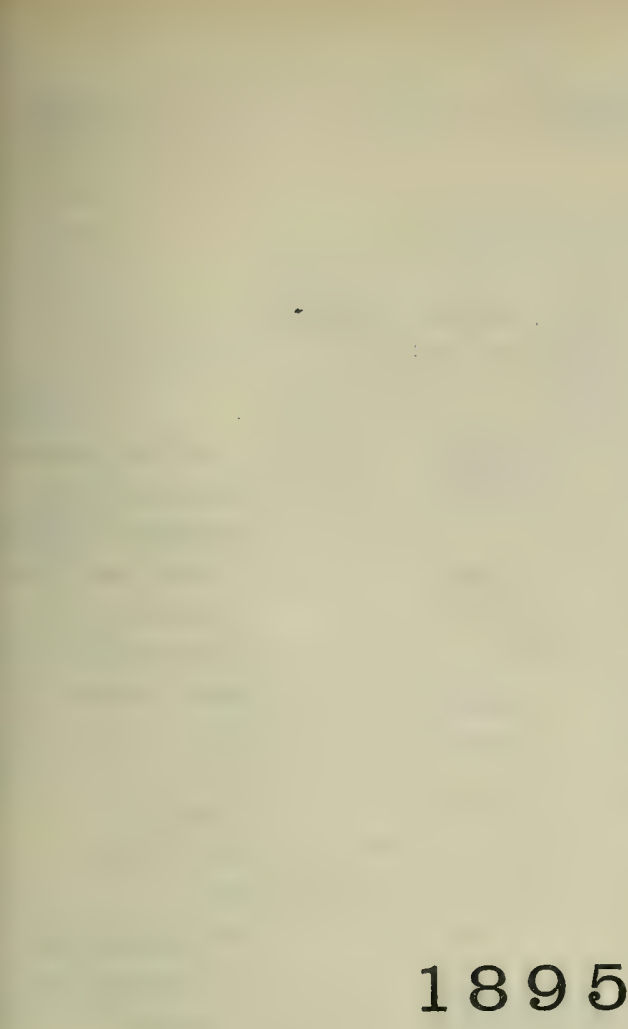

$$
5
$$

$x^{2}$

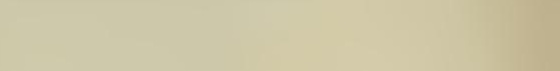

(1)

Cons

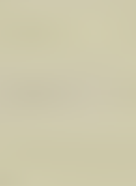

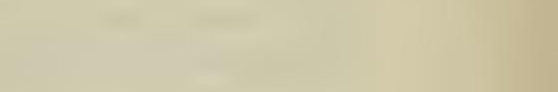
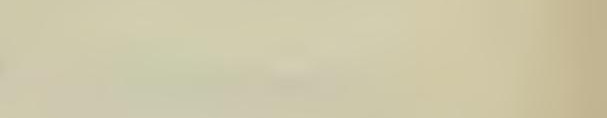

.

Then

(1) 
List OF Light Stations.

5. *Coningbeg Lt.-ship, Wexford, 43 excellent. $\quad x \quad x \quad 10\left\{\begin{array}{c}\text { A. B. Wall, J. Godkin, } \\ \text { and James Grant. }\end{array}\right.$

6. Barrels Rock Lt.-ship, do., ... 4 4 0 excellent. $\quad$ x $\quad$ × $4\left\{\begin{array}{l}\text { James Beahan, Thomas } \\ \text { Luccan, and Henry } \\ \text { Thompson. }\end{array}\right.$

7. Tuskar Rock, do., $\quad \ldots 111$ good. $\quad$ x $\quad$ x $7 \quad 7 \quad$ H. Kennedy.

7b. Blackwater Bank Lt.-ship, do., 411 excellent. $\quad x \quad x \quad 6\left\{\begin{array}{r}\text { Patrick Cullen and } \\ \text { Daniel Dunn. }\end{array}\right.$

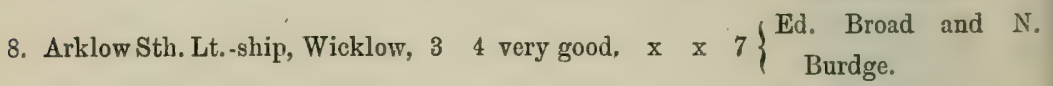

8. Arklow North Lt.-ship, do., 2 good. $\quad \mathrm{x} \quad \mathrm{x} 8\left\{\begin{array}{l}\text { John Pinston, J. } \\ \text { B e a h a n, a n d } \\ \text { Thomas Stapleton. }\end{array}\right.$

8a.Codling Bank Lt.-ship, do., 33 very good. $\times \quad \times \quad 7\left\{\begin{array}{l}\text { W. Clydesdale, Henry } \\ \text { Thompson, and J. } \\ \text { Godkin. }\end{array}\right.$

12b. South Rock Lt.-ship, Down, ... 10 fair. $\quad x \quad x \quad 3$ John Kearon.

13. Copeland (Mew) Island, do., ... 2 2 0 good. $\quad x \quad x \quad 3 \quad$ R. Armstrong.

16. Innishtrahull, Donegal, ........ 311 very good. $x \quad$ x 6 Geo. Gillespie.

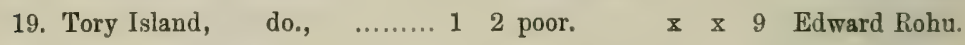

29. Clare Island, Mayo,............ 1 0 poor. $\quad$ x $\quad$ o 4 Kenneth Kerr.

36. Samphire Island, Kerry,....... 813 excellent. $\quad \mathbf{x} \quad \mathbf{x} \quad \frac{1}{2}$ George Dunleavy.

Fastnet sent a Spotted Crake; Old Head, Kinsale, a Fork-tailed Petrel ; Ifine Head, a Barn-Owl; Hook Tower, a Merlin and a Sparrow; Rockabill, the Leg and Wing of a Swift; St John's Point, Down, a Skylark and a Sheldrake; Rathlin Island, a Ring-Ouzel; Aranmore, a Cuckoo; Rathlin O'Birne, two Hedge Sparrows; Blacksod Point, a. Water-Rail, Glaucous Gull, and Gannet; Blacksod Bay, two Sclavonian Grebes; Slyne Head, S., the Leg and Wing of a Turnstone; Skelligs, a Swallow and four Guillemots.

Legs, Wings, etc., received, 81.

$0=$ No reply.

$\mathrm{x}=$ Schedules returned partly or wholly filled.

Spring, replies received from 13 stations. Autumn, replies received from 12 stations. 


\section{LeGS, Wings, etc., Received.}

Species. How Received. How Procured. Date. Name of Station.

Morlin,

Barn-Owl,

Spotted Flyeatcher,

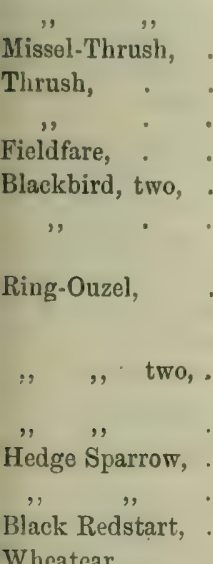

Wheatear,

"two,

Sedge Warbler,

(

Grasshopper

Warbler,

Whitethroat,

Blackcap;

Willow Wren,

,

,

,

Chiffchaff,

Long-tailed Tit, .

Yellow Wagtail, .

Meadow Pipit,

Skylark,

Rec'd. in flesh, Caught on cliff, 24/10 mo., Hook Tower.

Caughton a crag, 14/11 mo., Mine Head.

Got on rock, 19/4 mo,, Tuskar.

Wing, . Killed st., ${ }^{1}$. $30 / 7 \mathrm{mo}$, , ,

Leg and wing, Found dead, $12 / 2$ mo., Samphire Island. , $\quad 9 / 2 \mathrm{mo}$.,

Killed st., . 15/10 mo., Blackwater Banli Lt.-sh.

Found dead, $21 / 3 \mathrm{mo} .$, Samplire Island.

Legs and wings, s,

12/ 2 mo., ,, ,,

Leg and wing, Killed st., . $16 / 10$ mo,, Blackwater Bonle Lt.-sh.

$\left\{\begin{array}{c}\text { Skin (with } \\ \text { letter dated } \\ \text { Jan. 1896), }\end{array}\right\}\left\{\begin{array}{c}\text { Caught at } \\ \text { lantern, }\end{array}\right\}\left\{\begin{array}{c}\text { "about } \\ 12 \text { mo. } \\ \text { ago," }\end{array}\right\}$ Rathlin Island.

Rec'd. in flesh, $\left\{\begin{array}{c}\text { Caught on } \\ \text { lantern, }\end{array}\right\}\left\{\begin{array}{c}\text { Rec'd., } \\ 25 / 4 \text { mo., }\end{array}\right\}$ Innishtrahull.

Leg and wing, Caught, Sent 13/ 5 mo.,

Rec'd. in flesh, Shot, . . 18/10 mo., Rathlin O'Birne.

$\rightarrow$

,

Leg and wing,

",

Legsand wings,

,

,

,

Rec'd. in flesh,

,

,

,

Leg and wing, ,

Rec'd. in flesh,

Leg and wing,

,

Legs and wings,

Rec'd. in flesh,

,

,

Leg and wing,

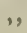

,

,
". . 21/10 mo., , , ",

Died on rock, 23/10 mo., Tuskar.

Found dead, $27 / 3$ mo., Blackwater Bank Lt. $s h$. 23/ 8 mo., Arklow S. Lt.-ship. ? $\quad$ ? / 3 mo., Innishtrahull.

Killed st., $\quad 30 / 7$ mo., Tuskar.

, . 29/ 7 mo., Blaclewater Bante Lt. sh.

Found dead, 12/ 5 mo., Arklow S. Lt. ship.

Killed st, : $20 / 4$ mo., Tuskar.

". $\quad$ 19/ 9 mo., Coningbeg Lt. ship.

, . 20/4 mo., Tuskar.

? $.16 / 5 \mathrm{mo}$,

Killed st., . 25/ 4 mo., Blackwater Bank Lt. sh.

," 15/10 mo., ,, ,"

,, . 20/ 4 mo., Tuskar.

," $30 / 7$ mo., ,:

". $\quad 29 / 7$ mo., Blackwater BankLt.-sh.

Died on board, 1/ 5 mo., Codiling Bank Lt. ship.

? Rec'd. 26/ 4 mo., Trustoar.

Shot, . 24/10 mo., Innishtrchull.

Killed st., . 19/9 mo., Tuskar.

? ? / $1 \mathrm{mo}$, Innishtrahull.

Killed st., . $21 / 2$ mo,, Blackwater Bank Lt. sh.

, . 15/10 mo.,

Dead on deck, 19/10 mo.s Arklow S. Lt. ship.

1 Killed st. = Killed striking lantern. 


\section{Legs, Wings, ETC., Received-continued.}

Species.

Skylark,

,'

Snow Bunting,

Corn Bunting,

Brambling, .

Sparrow,

Greenfiach, .

Starling,

Swallow,

,

,

1,

Swift,

Cuckoo,

Spotted Crake,

Water-Rail,

\section{How Received.}

Rec'd. in flesh,

Wing,

Leg and wing,

,

,

Rec'd. in flesh,

$$
\text { ," }
$$

Leg and wing,

Rec'd. in flesh,

Leg and wing,

,

Rec'd. in flesh,

Leg and wing,

Rec'd. in flesh,

\section{,}

Leg and wing,

Rec'd, in flesh, \{

Golden Plover, . Leg and wing,

Green Plover,
Turnstone, .
Dunlin, .
Common Gull, .
Glaucous Gull, .
Fork-tailed Petrel,
Storm Petrel,
Guillemot, four, .
Little Auk, .

Rec'd. in flesh,
How Procured. Date.

Name of Station.

Killed st., . 10/ 2 mo., St John's Point, Down.

$$
\begin{aligned}
& ? \quad \text { ? / } 2 \mathrm{mo}, \text { Innishtrahull. } \\
& ? \quad \text { ?/ } 1 \mathrm{mo}, \text {, }
\end{aligned}
$$

Killed st., ' $25 / 4$ mo., Tory Island.

$$
\text { ? ?/ } 4 \text { mo., Innishtrahull. }
$$

? About 22/12 mo., Hook Tower.

Caught, . 20/12 mo., Coningbeg Lt.-ship. , . 7/2 mo., Samphire Island.

Dead on deck, 17/4 mo., Coningbeg Lt. -ship.

Caught on deck, $17 / 4$ mo., Blackwater Bank Lt.-sh.

Died on board, 1/ 5 mo., Codling Bank Lt. ship.

$$
\text { ? } \quad 10 / 4 \text { mo., Skelligs. }
$$

Killedatlantern,30/ 7 mo., Rockabill.

$$
\begin{array}{cc}
\text { Shot, . } & 8 / 8 \mathrm{mo.} \text {, Aranmore. } \\
\text { ? } & 20 / 8 \mathrm{mo}, \text { fiastnet. }
\end{array}
$$

Found on deck, 24/ 9 mo., Arklow S. Lt. ship.

Killed st.

$\left.\begin{array}{l}\text { telephone } \\ \text { wire, }\end{array}\right\} 9 / 1$ mo., Blacksod Point.

Shot, . $7 / 2 \mathrm{mo}$, Samphire Island.

Killed st., - 25/ 4 mo, Blackwater Bank Lt. sh.

Shot, . 4/ 2 mo., Samphire Island.

Killed st., . 18/ 8 mo., Slyne Head, $S$.

Shot, . 11/ 3 mo., Samphire Istand.

Found dead, 12/ 2 mo.,

Probably shot, 23/ 2 mo., Blacksod Point.

Struck light, $20 / 11$ mo., Old Head, Kinsalc.

Wing, . . ? ? / 1 mo., Innishtrahull.

Rec'd. in flesh, ? . 10/4 mo., Skelligs.

Head and wing, Found on island, ?/ 5 mo., Tory Island.

SclavonianGrebes, two, In flesh, . Shot, . . 14/ 4 mo., Blrcksod Point.

Gannet, . . Rec'd. in flesh, Probably shot, 11/ 5 mo., ," ",

Brent Goose, . " . Shot, . . 19/11 mo., Samphirc Island.

Sheldrake, . . " ? 28/ 6 mo., St John's Point, Down.

Teal, . . Leg and wing, Found dead, $12 / 2$ mo., Samphirc Istand.

Scaup, . Rec'd. in flesh, ,, . 12/ 2 mo., ", ", 


\section{NDEX.}

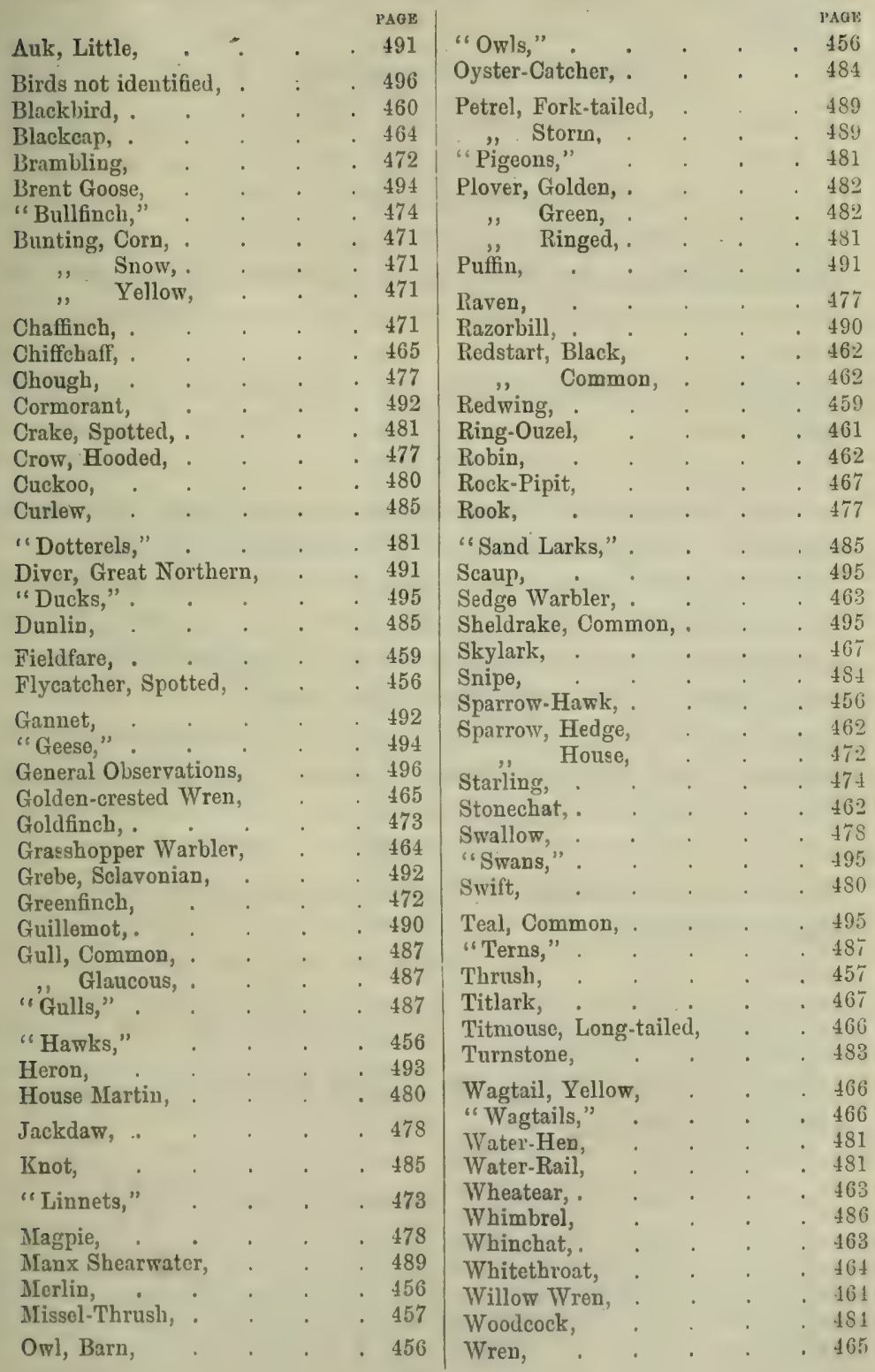


MerLin (Falco cesalon, Tunstall).

Hook Tower:-October 24th, a Hawk sent. [Merlin received in flesh.]

SPARROW-Hawk (Accipiter nisus, Linn.).

Coningber Light-ship.-September 29th, one rested on mainmast at 1 P.I. ; Hew S.E.; wind light E. : 30 th, one on ship at 11.30 A.I.; flew N.E.; wind light E.

Arklow North Light-ship.-February 25th, one going W. at 2.30 P.M. ; fresh breeze N.E., clear. November 21st, one, and some Larks, going W. during forenoon; wind moderate S.E., clear.

Innishtrahull.-August 17 th, one on island at 1 P.Mr. ; wind light $\mathrm{N}$.

\section{"HAwKs."}

Coningbeg Light-ship.-September 6th, one Hawk about light at 10 P.M. ; flew N.W. at 10.15 P.M. ; wind light S.E., clear.

Codling Bank Light-ship.-November 4th, one Hawk and one Chaffinch on ship; wind variable.

Samphive Island.-September 16 th, one Osprey or Fish-Hawk going E. at 9.15 A.M. ; wind light S.E., gloomy.

Skelligs.-April 10th, I think both species are here-namely, Peregrine and Kestrel. There are nearly always two pairs here.

BARN-OWL (Strix flammea, Linn.).

Mine Head.-November 14th, Barn-Owl caught in a crag. [Received in flesh.]

"Owhs."

Corling Banti Light-ship.-December 2nd, one Cat-Owl in ship at night.

Copcland (Mcw) Island.-November 4th, an Owl on island; wind light S.E., snow.

Spotted Flycatcher (Muscicapa grisole, Linn.).

- Tuskicer-April 19th, unknown bird got on rock-[Spotted Flycatcher received in flesh]. July 29th and 30th, great rush of Willow Warblers, "Grasshopper Warblers," and young Starlings all night; wind N.W.; some killed. [Wing of Spotted Flycatcher received.] 
MisseL-ThRUsh (Turdus viscivorus, Linn.).

Innishtrahull.-August 3rd, eight "Fieldfares" on island at 2 P.M. ; wind light,E. [Probably Missel-Thrushes.-R. M. B.]

Samphire Island.-February 12th, Thrush found dead. [Leg and wing of Missel-Thrush received.]

\section{Thrush (Turdus musicus, Linn.).}

Coningber Light-ship.-January 29th, several large flocks going N.W. about noon; wind light N.E. February 1st, several about light from 8 P.M. to midnight; one killed striking; wind fresh N.E., snow.

Barrels Rock Light-ship.-January 28th, flocks of Blackbirds, Thrushes, and Larks: 29th, several flocks, with Skylarks, flying towards land during day: 30th, a few, with Larks, flying towards land during day; two eaten by Gulls; fresh breeze S.E., clear: 31st, a few Thrushes, Larks, and Blackbirds flying to land. October 30th, large flock going $\mathrm{N}$. at 9.30 A.MI. ; wind moderate N.W. December 9th, a flock going N. ; fresh breeze W.: 13th, two rested on board and flew $\mathrm{N}$.

Blackwater Bank Light-ship_January 29th, Thrushes and Blackbirds about light from 1 A.Mr. to 3.30 A.M. ; wind moderate S.W., rain : 30th and 31st, flock of Thrushes going N.W.; wind fresh E. February 21st and 22nd, flocks of Thrushes and Larks about light; wind light N.: 28th, flock about light; wind W. March 26th, several Thrushes and Larks about light from 10 P.M. to midnight; one Thrush killed; wind light S.W., clear. September 24th, one rested at 8 A.M. October 13th, five about light from 10 P.Mr. to midnight; wind moderate S.W. : 14th and 15th, great rush of Larks, Thrushes, Starlings, and Warblers about light; many killed striking (see full note under Skylark) -[Leg and wing of Thrush received]: 20th, several Thrushes and Larks about light from 9 P.x. to midnight; wind light S.E., gloomy; two Thrushes killed. November 6th, flock of Thrushes about light from 9 P.M. to 11 P.M. ; gale S.W., clear: 15th, two about light: 17 th, flock going N. at 3 P.M. ; wind moderate N.W., clear. December 18th and 20th, flocks, with Lapwing and Larks, about light each night from 8 P.M. to midnight; wind moderate S.E. and light N.W. to N.E., gloomy.

Arklow South Light-ship.-January 24 th, a flock going N. at 
11.30 A.M. ; gale N.W., clear: 27th and 28th, a few, with Blackbirds and Starlings, going N.W. during day; gale N.

Arklow North Light-ship.-October 15th, 17th, 18th, and 19th, some, with Larks, noted each day; two killed striking on 15 th, one on 18th, and two on 19th.

St John's Point, Down.-February 10th, the weather here has been exceptionally severe, and the place around station is full of birds-Larks, Thrushes, a few Blackbirds, Linnets, Chaffinches, and Snow Buntings.

South Rock Light-ship.-April 18th, Thrushes about light; wind light S.W.

Copeland (Mew) Island.-February 6th, large numbers on island: 12th, large numbers of small land-birds have died on the island during the week-Blackbirds, Thrushes, Larks, Grey Linnets, Titlarks, Robin Redbreasts, and Wrens; a heavy fall of snow and severe frost since the 6th, wind variable from S.E. to S.W., and generally blowing hard. July, Thrushes here daily; breed on island. August, same birds here as in July.

Innishtrahull._- "In the first week in February a large quantity of birds died on island owing to frost; got three Snipe, two Woodcock, eight Thrushes, and five or six Skylarks all dead." June 30 th, four Thrushes on island; wind S.E. October 26th, a good many killed at lantern glass lately.

Clare Island.-February 7th, Skylark, Starling, and Thrushes; fresh breeze E., hazy; one killed. "These came to island during the hard frost and snow this month, and mostly all died from hunger and cold."

Samphire Island.-February 3rd, numbers of Golden and Lapwing Plover, Redwings, Thrushes, Fieldfares, and Skylarks going S.W. all day, flying past at intervals; strong breeze E., clear and frosty; also great numbers of Gulls of all sorts hovering about: 7th, vast numbers of Starlings, Skylarks, Thrushes, and Redwings going S. all day; strong breeze S.E. to S.W., heavy snow; "the island was literally covered with them resting on it, and at times they would darken the sky; I don't think I ever saw so many": Sth, Starlings, Thrushes, Redwings, and Fieldfares going S. all day; strong gale to storm S.E., clear and squally; "one continuous flight; they were all very exhausted, and numbers of Starlings fell on island; I never saw such a constant rush of birds; all on the island 
are quite exhansted; numbers of Rooks and Gulls killing and feeding on them-George Dunleavy": 9th, "Redwing" found dead-[Leg and wing of Thrush received]: 12th, Thrushes and other birds dead in numbers on island-[Leg and wing of Missel-Thrush received; sent as "Thrush"]; wind light S.E., clear, frosty.

\section{REDWING (T'urdus iliacus, Linn.).}

Tory Island.-November 20th, some Fieldfares and Redwings about light; gale S.E., rain; one Fieldfare and two Redwings killed: 22nd, numbers of both about light from 11 P.M. to midnight, none struck; fresh breeze N., misty: 23rd, numbers of both, with Starlings, about light from midnight to 4 A.M. ; one Blackbird disabled; wind N., misty.

Samphire Island.-February 3rd, numbers of Golden and Lapwing Plover, Redwings, and other birds; severe frost (see under Thrush): 4th, large flocks Lapwing, Redwing, and Fieldfares going S. at intervals all day; storm S.E., clear and frosty: 5th, Lapwings and Redwings at intervals all day going S.; strong gale E.S.E.: 6th, Redwings at intervals all day going S.; wind variable, snow showers: 7 th, vast numbers Starlings, Skylarks, Thrushes, and Redwings going S. all day; heavy snow (see under Thrush): 8th, Starlings, Thrushes, Fieldfares, and Redwings going S.; storm S.; "I never saw such a constant rush of birds; numbers of Rooks and Gulls killing and feeding on them" (see under Thrush): 9th, great number Starlings, Redwings-[Leg and wing of Thrush received; sent as "Redwing "] -aud Fieldfares on island all day; hurricane S.E., clear and squally: 11th, numbers of Starlings and Redwings (dead) on island at 10 A.M.; strong breeze E.S.E., hard frost: 12th, Redwings and other birds in numbers dead on island; wind light S.S.E., clear and frosty.

\section{FieldFare (Turdus pilaris, Linn.).}

Innishtrahull.-October 30 th, eight on island; strongbreeze S.E. Tory Island.-November 20th, some, with Redwings, about light; gale S.E.; one Fieldfare and two Redwings killed: 22nd, numbers of both about light from 11 P.M. to midnight, none struck; fresh breeze N., misty: 23rd, numbers, with Starlings, about light from midnight to 4 A.M.; one Blackbird disabled; wind N., misty. 
Samphire Island.-January 26th, large flocks Curlew and Fieldfares on Fenit Point at 1 P.M. ; "observed with telescope in fields on shore"; wind moderate N.W., snow showers. February 3rd, numbers of Golden and Lapwing Plover, Redwings, Thrushes, Fieldfares, and Skylarks going S.W. all day; frosty (see under Thrush): 4th, large flocks Lapwings, Redwings, and Fieldfares going S. at intervals all day; storm S.E., clear and frosty: 8th, Starlings, Thrushes, Fieldfares, and Redwings going S. all day; storm S.E.; "one continuous flight" (see interesting note under Thrush): 9th, great numbers Starlings, Redwings, and Fieldfares on island all day; hurricane S.E., clear and squally: 13th, "I think it strange that, among all the dead birds I have come across, I have not met with a dead Fieldfare. My experience of them always was that they would be the first to succumb to the frost and snow." March 21st, one Fieldfare found dead on island at noon; wind light W., clear. [Leg and wing received.]

\section{BlackBiRd (Turdus merula, Linn.).}

Coningbeg Light-ship.-October 15th, one killed striking; wind moderate S.W., gloomy: '29th, one passing ship at 10 A.M. ; chased and killed by Seagulls; wind fresh $\mathrm{N}$., clear. November 10th, one killed at midnight; gale W., clear.

Barrels Rock Light-ship.-January 28th, some, with Thrushes and Skylarks, going towards land during day; wind variable, clear; a few Larks and Thrushes lighted on board for a time, some of which were eaten by Gulls when passing ship: 31st, some, with Thrushes and Larks, flying towards land; wind fresh and variable, clear. October 29th, one hen Blackbird rested on ship and flew W.; strong breeze N.

Tuskar. - March 21st, Titlark, Wheatear, and Blackbirds round light; none lilled; wind moderate W. April 12 th, Blackbirds all night, several killed; wind N., hazy: 19th, Swallows, Wrens, Starlings, and Blackbirds all night; some killed; wind S.W., fog.

Blackwater Bank Light-ship.-January 29th, Thrushes and Blackbirds about light; wind moderate S.W., rain. October 14th and 15th, great rush of birds, including some Blackbirds (see full note under Lark): [16th, Leg and wing of Blackbird received, killed striking]. 
Arklow South Light-ship.-January 27th and 28th, a few going N.W.; gale N. October 15th, a few Blackbirds, Larks, and Starlings going S.W. from 8 A.M. to noon; wind moderate S.W., light rain; two Blackbirds found dead on deck.

Arklow North Light-ship.-January 13th, one about ship at 1 P.M. ; flew S.W. : 26th, two about ship at noon; flew N.W.

St John's Point, Down.--February 10th, the weather here has been exceptionally severe, and the place around station is full of Larks, Thrushes, a few Blackbirds, and other birds.

South Rock Light-ship.-January 8th, one at 10 P.M. killed striking; wind light S.E., clear. February 20th, several Larks and Blackbirds going N.W. at 11 A.M. ; wind light N.W.

Copeland (Mew) Island.-February 6th, large numbers of Blackbirds, Thrushes, and Linnets, and a few Robin Redbreasts, on island: 12th, large numbers of Blackbirds, Thrushes, Larks, Grey Linnets, Titlarks, Robin Redbreasts, and Wrens have died on island during the week; a heavy fall of snow and severe frost since the 6th; wind variable from S.E. to S.W., generally blowing hard. "During February there were large flocks of Wigeon, Teal, Curlew, Seapies, and a few Herons round island, also a good many Snipe. The birds named frequent the island every winter." July, Blackbirds daily; breed on island. August, same birds here as in July. November 3rd, flocks of Wild Duck daily; also Snipe and Blackbirds.

Innishtrahull.-July 12th, two on island; wind moderate W. October 26th, "a good many Blackbirds killed at lantern glass lately."

Tory Island.-November 23rd, one disabled striking; wind moderate $\mathrm{N}$.

Aranmore.-August 9th, "during the last two years only one bird, a male Blackbird, was observed at lantern."

Samphire Island.-February 11th, observed a few female Blackbirds on island; gale E., hard frost: 12th, Blackbirds and other birds in numbers dead on island; wind light S.E., frosty; legs and wings of male and female Blackbirds sent. [Received.]

RING-OvZer (Turdus torquatus, Linn.).

Tuskar:-September 19th, great rush of Warblers, Whinchats, Wagtails, and Ring-Ouzels striking, but nearly all blown into the sea (see full note under Whinchat). 
Rathlin.-[With letter dated January 1896: Ring-Ouzel, stuffed by light-keeper, received; "caught at lantern about twelve months ago."]

Innishtrahull.-April 16th, three disabled striking : 22nd, "I forward two birds caught at lantern a few nights ago. I take them to be Ringed Ouzels; none like them were ever seen on this island before. Another is on island, much whiter on the breast than those I send; it has a large half-moon of white on the breast. The three came together, but no more "- [Two RingOuzels received in flesh]. May 13th, "I send you the third Ouzel ; we had it caged for some time." [Received in flesh.]

\section{HEDGe SparRow (Accentor modularis, Linn.).}

Rathlin O'Birne.-- October 18th, "I am sending a small bird shot here, as I do not know what it is." [Hedge Sparrow received in flesh.] [Another received in flesh, shot on October 21st.]

RoBin (Erithacus rubecula, Linn,).

Copeland (Mew) Island.-February 6th, a few on island: 12th, large numbers of small land-birds, including Robins, have died on the island during the week; heavy snow (see under Blackbird).

Samphire Island.-January 29th, one Redbreast all diry. February 11th, two in coal-house; gale E., clear, hard frost.

REDSTART (Ruticilla phceniourus, Linn.).

Tuskar.-April 18th, Redstart at 10 P.M., killed striking; wind S.W., gloomy.

Black Redstart (Ruticilla titys, Scopoli).

Tuskar.-October 23rd, Blackstart died on rock; observed first on 15th, and remained till exhausted; came into house and died. [Black Redstart received in flesh.]

Stonechat (Pratincola mibicola, Linn.).

Arklow North Light-ship.-February 6th, one "Blackcap" round lanteru at midnight, killed striking; wind moderate S.E. [Probably Stonechat.-R. M. B.] 


\section{Whinchat (Pratincola rubetra, Linn.).}

Tuskan:-September 19th, "very large flocks of Warblers, Whinchats, Grey-headed Wagtails, and Ring-Ouzels, etc., were striking, but it was misty, and blowing fresh from N.E., and nearly all were blown into the sea. I notice, since I came here, that whenever we have a sudden change of wind, as we had last night to N.E., there are very large flocks of birds."

Codling Bank Light-ship.-April 18th, "one Whinchat" noted.

Wheatear (Saxicola cenanthe, Linn.).

Tuskar.-March 18th, one on rock at 10 A.M. : wind light E., clear: 21st, Titlark, Wheatear, and Blackbirds at midnight; wind moderate W. October 6th, Wheatears and Swallows going S.E. at 10 A.M. ; wind W.

Blackwater Bank Light-ship.-March 27th, one found dead; wind light S.E. [Leg and wing received]. April 17th, one on ship at 10 A.M. ; wind light N.E., hazy. July 30th, one on ship ; wind light N.E.

Arklow South Light-ship.-[August 23rd, Leg and wing of Wheatear, found dead, received.]

Innishtrahull.-March 23rd, one disabled; "first arrival"; gale S.W., foggy-[Legs and wings of two, male and female, dated "March," received]. October 26th, "a good many Wheatears killed at lantern glass lately."

Tory Island.-April 4th, two about station.

Scmphire Island.-March 27th, "strange to say, I have not seen any Wheatears yet; they generally appear at other stations about the 17th of March." October 16th, "I have never seen a Wheatear since I came here; it is the first place I ever have been on the coast that I have not met with them."

Sedge Warblen (Acroceplualus phragmitis, Bechst.).

Tuskar.-April 20th, "Sedge Warblers, Reed Warblers, and Willow Warblers at midnight; some of each killed striking" (see under Grasshopper Warbler). July 29th and 30th, great rush of Warblers and other birds; some Willow Warblers and "Grasshopper Warblers" killed striking-[Leg and wing of Sedge Warbler received, with leg and wing of Willow Wren, 
and wing of Spotted Flycatcher]; wind N.W., cloudy, slight haze.

Blackwater Bank Light-ship._-July 29th, four Sedge Warblers about light from 10 P.M. to midnight; one killed striking; wind light N.W., clear. [Leg and wing received.]

Arklow South Light-ship.-May 12th, one "Grey Wren" found dead; wind moderate S., fog. [Leg and wing of Sedge Warbler received.]

Griasshopper Warbler (Locustella ncevia, Bodd.).

Tuskar-April 20th, Sedge Warblers, Reed Warblers, and Willow Warblers at midnight; some of each killed striking; wind light N.E., fog. [Grasshopper Warbler, Whitethroat, and Willow Wren received in flesh.]

Whitethroat (Sylvia cinerea, Bechst.).

Coningbeg Light-ship.- September 19th, several small birds about light at midnight; several killed striking; wind light N.E., rain. [Whitethroat received in flesh.]

Tuskar.-April 18th, Whitethroat killed striking at 10 P.II. : 20th, Sedge Warblers, Reed Warblers, and Willow Warblers at midnight; killed striking; wind light N.E., fog. [Whitethroat, Grasshopper Warbler, and Willow Wren received in flesh.]

- Blackwater Bank Light-ship.-April 25th, "Plovers, Wrens, and Swallows about light"; four killed striking; wind light N.W., rain-[Legs and wings of Whitethroat and Golden Plover received]: 30th, and May 3rd, "Wrens" about light at 10 P.M.; wind S.W. and N.E. [Possibly Whitethroats.-R. M. B.]

BlackCaP (Sylvia atricapilla, Linn.).

Blackwater Bank Light-ship.-October 14th, great rush of Larks, Thrushes, Starlings, and "Warblers" about light from 8 P.M. to 6 A.M. on 15th; many killed striking; wind light S.W., gloomy. [Leg and wing of Blackcap received.]

Willow Wren (Phylloscopus trochilus, Linn.).

Tuskar:-April 20th, Sedge Warblers, Reed Warblers, and Willow Warblers at midnight; some killed striking; wind light N.E., fog-[Willow Wren, Whitethroat, and Grasshopper 
Warbler received in flesh]. July 29th, Willow Warbler's, "Grasshopper Warblers," and young Starlings all night; some killed striking; wind N.W., cloudy. "There was a great rush of Warblers on the nights of July 29th and 30th; also young Starlings and Martins; also what appeared to be a Water-Hen, but I could not catch her, though on the rock for a whole day. These nights were slightly hazy, but I thought it strange, as there was not a-[land?-R. M. B.]-bird of any description seen on the rock since May 27th.-H. KenNeDy." . [Legs and wings of Willow Wren and Sedge Warbler, and wing of Spotted Flycatcher received.]

Blachwater Bank Light-ship.-July 29th, two "Gold-Crests" about light from 10 P.M. to midnight; one killed striking; wind light N.W., clear. [Leg and wing of Willow Wren, labelled "Gold-Crest," received.]

Codling Bank Light-ship.-April 13th, one Willow Warbler found dead: 16th, one about ship; wind light E.: 17th, one, and 18th, two, with Swallows, on ship, and going N.W.; wind light and variable to calm, fog. May 1st, three on ship at 8 A.M.; died; calm and clear. [Legs and wings of two received.]

South Rock Light-ship. - April 13th, two "Sallypickers" about ship at 10 A.M. ; wind light E., clear.

Innishtratuull. - April 20th, four "Willow Warblers" on island at 4 P.M. ; "first arrival"; wind moderate N.E. May 26th, three at lantern at 11 P.M. ; one killed; wind light N.E. August 28th, four killed striking at 11 P.M.; wind moderate N.E.

Chiffehaff (Phylloscopus rufus, Bechst.).

Tuskar.-[April 26th, Chiffchaff received in flesh.]

Golden-Crested Wren (Regulus cristatus, Koch).

Copeland (Mew) Island.-October 18th, a Golden-crested Wren caught against lantern; wind light S., clear.

Innishtrahull. - September 8th, one disabled striking at 1.30 A.M. ; wind light S.W.

\section{WREN (Troglodytes parvulus, Koch).}

Coningbeg Light-ship.-April 18th, one "Wren" on deck at 10 A.M.; fog. 
Barrels Rock Light-ship.-April 18th, one "Wren" lighted on board.

Tuskar:-April 19th, "Wrens" and other birds at night. [Wrens here, and at the two previous stations, may have been Whitethroats or Willow Wrens.-R. M. B.]

Blackwater Bank Light-ship.-April 25th and 30th, and May 3rd, "Wrens" about light (see under Whitethroat).

Copeland (Mew) Island.-February 12th, large numbers of small land-birds, including some Wrens, have died during the week; heavy snow and severe frost since the 6th, generally blowing hard (see under Thrush). November 8 th, a Wren on island to-day.

Innishtrahull.-February 10th, one Wren on island at noon; gale S.E., misty.

Long-Talled Titmouse (Acreduia caudata, Linn.).

Innishtrahull.-October 10th, eight Long-tailed Tits on island all day; wind light N.: two shot on 24th-[Received in flesh]. "Neither I nor any one here have ever seen any of these birds before. I take them to be Long-tailed Tits."

\section{YelLow WAGTAIL (Motacilla Raii, Bonaparte).}

Tuskar:-September 19th, Whinchats, Warblers, Grey-head Wagtail, and Ringed Ouzel all night; killed striking; wind N.E., mist (see full note under Whinchat). [Yellow Wagtail received in flesh.]

\section{"WAgtails."}

Coningbeg Light-ship.-March 22nd, one Water Wagtail about ship at 2 P.M.; flew N.E. September 27th, two about ship; wind light E.: 29th, a flock of Water Wagtails going N.E. at 11 A.M. ; wind light E. ; two about ship at 2.30 P.M. ; flew N.E.

Codling Bank Light-ship.-September 30th, Wagtail going W. at 8 A.M.

Innishtra7ull.-May 8th, four Pied Wagtails going S. at noon; first arrival; wind light N.E., rain.

Samphire Island.-March 7th, one Wagtail on island; strong gale S.W.; "first seen for a long time": 20th, two; fresh breeze W. April 10th, one; strong breeze W.: 16th, one; strong breeze S.E. September 19th, one on island. 
Tirlari (Anthus pratensis, Linn.).

Coningbeg Light-ship.-March 30th, one about ship; wind light N. Aprił 3rd, two on deck; wind light N. September 5th, two about ship: 7 th, one about ship, then flew N.E.

Tuskar.-March 21st, one at midnight.

Codling Bank Light-ship.-March 18th, one going N.W.: 22 nd, one about ship : 30 th, one on ship: 31st, several on ship; wind moderate N.W.

Copcland (Mew) Island.-February 12th, large numbers of small land-birds have died on the island, including some Titlarks; heavy snow and frost since the 6th (see under Thrush). July, Titlarks daily; breed on island. August, same birds here as in July.

Innishtrahull.-[Leg and wing of Titlark received, dated Jạnuary.]

Rock-PIPIT (Anthus obscurus, Lath.).

Samphive Island-March 15th, about a dozen on island all day; wind strong S.W.; "always on island, but not so numerous." June 24th, several young on island, just beginning to fly, attended by the old birds.

\section{Sirylark (Alauda arvensis, Linn.).}

Coningbeg Light-ship.-January 29th, six about ship. February 21st, one found dead: 23rd, one do. March 3rd, flock of Larks and Starlings round lantern from 1 A.M. to 6 A.M.; several struck and fell overboard; wind light S., snow. April 1st, one on deck, flew N.E.: 7th, one do. September 18th, Skylarks and Starling about light at midnight; wind light N.W., gloomy: 19th, flock going N.E.; wind light N.E. October 18th, one on ship; wind S.E.

Barrels Rock Light-ship. - January 27th, some flying to land; wind moderate N.W.: 2Sth, flocks flying towards land; a few lit on board, some eaten by Gulls when passing ship; wind fresh, variable: 29th, several flocks flying towards land during day: 30th and 31st, a few flying towards land. November 17th, flock going N.W.; wind moderate W. December 1st, one flock remained an hour, and flew N.: 10th, four going N.E. 
Tuskar.-February 21st, Larks all night; some killed striking; fresh breeze N.E., misty.

Blackwater Bank Light-ship.-January 13th, flock of Larks going N.W.: 28th, four going N.W. February 18 th, one about ship: 21st, flock about light from 2 A.M. to 4 A.M. ; three killed striking ; wind moderate N.: 21st and 22nd, several flocks about light from 9 P.M. to 3.30 A.M.; wind light N. [Leg and wing of Skylark received]: 22nd and 23rd, several flocks of Larks about light from 11 P.M. to 5 A.M.; two killed striking; wind light N.W.; flock going S.E. at 5.30 A.M. March 3rd, flock about light from 3 A.M. to 4 A.M. ; wind light S.W., snow; and flock Larks and Lapwing going N.W. at noon; strong breeze N.E.: 26th, several at light; wind light S.W., clear. April 17th, one on ship. October 14th, great numbers of Larks, Blackbirds, Thrushes, Starlings, and Warblers about light from 8 P.M. to 6 A.M. on the 15th; many killed striking; wind light S.W., gloomy-[Legs and wings of Lark, Thrush, Blackbird, and Blackcap received]: 15th, flock going N.W.; wind S. : 20 th, some about light; wind light S.E. : 21 st and 27 th, November 8 th, 14 th, and, 17 th, flocks going N.W. each day. December 18th and 20th, flocks, with other birds, about light; wind variable, overcast: 27 th, flock going N.W.; wind S.E. : 28th, flock going N.W. ; gale S.E.

Arklow South Light-ship.-February 18th, a few about light from 9 P.M. to midnight; wind light S.E. : 23rd, small flock going N.W.; wind light N.E. : 24th, odd Larks going N.W.; wind N.W. October 15th, some going S.W. from 8 A.Mr. to noon; wind S.W., light rain: 16th, two large flocks going S.W.; wind moderate N.E.: 17th, three going S.W.: 18th, odd Skylarks passing S.W. during day, two rested on ship; wind moderate S.E.: [19th, Leg and wing of Skylark received, found dead on deck]: 21st, numerous flocks, with Starlings, going N.W.; "almost a constant rush" during day; wind light, variable, gloomy: 29 th, two going N.W. November 2 nd and 3rd, Starlings and Larks going W. during day, some rested on 2nd; wind moderate S.E. : 8th, "a constant rush" of Larks going N.W. during day; wind light N.W., clear: 14th, several flocks going N.W.; wind fresh S.W.: 24th, a flock going W.

Arklow North Light-ship.-January 22nd, two about decks; caught. February 3 rd and 4 th, flocks going W.; wind S.E. October 14th, several going N.W.; wind fresh S.W., rain: 15th, 
several, with Thrushes and Starlings, during past night; wind variable, fog; two Thrushes and one Lark killed striking: 17th, a few going N.: 18th, a few, with Thrushes and Starlings, about light: 19 th, several abont light: 21 st, a few about light; gale N.E. : 25 th, a few flocks, apparently Larks and Linnets, going N.W.; wind fresh N.W.: 27th, several large flocks do. going N.W. November 4th, a few going N.W.: 9th and 10th, a few flocks of Starlings and Larks going N.W.: 16th, several flocks going N.W.; wind strong N.E., rain: 18th, "several flocks of Larks and other small birds" going N.W.; wind fresh S.W.: 21st, some going W.; wind S.E.: 24 th, several flocks going N.W.; wind fresh N.E. : 29th, flocks going N.W. all day; wind S.E.

Codling Bank Light-ship.-January 13th, Larks going W.: 14th, great flocks Larks and Starlings going N.W. from 10 A.M. to 2 P.M.; wind fresh S.: 16th, flocks going W.; wind light S.W.: 17 th, flocks going N.W. 10 A.M. to 11 A.M.; fresh breeze N.W.: 20th, some going N.W.; wind light E.: 22nd, flocks going N.W. 10 A.M. to 11 A.M. ; fresh breeze N.W.: 25th, some going S.W. at midnight; several drowned alongside; gale N., snow: 26th, flocks going N.W. at midnight; none struck; wind moderate N.W.: 30 th, two died on ship: 31st, flocks going N.W. noon to 2 P.M. ; fresh breeze N.E. April 8th, one about ship. October 11th and 12th, one: 13th, several going N.W.; wind light W.: 15th and 16th, several from 10 A.M. to noon; wind moderate S.E. : 19 th, one: 20 th, a flock going E.; wind light S.: 22nd, 23rd, and 24th, several going N.W. during day; one drowned; wind fresh N.E.: 26th and 27th, flocks Larks and Starlings during day going N.W.; fresh breeze N.E.: 28th, Larks and Starlings on ship and going N.W.: 29th, flocks of do. going N.W. during day; strong breeze N.W.: 30th, flocks going N.W. and on ship; wind N., clear: 31st, flocks on ship; wind moderate E, clear. November 3rd, several during day; calm: 9th, flock going N.W.; wind moderate N.W. December 2nd, three: 20 th, several going N.W.; wind light N.

St John's Point, Down.-February 10th, "I am sending a Lark killed against glass. His claws, or rather the absence of them, I wish you to see-[Skylark received in flesh without feet, stumps healed and rounded]. The weather has been exceptionally severe, and the place is full of birds-Larks, 
Thrushes, a few Blackbirds, Linnets, Chaffinches, and Snow Buntings.-J. HIGGINBothaM."

Drogheda, N.-February 6th and 7th, large flocks going W. all day; gale N.W., snow. March 8th, "this is a poor place for the migration of birds; none killed since I joined this station."

South Rock Light-ship.-January 6th, several going W.; strong breeze N.: 8th, a flock going W.; wind N.E.: 16th, a flock going W.: 22nd, several about light at 8.30 P.M.; two killed; wind N.W. February 6th, flocks going S.E.; wind light N.W., snow: 7th, flocks going N. during day; strong breeze S.E., snow: 18th, flocks in all directions: 19th, 20th, and 21st, several going N.W. : 22nd and 23rd, several going E. and about light at 2 A.M. on $23 \mathrm{rd}$; two killed; wind N. April 21st, a few about light. October 23rd, several going N.W.: 24th, several about light; one killed; fresh breeze N.W. November 21st, several about light: 22nd, several, with Chaffinches, going W. during day; wind moderate N.W.: 25th, several about light at 10 P.M.; fresh breeze E.: 27th, several going W.; wind moderate S.E., gloomy: 30th, six going E. December 7th, four going W.; snow.

Copeland (Mew) Island.-February 12th, large numbers of small land-birds have died on the island during the weekBlackbirds, Thrushes, Larks, etc.; snow and severe frost since the 6 th (see under Blackbird).

Innishtrahull.-January 25th, fourteen on island; strong gale N., heavy snow. In the first week of February a large quantity of birds died owing to frost; got three Snipe, two Woodcock, eight Thrushes, and five or six Skylarks all dead[Wing of Lark received, dated "February"]. March 23rd, five at night; two killed striking; gale S.W. May 14th, two disabled striking at 2 A.M. ; wind light W., mist. October 26th, " a good many Skylarks, Thrushes, Blackbirds, and Wheatear's have been killed at lantern glass lately."

Clare Island.-February 7th, Skylark, Starling, and Thrushes; fresli breeze E; one killed. These came to island during the hard frost and snow this month, and mostly all died from hunger.

Samponive Island.-February 3rd, numbers of Golden and Lapwing Plover, Redwings, Thrushes, Fieldfares, and Skylarks 
going S.W. all day, flying past at intervals; strong breeze E., clear and frosty; also great numbers of Gulls of all sorts hovering about: 7th, vast numbers of Starlings, Skylarks, etc. (see interesting- note under Thrush). December 28th, several about lantern at 5 A.M. ; one killed striking.

SNow Bunting (Plectrophenax nivalis, Linn.).

St John's Point, Down.-February 10th, "the weather here has been exceptionally severe, and the place around station is full of birds, including Snow Buntings (I have not seen a white one this winter yet)."

Innishtrahull.- [Leg and wing of Snow Bunting, dated "January," received.] September 21st, a flock of Snow Bunting on island.

Tory Island.-Some Snow Buntings during the winter.

CoRn Bunting (Emberiza miliaria, Linn.).

Tory Island.-April 25th, one disabled striking at 2 A.M.; "evidently come here to nest." [Leg and wing of Corn Bunting received.]

Yellow Bunting (Emberiza citrinella, Linn.).

Arklow North Light-ship.-November 16th, three Yellowhammers going N.W.; strong breeze N.E.

Chaffincri (Fringilla ccelebs, Linn.).

Coningbeg Light-ship.-April 4th, one flew into cabin; went N.E. October 17 th, one rested, flying N.: 20 th, seven on ship for a few minutes; flew N.; wind light S.E.: 21st, two at noon; flew N. November 6 th, two rested at 7 A.M.

Barrels Roch Light-ship.-October 29th, three going N.W. December 7 th, four about ship; flew N.E.

Blacliwater Bank Light-ship.-October 27th and 30th, one on deck. November 1st, three about ship: 3rd, five going N.W.; wind light S.E.; flocks of Chaffinches and other birds going N.W. during day (see under Starling).

Arklow South Lightt-ship.-October 10th, one going N.: 17th, one going S.W.: 23rd, one going N.W.: 29th, one remained all 
day. November 17th, two going N.W.: 24th, one going N.W.; rested.

Arklow North Light-ship.-October 27th, several small birds about light; wind moderate N.W.; one Chaffinch killed striking: 31st, several small and large birds going N.W. during day; one Chaffinch on board; wind variable. November 4th, one do.: 10th, two for a few hours: 26 th, two on deck.

Codling Bonk Light-ship.-April 10th, one about ship: 11th, one do. October 18th, two: 19th, four and one Lark going W.; "one dead": 21st, 23rd, and 28th, one on ship: 30th, flocks Linnets, Larks, and Chaffinches going N.W. and about ship during day; wind moderate N.: 31st, one on ship. November 2nd, two: 4th, one Hawk and one Chaffinch on ship : 8th, one all day: 18th, several flocks Chaffinches and Starlings going N.W. all day; wind moderate S.W. December 2nd, one on ship : 20th and 28th, one noted.

St John's Point, Down.-February 10th, "the weather has been exceptionally severe, and the place is full of birds, including Chaffinches."

South Rock Light-ship.-April 3rd, one about ship. November 22nd, several Larks and Chaffinches going W. during day; wind moderate N.W.

Copeland (Mew) Island.-October 18th, one striking; caught and let go.

Samphire Island.-February 7th, a fer small flocks on island; strong breeze S.E., heavy snow.

Branbling (Fringilla montifringilla, Linn.).

Innishtratull.-April 24th, one on island; wind light N.E. [Leg and wing received, dated "April."] "Brambling are very rarely seen here." November $15 \mathrm{th}$, flock on island; gale N.W., squally.

House Sparnow (Passer domesticus, Linn.).

Hook Tower-[Male Sparrow received in flesh about $22 \mathrm{nd}$ December.]

GreEnFinch (Ligurinus chloris, Linn.).

Coningber Light-ship.-December 20th, one "Grey Linnet" caught on deck. [Greenfinch received in flesh.] 
Arklow South Light-ship.-October 30th, two Green Linnets rested on ship; flew N.W.

Arklow North Light-ship.-January 13th, two about ship; flew W.

Codling Bank Light-ship. - November 19th, one on ship; "stopped on ship till 24th; flew N.W." December 1st, Green Linnet going N.W.

Innishtrahull.-January 9th, nine on island.

GoLDFINCH (Carduelis elegans, Steph.).

Copeland (Mew) Island.- "I was told that after the heavy fall of snow on February 7th, there were immense flocks of Goldfinches along the shore of the mainland, near Donaghadee; large numbers were caught (as they were very weak) to be kept in cages. The people told me they were Scotch Goldfinches. Whether there is any difference between Irish Goldfinches and Scotch ones I don't know.-R. ARMstrong."

Innishtrahull.-May 6th, one caught on island.

Samphire Island.-March 16th, two Goldfinches remained about ten minutes. "The first I have ever observed here."

\section{"LinNETS."}

Coningbeg Light-ship.-February 11th, flock of Grey Linnets going N.W. October 10th, one Linnet going N.: 13th, one going N.E.: 24th, two rested on ship; flew N.E. November 1st, one rested on ship.

Ban'els Rock Light-ship.-October 27th, several flocks going N.W. from 11 A.M. to 2 P.M.; fresh breeze N., clear. December 2nd, three flocks going N.W.

Blachwater Bank Light-ship.-October 28th, flock going N.W. at noon; fresh breeze N.W. November 1st, flocks going N.W.; wind S.E.: 3rd, flocks, with Starlings and Chaffinches, going N.W.; wind S.E. : 11th, one remained on deck about an hour and a half: 22 nd, flock about light; fresh breeze N.W.

Arklow South Light-ship.-November 14th, several flocks, and Larks, going N.W.; fresh breeze S.W.

Artlow North Light-ship.-October 25th and 27th, flocks of small birds, "apparently Larks and Linnets," going N.W. 
November 18th, flocks Grey Linnets going N.W.; wind fresh S.E.

Codling Bank Light-ship.-April 3rd, one Linnet on ship. October 30th, flocks Linuets, Larks, and Chaffinches during day going N.W. and about ship; wind moderate N. December 20th, Linnets noted.

St John's Point, Down. - February 10th, severe weather; Linnets and other birds about station (see under Lark).

South Rock Light-ship.-November 24th, a few Linnets going W. ; wind moderate S.E.

Copeland (Mew) Island.-February 6th, large numbers Linnets on island: 12th, large numbers of small land-birds, including Linnets, on island; snow and severe frost since the 6th; generally blowing hard.

Innishtrahull.-January 28th, eight Grey Linnets on island; snow.

Samphire Island.-February 7 th, a few small flocks of Grey Linnets at noon; strong breeze S.E, heavy snow: 28th, three Grey Linnets on island. March 4th, seven: 10th, two: 12th, several. April 1st and tenth, two. September 13th, three going S.W.: 16th, a flock of about fifty on island at 8 A.M.; wind light S.E. October 14th, about thirty at noon; flew S.W.

\section{"Bullfinch."}

Tuskar-October 18th, "Finches" (Bull) all night; several killed; wind W., misty. "I am certain the birds were Bullfinches that were here in October. I never saw any of them before, which made me look them up, and I found them in vol. iii. of 'British Birds'; as it said they were common, I did not think it necessary to send you one-H. Kennedy" (in letter dated February 6th, 1896). [No leg or wing of a Bullfinch has yet been received from an Irish light station.R. M. B.]

\section{Staring (Strumus vulgaris, Linn.).}

Coningbeg Light-ship.-January 29th, several flocks going N.W. February 1st, one flew down on lower deck: 18th, six about ship; wind light S.E. March 3rd, flock of Larks and Starlings

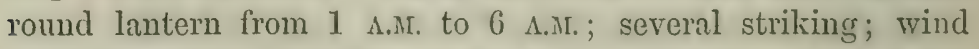
light S., snow: 18th, one going N.E. September 18th, some 
about light; wind light N.W., gloomy. October 15th, one killed striking at 11.30 P.M. ; wind moderate S.W., gloomy: 26th, one rested on ship; flew N.W.: 28th, two rested; went N.W.: 30 th, one killed striking at midnight. November 3rd, three rested on ship; went N.E. : 11th, one rested; went N.

Barrels Rock Light-ship.-January 27th, two flying to land. February 3rd, a flock flying towards land; wind fresh S.E.

Tuskar.-February 20th, Starling and Lapwing going N.W. at 10 P.M. ; several killed; fresh breeze N.E., misty. April 19th, Starlings all night, with Swallows and other birds; fog. July 29th, rush of birds at night, including young Starling; some killed (see under Willow Wren).

Blackwater Bank Light-ship.-January 13th, one about deck: 21st, flock going N.W.; gale N.E. : 28th, ten going N.W.: 31st, flock going N.W.; wind N.E. March 3rd, flock about light; wind light S.W., snow: 9th, two flocks going S.E.; fresh breeze S. July 30 th, four about light at midnight. October 14 th and 15 th, great rush of birds ; many killed (see full note under Skylark): 28th, flock going N.W.; wind moderate N.W. November 1st, flocks going N.W.; fresh breeze S.E.: 3rd, flocks Starlings, Chaffinches, and Linnets from 9.30 A.M. to 3 P.M. going N.W.; wind light S.E., overcast: 18th, one going N.W.: 27 th, flock about light 8 P.M. to 10 P.M. ; wind moderate E. December 20th, some about light at night; wind S.E., overcast : 27 th, flock going N.W.

Arklow South Light-ship.-January 27th and 28th, a few going N.W. during day; gale N. March 1st, small flock going N.W. October 15th, a few going S.W.; wind S.W., light rain: 21st, numerous flocks Larks and Starlings, "almost a constant rush," going N.N.W. during day; wind light variable, gloomy: 24th, a few small flocks going N.W. from 8 A.M. till noon; fresh breeze N.W.: 29 th, some flocks going N.W.; gale. N.E. November 1st, several rested; some flew S.W. : 2nd and 3rd, several, with Larks, going W. during day; some rested; wind moderate S.E. : 15th, a flock going S.IV. at 11 A.M.; gale S.W.: 19th, a flock going N.; gale S.E.

Arklow North Light-ship.-October 14th, a few, with Larks, going N.W.: 15th, some during night; fog: 18th and 19th, a few about light: 21st, several do.; gale N.E.: 27th, several flocks going N.W. November 4th, a few going N.W.: 9th, two flocks going N.W.: 10th, a few flocks going N.W. during 
forenoon; wind light S.W.: 14th and 15th, several flocks going N.W. during day; strong breeze S.W.: 24th and 29th, flocks going N.W.; wind N.E. and S.E.

Codling Bank Light-ship.-January 13th, Starlings, with Larks and Green Plover, going W.: 14th, great flocks, with Larks, going N.W. from 10 A.Mr. to 2 P.M. ; wind fresh S.: 16th, flocks going N.W. from 10 A.I. to 11.30 A.Mr, ; wind light S.W. : 21st, flocks going N.W. : 22nd, flocks, with Larks, going N.W.; fresh breeze N.W.: 28th, flocks going N.W. 10 A.n. to noon; strong breeze N. October 18th and 21st, one on ship: $24 \mathrm{th}$, flock going N.W.: 26 th and 27 th, flocks during day going N.W.; fresh breeze N.E.: 28th, some noted: 29th, flocks during day going N.IV.; strong breeze N.W. November 18th, several flocks Chaffinches and Starlings going N.W. all day; wind moderate S.W.: 20th, flocks going N.W. all day; wind variable. December 2nd, a flock going N.W.: 20th and 25th, Starling noted.

Drogheda, N.-February 7th, large flocks going W. all day; gale S.W., snow.

South Rock Light-ship.-January 14th, three going N.W.: 29 th, one about ship. February 6th, several about deck. April 13th and 17 th, one. November $23 \mathrm{rd}$, several about light at 9 P.M.

Copeland (Mew) Island.-April 4th, large flock all day, remain; they build on island. July and August, here daily.

Innishtrahull.-February 16th, eight on island; gale S.E.

Tory Island.-November 23rd, numbers of Fieldfares, Redwings, and Starlings about light from midnight to 4 A.M. ; wind moderate N.: 27 th, two about light at 3.30 A.M.; one disabled; wind light S.E. "Large quantities of Starlings kept about the island during the winter."

Clare Island.-February 7th, Skylarks, Starlings, and Thrushes; fresh breeze E.; one killed. These came to island during the hard frost and snow this montb, and mostly all died from hunger and cold.

Samphire Island.-January 29th, two all day. February 6th, great numbers of Starlings on lighthouse and island from 4 P.M. to 5 P.M. ; gale N.W. to N.E., snow showers: 7 th, vast numbers of Starlings, Skylarks, Thrushes, and Redwings going S. all day; strong breeze S.E. to S.W., heavy snow. "The island was literally covered with them resting on it, and at times they would darken the sky. I don't think I ever saw so many.- 
George Dunleavy "- $[\mathrm{Leg}$ and wing of Starling caught received]. 8th, Starlings, etc., going S. all day; storm from S.E. "One continuous flight; they were all very exhausted, and numbers of "Starlings fell on island. I never saw such a constant rush of birds; all on the island are quite exhausted; numbers of Rooks and Gulls killing and feeding on them.George Dunleavy." 9th, great number Starlings, etc., on island all day; hurricane S.E. "Only that these nights are so clear, vast numbers of birds would be caught and killed at lantern glass." 11th, numbers of Starlings and Redwings dead on island at 10 A.M. ; strong breeze S.E., clear, hard frost: 12th, Starlings, etc., dead in numbers; frosty: 13th, "I never saw such a rush of birds as there has been for the past week, but 1 observed no rare ones so far; they were composed of Lapwing and Golden Plover, Starlings, Redwings, Thrushes, Skylarks, Rooks, and Fieldfares, with some Grey Linnets. We have very heavy storms, with frost and snow; it is pitiful to see the hundreds of poor birds dead and dying all about the island, particularly Starlings; the sea is also covered with them, and Gulls feeding on them, although vast numbers of Gulls have died. I am told it is terrible the number of birds that are dead on shore.-George Dunleavy." March 21st, fifty noted. December 20th, twelve going S.

CHodgh (Pyrrhocorax graculus, Linn.).

Arklow North Light-ship._February 9th, one "Red-legged Jackdaw" going westward at noon; rested on ship's rail for three or four minutes; wind light E.N.E., clear. [The first record of a Chough from a light-ship.-R. M. B.]

Raven (Corvus corax, Linn.).

Samphire Island.-February 20th, one going S.W. March 12th, two going N.E. July 31st, one going N.E.

\section{Hooded Crow (Corvus cornix, Linn.).}

Arklow North Light-ship.-November 24th, one Hooded Crow noted.

Roor (Corvus frugilegus, Linn.).

Coningbeg Light-ship.-March 7th, five going S.W.; wind light W., clear: 18th, three going S.W.; wind light N.E.: 19th, 
one going N.W. : 30th, two "Crows" going N.E. April 15th, two going N.E.

Barrels Rock Light-ship.-March 31st, two "Crows" going N.

Tuskar.-March 22nd, "Crows" and Curlews going N.W. at 8 A.M. ; wind light S.W. April 12th, flocks of "Crows" going N.W. at $10 \mathrm{~A} . \mathrm{M}_{\text {. }}$; wind N., hazy.

Blackwater Bank Light-ship.-January 8th, one "Crow" about light at 9 P.M.; wind light N.W., clear. April 3rd, two "Crows" going N.W.

Arklow South Light-ship._-March 26th, three "Crows" going N. April 3rd, one going N.W.

Codling Bank Light-ship.-Danuary 25th, one "Crow" and Larks at midnight (see under Lark). February 7 th, one at noon going N.W.; gale S., clear. March 16th, one going N.W.: 23rd, two "Crows" going N.W. ; fog: 24th, four going N.W. April 4th, one (see under Green Plover).

Samphire Island,-February 7 th, numbers going S.W. at 2.30 P.M. ; strong breeze S.W., cloudy, snow showers: 8 th, great rush of birds; Rooks killing and eating exhausted ones (see full note under Starling): 18th, seven going S.W. March 16th, several Rooks going S.W. October 7th, great numbers going S.W. from 8 A.M. to 9 A.M. ; calm, clear: 10th, numbers going N.E. ; wind light N.E., clear: 28th, great numbers going S.W. all day; gale N.W., showers: 29th, numbers going S.W. at intervals all day; gale N.W., showers.

\section{JACKDAW (Corvus monedula, Linn.).}

Innishtrahull.-July 21st, two on island.

\section{Magrie (Pica rustica, Scop.).}

Samphire Island._-October 29th, four on island; gale N.W.

SWALLOW (Hirundo rustica, Linn.).

Coningbeg Light-ship.-April 15th, four going N.E.; first of the year; one on deck: 16th, one on deck: 17th, one found dead on deck-[Received in flesh]; several about ship; flew N.E. to land: 28th, several going N.E. during day; wind light S.W.: 30th, several going N.E. May 17th, several do. July 13th, one about ship; went N.E. August 24 th, one do. ; flew 
N.E. September 8th, a flock going N.: 20th, two flocks going S.W.; wind light N.E. : 21st, three flocks going S.W.; wind light S.E.: 22nd, one flock going S.W.: 23rd, several flocks going S.W. from 5.30 A.M. to 1 P.M. October 6 th, one or two going S.W.: 19th, two rested on ship; flew E.

Barrels Rock Light-ship.-April 12th, two going N.: 14th, do.: 16th, two lighted on board: 18th, two: 25th, five: 26th, six; one lighted and remained on board all night. May 13th, four on board during day; fog: 14th, eight about ship; four died on board; wind light N.W., fog.

Tuskar.-April 11th, one going N. at 7 A.M. : 19th, Swallows, "Wrens," Starlings, and Blackbirds all night; wind S.W., fog. September 25th, some going S.E. October 6th, do.: 19th, do. all day going S. November 20th, Swallows observed flying about railway sheds, Ballygeary. [Light-keeper on shore this day.-R. M. B.]

Blackwater Bank Light-ship.-April 5th, one going N.W. at 10 A.M. ; wind fresh S.W. : 8th, three going N.W.: 17th, two on ship; one caught-[Leg and wing received]: 22nd, two going N.W.: 23rd, one going N.W.: 25th, some, with other birds, about light; wind light N.W., rain: 29th, five going S.W. May 1st, two going N.W. at 6 A.M. : 3rd, flock of Swallows and "Wrens" about light from 10 P.N. to 11 P.M.; wind light N.E., light haze: 8th, flock of Swallows going N.W. at 8 A.M. ; wind moderate E.: 9th, several flocks going N.W.; wind light S.W.: 14th, flock going N.W. June 18th, three going N.W.: 19th, two going N.W. September 4th, flock going S. at 7 A.M.; wind light S.W.: 10th, one going N.W.: 16th, one going N.W.

Arklow South Light-stipp.-April 10th, 11th, and 12th, a few Swallows going N.W. ; wind light N.W. June 25th, one going N.W. August 5th, two going N.E. September 1st, small flocks going S.W. from 8 A.M. to noon; wind light S.W. : 2nd, a large number going S.W.; wind light S.W.: 3rd, a lot in small numbers during day going W.S.W. and W.; they "came from eastward" these three days: 7th, odd ones going W.S.W. all day; wind light W., clear.

Codling Bank Light-ship.-April 16th, one about ship: 17th, two going N.W.: 18th, three do.: 23rd, one killed striking; hazy: 24th, several going N.W. from 6 A.M. to 1 P.M. : 28th, three going N.W.: 30th, three going N.W. May 1st, several 
going N.W.; one died on board-[Leg and wing received]: 8th, several going N.W. June 1st, one going S.E. : 23rd, one going N.W.

Copeland (Mew) Island.-May 4th, some on island.

Clare Island.-May 4th, two flying round station; the first seen this year; gale S.W.

Samphire Island.-May 12th, two going E, first seen this year: 23rd, several about station: 28th, scarce up to this. August 22nd, great numbers about station 9 A.M. to noon. September 7th, hundreds about island, and going S.W., from 8 A.M. to 9 A.M.; calm; numbers rested about walls, etc.; several flew into dwellings; seemed quite tame.

Skelligs.-April 10th, "I am sending a species of Swallow to see if it is rare, as the Swallows here are not like any in cities and towns." [Swallow received in flesh.]

\section{House Martin (Chelidon urbica, Linn.).}

Tuskar.-July 29th and 30th, great rush of birds, including Martins (see under Willow Wren); one Martin killed striking at 11 P.M.; wind light N.E., overcast.

\section{SwIFT (Cypselus apus, Linn.).}

Barrels Rock Light-ship.-May 8th, four "large Swallows" about ship.

Arklow South Light-ship.-August 14th, one "large Swallow" going $\mathrm{W}$.

Codling Bank Light-ship._July 1st, "one Swallow, all black," about ship.

Rockabill.-July 30th, Swift killed at lantern. [Leg and wing received.]

Samphire Island.-June 17th, one noted. August 3rd, three going $\mathrm{S}$.

\section{CucKoo (Cuculus canorus, Linn.).}

Coningbeg Light-ship.-May 15th, one flew twice round ship and then went N.W. at 7 A.M.

Copeland (Mew) Island.-May 4th, heard on island.

Aranmore.-August 9th, "the accompanying bird, which was shot here yesterday, is not known to me"-[Young Cuckoo 
received in flesh]. "During the last two years only one bird, a male Blackbird, was observed on lantern glass at night."

Clare Island.-May 8th, "heard ; the first this year."

\section{"Pigeons."}

Coningbeg Light-ship.-August 19th, Rock-Dove lighted on ship at 3 A.M. ; caught; fog.

Tuskar.-September 27th, Dove on rock.

Copeland (Mew) Island.-June 18th, a Blue Pigeon flying in a circle, apparently very tired.

Innishtrahull.-December 6th, eight Pigeons on island all day; storm N.W.: 27 th, three; gale S.E.

Spotted Crake (Porzana maruetta, Leach).

Fastnet.-[August 20th, Spotted Crake received in flesh.]

\section{WATER-RAIL (Rallus aquaticus, Linn.).}

Tuskar.-August 19th, Water-Rail killed striking at 1 A.M.; wind E., fog. September 25th, one going S.E.

Arklow South Light-ship.-September 24th, several birds about light; one killed. [Leg and wing of Water-Rail received.]

Blacksod Point.-January 9th, "this bird was killed striking the telephone wire; it is a strange bird to me." [Water-Rail received in flesh.]

WATER-Hen (Gallinula chloropus, Linn.).

Tuskar.-July 29th and 30th, one Water-Hen on rock for a whole day; great rush of birds at this time (see under Willow Wren).

\section{"Ringed Plover" and "Dotterels."}

Tuskar.-May 27th, "Dotterels" on rock.

Copcland (Mew) Island.-May 7th, "Ring Plover" heard on island. June 18th, there are several pairs of Ring Plover here at present; they build on island. July and August, here daily.

Samphire Island.-February 22nd, some hundreds of " Ringed Dotterel " on rocks; wind light S.E. March 10th, great numbers of "Ringed Dotterel" on rock; calm; observed with telescope. 
Golden Plover (Charadrius pluvialis, Linn.).

Coningbeg Light-ship. - February 5th, two flocks "Grey Plover" going S.W.; fresh breeze E.: 11th, flock going S.W., flying high.

Blackwater Bank Light-ship.-April 25th, Plover, "Wrens," and Swallows about light from 9 P.M. to 2 A.M.; wind light N.W., rain ; four killed striking. [Legs and wings of Golden Plover and Whitethroat received.]

Arklow North Light-ship.-November 25th, three flocks of "Grey Plover" going W.; wind strong N.E.

Innishtrahull.-January 19th, four Golden Plover on island. February 21st, Lapwing and Golden Plover (eight) on island. September 18th, six Golden Plover going S.

Samphire Island.-February 1st, several flocks Golden and Lapwing Plover going S. from 10 A.M. to 3 P.M.; wind light S.E., frosty : 3rd, numbers of Golden and Lapwing Plover, Redwings, etc., going S.W. all day; frosty: 5th, " a rush of birds going S.W. for the last few days, Golden and Lapwing Plover, Fieldfares, Redwings, etc., frost; at night I can hear' then passing high overhead": 7th, a few small flocks of Lapwing and Golden Plover going S.; snow showers-[Leg and wing of Golden Plover (shot) received]: 8th, several flocks of do. going S. ; storm S.E. December 2nd, fifty Golden Plover going S.

Green Plover (Vanellus vulgaris, Bechst.).

Tuskar.-February 20th, Starling and Lapwing going N.W. at 10 P.M. ; several killed; fresh breeze N.E., misty.

Blackwater Bank Light-ship.-January 19th, flock going N.W. at 9 P.M. ; wind N.E. March 3rd, flock (see under Lark). December 18th, flocks about light from 8 P.Mr. to midnight; wind moderate S.E., overcast: 20 th, do., wind N.

Arklow South Light-ship.-January 3rd, six going N.E. February 20th, one lighted on ship at 8 A.M.; remained till 5 P.M. March 4th, two going S.E. November 23rd, a flock of "Plover" going E. ; gale N.E.

Arklow North Light-ship.-Jauuary 12th, several flocks of Plover going W. from 9 A.M. to 2 P.Mr. ; gale S.E., snow : 13th, several flocks going W. from 10 A.Mr, to 4 P.Mr; wind strong S.E. : 26th, four about ship; flew N.W. February 3rd and 4th, 
several flocks of Lapwing and Lark going W.; fresh breeze S.E. March 3rd, several all day going N. November $17 \mathrm{th}$, two flocks going W.

Codling Bank-Light-ship.-January 11th, great flocks Green Plover going W. during day; strong breeze S.: 12th, great tlocks going W.; gale S., snow : 13th, great flocks, with Larks and Starlings, going W.; wind variable: 15th, flocks of Plover going W. from 10 A.M. to noon; fresh breeze S.E. : 19th, flocks of Green Plover going W. from noon to 1 P.M.; wind light E. : 20th, Plover and Larks going W. from 10.30 A.M. to 11 A.M.; wind light $\mathrm{E}$. March 15th, flocks of Lapwing going W. from 6 A.M. to 5 P.M. ; wind moderate S.W. March 21st, two going W. : 22nd, four about ship : 31st, four going N.W. April 4th, six going W.

Innishtrahull.-January 13th, three Green Plover; gale S.E., snow. February 21st, Lapwing on island.

Clare Island.-February 7th, seven going S.

Samphire Island.-February 1st, several flocks Golden and Lapwing Plover going S. from 10 A.M. to 3 P.M.; frosty: 3rd, numbers going S.W. all day (see full note under Golden Plover): 4th, large flocks going S. all day, several shot-[Leg aud wing received]; storm S.E., frosty: 5th, at intervals all day going S.; gale S.E., frosty: 7 th, small flocks going S.; snow: 8th, several flocks going S.; storm S.E.: 11th, several large flocks going S.; strong breeze S.E., hard frost: 16th, single birds going $\mathrm{N}$. at intervals during day; storm from S.E.: 23rd, about fifty going S.W. March 1st, seven do.

\section{TuRnstone (Strepsilas interpres, Linn.).}

Innishtrahull.- "Frequent the isle, as other years."

Slyne Head, S.-August 18th, a bird killed striking lantern. [Leg and wing of Turnstone received.]

Scmphire Island.-February 11th, large flocks on rocks; strong breeze S.E., hard frost. March 10th, a large flock going N. : 25th, several large Hocks going E. April 11th, small flock groing S.E.: 18th, fifty on island: 20th, twenty; gale S.W.: 22 d, six. July 27 th, seven all day on island; wind moderate N.W. August 27th, a large flock going S.; gale W. December 9 th, about a hundred going N.W. 
Oyster-Catcher (Homatopus ostralegus, Linn.).

Coningbeg Light-ship.-May 8th, two going S.W.: 18th, six flew from Saltee Islands, and when at ship turned and flew W.

Copeland (Mew) Island. - January, flocks round island. February, large flocks. April 4th, flocks daily. June 2nd, "found their eggs." July and August, Seapies here.

Innishtrahull.- "Seapie frequent the island, same as other years."

Samphire Island.-February 11th, a few on rocks; hard frost. March 17th, three feeding: 25th, several large flocks of Seapies going E.; gale W., clear: 30th, twenty-one on island; shot two; gale N.W. During April, a few noted. May 20th, twenty-one on rocks : $22 \mathrm{nd}$, a large flock going S.E. June 16th, several going S.E.: $25 \mathrm{th}$, numbers on rocks. August 6th, sixteen : 23rd, seven. November $29 \mathrm{th}$, numbers on rocks.

Woodcock (Scolopax rusticula, Linn.).

Innishtrahull.-February 18th, four on island. "In the first week of February a large quantity of birds died on island owing to frost; got three Snipe, two Woodcock, eight Thrushes, and five or six Skylarks, all dead." June 25th, one Woodcock on island at 3 P.M. ; gale S., misty. September 29th, one all day. October 21st, one; gale S.E. November 24th, one; strong breeze S. December 29th, one; gale S.E.

Blacksod Point.-February 23rd, "very heavy frost and snow. Great numbers of birds died. The people here were killing the Snipe with sticks. There was also a great quantity of Woodcock."

Clare Island.-February 7th, Woodcock noted; wind moderate E., hazy. "Great many have come to island during the hard frost and snow this month."

SNIPE (Gallinago colestis, Frenzel).

Blackwater Bank Light-ship.-September 25th, one going N:W.

Copeland (Mew) Island.- "Large numbers on isle during January"; and in February to March there were a good many. October 18th, a few seen to-day: 27 th, every day since the 18th. November 3rd, Snipe noted. 
Innishtrahull.-January 30th, twelve all day; strong breeze S.E. February, frosty (see full note under Woodcock). July 2nd, three. September 27th, ten; strong breeze S.E. November 8th, three; gale S., fog. December 10th, four; strong breeze N.W.

Blacksod Point.-February 23rd, "heavy frost; the people here were killing the Snipe with sticks" (see under Woodcock).

DunLiN (Tringa alpina, Linn.).

Samphire Island.-March 11th, a large flock of Sand Larks about all day ; calm, clear; shot nineteen while passing end of island-[Leg and wing of Dunlin received]: 13th, Sand Larks in numbers going S.E. all day; wind strong S.W.: 17th, some thousands of Sand Larks going S. at 5.30 P.Mr.; calm. August 8th, a large flock of Sand Larks going S.E. September 19th, numbers of "Dunlings" heard passing S.W. at 9.30 P.M.

\section{Кмот (Tringa canutus, Linn.).}

Samphire Island.-March 10th, a large flock of Knot circling about; calm, clear; "first I have seen here." December 7th, a large flock going N.; strong gale N.W.

\section{"SAND LARKs."}

Arklow South Light-ship.-May 18th, one flew to ship from land and back again. June 21st, three flew from shore and returned.

Arklow North Light-ship.-November 26th, one Sea Lark on deck.

Copeland (Mew) Island.-July and August, breed on this island.

Innishtrcahull.- "Sand Larks frequent the island same as other years."

CURLEW (Numenius arquata, Linn.).

Coningbeg Light-ship.-March 10th, flock going W. at 9 P.M.: 11th, two flocks going N.E. April 28th, flock going N.E., flying high. July 27 th, several going N.W. at 9 P.M., flying high.

Barrels Rock Light-ship.-November 20th, several Curlew going N.W. 
Tuskar.-March 22nd, some going N.W.

Blackwater Bank Light-ship.-July 23rd, flock passed over ship 10 P.M. August 22nd, one Curlew going S.E.

Arklow South Light-ship.-February 21st, several round ship at 11.30 P.M. May 18th, five going N. June 29th, four going N.W. July 1st, two going W. August 15th, three going N.W.: 30 th, two do.

Arklow North Light-ship.-November 27th, several round light.

Codling Bank Light-ship.-March 23rd, one Curlew going E. June 2nd, several going S.E. at night: 24 th, two going N.W.

South Rock Light-ship. - February 8th, flock going S.W. April 18th, several about light.

Copeland (Mew) Island.-January, flocks round island the whole month; and large flocks in February. April 4th, seen daily.

Innishtrahull.-February 7th, a large flock at light for about an hour at 4 A.M. ; strong gale S.E., snow.

Clare Island.-July 25th, thirty round island.

Samphire Island.-January 26th, large flocks "observed with telescope on shore"; snow. February 11th, large flocks ; hard frost: 18th, several: 24th, numbers heard passing N. at 11 P.M., flying high. March 12th, great numbers going S.E. from 8 P.M. to 11 P.M., flying high and making a great noise; wind light S.E., clear: 13th, numbers all day going S.E.; wind strong S.W. April 10th, several going S.W.; gale N.W. June 19th, a few going S.E. : 23rd, numbers heard passing S.E at 10 P.I. ; calm, clear : 25 th, numbers on rocks. July 15th, two hundred on rock. August 10th, eleven going W. September 20th, six on island. November 20 th, eighteen going S.: 29th, numbers on rocks.

WHIMBREL (Numenius phoeopus, Linn.).

Coningbeg Light-ship.-April 7th, six "Maybirds" going N.E. at 8.30 P.M., flying high over ship ; clear.

Samphire Island.-February 13th, one "Jack Curlew" noted. May 13th, one Whimbrel going N.W. ; first seen: 14th, several going W. from 4 P.M. to 5 P.M. : 20th, numbers feeding, observed with telescope: 22nd, several going S.E.: 28th, " not yet very numerous." July 20th, one going W.: 21st, several heard going W. at 11 P.M.; strong breeze N.W. August 2ud, one: 
6th, two "Jack Curlew" on rocks: 7th, twelve going S.: 15th, seven going W.: 20th, numbers going S.W. 9.30 and 10.30 P.M.; wind fresh S.W.: 22nd, "flocks going S.W. all day and night, passing at intervals in flocks of from five to ten at a time; heavy lightning, with thunder at intervals, during night": 23rd, nine going S.W. September 13th, several heard passing W. at midnight.

\section{"Terns."}

Coningbeg Light-ship. - May 18th, several Common Terns round ship.

Barrels Rock Light-ship.-May 18th, several very large flocks of "Seamews" going E. in forenoon; wind light N.E.: 19th, several small flocks of do. going in various directions during day; wind moderate N.E.: 20th, two small flocks going W. June 1st, four large flocks going S.E. ; wind light S.

Copeland (Mew) Island.-May 8th, "Mews arrived" at daylight; wind moderate S.E. : 31st, "first egg seen on this date." September 9th, last bird seen this day; wind light S.E.

Innishtrahull.-May 15th, one flock Tern; first arrival; wind moderate N.W. June 16th, a flock going N.; gale S.W. "Teru hatch on island."

\section{CoMmon GuLL (Lames canus, Linn.).}

Samphire Island.-February 12th, "one found dead at highwater mark; supposed to be a Kittiwake of second year"[Common Gull received in flesh]; "numbers of Gulls dead on rocks"; hard frost lately (see under Thrush and Redwing).

\section{Gladcous Gull (Larus glaucus, O. Fabricius).}

Blacksod Point.-February 23rd, "I am sending you a Seagull; it is the only one of its species around here, and it only arrived a few days ago." [Very small Glaucous Gull received in flesh.]

\section{"GulLs."}

Coningbeg Liglut-ship.-October 29th, one Blackbird passing ship at 10 A.Mr. ; chased and killed by Gulls. November 7th, two small birds passing slip, wore chased by Sengulls to-day.

Barrels Roct: Light-ship.-January and February, Gulls con- 
stantly noted. January 28th, flocks of birds flying to land during day; a few Larks and Thrushes lit on board for a time, some of which were eaten by Gulls when passing ship: 30th, a few Larks and Thrushes flying to land; two eaten by Gulls. March 16th and 23rd, a large number of large and small Gulls during day about ship; Gulls noted constantly from 16th to end of April ; on March 18th and April 20th, 23rd, and 25th, as white and grey, and on 28th, 29th, and 30th, as grey. May 15th, 21st, and 22nd, a number: 25 th, a large number about ship; Gulls daily till end of month. November 30th, a large number of Murs and Grey and White Gulls about ship. December 5th to 24th, Gulls noted ("grey and white" on 19th).

Blackwater Bank Light-ship.-February 21st, Gulls (small Royals and Royals) are about ship almost daily.

Arklow South Light-ship.-August 19th, "nine Black-head Gulls" going S.W.

Arklow North Light-ship. - October 11th, a few noted. "Several large Seagulls remain about ship for the winter months; and by day, when they happen to get a small bird, such as a Blackbird or Lark, worn out after a long flight, they give it chase, kill it, and eat it, feathers and all; but they will never attack a flock, only a single bird."

Codling Bank Light-ship._- January, a few Herring Gulls and small common Gulls." February, "a few Gulls." March, great numbers. April, great flocks.

Innishtrahull.-August, Kittiwakes, Herring Gulls, Common Gulls, four Royal Gulls. "Seagulls all the year, four kindsHerring Gulls, Kittiwakes, 'Skywalks,' and generally a pair of Royal Gulls."

Clare Island.-March 15th, Seagulls resorting to cliffs in pairs.

Samphive Island.-January 25th, one Great Black-backed Gull: 27th, one "like a Kittiwake, but instead of the wings being tipped with black, they were tipped with white": 28th, large flocks of Kittiwakes on water: 31st, several Kittiwakes. February 3rd, "great numbers of Gulls of all sorts hovering about"; frost: 5th, four Great Black-backed Gulls, "two of them were birds of the second year"; frosty: Sth, great rush of birds; "all on the island are quite exhausted; numbers of 
Rooks and Gulls killing and feeding on them ": 12th, numbers of Gulls dead on rocks at noon; wind light S.E., frosty: 13th, "vast numbers of Gulls have died" (see full note under Starling). April 7th, eleven Lesser Black-backed Gulls feeding on dead Guillemots on water (see under Guillemot); wind moderate W.; four were old birds, seven birds of the second year: 20th, number of Kittiwakes: 25th, great numbers of different species feeding. One or two Great and Lesser Blackbacked Gulls noted occasionally to end of May. May 8th, large numbers of Kittiwakes about bay: 17th, numbers of different species. July 18th and 29th, two Black-headed Gulls. August 22nd, numbers of Kittiwakes feeding. September 21st, great numbers Kittiwakes and Common Gulls. December 2nd, four Great Black-backed Gulls.

\section{Manx Shearwater (Puffinus anglomum, Temminck).}

Coningbeg Light-ship.-March 7th, one going W.: 18th, several going W. during day: 27th, some about ship.

Barrels Rock Light-ship.-February 16th, two "Mackerel Cocks"; the first seen this year; fresh breeze S.E. : 19th, two. March 18th, two: 22nd, five: 24th, six. April 1st to end of month, some almost daily. May 1st to 4th, a few drifting. June 4th, several flocks of "Mackerel Cock" feeding inshore.

Arklow South Light-ship.-May 12th, some going in various directions. June 21st, several going N.E. : 23rd, a few going N.E.

Fork-tailed Petrel (Cymochorea leucorrhoa, Vieill).

Old Head, Kinsale.-November 20th, a Petrel struck light at \pm A.M.; " it is the largest I have ever seen." [Fork-tailed Petrel received in flesh.]

\section{Storm Petrel (Procellaria pelagica, Linn.).}

Coningbeg Light-ship.-May 16th, two round ship. July 16th, four Mother Carey's Chickens about ship; unsettled weather: $17 \mathrm{th}$, one: $25 \mathrm{th}$, one: $27 \mathrm{th}$, one lighted on ship: 2Sth, one do. August 7th, flock round ship all day. September 6th, four Mother Carey's Chickens about ship. October 2nd, two. November 13th, two. .

Blackwater Bank Light-ship.-July 15th, Petrel about ship. 
Arklow South Light-ship.-July 14th, several Petrel from 8 A.M. to noon flying about. August 29th, three going S.W.

Codling Bank Light-ship.-October 6th, three about ship.

Innishtrahull. - [Wing of Storm Petrel received, dated January.]

Clare Island.-July 26th, one struck and caught at base of Tower at 4 A.M. August 18th, one caught at 4 A.M.

\section{RAzorbilli (Alca torda, Linn.) and}

GUILlemot (Uria troile, Linn.).

Coningbeg Light-ship.-August 20th, "young Mur caught and let go, but never left vicinity of ship till October 19th; the crew fed him every day.-A. B. WALL."

Barrels Rock Light-ship.-January 8th, 9th, 10th, 13th, 14th, and 15th, from two to ten flocks of "Murs" noted about ship: 16th, 17th, and 18th, twenty to forty "Murs" about ship: 19th and 21st, several flocks: 22nd, about forty. Februaly, thirty to a hundred and fifty noted at intervals. April 11th to 30th, ten to a hundred constantly seen. Early in May a few : on 16 th, several large flocks of Parrots and Murs going in various directions: 21st, a large number of Murs, and some almost daily till end of month. June, some. November 30th, a large number of Murs, etc. December, forty to fifty at intervals about ship.

Arklow South Light-ship.-August 1st, 2nd, and 3rd, "a lot of Murs with young ones drifting past all day. Sea-birds more numerous than other seasons."

Arklow North Light-ship.-October 11th, a few Murs.

Innishtrahull.-August, some Parrots, Razorbills, and Puffins.

Samphire Island.-April 5th, "about fifty Guillemots floating dead close to island at 6 A.M. ; strong breeze S.W. I fished in a few to identify. I suppose they must have been caught in the nets of the fishing-boats and drowned, and thrown overboard" (see under Gulls). August 7th, young Razorbill and mother close to island ; first young one seen this season: 11 th, several Razorbills and their young fishing all day; gale S. IV.; numerous every day: 30th, numbers, with their young, fishing; gale. September 20th and 21st, numbers feeding. October 13th, one Guillemot in winter plumage, light grey, almost white. 
Slelligs.-April Loth, "I am forwarding four Guillemots; they are, I think, in full plumage, as they have only landed about seven days. I think the bad weather keeps them back[Four received in flesh]. Ringed Guillemots are not so numerous as the others. I have been here three years, and have some Ringed Guillemots' eggs. I obtained a very peculiar egg last season, turned at one point. It was a Guillemot's, as I got the bird sitting on it, and I got three in the same place. After lifting the first and second she finally deposited a third, all the same turn.-J. E. CUNNINGHAM."

\section{LitTle Auk (Mergulus alle, Linn.).}

Tory Island-May, remains of bird not known found on island. [Head and wing of Little Auk received.]

Puffin (Fratercula aretica, Linn.).

Barrels Rock Light-ship.-April 10th, fifty Parrots noted constantly to end of month. May, Parrots feeding about ship.

Blackwater Bank Light-ship. - July 13th, Puffin observed with young.

Innishtrahull.-August, "Puffin and Parrots frequent the island same as other years."

Clare Island.-April 12th, "Puffins have resorted to the cliffs in great numbers." July 20th, Puffins have departed.

Samphire Island.-September 21st, Puffins in great numbers.

Great Northern Diver (Colymbus glacialis, Linn.).

Samphire Island.-January 1st, two: 6th, one, asleep: 8th, three fishing: 17th, eight, four males and four females, close to island; "I take the mottled birds to be the males and the black ones females": 19th, about twenty seen all over the bay: 24th, large numbers of Cormorants and Great Northern Divers fishing close to island; again on 29th. March 17th, one "Whitethroated Diver" close to island: 26th, one Great Northern Diver. April 1st, one: 7th, "a Diver, species unknown, on water among the Plack-backed Gulls. It was the size of a small Cormorant; and I observed with a telescope that the throat and breast were white, head and back of neck a light bluish-grey, bill the same colour, back mottled grey and black 
like a male Great Northern Diver, for which I first took it, but it was much smaller and more slender. I did not see it dive; it kept swimming about the Gulls": 25th, one Great Northern Diver, "in summer plumage, beautifully marked on back with large white spots, white ring round neck, and head black, neck shaded with dark green ": 30 th, one, "beginning to show summer plumage." May 11th, one in summer plumage. These were the first I have ever seen alive in summer plumage. October 10th, one. November 3rd, two; very handsome, partly in summer plumage: 24 th, one going S.: 28th, one: 29 th, four. December 9 th, numbers, and Cormorants fishing.

Sclavonian Grebe (Podicipes auritus, Linn.).

Blacksod Point.-April 15th, "I was out in Blacksod Bay yesterday, and saw about six birds, and, thinking they were Duck, I fired and killed two of them; but I found they were birds I had never seen before. Mr Widdicombe, the lighthouse keeper, had never seen such a bird.-Thomas WLson, Coastguard." [Two Sclavonian Grebes received in flesh in full breeding plumage.]

\section{CoRmorant (Phalacrocorax carbo, Linn.).}

Barrels Rock Light-ship.-January 16th, four.

Samphire Island.-January 24th and 29th, large numbers of Cormorants and Great Northern Divers fishing. March 15th, great numbers of Brown Cormorants fishing. April 6th, five. June 18th, two large Green Cormorants. July 28th, one large White-breasted Cormorant; "first seen for some time": 11th, flocks of from three to seven Cormorants going $N$. all day. September 14th, numbers of Brown Cormorants fishing: 30th, five White-breasted Cormorants going N. October 5th, seven Cormorants in one flock going S. December 9th, some fishing.

\section{Gannet (Sula bassana, Linn.).}

Coningbeg Light-ship.-March šth, two going W. October 20th, eight going E. November 9 th, six passing E.

Barrels Rock Light-ship.-January 2nd, large flock: 3rd, a number: 15th, a large number Gannets feeding: 17th, 18th, 
and 24th, some. During February one to six going W. at intervals. March and April, a few noted almost daily. May 7 th, a large flock going W.: 13th, three flocks going W.: 14th, four flocks going W.: 15th, a number going W.: 20th, four flocks going W. ; constantly noted to end of month. November 27 th, a large number going N.E.: 29th, forty. December 4th, a large number feeding: 16th, do.: 1.9th, one hundred.

Blachwater Bank Light-ship.-March 7th, flock of Gannet going N.E.: 10th, several flocks going N.E. April 17th, flocks going S.W.: 25th, flock going N.E. May 1st, several flocks going N.E.: 11th, flock going N.E.

Arklow South Light-ship.-March 7th and 8th, small flocks Gannet going N.E. : 17th, a flock going N.E. April 3rd, five Gannets going N.E. May 18th, small flocks going in various directions. June 23rd, odd Gannets going N.E. August 10th, several going S.W.: 18th, flocks going S.W. September 24th, several going N.E. October 6 th, odd ones going S.W.

Arklow North Light-ship.-January 22nd, several going S. March 2nd, several flocks going N.E. "to Scotland for the breeding season" : 3rd, several all this day going N. October 11th, two going S.W.

Codling Bank Light-ship.-January and February, a few Gannet. March 19th, large flock of Gannet going N.E.; "great numbers this month." April, "great flocks this month."

Copeland (Mew) Island. - May 8th, several. June, they frequent this island all the summer.

Blacksod Point.-May 11th, Gannet sent. [Adult received in Hesh.]

Samphire Island.-August 24th, numbers fishing.

Heron (Ardea cinerea, Linn.).

Copeland (Mew) Island.-February, a few round island during the month. June 18th, Herons frequent the island all the summer.

Samphire Island.-January 28th, one going W. February 18th, three. Warch 17 th, one. May 27 th, one going S.E.; "much smaller than the ordinary Heron, and almost white; flew low and very sluggishly." August 19th, two large Herons fishing. 


\section{Brent Goose (Bernicla brenta, Pallas).}

Sumphire Island.-November 19th, one "Barnacle" shot and forwarded - [Brent Goose received in flesh]. "There are a good many about the place this season, but not as numerous as last year."

\section{"GeEsE."}

Arklow North Light-ship. - November 22nd, flock of Barnacle going N.E.

Copeland (Mew) Island.-April 26th, four Wild Geese on island : 28th, Wild Geese still here. November 3rd, nine going S.

Innishtrahull.-March 11th, three Wild Geese going N.E. April 5th, large flocks of Geese going S. September 24th, a flock going S.; gale N.W.: 30th, three Geese on island. October 7th, large flocks Barnacle going S. all day; gale N.W November 2nd, one Barnacle Goose on island; killed by islanders; strong breeze N.W.: 10th, a Brent Goose on island; killed.

Blacksod Point.-February 6th, there are no Wild Geese here.

Clare Island.-April 14th, two hundred to three hundred Wild Geese going $\mathrm{N}$.

Samphire Island.-February 4th, "Barnacle Geese are very numerous": 10th, a large flock of Barnacle going S.: 13th, "several large flocks Barnacle going N.; some hundreds of birds passed, making a great noise; none have come within shot of the island, although they pass every day in hundreds": 23rd, Barnacle in great numbers feeding about the bay. Narch 9 th, a large flock of Barnacle in the bay: 17th, three flocks, about a hundred birds, going N.: 24th, "these birds are getting scarce": 27th, three small flocks going N.: 30th, one. April 3rd, a large flock: 9th, two small flocks going N.: 13th, about a hundred going N., flying high, in the form of a letter V, with great noise; wind light $\mathrm{E}$ : $15 \mathrm{th}$, several large flocks going $\mathrm{N}$.: 19th, thousands going N.W. from 7 P.M. to 7.30 P.M.; wind moderate S.W., gloomy ; "in one continuous string, single file, flying high, and making a great noise; I suspect they are migrating, as I never saw them go the same course all the season": 21st, several flocks going $\mathrm{N}$. at 7 P.Ir.; strong breeze S.W. May 9th, Barnacle have left; none seen since April 21st: 14 th, two at noou. October 7 th, about a hundred going 
N.W.; first seen this season: 12th, five going N.W.: 14th, several flocks going $\mathrm{N}$. between 11 A.M. and noon. November 19 th, one on island; shot and forwarded-[Brent Goose received in flesh]: 20th, about a hundred feeding in the bay. December 9th, a flock of about two hundred Barnacle going N.: 24th, three flocks of Barnacle, over two hundred in each flock, going $\mathrm{N}$.

\section{"Swans."}

Blacksod Point.-February 23rd, "there were eleven Swans passed here (date not given) going S., but too high to get a shot at them."

Semphire Island.-December 22nd, two "Black Swans" going W. at 3 P.M. ; wind moderate E., gloomy.-George DunLeavy,

Common Sheldrake (Tadorna cornuta, S. G. Gmel.).

St John's Point, Down. - June 28th, "I am forwarding a Duck, as I do not know to what species it belongs." [Female Sheldrake received in flesh.]

\section{Common Teal (Nettion crecca, Linn.).}

Samphire Island.-February 12th, bird found dead at highwater mark on rocks, torn by Gulls or Crows, supposed to be a Teal; frosty weather. [Leg and wing of Teal received.]

Scaup (Fuligula marila, Linn.).

Samplire Island.-February 12th, supposed "Shovelbill" found dead on rocks at high-water mark; weather frosty. [Female Scaup received in flesh.]

\section{"Ducks."}

Barrels Roch Light-ship.-January 1st, four large flocks Wild Tuck going N.W., flying high. March 17th, two Wild Duck about ship; large, with red heads. October 28th, three Wild Duck going N.W. November 29 th, four about ship.

Blackwater Bank Light-ship.-March 9th, three Wild Ducks going E. July 10th, flock Wild Duck going N.E. at 11 A.M.; wind light S.W. [Unusual date.-R. M. B.]

Arklow South Light-ship.-September 6th, a large flock of Wild Uuck going W. October 13th, four Wild Duck going N. 
Arklow North Light-ship.-February 13th, flock of Wild Duck going N.E.: 15th, two Teal swimming round ship.

Codling Bant Light-ship.-January 5th, two flocks Wild Duck going N. February 6th, Wild Ducks going N.W.; thick snow. October 17th, one flock going W.

Copeland (Mew) Island.-January, flocks of Wild Duck round island the whole month; weather generally stormy. February, large numbers of Duck, Wigeon, and Teal round island; "some come here every winter." October 28 th, several flocks of Wild Ducks. November 3rd, flocks of Wild Duck daily.

Innishtrahull.-January 12th, "one Wild Duck (Teal)" killed striking at 11 P.M.; strong gale S.E., misty, rain. September 6th, two Teal on island; gale N.W.: 22nd, one Goosander on island; wind moderate N. November 4th, Goosander shot: 5th, "one Ferruginous Duck" [Wigeon?R. M. B.] on island: 13th, one Wild Duck and Goosander on water: 18th, one Tufted Duck on water.

Blacksod Point.-February 6th, "there are plenty of Wild Duck at night, but I cannot be absent from lighthouse."

Samphire Island.-February 4th, "observed a good many Duck and two couple of Sheldrakes pass N." : Sth, a few small flocks of Duck going S. : storm S.E. March 10th, "two Shovelbill Wigeon (male and female)."

\section{BIRdS NOT IDENTIFIED.}

Barrels Rock Light-ship.-December 3rd, several flocks of "Sea-Mice" going N.W. [Can hardly have meant Terns in this instance.-R. M. B.]

Blacksod Point.-May 11th, "I saw a strange bird on the water about a month ago on a very stormy day. It was abont the size of a Duck, nearly white, with one large feather sticking up out of its tail, the other colour was either grey or black." [Probably Long-tailed Duck.-R. M. B.]

\section{General Observations.}

Fastnct.- "The Fastnet is a poor llace for bircls, about the worst that I know of . . . very fer ever strike the light." -F. Ryan in lit. November 20th. 
1896 


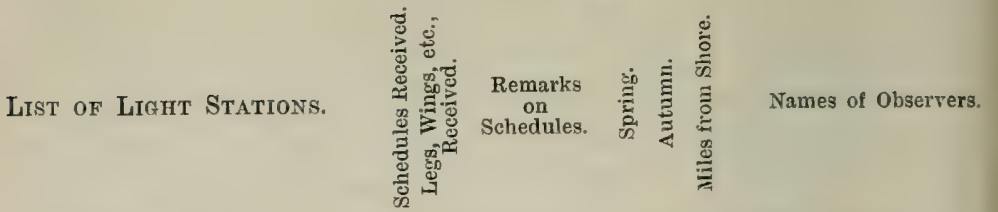

1. Fastnet, Cork, ................. 210 very good. o $x \quad 8$ E. Rohu.

5. Dungarvan, Waterford, ........ 1 0 very good. o $x$ - George Dunleavy.

5. ${ }^{*}$ Coningbeg Lt.-ship, Wexford, 56 excellent. $\quad x \quad x 10\left\{\begin{array}{c}\text { A. B. Wall and J. W. } \\ \text { Grant. }\end{array}\right.$

6. Barrels Rock Lt.-ship, do., 20 very good. $x \quad x \quad 4\left\{\begin{array}{c}\text { Henry Thompson and } \\ \text { Thos. Luccan. }\end{array}\right.$

7. Tuskar Rock, do, 320 very good. x $x \quad 7$ H. Kennedy.

7b. Blackwater Bank Lt.-ship, do., 39 very good. $x \quad x \quad 6\left\{\begin{array}{l}\text { Patrick Cullen, Daniel } \\ \text { Dunn, and Thos. } \\ \text { Luccan. }\end{array}\right.$

8. Arklow Sth. Lt.-ship, Wicklow, $3 \quad 5$ very good. $\quad x \quad$ x 7 E.Broadand N. Burdge. 8.*Arklow North Lt.-ship, do., 30 very good. $\quad x \quad x \quad 8\left\{\begin{array}{l}\mathrm{J} \text {. Beahan and } T \text {. } \\ \text { Stapleton. }\end{array}\right.$ 9a. Codling Bank Lt.-ship, Dublin, $3 \quad 0$ very good. $\quad \mathrm{x} \quad \mathrm{x} \quad 7,\left\{\begin{array}{c}\text { W. Clydesdale and J. } \\ \text { Godkin. }\end{array}\right.$

12. Rockabill, do., 13 good. $\quad 0 \quad x \quad 5$ H. Kelly.

12b. South Rock Lt. -ship, Down,... 20 good. $\quad$ x $\quad x \quad 3$ John Kearon.

15. Rathlin Island, Antrim, ........ 12 good.

x $\quad 06\left\{\begin{array}{c}\text { Joseph Higginbothau } \\ \text { and George Walsh. }\end{array}\right.$

16. Innishtrahull, Donegal, ....... 210 good.

x $\quad$ x 6 George Gillespie.

21. Ratblin O'Birne, do., ….... 312 very good.

o $x 2$ John Kennedy.

24. Broadhaven, Mayo, ............ 10 poor.

o $\mathrm{x}-$ F. Ryan.

27. Blackrock, do., ............ 13 poor.

o $\mathrm{x} 9 \mathrm{~J}$. Corish.

28. Blacksod, do., ........... 10 poor.

o $\mathrm{x}$ - Patrick Keenan.

29. Inishgort, do., ............ 13 good.

$x \quad-$ Richard Hamilton.

32. Arran Island, N., Galway, ..... 10 good.

o $\quad$ x 9 J. F. Friel.

36. Samphire Island, Kerry,........ 30 very good. o $x$ - George Dunleavy.

39. Skelligs, Kerry, .............. 1 0 good. $\quad 0 \quad x \quad 9$ Thomas King.

In addition to the above, Old Head, Kinsale, sent a Turtle Dove; and Mine Head, a Water-Hen.

Legs, Wings, etc., received, 84.

$0=$ No reply.

spring, replies received from 11 stations. $x=$ Schedules returned partly or wholly filled.

Autumn, replies received from 19 stations. 


\section{Legs，Wings， etc., Received.}

Species. How Received. How Procured. Date. Name of Station.

Pied Flycatcher, . Leg and wing, Killed st., ${ }^{1}$. $\quad 8 / 9$ mo., Fastnet.

Thrush,

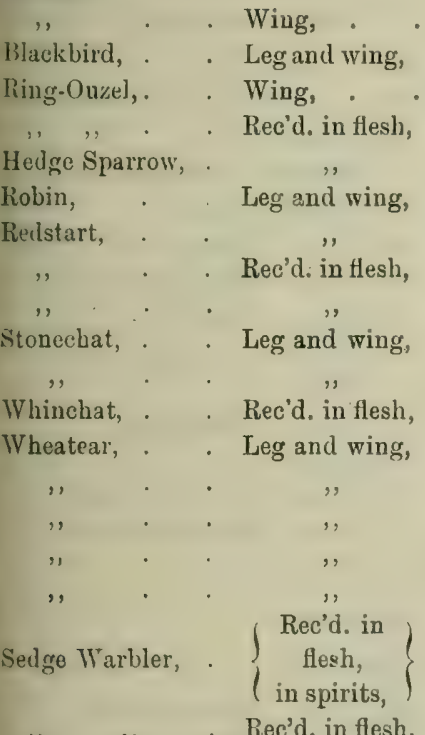

",

2/11 mo., Tushar:

4/ 4 mo., Innishtrahall.

Killed st., . 29/10 mo., Tuskar.

Prob. killed st., 11/ 9 mo.,

Killed st., . $5 / 5 \mathrm{mo}$, Innishtrahull.

\section{? $\quad 7 / 10 \mathrm{mo}$, Rathlin O'Birnc.}

Killed st., . 13/3 mo., Blackwater Bank Lt -sh.

Caught st., . $7 / 9 \mathrm{mo}$, Fastnet.

Killed st., . 11/9 mo., Tushar.

5/ 5 mo., Innishtrahull.

" . 13/3 mo., Tuskar.

,. . 4/ 4 mo., Innishtrahull.

, . 11/ $9 \mathrm{mo}$, , Tuskar.

? 25/10 mo., ,,

Killed st., . 15/ 4 mo,, Blackwater BankLt.-sh.
,
17/ $4 \mathrm{mo}$,

Dead on deck, 16/ 4 mo., Arklow S. Lt.-ship.

$$
\text { ". } 8 / 9 \mathrm{mo}, \text {, , }
$$

Killed st., . 11/9 mo., Fastnet.

? $8 / 8$ mo., Tuskar.
$? \quad 25 / 10$ mo., ,

Killed st., . $8 / 9$ mo., Fastnet.

, $\quad \begin{array}{r}5 \mathrm{mo} ., \\ ,\end{array} \quad$ Coningbeg Lt.-ship.
, 25/10 mo., Tuskar.

Dead on deck, 8/ 9 mo., Arklow S. Lt.-ship.

Blackcr21, . . Rec'd. in flesh, Picked up dead, 8/12 mo., Fastnet Buildings.

Barred Warbler,

Willow Wren, $\cdot\left\{\begin{array}{c}\text { Rec'd. in } \\ \text { flesh, } \\ \text { in spirits, }\end{array}\right\}$ $\left\{\begin{array}{c}\text { Found } \\ \text { wounded, }\end{array}\right\} 25 / 9$ mo., Rockabill.

Killed st., . $\quad 2 / 9$ mo., Fastnet.

, . 24/ 4 mo., Tuskar.

, 16/ 4 mo., Blackwater Bank Lt.-sh. 


\section{Legs, Wings, eTC., Received-continued.}

Species. How Received. How Procured. Date. Name of Station.

Iceland Gull, . Rec'd in flesh, Shot, . 30/10 mo., Rathlin O'Bime.

Fork-tailed Petrel, ， Caughtatlantern, 5/ 5 mo,, Fostnet.

Little Auk, . $\quad, \quad\left\{\begin{array}{c}\text { Found un- } \\ \text { injured } \\ \text { near base } \\ \text { of light. } \\ \text { house, }\end{array}\right\}\left\{\begin{array}{c}\text { about } \\ 12 / 12 \text { mo., }\end{array}\right\}$ Blackrock, Mayo.

Long-tailed Duck,

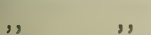

$\{$ Head, leg, $\}$

Shot, . . 16/10 mo, Rathlin O'Birne.

", Rec'd. in flesh, ? 18/1 mo., Inishgort.

Common Scoter, 


\section{N D E X.}

Auk, Little,

Barred Warbler,

PAGE 534

Birds not identified

Blackbird, .

Blackcap,

Brambling,

"Bullfinch,"

Bunting, Reed, .

$$
\text { ," Snow, . }
$$$$
\text { , Yellow, }
$$

Chaffinch,

Chiffchaff,

Chough,

Cormorant,

Corn-Crake,

Crow, Hooded,

Cuckoo,

Curlew,

Diver, Great Northern,

Duck, Long-tailed,

"Ducks," .

Dunlin,

Fieldfare, .

Flycatcher, Pied,

"Flycatchers," .

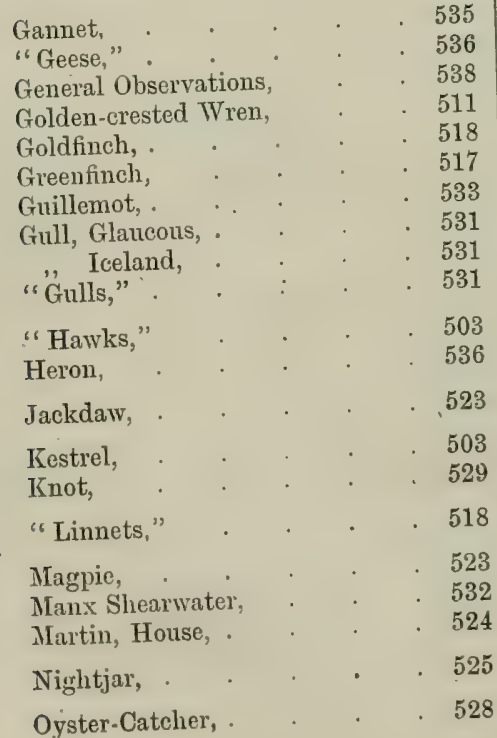

Pereorine Falcon, . . . 503

Petrel, Fork-tailed, . . . 533

533

528

525

526

$52 i$

526

534

$52 \cdot 2$

Raven, · · · . $583: 3$

Razorbill, Black · • 503

Redstart, Black, . . . 507

" . . $50 \%$

Ring.Ouzel, . . . 507

Robin, 507

Rook, . . . . . 522

"Sand Larks," . . . . . $52 ?$

Scoter, Common, . . . 537

Sedge Warbler, . . . . . 509

535

Skylark, . . 512

Snipe Common, . . . 528

528

503

507

517

517

519

508

$52: 1$

$53 i$

525

531

504

512

$52 i$

525

$511_{1}$

511

$52 j$

526

508

530

508

509

510

528

511

525 
Peregrine FÁlcon (Falco peregrimus, Tunstall).

Innishtrahull.-March 26th, one "Falcon Hawk" at \$.45 A.M. ; strong breeze N.W.

Skelligs.-September 27th, four Peregrine Falcons on rock at 9 A.M. ; gale N.W.

\section{Kestrel (Falco tinnunculus, Linn.).}

Skclligs.-September 26th, one on rock; strong breeze W. December 8th, one; strong breeze W.

SPARROW-HAwK (Accipiter nisus, Linn.).

Coningbeg Light-ship.-May 21st, one going N.E. at 4.30 A.M.; rested ten minutes; calm. September 7th, one large SparrowHawk about ship from 7 A.M. to 7.30 A.M.; flew N.W.; wind light S.E.

Tuskar,-October 20th, one at 9 A.M. on rock; wind moderate N.W.

Arklow North Light-ship.-May 21st, small "SparrowHawk" on ship's deck for five hours; strong breeze $\mathrm{N}$., clear. December 11th, one rested for some time.

Codling Bant Light-ship.-October 4th and 5th, one about ship; wind strong N.W.

Rockabill.-November 30th, two going W.; wind moderate S., clear.

Innishtrahull.-June 28th, one on island.

Slielligs.-October 1st, one on rock; wind moderate S.: 13th, one; wind light $\mathrm{E}$.

\section{"HAWKS."}

Arklow South Light-ship.-August 19th, one Hawk going N.W. at noon.

South Rock Light-ship.-March 30th, one flying E., following Linnet; "suppose Hawk to have chased Linnet from the land." November 3rd, one flying S.W.

Innishtrahull.-March 4th, one all day; wind fresh S.W.

Pied Flycatcher (Muscicapa atricapilla, Linn.).

Fustnet,-September 8th, three "Flycatchers"; two killed striking; one came into kitchen and remained catching flies; 
fresh breeze E., overcast, mist; and one small bird killed striking; leg and wing forwarded. [Legs and wings of one Pied Flycatcher and two Whitethroats, all marked "cannot say name," received.]

\section{"Flycatchers."}

Rockabill.-September 1st, six Flycatchers at light; two killed; wind N.E., haze.

\section{Throsh (Turdus musicus, Linn.).}

Coningbeg Light-ship.-February 14th, several, with Blackbirds, about light from 9 P.M. to midnight; wind light N.W., gloomy. March 13th, Blackbirds, Thrushes, and Starlings about light from 1 A.M. to 5 A.Mr; a very large number of each kind struck; wind light S.W., rain: 14th, Thrushes and other birds about light from 1 A.M. to 6 A.M. ; flew S.E. at 6 A.M.; wind light N.E. December 26th, several Starlings and Thrushes about light from 6 P.M. to midnight; wind moderate N.W.

Tuskar:-November 2nd, Starlings, Larks, Thrushes, and Blackbirds round light at 2 A.M.; some killed and disabled; gloomy-[Leg and wing of Thrush received, killed striking]: 12 th, Thrushes round light at 10 P.M.; some killed. December 13th, a few round light at 11 P.M.; some killed; rain.

Blackwater Bank Light-ship.-January 7th, flocks, with Larks, about light from 9 P.M. to 11 P.M. ; wind moderate N.E., gloomy: 11th, Thrushes about light from 8.30 P.M. to 10.30 P.M. ; overcast. February 6th, Starlings and Thrushes from 8.30 P.M. to 10.30 P.M.; overcast. March 11th, 12th, and 13th, Larks, Thrushes, Starlings, and Blackbirds about light; some killed: 14th and 15th, several Thrushes about light: 18th, flock going N.W.: 19th, going W.: 24th, several about light. April 5th, flock going N.; wind light N.W., clear. November 9th, two on deck from 9 P.Mr. to 7.30 A.M.: 16th, Thrushes, with Starlings, about light from 7 P.M. to midnight: $25 \mathrm{th}$, with Starlings about light from 6 P.M. to 8 P.M. December 21st, a few about ship at 11 A.M.

Arklow South Light-ship.-March 11th, 12th, and 13th, birds of various kinds about light during night, striking, some falling overboard, others on deck; Thrushes, Blackbirds, Starlings, and Larks noted; wind light N.E., heavy rain. April 
18th, Larks, Swallows, and Thrushes going N.W. at 5 A.M.; calm, hazy.

Arklow North Light-ship.-December 29th, some Thrushes and Starlings about light; wind moderate W.

Codling Bank Light-ship.-November 3rd, one at lantern; wind moderate N.E., clear.

Rockabill.-October 9th, three on rock; wind fresh S.W. December 3rd, a few about light; one killed striking, with one Blackbird, one Lark, and two Starlings; the only birds killed striking at this station during October, November, and December; wind fresh S.W., misty.

South Rock Light-ship.-February 13th, several about lantern at 1 A.M. killed striking; great number during night, with Larks, at lantern ; wind light S., haze: 14th, flocks of Larks, Thrushes, and Blackbirds about lantern; a great many killed and falling overboard; wind light N.W., clear: 17th, Larks and Thrushes about light; wind light S.W.

Innishtrahull.-January 13th, flock on island; gale N.W. [April 4th, Wing received.] August 8th, Thrushes and Blackbirds striking light at 11 P.M.; "first arrival"; wind moderate N.

Blackrock, Mayo.-November 5th to 18th, a few, with Blackbirds, Starlings, Green Linnets, and Chaffinches, visited rock; wind S.E., very cold.

Arran Island, N.-September 12th, flock of Starlings and Thrushes all day; wind moderate S. October 20th, six or seven going S.E. ; wind light N. January 1st 1897, "Since September, about six Starlings and nine or ten Thrushes have frequented the island almost daily,"

\section{REDWING (Turdus iliacus, Linn.).}

Tuskar.-October 16th, "Mountain Thrushes" all night; several killed and disabled; gale N.E., gloomy-[Possibly Redwings-R. M. B.]: 19th, some "Mountain Thrushes" killed; wind light N.W., rain.

Rockabill.-October 17th, one Thrush (Redwing) on rock at noon, with one Fieldfare, two Greenfinches, and seven Chaffinches; wind fresh N.W., clear.

Innishtrahull.—January 28th, three Redwing Thrushes all day on island; strong breeze $\mathrm{S}$. 
Fieldfare (Turdus pilaris, Linn.).

Rockabill.-October 17th, one, with one Redwing, two Greenfinches, and seven Chaffinches, on rock at noon; wind fresh N.W., clear.

BlaCKBIRD (Turdus merula, Linn.).

Coningbeg Light-ship.-February 14th, several, with Thrushes, about light from 9 P.M. to midnight; wind light N.W., gloomy. March 13th, some, with Thrushes and Starlings, about light from 1 A.M. to 5 A.M.; a very large number of each kind struck; wind light S.W., rain : 14th, Blackbirds and other birds about light from 1 A.M. to 6 A.M. ; flew S.E. at 6 A.M.; wind light N.E. October 13 th, one female killed striking at 2 A.M. ; wind moderate N.E., clear: 22nd, one cock rested, chased by Gulls, flew N.E. ; wind moderate N.E.

Tuskar.-February 5th, a few in the night. March, some killed striking. September 13th, Blackbirds all night; some killed; wind light E., gloomy. October 19th, several all night; some killed; rain: 29th, some, with Starlings and Larks, all night, striking on N.W. side of lantern; wind light N.W., gloomy-[Leg and wing of Blackbird received]: 31st, do., striking on S. side; strong breeze N.E., rain. November 2nd, Blackbirds, with Starlings, Larks, and Thrushes, round light at 2 A.M.; some birds killed and disabled; wind moderate $N$., gloomy. December 23rd, some round light all night; wind moderate S.W., showery.

Blackwater Bank Light-ship.-March 11th, 12th, and 13th, Larks, Thrushes, Starlings, and Blackbirds about light each night, striking; some birds killed (see under Titlark, Skylark, and Starling): 15th, several Blackbirds about light; cloudy: 24th, several do.; mist and fog.

Arklow South Light-ship.-March 11th, 12th, and 13th, Blackbirds, with Thrushes, Larks, and Starlings, striking during night, falling overboard and on deck; heavy rain.

Arklow North Light-ship.-December 23rd, Blackbird killed and eaten by "Royal Gull."

Rockabill.-October 9th, two on rock, with a few Thrushes and Starlings. "Remain a day or two, and when leaving generally go at night, so cannot tell direction taken." 
December 3rd, four at light; one killed striking; wind fresh S.W., misty.

South Rock Light-ship.-February 14th, flocks, with Thrushes, etc., about lantern; a great many killed and fell overboard; wind light N.W., clear.

Inmishtrahull.-August 8th, Thrushes and Blackbirds striking at 11 P.M. ; "first arrival"; wind moderate N.

Rathlin O'Birne.-October 24th, two all day; wind fresh N.E.: 27th, to the present date the only bird killed striking lantern here was one Blackbird.

Blackrock, Mayo.-November 5th to 18th, some, with Thrushes and other birds, visited rock during very cold weather (see under Thrush).

Arran Island, N.-Oetober 12th to 18th, two on island; wind $\mathbf{E}$.

\section{Ring-Ouzel (Turdus torquatus, Linn.).}

Tuskar.-September 11th, "Ouzels" striking at 10 P.M.; several killed; also Stonechats, Warblers, and one Redstart; wind light S.E., fog. [October 12th, Wing of Ring-Ouzel received, possibly killed on September 11th.]

Innishtrahull.-May 5th, one killed striking at midnight; with Willow Wren and Redstart; fog. [Received in flesh.]

Hedge Sparrow (Accentor modularis, Linn.).

Rathlin O'Birne.-[October 7th, Hedge Sparrow received in flesh.]

RoвIN (Erithacus rubecula, Linn.).

Blackwater Bank Light-ship.-March 13th, one Robin killed striking; light breeze S.W., rain. [Leg and wing received.]

Common Rejstart (Ruticilla phenicume, Linn.).

Fastnet.-September 7th, one caught at lantern at 11.30 P.x.; fresh breeze E., gloomy. [Leg and wing of Common Redstart received.]

Tushar.-September 2 nd, one on rock at 9 A.M., with nine Wagtails; wind light S., gloomy : 11th, "Blackstart" killed at 
10 P.M., with several "Warblers," "Stonechats," and "Ouzels"; wind light S.E., fog. [Redstart received in flesh.]

Innishtrahull.-May 5th, one killed striking at midnight, with Ring-Ouzel and Willow Wren; light breeze N., fog. [Received in flesh.]

Black Redstart (Ruticilla titys, Scopoli).

Skelligs.-October 3rd, one Black Redstart on rock; wind moderate S.: 4th, two; gale W.

\section{Stonechat (Pratincola rubicola, Linn.).}

Tuskar--[March 13th, Leg and wing of Stonechat received, killed striking.] August 1st, two "Stonechats" at 9 A.M.: 3rd, one all day. [Possibly Whinchats (see under latter).]

Rockabill.-September 2nd, three "Stonechats" at light about 1 A.M.; wind light E., haze; remain.

Innishtrahull. - [April 4th, Leg and wing of Stonechat received, killed striking.]

Skelligs.-November 12th, one on rock; light breeze S.; and one striking glass about midnight.

Whinchat (Pratincola rubetra, Linn.).

Tuskar. - August 8th, "one or two Whinchats" noted. September 11th, several "Stonechats" killed striking at 10 P.M.; wind light S.E., fog. [Whinchat received in flesh.]

\section{Wheatear (Saxicola cenanthe, Linn.).}

Fastnet.-September 6th, some Wheatears about lantern at 10.30 P.M.; one disabled; wind moderate E., gloomy.

Tuskar-April 8th, one. [October 25th, Leg and wing of Wheatear received.]

Blackwater Bank Light-ship. - April 15th, Wheatears and Sedge Warblers about light from 9 P.M. to midnight; wind moderate N.W., gloomy; ten killed - [ Leg and wing of Wheatear received]: 16th, Wheatears and Sedge Warblers from widnight to 4 A.M.; four killed; wind moderate N.W., gloomy: 17th, Wheatears and Sedge Warblers from 11 P.M. to midnight; six killed; light breeze N.W., gloomy-[Leg and 
wing of Wheatear received]: 18th, Wheatears, Sedge Warblers, and two Swallows about light from midnight to 4 A.M.; light breeze N.W., gloomy; three killed.

Arklow South Light-ship.-[April 16th, Leg and wing of Wheatear received; found dead on deck.] [September 8th, Leg and wing received; found dead on deck.]

Innishtrahull.-March 21st, fourteen all day on island; wind light S.E.: 25th, large numbers all day on island; wind moderate S.W. April 11th, four struck glass at 2.30 A.M.; wind light W., rain.

Samphire Island.-July 19th, two; wind fresh S.W.; "the first I have observed."

Skelligs.-September 24th, one on rock; two disabled striking at 10 P.M.; fresh breeze N.W.

\section{Sedge Warbler (Acrocephalus phragmitis, Bechst.).}

Fastnet. - September 11th, one small bird killed striking; wind moderate S.W., gloomy. [Sedge Warbler received in Hesh.]

Tuskar.-August 8th, "one or two of the enclosed Warblers are about rock these last few days, one of them of a very light colour"-[Sedge Warbler received in flesh]. [October 25th, Leg and wing of Sedge Warbler received.]

Blackwater Banh Light-ship.-May 5th, one killed striking; light breeze N.W., gloomy (see under Willow Wren).

\section{Whitethroat (Sylvia cinerea, Bechst.).}

Fastnet.-September 8th, three "Flycatchers"; two killed striking. One came into kitchen and remained catching flies; fresh breeze E., mist; and one small bird killed striking-leg and wing forwarded. [Legs and wings of one Pied Flycatcher and two Whitethroats, all marked "cannot say name," received.]

Coningbey Light-ship.-May 9th, a small bird caught on deck at 8 A.M. ; died-[Whitethroat received in flesh]. September 7 th, several small birds about light from 2 A.M. to 5 A.M. ; wind light S.E., haze; three killed striking; and several about light on following night from 12.30 A.M. to 5 A.M.; two killed. [Four Whitethroats received in flesh.] 
Tuskar. - [October 25th, Leg and wing of Whitethroat received.]

Arklow South Light-ship.-[September 8th, Leg and wing of Whitethroat received; found dead on deck.]

\section{BlackCaP (Sylvia atvicapilla, Linn.).}

Fastnet.-December 12th, "I send a little bird picked up) dead on mainland on the 8th inst., near the residence of a Dr Brideoake. A small patch of wood surrounds his house; there are very few patches of wood in this locality.-EDWARD RонU." [Male Blackcap received in flesh.]

BarRed Warbler (Sylvia nisoria, Bechst.).

Rockabill.-September 25th, unknown bird forwarded, fouud on rock wounded at 10 A.M. ; gale N., clear. [Barred Warbler received in flesh.]

WILlow WreN (Phylloscopus trochilus, Linn.).

Fastnet.-September 2nd, one found killed; wind light S.E., gloomy. [Received in flesh in spirits.]

Tuskar. - [April 24th, Leg and wing of Willow Wren received, killed striking.]

Blackwater Bank Light-ship.-April 15th, 16th, 17th, and 18th, Wheatears and "Sedge Warblers" about light each night: twenty-three birds killed striking; wind light to moderate N.W., gloomy - [Legs and wings of two Willow Wreus received, killed striking, April 16th and 17th]. May 5th, one "Sedge Warbler" killed striking; light breeze N.W., gloomy. [Possibly Willow Wren.]

Arklow South Light-ship.-[September 8th, Leg and wing of Willow Wren received; found dead on deck.]

Arklow North Light-ship. - April 15th, one "Sallypicker" killed striking - [Possibly Willow Wren]: 17th, several "Sallypickers" about light; two killed striking; six caught; calm, haze. May 9th, one "Sallypicker" on board for six hours; wind light N.E., hazy.

Codling Bank Light-ship.-April 16th and 17th, several small birds about light; some killed and fell overboard: 18th, two "Willow Warblers" on ship during day. 
Innistutrahull.-May 5th, one killed striking at midnight, with Ring-Ouzel and Redstart. [Received in flesh.]

Chiffchaff (Phylloscopus rufus, Bechst.).

T'uskar:- [September 11th, Chiffchaff received in flesh, killed striking.]

South Rock Light-ship. - March 25th, one "Sallypicker" about deck at 9 A.M. ; wind light, haze. [Probably Chiffchaff.]

GOLden-CRested Wren (Regulus cristatus, Koch).

Rockabill.-October 3rd, two on rock at 10 A.M.; light breeze S., clear.

Innishtrahull.-April 9th, two disabled striking at midnight; strong breeze W. [One received in flesh.]

WREN (Troglodytes parvulus, Koch).

Tuskar.-October 20th, Common Wren on rock at 9 A.M.; wind fresh N.E., clear.

Arklow South Light-ship.-April 18th, one Wren found in the lantern at 5.20 A.M. ; calm, hazy; let it go, and it flew $\mathrm{N}$.

Rockabill.-September 10th, two on rock; wind moderate S., clear. November 5th, two on rock; wind light $\mathrm{N}$.

Innishtrahuil.-[April 4th, Leg and wing received.]

\section{"WAgTAILS."}

F'astnct.-September 6th, one Pied Wagtail about lantern at 10.30 P.M. ; wind moderate E., gloomy.

Coningbery Light-ship.- September 9th, one Water-Wagtail about ship at 10 A.M. ; wind light S.W., fog; flew N.E.

Tuskar.-September 2nd, nine Wagtails on rock at 9 A.M.; wind light S., gloomy.

Arklow South Light-ship.-May 5th, one Wagtail rested on ship at 11 A.M. going N.; calm.

Codling Bank Light-ship.-September 7th, Wagtail going N.W.; light breeze $E_{\text {, }}$ haze.

South Rock Light-ship. - September 4th, one "Willie Wagtail" going W. at 9 A.M.; wind light S.E.: 12th, several "Willies" going N.W. during day; fresh breeze S.E. 
Samphire Island.-August 2nd, two at 5 A.I.; calm; and flock of six at 10 A.M.

Skelligs.-November 7th, one Pied Wagtail on rock; wind moderate W.

Tithark (Anthus pratensis, Linn.).

Coningbeg Light-ship.-March 10th, one on deck caught; wind light S.W. May 11th, one about ship; flew N.E.

Tuskar.-September 15th, several all day on rock; wind light E., gloomy. October 20th, some at 9 A.M. ; wind fresh N.E. [Leg and wing of one received, disabled striking]: [25th, Leg and wing of Titlark received].

Blackwater Bank Light-ship.-[March 12th, Leg and wing of Titlark received, killed striking.]

South Rock Light-ship.-September 6th, two going N.E.: 7th, several about light at 10 P.Mr. : 13th, several going N.W.; wind light S.E.: 14th, a number of Swallows and Titlarks going W.; fresh breeze S.W., rain: 15th, several: and 19th, one going W.

Blackrock, Mayo.-November, Titlarks observed every day.

Skylark (Alauda arvensis, Linn.).

Fastnet.-November 5th, one Lark disabled striking at 2 A.M.; wind light E., gloomy. [Leg and wing of Skylark received.]

Coningbeg Light-ship.-March 13th, two about light: 14th, some do. April 8th, one killed striking at 2 A.M. ; wind light N.W., gloomy. October 28th, two rested; flew N.E.

Barrels Rock Light-ship.-October 20th, ten large flocks at 8 . A.M. going N.; wind moderate N.W., clear.

Tuskar.-March, some killed. October 19th, flocks going N.W. at 10 A.M. ; wind N.W.: 23rd, flock going N.W. ; wind light N.W.: 27th, some on rock at 8 A.M.: 29th, Starlings, Blackbirds, and Larks all night, striking on N.W. side of lantern; light breeze N.W., gloomy-[Leg and wing of Lark received, killed striking]: 31st, do., striking on S. side; strong breeze N.E., rain.

Blackwater Bank Light-ship. - January 7th, Thrushes and Larks about light. March 7th, flock of Larks going N.W. at 6.30 A.M. ; wind light W.: 11th, 12 th, 13 th, 14th, and 15th, Larks, with Thrushes and other birds, about light at night; 
gloomy weather; some birds killed striking-[Leg and wing of Lark received, killed striking March 12th]: 24th, Larks, with Starlings and other birds, about light; wind light E., wist. July 6th, four Larks about light at midnight; light breeze S.W., rain. November 27th, flocks going N.W.; wind fresh E. Arklow South Light-ship.-January 6th, one rested on ship: 26th, one going E. Feuruary 14th, a few about light: 15th, one rested on ship: 16th, one disabled striking at 10 P.M. [Leg and wing received]: 17th, Larks about light; wind light S., gloomy. March 11th, 12th, and 13th, Larks, with Thrushes, Blackbirds, and Starlings, striking during night, falling overboard and on deck; heavy rain. April 18th, Larks, Swallows, and Thrushes going N.W. at 5 A.M.; calm, hazy. September th and 5th, a few Larks about light during night and morning; wind light N.E., haze: 28th, two going N. October 9th, one groing N.W.; rested on ship : 20th; several flocks of Larks and "G. Linnets" all day going N.; a very few about the light at night; wind N.E., clear: 23rd, flocks of Larks and Linnets going N. during day; wind strong W., sleet. November 17th, flock of Larks going N.W. December 27 th, a few about light from 8 P.M. to midnight.

Arklow North Light-ship.-October 24th and 25th, a few flocks, apparently Larks, going N.IV.; wind fresh N.: 27th, a large quantity of do.; some Chaffinches on board during day: 31st, several do. during day; three Chaffinches lit on board. November 6th, a Starling, a Lark, and a Chaffinch on board; wind light: 7th, two Larks going N.W. at noon; one killed by Sea Gull : 25th, one on board. December 17th, flocks of Larks and Grey Linnets going N.W.; wind N.W.: 26th, several flocks of Larks going N.W.; fresh breeze S.W.

Codling Bonk Light-ship.-February 12th and 13th, one on ship. March 9th, three going S.: 11th, one "Ground Lark" about ship: 14th, two Skylarks lit on ship : 17th, one going W.: 21st, one "Ground Lark" going N.W.: 30th, one "Ground Lark" about ship; flew W. July 19th, one Lark going N.W. September 7th, four on ship. October 1st, flock going S.W.: 3rd, flocks going W.; light breeze S.W.: 7th, one going W.: 10th, flocks going W.; strong breeze N.E.: 11th, great flocks of Larks and Chaftinches going W. from 9 A.M. to 11 A.M.; strong breeze N.E, hail: 13th, flocks of Larks and Chaffinches going 
W. from 9.30 A.M. to 11.30 A.Mr. one Lark killed; wind N.E.: 15 th and 16th, flocks of Larks going W.: 17th, great flocks going N.W. : 19th, great flocks, going "variously"; strong wind N.E.: 21st, flocks: 22nd, numbers of Chaffinches and Larks going W. November 4th, several flocks of Larks going W. all day; wind variable: 17 th, flock going W.: 29th, one striking; fell overboard.

Rockabill.-October 6th, six going N.W. November 25th, four on rock. December 3rd, two Starlings, one Blackbird, one Thrush, and one Skylark killed striking. With these exceptions, there were "no birds killed striking during October, November, and December."

South Rock Light-ship.-January 3rd, two about light; one killed striking: 7th, five about ship. February 5th and 12th, several about lantern: 13th, " a lot of Larks, Thrushes, etc., about lantern"; wind light S., haze: 14th, several going W.; flocks of Larks, Thrushes, and Blackbirds during night about lantern; a great many killed and falling overboard; wind light N.W., clear: 15th, a few going N.W. by day; wind light N.W., fog: 16th and 17th, some at light: 19th, a few do. November 4th, 5th, and 6th, several during day, generally going N.W.: 9th, two going N.W.: 11th, two going N.W.: 13th and 14th, several about light: 16th, flock going N.W.: 17th, Larks and Chaffinches going N.W. during day; wind moderate S.W.: 22nd some about light: 24 th, four going N.W.

Innishtrahull.-February 29th, flock on island all day; wind light S.W. August 27th, flocks on island all day; wind light N.

Rathlin O'Birne.-October 14th, large numbers of Skylarks all day going S.; moderate breeze N.E., clear: 22nd, twelve going W.: 29th, ten going N.; wind fresh N.E.

Samplire Island.-March 6th, one in coal-house, very exhausted; caught by children; gale N.W.

Snow Bunting (Plectrophenax nivalis, Iinn.).

Rockabill.-[February 27th, Snow Bunting received in flesh; "caught on lantern about a week ago."] October 29th, two on rock; fresh breeze N.E.

Innishtrahull.-[April 4th, two received in flesh; shot. Same 
date, Leg and wing received. "The last on the island; none ever remain later than the end of April."]

Rathlin O'Birne.-October 4th, two on island all day ; "young birds"; strong breeze S.W.: 19th, ten all day; great gale N. : 23rd, eleven going N. November 14th, six going E.; wind moderate S.

Broadhaven.--October 12th, two flocks near station.

Blackrock, Mayo.--September 28th, one "killed by a cat"; found dead; fog-[Leg and wing received]. November Sth, Snow Bunting observed, remaining.

Skelligs.-November 16 th, three on rock; wind light N.: 27 th, two.

\section{Reed Bunting (Emberiza schoeniclus, Linn.).}

Blackwater Bank Light-ship.-[March 12th, Leg and wing of Reed Bunting received, killed striking.]

\section{Yellow Bunting (Emberiza citrinella, Linn.).}

Coningbeg Light-ship.-January 8th, one rested at 10.30 A.M. ; Hew N.E. ; wind moderate N.E., clear. February 8th, two going N.E. ; wind moderate S.W.

Tuskar:-November 23rd, one flew into kitchen at noon; wind fresh N.E. [Received in flesh.]

Rockabill. - November 5th, one on rock; light breeze N. December 10th, two; strong breeze S.

Innishtrahull.-April 6th, four on island all day; gale W. August 2nd, three do. ; wind light N.

\section{Chaffinch. (Fingilla coelebs, Linn.).}

Festrut. - November 5th, numbers, with Starlings, about lantern; wind light $\mathrm{E}$.

Coningbeg Light-ship.-February 11th, two going N.E.; fog. March 10th, one about ship: 11th, one do. ; went N.E. : 14th, two do.; went N.E. April 19th, one rested; went N.E. May 5th, one on deck; went N.E. : 17 th, two going N.E. September 7 th, four about ship at 8 A.M., and one on deck in the evening; flew N.E. October 13th, one about ship; Hew N.W.: 22nd, two do.; flew N.W.: 23rd, one, and 27th, three rested: 28th, one hen 
Chaffinch about ship; flew N.W. November 1st, one Chaffinch about ship: 4th, five rested; flew N.E. December 18th, one about ship; flew N.E.

Barrels Rock Light-ship.-October 20th, two at 4 P.M. going N.; rested on board all night; wind moderate N.W.: 21st, several, with Green and Grey Linnets, going N.W. at 7.30 A.M. ; rested on board for three hours and went for the land; wind fresh N., hail : 22ud, four going N.W.

Tuskar.-October 20th, Chaffinches round light at 10 P.Mr.; one killed; wind fresh N.E., clear.

Blackwater Bank Light-ship.-February 13th, flock going N.W. November 3rd, one on deck; went N.W. December 11th, two about ship.

Arklow South Light-ship.-October 17th and 19th, great rushes of small birds all day going $\mathbf{N}$.; a very few about the light, none struck; a few Chaffinches rested on ship and flew $\mathrm{N}$. ; wind moderate $\mathrm{N}$. : 25 th, four on ship.

Arklow North Light-ship.-October 27th, some on board during day: 30th and 31st, flocks of small birds; three Chaffinches on board on 31st. November 3rd, a few going N.; two on board: 5th, one on board all night: 6th, one all day. December 14th, three on deck.

Codling Bank Light-ship.-February 13th, four going W. October 11th, great flocks of Larks and Chaffinches going N.W.; strong breeze N.E., hail: 12th and 13th, flocks of Chaffinches going N.W.; strong breeze N.E., hail : 17th, many going N.W. wind moderate N.: 19th, some noted: 20th, Chaffinches and "Bullfinches" on ship; wind fresh N.E., showers: 21st, Chaffinches going N.W., wind moderate N.: 22nd and 23rd, numbers going N.W.; wind fresh N.E. : 27th, three on ship: 29th, one do. November 2nd, a flock going N.: 5th, a flock going N.W.: 10th, some round light, struck and fell overboard; wind light W., clear: 14th, flock going W.; gale S.W., thick rain: 20 th, some going W.: 25 th, one going W.

Rockabill.-September 30th, five on rock. October 17th, seven, with two Greenfinches, a Redwing, and a Fieldfare; wind fresh N.W., clear: 24th, four on rock. December 24th, six do.

South Rock Light-ship.-February 18th, several on deck; wind light S. November 2nd, one going W.: 12th, one going 
N.W. : 17 th, several going N.W. during day; wind light S.W.: 26 th, one going N.W.

Innishtrahull.-February 10th, four on island; strong breeze N.W.

Blackrock, Mayo.-November 5th to 18th, Starlings, Green Linnets, Chaffinches, a few Thrushes, and Blackbirds visited rock; wind generally E. to S., very cold.

Skelligs.-September 20th, six on rock; light breeze N.: 22nd, three; gale S.

\section{Brambling (Fringilla montifringilla, Linn.).}

Innishtrahull.-February 4th, two flocks of Brambling all day on island; wind moderate S.W. March 18th, eight all day; wind strong W.

Tree Sparrow (Passer montanus, Linn.).

Tuskar,-October 22nd, Tree Sparrow caught exhausted on rock at 5 P.II., came from S.E. ; strong breeze N. [Received in Hesh.]

House Sparrow (Passer domesticus, Linn.).

Tuskar.-October 22nd, one killed striking.

Arllow South Light-ship.-May 8th, one at 10.45 A.M., was about ship for a couple of hours, going N.W. ; wind light N.E., haze.

GreENFINCH (Ligurinus chloris, Linn.).

Barrels Rock Light-ship.-October 21st, some Green and Grey Linnets, with Chaffinches, at 7.30 A.M., rested on board for three hours, and went N.W. for the land; fresh breeze N., hail.

Tuskar.-December 23rd, Green Linnet killed at light; moderate breeze S.W., showery. [Leg and wing received.]

Arlilow North Light-ship.-May 30th, one "Green Linnet" on deck during forenoon.

Rockabill.-October 17th, two, with some Chaffinches and a Redwing and Fieldfare, on rock. December 30th, two on rock; wind S.W., strong.

South Roch Light-ship.-September 8th, one Green Linnet going N.W.; wind light E, haze. 
Blackrock, Mayo.-November 5th to 18th, Green Linnets, with other birds, visited rock; wind E. to S., very cold (see under Chaffinch).

GoLdFinch (Carduelis elegans, Steph.).

Fastnet.-November 4th, one caught in kitchen; wind light E., gloomy.

Samphire Island.-January 3rd, "three Goldfinches and six Grey Linnets" going N.E.; wind moderate E. July 17th, one in garden.

\section{"LiNNETS."}

Coningbeg Light-ship.-May 18th, two "Grey Linnets" going N.E. at 11 A.M, September 6th, two "Linnets" going N.E. : 18th, three do. going S.W.: 20th, seven "Linnets" going W.: 30th, one flying N.W. October 3rd, flock flying N.W.: 15th, two rested on ship and flew N.W.: 21st, large flock flying N.; wind light N.E. : 22nd, large flock flying N.: 23rd and 27 th, a flock flying N. November 9th, large flock flying N.W.; wiud light N.E. December 19th, one rested; flew N.W.

Barrels Rock Light-ship.-October 21st, Green and Grey Linnets, with Chaffinches, at 7.30 A.M., rested on board for three hours, and went N.W. for the land.

Tuskar.-October 19th, flocks of "Grey Linnets" going N.W.: 23rd, flocks of "Linnets and Twites" going N.W.: 27th, "Grey Linnets" and Larks on rock at 8 A.M.

Arklow South Light-ship.-October 20th, several flocks "G. Linnets" all day going N.; a very few about the light at night; ivind N.E.: 23rd, flocks going N. during day; sleet: 31st, small flocks going N.; fresh breeze N. November 17th, four going S.W.

Arklow North Light-ship.-December 9th, flocks Grey Linnets going N.W.; strong breeze N.W.: 17th, flocks going N.W.: moderate breeze N.W.: 20th, some going N.W.: 30th, flocks going N.W.; gale S.W., rain.

Codling Bank Light-ship._-January 28th, three going N.E. South Rock Light-ship.-March 22nd, several going W.: 30th, one flying E., followed by Hawk; "suppose Hawk to have chased Linnet from the land"; wind light S.E., clear.

Blacksod Point.-October, Linnets going N. 
Samphire Island.-January 3rd, six going N.E.: 19th, two on island: 20th, six do. February 16th, two.

\section{TwITE (Linota flavirostris, Linn.).}

Rathlin O'Birne.-October 20th and 23rd, about twenty going N. each day; wind light N.E., clear: 26th, fifty going E.; wind moderate N.E. : 27th, thirty going E. ; one killed (? striking); wind fresh N.E., clear. November 5th, thirty all day; wind light N.: 10th and 12th, forty all day: [26th, one male and two female Twites received in flesh].

\section{"BULLFINCH."}

Codling Bank Light-ship.-October 20th, Chaffinches and "Bullfinches" on ship during day; fresh breeze N.W.

Innishtrahull.-March 16th, one "Bullfinch" on island; wind moderate W,

Starling (Sturnus vulgaris, Linn.).

Fastnet.-November 5th, numbers about lantern; wind light E., gloomy.

Dungarvan.-November 19th, large flocks about all day; wind fresh S.W., gloomy. December 1st, large flock do.; gale S.E.: 4th, hundreds feeding at 9 A.M.; fresh breeze N.E.: 17th, large flock: 22nd, several flocks all day: 28th, great numbers all day about station.

Coningbeg Light-ship.-March 10th, one killed striking at 11 P.M. ; wind light S.W. : 12th, large number about light from 1.30 A.M. to 6 A.M.; twelve killed striking; wind light N.E., rain : 13th, Blackbirds, Thrushes, and Starlings about light from 1 A.M. to 5 A.M.; a very large number of each kind struck; wind light S.W., rain: 14th, Starlings about light; wind light N.E. September 6th, two going N.E. October 13th, a flock going N.: 14th, do. N.W.: 15th, three do. N.W.: 16th, one killed striking at 2 A.M.: 17th, flock going N.W.: 19th, two flocks going N.: 21st and 27th, a flock going N.; wind generally N.E. : 28th, a flock flying N.E. : 29 th, a flock flying N.: 30th, one about ship; flew N.; chased by Gulls. November 3rd, one about ship; flew N.: 9th, flock going N.W.: 17th, several about light; fog: 25 th, one about ship: 
26th, several about light from 6 P.M. to midnight; gloomy: 27 th, several about light from 5.30 P.M. to 11.30 P.M. ; gloomy: 30th, six about light. December 1st, flock going N.E.: 9th, several about light from 5 P.M. to 5 A.M.; some killed, fell overboard; strong gale N.E., rain: 18th, two about ship; went N.W.: 19th, three about ship; went N.W.: 26th, several, with Thrushes, about light from 6 P.Mr. to midnight; wind moderate N.W., rain.

Barrels Rock Light-ship.-October 20th, large flock going N.

Tuskar.-March, some killed striking. October 19th, flocks going N.W.: 20th, some going N.W. at 10 P.M.; fresh breeze N.E., clear: 23rd, some going N.W.: 29th, Starlings, Blackbirds, and Larks all night, striking on N.W. side of lantern; wind light N.W., gloomy: 31st, do., striking on S. side; strong breeze N.E., rain. November 2 nd, Starlings and other birds round light at 2 A.M.; gloomy; some killed and disabled. December 13th, flocks going N.W.

Blackwater Bank Light-ship.--January 26th, some about light from 9 P.M. to 11 P.M.; fresh breeze S.W., drizzling rain. February 6th, Starlings and. Thrushes about light; wind moderate S.W., gloomy : 9th, Starlings about light from 9 P.M. to 10 P.M.; moderate breeze S.W. March $11 \mathrm{th}, 12 \mathrm{th}, 13 \mathrm{th}$, and 14th, some, with Thrushes and other birds, about light each night-[12th, Leg and wing of Starling received, killed striking]: 19 th, Thrushes and Starlings going W.: 24th, several Starlings, Thrushes, Larks, and Blackbirds about light; wind E., fog: 30th, Starlings about light; wind S.W., gloomy. October 23rd, some about light from 9 P.M. to 11 P.M. ; wind fresh S.W.: 25th, about light from 7 P.M. to 10 P.M. ; wind fresh N.W. November 16th, some, with Thrushes, about light from 7.30 P.M. to midnight; wind light N.E.: 22nd, flocks going N.W.: 25th, about light from 6 P.M. to 8 P.M. ; wind light E., gloony : 26th, flock going N.W. December 13th, a few about light: 20th and 24th, flocks going N.W.

Arklow South Light-ship. - March 11th, 12th, and 13th, Starlings, with Thrushes, Blackbirds, and Larks striking during night, falling overboard and on deck; heavy rain. October 21st, large flocks of Starlings during day going $\mathrm{N}$.: wind N.E., showery: $22 \mathrm{nd}$, flocks during day going N.; wind fresh N.E., sleet: $23 \mathrm{rd}$, flocks of Starlings, Larks, and Linnets 
going N.; wind strong S.W., sleet: 31st, flocks of Starlings going $\mathrm{N}$.; wind fresh N. November 16th, one flock going N.E. December 15th, a few flocks going N.: 18th and 19th, large flocks going N.W. ; wind fresh N.E., sleet.

Arklow North Light-ship.-November 3rd, a few going N.: 5 th, some at night: 25 th, a few, with other birds, about light. December 1st, two about light: 9th, flocks of Starlings and Grey Linnets going N.W. during day; strong breeze N.W.: 10th, flocks of Starlings and Lapwings going N.W.; strong breeze S., haze: 14th, two on deck: 29th, several about light: 31st, flocks going N.E. during day; fresh breeze S.W.

Codling Bank Light-ship.-February 3rd, one at light: 6th, one on ship. March 13th, three caught at lantern at 10 P.M. : 15 th, one about ship. October 7 th, four on ship: 12th, some do.: 16th, one killed striking; strong breeze N.E. : 19th, great flocks going W.; strong breeze N.E., showers: 20th, some on ship during day: 23rd, numbers of Starlings and Chaffinches going N.W.; light breeze N.W., showers : 26 th and 27 th, flocks going N.W.; wind N.W. November 14th, several flocks going W. ; gale S.W., thick rain : 26th, three going N.W.: 28th, one going N.W. December 29th, flock going N.W.

Rockabill.-October 9th, eight on rock: 24th, twelve do.; fresh breeze S.W. November 21st, four. December 3rd, five at light; two killed striking

South Rock Light-ship.-March 12th, one at light; wind light E.

Innishtrahull.-January 21st, nine on island all day; wind moderate S.E.

Rathlin O'Birne.-October 23rd, very large flock of Starlings going S.; wind fresh N.E. : 31st, three very large flocks going E. between 9 A.M. and 11 A.M. ; "these were the largest flocks I ever saw; I should say about two thousand were in one flock, it was like a cloud"; wind fresh N.E., clear. November 30th, about forty Starlings going W.; wind strong E., clear.

Blackrock, Mayo.-November 5th, some visited rock, remaining until the 18th; very cold wind S.E.

Blacksod Point.-October, Starlings going N.

Arran Island, N.-September 10th, flock going S., and at night two struck lantern: 12th, flock all day : 22nd, flock going S.; gale W. October 4th, flock going do.; gale W.: 30th, large 
flock all day. January 1st, 1897, "since September a few (about six) Starlings have frequented the island almost daily."

Samphire Island.-January 1st, six going N.E.: 7th, two on island: 19th, three. February 29th, a large flock; gale N.W. March 3rd, large numbers all day; strong gale N.W., hail : 12th, some about light; four struck; wind fresh N.W.

Skelligs.-September 30th, one at 2 A.M. on lantern sash; seven on rock; wind light E. October 20th, large flock on rock; wind light N. December 18th, large numbers on rock; wind light $\mathrm{N}$.

Chodgh (Pyrrhocorax graculus, Linn.).

Arklow North Light-ship.-June 10th, two "Jackdaws (redlegged)" going N.W. at 8.30 A.M. ; moderate breeze N.E., light haze.

Skelligs.-September 23rd, five on rock; strong breeze N.W. October 29th, six. December 11th, six.

\section{RaVen (Corvus corax, Linn.).}

Coningbeg Light-ship.-November 18th, one going N.E. at 4.15 P.M. ; wind moderate, clear.

Arran Island, N.--September to December, "one Raven, never leaves island."

Shelligs.-October 6th, two on rock; wind moderate N.W.

\section{HOOdED CRow (Corvus comix, Linn.).}

Innishtrahull.-September, two Grey-backed Crows

Samphire Island.-July 11th, one "Carrion or Hooded Crow" going S.W.

Sleelligs.-December 23rd, two on rock.

Rook (Corvus frugilegus, Linn.).

- Coningbeg Light-ship.-April 19th, two "Crows" passing at 7.30 A.M. ; wind light N.E.

Tuskar-October 22nd, "Crows" going N.W. at 9 A.M. November 12th, going N.W. at 10 A.M.

Arklow South Light-ship.-May 27th, two "Crows" going N.W. ; wind moderate N.E. 
Codling Bank Light-ship.-March 22nd, one going N., making a great noise; calm. April 3rd, 7th, and 27th, one "Crow" going N.W. October 17th, great flocks of "Crows" going N.W. from 9 A.M. to 10 A.M. ; wind moderate N., showers.

Rockabill.-November 21st, one going N.W. at noon.

Innishtrahull.-March 24th, flock going S. at 10.30 A.M.; light breeze S.W.

Arran Island, N.-September to December, two "Crows" frequent the island.

\section{JACKDAW (Corvus monedula, Linn.).}

Skelligs.-September 29th, large numbers going E.; wind strong S.W.

\section{Magpie (Pica rustica, Scop.).}

Skelligs.-October 25th, one Magpie on rock at 2 P.M.; wind fresh N.W.

\section{SWALLOW (Hirundo rustica, Linn.).}

Coningbeg Light-ship.-April 30th, one going N.E. May 1st, several do.; wind light N.E.: 5th and 6th, one going N.E.: 9th, several going N.E.; wind light N.E.: 10th, several going N.E., and flying round ship: 11th, four going N.E. ; wind light N.E. : 13th, four going N.E.: 22nd, two going N.E. June 14th, five going N.E. August 26th, one going N. September 1st, two going N.W.: 3rd, two going N.E. : 6th, three going N.E. : 7th, large flock going S.; wind light S.E. : 19th, several going S.W.; fresh breeze N.W.: 20th, six going S.W.: 24th, four about ship : 27 th, one, and 28 th, two, rested and flew S.E.

Barrels Rock Light-ship.-May 10th, several going N.W.; wind light N.E.

Tuskar. - March 31st, Swallow noted "coming across." September 13th, some all day going S.E.; light breeze E., gloomy: 20th and 21st, some going S.E.: 27th, some going N.W.; light breeze E., clear. October 12th, some going N.W. at noon; fresh breeze N.W., clear: 14th, some all day going N.W.; fresh breeze N., gloomy.

Blackwater Bank Light-ship. - April 13th, one at 11 A.M. going N.W.; wind light N.W., clear: 18th, two, with Wheatears 
and Sedge Warblers, about light between midnight and 4 A.M. May 14th, two going W.: 17th, one noted: 24th, two.

Arklow South Light-ship.-April 18th, Swallows noted going N.W. at 5 A.M.; calm, hazy: $20 \mathrm{th}$, odd Swallows going N.W. all day; calm, clear: 24th and 25th, several going N.W.; wind light, variable. May 8th, 23rd, 24th, and 29th, a few going N.W. June 2 nd, one about ship. July 1st, three going S. at 8.30 A.M. August 11th, 13 th, 17th, 18th, 23rd, and 30th, a few noted each day going S.E.; wind N.W. to S.W. September 14th, 19th, and 28th, a few noted. October 9th, one going S.W. ; gale S.W., clear.

Arklow North Light-ship.-April 19th, two in afternoon; calm : 20th, four do.: 28th, about twelve going N.W. May 8th, three going N.W. at sunset: 9 th, two about ship: 14th, several going N.W.: 24th, some going N.W.: 25th, several going N.E. during forenoon. June 2nd, three going N.W.: 3rd, five noted.

Codling Bank Light-ship.-March 30th, one going N. at 9 A.M. ; wind light S.E., clear; "the first seen this year." April 19th, several: 20th, two: 21st, one: 26th, lots of Swallows: 30th, one. May 7th, one: 9th, several large Swallows [Possibly Swifts-R. M. B.]: 10th, 11th, 23rd, and 26th, some noted. June 2nd, 8th, and 26th, one. September 20th, two going N.W. October 1st, several going S.W.; fresh breeze N.W., clear: 3rd, several going W. ; light breeze S.W., clear.

Rockabill.-September 6 th, four on rock at 2 P.M.

South Rock Light-ship.-September 14th, a number going W. ; wind fresh S.W., rain: 16th, one going W.

Scmphire Island.-May 18th, eight at 9.30 A.M. ; "first seen this season"; strong breeze N.W., shower: 21st, 22nd, and 30 th, and June 12th, Swallows noted.

House Martin (Chelidon urbica, Linn.).

Coningbeg Light-ship.-May 12th, two Martins going N.E. .14th, five round ship at 4 A.M. ; went N.E. June 24 th, three about ship at 7 P.M. ; flew N.W.

Barrels Roch Light-ship.-May 11th, three House Martins going N.W. at 7 P.M. ; wind moderate N.E.: 13th, one going N.W.: 19th and 23rd, four going N. at 7.30 P.M. June 1st, two small flocks going N.W.; wind light N.E., clear. 


\section{SwIFT (Cypselus apus, Linn.).}

Codling Bank Light-ship.-May 9th, several large Swallows going N. all day [Possibly Swifts-R. M. B.]; wind N.E., hazy.

Samphire Island.-May 16th, six at noon; "first seen this season"; calm, clear.

NightJaR (Caprimulgus europoeus, Linn.).

Samphire Island. - April 16th, a Goatsucker flying about island at 7 P.M. ; gale W., clear.

Cucкоo (Cuculus canorus, Linn.).

Coningbeg Light-ship.-May 1st, one going S.W. at 12.30 P.M. flying close by ship; calm.

\section{WRYNECK (Iÿnx torquilla, Linn.).}

Rockabill.-September 5th, strange bird killed striking at 1 A.M. ; wind moderate E., hazy. [Wryneck received in flesh.]

TurTle Dove (Turtur communis, Selby).

Fastnct. - September 28th, two Turtle Doves about rock during day; wind strong $\mathbf{E}$.

Old Head, Kinsale.-May 10th, Turtle Dove shot. [Received in flesh.]

\section{"Pigeons."}

Coningbeg Light-ship.-May 7th, two Pigeons going N.E. at 1.30 P.M.; wind light N.E., clear. November 18th, one about ship during fog; flew N.E.

Barvels Rock Light-ship.-January 8th, one Carrier Pigeon; "struck one of ship's shrouds at 6 P.M., and fell on deck, kept it all night, and on the 9 th let it go; it flew N.W.; No. on leg S950,33." May 29th, one Carrier Pigeon lit on board at 5 P.M.; remained fifteen minutes, and flew $\mathrm{N}$.; wind moderate N.E., clear.

Blachwater Bank Light-ship.-February 18th, one Pigeon about light at 3.30 A.M. ; wind light S.E., gloomy.

Arklow South Light-ship.-June 13th, two tame Pigeons at 6 P.M. going N.; rested for the night; wind light N.E., clear. 
"Caught one on morning of 14th; on its leg was a metal ring marked 762-P94D, and on second feather of wing PG278. Kept this bird till July 27th; it then flew off, and was not seen afterwards until September 1st, when it was brought back, having been caught at a farm-house."

Codling Bank Light-ship.-September 17th, one Pigeon going W. ; fresh breeze S.W., clear.

Innishtrahull-April 13th, two on island. June 18th, two.

Conn-Crake (Crex pratensis, Bechst.).

Tuskan:-[October 25th, Leg of Corn-Crake received.]

WATER-RAIL (Rallus aquaticus).

Coningbeg Light-ship.-November 2nd, a strange bird killed striking at 2.15 A.M. ; wind moderate N.E., clear. [Water-Rail received in flesh.]

Rathlin Island. - April 29th, one caught. [Received in flesh.]

Rathlin O'Birne.-December 3rd, one "Land-Rail" all day; gale S.E., clear. [Probably Water-Rail.-R. M. B.]

WATER-HEN (Gallinula chloropus, Linn.).

Mine Head.-[December 2nd, Water-Hen received in flesh: caught by light-keeper in gas-yard.]

Ringed Plover (Afgialitis hiaticola, Linn.).

Blackrock, Mayo._July 28th, one found dead. [Leg and wing received.]

\section{Golden Plover (Charadrius pluvialis, Linn.).}

Dungarvan.-December 15th, three going S.W.; first seen this season; wind light W.: 18th, numbers heard going S. at 1 A.M. ; wind light W., clear; heavy frost.

Coningbeg Light-ship._February 4th, several Grey Plover passing N.E. at 9 P.M. and 11 P.M. ; wind light S.W.

Innishtrahull.-March 6th, four on island; strong wind S. July 16th, eight do. August 29th, three all day; one killed.

Rathlin O'Birne.-October 6th, twenty going S. at 4 P.a.; 
wind strong S.W.: 8th, three going E.; gale S.W. : [12th, one shot, received in flesh].

\section{Green Plover (Vanellus vulgaris, Bechst.).}

Dungarvan.-December 13th, a large flock close to station at noon; first seen this season; strong gale S.E.: 16th, several heard passing N.E. at 9 P.M. ; seemed to be flying high, as they were not visible; wind light W., clear moonlight: 19th, a flock going N.E. at 9 P.M.; wind light N.W., heavy frost: 20th, numbers about fields all day.

Coningbeg Light-ship.-December 8th, one going N.E.

Barrels Rock Light-ship.-January 9th, several flocks going N. from 10 A.M. to 4 P.M. ; wind moderate N.E., clear.

Blackwater Bank Light-ship.-January 5th, flock of Plover about light from 8 P.Mr. to 10 P.M.; wind light S.W., gloomy. April 2nd, flock going N.W. at 9 P.M.; moderate breeze N.W. November 30th, flock of Lapwings about light at 11.30 P.M.; fresh breeze S.E., clear. December 1st, flock about light at 11 P.M. ; gale S.E., rain: 28th, a large flock of Plover at noon, flying low for the Irish land; strong breeze N.E., showery.

Arklow South Light-ship.-December 27th, one large flock of Green Plover going N. at 8.20 P.M. ; flew about the light for a few minutes; wind moderate S.W., showers.

Arklow North Light-ship.-December 10th, flocks of Starlings and Lapwings going N.W.; strong breeze S., light haze: 21st, a great number of Lapwing going $N$. during forenoon; fresh breeze S.E., clear.

South Rock Light-ship.-February 26th, three going N.W.; wind light N.W., clear.

Innishtrahull. - January 19th, one. February 24th, five. July 27th, two. August 30th, two.

Blacksod Point.-December, some Plover going N.E.

Samphire Island.-January 28th, a large flock going N.; wind moderate N.W.

TuRnstone (Strepsilas interpres; Linn.).

Dungarvan.-December 15th, three on rocks.

Samphire Island.-March 8th, four noted; heavy gale W.: 11 th, twenty. 
Oyster-CATCher (Homatopus ostralegus, Linn.).

Dungarvan.-November 28th, about a hundred going N.E.; strong gale E., gloomy. December 10 th, six on rocks.

Samphire Island.-January 3rd, large numbers.

Grex Phalarope (Phalaropus fulicarius, Linn.).

Skelligs.-October 8th, three Phalaropes seen in water at 2 P.M.; gale W. November 15th, two seen in water at 1 P.M.; strong breeze S.W.

Woodcock (Scolopax musticula, Linn.).

Tuskar.-October 22nd, one on rock at noon, disabled; wind fresh N., clear.

Innishtrahull.-June 4th, one at 7 P.M. on island; wind moderate S.E.

Skelligs.-October 11th, one on rock at $11 \mathrm{~A}, \mathrm{Mr}$.; wind moderate N.E. November 3rd, two at 3.30 P:M.; wind light E. December 4th, one; wind N.W.

Common Snipe (Gallinago calestis, Frenzel).

Fastnet.-September 8th, one killed striking; fresh breeze E., mist.

Arklow South Light-ship.-February 16th, one going N.W. at 11.30 A.M.

Innishtrahull.-February 19th, one. April 23rd, three. June 21st, three at noon. July 8th, four.

Rathlin O'Birne-October 6th, seven Snipe going S.; fresh breeze S.W.: [12th, Common Snipe received in flesh]: 28th, seven all day on island; wind moderate N.E., clear. November 9th, four; went S. in the evening. December 1st, one going S.: 10th, three going W.: 21st, ten going W.: 22nd, seven going $\mathrm{S}$.

JACK SNIPE (Gallinago gallinula, Linn.).

Rathlin O'Birne.-November 18th, one going S. December 24 th, two remaining on island. 
DUNLIN (Tringa alpina, Linn.).

Fastnet.-November 5th, one Sand Lark disabled striking at 2 A.M.; wind light E., gloomy. [Leg and wing of Dunlin received.]

Dungarvan.-December 15th, six Dunlins on rocks.

Rathlin O'Birne.-[September 9th, Dunlin, sent as strange bird, received in flesh.]

Samphire Island.-March 11th and 27th, four on island.

Кнот (Tringa canutus, Linn.).

Thstiar--[March 13th, Leg and wing of Knot received, killed striking.]

Samphire Island.-February 22nd, a large flock of "Knots" going S.E. at 5 P.M.

\section{"SANd LaRks."}

Coningbeg Light-ship.-March 25th, one Sand Lark rested; flew N. September 9 th, six going S. October 11th, two rested two hours, and flew N.W.

Arklow South Light-ship.-June 7th, two Sand Larks going N. at 11 A.M.

Arklow North Light-ship.-May 12th, several Sand Larks going N.W. from 9 A.M. till noon. June 6th, two going N.W.; fresh breeze $\mathrm{S}$., clear.

Codling Bank Light-ship.-May 8th, one Sand Lark lit on ship's rail and fell overboard; light breeze N.E., haze.

Blackrock, Mayo.-November, Sand Larks observed every day. Arran Island, N.-November, some Strand Larks visit daily. December, some remain all the time.

\section{CURLEW (Numenius arquata, Linn.).}

Coningbeg Light-ship.-March 11th, flock going N.E. at 10 P.M.; flying high. August 1st, several going S.E.: 2nd, two going S.E.: 29th, Hock going N.; flying over ship at 9 P.M.; strong breeze S.W.

Blackwater Bank Light-ship.-February 18th, flock going N.W. at 9 P.I. March 15th, Curlew about light; wind fresh S.W., cloudy. July 3rd, flock at 9 P.M. going N.W.

Arklow South Light-ship.-January 5th, some about ship 
during night. February 17 th, heard during night. November 4th, some heard from 9 P.M. to 10 P.M.; gloomy.

Arklow North Light-ship.-May 12th, three going N.W.: 25th, three going N.E.

Codling Bank Light-ship.-March 10th, flock going N.W. at 9 P.Mr.: 17th, one going N. April 19th and 23rd, several. May 1st, one: 25th, one going N. June 24th and 25th, one going N.W. July 19th, one going W.: 25th, flock going N.W August 18th, three going W.

South Rock Light-ship.-February 11th, one about lantern at 9 P.M.: 26th, four going E. March 13th, three going W. November 30th, one about light at 10 P.M.

Innishtrahull.-July 20th, large flocks all day; wind fresh S.W.

Blackrock, Mayo.-August 31st, five going S. September 18th, seven going $\mathrm{S}$.

Samphire Island.-January 3rd, large numbers noted. March 31st, about fifty going S.W. August 1st, several heard at 9 P.M. ; misty.

WHIMbReL (Numenius phoopus, Linn.).

Coningbeg Light-ship.-May 22nd, six Maybirds going N.E. at 9 P.M.; wind light N.E.

Barrels Rock Light-ship.-May 11th, several Whimbrel going N.W. at 10 P.M.; wind moderate N.E.: 14th, a flock of about twenty going N.W. at 10 P.M. June 5th, four going N.W. at 2 P.M.; lit on board for half an hour; wind light S.E.

Blackwater Bank Light-ship.-April 14th, flock going W. at 9 P.M.; wind fresh N.W. May 5th, flock noted.

Broadhaven.-September 10th, Whimbrel going S.; wind light S.W.

Blackrock, Mayo.-August 16th, three going S.W.; wind light S.W.

Samphire Island.-May 17th, four going N.E.; "first seen this season": 23rd, numbers about Fenit Point: 26th, four going N. July 9th, several heard passing E. at 11 P.M.: 20th, one: 25th, several going S.W.; gale N.E. August 1st, seven going S.W. : 2nd, three going S.W. at 5 A.Mr, and numbers going do. from 9 P.M. to 11 P.M.; wind light E., hazy: 5th, about a hundred 
going S.: 14th, four going S.W. at 5 A.M., flying very high ; numbers at 10 P.M.; wind moderate N.W.: 15th, numbers at 11 P.M. going S.W.; wind moderate N.W., cloudy: 17th, at present Whimbrels appear to be very numerous, all fiying S.W.

\section{"TERns."}

Dungarvan.-November 17 th, numbers of Terns about light at 10 P.M. ; wind light S.E., misty.

Tuskar.-August 3rd, two "Mews" noted.

Copeland (Mew) Island.-May 1st, the "Mew" or "Per" arrives about this date; builds on the island, and leaves about 1st October.

Innishtrahull.-May 18th, flock of Terns on island at 6 A.M. ; "first arrival"; light breeze N.E., fog. May 24th, "Sooty Tern"; light breeze $\mathrm{N}$.

Samphire Island.-July 8th, numbers of Terns about light at 10.30 P.M. ; wind moderate S.W., misty. August 11th, several "Sea-Mews" about light at 11 P.M. ; strong breeze W., mist.

\section{Glaucous Gulu (Larus glaucus, O. Fabricius).}

Rathlin O'Birne.-October 12th, Glaucous Gull shot at 11 A.M. ; wind fresh N.E., clear-[Received in flesh]: 23rd, two all day feeding round island; wind moderate N.E. : 27 th, one shot -[Received in flesh]: 30 th, one going S.; wind moderate N.E. November 3rd, one shot-[Received in flesh]. December 26th, one going W.; gale S.W.

\section{IcELAND GuLL (Larus leucoptemus, Faber).}

Rathlin O'Birne.-October 23rd, one Iceland Gull and two Glaucous Gulls all day; wind moderate N.E.: 30th, one Iceland Gull shot at 10 A.M.; wind fresh N.E., clear [Received in flesh]: 31st, one all day feeding round island; wind moderate N.E.

Skelligs.-December 27th, one Iceland Gull going S. at 3 P.Mr.

\section{"Gulls."}

Dungarvan.-November 25th, about a hundred Kittiwakes in lighthouse field. December 5th, about two hundred; mostly last year's birds. 
Coningbeg Light-ship.-October 22nd and 30th, Blackbird and Starling chased by Gulls.

Barrels Rock Light-ship.-June, Gulls constantly noted in large numbers.

Arklow North Light-ship.-April 13th, large number noted. May 10th, a few large Gulls: 13th and 26th, Gulls noted: 31st, and June 1st, Kittiwakes. June 3rd to 14th, Gulls frequently noted. November, several times noted: 7th, Lark killed by Seagull. December, frequently noted: 23rd, "Royal Gull" killed and ate a Blackbird.

Innishtrahull.-September, "Sea-fowl, same as other years, Herring Gulls, Kittiwakes, Black-backed Gulls, Puffins, Guillemots, Razorbills, two Grey-backed Crows, OysterCatchers, Redshanks."

Rathlin O'Birne.-December 30th, a large number of Gannets and Gulls fishing.

Blackrock, Mayo.-November, Gulls every day.

Samphire Island.-May 16th, eight Great Black-backed Gulls : 29th, great numbers of "Common Gulls:"

Manx ShearWater (Puffinus anglorum, Temminck).

Coningbeg Light-ship.-July 31st, two "Mackerel Cocks" flying round ship. August 6th, four about ship.

Barrels Rock Light-ship.-June 13th, 15th, and 24th, some about ship: 26th, many during forenoon. July 1st, four. October 22nd, flock of Shearwaters at 1 P.M. going W.; strong breeze N., clear.

Arklow South Light-ship. - April 21st, some "Mackerel Cock" flying about during day looking for fry. June Sth, Manx Shearwaters during day. August 4th, "Mackerel Cock" during day.

Arklow North Light-ship.-April 13th, a large number of "Mackerel Cock" at noon, feeding: 21st, a few: 29th, large flocks during day; wind fresh N.W. May 4 th and 5th, "Mackerel Cocks" during day; calm: 10th, a few: 11th, several Shearwaters during day; calm: 22nd, 23rd, and 29th, several do. fishing about ship. June 14th, a large number of "Mackerel Cocks" close to ship: 15th, large number during forenoon: 22nd, a few at 7 P.M. going S.W.: 25 th and 29 th, a few fishing. 
Codling Bank Light-ship.-March 15th, one Shearwater going N.E. at 5.30 A.M.: 24 th, a large flock at 2 P.M. going N.E.

Fork-Tateed Petrel (Cymochorea leucorrhoa, Vieill).

Fastnet.-May 5th, a bird caught at lantern at midnight. [Fork-tailed Petrel received in flesh.]

\section{Storm Petrel (Procellaria pelagica, Linn.).}

Coningbeg Light-ship.-May 22nd, two "Mother Carey's" about ship during day; wind light. June 17 th, one flew on board at 1.30 A.M.; thick, hazy. July 23rd, two astern at 6.30 P.M. : 29th, several astern at 6 A.M. ; wind fresh S.W. August 17th, four about ship; fresh breeze S.W. September 16th, large number about ship; wind moderate W.; "sure sign of very wild unsettled weather in channel ": 17th, several all day; strong breeze S.W., heavy sea: 18th, one: 21st, six. October 8th, seven; gale S.W. November 26th, two fell on deck and died; wind moderate $\mathrm{E}$.

Arklow North Light-ship.-May 27th, one feeding about ship.

Codling Bank Light-ship.-May 22nd, one about ship: 31st, one do. June 7 th, 16th, and 18th, one. July 25th, Storm Petrel about ship. September 25th and 27th, one about ship. October 9th, one.

Innishtrahull.—July 30th, one at 4 P.M. ; misty.

RAZORBILl (Alca torda, Linn.) and

Gulliemot (Uria troile, Linn.).

Fastnet. - December 24th and 25th, "large quantity of Razorbills going S. during day; wind strong S.W. to N.W., misty. As far as I have noticed, no Guillemots were mixed with them.-EDward RoHU."

Barrels Rock Light-ship.-May 26th, several flocks of "Murs" going N.W.: 27th, 28th, and 31st, "Murs" noted. Frequently noted during June. July 1st, about forty: 3rd, ten flocks of "Murs."

Arklow South Light-ship.-February 15th, a few Razorbills drifting past during day.

Arlelow North Light-ship._April 10th, "Murs" going N.E. : 13th, a large number noted: 18th, 21st, 22nd, and 23rd, a few. 
May 2nd, 3rd, 4th, 7th, and 9th, "Murs" noted: 29th, several Guillemots. June 13th, a few "Murs": 14th and 15th, a large number of "Murs": 25th and 29th, a few. November 10th, a few: 14th and 15th, flocks of "Murs": 24th, several "Murs." December 3rd, a few.

Samphire Island.-January 6th, seven fishing close to island; calm, clear.

\section{LitTle Auk (Mergulus alle, Linn.).}

Blackrock, Mayo.-[December 17th, Little Auk received in flesh, with letter dated 15/12/96; found uninjured near base of lighthouse, and died after being kept for two days.]

\section{Puffin (Fratercula arctica, Linn.).}

Barrels Rock Light-ship.-May 17th and 20th, large number of "Parrots" about ship during day: 22nd, some: 25th and 27th, and June 2nd, 8th, 24th, and 28th, "Parrots" noted.

Arklow South Light-ship.-March 29th, "Sea-Parrots" seeu for first time. April 16th and 17th, numerous flocks going N.; wind light N.W., clear.

Arklow North Light-ship.-April 22nd, "Parrots" during day: 23rd, 26th, 27th, and 29th, a few. May 13th and 26th, "Sea-Parrots" noted. December 13th, some "Sea-Parrots" [Razorbills ?] around ship; wind light S.W., clear.

Samphire Island.-January 5th, two: 6th, one, with seven Razorbills, fishing near island; "very seldom seen this season of the year so close to land-George Dunleavy"; calm, clear. July 12 th, two noted.

\section{Great Northern Diver (Colymbus glacialis, Linn.).}

Dungarvan.-December 3rd, four close to station : 13th, four ; strong gale S.E.

Ar7low North Light-ship.-May 13th, several "Northern Divers" fishing during day: 26th, several. June 3rd, a great number of "Northern Divers" and other sea-fowl near ship during day. December 19th, some about ship: 28th, some about ship; gale $\mathrm{N}$.

Rathlin O'Birne.-October 21st, one going N.; wind strong N.E. December 5th, one going S. 
Inishgort.-March 1st, "there are lots of Northern Divers here, large and small."

Samphire Island.-January 5th, numbers all day ; wind light E., clear. February 11th, one noted. March 8th, ten. April 8 th, one, "showing a great portion of its summer plumage."

Conmorant (Phalacrocorax carbo, Linn.) and ShaG ( $P$. graculus, Linn.).

Dungarvan.-November 19th, eight Comorants going S.W. December 15th, nine brown Comorants fishing:

Coningbeg Light-ship.-May 24th, large flock Comorants going S.E. at 4.30 A.M. ; wind light N.E., clear ; "not usual to see them going that-route." July 9th, a large flock passing ship flying S.E.; wind light S.E., clear: 14th, flock flying S. at noon; wind light S.W., clear. September 20th, six going N.E.

Tuskar:-December 9th, Cormorants landed on rock at 10 A.M. ; the first this winter.

Arklow South Light-ship.-May 8th, one Cormorant going E. 30th, two going N.E. August 3rd, one going N.E. September 18th, one going S.W. December 7th, two going N.W.

Arklow North Light-ship.-December 25th, one Cormorant about ship in forenoon; "rare bird to be seen so far from shore"; fresh breeze N.W., clear.

Blackrock, Mayo.-November, Cormorants observed every day.

Samphire Island.-August 13th, six going N.; "first seen for some time"; gale N.W.

Gannet (Sula bassana, Linn.).

Coningbeg Light-ship.-January 24th, several about ship. April 6th, two going N.W. June 25th, four going N.W. July 10th, two young ones going S.W. August 3rd, several fishing: 10 th, several going $\mathrm{E}$.

Barrels Rock Light-ship.-May 22nd, a few: 27th, some going W. July 3rd, two going W. : 5th, six going S.W.

Tuskar.-October 22nd, Gannets have returned, having been away all summer.

Arklow South Light-ship.-February 10th, four going E. 
April 20th, small flocks all day going N.E.: 22nd, three going N.E. August 4th, one going N.E.: 9th, some going N.E. September 14th, one going N.E.: 17th, one going S.W.: 18th, several going N.E. and S.W.

Arklow North Light-ship.-April 10th, a few going N.E.: 12th, three going N.E.: 1.4th, six going S.W.: 16th, ten going S.W.: 19th, a few going N.E. and N.W.: 20th, about thirty going N.E. and N.W. : 21st, 22nd, 23rd, 26th, and 27th, some noted, generally going E. 29th, some fishing. May 2nd and 7 th, some going N.E.: 13th, some going N.W.: 22nd, 23rd, and 31st, and June 1st and 3rd, fishing near ship: 4th and 7th, some going N.E. : 20th, seven going S.W.

Codling Bante Light-ship.-March 17th, several going S.IT.: 21st, several flocks going N.E.

Rathlin O'Birne.-December 28th, fourteen fishing round island: 30th, large numbers fishing; wind fresh S.W.

Blackrock, Mayo.-November, "observed every day."

\section{Heron (Ardea cinerea, Linn.).}

Coningbeg Light-ship.-January 20th, two going W. at noon; wind light S.E., clear.

Tuskar.-August 5th, one going E. at 7 A.M. ; wind moderate N.E., gloomy.

Blackrock, Mayo.-September 2nd, one going W. at 5.30 A.M.; light breeze N.; "watched this bird with telescope till it disappeared W."

Samphire Island.-February 15th, three going S.E. August 15th, one going $\mathrm{E}$.

Skelligs.-October 17th, one on rock; wind light E.

\section{"GEESE."}

Arklow North Light-ship.-December 18th, three Wild Geese going N.W.

Innishtrahull.-April 29th, large flocks of Geese going N. at 7 P.M. ; wind strong N. August 17th, flock on island; wind moderate S.: 26th, large flocks going S. at 3.30 P.M.; strong breeze N.W.

Rathlin O'Birne.-October 9th, one large Grey Goose going N.; strong breeze N.W.: 10th, twelve White-fronted Geese 
going N. at 10.30 A.II.; gale N., clear; "one of these birds very small": 17th, six White-fronted Geese going S.; strong breeze N.W.: 21st, five going S.; strong breeze N.E. : 22nd, one going N.: 23rd, five going S.: 27th, thirteen Grey Geese going S.; wind fresh N.E., clear. November 3rd, ten large Grey Geese going S.: 24th, three White-fronted Geese going S.: 2Sth, one going E. December 1st, thirteen going W.; gale E., clear: 6th, two Grey Geese groing S.: 12th, twenty White-fronted Geese going N.; fresh breeze S.E., clear.

Broadhaven.-October 1 Sth, twenty-one Baruacle going W.; gale N.: 25th, fifteen going W.; gale N. November 21st thirty going W.; strong wind S.W.

Blacksod. Point.-December, some Wild Geese going N.E.

Samphive Island.-January, Barnacle to be seen every day March 7th, great numbers of Barnacle going S.E.; gale S.W.; 13̈th, a continuous flock, in one line of over three miles in length, going N.; wind moderate W., drizzling rain: 31st, immense numbers going N.; wind light N.W. April 8th, large flock going N.; wind fresh W.

\section{"SWANs."}

Rathlin O'Birne.-November 1st, three white Swans, apparcntly old birds, going S.; wind moderate N.: 6th, ten white Sivans going S.; wind light S.,.clear: 21st, four going $S_{\text {. }}$; wind light S., clear. December $23 r d$, six white and two grey Swans going N.; wind light S.E., clear.

\section{LONG-TAILED DUCK (Harelda glacialis, Linn.).}

Innishtrahull.-September 15th, Long-tailed Duck on island all day; shot; strong wind N.E.

Tiathlin O'Birne.-October 16th, one shot, going W.; wind light N.E., clear. [Received in flesh.]

Inishgort.-January 18th, there is a flock of about a dozen in the bay- $[\mathrm{Head}, \mathrm{leg}$, and wing of female received]: 25th[Male received in flesh]. February 13th, Common Scoters observed to " mix with the Long-tail."

Common Scoter (Edemia nigra, Linn.).

Rathlin O'Birne.-November 16th, two Black Ducks going $\mathrm{N}$. at noon; light breeze $\mathrm{N}$. 
Inishgort.-February 13th, three observed, one shot-[Received in flesh]; "they mix with the Long-tail."

"Ducks."

Dunyarvan.-December 20th, one Sheldrake going N.E.

Burrels Rock Light-ship.-January 11th, seven Wild Duck going N.W.

Blackwater Bank Light-ship. - November 28th, a flock of Wild Duck going N.W.

Arklow North Light-ship.-December 15th, a flock of Teal going N.E.; fresh breeze N.: 18th, some Wild Duck going N.W.; fresh breeze N.

Codling Bank Light-ship.-October 25th, eight Wild Duck going W. November 5th, two flocks do. going N.W.

Innishtrahull.-August 12th, Wild Duck on island at 4 P.M.; wind strong $\mathrm{W}$.

Rathlin O'Bime.-December 25th, a large flock of Wigeon, about two hundred and fifty to three hundred, going S. at noon "to feeding ground in Sligo Harbour"; wind fresh S.W.

Samphive Island. - February 17th, three Duck and one Mallard going S. : 27th, one Sheldrake going N.

Skelligs.-December 26th, two Teal going N.E.

BiRdS NoT .IDENTIFIED.

Blackrock, Maryo.-October $17 \mathrm{th}$, two "Rock Vrens" remain. [? Rock Pipits.]

Inishyort.-March .1st, "a man here tells me he killed a bird some time since, "about the size of the Tail [? Teal] Duck, white breast, all down on it, no feathers, feet answered for a tail." "

General Observations.

Fastnct.-September 5th, one Bat about tower at 7.30 P.M. ; wind light. "No Bats observed before."

Old Head, Kinsale. - September 10th, Moth sent; it came in through the kitchen door last night. [Death's Head Moth received.]

Tuskar.-May 29th, birds very scarce this year; don't know the cause, unless the remarkable clear weather we have had all the spring. 
Blackwater Bank Light-ship. - December, little migration observed this autumn, the weather being clear.

Rockabill.-December, there were no birds killed striking during October and November, nor any in December, except on the 3rd; I have never seen less birds about the light. Very little fog or haze.

Innishtrahull.-October 24th, this has not been a very good season for birds.

Rathlin O'Birne.-October 27th, up to the present time there has been only one Blackbird killed striking the lantern, and no other bird.

Broadhaven.-December, "no birds killed at lantern since I came here."

Blacksod.-December, "no birds strike this lantern." 

List OF Light StAtions.

1. Fastnet, Co. Cork,

16 very good. $0 \quad x \quad 8$ Edward Rohu.

4. Mine Head, Waterford,

9 very good. 0 x - Charles Hawkins.

5. Dungarvan, do.

2 excellent. $\mathrm{x} x$ - George Dunleavy.

5๘.Hook Tower, Wexford,

7 fair.

$\mathrm{x} \cdot \mathrm{x}-\left\{\begin{array}{c}\text { M. Barry and James } \\ \text { Howlin. }\end{array}\right.$

5. ${ }^{*}$ Coningbeg Lt. -ship, Wexford, 57 excellent. $\times \quad \times 10\left\{\begin{array}{c}\text { A. B. Wall and J. W. } \\ \text { Grant. }\end{array}\right.$

6. Barrels Rock Lt.-ship, do., 20 poor.

× $\quad 4\left\{\begin{array}{l}\text { Henry Thompson and } \\ \text { John Doyle. }\end{array}\right.$

7. Tuskar Rock,

do., 224 good.

x $\times 7\left\{\begin{array}{c}\text { H. Kennedy and Jos } \\ \text { Higginbotham. }\end{array}\right.$

7a.Lucifer Shoals Lt. -ship, do., 41 very good. $x \quad x \quad 9\left\{\begin{array}{c}\text { James Byrne and John } \\ \text { Dwyer }\end{array}\right.$

76. Blackwater Bank Lt.-ship, do., 55 excellent. $\times$ x $6\left\{\begin{array}{l}\text { Patrick Cullen ami } \\ \text { Thomas Luccan. }\end{array}\right.$

8. Arklow Sth. Lt.-ship, Wicklow, 43 very good. $x \quad x \quad 7\left\{\begin{array}{c}\text { Ed. Broad and } N \text {. } \\ \text { Burdge. }\end{array}\right.$

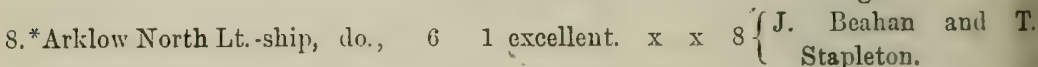

9a. Codling Bank Lt.-ship, Dublin, 54 very good. $x \quad x \quad 7\left\{\begin{array}{c}\text { W, Clydesdale and } J_{\text {, }} \text { Godkin. }\end{array}\right.$

12. Rockabill, Dublin, ............. 36 good. $\quad$ x $\quad x \quad 5$ Henry Kelly.

12b. South Rock Lt.-ship, Down,... 2 good. o $x \quad 3$ John Kearon.

13. Copeland (Mew) Island, do., ... 34 poor. $\quad$ x $\quad$ x 3 S. Staniforth.

16. Innishtrahull, Donegal, ........ 25 fair. $\quad x \quad 0 \quad 6 \quad$ J. Potter.

20. Aranmore, do., ......... 2 3 very good. o $x \quad 5 \quad$ J. C. MacGinley.

21. Rathlin O'Birne, do., ......... 2 0 very good. $x \quad 0 \quad 2$ John Konnedy.

32. Arran Island N., Galway, ..... 344 very good. $x \quad$ x 9 J. F. Friel.

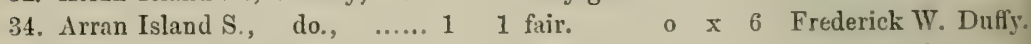

34. *Loop Head; Clare, ............. 10 poor. o 1 - John Hamilton.

36. Samphire Island, Kerry, ....... 10 poor. $\quad 0 \quad x \quad \frac{x}{2}$ Matthew Healy.

39. Skelligs, do., $\ldots . \ldots 3 \quad 1$ rery good. $x \times 9\left\{\begin{array}{c}\text { Thos. King and } \\ \text { French. }\end{array}\right.$

40. Bull Rock, Cork,.............. 1 , 0 fair. $\quad 0$ x 5 James Higginbotham.

Of the Stations that sent no Schedules, Carlingford fortrarded a Willow Tren St John's Point, Down, a bar-tailed Codwit, and the leg and wing of a Turnstone Rathlin Island, a Water-liail ; Blacksod Point, a Storm Petrel; Slyne Head, the le and wing of a Golden Plover; and Berehaven, a Fork-tailed Petrel.

Legs, wings, etc., receired, 180.

$0=$ No reply.

$\mathrm{x}=$ Schedules returned partly or wholly filled.

Spring, replies receivel from 16 stations. Autumn, replies received from 22 stations. 


\section{Legs, Wings, etc., Received.}

Species. How Received. How Procured. Date. Name of Station,

\section{Kestrel,} Spotted F Thrush,

",
",
",
",
",
".
Redwing,

Fieldfare,

\begin{tabular}{|c|c|}
\hline Blackbird, & Leg and wing, \\
\hline ," & " \\
\hline ,", & ", \\
\hline ," & , \\
\hline ," & $"$ \\
\hline ," & ", \\
\hline ," & ", \\
\hline ", & . \\
\hline ", & ", \\
\hline " & , \\
\hline ", & Wing," \\
\hline
\end{tabular}

Shot, . 13/11 mo., Mine Head. Struck lantern, ?/11 mo., Tuskar.

Disabled st., 22/10 mo., Fastnet.

Killed st., ${ }^{1}$ 3/ 2 mo, Tuskir.

4/ 1 mo., Blackwater Bank Li. sh.

5/ 2 mo.,

6/ 2 mo.,

$29 / 9 \mathrm{mo}$,

$18 / 10 \mathrm{mo}$,

$28 / 10 \mathrm{mo}$.

- 26/10 mo., Arran Island, N.

Struck lantern, $2 / 11$ mo., , , , ,

Killed st., . 23/11 mo., "2, ",

Struck lantern, 24/10 mo., Mine Head.

Killed st., 23/10 mo., Copeland (AIsw) Island.

three, . Legsand wings, ". . 25/10 mo., Arran Island, N.

two, . " " . 31/10 mo,, " " "

three, . " $\quad$ Struck lantern, 1/11 mo., " , "

Leg and wing, Killed st., . 2/11 mo., ., ",

three, . Legsand wings, Struck lantern, 19/11 mo., " ".

three, . ", . 28/11 mo., ", ",

two, . " " . . 18/12 mo., , " ",

two, . " , , . 20/12 mo., , ",

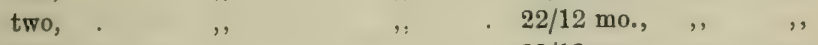

four, . " ", . $23 / 12 \mathrm{mo}_{0}, \quad$, "

Rec'd.inflesh, ? $\left\{\begin{array}{c}24 \text { or } \\ 25 / 12 \\ \text { mo., }\end{array}\right\}$ Hook Tower.

Killed st.; . 18/12 mo., Tuskar.

, . 23/11 mo., Blackwater Bank Lt. sh,

Struck lantern, 25/10 mo., Mine Head.

" . 26/10 mo., " "

". 29/10 mo., ", "

". 24/11 mo., Coningbeg Lt. ship.

Iilled st., . $5 / 2$ mo., Tuskar.

Struck lantern, ?/11 mo., ,"

Killed st., . 4/ 1 mo., Blackwater Bank Lt. sh.

\begin{tabular}{|c|c|c|c|}
\hline 1 & 18/10 mo, & ", & " \\
\hline " & 24/10 mo., & " & $"$ \\
\hline , & $22 / 11 \mathrm{mo}$., & $"$ & \\
\hline & $\begin{array}{l}28 / 10 \mathrm{mo}, \\
23 / 10 \mathrm{mo},\end{array}$ & $\begin{array}{l}\text { Codlting Bank } \\
\text { Arran Island, }\end{array}$ & $\begin{array}{l}L t_{0}-\operatorname{ship.} \\
N .\end{array}$ \\
\hline
\end{tabular}

1 Killed st.=Killed striking lantern. 


\section{Legs, Wings, ETC, Received-continued.}

Species, How Received. How Procured. Date. Name of Station.

Blackbird, two, . Legsandwings, Killed st., . $31 / 10$ mo., Arran Island, $N$.

Leg and wing, $\quad, \quad\left\{\begin{array}{c}? 10 \\ \text { or } 11 \\ \text { mo., }\end{array}\right\} \quad, \quad$ ",

"three, . Legsand wings, Struck lantern, $13 / 11$ mo, , ",
Ring-Ouzel, , Rec'd. in flesh, $\quad$. $30 / 10$ mo., Fastnet.

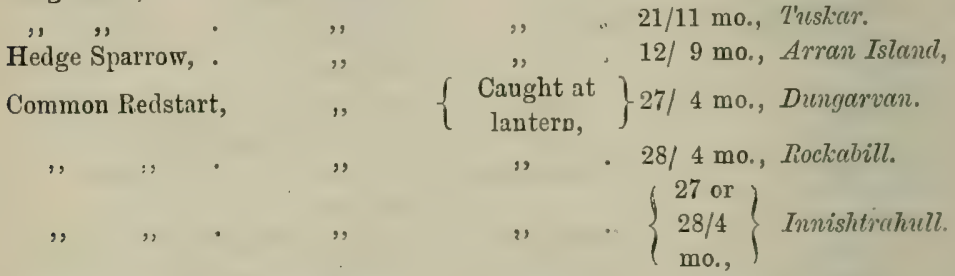

Black Redstart, . Leg and wing, ", : 13/10 mo., Fastnct.

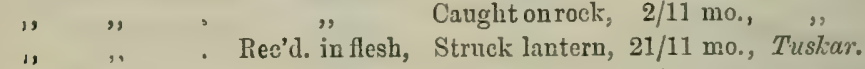

Stonechat, . . " Shot, . . 15/11 mo, Mine Head.

Whinchat, . Leg and wing, $\left\{\begin{array}{c}\text { Found on } \\ \text { lightship, }\end{array}\right\} 29 / 4$ mo., Blackwater Bank Lt.-s/ı.

Wheatear,

$\left\{\begin{array}{c}\text { Caught at } \\ \text { lantern, }\end{array}\right\} 31 / 10$ mo., Fastnet.

, two, . Legsand wings, Killed st, . $30 / 3$ mo., Tuskar.

". . Leg and wing, ", . $30 / 3 \mathrm{mo}$, B Blackwater Bant Lt. sht $_{\text {. }}$

, . . $\quad\left\{\begin{array}{c}\text { Found dead } \\ \text { on deck, }\end{array}\right\} 22 / 4$ mo., Arl.low S. Lt. shitp.

Sedge Warbler, . Rec'd. in flesh, ? . 30/ 4 mo., Tuskar (probably).

, , . Leg and wing,

, $\quad, \quad$ Rec'd. in flesh,

Whitethroat, . "

Filled st., . $\quad 7 / 5$ mo., Blactiwater Bunt:Lt. s/t.

, . 28/4 mo., Rockabill.

". 28/4 mo., Hook Tover.

, , $\quad\left\{\begin{array}{c}27 \text { or } \\ 28 / 4 \\ \mathrm{mo},\end{array}\right\}$ liockabill.

" " $\quad\left\{\begin{array}{c}\text { Killed on } \\ \text { island, }\end{array}\right\} 5 / 6$ mo., Tninishtrahull.

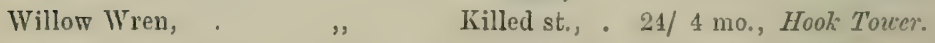

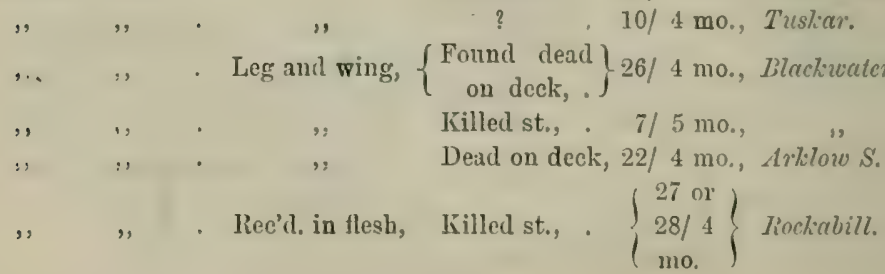




\section{LeGs, WiNgs, ETC., ReCEIVED-continued.}

Species. How Received. IIow Procured. Date. Name of Station.

\section{Willow Wren, . Leg and wing, $\left\{\begin{array}{c}\text { Caught at } \\ \text { lighthouse, }\end{array}\right\} 4 / 9$ mo., Carlivaforcl.}

Rec'd. in flesh, $\left\{\begin{array}{c}\text { Caught at } \\ \text { lantern, }\end{array}\right\} 28 / 4$ mo., Innishtiohull.

Chillchaf,, - Leg and wing, Killed st., - $31 / 3$ mo., Blackwater Bank Lt. -sh.

Golicn-crested Wren,

, , . Leg and wing,

- Rec'd. in flesh,

Wren, .

, .

Titlark,

is

is

Log and wing,

$"$

$$
\text { , }
$$

Rec'd. in flesh,
, , + ,

Leg and wing, $\left\{\begin{array}{c}\text { Caught at } \\ \text { lantern, }\end{array}\right\} 20 / 10$ mo., Fastriet.

Struck lantern, 21/11 mo., Tuskar.

$\left\{\begin{array}{c}\text { Dead in small } \\ \text { boat, }\end{array}\right\} 27 / 9$ mo., Lucifer Shoals Lt. ship.

Killed st., . $29 / 9$ mo., Blackwater Bank Lt. sh.

Struck lantern, 29/9 mo., Copcland (Mew) Island.

Killed st., . $30 / 10$ mo., Fastnet.

$$
\begin{aligned}
& \text { " . 30/10 mo., , } \\
& \text { " . 5/11 mo., ," } \\
& \text {, } \quad \text {. 3/11 mo., Coningbeg Lt.-ship. } \\
& \text { ". . 31/10 mo., Arran Island, } N \text {. }
\end{aligned}
$$

(

, . . Rec'd. in flesh,

$$
? \quad\left\{\begin{array}{c}
24 \text { or } \\
25 / 12 \\
\text { mo., }
\end{array}\right\} \text { Hook Tower. }
$$

Leg and wing, Struck lantern, 23/11 mo., Coningbeg Lt. ship.

Killed st., . 3/ 2 mo., Tuskar.

two, . Legsand wings,

Leg and wing,

$$
\text { , . ? ?/11 mo., ," }
$$

". $22 / 2$ mo., Blackwater Bank Lt. sh.

Found on deck, 14/10 mo.,

Killed st., . 29/10 mo.,

,

,

Found dead, 19/12 mo.,

Struck lantern, 23/10 mo., Copeland (Now) Island.

$"$

Caught, 2/2 mo., Rockabill.

Struck lantern, 21/ 4 mo., Arran Island, $N$.

Leg and wing, $\left\{\begin{array}{c}\text { Caught at } \\ \text { lantern, }\end{array}\right\} 13 / 4$ mo., Innishtrahull.

Dead on deck, 4/11 mo, Coningbeg Lt.-ship.

Killed st., . 5/11 mo.,

two, - Legsand wings, Struck lantern, ?/11 mo., Tuskar.

Leg and wing, Found on deck, 14/10 mo., Blackwater Bank Lt.-sh.

Found dead, 19/10 mo.,

Caught on deck, 18/12 mo., ", ,

Found dead, 19/12 mo., ,, ,

Killed, . 28/10 mo., Codling Bank Lt.-ship.

Killed st., . 26/10 mo,, Arran Istànd, $N$.

Kec'd, in flesh,

, . 1/11 mo., ,; , 


\section{Legs, Wings, etC., Received-continued.}

Species, How Received, How Procured. Date. Name of Station.

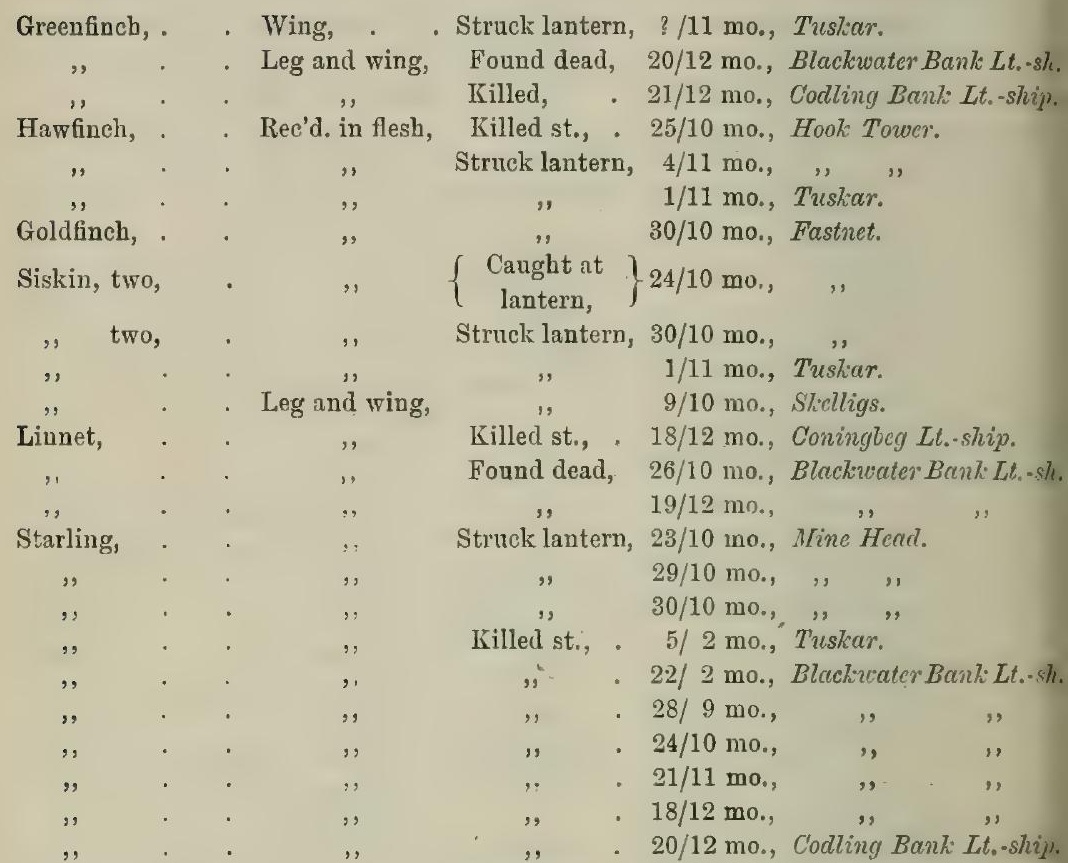

Disabled st., 23/10 mo., Copeland (Mcrv) Island.

Killed st., . $31 / 10$ mo., Arran Island, $N$.

Struck lantern, 18/12 mo, , , , ,

Jackdaw, . . . . $\quad$ Found disabled, 28/12 mo., Aranmorc.

Swallow, . . . . Dead on deck, 22/ 4 mo., Arklow S. Lt.-stip.

Nightjar, . . Rec'd. in flesh, $\left\{\begin{array}{c}\text { Exhausted } \\ \text { on rock, }\end{array}\right\} 23 / 5$ mo., Tuskar.

Corn.Crake, young, Leg and wing, $\left\{\begin{array}{c}\text { Caught near } \\ \text { station, }\end{array}\right\} 21 / 9$ mo., Dungarran.

Water-Rail, . Rec'd. in flesh, $\left\{\begin{array}{c}\text { Killed at } \\ \text { lantern, }\end{array}\right\} 27 / 3$ mo, Rockabill.

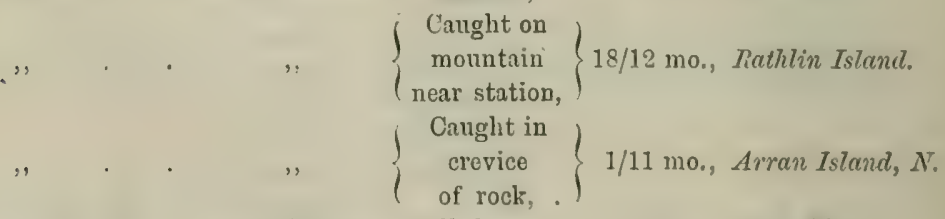

Golden Plover, . Leg and wing, Killed st., . 31/12 mo., Slyne Heckd.

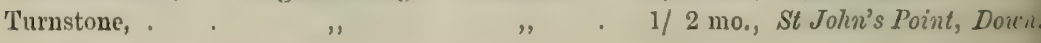


Legs, Wings, etc., Received-continued.

Species. How Received. How Procured. Date. Name of Station.

Snipe,. - . Leg, . Killed st., . $30 / 9 \mathrm{mo}$, Aman Island, $N^{Y}$.

Jack Snipe, . . Rec'd. inflesh, Disabled st., $28 / 3 \mathrm{mo}$, Arklow N. Lt. ship.

Dunlin, . . Leg and ring, Killed st., . $31 / 1 \mathrm{mo}$, Tuskar.

Purple Sandpiper, Wing, , ? ?/11 mo., ,,

Leg and wing, Struck lantern, 8/12 mo., Aranmore.

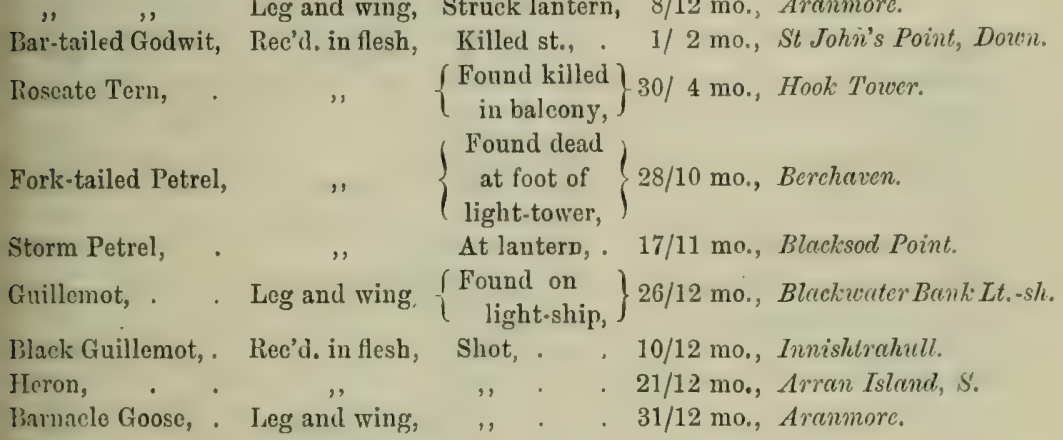




\section{N DEX.}

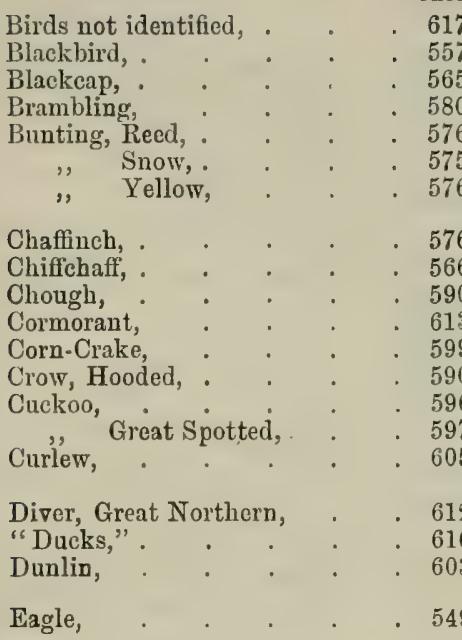

Fieldfare, . . . . 556

Flycatcher, Spotted, . . . 550

Gannet, . . . . . 613

"Geese" . . . 615

General Observations, . . 618

Godwit, Bar-tailed, . . . 604

Golden-crested Wren, . . 566

Goldfinch, . . . . . 582

Goose, Barnacle, : . 615

Greenfinch, $\quad 581$

Grouse, Red, . $\quad$. $\quad$. $\quad 599$

Guillemot, Black, . . . 612

", Common, . . 611

"Gulls," . . . . 608

Hawfinch, , . . . 580

"Hawks," . . . . 549

Heron, . . . . 615

Jackdaw, . . . . . 592

Kestrel, . . . . . 549

Linnet, . . . . . 583

Magpie, . • . . . 593

Manx Shearwater, . . . 609

Martin, House, . . . . 596 " Sand, . . . . 596

Nightjar, , , . . . 596

Oyster-Catcher, . . . . 602
PAGL

Partridge, . . . . . 599

Peregrine Falcon, . . 549

Petrel, Fork-tailed, . . . 610

Storm, . . . 610

Phalarope, Grey, . . . 602

Pigeons, . . . . 598

Plover, Golden, : : $\quad: 600$

"Green, . . . 600

, Ringed, . . . 600

Puffin, . . . . . 612

Raven, . . . . . 590

Razorbill, . . . . 611

Redstart, Black, . . . 562

, Common, . . . 562

Redwing, . . . 555

Ring Dove, . . . . 597

Ring-Ouzel, . . . . 561

Robin, . . . . . 561

Rook, . . . . 591

"Sand Larks," . . . . 603

Sandpiper, Common, . . . 604

" Purple, . . . 603

Sedge Warbler, . . . . 564

Shag, . . . . 613

Siskin, . . . . 582

Skylark, . . . . . 570

Snipe, Common, . . . 603

"Jack, . . . . 603

Sparrow-Hawk, : . : . 549

Sparrow, Hedge, . . . 561

, House, . . . 580

Starling, . , . . 5555

Stonechat, . . . . 562

Sivallow, . . . . 593

"Swans," . . . . 616

Swift, . . . . 590

Tern, Roseate, . . . 607

"Terns," . 608

Thrush, : $: 550$

Titlark, . . . . . 569

Turnstone, . . . . 602

Turtle Dove, . . . . 597

"Twite," . . . . . 585

"Wagtails," . . . . $56 s$

Water-Hen: . . . . 600

Water-Rail, . . 599

Wheatear, . . 563

Whimbrel, . . . . 606

Whinchat, . . . 563

Whitethroat,

Willow Wren, . . . 565

Woodcock, . . 602

Wren, . . : 568 


\section{EAGLE.}

Aranmoie.-September 16th, one Eagle hovering around lighthouse at 8 A.M. ; only one ever observed this year; wind fresh W., rain.

\section{Peregrine falcon (Folco peregrinus, Tunstall).}

Aranmore.-August 9th, two "Blue Hawks" at cliff at 4 l'... These birds breed at west end of island in cliffs.

Rathlin O'Birne.-April 21st, one "Falcon Hawk" going $\mathrm{E}$.

Sliclligs.-March 5th, two on rock; wind strong W. June 27 th, four at noon; wind light S.E. July 26th, one. August 31 st, one going N. December 10th, one.

Kestrel (Falco tinmunculus, Linn.).

MIine Hcad.-September 22nd, three Sparrow-Hawks and one Kestrel all day about station. November 15th, "SparrowHawk" shot-[Kestrel received in flesh]. "The Hawk was unusually tame for a bird of its kind, and on one occasion was accidentally chased out of one of my out-offices."

Skelligs.-February 10th, Kestrel-Hawk on rock. June 6th, one do.

SParrow-HawK (Accipiter nisus, Linn.).

Mine Head.-September 22nd, three, and one Kestrel, all day round station. [Possibly all Kestrels; see under latter:]

Dungarvan.-April 2nd, one going N.W. August 23rd, one "soaring" about station.

Coningbeg Light-ship.-November 10th, one in chase of Chaffinch; was attacked by Gulls, which saved life of Chaffinch.

Arkluw North Light-ship.-June 11th, one going N.W.; wind fresh S.W. October 13th, one noted: 22nd, one going N.E.; rested on ship's rigging; wind light S.E., clear.

Rockabill.-March 29th, one, and three "Crows," on rock at noon.

Shelligs.-August 9th, one on rock. October 2.ith, one all day. December 25th, one going $\mathrm{N}$.

\section{"Hawks."}

Nine Head.-October 30th, "we noticed a very peculiar" Hawk last week; it was nearly all a light grey or white, and a 
black head, with forked tail; about the same size as a Falcon. Probably it was mottled or speckled, but we could not get near enough to see. I never saw such another Hawk, if Hawk it was."

Dungarvan.-July 12th, one "Kite" going S.W.

Lucifer Shoals Light-ship.-April 9th, one Hawk at 7 A.M. ; came on board to pick at the crew's meat hanging forward; wind light W., clear. October $12 \mathrm{th}$, one rested on ship at 6.30 A.M. ; had a small bird, a Lark, which he ate; wind moderate $\mathrm{N}$.

Blackwater Banlo Light-ship.-April 29th, two Hawks and several small birds about light from 9 P.x. to midnight; strong breeze S.W., rain.

Aranmore.-September 15th, one "Fish-Hawk" perched on cliff; remains on island all the year round.

Arran Island, N.-July 10th, one on island. November 9th, one.

Bull Rock.-November 1st to 4 th, one about rock, picking the birds off, probably disabled ones (see under Thrush).

Spotted Flycatcher (Muscicapa grisola, Linn.).

Tuskar.-[December, wing of Spotted Flycatcher received, with legs and wings of two Larks, two Chaffinches, a Greenfinch, and a Purple Sandpiper, all said to have struck lantern between November 20 th and December 1st.]

\section{Thrush (Turdus musicus, Linn.).}

Fastnet.-October 22nd, one disabled striking at midnight; wind strong S.E., overcast-[Leg and wing received]: 24th, numbers of Starlings, Thrushes (Common and Redwing), Larks, Chaffinches, Blackbirds, etc., about light; some killed and disabled; wind fresh S.E., overcast: 26th, some about light, with Blackbirds, Chaffinches, Starlings, and Larks; wind moderate S.E., overcast: 30 th, great rush of birds, including Thrushes; imany killed of various species (see under Ring-Ouzel and Goldfinch); wind fresh N.E., overcast. November 3rd, numbers, with Redwings and other birds, about light; many birds killed; wind fresh S.E., overcast.

Mine IIcoul.-February 5th, five going N.W. March 5th, a 
few going W. April 3rd, twenty going N.E. October 5th, twenty near station: 9th, a flock going N.: 14th, about twenty going W.: 15 th to 19 th, some about station: $22 \mathrm{nd}$, some at night, striking. November 5th to 8th, Blackbirds, Thrushes, and Chaffinches all day; some going W.; some at light at night. December 20th, flocks of Blackbirds and Thrushes going W.; some at light; strong breeze to gale E., overcast, gloomy.

Dungarvan.-January 19th, Blackbirds and Thrushes all day about station; wind moderate E., gloomy: 24 th, numbers of Thrushes and Redwings all day; hard frost. February 26th, several Thrushes at lantern at 2 A.n.; five struck; gale S.W., misty.

Coningbeg Light-ship.-October 23rd, one killed striking; wind moderate S.E.: 24th, three killed striking; wind moderate S.E. November 19 th, large numbers of Thrushes, Stares, Skylarks, and Blackbirds about light; several killed and fell overboard; wind light, variable, gloomy.

Tuskar. - February 3rd, several "Thrushes (Redwing)" striking light at midnight; one killed; wind light S.W., fog[Leg and wing of Thrush received]. October, "there were from five to six hundred Blackbirds and Thrushes killed each night from the 20th to the 23rd, during dark, hazy nights; wind S.E."

Lucifer Shoals Light-ship.-October 27th, Starlings, Thrushes, and Blackbirds round light at $S$ P.x.; two Blackbirds, one Thrush, and one Starling killed striking; wind moderate S.IV., rain: 29th, Starlings; Blackbirds, Thrushes, and Chaffinches round light from 7 P.M. to about 6.30 A.M.; two Blackbirds and one Chaffinch killed; fresh breeze S.E., rain.

Blackwater Bant Light-ship.-January 1st, small llocks of Starlings and Thrushes going N.W.; wind light N.W., clear : [th, Leg and wing of Thrush received, killed striking]: 10th, twenty Blackbirds and Thrushes about light from 9 P.M. to midnight; wind light to moderate S., gloomy: 31st, five about light. February th, several about light; wind light S.W., gloomy: 5th, some, with Blackbirds, about light; one Thrush killed striking-[Leg and wing received]; wind light N.E., gloomy: 6th, Thrushes and Larks about light from midnight to 8 A.Ir. ; two Thrushes killed striking-[Log and wing of one received]; wind light S.li., gloomy: 19th, large number of 
Thrushes about light from 10 P.M. to midnight; went for the land; fresh breeze S.W., wet fog: 23rd, large number of Larks, Starlings, and. Thrushes about light from sunset till sunrise on following morning; about forty birds killed; wind S.W., overcast. April 20th, Blackbirds and Thrushes about light from 9 P.M. to midnight; wind fresh S., rain. September 28 th, about twelve Thrushes and Starlings about lantern from 8 P.n. to midnight; two Thrushes and one Starling killed striking; Thrushes falling overboard: 29th, from midnight to 4 A.M., twenty Thrushes, twenty Starlings, and four Gold-Crests round lantern; two killed-[ Leg and wing of one Thrush and one Golden-crested Wren received]; wind light S.W., thick mist. October 13th, Thrushes and Blackbirds about light; one Thrush killed, fell overboard; wind moderate S.E., rain : 18th, Thrushes, Blackbirds, and Larks about light; three Blackbirds and six Thrushes killed; many others struck and fell overboard-[Leg and wing of one Thrush and one Blackbird received]; wind moderate S.W., clear: $23 \mathrm{r}$ r, a few Thrushes and Starlings about light; four killed; light breeze S.E., overcast: 24 th, Thrushes and Starlings about light; eight killed, flew for the Irish land at daylight; wind moderate S.E., light haze: 27th, four going N.: [28th, Leg and wing of Thrush received, killed striking]: 29th, large number of Blackbirds, Thrushes, and Starlings, with a few Chaffinches, about light; ten killed; large flock went N.W. at daylight; wind moderate S., cloudy: 30th, large number of Blackbirds and Thrushes about light; twenty Blackbirds and forty Thrushes striking; Hew for land at daylight; wind moderate S., haze : 31st, about a hundred Thrushes, Blackbirds, and other birds about light; wind moderate S.E. November 3rd, large Hocks of Thrushes and Blackbirds going N., flying high: 7th, four going N.: 21st, a few about light from 2 A.M. to 4 A.M.; went for land; wind light S.W., haze: 22nd, four, and six Blackbirds, about light from 1 A.M. to 5 A.M.; two killed; light breeze S.IV., cloudy: 23rd, large number of Starlings, Blackbirds, and Thrushes about light; two killed striking (see under Fieldfare); wind light N.E., cloudy. December 18th, flock of Chaffinches and Thrushes going N.W. at 11 A.M. ; two flocks of Thrushes going do. at 2 P.M.; wind light S.W., clear: 19th, Larks, Blackbirds, Thrushes, and Starlings at light from midnight to 7 A.x.; about a hundred 
killed and fell overboard; wind light S.E., overcast; Thrushes and Chaffinches at 11 A.M. going N.W.; two found dead (see under Chaffinch); clear: 24th, four Thrushes about ship at 9 P.M.; one found dead ; strong breeze S.W., overcast : 25th, large number of Starlings and Thrushes in the afternoon going N.W.; wind strong S.W., showery.

Arklow South Light-ship.-February 3rd, Starlings, Thrushes, and Larks all night about ship; several struck and fell overboard; wind light S.W.; fog.

Arklow North Light-ship.-January 3rd, two killed; wind light W., rain: 23rd, two going $N$. during forenoon; lit on board for a short time; strong breeze N.E., snow. February 5 th, a few about ship day and night; wind light N.E., light haze. October 18th, one, and two Golden Wrens, about lantern; Thrush killed, also one Golden Wren; wind moderate W., clear.

Codling Bank Light-ship.-June 5th, two on ship at 3 A.M.; calm, light haze. October 28th, one on ship.

Rockabill.--January 9th, six about light at 4 A.M.; three, with one Fieldfare, two Blackbirds, a Lark, and a Starling, killed or disabled striking; wind moderate $\mathrm{E}$, haze : 22nd, one on rock; gale N.E. April 25th, four, and five Larks, about light at 1 A.M. ; wind E., haze. October 2nd, Blackbirds, Starlings, and Thrushes on rock; remained all day: 21st, large numbers of birds about light at 2 A.M. ; seven Thrushes, six Blackbirds, twelve Skylarks and Starlings, four Fieldfares, nine Chaffinches, one Golden-crested Wren, and two Greenfinches killed striking; wind light S.E., fog; "what did strike were killed, got none disabled next morning": 29th, a very large number of birds about light at 3 A.M.; fifteen Thrushes, seven Fieldfares, twelve Blackbirds, eight Chaffinches, one Golden Plover, one Rock Pigeon, and sixteen Starlings killed striking; all away at daylight, except some disabled Starlings; wind fresh S.E., fog. November 10th, Thrushes and other birds about light at 1 A.M.; four killed striking, with two Larks and two Fieldfares; wind light S., misty.

South Rock Light-ship.-October 28th, several Larks, Starlings, Thrushes, and Blackbirds about light during night, a good many striking and falling overboard; wind moderate S., haze. November 25th, Larks, Thrushes, and Blackbirds about light 
from 8 P.M. to midnight; two killed; wind moderate S.E., clear.

Copeland (Mew) Island. - October 29th to 31st, flocks of Thrushes and Blackbirds and a few Fieldfares each night from 10 P.M. to 11 P.M., about a dozen got killed; "some of these Thrushes and Blackbirds frequent the island"; wind light S.E., fog. November 20th, a flock of Fieldfares and some Blackbirds and Thrushes from 10 P.M. to midnight; haze. December 18th, a few Starlings, Thrushes, and Blackbirds, and a great number of Larks about light; fog.

Innishtrahull.-January 6th, one on island; gale S.E., misty. March 8th, two; wind light S., misty.

Aranmore.-November 13 th, two about station; wind strong S.W., squally and snow. December 29th, one on wall; wind fresh S.W., squally.

Arran Island, N.-October 23rd, "first time Blackbirds and Thrushes seen on island since beginning of summer": 26th, one Thrush killed striking-[Leg and wing received]; wind fresh S.E., gloomy. November 2nd, one do. [Leg and wing received]; wind light N.E., haze: 23rd, nine "Thrushes" on island all day; four killed striking-[Legs and wings of one Thrush and three Redwings received]; wind light S., gloomy. December 3rd, six all day: 4th, eight do.: 18th to 26th, several "Thrushes" and Blackbirds noted daily (see under Redwing, to which species belong all legs and wings sent during December from this station). "When the wind is off the land, a good many visit isle."

Arran Island, S.-October 23rd, one at 1 A.M., killed striking; wind moderate S.E., misty: $30 \mathrm{th}$, six at 4 A.Mr., killed striking; wind light S.E., gloomy : 31st, eight going S.E. Are residents of this island, and very seldom seen at night.

Skelligs.-January 18th, four on rock; one striking, not killed; wind fresh S.E. November 6th, four all day; wind strong S.E. December 30 th, numbers on rock all day; wind fresh W.

Bull Rock:-November 1st to 4th, Starlings, Blackbirds, Thrushes, and Larks around light for past four nights, and on rock during day-time; four Starlings, ten Blackbirds, four Thrushes, and four Larks killed; wind moderate E., dark gloomy weather. 
REDWING (Turdus iliacus, Linn.).

Fastnet. - October 23rd, one found, killed striking; wind strong S.E., overcast-[Leg and wing received]: 24th, numbers, with Thrushes and other birds, about light; wind fresh S.E., overcast: 30 th, very large rush of Blackbirds, Thrushes, Redwings, and Chaffinches with other birds; numbers killed and fell into the sea (see additional particulars under Ring-Ouzel and Goldfinch); wind fresh N.E., overeast. November 3rd, numbers of Chaffinches, Thrushes, Redwings, Starlings, and Blackbirds about lantern; many killed; fresh breeze S.E., overcast.

Mine Head.-February 1st, five "Mountain Thrushes" noted in morning; wind moderate W., misty-[Possibly Redwings or Missel Thrushes.-R. M. B.]. [October 24th, Leg and wing received; struck lantern]: 30th, Redwings and Skylarks all day going W.; wind S.E., misty.

Dungarvan.-January 24th, numbers of Thrushes and Redwings all day; hard frost.

Roclicbill.-March 3rd, two "Thrushes (Redwing)" on rock at 9 A.M.; gale N.W., clear. October 6th, two "Thrushes (Redwing)" at noon, with several Chaffinches, Greenfinches, and Golden-crested Wrens; "the Thrushes left at 3 P.M., going W."; wind light S.W., cloudy.

Copeland (Mow) Island.-October 23rd, "Thrush". and other birds about light; a Lark, Thrush, and Starling killed or disabled striking-[Leg and wing of Redwing, killed striking, received, with do. of Lark and Starling]; wind moderate S.E., gloomy, haze.

Arran Island, N.-October 25th, three "Thrushes" killed striking-[Legs and wings of three Redwings received]; wind light E., gloomy : 31st, two "Thrushes" killed striking-[Legs and wings of two Redwings received]; wind light N.E., drizzling rain. November 1st, three "Thrushes" killed striking-[Legs and wings of three Redwings received]; wind light N.E., misty: 2nd, one "Thrush" killed striking-[Legs and wings of one Thrush and one Redwing received]; wind light N.E., haze: 19th, six "Thrushes" on island at 2 P.M. ; three killed striking[Legs and wings of three Redwings received]; wind moderate S., cloudy: 23rd, nine "Thrushes" all day on island; four 
killed striking-[Legs and wings of three Redwings and one Thrush received]; wind light S., gloomy. December 3rd, six "Thrushes" all day on island-[Some, if not all of them, probably Redwings.-R. M. B.]; wind light S.E., cloudy: 4th, eight do. all day: 18th, several do. and Blackbirds all day; three killed striking-[Legs and wings of two Redwings and one Starling received]; wind light E., gloomy: 19th, "Thrushes" and Blackbirds all day : 20th, do.; two killed-[Legs and wings of two Redwings received]; wind light E., gloomy: 21st, "Thrushes" and Blackbirds all day: 22nd, do.; two killed striking-[Legs and wings of two Redwings received]; wind do.: 23rd, "Thrushes" and Blackbirds all day; four killed striking-[Legs and wings of four Redwings received]; wind moderate S.E., gloomy : 24th and 26th, "Thrushes" and Blackbirds all day; wind fresh S.E. and S., misty. "It is only when wind is off the land, i.e., from S. to E.N.E., that these birds visit this isle."

Skelligs.-March 11th, one on rock at 11 A.M. ; wind moderate W., mist.

Fieldfare (Turdus pilaris, Linn.).

Fustnet.-October 30th and 31st, great rush of birds from 9 P.M. to 6 A.M.; many killed and falling into the sea; one Fieldfare at lantern at 3 A.M.; ten species noted (see under Ring-Ouzel and Goldfinch); wind fresh N.E., overcast.

Mine Head.-December 20th, a few noted.

Hook Tower:-[December 24th or 25th, Fieldfare received in flesh.]

Tuskar.-December 18th, "bird of the Thrush family" killed striking lantern-[Fieldfare received in flesh].

Blackwater Bank Light-ship.-November 23rd, a large number of Starlings, Blackbirds, and Thrushes about light from 6 P...r. to 8 P.M. ; two killed striking-[Leg and wing of Fieldfare, sent as "Thrush," received]; wind light N.E., cloudy.

Rockabill.-January 9th, two about light; one killed, with a fèw Thrushes and other birds; wind moderate E., haze. October 21st, large number of birds about light (see under Thrush); four Fieldfares killed striking; wind light S.E., fog: 29 th, a very large number of birds about light (see under Thrush); seven Fieldfares killed striking; wind fresh S.E., fog. 
November 10th, Larks, Thrushes, and Fieldfares about light; two Fieldfares killed striking; wind light S., misty.

Copeland (Mew) Island.-October 29th to 31st, flocks of Thrushes and Blackbirds and a few Fieldfares about light each night from 10 P.M. to 11 P.M. ; about a dozen killed; wind light to moderate S.E., fog. November 25th, flock of Fieldfares and some Blackbirds and Thrushes from 10 P.M. to midnight; gentle breeze S., haze. December 22nd, one Fieldfare caught resting on balcony at 4 A.M. ; fresh breeze S.E., gloomy.

Aranmore.-November 23rd, twenty "Fairfields" outside station; wind moderate S.W., cloudy.

Rathlin O'Birne.—January 7th, two going E.; wind fresh E., clear.

Sliclligs.-September 29th, three "Fieldfares" on rock; wind light N.E. November 11th, six; wind strong S.W. December 14th, three at noon; wind fresh S.W., haze.

\section{BlackBIRd (Turdus merula, Linn.).}

Fustnet-October 22nd, two at lantern; one killed striking; strong breeze S.E., overcast: 24th, numbers, with Starlings, Thrushes, and other birds about light; some killed; wind fresh S.E., overcast: 26th, Blackbirds, Chaffinches, Thrushes, and other birds about light; some killed; wind moderate S.E., overcast: 30 th and 31st, very large rush of Blackbirds, Thrushes, Redwings, and Chaffinches; numbers killed and fell into the sea (see further particulars under Ring-Ouzel); wind fresh N.E., overcast. November 3rd and 4th, numbers of Chaffinches, Thrushes, Redwings, Starlings, and Blackbirds about lantern; many killed; wind fresh S.E., overcast, gloomy.

Mine Head.-March 5th, a few going W.; wind fresh W., clear. April 3rd, five going N.E. October 14th, twelve going N.: 15th to 19th, Blackbirds, Thrushes, and Plover round station: 22nd, Blackbirds and Thrushes going W. night and day; some striking: 25 th, about twenty going W.; some struck lantern; wind moderate S.E., overcast-_ [Legs and wings received of three killed striking October 25th, 26th, and 29th]. November 5 th to 8th, Blackbirds, Thrushes, and Chaffinches all day; some going W., some at light. December 20th, flocks of Blackbirds and Thrushes going W.; some at light; gale E., overcast. 
Dungarvan.-January 18th, Blackbirds and Thrushes all day about station; frost.

Coningbey Light-ship.-March 6th, hen Blackbird killed striking; wind moderate S., rain. October 24th and 25th, one killed striking each night; wind moderate S.E., overcast. November 19th, large numbers of Thrushes, Stares, Sliylarks, and Blackbirds about light; several killed and fell overboard; wind variable, gloomy: 24th, one male Blackbird killed striking; wind light S.E., clear. [Leg and wing received.]

Tuskar.-February 5th, some going N.W. at 10 P.M.; one killed striking; wind ljght S.W., mist-[Leg and wing received]: 20 th, some at light at 9 P.Mr; several striking; wind moderate W.: 22nd, three females killed striking; wind moderate S.W., cloudy: 23rd, nine females lilled striking; wind fresh S.W. October, "there were from five to six hundred Blaclibirds and Thrushes killed each night from the 20th to the 23rd, during dark hazy nights; wind S.E." [December, Leg and wing received; struck lantern "between November 20th and December 1st."]

Lucifor Shoals Light-ship.-October 20th, one about lantern at 8 P.M.; calm: 23rd, several, with Starlings, round lantern; wind moderate E., clear: 27 th, Starlings, Thrushes, and Blackbirds round lantern; two Blackbirds killed striking; wind moderate S.W., rain: 29th, Starlings and Blackbirds round light, with other birds; two Blackbirds and one Chaffinch striking; wind fresh S.E.: 31st, Starlings and Blackbirds round lantern; two Blackbirds killed; wind moderate S.E., gloomy.

Bicaclucater Bank Light-ship.-[January 4th, Leg and wing received, killed striking]: 10th, about twenty Thrushes and Blackbirds about light from 9 P.M. to midnight; wind S., clouly. February 5th, Thrushes and Blackbirds about light. March 27th, two Blackbirds going N.W. at 9 P.M. April 20th, Blackbirds and Thrushes about light; wind fresh S., rain. Septemluer 30th, large flock of Blackbirds going N.W., flying low, at 8.40 A.I.; wind moderate N., clear. October 13th, some, with Thrushes, about light: 18th, some, with Thrushes and Larks, about light; three Blackbirds killed striking-[Leg and wing of one received]: 23rd, two going N.W.: 2tth, about thirty round light from sunset to midnight-[Leg and wing of one, killed striking, received]; wind light S.E., haze: 29th, large 
number of Blacklirds, Thrushes, and other birds about light: 30 th, large number of I3lackbirds and Thrushes about light; twenty Blackbirds striking: 31st, about a hundred Thrushes, Blackbirds, Larks, and Starlings about light; wind moderate S.E., showery. November 3rd, large flocks of Thrushes and Blackbirds going N., flying high, at 8 A.M. and 10 A.M.; wind fresh E., clear: 22nd, six Blackbirds and four Thrushes about light, two killed striking-[Leg and wing of Blackbird received]; light breeze S.W., cloudy: 23rd, large number of Starlings, Blackbirds, and Thrushes about light. December 18th, a few Starlings and Blackbirds do.: 19th, flock of Larks, Blackbirds, 'Thrushes, and Starlings about light from midnight to 7 A.M. ; about a hundred killed and fell overboard; light breeze S.E., overcast.

Arklow North Light-ship.-February 8th, one, and three Starlings, about ship.

Codling Bant. Light-ship.-October 28th, lots of small birds about light at night; several killed and disabled, some falling overboard-[Leg and wing of Blackbird, with leg and wing of Chaffinch, received]; wind moderate S., gloomy: 30th, Blackbirds and Starlings passing during day; fog. December 25th, one Blackird about light.

Rockicbill.-January 5th, five about light; two killed; hazy: 22nd, two, and one Thrush, on rock; gale N.E. March 3rd, two, and two "Redwing Thrushes," on rock; gale N.W. October 2nd, nine, with some Starlings and Thrushes, remained all day; wind light W.: 21st, a large number of birds about light at 2 A.M.; six Blackbirds killed striking, with thirty-five other birds (see under Thrush); wind light S.E., fog: 29th, a very large number of birds about light at 3 A.M.; twelve Blackbirds and forty-eight other birds killed striking: (see under Thrush); wind fresh S.E., fog. November 23rd, Blackbirds about light at 11 P.I. ; three lilled striking; wind light S.W., fog.

South Rocki Light-ship.-October 2sth, several Larlis, Starlings, Thrushes, and Blackbirds about light during night; a good many striking and falling overboard; wind moderate S., haze. November 25th, several Larks, Thrushes, and Blackbirds about light from 8 P.x. to midnight; two lilled; wind moderate S.E., clear: a few Larks and Blackbirds about light between 
9 P.M. and 11 P.M. on 26th, 28th, 29th, and 30th; wind strong W. or N.W.

Copcland (Mew) Island.-October 23rd, some struck lantern; wind moderate S.E., gloomy: 29th to 30 th, flocks of Thrushes and Blackbirds and a few Fieldfares each night from 10 P.x. to 11 P.M. ; about a dozen got killed; wind light S.E., fog. November 25th, a flock of Fieldfares and some Blackbirds and Thrushes from 10 P.M. to midnight; haze. December 18th, a few Starlings, Thrushes, and Blackbirds, and a great number of Larks, about light from 11 P.M. to 3 A.M. on 19th; three Larks killed or disabled; "these birds (except Blackbird) were probably attracted by our increased light during fog from the Copeland islands"; wind moderate S.E., fog.

Dunvee Head.-December 1st, a white Blackbird frequently seen near lighthouse recently.

Aranmore.-November 6th, four about garden; very scarce here during winter months; wind moderate $\mathrm{E}$.

Arran Island, N.-February 16th, flock going W. at 4 P.M. ; wind moderate S.W., clear: 20th, flock of Blackbirds and Starlings going N.E. October $23 \mathrm{rd}$, one killed striking at 2 A.M. [Wing received]; "Blackbirds and Thrushes seen on island for first time since beginning of summer;" wind light E., dark: 31 st, two killed striking at 2 A.M. [Legs and wings received], and one killed striking at 3.30 A.M. [Leg and wing, with no date, received with others killed striking during October and November, probably belong to this specimen]. November 13 th, eight on island; three killed striking-[Legs and wings of three received]; wind light S.E., gloomy. December 18th, "several Thrushes and Blackbirds all day on island; three killed striking" (see under Starling): 19th to 26th, Thrushes and Blackbirds noted daily. "It is only when wind is off the land, i.c., from S. to E.N.E., that these birds 'visit this isle."

Arran Island, S.-October 23rd, male Blackbird killed striking at 4 A.M. ; wind moderate S.E., misty : 30 th, female killed

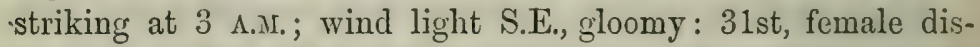
abled at 8 P.M. ; wind moderate S.E., overcast. Residents, and very seldom seen at night.

Shelligs.-January 24 th, two on rock at 10 A.1. ; wind light N.W., mist. October 29th, five at 8 A.M. ; wind strong S.W., mist. December 11th, two all day; wind moderate N.W. 
Bull Rock-October 23rd, 24th, and 25th, ten Starlings, three hen Blackbirds, and four Larks killed against lantern; during the day these birds were numerous on rock up to 10 A.M. or 11 A.M. each day; wind E. ; dark, gloomy weather at night. November 1st to 4th, Starlings, Blackbirds, Thrushes, and Larks around light for past four nights, and on rock during daytime; four Starlings, ten Blackbirds (all females), four Thrushes, and four Larks killed; wind moderate E. ; dark, gloomy weather.

\section{RING-OvZEL (Turdus torquatus, Linn.).}

Fastnet.-Great rush of birds from 9 P.M. on October 30th to 6 A.M. on 31 st ; many fell into the sea; those caught were chiefly Blackbirds, Thrushes, Redwings, and Chaffinches; also killed or caught one Fieldfare, two Wrens, one Wheatear, one Goldfinch, two Siskins, and "two birds, size of Blackbirds, caught striking at 11 P.M. and 3 A.M." [Ring-Ouzel received in flesh; with Goldfinch; Wren, and two Siskins.]

Tuskar.-[November 21st, Ring-Ouzel received in flesh, with Black Redstart and Golden-crested Wren, accompanying letter clated November 18th; no white ring on this specimen. In letter of December $19 \mathrm{th}$, it is stated that the above three birds "struck lantern during middle watch; weather misty."]

Innishtrahull.-April 27 th, one at lantern at 11.30 1...1.

Hedge Sparrow (Accentor modularis, Linn.).

Mine Head.-September 12th, some all day; wind light E. October 27th, Hedge Sparrows noted.

Dungarvan.-April 22nd, one in hedge close to station; " first I have seen here-GEorge DUNLEAVY."

Arren Island, N.-[September 12th, one received in llesh; caught striking lantern.]

\section{Robin (Erithacus rubecula, Linn.).}

Ainc Hcud.-September 16th, three Robin Redbreasts round station; wind light $\mathrm{W}$.

Dungarvan.-May 25th, two noted, young birds just able to fly. September 15th, two ; "first seen for a long time."

Tuskicur.-February 5th, Robin on rock at 10 A.M. ; wind light S.W., mist : 13 th, one on rock at 9 A.M.; wind light WV., fog. 
Blactwater Bank Light-ship.-November 10th, three Robins going N.W.; wind moderate S.E., haze.

Aranmore.-September 2nd, one Robin Redbreast on garden wall ; rare on island; gale N., cloudy.

\section{Redstart (Ruticilla phœnicurus, Linn.).}

Dungarvan.-April 27th, "I am forwarding by this day's post a small bird I caught at lantern glass at 12.45 A.M. this morning"-[Redstart, adult male, received in flesh]; wind moderate S.E., misty.

Rockabill.-April 20th, one Redstart on rock at 1 r.Mr.; wind moderate N.W., clear: 28th, two Redstarts at light at 11 1...1.; one killed-[Redstart, adult male, received in flesh]; wind moderate E., haze.

Innishtrahull.-April 27 th, one at lantern at 9 P.M., forwarded - [Redstart, adult male, received in flesh, labelled as caught at lantern on 28th]; wind light W., misty.

\section{Black Redstart (Ruticilla titys, Scopoli).}

Festnct.-October 13th, one Redstart striking lantern at 4.30 A.M.; wind moderate N.E., misty- [Leg and wing of Black Redstart received]: 20th, one on rock during day, evidently came last night; wind light S.E., misty-[Probably Black Redstart._R. M. B.]. November 2 ud, one at 2 P.M.; strong breeze S.E., overcast. [Leg and wing of Black Redstart received, caught on rock.]

Mine Head.-November 12th, two "Blackstarts" noted; gale S.W., mist.

Tuskcr:-[November 21st, received in flesh Black Redstart, ling-Ouzel, and Golden-crested Wren, with letter dated November 18th; a later letter $(19 / 12 / 97)$ states that "they struck lantern during middle watch: weather misty."]

\section{Stonechat (Pratincola rubicola, Linn.).}

Mine ITcad.-September 12th, "Stonechats" all day about station; wind light E., overcast-[Possibly Wheatears]. November 15th, unknown bird shot and forwarded-[Stonechat received in 1lesh]: 22nd, Stonechats at noon; wind light N., overcast. 
Lucifer Shouls Light-ship.-April 27th, one "Blackhead" lit on ship; remained all day. [Probably either Blackcap or Stonechat.-R. M. B.]

Codling Bank Light-ship.-April 21st, one Stonechat in ship at 10 A.M. ; wind light S.E., for : 27 th, one about ship; haze.

Rockabill.-March 28th, two at light at 2.30 A.M. [Possibly Wheatears.-R. M. B.] ; one killed; fresh breeze S.W., haze.

South Rock Light-ship.-October 18th, several Larks and "Stonechats" going N.W. during day; wind moderate S.W., clear.

Innishtrahull.-January $27 \mathrm{th}$, one on island at 1 I.M.; wind strong $N$., snow.

Rathlin O'Birne.-March 22nd, two all day; remain to breed; gale S.W.: 25th, eight. [Wheatear?-R. M. B.]

Whinchat (Pratincola rubetra, Linn.).

Blaclwater Bank Light-ship.-April 29th, "Wheatear" found dead on deck at 5 P.M. [Leg and wing of male Whinchat received]; wind fresh S.W., clear.

\section{Wheatear (Saxicola cenanthe, Linn.).}

Fastnct.-October 30th and 31st, great rush of many species of birds from 9 P.M. to 6 A.M., chiefly Blackbirds, Thrushes, Redwings, and Chaffinches (see under Ring-Ouzel and Goldfinch); one Wheatear caught at lantern. [Leg and wing received.]

Dungarvan.-April 19th, one; first.seen. May 9th, a young bird, not fully fledged, noted. August 15th, several close to station; wind light W., showers: 20th, three noted, all young birds.

Coningbeg Light-ship. - September Sth, one "White-tail" alout ship; wind light S.E. October 26th, one rested on ship and flew N.E. at 5.30 P.M.; wind moderate S., clear.

Tusticur.-March 20th, one on rock at 7 A.M.; wind light S.TV., fog: 30 th, two killed striking at 11 P.M.; wind moderate S.W., overcast. [Legs and wings of two received.]

Blackutater Bank Light-ship.-March 30th, about twenty about light from 10 r.M. to midnight; fresh breeze S.IV., overcast; one killed striking-[Leg and wing received]: 31st, from midnight to 2 A.M. about two hundred Wheatears and Larks 
round light, with about forty "Twites" and some "Golden Wrens" (see under Chiffchaff); about forty birds killed; large number falling overboard after striking lantern; large flock went for land at 2 A.M. ; light rain. September 20th, ten Wheatears about light, went N.W.; wind moderate N.W., haze. Arklow South Light-ship.-April 22nd, a lot of small birds about light--[Leg and wing of Wheatear received, also of Willow Wren and Swallow, all found dead on deck]; wind light E., dark night.

Rockabill.-March 28th, two "Stonechats" at light at 2.30 A.M. [Probably Wheatears.-R. M. B.]; one killed; fresh breeze S.W., haze.

Innishtrahull.-March 28th, two at lantern at 2 A.M.; wind light N., misty. April 27th, three do. at 11.30 1.M. ; Redstart, Willow Wren, and Ring-Ouzel at lantern same night; wind light W., misty.

Skelligs.-June 21st, two on rock at 2 P.M.

Sedge Warbler (Acrocephalus phrorgmitis, Bechst.).

Thuskar.-[April 30th, one received in flesh, presumably from this station.]

Blachwater Bant Light-ship. - April 21st, flock of Sedge Warblers about light from 8.30 P.M. to 10.30 P.M. ; wind light E., overcast; three killed and fell overboard. May 7th, two large flocks of "Wrens and Warblers" about light from 1 A.M. to 4 A.M., then went N.W.; ten killed; wind light W., rain[Leg and wing of Sedge Warbler, and do. of Willow Wren, lilled striking, received]: Sth, large flock of "Wrens and Warblers" about light from midnight to 3 A.M., Hew for land; twenty killed; wind light S.W., overcast.

Rockabill.-April 28th, seven about light at 11 P.M.; two, and a Redstart, killed striking-[Sedge Warbler received in flesh, with Redstart, Whitethroat, and Willow Wren]; wind moderate E, haze.

\section{Whitethroat (Sylvia cinerea, Bechst.).}

Hook Toucer-April 28th, little bird killed striking. [Whitethroat received in flesh.] 
Rockabill.-April 27th, five "Chiffchaffs" and seven "Flycatchers" about light at 11 P.M.; one killed: 28th, two Sedge Warblers and one Redstart killed-[Whitethroat, sent as "Flycatcher, killed striking April 28th," received in flesh, with Willow Wren, sent as "Chiffchaff," and Sedge Warbler and Redstart correctly named, all labelled as killed on 28th]; wind on both days moderate $\mathbf{E}$, haze.

Innishtrahull.--June 5th, bird, name uncertain, on island at 11 A.M. ; forwarded in flesh-[Whitethroat received in flesh]; wind light N., fog.

Blackcap (Sylvia atricapilla, Linn.).

Lucifer Shorls Light-ship.-April 27th, one "Blackhead" lit on board at 6 A.M., remained on board all day; light breeze E., light haze, gloomy. [Probably either Blackcap or Stonechat.R. M. B.]

\section{Willow Wren (Phylloscopus trochilus, Linn.).}

IFine Head.-September 22nd, "Flycatchers" and "Willow Warblers" all round; some striking "slightly"; wind moderate W.

Hook Toucr.-April 24th, small bird killed striking. [Willow Wren received in flesh.]

Tuskar.-[April 10th, Willow Wren received in flesh.]

Blackwater Bank Light-ship.-April 26th, one "Wren" found dead at 9 A.M. [Leg and wing of Willow Wren received]; light breeze E., rain : 28th, two "Wrens" alighted on ship at 6 A.M.; calm, hazy. May 7th, two large flocks of "Wrens" and Warblers about light from 1 A.M. to 4 A.M.; ten killed-[Leg and wing of Willow Wren, also of Sedge Warbler, killed striking, received]; light breeze W., rain: 8th, large flock of "Wrens" and Warblers about light from midnight to 3 A.M.; twenty killed; light breeze S.W., overcast.

Arlilow South Light-ship.-April 22nd, a lot of small birds about light at night-[Leg and wing of Willow Wren received, found dead on deck, with legs and wings of Wheatear and Swallow, do.]; wind light E., dark.

Arlilow North Light-ship.-May 7th, two "Sallypickers" lit on board during forenoon; wind light S.W., rain. 
Codling Banti Light-ship.-April 12th, one Willow Warbler on ship at noon; wind light S.E., light haze : 22nd, one on ship at 10 A.M. ; wind moderate E., light haze.

Rockabill.-April 27th, five "Chiffchaffs" and seven "Flycatchers" about light; one killed: 28th, seven Sedge Warblers and two Redstarts about light; two Sedge Warblers and one Redstart killed-[Willow Wren, sent as Chiffchaff, received in flesh, with a Whitethroat, sent as "Flycatcher," and a Sedge Warbler and Redstart correctly named, all labelled as killed striking on 28th]; wind moderate E., haze.

Carlingford.-September 4th, a strange bird caught at night. [Willow Wren received in flesh.]

Innishtrahull.-April 11th, four Willow Warblers on island at 2 P.M.; wind light S.E., misty: 20th, one at lantern at 11 P.I.; wind light S.E., clear: 27th, one Willow Warbler at 10 P.M. ; one "Chiffchaff" at midnight, injured; forwarded in flesh-[Willow Wren received in flesh, sent as "Chiffchaff, caught at lantern April 28th"]; wind light W., misty.

Slielligs.-April 1st, one "Willow Warbler" on rock at 8 A.M.; wind moderate N.E.: 3rd, two at noon; wind moderate E., mist: 25 th, one on rock; wind light S.E. September 8th, seven at 8.30 A.M. ; wind light S., misty.

\section{Chiffchaff (Phylloscopus rufus, Bechst.).}

Mine Head.-April 27th, "Chiffchaffs" at lantern at midnight; light wind S., overcast, gloomy.

Blackwater Bank, Light-ship.-March 31st, some "Golden Wrens" noted, with large numbers of Wheatears and Larks round light from midnight to 2 A.M. ; about forty birds killed; large numbers falling overboard after striking lantern-[Leg and wing of Chiffchaff received, sent as "Golden Wren," killed striking]; wind W., light rain.

\section{GOLDEN-CRESTED WREN (Regulus cristatus, Koch).}

Fastnet.-October 23rd, one caught in kitchen at 10.30 A.Mr; wind strong S.E., overcast. November 5th, one caught in dwelling at 7.30 A.M.; wind light S.E., cloudy.

Dungarvan.-April 5th, four about light at 12.10 A.M. ; one struck; wind moderate N.E., gloomy. 
Coningbery Light-ship.-November 5th, two small birds about ship at 3 P.xr.; one caught and sent by post-[Golden-crested Wren received in flesh]; other "small birds" about light same night from 6 P.M. to 11 P.M.; several killed and fell overboard; wind light S.E.

Tushar:- [November 21st, one received in flesh, with Ring-Ouzel and Black Redstart, accompanying letter dated November 18th. "Struck lantern during middle watch; weather misty."]

Lucifer Shoals Light-ship.-September 27th, one "Golden Wren" about ship at 10.30 P.M.; it rested and died from exhaustion; wind light S.W., clear. [Golden-crested Wren received in flesh.]

Blachwater Bant Light-ship. - September 21st, four GoldCrests and one Wagtail about light at 10 P.M. ; one Gold-Crest on board during night; wind light N.W., cloudy: 29th, twenty Thrushes, twenty Starlings, and four Gold-Crests about lantern from midnight to 4 A.I. ; two found killed on deck--[Leg and wing of Golden-crested Wren, with do. of Thrush, received]; wind light S.W., thick mist.

Arllow North Light-ship.-February 4th, "Golden Wrens," with Larks, about light; one killed; wind light S.W., rain. April 30th, Sand Larks and Golden Wrens [? Willow Wrens -R.M.B.] going N.W. during night; wind moderate N., clear. October 18th, one Thrush and two "Golden Wrens" about lantern at 9.15 P.I.; Thrush and one "Golden Wren" killed; mind moderate W., clear.

Rockabill.-October 6th, two on rock; remained till 7th; wind light S.W., cloudy: 21st, a large number of birds about light; one Golden-crested Wren and forty other birds killed striking (see under Thrush); wind light S.E., fog.

Copeland (Mew) Island.-September 29th, one bird, name unknown, struck lantern at midnight-[Golden-crested Wren received in flesh]; wind light $W$., clear.

Innishtrahull.-March 22nd, one at lantern from 1 A.M. to 4 A.M. ; wind light S.E., haze: $27 \mathrm{th}$, two do. at 1 A.M.; wind light S., haze: 28 th, four do. at 1 A.M. ; wind light N., haze.

Slielligs.-March 26th, one on rock at 8 A.M.; gale S.W.: 29 th, two at noon; wind light E. April 11th, two at 9.30 A.M.; wind moderate S.W., mist. 


\section{WREN (Troglodytes parvulus, Koch).}

Fastnet.-October 30th and 31st, great rush of birds between 9 P.M. and 6 A.M.; many killed and fell into the sea; two Wrens killed striking at 11 P.M.; ten species noted (see under RingOuzel and Goldfinch); wind fresh N.E., overcast. [Wren in flesh, and leg and wing of another, received.]

Coningbeg Light-ship.-March 6th, one Wren on deck from 6 A.M. to 9 A.M. ; flew N.E. to land; wind moderate S., clear.

Rockabill.-January 20th, one Wren on rock at 10 A.M.; gale E., clear. April 4th, two on rock at noon ; wind moderate E., haze.

Bull Rock.-November 1st to 4th, two Common Wrens on rock; wind moderate E., hazy.

\section{"WAGTAILs."}

Mine Head.-February 20th, four Wagtails going W.; strong breeze W., misty. September 10 th and 12th, some at station all day; wind light E., overcast. December 9 th, several; gale N.W.

Dungarvan.-August 12th, seven, in one flock, going S.W.; wind moderate W.: 26th, very numerous all day about station; wind strong W., squally. September 4th, nine going S.W.; fresh breeze W., rain: 10th, five going S.W.

Coningbeg Light-ship.-November 3rd, one going N.E.

Lucifer Shoals Light-ship.-September 9th, five at 11 A.Mr. going W.; wind moderate E.: 10th, four going N.W.; light breeze E. : 13th, two going N.W.; calm: 16th, three going W.; moderate breeze N.W.

Blachwater Bank Light-slip.-April 24th, two going N.W.; wind E. September 11th, two, and four Linnets, going N.W.: 12th, two "White Wagtails" going N.W. ; wind light E.: 13th, five Linnets and three Wagtails going N.W.; two "White Wagtails" rested on ship at 3 P.M., remained ten minutes, then flew to land; wind light N.E.: 21st, four Gold-Crests and one Wagtail about light; wind light N.W., cloudy.

Arlilow South Light-ship.-April 21st, one going N. September 23rd, one going N.W.

Arlitorr North Light-ship.-April 28th, three Water Wagtails going N.W. June 10th, one "Yellow Water Wagtail" and 
two Green Linnets going N.W. ; wind light S., clear. September 30th, two Wagtails going N.W.

Codling Bank Light-ship.-April 15th, three "W. Wagtails" in ship; wind moderate S.W., clear: 16th, three in ship; wind strong N.W., clear: 28th, one going N. May 10th, one going N.W.: 14th, one "W. Wagtail" going N.W. at 5 A.M. September 12th, one lit on ship; stopped all day and night; wind light, haze: 14th, one at 10 A.M. going N.W.

Rockabill.-April 29th, one at light at 12.30 A.M.; killed; wind moderate W., haze.

Aranmore.-August 6th, two on wall; first observed here; wind light S.W., clear.

Skelligs.-September 9th, one Pied Wagtail on rock; wind light N.E.

TITLARK (Anthus pratensis, Linn.).

Fastnct.-November 5th, four "Rock Pipits" found killed at lantern; wind light S.E., cloudy. [Leg and wing of Meadow Pipit received.]

Mine Head.-September 10th and 12th, Titlarks and Skylarks going W. all day; wind light E., overcast. October 30th, Titlarks noted; "inhabitants of the place."

Dungarvan.-June 7th, Pipits very numerous about station all day.

Coningbeg Light-ship.-March 16th, one, and one Chaffinch, about ship; flew N.E. to land. April 22nd, one died on deck. May 9th, one rested and flew N.W. September 12th, two on upper deck; flew N.E.: 13th, four going N.E.: 15th, one do. November 3rd, one "Skylark" killed against lantern; leg and wing sent-[Leg and wing of Titlark received]; wind fresh S.E., clear.

Tuskar.-March 7th, one on rock; light breeze N.: 25th, several on rock.

Lucifer Shoals Light-ship.-April 23rd, one lit on board; wind fresh E. May 9th, one do., and two going N.W.; light breeze N.W. December 4th, several flocks of "Bog Larks" going N.W. [? Titlarks]; wind light N.W., clear.

Arklow North Light-ship.-April 24th, one died on deck.

Codling Bank Light-ship.-April 23rd, one in ship; wind fresh E., haze : 24 th, one about ship; wind moderate E, haze: 
25th, several on ship during day; wind light E., haze: 26th, great numbers about ship from 8 A.M. to 2 P.M.; wind light N.E, light haze.

South Rock Light-ship. - November 22nd, one at 9 A.I. going $\mathrm{W}$.

Aranmore. - November 28th, three on wall; gale N.W., hail.

Arran Island, N.-October 31st, one killed striking[Received in flesh; sent as "Linnet"]; wind moderate N.E., drizzling rain.

Skelligs.-August 17 th, eight on rock all day; wind moderate N.W.

\section{SkYLARK (Alauda arvensis, Linn.).}

Fastnet.-October 19th, two caught striking, with two Chaffinches; others struck, but they fell over cliff; wind light S.E., fog-[Leg and wing of Skylark received]: 24th, numbers, with Starlings and other birds, striking light; some killed and disabled; wind fresh S.E., overcast: 25th, numbers of Larks and Starlings about lantern; some killed; strong breeze S.E., overcast: 26th, Larks, with Blackbirds, Chaffinches, Thrushes, and Starlings, about light; some killed. November 24th, one about lantern.

Mine Head.-April 27th, some at lantern at midnight; wind light S., overcast. September 10 th and 12th, Titlarks and Skylarks going W. October 5th, about twenty Skylarks all day; wind light S.: 30th, Redwings and Skylarks going W.; wind S.E., misty. November 14th, flocks going W.; gale N.: 23rd, flock all day; wind light N., overcast.

Dungarvan.-January $7 \mathrm{th}$, several large flocks of Starlings and Skylarks going E., flying very low, and all going in the one direction; "they kept passing in alternate Hocks, Starlings first, Larks next, and so on-George Dunleavy;" wind light S.E., gloomy. February 25th, several at 10 P.M. Hying in rays of light, none coming close to the lantern glass: gale S.W., misty. November 24 th, numbers about light from 10 P.M. to 11.30 P.M.; four struck; wind light S.E., gloorny, rain.

Hook Tower.-[December 24th or 25th, Skylark received in Hlesh.]

Coningbey Light-ship.-February 4 th, one about ship; flew 
N.E. March 17 th, one do. June 26th, several rested on ship; fog. August 28th, one noted. October 1st, one rested; flew N.E. : 22nd, one, and two Starlings, rested; flew N. November 3rd, one going N.E.: 5th, several about ship: 7 th, flock going N.: 17th, Larks and Chaffinches about light; some killed and fell overboard ; wind moderate S.W., rain : 19th, large numbers of Thrushes, Stares, Skylarks, and Blackbirds about light; several killed and fell overboard; gloomy: 23rd, one killed striking at 8.30 P.M. [Leg and wing received.]

Ban'els Rock Light-ship.-November 2nd, large flock going N.W.; wind moderate S.E., clear.

Tuskar.-February 3rd, several striking at midnight; one lilled-[Leg and wing received]; wind light S.W., fog: 22nd, some about lantern from 7 P.M. to midnight; nine killed; wind moderate S.W., cloudy: 23rd, several about light from 7 P.M. until 3 A.M. on 24th; seventeen killed; wind fresh S.W., cloudy. [December, Legs and wings received of two Larks, said to have struck lantern between November 20th and December 1st.]

Lucifer Shoals Light-ship.-October 18th, three flocks going N.W.; wind moderate S.W.: 19th, flocks going N.W.; wind light W.: 30th, several small flocks of Larks and Linnets going S.E., "towards Wales"; calm. November 2nd, small flocks Linnets and Larks going S.E.; wind moderate S.E., clear: 17th, several small flocks of Larks going W.; moderate breeze S.W., rain: 1Sth, about twenty Larks in twos and threes going W.; light breeze N.W.: 19th, two going W.: 21st, four rested; calm. December 10th, one going W.: 25th, one rested.

Blackwater Bank Light-ship.-February 3rd and 4th, some about light from 10 P.M. to 7 A.M.; went N.W.; calm, fog: 6th, some, with Thrushes, at light from midnight to 8 A.M.: 22nd, Curlew, Larks, and Starlings about light from 8 P.M.; went towards land at midnight; wind light S.IV., haze; two birds killed-[Leg and wing of Lark and Starling received]: 231 d, large number of Larks, Starlings, and Thrushes round light all night; about forty killed. March 2nd, a few about light; wind light W., drizzle: 21st, ten going N.W.; wind light S.W., fog: 22nd, flocks of Starlings and Larks going N.W.; wind moderate S.W., rain: 25th, large number of Curlew, Larks, and Starlings about light from 7 P.M.; went towards land at midnight: 31st, about two hundred Wheatears 
and Larks about light from midnight to 2 A.M.; about forty killed striking, large number falling overboard; large flock went towards land at 2 A.M. ; light rain. September 25th, two "Ground Larks" going S.E.; remained two hours on ship: 27th, flock going N.W. ; wind light S.W.; four Larks and two Petrels about light. October 8th, four Larks going N.W.: 9th, one "Ground Lark" do.: 14th, one Lark found dead at noou -[Leg and wing received]; wind light S.W., clear: 18th, Thrushes, Blackbirds, and Larks about light; three Blackbirds and six Thrushes killed; many other's struck and fell overboard; wind moderate S.W., clear: 19th and 20th, flocks of Larks going N.W.; calm: 21st, five "Ground Larks" going E. : 29th, rush of Blackbirds and other birds about light; ten killed-[Leg and wing of Lark received]; wind moderate S., cloudy: 31st, about a hundred Thrushes, Blackbirds, Larks, and Starlings about light; wind moderate S.E., showery. November 9th, four Larks going N.W. December 13th, two going N.W.: 18th, flocks of Larks about light from 9 P.x. to midnight; one found dead on deck-[Leg and wing received]; wind light N.E., overcast: 19 th, from midnight to 7 A.M. flocks of Larks and other birds about light; about a hundred killed and fell overboard; light breeze S.E., overcast; at 11 A.M. flocks of Linnets, Larks, and other birds going N.W.; clear: 25th, flock of Larks going N.W. at noon; strong breeze S.W., showery. Arklow South Light-ship.-February 3rd, Starlings, Thrushes, and Larks about ship all night; several struck and fell overboard; wind light S.W., fog: 6th, one Lark about ship. April 19th, two going N.W. October 18th, two going N.W.: 19th, five going N.W.: 29th and 30th, a lot of Starlings, Larks, and other small birds about light; wind moderate S.E., haze. November 22nd and 23rd, some going N. December 1Sth, some going N.W.

Arklow North Light-ship.-February 1st, several about light, five killed; wind light S.E., rain: 2nd, Larks and Starlings about light; two Larks and three Starlings killed; wind light N.W., overcast: 3rd, Larks and Starlings at light; five Larks and two Starlings killed; wind light S.W., fog: 4th, "Golden Wrens" and Larks at light; one "Golden Wren" and four Larks killed; wind light S.W., rain: 11th, Larks and Linnets at light; three Larks and one Linnet killed; wind light E., 
overcast: 15th, two Green Linnets and one Lark found dead on deck. March 6th, about a hundred small land-birds, probably Larks, going N.W. during day: 14th, a few Larks going N.; two killed by Sea-Gull. October 3rd, several going W.; wind fresh N.E.: 4th, several Skylarks and Green Linnets going E. during day; wind light N.W.: 6th, a number of small birds, probably Larks and Starlings, going N.W. during day; wind fresh W.: 8th, several Larks and Starlings going N.W.; wind fresh S.W.: 9th, Larks and Starlings going W.; wind moderate N.W. : 10th, Larks and Green Linnets going N.W. ; wind fresh S.W. : 17th, some flocks of Larks and Linnets going N.W.; gale S.W.: 19 th and 20th, several flocks of Larks going N.W.: 21st, Larks and Green Linnets going N.W.

Codling Bank Light-ship.-January 25th, five about ship; gale N. February 4 th, four do. at 7 A.M., and flock at 11 A.M.; several caught; wind light S.W., fog: 5th, several flocks during day; wind variable, fog: one or two noted on 6th, 8th, 12th, 14th, 18th, 20th, and 28th. March 7th, one going E.: 8th, a flock going E.: 15th, some going E.: 18th, several "Ground Larks" going different ways: 20th, several Larks, with Chaffinches, going N.W. from 9 A.M. to 2 P.M.; wind light S.W., light haze and fog. May 16th, one at 11 A.M. going N.W. September $14 \mathrm{th}$, several flocks of "Ground Larks" going N.W. from 6 A.M. to 9 A.M. ; calm: 23rd, two do. going N.W.: 27th, flocks of do. going N.W.; wind light S.W. October 4th, several Larks going N.W. from 10 A.M. to noon: 8th, several going N.W.; wind fresh N.W., clear: 12th, great flocks going N.W. from 8 A.M. to noon; wind moderate N.W., clear: 17 th, five going N.W.; gale S.W., light haze: 18th and 19th, great lots of Larks going N.W. from 9 A.M. to noon; wind moderate S.W., clear: 21st, flocks going N.W.; fog. November 3rd, several "Ground Larks" going E.; wind variable, clear: 5th, flock of Skylarks going N.W.; wind E.: 16th, flock of Larks going N.W.; wind fresh S.W., overcast: 19th, flock going N.W.; wind moderate W, clear: 21st, several do. December 10th, two flocks going N.W.; wind fresh W.: 18th, great flocks of Larks and Chaffinches about light, and going "variously" all day; wind light S.W., haze : 24th, three Larks going N.W.

Rockabill.-January 9th, seven about light; one killed striking; wind moderate E., haze. March 7th, three about 
light; one killed striking; wind moderate E, cloudy: 27th, a dozen about light at 2 A.M.; seven, and one Water-Rail, killed striking; wind fresh S., haze. April 25th, five, with four Thrushes, about light. October 10th, six, with two Yellowhammers, six Chaffinches, and ten Starlings, on rock in the afternoon; strong breeze S.W., clear: 11th, the Skylarks left rock and went N.W., Starlings and Chaffinches remaining: 20 th, nine on rock at 3 P.M.; wind light S.E., cloudy: 21st, a large number of birds about light at 2 A.M.; forty-one killed striking; a dozen "Skylarks and Starlings" amongst them (see under Thrush); wind light S.E., fog. November 10th, Larks, Thrushes, and Fieldfares about light at 1 A.M.; two Larks and six other birds killed striking; wind light S., misty. December 31st, six on rock.

South Rock Light-ship.-October: 12th, several Larks and Linnets going N.W.; wind moderate N.W.: 13th, several Larks and Chaffinches going do.; wind light N.E.: 14th, flocks of Larks going N.W.; wind moderate E.: 15th, several going N.W.: 1Sth, several Larks and "Stonechats" going N.W.: 19th, flocks going W.: 20th, some, with Chaffinches, going W.: 21st, some, and two Linnets, going W.: 22nd, a few, with Linnets and Starlings, going W.: 23rd, a few about light at 10 P.M. ; wind light S.E., clear: 24th, a few going S.E. during day; wind light S.E.: 25th, a few about light; haze: 26th, two going S.E.; several about light; haze: 27 th and 28 th, some about light; haze: 29th, a good number during day; haze: 30th, Larks and Starlings about light; many striking and falling overboard; wind light E., fog: 31st, a great number of Larks going $\mathrm{E}$. during day; wind moderate $\mathrm{E}$, haze. November 10th, a few about light: 11th, some going N.W.: 12 th, some going E. ; wind strong S.IV., rain: 13 th, two going E. some about light: 14th, some going E.: 15th, a few about light: 17th, a few do.: 18th and 19th, a few going E.: 20th, several, and 21st, a couple about light: $23 \mathrm{rd}$, a few going S. at 11 A.M.; a few about light at night: 24th, a few about light: 25th, some, with Thrushes and Blackbirds, about light; two birds killed striking; wind moderate S.E., clear: 26th, a few going W. at 11 A.M.; a few, with Blackbirds, about light: 27 th and 28th, a few going W.: 28th and 29th, a few, with Blackbirds, about light; wind strong N.W. December 1st, a few at 
light: 2nd, two going S.: 4th, a few going S.: 6th, a few going S., and a few about light at 9 P.M. : 10 th, a couple going S.W. at $8 \mathrm{~A} . \mathrm{Mr}$.

Copeland (Mew) Island.-October 23rd, some about light, with other birds, at 10 P.M. ; Lark, "Thrush," and Starling killed striking-[Legs and wings received of Lark, Redwing, and Starling]; wind moderate S.E., gloomy. December 18th, a great number of Larks about light from 11 P.M. to 3 A.M. on 19 th, one killed; fog.

Innishtrahull.-Jantary 26th, twenty on island at 4 P.M.; wind fresh N.W., snow. February 6th, three at lantern at 4 A.M. ; wind light S., mist. March 21st, two at lantern at 9 P.M.; disabled; wind light S.W., misty: 22nd, five from 1 A.M. to 4 A.M.; disabled; wind light S.E., haze: 27 th, five at 11 P.M.; not injured: 28th, two at 1.30 A.M.

Rathlin O'Birne.-February 5th, ten going S.; wind moderate E. March 24th, six all day; gale S.W.

Arran Island, S.-Autumn, Skylarks are residents, and very seldom seen at night.

Bull Rock.-October 23rd to 25th, four killed against lantern, with ten Starlings and three Blackbirds; numerous on rock each day to 10 A.M. or 11 A.M. ; wind E., dark, gloomy weather at night. November 1st to 4th, Larks, with other birds, round light each night, and on rock during daytime; four killed striking; also four Starlings, ten Blackbirds, and four Thrushes; wind moderate E, dark, gloomy weather.

\section{Snow Bunting (Plectrophenax nivalis, Linn.).}

Mine Head.-March 5th, five going N.W.; wind fresh W. November 12 th, three noted. December 10 th, two going N.W.; strong breeze W.: 12th, ten noted: 20th, two or three noted; gale $\mathrm{E}$, overcast.

Rockabill.-February 2nd, unknown bird caught on rock[Snow Bunting received in flesh]: 14th, two Snow Buntings on rock at 9 A.M. : 19th, one at light at 1 A.M. ; killed; wind moderate W., haze.

Innishtrahull.-January 24 th, flock on island at 3 P.M.; fresh breeze N.W. March 22nd, one at lantern from 1 A.M. to 4 A.M.; wind light S.E., haze. 
Arcunmore.-October 20th, eighteen on wall at 9 A.M.; the first seen; wind moderate S.W. November 3rd, ten; wind fresh S.E., misty. December 26th, five; wind strong S.W., misty.

Rathlin O'Birne.-January 9th, large flock going W.; wind moderate E. : 16th, six going S.: 21st, ten, and 23rd, eight all day; wind light $N$. February 8 th, ten going $\mathrm{S}$.; wind fresh S.E.

Arran Island, N.-April 1st, one, in summer plumage, on island; wind light N.E. : 15th, two do. all day; gale W.: 21st, one killed striking-[Adult male, in summer plumage, received in flesh]; fresh breeze N.E., fog. "This bird came to island on 1st inst.; a second arrived on the 15th, and left when this one was killed." July 6th, one all day; wind moderate W., gloomy: 20 th, two at 8 P.M. ; wind light N.W. October 30th, three at 9 A.M. ; wind light S.E.

Skelligs.-October 3rd, several on rock at noon; wind light N. Bull Rock.-October 10th, two on rock at $10 \mathrm{~A} . \mathrm{Mr}$; first this year; wind fresh N.W:

Reed Bunting (Emberiza schoniclus, Linn.).

Innishtrahull.-April 13th, one Black-headed Bunting at lantern at 2 A.M.; disabled striking-[Leg and wing of Reed Bunting received]; wind light S.E., misty.

\section{YeLLow BuntiNG (Emberiza citrinella, Linn.).}

Rockabill.-February 5th, two on rock; wind light S.E., haze. October 10th, two, with a number of Larks, Chaffinches, aud Starlings, on rock; strong breeze S.W. December 18th, two on rock; wind light $\mathrm{W}$.

Skelligs.-May 30th, one on rock at 4 P.M. ; wind fresh S.W.

Chaffinch (Fringilla calebs, Linn.).

Fastnet.-October 18th, three hen Chaffinches caught at lantern at midnight; wind light S.W., cloudy-[Leg and wing received]: 19th, a number of birds struck lantern; two Larks and two cock Chaffinches caught striking; others fell over cliff; wind light S.E., fog: 24th, numbers of Starlings, Thrushes, Larks, Chaffinches, Blackbirds, etc., about light; some killed; 
wind fresh S.E., overcast: 26th, Blackbirds, Chaffinches, Thrushes, Starlings, and Larks about light; some killed; wind moderate S.E., overcast: 30 th and 31st, very large rush of birds; quantities killed, and fell into the sea; those caught were chiefly Blackbirds, Common Thrush, and Redwing; also large numbers of Chaffinches (for additional particulars see under Goldfinch); wind fresh N.E., overcast. November 3rd and 4th, numbers of Chaffinches, Thrushes, Redwings, Starlings, and Blackbirds during night; many killed; wind fresh S.E., overcast.

Mine Hcad.-February 5th, several going N.W.; wind fresh E., misty. March 5th, flock going N.W.; wind fresh W.: 12th, Green Linnets and Chaffinches going W.; fresh breeze N.W.: 20 th, flock of Chaffinches going S.W. at noon; fog. October 25th, about a hundred Chaffinches in the morning; some going W.; several struck; wind moderate S.E., overcast: 29 th, some all day. November 5 th to 8 th, about fifty; some going W., some at light: 23rd, some all day; wind light N. December 3rd, a few.

Dungavvan.-January 18th, numbers all day about station; frost: 19th and 20th, very numerous; wind E., gloomy: 29th, numbers all day; gloomy; several came into house, looking for food. December 8th, several about station; fresh breeze S.W.

Coningbeg Light-ship.—January 23rd, two going N.W.; rested two hours; light snow showers. March 16th, one about ship. April 5th and 6th, one on deck. October 23rd, two on ship; flew N.E.; overcast: 24 th, three rested. November 2 nd and 3rd, one on deck: 4th, one dead on deck at 8 A.M. [Leg and wing received]: 5th, one killed striking-[Leg and wing received]: 9th, one flying N.E.: 10th, one rested on ship; "Sparrow-Hawk in chase of Chaffinch, attacked by Gulls, which saved life of Chaffinch": 17th, Larks and Chaffinches about light; several killed, fell overboard; wind S.W., haze: 18th, one about ship; flew N.E. December 2nd, one about ship; not able to reach land; wind fresh N.E. : 20 th, one about ship from 9 A.M. to 2 P.M. ; died from fatigue; wind S.E.

Barrels Rock Light-ship.-November 3rd, several going N. at 7.30 A.M. ; three rested on ship till noon; wind moderate S.E., clear: 5th, flocks of Starlings and Chaffinches going N.W.; wind light N.E., clear. 
Tuskar.-February 13th, one on rock at 9 A.M.; wind light W., fog. March 7th, one male Chaffinch on rock; wind light N. : 25th, one at 8 A.I.; light breeze W., mist. [December, Legs and wings of two received; believed to have struck lantern between November 20 th and December 1st.]

Lucifer Shoals Light-ship.-April 27th, one Chaffinch and one "Blackhead" lit on board, remained all day; light breeze E., hazy. October 13 th, one rested on ship at 9 A.M., left and went E.; wind moderate E.: 14th, one at 9 A.M., rested on ship and died exhausted; wind moderate S.E., hazy: 22nd, four rested at 10 A.M., went W.; light breeze S.E.: 24th, four at 2 P.Mr, remained all night, one died; fresh breeze S.E., clear: 26th, several going W. from 3 P.M. to 5 P.M.; some of these rested on ship; wind moderate S.E., clear: 29th, some, with Starlings, Blackbirds, and Thrushes, around lantern from 7 P.M. ; left for the land about 6.30 A.M.; two Blackbirds and one Chaffinch striking; fresh breeze S.E. November 4th and 6th, two rested each day; wind light S.E.

Blackwater Bank Light-ship.-March 22nd, flocks of Starlings, Larks, and Chaffinches going N.W. ; wind moderate S.W., rain. September 19th, three going N.W. October 14th, Chaffinch dead on deck at 8 A.M.; wind fresh S.E., rain-[Leg and wing received]: 15th, flock going $\mathrm{N}$.; wind strong S.W.: 18th, flock going N.W.; wind fresh S.W.: 19th, one dead on deck at 8 A.M.; wind light N.IV. [Leg and wing received]: 21st, flock going N.W.; wind light S., gloomy: 23rd, about twenty going N.W. during day; wind S.E., gloomy: 25̃th, ten going N.W.: 27th, one going N.W.: 29th, a few about light. November 1st, four going N.W.: 5th, four remained about ship during day: 8th, four going N.W.: 18th, four about ship, remained till dark; wind light N.W. December 18th, flock going N.W. [Leg and wing of one caught on deck received]; wind light S.W.: 19th, flocks of Linnets, Larks, Thrushes, and Chaffinches going N.W. at 11 A.M.; two found dead on deck-[Leg and wing of Chaffinch, also of Linnet and Lark, found dead on deck, received]; wind light S.E., clear: 26th, one about ship at 10 A.M. ; wind strong S.W.

Arklow South Light-ship.-October 19th, some going N.W.; wind light N.W. December 18th, some going N.W.; wind light N.E. 
Arklow North Light-ship.-October 24th, several flocks of Starlings and Chaffinches going N.IV. during day; three of the latter died on deck exhausted; wind light E., clear.

Codling Bank Light-ship. - March 15th, flock, with some Larks, going E. from 1 P.M. to 4 P.M.; wind moderate S.W.: 20th, Larks and Chaffinches going N.W. from 9 A.M. to 2 P.M.; wind light S.W., fog. October 18th and 19th, several each day going N.W. and on ship; wind moderate to light S.W., clear: 20th, several in ship during day; wind light S.W.: 22nd, one in ship : $23 \mathrm{rd}$, one do. : 24 th, several on ship from 9 A.M. to 5.30 P.M. ; wind light E. : 25 th, several, and one Green Linnet, in ship during day, one killed; flock at 4.50 P.M. round ship, went W.; wind light S.E., haze: 26 th, flock at 7.30 A.M. on ship and going N.W.; several in ship during day, one killed; wind light S., light haze : 27 th and 28th, lots of small birds about light at night, several killed and disabled, some falling overboard-[Leg and wing of Chaffinch, with leg and wing of Blackbird, both killed on 28th, received]; wind light S., rain: 29th, one in ship. November $4 \mathrm{th}$, one found dead on deck: 7 th, one do.: 22nd, two going W. December 2nd, one going N.W.: 18th, great flocks of Larks and Chaffinches about light and going "variously" all day ; wind light S.W., haze; several Chaffinches and Green Linnets in ship during night; wind light S.E., overcast: 22 nd, one on ship at 8 A.M. : 23rd, one do.: 24th, one going N.E.: 26th, one going N.W.

Rockctill.-January 15 th, six on rock; wind moderate N.E., clear. February 10th, four on rock; wind W., haze. October 6th, ten on rock, with seven Greenfinches, two "Redwing Thrushes," and two Golden-crested Wrens; Chaffinches and Gold-Crests remained until 1 P.M. on the 7th; wind light S.W., cloudy : 10th, six on rock, with some Skylarks, Yellowhammers, and Starlings; strong breeze S.W., clear: 11th, Larks went N.W., Chaffinches and Starlings remain about rock: 21st, a large number of birds about light (see under Greenfinch); nine Chaffinches and thirty-two other birds killed striking; wind light S.E., fog: 29th, a very large number of birds about light at 3 A.M. ; eight Chaffinches and fifty-two other birds (chiefly Thrushes, Blackbirds, and Starlings) killed striking; all gone at daylight except a number of disabled Starlings; wind fresh S.E., fog. December 12 th, three on rock; wind fresh S., clear. 
South Rock Light-ship.-October 13th, some, with Larks, going N.W.; wind light N.E., clear: 20th, some, with Larks, going W.; wind light S.W., clear: 28th, one on deck: 29th, a few going N.W. during day : 30 th, one going N.W.

Arran Island, N.-October 26th, one "Hedge Sparrow " killed striking-[Leg and wing of Chaffinch received]; wind fresh S.E., gloomy. [November 1st, Chaffinch killed striking, received in flesh.]

Arran Island, S.-October 31st, one disabled striking at 10 P.M.; wind moderate S.E., overcast.

Skelligs.-March 23rd, six on rock; wind moderate S., mist. August 29th, two on rock; gale W. September 27th, four do.; wind moderate S. November 17th, five do.; wind light W., mist.

Brambling (Fringilla montifringilla, Linn.)?

Sleelligs.-May 29th, one "Mountain Finch" on rock at noon; wind strong S.W.-Thomas King.

\section{House Sparrow (Passer domesticus, Lińn.).}

Dungarvan.-July 13th, fifty noted; "first seen about station since I came, although they are numerous in the neighbourhood." -Geo. Dunleavy.

Coningbeg Light-ship.-October 19th, one "cock Sparrow" rested on ship and flew N.E.; wind light, variable, clear.

Arran Island, N.-Autumn, when the wind is off the land, a good number of Thrushes, Blackbirds, Starlings, Linnets, "Sparrows," and Curlew visit island.

Arran Island, S.-Autumn, Blackbirds, Thrushes, Linnets, Sparrows, and Skylarks are residents, but are very seldom seen at night.

HaWfinch (Coccothranstes vulgaris, Pallas).

Hook Tover.-October 25th, a little bird found killed against lantern glass; wind fresh S.E., cloudy-[Male Hawfinch received in flesh]. [November 5th, Hawfinch received in flesh, killed striking on 4th.]

Tuskar.-November, two unknown birds forwarded which struck lantern on night of the 1st instant, at 3.30 A.M. ; wind S.E., hazy. [Hawfinch and Siskin received in flesh.] 


\section{GreEnFinch (Ligurinus chioris, Linn.).}

IIine Head.-March 12th, Green Linnets and Chaffinches going W.; wind fresh N.W. October 5th, several all day; wind light S. : 24 th, Greenfinches noted round the farmhouses ; moderate breeze E., overcast. November 5th to 8th, flocks noted: 23rd, some all day.

Dungarvan.-January 18th, numbers of Chaffinches and Green Linnets all day about station; wind N.E., frost: 19th, numbers do., with Blackbirds and Thrushes; wind moderate E., gloomy.

Tuskar:-[December, wing of Greenfinch received; believed to have struck lantern between November 20th and December 1st.]

Blackwater Bank Light-ship.-December 20th, one found dead on deck at 10 A.M. [Leg and wing received]; fresh breeze S.E., clear.

Arklow South Light-ship.-December 18th, a few flocks of Green Linnets going N.W. from 2 P.M. to 4 P.M.; wind light N.E, overcast.

Arklow North Light-ship.-February 14th, two Green Linnets and one Lark found dead on deck; calm, clear. April 7th, four about ship all day; wind light N.W., clear: 20th, one died on deck; wind moderate S.W., clear: 27th, two died on deck; wind light N.E., clear. June 10th, one Yellow Water-Wagtail and two Green Linnets going N.W. during forenoon; wind light S., clear: 18th, one on ship, died on deck; wind fresh N.W., clear. October 4th, going E. during day; wind light N.W., clear: 10th, some going N.W., one died; wind fresh S.W., clear: 21st, some going N.W. during day, one found dead; wind light and variable, light haze.

Codling Bank Light-ship.-October 25th, one on ship and one killed; wind light S.E., light haze. November 22nd, four going W. December 18th, several on ship during night, one killed; wind light S.E., overcast: 19th, two on ship; haze: [21st, Leg and wing of male Greenfinch received, "killed "].

Rockabill.-January 7 th, two on rock; wind fresh E., haze. February 5th, two do.; wind light S.E., haze. October 6th, seven on rock at noon; wind light S.W., cloudy: 21st, Greenfinch, with large number of other birds, about light at 2 A.M., 
two killed striking, with six Blackbirds, a dozen Skylarks and Starlings, four Fieldfares, seven Thrushes, nine Chaffinches, and one Golden-crested Wren; all birds that struck on this night were killed, none found disabled next morning; wind light S.E., fog.

Skelligs.-June 2nd, one on rock; wind moderate S.

\section{GoLDFINCH (Carduelis elegans, Stephens).}

Fustnet.-October 30th and 31st, great rush of birds from 9 P.M. to 6 A.M., chiefly Blackbird, Thrush, Redwing, and Chaffinch; many killed and fell into the sea; one Fieldfare, two Common Wrens, one small bird-[Siskin.-R. M. B.], two birds size of Blackbird-[Ring-Ouzels.-R. M. B.], and one Wheatear, killed or caught striking; one Goldfinch killed striking, picked up dead-[Goldfinch received in flesh, with male and female Siskin, Ring-Ouzel, and Wren]. "This is the second Goldfinch I have got since coming here.-E. RoHU" (see "Migration Report," 1896, p. 518). Wind fresh N.E., overcast.

Dungarvan.- September 19th, three in lighthouse field; wind moderate N.W., clear.

Codling Bank Light-ship.-May 9th, two lit on ship at 5 A.M. for about ten minutes, and then went W.; wind moderate N.W., clear.

Aranmore-October 22nd, one on hedge at east side of island; only one ever observed here; wind moderate S.E., clear. -J. C. MacGinley. [But see "Migration Reports" for 1882, 1884, 1886, 1887, and 1890.]

\section{Siskin (Carduelis spinus, Linn.).}

Irestnct.-October 24th, two small birds, name not known, caught at lantern between 2 A.M. and 4 A.M.; wind fresh S.E., overcast-[Two Siskins received in flesh]: 30 th and 31st, unknown bird forwarded, struck lantern in a rush of many species between 9 P.M. and 6 A.M. (see under Goldfinch); wind frèsh N.E., overcast. [Two Siskins received in flesh, with Goldfinch, Ring-Ouzel, and Wren.]

Tuskar:-November, two unknown birds forwarded which struck lantern on night of the 1 st instant at 3.30 A.M. ; wind S.E., hazy. [Male Siskin and Hawfinch received in flesh.] 
Codling Bank Light-ship.-October 27th, one Siskin in ship; wind moderate S., light haze.

Skclligs.-October 9th, four on rock at 4 P.M., leg and wing forwarded. [Leg and wing of Siskin, caught at lantern, received.]

\section{LINNET (Linota cannabina, Linn.).}

Mine Head.-September 19th, about fifty noted; wind light N. October 8th, a great many; wind fresh W.: 9th, "Swallows and Linnets," great flocks day and night, some struck lantern ; wind light W.: 14th, great flocks of Linnets going W.; wind light W.; rain and mist. December 3rd, flocks all day about station ; wind light N.W.

Coningbey Light-ship.-March 13th, one about ship, died on deck; wind N.E., light haze: 27th, two about ship; flew N.; dense fog. October 9th, flock going N.W.: 19th, several flocks; wind light S.W., clear: 21st, three flocks going S.E.; wind light E., haze: 25th, several flocks going S.; wind S.E., light haze: 26 th, flock going N.E. ; wind fresh S. November 3rd, flock of Grey Linnets going N.E.; wind moderate E.: 6th, one Grey Linnet on deck, flew N. December 18th, one "cock Linnet" lilled striking at 8.30 P.M. ; wind moderate S.E., gloomy-[Leg and wing of Linnet received]: 19th, several flocks passing ship, tlying N.E. ; wind moderate S.E., gloomy.

Lucifer Shoals Light-ship.-February 24th, two flocks, about a dozen in each, going N.W.; strong breeze S.W. April 13th, one going N.W.: 15th, two going N.W.: 17th, one going W.: 21 st, two going N.W. October 10th, one rested on ship: 30th, several small flocks of Larks and Linnets from 11 A.M. to 3 P.M. going S.E. towards Wales; calm. November 2nd, several small flocks of Linnets and Larks going S.E. from 11 A.M. to 2 P.M.; wind moderate S.E., clear. December 6th, one Linnet.

Blackwater Bank Light-ship.--September 11th, four, and two Wagtails, going N.W.: 13th, five, and three Wagtails, going N.W.: 16th, two Grey Linnets lit on board, then flew S.E.: 19th, one going N.W. Octoler 25th, ten going N.W.: 26th, one found dead on ship-[Leg and wing received]. November 8th, two going N.W. : 10th, "three Robins and a Linnet" going N.W.; wind moderate S.E., haze : 18 th, two about ship, remained till dusk. December 12th, three going N.W.: 17th, four do.; 
fog: 19th, flocks of Linnets, Larks, Thrushes, and Chaffinches going N.W. at 11 A.Mr; wind light S.E., clear; two found dead on deck-[Leg and wing of Linnet, also of Chaffinch, received]: 25th, flock going N.W.; wind strong S.W.

Arklow South Light-ship.-April 26th, two Grey Linnets going N.W., rested a while on ship; wind light N.E., gloomy: 28th, some going N.W. May 4th, some passing in twos and threes, N.W. and N.E.; fresh breeze S.W., cloudy: 16th, one going N.E. September 12th, two going S.E. October 18th and 19th, flocks going N.W. during day; wind westerly. December 3rd, large flock going N.W. at 9 A.M. ; wind light N.W., clear.

Arklow North Light-ship.-February 6th, several flocks of Grey Linnets going W. during day, two killed; calm: 11th, Larks and Linnets about light during night, three Larks and one Linnet killed; wind light E., overcast. October 17th, several flocks of Larks and Linnets going N.W.; gale S.W., showery.

Codling Bank Light-ship.-April 19th, two going N.W. May 12 th, four lit on ship at 4.30 A.M., stopped thirty minutes, then Hew W. December 5th, one in ship: 11th, one do.

South Rock Light-ship.-October 12th, several, with Larks, going N.W. during day; wind moderate N.W., clear: 21st, two going W. : 22nd, a few Larks, Linnets, and Starlings going W. November 20th, one going S.W. December 3rd, three going S.W.: 4th, a few going S.W.: 5th, two going W.: 7th, one going W.: 8th, three, and 9 th, two, "wanted to get W.N.W., but unable with force of wind"; heavy gale W. to W.N.W., clear.

Innishtrahull.-May 23rd, one on island; wind light N., misty. Aranmore.-October 26th, flock of Grey Linnets flying about; strong breeze S.: 27th, flock "Rose Linnets," one caught with bird-lime; wind fresh S.E., clear. November 5th, twenty-five going W.; wind light S.E., misty. December 5th, four about station: 26th, eighteen going $\mathrm{E}$; wind strong S.W., misty.

Arran Island, N.-September 6th, three "Linnets" on island; wind moderate W. (see under Titlark): 29th, two going E. ; wind strong N., showery. "When the wind is S.E., E., or N.E., i.e., off the land, a good many visit isle."

Arran Island, S.-Autumn, Linnets are residents, but are very seldom seen at night. 
"TwiTe."

Blackwater Banli Light-ship.- March 31st, about forty "Twites" noted, with large number of Wheatears and Larks round light from midnight to 2 A.M.

\section{StarLING (Sturnus vulgaris, Linn.).}

Fastnet.-October 24th, numbers of Starlings, Thrushes, liedwings, Larks, Chaffinches, and Blackbirds at light during night; some killed, some disabled; wind fresh S.E., overcast: 25th, numbers of Larks and Starlings; some killed striking; strong breeze S.E., overcast: 26th, some, with Blackbirds, Chaffinches, Thrushes, and Larks, at light; some killed striking; wind modernte S.E., overcast. November 3rd and 4th, numbers of Chaffinches, Thrushes, Redwings, Starlings, and Blackbirds about light; many killed; wind fresh S.E., overcast.

Mine Head.-February 3rd, flock at noon going W.; fog: 20th, flock noted. March 9th and 12th, Stares going W. October 14th, about fifty going W.; wind light W., mist and rain : 23rd, great flocks all day; some at lantern; wind fresh E., overcast-[Leg and wing of Starling, striking October 23rd, received: do., striking 29 th: do., 30 th]. November 5 th to 8 th, flocks; some at light: 14th, some going N.W.; gale N. December 3rd, great flocks all day; wind light N.W.

Dungarvan.-January 7th, several large flocks of Starlings and Skylarks going E., flying very low; "kept passing in alternate flocks;" wind light S.E., gloomy: 27th, great numbers of Lapwings and Starlings in fields about station from 9 A.M. to 11 A.M. ; wind moderate N.W., clear; slight fall of snow last night, with hard frost. February 6th, 9th, 10th, and 12th, flocks noted near station: 26th, a large flock going S.W.; strong breeze S.TY., gloomy. March 1st, numerous flocks going S.W.; wind light S.W., clear. "Birds seem to be leaving this locality." October 12th, flock of about a hundred in fields near station; calm, clear: 19th, large flocks near station; calm, hazy: 20th, great numbers all day; calm, foggy. November 1st, very numerous; wind light E., gloomy: 11th, about two hundred: 24th, a flock of some thousands going N.E.; wind light E., gloomy: 26th, Curlew and Starling very numerous all day; wind S.IV., rain. December 10th, Starling very numerous; strong breeze W., clear. 
Coningbeg Light-ship.-January 3rd and 6th, some about light; none killed; rain. February 3rd, three about lantern; dense fog; one killed striking. October 22nd, two, and one Lark, rested on ship and flew N.: 24th, several going N.E. during day; two killed striking at night. November 7 th, two going N.E.: 8th, two about ship for three hours; flew N.E. at 4 P.M. : 19th, large numbers of Thrushes, Stares, and other birds about light; several killed striking and fell overboard; wind light, variable, gloomy.

Barrels Rock Light-ship.-November 1st, large flock going N.W.; wind light S.E., gloomy: 2nd, ten going N.W.; wind moderate S.E., clear: 3rd, several flocks going N.W.; wind moderate S.E., clear: 5th, flocks of Starlings and Chaffinches going N.W.; wind light N.E, clear.

Tuskar.-February 5th, one killed striking at midnight; fog - [Leg and wing received]: 22nd, some about lantern; twelve killed, with nine Larks and three Blackbirds; moderate breeze S.W., gloomy: 23rd, great numbers at light, going N.W., at 7.30 P.M. ; dozens killed, with seventeen Larks and nine Blackbirds; fresh breeze S.W. March 2nd, some about light; several striking; wind S.W., overcast.

Lucifer Shoals Light-ship.-August 3rd, two rested on ship from 5 A.M. to 6 A.M. ; left for the land W.N.W.; light breeze N.E., clear. October 20th, four about lantern at 8 P.Mr. ; hazy 21st, two rested on ship at 9. A.M. ; flew towards land: 22 nd, a dozen about light at 9 P.M.; wind moderate S.E., clear: $23 \mathrm{rd}$, some, with Blackbirds, round light at 8 P.MI.: 24th, four on ship; went W.: 25th to November 1st, Starlings every night noted round lantern; sometimes with Blackbirds, Thrushes, Chaffinches, and small birds; one Starling killed striking night of October 27th, with two Blackbirds and one Thrush ; rain; wind southerly on all these nights. October 31 st, half-a-dozen rested on ship all day; wind moderate S.E., clear.

Blackwater Bank Light-ship.-January 1st, small flocks, with Thrushes, going N.W.; wind light N.W., clear. February 22nd, about forty Curlew, Larks, and Starlings about light; two killed -[Leg and wing of Starling, also leg and wing of Lark, received]: 23rd, large number of Larks, Starlings, and Thrushes at light from sunset to sumrise on 24th; about forty killed; a large flock of Starlings left ship for Irish land at daylight; wind moderate 
S.W., overcast: 24th, Curlew and Starling at light from S P.M. to midnight; strong breeze S.W., overcast. March 14th, six about light from 1 A.M. to 6 A.M.; gale S.E., rain: 22 nd, flocks of Starlings, Larks, and Chaffinches going N.W.; wind moderate S.W., rain: 25th, a large number of Curlew, Larks, and Starlings about light from 7 P.M. to midnight; left for land; wind moderate S.W., fog and haze. September 28th, about twelve Thrushes and Starlings about light; one Starling killed-[Leg and wing received]: 29th, about twenty, with Thrushes and Golden-crested Wrens, round light from midnight to 4 A.M.; thick mist. October 13th, large flock going N.W.; wind moderate E., clear: 14th, flocks going $\mathrm{N}$; ; wind fresh S.E., rain: 19th, flock going N.W.; wind light N.W., clear: 21st, two flocks going N.W.: 22nd, flock going N.W. : 23rd, Thrushes and Starlings, about forty of each, about light; four birds killed; light breeze S.E., overcast: $24 \mathrm{th}$, do., about twenty of each, about light; eight birds killed-[Leg and wing of Starling received]; flew for land at daylight; wind moderate S.E., light haze: 29th, large number of Blackbirds, Thrushes, Starlings, and a few Chaffinches about light after sunset; ten birds killed; large flock went N.W. at daylight; wind moderate S., cloudy: 31st, about a hundred Thrushes, Blackbirds, Larks, and Starlings about light; wind moderate S.E., showery. November 7th, six going N.: 21st, a few Starlings and Thrushes about light from 2 A.M. to 4 A.M.; one killed-[Leg and wing of Starling received]; went for land at 4 A.M.; light breeze S.W., haze: 23rd, large number of Starlings, Blackbirds, and Thrushes about light; two killed; wind light N.E., cloudy. December 3rd, six going N.W.; wind light W., clear: 12th, two flocks going N. and N.N.W.: 13th, flock and two Larks going N.W.; fresh breeze S.W., clear: 14th, flock going N.W.; strong breeze S.W., clear: 18th, a few Starlings and Blackbirds about light from 9 P.M. to midnight; one found dead on deck[Leg and wing of Starling, killed striking, received]; wind light N.E., overcast: 19th, from midnight to 7 A.M., flocks of Larks, Blackbirds, Thrushes, and Starlings round light; about a hundred killed and fell overboard; flock of Starlings at 9 A.Mr. going N.W.; light breeze S.E., overcast: 25 th, a large number of Starlings and Thrushes in the afternoon going N.W.; wind strong S.W., showery. 
Arllow South Light-ship.-February 3rd, Starlings, Thrushes, and Larks about ship all night, several struck and fell overboard; wind light S.W., fog and haze. October 15th, flocks during forenoon going S.W.; strong breeze S.W., cloudy: 19th, flocks going N.W., a constant rush during day; wind light N.W., clear : 29 th and $30 \mathrm{th}$, a lot of Starlings, Larks, and other small birds about light during night; wind moderate S.E., light haze: 31st, do., some Wild Duck among them this night. December 19th, one going N.W.

Arklow North Light-ship.-January 12th, some about light: $13 \mathrm{th}$, do., and resting on lantern; wind fresh N.E., gloomy: 23rd, a few birds, probably Starlings, about light; wind moderate $N$., snow showers. February 2nd, Skylarks and Starlings about light; wind light N.W., overcast; three Starlings killed : 3rd, Skylarks and Starlings about light; wind light S.W., fog; two Starlings killed: Sth, three about ship. March $22 \mathrm{nd}$, about thirty going $\mathrm{N}$. at sunrise, after lantern was lowered. October 6th, a number of small birds, probably Larks and Starlings, going N.W. during day; wind fresh W., clear: Sth, several Larks and Starlings going N.W.; wind fresh S.W., clear: 9th, Larks and Starlings going W.; wind moderate N.W., clear: 11th and 23rd, flocks of Starlings going" N.W.: 24th, flocks of Starlings and Chaffinches going N.W. ; wind light E., clear.

Codling Bank Light-ship.-January 11th, four going W. February 6th, one about ship: 28th, one do. October 14th, flock going N.; wind moderate S.E., clear: 28 th, several going N.W.; wind light S., haze: 29th, one Water-Hen and one Starling in ship at 9 A.M. : 30 th, some during day, one at night; wind S.E., fog. November 14th, flock going N.W.; wind fresh N.E., clear: 22nd, flock going W.; wind light W. December 1st, several flocks going N.W.; strong breeze N.E.: 2nd, several flocks going N.W.; wind moderate N.E., clear: :rrd, several going N.W. during day; wind light S.TV., clear: 12th, three going N.W.: 19th, one all day in ship: 20th, one killed striking lạntern. [Leg and wing received.]

Rockabill.-January 10th, four about light at 2 A.Mr., one killed; wind moderate $\mathrm{E}$, haze. March 5th, six on rock, October 2nd, some, with Blackbirds and Thrushes, remained all day; wind light WV., clear: 10th, ten ou rock, with Larks, Yellowhammers, and Chaffinches; wind strong S.W., clear: 
11th, remain about rock: 21st, large number of birds about light at night; a dozen "Larks and Starlings" killed striking with a number of Thrushes and other birds; wind light S.E., fog: 29 th, a very large number of birds about light (see under Thrush); sixteen Starlings and forty-four other birds killed striking; a number of disabled Starlings remained at daylight, all others away; wind fresh S.E., fog.

South Rock Light-ship.-October 22nd, a few Larks, Linnets, and Starlings going W. during day; wind light E.: 28th, several Larks, Starlings, Thrushes, and Blackbirds about light during night, a good many striking and falling overboard; wind moderate S., haze : 30th, a good number of Larks and Starlings about light, many striking and falling overboard; wind light E., fog.

Copeland (Mcw) Island.-October 23rd, some, with I Iarks and other birds, about light, one disabled striking-[Leg and wing received]; wind moderate S.E.; hazy and gloomy. December 18th, a few Starlings, Thrushes, and Blackbirds, and a great number of Larks, about light from 11 P.M. to 3 A.M. on 19 th.

Innishtrahull.-January 1st, one on island: 26th, four; snow: 30th, flock going S. at noon; wind moderate N., clear. March 28th, one at lantern at 1 A.M. ; wind light N., haze.

Aranmore. -Starlings very scarce on this island (see under General Observations).

Arran Island, N.-January 10th, several going E.; wind light S.W., gloomy. February 20th, flock of Blackbirds and Starlings going N.E.; wind moderate S.W., cloudy : 25 th, flock on island; gale S.W. October 31st, one killed striking-[Leg and wing received, with legs and wings of several Blackbirds and Redwings, and one Titlark, killed striking same night]; wind light N.E., drizzling rain. December 18th, several "Thrushes and Blackbirds" on island all day, three killed striking-[Legs and wings of a Starling and two Redwings received]; wind light E., gloomy. "When the wind is off the land, a good many visit isle."

Arran Island, S.-October 31st, one at 8.30 P.M., killed striking; wind fresh S.E., overcast.

Bull Rock.-October 20th, one killed striking at 2 A.M.; wind strong S.W., clear ; flock at 10 A.M. going E.; wind strong S.E., haze: 23rd, 24th, and 25th, ten Starlings, three hen Blackbirds, 
and four Larks killed against lantern; wind E., dark, gloomy weather at night; during day these birds were numerous on rock up to 10 A.M. or 11 A.M. each day. November 1st to 4 th, Starlings, Blackbirds, Thrushes, and Larks around light for past four nights, and on rock during daytime; four Starlings, ten Blackbirds, four Thrushes, and four Larks killed; wind moderate $\mathrm{E}_{\text {., dark, gloomy weather. }}$

\section{Chough (Pyrrhocorax graculus; Linn.).}

Mine Head.-October 12th, Choughs noted.

Dungarvan.-November 21st, three at 3.30 P.n. going N.; "first I have seen about here; they were flying high and very rapidly, and giving notes all the time" (see under Jackdaw); wind light S.E., gloomy. December 15 th, one about station; gale N.W.

Arlilow North Light-ship.-April 13th, one supposed Redlegged Jackdaw rested for a time on ship's rail, going W.; wind fresh S.E., rain. June 22nd, two Red-legged Jackdaws going W. at 11 A.M. ; wind moderate S.W., light haze.

Rathlin O'Bime.-February 11th, two all day. "These birds are here for the past two months."

Skelligs.-January 26th, twelve on rock; wind moderate $\mathrm{N}$. May 4th, eleven noted. July 27th, eight going E. November 26 th, four on rock all day.

\section{RAVEN (Corvus corax, Linn.).}

Mine Houd.-April, a great number of "Crows and Ravens" around this place all the spring.

Skelligs.-February 16th, two on rock; wind light S.IT., gloomy. July 8th, two on rock all day.

Hooded CRow (Corvus cornix, Linn.).

Dungarvan.-January 28th, six Grey-backed or Carrion Crows about station: 29 th, two noted. April 21st, six on rocks. July 28th, four do. December 23rd, one going N.E.

Blachwater Bank Light-ship. - March 28th, four Hooded Crows at 11 A.M. going N.W.; fresh breeze N., clear.

Arklow North Light-ship.-February 14th, five Grey Crows groing W.; wind light N.W., clear. April tth, one Crow (Grey- 
back) going N.; wind moderate E., clear. June 15th, two Grey-backed Crows going N.W.; wind moderate S.W., rain. October 2nd, three going N.W. ; wind light N.W., clear.

Arran Island, N.-November, two "Grey-back Crows" always about.

Slielligs.-February 24th, two on rock. June 12th, six. July 1Sth, six. August 21st, two on rock. November 30th, three going $\mathrm{S}$.

Rook (Corvus frugilegus, Linn.).

Fastnet.-November 24th, four "Common Crows" about lantern at 9 P.M., two disabled striking ("this is the first case of Crows striking that I have noticed."-E. RouU); wind light S., cloudy.

Mine Head.-April, a great number of "Crows and Ravens" around this place all the spring. September 10th, flocks of Rooks in fields.

Dungarvan.-January 25th, great numbers of Rooks about station: "Rooks to be seen every day, but not in such numbers."

Coningbey Light-ship.-January 23rd, two "Crows" about ship, flying low, going N.W.; light snow showers. May 24th, nine going N.W., flying high; wind light N.E., clear. December 2nd, one going N.E., not able to reach land; fresh breeze N.E.; one at 7.30 P.n. rested five minutes on ship and flew N.W

Tuskcur:-March 17th, one on rock at 8 A.M. ; strong breeze S.W., rain: 19th, one going N.W.; strong breeze W.: 25th, one going N.W.; light breeze W., mist.

Lucifer Shoals Light-ship.-May 14th, one "Crow" lit on ship at noon, flew away for land at 2.30 P.M. ; "a small Crow"; wind light W., clear-[Possibly Jackdaw]. November 19th, seven "Crows" going W. at 1.45 P.M.; wind moderate W., clear, 24th, one rested on ship; wind light S., gloomy.

Blachuater Bank Light-ship.-March 19th, two at noon going N.W.; flock at 4.30 P.N. going do.; strong breeze N.W., clear : 24 th, four going N.W.; gale W., clear. October 13th, two going N.W.; wind moderate E., clear.

Arklow South Light-ship.-March 27th, four "Crows" going N.W.; heavy gale N.W., clear. April 12th, three going S.W.; wind light S.E., overcast. 
Arlslow North Light-ship.-January 25th, one going N.W., flying low; wind fresh N.W., clear, snow showers. April 2nd, three "Black Crows" going N.W.; wind moderate E., clear: 5th, several do. going N.W.; fresh breeze S.E., clear: 10th, several do. going N.W. ; wind moderate N.W., clear : 21st, four going W.; wind light E., haze: 25th, two going N.; wind fresh E. clear. August 7th, five going N.W.; wind light S.W., clear.

Codling Bank Light-ship.-March 13th, two Rooks going N.W.; wind light N.W., clear: 18 th, one at 10 A.I. going N.W., one at 11 A.M. do.; wind strong N.W., clear: 19th, one at 10.30 A.M. lit on ship for thirty minutes, then flew N.W.: 20th, flocks at 8.30 A.M. and 10 A.M. gaing N.W.; wind light S.W., hazy: 30th, one going N.W.; wind light W., clear. April 2nd, two going N.W.; wind light N.E.: 9th, one "Crow" going N.W.; wind light S.W.: 19th, two "Crows" going N.W.; wind light S.W., clear. May 6th, one Rook going W.; wind moderate N.W., clear. October 28th, two "Crows" going N.W.; wind light S., haze. November 20th, one Rook going N.W.; wind light W., clear.

Rockabill.-March 29th, three "Crows" and one Sparrow Hawk on rock at noon; wind moderate N.W., clear.

Aranmore-November 20th, forty "Crows" going N.; wind moderate S.W., misty; "first large flock ever observed at this station."

Rathlin O'Birne. - January 1st, twenty going W.; wind moderate S.W., clear.

Skelligs.-February 27th, three on rock; wind light S.W.

Bull Rock.-November 1st, twenty "Crows" settled on rock at 11 A.M., stayed one hour ; wind light S.E., clear.

\section{JACKDAW (Corvus monedula, Linn.).}

Dungarvan.-November 21st, three going N.E., "flying high and making a great noise."

Arklow South Light-ship.-March 19th, two at noon; heavy gale N.IV., clear; "seemed as if they were blown off shore, trying to get back."

Rockabill.-J January 7th, one going W.; wind fresh E., haze.

South Rock Light-ship.-November 24 th, one at \pm P.Mr., went to roost in ship; wind moderate S.E. : 25th, Jackdaw left at 6 A.M., going $W$. 
Arcnmorc.-December 28th, one found disabled in lighthouse yard; wind moderate S.W., misty. [Leg and wing received.]

Arran Island, $N$.-October 7th, two on island all day; wind S.E., gloomy.

Loop Head.-November $15 \mathrm{th}$, are very rare visitors here; numbers, with other birds, frequented station in the winter of 1893 (see under General Observations).

Magpie (Pica r'ustica, Scopoli).

Mine Head.-February 20th, three noted. September 16th, four.

Dungarvan.-February 3rd, four noted fighting; " allowed me to go up and catch them, as both pairs had a hold of each other, and were lying on the ground quite exhausted." Magpies numerous about here.

Innishtrahull. - March 7th, one flying about at 5 P.м.; "appeared very much frightened and confused;" wind moderate S., misty: 8th, same bird flying about all day.

\section{SWALLOW (Hirundo rustica, Linn.).}

Mine Head.-April 27th, about fifty at station; wind light S.E. September 12th, great numbers all day; wind light E. October 5th, great numbers all day; wind light S.: 9th, Swallows and Linnets, great flocks, day and night; some struck lantern; great numbers of Swallows; wind light W.

Dungartan.-April 21st, Swallows very numerous; first seen this season; wind light E., fog and rain. May 12th, 17th, and 30th, June 4th and 9th, and August 2nd, Swallows noted; generally as numerous: August 5th, thirty-four going S.W.; "they flew in circles, but still made headway to the S.W.; they also kept up an incessant chatter." September 1st, five noted flying about station: 3 rd, seven: 24th, one going N.E.

Coningbeg Light-ship.-March 19th, two [Probably SandMartins. -R. M. B.] rested on ship and flew N.E.: 27th, four flying N.E; dense fog. May 1st, two, and 3rd, one, flying N.W.; wind light N.W., clear: 10th, several flocks flying N.W. from 9 A.Mr. to 4 P.M.; wind W., thick haze: 16th, 19th, 20th, and 24 th, two to six noted each day flying N.E. or N.W.; wind 
N.E. or E. September 26th, one going S.E.: 29th, one rested on ship and died; wind moderate N.W., clear. October 12th, three rested on ship; calm, clear.

Thuskar.-March 29th, one going N.W.; light breeze N.

Lucifer Shoals Light-ship.-March 30th, two going N.W.; wind S.W., clear. April 14th, 17th, 19th, and 20th, one or two each day going N.W.; wind generally N.W., moderate or fresh. May 1st to 21st, frequently noted going N.W.: on 10th, "Swallows flying in by twos and threes from 8 A.n. to 2 P.м.;"; wind moderate W., clear. September 6 th and 7 th, one each day going N.W. October 7th, one going N.W.: 10th, two going $\mathrm{N}$.; wind moderate W., clear.

Blackwater Bank Light-ship.-March 22nd, one [Probably Sand-Martin.-R. M. B.] going N.W. April 13th, two going N.W.: 20th, flock at 5.30 P.M. going N.W.; wind moderate W., clear: 21st, five at 11 A.M., and six at 2 P.M., going N.W.; light breeze E., gloomy: 25th, two going N.W.; several about light from 9 P.x. to 11 P.M.; light breeze E., rain: 26th and 27th, flocks going N.W.; light breeze N.E., clear and hazy: 28th, flocks going N.W.; wind light S.W., haze. May 1st, about ten flying N.W. for Irish land; fresh breeze S.W., clear: 4th, flock going N.W., flying low; strong breeze S.W., overcast: 5th, about ten flying N.W. in pairs; fresh breeze N.W., hail showers: 9 th, two small flocks going N.W.; wind light N.W., clear. September 26th, flock of about fourteen going N.W., flying low; wind fresh S.W., clear : 28th, large flock going S. at 8.40 A.M.; light breeze S.W., clouds.

Arklow South Light-ship.-March 22nd, two [Probably SandMartins.-R. M. B.] rested on ship at 11 A.M.; gale S.W., haze, rain. April 18th, one, "first seen this season," going N.W. at noon; wind light W., clear: 20th, small flocks going N.W. during day; wind moderate S.W., cloudy: 21st, constantly passing all day, "in two streams," going N.W.; wind light S. to S.E.; fog, followed by rain: 22nd, constantly passing all day going $\mathrm{N}$.; a lot of small birds about light at night-[Leg and wing of Swallow, with legs and wings of a Wheatear and a Willow Wren, all found dead on deck, received]; wind light $\mathbf{E}$., gloomy; dark night: 23rd, 24th, 25th, and 26th, "a lot of Swallows all day" noted on each of these days, going N.W.; wind chiefly. N.E., light to fresh, gloomy weather: 27 th, small 
flocks all day going N.W.: 28th, odd Swallows going N.TV.: 29th, one groing W.: 30th, and May 1st, 2nd, 3rd, 6th, 8th, 9 th, 11th, 12th, 13th, 14th, 16th, 18th, and 19th, some noted each day going N.W.: May 21st (in letter), "they were exceptionally numerous this season": 27 th, one noted flying about, and resting on ship all day; it was found dead at 8 P.M. September 23rd, one going N.E.; fresh breeze S.W., cloudy: 26th and 27th, some going N.W.; wind moderate S.W.: 28th, going various directions; wind light S.W., cloudy; "most of them flying to the N.W. and N."

Arllow North Light-ship.-March 24th, one Swallow seen [Probably Sand-Martin.-R. M. B.]; gale W., clear. April 19th, a number during day going N.W.; fresh breeze S.W., clear: 20th, several going N.W.; wind moderate S.W., clear: 21st, several noted; wind light E., haze: 24 th, three about ship: 26th, several going N.W.; wind moderate S.E., clear: 27 th, some about ship; wind light N.E., clear. May 1st, a few going N.W.; and 2nd, a large quantity going do.; wind moderate S.W., clear: 3rd, 8th, 10th, 20th, and 27th, a few noted, generally going N.W. June 4th, 5th, 7th, 14th, and 21st, a few, generally going N.W.: 23rd, a number about ship during forenoon; wind light S., fog. August 10th, two Martins and one Swallow going N.E.; wind moderate S.W., rain. September 22nd, a few going N.W.; wind moderate W., clear: 26th, two going N.W.: 27th, two going W.

Codling Bank, Light-ship.-April 16th, one going N.W.: 19th, one going N.W. at 11. A.M.; two going N.W. at 6 P.M.: 20th, one in ship, and one going N.W. : 26th, several-going N.W.; wind light N.E., light haze: 27 th, two about ship: 28 th, one going N.W. May 1st, 2nd, 3rd, Sth, 14th, and 16th, several going N.W.: 18th, flock going N.W.: 22nd, several, and 26th, two, going N.W. June 2nd, two about ship. September 27th, several groing S.W. from 10 A.M. to 1 P.M.; wind light S.W., clear. October 27 th, six going S.E. ; wind moderate S., haze.

Rockabill.-April 19th, three on rock at 2 P.M.

Aranmore.-September 8th, eighteen about lighthouse; wind light $\mathrm{E}$, clear.

Rathlin O'Birne-April 4th, two all day; wind fresh E.: 10 th, four all day; wind light $\mathrm{S}$.

Arran Island, N.-June 10th, one going E. 
Skelligs.-April 15th, one "Purple Martin" on rock at 4 P.M.; wind fresh W.

House-Martin (Chelidon urbica, Linn.).

Barrels Rock Light-ship. - May 31st, two House-Martins going N.W. ; first seen this season; wind N.W., clear. June 1st, one going N.; rested on ship; appeared very tired; calm, clear.

Artilow North Light-ship.-August 10th, two Martins going N.E.

\section{SAND-MarTin (Cotile riparia, Linn.).}

Coningbeg Light-ship. - March 19th, two "Swallows"[Probably Sand-Martins.-R. M. B.]-rested on ship, and flew N.E.; wind fresh N.W., clear.

Blackwater Bank Light-ship.-March 22nd, one "Swallow"[Probably Sand-Martin.-R. M. B.]-going N.W.; strong breeze S.W., clear.

Arklow South Light-ship.-March 22nd, two "Swallows"[Probably Sand-Martins.-R. M. B.] -rested on ship at 11 A.M. ; gale S.W., haze, rain.

Arklow North Light-ship.-March 24th, one "Swallow" seen -[Probably Sand-Martin.-R. M. B.]; gale W., clear.

\section{SwIFT (Cypselus apus, Linn.).}

Dungarvan.-May 21st, several all day; "I also observe that a pair have built along with the Swallows in ventilators of tower": 25th, numbers noted. June 2nd, 4th, 9th, 13th, and 24 th, Swifts noted. July 16th, about twenty noted. August 2nd, "have seen no Swifts for the last week, and they must have left."

Codling Bank Light-ship.-May 10th, two going N.W.: 1.9th, one going N.W. : 31st, two going N.W. ; wind fresh S.TV., clear.

Nightjar (Caprimulgus europaus, Linn.).

Tuslar.-[May 23rd, male Nightjar, caught exhausted on rock, received in flesh.]

Cuскоо (Cuculus canorus, Linn.).

Inmishtrahull.-May 20th, one heard on islaud at 6 P..r.; Corn-Crake same day at 7 P.s.; wind light N., misty. 
Great Spotted Cuckoo (Coccystes glanclarius, Linn.).

Sliclligs.-April 30th, "Great Spotted Cuckoo on rock at 8 A.M. ; very tired looking, and could easily have been killed, but no means of shooting it; wind fresh S.W." [In answer to inquiries, the following particulars are added in letter bearing date August 25th:- "This bird was about the size of a Sparrow-Hawk, but more bulky in body; feathers ruffled and loose, and appeared very much fatigued; back, a dark slatecolour; wing, same colour as back, but all feathers white at the points; throat, orange or yellow ; breast of a light slate-colour or grey; under tail, white ; all tail feathers white at the points; crest of a lighter colour than back, and slightly erected; bill of a bluish black; tail about seven or eight inches long, and inclines downwards. The bird, when first observed, was coming from S.W., and lit on rock, and when approached within twenty yards would fly about the same distance to another rock, and continued so for about a half-hour; it seemed very much frightened by the large numbers of Puffins that were flying about at that time. I had a good opportunity of seeing it, as I followed it about from one place to another with the telescope. I lost sight of it at N.E. point of rock amongst the Puffins. As far as I can judge from the books at station, it resembles no other bird but the Great Spotted Cuckoo.-Thos. King." (See Zoologist, 1897, p. 574; also Saunders's "Illustrated Manual of British Birds," 2nd edition (1898), p. 289. The description appears to be that of a Great Spotted Cuckoo in nearly adult plumage. - R. M. B.]

Ring Dove (Columba palumbus, Linn.).

Dungarvan.-July 15th, two Wood-Quests going W. August 16th, about twenty near station; "these birds are very numerous in the vicinity."

Turtle Dove (I'urtur communis, Selby).

Coningber Iright-s7ip.-July 12th, one Dove at 6 A.11., rested on ship and went N.E., flying low ; wind light E., haze.

Arklow North Light-ship.-June 7th, one Grey Dove and some Swallows about ship during forenoon; Dove exhausted and captured alive; wind light N.E., clear. 
Bercharen.-October or November, "a Turtle Dove also caught, and is alive on rock" (undated letter received November 6th, enclosing Fork-tailed Petrel found dead October 28th).

\section{Pí́enons.}

Mine Head-March 5th, flock of Rock Pigeons going N.IV. September 10th, some all day; "flocks of these all season; stop in cliffs." December 27th, great many Pigeons noted.

Coningbery Light-ship.-March 23rd, Pigeon and Sea-Gull caught in small boat; fresh breeze S.W., clear. Jume 28th, Pigeon caught on ship. July 11th, one caught on ship; had rubber band on left leg marked P. 55. October 9tb, one flew round ship and went N.W.

Lucifer Shoals Light-ship.-June 13th, one Carrier Pigeon rested on ship at 10 A.Mr, went N.TW.; wind light N.E. December 7 th, one Pigeon going W.; gale S.W., rain.

Blacluveter Bank Light-ship.-January 17th, one alighted on deck at 6 P.M. ; wind light N.W., clear.

Arklow South Light-ship.-June 23rd, one Carrier Pigeon going S.W., fog. October 24 th, one caught on top of lantern at 6.15 P.M. ; had ring on its leg with W $97 \mathrm{~L}$ and 16.34 on it.

Arklow North Light-ship.-June 2nd, one Rock Pigeon during day, rested on ship's rail and flew N.W. ; wind light S.E., clear. July 7th, Carrier Pigeon lit on board at 8.30 A.Mr., left at 4.45 P.M. and flew for the shore; wind fresh N.W., clear.

Codling Bank Light-ship. - September 21st, two Carrier Pigeons going N.IV. at 1230 P.M. ; one lit on ship, had ring on leg with B. 1890 D. 109 engraver on it; left ship at 3.30 P.Mr; a Gull (Skua Gull) followed and killed it; wind fresh N. IT., clear.

Rockabill.--October 29th, a very large number of birds about light at 3 A.Mr., sixty killed striking, one Rock Pigeon amongst them (for full details see under Thrush); wind fresh S.E., fog:

Innishtrahull.-May 6th, two Rock Pigeons on island; wind light W., clear.

Arcumore.-August 15̆th, eight Pigeons going S.TV.; build in cliffs at west side of island.

Arran Island, $N$.-June Sth, two going E.: 15th, one going S.E. August 4th, two going S.: Sth, two going E.: 30 th, one on island. November 19 th, two going E. 
Skelligs.-February 4th, two on rock. May 24th, six Rock Pigeons. June 17th, one "Passenger Pigeon" on rock at 8 A.M. ; wind moderate N.W. October 19 th, one Rock Dove at 8 A.M.

\section{Red Grouse (Lagopus scoticus, Latham).}

Aranmorc.-September 23rd, four Grouse seen flying W.; heavy gale S.W., cloudy.

\section{Partridge (Perdix cinerea, Latham).}

Aranmore.-October 3rd, five on mountain; wind light N.W., misty.

\section{Corn-Crake (Crex pratensis, Bechstein).}

Dungarvan.-June 3rd, one heard; "first heard this summer": 7th, several at 1 A.Mr. July 2nd, several all night; "heard nearly every night for the last month, but seem to be more numerous to-night;" wind light N.W., clear. September 21st, one young Corn-Crake close to station; "was run down and caught by Dr Williams of Dungarvan;" "I think it very late in the season for one to be seen, as I have heard none for some length of time." [Leg and wing received.]

Arklow South Light-ship.-April 27th, one going N.E. at 11 A.M. ; wind light, variable, gloomy.

Innishtrahull.-May 20th, one on island at 7 P.I.; Cuckoo same day at 6 P.M. ; wind light N., misty.

Slelligs.-May 11th, one Land-Rail on rock at noon; wind light N. September 1st, one on rock at 4 P.M.; wind light N.W.

\section{WATER-RAIL (Rallus aquaticus, Linn.).}

Rockatill. - March 27th, Water-Rail killed at lantern at 2 A.M. ; wind fresh S., haze. [Received in flesh, with letter dated March 29th; sent as "bird like a Corn-Crake, but the bill rather long."]

Rathlin Island. - December 18th, a bird canght on the mountain, seems rare in this part. [Water-Rail received in flesh.]

Rathlin O'Birne.-January Sth, one "Land-Rail" on island, remaining-[Probably Water-Pail]; strong wind E.; "seen this 
bird before, but was not sure of its name": 19th, one "LandRail" remains on island.

Arren Island, $N$.-November 1st, large bird, name unknown, caught in crevice of a rock-[Water-Pail received in flesh]; wind light N.E., misty.

\section{WATER-Hen (Gallinula chloropus, Linn.).}

Codling Bank Light-ship.-October 29th, one in ship at 9 A.M.; wind light S., clear.

Ringed Plover (AEgialitis hiaticula, Linn.).

Innishtrahull.-January 3rd, several "Dotterel" on island; gale S., clear.

Golden Plover (Charadrius pluvialis, Linn.).

Dungarvan.-January 27 th, two going S.W.; hard frost. December 7 th, several going S.W. at 12.15 A.M. (heard but not visible); light breeze N.W., clear.

Rockcibill.-October 29th, very large number of birds about light, one Golden Plover killed striking, with seven Fieldfares, twelve Blackbirds, fifteen Thrushes, eight Chaffinches, a Rock Pigeon, and sixteen Starlings; wind fresh S.E., fog.

Innishtrahull-January 26th, two on island; strong breeze N.W., snow. February 2nd, ten do.; gale S.E., misty.

Aranmore.-September 13th, one "Grey Plover" shot; wind light S., misty.

Rathlin O'Birne.-January 11th, two going S.: 25th, twenty going S.; wind moderate N.W., snow showers. March 3rd, ten going S.; wind fresh W.: 18th, twelve going $\mathrm{S}$; wind strong S.W. April 13th, six going S.; wind fresh E. : 17th, twenty going S., black on breast; wind moderate S.W.

Broadhaven.-January 18th, two flocks close to station.

Slyne Hecul.-[March, leg and wing received, with letter dated $25 / 3 / 97$; no details.]

Green Plover (Vanellus vulgaris, Bechstein).

Aine Head. - February 5th, twenty Plover going N.W. March 20th, flock going S.W. October 15th to 19th, Plover 
all round station; fresh breeze to gale S.W.: 27 th, thirty going N.W. November 10th, flock going N.W. December 18th, great flock going W.

Dungarvan.-January 27th, great numbers of Lapwings and Starlings in fields about station from 9 A.M. to 11 A.M.; wind moderate N.W., clear ; slight fall of snow last night, with hard frost. February 12 th, numbers of Starlings and Lapwings all day; wind light E., fog and rain. October 13th, several Lapwings going N.E. ; wind light S.E., drizzling rain. November 10th, several going W.; wind light S., clear. December 6th, thirty going W.; fresh breeze N.W., squally: 18th, flock of thirty going S.W.; fresh breeze E., gloomy: 19th, large flocks of Curlew and Lapwing all day; wind strong, gloomy: 28th, several flocks going S., 6.30 P.M. to 8 P.M.; strong breeze S.W., clear, moonlight.

Comingbeg Light-ship. - February 23rd, two going S.E. November 19th, several Plover about ship from 8 P.M. to midnight, none killed; wind light, variable, gloomy.

Barrels Rock Light-ship.-November 5th, flock of about two huudred going N.W. at 9 A.M. ; wind light N.E., clear: 14th, large flock about ship at 8 P.M., left ship at midnight; wind moderate S.E., rain.

Blaclivater Bant: Light-ship.-January 7th, large flock of Plover going N.W., flying low; wind light S., clear: 31st, flock of Lapwing going N. at 9.45 P.M. ; wind light S.W., overcast. February 5th, flock at 10 P.M. going N.W.; wind light N.E., gloomy. December 24th, flock at 7.45 P.M. going N.W.; wind strong S.W., overcast.

Arklow North Light-ship.-March 20th, a Plover going W. at 6 P.M. ; wind light S.W., haze.

Rockabill.-March 11th, a flock going W.; wind moderate S., cloudy.

Innishtrahull.-January 2nd, thirteen on island; wind fresh S.W., haze.

Aranmore.-August 10th, four on mountain, first observed this year; strong breeze N.E., clear. November 21st, two noted, "seldom on this island"; wind fresh S.W., cloudy.

Arren Islend, N.-October 24th, one on island all day; wind light E., gloomy: 25th, thirty going S. at 10 A.M.; wind light E., gloomy. 


\section{TuRnstone (Strepsilas interpres, Linn.).}

Dungarvan.-March 21st, a large flock going S.W. at 6 P.M. ; wind light $\mathrm{E}$., fog.

St John's Point, Down.-February 1st, two unknown birds killed against lantern. [Leg and wing of Turnstone received, with Bar-tailed Godwit in flesh.]

Oyster-CATCher (Homatopus ostralegus, Linn.).

Dungarvan.-January 6th, about a hundred going N.E.; heavy gale S.E.: 30th, three in lighthouse field. March 9th and 14th, numbers on rocks: 23rd, about fifty going N.E.: 31st, large flock going N.E. April 21st, numbers on rocks: 23rd, about thirty on rocks: 28th, about fifty going E. May 1st, numbers on rocks: 30 th, three going S.W. June $3 \mathrm{rd}$, twentyfour going S.W.: 6th, eleven going W. August 20th, thirtyeight on rocks. September 10th, fifteen going S.W.: 12th, thirty going E. : 13 th, twenty-one on rocks. October 25 th, five in field. November 16 th, about a hundred on rocks.

Copeland (Mew) Island.-December, small flocks of Seapies or "Red-Legs" on the rocks.

Aranmore.-September 30th, twenty Seapies on rocks; wind fresh N.E., misty.

Shelligs.-August 5th, three on rock; wind moderate S.IV., mist.

Grex Phalarope (Phalaropus fulicarius, Linn.).

Skclligs.-December 27th, four Phalaropes in water at 1 P.x.; wind strong W. [Probably Grey Phalaropes.-R. M. B.]

Woodcock (Scolopax rusticula, Linn.).

Innishtrahull.-January 26th, one on island; wind strong N.W., snow. February 4th, one on island; gale S.E., mist.

Arannore.-September 29th, two seen on mountain, not plentiful here; wind moderate S.W., clear. December 3rd, one on hill outside wall; gale S., misty.

Rathlin O'Birne.-February 7th, one going S.; wind moderate S.E. : 16th, one going S. 
Common Snipe (Gallinago calestis, Frenzel), and JACK SNIPE (Gallinago gallinula, Linn.).

Mine Head.-November 13th, six Snipe noted; light breeze S., mist, fog.

Arklow North Light-ship.-March 28th, a bird, apparently a Snipe, struck lantern and fell on deck; wind strong, variable, clear. [Jack Snipe, disabled striking, received in flesh.]

Copeland (Mew) Island.-November, some Snipe seen frequently during this month.

Innishtrahull.-February 1st, one on island; gale N.E., mist. Aranmore.-September 28th, one Jack Snipe shot; strong breeze S., clear. November 22nd, one Snipe lit in lighthouse park at 8 A.M. ; wind moderate S.W., cloudy.

Rathlin O'Birne.-January 11th, two Snipe going S., one Jack Snipe all day; wind light S., haze : 26th, ten Snipe going S. ; wind moderate N.W., snow showers. February 12th, two all day; wind moderate E., clear. March 3rd, three going S.; wind fresh W.

Arren Island, N.-September 30th, one killed striking lantern at midnight-[Leg of Common Snipe received]; wind light N., haze. October 13th, two on island; wind S.E., gloomy.

DunLin (Tringa alpina, Linn.).

Dungarvan.-January 26th, thirteen in lighthouse field.

Tuskar:-January 31st, one "Sandpiper" killed striking at \pm A.M.; wind light W., drizzle. [Leg and wing of Dunlin received.]

Purple Sandpiper (Tringa striata, Linn.).

Tuskar:-[December, wing of Purple Sandpiper received, with other wings, including a Spotted Flycatcher's, said to have "all struck lantern between November 20th and December 1st."] Aranmore.-December Sth, one "Strand Lark" killed striking lantern at 8.30 P.M. ; not certain of species, wing forwarded[Leg and wing of Purple Sandpiper received] ; heavy gale N.W., hail showers.

"SANd Larks."

Coningley Light-ship.-February 12th, one "Sand Lark about 
lantern, caught and kept for three days. March 12th, two about ship : 26th, one.

Lucifer Shoals Light-ship.-April 22nd, one "Sandpiper" on board-[Possibly Common Sandpiper.-R. M. B.]. September" 8th, "one small Sandpiper" (not certain of right name) rested on ship all day; wind light S.E. November 6 th, a Sandpiper about the size of a Thrush, with a long bill, rested on ship at 11 A.M.

Blackwater Bank Light-ship.-September 18th, two "Sandpipers" going S.E. at noon, hovered about ship for an hour; wind moderate N., clear.

Arklow South Light-ship.-April 27th, one going N.

Arlilow North Light-ship.-February 13th, one on deck all day, died; wind light W., clear. April 25th, one going N.: 30th, Sand Larks and Golden Wrens going N.W. during night, two killed (Sand Larks struck lantern whilst passing in a flock); wind moderate N., clear. June 4th, three Swallows and one Sand Lark noted; Sand Lark captured and eaten by Royal Gull. October 5th, a number going N.E. in the afternoon; wind strong S., clear.

Rockabill.-April 29th, one "Sandpiper" about light at 12.30 A.M. ; wind moderate W., haze.

Aranmore.-October 3rd, five "Sandpipers" on grass at top of cliff; light breeze N.W., misty : 31st, Strand Larks on rocks; wind light N.E., clear. December 15th, four "Strand Larks" feeding on wet ground inside station; wind moderate W., clear: 30th, five outside wall; heavy gale S.W., squally.

Arran Island, N.-November, "Strand Larks seem never to leave the isle or vicinity."

\section{Common Sandpiper (Totanus hypoleucus, Linn.).}

Lucifor Shoals Light-ship.-April 22nd, one Sandpiper flew on board at 11.30 A.M., did not see when it left; wind moderate S.E., gloomy. [Possibly Common Sandpiper.]

\section{BAR-TAILEd Godwit (Limosa lapponica, Linn.).}

St John's Point, Dorn.-February 1st, two unknown birds killed against lantern. [Bar-tailed Godwit in tlesh, and leg and wing of Turnstone, received.] 


\section{CƯRLEW (Numenius arquata, Linn.).}

IIne Head.-March 9th, two going W. April 27th, Curlew at lantern at midnight; light breeze S., overcast. October 17th, eight going W. November 5th to 8th, four noted: 13 th, two.

Dungarvan.-February 21st, large flock going S.W.; wind light W., clear: 22nd, numbers going do.; wind moderate W., gloomy. March 9th, the out-lying rocks called the Runners are a great resort for Duck, Teal, Wigeon, and Curlew: 11th, great numbers in fields near station; gale S.E., rain : 14th, and April 21st, numbers of Curlew and Oyster-Catehers on rocks. June 7th, twenty-one going S.IV., flying low, almost skimming the water: 26th, twelve going S.W. September 1st, thirty in lighthouse field: 10th, thirty going S.W.: 27 th, great numbers going S.W.; wind light S., clear. October 10 th, great numbers going W.; wind moderate N.W., gloomy. November 1st and 26th, and December 19th and 21st, numerous in fields near station.

Coningbey Light-ship.-March 25th, flock of May-birds going N.E. [Perhaps Curlews.-R. M. B.] : 28th, two Curlews flying N. Jume 25th, flock going N.E., flying high. July 17th, several flying N.: 30th, flock going N.E. October 4th, flock going S.E.

Tuskur.-February 20th, some going S.E. at 11 A.M., some about light at 9 P.M.; wind moderate W.: 23rd, some about lantern; fresh breeze S.W., cloudy.

Lucifer Shoals Light-ship.-August 4th, one going N.W.

Blackwater Bank Light-ship.-February 21st, large Hock about light from 8 P.M., went for the Irish land at midnight; wind moderate W., cloudy and clear: 22 nd, about forty Curlew, Larks, and Starlings about light from 8 P.M. to midnight, a Lark and Starling killed striking, went for the land; wind light S.W., light haze: 24th, Curlew and Starling at light from 8 P.M. to midnight. March 2nd, a few, with Larks, about light from 10 P.M. to midnight; wind light W., drizzle: 25th, a large number of Curlew, Larks, and Starlings about light from 7 P.M., left ship at midnight for land; wind moderate S.W., fog and haze. May 2nd, large flock going N.E., flying high over ship at 10 P.M. ; wind moderate N.W., clear: 13th, two small flocks going N.E. at 1 A.Mr. and 3.A.M.; wind light N.E., clear. 
Arklow South Light-ship.-April 27th and 28th, some heard during early part of each night; wind light, variable, gloomy, May 1st, heard during first part of night; wind light N.W. to S.W., clear. May 14th, two going N.E. ; wind light S.W., clear. [All the notes may refer to Whimbrel.-R. M. B.]

Arklow North Light-ship.-June 21st, five going N W.; wind moderate S.W., clear.

Codling Bank Light-ship.-January 21st, one "Whimbrel" going N.W. [Probably Curlew]. February 20th, one "Whimbrel" going S.E. : 27th, two noted. March 19th, five Curlews going E.; wind fresh N.W., clear.

Copeland (Mew) Island.-November, Curlew plentiful during this month. December 19th, a few hovered around the light for half an hour from 3 A.M. and then left; wind moderate S.E., fog.

Innishtrahull.-January 10th, five on island; wind light S., clear. April 27th, several heard at midnight; wind light W., misty. [Whimbrel ?-R. M. B.]

Aranmore.-August 2nd, forty going S.W.; wind light N.E., overcast. September 25 th, ten flying W.; not often seen at the cliffs where lighthouse is built; gale S.W., clear.

Arran Island, N.-July 3rd, two going E. August 15th, flocks going S.; wind light S.W., showers. September 15th, two going S. October 4th, three going S.: 25th, seven going S.E.; wind light S.E., gloomy. November 3rd and 5th, nine each day going S.; wind light E, gloomy. "When the wind is off the land, a good many visit isle."

Arran Island, S-October 23rd, one at 9.30 P.M., killed striking lantern; wind light S.E., misty.

\section{Whimbrel (Numenius phoopus, Linn.).}

Dungarvan.-April 22nd, one on rocks at noon, "first seen this season"; wind fresh E, clear: 24th, three noted: 26th, numbers going N.E., in flocks of from three to twelve, at intervals of from ten to fifteen minutes, flying high; wind moderate S.E., gloomy: 27 th, great numbers, from 1 A.M. to 3 A.M., going N.E. ; wind S.E., misty, rain: 28 th, several flocks from 1 P.Mr. to 4 P.M., very large llocks from 10.30 P.M. to 11.30 P.M. ; "all that passed this day went S.W., though on previous days it was N.E. they were flying;" wind light S.W., 
clear: 30th, numbers going S.W.; " at 4 P.M. fifteen passed flying very high, greatly scattered, and wheeling from side to side in their flight, also flying very slow as if exhausted;" wind moderate W., clear. May 3rd, very numerous all day about vicinity of station; showers of hail: 5 th, several going N.: 6th, numbers all day going S.W.; wind S.W., showery: 17th, numbers all day about rocks. June 3rd, thirteen going S.W.; calm, clear. July 5th, six going S.W.; strong breeze W., clear : 19th, numbers going S.W. at 10.30 P.M. ; wind light S., misty, rain: 27th, numbers going S., 10 P.M. to 11.30 P.M.; wind moderate W., rain. August 1st, numbers going S. at 11.45 P.M. ; calm, hazy.

Coningbeg Light-ship.-March 25th, flock of May-birds going N.E. [Curlews? - R. M. B.] ; wind light E., overcast.

Barrels Rock Light-ship.-April 25th, three going N., first seen this spring; wind light E., light showers.

Blaclwater Bank Light-ship.-April 30th, flock going N.W.; wind fresh S.W., rain. May 7 th, flock going N., flying high; wind light N.W., rain.

Arklow South Light-ship. - April 27th and 28th, "some Curlew heard during early part of each night"; wind light, variable, gloomy. [Probably Whimbrel, also other entries from this station under Curlew.-R. M. B.]

Arklow North Light-ship.-April 29th, several "May-birds (Curlew)" going N.W.; wind fresh to strong S.W., clear. August 26th, one Whimbrel going N.W.; wind strong S., rain.

Codling Bant Light-ship.-April 27th, several flying over ship at 9.15 P.M. ; wind light $\mathrm{E}$., light haze.

Innishtrahull.-April 27th, several Curlew heard at midnight; wind light W., misty-[Probably Whimbrel.-R. M. B.]. May 2nd, eight "May-birds" on island at noon; gale W., misty.

\section{Roseate Tern (Sterna Dougalli, Montagu).}

Hook Tower.-April 30th, bird found killed in tower balcony with black back to head, and light slate back and wings, white breast, with a beautiful delicate pink hue through breast feathers, red legs and feet, and long forked tail; appears to be the first of its kind caught about here. [Roseate Tern, adult male, received in flesh.] 
"Terns."

Codling Bonk Light-ship.-May 14th, four "Northern Terns" going S.W. at 1 P.M. ; wind light S.W., clear: 19th, two "Northern Terns" going S.W. at 5 P.M. ; wind moderate N.E., clear.

Copeland (Mew) Island.-May 7th, the "Mew" made its first appearance for the season, flocks came from the E. at sunrise; light breeze W., clear. August 21st, the "New" all cleared off the island.

\section{"GULLS."}

Fastnet.-January 12 th to 15 th, two splendid white Gulls about rock, about size of Herring Gull, one slightly smaller than the other; pure white, beak white with black tip, legs white; "this must be the Ivory Gull"-[Most likely Glaucous or Iceland Gulls.-R. M. B.]; wind N.E., strong, clear.

Mine Hcad.-Barch and April, a few Common Gulls passing in all directions; "no particular movement of sea-birds."

Dungervan.-February 10 th, about fifty Herring Gulls going E. : 14th, numbers of "Kittiwakes" feeding in lighthouse field. June 7th, hundreds of Herring Gulls fishing: 24th, July 4th, and August 1st, great numbers of Herring Gulls in bay. August 8th, immense numbers of Kittiwake Gulls, Razorbills, and Puffins fishing in bay: 14th, great numbers of Gannets, Razorbills, and Kittiwake Gulls do.: 20th, great numbers of Kittiwake, Herring, and Lesser Black-backed Gulls, and Razorbills and Puffins do.: 26th, large flocks of Kittiwakes. September 9th, hundreds of Kittiwakes going W., flying very high in one continuous flock, about 100 yards wide and about a mile in length; wind light S.E., clear: 12 th and 13th, great numbers do., fishing in harbour: 14th, thousands of Kittiwakes and Razorbills all day, fishing in harbour; calm, clear. October 9 th, thousands of Kittiwakes going S.W.; wind light W., clear: 25th, hundreds do., going S.W.; gale E., gloomy. November 11th, hundreds do., resting on water in bay; wind light S.E., gloomy. December 16th, one cream-coloured Gull, supposed to be an Aretic-[Glaucous or Iceland.-R. M. B.] Gull, soaring; gale S.W., squally.

Arlilow North Light-ship.-Gulls occasionally noted during every month. March 14th, two larks killed by Sea-gull. May 
17th, some "Black-heads" noted, with Shearwaters. June 4th, Sand Lark captured and eaten by "Royal Gull." September 17th, several Kittiwake about ship during day; moderate to fresh breeze N.W., clear.

Codling Banh Light-ship.-April, great flocks of Gannet, Puffin, and Razorbill Puffin, several Black-back and Herring: Gulls, also small Common Gulls and lots of Manx Shearwaters passing station during this month. June, Gannets, small Gulls, and Puffins passing and about ship this month. September 21st, Carrier Pigeon lit on ship, left at 3.30 P.M. ; a Gull (Skua Gull) followed and killed it. October, several Gamets, Herring Gulls, small Common Gulls, Puffins, Razorbills, and Skua Gulls about ship and passing during this month. December, several Gannets, Herring Gulls, Black-back Gulls, small Common Gulls, and "Puffins" about station this month.

Arcanmore.-August 5th, one "Royal Gull" going S.W.; very scarce here: 27 th, two "Royal Gulls" going W. December" 22nd, a hundred Gulls fishing: 23rd, two "Royal Gulls" feeding.

Rathlin O'Birne.-January 3rd, one Glaucous Gull going W. at noon; wind strong S.W., rain. February 18 th, one do. going E. at 1 P.M. ; wind moderate S.W., clear.

Manx Shearwater (Puffinus angionum, Temminck).

Coningbery Light-ship.-September 2nd, one about ship.

Tuskicr:-March 4th, several dozen near rock at noon; gale S.W.

Arklow South Light-ship.-March 27th, one fishing near ship. April 17th, some passing various directions. May 4 th, a few going N.W. and N.E. : 7th, some going N.E.

Arklow North Light-ship.-March 23rd, some Mackerel Cocks going N.E., first seen this year' wind moderate N., clear: 24 th and 26th, a few noted: 27 th, about a hundred, going in various directions; wind variable, strong: 28 th, a few going in various directions. April 6th, 11th, and 12th, Shearwaters going N.E.: 23rd, some about ship. May 16th, several "Murs, Mackerel Cocks, and Shearwaters, also a few Parrots and Gannets about ship": 17th, some Black-heads and Shearwaters do.: 26th, Mackerel Cocks going N.E.; drifting, feeding on small fish: 31st, some groing in "various directions." June 1st, Shear- 
waters going various directions: $12 \mathrm{th}, 13 \mathrm{th}$, and $26 \mathrm{th}$, some feeding near ship. July 15th, large quantity of Mackerel Cocks at sunrise; wind light E. 20th, large quantity during day: 22nd, do. August 6th, Shearwaters noted. October 7th, a number of Shearwaters going N.W.; wind light S.W., clear.

Codling Bank Light-ship.-March 13th, two Shearwaters going N.W.: 14th, two going S. April, lots of Manx Shearwaters passing station during this month.

\section{Storm Petrel (Procellaria pelagica, Linn.).}

Coningbeg Light-ship.-July 5th, two flying astern of ship; wind fresh S.W.: 24th, four, and 25th, three do.; wind fresh S.W. August 25th to September 2nd, "Mother Carey's Chickens" noted daily; "from first appearance of Mother Carey's Chickens very strong heavy weather up to 2/9/97, and a heavy sea running; this bird's appearance indicates very heavy weather in Channel;" wind S.W. September 21st to 24th, some daily about ship; wind generally fresh S.W. October 13th, 15 th, and 17th, some about ship; gale S.W. on 17th: 25th, one caught on deck; fresh breeze S.E. November 17th, two caught on upper deck; wind light variable, gloomy.

Lucifer Shoals Light-ship.-October 16th, one about ship; wind strong S.W.: 17th, several; gale S.W.

Blackwater Bank Light-ship.-September 27th, two Petrels about light from 9 P.M. to 10 P.M. ; one killed; wind light S., half cloudy.

Arklow North Light-ship.-August 26th, one about ship; wind strong S., rain.

Codling Bank Light-ship.-June 1st, one about ship at 4 P.M.; calm, haze.

Aranmore.-September 12th, one struck light at 8 P.M.; first seen at this station; not "Fork-tail"; wind moderate S., misty.

Blacksod Point.-[November 17th, one caught at lantern, received in flesh.]

\section{Fork-Tailed Petrel (Cymochorea leucorrhoa, Vieill).}

Berehaven.-October 28th, a bird, supposed to be a Forktailed Perrel, found dead at foot of tower, having struck 
lantern; wind S.E., cloudy and gloomy, slight mist. [Forktailed Petrel, thin starved specimen, received in flesh.R. M. B.]

Pazorbill (Alca torda, Linn.) and GoILlejot (Uria troile, Linn.).

Dungurven.-April 16th, several Razorbills all day, strong breeze W. June 7 th, hundreds: 10th, great numbers of Razorbills and their young all day: 26th, numbers all day. July 4th, numbers of Guillemots, Pazorbills, and Herring Gulls fishing in bay. Ausgust 3rd, numbers of Razorbills and Guillemots fishing: Sth and 20th, great numbers of Gulls, Razorbills, and Puffins. September 14th, thousands of Kittiwakes and Razorbills.

Coningbery Light-ship._-March 2Sth, "Mur" caught in small boat after heavy gale.

Blaclivater Bank Light-ship.-January 10th, ten "Murs" about ship; wind light S., rain. May 5th, a large number during day, several floated by dead; wind fresh N.W., squally : 9th, several large flocks going N.E.; wind light N.WW., clear. November 4th, several large flocks going S.W. during day: wind light E., clear: 13th and 14th, flocks each day going S.E.; on 14 th some also going W.; wind N., cloudy. December 26th, one "Puffin" found dead on deck at 9.30 P.M. [Leg and wing of Guillemot received]; heavy gale S.W., rain.

Aillow South Light-shij.-April 26th, Razorbills pass with the tide, drifting.

Arlilow North Light-ship.-January 15th, flocks of "Murs" noted: 21st, a few do.: 28th, a few "Murs." March 2nd and 3rd, flocks of "Murs" going N.E.; wind strong, variable: 5̃th, 7th, and 10th, "Murs" noted going "various" directions: 14th, going N.: 17th, about sixty: 23rd, about twenty going N.E.: 27 th, about fifty: and 28th, a few. April 5th, several noted. May 5th, a few: 16 th to $26 \mathrm{th}$, frequently noted. July 1st, a few: 20th, a large quantity during day; wind light N.E. August 2nd, a considerable quantity, and "great numbers of sea-birds" several times noted during this month: 14th, number of Guillemot fishing.

Codling Bonk Light-ship.-April, graat flocks of Gannet, Puttin, and Razorbill Pulfia, also several Blackback Gall and 
Herring Gull, also small Common Gulls, and lots of Manx Shearwaters passing station during this month. June, Gannets, small Gulls, and "Puffins" passing and about ship this month. October, several Gannets, Herring Gulls, small Common Gulls, "Puffins," Razorbills, and Skua Gulls about ship and passing during this month. December, several Gannets, Herring Gulls, Blackback Gulls, small Common Gulls, and "Puffins" about station this month. ["Puffins" may be Guillemots or Razorbills.-R. M. B.]

Shelligs.-Razorbills and Guillemots frequent this rock all the year round.

\section{Black Goillemot (Uria grylle, Linn.).}

Innishtrahull.-[December 10th, Black Guillemot shot on island, received in flesh.]

\section{Puffin (Fratercula arctica, Linn.).}

Arklow South Light-ship.-April 13th, odd Sea Parrots drifting past; first seen this season; wind moderate S.E., rain: 15th, some passing: 16th and 17th, small flocks going N.W.; wind strong S.W., showery: 19th and 21st, small flocks going various directions: 26th, two flocks going N.E.: 29th, small flocks going S.W. May 7 th, some drifting past.

Arklow North Light-ship.-May 13th, two Parrots about ship, the first seen this year; wind light N., clear: 16th, 22nd, and 25 th, a few about ship. June 1 st to 5 th, frequently noted: 24 th, some fishing about ship. July 1st, 4th, and 6th, a few fishing. August 11th, numbers of Sea Parrots and their young fishing; wind strong S.W., showery.

Rathlin O'Birne.-March 12th, "large flocks of 'Puffin' all day going N."; wind fresh N.W. [Early, if identification be correct.-R. M. B.]

\section{"Great Nortuern Diver."}

Dunyarvan.-January 7 th, great numbers fishing in bay all day; wind light to moderate S.E., gloomy. March 5th, two noted, "first seen for some weeks": 7th, three: 8th, numbers all day fishing; wind fresh S.W.: 19th, four: 2tth, numerous all day; wind strong N.W. April Sth, several: 24th, one. 
May 2nd, two. December 21st, five, "first seen this winter"; strong breeze S.E.

Arklow North Light-ship.--January 1st, and February 9th and 10th, some about ship. April 3rd, 6th, 11th, and 12th, some going N.E.: 22nd, several about ship. August 4th and 5 th, a great number, accompanied by their young.

Codling Bank Light-ship._-May Sth, one going N.E.

Aranmore.-August 31st, one under cliff; only one seen on this part of island; strong wind S.W., cloudy.

Rathlin O'Birne.-February 9th, one going S. March 9th, one going $\mathrm{N}$.

\section{Corirorant (Phalacrocorax carbo, Linn.) and}

ShaG ( $P$.graculus, Linn.).

Dungarvan. - March 10th, Cormorants very numerous all day. April 5th, four ("white-breasted") going E.: 15th, very numerous: 19th, one "large Green Cormorant" going W. August 21st, six "Crested Cormorants" going W.; "Crested Cormorants seldom seen here." September 8th, a flock of fifteen "large Green Cormorants" going N.E. December 16th, seven Cormorants going N.E.

Coningbeg Light-ship. - October 20th, two about ship. December 23rd, do.

Arklow South Light-ship.-May 19th, one going N.

Arklow North Light-ship. - June 25th, one going N.E. August 20th, one going do. October 12th, three going W.

Corling Bank Light-ship.--January 11th, one going N.W. March 23rd, one going N.E. May 14th, one going S.E. June 3rd, two going N.E. October 13th, one going S.E.

Aranmore.-August 22nd, twenty going S.W.; fresh breeze S.W., fog.

Arran Island, N.-November, three or four always about rock.

Skelligs.-Cormorants frequent this rock all the year round.

Gannet (Sula bassana, Linn.).

IIine Head-February 20th, a few seen on the water. September 13th, about fifty going N.E. : 19 th, twenty on water.

Dungarvan.-July 5th, numbers. August 6th and 14th, great numbers, fishing. 
Coningbeg Light-ship.-March 16th, several flying round ship, May 16th, several about ship: 22nd, three flocks going N.W. July 14 th, 15th, and 20th, some about ship. September 7 th, 9th, 13th, 24th, and 27th, some about ship. October 13th, 14th, and 18th, several about ship: 19th, large flock. December 24th, three: 28 th, two.

Lucifer Shoals Light-ship.-April 22nd, eight going S.W.: 23rd, seven going N.E.

Blackwater Bank Light-stip. - February 22nd, flock going N.E. May 12 th, large number going N.E., flying in pairs.

Arklow South Light-ship.-March 27th, some fishing during day. April 13th, small flocks going N.E.: 30th, and May 3rd, small flocks going various directions: 7 th, $11 \mathrm{th}, 13 \mathrm{th}$, and $16 \mathrm{th}$, small flocks going N. and N.E.

Arklow North Light-ship._-March 5th, three going W. : 23rd, twenty, black and white, going N.E.: 24th, a few going N.W.: 26th, 27th, and 28th, a few going various directions. April 3rd, some going N.E. : 9th and 10th, some going N.E. May 1st, a few going W.: 10th, twenty-five going N.E.: 13th, several going N.E. : 14th, large flocks going N.E.: 16th, a few about ship : 19th, large flocks going N.E.: 20th, 22nd, 23rd, and 24th, flocks going N.E. : 25th, a few flocks going N.E.: 26th and 27th, a few going N.E. June 26th, some going N.E. July 12th, several going N.E. : 26th, some going N.E.: 27th, do.: 30th, and July 9 th, 14th, 16th, and 28th, fishing about ship. September 17th, a few going N.E.: 26th, ten going S.W.

Codling Bank Light-ship.-April, great flocks of Gannet and other sea-fowl (see under Razorbill and Guillemot) passing station during this month. October, several Gannet, Herring Gulls, small Common Gulls, Puffins, Razorbills, and Skua Gulls about ship and passing. December, several Gannet.

Aranmore.-September 6th, five fishing. December 19th, eight do.

Arran Island, N.-February 27th, one going N.W. at noon struck balcony, killed; sun shining very brightly, clear. [The first recorded instance of any bird killed striking an Irish lighthouse in daytime. No doubt dazzled by reflected rays of sun.R. M. B.]. March 1Sth and 31st, several about island all day. May, several every day diving about rock.

Bull Rock.-October 15th, one young Gannet, the first of this 
year's hatching seen to leave nest for water: 26th, all Gannets have left rock and its vicinity this day.

\section{Heron (Ardea cinerea, Linn.).}

Copcland (Mew) Island.-November, two or three seen frequently during this month.

Arran Island, S.-[December 21st, old male Heron shot, received in flesh.]

\section{Barnacle Goose (Bernicla leucopsis, Bechst.).}

Dungarvan.-February 9th, one going $\mathrm{E}$.; "rarely seen here." Aranmore.-October 7 th, forty at 8 A.M. going N.W., first flock seen passing this year; wind light $\mathrm{S}$.; thirty-eight at 4 P.M. going do.; wind fresh S.W., cloudy. November 10th, forty at 7.30 A.Mr, going $W$.; light breeze S., rain : 12th, fifteen at 6.30 P.M. going do.; strong breeze S.W., hail showers. December 1st, ten going S.W.; strong breeze N.E., showery: 24th, eighteen feeding; fresh breeze S.: 25 th, twenty at noon going W.; strong breeze S.W., showers : 31st, fourteen going E.; "these birds appear to feed on island" $-[\mathrm{Leg}$ and wing of one received, shot]; wind moderate N.W., mist; mild weather.

Rathlin O'Birne.-March 29th, fifteen going N.; wind strong N.W.: 31st, ten going $\mathrm{N}$. ; wind fresh $\mathrm{N}$.

Arran Island, N.-December, I have watched particularly for Barnacle or Brent, but have not seen any either in vicinity or passing.

\section{"GeEse"}

Mine Head.-April 13th and 14th, flock of Wild Geese each day going N.E. November 22nd, six going N.

Dungarvan.-January 30th, one going S.W.; " a very large bird." October 19th, two Wild Geese going S. at 7 A.Mr.; calm, hazy. November 6th, five Brent Geese going E., "first I have seen for years"; strong breeze E., gloomy. December 5th, four Wild Geese going S.W.; "flying high and giving tongue"; moderate breeze S.W., rain.

Arklow North Light-ship.-October 13th, one noted.

Codling Bank Light-ship.-January 12th, two Wild Geese noted.

Innishtrahull._January 15th, six on island at 8 A.M.; flew 
S. at 8.30 A.M. ; wind light S., clear. April 21st, from two to three hundred going N. at 6.30 P.M.; wind moderate S.E., clear.

Rathlin O'Birne.-January 5th, four White-fronted Geese going $\mathrm{N}$.; strong breeze S.E., cloudy and clear: 10th, three do.: 14th, sixteen going S.: 15 th, ten going S.: 24 th, twelve going N.: 28th, seven going N.E. February 27 th, eight very large Grey Geese going N. March 3rd, nine White-fronted Geese going N.; wind fresh W.

Arren Island, N.-January 20th, three going N.; wind fresh N.E., clear. October 28 th, seven going S.; wind moderate S.E., gloomy. December, have watched particularly for Barnacle or Brent, but not seen any.

Arran Island, S.-October 31st, eight going S.W.; wind light S.E., clear.

Skelligs.-December 22nd, four Grey Geese on rock all day; wind fresh $\mathrm{S}$.

\section{"Swans."}

Arconmore.-December 24th, two at 10.30 A.M.; feeding on lake shore; these birds remained on island three days, not seen since 1894 ; fresh breeze S., cloudy.

Rathlin O'Birne.-January 6th, seven white and two grey Swans at 11 A.Mr. going N.; gale E., mist: 21st, four white Swans at 11 A.M. going S.; wind light $\mathrm{N}$., clear. March 7 th, four white Swans at 1.30 P.M. going N.; wind moderate E. April 21st, two going do.; wind fresh E.

Broadhaven.-January 21st, thirty at 8 A.M. going W. ; wind moderate N.E.

\section{"Ducks."}

Dungarvan.-January 5th, about a hundred and fifty large Ducks going E.; gale S.E., gloomy. March 9th, thirty-one Mallard and Duck and six Teal about rocks; "the outlying rocks, called the Runners, are a great resort for Duck, Teal, Wigeon, and Curlew ": 19th, one Sheldrake (supposed from the plumage to be female) going S.IT. April 2nd, one Sheldrake (male) going N.E. May th, one "Saw-bill Wigeon"[Merganser ?] (male) going S.W.; "first seen since I came to this station": 17 th, two Sheldrake, male and female, on water. 
August 27th, one Sheldrake going S.W. October 1st, about a hundred Duck swimming about bay; wind light N.W., clear: $2 \mathrm{nd}$, hundreds of Duck noted. November 11th, to this date from 1st October Duck to be seen almost every day in more or less numbers: 21st, about a hundred Duck and Mallard: 22nd, do. very numerous. December 18th, a flock of thirteen Wigeon: 21st, thirteen Duck noted: 22nd, male and female Merganser going N.E.; "first seen this winter."

Coningbeg Light-ship.-October 9th, two Wild Duck flying N.W.: 23rd, one on water near ship. November 5th, two flying N.W.

Barrels Rock Light-ship.-November 4th, large flock of Wild Duck going N.W. at 10 P.M. ; calm, clear.

Arklow South Light-ship.-October 31st, some Wild Duck among Starlings and other birds about light this night; wind S.E., light haze.

Arklow North Light-ship.-February 7th, flock of Wild Duck going N.W.: 12th, two Wild Duck and one Mallard going N.W.; wind moderate S.E., overcast.

Codling Bank Light-ship.-January 12th, great flocks of Duck and Wigeon noted; wind light S.E. April 6th, several flocks of Wigeon going N.E.; wind moderate S.W., clear.

Copeland (Mew) Island.-November, some Teal seen frequently during this month. December, a few Wild Duck frequent the marshes on the island.

Innishtrahull.-June 3rd, one in water at landing; wind light E., misty.

Aranmore-September 20th, ten on small lake; fresh breeze N.W., clear. October 7th, three Teal on stream at lough shore; wind light S., cloudy.

Rathlin O'Bime.-April 19th, nine going N.; wind fresh S. Arran Island, N.-November 1st, three Wigeon going S.; wind light $\mathrm{E}$, hazy.

\section{BiRDS NOT IDENTIFIED.}

Dungarvan.-June 9th, bird the size of a large Cormorant, quite black, shaped like a Great Northern Diver, and had bill and head like Northern Diver, but smaller and finer; wings larger; it flew very fast, without any apparent exertion. December Sth, bird much larger than a Gannet, dark grey, with 
a white bar at root of tail, a dark bill shaped like a Northern Diver's, the body and neck long and slender, with very long swallow-shaped wings. "I took it for a young Gannet until I got the telescope to bear on it; I calculate that the spread of the wings was fully eleven or twelve feet; the flight resembled a Gannet's."

\section{General Observations.}

IIine Head.-February, no birds strike the lantern here, and they are hardly ever seen hovering near it, I suppose on account of its being so much shut in from the land, as twothirds of the light is cut off from shore direction.

Rockabill.-Spring, not many birds seen from January until about the middle or 20th of April. On April 27th and 28th there were a large number of small birds to be seen passing by the rays of the light, but not close enough to distinguish. Not many of them struck the glass, and only a few to be seen about the rock in day-time. Autumn, the largest numbers seen were on the 21st and 29th of October. Very few seen in November and December.

St John's Point, Down.-February, I have not sent you any notes from here, simply because no birds strike here except Starling.

Copeland (Mew) Island.-May, no rare birds visited during the spring. No birds killed or disabled.

Lough Swilly.-April 29th, curious looking moth caught yesterday. [Puss Moth (Cerurc vinula, Linn.) received.]

Aranmore.- "Few rare birds to be seen here, and seldom any of the common species (such as Thrush, Blackbird, Starling, etc.) strike the lantern. It may be the red and white alternate Hashes which cause this, as when I was at Rathlin O'Birne (next station) the white bright light there at the time caused many to strike at the end of autumn and beginning of winter. Starlings and other birds, which in other places are to be seen in flocks, are very scarce on this island.-J. C. MIACGINLEY."

Rathlin O'Birne.-January, February, March, and April, no birds struck glass of lantern.

Broadhaven.-This is a poor place for birds.

Arran Island, N.-Spring, very few small birds touch upon this island at all; in fact, all kinds of birds seem scarce about the 
place. Autumn, when the wind is N.W., Wr., or S.W., there are very few birds seen about here; but, on the other hand, when the wind is S.E., E., or N.E. (i.e., off the land), a good number visit island, such as Thrushes, Blackbirds, Starlings, Linnets, "Sparrows," and Curlew.

Arran Island, S.-Very few birds strike lantern of this lighthouse.

Loop Head.- "November 15th, we have not nearly so many migrants along the coast as are seen on the east coast of Ireland. Birds in spring and autumn are as numerous about Tuskar, Rockabill, and the Maidens as they are about Heligoland. During the most severe frost we had here, in the winter of 1893 , there was a very large number of birds in the vicinity of this station, consisting of Blackbirds, Thrushes, Redwings, Starlings, Larks, 'Bullfinches,' Titlarks, 'Warblers,' Curlews, 'Grey Plover,' Lapwing, 'Crows,' Woodcock, and Jackdaws. The latter are very rare visitors here. As an instance of the number of birds we had, and the severity of the frost, I was able to catch several Curlew and Lapwing with my hands. Within half a mile of the station I counted over four hundred dead birds along the road.-John Hamilton."

Samphire Island. - No rush of birds in this locality worth recording. Not even one bird struck lantern during the last twelve months. (Letter dated 16th March 1898.) 



\section{A P P E N D I X.}

\section{MEASUREMENTS OF WINGS OF BIRDS \\ Obtained at Irish Light-Stations.}

(Chiefly killed striking lanterns.)

Species.

Falco peregrinus ${ }^{1}$

Peregrine Falcon (4),

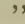

,

Falco cesalon -

Merdin (3),

Falco tinnunculus-

Kestrel (6),

"

",

,

,

"

Asio otus-

LONG-EARED OWL (1),

Lanius pomeranus-

Woodchat Shrike (1),

Muscicapa grisola-

Spotted Flyoatcher (14),

\section{Length of}

in inches.

Date.

Station.
14.500, Feb. 10, /89, Slyne Head. Jan. 18, /98, Rathlin Island.

14.000, Sept. 18, /98, Fastnet.

12.200, May 3, /99, Mine Head.
- 9.075, Oct. $24, / 87$, Tearaght.

- 9.000, , /95, Hook Tower.

- $8 \cdot 750$, Mar. 21, /93, , ,
- 9.875, ? /91, Tearaght or Skelligs.

- 9·850, Nov. 27, /94, Lucifer Shoals Lt.-ship.

- $9 \cdot 500, \quad$ ? $/ 91$, Skelligs or Tearaght.

- 9.425, Nov. 13, /97, Mine Head.

- 9.375, Mar. 27, /92, Tearaght.

- 9·300, April 19, /90, Rathlin.
. 11.400, Nov. 13, /87, Tuskar.

- 3•825, Aug. 16, /93, Blackwater Bank Lt.-ship. Spring-

- 3.425, June 1, /87, Barrels Rock Lt.ship.

3.375, May 17, /93, Blackwater Bank Lt.-ship.

,1 April 18, /95, Tuskar.

, May 28, /98, Fastnet.

$3 \cdot 350, \quad, \quad 23, / 90$, Tuskar.

, " 26, /92, Arklow S. Lt.-ship.

3.300, " 18, /88, Coningbeg Lt.-ship.

3·250, " 16, /93, Arklow S. Lt.-ship.

- 3·200, "10, /99, Blackwater Bank Lt.-ship. Autumn-

- 3.375, July 30, /95, Tuskar.

, Nov. 20-30, /97, , 3.350 , Oct. 2,/87, Tearaght.

3.275, Sept. 21, /87, Coningbeg Lt.-ship.

$3 \cdot 225,\left\{\begin{array}{c}{[\text { Rec'd. Oct. }} \\ 20, / 89],\end{array}\right\}$ Blackrock, Mayo.

1 Most of the Falconidr were shot. 
Species.

MIuscicapa parva-

Red-breasted Flycatcher (4),

$\begin{array}{lll}" & " & \\ " & ",\end{array}$

Muscicapa atricapillaPind Flycatcher (4),

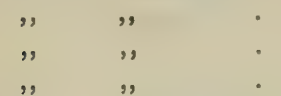

\section{Turdus viscivorus-}

Missel-Thrush (12), .

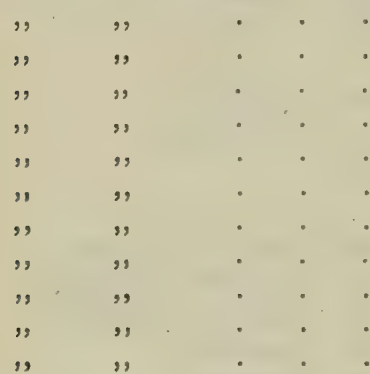

Turdus musicus-

Thrush (94),
Length of in inches.

Date.

Station.
2.900, Sept. 24, /98, Blackwater Bank Lt.-ship. $2 \cdot 750$, Oct. $20, / 90$, Tearaght. $2 \cdot 650, \quad, \quad 28, / 95$, Tory Island. $2 \cdot 625, \quad, \quad 23, / 87$, Arklow S. L. -ship.
$3 \cdot 175$, Sept. 28, /88, Tuskar.

$3 \cdot 050$, " 21, /86, Tearaght.

" Oct. 5, $/ 86$, Fastnet.

Sept. 8, /96, ,

6.200, Mar. 6, /89, Rockabill.

, Feb. 20, /90, Maidens.

$6 \cdot 150, \quad, 26, / 90$, ,

$6 \cdot 100$, Nov. 6, /91, Fastnet.

6.075, Jan. 19, /91, Oyster Island.

$6 \cdot 000$, Oct. (?), $/ 86$, Tuskar.

, Nov. $12, / 87$, ,"

" $, 30, / 88$, Aranmore.

, $\quad$, 6, /91, Hook Tower.

5.975 , Dec. 16, /90, ,, , 1

$5 \cdot 875$, Feb. 2, /95, Samphire Island. ${ }^{2}$

5.850, Nov. 23, /92, Hook Tower.

4.775, Feb. 7, /88, Coningbeg Lt.-sbip.

Mar. 19, /91, Lucifer Shoals Lt.-ship.

Nov. 3, /91, Blackwater Bank Lt.-ship.

4.750 , Feb. 19, /87, Tuskar.

, Jan, 18, /88, Coningbeg Lt.-ship.

Oct. 27, /91, Rockabill.

Jan. 22, /98, Blackwater Bank Lt.-ship.

Oct. $8, / 98$, Arklow S. Lt.-ship.

Nov. 9, /98, Mine Head.

4.725, Jan. 11, /90, Tearaght.

Feb. 20, /90, Maidens.

Nov. 19, /90, Arklow S. Lt. -ship.

, 27, /94, Coningbeg Lt.-ship.

Feb. 28, /90, Maidens.

Dec. $9, / 90$, Blackwater Bank Lt,-ship.

Feb. 8, /91, Arklow S. Lt.-ship.

Dec. 24, $/ 91$, Blackwater Bank Lto-ship.

Feb. 3, /97, Tuskar.

Oct. $6, / 98$, Blackwater Bank Lt.-ship.

, 15, /98, Tearaght.

, 7, /86, Rockabill. 
Species.

Turdus musicusTurush (94),
Length of wing in inches.

Date.

Station.
4.675, Nov. 18, /89, Arklow S. Lt.-ship.

,, 18,/90, Coningbeg Lt.-ship.

Jan. 8, /91, South Rock Lt.-ship.

,. 19, /98, Blackwater Bank Lt.-ship.

Oct. 8, /98, Arklow S. Lt. ship.

Nov. 19, /98, Skulmartin Rock Lt.-ship.

Oct. (?), /87, Tearaght.

April 21, /90, Arklow N. Lt.-ship.

Nov. $17, / 90$, Oyster Island.

Feb. 4, /91, Arklow S. Lt.-ship.

(?) Dec. $7, / 91, \quad$ ?

Mar. 23, /92, Blackwater Bank Lt.-ship.

$\cdot 625$

,

\section{, ,}

,

,

, $4 \cdot 600$

,

,

,

"

,"

,

,

,

,

"

,

,

,

,

,

,

,

,"

, 4.550 ,

$$
\text { , }
$$$$
\text { , }
$$$$
\text { , }
$$

Feb. 7, /88,

Dec. $19, / 90$,

April 2, /91,

Jan. 8, /93,

Oct. $15, / 95$,

$26, / 97$,

Nov. 11, /87,

Oct. $16, / 88$,

Nov. 6, /88,

" $9, / 88$,

, $30, / 88$,

Oct. $21, / 89$ $26, / 89$

Feb, $25, / 90$,

Nov. 14, /90,

$5, / 91$,

Sept. 29, /97,

Oct. 22, /97,

Mar. 19, /87,

Oct. $21, / 87$,

Jan. 16, /91,

Oct. 27, /91,

Mar. 19, /92,

Oct. $29, / 92$,

Nov. 2, /96,

Oct. $12, / 98$,

April 4, /91,

Feb. 10, /91,

Mar. 19, /91,

Oct. 28, /91,

Sept. 23, /92,

Nov. 9, /94,

April 4, /96,

Oct. 28, /97,

Jan. 22, /98,
Coningbeg Itt.-ship.

Maidens.

Blackwater Bank Lt.-ship.

Hook Tower.

Blackwater Bank Lt.-ship.

Arran Island, N.

Arklow S. Lt.-ship.

Tuskar.

Tearaght.

Copeland (Mew) Island.

Aranmore.

Tearaght.

Tuskar.

Barrels Rock Lt.-ship.

Blackwater Bank Lt.-ship.

South Rock Lt.-ship.

Blackwater Bank Lt. -ship.

Fastnet.

Coningbeg Lt. -ship.

Tuskar.

Arklow S. Lt.-ship.

Hook Tower.

Blackwater Bank Lt.-ship.

Arklow S. Lt. -ship.

Tuskar.

Skulmartin Rock Lt.-ship.

South Rock Lt.-ship.

Arklow S. Lt.-ship.

Lucifer Shoals Lt.-ship.

Barrels Rock Lt. -ship.

Arklow N. Lt.-ship.

Arklow S. Lt.-ship.

Innishtrahull.

Blackwater Bank Lt.-ship. 
Species.

Turdus musicusThrush (94),

Turdus iliacusREDWING (53), .
Leugth of in inches.

Date.

Station.

\begin{tabular}{|c|c|c|c|c|c|c|c|c|}
\hline Гhrus & ), & • & • & . & . 4.525, & Jan. & $28, / 85$ & Tearaght. \\
\hline ", & . & . & . & - & . & Oct. & $(?), / 86$ & Tuskar. \\
\hline ," & . & . & . & - & , & Dec. & $25, / 86$ & Rathlin O'Birne. \\
\hline ," & . & . & . & - & . & Oct. & $26, / 90$ & Hook Tower. \\
\hline ", & . & - & . & . & . & Feb. & $7, / 91$ & Arklow S. Lt.-ship. \\
\hline, & . & . & . & . & , & Jan. & $4, / 97$ & Blackwater Bank Lt.-ship. \\
\hline ", & . & . & - & . & . & Oct. & $18, / 97$ & ", \\
\hline , & . & - & - & . & . & Nov. & $10, / 98$ & Tuskar. \\
\hline , & . & . & . & . & . $4 \cdot 500$ & Feb. & $8, / 86$ & Mine Head. \\
\hline , & . & . & . & . & , & June & $2, / 86$ & Coningbeg Lt.-ship. \\
\hline, & . & . & - & . & . & Mar. & $21, / 87$ & Arklow S. Lt.-ship. \\
\hline ," & . & - & . & . & . & Jan. & $17, / 88$ & ," \\
\hline ," & · & . & - & . & , & Feb. & $23, / 89$ & , \\
\hline , & $\cdot$ & - & . & . & , & Nor. & 6, /91, & Fastnet. \\
\hline, & . & . & . & . & $;,$ & & $2, / 94$ & Blackwater Bank Lt.-ship. \\
\hline , & . & . & . & . & ", & Feb. & $9, / 95$ & Samphire Island: ${ }^{1}$ \\
\hline ", & . & . & . & . &, & Nov. & $10, / 98$ & Dungarvan. \\
\hline ," & . & . & . & . & $4 \cdot 475$ & Mar. & . $10, / 87$ & Coningbəg Lt,-ship. \\
\hline, & . & . & . & . &, & Dec. & $13, / 92$ & Blackwater Bank Lt.-8hip. \\
\hline, & . & . & . & . & . $4 \cdot 150$ & Nov. & . 6,187 & Coningbeg Lt.-ship. \\
\hline ", & . & . & . & . & , & Feb. & $23, / 90$ & Arklow S. Lt.-ship. \\
\hline , & . & . & . & . & , & Dec. & $19, / 90$ & Tearaght. \\
\hline ", & . & . & . & . &, & Jan. & $30, / 92$ & Blackwater Bank Lt.-ship. \\
\hline , & . & . & - & , & $4 \cdot 425$ & Mar. & $11, / 88$ & Arklow S. Lt.-ship. \\
\hline , & . & . & . & . & . $4 \cdot 400$ & Nov. & 12,187 & Fastnet. \\
\hline , , & & - & . & . & $4 \cdot 300$ & Mar. & $18, / 90$ & Tuskar. \\
\hline Turdu & iacus- & & & & Autumn- & & & \\
\hline REDW & $(53)$ & . & . & . & . $4 \cdot 825$ & Oct. & $26, / 86$ & Coningbeg Lt.-ship. \\
\hline , & & . & . & . & , & Dec. & $22, / 87$ & $?$ \\
\hline , & & . & . & . & . $4 \cdot 800$ & Nor. & $23, / 97$ & Arran Island, N. \\
\hline , & & . & . & . & $4 \cdot 775$ & Oct. & $16, / 87$ & Tory Island. \\
\hline , & & . & . & . & $4 \cdot 750$ & & $14, / 89$, & Maidens. \\
\hline ," & & . & . & . & . $4 \cdot 725$ & Nov. & . 6, /88, & Tearaght. \\
\hline , & & . & . & . & . & Oct. & $24, / 97$ & Mine Head. \\
\hline :, & & - & . & - & . $4 \cdot 700$ & , & $28, / 86$ & Rockabill. \\
\hline , & & . & . & . & . & , & $25, / 97$ & Arran Island, N. \\
\hline , & & . & . & . & . & Nov. & $23, / 97$ & ", \\
\hline , & & . & . & . & . & Dec. & $22, / 97$ & , \\
\hline , & & . & . & . & . $4 \cdot 675$ & Oct. & $19, / 89$ & Maidens. \\
\hline , & & - & . & . & , & ," & $20, / 89$ & , \\
\hline , & & - & . & . & , & Dec. & $24, / 90$ & Blackwater Bank Lt.-ship. \\
\hline ," & & . & . & . & , & Jan. & $10, / 93$ & Arklow S. Lt.-ship. \\
\hline , & & . & . & . & ,, & Nov. & $1, / 97$ & Arran Island, N. \\
\hline ," & & - & . & - & , & Dec. & $23, / 97$ & , \\
\hline ", & & - & . & $\cdot$ & , & ," & $23, / 97$ & \\
\hline
\end{tabular}


Species.

Turdus iliacus-

REDWING (53), .

Length of
wing
in inches.

A utumn

4.675 , Nov. 8, /98, Tuskar.

$4 \cdot 650$, Dec. $19, / 90$, Tearaght.

$4 \cdot 625$, Oct. $17, / 87$, Tuskar.

,, 17, /87, ,

Nov. 11, /90, South Rock Lt.-ship.

Oct. 23, /97, Fastnet.

Nov. 19, /97, Arran Island, N.

"19, /97, , .,

Dec. $23, / 97$,

Oct. $26, / 89$, Tuskar.

Dec. 22, /97, Arran Island, N.

4.575, Nov. 11, /87, Barrols Rock Lt.-ship.

" $\quad$ " 9, /88, Copeland (Mew) Island.

"Jan. 9, /93, Hook Tower.

4.550, Oct. 23, /97, Copeland (Mew) Island.

, Nov. 19, /97, Arran Island, N.

, Dec. 23, $/ 97$,

$4 \cdot 525$,

,

,

,

, $4 \cdot 500$, $4 \cdot 450$,

,

,

,

,

$4 \cdot 425$,

$4 \cdot 400$,

$4 \cdot 375$,

$4 \cdot 350$,

Spring-

4.550, Mar. 5, /91, Arklow S. Lt.-ship.

Oct. $16, / 85$, Eagle Island.

Nov. 12, 87 , Fastnet.

Sept. 20, /92, Rockabill.

Jan. 10, /93, Blackwater Bank Lt.-ship.

Dec. $18, / 97$, Arran Island, N.

, 20, /97,

Nov. 12, /87, Innishtrahull.

Oct. 27, /91, Rockabill.

Nov. 7, /91, Hook Tower.

"1, 197, Arran Island, N.

,23, /97,

Dec. $20, / 97$,

, $18, / 97$,

Nov. $1, / 97$,

$12, / 87$

, ,

, ,

, ,

" ,

Tuskar.

8, /94, Codling Bank Lt. -ship.

$4 \cdot 400$, Feb. 16, /88, Mine Head. ${ }^{1}$

\section{Autumn-}

$6 \cdot 125$, (?) Nov. $19, / 92$, Innishtrahull.

6.000, Dec. 9, /90, Arklow S. Lt,-ship.

$5 \cdot 975$, , 6, /90, Hook Tower.

Nov. 13, /93, Blackwater Bank Lt.-ship.

$5.950, \quad$, $19, / 98$, Maidens.

5.900, Dec. 15, /98, Blackwater Bank Lt.-ship.

$5 \cdot 875$, Nov. 5, /91, Copeland (Mew) Island.

$5 \cdot 825$, , 22, /92, Maidens.

1 Shot on mainland. 
Species.

\section{Turdus pilaris-}

Fieldfare (38),
Length of
wing Date. in inches.

Autumn-

5.825, Nov. 10, /98, Tuskar.

$\begin{array}{crr}\text { 5.800, } & \text {, } & \text { 4, } / 98, \quad \text {, }\end{array}$

$5 \cdot 775, \quad, \quad 7, / 87$, Tuskar.

6,188 , Tearaght.

9, /98, Tuskar.

10, /87, Eagle Island.

$5 \cdot 750$, Dec. (?) 20,/97, Hook Tower.

$5 \cdot 725$, Oct. 24, /86, Rockabill.

27,186 , Innishtrahull.

Nov. 26, /86, Arklow S. Lt. -ship.

Oct. 16, 187, Tory Island.

Nov. 6,/91, Fastnet.

5.700, Jan. 30, /92, Blackwater Bank Lt.-ship.

Dec. 18, 197, Tuskar.

Oct. 21, /98, Bull Rock.

Nov. 9,/98, Tuskar.

Dec. 19, /87, Mine Head. ${ }^{1}$

5.650, Nov. 2,/88, Copeland (Mew) Island.

- 5.625, „, 23, /97, Blackwater Bank Lt.-ship.

$5 \cdot 600$, „, 9, /87, Tuskar.

Dec. 8, $/ 90$, Tearaght.

5.575, Nov. 16, /98, Blackwater Bank Lt.-ship.

$5 \cdot 550$, , 7,/91, Tearaght.

$5 \cdot 475$, Oct. 16, $/ 87$, Tory Island.

- 5.425, Dec. 19,/90, Maidens.

Spring-

5.750, April 20, /90, Copeland (Mew) Island.

5.700, Mar. 21, /95, Samphire Island. ${ }^{2}$

5.625, (?) April, /89, Blackwater Bank Lt.-ship.

April 28, /91, Arklow S. Lt.-ship.

$$
\text { Species. Dex. }{ }^{3} \begin{aligned}
& \text { Length of } \\
& \text { wing } \\
& \text { in inches. }
\end{aligned} \text { Date. Station. }
$$

Turdus merula, BLACKBIRD (120)

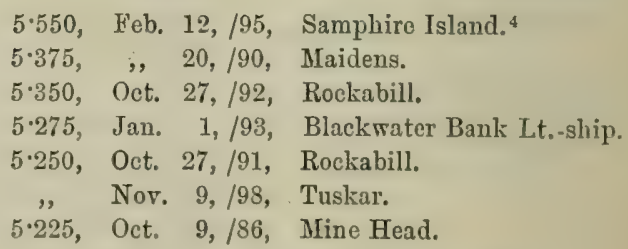




Species. Sex. $\begin{gathered}\text { Length of } \\ \text { wing } \\ \text { in inches. }\end{gathered} \quad$ Date. Station.

T'urdus merula-

\section{Blackbird (120)}

. $\delta$

. $\delta$

. $\delta$

. $\delta$

. 8

. 8

. $\delta$

. $\delta$

. 8

. $\delta$

. $\delta$

. 8

. $\delta$

. $\delta$

. $\delta$

. $\delta$

. $q$

. $\delta$

. ๆ

. $\delta$

. $q$

- 우

. $q$

. $\delta$

.

. ? 8

. ㅇ

- ช์

. $\delta$

. $\delta$

. $\delta$

. के

. $\delta$

. $\delta$

. $\delta$

. ㅇ

. 8

.

.

. $\delta$

. $\delta$

.

.
$5 \cdot 225$, Dee. 22, /92, Hook Tower.

, Nov. 24, /97, Coningbeg Lt.-ship.

$5 \cdot 200$, , 29, /88, Aranmore.

" , 7,/91, Tearaght.

5:175, Feb. 20, /87, Coningbeg Lt.-ship.

Nov. 9, /98, T'uskar.

$5 \cdot 150$, Oct. 27, /91, Barrels Rock Lt.-ship.

Nov. 13, /97, Arran Island, N.

$5 \cdot 125$, Feb. 19, /87, T'uskar.

Oct. 3, $/ 89$, Maidens.

Nov. 7, /91, Tearaght.

Oct. 17, /92, Arklow S. Lt.-ship.

Aug. 15, /93, Blackwater Bank Lt.-ship.

Nov. 9, /98, Mine Head.

$5 \cdot 100$, June 2, /86, Coningbeg Lt.-ship.

Oct. 3, /94, Blackwater Bank Lt.-ship.

Jan. $4, / 97$,

Oct. $24, / 98$,

, $7, / 86$,

Nov. $12, / 87$,

Feb. $22, / 90$

Arklow S. Lt.-ship.

April 4,/91, South Rock Lt.-ship.

Oct. 26-27,/91, Hook Tower.

, 26-27,/91,

Mar. 26, /92, Blackwater Bank Lt.-ship.

Oct. 17, /92, Arklow S. Lt.-ship.

, 25, /92, Blackwater Bank Lt.-ship.

Dec. $13, / 92$,

Nov. 13, /97,

$9, / 98$

Arran Island, N.

Mine Head.

$5 \cdot 050$,

$, 4, / 90$,

, $25, / 92$

Oct. 28, /97,

Nov, 13, /97, Arran Island, N.

," 9, /98, Tuskar.

, 10, /87, Arklow S. Lt.-ship.

Feb. 24, 190, Barrels Rock Lt.-ship.

Dec. 21, /90, Tearaght.

Oct. 27, /91, Arklow S. Lt.-ship.

Nov. 7, /91, Fastnet.

Oct. 2, /92, Rockabill.

Nov. 11, /92, Arklow N. Lt. -ship.

, 18, /92,

, 8, /98, Tuskar.

9, /98, Mine Head. 
Station.

Turdus merula-

BLACKBIRD (120), . .

.

",$\quad . \quad$.

,,$\cdot .9$

,,$\quad . \quad$.

9

,

,

19

,

2

9

" • . . . 우

"

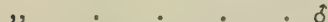

ช

g

,

,

,

,

,

29

,

,

,

,

19

,
5.000, Nov. 10, /87, Blackrock, MIayo. April 4, /91, South Rock Lt.-ship. Oct. 27, /92, Rockabill.

Nov. 15, /92, Tearaght.

, 27, /94, Rockabill.

$4 \cdot 975$, Oct. $16, / 87$, Tory Island.

, $\quad$ "27, /91, Arklow S. Lt.-ship.

, 18, /92, Hook Tower.

Nov. 22, /92, Rockabill.

Dec. 24, /92, Blackwater Bank Lt. -ship.

Nov. 27, /94, Rockabill.

Oct. 29, /97, Mine Head.

Feb. 18, /98, Blackwater Bank Lt.-ship.

Oet. 8, /98, Arklow N. Lt.-ship.

$4.950, \quad, \quad 23, / 86$, Coningbeg Lt.-ship.

,

Mar. 20, /87,

, 19, /91, Lucifer Shoals Lt.-ship.

Oct. $26, / 89$, Tuskar.

, $21, / 87$,

, 26-27, /91, Hook Tower.

, 26-27,/91, , ",

Feb. 5, /97, Tuskar.

4.925, Mar. 29, /87,

July $16, / 87$, Hook Tower.

Mar. 13, /90, Innishtrahull.

"17, /90, Lucifer Shoals Lt. -ship.

Feb. 12, /95, Samphire Island. ${ }^{1}$

Oct. 25, /97, Mine Head.

13

$4 \cdot 900$,

,

Dec. 4, /86, Coningbeg Lt.-ship.

Oct. 16, /88, Tuskar.

Mar. 17, /90, Lucifer Shoals Lt.-ship.

Oct. 6, /91, Copeland (MIew) Island.

Nov. 7, /91, Tearaght.

" 10, /92, Codling Bank Lt.-ship.

Dec. 24, /92, Blackwater Bank Lt.-ship.

Nov. 8, /98, Tuskar.

"

$4 \cdot 875$,

", $8, / 98$,

Oct. $16, / 88$,

,

Nov. 13, /90, Blackwater Bank Lt.-ship.

, 16, /90, Arklow S. Lt.-ship.

Oct. 15, /92, Hook Tower.

Nov. 2, /94, Blackwater Bank Lt. -ship.

,24, /94, Coningbeg Lt.-ship.

Oct. 29, /96, Tuskar.

,, 18, /97, Blackwater Bank Lt.-ship.

1 Found dead during severe frost. 
Species.

Sex.
Length of

in inches.
Date.

Station.

\section{Turdus merula-}

\section{BLACKBIRD (120),}

$4 \cdot 875$, Nov.20-30, $/ 97$, 'Tuskar.

,, Oct. 16, $/ 98$, Copeland (Mew) Island.

, Nov. 10, /98, Tuskar.

$4 \cdot 850$, Oct. $16, / 85$, Eagle Island.

" , 2, /86, Mine Head.

,Mar. 3, /87, Coningbeg Lt.-ship.

, Oct. 3,/89, Innishtrahull.

, $\left\{\begin{array}{r}{\left[\text { Rec'd. }_{2} \text { May }\right.} \\ 22, / 92],\end{array}\right\}$ Blackwater Bank Lt. -ship.

,$\quad$ Oct. 26, /97, Mine Head.

4.800, Nov. 7,/87, Tuskar.

"Dec. 9, /90, Blackwater Bank Lt.-ship.

, April 2,/91,

, Oct. $16, / 95$,

$4 \cdot 775$,

"6, 67 ,

April 6, /91, Blackwater Bank Lt.-ship.

Nov. 9, /98, Tuskar.

$4 \cdot 750$,

9, /94, Arklow S. Lt.-ship.

Oct. 24, /97, Blackwater Bank Lt.-ship.

Nov. 22, /97,

Oct. 19, /98, Skulmartin Lt. -ship.

, 28, /98,

Blackwater Bank Lt.-ship.
$6, / 98$,
Species.

Turdus torquatus,

Ring-Odzel (15),

\section{Length of} wing in inches.

Date.

Station.

\section{Spring-}

5.725, April 19, /89, Innishtrahull.

$5 \cdot 650$, May $5, / 96$,

$5 \cdot 625$, April 12, /90, Copeland (Mew) Island.

$5 \cdot 475, \quad, 16, / 95$, Innishtrahull.

. $\quad$. $\quad$ " $\quad 16, / 85$, Hook Tower.

- 5.300, "3, /91, Fastnet.

Autumn-

5•650, Sept. 11, /96, Tuskar.

$5 \cdot 600, \quad, \quad 29, / 88$,

$5 \cdot 525$, Oct. (?), /84, Skelligs.

$5 \cdot 450$, Nov.(?17), 197, Tuskar.

5.400 , Oct. $30, / 97$, Fastnet.

$5 \cdot 350$, Sept. 21, /87, Tuskar.

$5 \cdot 125$, " 29, /88, ,

Without Date-

$5 \cdot 400$,
Rathlin Island. 
Species.

Accentor modularisHedGe-Sparrow (4),

Erithacus rubeculaRedbreast (2), .

Ruticilla phonicurusCommon Renstart (9),

Ruticilla titys-

Black Redstart (22),
Length of in inches.

Date.

Station.
2700, Mar. 13, /92, Tearaght.

, Oct. 7,/96, Rathlin O'Birne.

"Sept. 12, $/ 97$, Arran Island, N. $2 \cdot 675$, Oct. $18, / 95$, Rathlin O'Birne.
- 3.050, Nov. 1, /91, Rockabill.

- 2.925, Mar. 13, /96, Blackwater Bank Lt.-ship.

Spring-

. $3 \cdot 075,\left\{\begin{array}{c}\text { May (? } 4 \text { or } \\ 11), / 94,\end{array}\right\}$ Rockabill.

- 3.050, April 26, /98, Innishtrahull.

- 3.025, ,, 28, /97,

- 2.975, May 5,/91, Tuskar.

- " "5,/96, Innishtrahull.

Autumn-

- 3·125, Oct. 5, 187, Fastnet.

- $3 \cdot 100$, Sept. 10,/96, Tuskar.

- 3.050, Nov. 7,/91, Killybegs.

- 3.000, Sept. 7,/96, Fastnet.

Aitumn-

- 3.550, $\left\{\begin{array}{c}\text { Nov. (first } \\ \text { week) } / 86,\end{array}\right\}$ Tuskar.

- 3•420, Oct. $31, / 99$, Wicklow Head. ${ }^{1}$

- $3 \cdot 400, " 28, / 88$, Fastnet.

. , " 23, $/ 95$, Tuskar.

- " " $\quad$ " 28, $/ 99$, Wicklow Head. ${ }^{1}$

- 3.375, ,, 30,/86, Fastnet.

. " " $19, / 87, \quad$,

- " " $\quad 23, / 87$, Arklow S. Lt.-ship.

- 3*350, ,29,/88, Fastnet.

" Nov.(?17),/97, Tuskar.

-3.325, Oct. 20,/87, Skelligs.

- "Nov. 10, /98, Tuskar.

- 3.275, Oct. 20,/87, Tearaght.

- 3·250, Nov. $13, / 84$, Fastnet.

- $\quad$ Oct. $23, / 93$, Ballycotton. ${ }^{1}$

- 3.225, ", 23, /87, Skelligs.

- "Nov. 2,/97, Fastnet.

- , " $, 16, / 99$, Skelligs.

- $3 \cdot 200$, Oct. $13, / 97$,

- $3 \cdot 175$, Nov. 16, /98, Tuskar.

Spring-

- 3•300, Mar. 16, /99, Blackwater Bank Lt,-ship.

," $\quad$,

Pratincola rubicola-

Stonechat (22),
- ", „, 18, /99, Coningbeg Lt.-ship.

$2 \cdot 725$, Oct. 20,/87, Fastnet. 
Species.

Pratincola mibicolaSTONECHaT (22),

Pratincola rubetraWHINCHAT (15),

Saxicola cenantheWhEATEAR (81),

Length of

in inches.

Date.

Station.

$2 \cdot 700$, Jan. 10, /92, Killybegs.

$2 \cdot 675, \quad, \quad 10, / 92, \quad$,

"Nov. 15, /97, Mine Head, ${ }^{1}$

"Fob. 18, /99, Blackwater Bank Lt.-ship.

2*650, Mar. 18, /90, Kish Bank Lt.-ship.

Jan. 10, /92, Killybegs.

$2 \cdot 625$, Feb, 14, /86, Mine Head. ${ }^{1}$

"Dec. 17, /90, Hook Tower. ${ }^{1}$

"Jan. 14, /92, Innishtrahull.

, Mar. 13, /96, Tuskar.

, April 4, /96, Innishtrahull.

"Feb. 18, /99, Blackwater Bank Lt.-ship.

" Mar. 1, /99,

$2 \cdot 600$, Jan. 10, /92, Killybegs.

2.575, Feb. 17, /99, Arklow N. Lt.-ship.

- " Mar. 1, /99, Blackwater Bank Lt.-ship.

Spring-

- 3·100, May 2, /89, Arran Island, S.

3.075, April 29, /97, Blackwater Bank Lt.-ship.

3.050, May 4,/89, Rockabill.

$3 \cdot 025,\left\{\begin{array}{c}\text { Probably May } \\ 4, / 89,\end{array}\right\}$ Arklow S. Lt. -ship.

3.000, May 9, /88, Tuskar.

" , 11-12, /99, Blackwater Bank Lt.-ship.

2.950, ", 12, /88, Tearaght.

,$\quad\left\{\begin{array}{c}\text { Probably May } \\ 12, / 98,\end{array}\right\}$ Tuskar (probably).

2.925, May 4, /89, Rockabill.

$2 \cdot 875$, „25, $/ 92$, Blackwater Bank Lt.-ship.

2•850, , , 7, /86, Coningbeg Lt.-ship.

- , " 4, /89, Rockabill.

Autumn-

3.075, Sept. 11, /96, Tuskar.

- 29950, Nov. 9, /90, Blackwater Bank Lt.-ship.

- $\quad\left\{\begin{array}{c}{[\text { Rec'd. Sept. }} \\ 4, / 89],\end{array}\right\}$ Copeland (Mew) Island.

Spring-

$4 \cdot 150$, April 21, $/ 88$, Fastnet.

" Mar. 195, Innishtrahull.

4.100, April 18, /90, Rockabill.

$3.975, \quad, \quad 17, / 90$, Arklow N. Lt,-ship.

3.950, May $8, / 90$, Maidens.

3.925, April 6, /89, Arklow S. Lt.-ship.

$\begin{array}{lllll}, & \quad, & 6, / 89, & , & \end{array}$

1 Shot on mainland. 
Species.

Saxicola wanthe-

WheAtear (81),
Length of wing

Date.

Station.
Spring-

3.875, April 1-7,/86, Eagle Island.

Mar. 28, /89, South Rock Lt.-ship.

April 9,/91, Tuskar.

, 18, /93, Maidens.

$3 \cdot 850$

$3 \cdot 825$,

,

$3 \cdot 800$

4, /91, South Rock Lt.-ship.

7, /91, Arklow S. Lt.-ship.

10, /91, Blackwater Bank Lt.-ship.

$\begin{array}{lrl}\text { Mar. } & 10, / 91, & \text { Blackwater Ba } \\ & 195, & \text { Innishtrahull. }\end{array}$

"15, /87, Tuskar.

April 6, /89, Lucifer Shoals Lt.-ship.

, 2, /91, Blackwater Bank Lt.-ship.

,4, /91, South Rock Lt.-ship.

, 12, /91, Arklow S. Lt. -ship.

Mar. 26, /92, Blackwater Bank Lt. -ship.

April 7, /94,

$6 ; / 89$, Lucifer Shoals Lt.-ship.

$3 \cdot 775$,

Mar, 18, /90, Tuskar.

(?)Apr. 12,/90, Arklow S. Lt.-ship.

April 7, /91,

Mar. 26, /92,

Hook Tower.

April 5, /94,

Rockabill.

Mar. 30, 197, Tuskar.

April $6, / 89$,

Arklow S. Lt.-ship.

7, /89, Blackwater Bank Lt. -ship.

Mar. 17, /90, Lucifer Shoals Lt.-ship.

April 24, /90, Rockabill.

" 6, $/ 91$, Blackwater Bank Lt.-ship.

" 12, /91, Arklow S. Lt.-ship.

, 10, /94, Innishtrahull.

Mar. 27, 195, Blackwater Bank Lt.-ship.

April 4, /91, South Rock Lt.-ship.

10, /91, Arklow S. Lt.-ship.

15, /96, Blackwater Bank Lt. -ship.

Mar. 30, /97,

April 6, /89,

$9, / 89$,

10, /91,

Mar. $30, / 97$,

April 6,/89,

$28, / 89$,

$23, / 89$,

$18, / 90$,

$24, / 90$,

Mar. 17, /91,

April 4, /91,

$5, / 91$,

$16, / 96$
Arklow S. Lt. -ship.

Howth Baily.

Tuskar.

Lucifer Shoals Lt. -ship.

Arran Island, S.

South Rock Lt.-ship.

Rockabill.

"

Coningbeg Lt. -ship.

South Rock Lt. -ship.

Lucifer Shoals Lt,-ship.

Arklow S. Lt. ship. 
Species.

Saxicola anantheWheATEAIr (81),

\section{Length of} in inches.

Date.

Station.
Spring-
- $3 \cdot 625$, April 13, /91, Arklow S. Lt.-ship.

,$\quad\left\{\begin{array}{c}{[\text { Rec'd. April }} \\ 10, / 94],\end{array}\right\}$ Innishtrahull.

3•600, April 10,/91, Blackwater Bank Lt.-ship.

,, ., 13, /91, Arklow S. Lt.-ship.

3.550, May 9,/88, Tuskar.

April 24, /90, Rockabill.

, 11, /91, Arklow N. Lt.-ship.

" 22, /97, Arklow S. Lt.-ship.

, 29, /92, Tuskar.

Autumn-"

4.125, Sept. 14, /90, Tearaght.

" , 18, /91, Blackwater Bank Lt.-ship.

,29, /92, Arklow N. Lt. -ship.

4.000 , Aug. 27, /85, Tearaght.

, $, \quad 23, / 85$, Arklow S. Lt. ship.

3.950 , Oct. 3, /91, Blackwater Bank Lt.-ship.

, , $\quad 31, / 97$, Fastnet.

3.900 , Sept. $28, / 92$, (?) Tuskar.

$3.875, \quad, \quad 4, / 86$, Coningbeg Lt. -ship.

," Aug. 15, /93, Blackwater Bank Lt.-ship.
3.800 , Sept. 8, /96, Arklow S. Lt.-ship.

$3 \cdot 775$, July 29, /90, Tearaght.

3.725, Aug. 21, /97, Arklow S. Lt.-ship.

$3 \cdot 700,\left\{\begin{array}{c}\text { Rec'd. Oct. } \\ 25, / 96,\end{array}\right\}$ Tuskar.

3.675, Aug. 9, /88, Arklow S. Lt.-sbip.

, , 19, /89, Maidens.

$3.550, \quad, \quad 22, / 88$, Mine Head.

Spring-

2·700, April 28, /94, Blackwater Bank Lt.-ship.

2.675, May 11,/89, Rockabill.

\begin{tabular}{|c|c|c|c|}
\hline & & & \\
\hline 625 , &, & $10, / 86$ & Tuskar. \\
\hline ," & 3 & $10, / 88$ & Mine Head. \\
\hline " & ", & $9, / 88$ & Tuskar. \\
\hline ", & , & $20, / 88$ & Mine Head. \\
\hline$"$ & , & 3, /89, & Tuskar. \\
\hline ", & , & $14, / 89$, & Arklow S. Lt.-ship. \\
\hline & , & $23, / 92$ & Maidens. \\
\hline $2 \cdot 600$ & Apri & $124, / 90$ & Rockabill. \\
\hline $2 \cdot 575$ & May & $10, / 86$ & Tuskar. \\
\hline , & ", & $10, / 86$ & Mine Head. \\
\hline , & , & $16, / 86$ & $?$ \\
\hline " & , & $16, / 86$ & $?$ \\
\hline , & " & $15, /$ & Coningbeg Lt. -shi \\
\hline , & ", & $30, / 8$ & $"$ \\
\hline
\end{tabular}


Species.

Acrocephatus phragmitisSedge Warbler (102),
Length of wing in inches.
Station.

\section{Spring-}

2.575, May 7,/89, Copeland (Mew) Island.

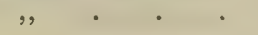

- " " $\quad 14,189$, Arklow S. Lt.-ship.

, , 16-17, /90, Tuskar.

, April 25, /93, Hook Tower.

$2 \cdot 550$, May 16,185 , Tuskar.

", ", 9, /88, Coningbeg Lt.-ship.

18, 188, Mine Head.

$7, / 89$, Copeland (Mew) Island.

22, 189, Arran Island, S.

10, /90, Arklow N. Lt.-ship.

$10, / 90$,

6, /91, Maidens.

$8, / 91$,

24, /92, Hook Tower.

17, /93, Maidens.

18, /93, Hook Tower.

7, /97, Blackwater Bank Lt.-ship.

9, /88, Coningbeg Lt.-ship.

$18, / 88$,

16, /90, Tuskar.

24, /92, Howth Baily.

20, /98, Arran Island, N.

6, 186, Mine Head.

8, 190, Copeland (Mew) Island.

$8, / 90$, Hook Tower.

$10, / 90, \quad,$,

6, /91, Blackwater Bank Lt.-ship.

23, /92, Arklow N. Lt.-ship.

April 28, /97, (?) Tuskar.

$2 \cdot 475$

$20, / 90$,

Hook Tower.

May $27, / 93$

Copeland (Mew) Island.

, 12, /95, Arklow S. Lt.-ship.

" 24, /92, Hook Tower.

i) $29, / 92$,

24, /93, Innishtrahull.

April 28, /97, Rockabill.

,

$2 \cdot 375$, May $24, / 92, \quad$ Howth Baily.
," ', $17, / 93$, Killybegs.

Autumn-

$2 \cdot 600$, Sept. $23, / 86$, Tuskar.

Aug. 10, /88,

July 29, /95, Blackwater Bank Lt.-ship.

$2 \cdot 575$, Sept. 14,/91, Rockabill.

, July $31, / 94$, Tuskar.

2.550, Sept. (?), /86, Hook Tower.

" Aug. 10, $/ 90$, Tuskar. 
Species.

Acrocephalus phragmitisSedge Warbler (102),

Length of wing in inches.

Date,

Station.

Autumn-

2.550, Aug. 10,/90, Tuskar.

", July $30, / 95, \quad$,

2.525, Aug. 9, /88, Arklow S. Lt.-ship.

" Sept. 6, $\quad$ " 89 , old Head, Kinsale.

, Aug. 11, $/ 90$, Tuskar.

, , 11, $/ 90$, ,

, , $\quad 11, / 90, \quad$,

, " 23, /92, Hook Tower.

, Sept. 11, /96, Fastnet.

2.500, Aug. 4, /89, Old Head, Kinsale.

," $\quad 8, / 90$, Tuskar.

"10, 190, ,"

, 16, /93, Blackwater Bank Lt.-ship.

,, Rec'd.Oct.25, /96, Tuskar.

2*475, Aug. 25, /86, Mine Head.

\begin{tabular}{|c|c|c|c|}
\hline ", & , & $10, / 88$ & Tuskar. \\
\hline , & , & $10, / 88$ & ", \\
\hline , & , & $10, / 88$ & ," \\
\hline ," & , & $11, / 90$ & $"$ \\
\hline , & , & $11, / 90$ & $"$ \\
\hline , & 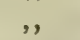 & $13, / 93$ & Howth Baily. \\
\hline , & July & $31, / 94$ & Tuskar. \\
\hline , & ", & $31, / 94$ & $"$ \\
\hline & Sept. & $6, / 94$ & " \\
\hline$\cdot 450$ & Aug. & $10, / 88$ & , \\
\hline , & $\because$ & $11, / 90$ & ", \\
\hline , & Nov. & $9, / 90$ & Blackwater Bank Lt.-ship. \\
\hline ", & Sept. & $6, / 94$ & Tuskar. \\
\hline $2 \cdot 425$ & Aug. & $\begin{array}{r}6, / 88, \\
11, / 90\end{array}$ & $"$ \\
\hline ", & July & $31, / 94$, & ", \\
\hline $2 \cdot 400$ & Oct. & $6, / 87$, & $"$ \\
\hline , & Aug. & $9, / 88$ & Arklow S. Lt.-ship. \\
\hline ", & " & $9, / 88$ & " \\
\hline , & , & $11, / 90$ & Tuskar. \\
\hline , &, & $11, / 90$ & , \\
\hline ," & ", & $11, / 90$ & " \\
\hline & , & 11, /90, & ") \\
\hline
\end{tabular}

Giasshopper Warbler (7), . 2•600, April 14,/98, ,"

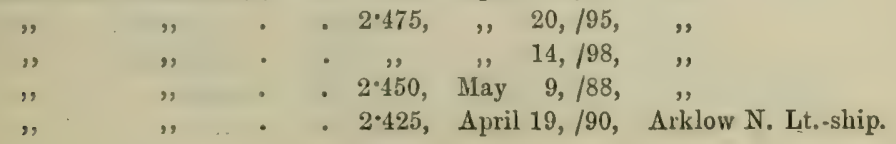


Species.

Locustella, noevia-

Grasshopper WarbLer (7)

Sylvia cinereaWhiteTHROAT (66),
Length of

wing

in inches.
Date.

Station.

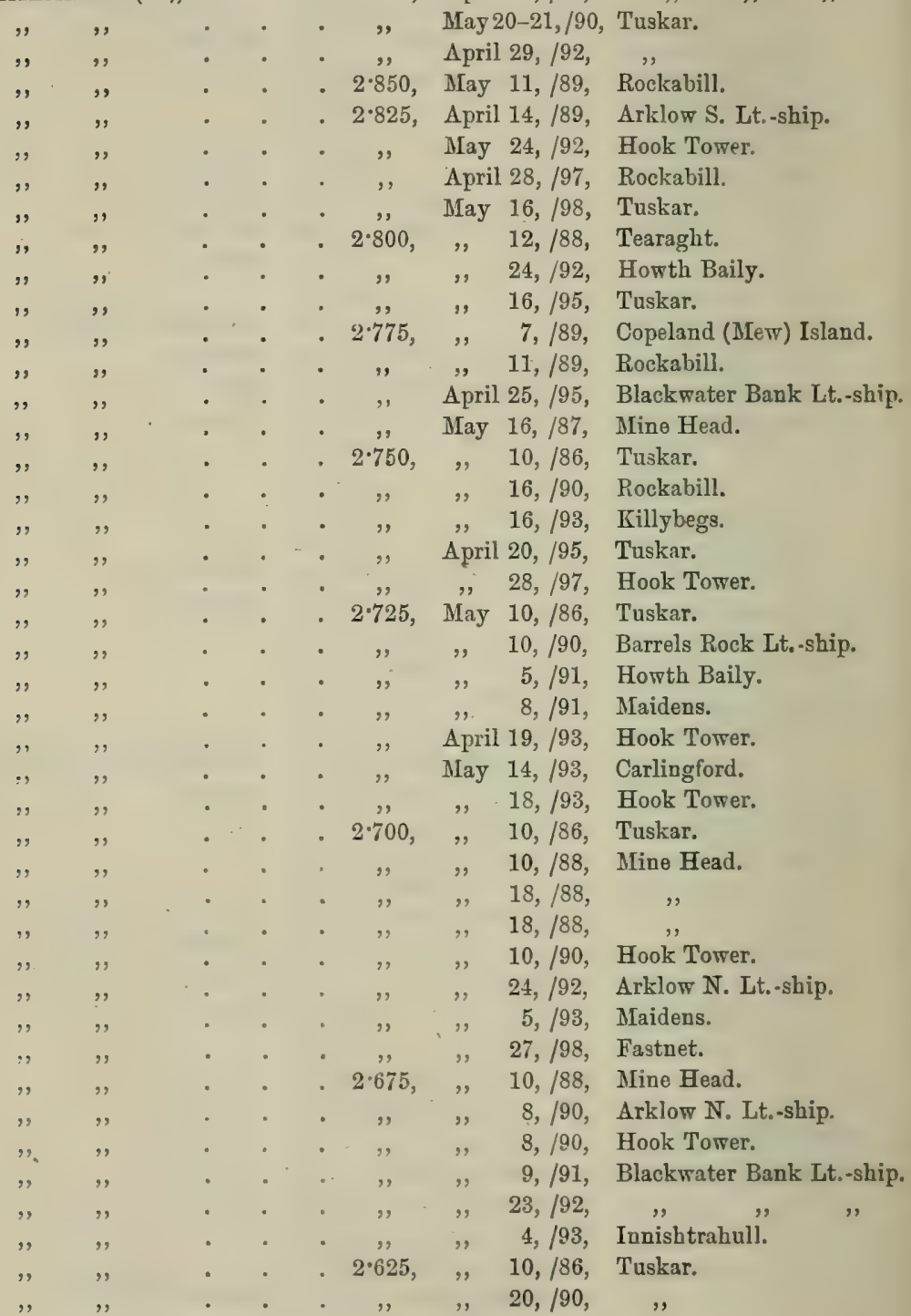


Species.

Sylvia cinerca-

Whitethroat $(66)$, .

\section{Length of}

wing

in inches.

Date.

Station.

\section{Spring-}

2*625, May 21, /90, Copeland (Mew) Island.

- Autumn-" $9, / 96$, Coningbeg Lt.-ship.

2.925, Sept. 20, /87, Mine Head.

- 2850, i 19, /95, Coningbeg Lt. ship.

- 2.825, $\left\{\begin{array}{c}{[\text { Rec'd. Oct. }} \\ 25, / 96]\end{array}\right\}$ Tuskar.

- ' Sept. 8, /96, Fastnet.

- $2 \cdot 800$, „22,/88, Tuskar.

$2 \cdot 775$

," $27, / 88, \quad$,

Aug. 12, /93,

Sept. 25, /94, Blackwater Bank Lt.-ship.

$\begin{array}{ccrl}2 \cdot 750, & \quad, \quad 8, / 96, & \text { Arklow S. Lt. } \text {-ship. }\end{array}$

, $8, / 96$,

,23, /86, Tuskar.

$2 \cdot 725$

" " 11, /88, Hook Tower.

$2 \cdot 700$, Aug. 31, /88, Tuskar.

Sept. 1, /94, "

Sept. 8, /96, Coningbeg Lt.-ship.

$2 \cdot 675$, Nov. 9, /90, Blackwater Bank Lt.ship.

Sept. 8, /96, Coningbeg Lt.-ship.

" Aug. 24, /98, Blackwater Bank Lt.-ship.

$2 \cdot 625$, Sept. $8, / 96$, Fastuet.

Without date-

- 2·750, $\left\{\begin{array}{c}{\left[\operatorname{Rec}^{3} \text {. Feb. }\right.} \\ / 93],{ }^{1}\end{array}\right\}$ Hook Tower.

Sylvia curruca-

Lesser Whitethroat (2), . $2 \cdot 625$, Oct. 10, / 99 , Innishtrahull.

"ylvia hortensis-

Garden Warbler (2), . $\quad 3.050$, May 11-12,/99, Blackwater Bank Lt. ship.

$2 \cdot 600$, ", $1, / 90$, Tearaght.

- $2 \cdot 775$, Oct. 4, /86, Coningbeg Lt.-ship.

\section{Sylvia atricapilla-}

BLACKCAP (5), .

Phylloscopus sibilatrixWOOD-WARBLET: (1), . Phylloscopus trochilusWILLOW WrEN (73), .

$$
\begin{array}{crrl}
2 \cdot 875, & \text { Dec. } 8, / 96, & \text { Fastnet Buildings. } \\
2 \cdot 850, & \text { Sept. 27, } / 92, & \text { Innishtrahull. } \\
2 " & \text { Oct. } 15, / 95, & \text { Blackwater Bank Lt.-ship. } \\
2 \cdot 825, & \text { " } & 4, / 86, & \text { Tearaght. } \\
", \quad \text { " } & 31, / 86, & \text { Eagle Island. }
\end{array}
$$

- 2•875, May 27, /90, Blackrock, Mayo.

Spring-
2:850, April 18, /93,. Maidens.
$2 \cdot 825$, „24, /97, Hook Tower.
$2 \cdot 800$, Nay 6,/91, Maidens. 
Species.

Phylloscopus trochilusWillow Wren (73), 。

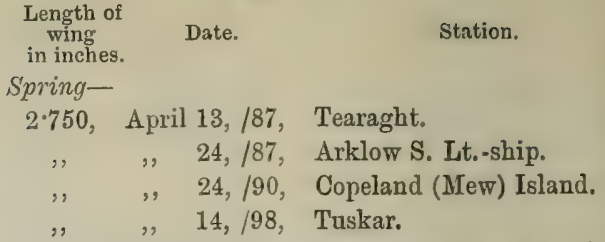


Speciey.

Phylloscopus trochilus-

WiLlow WreN (73), .

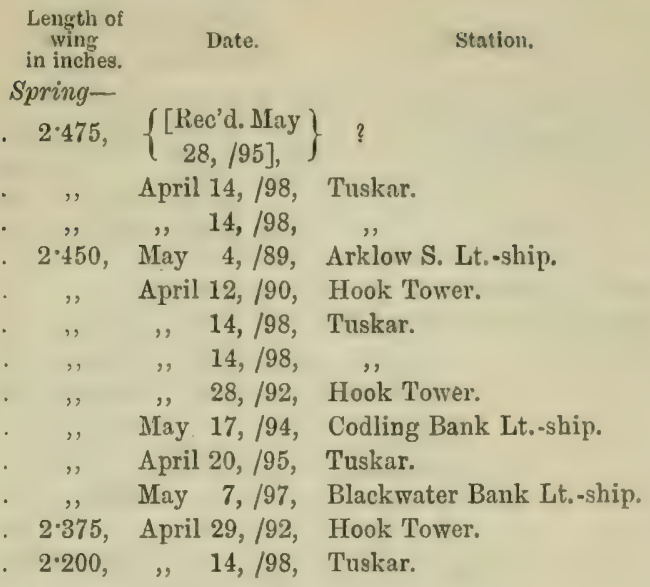

2.575, April 7,/89, Blackwater Bank Lt.-ship.

, Mar. 24, /92,

2.475, April 8, /89, Lucifer Shoals Lt.-ship.

$2 \cdot 425$, " 4, /91, Tuskar.

, , $5, / 91$,

"10,/91, Blackwater Bank Lt. -ship.

" M"ar. 31, /97,

$2 * 400, \quad$ April 11, /89, Rockabill.

„11, /98, Tuskar.

, 3, /99, Blackwater Bank Lt.-ship).

$2 \cdot 300,\left\{\begin{array}{c}{\left[R^{\prime} c^{\prime} \text {. April }\right.} \\ 26, / 95],\end{array}\right\}$ Tuskar.

2·275, April 3, /94, Hook Tower.

$2 \cdot 225,\left\{\begin{array}{c}{[\text { Rec'd. April }} \\ 24, / 90],\end{array}\right\}$ Rockabill.

,$\quad\left\{\begin{array}{c}{\left[\text { Rec'd. April }_{26, / 92],}\right.}\end{array}\right\}$ Innishtrahull.

2·200, April 14, /98, Tuskar.

$2 \cdot 150, \quad$, 14, /98, , 
Species.

Phylloscopus rufusChiffehaff (20),

Regulus cristatus-

Golden-crested Wren (50),

\begin{tabular}{|c|c|c|c|}
\hline " & ", & " & • \\
\hline " & " & " & • \\
\hline " & $"$ & $"$ & • \\
\hline ," & , & ", & • \\
\hline ", & ", & ", & . \\
\hline , & $"$ & , & - \\
\hline$"$, & ", & $"$ & . \\
\hline ", & $"$ & ", & • \\
\hline$"$ & $"$ & , & • \\
\hline ", & $"$ & $"$ & · \\
\hline , & $"$ & $"$ & . \\
\hline$"$ & $"$ & $"$ & . \\
\hline " & $"$ & ", & . \\
\hline " & $"$ & $"$ & $\because$ \\
\hline ", & ", & $"$ & . \\
\hline " & $"$ & $"$ & . \\
\hline " & " & " & . \\
\hline$"$ & , & $"$ & . \\
\hline ", & , & $"$ & . \\
\hline$"$ & $"$ & $"$ & . \\
\hline " & $"$ & ", & . \\
\hline$"$ & ", & ", & . \\
\hline , &, & , & . \\
\hline$"$ & ", & " & . \\
\hline " & " & " & . \\
\hline , & , & , & . \\
\hline , & , & ", & . \\
\hline$"$ & ", & ," & . \\
\hline ", & $"$ & , & . \\
\hline ", & , & ", & . \\
\hline$"$ &, & ", & . \\
\hline " & $"$ & ," & . \\
\hline$"$ & ; & ", & . \\
\hline ", & ", & ," & . \\
\hline " & ", & ," & . \\
\hline ", & ", & , & . \\
\hline " & $"$ & , & . \\
\hline
\end{tabular}

Length of in inches.

Date.

Station.
Autumn-

2.325, Sept. 2, /86, Mine Head.

$2 \cdot 300, \quad$,23, $/ 86$, Tuskar.

$2 \cdot 275$, Oct. 2, /86, Rockabill.

2.225, Sept. 11, /96, Tuskar.

Autumn-

2.225, Nov. 15, /90, Tearaght.

$2 \cdot 200$, Oct. $20, / 98$, Skulmartin Lt.ship.

2.175, Sept. 18, /98, Arklow S. Lt.-ship.

Nov. (? 20), /93, Innishtrahull.

$2 \cdot 150$, Oct. $30, / 89$, Kish Bank Lt.-ship.

Sept. 3,/93, Tuskar.

, 15, /98, Carlingford.

Oct. 21, /98, Arran Island, S.

$2 \cdot 125$, , 1, /88, Crookhaven.

,16,/88, Tuskar.

Sept. 26, /89, Old Head, Kinsale.

Nov. 6, /91, Hook Tower.

Sept. 14, /93, Arklow S. Lt.-ship.

,29, /97, Copeland (Mer) Island.

, 15, /98, Wicklow Head.

,. 22, /98, Blackwater Bank Lt.-ship.

$2 \cdot 100, \quad \because \quad 27, / 97, \quad$ Lucifer Shoals Lt.-ship.

,24, /98, Wicklow Head.

Oct. 21, /90, Tearaght.

20, /98, South Rock Lt:-ship.

21, /98, Arran Island, S.

," 2, $/ 94$, Arklow N. Lt.-ship.

21, /98, Arran Island, S.

Nov. 19, /98, Arklow S. Lt.-ship.

2.050, Aug. 27, /88, Copeland (Mew) Island.

Sept. 19, /89, Arran Island, S.

,, 13, /93, Rockabill.

Oct. 23, /93, Ballycotton.

, 8, /94, Maidens.

Nov. 5, /97, Coningbeg Lt.-ship.

, ? 17, /97, Tuskar.

.

Oct. 19, /90, Arklow N. Lt. -ship.

Sept. 15, /93, Blackwater Bank Lt.-ship.

Oct. 10,/93, Coningbeg Lt.-ship.

Sept. 15, /98, Carlingford.

$2 \cdot 000, \quad, \quad 12, / 89$, Innishtrahull.

" $\quad$ "29, $/ 97$, Blackwater Bank Lt.-ship.

,

$13, / 98$,

Spring-

$2 \cdot 175$, Mar. 19, /93, Innishtrahull.

$2 \cdot 150, \quad, \quad 21, / 90$, Maidens. 
Species.

Regulus cristatus-

Golden-Crested Wren (50),

Troglodytes parvulusCommon Wren (12),

Parnes major-

Great Titmouse (2),

Parnes ccruleus-

Blue Titmouse (1), .

\section{Acredula caudatc-}

LONG-TAILED TitMouse (2),

Motacilla lugubris-

Pied Wagtail (2),

\section{Motacilla melanope-}

Grey Wagtail (2),

\author{
Length of \\ wing \\ in inches. \\ Date.
}

Station.

Spring-

2'150, Mar. 25, /90, Maidens.

$2 \cdot 100$, April 9, /89, Coningbeg Lt.-ship.

,$\quad$ Mar. 23, $/ 92$, Innishtrahull.

2.025, April 11, /91, Arklow N. Lt.-ship.

, . 28, $/ 91$, Rockabill.

$, \quad, \quad 9, / 96$, Innishtrahull.

\section{Autumn-}

1.975, Oct. $16, / 88$, Tuskar.

- 1·950, „21, /98, Arran Island, S.

$1.900, " 30, / 97$, Fastnet.

, Nov. 19, /98, Maidens.

$1 \cdot 850, \quad$ „16, /85, Skelligs.

,$\quad$ Oct. $30, / 97$, Fastnet.

1.825, Nov. 14, /84, Eagle Island.

1.800 , (?) Oct. $15, / 89$, Tearaght.

- 1.775, Jan. 1,/91, ,

Spring-

- 1.925, April 4, /96, Innishtrahull.

- 1.850, May 12,/99, Maidens.

Without Date-

- 1850, ? /89, Blackrock, Mayo. ${ }^{1}$

3.050, Oct. 14, /89, Coningbeg Lt.-ship.

$2 \cdot 800$, , 16, /99, Fastnet.

- 2500, Mar. 14, 187, Mine Head. ${ }^{2}$

- 2375 , Oct. $27, / 95$, Innishtrahull.

, " $27, / 95$, ,

$3 \cdot 625$, Feb. 28, /87, Fastnet. ${ }^{3}$

3.350, Sept. 22, /87, Tuskar.

$3 \cdot 250$, Oct. $8, / 87$, Coningbeg Lt.-ship.

,9

I It may be of interest to compare the average measurement of Wrens' wings from Irish lightstations, i.e., 1 S 50 , with measurements of some other specimens, including the Icelandic and intermediate forms, in my collection:-

Troglodytes borealis, from Reykjavik, Iceland (Received April 1893), ․ . $\quad 2 \cdot 250$

" " , " Skuo, Faröe (June 1892), . . . . . . 2200

", , , , , , . . . . . . . 2. 2175

parvulus, , Foula, Shetland (June 1890), . . . . . 2.000

, ", TVeysdale Voe, Shetland (June 1890), . . . 2.000

Wren from St Kild " " " " "

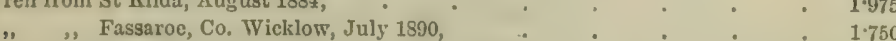

2 Shot on mainland.

3 This may be the wing of a White Wagtail (JI, alba).

4 Probably shot on mainland. 
Species.

Motacilla raii-

YeLLOW WAGTAIL (2),

"

Anthus pratensis-

Meadow Pipit (34),
Length of

in inches.
Date.

Station.
3.325, Sept. 11, /93, Hook Tower.

, 19, /95, Tuskar.
$3 \cdot 375$, Feb. 20 or 6,/90, Maidens.

Nov. 6, /91, Fastnet.

3:350, Jan. 10, /92, Blackwater Bank Lt.-ship.

3.325, Mar. 14, /88, Coningbeg Lt.-ship.

" Oct. 17, 192, Blackwater Bank Lt.-ship.

3.300, Nov. 13, /87, Coningbeg Lt.-ship.

, Oct. $22, / 89$, Maidens.

3·250, , 29, /86, Barrels Rock Lt,-ship.

, $\quad$, 8, /87, Coningbeg Lt.-ship. $\left\{\begin{array}{c}{[\text { Rec'd.Aug. }} \\ 19, / 90,]\end{array}\right\}$ Lucifer Shoals Lt.-ship.

$3 \cdot 225$, Mar. 27, $/ 90$,

$3 \cdot 200$, Sept. 29, /88, Tuskar.

April 19, /90, Blackrock, Mayo.

Mar. 14, /99, Coningbeg Lt. -ship.

$\ddot{175}$, Oct. $23, / 87$, Skelligs. $\left\{\begin{array}{c}{[\text { Rec'd.Jan. }} \\ 22, / 91,]\end{array}\right\}$ Hook Tower.

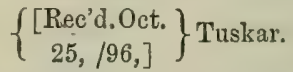

3.150, April 11, /89, South Rock Lt.-ship.

3.125, Oct. 6, /85, Coningbeg Lt.-ship.

, Mar. 29, /87, Tuskar.

Feb. 27, /91, Arklow N. Lt.-ship.

Mar. 12, /96, Blackwater Bank Lt.-ship.

$3 \cdot 100$

Sept. 21, 187, Coningbeg Lt.-ship.

Nov. 9, /98, Mine Head. ${ }^{1}$

3.075, Mar. 6, /87, Fastnet.

, Nov. 3, /97, Coningbeg Lt.-ship.

" " 5, /97, Fastnet.

$3 \cdot 025$, Oct. $29, / 86$,

, April 11, /89, Rockabill.

, Mar. 18, /91, Coningbeg Lt.-ship.

Jan. $\quad / 95$, Innishtrahull.

Oct. 28, /98, Blackwater Bank Lt,-ship.

3.000, - Sept. 21, /87, Coningbeg Lt.-ship.

, Oct. 20, /96, Tuskar.

Anthus obscurusRock Pipit (6), .

\author{
$3 \cdot 625, \quad, \quad 20, / 89$, Tearaght. \\ $3 \cdot 600$, Sept. 10, /85, \\ $3 \cdot 525$, Oct. $8-14, / 86$, Eagle Island, W.
}


Species.

Anthus obscuerus-

Rook Pipit (6), .

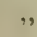

Alauda arvensis -

SKYLARK (113), .

\section{Length of}

in inches.

Date.

Station.
3.425, Sept. 14, /86, Eagle Island, E.

$3 \cdot 325$, Oct. 14, /86, Ratblin O'Birue.

$\left\{\begin{array}{c}{\left[\text { Rec'd.Jan. }_{22, / 91,]}\right.}\end{array}\right\}$ Hook Tower.

4.800, (?) Oct. $28, / 86$, Arklow S. Lt.-ship.

4.725, Feb. 21, /95, Blackwater Bank Lt.-ship.

$4 \cdot 625$, Oct. $15, / 95$,

$4 \cdot 600$, , 16, /89, Maidens.

,28, $/ 89$,

,24, $/ 90$, Hook Tower.

Feb. 10, /91, Arklow S. Lt. -ship.

, 27, /92, Blackwater Bank Lt.-ship.

$4 \cdot 575$

Dec. 29, 190, Arklow S. Lt.-ship.

Feb. 4, /91,

Oct. 26 or 27,/91, Hook Tower.

Dec. 19, /97, Blackwater Bank Lt.-ship.

550 , Sept. 26, /89, Maidens.

Mar. [12-25],/90, , ,

$4 \cdot 525$, Feb.[14-22], /90,

4.500 , Oct. 18, /87, Tory Island.

,25, /92, Blackwater Bank Lt.-ship.

Feb. 3, /97, Tuskar.

Oct. 19, /98, Skulmartin Lt.-ship.

4.475 , Feb. 19, /91, Arklow S. Lt.-ship.

, Oct. 29, /97, Blackwater Bank Lt.-ship.

4.450, Mar. [12-25], /90, Maidens.

, Oet. 23, /97, Copeland (Mew) Island.

4.425, , , 7, /98, Arklow S. Lt. -ship.

4.400, Nov. 20, /98, Skulmartin Lt.-ship.

4.375, Jan. 10, /93, Arklow S. Lt.-ship.

Nov. 8, /98, Tuskar.

$4 \cdot 350$, Oct. [8-14],/86, Eagle Island.

Nov. 22, /92, Rockabill.

4.300, ", 14, /90, Blackwater Bank Lt.-ship.

,Jan. 21, /92, South Rock Lt.-ship.

4.275, Oct. 3,/89, Maidens.

Eeb. [14-22], /90,

Oct. 26 or $27, / 91$, Hook Tower.

Feb. 20 or $26, / 92$,

$4 \cdot 250$, Sept. $30, / 89$, Maidens.

, Feb.[14-22], /90, ",

, [14-22], $/ 90$,

Dec. 14, /90, Blackwater Bank Lt.-ship.

Nov. 5, /96, Fastnet.

, $23 / 97$ Coningbeg Lt. -ship. 
Species.

Alauda arvensisSKYLARK (113),

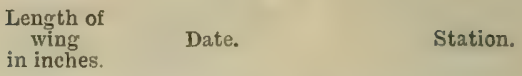

Date.

Station.

4.225, Mar, 23, /86, Mine Head.

Arklow S. Lt.-ship.

Oct. $12, / 90$, Arklow N. Lt.-ship.

April 10, /91, Arklow S. Lt.-ship.

Oct. 26 or $27, / 91$, Hook Tower.

Dec. 13, $/ 92$, Blackwater Bank Ist.-ship.

Jan. 17, /93,

$4 \cdot 200,\left\{\begin{array}{c}{\left[\operatorname{Rec}^{\prime} d . \text { June }\right.} \\ 2, / 86],\end{array}\right\}$ Coningbeg Lt. -ship.

Oct. 14, $/ 87$, Fastnet.

26, 189, Tuskar.

,, 26 or 27,/91, Hook Tower.

Sept. 23, /92,

Dec. $16, / 92$,

,,

Jan. 1, /94,

Arklow S. Lt.-ship.

Nov. 27, /94, Coningbeg Lt.-ship.

$4 \cdot 175$, Mar. 12-25, /90, Copeland (Mow) Island.

, $12-25, / 90$,

Nov. 16, /90, Arklow S. Lt.-ship.

Feb. 17, $/ 96$,

Oct. 20,/97, Fastnet.

Dec. 24 or 25, $/ 97$, Hook Tower.

Oct. $\quad 6, / 98$, Blackwater Bank Lt.-ship.

Nov. 9, /98, Tuskar.

$4 \cdot 150, \quad$ Feb. 19, /87, ,

, Oct. 3, $/ 89$, Maidens.

" $, \quad 3, / 89$,

April 5, /91, Tuskar.

Mar. 14, $/ 98$, Blackwater Bank Lt. -ship.

125 , Oct. 19, /87, Tuskar.

Mar. 11, /88, Arklow S. Lt.-ship.

Dec. 12, /90, South Rock Lt.-ship.

Mar. 26, /92, Hook Tower.

Nov. 1, /92, Tearaght.

Oct. $29, / 96$, Tuskar.

$4 \cdot 100$

"28, /86, Coningbeg Lt.-ship.

,22, /88, Fastnet.

(?'Dec.) 7,/91, Tearaght.

Dec. 21, /91, Copeland (Mew) Island.

4.075, Mar, 29, /87, Tuskar.

Nov. 15, 192, Blackwater Bank Lt.-ship.

19, /98, Maidens.

$4 \cdot 050$, Oct. $21, / 87$, Tuskar.

$16, / 88$,

Nov. 17, /90, Blackwater Bank Lt.-ship.

Mar. 26, /92, Hook Tower.

Nov. 22, 192, Blackwater Bank Lt.-ship. 
Species.

Alauda arvensis-

SKYtuate (113), .

$$
\begin{aligned}
& \text { Length of } \\
& \text { wintr }
\end{aligned}
$$

in inches.

Date.

Station.

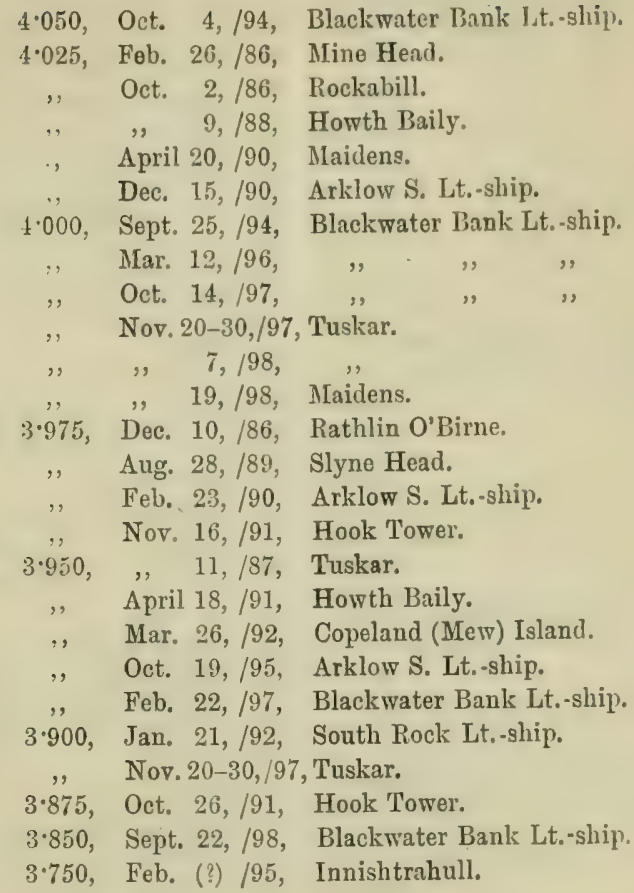

Alauda brachydactylaSHont-toed LARK (1),

Alauda arborcaWOOD-LARK (1),

Plectrophonax niralis Snow Bunting (24),

3.875, , 24, /87, Tearaght.

$4 \cdot 800,\left\{\begin{array}{c}{\left[\text { Rec'd. May }_{24, / 93],}\right.}\end{array}\right\}$ Innishtralull. $4 \cdot 500$, Oct. $31, / 88$, Tearaght.

, Nov. 28, /98, Blacksod Point.

$4 \cdot 475$, Oct. 4, /86, Fastnet.

4־400, Dec. 15,/91, Hook Tower.

$$
\text { , 15, /91, ,, , }
$$

Oct. 29, /92, Tuskar.

4'375, Mar. 27, /89, Slyne Head.

4.325, Oct. 7,/91, Hook Tower.

$4 \cdot 275$, May $3, / 87$, Tearaght.

Oct. 11, /89, Coningbeg Lt. -ship.

$4 \cdot 250$, Nov. 9, /92, Innishtrabull.

4:200, Oct. 31, /86, Rockabill.

(?) Sept. 20, /89, Tearaght. 
Species.

Plectrophenux nivalisSnow Bunting (24), .

Emberiza schoeniclusReed Bunting (6), .

$\begin{array}{ll}", & , \\ ", & , \\ , & , \\ , & ,\end{array}$

Emberiza miliariaCorn Bunting (4),

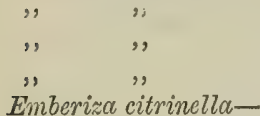

Yellowhammer (6), .

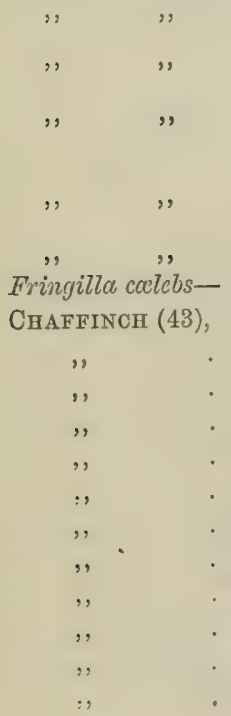

Length of
wing
in inches. Date. Station.

4.175, Dec. 15, /91, Hook Tower.

$\begin{array}{cll}\text { 4.150, Jan. (?) } / 95, & \text { Innishtrahull. } \\ 4 \cdot 125, & \text { Feb. 26, } / 96, & \text { Rockabill. } \\ 4 \cdot 075, & \text { Sept. 19, } / 89, & \text { Old Head, Kinsale } \\ 4 \cdot 050, & \text { April 4, } / 96, & \text { Innishtrahull. } \\ , & \text { Sept. 28, } / 96, & \text { Blackrock, MIayo. } \\ , & \text { Feb. 2, } / 97, & \text { Rockabill. } \\ 4 \cdot 000, & \text { Dec. 15, /91, } & \text { Hook Tower. } \\ 3 \cdot 925, & \text { April 4, } 496, & \text { Innishtrahull. }\end{array}$

Spring-

3•125, Mar. 3, /96, Blackwater Bank Lt.-ship.

$3 \cdot 100$, Feb. 8, /86, Mine Head.'

3.000, April 13,/97, Innishtrahull.

Autumn-

3.100, Nov. 15, /87, Arklow S. Lt.-ship.

3.025, „, 19, /98, Maidens.

3.000, ", 19, /98, Skulmartin Lt.-ship.

3:975, April 25, /95, Tory Island.

3.850 , July $1, / 89$, Innishtrahull.

$3 \cdot 575$, Feb. 8, /86, Mine Head. ${ }^{1}$

$3 \cdot 475$, ? $\because 87$, , . ,

Spring-

3.550, Mar. 3, /86, , , , I

3.525, , 7, $/ 98$, Copeland (Mew) Island.

$3.475,\left\{\begin{array}{c}\text { Feb. } 20 \\ 26, / 90,\end{array}\right\}$ or Maidens.

$3 \cdot 375$, Mar. 28, $/ 90$, ,

Autumn-

$3.500,\left\{\begin{array}{c}{[\text { Rec'd. Nov. }} \\ 30, / 37],\end{array}\right\}$

3.225, Nov. 23, /96, Tuskar.

Autumn-

3.725, Dec. 19, /97, Blackwater Bank Lt.-ship.

$3 \cdot 675$, Oct. (?) $/ 86$, Tuskar.

3.550 , , 17,/87, Fastnet.

$3 \cdot 525$, , 17, /87, Tuskar.

" , 28, $/ 91$, Tearaght.

", $28, / 91, \quad$,"

$3 \cdot 475, \quad, \quad 28, / 86$, Rockabill.

, " 27, /91, Barrels Rock Lt. -ship.

Nov. 1, /92, Tearaght.

$3 \cdot 450$, " . 7, /87, Barrels Rock Lt.-ship.

Oct. 24, /92, Rockabill.

$3 \cdot 375$, Nov. 13, /87, Coningbeg Lt.-ship.

1 Shot on mainland. 
Species.

Fringilla coelcbs-

Cinaffincir (43),

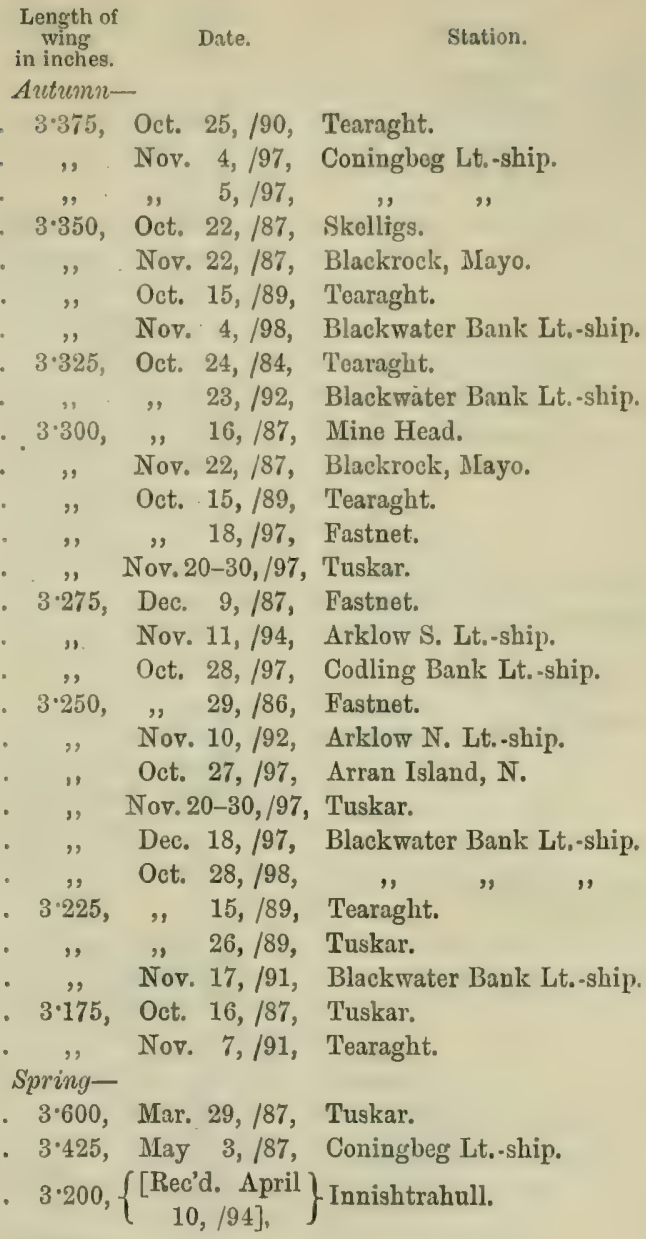

Autumn-

- 3750 , Nov. 10, /87, Skelligs.

$3 \cdot 725$, Oct. $20, / 87$, Tearaght.

- 3.600, Nov. 12, /87, Arklow S. Lt.-ship.

- 3.500, " 6, /91, Fastnet.

3.375, Dec. 28, /89, Arklow S, Lt.-ship.

Spring-

$3 \cdot 650$, April (?) $/ 95$, Innishtrahull.

- 3.475, (?) April 5, /91, Tuskar.

- $2 \cdot 725$, Oct. $22, / 96, \quad$,

3.075, June 1, /89, Slyne Head.

2.925, Dec. 22, /95, Hook Tower. 
Species.

Passer domesticus-

House Sparrow (3), Ligurinus chlorisGrEENFINCH (12),

Coceothraustes vulgarisHAWFINOH (2), 。

Carduelis elegansGoLdFinch (5), .

Carductis spinus -

Siskin (14),

$\begin{array}{ll}, & \cdot \\ , & \cdot \\ , & \cdot \\ , & \cdot \\ , & \cdot \\ , & \cdot \\ , & \cdot \\ , & \cdot \\ , & \cdot \\ , & \cdot \\ , & \cdot\end{array}$

Linota rostrata-

MLALY Redpole (8), .
Length of
in inches.
Date.

Station.
2.900, Nov. 5, 193, Codling Bank Lt,-ship.

3.525, , 9, /87, Lucifer Shoals Lt.-ship. 35500 , ,20-30, /97, Tuskar.

" Dec. 21, /97, Codling Bank Lt.-ship.

3475 , Nov. 12, /87, Blackrock, MIayo.

Oct. $19, / 89$, Tearaght.

Dec. 17, $/ 90$, Hook Tower. ${ }^{1}$

", "23, /96, Tuskar.

3.375 , Oct. 2, /89, Tearaght.

$3 \cdot 350, \quad$,28, /86, Rockabill.

"Dec. 20, /95, Coningbeg Lt. -ship.

$3 \cdot 325$, Oct. $20, / 87$, Tearaght.

,Dec. 20, /97, Blackwater Bank Lt.-ship.

4.175, Nov, 1, $/ 97$, Tuskar.

$4.075, \quad, \quad 4, / 97$, Hook Tower.

$3 \cdot 175$, Oct. 16, /89, Old Head, Kinsale.

3.025, Nov. 9, /97, Hook Tower.

2.950, Feb. 2, /86, Mine Head. ${ }^{1}$

Oct. 21, /98, Lucifer Shoals Lt.-ship).

$2 \cdot 875$, " $30, / 97$, Fastnet.

$$
\begin{aligned}
& 3 \cdot 000, \quad, \quad 24, / 8 i \\
& 2.975 \text {, Dec. 3, } / 87 \text {, Tuskar. } \\
& \text { 2.950, Oct. 20,/87, Fastnet. } \\
& \text { Oct. } 9, / 97 \text {, Skelligs. } \\
& 2.925 \text {, Nov, 1, /97, Tuskar. } \\
& 2.850 \text {, Oct. 18, /87. Fastnet. } \\
& \text {, " 24, /87, Skelligs. } \\
& \text { 2.825, , 30, /97, Fastuet. }
\end{aligned}
$$

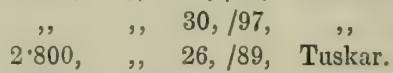

$$
\begin{aligned}
& 2 \cdot 750, \quad \text {,24, /97, Fastnet. } \\
& 2 \cdot 650 \text {, Nov. 18, /87, Skelligs. } \\
& \text { 2.575, Oct. 24, /87, Tearaght. }
\end{aligned}
$$$$
\text { , Nov. 12, 187, Coningbeg Lt.-ship. }
$$ 
Species.

\section{Linota rostrata-}

Mealy Redpole (8), .

Linote cannabina-

LINNET (9),

"

,

,

,

,

,

,

Linota flavirostrisTwite (7),

$$
\text { , }
$$

,$$
3
$$

,

,

, (young),

Loxic curvirostra-

Crossirill (1), (young), Sturnus vulgaris-

StamLing (71), .
Length of wing

in inches,

Date.

Station.
3·125, Sept. 14, /90, Tearaght. 3.050, Jan. 3, /95, Innishtrahull.

3॰200, Dec. 19, /97, Blackwater Bank Lt. ship.

$3 \cdot 175, \ldots 11, / 92$,

$3 \cdot 150, \quad, \quad 12, / 90$,

Mar. 27, /92,

Nov. 7, /93, Codling Bank Lt.-ship.

Dec. 18, 197 , Coningbeg Lt.-ship.

$3 \cdot 125$

Oct. 26, /97,

Blackwater Bank Lt.•ship.

$3 \cdot 075$, Jan. 12, /94,

$3 \cdot 050$,

? Mine Head."

2.975, Nov, 26, /96, Rathlin O'Birne.

2.950, Jan. 10, /92, Killybegs.

2.925, $\left\{\begin{array}{c}{[\text { Rec'd. April }} \\ 11,194],\end{array}\right\}$ Innishtrahull.

2.900 , Oct. $30, / 88$, Tearaght.

Nov. 26, /96, Rathlin O'Birne.

$2 \cdot 875, \quad, \quad 26, / 96$,

$2 \cdot 525$, Sept. 1,/89, Tearaght.

- 3575, „s 9, /98, Coningbeg Lt.-ship.

$5 \cdot 400$, June $2, / 86$,

5.325, Feb. 23, /89, Arklow S. Lt.-ship.

$5 \cdot 300$, April 7,/91,

, Dec. 24, /91,

5.275, Oct. 27, /91, Rockabill.

, , 27, /91, Barrels Rock Lt.-ship.

" $\quad$ "23, /97, Copeland (Mew) Island.

5.250, Mar. 20, /87, Coningbeg Lt.-ship.

, Oct. 26,189 , Tuskar.

, $\quad$, 27, /91, Arklow S. Lt.-ship.

"23, /97, Mine Head.

" " " 24, /97, Blackwater Bank Lt.-ship.

5.200, Nov, 13, /89, Maidens.

Feb. 20, /90,

Oct. 7, /98, Blackwater Bank Lt.-ship.

5.175, Nar. 2, /86, Coningbeg Lt.ship.

Oct. 16, /87, Tuskar.

"Sept. 28, /97, Blackwater Bank Lt.-ship.

5·150, Feb. 4, /91, Arklow S. Lt.-ship.

$5 \cdot 125$, Oct. 16, $/ 87$, Tuskar.

Feb. 23, /90, Barrels Rock Lt. -ship.

Dec. 24, /91, Blackwater Bank Lt.-ship.

"25, /91, Arklow S. Lt.-ship. 
Species.

Sturnus vulgaris-

STARLiNg (71),
Length of . Date. Station.
wing
in inches.

$5 \cdot 125$, Oct. 30,197 , Mine Head.

$5 \cdot 100$, , 26, /91, Hook Tower.

,, Nov. 17, /91, ,, ,

"Dec. 13, /92, Blackwater Bank Lt.-ship.

5.075, „, 10, /87, Arklow S. Lt.-ship.

$\begin{array}{ccl}" \quad \text { Oct. } 19, / 89, & \text { Tearaght. } \\ \text { " } \quad \text { 26, } / 92, & \text { Arklow S. Lt.-ship. }\end{array}$

" $\quad$ "29, /97, Mine Head.

Jan. 26, /98, Blackwater Bank Lt.-ship.

5.050, (?) Feb. 23, /90, Arklow S. Lt.-ship.

Dec. 19, /90, Maidens.

? 191 , Tearaght.

Mar. 5, /92, Hook Tower.

,24, $/ 92$, Blackwater Bank Lt. -ship.

, 25, /92, Hook Tower.

Dec. 27, /92, Innishtrahull.

.025 , Oct. 31, /86, Fastnet.

Mar. 19, /87, Coningbeg Lt.-ship.

$18, / 90$, Tuskar.

April 10, /91, Arklow S. Lt.-ship.

Jan. 20, /98, Blackwater Bank Lt.-ship.

Dec. 11, /85, Mine Head.

Nov. 13, /87, Fastnet.

April 11, /91, Arklow N. Lt.-ship.

Feb. 7,/95, Samphire Island.

Oct. 18, /98, Dungarvan.

"21, /98, Blackwater Bank Lt.-ship.

Mar. 12, /99,

,) $13, / 99$,

Nov. 3, /92,

Feb. 22, /97,

Dec. $18, / 97$,

Oct. 4, /86, Rockabill.

, (?), /86, Tuskar.

Mar. 29, /87,

[? May-Nov.]/89, Arklow S. Lt.-ship.

Dec. 18, /97, Arran Island, N.

,, 20,/97, Codling Bank Lt. -ship.

Feb. 18, /98, Blackwater Bank Lt.-ship.

Sept. 19, /89, Arran Island, S.

$4 \cdot 925$,

$4 \cdot 900$,

April 2, /91, Blackwater Bank Lt.-ship.

Oct. 16, /93,

Feb. 5, /97, Tuskar.

Nov. 21, /97, Blackwater Bank Lt.-ship.

, 20, /98, Bull Rock.

$4.850, \quad$ " 5, /90, Blackwater Bank Lt.-ship.

4.825, Dec. 31, /90, Tearaght. 
Species.

\section{Sturnus velgaris-}

Starling (7i) (young), Pyrrhocorax graculusChodgh (2),

Corveus frugilegusRook (3), .

,

Corvus monedula-

JACKDAW (2),

Himendo rustica-

Swallow (12), :

\section{Chelidon arbicc-}

House-Martin (2), .

\section{Cotile riparia-}

Sand-MIARTin (6),

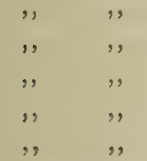

Cypsetus apus-

Swift (6), .

Caprimulgnes curopaess-

Nightjar (1),

Cuculus canorus-

Cucroo (11),

\section{Length of}

wing

Date.

Station.

$4 \cdot 750$, July $30, / 95$, Rockabill.

11.800, Mar. (?) $/ 90$, Tearaght.

10.125, Nov, 2, /88, Slyne Head.

12・175, July 29, /89, Innishtrahull.

- $12 \cdot 100$, Nov. $18, / 98$, Blackwater Bank Lt.-ship.

$11 \cdot 750$, (?), , 5, /90, Tearaght.

- 9·175, Dec. 28, /97, Aranmore.

- $9 \cdot 000, \quad 2, / 90$, Tearaght.

Spring-

5.150, May 13,/90, Innishtrahull.

5.125, , 25, /85, Tearaght.

," , 4, /87, Coningbeg Lt.-ship.

5.050, " 18, /90, Tearaght.

, " 8, $/ 92$, Codling Bank Lt.-ship.

5.025, April 17, /95, Coningbeg Lt.-ship.

$5 \cdot 000$, , 23, /92, Blackwater Bank Lt.-ship.

$4.950, \quad$,25, /91, Skelligs.

4.875, May 1,/95, Codling Bank Lt.-ship.

4.850, April 30, /90, Barrels Rock Lt.-ship.

4.825, June 2,/91, Tearaght.

Autumn-

4.925, Oct. 5, /87, Fastnet.

4:375, MIay 4, /89, Rockabill.

- 4.275, April 23, /91, Skelligs.

4.275, April 4, /99, Blackwater Bank Lt.-ship.

4.200 , , 3, $/ 99$, , , ",

, " $19, / 89, \quad$, , ,

$4 \cdot 175$, May $6, / 91, \quad,, \quad$,

$4 \cdot 150, \quad$, 9, /88, Tearaght.

4.050, April 26, /91, Arklow S. Lt.-ship.

7.000, May 24, /87, Tuskar.

$6.900, \quad, 16, / 86$, ,

6.850, July 2,/98, Blackwater Bank Lt.-ship.

6.650 , " 31, /89, Fastnet.

$6.525, \quad, \quad 30, / 95$, Rockabill.

6.125, Aug. 8, /89, Wicklow Head.

- 7·425, May 23, /97, Tuskar.

Spring-

9·300, April 29, /99, Blackwater Bank Lt.-ship.

$9 \cdot 200, \quad, \quad 18, / 93$, Hook Tower. 
Species.

\section{Cuculus canorns-}

Cuckoo (11),

$\begin{array}{ll}\text { " } & \text {. } \\ " & \text {. } \\ " & \text {. }\end{array}$

\section{, (young),}

", (young),

Upupa epops-

HоOРоE (1),

Iynx torquilla-

WRYNECK (1), Alcedo ispida-

KINGFISHER (1),

Columba cencus-

STOCK-Dove (1),

Calumba livia-

Rock-Dove (2),

\section{Turtur communis -}

TURTLE Dove (11),

Perdix cinerea-

Partridge (1), .

Coturnix communis-

QuaIL (3), .

Crex pratensis-

CORN-CR̀AKE (8),

\section{Length of}

wing

in inches.

Date.

Station.

Spring-

8.850, April 29, 199, Blackwater Bank Lt.-ship.

8.825, May $7, / 89$, Copeland (Mew) Island.

- 8.800, , 20,/90, Oyster Island.

. 8.500, ,, 10,/90, Blackwater Bank Lt.-ship.

- 8.300 , April 29, /99, ", ,

- $8 \cdot 175$, , $30, / 88$, Coningbeg Lt.-ship.

- 7.900, May 8,/89, Rockabill.

Autumn-

8.075, Aug. 8, /95, Aranmore.

. $6 \cdot 100, \quad, \quad 8, / 98$, ,

. 5'675, April 12, /87, Eagle Island.

3.600, Sept. 17, /98, Fastnet.

3•050, July 20, /98, Blackwater Bank Lt.-ship.

$8 \cdot 500$, Oct. 19, /87, Tuskar.

9.550, Aug. 27, /89, Copeland (Merv) Island.

8.700, Dee. 14, /89, Hook Tower. ${ }^{1}$

7.375, June 27, /87, Blackrock, Mayo.

$7 \cdot 250$, May 10, /96, Old Head, Kinsale. ${ }^{1}$

- 7·075, April 20, /93, Bull Rock.

$$
\begin{aligned}
& 7 \cdot 025, \quad \text { June } 12, / 93, \quad \text { Killybegs. }{ }^{1} \\
& \text { 7.000, May 19,/88, Tuskar. } \\
& 6 \cdot 950 \text {, April 3,/91, Tearaght. } \\
& 6.850 \text {, Aug. 19, /89, Old Head, Kinsale. }{ }^{1} \\
& \text { 6.825, Sept. 19, /93, Slyne Head. } \\
& 6 \cdot 750,\left\{\begin{array}{c}
{[\text { Rec.'d Sept. }} \\
5, / 89],
\end{array}\right\} \text { Fastnet. }
\end{aligned}
$$$$
\text { 6.725, May } 8, / 90 \text {, Tuskar. }
$$

6'100, Jan. 28, /87, Mine Head. ${ }^{1}$

4.450, May 14, /93, Coningbeg Lt.-ship.

4.425, April 1, /92, Lucifer Shoals Lt.-ship.

4*200, May 14, /93, Blackwater Bank Lt.-ship.

Spring-

$\begin{array}{crrl}5 \cdot 950, & , & 6, / 89, & \text { Maidens. } \\ 5 \cdot 675, & , & 1, / 87, & \text { Mine Head. } \\ 5 \cdot 625, & \text { " } & 15, / 84, & \text { Rockabill. } \\ ,, & \text { " } & \text { (?) } / 85, & \text { Tuskar. }\end{array}$

1 Shot on mainland, 
Species.

Crex pratensis-

Corn-Crake (8),

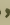

s)

Porzana maruetta-

Spotted Crake (2),

11 19

Rallus aquaticus-

WATER-RAIL (29),

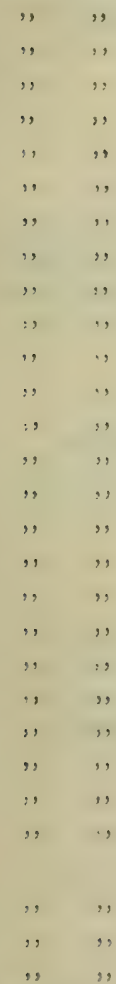

Gallinula chloropusWATER-HEN (6),

\section{Length of wing} in inches.

Date.

Station.

\section{Spring-}

5 500, April 19, /91, Tearaght.

5.375 , June $16, / 87$, Skelligs.

$5 \cdot 325$, May $19, / 88$, Tearaght.

Autumn-

5.850, Sept. 23, 186, Tuskar.

4.750, Oct. 25, 187, Tearaght. 4.350, Aug. 20, /90, Fastnet.

\section{Autumn-}

4.900, Nov, 19, /87, Tearaght.

4.875 , Oct. 4, /98, Barrels Rock Lt.-ship.

4.850, Nov. 2, /96, Coningbeg Lt. -ship.

$4.800, \quad$ 5, /91, Hook Tower.

, Dec. 18, /97, Rathlin Island.

$4 \cdot 775$, Oct. 29, /92, Tuskar.

$4.750, \quad$,27, /91, Galley Head.

, " 21, 193, Barrels Rock Lt.-ship.

4.675, Nov. 12, /87, Innishtrahull.

. $\quad 18, / 87$, Tory Island.

"Dec. 21, /91, Killybegs. ${ }^{1}$

4.550, Nov. 5, /88, Copeland (Mew) Island.

, Jan. 9, /95, Blacksod Point.

4.525, Dec. 23, /91, Rathlin O'Birne.

$4 \cdot 500$, Nov. 14, /87, Tuskar.

, $\quad$, 1, /97, Arran Island, $\mathbf{N}$.

4.475, , 11, /97, Rockabill.

$4 \cdot 450$, , 26, /94, Tory Island.

"Sept, 24, /95, Arklow S. Lt. -ship.

$4 \cdot 400$, Oct. 27, /86, Fastnet.

, Nov, 8, /87, Hook Tower.

4:375, Sept. 5, /98, Blackrock, Mayo.

$4: 350$, Oct. 6, /87, Coningbeg Lt.-ship.

$4 \cdot 300$, Nov. 8, /98, South Rock Lt. ship.

" $\quad 10, / 98$, Copeland (Mew) Island.

$4 \cdot 225$, Sept. 5, /89, Rathlin O'Birne.

Spring-

4.750, Mar, 29, /97, Rockabill.

4.450, April 6, /91, Blackwater Bank Lt.-ship.

$4 \cdot 100$, "29, /96, Rathlin Island.

Spring-

7·075, April 10, /89, South Rock Lt.-ship.

6.725, " 2, /94, Drogheda, N.

Autumn-

6.825, Dec, 2, 196, Mine Head.

I Shot on mainland. 
Species.

Gallinula chloropusWATER-HEN (6),

Fulica atra-

BALd Соот (4), .

AEgialitis hiaticolaRinged Plover (7),

Charadrius pluvialis Golden Plover (9),

Squatarola helveticaGrey Plover (2),

,,

Vanellus vulgaris-

LAPWING (5),

Strepsilas interpresTurnstone (13),

\section{Length of} wing in inches.

Date.

Station.

\section{Autumn-}

6.525, Aug. 23, 192, Blackwater Bank Lt.-ship. 6.475 , Nov. 7, /98, Rockabill.

6.325, Sept. 16, /88, Tuskar.

\subsection{5, Nov. 9, /98, Copeland (Mew) Island.}

$7 \cdot 950$, Oct. $26, / 89$, Dungarvan.

7.875, Sept. 22, /87, Arklow S. Lt.-ship.

7.650, Nov. 24, 192, Blackwater Bank Lt.-ship.

$5 \cdot 425,\left\{\begin{array}{c}{[\text { Rec.'d April }} \\ 25, / 92],\end{array}\right\}$ Rathlin O'Birne.

5.300, July 28, /96, Blackrock, Mayo.

$5 \cdot 275$, Dec. 20, /98, Aranmore. ${ }^{1}$

5.225, Jan. 2, /93, Drogheda, N. ${ }^{1}$

,, May $17, / 93$, Maidens.

$5 \cdot 175$, Nov. 27, /94, Samphire Island.

5'100, April 1-7;/99, Rathlin 0'Birne. ${ }^{1}$

\begin{tabular}{|c|c|c|}
\hline$\cdot 775$ & Feb. $7, / 95$, &.$^{1}$ \\
\hline 600 , & ? Nov. $30, / 88$ & Aranmore. ${ }^{1}$ \\
\hline $7 \cdot 475$ & Oct. $12, / 96$, & Rathlin'O'Birne. ${ }^{1}$ \\
\hline $7 \cdot 450$ & Dec, 21, /86, & Mine Head. ${ }^{1}$ \\
\hline $7 \cdot 375$ & $11, / 90$ & Maidens. \\
\hline $7 \cdot 300$ & $9, / 91$ & South Rock Lt.-ship. \\
\hline $\begin{array}{l}7 \cdot 275 \\
6 \cdot 600\end{array}$ & $\begin{array}{c}\text { April } 15, / 92, \\
\quad 25, / 95, \\
\text { Dec. } 31, / 97,\end{array}$ & $\begin{array}{l}\text { Rathlin O'Birno. } \\
\text { Blackwater Bank Lt.-ship. } \\
\text { Slyne Head. }\end{array}$ \\
\hline
\end{tabular}

- 7·850, Jan. $14, / 93$, Drogheda, N. ${ }^{1}$

- $7 \cdot 625$, Oct. $9, / 93$, " " 1

- 8.875, Oct. 17, /98, Copeland (Mew) Island.

$8 \cdot 850$, Feb. 16, /87, Rockabill.

$8 \cdot 750$, Nov, 22, /92, Maidens.

$8 \cdot 350$, Feb. 4, /95, Samphire Island. ${ }^{1}$

$8 \cdot 300,\left\{\begin{array}{c}{[\text { Rec.'d Nov, }} \\ 29, / 92],\end{array}\right\}$ Drogheda, N.

\section{Autumn-}

$6 \cdot 250$, Oct. 9, /93, Drogheda, N. ${ }^{1}$

$6 \cdot 150$, Aug. 18, /95, Slyne Head.

$6 \cdot 125$, Sept. 24, /92, Hook Tower.

6.025, Oct. 25, /92, Drogheda, N. ${ }^{1}$

$6 \cdot 000$, Dec. 11, /91, Hook Tower. ${ }^{1}$

$5 \cdot 900, \quad$, 31, /91, " "

,, Nov: 17, 186, Blackrock, Mayo. 
Species.

Strepsilas interpres-

TuRnstone (13),

Phataropus fulicariusGrex Phalarope (7),

19 19

Scolopax rusticulaWoodcock (10),

Gallinago colestisCommon Snipe (14),

,
Length of

wing

in inches.

Date.

Station.

Spring-

$6 \cdot 225$, April 7, 186, Eagle Island. ${ }^{1}$

6.125, Fob, 1, /97, St John's Point, Down.

$6 \cdot 100,\left\{\begin{array}{c}{[\text { Rec'd. May }} \\ 24, / 93],\end{array}\right\}$ Innishtrahull. ${ }^{2}$

5.925, Mar. 10, /89,

$5 \cdot 900$, May 3, 198 , Samphire Island. ${ }^{1}$

5.625, June 6, /98, Tuskar. ${ }^{1}$

$5 \cdot 250$, Nov. 5, /92, Rockabill.

5.125, Aug. 22, /92, Arklow S. Lt.-ship.

4.975, $\left\{\begin{array}{c}\text { Oct. } 12 \\ 22, / 91,\end{array}\right.$ or ? Rathlin O'Birne or Killy-

$4 \cdot 925,\left\{\begin{array}{c}\text { Oct. } 12 \\ 22, / 91,\end{array}\right.$ or ? Rathlin O'Birne or Killy-

Oct. 17, /93, Slyne Head.

4.850, Nov. 1, /89, Slyne Head.

$7 \cdot 850$, Nov. 18, 185, Killybegs.

7·775, Jan. 1, /91, Blackwater Bank Lt.-ship.

$7 \cdot 750$, Nov, 9, /90, Maidens.

7.725; Dec. 24, /91, Hook Tower.

, Nov. 22, 192, Maidens.

$7 \cdot 550$, Oct. 26, /89, Innishtrahull.

$7 \cdot 475$, Nov. 11, $/ 87$, Tuskar.

$7 \cdot 450, \quad$, 28, /94, Samphire Island.

$7 \cdot 375, \quad, \quad 9, / 98$, Tuskar.

$7 \cdot 225, \quad, 29, / 88$, Aranmore.

Autumn-

5.475, Nov. 9, /88, Arklow S. Lt.-ship.

5.400, Jan. 18, /86, Mine Head.1

5.300, Sept. 9, /88, Arklow S. Lt.-ship.

$5 \cdot 250, \quad$ Dec. $9, / 90, \quad$ Maidens.

$5 \cdot 225$, Nov. 30, /88, Aranmore.

"Dec. 24, /91, Hook Tower.

$5 \cdot 200$

24, /91,

$5 \cdot 175,\left\{\begin{array}{c}{[\text { Rec'd. Oct. }} \\ 12, / 96],\end{array}\right\}$ Rathlin O'Birne.

$5 \cdot 150$, Dec. 18, /86,

$5 \cdot 125$, , 16, /98, Tuskar.

5•050, Nov. 13-14,/93, Blackwater Bank Lt.-ship.

Spring-

$5 \cdot 175$, May 2, 189 , Arran Island, S.

- 5॰050, April 6, /89, Innishtrahull. 
Species.

Gallinago gallinulaJACK SNIPE (11),

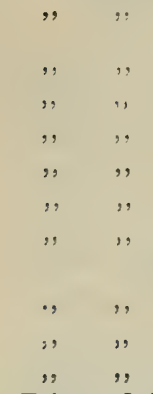

Tringa alpina-

DunLin (24),

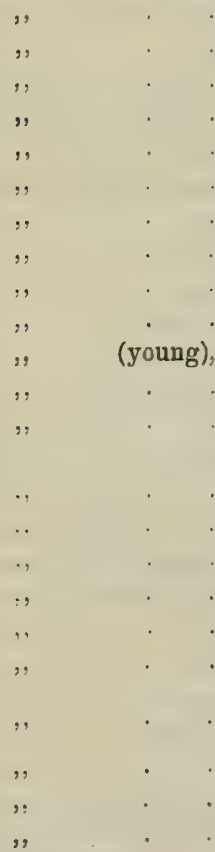

Tringa striata-

Purple Sandpiper (14),

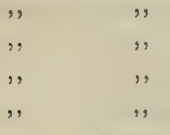

2 Shot.
Length of

in jing

Date.

Station.
4.675, Sept. 28, 186, Rockabill.

$4.575,\left\{\begin{array}{c}\text { ? found Dec. } \\ 10, / 92],\end{array}\right\}$ Howth Baily.

4.550 , Oct. 2, /89, Slyne Head.

4.475 , Nov. 12, /88, Aranmore. ${ }^{1}$

$4 * 450$, , 11, $/ 87$, Tuskar.

$4 \cdot 400$, Oct. $7, / 87$, ,

$4 \cdot 375$, Nov, $10, / 98$, ,

4'225, Dec. 9,/99, ,,

Spring-

4.625, Mar. 28, 197, Arklow N, Lt. -ship.

4.425, April 12, /91, South Rock Lt.-ship.

$4 \cdot 150, \quad, 21, / 90$, Hook Tower.

Autumn-

4.875, Dec. 26, /92, ,, ,

$4 \cdot 750$, Jan. 31, /97, Tuskar.

$4 \cdot 725$, Oct. 28, /86, Rockabill.

, Sept. 20, 192, Hook Tower.

, Nov. 24, /93, Arran Island, $\mathbb{N}$.

$4 \cdot 650, \quad, 25, / 94$, Rockabill.

$4.625, \quad$, 5, /96, Fastnet.

$4 \cdot 550$, Sept. $9, / 96$, Rathlin O'Birne. ${ }^{2}$

4.500, Nov: 12, 189, Kish Bank Lt.-ship.

$4 \cdot 475$, " 15, /90, Hook Tower.

" " $15, / 90, \quad, \quad$,

4.450, Aug. 23, 194, Arklow S. Lt.-ship.

4.400, " 12, /86, Coningbeg Lt.-ship.

3.950, Jan, 5, /94, Arklow S. Lt.-ship.

Spring-

4.700, Mar. 11, /95, Samphire Island. ${ }^{1}$

4.575, April 8, /94, St John's Point, Down.

4.525, May 25, /90, Arklow S. Lt.-ship.

4.500, April 18, /90, Rockabill.

May 11, /93, Howth Baily.

4.475, April 19, /91, Arklow N. Lt.-ship.

,$\quad\left\{\begin{array}{c}{[\text { Rec'd. Feb. }} \\ 26, / 93],\end{array}\right\}$ Hook Tower.

4.450, May 31, /86, Coningbeg Lt.-ship.

$4 \cdot 425, \quad, \quad 2,199$, Blackwater Bank Lt. -ship.

$4 \cdot 375, \quad ; \quad 16, / 93$, Eagle Island.

Autumn-

5·375, Nov. 7, 199, Rathlin O'Birne.

$5 \cdot 250, \quad, \quad 1, / 92$, Tearaght. ${ }^{1}$

" , 13-14, /93, Blackwater Bank Lt.-ship.

$5 \cdot 125$, Dec. 28, /90, Tearaght. ${ }^{3}$

$5 \cdot 100$, Nov. 14, /90, Hook Tower. ${ }^{1}$ 
Species.

Tringa striata-

Pdrple Sandpiper (14),

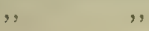

, , ,

, ,

, , ,

,.

Tringa conutus-

КNoт (4),

Calidris arenaria-

SANDERLING (1),

Totanus hypoleucus-

COMMON SANDPIPER (9),

Totanus calidris-

Redshank (2), 。

Limosa lapponica-

BAR-TAILED Godwit (1),

Numenius arquata-

CuRlew (1),

Numenirus phoeopus-

WHIMBREL (5), .

Sterna fluviatilis-

Common TerN (1),

\section{Length of in inches.}

Date.

Station.

\section{Autumn-}

$5 \cdot 100$, Dec. 8, 197, Aranmore.

5•050, Nov. 20-30, /97, Tuskar.

," Dec. 12, $/ 98$, Aranmore. ${ }^{1}$

$5 \cdot 000$, Nov. 3, /86, Rathlin O'Birne.

4.975, Oct. 29, /92, Tuskar.

Spring-

5.050, May 18, /88, Fastnet.

5.025, " 16, /93, Blackwater Bank Lt.-ship.

4.975 , Mar. 29, /87, Tuskar.

$4 \cdot 400$, April 7, /86, Eagle Island. ${ }^{1}$

Spring-

6.975 , Mar. 13, /96, Tuskar.

Autumn-

- 6750, Jan. 12, /93, Drogheda, N.1

6.425 , Oct. 2, /89, Slyne Head.

$6.000, \quad, \quad 2, / 89, \quad, \quad$,

5 100 , Aug. 30, /94, Blackwater Bank Lt.-ship.

Autumn-

$4 \cdot 475$, July (?) 26, /88, Mine Head.

4 4*200, „, 16, /93, Coningbeg Tt,-ship.

Spring-

4*425, May 5, 188 , Mine Head. ${ }^{1}$

$4 \cdot 400$, , 6, /88, Tuskar.

$4 \cdot 325, \quad, \quad 5, / 92, \quad$ Howth Baily.

$4 \cdot 300, \quad, \quad 16, / 93$, Blackwater Bank Lt.-ship.

4.275, April 23, /92, ", " ,

4.175, May 17, /86, Coningbeg Lt.-ship.

- 4'125, „ 8, /88, Arklow N. Lt.-ship.

6.375, Mar. 1, /98, Berehaven. ${ }^{2}$

- 6.225, Aug. 20, /89, Slyne Head. ${ }^{1}$

. $8 \cdot 000$, Feb. 1, /97, St John's Point, Down.

11·750, Mar. 24, 192, Blackwater Bank Lt.-ship. Spring-

- $10 \cdot 250$, July $26, / 89$, Innishtrahull. ${ }^{1}$

$10 \cdot 000$, May 23, /90, ,

$9 \cdot 550$, June 5, /89, Slyne Head. ${ }^{3}$

Autumn-

9700, Sept. 2, /89, Coningbeg Lt.-ship.

$9 \cdot 500$, ", 2, /90, Tearaght. ${ }^{3}$

. 10.000, Oct. 6, /87, Coningbeg Lt.-ship.

1 Shot.

2 Killed by cat.

3 Killed by Perogrine. 


\section{Species.}

Sterna macrura-

Arctic Tlina (2),

\section{Sterna minuta-}

Lesser Terin (1),

Larus glaucus-

Gladcous Gulu (4),

$\begin{array}{ll}, & , \\ ,, & ,\end{array}$

Larnes leucopterusICELAND GULL (3),

$$
\text { , , , }
$$

Rissa tridactyla-

Kittiwake (1), .

\section{Puffinus anglorum-}

Manx Shearwater (4),

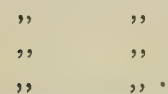

Oceanodroma leucorrhoaFonk-tailed Petrel (6),
Length of wing in inches.

Date.

Station.

\section{$9 \cdot 900$ \\ - 9·750, Oct. $9, / 90$, Tearaght.}

. 6.750, May 14, /93, Hook Tower.

- 18.750, Oct. 12, /96, Rathlin O'Birne. ${ }^{1}$

$\begin{array}{cccc}\text { - } 17 \cdot 500, & \text { Fov. 3, } / 96, & \text { ". } 23, / 95, & \text { Blacksod Point. }{ }^{1} \\ \text {. } & \text { Oct. 27, /96, Rathlin O'Birne. }{ }^{1}\end{array}$

- 16.250, Oct. 3, /96, Rathlin O'Birne. ${ }^{1}$

. 16.000, April 29, /99, Spit Bank. ${ }^{1}$

. $15 \cdot 500, \quad, 16, / 99$, , 1

. 11·750, Dec. 16, /90, Tearaght.

- 9.375, May 23, /89, Slyne Head. $9 \cdot 125$, , 15, /87, Coningbeg Lt.-ship. ", " 22, /89, Old Head, Kinsale. - $9 \cdot 000$, ? April 25, /93,

Spring-

- 6*475, May 5, /96, Fastnet.

\section{Autumn-}

- 6•400, Nov. 20, /95, Old Head, Kinsale. 6.375, Sept. 9, /92, Blackrock, Mayo. 6.225, Oct. 28, /97, Berehaven, 6.000, Nov. 15, /87, Blackrock, Mayo. $6 \cdot 250$, July $6, / 88$, Tearaght.

Procellaria pelagicaStorm Petrel (19),

\section{Autumn-}

$5 \cdot 000$, Jan. 195 , Innishtrahull.

4.975 , Sept. 19, /89, Tearaght. ${ }^{2}$

4.950, Aug. 30, /90, Rathlin O'Birne.

, ", 11, /91, Skelligs.

$4 \cdot 875$, " 15, /90, St John's Point, Down.

$4 \cdot 800$, Nov. 17,190 , Blackwater Bank Lt.-ship.

4.775, Aug. 15, /90, St John's Point, Down.

4.750, Sept. 15, 187, Tory Island.

"Nov. 5, /91, Blackwater Bank Lt,-ship.

" , 6, $/ 91$, Tuskar.

"July $26, / 98$, Arran Island, N.

$4^{\circ} 650$, Aug. 20, 190, Rathlin Island.

$4 \cdot 625$, $, 5, / 85$, Tearaght.

"Nov. 17, /91, Hook Tower.

"July $26, / 98$, Arran Island, N. 
Species.

Procellaria pelagica-

Storm Petrel (19), .

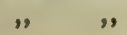

"

Uria troile-

Common Guillemot (1), . Mergulus alle-

LITTLE AUK (2),

Fratercula arctica-

PUfFin (2),

(young),

Podicipes fuviatilis-

LitTle Grebe (2),

\section{Botaumes stellaris-}

Bittern (1), 。

Anser albifrons-

WHITE-FRONTED GOOSE (1), Nettion creccc-

TeAL (1), .

Mareca penelope-

WIGEON (1),

Fuligula marila-

SCAUP (2),

,

Clangula glaucion-

GoLDEN-Ere (1),

Harelda glacialis-

Long-TaIled Duck (1),

Edemia nigra-

Common Scoter (3),
Length of wing in inches.

Date.

Station.

\section{Autumn-}

- 4.600, Nov. 17, /97, Blacksod Point.

- 4.575, „, 14, /91, Hook Tower.

- 4550, Sept, $21, / 87$, Coningbeg Lt.-ship.

Spring-

4.825, May 24, 186, Eagle Island.

- 7·700, Dec. 27, /97, Blackwater Bank Lt.-ship.

4.725, „15, /96, Blackrock, Mayo.

4.375, May (?) $/ 95$, Tory Island.

$5 \cdot 750$, Oct. $30, / 88$, Fastnet.

- 5•400, Dec. $8, / 90$, Tearaght.

- 3.975, Nov. 16, /89, Slyne Head.

- 3.875, Dec. 25-26, /98, Berehaven. ${ }^{1}$

. 12.250, Aug. 27, /93, Slyne Head. ${ }^{2}$

. 15•450, May 3,/87, Rathlin O'Birne. ${ }^{1}$

- 6.900, Oct, 22, /90, Oyster Island.

.10.200, ", 19, /89, Maidens.

- $8 \cdot 675$, Feb. 28, /94, Drogheda, N. ${ }^{1}$

- $8 \cdot 275$, Oct. $15, / 88$, Innishtrahull. ${ }^{1}$

- 7·825, Mar. 18, /99, Aranmore. ${ }^{1}$

- $7 \cdot 625$, Jan, $18, / 96$, Inishgort. ${ }^{1}$

8.950, April 15, /91, Blackwater Bank Lt.ship.

- 8850, Nov. (?), /89, Maidens.

8.475, April 15, /91, Blackwater Bank Lt.-ship.

1 Shot. 2 Caught in pool. 
TABLE Showing the Average Length of Wing, and the relative Amount of Variation, in Thirty-five Species of Birds obtained at Irish Light Stations.

\begin{tabular}{|c|c|c|c|c|c|c|c|c|}
\hline & & & $\begin{array}{c}\text { Number } \\
\text { of wings } \\
\text { measured. }\end{array}$ & $\begin{array}{c}\text { Average } \\
\text { length } \\
\text { in inches. }\end{array}$ & Longest. & Shortest. & $\begin{array}{c}\text { Difference } \\
\text { between } \\
\text { extremes. }\end{array}$ & $\begin{array}{c}\text { Percentage } \\
\text { of } \\
\text { variation. }\end{array}$ \\
\hline Muscicapa grisola, . & & . & 14 & $3 \cdot 33$ & $3 \cdot 425$ & $3 \cdot 200$ & 0.225 & 7 \\
\hline Turdus viscivorus, . & & - & 12 & $6 \cdot 03$ & $6 \cdot 200$ & $5 \cdot 850$ & 0.350 & 6 \\
\hline ", musicus, . & & . & 94 & $4 \cdot 60$ & $4 \cdot 775$ & $4 \cdot 300$ & 0.475 & 10 \\
\hline , iliacus, & & . & 53 & $4 \cdot 60$ & $4 \cdot 825$ & $4 \cdot 350$ & $0 \cdot 475$ & 10 \\
\hline "pilaris, & & . & 38 & $5 \cdot 75$ & $6 \cdot 125$ & $5 \cdot 425$ & 0.700 & 12 \\
\hline "merula, . & & . & 120 & $4 \cdot 97$ & $5 \cdot 550$ & $4 \cdot 725$ & 0.825 & $16 \cdot 5$ \\
\hline torquatus, . & . & . & 15 & $5 \cdot 46$ & $5 \cdot 725$ & $5 \cdot 125$ & 0.600 & 11 \\
\hline Ruticilla titys, . & . & . & 22 & $3 \cdot 32$ & 3.550 & $3 \cdot 175$ & 0.375 & $11 \cdot 5$ \\
\hline Pratincola rubicola, & & . & 17 & $2 \cdot 64$ & $2 \cdot 725$ & $2 \cdot 575$ & $0 \cdot 150$ & $5 \cdot 5$ \\
\hline , rubetra, & & . & 15 & $2 \cdot 98$ & $3 \cdot 100$ & $2 \cdot 850$ & 0.250 & 8.5 \\
\hline Saxicola onanthe, . & & . & 81 & $3 \cdot 78$ & $4 \cdot 150$ & $3 \cdot 525$ & 0.625 & 16.5 \\
\hline Acrocephalus phrag & mitis & & 102 & $2 \cdot 51$ & $2 \cdot 700$ & $2 \cdot 375$ & 0.325 & 13 \\
\hline Sylvia cinerea, & - & - & 66 & $2 \cdot 75$ & 2.925 & $2 \cdot 625$ & 0.300 & 11 \\
\hline Phylloscopus trochitu & $u s$ & . & 73 & $2 \cdot 57$ & $2 \cdot 850$ & $2 \cdot 200$ & 0.650 & 25 \\
\hline , rufus, & & . & 20 & $2 \cdot 35$ & $2 \cdot 575$ & $2 \cdot 150$ & 0.425 & 18 \\
\hline Regulus cristatus, . & . & . & 46 & $2 \cdot 10$ & $2 \cdot 225$ & $2 \cdot 000$ & 0.225 & 9.5 \\
\hline Troglodytes parvulu & & . & 12 & 1.87 & $1: 975$ & $1 \cdot 775$ & 0.200 & 11 \\
\hline Anthus pratensis, . & - & . & 34 & $3 \cdot 17$ & 3.375 & 3.000 & 0.375 & 12 \\
\hline Alauda arvensis, . & - & . & 113 & $4 \cdot 20$ & $4 \cdot 800$ & $3 \cdot 750$ & 1.050 & 25 \\
\hline Plectrophenax nival & lis, & - & 24 & $4 \cdot 24$ & $4 \cdot 800$ & 3.925 & 0.875 & 20.5 \\
\hline Fringilla colebs, . & . & . & 43 & $3 \cdot 35$ & $3 \cdot 725$ & $3 \cdot 175$ & 0.550 & 16 \\
\hline Ligurinus chloris, . & . & . & 12 & $3 \cdot 43$ & $3 \cdot 525$ & $3 \cdot 325$ & 0.200 & 6 \\
\hline Carduelis spinus, & . & . & 14 & $2 \cdot 85$ & $3 \cdot 000$ & 2.575 & 0.425 & 15 \\
\hline Sturnus vulgaris, & . & . & 70 & $5 \cdot 08$ & $5 \cdot 400$ & $4 \cdot 825$ & 0.575 & $11 \cdot 5$ \\
\hline Hirundo rustica, & . & . & 12 & $5 \cdot 00$ & $5 \cdot 150$ & $4 \cdot 825$ & 0.325 & 6.5 \\
\hline Cucutus canorus, & . & . & 10 & $8 \cdot 60$ & $9 \cdot 300$ & $7 \cdot 900$ & $1 \cdot 400$ & 16 \\
\hline Turtur communis, & . & . & 11 & 6.99 & $7 \cdot 375$ & 6.725 & 0.650 & 9 \\
\hline Rallus aquaticus, & & . & 29 & $4 \cdot 56$ & $4 \cdot 900$ & $4 \cdot 100$ & 0.800 & $17 \cdot 5$ \\
\hline Strepsilas interpres, & & - & 13 & 6.02 & $6 \cdot 250$ & $5 \cdot 625$ & 0.625 & 10 \\
\hline Scolopax rusticula, & & . & 10 & $7 \cdot 59$ & $7 \cdot 850$ & $7 \cdot 225$ & 0.625 & 8 \\
\hline Gallinago colestis, & & . & 14 & $5 \cdot 22$ & $5 \cdot 475$ & $5 \cdot 050$ & 0.425 & $S$ \\
\hline ,, gallinula & & . & 11 & $4 \cdot 45$ & $4 \cdot 675$ & $1 \cdot 150$ & 0.525 & $11 \cdot 5$ \\
\hline Tringa alpina, & . & ${ }^{\circ}$ & 24 & $4 \cdot 54$ & 4.875 & 3.950 & 0.925 & $20 \cdot 5$ \\
\hline "striata, & . & . & 14 & $5 \cdot 05$ & $5 \cdot 375$ & $4 \cdot 400$ & 0.975 & 19 \\
\hline Procellaria pelagica & & . & 19 & 4.75 & $5 \cdot 000$ & 4.550 & 0.450 & $9 \cdot 5$ \\
\hline
\end{tabular}

Evory species of which ten or more wings were available for measurement is included in above Table. 


\section{N D E X.}

Roman Numerals refer to Preliminary Matter,

Arabic ", italicised to "Analysis," Parts I. and II.

, , unitalicised to the "Reports."

Accentor modularis, 38, 18, 76, 146, $274,345,398,462,507,561,630$.

Accipiter nisus, 4, 274, 339, 390, 456, 503, 549.

Acredula caudata, 94, 466, 641 .

Acrocephalus navius, $6 \%, 21,80,149$, $287,464,635$.

phragmitis, $60,20,79$ $148,219,286,347,402,463,509$, $564,633,660$.

schonobcenus, $60,20,79$ $148,219,286,347,402,463,509$, $564,633,660$.

Arialitis hiaticola, 195, 42, 104, 176, $242,310,367,429,481,526,600$, 654 .

Alauda arborea, 110, 615 .

arvensis, 102, 214, 24, 85, 155 , '224, 292, 352, 408, 467, 512, 570', 643,660 . 645.

brachydactyla, $\% 2, \quad 110, \quad 159$

Alca torda, 243, 51, 116, 188, 256, 324, $376,441,490,533,611$.

Alcedo ispida, 180, 240, 308, 652.

Ampelis garrulus, 94, 330 .

Aualysis, Part I1., 263.

Anas boscas, 259, 27\%.

, strepera, 259.

Anser albifrons, 253, 659.

, brachyrhynchus, 255.

". cinereus, 255.

", segetum, 255.

Anthus obscurus, 102, 85, 155, 224, 291, $352,408,467,642$.

"pratensis, 99, 24, 84, 154, 223, $291,351,407,467,512,569,642$, 660

Aquila chrysaëtus, 1 .

Ardea cinerea, 252, 54, 121, 192, 260 , $327,379,445,493,536,615$.

Asio accipitrinus, 5 .

, otus, 5, 621 .

A'uk, Little, 245, 189, 491, 534, 659.

Bald Coot, 195, 41, 104, 310, 654 .

Barn Owl, 7, 276, 456.

Barnacle Goose, 255, 274.

Barred Warbler, 73, 278, 510.

Bats, 284, 1 3, 265, 331, 449, 538.

Bean Goose, 255 .

Bernicla brenta, 255, 327, 494

, leucopsis, 255 .
Bewick's Swan, 25\%.

Birds not iclentitied, 57, 123, 195, 253, $330,381,448,496,538,617$.

Bittern, 253, 379, 659 .

Blackbird, xxv, 29, 102, 271, 27y, 278, $280,281,15,73,142,213,281,343$, $396,460,506,557,626,660$.

Blackcap, 74, 282, 80, 220, 288, 464, 510, 565,630 .

Black Guillemot, 245, 50, 257, 324, 376, 612.

Black-headed Gull, 228, 252

Black Redstart, xxv, 45, 184, 273, 19, 76, $217,346,462,508,562,630,660$.

Blue Titmouse, 93,276 .

Botaurus stellaris, 253, 379, 659

Brambling, xxv, 124, 131, 132, 273, 280, $29,90,161,229,415,472,517,580$, 647.

Brent Goose, 255, 327, 494.

Buffon's Skua, 23\%.

Bullfinch, 139, 276, 278, 31, 93, 164, $300,359,474,519$.

Bunting, Corn, 117, 276, 88, 159, 228, $296,471,646$.

, Lapland, 116, 278, 279.

,. $\quad$ Reed, 116, 276, 515, 576, 646.

,. Snow, xxv, 111, 192, 273, 280, $27,87,159,227,295,354,412,471$, $514,575,645,660$.

Yellow, 117, 28, 89, 159, 228,

Yellow, 117, 28, 89, 159,
$296,355,413,471,515,576,646$.

Calcarius lapponicus, 116.

Cabidris arenaria, 216, 435, 657.

Caprimulgus europaeus, $175,39,240,365$, $427,525,596,651$.

Carduelis elegans, 129, 91, 162, 230, 298, $357,416,473,518,582,648$. spinus, 131, 91, 230, 298, 582 . 648,660 .

Certhia familiaris, 92.

Chaffinch, xxv, 119, 135, 139, 272, 27\%, $278,281,28,89,160,228,296,357$, $413,471,515,576,646,660$.

Charadrius pluvialis, 196, 42, 105, 176 , $243,310,367,429,482,526,600$, 654.

Chelidon urbica, 169, 38, 101, 173, 239, $364,480,524,596,651$

Chiffchaff, $\mathrm{xxv}, 61,80,279,22,81,152$, $221,289,404,465,511,566,639,660$.

Chionis alba, 203, 314. 
Chough, 148, 276, 35, 96, 169, 235, 304, $361,421,477,522,651$.

Cinclus aquaticus, $12,68$.

Clangula glaucion, 260, 659 .

Coal Titmouse, 94, 976 .

Coccothraustes chloris, 127, 29, 91, 162 , $229,298,357,416,472,517,581$, 648,660 .

vulgaris, $187,161,5$
Coccystes glandarius, $180,597$.
Columba livia, 182, 102, 240, 652.

vulgaris, 127, 161, 580, 648.

," onas, 182, 652.

, palumbus, 182, 597.

Colymbus glacialis, 247, 52, 118, 190, $257,325,377,443,491,534,612$.

Contents, ix. septentrionalis, 247 .

Coot, Bald, 195, 276, 41, 104, 310, 654.

Coracias garrulus, $180,330$.

Cormorant, Common, 249, 276, 52, 118, $190,258,325,378,443,492,535,613$.

, $\quad$ Green, 249, 52, 118, 190, 258, $325,378,443,535,613$.

Corn Bunting, 117, 276, 88, 159, 228, $296,471,646$.

Corn-Crake, xxv, 186, 279, 41, 103, 176, $241,309,366,428,526,599,652$.

Corvus corax, 149, 35, 97, 169, 235, 304, $361,421,477,522,590$.

, cornix, 150, 36, 97, 169, 235, 304, $362,421,477,522,590$.

" frugilegus, 151, 36, 98, 169, 236, $305,362,422,477,522,591,651$.

, monedula, 158, 37, 99, 171, 237, $305,362,423,478,523,592,651$.

Cotile riparia, 162, 170, 38, 101, 173, 239, 596,651 .

Coturnix communis, 185, 309, 366, 652.

Crake, Corn-, xxv, 186, 249, 41, 103, 176, 241, 309, 366, 428, 526, 599, 652 . Spotted, 190, 282, 481, 653 .

Creeper, Tree-, 92, 276.

Crex pratensis, 186, 41, 103, 176, 241, $309,366,428,526,599,652$.

Crossbill, 140, 278, 649 .

Crow, Carrion, 278 .

, Hooded, 150, 276, 278, 36, 97, 304, $362,421,477,522,590$.

Cuckoo, xxv, 176, 39, 101, 174, 240, 308, $365,427,480,525,596,651,660$.

" Great Spotted, 180, 279, 597.

Cuculus canorus, $176,39,101,174,240$, $308,365,427,480,525,596,651,660$.

Curlew, Common, 219, 2S0, 46, 110, 182 , $248,318,372,435,485,529,605,657$. Stone, 195, 367.

Curlew-Sand piper, 215, 27\%.

Cygnus Bewicki, 25\%. ,' musicus, $25 \%$.

", olor, 259.

Cymochorea leucorrhoa, 240, 50, 115, 187 , $323,489,533,610,658$.

Cypselus apus, 172, 39, 101, 174, 240, $308,365,426,480,525,596,651$.

Dabchick, \&48, 118, 659.

Dafila acuta, 259.

Dendrocopus major, 181.

Diagram, 16.
Dipper, 12, $276,68$.

Distances, Table of, xxii.

Diver, Great Northern, 247, 52, 118, 190, $257,325,377,443,491,534,612$.

" "Dotterel," 481.

Dove, Ring-, 18\%, 597.

" Rock-, 182, 276, 102, 240, 652.

, Stock-, 182, 652 .

"Turtle-, xxv, 183, 279, 40, 102, 174, $241,365,525,597,652,660$.

Duck, Common Sheld-, 259, 495.

, Eider, 261, 195, 448.

, Golden-eye, 260, 659 .

"Long-tailed, 260, 537, 659.

"Pintail, 259, 27\%.

, Pochard, 2\%\%.

, Scaup, 260, 55, 447, 495, 659.

., Shoveller, 259 .

," Tufted, 260, 2y\%.

," Wild, 259, 27\%.

" D'ucks," 56, 122, 194, 262, 329, 380, 447, $495,538,616$.

Dunlin, xxv, 213, 272, 250, 108, 180, 247, $316,370,434,485,529,603,656,660$.

Eagle, Golden, 1.

White-tailed or Sea, 1.

“ Éagle," 66, 133, 549.

Eider Duck, 261, 195, 448.

Emberiza cilrinella, $117,28,89,159,228$, $296,355,413,471,515,576,646$.

" 471,646 . miliaria, $117,88,159,228,296$,

, schoeniclus, $116,515,576,646$.

Enithacus rubecula, 38, 18, 76, 146, 216 , $284,345,399,462,507,561,630$.

Falco cesalon, 3, 274, 339, 456, 621.

, candicans, 1, 133, 204.

$"$ peregrinus, $\mathscr{Q}, 66,133,201,274$, $339,390,503,549,621$.

, subbuteo, $3,133$.

") tinnunculus, 3, 66, 133, 204, 274, $339,390,503,549,621$.

Falcon, Greenland, 1,274, 133, 204.

"Peregrine, 2, 66, 133, 204, 274, $339,390,503,549,621$.

Fieldfare, 26, $271,27 \%, 280,14,72,141$, $212,280,343,396,459,506,556,625$, 660 .

Finch, Mountain, 124, 29, 90, 161, 229, $415,472,517,580,647$.

Fire-Crest, 90.

Flycatcher, Pied, $\mathrm{xxv}, 10,75,181,273$, 278, 28. $, 9,135,503,622$.

, Red-breasted, 10, 72, 278, 279, 8, 68, 135, 391, 622 .

"Spotted, xxv, 8, 279, 282, 68, $135,340,456,550,621,660$.

"Flycatchers," 207, 391, 504.

Fratercule arctica, 246, 51, 117, 190, 257, $325,377,442,491,534,612$, 659 .

Fringilla colebs, $119,135,139,28,89$, $160,228,296,357,413,471,515$, $576,646,660$.

1 , montifringilla, $124,131,132$, $29,90,161,229,415,472,517,580$, 647.

Eulica atra, 19j, 41, 104, 310, 654. 
Fuligula cristata, 260.

, ferina, 260 .

" marila, 260, 55, 447, 495, 659.

Gadwall, 259.

Gallinago colestis, 209, 213, 44, 107, 180, $246,315,370,433,484,528,603$, 655,660 .

" gallinula, 212, 44, 107, 180, $246,316,370,433,528,603,656$, 660 .

Gallinula chloropus, 193, 41, 104, 242, $310,429,481,526,600,653$.

Gannet, 249, 53, 119, 191, 259, 326, 378, $444,492,535,613$.

Garden-Warbler, $73,637$.

Garrulus glandarius, 161.

"Geese," 55, 121, 193, 261, 327, 379, 445, $494,536,615$.

General Observations, 123, 196, 264, 330, $382,448,496,538,618$.

Glatcous Gull, 230, 27 4, 374, 487, 531, 658 .

Goatsucker, $175,39,240,365,427,525$, 596,651 .

Godwit, Bar-tailed, 218, 604, 657.

Gold-Crest, xxv, 83, 271 , $27 \%, 22,81,152$, $221,289,349,404,465,511,566$, 640,660 .

Golden Eagle, 1.

, Oriole, 11.

'Plover, 196, 42, 105, 176, 243, $310,367,429,482,526,600,654$.

Golden-crested Wren, $83,271,27 \%, 278$, $22,81,152,221,289,349,404,465$, $511,566,640,660$

Golden-Eye, 260, 659 .

Goldfinch, 129, 91, 162, 230, 298, 357, $416,473,518,582,648$.

Goose, Barnacle, 255, 27/4.

" Bean, 255, 27\%.

"Brent, 255, 327, 494.

"Grey-leg, 255, 27\%.

"Pink-footed, 255.

"White-fronted, 253, 659 .

Grasshopper-Warbler, $x x y, 6 \%, 21,80$, $149,287,461,635$.

Great-crested Grebe, $248,27 \%$.

"Grey Shrike, 278 .

" Northern Diver, 24\%, 2\%7, 52, 118, $190,257,325,377,443,491,534,612$.

"Spotted Woodpeclier, 181.

, Titmouse, 93, 276, 83, 641 .

Grebe, Eared, $248,378$.

, Great-crested, 248, 2\%\%.

"Little, 2/8, 118, 659 .

, Sclavonian, 248, 492.

Green Plover, 199, 42, 105, 177, 243, 311 . $368,430,482,527,600,654$.

Greenfinch, xxv, 127, 272, 278, 280, 29, $91,162,229,298,357,416,472,517$, $581,648,660$.

Greenland Falcon, 1, 2\%4, 133, 204. . Redpoll, 133, 92, 162, 298, 3̈̆ 7, 648. (See Mealy Redpoll.)

Greensliank, 218, 27\%.

Grey Phalarope, 203, 2S5, 107, 246, 315, $369,528,602,655$.

"Plover, 199, 42, 367, 654 .

", Shrike, 8 .

"Wagtail, 98, 153, $6 \pm 1$.
Grey-leg Goose, „55.

Grouse, Red, 185, 276, 176, 428, 599.

,. Pallas's Sand-, 185, 40.

Guillemot, Black, $245,50,257,324,376$, 612.

"Common, 243, 51, 116, 188, $256,324,376,441,490,533,611$, 659 .

Gull, Black-headed, 22S, 252.

,Common, 228, 487.

" Glaucous, 230, 274, 374, 487, 531, 658.

, Great Black-backed, 230.

,' Herring, 228.

"Iceland, 230, 274, 252, 531, 658 .

" Kittiwake, 234, 185, 658.

"Lesser Black-backed, 229.

"Sabine's, 228.

"G'Gulls," 48, 113, 185, 252, 321, 374, 438, $487,531,608$.

Homatopus ostralegus, 202, 43, 106, 179 , $245,313,369,432,484,528,602$.

Haliaëtus albicilla, 1.

Harelda glacialis, 260, 537, 659.

Haw finch, 127, 161, 580, 648 .

Hà̀k, Sparrow-, 4, 276, 274, 339, 390, $456,503,549$.

"Hawks," 7, 66, 134, 205, 275, 339, 391, $456,503,549$.

Hedge-Sparrow, 38, 276, 18, 76, 146, 274, $345,398,462,507,561,630$.

Hen-Harrier, 276 .

Heron, 252, 276, 282, 54, 121, 192, 260, $327,379,445,493,536,615$.

Herring-Gull, $22 S$.

Himundo mustica, 161, 169, 37, 99, 17\%, $237,306,363,423,478,523,593$, 651,660 .

Hobby, 3, 133.

Hooded Crow, 150, 276, 36, 97, 304, 362 , $421,477,522,590$.

Hoopoe, $180,39,652$.

House-Martin, 169, 38, 101, 173, 239, $364,480,524,596,651$.

House-Sparrow, 126, 276, 90, 230, 297, $357,415,472,517,580,647$.

Iceland Gull, 230, 274, 252, 531, 658.

Icterine Warbler, 278.

Insects, 284.

Iÿx torquilla, 181, 308, 525, 652 .

Jackdaw, 158, 37, 99, 171, 237, 305, 362, $423,478,523,592,651$.

Jack Snipe, xxv, 212, 242, 44, 107, 180, $246,316,370,433,528,603,656,660$. Jay, 161, 276, 278.

Kestrel, 3, 66, 133, 204, 274, 339, 390, $503,549,621$.

Kingfisher, $180,276,240,308,652$.

Kittiwake, $934,185,658$.

Knot, 216, 45, 108, 371, 435, 485, 529, 657.

Lagopus scoticus, 185, 176, 428, 599.

Land-Rail, 186, 41, 103, 176, 211, 309, $366,428,526,599,652$.

Lanius collurio, 8 . 
Lanius major, 8.

", pomeranus, $8,340,621$.

Lapwing, 199, 280, 281, 42, 105, 177, 243, $311,368,430,482,527,600,654$.

Lark, Short-toed, 72, 110, 278, 279, 159, 645.

" Sky-, xxv, 102, 214, 241, 24, 85, $155,224,292,352,408,467,512$, $570,643,660$.

"Wood-, 110, 278, 645.

Larus argentatus, 228.

" canus, 228, 487.

", fuscus, 229.

", glaucus, 230, 374, 487, 531, 658.

" leucopterus, $230,252,531,658$.

" marinus, 230

" ridibundus, $228,252$.

Jights, List of Irish, xi

Ligurinus chloris, 12\%, 29, 91, 162, 229, $298,357,416,472,517,581,648,660$.

Limosa lapponica, 218, 604, 657.

Linnet, xxv, 135, 272, 276, 298, 417, 583, 649.

"Linnets," 29, 92, 162, 230, 358, 473, 518.

Linota cannabina, 135, 298, 417, 583, 649 . " flavirostris, 13\%, 31, 93, 300, 418, $519,649$. "648.

"' rostrata, 133, 92, 162, 298, 357, 648.

" rufescens, 134.

List of Irish Lights, xi.

Locust, 284.

Locustella ncevia, 67, 21, 80, 149, 287, 464,635

Long-tailed Titmouse, 94, 276, 466, 641.

Loxia curvirostra, 140, 649.

Magpie, 159, 276, 278, 37, 99, 172, 237, $306,363,478,523,593$.

Mallard, 259.

Maux Shearwater, 23\%, 49, 115, 187, 254, $323,375,440,489,532,609,658$.

Maps, ii, 9, 43, 46, 51, 64, S6, 132, $13 \%$, $206,26 \%$.

MIareca penelope, 260, 122.

Martin, House-, 169, 299, 38, 101, 173, $239,364,480,524,596,651$.

" Purple, 278 .

" Sand-, 162, 170, 279, 38, 101, $173,239,596,651$.

Meadow Pipit, xxv, 99, 271, 278, 24, 84, $154,223,291, .351,407,467,512$, $569,642,660$.

Megalestris catarrhactes, 236.

Merganser, Red-breasted, 262, 262.

Mergulus alle, 245, 189, 491, 534, 659.

Mcrgus serrator, 262, 262.

Merlin, 3, 274, 339, 456, 621 .

Migration Routes, 266, 269.

Misseł-Thrush, xxv, 12, 278, 9, 68, 135, $207,276,340,457,622,660$.

Moor-Hen, 193, 41, 104, 242, 310, 429, $481,526,600,653$.

Motacilla alba, $9 S$.

" tlara, 99.

" lugubris, 95, 290, 641.

", melanope, 98, 153, 641 .

") raii, $99,126,350,466,642$.
Moth, Death's Head, 285.

Mountain Finch, 124, 29, 90, 161, 229, $415,472,517,580,647$.

Movements, Return, 274 .

Mrscicapa atricapilla, 10, 75, 181, 9, 135, 503,622

$"$ grisola, $8,8,68,135,340$, $456,550,621,660$.

" parva, 10, 72, 8, 68, 135.

Nettion creccu, 259, 194, 495, 659.

Nightjar, $175,279,39,210,365,427,525$, 596,651 .

Numenius arquata, 219,46, 110, 182, $248,318,372,435,485,529,605,657$.

" phecopus, 221, 47, 111, 183, $250,320,373,437,487,530,606$, 657.

Nyctea scandiaca, 4, 8, 276.

Oceanites oceanicus, 205.

Oceanodroma leucorrhoa, 240,50, 115, $187,323,489,533,610,653$.

Edemia nigra, 261, 56, 122, 262, 537, 659.

, perspicillata, 262, 56 .

Q'dicnemus scolopax, 195, 367.

Oriole, Golden, 11, 278.

Oriolus galbula, 11.

Ortolan, 278.

Ouzel, Ring-, xxv, 35, 17, 75, 145, 216, $284,461,507,561,629,660$.

O'vl, Water-, 12, 68.

" Long-eared, 5, 621.

". Short-eared, 5 .

", Snowy, 4, 274, 8, 276.

"Tawny, $\%$

“'Owls," 135, 206, 276, 456.

Oyster-Catcher, 202, 27\%, 43, 106, 179 , $245,313,369,432,484,528,602$.

Pallas's Sand-Grouse, 185, 40.

Partridge, 185, 276, 176, 599, 652.

Parus ater, 94.

" carulens, 93, 641 .

" major, 93, 83, 641 .

Passer domesticus, 126, 90, 230, 297, 357, $415,472,517,580,647$.

montanus, 126, 517, 647.

Përdix cinerea, $185,176,599,652$

Peregrine Falcon, $2,66,133,204,27 £$, $339,390,503,549,621$.

Petrel, Fork-tailed, 240, 50, 115, 187, $323,489,533,610,658$.

, Storm, xxv, 240,50,116, 187, $255,323,376,441,489,533,610$, 658,660 .

Whilson's, 205.
Phacrocorax carbo, 249, 52, 118, 190, $258,325,378,443,492,535,613$.

" 1 graculus, 249, 52, 118 , $190,258,325,378,443,535,613$.

Phalarope, Grey, 203, 2S5, 107, 246, 315, $369,528,602,655$.

, Ked-necked, 205

Phalaropus fulicarins, 203, 107, 246, $315,369,528,602,655$.

", hyperboreus, 205. 
Pheasant, 276 .

Phylloscopus mufus, 61, SO, 22, 81, 152, $221,289,404,465,511,566,639$, 660.

,

is

sibilatrix, $\% 6,151,637$. superciliosus, $72,83,150$.

trochilus, 61, $7 y, 214,22$,

$80,151,220,288,348,403,464,510$, $565,637,660$.

Pica mustica, 159, 37, 99, 172, 237, 306, $363,478,523,593$

Pied Wagtail, 95, 290, 641.

"Pigeons," 182, 40, 103, 174, 241, 309, $366,427,481,525,598$.

Pintail, 259.

Pipit, Meadow, xxv, 99, 2y1, 2S0, 2S1, $24,84,154,223,291,351,407,467$. $512,569,642,660$.

Rock, 102, 276, 85, 155, 224, 291, $352,408,467,642$.

Plectrophenax nivalis, 111, 192, 27, 87, $159,227,295,354,412,471,514$, $575,645,660$.

Plover, Golden, 196, 42, 105, 176, 243, $310,367,429,482,526,600,654$. Green, $199,42,105,177,243$,

$311,368,430,482,527,600,654$. Grey, $199,42,367,654$.

Ringed, 195, 42, 104, 176, 242, $310,367,429,481,526,600,654$.

Pochard, 260, 27\%.

Podicipes curitus, 24S, 492.

cristatus, 248.

, fluviatilis, 248, 118, 659.

$\because \quad$ nigricollis, 248,378 .

Porwana maruetta, 190, 481, 653.

Pratincola rubetra, 50, 126, 19, 77, 147 $218,285,346,463,508,563,631$, 660 .

" rubicola, 49, 147, 217, 285, $346,462,508,562,630,660$.

Procellaria pelagica, $240,50,116,187$, $255,323,376,441,489,533,610$, 658,660 .

Puflin, 246, 51, 117, 190, 257, 325, 377, $442,491,534,612,659$.

Puffinus anglorum, 23\%, 49, 115, 187, $254,323,375,440,489,532,609$, 658.

, gravis, $23 \%$.

Pyjrhocorax graculus, $148,35,96,169$, $234,304,361,421,477,522,651$.

Pyrrhula curopace, 139, 31, 93.

Quail, 185, 309, 366, 652.

Querquedula crecca, \$59, 194, 495, 659 .

Rail, Land-, 186, 41, 103, 176, 241, 309 , $366,428,526,599,652$.

VVater-, xxv, 190, 273, 41, 104, 176 $242,309,366,429,481,526,599,653$, 660 .

Rallus arruaticus, $190,41,104,176,242$, $309,366,429,481,526,599,653$, 660 .

Raven, $149,35,97,169,235,304,361$, $421,477,522,590$

Razorbill, 243, 51, 116, 188, 256, 321 , $376,441,490,533,611$.

Recipe for Preserving Legs and Wings, 285.
Redbreast, $38,18,76,146,216,284,345$, $399,462,507,561,630$.

Rerl Grollce, 185, 270, 176, 428, 599.

Redpoll, Lesser, 134, 276, 278.

Mealy, xxv, 133, 273, 278, 279, $92,162,298,357,618$.

Redshank, 218,46, 109, 182, 248, 318, $376,657$.

Redstart, Black, xxv, $45,184,273,280$ $19,76,217,346,462,508,562,630$, 660 .

" Common, $\mathrm{xxv}, 37,42,279,252$ $18,76,146,217,399,462,507,562$, 630.

Redwing, $\mathrm{xxv}, 21,2 \% 1,2 y \%, 280,13,71$, $140,211,279,342,395,459,505$, $555,624,660$.

Reed-Bunting, 116, 276, 515, 576, 646.

Regulus cristatus, $83,22,81,152,221$, $289,349,404,465,511,566,640,660$. ignicapillus, 90.

Réturn Movements, $2 y_{4}$

Ring-Dove, 182, 597.

ling-Ouzel, xxv, 35, 289, 282, 17, 75, $145,216,284,461,507,561,629$, 660.

Rissa tridactyla, 234, 185, 658.

Robin, 38, 276, 18, 76, 146, 216, 281, 345, $399,462,507,561,630$.

Rock-Dove, 182, 276, 102, 240, 652.

Rock-Pipit, 102, $276,85,155,224,291$, $352,408,467,642$.

Roller, 180, 330.

Rook, 151, 278, 2S1, 2S2, 36, 98, 169, $236,305,362,422,477,522,591,651$.

Rotche, 245, 189, 491, 534, 659 .

Routes, Migration, 266, 269.

Ruticilla phonicurus, 3\%, 42, 18, 76, 146, $217,399,462,507,562,630$.

titys, $45,184,19,76,217,346$, $462,508,562,630,660$.

Sabine's Gull, 228

Sanderling, 216, 435, 657.

Sand-Grouse, Pallas's, 185, 40.

"Sand Larks," 45, 109, 181, 247, 317 , $371,435,486,529,603$.

Sand-Martin, 162, $170,38,101,173,239$, 596,651 .

Sandpiper, Common, xxv, 217, 279, 45, $317,371,604,657$.

," Curlew, 215, 27\%.

Purple, xxv, 192, 215, 273, $45,108,181,247,317,371,603,656$, 660 .

Sáxicola "Schinz's," 218. $218,285,346,400,463,508,563$, 631,660 .

Scrup, 260, 55, 447, 495, 659 .

Scolopax rusticula, 205, 213, 43, 107, 179, $246,315,369,433,484,528,602$, 655,660 .

Scoter, Common, 261, 56, 122, 262, 537 , 659.

Surf., 262, 274, 56.

Selige-Warbler, xxv, 60, 227, 20, 79, 148, $219,286,347,402,463,509,561,633$, 660. 
Serin, 278 .

Shag, 249, 276, 52, 118, 190, 258, 325, $378,443,535,613$.

Shearwater, Great, $23 \%$.

Manx, 23\%, 49, 115, 187, 254, $32 \ddot{3}, 375,440,489,532,609,658$.

Sheathbill, Yellow-billed, 203, 279, 314.

Sheldrake, Common, 259, 495.

Shoveller, 259, 2y\%:

Shrike, Great Grey, 8, 278.

" Red-backed, 8,278

"Woodchat, 8, 278, 299, 282, 340, 621.

Siskin, xxv, 131, 273, 280, 91, 230, 298, $582,648,660$.

Skua, Buffon's, $23 \%$.

, Great, 236

" Pomatorhine, 236, 2ry.

" Richardson's, 236, 27\%.

"S'kuas," 236, 49, 115, 440.

Skylark, xxv, 102, 214, 271, 27y, 278, 280 $281,24,85,155,224,292,352,408$, $467,512,570,643,660$.

Snipe, Common, xxv, 209, 213, 271, 280 , $44,107,180,246,315,370,433,484$, $528,603,655,660$.

,Jack-, xxv, 212, 272, 280,44, 107, 180 $246,316,370,433,528,603,656,660$.

Snow-Bunting, xxจ, 111, 192, 273, 27, 87, $159,227,295,354,412,471,514,575$, 645,660 .

Snowy Owl, 4, 8, 276.

Somateria mollissima, 261, 195, 448.

Song-Thrush, xxv, 13, 102, 106, 271, 27\%, $278,280,281,9,69,136,207,276$, $340,392,457,504,550,622,660$.

Sparrow-Hawk, 4, 276, 274, 339, 390 $456,503,549$.

Hedge-, 38, 276, 18, 76, 146 , $274,345,398,462,507,561,630$.

House-, 126, 276, 90, 230, 297 $357,415,472,517,580,647$.

, Tree-, 126, 517, 647 .

Sṕculula clypeata, 259.

Squatarola helvetica, 199, 42, 367, 654 .

Starling, $\mathrm{xxv}, 102,140,2 \% 1,2 \%, 280$, $281,282,31,94,164,231,300,359$, $418,474,519,585,649,660$. Rose-coloured, 278 .

Stercorarizes crepidatus, 236. , parasiticus, $23 \%$.

, pomatorhinus, 236.

Stema cantiaca, 223.

, dougalli, 223, 607.

"Aluviatilis, 224, 112, 184, 251, $437,657$.

". macrurc, 224, 112, 184, 251, 658.

," minuta, $227,373,658$.

Stint, Little, $215,27 \%$

"Stint, Temminck's," 218.

Stock-Dove, 182, 652.

Stonechat, $\mathrm{xxv}, 49,147,217,285,346$, $462,508,562,630,660$.

Stone-Curlew, 195, 367.

Strepsilas interpres, 201, 106, 178, 245, $313,368,432,483,527,602,654,660$.

Strix flammea, $7,456$.

Sturnus vulgaris, 102, 140, 31, 94, 161, $231,300,359,418,474,519,585$, 649,660 .
Sula bassana, 249, 53, 119, 191, 259, 326, $378,444,492,535,613$.

Surf-Scoter, 262, $274,56$.

Swallow, xxv, 161, 169, 279, 281, 37, 99, $172,237,306,363,423,478,523,593$, 651,660 .

Swan, Bewick's, 25\%.

"Mute, 259.

, Whooper, $25 \%$.

"S"wans"" 194, 328, 380, 447, 495, 537, 616.

Swift, 172, 279, 39, 101, 174, 240, 308, $365,426,480,525,596,651$.

Sylvia atricapilla, $74,80,220,288,464$, $510,565,630$. cinerea, $61,68,21,80,150,220$,

$287,348,402,464,509,564,636,660$. curruca, 79, 181, 150, 637.

hortensis, $73,637$.

nisoria, 7\%, 510.

Sy'rnium aluco, 7 .

Syrrhaptes paradoxns, 185, 40.

Tadorna cornuta, 259, 495.

Teal, 259, 194, 495, 659.

Tern, Arctic, 224, 279, 112, 184, 251, 658.

" Common, 224, 279, 112, 184, 251 , $437,657$.

"Lesser, 227, 279, 373, 658 .

" Roseate, 223, 279, 607.

Sandwich, 223, 27\%.

"Terns," 224, 47, 112, 320, 373, 437, 487, 531,608 .

Thrush, Missel-, xxv, 12, 9, 68, 135, 207 , $276,340,457,622,660$.

" Song-, xxv, 13, 102, 106; 271, 24\%, 278, 280, 281, 9, 69, 136, 207, $276,340,392,457,504,550,622$, 660 .

White's, 278.

Titlark, 99, 24, 84, 154, 223, 291, 351, $407,467,512,569,642,660$.

Titmouse, Blue, 93, 276, 641 .

, Coal, 94, 276, 278.

, Great, 93, 276, 83, 641.

", Long-tailed, 94, $276,466,611$.

"Tits," 83, 153, 222, 406.

Totanus calidris, 218, 46, 109, 182, 248, $318,376,657$.

, canescens, 218 .

"604, 657 .

Tree-Creeper, 92, 276, 278.

Tree-Sparrow, 126, 517, 6 17 .

Tringa alpina, 213, 108, 180, 217, 316, $370,434,485,529,603,656,660$.

,$\quad$ canutus, $216,45,108,371,435$, $485,529,657$.

2) minuta, 215.

"striata, 192, 215, 45, 108, 181, $247,317,371,603,656,660$. subarquata, 215.

Troglodytes parvulus, 90, 23, 82, 153, 221, $290,350,405,465,511,568,641,660$. Tufted Duck, $2 y \%$.

Turdus iliacus, 21, 13, 71, 140, 211, 279, $342,395,459,505,555,624,660$.

" merula, 29, 102, 15, 73, 142, 213. $281,343,396,460,506,557,626$, 660 . 
Therdus musicus, 13, 102, 106, 9, 69 $136,207,276,340,392,457,504,550$, 622,660 .

"pilaris, 26, 14, 72, 141, 212, 280, $343,396,459,506,556,625,660$.

"torquatus, 35, 17, 75, 145, 216, $284,461,507,561,629,660$.

"viscivomes, 12, 9, 68, 135, 207, $276,340,457,622,660$.

"'urnstone, 201, 106, 178, 245, 313, 368, $432,483,527,602,654,660$.

Turtle-Dove, xxv, 183, 40,102, 174, 241, $365,525,597,652,660$.

Turtur communis, 183, 40, 102, 174, 241, $365,525,597,652,660$.

Twite, xxv, 13\%, 273, 276, 31, 93, 300, $418,519,649$.

Upupc epops, $180,39,652$.

Uria grylle, 245, 50, 257, 324, 376, 612.

") troile, 243, 51, 116, 188, 256, 324, $376,441,490,533,611,659$.

Vanellus vulgaris, 199, 42, 105, 177, 213, $311,368,430,482,527,600,654$.

Wagtail, Grey, 98, 153, 641.

$\Rightarrow \quad$ Pied, 95, 281, 290, 641.

$\because \quad$ White, $98,278$.

"Yellow, 99, 126, 279, 350, 466,

"Wagtails," 23, 83, 153, 222, 290, 350, $406,466,511,568$.

Warbler, Barred, 73, 278, 510.

". Blackcap, 74, 80, 220, 288, 464, $510,565,630$.

,. Garden, 73, 279, 637.

" Grasshopper, xxv, 67, 279, 21, $80,149,287,464,635$.

Icterine, 278 .

$$
\text { ", }
$$

Serige, xxv, 60, 27\%, 279, 282, $20,79,148,219,286,347,402,463$, $509,561,633,660$.

\section{, Rufous, 278 .}

" Willow, y7, 214, 22, 80, 151, $220,288,348,403,461,510,565$, 637,660 .

Wood, 76, 279, 151, 637.
$"$ Yellow-browed, 72, 83, 278, 279,
Water-IIen, 193, 276, 41, 104, 242, 310, $429,481,526,600,653$.

Water-Ouzel, 12, 68.

Water-Rail, Xxv, 190, 273, 278, 41, 104, $176,242,309,366,429,481,526$, $599,653,660$.

Waxwing, 94, 278, 330.

Wheatear, xxv, 53, 61, 27y, 279, 19, 78, $147,218,285,346,400,463,508$, $563,631,660$.

Whimbrel, $221,47,111,183,250,320$, $373,437,487,530,606,657$.

Whinchat, $\mathrm{xxv}, 50,126,279,282,19,77$, $147,218,285,346,463,508,563$, 631,660 .

Whitethroat, Greater, xxv, 61, 68, 27\%, 279, 282, 21, 80, 150, 220, 287, 348, $402,464,509,5 \hbar 4,636,660$. "282, 150, 637.

Whooper, 25\%.

Wigeon, 260, 122.

Willow-Wren, xxv, 61, ry, 214, 27y, 279, $22,80,151,220,288,348,403,464$, $510,565,637,660$.

Woodchat Shrike, $8,340,621$.

Woodcock, xxv, 205, 213, 271, 280, 43, $107,179,246,315,369,433,484$, $528,602,655,660$.

Wood-Lark, 110, 278, 645.

Woodpecker, Great Spotted, 181.

Wood-Pigeon, 182, 597.

Wood-Wren, $76,151,637$.

Wren, 90, 276, 23, 82, 153, 221, 290 , $350,405,465,511,568,641,660$.

Fire-crested, 90.

, Golden-crested, $83,22,81,152$, $221,289,349,404,465,511,566$, 640,660 .

Willow-, $\mathrm{xxv}, 61,7 \%, 214,27 \%$, $22,80,151,220,288,348,403,464$, $510,565,637,660$.

Wood-, 76, 151, 637.

W'ryneck, 181, 282, 308, 525, 652 .

Xema sabinii, 228.

Yellowhammer, 117, 276, 28, 89, 159, $228,296,355,413,471,515,576$, 

